\title{
Cleanup Verification Package for the 118-F-1 Burial Ground
}

\author{
Prepared for the U.S. Department of Energy \\ by Washington Closure Hanford
}




\section{EXECUTIVE SUMMARY}

This cleanup verification package documents completion of remedial action for the 118-F-1 Burial Ground on the Hanford Site. The 118-F-1 Burial Ground is a combination of two locations formerly called Minor Construction Burial Ground No. 2 and Solid Waste Burial Ground No. 2. The 118-F-1 site is located in the 100-FR-2 Operable Unit of the 100-F Area, approximately $300 \mathrm{~m}(1000 \mathrm{ft})$ southwest of the $105-\mathrm{F}$ Reactor Building. This waste site received radioactive equipment and other miscellaneous waste from 105-F Reactor operations. The burial ground was used between 1954 and 1965, and contained three unlined burial trenches and a burial pit. Waste buried at this site included: dummy elements and irradiated process tubing; gun barrel tips, steel sleeves, and metal chips removed from the reactor; filter boxes containing reactor graphite chips; and miscellaneous construction solid waste.

Remedial action at the 118-F-1 site began on December 27, 2005, and was completed on June 22, 2007. Remedial action activities involved removing the uncontaminated overburden, the buried contaminated debris, and the underlying contaminated soil. All contaminated materials were disposed of at the Environmental Restoration Disposal Facility. Results of the verification sampling, laboratory analyses, and data evaluations for the 118-F-1 site (which includes the remediation footprint, the overburden/below cleanup level and the waste sorting pile areas) indicate that all remedial action objectives and goals for direct exposure, protection of groundwater, and protection of the Columbia River have been met (see Table ES-1).

Soil cleanup levels were established in the Record of Decision for the 100-BC-1, 100-BC-2, 100-DR-1, 100-DR-2, 100-FR-2, 100-HR-2, and 100-KR-2 Operable Units, Hanford Site (100 Area Burial Grounds), Benton County, Washington (ROD) (EPA 2000) based on a limited ecological risk assessment. Although not required by the ROD (EPA 2000), a comparison against ecological risk screening levels has been made for the site contaminants of concern/contaminants of potential concern. Screening levels were exceeded for seven site constituents. It is believed that the 
exceedance of screening values does not indicate the existence of risk to ecological receptors, as the concentrations for these constituents are within the range of Hanford Site background levels or are consistent with those seen elsewhere at the Hanford Site. The one exception is lead, which is believed to be present due to the historic application of lead-arsenate pesticides. The exceedance of soil screening values by lead at the site will be evaluated in the context of additional lines of evidence for ecological effects. A baseline risk assessment for the river corridor portion of the Hanford Site began in 2004 , which includes a more complete, quantitative ecological risk assessment. That baseline risk assessment will be used as part of the final closeout decision for this site.

The site meets cleanup standards and has been reclassified as Interim Closed Out in accordance with the Hanford Federal Facility Agreement and Consent Order (Ecology et al. 1989) and the Waste Site Reclassification Guideline TPA-MP-14 (RL-TPA-90-0001) (DOE-RL 2007). A copy of the waste site reclassification form is included as Attachment ES-1 to this document. 


\section{Table ES-1. Summary of Cleanup Verification Results for the 118-F-1 Burial Ground. (2 pages)}

\begin{tabular}{|c|c|c|c|c|}
\hline $\begin{array}{l}\text { Regulatory } \\
\text { Requirement }\end{array}$ & Remedial Action Goals & Results & $\begin{array}{l}\text { Remedial } \\
\text { Action } \\
\text { Objectives } \\
\text { Attained? }\end{array}$ & Ref. \\
\hline $\begin{array}{l}\text { Direct Exposure - } \\
\text { Radionuclides }\end{array}$ & $\begin{array}{l}\text { 1. Attain } 15 \mathrm{mrem} / \mathrm{yr} \text { dose rate } \\
\text { above background over } 1000 \\
\text { years. }\end{array}$ & $\begin{array}{l}\text { 1. Maximum dose rate calculated } \\
\text { by RESRAD is } 4.59 \mathrm{mrem} / \mathrm{yr} \text {. }\end{array}$ & Yes & e \\
\hline $\begin{array}{l}\text { Direct Exposure - } \\
\text { Nonradionuclides }\end{array}$ & 1. Attain individual COC RAGs. & $\begin{array}{l}\text { 1. All individual COC concentrations } \\
\text { are below the RAGS. }\end{array}$ & Yes & $e, f$ \\
\hline \multirow[t]{4}{*}{$\begin{array}{l}\text { Meet Nonradionuclide } \\
\text { Risk Requirements }\end{array}$} & $\begin{array}{l}\text { 1. Hazard quotient of less than } 1 \\
\text { for noncarcinogens. }\end{array}$ & $\begin{array}{l}\text { 1. The hazard quotients for } \\
\text { individual nonradionuclide cOCs } \\
\text { in the shallow zone and } \\
\text { overburden are less than } 1 .\end{array}$ & Yes & g \\
\hline & $\begin{array}{l}\text { 2. Cumulative hazard quotient of } \\
\text { less than } 1 \text { for noncarcinogens. }\end{array}$ & $\begin{array}{l}\text { 2. The cumulative hazard quotient is } \\
\text { less than } 1 \text { for the shallow zone } \\
\text { and overburden. }\end{array}$ & Yes & $g$ \\
\hline & $\begin{array}{l}\text { Ex. Excess cancer risk of }<1 \times 10^{-6} \\
\text { for individual carcinogens. }\end{array}$ & $\begin{array}{l}\text { 3. Excess cancer risk values for } \\
\text { individual nonradionuclide COCs } \\
\text { are less than } 1 \times 10^{-6} \text {. }\end{array}$ & Yes & $g$ \\
\hline & $\begin{array}{l}\text { 4. Attain a total excess cancer risk } \\
\text { of }<1 \times 10^{-5} \text { for carcinogens. }\end{array}$ & $\begin{array}{l}\text { 4. Total excess cancer risk is less } \\
\text { than } 1 \times 10^{-5} \text {. }\end{array}$ & Yes & $g$ \\
\hline \multirow[t]{4}{*}{$\begin{array}{l}\text { Groundwater/River } \\
\text { Protection - } \\
\text { Radionuclides }\end{array}$} & $\begin{array}{l}\text { 1. Attain single COC groundwater } \\
\text { and river RAGS. }\end{array}$ & $\begin{array}{l}\text { 1. Cesium-137, cobalt- } 60 \text {, nickel- } \\
63 \text {, strontium-90, and tritium are } \\
\text { calculated to reach groundwater } \\
\text { in the } 1,000 \text { years of the } \\
\text { RESRAD model run. However, } \\
\text { none of these constituents is } \\
\text { predicted to migrate to } \\
\text { groundwater (and thus the } \\
\text { Columbia River) at } \\
\text { concentrations exceeding } \\
\text { groundwater or river criteria } \\
\text { within } 1,000 \text { years. Therefore, } \\
\text { residual concentrations achieve } \\
\text { the remedial action objectives for } \\
\text { groundwater and river protection. }\end{array}$ & \multirow[t]{2}{*}{ Yes } & b \\
\hline & $\begin{array}{l}\text { 2. Attain National Primary Drinking } \\
\text { Water Regulations 4-mrem/yr } \\
\text { (beta/gamma) dose standard to } \\
\text { target receptor/organ. }\end{array}$ & $\begin{array}{l}\text { 2. All organ specific doses are below } \\
\text { the } 4-\mathrm{mrem} / \mathrm{yr} \text { dose standard. }\end{array}$ & & $h$ \\
\hline & $\begin{array}{l}\text { 3. Meet drinking water standards for } \\
\text { alpha emitters: the more } \\
\text { stringent of } 15 \mathrm{pCi} / \mathrm{L} \mathrm{MCL} \text { or } \\
1 / 25^{\mathrm{th}} \text { of the derived } \\
\text { concentration guide for } \mathrm{DOE} \\
\text { Order } 5400.5 \text {. }^{\mathrm{b}}\end{array}$ & $\begin{array}{l}\text { 3. RESRAD modeling indicates that } \\
\text { the alpha emitting COCs will not } \\
\text { impact groundwater. Therefore, } \\
\text { the alpha activity is } 0 \mathrm{pCi} / \mathrm{L} \text { for } \\
\text { all years. }\end{array}$ & N/A & $\mathrm{h}$ \\
\hline & $\begin{array}{l}\text { 4. Meet total uranium standard of } \\
21.2 \mathrm{pCi} / \mathrm{L} \text {. }\end{array}$ & $\begin{array}{l}\text { 4. Isotopic uranium } \\
\text { concentrations are below } \\
\text { background. }\end{array}$ & N/A & e \\
\hline
\end{tabular}


CVP-2007-00001

Rev. 0

\section{Table ES-1. Summary of Cleanup Verification Results for the 118-F-1 Burial Ground. (2 pages)}

\begin{tabular}{|c|c|c|c|c|}
\hline $\begin{array}{c}\text { Regulatory } \\
\text { Requirement }\end{array}$ & Remedial Action Goals & Results & $\begin{array}{l}\text { Remedial } \\
\text { Action } \\
\text { Objectives } \\
\text { Attained? }\end{array}$ & Ref. \\
\hline $\begin{array}{l}\text { Groundwater/River } \\
\text { Protection - } \\
\text { Nonradionuclides }\end{array}$ & $\begin{array}{l}\text { Attain individual nonradionuclide } \\
\text { groundwater and river cleanup } \\
\text { requirements. }\end{array}$ & $\begin{array}{l}\text { 1. Residual concentrations of lead } \\
\text { exceeded soil RAGs for the } \\
\text { protection of groundwater and/or } \\
\text { the Columbia River. However, it } \\
\text { is predicted that lead will not } \\
\text { migrate to groundwater (and thus } \\
\text { the Columbia River) at } \\
\text { concentrations exceeding } \\
\text { groundwater or river criteria } \\
\text { within } 1,000 \text { years. }{ }^{d} \text { Therefore, } \\
\text { residual concentrations achieve } \\
\text { the remedial action objectives for } \\
\text { groundwater and river protection. }\end{array}$ & Yes & e \\
\hline $\begin{array}{l}\text { Other Supporting } \\
\text { Information }\end{array}$ & \multicolumn{3}{|c|}{ 1. Sample location design calculation brief (Appendix B). } & $\mathrm{i}$ \\
\hline
\end{tabular}

a "National Primary Drinking Water Regulations" (40 Code of Federal Regulations 141).

b Radiation Protection of the Public and the Environment (DOE Order 5400.5).

c Based on the isotopic distribution of uranium in the Hanford Site background, the $30 \mu \mathrm{g} / \mathrm{L}$ MCL (40 CFR 141) corresponds to 21.2 $\mathrm{pCi} / \mathrm{L}$. Concentration-to-activity calculations are documented in Calculation of Total Uranium Activity Corresponding to a Maximum Contaminant Level for Total Uranium of 30 Micrograms per Liter in Groundwater, 0100X-CA-V0038 (BHI 2001).

d 100 Area Analogous Sites RESRAD Calculations, 0100X-CA-V0050, Rev. 0, Bechtel Hanford, Inc., Richland, Washington (2005).

- 118-F-1 Burial Ground Cleanup Verification RESRAD Calculation Brief, 0100F-CA-V0280, Rev. 0, Washington Closure Hanford, Richland, Washington (2007).

f 118-F-1 Burial Ground Cleanup Verification 95\% UCL Calculations, 0100F-CA-V0279, Rev. 1, Washington Closure Hanford, Richland, Washington (2007).

g 118-F-1 Burial Ground Hazard Quotient and Carcinogenic Risk Calculations, 0100F-CA-V0283, Rev. 0, Washington Closure Hanford, Richland, Washington (2007).

h 118-F-1 Burial Ground Comparison to Drinking Water Standards (MCL) Calculation, 0100F-CA-V0281, Rev. 0, Washington Closure Hanford, Richland, Washington (2007).

i 118-F-1 Burial Ground Shallow Zone, Process Trenches, and Overburden Sample Design, 0100F-CA-V0282, Rev. 0, Washington Closure Hanford, Richland, Washington (2007).

$\mathrm{COC}=$ contaminant of concern

$\mathrm{MCL}=$ maximum contaminant level

RAG = remedial action goal

$\mathrm{N} / \mathrm{A}=$ not applicable

RESRAD = RESidual RADioactivity (dose model) 


\section{Attachment ES-1}

\section{Waste Site Reclassification Form}

\begin{tabular}{|c|c|c|}
\hline \multirow[b]{2}{*}{ Date Submitted: $10 / 08 / 07$} & WASTE SITE RECLASSIFICATION FORM & \multirow{5}{*}{ Control Number: $2007-019$} \\
\hline & Operable Unit(s): $\quad 100-F R-2$ & \\
\hline Originator: L.M. Dittmer & Waste Site Code: $\quad 118-\mathrm{F}-1$ & \\
\hline \multirow[t]{2}{*}{ Phone: $\quad 372-9227$} & Type of Reclassification Action: & \\
\hline & $\begin{array}{l}\text { Closed Out } \square \quad \text { Interim Closed Out } \otimes \text { No Action } \square \\
\text { RCRA Postclosure } \square \quad \text { Rejected } \square \quad \text { Consolidated } \square\end{array}$ & \\
\hline
\end{tabular}

This form documents agreement among parties listed authorizing classification of the subject unit as Closed Out, Interim Closed Out, No Action, RCRA Postclosure, Rejected, or Consolidated. This form also authorizes backfill of the waste management unit, if appropriate, for Closed Out and Interim Closed Out units. Final removal from the NPL of No Action and Closed Out waste management units will occur at a future date.

\section{Description of current waste site condition:}

Remedial action at this site has been performed in accordance with remedial action objectives and goals established by the U.S. Environmental Protection Agency and the Washington State Department of Ecology, in concurrence with the U.S. Department of Energy, Richland Operations Office. The selected remedial action involves (1) excavating the site to the extent required to meet specified soil cleanup levels, (2) disposing of contaminated excavation materials at the Environmental Restoration Disposal Facility at the 200 Area of the Hanford Site, and (3) backfilling the site with clean soil to adjacent grade elevations. The excavation and disposal activities have been completed.

\section{Basis for reclassification:}

In accordance with this evaluation, the verification sampling results support a reclassification of this site to Interim Closed Out. The current site conditions achieve the remedial action objectives and the corresponding remedial action goals established in the Record of Decision for the 100-BC-1, 100-BC-2, 100-DR-1, 100-DR-2, 100-FR-2, 100-HR-2, and 100-KR-2 Operable Units, Hanford Site (100 Area Burial Grounds), Benton County, Washington, U. S. Environmental Protection Agency, Region 10, Seattle, Washington. The results of verification sampling show that residual contaminant concentrations do not preclude any future uses (as bounded by the rural-residential scenario) and allow for unrestricted use of shallow zone soils (i.e., surface to $4.6 \mathrm{~m}[15 \mathrm{ft}]$ deep). The results also demonstrate that residual contaminant concentrations are protective of groundwater and the Columbia River. The 118-F-1 excavation area has a maximum depth of approximately $5.5 \mathrm{~m}$ (18 ft), which includes a shallow zone and a deep zone. However, the entire excavation area is considered one decision unit, and is closed out using the more restrictive shallow zone cleanup criteria; therefore, institutional controls to prevent uncontrolled drilling or excavation into the deep zone are not required. The basis for reclassification is described in detail in the Cleanup Verification Package for the 118-F-1 Burial Ground (CVP 2007-00001), Washington Closure Hanford, Richland, Washington.

Waste Site Controls:

Engineered Controls: Yes $\square$ No $\square \quad$ Institutional Controls: Yes $\square$ No $\square \quad$ O\&M requirements: Yes $\square$ No $\square$ If any of the Waste Site Controls are checked Yes specify control requirements including reference to the Record of Decision, TSD Closure Letter, or other relevant documents.

S. L. Charboneau

DOE Federal Project Director (printed)

N/A

Ecology Project Manager (printed)

R. A. Lobos

EPA Project Manager (printed)
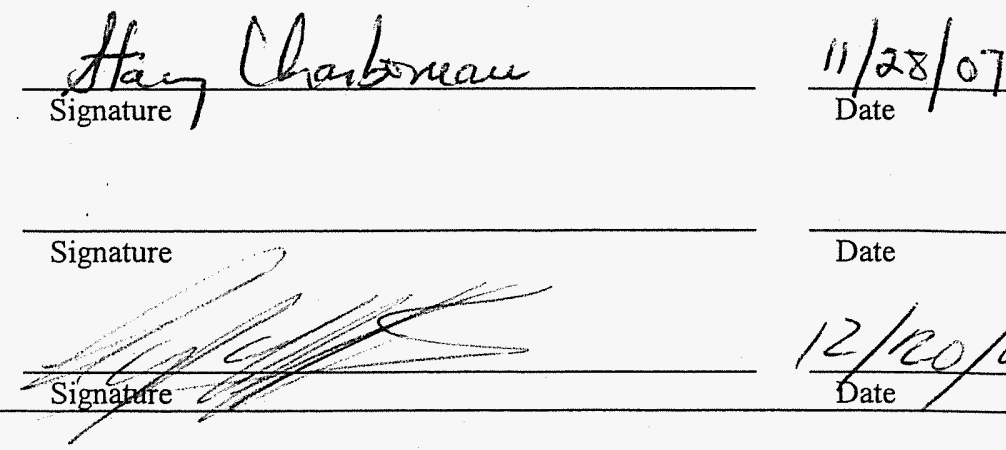
CVP-2007-00001

Rev. 0

ES-6 


\section{CONTENTS}

1.0 STATEMENT OF PROTECTIVENESS ...................................................... 1

2.0 BACKGROUND AND GENERAL SITE INFORMATION ................................ 1

2.1 GENERAL SITE INFORMATION.................................................. 1

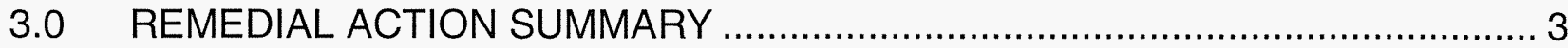

3.1 EXCAVATION AND DISPOSAL …............................................. 3

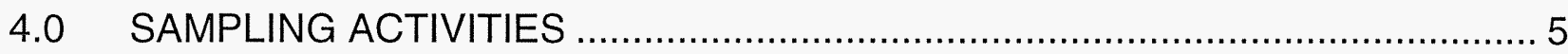

4.1 CONTAMINANTS OF CONCERN FOR VERIFICATION SAMPLING .......5

4.2 VERIFICATION SAMPLING DESIGN …….................................. 5 4.2.1 Decision Unit Sampling ......................................................... 5

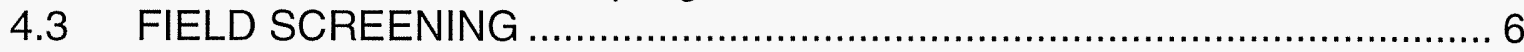

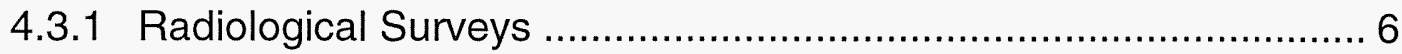

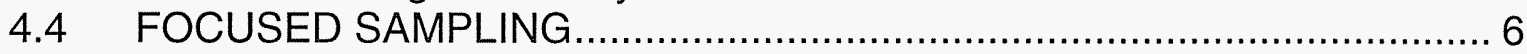

4.5 VERIFICATION SAMPLING ......................................................... 7

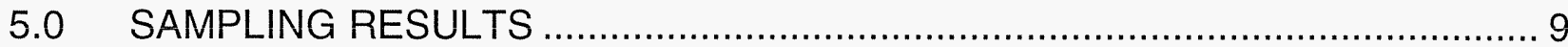

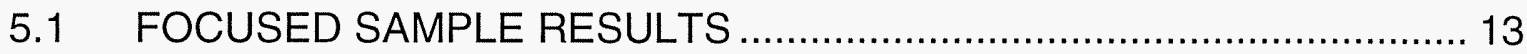

5.2 DATA QUALITY ASSESSMENT PROCESS ...................................... 14

6.0 CLEANUP VERIFICATION DATA EVALUATION ....................................... 14

6.1 DIRECT EXPOSURE SOIL REMEDIAL ACTION GOALS ATTAINED.... 14

6.2 GROUNDWATER AND COLUMBIA RIVER REMEDIAL ACTION GOALS ATTAINED..................................................................... 18

6.3 WAC 173-340 THREE-PART TEST FOR NONRADIONUCLIDES ......... 20

6.4 COMPARISON OF SAMPLE DATA TO ECO-SCREENING LEVELS..... 21

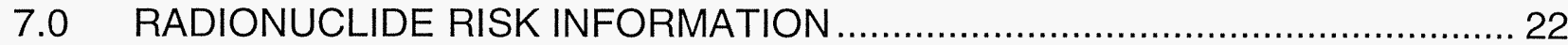

8.0 SUMMARY FOR WASTE SITE RECLASSIFICATION ................................ 23

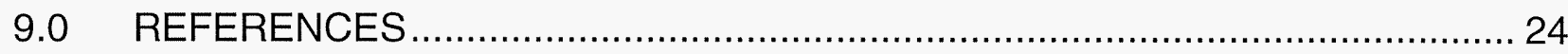

\section{APPENDICES}

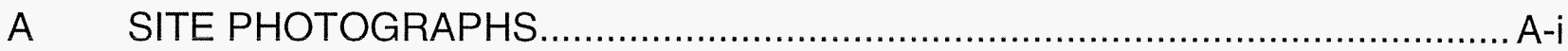

B RESRAD INPUT PARAMETERS \& CALC BRIEF EXCERPTS ....................... B-i

B1 118-F-1 Burial Ground Shallow Zone, Process Trenches, and Overburden Sample Design, 0100F-CA-V0282, Rev. 0.

B2 118-F-1 Burial Ground Hazard Quotient and Carcinogenic Risk Calculations, 0100F-CA-V0283, Rev. 0.

B3 118-F-1 Burial Ground Cleanup Verification 95\% UCL Calculations, 0100F-CA-V0279, Rev. 1

B4 118-F-1 Burial Ground Comparison to Drinking Water Standards (MCL) Calculation, 0100F-CA-V0281, Rev. 0.

B5 118-F-1 Burial Ground Cleanup Verification RESRAD Calculation Brief, 0100F-CA-V0280, Rev. 0 


\section{FIGURES}

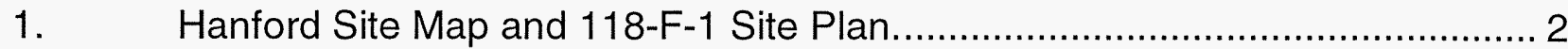

2. 118-F-1 Burial Ground Post-Excavation Boundary Map................................. 4

3. 118-F-1 Focused Sampling Locations for Remediation Footprint..................... 8

4. RESRAD Analysis for the Remediation Footprint- All Radionuclides, All-Pathways Dose Rate Estimate............................................................. 15

5. RESRAD Analysis for the Overburden/BCL soil- All Radionuclides, ............ 16

6. RESRAD Analysis for the Waste Sorting Trenches- All Radionuclides, All-Pathways Dose Rate Estimate......................................................... 17

7. Dose Rate to Organs from Groundwater.................................................. 19

8. RESRAD Analysis - Radionuclide Risk, All Pathways Remediation Footprint. .............................................................................. 22

9. RESRAD Analysis - Radionuclide Risk, All Pathways Waste Sorting Trenches......................................................................... 23

10. RESRAD Analysis - Radionuclide Risk, All Pathways Overburden/BCL. 23

\section{TABLES}

1. Number of Verification Samples for the 118-F-1 Burial Ground. ..................... 6

2. 118-F-1 Focused Samples. ...................................................................... 7

3. Comparison of Statistical Contaminant Concentrations to Action Levels for the 118-F-1 Excavation Shallow Zone Verification Sampling.................... 9

4. Comparison of Statistical Contaminant Concentrations to Action Levels for the 118-F-1 Waste Sorting Trench Shallow Zone Verification Sampling... 11

5. Comparison of Statistical Contaminant Concentrations to Action Levels for the 118-F-1 Overburden-Below Cleanup Level Verification Sampling. ..... 12 6. Comparison of Maximum Contaminant Concentrations to Action Levels for the 118-F-1 Focused Verification Sampling Event.

7. Estimated Peak Radionuclide Groundwater Concentrations in the Soils for $118-\mathrm{F}-1$

8. Summary of the WAC 173-340 Three-Part Test for the 118-F-1 Burial Ground 


\section{ACRONYMS AND ABBREVIATIONS}

$\begin{array}{ll}\text { BCL } & \text { below cleanup level } \\ \text { COC } & \text { contaminant of concern } \\ \text { COPC } & \text { contaminant of potential concern } \\ \text { CVP } & \text { Cleanup Verification Package } \\ \text { DOE-RL } & \text { U.S. Department of Energy, Richland Operations Office } \\ \text { DQA } & \text { data quality assessment } \\ \text { ENRE } & \text { ENvironmental REstoration database } \\ \text { EPA } & \text { U.S. Environmental Protection Agency } \\ \text { ERDF } & \text { Environmental Restoration Disposal Facility } \\ \text { GPERS } & \text { Global Positioning Environmental Radiological Surveyor } \\ \text { HEIS } & \text { Hanford Environmental Information System } \\ \text { PAH } & \text { polycyclic aromatic hydrocarbon } \\ \text { RAG } & \text { remedial action goal } \\ \text { RDR/RAWP } & \text { remedial design report/remedial action work plan } \\ \text { RESRAD } & \text { RESidual RADioactivity dose assessment model } \\ \text { ROD } & \text { record of decision } \\ \text { SAP } & \text { sampling and analysis plan } \\ \text { SSNF } & \text { suspect spent nuclear fuel } \\ \text { TPH } & \text { total petroleum hydrocarbons } \\ \text { UCL } & \text { upper confidence limit } \\ \text { VOA } & \text { volatile organic analysis } \\ \text { WAC } & \text { Washington Administrative Code }\end{array}$


CVP-2007-00001

Rev. 0 


\subsection{STATEMENT OF PROTECTIVENESS}

This report demonstrates that the 118-F-1 waste site meets the objectives for interim closure as established in the Remedial Design Report/Remedial Action Work Plan for the 100 Area (RDR/RAWP) (DOE-RL 2005) and the Record of Decision for the 100-BC-1, 100-BC-2, 100-DR-1, 100-DR-2, 100-FR-2, 100-HR-2, and 100-KR-2 Operable Units, Hanford Site (100 Area Burial Grounds), Benton County, Washington (ROD) (EPA 2000). The results of verification sampling show that residual contaminant concentrations do not preclude any future uses (as bounded by the rural-residential scenario) and allow for unrestricted use of shallow zone soils (i.e., surface to $4.6 \mathrm{~m}$ [15 ft] deep). The results also demonstrate that residual contaminant concentrations are protective of groundwater and the Columbia River.

\subsection{BACKGROUND AND GENERAL SITE INFORMATION}

The purpose of this cleanup verification package is to document that the 118-F-1 Solid Waste Burial Ground site was remediated in accordance with the ROD (EPA 2000). Remedial action objectives and goals for the 118-F-1 site were established by the U.S. Environmental Protection Agency (EPA) and the U.S. Department of Energy, Richland Operations Office (DOE-RL), in concurrence with the Washington State Department of Ecology. These goals and objectives are documented in the ROD (EPA 2000) and the Remedial Design Report/Remedial Action Work Plan for the 100 Area (RDR/RAWP) (DOE-RL 2005). The ROD (EPA 2000) provides the U.S. Department of Energy, Richland Operations Office, the authority, guidance, and objectives to conduct this remedial action.

The preferred remedy specified in the ROD (EPA 2000) and conducted for the $118-\mathrm{F}-1$ site included (1) excavating the site to the extent required to meet specified soil cleanup levels, (2) disposing of contaminated excavation materials at the Environmental Restoration Disposal Facility (ERDF) at the 200 Area of the Hanford Site, and (3) backfilling the site with overburden and clean soil to the average adjacent grade elevation. Excavation was driven by remedial action objectives for direct exposure, protection of groundwater, and protection of the Columbia River.

\subsection{GENERAL SITE INFORMATION}

The 118-F-1 site is located in the 100-FR-2 Operable Unit of the 100-F Area approximately $300 \mathrm{~m}$ (1000 ft) southwest of the 105-F Reactor Building (Figure 1). The 118-F-1 Burial Ground is a combination of two locations formerly called Minor Construction Burial Ground No. 2 and Solid Waste Burial Ground No. 2. This waste site received radioactive equipment and other miscellaneous waste from 105-F Reactor operations. According to the Waste Information Database System (WIDS), the burial ground was used between 1954 and 1965 and contained three unlined burial trenches 
Figure 1. Hanford Site Map and 118-F-1 Site Plan.

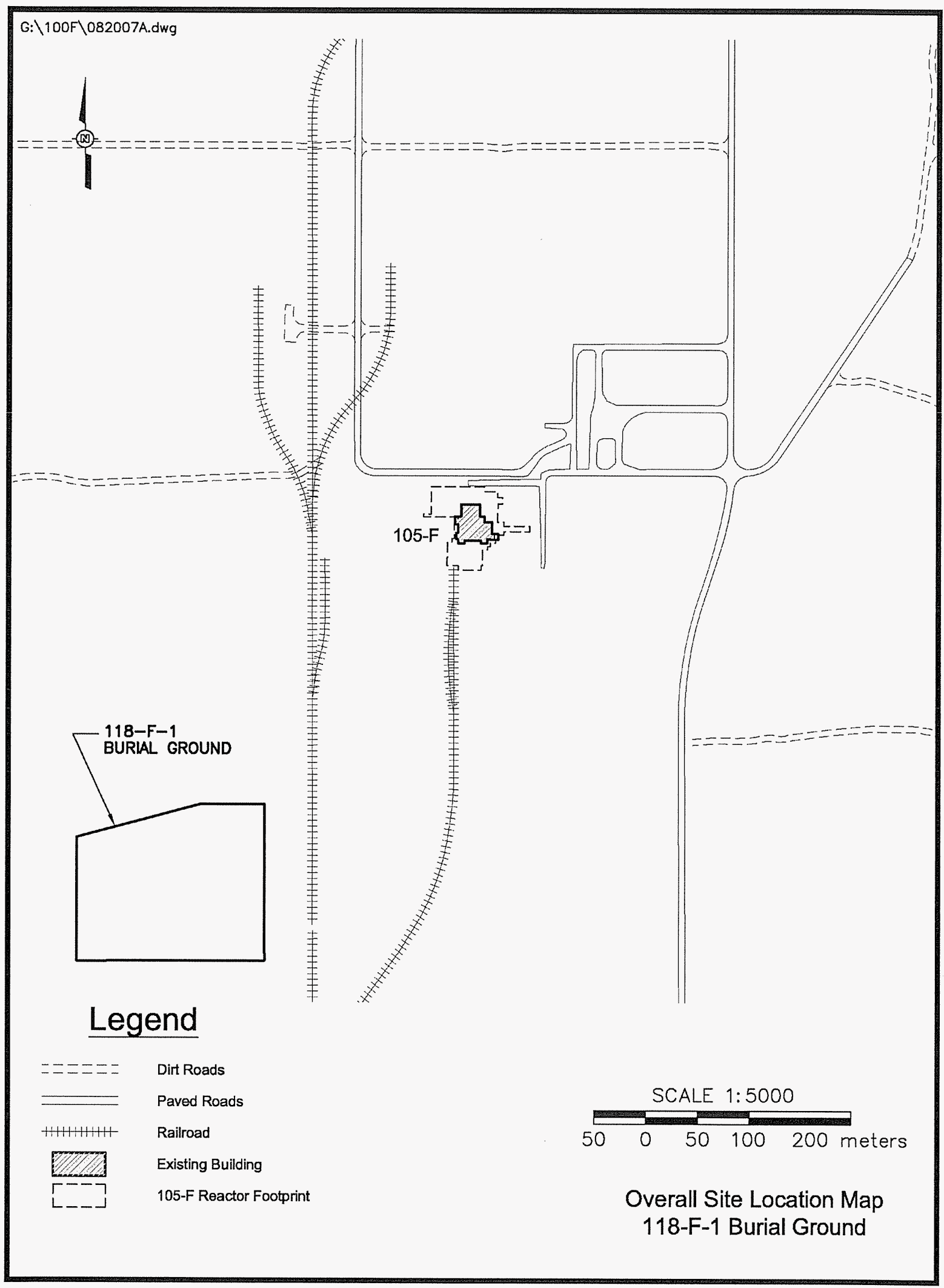


and a burial pit. A geophysical investigation was conducted at the 118-F-1 Burial Ground in 2002, with results indicating that the footprint of buried debris was less than what was indicated in WIDS (BHI 2002a). Test pitting was conducted to augment the geophysical data and provide a more conclusive data set regarding the boundaries of the buried debris. The test pitting activities were conducted in representative areas where the geophysical investigation did not detect buried debris or potential trench boundaries. The excavations confirmed these areas do not contain debris (BHI 2002b).

Wastes buried at this site included: dummy elements and irradiated process tubing; gun barrel tips, steel sleeves, and metal chips removed from the reactor; filter boxes containing reactor graphite chips; and miscellaneous construction solid waste.

\subsection{REMEDIAL ACTION SUMMARY}

\subsection{EXCAVATION AND DISPOSAL}

Remedial action at the 118-F-1 site began on December 27, 2005. Removal of the uncontaminated overburden was completed on January 6, 2006. On August 7, 2006, excavation and sorting of contaminated material from the areas within the three trenches and burial pit indicated within the footprint of buried debris, per the geophysical investigation (BHI 2002a), was initiated. Contaminated material was placed in trenches west of the burial ground excavation areas for waste sorting. All contaminated materials were disposed at ERDF. Suspect Spent Nuclear Fuel (SSNF) was discovered during the waste debris sorting operation, and eight pieces of SSNF are to be dispositioned. All remedial activities (excavation, sorting, and load-out) were completed on June 22, 2007. Approximately 88,800 metric tons $(97,900$ U.S. tons) of waste and contaminated soil from the 118-F-1 Burial Ground was disposed of at ERDF and approximately 13,400 bank cubic meters (BCMs) of soil (overburden/below contaminant level [BCL] stockpile material) was segregated for use as clean backfill material. The post-remediation boundary map is shown in Figure 2. At the conclusion of excavation activities, the

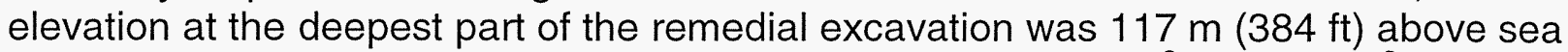
level. The remediation excavation was approximately $11,600 \mathrm{~m}^{2}\left(125,000 \mathrm{ft}^{2}\right)$ in area with a maximum depth of approximately $5.5 \mathrm{~m}(18 \mathrm{ft})$.

Wastes encountered in the 118-F-1 Burial Ground included reactor related waste including aluminum fuel spacers, splines, reactor hardware, equipment, piping, graphite dust, sheet metal, concrete, cardboard, wood timbers, other miscellaneous debris, and SSNF. Photographs of waste excavated from the 118-F-1 Burial Ground are provided in Appendix A. 
Figure 2. 118-F-1 Burial Ground Post-Excavation Boundary Map.

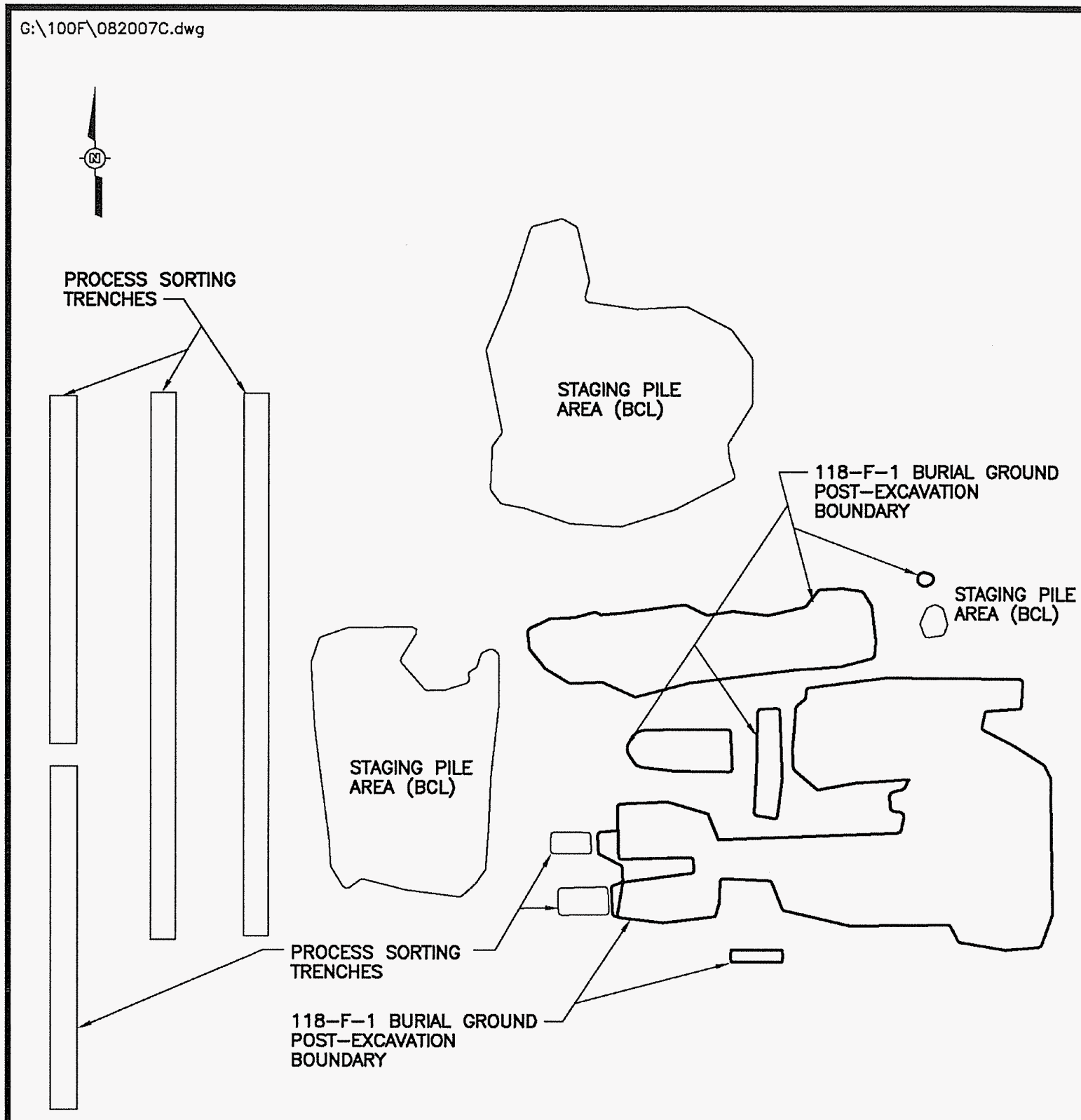

SCALE 1:2000

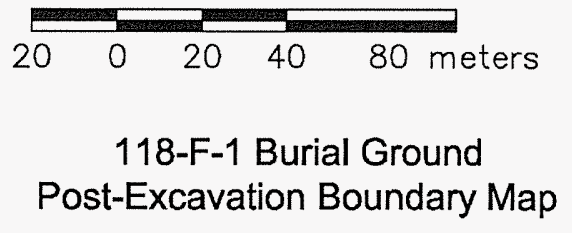




\subsection{SAMPLING ACTIVITIES}

\subsection{CONTAMINANTS OF CONCERN FOR VERIFICATION SAMPLING}

The 100 Area Burial Grounds Remedial Action Sampling and Analysis Plan (SAP) (DOE-RL 2001) identified contaminants of concern (COCs) (Table A-1, page A-21) for the 118-F-1 Burial Ground include tritium (H-3), carbon-14, cobalt-60, nickel-63, strontium-90, silver-108m, cesium-137, europium-152, europium-154, cadmium, lead, and mercury. In addition, because SSNF was encountered in the 118-F-1 Burial Ground, americium-241, plutonium-238, plutonium-239, plutonium-240, and uranium238 were added to the list of COCs for the site.

During excavation, in-process samples were collected as necessary and analyzed for the identified COCs and for a wide range of metals, semi-volatile organic compounds, polychlorinated biphenyls, pesticides, gamma energy emitting isotopes, gross alpha radiation, and gross beta radiation. Based on the results of this sampling, no additional COCs beyond those listed above have been identified for the burial ground. The COCs/contaminants of potential concern (COPCs) detected at the 118-F-1 Burial Ground and their respective points of compliance, and the remedial action goals (RAGs), are summarized in Tables 3 through 5 (Section 5.0) of this Cleanup Verification Package.

\subsection{VERIFICATION SAMPLING DESIGN}

This section describes the basis for selection of an appropriate sample design and the determination of the number of verification samples to collect at the 118-F-1 Burial Ground.

\subsubsection{Decision Unit Sampling}

The sample strategy for the 118-F-1 Burial Ground is identified in the Burial Ground SAP (DOE-RL 2001) and specifies the site to be divided into decision units (e.g., shallow zone and deep zone) based on the size of the site. The SAP also specifies the number of verification samples to collect in each decision unit. The division of the site into decision units is also a function of the applicable RAGs. The direct exposure, groundwater protection, and river protection RAGs are applicable to soils within $4.6 \mathrm{~m}$ $(15 \mathrm{ft})$ of the ground surface. This soil zone is referred to as the shallow zone. The groundwater protection and river protection RAGs are applicable to soils greater than

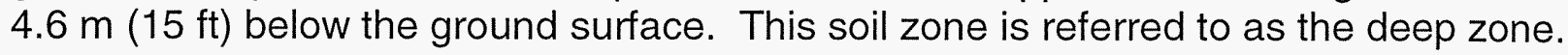

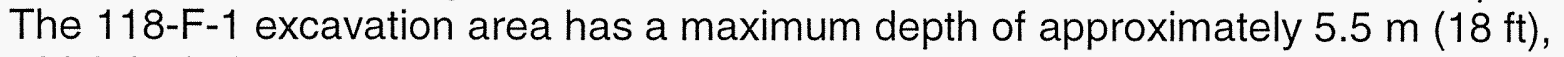
which includes a shallow zone and a deep zone. However, the entire excavation area is considered one decision unit, and will be closed out using the more restrictive shallow zone cleanup criteria.

The 118-F-1 Burial Ground contains three decision units as follows: (1) shallow zone excavation decision unit, which includes the nine trench excavations and area between them, (2) overburden/BCL stockpile, which combines three overburden stockpile areas 
into one decision unit, and (3) staging pile (labeled process or waste sorting trenches in remediation and sampling documentation) that includes the area where the waste was staged prior to removal for disposal. The calculation of the number of verification samples to collect in each of the decision units is four composite samples. This calculation, and the sample locations, is located in the sample design calculation in Appendix $B$. All of these decision units will be closed out using the more restrictive shallow zone cleanup criteria.

Table 1. Number of Verification Samples for the 118-F-1 Burial Ground.

\begin{tabular}{|l|c|c|c|c|}
\hline \multicolumn{1}{|c|}{$\begin{array}{c}\text { Decision } \\
\text { Unit }\end{array}$} & $\begin{array}{c}\text { Waste Site } \\
\text { Footprint }\left(\mathrm{ft}^{2}\right)\end{array}$ & $\begin{array}{c}\text { Size Classification } \\
\left(\mathrm{ft}^{2}\right)\end{array}$ & $\begin{array}{c}\text { Decision } \\
\text { Subunits }\end{array}$ & $\begin{array}{c}\text { Verification } \\
\text { Samples }\end{array}$ \\
\hline Excavation Shallow Zone & 125,000 & $\begin{array}{c}\text { Medium } \\
(>100,000 \text { to } \\
400,000)\end{array}$ & 4 & 17 composite \\
\hline Overburden/BCL pile & 117,500 & $\begin{array}{c}\text { Medium } \\
(>100,000 \text { to } \\
400,000)\end{array}$ & 4 & 16 composite \\
\hline Waste Sorting Trenches & 58,500 & Small $(<100,000)$ & 1 & 5 composite \\
\hline
\end{tabular}

$\mathrm{BCL}=$ below cleanup level

\subsection{FIELD SCREENING}

\subsubsection{Radiological Surveys}

Radiological field screening was conducted during the site remedial actions as specified in the SAP (DOE-RL 2001). The field screening campaign was used to guide the excavation to quickly assess the presence and level of radiological contamination. Field screening at the site included radiological mapping over more than $50 \%$ of the site excavation and waste sorting trench surface area using a Global Positioning Environmental Radiological Surveyor (GPERS) with instrumentation specific to the detection of radiation associated with gamma emitting radionuclides. Any radiological "hot spots" identified as requiring additional remediation were targeted and soil (containing scattered metal debris) was removed until the radiation was no longer detected at the location. These areas were resurveyed to confirm that waste site excavation was complete. The GPERS surveys are provided in Figures C1-C26 of Appendix C. The overburden/BCL material was surveyed for radioactivity using GPERS throughout the remedial process, as shown in Figures C27-C29 of Appendix C. No contamination was identified for the overburden/BCL material.

\subsection{FOCUSED SAMPLING}

Focused samples are collected to verify the absence of contamination in residual soil beneath locations exhibiting visual stains, locations of buried liquid wastes or equipment, mercury-containing piping, or large inventories of dangerous/hazardous 
wastes (e.g., lead bricks). Additionally, focused samples may be collected from locations where process knowledge indicates the potential for elevated concentrations of alpha or beta contamination, or where waste characterization sampling results indicate elevated concentrations of chemical contaminants above the RAGs.

Three areas of the 118-F-1 Burial Ground excavation were identified with anomalous or distinctive type waste forms. These include a steel canister of radiologically contaminated graphite chips or dust that appeared to be from reactor core boring operations. A photograph of the canister is provided in Appendix A. The canister was approximately $4 \mathrm{ft}$ in diameter and approximately $6 \mathrm{ft}$ long and was likely a vacuum canister used to remove waste graphite during reactor core boring operations. The canister was open at one end. The other two areas noted were excavated asbestos concrete siding or roofing (transite) materials. Transite volumes in each area were relatively low. Approximately one ERDF container of asbestos transite material was removed from each location.

Three focused samples associated with the graphite chips/dust area were analyzed for carbon-14 and tritium $(\mathrm{H}-3)$. Analyte selection was based on in-process characterization data of the graphite waste. The six focused samples associated with the asbestos material were analyzed for asbestos. Focused sample locations are shown on Figure 3.

Table 2. 118-F-1 Focused Samples.

\begin{tabular}{|c|l|l|l|}
\hline $\begin{array}{c}\text { Focused } \\
\text { Sample }\end{array}$ & Location & \multicolumn{1}{|c|}{ Associated Anomaly } & \multicolumn{1}{|c|}{ COCs } \\
\hline FS-1 & Area A2 & Asbestos concrete siding or roofing (transite) & Asbestos \\
\hline FS-2 & Area A2 & Asbestos concrete siding or roofing (transite) & Asbestos \\
\hline FS-3 & Area A2 & Asbestos concrete siding or roofing (transite) & Asbestos \\
\hline FS-4 & Area C10 & Open canister with graphite chips or dust & Carbon-14, tritium \\
\hline FS-5 & Area C10 & Open canister with graphite chips or dust & Carbon-14, tritium \\
\hline FS-6 & Area C10 & Open canister with graphite chips or dust & Carbon-14, tritium \\
\hline FS-7 & Area D4 & Asbestos concrete siding or roofing (transite) & Asbestos \\
\hline FS-8 & Area D4 & Asbestos concrete siding or roofing (transite) & Asbestos \\
\hline FS-9 & Area D4 & Asbestos concrete siding or roofing (transite) & Asbestos \\
\hline
\end{tabular}

\subsection{VERIFICATION SAMPLING}

Final cleanup verification samples were collected in May 2007 and June 2007 to confirm acceptability of residual contaminant concentrations in the soil at the 118-F-1 waste site. Each verification sample was a composite formed by combining soil collected at four randomly selected nodes within each of the sampling decision subunits. The verification samples were submitted to offsite laboratories for analysis using approved EPA 
Figure 3. 118-F-1 Focused Sampling Locations for Remediation Footprint. $G: \backslash 100 F \backslash 082007 D . d w g$

1

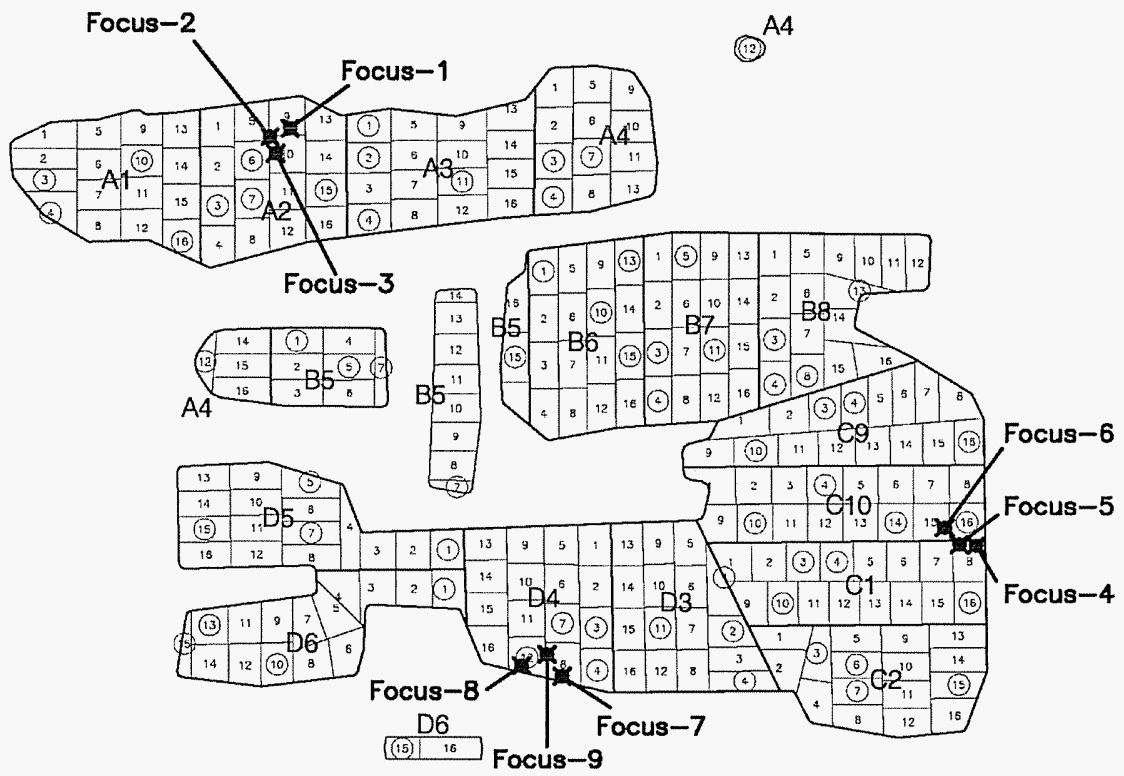

Legend

$15015 \quad 30 \quad 60$ meters
118-F-1 Burial Ground
Shallow Zone Focus Sample
Location Map


analytical methods, as required per the SAP (DOE-RL 2001). The sample design methodology and sample location figures are presented in the calculation brief for verification sample design in Appendix B. An aerial photograph of the 118-F-1 Burial Ground, post-excavation, is presented in Appendix A.

\subsection{SAMPLING RESULTS}

Verification samples were analyzed using U.S. EPA-approved analytical methods. The 95\% upper confidence limit on the true population mean for residual concentrations of COCs and COPCs was calculated for the excavation area as specified by the RDR/RAWP (DOE-RL 2005), with calculations provided in Appendix B. When a nonradionuclide COC or COPC was detected in fewer than $50 \%$ of the verification samples collected, the maximum detected value was used for comparison against the RAGs. If no detections for a given COC/COPC were reported in the data set, then no statistical evaluation or calculations were performed for that COC/COPC.

Comparisons of the statistical and maximum results for COCs and COPCs with the site RAGs for the excavation area, waste sorting trenches, and overburden/BCL piles are summarized in Tables 3 through 5, respectively. Contaminants that were not detected by laboratory analysis are excluded from these tables. Calculated cleanup levels are not presented in the Cleanup Levels and Risk Calculations Database (Ecology 2005) under Washington Administrative Code (WAC) 173-340-740(3) for aluminum, calcium, iron, magnesium, potassium, silicon, and sodium; therefore, these constituents are not considered site COPCs. The laboratory-reported data results for all constituents are stored in the Environmental Restoration (ENRE) project-specific database prior to archival in Hanford Environmental Information System (HEIS) and are presented in Appendix B.

Table 3. Comparison of Statistical Contaminant Concentrations to Action Levels for the 118-F-1 Excavation Shallow Zone Verification Sampling. (2 Pages)

\begin{tabular}{|c|c|c|c|c|c|c|}
\hline \multirow[b]{2}{*}{ COC/COPC } & \multirow[b]{2}{*}{$\begin{array}{l}\text { Statistical } \\
\text { Result } \\
\text { (pCi/g) }\end{array}$} & \multicolumn{3}{|c|}{ 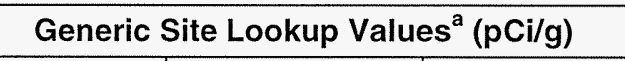 } & \multirow{2}{*}{$\begin{array}{l}\text { Does the } \\
\text { Statistical } \\
\text { Result } \\
\text { Exceed } \\
\text { Lookup } \\
\text { Values? }\end{array}$} & \multirow{2}{*}{$\begin{array}{l}\text { Does the } \\
\text { Statistical } \\
\text { Result Pass } \\
\text { RESRAD } \\
\text { Modeling? }\end{array}$} \\
\hline & & $\begin{array}{c}\text { Shallow } \\
\text { Zone } \\
\text { Lookup } \\
\text { Value }^{b}\end{array}$ & $\begin{array}{l}\text { Groundwater } \\
\text { Protection } \\
\text { Lookup Value }\end{array}$ & $\begin{array}{c}\text { River } \\
\text { Protection } \\
\text { Lookup } \\
\text { Value }\end{array}$ & & \\
\hline Americium-241 & 0.063 & 31.1 & $--^{c}$ & $--^{c}$ & No & \multirow[t]{7}{*}{$Y_{e s}^{e}$} \\
\hline Carbon-14 & 0.83 & 5.16 & $--^{c}$ & $--^{c}$ & No & \\
\hline Cesium-137 & 0.21 & 6.2 & $1,465^{d}$ & $1,465^{d}$ & No & \\
\hline Cobalt-60 & 0.038 & 1.4 & $13,900^{d}$ & $13,900^{d}$ & No & \\
\hline Europium-152 & 0.054 & 3.3 & $--^{c}$ & $-c^{c}$ & No & \\
\hline Europium-154 & 0.053 & 3.0 & $--^{c}$ & $--^{c}$ & No & \\
\hline Nickel-63 & 2.3 & $83^{d}$ & $83^{d}$ & $83^{d}$ & No & \\
\hline
\end{tabular}


Table 3. Comparison of Statistical Contaminant Concentrations to Action Levels for the 118-F-1 Excavation Shallow Zone Verification Sampling. (2 Pages)

\begin{tabular}{|c|c|c|c|c|c|c|}
\hline \multirow[b]{2}{*}{$\mathrm{COC} / \mathrm{COPC}$} & \multirow[b]{2}{*}{$\begin{array}{l}\text { Statistical } \\
\text { Result } \\
\text { (pCi/g) }\end{array}$} & \multicolumn{3}{|c|}{ Generic Site Lookup Values ${ }^{a}(\mathrm{pCi} / \mathrm{g})$} & \multirow{2}{*}{$\begin{array}{l}\text { Does the } \\
\text { Statistical } \\
\text { Result } \\
\text { Exceed } \\
\text { Lookup } \\
\text { Values? }\end{array}$} & \multirow{3}{*}{$\begin{array}{l}\text { Does the } \\
\text { Statistical } \\
\text { Result Pass } \\
\text { RESRAD } \\
\text { Modeling? }\end{array}$} \\
\hline & & $\begin{array}{l}\text { Shallow } \\
\text { Zone } \\
\text { Lookup } \\
\text { Value }^{b}\end{array}$ & $\begin{array}{l}\text { Groundwater } \\
\text { Protection } \\
\text { Lookup Value }\end{array}$ & $\begin{array}{l}\text { River } \\
\text { Protection } \\
\text { Lookup } \\
\text { Value }\end{array}$ & & \\
\hline Plutonium-238 & 0.028 & 37.4 & $--^{c}$ & $--^{c}$ & No & \\
\hline Plutonium-239/240 & 0.11 & 33.9 & $--^{c}$ & $--^{c}$ & No & \multirow{5}{*}{ Yes $^{e}$} \\
\hline Silver-108m & 0.017 & 2.38 & $--^{c}$ & $--^{c}$ & No & \\
\hline Strontium-90 & 0.38 & 4.5 & $27.6^{\mathrm{d}}$ & $27.6^{d}$ & No & \\
\hline Tritium & 1.4 & 15.8 & 15.8 & 15.8 & No & \\
\hline Uranium-238 & $0.0(<B G)$ & $1.1^{f}$ & $1.1^{f}$ & $1.1^{f}$ & No & \\
\hline \multirow[b]{2}{*}{$\mathrm{COC} / \mathrm{COPC}$} & \multirow[b]{2}{*}{$\begin{array}{c}\text { Statistical } \\
\text { Result } \\
(\mathrm{mg} / \mathrm{kg})\end{array}$} & \multicolumn{3}{|c|}{ Remedial Action Goals ${ }^{\mathrm{a}}$ (mg/kg) } & \multirow[b]{2}{*}{$\begin{array}{l}\text { Does the } \\
\text { Statistical } \\
\text { Data Set } \\
\text { Exceed } \\
\text { RAGs? }\end{array}$} & \multirow[b]{2}{*}{$\begin{array}{c}\text { Does the } \\
\text { Statistical } \\
\text { Result Pass } \\
\text { RESRAD } \\
\text { Modeling? }\end{array}$} \\
\hline & & $\begin{array}{c}\text { Direct } \\
\text { Exposure }\end{array}$ & $\begin{array}{l}\text { Soil Cleanup } \\
\text { Level for } \\
\text { Groundwater } \\
\text { Protection }\end{array}$ & $\begin{array}{l}\text { Soil } \\
\text { Cleanup } \\
\text { Level for } \\
\text { River } \\
\text { Protection }\end{array}$ & & \\
\hline Cadmium & 0.10 & $13.9^{9}$ & $0.81^{h}$ & $0.81^{\mathrm{h}}$ & No & -- \\
\hline Lead & 5.4 & $353^{i}$ & $10.2^{h}$ & $10.2^{h}$ & No & -- \\
\hline Mercury & 0.0076 & $24^{j}$ & $0.33^{h}$ & $0.33^{h}$ & No & -- \\
\hline
\end{tabular}

a Lookup values and remedial action goals (RAGs) obtained from the 100 Area Remedial Action Sampling and Analysis Plan (RDR/RAWP) (DOE-RL 2005) or calculated per Washington Administrative Code (WAC) 173-340-720, 730, and 740, Method B, 1996, unless otherwise noted.

b Activity corresponding to a single-radionuclide $15 \mathrm{mrem} / \mathrm{yr}$ exposure as calculated using a generic RESidual RADioactivity (RESRAD) model (DOE-RL 2005).

c No value-RESRAD modeling predicts the contaminant will not reach groundwater within 1,000 years.

d Revised lookup value per 100 Area Radionuclide and Nonradionuclide Lookup Values for the 1995 Interim Remedial Action Record of Decision (BHI 2004).

e 118-F-1 Burial Ground Cleanup Verification RESRAD Calculation Brief (Appendix B).

$f$ The calculated lookup value is below the Hanford-specific statistical soil background activity. The value presented is the Hanfordspecific statistical soil background activity (DOE-RL 1996).

g Carcinogenic cleanup level calculated based on the inhalation exposure pathway per WAC 173-340-750[3], 1996 (Method B for air quality) and an airborne particulate mass loading rate of $0.0001 \mathrm{~g} / \mathrm{m}^{3}$ (WDOH 1997).

$\mathrm{h}$ Where cleanup levels are less than background, cleanup levels default to background or required detection limits per Ecology 1996, WAC 173-340-700(4)(d) and WAC 173-340-707(2), respectively.

Use EPA, 1994, Guidance Manual for the Integrated Exposure Uptake Biokinetic Model for Lead in Children, EPA/540/R-93/081, Publication No. 9285.7, U.S. Environmental Protection Agency, Washington, D.C.

i Remedial action goal established in the 100 Area Remedial Design Report/Remedial Action Work Plan.

- $\quad$ = not applicable

BG = background (obtained from DOE-RL [1996] and DOE-RL [2001], unless otherwise noted)

$\mathrm{COC}=$ contaminant of concern

$\mathrm{COPC}=$ contaminant of potential concern

RAG = remedial action goal

RESRAD = RESidual RADioactivity (dose-assessment model) 
Table 4. Comparison of Statistical Contaminant Concentrations to Action Levels for the 118-F-1 Waste Sorting Trench Shallow Zone Verification Sampling). (2 Pages)

\begin{tabular}{|c|c|c|c|c|c|c|}
\hline \multirow[b]{2}{*}{ COC/COPC } & \multirow[b]{2}{*}{$\begin{array}{l}\text { Statistical } \\
\text { Result } \\
(\mathrm{pCi} / \mathrm{g})\end{array}$} & \multicolumn{3}{|c|}{ 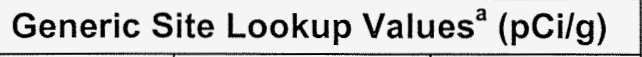 } & \multirow{2}{*}{$\begin{array}{l}\text { Does the } \\
\text { Statistical } \\
\text { Result } \\
\text { Exceed } \\
\text { Lookup } \\
\text { Values? }\end{array}$} & \multirow[b]{2}{*}{$\begin{array}{c}\text { Does the } \\
\text { Statistical } \\
\text { Result Pass } \\
\text { RESRAD } \\
\text { Modeling? }\end{array}$} \\
\hline & & $\begin{array}{l}\text { Shallow } \\
\text { Zone } \\
\text { Lookup } \\
\text { Value }^{b}\end{array}$ & $\begin{array}{c}\text { Groundwater } \\
\text { Protection } \\
\text { Lookup } \\
\text { Value }\end{array}$ & $\begin{array}{l}\text { River } \\
\text { Protection } \\
\text { Lookup } \\
\text { Value }\end{array}$ & & \\
\hline Americium-241 & 0.089 & 31.1 & $--^{c}$ & $--^{c}$ & No & \multirow{13}{*}{ Yes $^{c}$} \\
\hline Carbon-14 & 0.32 & 5.16 & $--^{c}$ & $--^{c}$ & No & \\
\hline Cesium-137 & 0.45 & 6.2 & $1,465^{\mathrm{d}}$ & $1,465^{\mathrm{d}}$ & No & \\
\hline Cobalt-60 & 0.074 & 1.4 & $13,900^{d}$ & $13,900^{d}$ & No & \\
\hline Europium-152 & 0.14 & 3.3 & $-{ }^{c}$ & $--^{c}$ & No & \\
\hline Europium-154 & 0.063 & 3.0 & $--^{c}$ & $--^{c}$ & No & \\
\hline Nickel-63 & 4.4 & $83^{d}$ & $83^{d}$ & $83^{d}$ & No & \\
\hline Plutonium-238 & 0.10 & 37.4 & $--^{c}$ & $\ldots{ }^{c}$ & No & \\
\hline Plutonium-239/240 & 0.13 & 33.9 & $--^{c}$ & $--^{c}$ & No & \\
\hline Silver-108m & 0.013 & 2.38 & $--^{c}$ & $--^{c}$ & No & \\
\hline Strontium-90 & 0.22 & 4.5 & $27.6^{d}$ & $27.6^{d}$ & No & \\
\hline Tritium & 2.0 & 15.8 & 15.8 & 15.8 & No & \\
\hline Uranium-238 & $0.0(<\mathrm{BG})$ & $1.1^{e}$ & $1.1^{\mathrm{e}}$ & $1.1^{\mathrm{e}}$ & No & \\
\hline \multirow[b]{2}{*}{ COC/COPC } & \multirow[b]{2}{*}{$\begin{array}{c}\text { Statistical } \\
\text { Result } \\
(\mathrm{mg} / \mathrm{kg})\end{array}$} & \multicolumn{3}{|c|}{ Remedial Action Goals ${ }^{\mathrm{a}}$ (mg/kg) } & \multirow[b]{2}{*}{$\begin{array}{l}\text { Does the } \\
\text { Statistical } \\
\text { Data Set } \\
\text { Exceed } \\
\text { RAGs? }\end{array}$} & \multirow[b]{2}{*}{$\begin{array}{l}\text { Does the } \\
\text { Statistical } \\
\text { Result Pass } \\
\text { RESRAD } \\
\text { Modeling? }\end{array}$} \\
\hline & & $\begin{array}{c}\text { Direct } \\
\text { Exposure }\end{array}$ & $\begin{array}{l}\text { Soil Cleanup } \\
\text { Level for } \\
\text { Groundwater } \\
\text { Protection }\end{array}$ & $\begin{array}{l}\text { Soil } \\
\text { Cleanup } \\
\text { Level for } \\
\text { River } \\
\text { Protection }\end{array}$ & & \\
\hline Cadmium & 0.10 & $13.9^{f}$ & $0.81^{9}$ & $0.81^{g}$ & No & -- \\
\hline Lead & 18 & $353^{h}$ & $10.2^{g}$ & $10.2^{g}$ & Yes & Yes $^{k}$ \\
\hline Mercury & 0.020 & $24^{i}$ & $0.33^{9}$ & $0.33^{g}$ & No & -- \\
\hline
\end{tabular}

a Lookup values and remedial action goals (RAGs) obtained from the 100 Area Remedial Action Sampling and Analysis Plan (RDR/RAWP) (DOE-RL 2005) or calculated per Washington Administrative Code (WAC) 173-340-720, 730, and 740, Method B, 1996, unless otherwise noted.

b Activity corresponding to a single-radionuclide $15 \mathrm{mrem} / \mathrm{yr}$ exposure as calculated using a generic RESidual RADioactivity (RESRAD) model (DOE-RL 2005).

c No value--RESRAD modeling predicts the contaminant will not reach groundwater within 1,000 years.

d Revised lookup value per 100 Area Radionuclide and Nonradionuclide Lookup Values for the 1995 Interim Remedial Action Record of Decision (BHI 2004).

e 118-F-1 Burial Ground Cleanup Verification RESRAD Calculation Brief (Appendix B).

$f$ The calculated lookup value is below the Hanford-specific statistical soil background activity. The value presented is the Hanfordspecific statistical soil background activity (DOE-RL 1996).

9 Carcinogenic cleanup level calculated based on the inhalation exposure pathway per WAC 173-340-750[3], 1996 (Method B for air quality) and an airborne particulate mass loading rate of $0.0001 \mathrm{~g} / \mathrm{m}^{3}$ (WDOH 1997).

h Where cleanup levels are less than background, cleanup levels default to background or required detection limits per Ecology 1996 WAC 173-340-700(4)(d) and WAC 173-340-707(2), respectively.

i Use EPA, 1994, Guidance Manual for the Integrated Exposure Uptake Biokinetic Model for Lead in Children, EPA/540/R-93/081, Publication No. 9285.7, U.S. Environmental Protection Agency, Washington, D.C.

i Remedial action goal established in the 100 Area Remedial Design Report/Remedial Action Work Plan.

k Based on the 100 Area Analogous Sites RESRAD Calculations (BHI 2005), residual concentrations are not expected to migrate more than $2 \mathrm{~m}(6.6 \mathrm{ft}$ ) vertically in 1,000 years (based on the lowest soil-partitioning distribution coefficient [lead] of $30 \mathrm{~mL} / \mathrm{g}$ ). The vadose

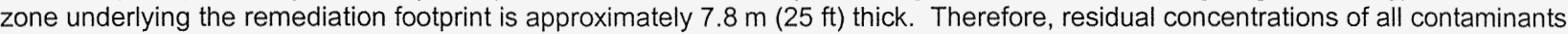
are predicted to be protective of groundwater and the Columbia River.

- $\quad$ not applicable 
Table 4. Comparison of Statistical Contaminant Concentrations to Action Levels for the 118-F-1 Waste Sorting Trench Shallow Zone Verification Sampling). (2 Pages)

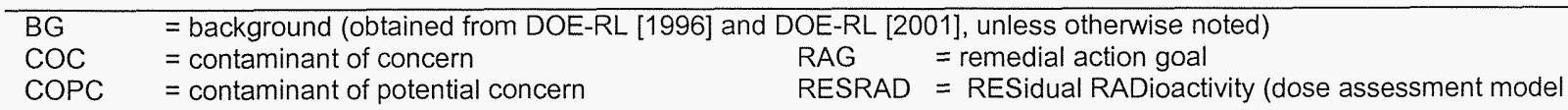

Table 5. Comparison of Statistical Contaminant Concentrations to Action Levels for the 118-F-1 Overburden-Below Cleanup Level Verification Sampling. (2 Pages)

\begin{tabular}{|c|c|c|c|c|c|c|}
\hline \multirow[b]{2}{*}{ COC/COPC } & \multirow[b]{2}{*}{$\begin{array}{l}\text { Statistical } \\
\text { Result } \\
\text { (pCi/g) }\end{array}$} & \multicolumn{3}{|c|}{ 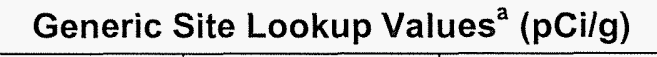 } & \multirow{2}{*}{$\begin{array}{c}\text { Does the } \\
\text { Statistical } \\
\text { Result } \\
\text { Exceed } \\
\text { Lookup } \\
\text { Values? }\end{array}$} & \multirow{2}{*}{$\begin{array}{c}\text { Does the } \\
\text { Statistical } \\
\text { Result } \\
\text { Pass } \\
\text { RESRAD } \\
\text { Modeling? }\end{array}$} \\
\hline & & $\begin{array}{l}\text { Shallow } \\
\text { Zone } \\
\text { Lookup } \\
\text { Value }^{b}\end{array}$ & $\begin{array}{l}\text { Groundwater } \\
\text { Protection } \\
\text { Lookup } \\
\text { Value }\end{array}$ & $\begin{array}{c}\text { River } \\
\text { Protection } \\
\text { Lookup } \\
\text { Value }\end{array}$ & & \\
\hline Americium-241 & 0.23 & 31.1 & $--^{c}$ & $--^{c}$ & No & \multirow{12}{*}{$\mathrm{Yes}^{\mathrm{e}}$} \\
\hline Cesium-137 & $0.0(<B G)$ & 5.16 & $--^{c}$ & $--^{c}$ & No & \\
\hline Cobalt-60 & 0.0075 & 6.2 & $1,465^{d}$ & $1,465^{\mathrm{d}}$ & No & \\
\hline Europium-152 & 0.041 & 1.4 & 13,900 & 13,900 & No & \\
\hline Europium-154 & 0.018 & 3.3 & $-^{c}$ & $--^{c}$ & No & \\
\hline Nickel-63 & 2.5 & 3.0 & $--^{c}$ & $--^{c}$ & No & \\
\hline Plutonium-238 & 0.16 & $83^{d}$ & $83^{d}$ & $83^{d}$ & No & \\
\hline Plutonium-239/240 & 0.13 & 37.4 & $--^{c}$ & $--^{c}$ & No & \\
\hline Silver-108m & 0.011 & 33.9 & $--^{c}$ & $-^{c}$ & No & \\
\hline Strontium-90 & $0.0(<B G)$ & 4.5 & $27.6^{\mathrm{d}}$ & $27.6^{\mathrm{d}}$ & No & \\
\hline Tritium & 2.5 & 15.8 & 15.8 & 15.8 & No & \\
\hline Uranium-238 & $0.0(<B G)$ & 15.8 & 15.8 & 15.8 & No & \\
\hline \multirow[b]{2}{*}{ COC/COPC } & \multirow[b]{2}{*}{$\begin{array}{c}\text { Statistical } \\
\text { Result } \\
(\mathrm{mg} / \mathrm{kg})\end{array}$} & \multicolumn{3}{|c|}{ Remedial Action Goals ${ }^{a}$ (mg/kg) } & \multirow[b]{2}{*}{$\begin{array}{l}\text { Does the } \\
\text { Statistical } \\
\text { Data Set } \\
\text { Exceed } \\
\text { RAGs? }\end{array}$} & \multirow[b]{2}{*}{$\begin{array}{c}\text { Does the } \\
\text { Statistical } \\
\text { Result } \\
\text { Pass } \\
\text { RESRAD } \\
\text { Modeling? }\end{array}$} \\
\hline & & $\begin{array}{c}\text { Direct } \\
\text { Exposure }\end{array}$ & $\begin{array}{l}\text { Soil Cleanup } \\
\text { Level for } \\
\text { Groundwater } \\
\text { Protection }\end{array}$ & $\begin{array}{l}\text { Soil } \\
\text { Cleanup } \\
\text { Level for } \\
\text { River } \\
\text { Protection }\end{array}$ & & \\
\hline Cadmium & 0.0 & $13.9^{f}$ & $0.81^{\mathrm{g}}$ & $0.81^{\mathrm{g}}$ & No & -- \\
\hline Lead & 12 & $353^{h}$ & $10.2^{g}$ & $10.2^{g}$ & Yes & Yes $^{j}$ \\
\hline Mercury & 0.0076 & $24^{i}$ & $0.33^{9}$ & $0.33^{9}$ & No & -- \\
\hline
\end{tabular}

a Lookup values and remedial action goals (RAGs) obtained from the 100 Area Remedial Action Sampling and Analysis Plan (RDR/RAWP) (DOE-RL 2005) or calculated per Washington Administrative Code (WAC) 173-340-720, 173-340-730, and 173-340-740, Method B, 1996, unless otherwise noted.

b Activity corresponding to a single-radionuclide $15 \mathrm{mrem} / \mathrm{yr}$ exposure as calculated using a generic RESidual RADioactivity (RESRAD) model (DOE-RL 2005).

c No value-RESRAD modeling predicts the contaminant will not reach groundwater within 1,000 years.

d Revised lookup value per 100 Area Radionuclide and Nonradionuclide Lookup Values for the 1995 Interim Remedial Action Record of Decision (BHI 2004).

e 118-F-1 Burial Ground Cleanup Verification RESRAD Calculation Brief (Appendix B).

f Carcinogenic cleanup level calculated based on the inhalation exposure pathway per WAC 173-340-750[3], 1996 (Method B for air quality) and an airborne particulate mass loading rate of $0.0001 \mathrm{~g} / \mathrm{m}^{3}$ (WDOH 1997).

9 Where cleanup levels are less than background, cleanup levels default to background or required detection limits per Ecology 1996 , WAC 173-340-700(4)(d) and WAC 173-340-707(2), respectively.

h Use EPA, 1994, Guidance Manual for the Integrated Exposure Uptake Biokinetic Model for Lead in Children, EPA/540/R-93/081, Publication No. 9285.7, U.S. Environmental Protection Agency, Washington, D.C. 
Table 5. Comparison of Statistical Contaminant Concentrations to Action Levels for the 118-F-1 Overburden-Below Cleanup Level Verification Sampling. (2 Pages)

\footnotetext{
Remedial action goal established in the 100 Area Remedial Design Report/Remedial Action Work Plan.

Based on the 100 Area Analogous Sites RESRAD Calculations (BHI 2005), residual concentrations are not expected to migrate more than $2 \mathrm{~m}$ ( $6.6 \mathrm{ft}$ ) vertically in 1,000 years (based on the lowest soil-partitioning distribution coefficient [lead] of $30 \mathrm{~mL} / \mathrm{g}$ ). The vadose

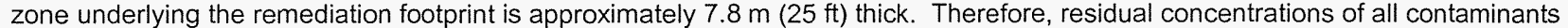
are predicted to be protective of groundwater and the Columbia River.

- $\quad$ not applicable

BG = background (obtained from DOE-RL [1996] and DOE-RL [2001], unless otherwise noted)

$\mathrm{COC}=$ contaminant of concern $\mathrm{RAG}=$ remedial action goal

COPC = contaminant of potential concern RESRAD = RESidual RADioactivity (dose-assessment model)
}

\subsection{FOCUSED SAMPLE RESULTS}

Nine focused samples were collected from the 118-F-1 waste site. The sample locations are shown in Figure 3. Six of the focused samples were of suspect asbestoscontaining material. The asbestos sample results were reported as either less than $1 \%$ or none detected.

The three remaining focused samples were collected of soil underlying anomalous media found within the trenches during the remedial excavations. Statistical analysis (e.g., calculation of a $95 \% \mathrm{UCL}$ value) is inappropriate to use for evaluation of focused samples; therefore, the sample results for each focused sample are evaluated using the maximum detected activity for each $\mathrm{COC} / \mathrm{COPC}$ and comparing the value directly to the cleanup level. Table 6 provides a comparison of the maximum result of the three focused samples against the cleanup criteria. Individual sample results are provided in Appendix B.

Table 6. Comparison of Maximum Contaminant Concentrations to Action Levels for the 118-F-1 Focused Verification Sampling Event. (2 Pages)

\begin{tabular}{|c|c|c|c|c|c|c|}
\hline \multirow[b]{2}{*}{ COC/COPC } & \multirow[b]{2}{*}{$\begin{array}{c}\text { Maximum } \\
\text { Result } \\
(\mathrm{pCi} / \mathrm{g})\end{array}$} & \multicolumn{3}{|c|}{ Generic Site Lookup Values $^{\mathrm{a}}(\mathrm{pCi} / \mathrm{g})$} & \multirow{2}{*}{$\begin{array}{l}\text { Does the } \\
\text { Statistical } \\
\text { Result } \\
\text { Exceed } \\
\text { Lookup } \\
\text { Values? }\end{array}$} & \multirow{2}{*}{$\begin{array}{c}\text { Does the } \\
\text { Statistical } \\
\text { Result } \\
\text { Pass } \\
\text { RESRAD } \\
\text { Modeling? }\end{array}$} \\
\hline & & $\begin{array}{l}\text { Shallow } \\
\text { Zone } \\
\text { Lookup } \\
\text { Value }^{6}\end{array}$ & $\begin{array}{c}\text { Groundwater } \\
\text { Protection } \\
\text { Lookup } \\
\text { Value }\end{array}$ & $\begin{array}{l}\text { River } \\
\text { Protection } \\
\text { Lookup } \\
\text { Value }\end{array}$ & & \\
\hline Carbon-14 & 1.67 (ND) & 5.16 & $-c^{c}$ & $--^{c}$ & No & \multirow[t]{2}{*}{$Y_{e s}^{d}$} \\
\hline Tritium & 0.541 (ND) & 15.8 & 15.8 & 15.8 & No & \\
\hline
\end{tabular}


Table 6. Comparison of Maximum Contaminant Concentrations to Action Levels for the 118-F-1 Focused Verification Sampling Event. (2 Pages)

\footnotetext{
a Lookup values and remedial action goals (RAGs) obtained from the 100 Area Remedial Action Sampling and Analysis Plan (RDR/RAWP) (DOE-RL 2005) or calculated per Washington Administrative Code (WAC) 173-340-720, 173-340-730, and 173-340-740, Method B, 1996, unless otherwise noted.

b Noncarcinogenic cleanup level calculated from WAC 173-340-740(3), 1996 (Method B for soils) (as presented in the RDR/RAWP [DOE-RL 2005]). Updated oral reference dose values (as provided in the Integrated Risk Information System [IRIS]) yield Method B direct exposure RAG values of $16,000 \mathrm{mg} / \mathrm{kg}$ and $120,000 \mathrm{mg} / \mathrm{kg}$ for barium and chromium, respectively.

c No value-RESRAD modeling predicts the contaminant will not reach groundwater within 1,000 years.

d 118-F-1 Burial Ground Cleanup Verification RESRAD Calculation Brief (Appendix B).

-- $\quad=$ not applicable

BG = background (obtained from DOE-RL [1996] and DOE-RL [2001], unless otherwise noted)

$\mathrm{COC}=$ contaminant of concern

$\mathrm{COPC}=$ contaminant of potential concern

ND $\quad=$ not detected

RESRAD = RESidual RADioactivity (dose-assessment model)
}

\subsection{DATA QUALITY ASSESSMENT PROCESS}

A data quality assessment (DQA) is performed to compare the verification sampling approach, the field logbooks (WCH 2007a, b), and resulting analytical data with the sampling and data quality requirements specified by the project objectives and performance specifications.

The DQA for the 118-F-1 site established that the data are of the right type, quality, and quantity to support site verification decisions within specified error tolerances. All analytical data were found to be acceptable for decision-making purposes. The evaluation verified that the sample design was sufficient for the purpose of clean site verification. The cleanup verification sample analytical data are stored in the ENRE project-specific database for data evaluation prior to its archival in the HEIS and are summarized in Appendix B. The detailed DQA is presented in Appendix D.

\subsection{CLEANUP VERIFICATION DATA EVALUATION}

This section demonstrates that remedial actions at the 118-F-1 site have achieved the applicable RAGs. Sections 5.4 and 5.5 address attainment of direct exposure RAGs and groundwater and Columbia River protection RAGs, respectively. Section 5.6 summarizes the results of the WAC 173-340 three-part test performed in the 95\% UCL calculation brief (Appendix B). This test is required for nonradionuclide COCs only and is based on the most restrictive RAG (defined as the lowest of the direct exposure, groundwater protection, and river protection RAGs).

\subsection{DIRECT EXPOSURE SOIL REMEDIAL ACTION GOALS ATTAINED}

\subsubsection{Radionuclides}

The individual radionuclide cleanup verification statistical values (Tables 3 through 5 ) were entered into the RESRAD computer code, Version 6.30 (ANL 2005), to estimate the dose rate and the impact on groundwater and the river from residual $\mathrm{COC}$ 
concentrations. Separate RESRAD runs were performed for the excavation area, the overburden/BCL decision unit, and the waste sorting trenches.

The results of the 118-F-1 RESRAD dose rate estimates for the all-pathways scenarios for the excavation area, the overburden/BCL, and the waste sorting trenches are shown in Figures 4 through 6 . These dose rates represent the dose contributions from soils at relevant time periods. The 2018 date corresponds to the 30 -year site cleanup schedule of the Hanford Federal Facility Agreement and Consent Order (Ecology et al. 1989). All dose rate estimates are less than the $15 \mathrm{mrem} / \mathrm{yr}$ RAG. The RESRAD computations are shown in detail in the calculation briefs presented in Appendix B.

6.1.1.1 118-F-1 Remediation Footprint. The estimated maximum total all-pathways dose rate from the 118-F-1 Burial Ground remediation footprint is $4.59 \mathrm{mrem} / \mathrm{yr}$ at year zero (2007) and decreases to $4.73 \times 10^{-2} \mathrm{mrem} / \mathrm{yr}$ in 1,000 years (Figure 4). The estimated dose rate in the year 2018 is $1.95 \mathrm{mrem} / \mathrm{yr}$. The all-pathways dose rate estimate remains below the direct exposure RAG.

Figure 4. RESRAD Analysis for the Remediation Footprint- All Radionuclides, All-Pathways Dose Rate Estimate.

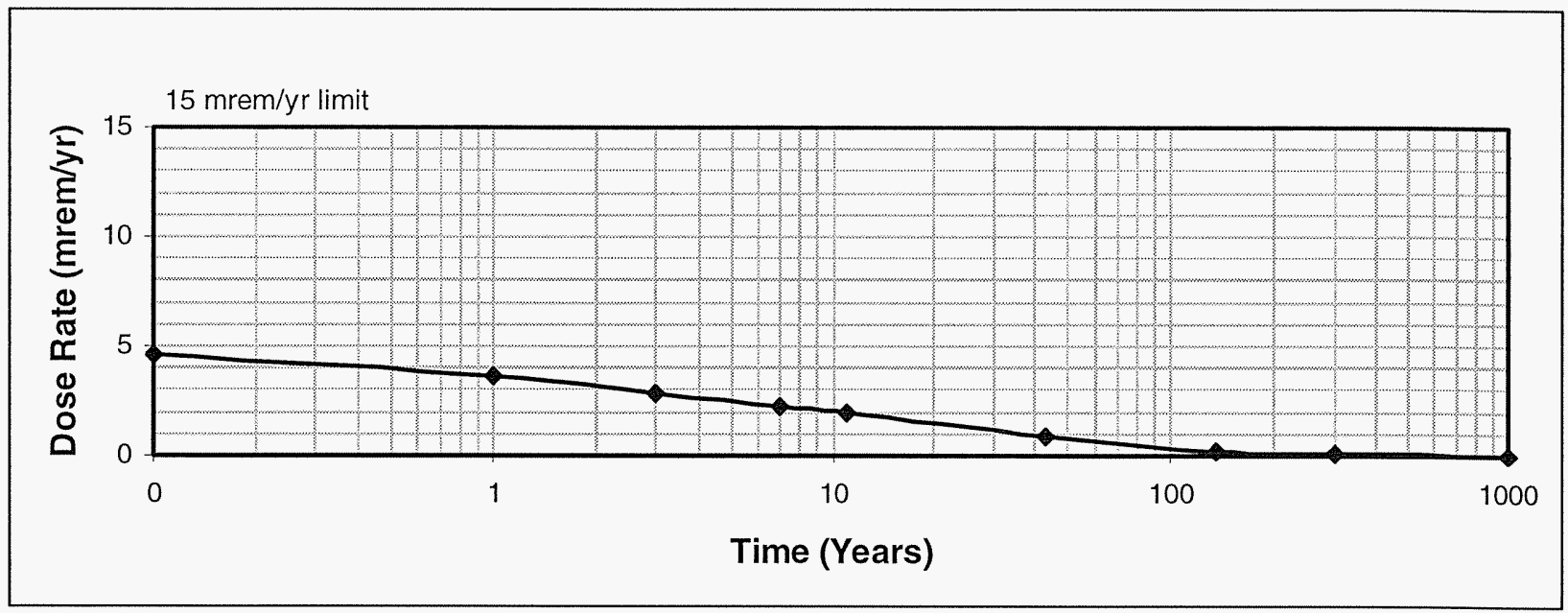

6.1.1.2 118-F-1 Overburden/BCL Soil. The estimated maximum total all-pathways dose rate from the 118-F-1 Burial Ground overburden/BCL soil is $4.23 \mathrm{mrem} / \mathrm{yr}$ at year zero (2007) and decreases to $7.36 \times 10^{-2} \mathrm{mrem} / \mathrm{yr}$ in 1,000 years (Figure 5). The estimated dose rate in the year 2018 is $4.69 \times 10^{-1} \mathrm{mrem} / \mathrm{yr}$. The all-pathways dose rate estimate remains below the direct exposure RAG. 
Figure 5. RESRAD Analysis for the Overburden/BCL soil- All Radionuclides, All-Pathways Dose Rate Estimate.

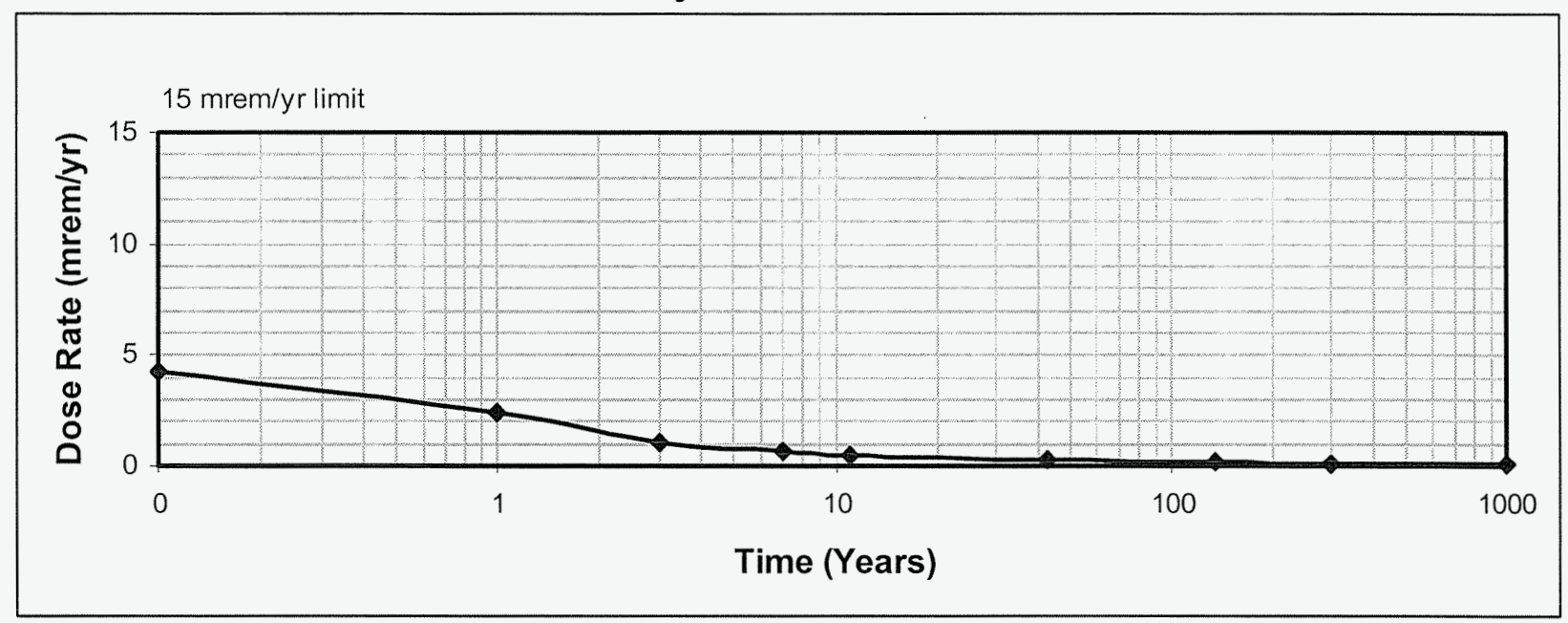

6.1.1.3 118-F-1 Waste Sorting Trenches. The estimated maximum total all-pathways dose rate from the 118-F-1 Burial Ground waste sorting trenches is $4.06 \mathrm{mrem} / \mathrm{yr}$ at year zero (2007) and decreases to $6.01 \times 10^{-2} \mathrm{mrem} / \mathrm{yr}$ in 1,000 years (Figure 6). The estimated dose rate in the year 2018 is $2.21 \mathrm{mrem} / \mathrm{yr}$. The all-pathways dose rate estimate remains below the direct exposure RAG.

Figure 6. RESRAD Analysis for the Waste Sorting Trenches- All Radionuclides, All-Pathways Dose Rate Estimate.

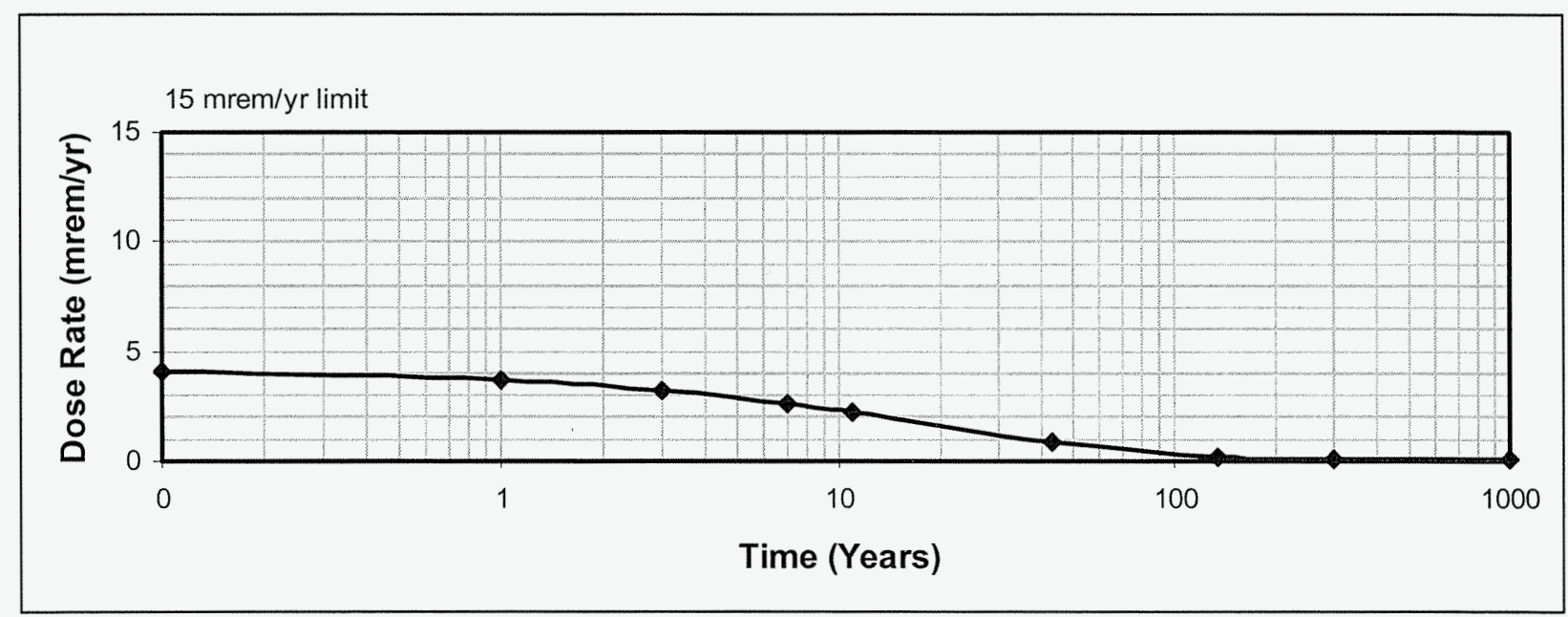

\subsubsection{Nonradionuclides}

6.1.2.1 Direct Comparison to RAGs. Tables 3 through 5 compare the cleanup verification statistical values to the direct exposure RAGs. All nonradionuclides are below the direct exposure cleanup criteria and, therefore, all applicable RAGs are met. 
6.1.2.2 Noncarcinogenic Hazard Quotient RAG Attained. For noncarcinogenic COCs, WAC 173-340-740(3)(a)(iii)(A) and (B) specify the evaluation of the hazard quotient which is given as a daily intake divided by a reference dose. Both individual and cumulative hazard quotient values must be less than 1.0. Hazard quotient calculations were performed for the 118-F-1 Burial Ground using the highest statistical value from all sampling areas.

The details and results of the hazard quotient calculations are provided in the hazard quotient and carcinogenic risk calculation brief (Appendix B). Results of the hazard quotient calculations show that all individual hazard quotients are less than one and the cumulative hazard quotient for the 118-F-1 waste site is $1.1 \times 10^{-1}$ (Appendix B). Therefore, the noncarcinogenic hazard quotient RAG has been attained for the 118-F-1 waste site.

6.1.2.3 Carcinogenic Risk RAG Attained. For individual nonradionuclide carcinogenic COCs, the WAC 173-340 Method B cleanup limits are based on an incremental cancer risk of $1 \times 10^{-6}$. For nonradionuclide carcinogenic COCs, the total excess cancer risk must be less than $1 \times 10^{-5}$. Carcinogenic risk calculations were performed for the 118-F-1 Burial Ground using the highest statistical value from all sampling areas for the nonradionuclide carcinogenic COCs. The details and results of the hazard quotient calculations are provided in the hazard quotient and carcinogenic risk calculation brief (Appendix B).

Results of the carcinogenic risk calculations show that all individual nonradionuclide carcinogenic COCs have an incremental cancer risk below $1 \times 10^{-6}$ (Appendix B). The calculated total excess cancer risk for the 118-F-1 waste site is zero, which is below the Remedial Action Objective (RAO) of $1 \times 10^{-5}$. The nonradionuclide carcinogenic risk RAG has been attained for the $118-\mathrm{F}-1$ waste site.

\subsection{GROUNDWATER AND COLUMBIA RIVER REMEDIAL ACTION GOALS ATTAINED}

\subsubsection{Radionuclides}

The estimated groundwater concentrations for all of the radionuclide COCs contributed by the site soils are shown in the RESRAD calculation brief (Appendix $B$ ). Among the radionuclide contaminants of concern, only cesium-137, cobalt-60, nickel-63, strontium-90, and tritium are calculated to reach groundwater (and, therefore, the Columbia River) in 1,000 years at concentrations significantly below the RAGs. Table 7 gives the total peak concentrations predicted for each radionuclide $\mathrm{COC}$ along with the individual RAGs for comparison. The peak concentration for each $\mathrm{COC}$ is the maximum value, as predicted by RESRAD modeling, from the sampling areas (i.e., remediation footprint, overburden/BCL, and waste sorting pile area). No COC concentration is predicted to exceed the RAGs; therefore, the groundwater and Columbia River protection RAOs are attained. 
Figure 7 shows the individual organ dose rate for beta- and gamma-emitting radionuclides predicted over 1,000 years as shown in the comparison to drinking water standards calculation brief (MCL calculation brief in Appendix B). The cumulative dose for each total body, bone, liver, and gastrointestinal tract for all beta- and gammaemitting COCs is less than the $4 \mathrm{mrem} / \mathrm{yr}$ standard over 1,000 years. Results of the RESRAD calculations are shown in the MCL calculation brief (Appendix B).

Non-uranium, alpha-emitting radionuclide COCs/COPCs were not detected in the verification soil samples and no uranium isotopes were detected above background levels in the verification soil samples. Therefore, the drinking water concentration standard for non-uranium alpha emitters and the uranium standard of $30 \mu \mathrm{g} / \mathrm{L}$ have been met.

Table 7. Estimated Peak Radionuclide Groundwater Concentrations in the Soils for 118-F-1.

\begin{tabular}{|l|c|c|c|}
\hline \multicolumn{1}{|c|}{ Radionuclide } & $\begin{array}{c}\text { Peak Concentration } \\
(\mathbf{p C i} / \mathbf{L})^{\mathrm{a}}\end{array}$ & $\begin{array}{c}\text { RAG } \\
(\mathrm{pCi} / \mathrm{L})\end{array}$ & $\begin{array}{c}\text { RAGs Attained? } \\
\text { (Yes/No) }\end{array}$ \\
\hline Cobalt-60 & 0.000531 & $100^{\mathrm{b}}$ & Yes \\
\hline Cesium-137 & 0.0184 & $60^{\mathrm{b}}$ & Yes \\
\hline Nickel-63 & 2.63 & $50^{\mathrm{b}}$ & Yes \\
\hline Strontium-90 & 0.11 & $8^{\mathrm{c}}$ & Yes \\
\hline Tritium & 1,800 & $20,000^{\mathrm{C}}$ & Yes \\
\hline
\end{tabular}

a The peak concentration is the maximum predicted value from the three sampling areas (remediation footprint, overburden/BCL, and waste sorting pile area). All results are presented in the $\mathrm{MCL}$ calculation brief (Appendix B).

${ }^{b}$ Lookup value corresponding to a dose rate of $4 \mathrm{mrem} / \mathrm{yr}$.

c EPA drinking water promulgated MCL (40 CFR 141.66).

CFR = Code of Federal Regulations

EPA = U.S. Environmental Protection Agency

$\mathrm{MCL} \quad=$ maximum cleanup level

RAG = remedial action goal 
Figure 7. Dose Rate to Organs from Groundwater.

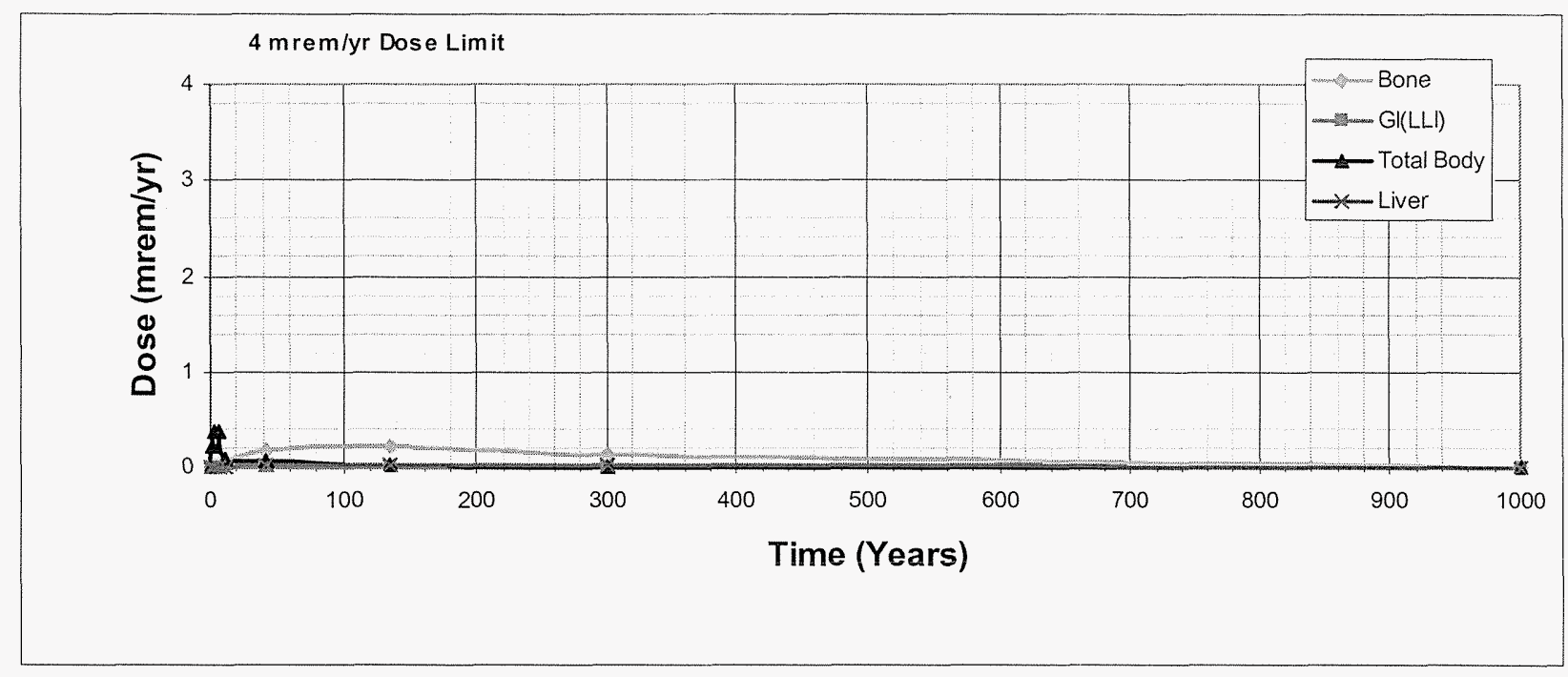

\subsubsection{Nonradionuclides}

Tables 3 through 5 compare the statistical verification results to the groundwater protection RAGs for all sampling areas. The tables show that the statistical results for lead exceed the soil RAGs for the protection of groundwater. The residual concentrations of lead, however, are not predicted to reach groundwater (and, therefore, the Columbia River) in 1,000 years based on the 100 Area Analogous Sites RESRAD Calculations (BHI 2005) and their contaminant-specific soil partitioning coefficient $\left(\mathrm{K}_{\mathrm{d}}\right)$ values. Given the soil-partitioning coefficients of lead $(30 \mathrm{~mL} / \mathrm{g})$ the results of RESRAD modeling (BHI 2005) indicate that these constituents will not migrate vertically more than $3 \mathrm{~m}(10 \mathrm{ft})$ in 1,000 years. The vadose zone underlying the $118-\mathrm{F}-1$ site is greater than $3 \mathrm{~m}(10 \mathrm{ft})$ thick and, as such, these contaminants will not reach groundwater (and, therefore, the Columbia River) in 1,000 years.

\subsection{WAC 173-340 THREE-PART TEST FOR NONRADIONUCLIDES}

Sections 5.4 and 5.5 looked separately at compliance with direct exposure RAGs and groundwater and Columbia River protection soil RAGs, respectively. When using a statistical sampling approach, a RAG requirement for nonradionuclides is the WAC 173-340-740(7)(e) three-part test. The WAC 173-340 three-part test consists of the following criteria: (1) the cleanup verification statistical value must be less than the cleanup level, (2) no single detection can exceed two times the cleanup criteria, and (3) the percentage of samples exceeding the cleanup criteria must be less than $10 \%$.

The application of the three-part test for the 118-F-1 waste site is included in the $95 \%$ UCL calculation brief (Appendix B). Only the COCs/COPCs that failed one or more parts of the WAC 173-340 three-part test are provided in Table 8 . The table lists the most restrictive RAG, the maximum detected value, the total number of samples 
collected, and the percentage of samples exceeding the RAG. The final column of the table describes the result of applying the three WAC 173-340-740(7)(e) criteria using the values listed in the preceding columns.

Residual concentrations of lead fail the three-part test in comparison against the soil RAGs for the protection of groundwater and/or the Columbia River. Based on RESRAD modeling (BHI 2005) and contaminant-specific soil-partitioning coefficient values, these constituents will not vertically migrate more than $3 \mathrm{~m}(10 \mathrm{ft})$ in 1,000 years. Given a vadose zone thickness greater than $3 \mathrm{~m} \mathrm{(10} \mathrm{ft)} \mathrm{thick} \mathrm{underlying} \mathrm{the} \mathrm{118-F-1} \mathrm{waste} \mathrm{site,}$ residual concentrations are not predicted to reach groundwater (and, therefore, the Columbia River) within 1,000 years. As such, all non-radionuclide statistical verification data sets pass the WAC 173-340 three-part test.

Table 8. Summary of the WAC 173-340 Three-Part Test for the 118-F-1 Burial Ground ${ }^{\mathrm{a}}$.

\begin{tabular}{|c|c|c|c|c|c|c|}
\hline $\mathrm{COC} / \mathrm{COPC}$ & $\begin{array}{c}\text { Most } \\
\text { Restrictive } \\
\text { Applicable } \\
\text { RAG }\end{array}$ & $\begin{array}{c}\text { Statistical } \\
\text { Cleanup } \\
\text { Verification } \\
\text { Value } \\
{\text { (mg/kg })^{\mathrm{b}}}^{\text {(m) }}\end{array}$ & $\begin{array}{l}\text { Maximum } \\
\text { Detected } \\
\text { Cleanup } \\
\text { Verification } \\
\text { Value } \\
(\mathrm{mg} / \mathrm{kg})^{\mathrm{c}}\end{array}$ & $\begin{array}{c}\text { Total } \\
\text { Number of } \\
\text { Samples }^{d}\end{array}$ & $\begin{array}{c}\text { Percentage } \\
\text { of Cleanup } \\
\text { Verification } \\
\text { Data Set } \\
\text { Exceeding } \\
\text { RAG }^{\mathrm{e}}\end{array}$ & $\begin{array}{c}\text { Cleanup } \\
\text { Criteria } \\
\text { Attained? }\end{array}$ \\
\hline \multicolumn{7}{|c|}{ Waste Sorting Trenches } \\
\hline Lead & $10.2^{g}$ & 18 & 32 & 5 & $20 \%$ & Yes $^{f}$ \\
\hline \multicolumn{7}{|c|}{ Overburden/BCL Piles } \\
\hline Lead & $10.2^{\mathrm{g}}$ & 12 & 22.8 & 16 & $37.5 \%$ & Yes $^{f}$ \\
\hline
\end{tabular}

${ }^{a}$ Only the COCs/COPCs that failed the WAC 173-340 Three-Part Test are presented.

b Criterion is statistical value cannot exceed most restrictive applicable RAG.

c Criterion is no single detection can exceed two times the most restrictive applicable RAG.

d Total number of samples in the decision unit may include field duplicate samples, which are included in the evaluation as separate samples.

e Criterion is percentage of data set exceeding the most restrictive applicable RAG cannot exceed $10 \%$.

f Based on the 100 Area Analogous Sites RESRAD Calculations (BHI 2005) and contaminant-specific soil-portioning coefficient $\left(K_{d}\right)$ value, contaminant will not migrate vertically more than $3 \mathrm{~m} \mathrm{(10} \mathrm{ft)} \mathrm{in} \mathrm{1,000} \mathrm{years.} \mathrm{As} \mathrm{the} \mathrm{vadose} \mathrm{zone} \mathrm{underlying} \mathrm{the} \mathrm{site} \mathrm{is}$ greater than $3 \mathrm{~m}(10 \mathrm{ft}$ ) thick, the contaminant will not reach groundwater (and thus the Columbia River) in 1,000 years.

9 Where cleanup levels are less than background, cleanup levels default to background (WAC 173-340-700[4][d]) (1996).

COC = contaminant of concern

COPC = contaminant of potential concern

RAG = remedial action goal

RESRAD = RESidual Radioactivity (dose model)

WAC = Washington Administrative Code

\subsection{COMPARISON OF SAMPLE DATA TO ECO-SCREENING LEVELS}

Soil cleanup levels were established in the ROD (EPA 2000) based on a limited ecological risk assessment. Although not required by the ROD (EPA 2000), a comparison against ecological risk screening levels has been made for the site COCs/COPCs. Screening levels were not exceeded for the site constituents, with the exception of antimony, arsenic, boron, lead, selenium, silver, and vanadium.

Exceedance of screening values does not necessarily indicate the existence of risk to 
ecological receptors. It is believed that the presence of these constituents does not pose a risk to ecological receptors as concentrations of antimony, arsenic, selenium, silver, and vanadium are within the range of Hanford Site background levels and boron concentrations are consistent with those seen elsewhere at the Hanford Site (no established background value is available for boron). The presence of lead is believed to be due to historic application of lead-arsenate pesticides. The exceedance of soil screening values by lead at the site will be evaluated in the context of additional lines of evidence for ecological effects. A baseline risk assessment for the river corridor portion of the Hanford Site began in 2004, which includes a more complete quantitative ecological risk assessment. That baseline risk assessment will be used as part of the final closeout decision for this site.

\subsection{RADIONUCLIDE RISK INFORMATION}

The radionuclide RAG for direct exposure is derived from the ROD (EPA 2000) and is expressed in terms of an allowable radiation dose rate above background (i.e., $15 \mathrm{mrem} / \mathrm{yr}$ ). The RAG evaluation (Section 5.0) involved using the RESRAD model to estimate total annual radiation dose rates for 1,000 years for comparison to the RAG. Radiation presents a carcinogenic risk, and the RESRAD model also calculates the excess lifetime cancer risk (ELCR) associated with the estimated radiation dose rates using the EPA's Health Effects Assessment Summary Tables (update dated April 16, 2001, "Update of Radionuclide Carcinogenicity Slope Factors," available on the Internet at www.epa.gov/radiation/heast). The "National Oil and Hazardous Substances Pollution Contingency Plan" (40 Code of Federal Regulations 300) presents a target range for residual risk of $10^{-4}$ to $10^{-6}$.

Figures 8 through 10 illustrate ELCR for the remediation footprint, overburden/BCL, and waste sorting pile area as estimated using the RESRAD model. Because of radioactive decay, the risk decreases over time. The maximum predicted ELCR occurs at present (year 2007). The maximum ELCR is $9.95 \times 10^{-5}$ for the remediation footprint, $5.42 \times 10^{-5}$ for the overburden/BCL soil and $1.55 \times 10^{-4}$ for the waste sorting pile area. The ELCR predicted for the year 2018 is $3.79 \times 10^{-5}$ for the remediation footprint, $4.10 \times 10^{-5}$ for the overburden/BCL soil and $9.57 \times 10^{-5}$ for the waste sorting pile footprint. All three sampling areas meet the target risk range of $10^{-4}$ to $10^{-6}$. 
Figure 8. RESRAD Analysis - Radionuclide Risk, All Pathways - Remediation Footprint.

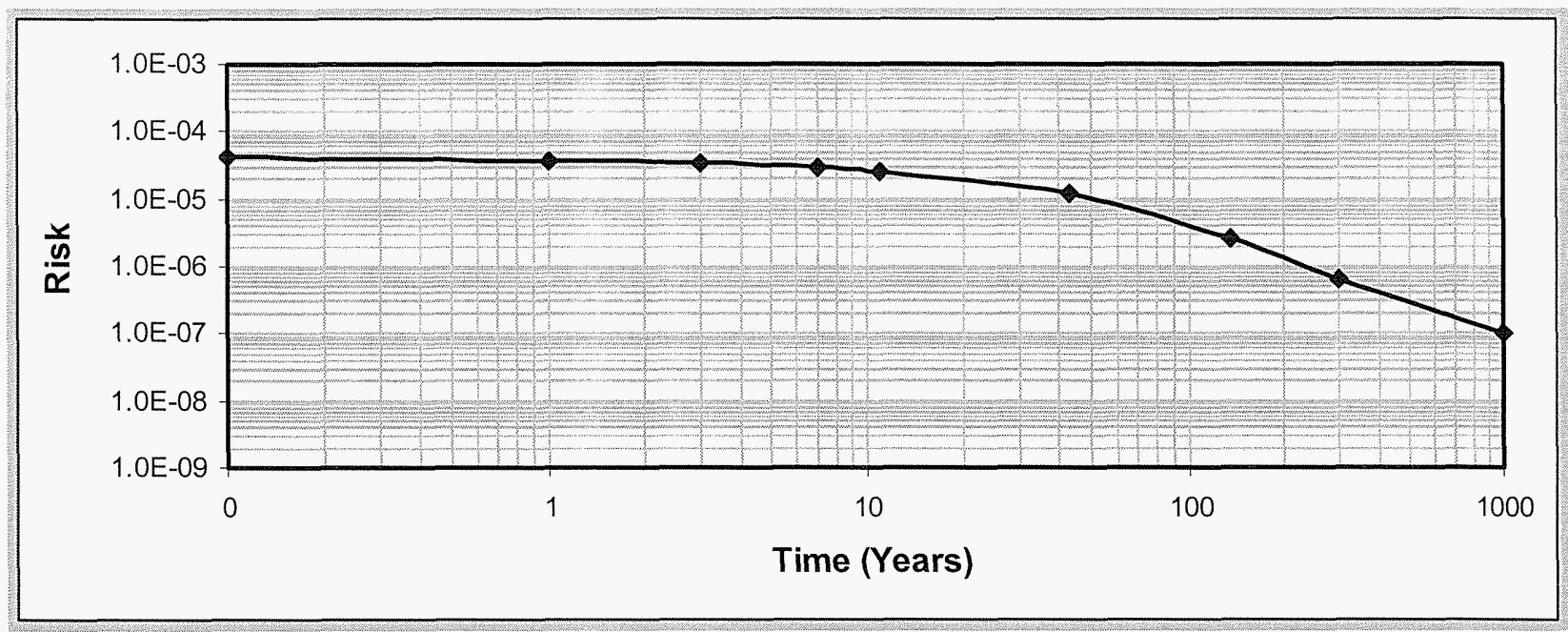

Figure 9. RESRAD Analysis - Radionuclide Risk, All Pathways - Waste Sorting Trenches.

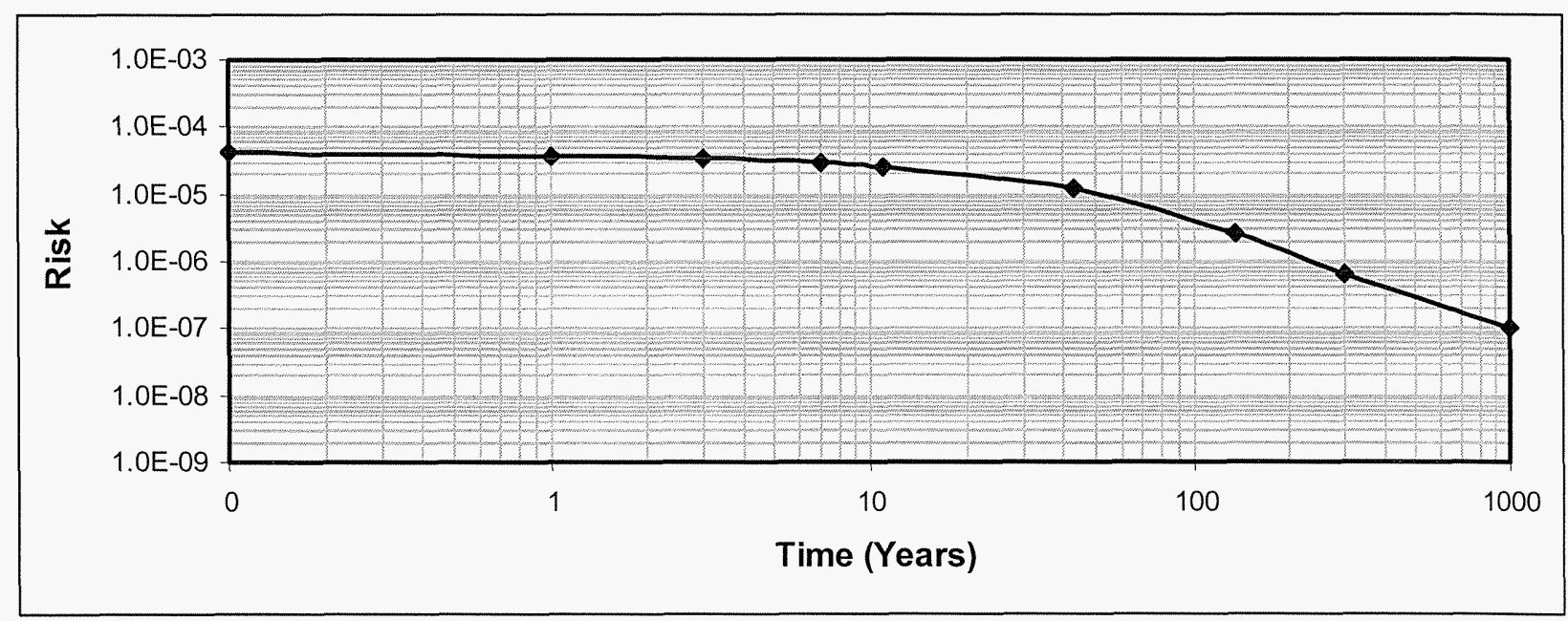


Figure 10. RESRAD Analysis - Radionuclide Risk, All Pathways Overburden/BCL.

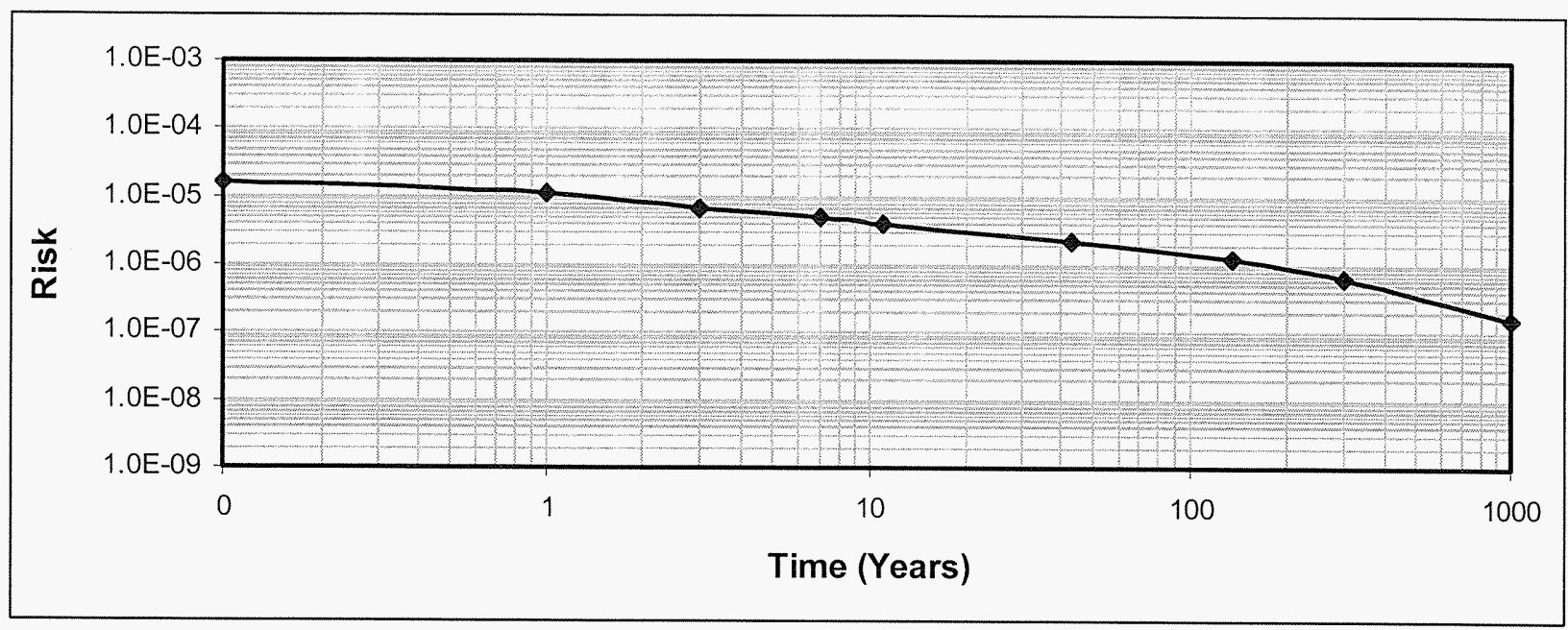

\subsection{SUMMARY FOR WASTE SITE RECLASSIFICATION}

This cleanup verification package demonstrates that remedial action at the 118-F-1 site has achieved the RAOs and corresponding RAGs established in the ROD (EPA 2000) and RDR/RAWP (DOE-RL 2005). The remaining soils at the 118-F-1 site have been sampled, analyzed, and modeled. The results of this effort indicate that the materials from the 118-F-1 site containing COCs at concentrations exceeding RAGs have been excavated and disposed of at ERDF. These results also indicate that residual concentrations will support future land uses that can be represented (or bounded) by a rural-residential scenario and that residual concentrations throughout the site pose no threat to groundwater or the Columbia River. The 118-F-1 excavation area has a

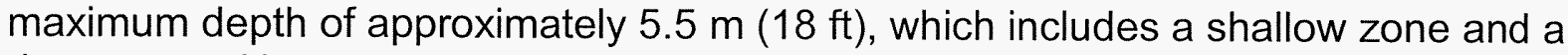
deep zone. However, the entire excavation area is considered one decision unit, and will be closed out using the more restrictive shallow zone cleanup criteria; therefore, institutional controls to prevent uncontrolled drilling or excavation into the deep zone are not required. The 118-F-1 site is verified to be remediated in accordance with the ROD (EPA 2000) and may be backfilled.

\subsection{REFERENCES}

40 CFR 141, "National Primary Drinking Water Regulations," Code of Federal Regulations, as amended.

40 CFR 300, "National Oil and Hazardous Substances Pollution Contingency Plan," Code of Federal Regulations, as amended. 
ANL, 2005, RESRAD for Windows, Version 6.30, Argonne National Laboratory, Environmental Assessment Division, Argonne, Illinois.

BHI, 2001, Calculation of Total Uranium Activity Corresponding to a Maximum Contaminant Level for Total Uranium of 30 Micrograms per Liter in Groundwater, 0100X-CA-V0038, Rev. 0, Bechtel Hanford, Inc., Richland, Washington.

$\mathrm{BHI}, 2002 \mathrm{a}$, Results of the Geophysical Investigation Conducted at $100 \mathrm{~F}$ Sites, 118-F-1, 118-F-2, 118-F-3, 118-F-5, 118-F-6, 118-F-7, and 118-F-9, ERC Team Interoffice Memorandum, CCN 096523, dated March 11, 2002, Bechtel Hanford, Inc., Richland, Washington.

BHI, 2002b, Report on the Test Pitting/Trenching in the 118-F-1, 118-F-5, and 118-F-6, Burial Grounds, ERC Team Interoffice Memorandum, CCN 101418, dated August 29, 2002, Bechtel Hanford, Inc., Richland, Washington.

BHI, 2004, 100 Area Radionuclide and Nonradionuclide Lookup Values for the 1995 Interim Remedial Action Record of Decision, 0100X-CA-V0046, Rev. 0, Bechtel Hanford Inc., Richland, Washington.

BHI, 2005, 100 Area Analogous Sites RESRAD Calculations, Calculation No. 0100X-CA-V0050, Rev. 0, Bechtel Hanford, Inc., Richland, Washington.

DOE Order 5400.5, Radiation Protection of the Public and the Environment, U.S. Department of Energy, Washington, D.C.

DOE-RL, 1996, Hanford Site Background: Part 2, Soil Background for Radionuclides, DOE/RL-96-12, Rev. 0, U.S. Department of Energy, Richland Operations Office, Richland, Washington.

DOE-RL, 2001, 100 Area Burial Grounds Remedial Action Sampling and Analysis Plan, DOE/RL-2001-35, Rev. 0, U.S. Department of Energy, Richland Operations Office, Richland, Washington.

DOE-RL, 2005, Remedial Design Report/Remedial Action Work Plan for the 100 Area, DOE/RL-96-17, Rev. 5, U.S. Department of Energy, Richland Operations Office, Richland, Washington.

DOE-RL, 2007, Tri-Party Agreement Handbook Management Procedures, RL-TPA-90-0001, Rev. 1, Guideline Number TPA-MP-14, "Maintenance of the Waste Information Data System (WIDS)," U.S. Department of Energy, Richland Operations Office, Richland, Washington.

Ecology, EPA, and DOE, 1989, Hanford Federal Facility Agreement and Consent Order, 2 vols., as amended, Washington State Department of Ecology,

U.S. Environmental Protection Agency, and U.S. Department of Energy, Olympia, Washington. 
Ecology, 2005, Cleanup Levels and Risk Calculations (CLARC) Database, Washington State Department of Ecology, Olympia, Washington, <https://fortress.wa.gov/ecy/clarc/CLARCHome.aspx>.

EPA, 1994, Guidance Manual for the Integrated Exposure Uptake Biokinetic Model for Lead in Children, EPA/540/R-93/081, Publication No. 9285.7, U.S. Environmental Protection Agency, Washington, D.C.

EPA, 2000, Record of Decision for the 100-BC-1, 100-BC-2, 100-DR-1, 100-DR-2, 100-FR-2, 100-HR-2, and 100-KR-2 Operable Units, Hanford Site (100 Area Burial Grounds), Benton County, Washington, U.S. Environmental Protection Agency, Region 10, Seattle, Washington.

WAC 173-303, 2004, "Dangerous Waste Regulations," Washington Administrative Code.

WAC 173-340, 1996, "Model Toxics Control Act - Cleanup," Washington Administrative Code.

WCH, 2007a, 100F Remedial Sampling, Logbook EFL-1174-2 pp 1-29, 76-87 and 91-92, Washington Closure Hanford, Richland, Washington.

WCH, 2007b, 100F Remedial Sampling, Logbook EFL-1174-3 pp 11-17, Washington Closure Hanford, Richland, Washington.

WCH, 2007c, 118-F-1 Burial Ground Cleanup Verification RESRAD Calculation Brief, 0100F-CA-V0280, Rev. 0, Washington Closure Hanford, Richland, Washington.

WCH, 2007d, 118-F-1 Burial Ground Cleanup Verification 95\% UCL Calculations, 0100F-CA-V0279, Rev. 0, Washington Closure Hanford, Richland, Washington.

WCH, 2007e, 118-F-1 Burial Ground Hazard Quotient and Carcinogenic Risk Calculations, 0100F-CA-V0283, Rev. 0, Washington Closure Hanford, Richland, Washington.

WCH, 2007f, 118-F-1 Burial Ground Comparison to Drinking Water Standards (MCL) Calculation, 0100F-CA-V0281, Rev. 0, Washington Closure Hanford, Richland, Washington.

WCH, 2007g, 118-F-1 Burial Ground Shallow Zone, Process Trenches, and Overburden Sample Design, 0100F-CA-V0282, Rev. 0, Washington Closure Hanford, Richland, Washington.

WDOH, 1997, State of Washington Department of Health Interim Regulatory Guidance: Hanford Guidance for Radiological Cleanup, WDOH/320-015, Rev. 1, Washington State Department of Health, Richland, Washington. 
CVP-2007-00001

Rev. 0 
CVP-2007-00001

Rev. 0

APPENDIX A

118-F-1 WASTE SITE REMEDIATION PHOTOGRAPHS 
CVP-2007-00001

Rev. 0 
CVP-2007-00001

Rev. 0

Photograph A-1. Aerial View of the 118-F-1 Burial Ground and Surrounding Area (April 2007).

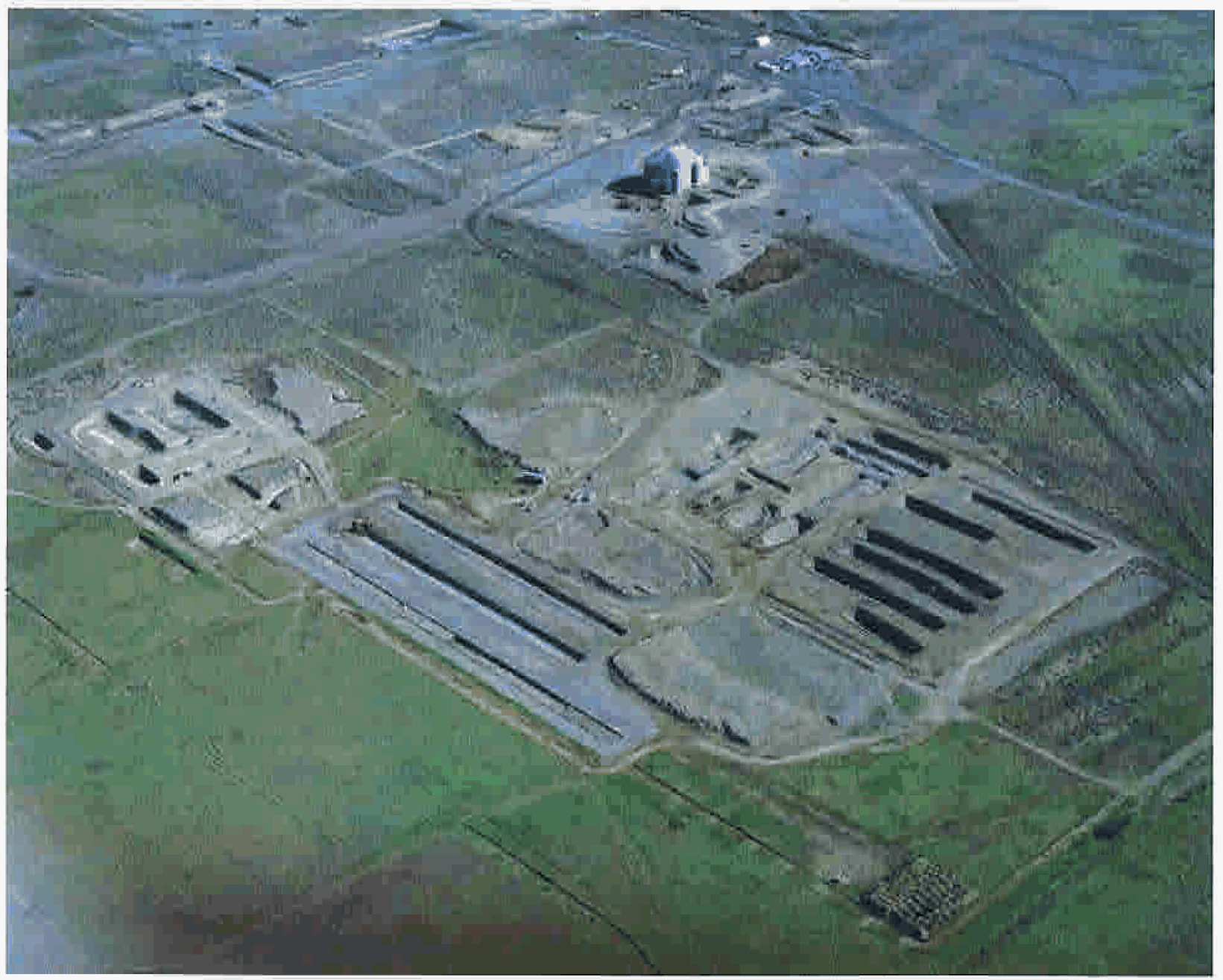




\section{Photograph A-2. Steel Canister Containing Graphite.}

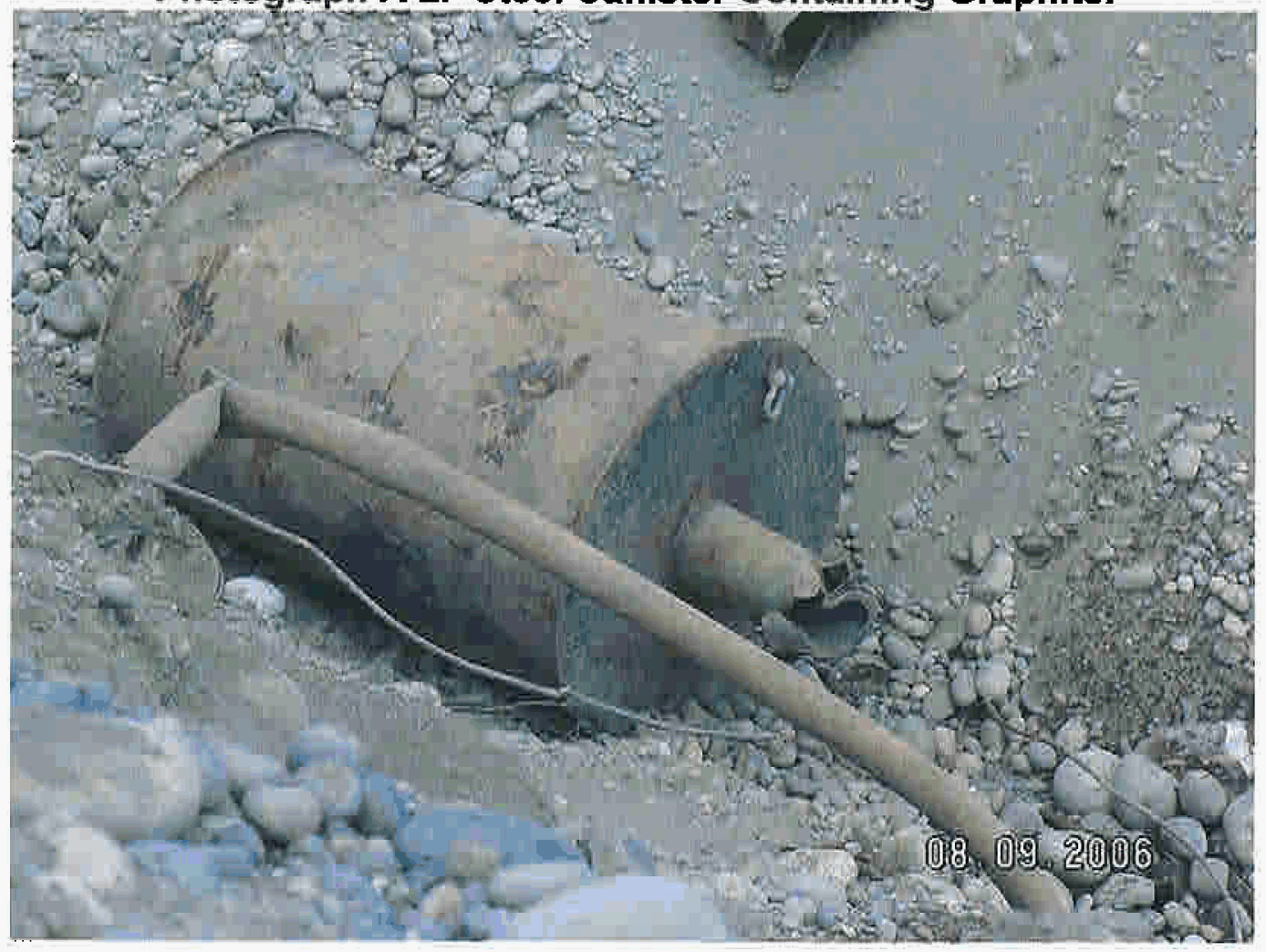

Photograph A-3. Perforated Spacers and Timber.

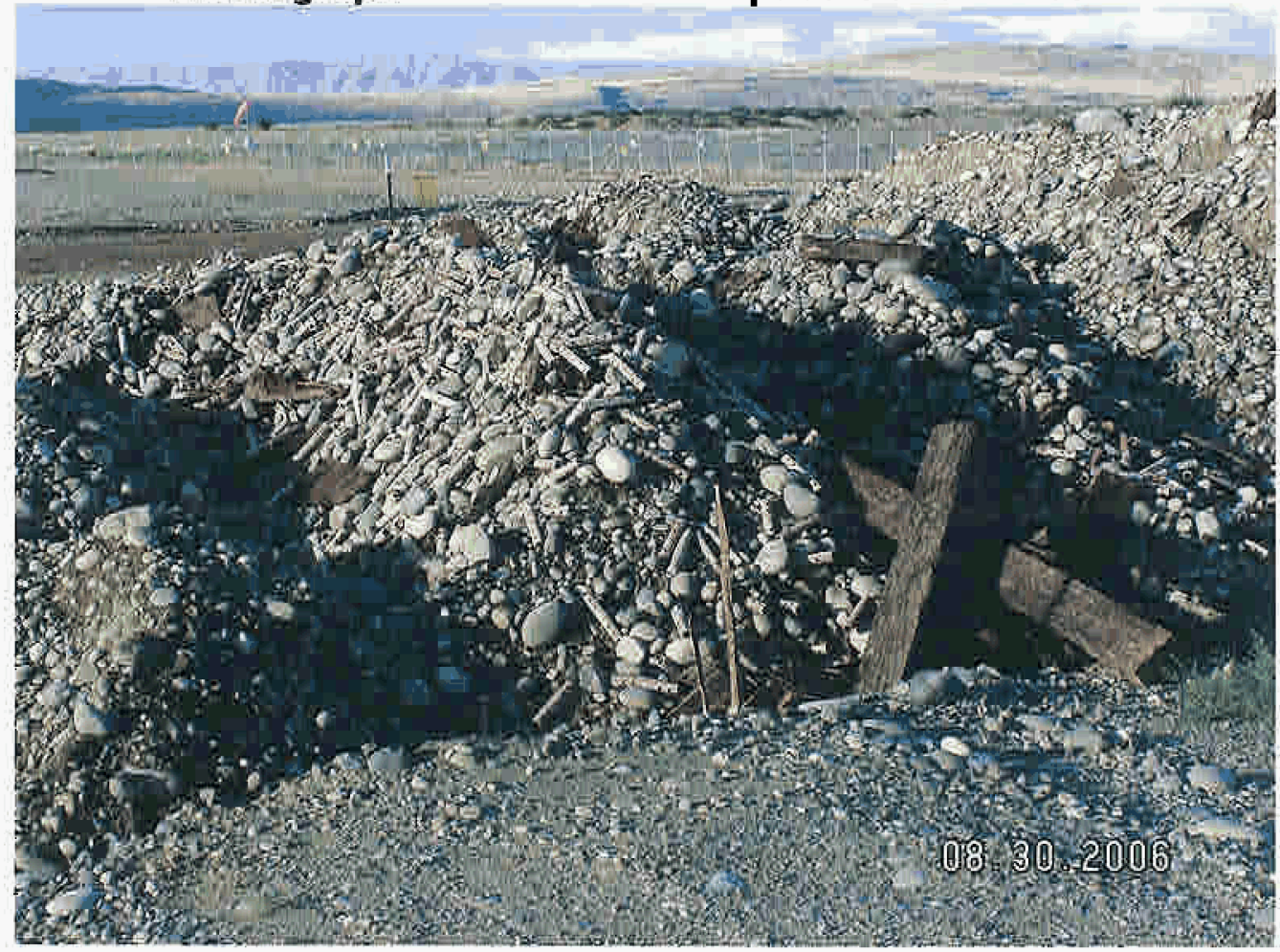


Photograph A-4. 118-F-1 Metal and Concrete Debris.

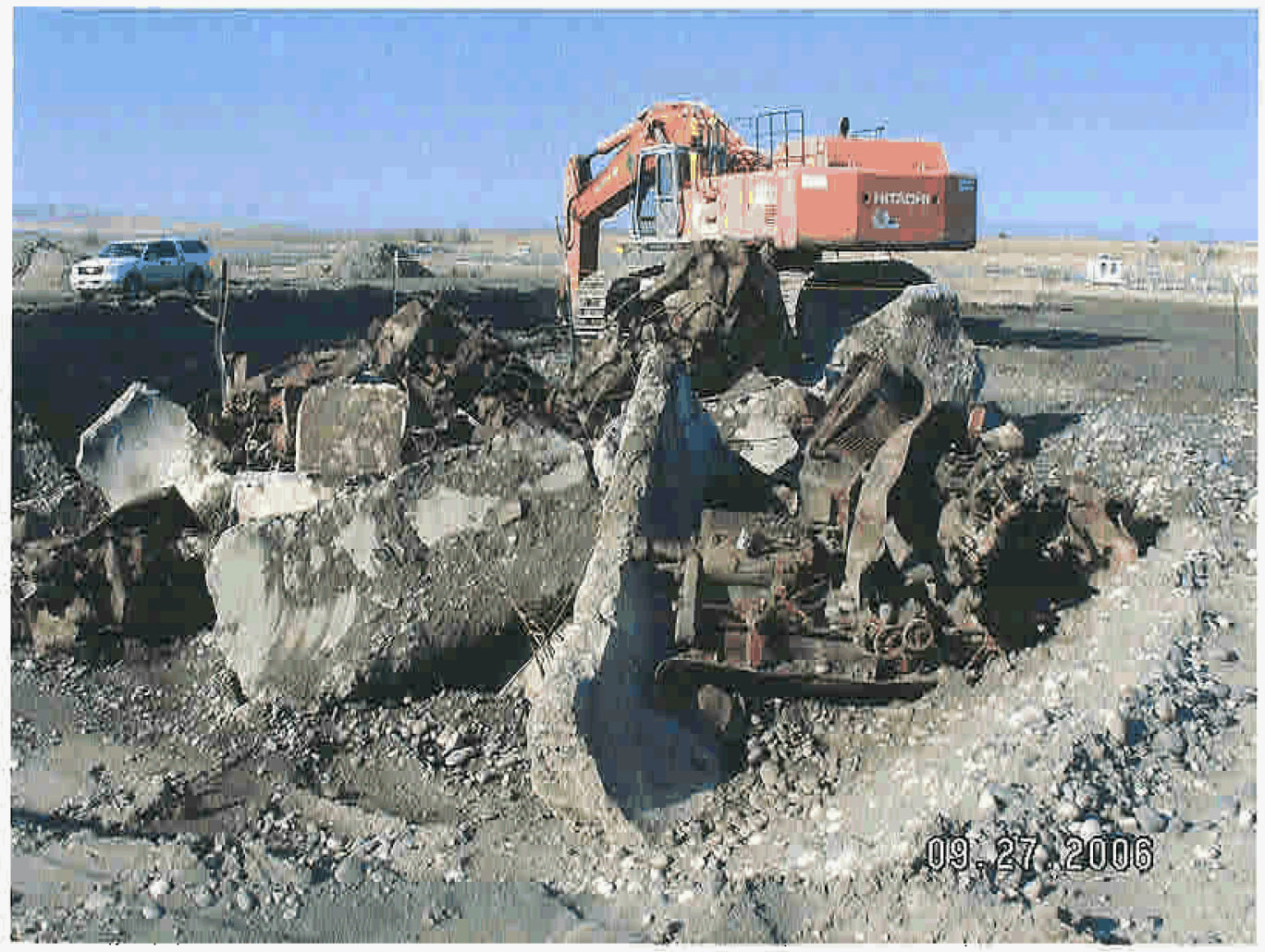


CVP-2007-00001

Rev. 0

A-4 


\section{APPENDIX B}

RESRAD INPUT PARAMETERS

AND CALCULATION BRIEF EXCERPTS

$B-i$ 
CVP-2007-00001

Rev. 0

\section{CALCULATION BRIEF EXCERPTS}


CVP-2007-00001

Rev. 0

\section{DISCLAIMER FOR CALCULATIONS}

The calculations that are provided in the following appendix have been generated to document compliance with established cleanup levels. These calculations should be used in conjunction with other relevant documents in the administrative record. 


\section{CALCULATION BRIEFS}

The following calculation briefs have been prepared in accordance with ENG-1, Engineering Services, ENG-1-4.5, "Project Calculations," Washington Closure Hanford, Richland, Washington.

118-F-1 Burial Ground Shallow Zone, Process Trenches, and Overburden Sample Design, 0100F-CA-V0282, Rev. 0, Washington Closure Hanford, Richland, Washington (2007).

118-F-1 Burial Ground Hazard Quotient and Carcinogenic Risk Calculations, 0100F-CA-V0283, Rev. 0, Washington Closure Hanford, Richland, Washington (2007).

118-F-1 Burial Ground Cleanup Verification 95\% UCL Calculations, 0100F-CA-V0279, Rev. 1, Washington Closure Hanford, Richland, Washington (2007).

118-F-1 Burial Ground Comparison to Drinking Water Standards (MCL) Calculation, 0100F-CA-V0281, Rev. 0, Washington Closure Hanford, Richland, Washington (2007).

118-F-1 Burial Ground Cleanup Verification RESRAD Calculation Brief, 0100F-CA-V0280, Rev. 0, Washington Closure Hanford, Richland, Washington (2007).

NOTE: The calculation briefs referenced in this appendix are kept in the active Washington Closure Hanford project files and are available upon request. When the project is completed, the files will be stored in a U.S. Department of Energy, Richland Operations Office repository. Only excerpts of the calculation briefs are included in this appendix. 


\section{CALCULATION COVER SHEET}

Project Title: 118-F-1 Burial Ground Sample Design

Job No. 14655

Area: $\quad 100-\mathrm{F}$

Discipline: Environmental Engineering

*Calculation No: 0100F-CA-V0282

Subject: $\quad$ 118-F-1 Burial Ground Shallow Zone / Stockpile (BCL) Sampling Plan

\begin{tabular}{lll} 
& $\begin{array}{l}\text { Excel, Autodesk World, } \\
\text { and Autodesk Land } \\
\text { Map }\end{array}$ Program No: $\quad \begin{array}{l}\text { Excel 2003, World R2, and Land Map } \\
2004\end{array}$ \\
\hline
\end{tabular}

The attached calculations have been generated to document compliance with established cleanup levels. These calculations should be used in conjunction with other relevant documents in the administrative record.

Committed Calculation $₫ \quad$ Preliminary $\square \quad$ Superseded $\square \quad$ Voided $\square$

\begin{tabular}{|c|c|c|c|c|c|c|}
\hline Rev & Sheel Nunbers & Originator & Checker & Heviever & Approval & Horve \\
\hline 0 & Total $=11 \mathrm{Shts}$ & $\begin{array}{l}\text { 2. } \\
7.6 .0^{-67}\end{array}$ & $\begin{array}{l}\text { R. CLU } \\
\text { B.A. Christensen } \\
2007.7 \cdot \text { il }\end{array}$ & N/A & $\begin{array}{l}\text { SU CeN } \\
\text { s.w. Callison } \\
7-11-07\end{array}$ & $7-1 /-07$ \\
\hline & & & & & & \\
\hline & & & & & & \\
\hline & & & & & & \\
\hline
\end{tabular}

SUMMARY OF REVISION

\begin{tabular}{|l|l|}
\hline & \\
\hline & \\
\hline & \\
\hline & \\
\hline
\end{tabular}




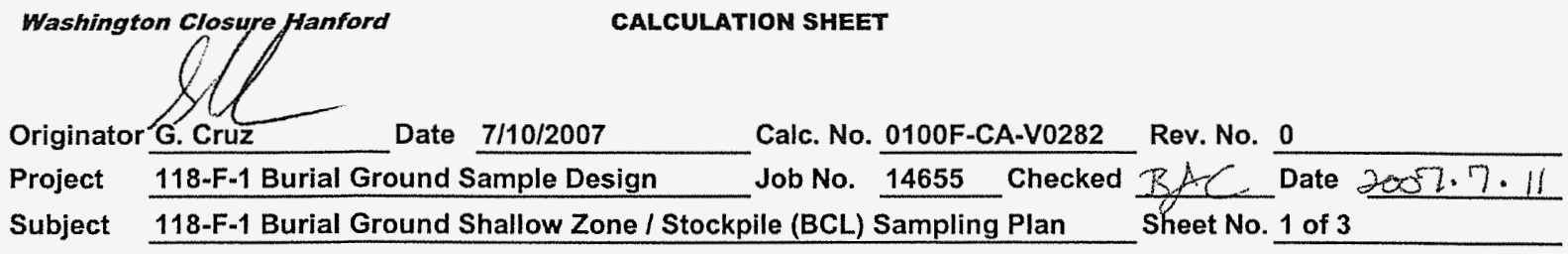

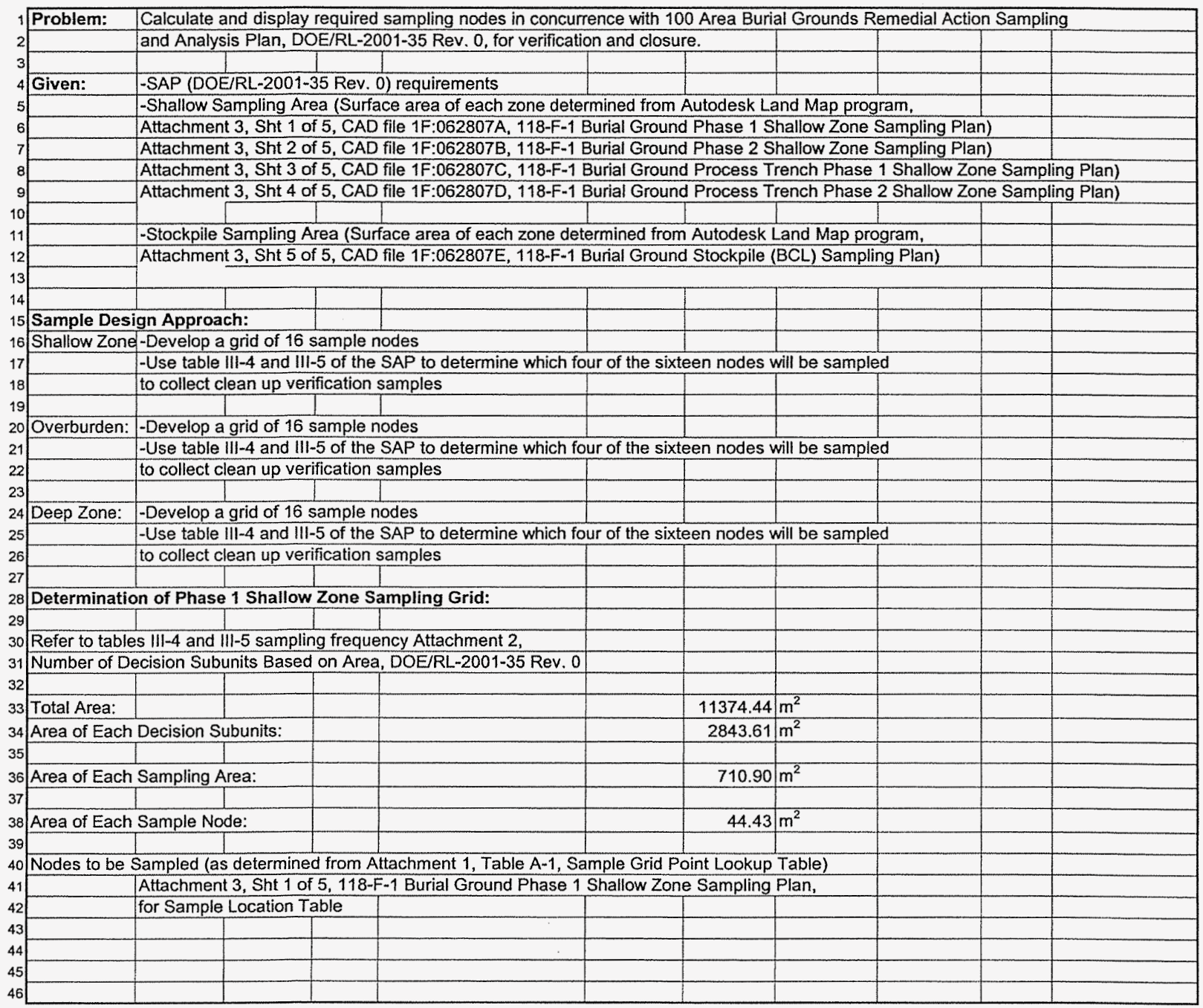


CVP-2007-00001

Rev. 0

Originator G. Cruz

Date $7 / 10 / 2007$

Calc. No. 0100F-CA-V0282 Rev. No. 0

Project 118-F-1 Burial Ground Sample Design Job No. 14655 Checked B Subject 118-F-1 Burial Ground Shallow Zone / Stockpile (BCL) Sampling Plan Sheet No. 2 of 3

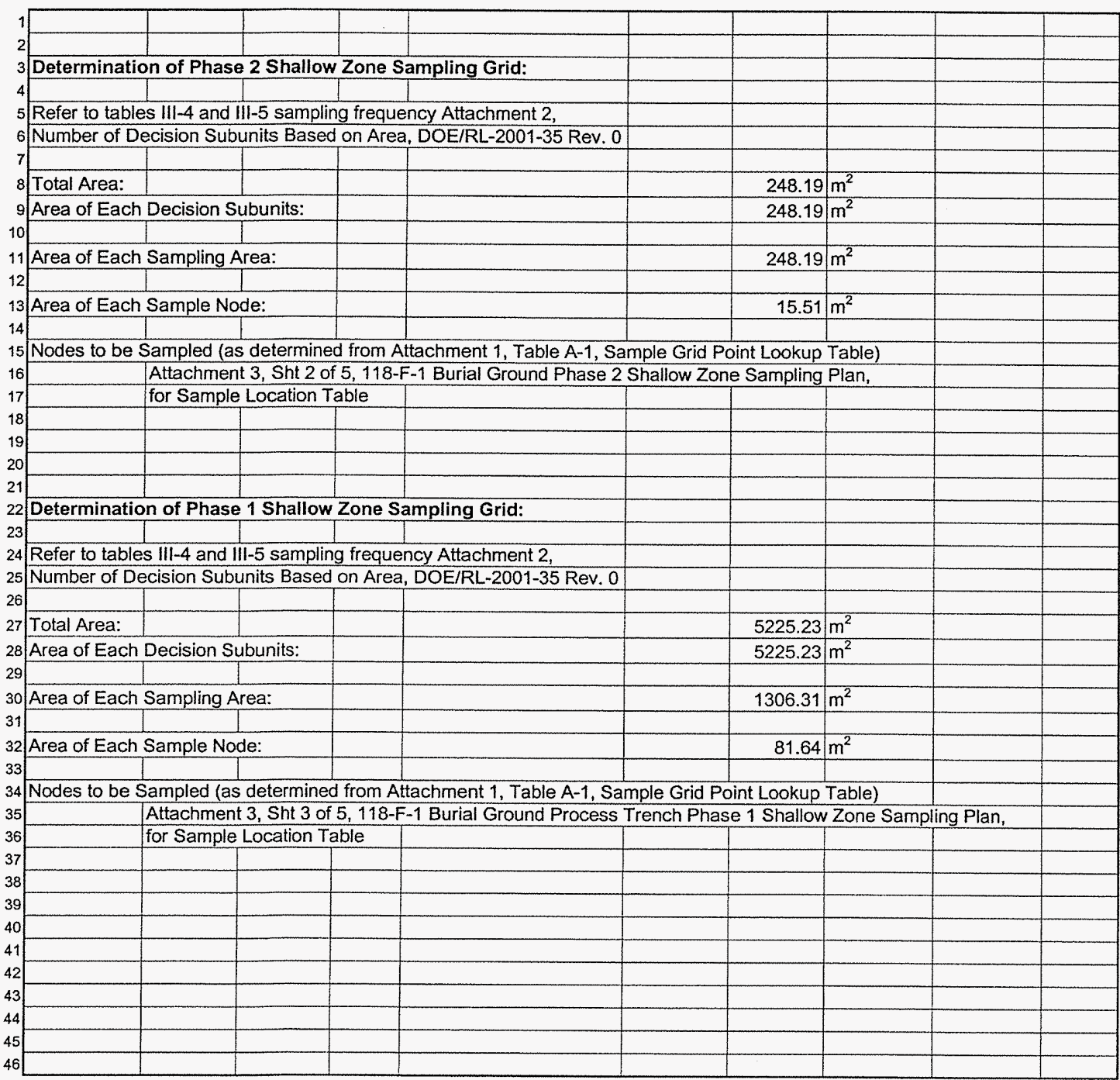


CVP-2007-00001

Rev. 0

Originator G. Cruz Date 7/10/2007

Project 118-F-1 Burial Ground Sample Design

Subject 118-F-1 Burial Ground Shallow Zone / Stockpile (BCL) Sampling Plan
Calc. No. 0100F-CA-V0282 Rev. No. 0

Job No. 14655 Checked $\angle A C$ Date $2007-2.11$ Sheet No. 3 of 3

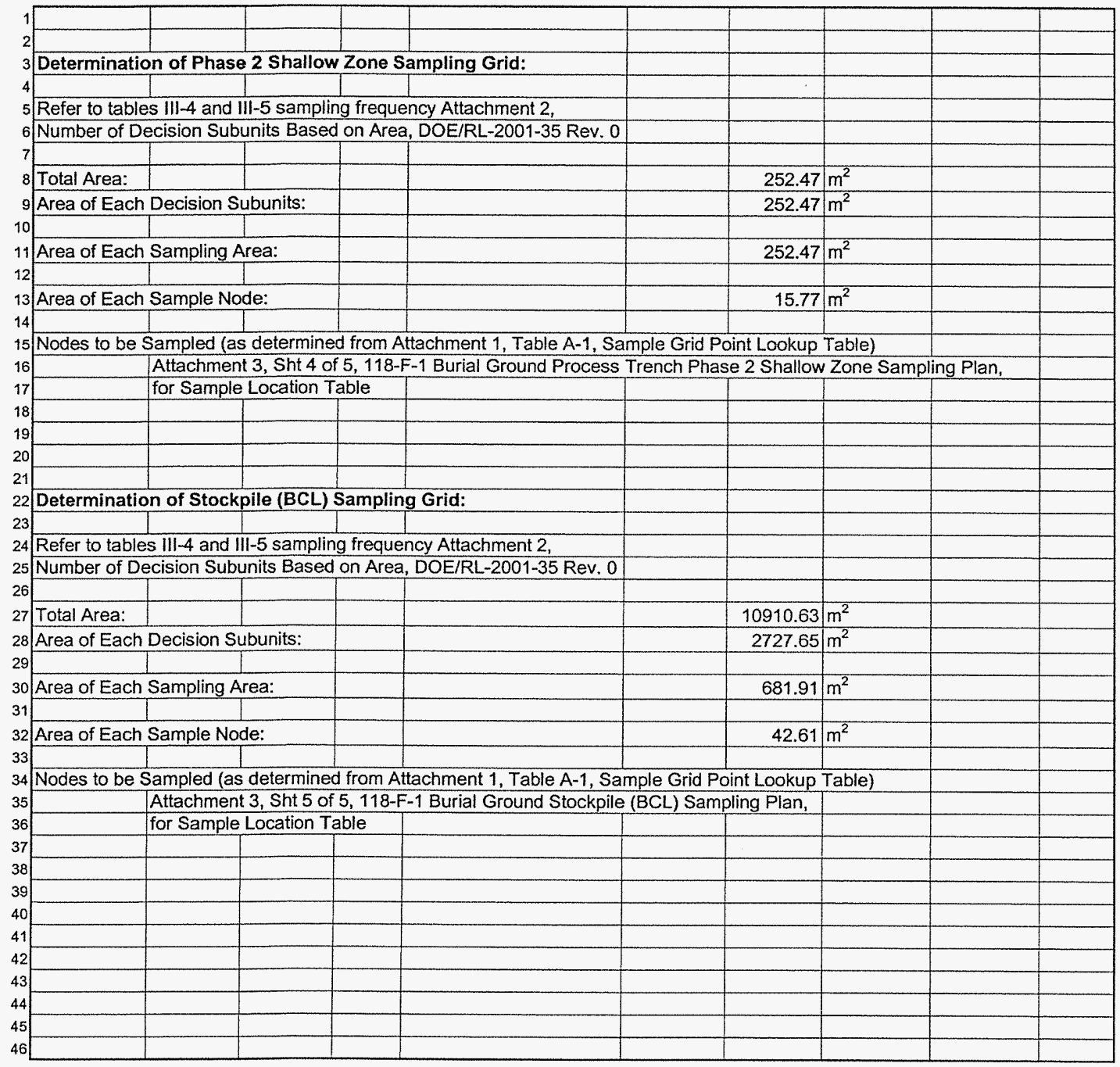


CVP-2007-00001

Rev. 0

Washington Closure Hanford

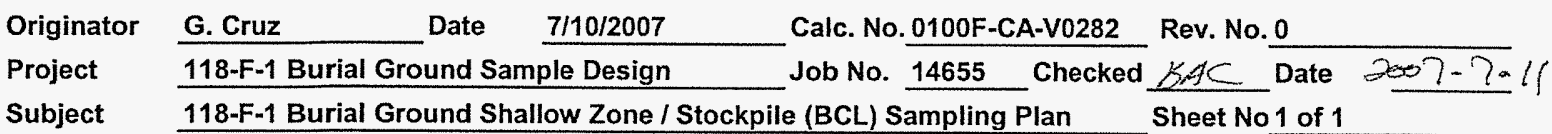

1 ATTACHMENT 1 ${ }_{3}$ Sample Grid Point Lookup Table.

\begin{tabular}{|c|c|c|c|c|c|c|c|c|c|c|}
\hline Default Plan & $\begin{array}{c}\text { Sampling } \\
\text { Area } 1\end{array}$ & $\begin{array}{c}\text { Sampling } \\
\text { Area } 2\end{array}$ & $\begin{array}{c}\text { Sampling } \\
\text { Area } 3\end{array}$ & $\begin{array}{l}\text { Sampling } \\
\text { Area } 4\end{array}$ & $\begin{array}{l}\text { Sampling } \\
\text { Area } 5\end{array}$ & $\begin{array}{c}\text { Sampling } \\
\text { Area } 6\end{array}$ & $\begin{array}{l}\text { Sampling } \\
\text { Area } 7\end{array}$ & $\begin{array}{c}\text { Sampling } \\
\text { Area } 8\end{array}$ & $\begin{array}{c}\text { Sampling } \\
\text { Area } 9\end{array}$ & $\begin{array}{c}\text { Sampling } \\
\text { Area } 10\end{array}$ \\
\hline Closeout & 3 & 6 & 1 & 4 & 5 & 1 & 3 & 3 & 4 & 16 \\
\hline Closeout & 4 & 7 & 11 & 3 & 15 & 15 & 5 & 13 & 10 & 10 \\
\hline Closeout & 16 & 3 & 2 & 7 & 7 & 10 & 11 & 4 & 3 & 14 \\
\hline Closeout & 10 & 15 & 4 & 12 & 1 & 13 & 4 & 8 & 16 & 4 \\
\hline Not Sampling & 2 & 14 & 5 & 9 & 13 & 12 & 8 & 2 & 14 & 8 \\
\hline Not Sampling & 13 & 10 & 9 & 13 & 2 & 16 & 1 & 12 & 5 & 3 \\
\hline Not Sampling & 6 & 1 & 10 & 8 & 14 & 4 & 16 & 5 & 8 & 6 \\
\hline Not Sampling & 1 & 9 & 13 & 1 & 10 & 5 & 12 & 1 & 1 & 15 \\
\hline Not Sampling & 9 & 12 & 7 & 5 & 6 & 2 & 6 & 7 & 15 & 9 \\
\hline Not Sampling & 15 & 16 & 15 & 14 & 16 & 6 & 2 & 15 & 11 & 1 \\
\hline Not Sampling & 8 & 13 & 8 & 10 & 12 & 11 & 13 & 14 & 2 & 12 \\
\hline Not Sampling & 5 & 2 & 3 & 11 & 4 & 3 & 9 & 10 & 7 & 11 \\
\hline Not Sampling & 7 & 11 & 14 & 15 & 11 & 14 & 14 & 6 & 13 & 2 \\
\hline Not Sampling & 11 & 4 & 6 & 2 & 9 & 7 & 7 & 11 & 9 & 7 \\
\hline Not Sampling & 12 & 8 & 16 & 16 & 3 & 8 & 15 & 9 & 6 & 13 \\
\hline Not Sampling & 14 & 5 & 12 & 6 & 8 & 9 & 10 & 16 & 12 & 5 \\
\hline
\end{tabular}

24 the nodes in the northwesternmost node. Then number consecutively left to right 
CVP-2007-00001

Rev. 0

Originator G. Cruz

Date $7 / 10 / 2007$

Calc. No. 0100F-CA-V0282

Rev. No. 0

Project 118-F-1 Burial Ground Sample Design

Job No. 14655 Checked

Subject 118-F-1 Burial Ground Shallow Zone / Stockpile (BCL) Sampling Plan

Sheet No. 1 of 1

\section{ATTACHMENT 2}

\begin{tabular}{|c|c|c|}
\hline Decision Units & Waste Site Size & $\begin{array}{l}\text { Number of Decision } \\
\text { Units }\end{array}$ \\
\hline \multirow{3}{*}{$\begin{array}{l}\text { Site verification (shallow) } \\
0 \text { to } 4.6 \mathrm{~m}(15 \mathrm{ft})\end{array}$} & $\begin{array}{l}\text { Small area of exposed surface after excavation } \\
\leq 9290 \mathrm{~m}^{2}\left(\leq 100,000 \mathrm{ft}^{2}\right)\end{array}$ & 1 \\
\hline & $\begin{array}{l}\text { Medium area of exposed surface after } \\
\text { excavation }>9290 \mathrm{~m}^{2} \text { but } \leq 37161 \mathrm{~m}^{2} \\
\left(>100,000 \mathrm{ft}^{2} \text { but } \leq 400,000 \mathrm{ft}^{2}\right)\end{array}$ & 4 \\
\hline & $\begin{array}{l}\text { Large area of exposed surface after excavation } \\
>37161 \mathrm{~m}^{2}\left(>400,000 \mathrm{ft}^{2}\right)\end{array}$ & 8 \\
\hline \multirow{3}{*}{$\begin{array}{l}\text { Site verification (deep) } \\
>4.6 \mathrm{~m}(>15 \mathrm{ft})\end{array}$} & $\begin{array}{l}\text { Small area of exposed surface after excavation } \\
\leq 9290 \mathrm{~m}^{2}\left(\leq 100,000 \mathrm{ft}^{2}\right)\end{array}$ & 1 \\
\hline & $\begin{array}{l}\text { Medium area of exposed surface after } \\
\text { excavation }>9290 \mathrm{~m}^{2} \text { but } \leq 37161 \mathrm{~m}^{2} \\
\left(>100,000 \mathrm{ft}^{2} \text { but } \leq 400,000 \mathrm{ft}^{2}\right)\end{array}$ & 4 \\
\hline & $\begin{array}{l}\text { Large area of exposed surface after excavation } \\
>37161 \mathrm{~m}^{2}\left(>400,000 \mathrm{ft}^{2}\right)\end{array}$ & 8 \\
\hline \multirow{3}{*}{ Overburden/layback piles } & $\begin{array}{l}\text { Small area of exposed surface after excavation } \\
\leq 9290 \mathrm{~m}^{2}\left(\leq 100,000 \mathrm{ft}^{2}\right)\end{array}$ & 1 \\
\hline & $\begin{array}{l}\text { Medium area of exposed surface after } \\
\text { excavation }>9290 \mathrm{~m}^{2} \text { but } \leq 37161 \mathrm{~m}^{2} \\
\left(>100,000 \mathrm{ft}^{2} \text { but } \leq 400,000 \mathrm{ft}^{2}\right)\end{array}$ & 4 \\
\hline & $\begin{array}{l}\text { Large area of exposed surface after excavation } \\
>37161 \mathrm{~m}^{2}\left(>400,000 \mathrm{ft}^{2}\right)\end{array}$ & 8 \\
\hline
\end{tabular}

- The shallow zone, deep zone, and overburden each represent single decision units. Because sites may not have a deep zone, there may be two or three decision units.

Note: 1.) Metric equivalents added to original SAP table.

Table III-5. Sampling Frequency Based on Size of Remediated Waste Site.

\begin{tabular}{|c|c|c|c|c|}
\hline Exposed Surface Area After Excavation & $\begin{array}{c}\text { Number of } \\
\text { Decision } \\
\text { Subunits }\end{array}$ & $\begin{array}{c}\text { Number of } \\
\text { Blocks }\end{array}$ & $\begin{array}{c}\text { Number of } \\
\text { Discreet } \\
\text { Samples }\end{array}$ & $\begin{array}{c}\text { Number of } \\
\text { Composite } \\
\text { Samples }\end{array}$ \\
\hline $\begin{array}{c}\text { Small site } \\
\leq 9290 \mathrm{~m}^{2}\left(\leq 100,000 \mathrm{f}^{2}\right)\end{array}$ & 1 & 4 & 16 & 4 \\
\hline $\begin{array}{c}\text { Medium site } \\
>9290 \mathrm{~m}^{2}\left(>100,000 \mathrm{f}^{2}\right) \text { but } \\
\leq 37161 \mathrm{~m}^{2}\left(\leq 400,000 \mathrm{f}^{2}\right)\end{array}$ & 4 & 16 & 64 & 16 \\
\hline Large site $\leq 37161 \mathrm{~m}^{2}\left(>400,000 \mathrm{ft}^{2}\right)$ & 8 & 32 & 128 & 32 \\
\hline
\end{tabular}

Note: 2.) The term "sample areas" is used interchangebly with "blocks" in this sample design 3.) Metric equivalents corrected from original SAP table. 


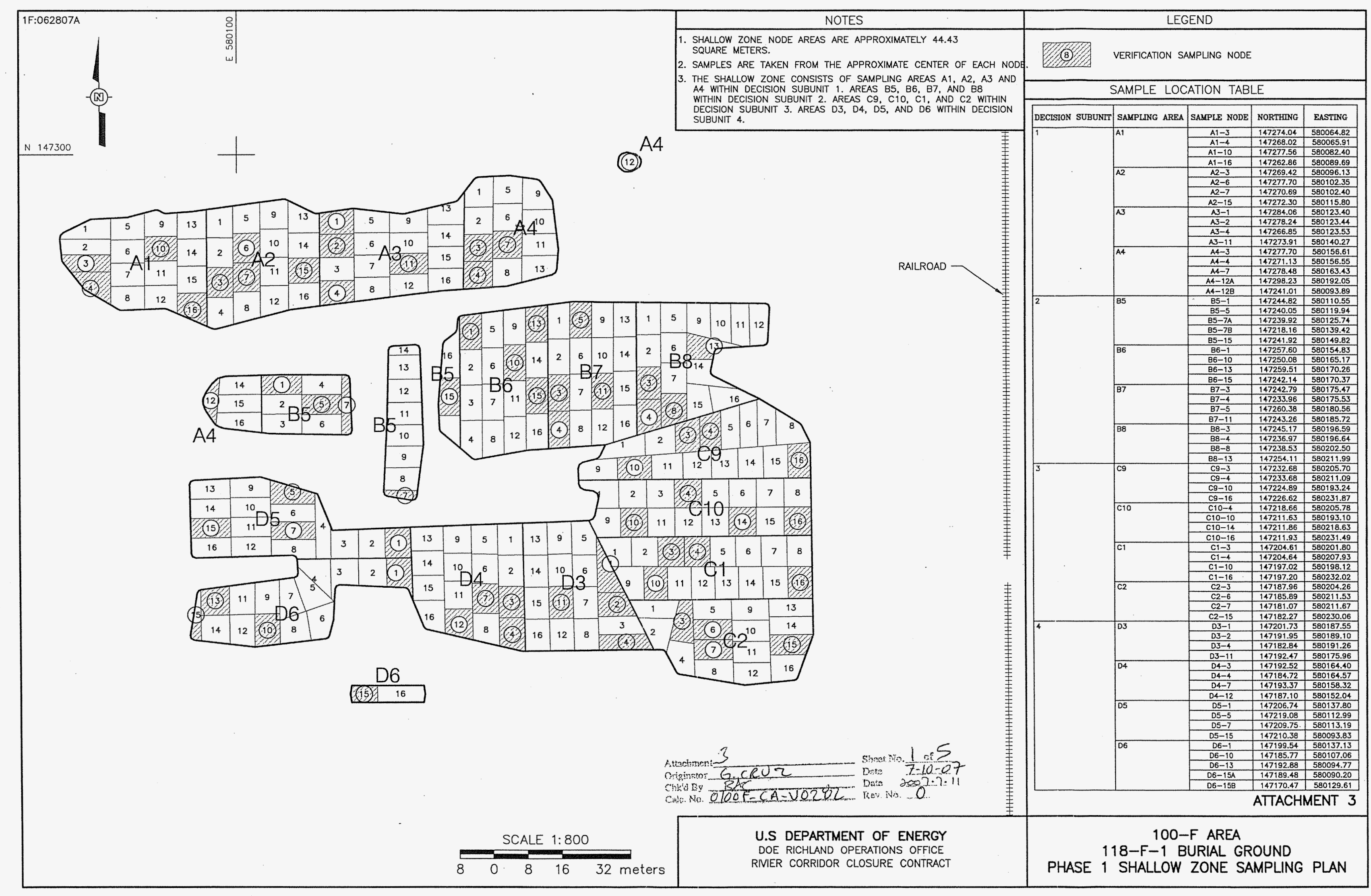




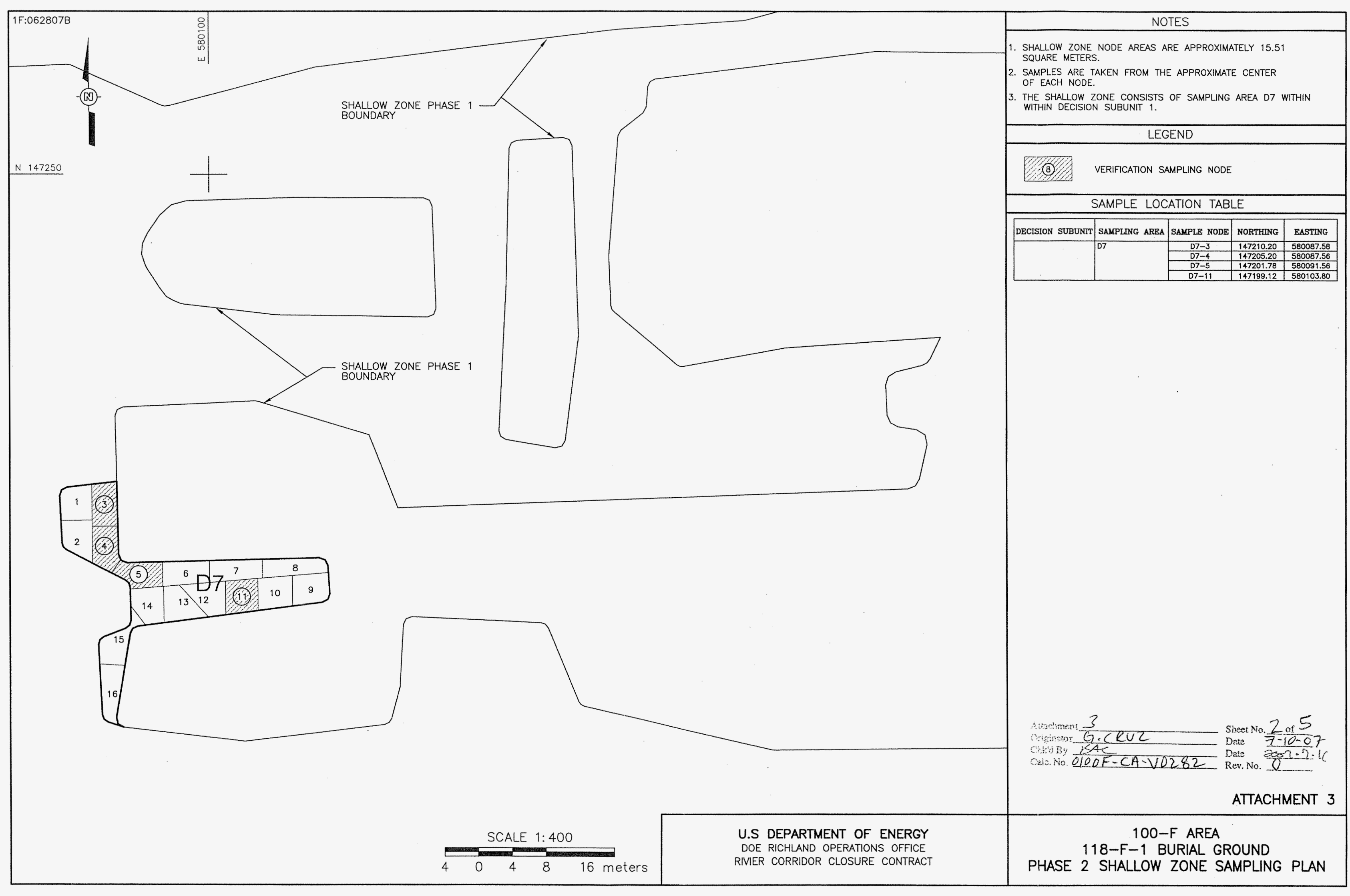




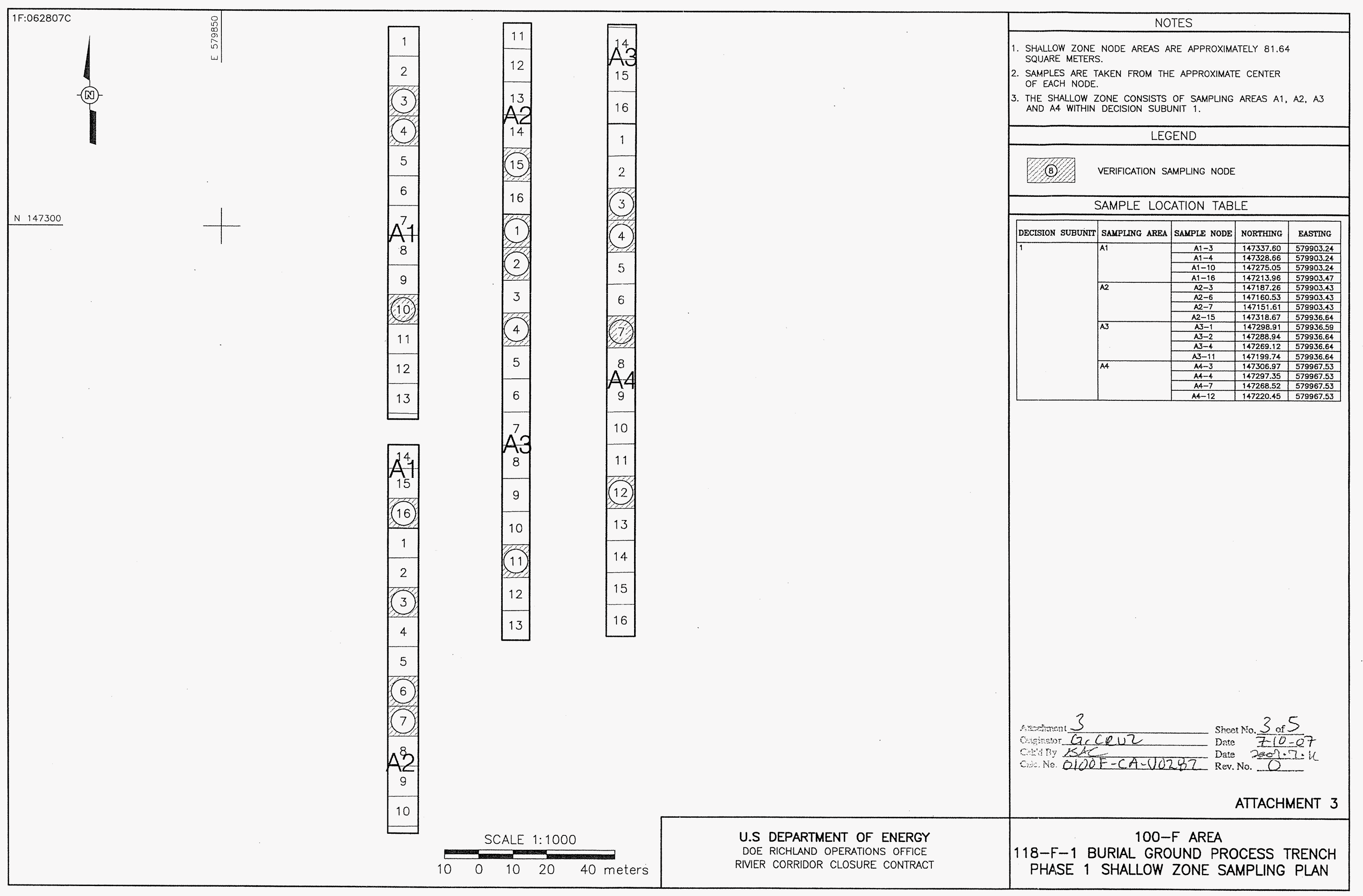




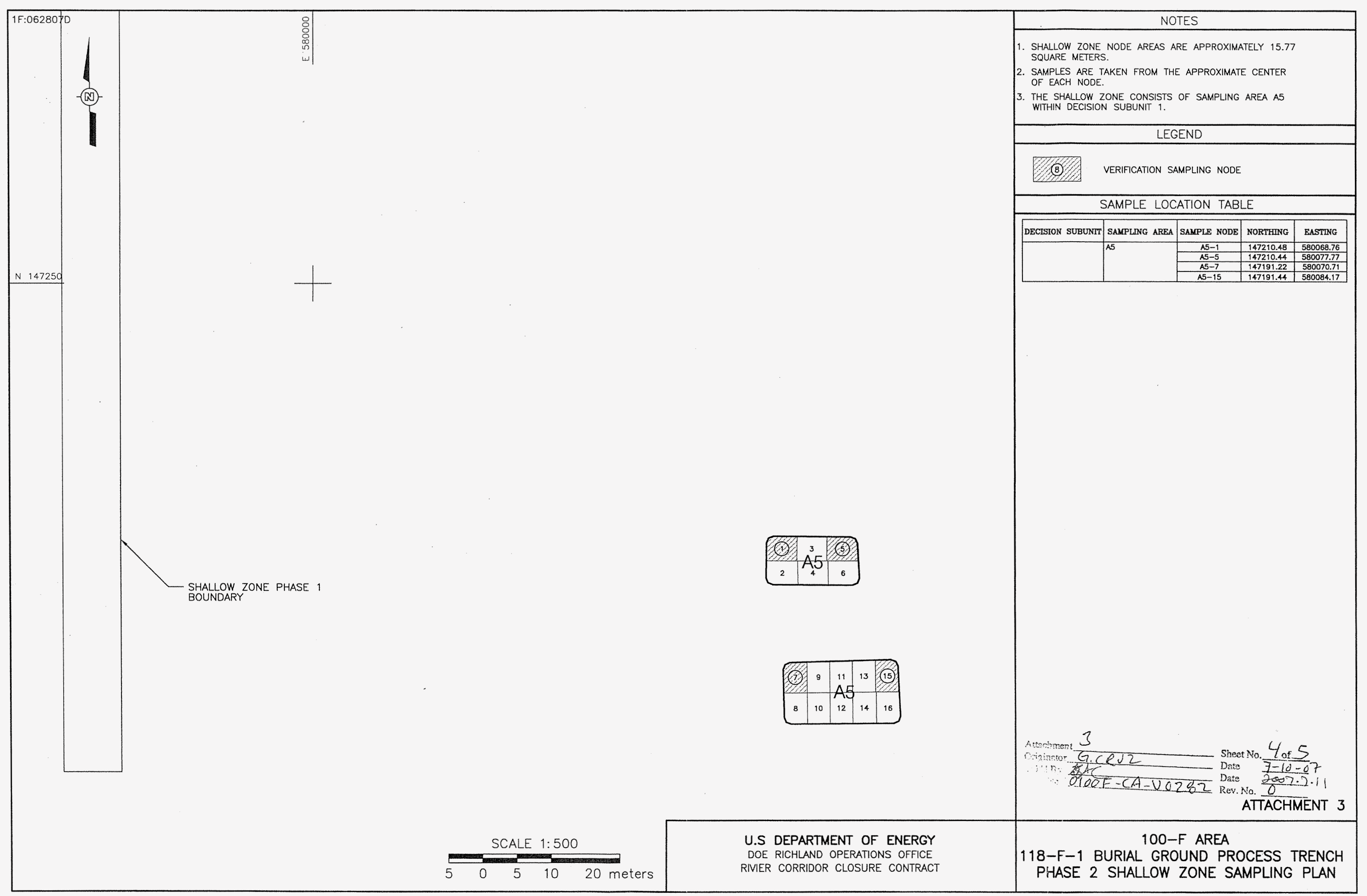




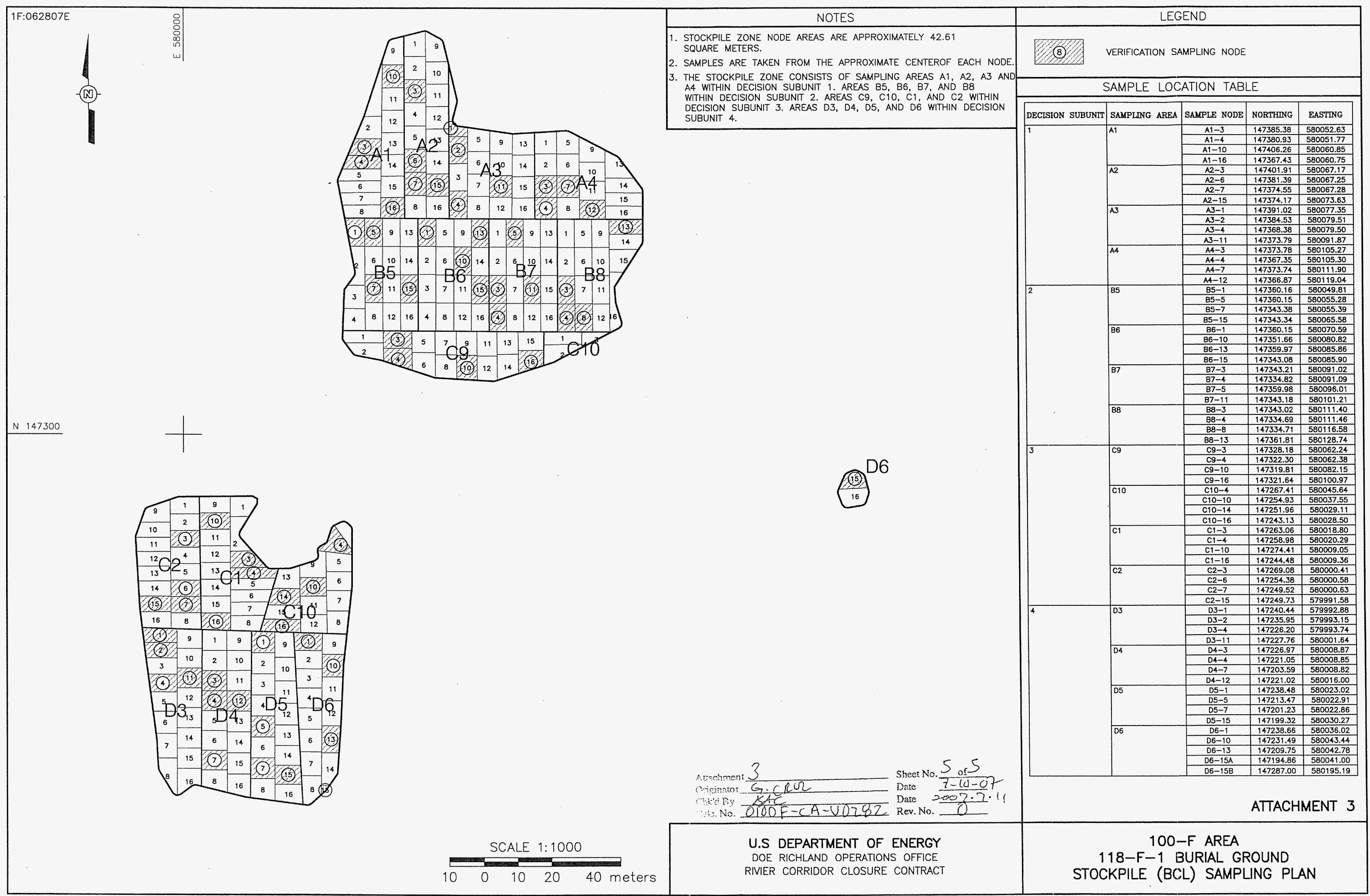




\section{CALCULATION COVER SHEET}

Project Title: 100-F Area Field Remediation

Job No. 14655

Area: $100-\mathrm{F}$

Discipline: Environmental

Calculation No: 0100F-CA-V0283

Subject: 118-F-1 Burial Ground Hazard Quotient and Carcinogenic Risk Calculation

Computer Program: Excel Program No: Excel 2003

The attached calculations have been generated to document compliance with established cleanup levels. These calculations should be used in conjunction with other relevant documents in the administrative record.

Committed Calculation $\bigotimes \quad$ Preliminary $\square \quad$ Superseded $\square \quad$ Voided

\begin{tabular}{|c|c|c|c|c|c|c|}
\hline Reve & Sheor Numbers & originator & Checker & Roviewer & Approval & D. Dare \\
\hline 0 & $\begin{array}{l}\text { Cover }=1 \\
\text { Summary }=3\end{array}$ & Egra & $\begin{array}{l}\text { K. A. Anselm } \\
\text { KC a Camarlma }\end{array}$ & $\begin{array}{l}\text { H. M. Sulloway } \\
\text { N.M. Sullorion }\end{array}$ & J.D. Fancher & $7 / 10 / 07$ \\
\hline & & & & & & \\
\hline & & & & & & \\
\hline & & & & & & \\
\hline
\end{tabular}

SUMMARY OF REVISION

\begin{tabular}{|l|l|}
\hline & \\
\hline & \\
& \\
& \\
\hline
\end{tabular}

WCH-DE-018 (05/08/2007)

DE $01-437.03$ 
Washington Closure Hanford, Inc. CALCULATION SHEET

Originator: E. J. Farris EnF

\begin{tabular}{r|r|r|r|l|}
\hline Project: & Date: & $07 / 12 / 07$ & Calc. No.: & 0100 F-CA-V0283 \\
\hline
\end{tabular}

Subject: $118-\mathrm{F}-1$ Burial Ground Hazard Quotient and Carcinogenic Risk Calculation

\begin{tabular}{c|c|} 
Rev.: & 0 \\
\hline Date: & $2 / 12 / 07$ \\
\hline
\end{tabular}

Sheet No. 1 of 3

\section{PURPOSE:}

Provide documentation to support the calculation of the hazard quotient (HQ) and carcinogenic (excess cancer) risk for the 118-F-1 Burial Ground Cleanup Verification Package. In accordance with the remedial action goals (RAGs) in the remedial design report/remedial action work plan (RDR/RAWP) (DOE-RL 2005), the following criteria must be met:

1) An $\mathrm{HQ}$ of $<1.0$ for all individual noncarcinogens

2) A cumulative $H Q$ of $<1.0$ for noncarcinogens

3) An excess cancer risk of $<1 \times 10^{-6}$ for individual carcinogens

4) A cumulative excess cancer risk of $<1 \times 10^{-5}$ for carcinogens.

\section{GIVEN/REFERENCES:}

1) DOE-RL, 2005, Remedial Design Report/Remedial Action Work Plan for the 100 Areas, DOE/RL-96-17, Rev. 5, U.S. Department of Energy, Richland Operations Office, Richland, Washington.

2) EPA, 1994, Guidance Manual for the Integrated Exposure Uptake Biokinetic Model for Lead in Children, EPA/540/R-93/081, Publication No. 9285.7-15-1, U.S. Environmental Protection Agency, Washington, D.C.

3) WAC 173-340, "Model Toxics Control Act - Cleanup," Washington Administrative Code, 1996.

4) WCH, 2007, 118-F-1 Burial Ground Cleanup Verification 95\% UCL Calculation, Calculation No. 0100F-CA-V0279, Washington Closure Hanford, Inc., Richland, Washington.

\section{SOLUTION:}

1) Generate an HQ for each noncarcinogenic constituent detected above background or required detection limit/practical quantitation limit and compare it to the individual HQ of $<1.0$ (DOE-RL 2005).

2) Sum the HQs and compare this value to the cumulative HQ of $<1.0$.

3) Generate an excess cancer risk value for each carcinogenic constituent detected above background or required detection limit/practical quantitation limit and compare it to the excess cancer risk of $<1 \times 10^{-6}$ (DOE-RL 2005).

4) Sum the excess cancer risk value(s) and compare it to the cumulative cancer risk of $<1 \times 10^{-5}$. 
Washington Closure Hanford, Inc. CALCULATION SHEET

\begin{tabular}{|c|c|c|c|c|c|c|c|}
\hline Originator: & E. J. Farris 2 f & Date: & $07 / 12 / 07$ & Calc. No.: & $0100 \mathrm{~F}-\mathrm{CA}-\mathrm{V} 0283$ & Rev.: & 0 \\
\hline Project: & 100-F Area Field Remediation & Job No: & 14655 & Checked: & K. A. Anselm Kaa & Date: & $71 / 2(0)$ \\
\hline Subject: & \multicolumn{5}{|c|}{ 118-F-I Burial Ground Hazard Quotient and Carcinogenic Risk Calculation } & \multicolumn{2}{|c|}{ Sheet No. 2 of 3} \\
\hline
\end{tabular}

\section{METHODOLOGY:}

Hazard quotient and carcinogenic risk calculations were computed using the data from the 118-F-1 Burial Ground Cleanup Verification 95\% UCL Calculation, Calculation No. 0100F-CA-V0279 (WCH 2007). Of the contaminants of concern and contaminants of potential concern in WCH (2007), boron and molybdenum require the HQ and risk calculations because these analytes were detected and a Washington State or Hanford Site background value is not available. Copper, lead, selenium, silver, and zinc are included because they were detected at a concentration above their respective Washington State or Hanford Site background value. Arsenic was detected above the Hanford Site Background value but below the WAC 173-340 Method A cleanup level. Due to the intent of Method A cleanup values and the allowance to use such values for arsenic (DOE-RL 2005), arsenic has been excluded from the Method B individual analyte and cumulative risk requirements. An example of the HQ and risk calculations is presented below:

1) For example, the maximum value for boron is $3.3 \mathrm{mg} / \mathrm{kg}$, divided by the noncarcinogenic RAG value of $16,000 \mathrm{mg} / \mathrm{kg}$ (boron is identified as a noncarcinogen in WAC 173-340-740[3]), is $2.1 \times 10^{-4}$. Comparing this value, and all other individual values, to the requirement of $<1.0$, this criteria is met.

2) After the HQ calculation is completed for the appropriate analytes, the cumulative HQ can be obtained by summing the individual values. The sum of the HQ values is $1.1 \times 10^{-1}$. Comparing this value to the requirement of $<1.0$, this criteria is met.

3) To calculate the excess cancer risk, the maximum value is divided by the carcinogenic RAG value, then multiplied by 0.000001 . There are no carcinogenic analytes detected above background levels; therefore, this calculation is not applicable and the requirement of $<1 \times 10^{-6}$ is met.

4) After these calculations are completed for the carcinogenic analytes, the cumulative excess cancer risk can be obtained by summing the individual values. There are no carcinogenic analytes detected above background levels; therefore, this calculation is not applicable and the requirement of $<1 \times 10^{-5}$ is met.

\section{RESULTS:}

1) List individual noncarcinogens and corresponding HQs $>1.0$ : None

2) List the cumulative noncarcinogenic $H Q>1.0$ : None

3) List individual carcinogens and corresponding excess cancer risk $>1 \times 10^{-6}$ : None

4) List the cumulative excess cancer risk for carcinogens $>1 \times 10^{-5}$ : None.

Table 1 shows the results of the calculations. 
Washington Closure Hanford, Inc. CALCULATION SHEET Originator: E. J. Farris EnF

\begin{tabular}{l|l|l|l|l|l} 
Project: & $100-\mathrm{F}$ Area Field Remediation & Job No: & 14655 & Checked: & K. A. Anselm $K a C$
\end{tabular}

Subject: $118-\mathrm{F}-1$ Burial Ground Hazard Quotient and Carcinogenic Risk Calculation

Table 1. Hazard Quotient and Excess Cancer Risk Results for 118-F-1 Burial Ground.

\begin{tabular}{|c|c|c|c|c|c|}
\hline $\begin{array}{l}\text { Contaminants of Potential Concern } \\
\text { and Contaminants of Concern }\end{array}$ & $\begin{array}{c}\text { Maximum or } \\
\text { Statistical Value }^{\mathrm{a}} \\
(\mathrm{mg} / \mathrm{kg})\end{array}$ & $\begin{array}{c}\text { Noncarcinogen } \\
\text { RAG }^{\mathbf{b}} \\
(\mathbf{m g} / \mathbf{k g})\end{array}$ & $\begin{array}{c}\text { Hazard } \\
\text { Quotient }\end{array}$ & $\begin{array}{c}\text { Carcinogen } \\
\text { RAG }^{\mathbf{b}} \\
(\mathrm{mg} / \mathrm{kg})\end{array}$ & $\begin{array}{l}\text { Carcinogen } \\
\text { Risk }\end{array}$ \\
\hline \multicolumn{6}{|l|}{ Metals } \\
\hline Boron & 3.3 & 16,000 & $2.1 \mathrm{E}-04$ & - & -- \\
\hline Copper & 126 & 2,960 & $4.3 \mathrm{E}-02$ & - & -- \\
\hline Lead $^{c}$ & 18 & 353 & $5.1 \mathrm{E}-02$ & $\cdots$ & - \\
\hline Molybdenum & 0.9 & 400 & $2.3 \mathrm{E}-03$ & -- & $-\cdots$ \\
\hline Selenium & 1.5 & 400 & $3.8 \mathrm{E}-03$ & $\ldots$ & $-\cdots$ \\
\hline Silver & 4.3 & 400 & 1.1E-02 & - & - \\
\hline Zinc & 95.3 & 24,000 & $4.0 \mathrm{E}-03$ & -. & $\overline{-\cdots}$ \\
\hline \multicolumn{6}{|c|}{ Totals } \\
\hline \multicolumn{3}{|c|}{ Cumulative Hazard Quotient: } & 1.1E-01 & & \\
\hline \multicolumn{5}{|l|}{ Cumulative Excess Cancer Risk: } & $0.0 \mathrm{E}+00$ \\
\hline \multicolumn{6}{|l|}{ Notes: } \\
\hline \multicolumn{6}{|l|}{$\mathrm{RAG}=$ remedial action goal } \\
\hline \multicolumn{6}{|c|}{$--=$ not applicable } \\
\hline \multicolumn{6}{|c|}{${ }^{\mathrm{a}}=$ From 118-F-1 Burial Ground Cleanup Verification 95\% UCL Calculation, Calculation No. 0100F-CA-V0279 (WCH 2007). } \\
\hline \multicolumn{6}{|c|}{$\mathrm{b}=$ Value obtained from Washington Administrative Code (WAC) 173-340-740(3), Method B, 1996, unless otherwise noted. } \\
\hline
\end{tabular}

\section{CONCLUSION:}

This calculation demonstrates that the 118-F-1 Burial Ground site meets the requirements for the hazard quotients and carcinogenic (excess cancer) risk as identified in the RDR/RAWP (DOE-RL 2005). 


\section{CALCULATION COVER SHEET}

Project Title: 100-F Field Remediation

Job No. 14655

Area: $100-\mathrm{F}$

Discipline: Environmental

${ }^{*}$ Calculation No: 0100F-CA-V0279

Subject: 118-F-1 Burial Ground Cleanup Verification 95\% UCL Calculations

Computer Program: Excel

Program No: Excel 2003

The attached calculations have been generated to document compliance with established cleanup levels. These calculations should be used in conjunction with other relevant documents in the administrative record.

Committed Calculation $\bar{\varnothing} \quad$ Preliminary $\Gamma$ Superseded $\Gamma \quad$ Voided $\Gamma$

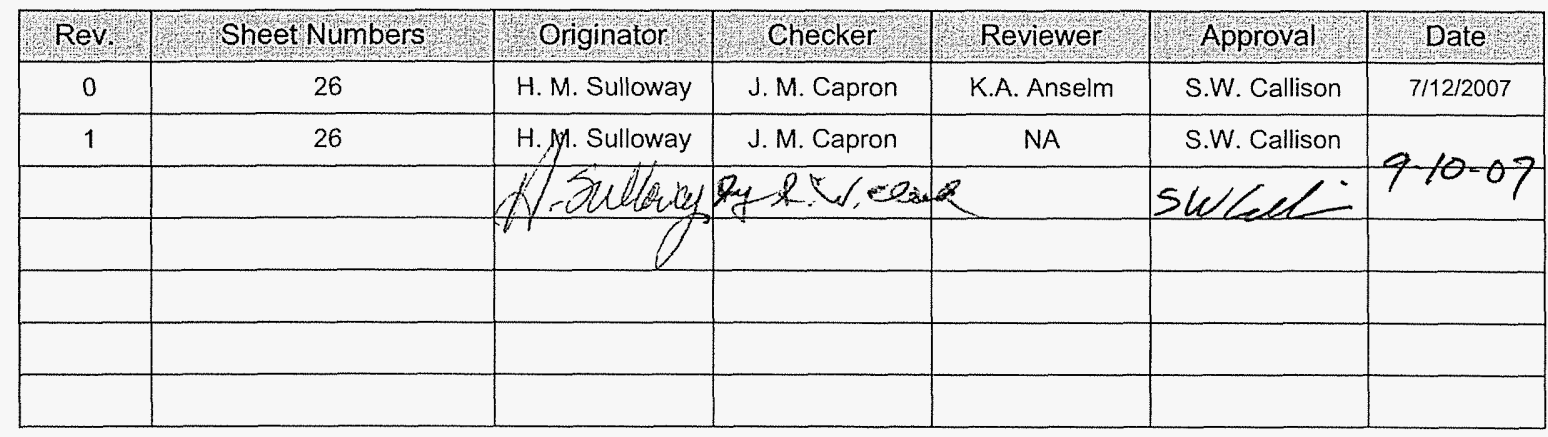

SUMMARY OF REVISION

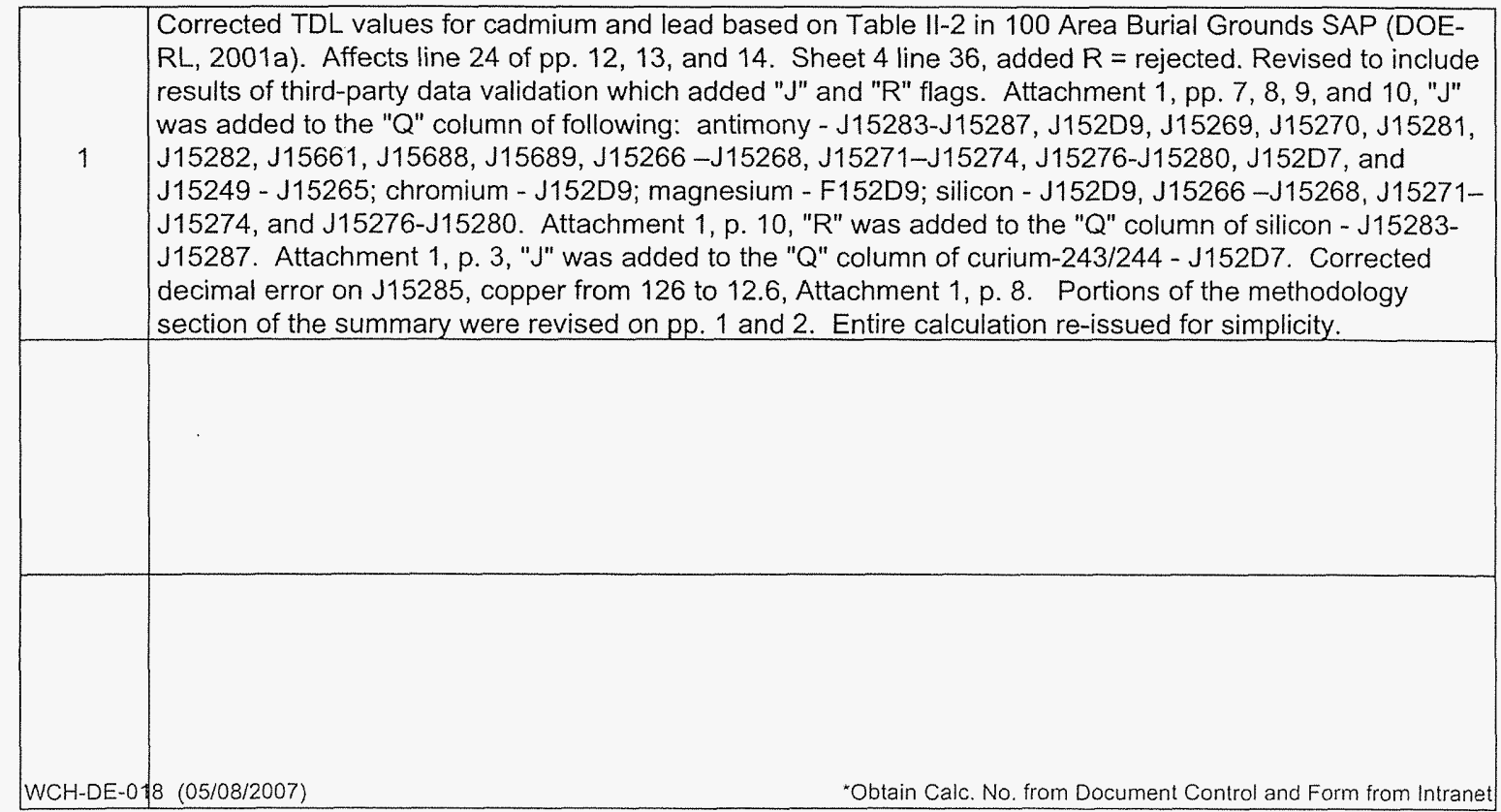




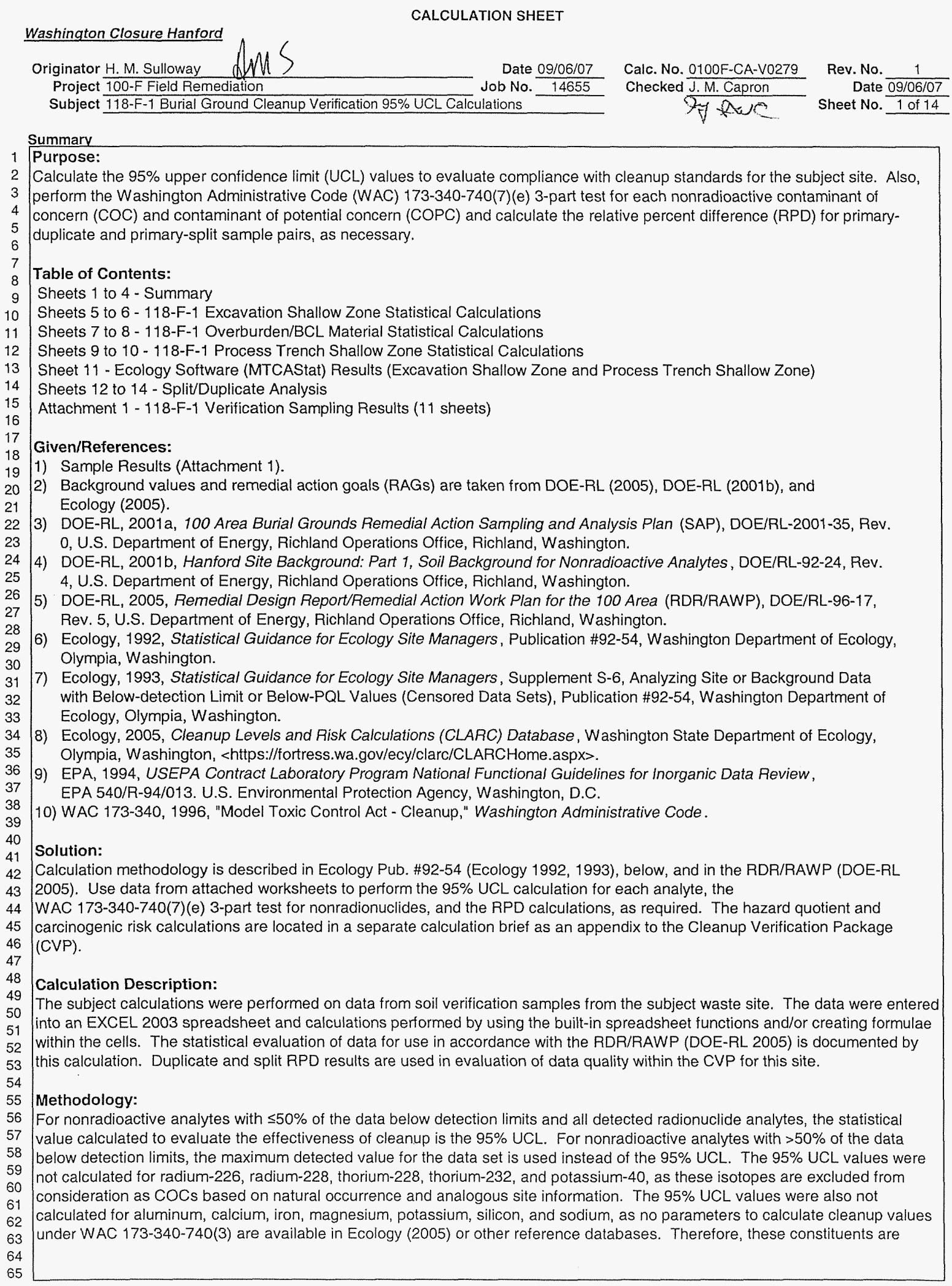




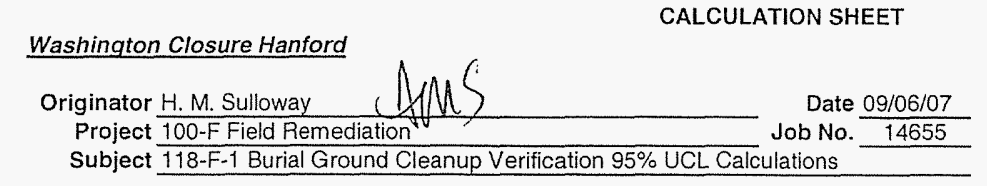

Summary (continued)

1 not considered site COCs/COPCs.

All calculations for Americium-241 and uranium isotopes were performed using data from isotope-specific analysis rather than data resulting from gamma spectroscopy.

(1)

Initial data results from the of split sample J152D7 showed significantly greater results of lead and cadmium than seen in the other split, or any other samples. Based on this review of the data, the laboratory was requested to reanalyze the sample. Results from the second analysis correlate well with the other data and replaced the original data for J152D7.

All nonradionuclide data reported as being undetected are set to $1 / 2$ the detection limit value for calculation of the statistics (Ecology 1993). For radionuclide data, calculation of the statistics is done using the reported value. In cases where the laboratory does not report a value below the minimum detectable activity (MDA), half of the MDA is used in the calculation. For the statistical evaluation of duplicate sample pairs, the samples are averaged before being included in the data set, after adjustments for censored data as described above.

For nonradionuclides, the WAC 173-340 statistical guidance suggests that a test for distributional form be performed on the data and the $95 \%$ UCL calculated on the appropriate distribution using Ecology software. For nonradionuclide small data sets ( $\mathrm{n}<10$ ) and all radionuclide data sets, the calculations are performed assuming nonparametric distribution, so no tests for distribution are performed. For nonradionuclide data sets of ten or greater, distributional testing and calculation of the $95 \%$ UCL is done using Ecology's MTCAStat software (Ecology 1993). Due to differences in addressing censored data between the RDR/RAWP (DOE-RL $2005 \mathrm{~b}$ ) and MTCAStat coding and due to a limitation in the MTCAStat coding (no direct capability to address variable quantitation limits within a data set), substitutions for censored data are performed before software input and the resulting input set treated as uncensored.

The WAC 173-340-740(7)(e) 3-part test is performed for nonradionuclide analytes only and determines if:

1) the $95 \%$ UCL exceeds the most stringent cleanup limit for each COPC/COC,

2) greater than $10 \%$ of the raw data exceed the most stringent cleanup limit for each COPC/COC

3) the maximum value of the raw data set exceeds two times the most stringent cleanup limit for each COPC/COC.

The RPD values are evaluated for analytes detected in a primary-duplicate or primary-split sample pair for the purposes of data quality assessment within the CVP. The RPD is calculated when both the primary value and the duplicate value for a given analyte are above detection limits and are greater than 5 times the target detection limit (TDL). The TDL is a laboratory detection limit predetermined for each analytical method, listed in Table II-2 of the SAP (DOE-RL 2001a). The RPD calculations use the following formula:

$$
\operatorname{RPD}=[|M-S| /((M+S) / 2)]^{*} 100
$$

where, $M=$ main sample value $\quad S=$ split (or duplicate) sample value

For quality assurance/quality control (QA/QC) split and duplicate RPD calculations, a value less than $30 \%$ indicates the data compare favorably. For regulatory splits, a threshold of $35 \%$ is used (EPA 1994). If the RPD is greater than $30 \%$ (or $35 \%$ for regulatory split data), further investigation regarding the usability of the data is performed. To assist in the identification of anomalous sample pairs, when an analyte is detected in the primary or duplicate/split sample, but was quantified at less than 5 times the TDL in one or both samples, an additional parameter is evaluated. In this case, if the difference between the primary and duplicate/split results exceeds a control limit of 2 times the TDL, further assessment regarding the usability of the data is performed. Additional discussion is provided in the data quality assessment section of the applicable CVP, as necessary.

The results presented in the summary tables that follow are for use in risk analysis and the CVP for this site. In addition to the statistical samples collected at the subject site, focused samples were collected from selected locations based on observations made during site remediation. Statistical methodology is not applicable to non-statistical sampling, and direct evaluation of detected values will be used as the compliance basis. 


\section{CALCULATION SHEET}

\section{Washington Closure Hanford \\ Originator H.M. Sulloway $\mathrm{WMS}$ \\ Project 100 -F Field Remediation \\ Subject $118-F-1$ Burial Ground Cleanup Verification $95 \%$ UCL Calculation}

Summary (continued)

1 Excavation Shallow Zone - WAC 173-340 3-Part Test for most stringent RAG

2 95\% UCL > Cleanup Limit?

$3>10 \%$ above Cleanup Limit?

NO

4 Any sample $>2 \times$ Cleanup Limit?

6 All data sets evaluated meet the 3-part test criteria when compared

7 to the most stringent cleanup limit.

8

9 OB/BCL - WAC 173-340 3-Part Test for most stringent RAG:

$1095 \%$ UCL > Cleanup Limit?

$11>10 \%$ above Cleanup Limit?
12 Any sample $>2 x$ Cleanup Limit?

YES

YES

14 Because of the "yes" answer to the 3-part test for lead,

15 additional evaluation of the attainment of cleanup criteria will be

16 performed.

18 Process Trench Shallow Zone - WAC 173-340 3-Part Test for most stringent RAG:

19 95\% UCL > Cleanup Limit?

YES

$20>10 \%$ above Cleanup Limit?

21 Any sample $>2 x$ Cleanup Limit?

YES

22

23 Because of the "yes" answer to the 3-part test for lead,

24 additional evaluation of the attainment of cleanup criteria will be

25 performed.
Calc. No. 0100F-CA-V0279

Checked J.M. Capron

Presue
Rev. No.

Date 09/06/07

Sheet No. 3 of 14 
Rev. 0

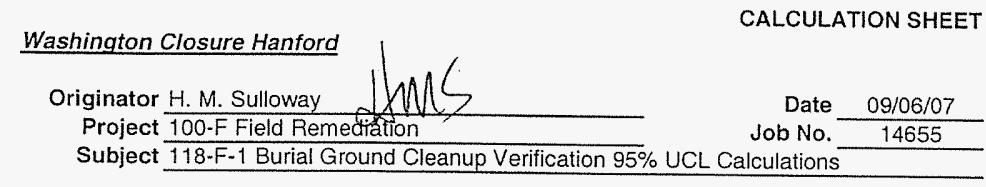

1 Summary (continued)

\begin{tabular}{|c|c|c|c|c|c|}
\hline \multirow[t]{2}{*}{2} & \multicolumn{5}{|c|}{ Results Summary } \\
\hline & Analyte & $\begin{array}{c}\text { Excavation } \\
\text { Shallow Zone }\end{array}$ & OB-BCL & $\begin{array}{c}\text { Process Trench } \\
\text { Shallow Zone }\end{array}$ & Units \\
\hline 4 & Americium-241 & 0.063 & 0.23 & 0.089 & $\mathrm{pCi} / \mathrm{g}$ \\
\hline 5 & Carbon-14 & 0.83 & 1.9 & 0.32 & $\mathrm{pCi} / \mathrm{g}$ \\
\hline 6 & Cesium-137 & 0.21 & $0(<B G)$ & 0.45 & $\mathrm{pCi} / \mathrm{g}$ \\
\hline 7 & Cobalt- 60 & 0.038 & 0.0075 & 0.074 & $\mathrm{pCi} / \mathrm{g}$ \\
\hline 8 & Europium-152 & 0.054 & 0.041 & 0.14 & $\mathrm{pCl} / \mathrm{g}$ \\
\hline 9 & Europium-154 & 0.053 & 0.018 & 0.063 & $\mathrm{pCi} / \mathrm{g}$ \\
\hline 10 & Nickel-63 & 2.3 & 2.5 & 4.4 & $\mathrm{pCi} / \mathrm{g}$ \\
\hline 11 . & Plutonium-238 & 0.028 & 0.16 & 0.10 & $\mathrm{pCi} / \mathrm{g}$ \\
\hline 12. & Plutonium-239/240 & 0.11 & 0.13 & 0.13 & $\mathrm{pCi} / \mathrm{g}$ \\
\hline 13 & Silver-108m & 0.017 & 0.011 & 0.013 & $\mathrm{pCi} / \mathrm{g}$ \\
\hline 14 & Strontium-90 & 0.38 & $0(<B G)$ & 0.22 & $\mathrm{pCi} / \mathrm{g}$ \\
\hline 15 & Tritium $(\mathrm{H}-3)$ & 1.4 & 2.5 & 2.0 & $\mathrm{pCi} / \mathrm{g}$ \\
\hline 16 & Uranium-238 & $0(<B G)$ & $0(<B G)$ & $O(<B G)$ & $\mathrm{pCi} / \mathrm{g}$ \\
\hline 17 & Cadmium & 0.10 & 0.00 & 0.10 & $\mathrm{mg} / \mathrm{kg}$ \\
\hline 18 & Lead & 5.4 & 12 & 18 & $\mathrm{mg} / \mathrm{kg}$ \\
\hline 19 & Mercury & 0.00 & 0.00 & 0.020 & $\mathrm{mg} / \mathrm{kg}$ \\
\hline
\end{tabular}

21 Abbreviations/Acronyms:

$22 \mathrm{BCL}=$ below cleanup levels

$23 \mathrm{BG}=$ background

$24 \mathrm{COC}=$ contaminant of concern

$25 \mathrm{COPC}=$ contaminant of potential concern

$26 \mathrm{CVP}=$ Cleanup Verification Package

$27 \mathrm{GW}=$ groundwater

$28 \mathrm{MDA}=$ minimum detectable activity

29 MTCA $=$ Model Toxics Control Act

$30 \mathrm{NA}=$ not applicable

$31 \mathrm{OB}=$ overburden

$32 \mathrm{PQL}=$ practical quantitation limit

$33 P T=$ process trench

$34 \mathrm{Q}=$ qualifier

$35 \mathrm{QANQC}=$ quality assurance/quality control

$36 \mathrm{R}=$ rejected

36 RAG = remedial action goal

37 RDR/RAWP $=$ Remedial Design Report/Remedial Action Work Plan

38 RESRAD = RESidual RADioactivity (dose assessment model)

$39 \mathrm{RPD}=$ relative percent difference

40 SAP $=$ Sampling and Analysis Plan

$41 \mathrm{TDL}=$ target detection limit

$42 \mathrm{U}=$ undetected

$43 \mathrm{UCL}=$ upper confidence limit

$44 \mathrm{WAC}=$ Washington Administrative Code
Calc. No. 0100F-CA-V0279 Checked J.M. Capron

$$
2 y-x=0
$$

Rev. No. 1

Date $09 / 06 / 07$

Sheet No. 4 of 14 
CVP-2007-00001

Rev. 0

B-22 
Washington Closure Hanford

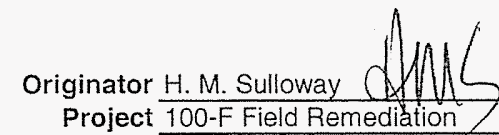

Subject 118-F-1 Burial Ground Cernup Verification $05 \%$ UCC Calculations

118-F-1 Excavation Shallow Zone Statistical Calculatio

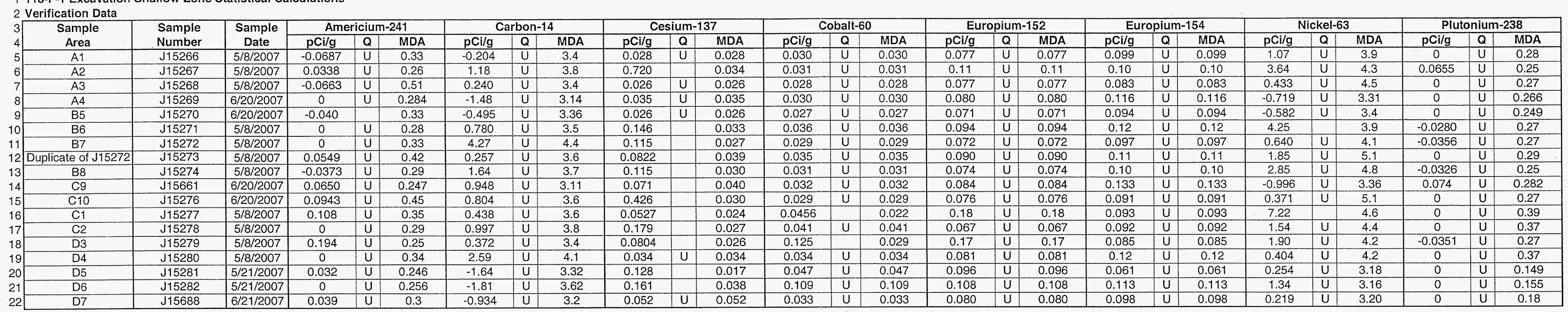

23 Statistical Computation Input Data

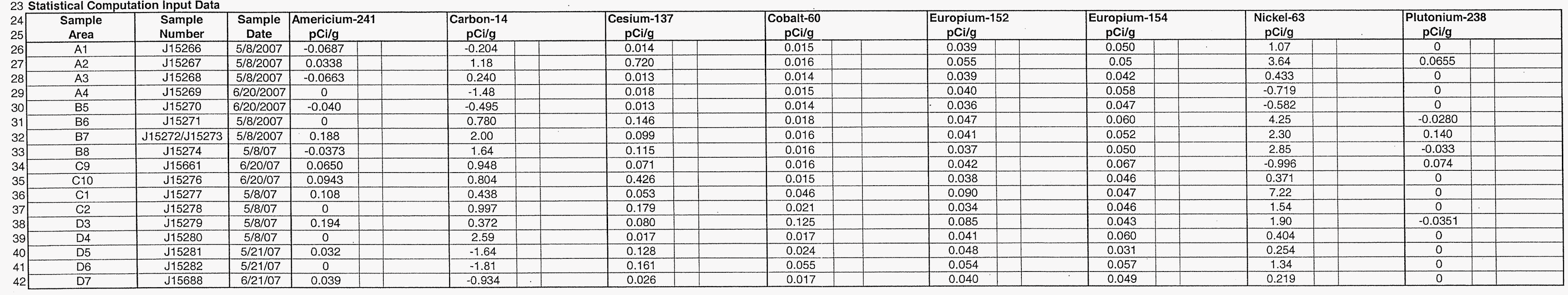

43 Statistical Computations

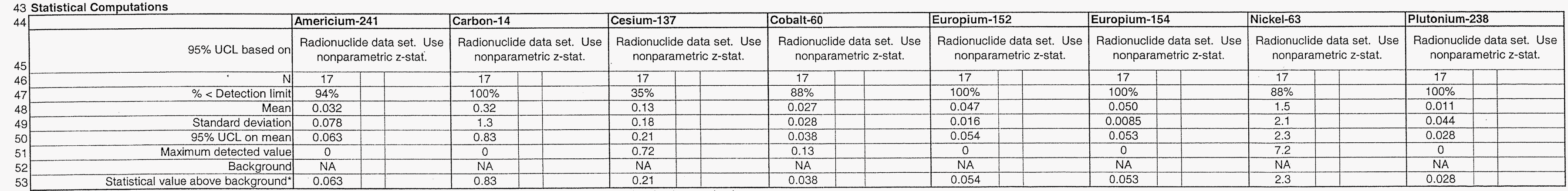

\begin{tabular}{|l|l|l|l|l|}
\hline 53 & Statistical value above background* & 0.063 & 0.83 & 0.21
\end{tabular}
CALCULATION SHEET

$$
\begin{gathered}
\text { Date } \frac{09 / 06 / 07}{14655} \\
\text { Job No. }
\end{gathered}
$$

Calc. No. $0100 \mathrm{~F}-\mathrm{CA}-\mathrm{V} 0279$

$$
\text { by tere }
$$

Rev. No. $\frac{1}{\text { Date }} \frac{1}{09 / 06 / 07}$

Date
heg/06/07
hof 14 


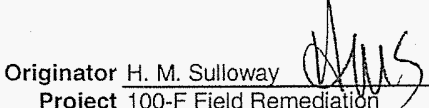

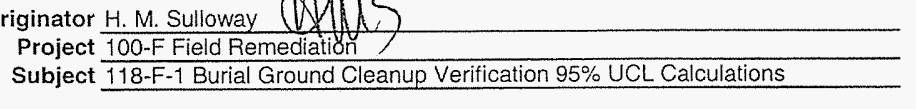

CALCULATION SHEET

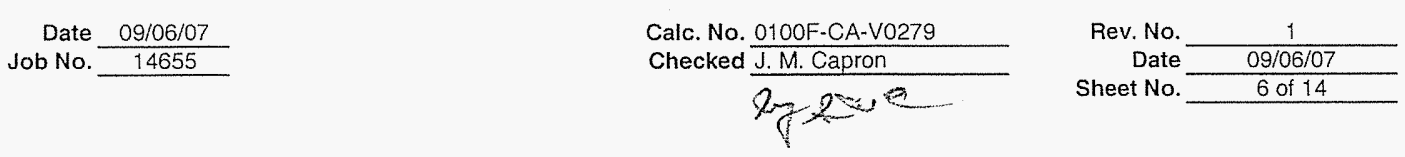
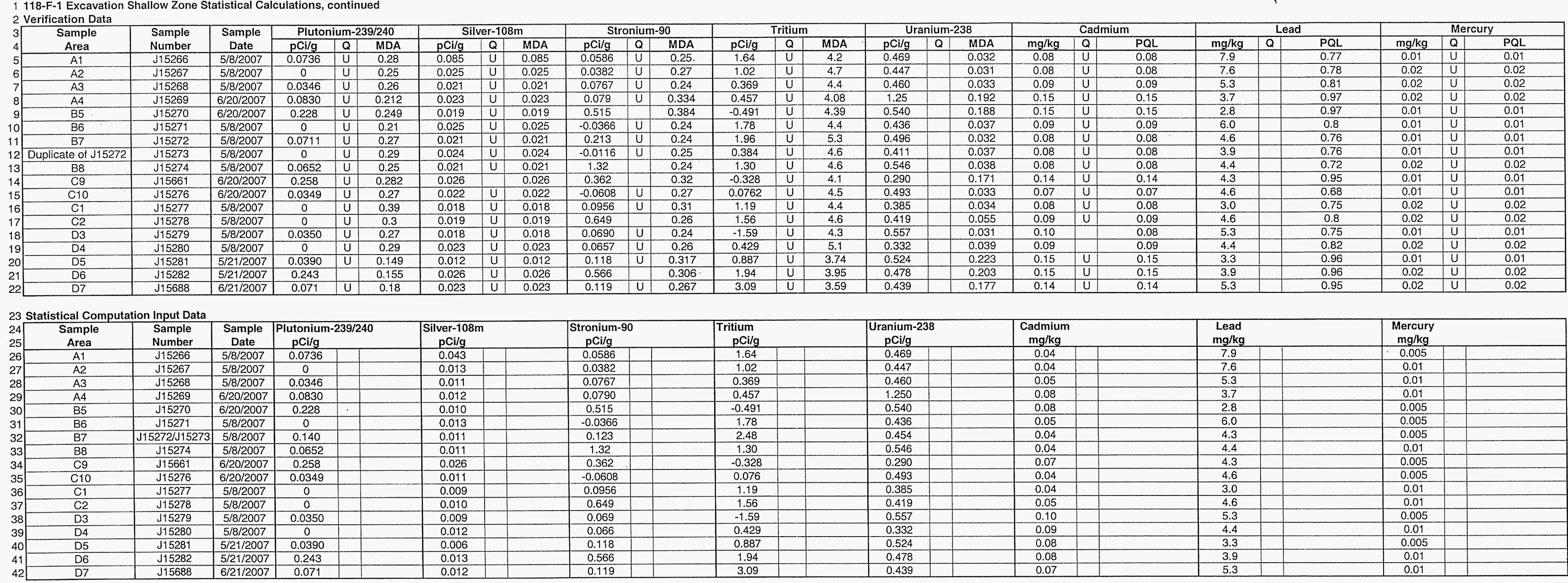

43 Statistical Computations

\begin{tabular}{|c|c|c|c|c|c|c|c|c|c|c|c|c|c|c|c|c|c|}
\hline \multirow{3}{*}{\multicolumn{2}{|c|}{$95 \%$ UCL based or }} & \multirow{2}{*}{\multicolumn{2}{|c|}{$\begin{array}{l}\text { Plutonium-239/240 } \\
\text { Radionuclide data set. Use } \\
\text { nonparametric z-stat. }\end{array}$}} & \multirow{2}{*}{\multicolumn{2}{|c|}{\begin{tabular}{|l} 
Silver-108m \\
$\begin{array}{l}\text { Radionulidid data set. Use } \\
\text { nonparametric z-stat. }\end{array}$
\end{tabular}}} & \multirow{2}{*}{\multicolumn{2}{|c|}{\begin{tabular}{|l} 
Stronium-90 \\
$\begin{array}{l}\text { Radionudide data set. Use } \\
\text { nonparamentic z-stat. }\end{array}$
\end{tabular}}} & \multirow{2}{*}{\multicolumn{2}{|c|}{\begin{tabular}{|l|} 
Tritium \\
$\begin{array}{l}\text { Radionuclide data set. Use } \\
\text { nonparametric z-stat. }\end{array}$
\end{tabular}}} & \multirow{2}{*}{\multicolumn{2}{|c|}{\begin{tabular}{|l|} 
Uranium-238 \\
$\begin{array}{l}\text { Radionudide data set. Use } \\
\text { nonparametric z-slat. }\end{array}$
\end{tabular}}} & \multirow{2}{*}{\multicolumn{2}{|c|}{$\begin{array}{l}\text { Cadmium } \\
\text { Greater than } 50 \% \text { below detection. } \\
\text { Default to max. value. }\end{array}$}} & \multirow{2}{*}{\multicolumn{2}{|c|}{$\begin{array}{l}\text { Lead } \\
\text { Large data set }(n>10) \text {, use } \\
\text { MTCAStat lognormal distribution. }\end{array}$}} & \multirow{3}{*}{\multicolumn{2}{|c|}{$\begin{array}{l}\text { Mercury } \\
\text { Greater than } 50 \% \text { below detection. } \\
\text { Default to max. value. }\end{array}$}} \\
\hline & & & & & & & & & & & & & & & & & \\
\hline & & 17 & & 17 & & 17 & & & & 17 & & & & & & & \\
\hline & $\%<$ Detection limit & $94 \%$ & & $94 \%$ & & & & & & & & & & & & & \\
\hline \multirow{4}{*}{50} & & 0.077 & & $\frac{0.013}{0.0085}$ & & 0.24 & & 0.93 & & 0.50 & & 0.059 & & $\frac{4.7}{14}$ & & 0.0076 & \\
\hline & $\begin{array}{l}\text { Standard deviation, } \\
95 \% \text { UCL on mean }\end{array}$ & 0.080 & & $\begin{array}{l}0.0065 \\
0.017\end{array}$ & & $\begin{array}{l}0.35 \\
0.38 \\
\end{array}$ & 7 & $\frac{1.2}{1.4}$ & & $\begin{array}{l}0.21 \\
0.58 \\
\end{array}$ & & $\begin{array}{l}0.021 \\
0.067\end{array}$ & & $\frac{1.4}{5.4}$ & & $\begin{array}{l}0.0026 \\
0.0087\end{array}$ & \\
\hline & Maximum detected value & 0.24 & & 0.026 & & 1.3 & & 0 & & $\frac{1.3}{1.1}$ & & $\frac{0.10}{\mathrm{NA}}$ & & $\frac{7.9}{N A}$ & & 0.00 & \\
\hline & $\begin{array}{l}\text { Statistical value above backgroundo } \\
t^{*}\end{array}$ & $\frac{N A}{0.11}$ & & $\begin{array}{l}\mathrm{NA} \\
0.017 \\
\end{array}$ & & $\frac{\mathrm{NA}}{0.38}$ & & $\frac{\mathrm{NA}}{1.4}$ & 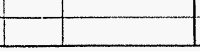 & $0(<B G)$ & $\square$ & $\frac{\mathrm{NA}}{0.10}$ & & $\frac{\mathrm{NA}}{5.4}$ & & 0.00 & \\
\hline \multirow{2}{*}{\multicolumn{2}{|c|}{ 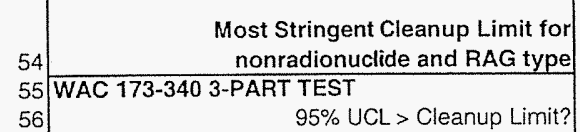 }} & & & & & & & & & & & & & & & & \\
\hline & & & & & & & & & & & & \multicolumn{2}{|l|}{$\mathrm{NA}$} & \multirow{2}{*}{\multicolumn{2}{|c|}{$\frac{N A}{N A}$}} & \multirow{2}{*}{\multicolumn{2}{|c|}{$\begin{array}{l}\mathrm{NA} \\
\mathrm{NA} \\
\end{array}$}} \\
\hline & $\begin{array}{l}>5 \% \text { absve Cleanup Limit? } \\
>10 \% \text { ? }\end{array}$ & & & & & & & & & & & \multirow{2}{*}{\multicolumn{2}{|c|}{$\frac{N A}{N A}$}} & & & & \\
\hline & Any sample $>2 \times$ Cleanup Limit? & & & & & & & & & & & & & \multirow{2}{*}{\multicolumn{2}{|c|}{ 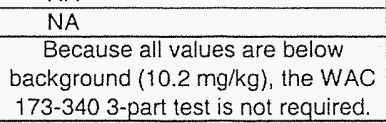 }} & \multirow{2}{*}{\multicolumn{2}{|c|}{ 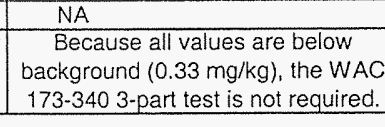 }} \\
\hline & WAC 173-340 Compliance? & & & & & & & & & & & \multicolumn{2}{|c|}{ 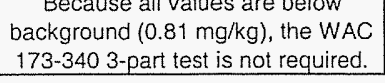 } & & & & \\
\hline
\end{tabular}


Washington Closure Hanford

Originator H.M. Sulloway $)$ LMUS Project $\frac{100-F \text { Field Rermediation }}{118-F-1 \text { Burial Ground Cleanup Verification } 95 \% \text { UCL Calculations }}$ Subjet
CALCULATION SHEET

Date $\frac{09 / 06 / 07}{14655}$
Job No.
Calc. No. 0100F-CA-V0279 lo sure
Rev. No. $\frac{1}{09 / 06 / 07}$ $\begin{aligned} \text { Date } & \frac{1}{09 / 06 / 07} \\ \text { Sheet No. } & \text { of } 14\end{aligned}$

1 118-F-1 Overburden/BCL Material Statistical Calculation

\begin{tabular}{|c|c|c|c|c|c|c|c|c|c|c|c|c|c|c|c|c|c|c|c|c|c|c|c|c|c|c|c|}
\hline \multirow{3}{*}{\multicolumn{2}{|c|}{$\begin{array}{c}\begin{array}{c}\text { amplea } \\
\text { Area } \\
\text { A1 }\end{array}\end{array}$}} & \multirow{2}{*}{$\begin{array}{l}\text { Sample } \\
\text { Number }\end{array}$} & \multirow{2}{*}{$\begin{array}{c}\text { Sample } \\
\text { Date }\end{array}$} & \multicolumn{3}{|c|}{ Americium-241 } & \multicolumn{3}{|c|}{ Carbon-14 } & \multicolumn{3}{|c|}{ Cesium-137 } & \multicolumn{3}{|c|}{ Cobalt-60 } & \multicolumn{3}{|c|}{ Europium-152 } & \multicolumn{3}{|c|}{ Europium-154 } & \multirow{2}{*}{\multicolumn{3}{|c|}{ Nickel-63 }} & \multirow{2}{*}{\multicolumn{3}{|c|}{$\begin{array}{l}\text { Plutonium-238 } \\
\end{array}$}} \\
\hline & & & & pCi/g & & MDA & $\mathrm{pCi} / \mathrm{g}$ & & MDA & $\mathrm{pCi} / \mathrm{g}$ & Q & MDA & $\mathrm{pCi} / \mathrm{g}$ & $Q$ & MDA & $\mathrm{pCi} / \mathrm{g}$ & Q & MDA & $\mathrm{pCi} / \mathrm{g}$ & Q & MDA & $\mathrm{pCi/g}$ & & & $\mathrm{pCi} / \mathrm{g}$ & & MDA \\
\hline & A1 & & & -0.0434 & $\bar{U}$ & 0.42 & -0.931 & $U$ & $\frac{2.5}{35}$ & & & 0.041 & 0.032 & $\frac{U}{U}$ & 0.032 & & $\frac{U}{U 1}$ & & 0.1 & 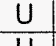 & 0.1 & 0.904 & $U$ & 4.8 & -0.0321 & U & 0.35 \\
\hline & $\frac{A 2}{A 3}$ & $\begin{array}{ll}115250 \\
115251\end{array}$ & & -0.0304 & U & 0.23 & -1.48 & U & $\begin{array}{l}3.5 \\
3.39\end{array}$ & 0.039 & $\frac{U}{U}$ & 0.039 & 0.031 & $\frac{U}{11}$ & 0.031 & 0.075 & 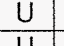 & 0.075 & 0.093 & $\begin{array}{l}U \\
\end{array}$ & 0.093 & 2.66 & U & 4.9 & 0.0351 & $\begin{array}{l}U \\
1\end{array}$ & 0.27 \\
\hline & A3 & $\frac{J 15251}{\sqrt{15252}}$ & $5 / 2 / 2007$ & 0 & 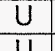 & 0.26 & $\begin{array}{l}-0.433 \\
-0.078 \\
x\end{array}$ & U & 3.9 & 0.027 & $\frac{u}{u}$ & 0.027 & 0.025 & $\frac{U}{11}$ & 0.025 & 0.066 & $\frac{U}{11}$ & 0.066 & 0.09 & $\begin{array}{l}U \\
1\end{array}$ & $\begin{array}{r}0.09 \\
0092 \\
092\end{array}$ & 1.03 & $\frac{U}{11}$ & 4.7 & 0.0777 & $\frac{U}{11}$ & 0.25 \\
\hline & $\frac{\mathrm{A} 4}{\mathrm{~B} 5}$ & $\frac{115222}{115253}$ & 212007 & $\begin{array}{c}0 \\
-0.0384\end{array}$ & $\frac{U}{u}$ & $\begin{array}{l}0.3 \\
0.29 \\
Y\end{array} \mathrm{l}$ & $\begin{array}{l}-0.978 \\
-0.0977\end{array}$ & $\frac{u}{u}$ & $\frac{3.5}{3.8}$ & $\frac{0.035}{0.0434}$ & & & & $\frac{U}{U}$ & $\begin{array}{l}0.031 \\
0.032\end{array}$ & $\frac{0.089}{0.087}$ & $\frac{u}{u}$ & $\begin{array}{l}0.089 \\
0.087\end{array}$ & 0.092 & $\frac{u}{u}$ & $\frac{0.092}{0.11}$ & $\begin{array}{l}0.256 \\
-0.183 \\
-18\end{array}$ & $u$ & $\frac{4.4}{3.9}$ & $\frac{0}{0}$ & $\frac{U}{U}$ & 0.21 \\
\hline & $\mathrm{B} 6$ & & & 0 & $u$ & & & U & 3.9 & 0.0346 & & & & U & & 0.075 & $\bar{U}$ & & 0.096 & $\frac{U}{U}$ & & 0.688 & $\vec{U}$ & $\frac{3.9}{4.2}$ & 0.0662 & $\mathrm{u}$ & 0.25 \\
\hline & & & & 0 & U & & & U & 4. & & U & & & U & & & U & & 0.096 & U & & 0 & U & 3.7 & 0.034 & U & 0.26 \\
\hline & B8 & & & -0.041 & $U$ & & & U & 3.7 & & & & & $u$ & & 0.086 & U & & 0.091 & U & & 0.225 & $U$ & 3.9 & 0 & U & 0.38 \\
\hline & $\mathrm{C9}$ & & & & $u$ & 0.062 & & & 3.4 & & u & 0.4 & & $U$ & & 0.077 & $U$ & & 0.11 & $U$ & & 0 & $U$ & 3.6 & 0 & $U$ & 0.31 \\
\hline & $\mathrm{C10}$ & & & 0.599 & & & -0.041 & $U$ & 3.3 & 0.0 & & & & $U$ & & 0.073 & $U$ & 0.0 & 0.089 & $U$ & 0.08 & 1.50 & $U$ & 6.6 & -0.0783 & $U$ & 0.43 \\
\hline & C1 & & $5 / 3 / 2$ & 0 & $U$ & 0.3 & & $U$ & $\begin{array}{l}3.7 \\
3.3\end{array}$ & 0.0483 & & 0.041 & 0.037 & U & & 0.087 & U & & 0.11 & U & 0.1 & & $\cup$ & 6.1 & -0.0501 & $U$ & 0.38 \\
\hline & $\begin{array}{l}\mathrm{C} 2 \\
\mathrm{D} 3\end{array}$ & & $5 / 3 / 2007$ & -0.032 & $\frac{U}{u}$ & 0.31 & $\begin{array}{c}-0.412 \\
-0.442\end{array}$ & $\frac{U}{u}$ & $\frac{3.3}{4}$ & $\frac{0.0592}{0.0556}$ & & $\begin{array}{l}0.029 \\
0.029\end{array}$ & $\frac{0.028}{0.028}$ & $\frac{U}{U}$ & & $\frac{0.082}{0.073}$ & $\frac{U}{U}$ & $\frac{0.082}{0.073}$ & $\begin{array}{l}0.088 \\
0.093\end{array}$ & $\frac{U}{u}$ & $\frac{0.088}{0.093}$ & $\begin{array}{l}0.698 \\
0.872\end{array}$ & $\frac{U}{U}$ & $\frac{6.5}{6.5}$ & $\frac{0.0947}{0}$ & $\frac{U}{U}$ & 0.24 \\
\hline & Duplicate & & & & 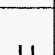 & & & 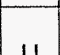 & & 0.030 & & & & & & & 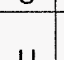 & & & 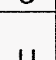 & & & 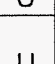 & & 0091 & & \\
\hline & $\begin{array}{l}\frac{J 15261}{D 4} \\
\mathrm{D} 4\end{array}$ & & & $\frac{-.000}{0.032}$ & $\frac{U}{U}$ & & & & & & & & & u & & 0.086 & & 0.086 & 0.12 & $U$ & & $\begin{array}{c}0.410 \\
-0.115\end{array}$ & $U$ & $\begin{array}{l}6.2 \\
0.43\end{array}$ & 0.0281 & $u$ & $\frac{0.27}{0.29}$ \\
\hline & D5 & $\frac{J 15263}{J 15264}$ & & $\begin{array}{r}-.0064 \\
-0.0982 \\
\end{array}$ & $\bar{U}$ & $\begin{array}{l}0.38 \\
\end{array}$ & $\begin{array}{r}-0.01 \\
-1.51\end{array}$ & $\mathrm{U}$ & $\begin{array}{l}3.0 \\
3.8\end{array}$ & 0.0449 & & 0.03 & 0.028 & $\mathrm{U}$ & 0.028 & 0.082 & $u$ & 0.082 & 0.09 & $\bar{U}$ & 0.09 & 0.0953 & $U$ & 0.36 & 0.0476 & U & 0.36 \\
\hline
\end{tabular}

\section{Statistical Computation Input Data}

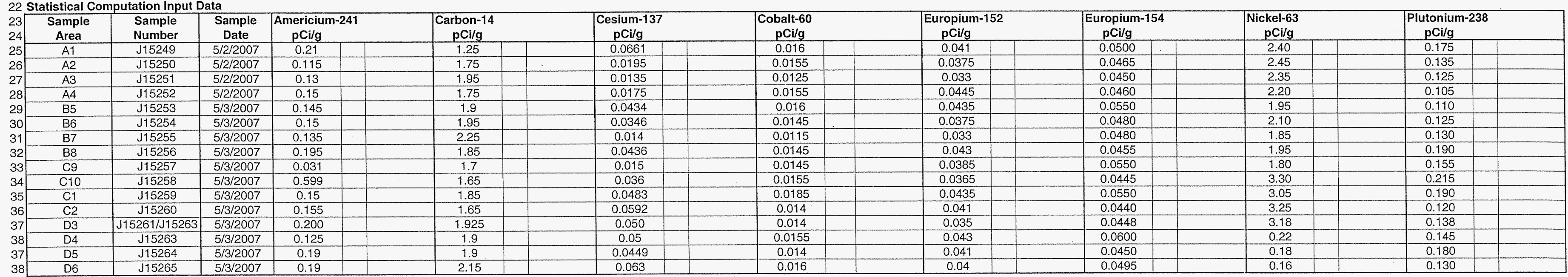

\section{Statistical Computation}

Cesium-137

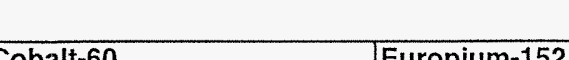

uropium-154

Nickel-63 Plutonium-238

\begin{tabular}{|c|c|c|c|c|c|c|c|c|c|c|c|c|c|c|c|c|c|c|}
\hline \multirow{3}{*}{41} & 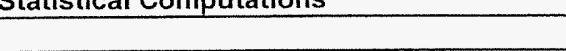 & \multicolumn{2}{|c|}{ Americium-241 } & \multicolumn{2}{|c|}{ Carbon-14 } & \multicolumn{4}{|c|}{ Cesium-137 } & \multicolumn{2}{|c|}{ Europium-152 } & \multicolumn{2}{|c|}{ Europium-154 } & \multicolumn{3}{|c|}{ Nickel-63 } & \multicolumn{2}{|c|}{ Plutonium-238 } \\
\hline & $95 \%$ UCL based on & $\begin{array}{r}\text { Radionuc } \\
\text { nonpa }\end{array}$ & $\begin{array}{l}\text { e data set. Use } \\
\text { metric } z \text {-stat. }\end{array}$ & $\begin{array}{r}\text { Radionuc } \\
\text { nonpa }\end{array}$ & $\begin{array}{l}\text { e data set. Use } \\
\text { metric z-stat. }\end{array}$ & $\begin{array}{c}\text { Radionucli } \\
\text { nonparz }\end{array}$ & $\begin{array}{l}\text { e data set. Use } \\
\text { netric } z \text {-stat. }\end{array}$ & \begin{tabular}{|c} 
Radionuc \\
nonpa
\end{tabular} & $\begin{array}{l}\text { de data set. Use } \\
\text { ametric z-stat. }\end{array}$ & \begin{tabular}{|c|} 
Radionuc \\
nonpal
\end{tabular} & $\begin{array}{l}\text { e data set. Use } \\
\text { metric } z \text {-stat. }\end{array}$ & $\begin{array}{c}\text { Radionuc } \\
\text { nonpa }\end{array}$ & $\begin{array}{l}\text { e data set. Use } \\
\text { metric z-stat. }\end{array}$ & $\begin{array}{l}\text { Radionur } \\
\text { nonpa }\end{array}$ & $\begin{array}{l}\text { de da } \\
\text { mets }\end{array}$ & $\begin{array}{l}\text { ta set. Use } \\
\text { ric z-stat. }\end{array}$ & $\begin{array}{l}\text { Radionuc } \\
\text { nonpal }\end{array}$ & $\begin{array}{l}\text { e data set. Use } \\
\text { metric } z \text {-stat. }\end{array}$ \\
\hline & & 16 & & 16 & & 16 & & 16 & & 16 & & 16 & & 16 & & & 16 & \\
\hline 43 & $\%<$ Detection limit & $94 \%$ & & $100 \%$ & & $25 \%$ & & $100 \%$ & & $100 \%$ & & $100 \%$ & & $100 \%$ & & & $100 \%$ & \\
\hline & Mean & 0.18 & & 1.8 & & 0.039 & & 0.015 & & 0.039 & & 0.049 & & 2.0 & & & 0.15 & \\
\hline & Standard deviation & 0.12 & & 0.23 & & 0.018 & & 0.0016 & & 0.0038 & & 0.0049 & & 1.0 & & & 0.033 & \\
\hline & $95 \%$ UCL on mean & 0.23 & & & & 0.046 & & 0.016 & & 0.041 & & 0.051 & & 2.5 & & & 0.16 & \\
\hline & Maximum detected value & 0.60 & & 0 & & 0.066 & & & & 0 & & 0 & & 0 & & & & \\
\hline 48 & Background & NA & & NA & & 1.1 & & 0.008 & & NA & & 0.033 & & NA & & & 0.004 & \\
\hline & Statistical value above background & 0.23 & 1 & 1.9 & & $O(<B G)$ & & 0.0075 & & 0.041 & & 0.018 & & 2.5 & & & 0.16 & \\
\hline
\end{tabular}

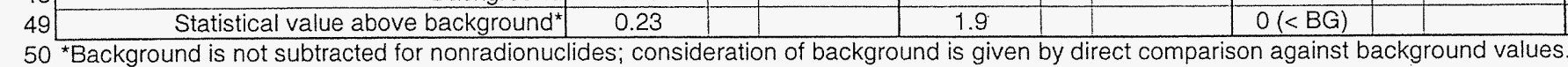
\begin{tabular}{c|c}
0.008 & 0.075 \\
\hline
\end{tabular} 0.041 $\frac{0.051}{0}$ 
Washington Closure Hanford Originator H.M. Sulloway dtuMS
Project
Subject $\frac{100-\text { F Field Remediation }}{118-\text { - }-1 \text { Burial Ground Clean }}$

CALCULATION SHEET tions, continued
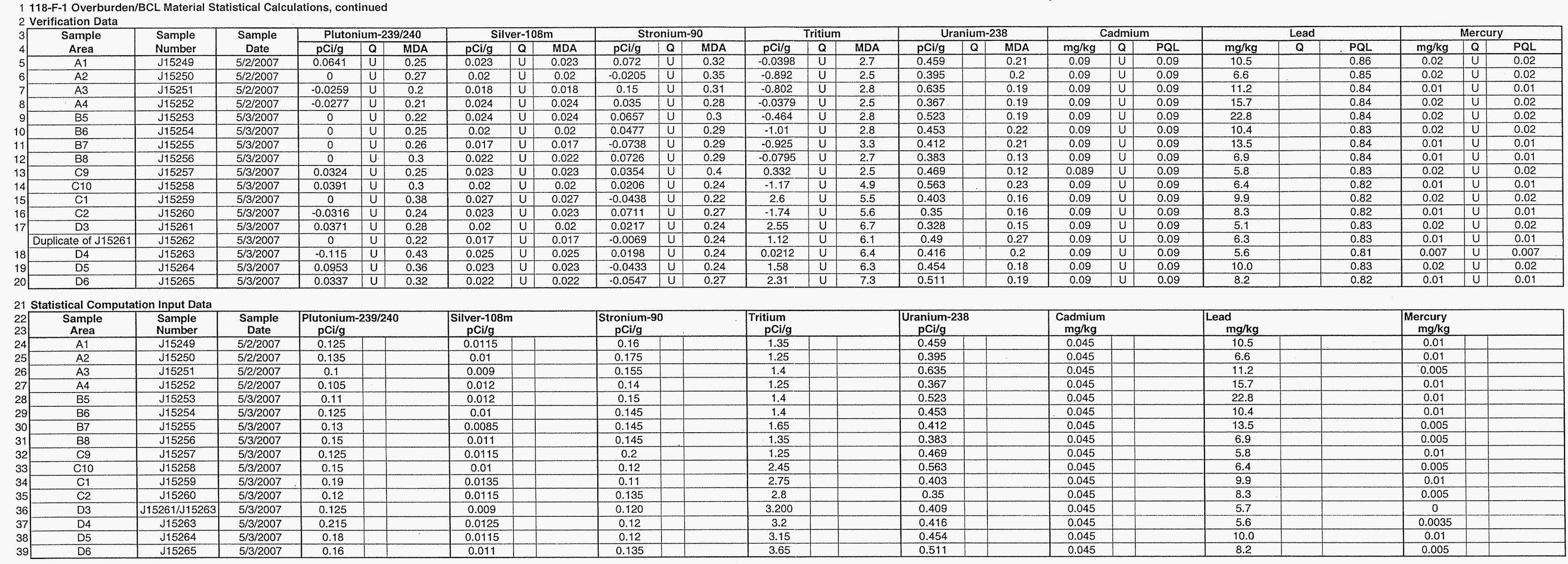

\section{Statistical Computation}

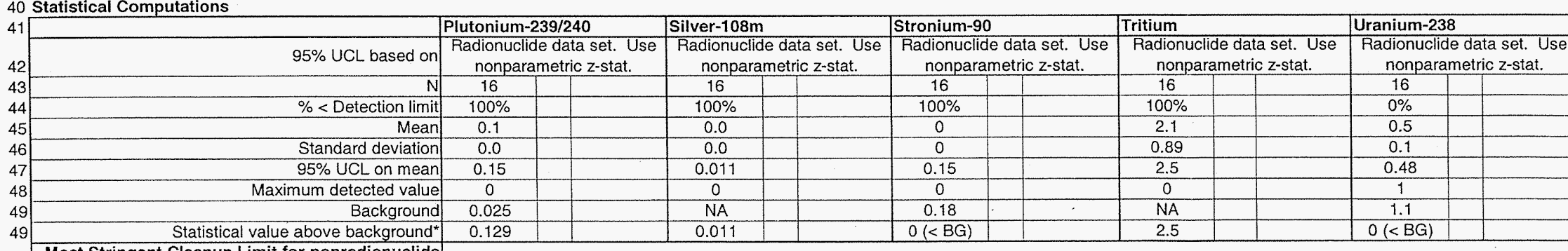

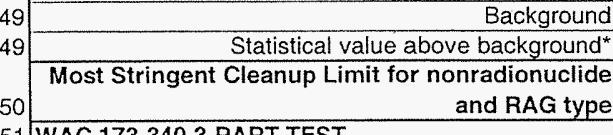

\begin{tabular}{l|l}
50 & Most Stringent Cleanup Limit for nonradionuclide \\
and RAG type \\
52 & WAC 173-340 3-PART TEST \\
$55 \%$ UCL > Cleanup Limit?
\end{tabular}

53

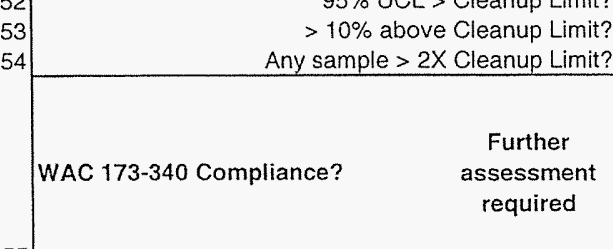

${ }_{56}^{55}$

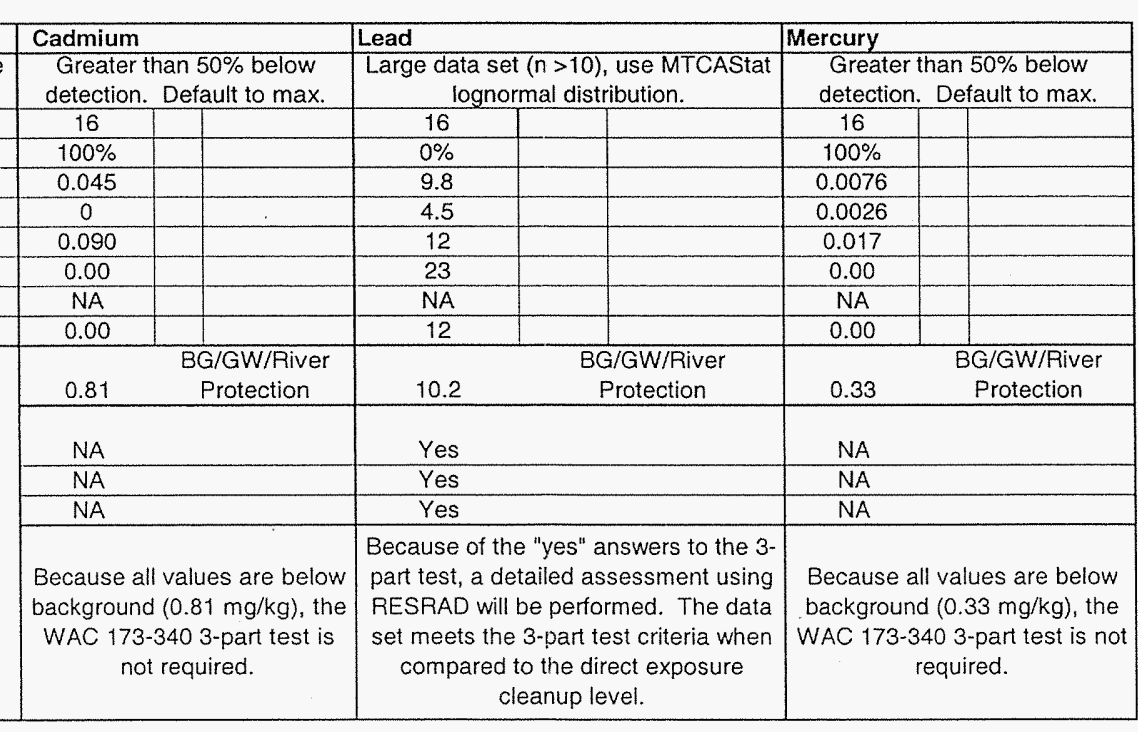


Originator H. M. Sulloway dtwh
Project 100 - Field Remedation
CALCULATION SHEET
Date $\frac{09 / 06 / 07}{14655}$
Job No.
Calc. No. 0100F-CA-V0279
Checked J. M. Caaron
lytere
Rev. No. $\frac{1}{\text { Date }}$
Sheet No. $\underline{09 / 06 / 17}$
of 14

$118-F-1$ Process
2 Verification Data
ata

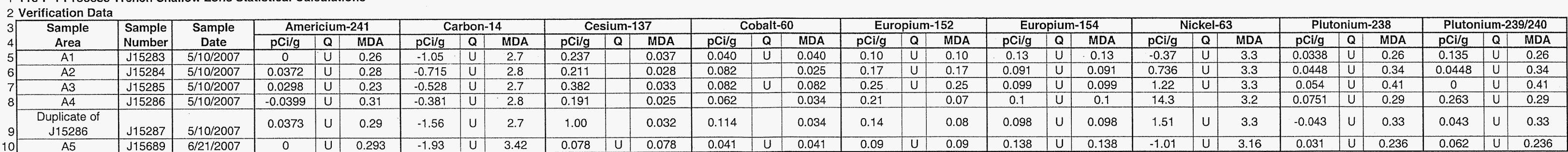

\begin{tabular}{|c|c|c|c|c|c|c|c|c|c|c|c|}
\hline $\begin{array}{c}\text { Sample } \\
\text { Area }\end{array}$ & $\begin{array}{l}\begin{array}{l}\text { Sample } \\
\text { Number }\end{array} \\
\text { Nunber }\end{array}$ & $\begin{array}{c}\text { Sample } \\
\text { Date }\end{array}$ & \begin{tabular}{|} 
Americium-241 \\
pCi/g
\end{tabular} & $\begin{array}{c}\text { Carbon-14 } \\
\text { pCl/g }\end{array}$ & $\begin{array}{c}\text { Cesium- } \\
\text { pcilgg }\end{array}$ & $\begin{array}{c}\text { Cobalt-6c } \\
\text { pCi/gg }\end{array}$ & \begin{tabular}{|c} 
Europiun \\
pCilg
\end{tabular} & \begin{tabular}{|c} 
Europiur \\
pcilgg
\end{tabular} & $\begin{array}{c}\text { Nickel-63 } \\
\text { pCilg }\end{array}$ & $\begin{array}{l}\text { Plutoniu } \\
\text { pCilg }\end{array}$ & $\begin{array}{c}\text { Plutoniun } \\
\text { pCi/g }\end{array}$ \\
\hline $\begin{array}{l}A 1 \\
A 2 \\
\end{array}$ & $\begin{array}{l}\frac{J 15283}{J 15284} \\
\end{array}$ & 5 5/10/2007 & $\begin{array}{c}0 \\
0.037 \\
0.037\end{array}$ & $\begin{array}{c}-1.05 \\
-0.715 \\
\end{array}$ & $\begin{array}{l}0.237 \\
0.211 \\
\end{array}$ & $\begin{array}{l}0.020 \\
0.082 \\
.041\end{array}$ & $\begin{array}{l}0.050 \\
0.085 \\
.025\end{array}$ & \begin{tabular}{|l|}
0.065 \\
0.046 \\
0.050
\end{tabular} & \begin{tabular}{|l|l|}
-0.370 \\
0.736 \\
.300
\end{tabular} & $\begin{array}{l}0.0338 \\
0.0448 \\
0.50\end{array}$ & $\begin{array}{l}0.135 \\
-0.0448 \\
0.0000\end{array}$ \\
\hline A3 & $\frac{515285}{315286 /}$ & $5 / 10 / 2007$ & 0.030 & -0.528 & 0.382 & 0.041 & 0.125 & 0.050 & 1.220 & 0.0540 & 0.0000 \\
\hline${ }_{A 4}^{A 4}$ & J15287 & $5 / 1 / 20007$ & 0.150 & $\begin{array}{r}1.38 \\
-1.93\end{array}$ & \begin{tabular}{|l}
0.596 \\
0.039
\end{tabular} & $\begin{array}{l}0.008 \\
0.021\end{array}$ & 0.045 & 0.069 & $\begin{array}{l}-1.08 \\
-1.01\end{array}$ & $\begin{array}{l}0.1030 \\
0.0310\end{array}$ & $\begin{array}{l}0.150 \\
0.062\end{array}$ \\
\hline
\end{tabular}

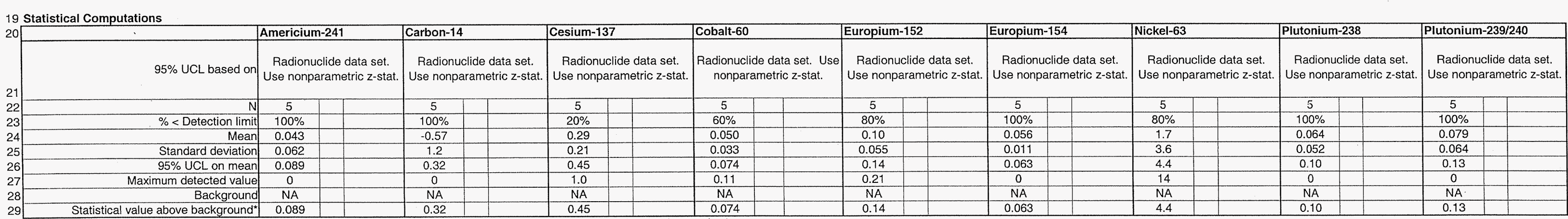

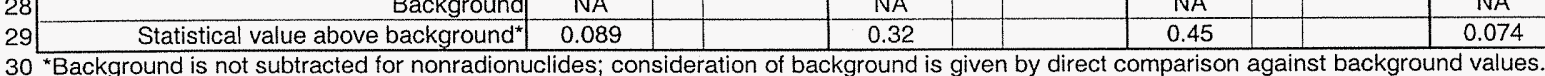


Washington Closure Hanford

Originator H.M. Sulloway $\mathrm{d} M M S$

Subject 118 -F-1 Burial Ground Cleanup Verification 95\% UCL Calculations
CALCULATION SHEET

Date $\frac{09 / 06 / 07}{14655}$
Job No.

Calc. No. $0100 F-C A-V 0279$ sy $8 x u^{2}$ $\begin{aligned} \text { Rev. No. } \frac{1}{\text { Date }} & \frac{1}{09 / 06 / 07} \\ 10014 & \end{aligned}$

1118-F-1 Process Trench Shallow Zone Statistical Calculations, continued

\begin{tabular}{|c|c|c|c|c|c|c|c|c|c|c|c|c|c|c|c|c|c|c|c|c|c|c|c|}
\hline \multirow{2}{*}{$\begin{array}{c}\text { Sample } \\
\text { Area } \\
\end{array}$} & \multirow{2}{*}{$\begin{array}{l}\text { Sample } \\
\text { Number } \\
14502\end{array}$} & \multirow{2}{*}{$\begin{array}{c}\text { Sample } \\
\text { Date } \\
\end{array}$} & \multicolumn{3}{|c|}{ Silver-108m } & \multicolumn{3}{|c|}{ Stronium-90 } & \multicolumn{3}{|c|}{ Tritium } & \multicolumn{3}{|c|}{ Uranium-238 } & \multicolumn{3}{|c|}{ Cadmium } & \multicolumn{3}{|c|}{ Lead } & \multicolumn{3}{|c|}{ Mercury } \\
\hline & & & pCi/g & $Q$ & MDA & pCi/g & & MDA & $\mathrm{pCi} / \mathrm{g}$ & & MDA & $\mathrm{pCi/g}$ & & MDA & $\mathrm{mg} / \mathrm{kg}$ & & $P Q L$ & $\mathrm{mg} / \mathrm{kg}$ & & $P Q L$ & $\mathrm{mg} / \mathrm{kg}$ & $Q$ & $P Q L$ \\
\hline$\frac{A 1}{A 2}$ & & & 0.026 & $U$ & 0.026 & 0.180 & 0 & 0.25 & $\frac{1.58}{0}$ & $\frac{U}{U}$ & $\frac{3.9}{3.9}$ & 0.429 & & 0.16 & $\begin{array}{l}0.08 \\
0.10\end{array}$ & 0 & $\frac{0.08}{0.09}$ & $\begin{array}{l}2.7 \\
.0\end{array}$ & & 0.7 & 0.02 & 0 & 0.01 \\
\hline & & & $\frac{0.020}{0.020}$ & $\frac{u}{u}$ & & $\frac{0.176}{0.176}$ & 0 & 0.22 & 0 & $\mathrm{u}$ & 3.9 & $\begin{array}{l}0.104 \\
0.704\end{array}$ & & 0.2 & 0.10 & & $\frac{0.99}{0.09}$ & $\frac{2.0}{29}$ & & & & & $\begin{array}{l}0.01 \\
0.01\end{array}$ \\
\hline & & & 0.023 & U & 0.023 & 0.338 & & 0.23 & 1.18 & $u$ & 3.9 & 0.465 & & 0.19 & 0.0 & $U$ & 0.08 & 3.4 & & 0.77 & 0.02 & & 0.01 \\
\hline Duplicate of & & & 0.021 & $u$ & 0.021 & 0.144 & u & 0.22 & 0.122 & $u$ & 4.1 & 0.297 & & 0.21 & 0.09 & $u$ & 0.09 & 4.2 & & 0.84 & 0.02 & u & 0.02 \\
\hline & 1156 & & 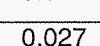 & & 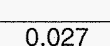 & -0.016 & & & 2.38 & - & 3.81 & 0.406 & U & 0.173 & 0.15 & U & 0.15 & 32 & & 0.96 & 0.01 & $U$ & 0.01 \\
\hline
\end{tabular}

\begin{tabular}{|c|c|c|}
\hline A5 & J15689 & 6/21/2007 \\
\hline
\end{tabular}

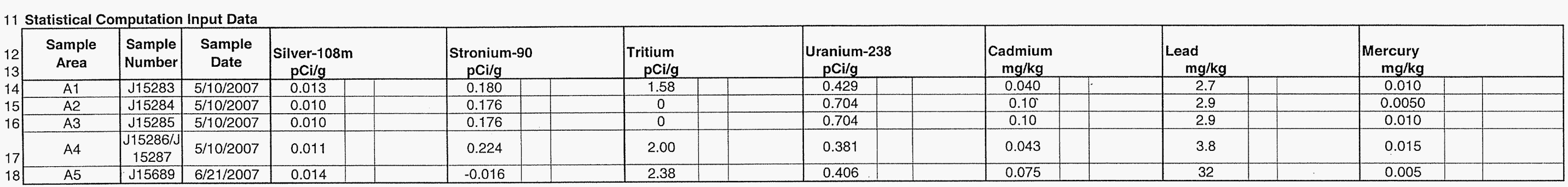

\begin{tabular}{|c|c|c|}
18 & A5 & J15689 \\
\hline
\end{tabular}

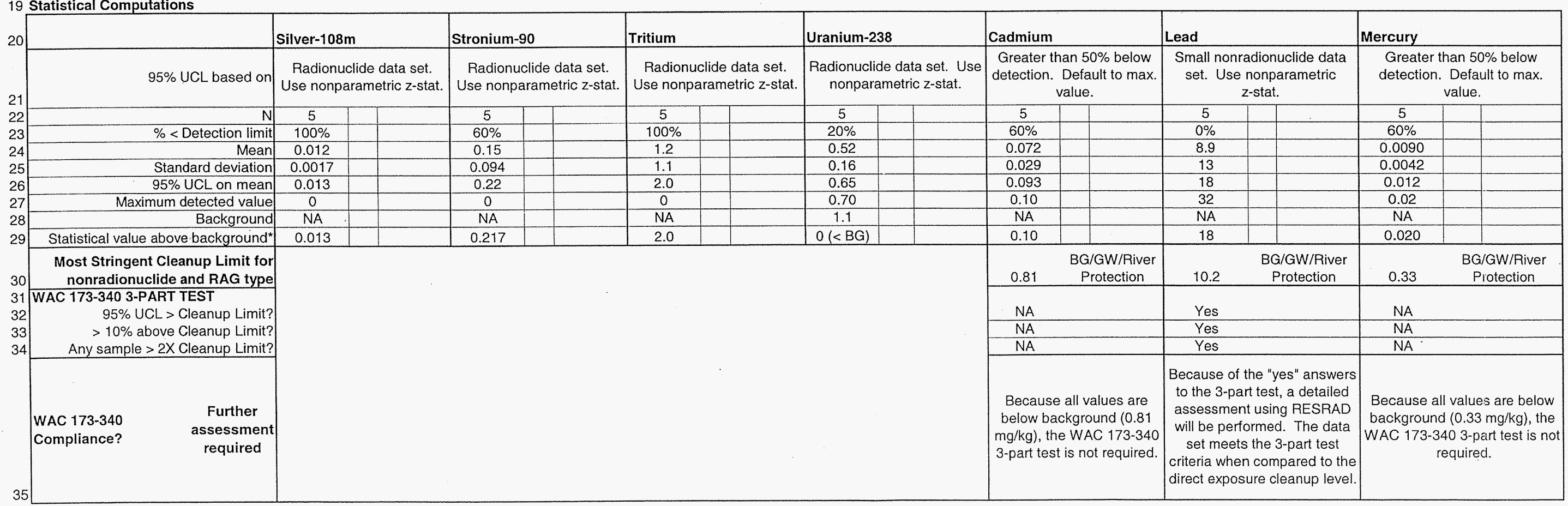


Washington Closure Hanford

Originator H.M. Sullowax L Ith

Project 100-F Field Remediation

Subject 118-F-1 Burial Ground Cleanup Verification 95\% UCL Calculation

\section{CALCULATION SHEET}

Date 09/06/07 Calc. No. 0100F-CA-V0279 Job No. 14655 Checked J.M. Capron

Ecology Software (MTCAStat) Results

Rev. No.

Date

Sheet No.

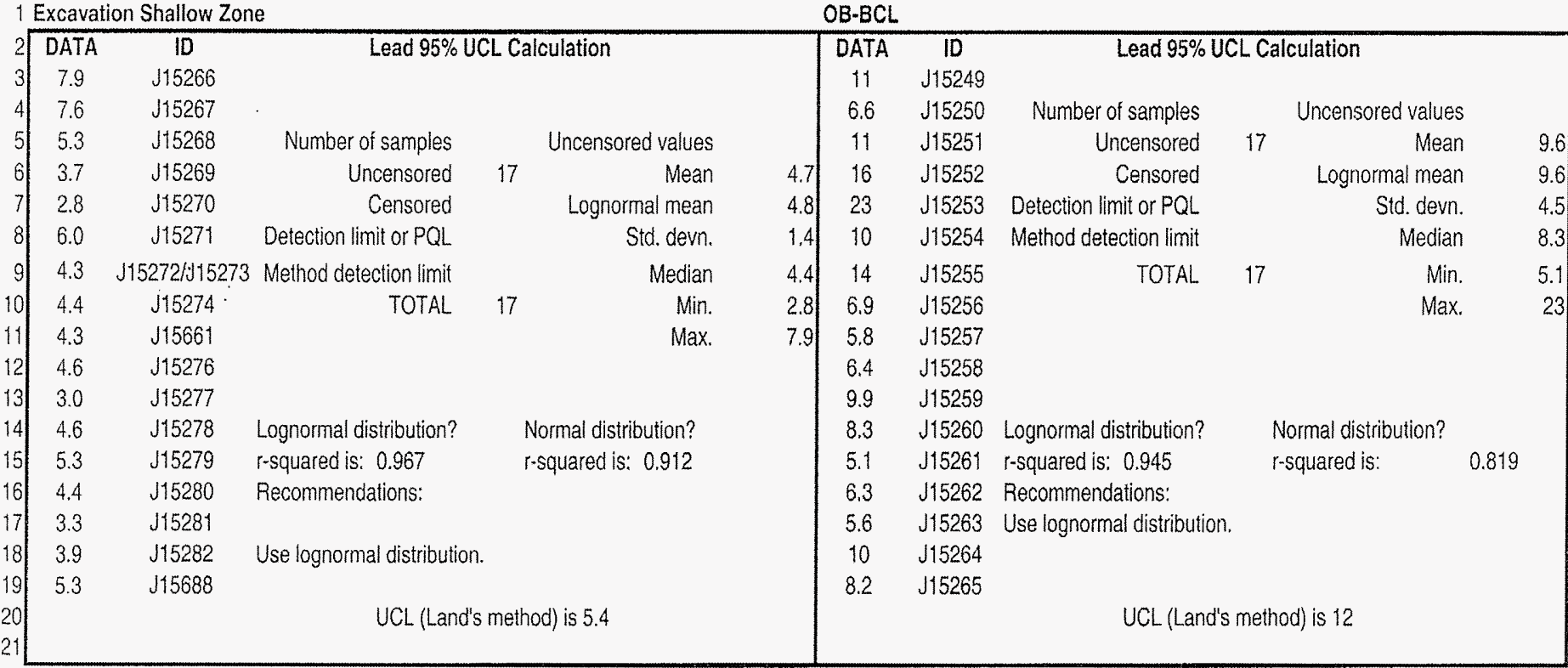


CVP-2007-00001

Rev. 0 
Washington Closure Hanford

Originator H. M. Sulloway dX)

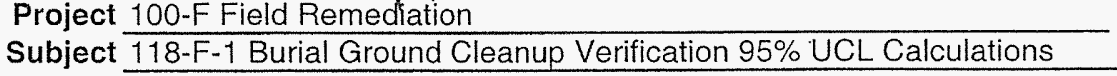

CALCULATION SHEET

Date $\quad 09 / 06 / 07$

Job No. $\frac{096 / 07}{14655}$
Calc. No. 0100F-CA-V0279

ey $x<x=$
Rev. No. 1

Date 12 of 14

\begin{tabular}{|c|c|c|c|c|c|c|c|c|c|c|c|c|c|c|c|c|c|c|c|c|c|c|c|c|c|c|}
\hline \multirow{2}{*}{ 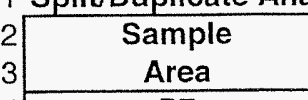 } & \multirow{2}{*}{$\begin{array}{l}\text { Sample } \\
\text { Number } \\
\end{array}$} & \multirow{2}{*}{$\begin{array}{c}\text { Sample } \\
\text { Date }\end{array}$} & \multicolumn{3}{|c|}{ Americium-241 } & \multicolumn{3}{|c|}{ Carbon-14 } & \multicolumn{3}{|c|}{ Cesium-137 } & \multicolumn{3}{|c|}{ Cobalt-60 } & \multicolumn{3}{|c|}{ Europium-152 } & \multicolumn{3}{|c|}{ Europium-154 } & \multicolumn{3}{|c|}{ Nickel-63 } & \multicolumn{3}{|c|}{ Plutonium-238 } \\
\hline & & & $\mathrm{pCi} / \mathrm{g}$ & Q & MDA & $\mathrm{pCi} / \mathrm{g}$ & Q & MDA & $\mathrm{pCi} / \mathrm{g}$ & $\begin{array}{ll}Q \\
\end{array}$ & MDA & $\mathrm{pCi} / \mathrm{g}$ & Q & MDA & $\mathrm{pCi} / \mathrm{g}$ & Q & MDA & $\mathrm{pCi} / \mathrm{g}$ & Q & MDA & $\mathrm{pCi} / \mathrm{g}$ & $Q$ & MDA & $\mathrm{pCi/g}$ & $Q$ & MDA \\
\hline & $J 15272$ & & 0 & $U$ & 0.33 & 4.27 & $\mathrm{U}$ & 4.4 & 0.115 & & 0.027 & 0.029 & $u$ & 0.029 & 0.072 & $\mathrm{U}$ & 0.072 & 0.097 & $\mathrm{U}$ & 0.097 & 0.64 & $U$ & 4.1 & -0.0356 & $\mathrm{U}$ & 0.27 \\
\hline Duplicate of $\mathrm{J} 15272$ & J15273 & & 0.0549 & $u$ & & 0.257 & $\mathrm{U}$ & 3.6 & 0.0822 & & & 0.035 & $\mathrm{U}$ & & 0.09 & $U$ & 0.09 & 0.11 & $U$ & & 1.85 & $U$ & & 0 & $\mathrm{U}$ & 0.29 \\
\hline Split of J15272 & J152D8 & $5 / 8 / 2007$ & 0.015 & $U$ & 0.0398 & -0.0753 & $U$ & & 0.0366 & & 0.0157 & -0.0045 & $U$ & 0.0165 & 0.028 & $U$ & 0.0377 & -0.00259 & $U$ & 0.0563 & 5.3 & & 5.25 & -0.00234 & U & 0.0561 \\
\hline \multicolumn{27}{|c|}{1} \\
\hline \multicolumn{3}{|c|}{$\begin{array}{l}\text { TDL } \\
\text { Both >PQL? }\end{array}$} & \multicolumn{3}{|c|}{$\frac{1}{\text { No - evaluate difference }}$} & \multicolumn{3}{|c|}{$\begin{array}{l}50 \\
\text { No - evaluate difference }\end{array}$} & \multicolumn{3}{|c|}{0.1} & \multicolumn{3}{|c|}{0.05} & \multicolumn{3}{|c|}{$\begin{array}{c}0.2 \\
\text { No - evaluate difference }\end{array}$} & & \multicolumn{3}{|c|}{30} & \multicolumn{3}{|c|}{1} \\
\hline \multirow[t]{2}{*}{ Duplicate Analysis } & \multicolumn{2}{|c|}{$\begin{array}{l}\text { Botn > PUL? } \\
\text { Both > } x \text { TTLL? }\end{array}$} & & \multicolumn{3}{|c|}{ No - evaluate difference } & \multicolumn{3}{|c|}{$\begin{array}{l}\text { Yes (continue) } \\
\text { No - evaluate difference }\end{array}$} & & & & & & & & & & & & & & & \\
\hline & Differen & 2xTDL? & & & & & - & & & & & & & & & & & & 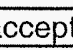 & table & No- & & & No-a & & table \\
\hline & & QL? & No-eve & luate $\mathrm{c}$ & fference & No-eva & late & fference & & & & No - eval & luate d & lifference & No-eva & auatec & lifference & No-evalt & lated & lifference & No-eval & luated d & difference & No-evalu & a dalec & lifference \\
\hline Split Analysis & Both & [DL? & & & & & & & No - eval & uate & lifference & & & & & & & & & & & & & & & \\
\hline & Differen & (IDI & No. & acce & & & acce & & No- & acce! & table & & accep & table & & acce & & & ICC6 & & & & & & & ble \\
\hline
\end{tabular}

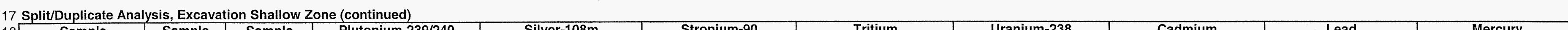

\begin{tabular}{|c|c|c|c|c|c|c|c|c|c|c|c|c|c|c|c|c|c|c|c|c|c|c|c|c|c|c|c|}
\hline \multirow{2}{*}{$1 8 \longdiv { 1 8 }$} & \multirow{2}{*}{$\begin{array}{c}\text { Sample } \\
\text { Area }\end{array}$} & \multirow{2}{*}{$\begin{array}{l}\text { Sample } \\
\text { Number }\end{array}$} & \multirow{2}{*}{$\begin{array}{c}\text { Sample } \\
\text { Date }\end{array}$} & Pluton & $4 \mathrm{~m}-2$ & $39 / 240$ & \multicolumn{3}{|c|}{ Silver-108m } & \multicolumn{3}{|c|}{ Stronium-90 } & \multicolumn{3}{|c|}{ Tritium } & \multicolumn{3}{|c|}{ Uranium-238 } & \multicolumn{3}{|c|}{ Cadmium } & \multicolumn{3}{|c|}{ Lead } & \multicolumn{3}{|c|}{ Mercury } \\
\hline & & & & $\mathrm{pCi/g}$ & Q & MDA & $\mathrm{pCi} / \mathrm{g}$ & \begin{tabular}{|l|l} 
Q \\
\end{tabular} & MDA & $\mathrm{pCi} / \mathrm{g}$ & Q & MDA & $\frac{\mathrm{pCi} / \mathrm{g}}{106}$ & Q & MDA & $\mathrm{pCi/g}$ & $\mathbf{Q}$ & MDA & & \begin{tabular}{|l|} 
Q \\
\end{tabular} & $P Q L$ & $\mathrm{mg} / \mathrm{kg}$ & Q & $\mathrm{PQL}$ & $\mathrm{mg} / \mathrm{kg}$ & 0 & $P Q L$ \\
\hline & & $J 15272$ & & 0.0711 & U & 0.27 & & U & 0.021 & 0.213 & U & 0.24 & 1.96 & 0 & 5.3 & 0.496 & & 0.032 & 0.08 & U & 0.08 & 4.6 & & 0.76 & & & \\
\hline & Duplicate of $\mathrm{J} 15272$ & $J 15273$ & $5 / 8 / 2007$ & 0 & $\mathrm{U}$ & 0.29 & 0.024 & $\mathrm{U}$ & 0.024 & -0.0116 & $\mathrm{U}$ & 0.25 & 0.384 & $\mathrm{U}$ & 4.6 & 0.411 & & 0.037 & 0.08 & U & 0.08 & 3.9 & & 0.76 & 0.01 & U & 0.01 \\
\hline \multirow{3}{*}{\multicolumn{4}{|c|}{$\begin{array}{l}23 \text { Analysis: } \\
24 \text { - }\end{array}$}} & \multirow{3}{*}{\multicolumn{3}{|c|}{1}} & -0.00498 & U & 0.0116 & 0.0976 & $u$ & 0.141 & 0.0131 & U & 0.0366 & 0.191 & & 0.047 & 0.14 & $u$ & 0.14 & 3.4 & & 0.15 & 0.0068 & & 0.0068 \\
\hline & & & & & & & \multirow{2}{*}{\multicolumn{3}{|c|}{$\begin{array}{c}0.1 \\
\text { No - evaluate difference }\end{array}$}} & \multirow{2}{*}{\multicolumn{3}{|c|}{$\frac{1}{1}$}} & \multirow{2}{*}{\multicolumn{3}{|c|}{$\begin{array}{c}400 \\
\text { No - evaluate difference }\end{array}$}} & \multirow{2}{*}{\multicolumn{3}{|c|}{$\frac{1}{\text { continuel }}$}} & \multirow{2}{*}{\multicolumn{3}{|c|}{0.5}} & \multicolumn{3}{|c|}{1} & \\
\hline & & & & & & & & & & & & & & & & & & & & & & & $\frac{1}{\text { sonti }}$ & & No- eval & $\frac{0.2}{\text { aluated }}$ & lifference \\
\hline \multirow{6}{*}{$\begin{array}{l}29 \\
30 \\
31\end{array}$} & Duplicate Analysis & \multicolumn{2}{|c|}{$\begin{array}{l}\text { Both > PQL? } \\
\text { Both >5XTDL? }\end{array}$} & \multicolumn{3}{|c|}{ No - evaluate difference } & \multicolumn{3}{|c|}{ TNo - evaluate amerence } & \multirow{2}{*}{\multicolumn{3}{|c|}{ No - evaluale umierence }} & \multicolumn{3}{|c|}{ No - evaluate difference } & \multirow{2}{*}{\multicolumn{3}{|c|}{ No - evaluate difference }} & \multicolumn{3}{|c|}{ No-evaluate difference } & No - evalu & ate $c$ & ifference & & & \\
\hline & & & & & & & & & & & & & & & & & & & & & & & & & & & \\
\hline & & Differenc & $>2 \times T D L ?$ & No- & accep & able & No-e & accep & able & No-a & accep & able & No- & accep & table & No- & accer & table & No-e & accept & & No-as $\quad$, & ccep & table & No- & - accep & table \\
\hline & & Both & PQL? & No - eval & Late & ifference & No- evali & uate $c$ s & fference & No- evalu & uate $d$ & fference & No - eva & luated & lifference & Yes & (cont & nue) & No - evalt & luate $d$ & fference & Yes (c & conti & nue) & No-eval & aluate $d$ & ifference \\
\hline & Split Analysis & Both & XTDL? & & & & & & & & & & & & & No-eval & uate & ifference & & & & No- evalu & atate & ifference & & & \\
\hline & & $\frac{1}{\text { Differen }}$ & SVTOI? & $N$ & 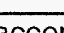 & thenge & $\mathrm{Na}=\mathrm{a}$ & accor & ablo & No-a & acren & able & & 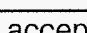 & table & No- & 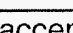 & table & 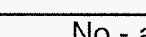 & arcent & & $\mathrm{No}-\mathrm{O}-\mathrm{s}$ & ocer & the & & & \\
\hline
\end{tabular}


Washington Closure Hanford

$\underset{\text { Originator }}{\text { H. M. Sulloway Cect }}$

Subject $\frac{118-\mathrm{F}-1 \text { Burial Ground Cleanup Verification } 95 \% \text { UCL Calculations }}{1.00}$
CALCULATION SHEET

$$
\begin{array}{r}
\text { Date } \\
\text { Job No. } \frac{09 / 06 / 07}{14655}
\end{array}
$$

Calc. No. 0100F-CA-V0279

$$
\text { ly. } k \text { we }
$$

Rev. No.

Sheet No. $\overline{13 \text { of } 14}$

\section{Split/Duplicate Analysis, OB-BC}

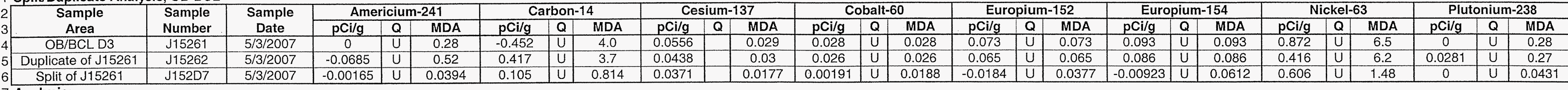

\begin{tabular}{|c|c|c|c|c|c|c|c|c|c|c|}
\hline & nalys & & & & & & & & 30 & \\
\hline \multirow{4}{*}{\multicolumn{2}{|c|}{ Duplicate Analysis }} & Both > MDA? & $\frac{1}{\text { No - evaluate difference }}$ & $\begin{array}{l}50 \\
\text { No - evaluate difference }\end{array}$ & $\frac{0.1}{\text { Yes (continue) }}$ & $\begin{array}{l}0.05 \\
\text { No - evaluate difference }\end{array}$ & \begin{tabular}{|c|}
0.2 \\
No - evaluate difference
\end{tabular} & $\begin{array}{l}0.2 \\
\text { No - evaluate difference }\end{array}$ & No - evaluate difference & No - evaluate difference \\
\hline & & Both > 5xTDL? & & & No- evaluate difference & & & & & \\
\hline & & & & & & & & & & \\
\hline & & Difference $>2 \times T D L$ ? & No - acceptable & No - acceptable & No - acceptable & No - acceptable & No - acceptable & No - acceptable & No - acceptable & No - acceptable \\
\hline \multirow{3}{*}{\multicolumn{2}{|c|}{ Split Analysis }} & $\begin{array}{l}\text { Both > MDA? } \\
\text { Beth }\end{array}$ & No-evaluate difference & No - evaluate difference & $\begin{array}{c}\text { Yes (continue) } \\
\text { No-evaluate differen }\end{array}$ & No- evaluate difference & No - evaluate difference & No - evaluate difference & No - evaluate difference & No - evaluate difference \\
\hline & & RPD & & & & & & & & \\
\hline & & Difference $>2 \times T D L ?$ & No - acceptable & No - acceptable & No - acceptable & No - acceptable & No - acceptable & No - acceptable & No - acceptable & No-acceptable \\
\hline
\end{tabular}
\begin{tabular}{l|c|c}
5 & Duplicate of J15261 & $\mathrm{J} 152$ \\
\hline Split of J15261 & $\mathrm{J} 152 \mathrm{D}$ \\
\hline
\end{tabular}

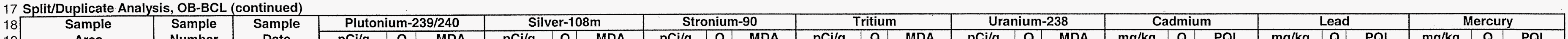

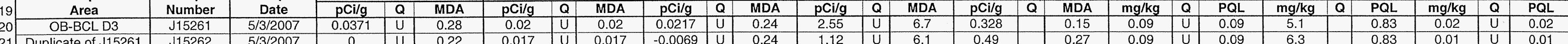

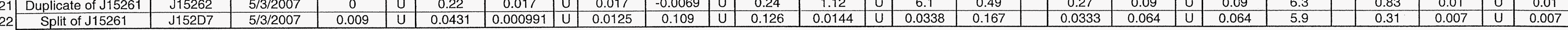
23 Analysis:

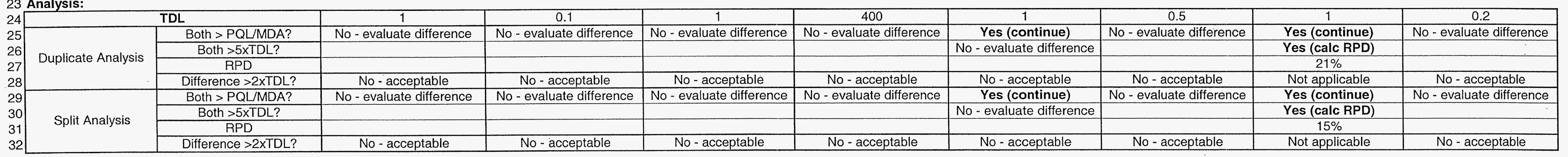


Washington Closure Hanford tubs

Originator H. M. Sulloway dXW Subject 100 -F Field Remediation

\section{CALCULATION SHEET}

$$
\begin{gathered}
\text { Date } \\
\text { Job No. } \frac{09 / 06 / 07}{14655}
\end{gathered}
$$

Calc. No. 0100F-CA-V0279

Checked J.M. Capron

$$
\text { by trate }
$$

Rev. No. 1

\begin{tabular}{|c|c|c|c|c|c|c|c|c|c|c|c|c|c|c|c|c|c|c|c|c|c|c|c|c|c|c|c|}
\hline \multirow{2}{*}{\multicolumn{2}{|c|}{$\begin{array}{c}\text { Sample } \\
\text { Area }\end{array}$}} & \multirow{2}{*}{$\begin{array}{l}\text { Sample } \\
\text { Number }\end{array}$} & \multirow{2}{*}{$\begin{array}{l}\text { Sample } \\
\text { Date }\end{array}$} & \multicolumn{3}{|c|}{ Americium-241 } & \multicolumn{3}{|c|}{ Carbon-14 } & \multicolumn{3}{|c|}{ Cesium-137 } & \multicolumn{3}{|c|}{ Cobalt-60 } & \multicolumn{3}{|c|}{ Europium-152 } & \multicolumn{3}{|c|}{ Europium-154 } & \multicolumn{3}{|c|}{ Nickel-63 } & \multicolumn{3}{|c|}{ Plutonium-238 } \\
\hline & & & & $\mathrm{pCi} / \mathrm{g}$ & Q & MDA & $\mathrm{Ci} / \mathrm{g}$ & Q & MDA & $\mathrm{pCi} / \mathrm{g}$ & $Q$ & MDA & $\mathrm{pCi} / \mathrm{g}$ & $Q$ & MDA & $\mathrm{pCi} / \mathrm{g}$ & Q & MDA & $\mathrm{pCi/g}$ & $Q$ & $\mathrm{MDA}$ & $\mathrm{pCi} / \mathrm{g}$ & Q & MDA & $\mathrm{pCi} / \mathrm{g}$ & $\mathrm{Q}$ & MDA \\
\hline & & $J 15286$ & $5 / 10 / 2007$ & $\frac{1039}{-0.0399}$ & U) & 0.31 & -0.381 & Uी & 2.8 & 0.191 & & 0.025 & 0.0622 & & 0.034 & & & & & $U$ & & 14.3 & & 3.2 & & & 0.29 \\
\hline & Duplicate of J15286 & J15287 & $5 / 10 / 2007$ & 0.0373 & U & 0.29 & -1.56 & $\mathrm{u}$ & 2.7 & 1.00 & & 0.03 & 0.114 & & 0.0 & 0.144 & & 0.07 & 0.098 & $U$ & 0.0 & 1.51 & U & 3.3 & -0.043 & U & 0.33 \\
\hline & Split of $J 15286$ & J152D9 & $5 / 3 / 2007$ & 0.0479 & & 0.0186 & -0.0905 & U & 0.823 & 0.0877 & & 0.0169 & 0.14 & & 0.0201 & 0.071 & $U$ & 0.0307 & 0.021 & $\mathrm{U}$ & 0.0633 & 8.61 & & 5.8 & -0.00197 & & 0.0409 \\
\hline \multicolumn{28}{|c|}{ Analysis: } \\
\hline & \multicolumn{3}{|c|}{ th > PQL? } & \multirow{2}{*}{\multicolumn{3}{|c|}{$\frac{1}{\text { No - evaluate difference }}$}} & \multicolumn{3}{|c|}{$\frac{50}{50 \text { evaluate difference }}$} & Yes & $\frac{.1}{\text { cont }}$ & nue) & \multicolumn{3}{|c|}{ 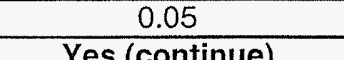 } & \multicolumn{3}{|c|}{0.2} & \multicolumn{3}{|c|}{0.2} & \multicolumn{3}{|c|}{30} & \multicolumn{3}{|c|}{1} \\
\hline & \multirow[t]{3}{*}{ Duplicate Analysis } & \multicolumn{2}{|c|}{ Both $>5 \times$ TDL? } & & & & & \multirow{2}{*}{\multicolumn{3}{|c|}{ No - evaluate difference }} & \multirow{2}{*}{\multicolumn{3}{|c|}{ No- evaluate difference }} & \multirow{2}{*}{\multicolumn{3}{|c|}{ No- evaluate difference }} & & & & & & & & & \\
\hline & & & & & & & & & & & & & & & & & & & & & & & & & \\
\hline & & $\frac{\text { Differen }}{\text { Both }}$ & 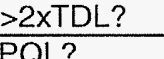 & No- & accer & able & No- & accep & able & $\frac{\text { Yes-as }}{\text { Yes }}$ & sess & further & $\frac{\text { Mo-t }}{\text { nosd }}$ & cccep & table & $\frac{N_{0}-a}{\text { Yogd }}$ & accep & table & No- & accep & table & No- & accep & otable & No- & accep & table \\
\hline & & Both & XTDL? & & & & & & & No-eval & (1) & Ifference & No-eval & lated & $\begin{array}{l}\text { nuve) } \\
\text { ifforanconsen }\end{array}$ & No ovalu & tans & $\begin{array}{l}\text { nue) } \\
\text { ifforon }\end{array}$ & & & & Non & ont & inue) & & & \\
\hline & Split Analysis & 1 & & & & & & & & & & & & & & & & & & & & & & & & & \\
\hline & & Differen & $>2 \times T D L ?$ & No- & accel _ & able & No- & accer & able & No- & accer & able & No-s & iccep & table & No- ${ }^{-}$ & accep & table & & accep & table & & accer & btable & & & able \\
\hline
\end{tabular}

Sheet No. 14 of 14

17 Split/Duplicate Analysis, Process Trench Shallow Zone (continued)

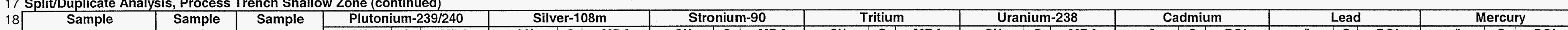

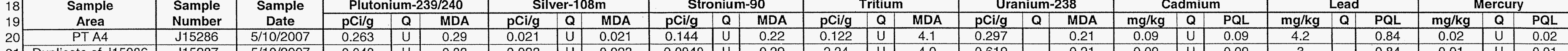
\begin{tabular}{l|l|l|l|l|l|l|l|l|l|}
21 & Duplicate of J15286 & $J 15287$ & $5 / 10 / 2007$ & 0.043 & $U$ & 0.33 & 0.023 & $U$ & 0.022 \\
\hline
\end{tabular}

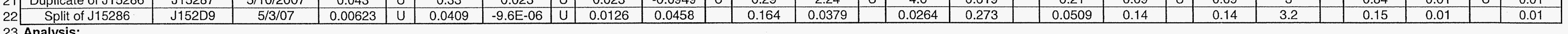

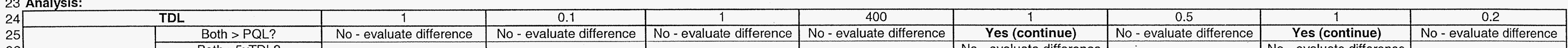

Duplicate Analysis

Split Analysi

\begin{tabular}{|c|} 
Both $>$ PQL? \\
\hline Both $>5 \times T D L ?$ \\
\hline PPD \\
\hline Difference $>2 \times T D L ?$ \\
\hline Both $>$ PQL? \\
\hline Both $>5$ TQTDL? \\
\hline RPD \\
\hline Difference $>2 \times T D L ?$
\end{tabular}

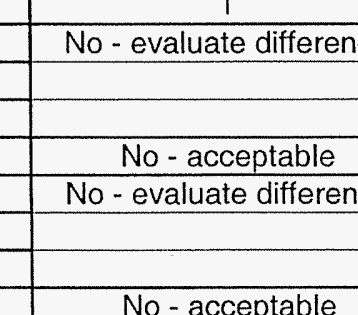

\begin{tabular}{|c|c|}
\hline s the & miterence \\
\hline No r contablo & An \\
\hline$\frac{\text { No - acceptable }}{\text { No - evaluate difference }}$ & $\begin{array}{l}\text { No - acceptable } \\
\text { No - evaluate difference }\end{array}$ \\
\hline & \\
\hline
\end{tabular}

\begin{tabular}{|c|} 
No- evaluate differenc \\
\hline No- acceptable \\
No - evaluate difference \\
\hline
\end{tabular}
No- evaluate difference

No - acceptable
- - valuate difference
No-evaluate difference No - evaluate difference Yes (continue)
No- evaluate difference No - evaluate difference

Difference $>2 \times T D L$ ?

No - acceptable

o- acceptable

No - acceptable

No - acceptable

No - acceptable

No - acceptable

No - acceptable 
Attachment 1. 118-F-1 Verification Sampling Results.

\begin{tabular}{|c|c|c|c|c|c|c|c|c|c|c|c|c|c|c|c|c|c|c|c|c|}
\hline \multirow{2}{*}{ Sample Location } & \multirow{2}{*}{$\begin{array}{c}\text { Sample } \\
\text { Number } \\
\end{array}$} & \multirow{2}{*}{$\begin{array}{c}\text { Sample } \\
\text { Date } \\
\end{array}$} & \multicolumn{3}{|c|}{ Americium-241 } & \multicolumn{3}{|c|}{ Americium-241 GEA } & \multicolumn{3}{|c|}{ Carbon-14 } & \multicolumn{3}{|c|}{ Cesium-137 } & \multicolumn{3}{|c|}{ Cobalt-60 } & \multicolumn{3}{|c|}{ Curium-242 } \\
\hline & & & $\mathrm{nCi} / \mathrm{g}$ & $Q$ & MDA & $\mathrm{pCi} / \mathrm{g}$ & $Q$ & MDA & $\mathrm{pCi} / \mathrm{g}$ & Q & MDA & $\mathrm{pCi} / \mathrm{g}$ & Q & MDA & $\mathrm{pCi} / \mathrm{g}$ & $Q$ & MDA & $\mathrm{pCi} / \mathrm{g}$ & $Q$ & $\mathrm{MDA}$ \\
\hline SZ Area $1 \mathrm{~A} 1$ & $\mathrm{~J} 15266$ & $5 / 8 / 07$ & -0.0687 & $\mathrm{U}$ & 0.33 & 0.1 & $\mathrm{U}$ & 0.1 & -0.204 & $\mathrm{U}$ & 3.4 & 0.028 & $\mathrm{u}$ & 0.028 & 0.03 & $\mathrm{U}$ & 0.03 & 0 & $\mathrm{U}$ & 0.27 \\
\hline SZ Areal $1 \mathrm{~A} 2$ & $\mathrm{~J} 15267$ & $5 / 8 / 07$ & 0.0338 & $\mathrm{U}$ & 0.26 & 0.042 & $\mathrm{U}$ & 0.042 & 1.18 & $\mathrm{U}$ & 3.8 & 0.720 & & 0.034 & 0.031 & $\mathrm{U}$ & 0.031 & 0 & $\mathrm{U}$ & 0.27 \\
\hline SZ Area 1 A3 & $\mathrm{J15268}$ & $5 / 8 / 07$ & -0.0663 & $\mathrm{U}$ & 0.51 & 0.17 & $\mathrm{U}$ & 0.17 & 0.240 & $\mathrm{U}$ & 3.4 & 0.026 & $\mathrm{U}$ & 0.026 & 0.028 & $\mathrm{U}$ & 0.028 & 0 & $\mathrm{U}$ & 0.53 \\
\hline SZ Area $1 \mathrm{A4}$ & $\mathrm{J1} 5269$ & $6 / 20 / 07$ & 0 & $\mathrm{U}$ & 0.284 & 0.24 & $\mathrm{U}$ & 0.243 & -1.48 & $\mathrm{U}$ & 3.14 & 0.035 & $\mathrm{U}$ & 0.035 & 0.030 & $\mathrm{U}$ & 0.030 & 0.076 & $\mathrm{U}$ & 0.292 \\
\hline SZ Arca 2B5 & $\mathrm{J} 15270$ & $6 / 20 / 07$ & -0.040 & & 0.33 & 0.090 & $\mathrm{U}$ & 0.090 & -0.495 & $\mathrm{U}$ & 3.36 & 0.026 & $\mathrm{U}$ & 0.026 & 0.027 & $\mathrm{U}$ & 0.027 & 0 & $\mathrm{U}$ & 0.311 \\
\hline SZ Area 2 B6 & $J 15271$ & $5 / 8 / 07$ & 0 & $\mathrm{U}$ & 0.28 & 0.27 & $\mathrm{U}$ & 0.27 & 0.780 & $\mathrm{U}$ & 3.5 & 0.146 & & 0.033 & 0.036 & $\mathrm{U}$ & 0.036 & 0 & $\mathrm{U}$ & 0.29 \\
\hline SZ Area 2B7 & $\$ 15272$ & $5 / 8 / 07$ & 0 & $\mathrm{U}$ & 0.33 & 0.09 & $\mathrm{U}$ & 0.090 & 4.27 & $\mathrm{U}$ & 4.4 & 0.115 & & 0.027 & 0.029 & $\mathrm{U}$ & 0.029 & 0 & $\mathrm{U}$ & 0.35 \\
\hline Duplicate of 115272 & $\mathrm{~J} 15273$ & $5 / 8 / 07$ & 0.0549 & $\mathrm{U}$ & 0.42 & 0.25 & $\mathrm{U}$ & 0.25 & 0.257 & $\mathrm{U}$ & 3.6 & 0.0822 & & 0.039 & 0.035 & $\mathrm{U}$ & 0.035 & 0.0571 & $\mathrm{U}$ & 0.44 \\
\hline Split of $\mathrm{J15272}$ & 115208 & $5 / 8 / 07$ & 0.015 & $\mathrm{U}$ & 0.0398 & & & & -0.0753 & $\mathrm{U}$ & 0.821 & 0.0366 & & 0.0157 & -0.0045 & $\mathrm{U}$ & 0.0165 & & & \\
\hline SZ Area 2 BS & J15274 & $5 / 8 / 07$ & -0.0373 & $\mathrm{U}$ & 0.29 & 0.039 & U & 0.039 & 1.64 & $\mathrm{U}$ & 3.7 & 0.115 & & 0.030 & 0.031 & $\mathrm{U}$ & 0.031 & 0 & $\mathrm{U}$ & 0.3 \\
\hline S2. Area 3C9 & $\mathrm{J} 15661$ & $6 / 20107$ & 0.065 & $\mathrm{U}$ & 0.247 & 0.268 & $\mathrm{U}$ & 0.268 & 0.948 & U & 3.11 & 0.071 & & 0.040 & 0.032 & $\mathrm{U}$ & 0.032 & 0 & $\mathrm{U}$ & 0.253 \\
\hline$S Z$ Area $3 \mathrm{ClO}$ & $\mathrm{J} 15276$ & $6 / 20 / 07$ & 0.0943 & $\mathrm{U}$ & 0.45 & 0.17 & $\mathrm{U}$ & 0.17 & 0.804 & $\mathrm{U}$ & 3.6 & 0.426 & & 0.030 & 0.029 & $\mathrm{U}$ & 0.029 & 0 & $\mathrm{U}$ & 0.37 \\
\hline SZ Area $3 \mathrm{Cl}$ & $\mathrm{J} 15277$ & $5 / 8 / 07$ & 0.108 & $\mathrm{U}$ & 0.35 & 0.080 & $\mathrm{U}$ & 0.080 & 0.438 & $\mathrm{U}$ & 3.6 & 0.0527 & & 0.024 & 0.0456 & & 0.022 & 0.0375 & $\mathrm{U}$ & 0.29 \\
\hline SZ Area $3 \mathrm{C} 2$ & J15278 & $5 / 8107$ & 0 & $\mathrm{U}$ & 0.29 & 0.033 & $\bar{U}$ & 0.033 & 0.997 & U & 3.8 & 0.179 & & 0.027 & 0.041 & $\mathrm{U}$ & 0.041 & 0.0392 & U & 0.30 \\
\hline SZ Area 4 D3 & $\mathrm{J} 15279$ & $5 / 8 / 07$ & 0.194 & $\mathrm{U}$ & 0.25 & 0.15 & $\mathrm{U}$ & 0.15 & 0.372 & $\mathrm{U}$ & 3.4 & 0.0804 & & 0.026 & 0.125 & & 0.029 & 0 & $\mathrm{U}$ & 0.26 \\
\hline SZ Area 4 D4 & $J 15280$ & $5 / 8107$ & 0 & $\mathrm{U}$ & 0.34 & 0.26 & $\mathrm{U}$ & 0.26 & 2.59 & $\mathrm{U}$ & 4.1 & 0.034 & $\mathrm{U}$ & 0.034 & 0.034 & $\mathrm{U}$ & 0.034 & 0 & U & 0.35 \\
\hline SZ Area 4 DS & J15281 & $5 / 21 / 07$ & 0.032 & $\mathrm{U}$ & 0.246 & 0.028 & $\mathrm{U}$ & 0.028 & -1.64 & $\mathrm{U}$ & 3.32 & 0.128 & & 0.017 & 0.047 & $\mathrm{U}$ & 0.047 & 0 & $\mathrm{U}$ & 0.251 \\
\hline SZ Area 4 D6 & 115282 & $5 / 21 / 07$ & 0 & $U$ & 0.256 & 0.043 & $\bar{U}$ & 0.043 & -1.8 & $\mathrm{U}$ & 3.62 & 0.161 & & 0.038 & 0.109 & 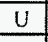 & 0.109 & 0.034 & $\mathrm{U}$ & 0.262 \\
\hline SZ Area 4 D7 & 115688 & $6 / 21107$ & 0.039 & $\mathrm{U}$ & 0.300 & 0.098 & $U$ & 0.098 & -0.934 & $\mathrm{U}$ & 3.20 & 0.052 & $\mathrm{U}$ & 0.052 & 0.033 & $\mathrm{U}$ & 0.033 & 0 & $\mathrm{U}$ & 0.307 \\
\hline $\mathrm{OB} / \mathrm{BCL} \mathrm{A} 1$ & $J 15249$ & $5 / 2 / 107$ & -0.0434 & U & 0.42 & 0.1 & $\mathrm{U}$ & 0.1 & -0.931 & $\mathrm{U}$ & 2.5 & 0.0661 & & 0.041 & 0.032 & $\mathrm{U}$ & 0.032 & 0.0921 & $\mathrm{U}$ & 0.35 \\
\hline $\mathrm{OB} / \mathrm{BCL} \mathrm{A} 2$ & .115250 & $5 / 2 / 07$ & -0.0304 & $\mathrm{U}$ & 0.23 & 0.036 & U & 0.036 & -1.48 & $\mathrm{U}$ & 3.5 & 0.039 & $\mathrm{U}$ & 0.039 & 0.031 & $\mathrm{U}$ & 0.031 & 0.0644 & $\mathrm{U}$ & 0.25 \\
\hline $\mathrm{OB} / \mathrm{BCL} \mathrm{A} 3$ & J15251 & $5 / 2 / 07$ & 0 & $\mathrm{U}$ & 0.26 & 0.046 & U & 0.046 & -0.433 & $\mathrm{U}$ & 3.9 & 0.027 & $\mathrm{U}$ & 0.027 & 0.025 & $\mathrm{U}$ & 0.025 & 0.0356 & $\mathrm{U}$ & 0.27 \\
\hline$O B / B C L A 4$ & $\mathrm{~J} 15252$ & $5 / 2 / 07$ & 0 & $\mathrm{U}$ & 0.30 & 0.22 & $\mathrm{U}$ & 0.22 & -0.978 & $\mathrm{U}$ & 3.5 & 0.035 & $\mathrm{U}$ & 0.035 & 0.031 & U & 0.031 & 0.0419 & $\mathrm{U}$ & 0.32 \\
\hline $\mathrm{OB} / \mathrm{BCL} B 5$ & $\mathrm{~J} 15253$ & $5 / 3 / 07$ & -0.0384 & $\mathrm{u}$ & 0.29 & 0.11 & $\mathrm{U}$ & 0.11 & -0.937 & U & 3.8 & 0.0434 & & 0.030 & 0.032 & $U$ & 0.032 & 0.0813 & $\mathrm{U}$ & 0.31 \\
\hline $\mathrm{OB} / \mathrm{BCL} \mathrm{B} 6$ & $\mathrm{~J} 15254$ & $5 / 3 / 07$ & 0 & $\mathrm{U}$ & 0.30 & 0.035 & $\mathrm{U}$ & 0.035 & -1.34 & $\mathrm{U}$ & 3.9 & 0.0346 & & 0.026 & 0.029 & $\mathrm{U}$ & 0.029 & 0.0838 & $\mathrm{U}$ & 0.32 \\
\hline $\mathrm{OB} / \mathrm{BCL} \mathrm{B} 7$ & $\mathrm{~J} 15255$ & $5 / 3 / 07$ & 0 & $\mathrm{U}$ & 0.27 & 0.045 & $\mathrm{U}$ & 0.045 & -2.29 & $\mathrm{U}$ & 4.5 & 0.028 & $\mathrm{U}$ & 0.028 & 0.023 & $\mathrm{U}$ & 0.023 & 0.0373 & $\mathrm{U}$ & 0.28 \\
\hline $\mathrm{OB} / \mathrm{BCL} \mathrm{B} 8$ & $\mathrm{~J} 15256$ & $5 / 3 / 07$ & -0.0410 & $\mathrm{U}$ & 0.39 & 0.21 & $\mathrm{U}$ & 0.21 & -1.48 & $\mathrm{U}$ & 3.7 & 0.0436 & & 0.030 & 0.029 & $\mathrm{U}$ & 0.029 & 0.0868 & $\mathrm{U}$ & 0.33 \\
\hline $\mathrm{OB} / \mathrm{BCL} C 9$ & 115257 & $5 / 3 / 07$ & 0 & $\mathrm{U}$ & 0.062 & 0.10 & $\mathrm{U}$ & 0.10 & -0.334 & $\mathrm{U}$ & 3.4 & 0.0300 & $\mathrm{U}$ & 0.030 & 0.029 & $\mathrm{U}$ & 0.029 & 0.0275 & $\mathrm{U}$ & 0.053 \\
\hline $\mathrm{OB} / \mathrm{BCLClO}$ & $\mathrm{J15258}$ & $5 / 3 / 07$ & 0.599 & & 0.31 & 0.033 & $\mathrm{U}$ & 0.033 & -0.041 & U & 3.3 & 0.0360 & & 0.029 & 0.031 & $U$ & 0.031 & -0.0422 & $\mathrm{U}$ & 0.32 \\
\hline $\mathrm{OB} / \mathrm{BCLCl}$ & J15259 & $5 / 3 / 07$ & 0 & $\mathrm{U}$ & 0.3 & 0.24 & $\mathrm{U}$ & 0.24 & -1.11 & $\mathrm{U}$ & 3.7 & 0.0483 & & 0.041 & 0.037 & $\mathrm{U}$ & 0.037 & 0.0419 & $\mathrm{U}$ & 0.32 \\
\hline $\mathrm{OB} / \mathrm{BCL} \mathrm{C} 2$ & 315260 & $5 / 3 / 07$ & -0.0320 & $\mathrm{U}$ & 0.31 & 0.21 & $\mathrm{U}$ & 0.21 & -0.412 & $\mathrm{U}$ & 3.3 & 0.0592 & & 0.029 & 0.028 & $\mathrm{U}$ & 0.028 & 0.0677 & $\mathrm{U}$ & 0.26 \\
\hline OB/BCL D3 & $\mathrm{J} 15261$ & $5 / 3 / 07$ & 0 & $\mathrm{U}$ & 0.28 & 0.091 & $\mathrm{U}$ & 0.091 & -0.452 & $\mathrm{U}$ & 4 & 0.0556 & & 0.029 & 0.028 & $\mathrm{U}$ & 0.028 & 0 & $\mathrm{U}$ & 0.29 \\
\hline Duplicate of $J 15261$ & $\mathrm{~J} 15262$ & $5 / 3 / 07$ & -0.0685 & $\mathrm{U}$ & 0.52 & 0.031 & $\mathrm{U}$ & 0.031 & 0.417 & $\mathrm{U}$ & 3.7 & 0.0438 & & 0.030 & 0.026 & $\mathrm{U}$ & 0.026 & 0 & $\mathrm{U}$ & 0.55 \\
\hline Split of J15261 & J15207 & $5 / 3 / 07$ & -0.00165 & $\mathrm{U}$ & 0.0394 & & & & 0.105 & $\mathrm{U}$ & 0.814 & 0.0371 & & 0.0177 & 0.00191 & $\mathrm{U}$ & 0.0188 & & & \\
\hline OB/BCL D4 & 115263 & $5 / 3 / 07$ & 0.0324 & $\mathrm{U}$ & 0.25 & 0.22 & U & 0.22 & -0.670 & $\mathrm{U}$ & 3.8 & 0.0500 & & 0.038 & 0.031 & $\mathrm{U}$ & 0.031 & -0.0343 & $\mathrm{U}$ & 0.26 \\
\hline OB/BCL D5 & J15264 & $5 / 3 / 07$ & -0.0982 & $\mathrm{U}$ & 0.38 & 0.20 & $\mathrm{U}$ & 0.2 & -1.51 & $\mathrm{U}$ & 3.8 & 0.0449 & & 0.030 & 0.028 & $\mathrm{U}$ & 0.028 & 0 & $\mathrm{U}$ & 0.40 \\
\hline OB/BCL D6 & $J 15265$ & $5 / 3 / 07$ & -0.0500 & $\overline{\mathrm{U}}$ & 0.38 & 0.097 & $\mathrm{U}$ & 0.097 & -1.65 & $\mathrm{U}$ & 4.3 & 0.0630 & & 0.032 & 0.032 & $\bar{U}$ & 0.032 & 0 & $\overline{\mathrm{U}}$ & 0.40 \\
\hline
\end{tabular}

Note: The following abbreviations apply to all Attachment I tables.

Note: Data qualified with B. $C, N$, and/or $J$ are considered acceptable values.

$B=$ method blank contamination $\quad O B=$ overburden

$B C L=$ below cleanup levels

$\mathrm{PQL}=$ practical puntitution limit

$C=$ method blank contanination $\quad P T=$ process trench

GEA = gammi anergy andysis

$Q=$ qualifie

$\mathrm{J}=$ estimated

$\mathrm{R}=$ rejected
$\mathrm{SZ}=$ shallow zon

$\mathrm{N}=$ spiked anaiyte recovery outside control limits $\quad \mathrm{U}=$ undetected

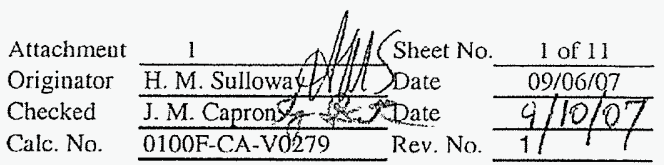


Attachment 1. 118-F-1 Verification Sampling Results.

\begin{tabular}{|c|c|c|c|c|c|c|c|c|c|c|c|c|c|c|c|c|c|c|c|c|}
\hline \multirow{2}{*}{ Sample Location } & \multirow{2}{*}{$\begin{array}{c}\text { Sample } \\
\text { Number }\end{array}$} & \multirow{2}{*}{$\begin{array}{c}\text { Sample } \\
\text { Date }\end{array}$} & \multicolumn{3}{|c|}{ Amcricium-241 } & \multicolumn{3}{|c|}{ Americium-241 GEA } & \multicolumn{3}{|c|}{ Carbon-14 } & \multicolumn{3}{|c|}{ Cesium-137 } & \multicolumn{3}{|c|}{ Cobalt- 60} & \multicolumn{3}{|c|}{ Curium-242 } \\
\hline & & & $\mathrm{pCi} / \mathrm{g}$ & $Q$ & $\mathrm{MDA}$ & $\mathrm{pCi} / \mathrm{g}$ & $Q$ & MDA & $\mathrm{pCi} / \mathrm{g}$ & Q & MDA & $\mathrm{pCi} / \mathrm{g}$ & Q] & MDA & $\mathrm{pCi} / \mathrm{g}$ & Q & MDA & $\mathrm{pCi} / \mathrm{g}$ & $Q$ & $\mathrm{MDA}$ \\
\hline PTA1 & $\mathrm{J} 15283$ & $5 / 10 / 07$ & 0 & $\bar{U}$ & 0.26 & 0.27 & $\mathrm{U}$ & 0.27 & -1.05 & $\mathrm{U}$ & 2.7 & 0.237 & & 0.037 & 0.040 & $\mathrm{U}$ & 0.040 & 0 & $\mathrm{U}$ & 0.27 \\
\hline PT A2 & $\mathrm{J} 15284$ & $5 / 10 / 07$ & 0.0372 & $\mathrm{U}$ & 0.28 & 0.035 & $\bar{U}$ & 0.035 & -0.715 & $\mathrm{U}$ & 2.8 & 0.211 & & 0.028 & 0.0817 & & 0.025 & 0.0387 & $U$ & 0.30 \\
\hline PT A3 & $\mathrm{J} 15285$ & $5 / 10 / 07$ & 0.0298 & $\mathrm{U}$ & 0.23 & 0.17 & $\mathrm{U}$ & 0.17 & -0.528 & $\bar{U}$ & 2.7 & 0.382 & & 0.033 & 0.082 & $\mathrm{U}$ & 0.082 & -0.0310 & $\mathrm{U}$ & 0.24 \\
\hline PT A4 & $J 15286$ & $5 / 10 / 07$ & -0.0399 & $\bar{U}$ & 0.31 & 0.09 & $\bar{U}$ & 0.09 & -0.381 & $\mathrm{U}$ & 2.8 & 0.191 & & 0.025 & 0.0622 & & 0.034 & 0.0415 & $\mathrm{U}$ & 0.32 \\
\hline Duplicate of $J 15286$ & $J 15287$ & $5 / 10 / 07$ & 0.0373 & $\mathrm{U}$ & 0.29 & 0.039 & $\bar{U}$ & 0.039 & -1.56 & $\bar{U}$ & 2.7 & 1.00 & & 0.032 & 0.114 & & 0.034 & 0 & U & 0.30 \\
\hline Split of $J 15286$ & $\mathrm{~J} 152 \mathrm{D} 9$ & $5 / 10 / 07$ & 0.0479 & & 0.0186 & & & & -0.0905 & $\mathrm{U}$ & 0.823 & 0.088 & & 0.0169 & 0.140 & & 0.0201 & & & \\
\hline PT A5 & $\mathrm{J} 15689$ & $6 / 21 / 07$ & 0 & $\mathrm{U}$ & 0.293 & 0.297 & $\mathrm{U}$ & 0.297 & -1.93 & $\mathrm{U}$ & 3.42 & 0.078 & $U$ & 0.078 & 0.041 & $\mathrm{U}$ & 0.041 & 0 & U & 0.299 \\
\hline
\end{tabular}

\begin{tabular}{|c|c|c|c|c|c|c|c|c|c|c|c|c|c|c|c|c|c|c|c|c|}
\hline \multirow{2}{*}{ Sample Location } & \multirow{2}{*}{$\begin{array}{l}\text { Sample } \\
\text { Number }\end{array}$} & \multirow{2}{*}{$\begin{array}{c}\text { Sample } \\
\text { Date }\end{array}$} & \multicolumn{3}{|c|}{ Curium-243/244 } & \multicolumn{3}{|c|}{ Europium-152 } & \multicolumn{3}{|c|}{ Europium-154 } & \multicolumn{3}{|c|}{ Europium-155 } & \multicolumn{3}{|c|}{ Nickel-6.3 } & \multicolumn{3}{|c|}{ Plutonium-238 } \\
\hline & & & $\mathrm{pCi} / \mathrm{g}$ & $Q$ & MDA & $\mathrm{pCi} / \mathrm{g}$ & $Q$ & MDA & $\mathrm{pCi} / \mathrm{g}$ & $Q$ & MDA & $\mathrm{pCi} / \mathrm{g}$ & Q] & MDA & $\mathrm{pCi} / \mathrm{g}$ & $\mathrm{Q}$ & MDA & $\mathrm{pCi} / \mathrm{g}$ & $Q$ & $\mathrm{MOA}$ \\
\hline SZ Area $\mid \mathrm{Al}$ & 115266 & $5 / 8 / 07$ & -0.0344 & $\bar{U}$ & 0.33 & 0.077 & U & 0.077 & 0.099 & U & 0.099 & 0.082 & U & 0.082 & 1.07 & $\overrightarrow{\mathrm{U}}$ & 3.9 & 0 & $\mathrm{U}$ & 0.28 \\
\hline SZ Area $1 \mathrm{~A} 2$ & $\mathrm{~J} 15267$ & $5 / 8 / 07$ & 0 & $\mathrm{U}$ & 0.32 & 0.11 & $\mathrm{U}$ & 0.11 & 0.10 & $\bar{U}$ & 0.10 & 0.070 & $\mathrm{U}$ & 0.070 & 3.64 & $\mathrm{U}$ & 4.3 & 0.0655 & 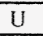 & 0.25 \\
\hline SZ Area $1 \mathrm{AB}$ & $\mathrm{J15268}$ & $5 / 8 / 07$ & 0.199 & $\mathrm{U}$ & 0.51 & 0.077 & $\mathrm{U}$ & 0.077 & 0.083 & $\bar{U}$ & 0.083 & 0.097 & $\mathrm{U}$ & 0.097 & 0.433 & $\mathrm{U}$ & 4.5 & 0 & $\mathrm{U}$ & 0.27 \\
\hline SZ Area 1 A4 & 515269 & $6 / 20 / 07$ & 0 & $\mathrm{U}$ & 0.285 & 0.080 & $\mathrm{U}$ & 0.080 & 0.116 & $\bar{U}$ & 0.116 & 0.094 & $\bar{U}$ & 0.094 & -0.719 & $\bar{U}$ & 3.31 & 0 & $\mathrm{U}$ & 0.266 \\
\hline SZ, Are: 2BS & 515270 & $6 / 20 / 07$ & 0.04 & $\mathrm{U}$ & 0.488 & 0.071 & $\mathrm{U}$ & 0.071 & 0.094 & $\mathrm{U}$ & 0.094 & 0.077 & $\mathrm{U}$ & 0.077 & -0.582 & $\mathrm{U}$ & 3.4 & 0 & $\mathrm{U}$ & 0.249 \\
\hline SZ Area $2 \mathrm{~B} 6$ & $\mathrm{J15271}$ & $5 / 8 / 07$ & 0.0723 & $\mathrm{U}$ & 0.35 & 0.094 & $\bar{U}$ & 0.094 & 0.12 & $\mathrm{U}$ & 0.12 & 0.099 & $\mathrm{U}$ & 0.099 & 4.25 & & 3.9 & -0.0280 & $\mathrm{U}$ & 0.27 \\
\hline SZ Area 2 B7 & $J 15272$ & $5 / 8107$ & -0.0436 & $\mathrm{U}$ & 0.33 & 0.072 & $\mathrm{U}$ & 0.072 & 0.097 & $\bar{U}$ & 0.097 & 0.077 & $\bar{U}$ & 0.077 & 0.640 & $\overline{\mathrm{U}}$ & 4.1 & -0.0356 & $\bar{U}$ & 0.27 \\
\hline Duplicute of 115272 & $J 15273$ & $5 / 8 / 07$ & 0.0550 & $\mathrm{U}$ & 0.53 & 0.090 & $\mathrm{U}$ & 0.090 & 0.11 & $\mathrm{U}$ & 0.11 & 0.096 & $\bar{U}$ & 0.096 & 1.85 & $\bar{U}$ & 5.1 & 0 & $\mathrm{U}$ & 0.29 \\
\hline Splil of J15272 & 115208 & $5 / 8 / 07$ & 0.0416 & & 0.0399 & 0.028 & $\mathrm{U}$ & 0.0377 & -0.00259 & $\mathrm{U}$ & 0.0563 & 0.00251 & $\mathrm{u}$ & 0.0400 & 5.30 & & 5.25 & -0.00234 & $\bar{U}$ & 0.0561 \\
\hline S7. Areal 2 B8 & 315274 & $5 / 8 / 07$ & 0.0373 & $\mathrm{U}$ & 0.29 & 0.074 & $\mathrm{U}$ & 0.074 & 0.10 & $\mathrm{U}$ & 0.10 & 0.064 & $\mathrm{U}$ & 0.064 & 2.85 & $\mathrm{U}$ & 4.8 & -0.0326 & $\mathrm{U}$ & 0.25 \\
\hline SZ Area $3 \mathrm{CO}$ & $J 15661$ & $6 / 20 / 07$ & 0.097 & $\mathrm{U}$ & 0.309 & 0.084 & $\mathrm{U}$ & 0.084 & 0.133 & $\bar{U}$ & 0.133 & 0.103 & $\bar{U}$ & 0.103 & -0.996 & $U$ & 3.36 & 0.074 & $\bar{U}$ & 0.282 \\
\hline SZ Area $3 \mathrm{ClO}$ & .115276 & $6 / 20 / 07$ & -0.0472 & $\mathrm{U}$ & 0.63 & 0.076 & $\mathrm{U}$ & 0.076 & 0.091 & $\mathrm{U}$ & 0.091 & 0.097 & $\bar{U}$ & 0.097 & 0.371 & $\mathrm{U}$ & 5.1 & 0 & $\mathrm{U}$ & 0.27 \\
\hline SZ Area $3 \mathrm{Cl}$ & $\mathrm{J} 15277$ & $5 / 8 / 07$ & 0.0723 & $\mathrm{U}$ & 0.48 & 0.18 & $\bar{U}$ & 0.18 & 0.093 & $U$ & 0.093 & 0.069 & $\mathrm{U}$ & 0.069 & 7.22 & & 4.6 & 0 & $\mathrm{U}$ & 0.39 \\
\hline SZ Area $3 \mathrm{C} 2$ & J15278 & $5 / 8 / 07$ & 0.189 & $\mathrm{U}$ & 0.46 & 0.067 & $\mathrm{U}$ & 0.067 & 0.092 & $\mathrm{U}$ & 0.092 & 0.066 & $\mathrm{U}$ & 0.066 & 1.54 & $\bar{U}$ & 4.4 & 0 & $\mathrm{U}$ & 0.37 \\
\hline SZ Area 4D3 & $J 15279$ & $5 / 8 / 07$ & 0 & $\overline{\mathrm{U}}$ & 0.31 & 0.17 & $\bar{U}$ & 0.17 & 0.085 & $\mathrm{U}$ & 0.085 & 0.086 & $\mathrm{U}$ & 0.086 & 1.90 & $\mathrm{U}$ & 4.2 & -0.0351 & U & 0.27 \\
\hline SZ Area 4D4 & $\mathrm{J} 15280$ & $5 / 8 / 07$ & 0.0440 & $\mathrm{U}$ & 0.34 & 0.081 & $\mathrm{U}$ & 0.081 & 0.12 & $\mathrm{U}$ & 0.12 & 0.094 & $\mathrm{U}$ & 0.094 & 0.404 & $\mathrm{U}$ & 4.2 & 0 & $\overline{\mathrm{U}}$ & 0.37 \\
\hline SZ Area 4D5 & 315281 & $5 / 21 / 07$ & -0.064 & $\mathrm{U}$ & 0.355 & 0.096 & $\mathrm{U}$ & 0.096 & 0.061 & $\mathrm{U}$ & 0.061 & 0.054 & $\mathrm{U}$. & 0.054 & 0.254 & $\bar{U}$ & 3.18 & 0 & $\overline{\mathrm{U}}$ & 0.149 \\
\hline SZ Area 4 D6 & $\mathrm{J} 15282$ & $5 / 21 / 07$ & -0.034 & $\mathrm{U}$ & 0.256 & 0.108 & $\mathrm{U}$ & 0.108 & 0.113 & $\mathrm{U}$ & 0.113 & 0.081 & U & 0.081 & 1.34 & $\overline{\mathrm{U}}$ & 3.16 & 0 & U & 0.155 \\
\hline SZ Area 4 D7 & $\mathrm{J15688}$ & $6 / 21 / 07$ & 0.079 & $\mathrm{U}$ & 0.300 & 0.080 & $U$ & 0.080 & 0.098 & $\mathrm{U}$ & 0.098 & 0.083 & $\bar{U}$ & 0.083 & 0.219 & $\mathrm{U}$ & 3.20 & 0 & $\mathrm{U}$ & 0.180 \\
\hline OB/BCL AI & 315249 & $5 / 2 / 07$ & 0.130 & $\overline{\mathrm{U}}$ & 0.42 & 0.082 & $\bar{U}$ & 0.082 & 0.10 & $\overline{\mathrm{U}}$ & 0.10 & 0.083 & $\mathrm{U}$ & 0.083 & 0.904 & $\bar{U}$ & 4.8 & -0.0321 & $\bar{U}$ & 0.35 \\
\hline $\mathrm{OB} / \mathrm{BCL} \mathrm{A} 2$ & 515250 & $5 / 2 / 07$ & -0.0608 & $\overline{\mathrm{U}}$ & 0.29 & 0.075 & $\mathrm{U}$ & 0.075 & 0.093 & $U$ & 0.093 & 0.066 & $\mathrm{U}$ & 0.066 & 2.66 & $\mathrm{U}$ & 4.9 & 0.0351 & $\mathrm{U}$ & 0.27 \\
\hline OB/BCL $A 3$ & $J 15251$ & $5 / 2 / 07$ & 0 & $\mathrm{U}$ & 0.26 & 0.066 & $\bar{U}$ & 0.066 & 0.090 & $\bar{U}$ & 0.090 & 0.065 & $\mathrm{U}$ & 0.065 & 1.03 & $\mathrm{U}$ & 4.7 & 0.0777 & $\mathrm{U}$ & 0.25 \\
\hline $\mathrm{OB} / \mathrm{BCL} A 4$ & $J 15252$ & $5 / 2 / 07$ & 0.0396 & $U$ & 0.38 & 0.089 & U & 0.089 & 0.092 & $\bar{U}$ & 0.092 & 0.12 & 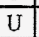 & 0.12 & 0.256 & $\bar{U}$ & 4.4 & 0 & $\mathrm{U}$ & 0.21 \\
\hline $\mathrm{OB} / \mathrm{BCL} \mathrm{B} 5$ & $J 15253$ & $5 / 3 / 07$ & .0 .0385 & $\mathrm{U}$ & 0.29 & 0.087 & $\bar{U}$ & 0.087 & 0.11 & $\mathrm{U}$ & 0.11 & 0.091 & $\mathrm{U}$ & 0.091 & -0.183 & $\overline{\mathrm{U}}$ & 3.9 & 0 & $\mathrm{U}$ & 0.22 \\
\hline $\mathrm{OB} / \mathrm{BCL} \mathrm{B} 6$ & $\mathrm{J15254}$ & $5 / 3 / 07$ & 0.0396 & $\mathrm{U}$ & 0.38 & 0.075 & $\mathrm{U}$ & 0.075 & 0.096 & $U$ & 0.096 & 0.066 & U & 0.066 & 0.688 & $\overline{\mathrm{U}}$ & 4.2 & 0.0662 & $\mathrm{U}$ & 0.25 \\
\hline $\mathrm{OB} / \mathrm{BCL} \mathrm{B} 7$ & $J 15255$ & $5 / 3 / 07$ & -0.0353 & $\bar{U}$ & 0.27 & 0.066 & $\mathrm{U}$ & 0.066 & 0.096 & $\mathrm{U}$ & 0.096 & 0.061 & $U$ & 0.061 & 0 & $\mathrm{U}$ & 3.7 & 0.0340 & $\mathrm{U}$ & 0.26 \\
\hline OB/BCL B8 & $\mathrm{J} 15256$ & $5 / 3 / 07$ & 0 & $\mathrm{U}$ & 0.59 & 0.086 & $\mathrm{U}$ & 0.086 & 0.091 & $\mathrm{U}$ & 0.091 & 0.11 & $\mathrm{U}$ & 0.11 & 0.225 & $\bar{U}$ & 3.9 & 0 & $\mathrm{U}$ & 0.38 \\
\hline $\mathrm{OB} / \mathrm{BCL} C 9$ & $\mathrm{~J} 15257$ & $5 / 3 / 07$ & 0.0456 & $\bar{U}$ & 0.094 & 0.077 & $\bar{U}$ & 0.077 & 0.11 & $\bar{U}$ & 0.11 & 0.084 & $\mathrm{U}$ & 0.084 & 0 & $\bar{U}$ & 3.6 & 0 & $\overline{\mathrm{U}}$ & 0.31 \\
\hline $\mathrm{OB} / \mathrm{BCL} C \mathrm{Cl}$ & $J 15258$ & $5 / 3 / 07$ & 0.120 & $\overline{\mathrm{U}}$ & 0.38 & 0.073 & $\bar{U}$ & 0.073 & 0.089 & $\overline{\mathrm{U}}$ & 0.089 & 0.063 & $\mathrm{U}$ & 0.063 & 1.50 & $\mathrm{U}$ & 6.6 & -0.0783 & $\bar{U}$ & 0.43 \\
\hline $\mathrm{OB} / \mathrm{BCLCl}$ & 115259 & $5 / 3 / 107$ & -0.0397 & $\mathrm{U}$ & 0.30 & 0.087 & $\bar{U}$ & 0.087 & 0.11 & $\mathrm{U}$ & 0.11 & 0.11 & $\bar{U}$ & 0.11 & 1.80 & U & 6.1 & -0.0501 & $\bar{U}$ & 0.38 \\
\hline $\mathrm{OB} / \mathrm{BCL} C 2$ & 515260 & $5 / 3 / 07$ & 0.0320 & $\mathrm{U}$ & 0.31 & 0.082 & $\mathrm{U}$ & 0.082 & 0.088 & $\bar{U}$ & 0.088 & 0.11 & $\mathrm{U}$ & 0.11 & 0.698 & $\overline{\mathrm{U}}$ & 6.5 & 0.0947 & $\bar{U}$ & 0.24 \\
\hline
\end{tabular}

Attachment 1 Sheet No. 2 of 11

Originator H.M. Sullowa Datc $01006 / 07$ 
Attachment 1. 118-F-1 Verification Sampling Results.

\begin{tabular}{|c|c|c|c|c|c|c|c|c|c|c|c|c|c|c|c|c|c|c|c|c|}
\hline \multirow{2}{*}{ Sample Location } & \multirow{2}{*}{$\begin{array}{c}\text { Sample } \\
\text { Number }\end{array}$} & \multirow{2}{*}{$\begin{array}{c}\text { Sample } \\
\text { Date }\end{array}$} & \multicolumn{3}{|c|}{ Curiunl-243/244 } & \multicolumn{3}{|c|}{ Europium-152 } & \multicolumn{3}{|c|}{ Europium-154 } & \multicolumn{3}{|c|}{ Europium-155 } & \multicolumn{3}{|c|}{ Nickel-63 } & \multicolumn{3}{|c|}{ Plutonium-238 } \\
\hline & & & $\mathrm{pCi} / \mathrm{g}$ & $Q$ & MDA & $\mathrm{pCi} / \mathrm{g}$ & $Q$ & $\mathrm{MDA}$ & $\mathrm{pCi} / \mathrm{g}$ & $Q$ & MDA & $\mathrm{pCi} / \mathrm{g}$ & $Q$ & $\mathrm{MDA}$ & $\mathrm{pCi} / \mathrm{g}$ & $Q$ & MDA & $\mathrm{pCi} / \mathrm{g}$ & $Q$ & MDA \\
\hline OB/BCLD3 & $\mathrm{J} 1526 \mathrm{I}$ & $5 / 3 / 07$ & -0.0361 & $\mathrm{U}$ & 0.35 & 0.073 & $\mathrm{U}$ & 0.073 & 0.093 & $\mathrm{U}$ & 0.093 & 0.077 & $\mathrm{U}$ & 0.077 & 0.872 & U & 6.5 & 0 & U & 0.28 \\
\hline Duplicate of J15261 & 515262 & $5 / 3 / 07$ & 0 & $\mathrm{U}$ & 0.52 & 0.065 & $\mathrm{U}$ & 0.065 & 0.086 & $\mathrm{U}$ & 0.086 & 0.060 & $\mathrm{U}$ & 0.06 & 0.416 & $\mathrm{U}$ & 6.2 & 0.0281 & $\mathrm{U}$ & 0.27 \\
\hline Split of J15261 & $\mathrm{J152D7}$ & $5 / 3 / 07$ & 0.0412 & J & 0.0395 & -0.0184 & $\mathrm{U}$ & 0.0377 & -0.00923 & $\mathrm{U}$ & 0.0612 & 0.0685 & $\mathrm{U}$ & 0.0536 & 0.606 & $\mathrm{U}$ & 1.48 & 0 & U & 0.0431 \\
\hline $\mathrm{OB} / \mathrm{BCL} \mathrm{D} 4$ & $\mathrm{~J} 15263$ & $5 / 3 / 07$ & -0.0325 & $\mathrm{u}$ & 0.31 & 0.086 & U & 0.086 & 0.12 & $\mathrm{U}$ & 0.12 & 0.10 & $\mathrm{U}$ & 0.10 & 0.471 & $\mathrm{U}$ & 5.9 & -0.115 & $U$ & 0.43 \\
\hline OB/BCLD5 & $\mathrm{J} 15264$ & $5 / 3 / 07$ & 0.148 & $\mathrm{U}$ & 0.38 & 0.082 & $\mathrm{U}$ & 0.082 & 0.090 & $\overline{\mathrm{U}}$ & 0.090 & 0.11 & $\mathrm{U}$ & 0.11 & .0 .0824 & $\bar{U}$ & 6.2 & 0.0953 & $U$ & 0.36 \\
\hline OB/BCLD6 & $J 15265$ & $5 / 3 / 07$ & -0.100 & $\mathrm{U}$ & 0.48 & 0.080 & $\mathrm{U}$ & 0.080 & 0.099 & $\mathrm{U}$ & 0.099 & 0.080 & U & 0.080 & 0.837 & $\mathrm{U}$ & 5.2 & 0.0337 & U & 0.32 \\
\hline PTAl & $J 15283$ & $5 / 10 / 07$ & -0.0686 & $\bar{U}$ & 0.33 & 0.10 & $\overline{\mathrm{U}}$ & 0.10 & 0.13 & $\bar{U}$ & 0.13 & 0.10 & $\mathrm{U}$ & 0.10 & -0.370 & $\bar{U}$ & 3.3 & 0.0338 & $\bar{U}$ & 0.26 \\
\hline PT A2 & $J 15284$ & $5 / 10 / 07$ & 0.149 & U & 0.28 & 0.17 & $U$ & 0.17 & 0.091 & $\mathrm{U}$ & 0.091 & 0.060 & $\mathrm{U}$ & 0.060 & 0.736 & $\mathrm{U}$ & 3.3 & 0.0448 & $\mathrm{U}$ & 0.34 \\
\hline PT A3 & $\mathrm{J} 15285$ & $5 / 10 / 07$ & 0.149 & $\bar{U}$ & 0.29 & 0.25 & $\mathrm{U}$ & 0.25 & 0.099 & $\mathrm{U}$ & 0.099 & 0.10 & $U$ & 0.10 & 1.22 & $\mathrm{U}$ & 3.3 & 0.054 & $\mathrm{U}$ & $0.4 \mathrm{I}$ \\
\hline PTA4 & $J 15286$ & $5 / 10 / 07$ & 0.0400 & $\bar{U}$ & 0.31 & 0.210 & & 0.065 & 0.10 & $\bar{U}$ & 0.10 & 0.077 & $\mathrm{u}$ & 0.077 & 14.3 & & 3.2 & 0.0751 & $\bar{U}$ & 0.29 \\
\hline Duplicate of J15286 & $J 15287$ & $5 / 10 / 07$ & 0.0370 & $\bar{U}$ & 0.290 & 0.144 & & 0.077 & 0.098 & $\bar{U}$ & 0.098 & 0.061 & $\mathrm{U}$ & 0.061 & 1.51 & $\bar{U}$ & 3.3 & -0.043 & $U$ & 0.33 \\
\hline Split of J15286 & J152D9 & $5 / 10 / 07$ & 0.0403 & & 0.0186 & 0.071 & $\mathrm{U}$ & 0.0307 & 0.021 & U & 0.0633 & 0.0114 & $U$ & 0.0401 & 8.61 & & 5.80 & -0.0020 & $\mathrm{U}$ & 0.0409 \\
\hline PT A5 & $\mathrm{J} 15689$ & $6 / 21 / 07$ & -0.038 & U & 0.293 & 0.090 & $\mathrm{U}$ & 0.090 & 0.138 & $\mathrm{U}$ & 0.138 & 0.116 & $\bar{U}$ & 0.116 & -1.01 & $\mathrm{U}$ & 3.16 & 0.031 & $U$ & 0.236 \\
\hline
\end{tabular}

\begin{tabular}{|c|c|c|c|c|c|c|c|c|c|c|c|c|c|c|c|c|c|c|c|c|}
\hline \multirow{2}{*}{ Sample Location } & \multirow{2}{*}{$\begin{array}{c}\text { Sample } \\
\text { Number }\end{array}$} & \multirow{2}{*}{$\begin{array}{c}\text { Sample } \\
\text { Date }\end{array}$} & \multicolumn{3}{|c|}{ Plutonium-239/240 } & \multicolumn{3}{|c|}{ Potassium-40 } & \multicolumn{3}{|c|}{ Radium-226 } & \multicolumn{3}{|c|}{ Radium-228 } & \multicolumn{3}{|c|}{ Silver-108m } & \multicolumn{3}{|c|}{ Thorium-228 GEA } \\
\hline & & & $\mathrm{pCi} / \mathrm{g}$ & $Q$ & MDA & $\mathrm{pCig}$ & $\mathbf{Q}$ & MDA & $\mathrm{pCi} / \mathrm{g}$ & $Q$ & MDA & $\mathrm{pCi} / \mathrm{g}$ & $Q$ & MDA & $\mathrm{pCi} / \mathrm{g}$ & $Q$ & $\mathrm{MDA}$ & $\mathrm{pCi} / \mathrm{g}$ & $Q$ & $\mathrm{MD \Lambda}$ \\
\hline SZ Area $1 \mathrm{Al}$ & 515266 & $5 / 8 / 07$ & 0.0736 & $\overline{\mathrm{U}}$ & 0.28 & 13.1 & & 0.26 & 0.403 & & 0.048 & 0.613 & & 0.12 & 0.085 & $\mathrm{U}$ & 0.085 & 0.742 & & 0.051 \\
\hline SZ Area 1 A2 & $\sqrt{15267}$ & $5 / 8 / 07$ & 0 & $\mathrm{U}$ & 0.25 & 14.2 & & 0.29 & 0.442 & & 0.061 & 0.566 & & 0.12 & 0.025 & $\mathrm{U}$ & 0.025 & 0.643 & & 0.042 \\
\hline SZ Areal $1 \mathrm{~A} 3$ & $J 15268$ & $5 / 8 / 07$ & 0.0346 & $\bar{U}$ & 0.26 & 11.1 & & 0.31 & 0.355 & & 0.06 & 0.525 & & 0.10 & 0.021 & 0 & 0.021 & 0.635 & & 0.049 \\
\hline SZ Area $1 \mathrm{~A} 4$ & $J 15269$ & $6 / 20 / 07$ & 0.083 & $\bar{U}$ & 0.212 & 12.8 & & 0.268 & 0.361 & & 0.061 & 0.610 & & 0.132 & 0.023 & $\mathrm{U}$ & 0.023 & 0.526 & & 0.040 \\
\hline SZ Area 2B5 & $\mathrm{J} 15270$ & $6 / 20 / 07$ & 0.228 & $\bar{U}$ & 0.249 & 11.9 & & 0.211 & 0.364 & & 0.044 & 0.649 & & 0.086 & 0.019 & $\bar{U}$ & 0.019 & 0.654 & & 0.045 \\
\hline SZ Area 2 B6 & $\mathrm{J} 15271$ & $5 / 8 / 07$ & 0 & $\overline{\mathrm{U}}$ & 0.21 & 12.8 & & 0.34 & 0.467 & & 0.066 & 0.599 & & 0.13 & 0.025 & $\bar{U}$ & 0.025 & 0.686 & & 0.069 \\
\hline SL Area 2 B7 & $\mathrm{J15272}$ & $5 / 8 / 07$ & 0.0711 & $\mathrm{U}$ & 0.27 & 12.1 & & 0.26 & 0.397 & & 0.044 & 0.545 & & 0.10 & 0.021 & $U$ & 0.021 & 0.687 & & 0.050 \\
\hline Duplicate of $J 15272$ & $\mathrm{J15273}$ & $5 / 8 / 07$ & 0 & $\mathrm{U}$ & 0.29 & 12.2 & & 0.27 & 0.397 & & 0.064 & 0.592 & & 0.14 & 0.024 & $U$ & 0.024 & 0.604 & & 0.044 \\
\hline Split of J15272 & J152D8 & $5 / 8 / 07$ & -0.00234 & $\overline{\mathrm{U}}$ & 0.0561 & & & & & & & & & & -0.00498 & $U$ & 0.0116 & & & \\
\hline SZ Areal 2 B8 & $J 15274$ & $5 / 8 / 07$ & 0.0652 & $\mathrm{U}$ & 0.25 & 13.3 & & 0.30 & 0.393 & & 0.056 & 0.585 & & 0.10 & 0.021 & $\mathrm{U}$ & 0.021 & 0.618 & & 0.037 \\
\hline SZ Area $3 \mathrm{Cg}$ & $\mathrm{J} 15661$ & $6 / 20 / 07$ & 0.258 & $\mathrm{U}$ & 0.282 & 12.3 & & 0.331 & 0.421 & & 0.066 & 0.538 & & 0.143 & 0.026 & & 0.026 & 0.514 & & 0.043 \\
\hline SZ Area $3 \mathrm{ClO}$ & $\mathrm{J} 15276$ & $6 / 20 / 07$ & 0.0349 & $\mathrm{U}$ & 0.27 & 13.0 & & 0.23 & 0.393 & & 0.059 & 0.591 & & 0.11 & 0.022 & $\mathrm{U}$ & 0.022 & 0.722 & & 0.052 \\
\hline SZ Area $3 \mathrm{Cl}$ & J15277 & $5 / 8 / 07$ & 0 & $\bar{U}$ & 0.39 & 14.1 & & 0.2 & 0.375 & & 0.043 & 0.630 & & 0.097 & 0.018 & $\bar{U}$ & 0.018 & 0.645 & & 0.042 \\
\hline SZ Area 3C2 & 115278 & $5 / 8 / 07$ & 0 & $\mathrm{U}$ & 0.3 & 13.3 & & 0.24 & 0.397 & & 0.048 & 0.589 & & 0.096 & 0.019 & $\mathrm{U}$ & 0.019 & 0.574 & & 0.031 \\
\hline SZ Area 4D3 & J15279 & $5 / 8 / 07$ & 0.0350 & $\mathrm{U}$ & 0.27 & 12.5 & & 0.26 & 0.451 & & 0.047 & 0.627 & & 0.11 & 0.018 & $\mathrm{U}$ & 0.018 & 0.686 & & 0.047 \\
\hline SZ Areal 4 D4 & $\mathrm{J} 15280$ & $5 / 8 / 07$ & 0 & $\mathrm{U}$ & 0.29 & 12.5 & & 0.27 & 0.424 & & 0.063 & 0.692 & & 0.14 & 0.023 & $\mathrm{U}$ & 0.023 & 0.584 & & 0.042 \\
\hline SZ Area 4D5 & 115281 & $5 / 21 / 07$ & 0.039 & $\mathrm{U}$ & 0.149 & 15.6 & & 0.136 & 0.410 & & 0.031 & 0.629 & & 0.073 & 0.012 & $\mathrm{U}$ & 0.012 & 0.624 & & 0.021 \\
\hline SZ Area 4DG & $\mathrm{J} 15282$ & $5 / 21 / 07$ & 0.243 & & 0.155 & 14.5 & & 0.310 & 0.388 & & 0.066 & 0.546 & & 0.137 & 0.026 & $\mathrm{U}$ & 0.026 & 0.619 & & 0.04 \\
\hline SZ Area 4 D7 & $\mathrm{J} 15688$ & $6 / 21 / 07$ & 0.071 & $\mathrm{U}$ & 0.180 & 14.4 & & 0.277 & 0.424 & & 0.043 & 0.700 & & 0.131 & 0.023 & U & 0.023 & 0.845 & $U$ & 0.052 \\
\hline
\end{tabular}
Sheet No. $\quad 3$ of 11 Originator H. M. Sulloway Date 09/06/07 $\begin{array}{llll}\text { Checked } & \text { J.M. Capron } & \text { Date } & 09 / 06 / 07 \\ \text { Calc. No. } & \text { Rev. No. } & \end{array}$ 
Attachment 1. 118-F-1 Verification Sampling Results.

\begin{tabular}{|c|c|c|c|c|c|c|c|c|c|c|c|c|c|c|c|c|c|c|c|c|}
\hline \multirow{2}{*}{ Sample Location } & \multirow{2}{*}{$\begin{array}{l}\text { Sample } \\
\text { Number }\end{array}$} & \multirow{2}{*}{$\begin{array}{c}\text { Sample } \\
\text { Date }\end{array}$} & \multicolumn{3}{|c|}{ Plutonium-239/240 } & \multicolumn{3}{|c|}{ Potassium- 40} & \multicolumn{3}{|c|}{ Radium-226 } & \multicolumn{3}{|c|}{ Radium-228 } & \multicolumn{3}{|c|}{ Silver-108m } & \multicolumn{3}{|c|}{ Thorium-228 GEA } \\
\hline & & & $\mathrm{pCi} / \mathrm{g}$ & $Q$ & $\mathrm{MDA}$ & $\mathrm{pCi} / \mathrm{g}$ & $\mathrm{Q}$ & $\mathrm{MDA}$ & $\mathrm{pCi} / \mathrm{g}$ & $Q$ & MDA & $\mathrm{pCi} / \mathrm{g}$ & Q & $\mathrm{MDA}$ & $\mathrm{pCj} / \mathrm{g}$ & $Q$ & $\mathrm{MDA}$ & $\mathrm{pCi} / \mathrm{g}$ & $Q$ & MDA \\
\hline $\mathrm{OB} / \mathrm{BCL} \mathrm{Al}$ & $\mathrm{J} 15249$ & $5 / 2 / 07$ & 0.0641 & $U$ & 0.25 & 12.4 & & 0.26 & 0.481 & & 0.049 & 0.739 & & 0.12 & 0.023 & $\mathrm{U}$ & 0.023 & 0.836 & & 0.052 \\
\hline $\mathrm{OB} / \mathrm{BCL} \mathrm{A2}$ & $\mathrm{J15250}$ & $5 / 2 / 07$ & 0 & $\mathrm{U}$ & 0.27 & 12.1 & & 0.26 & 0.434 & & 0.049 & 0.692 & & 0.12 & 0.020 & $u$ & 0.02 & 0.667 & & 0.039 \\
\hline $\mathrm{OB} / \mathrm{BCLA3}$ & $\mathrm{J} 1525 !$ & $5 / 2 / 07$ & -0.0259 & $\mathrm{U}$ & 0.20 & 13.2 & & 0.29 & 0.586 & & 0.050 & 0.734 & & 0.12 & 0.018 & $\mathrm{U}$ & 0.018 & 0.778 & & 0.033 \\
\hline $\mathrm{OB} / \mathrm{BCL} \mathrm{A} 4$ & $\mathrm{~J} 15252$ & $5 / 2 / 07$ & -0.0277 & $U$ & 0.21 & 12.8 & & 0.30 & 0.468 & & 0.065 & 0.817 & & 0.12 & 0.024 & $\mathrm{U}$ & 0.024 & 0.840 & & 0.057 \\
\hline $\mathrm{OB} / \mathrm{BCL} \mathrm{B} 5$ & $\mathrm{~J} 15253$ & $5 / 3 / 07$ & 0 & $\mathrm{U}$ & 0.22 & 13.5 & & 0.29 & 0.555 & & 0.059 & 0.918 & & 0.12 & 0.024 & U & 0.024 & 1.04 & & 0.054 \\
\hline $\mathrm{OB} / \mathrm{BCL} \mathrm{BO}$ & $\mathrm{J} 15254$ & $5 / 3 / 07$ & 0 & $\mathrm{U}$ & 0.25 & 12.2 & & 0.28 & 0.453 & & 0.051 & 0.703 & & 0.13 & 0.020 & $\mathrm{U}$ & 0.020 & 0.706 & & 0.038 \\
\hline OB/BCL B 7 & $J 15255$ & $5 / 3 / 07$ & 0 & $\mathrm{U}$ & 0.26 & 13.2 & & 0.26 & 0.451 & & 0.047 & 0.727 & & 0.11 & 0.017 & $\mathrm{U}$ & 0.017 & 0.732 & & 0.031 \\
\hline $\mathrm{OB} / \mathrm{BCL} \mathrm{B} 8$ & $\mathrm{~J} 15256$ & $5 / 3 / 07$ & 0 & $\mathrm{U}$ & 0.30 & $11: 5$ & & 0.37 & 0.482 & & 0.056 & 0.718 & & 0.12 & 0.022 & $\mathrm{U}$ & 0.022 & 0.810 & & 0.051 \\
\hline OB/BCLC9 & $J 15257$ & $5 / 3 / 107$ & 0.0324 & $\mathrm{U}$ & 0.25 & 11.5 & & 0.29 & 0.404 & & 0.053 & 0.571 & & 0.14 & 0.023 & $\mathrm{U}$ & 0.023 & 0.766 & & 0.056 \\
\hline $\mathrm{OB} / \mathrm{BCL} \mathrm{C} 10$ & $\mathrm{J15258}$ & $5 / 3 / 07$ & 0.0391 & $\mathrm{U}$ & 0.30 & 11.9 & & 0.30 & 0.386 & & 0.054 & 0.648 & & 0.12 & 0.020 & $\mathrm{U}$ & 0.020 & 0.638 & & 0.036 \\
\hline $\mathrm{OB} / \mathrm{BCLCl}$ & J15259 & $5 / 3 / 107$ & 0 & U & 0.38 & 13.2 & & 0.36 & 0.474 & & 0.061 & 0.719 & & 0.14 & 0.027 & U & 0.027 & 0.844 & & 0.073 \\
\hline $\mathrm{OB} / \mathrm{BCL} \mathrm{C} 2$ & $J 15260$ & $5 / 3107$ & -0.0316 & $\mathrm{U}$ & 0.24 & 11.7 & & 0.34 & 0.465 & & 0.061 & 0.702 & & 0.11 & 0.023 & $\mathrm{U}$ & 0.023 & 0.833 & & 0.062 \\
\hline $\mathrm{OB} / \mathrm{BCL} \mathrm{D3}$ & $J 15261$ & $5 / 3 / 307$ & 0.0371 & $\mathrm{U}$ & 0.28 & 12.7 & & 0.23 & 0.406 & & 0.043 & 0.721 & & 0.10 & 0.020 & $\mathrm{U}$ & 0.020 & 0.808 & & 0.050 \\
\hline Duplicate of J15261 & $J 15262$ & $5 / 3 / 07$ & 0 & $\mathrm{U}$ & 0.22 & 12.4 & & 0.23 & 0.404 & & 0.045 & 0.713 & & 0.11 & 0.017 & $\mathrm{U}$ & 0.017 & 0.642 & & 0.036 \\
\hline Split of J15261 & J152D7 & $5 / 3 / 07$ & 0.00900 & $\mathrm{U}$ & 0.0431 & & & & & & & & & & 0.000991 & $\mathrm{U}$ & 0.0125 & & & \\
\hline OB/BCL D4 & $\mathrm{J} 15263$ & $5 / 3 / 07$ & 0 & $\mathrm{U}$ & 0.29 & 12.4 & & 0.33 & 0.433 & & 0.057 & 0.654 & & 0.12 & 0.025 & $\mathrm{U}$ & 0.025 & 0.553 & & 0.044 \\
\hline $\mathrm{OB} / \mathrm{BCL} \mathrm{DS}$ & $J 15264$ & $5 / 3 / 07$ & 0.0476 & $\mathrm{U}$ & 0.36 & 12.8 & & 0.30 & 0.494 & & 0.049 & 0.797 & & 0.13 & 0.023 & $\mathrm{U}$ & 0.023 & 0.842 & & 0.054 \\
\hline OB/BCLD6 & 515265 & $5 / 3 / 07$ & -0.0337 & $\mathrm{U}$ & 0.26 & 12.7 & & 0.26 & 0.477 & & 0.049 & 0.703 & & 0.13 & 0.022 & $\mathrm{U}$ & 0.022 & 0.853 & & 0.047 \\
\hline PT A1 & $\mathrm{J} 15283$ & $5 / 10 / 07$ & 0.135 & $\mathrm{U}$ & 0.26 & 13.6 & & 0.36 & 0.413 & & 0.070 & 0.556 & & 0.15 & 0.026 & $\mathrm{U}$ & 0.026 & 0.496 & & 0.044 \\
\hline PT A2 & $\mathrm{J} 15284$ & $5 / 10 / 07$ & 0.0 & $\mathrm{U}$ & 0.34 & 12.8 & & 0.26 & 0.392 & & 0.048 & 0.448 & & 0.092 & 0.020 & $\mathrm{U}$ & 0.02 & 0.485 & & 0.035 \\
\hline $\mathrm{PT}$ A3 & $\mathrm{J} 15285$ & $5 / 10 / 07$ & 0 & $\mathrm{U}$ & 0.41 & 11.9 & & 0.20 & 0.384 & & 0.056 & 0.636 & & 0.13 & 0.023 & $\bar{U}$ & 0.023 & 0.626 & & 0.059 \\
\hline PT A4 & $\mathrm{J} 15286$ & $5 / 10 / 07$ & 0.263 & $\mathrm{U}$ & 0.29 & 12.4 & & 0.24 & 0.375 & & 0.049 & 0.623 & & 0.11 & 0.021 & $\mathrm{U}$ & 0.021 & 0.600 & & 0.051 \\
\hline Duplicate of J15286 & $\mathrm{J15287}$ & $5 / 10 / 07$ & 0.0430 & $\mathrm{U}$ & 0.33 & 12.7 & & 0.27 & 0.386 & & 0.051 & 0.466 & & 0.10 & 0.023 & $\bar{U}$ & 0.023 & 0.516 & & 0.036 \\
\hline Split of J15286 & $\mathrm{J152D9}$ & $5 / 10 / 07$ & 0.00623 & $\mathrm{U}$ & 0.0409 & & & & & & & & & & $-9.6 \mathrm{E}-06$ & $\mathrm{U}$ & 0.0126 & & & \\
\hline PT A5 & $\mathrm{J15689}$ & $6 / 21 / 07$ & 0.062 & $\mathrm{U}$ & 0.236 & 13.7 & & 0.343 & 0.544 & & 0.071 & 1.02 & & 0.146 & 0.027 & u & 0.027 & 0.813 & & 0.047 \\
\hline
\end{tabular}

\begin{tabular}{|c|c|c|c|c|c|c|c|c|c|c|c|c|c|c|c|c|c|c|c|c|}
\hline \multirow[t]{2}{*}{ Sample Location } & \multirow{2}{*}{$\begin{array}{l}\text { Sample } \\
\text { Number }\end{array}$} & \multirow{2}{*}{$\begin{array}{c}\text { Sample } \\
\text { Date }\end{array}$} & \multicolumn{3}{|c|}{ Thorium-232 GEA } & \multicolumn{3}{|c|}{$\begin{array}{c}\text { Total beta } \\
\text { radiostrontium }\end{array}$} & \multicolumn{3}{|c|}{ Tritium } & \multicolumn{3}{|c|}{ Uranium-233/234 } & \multicolumn{3}{|c|}{ Uranium-235 } & \multicolumn{3}{|c|}{ Uranium-235 GEA } \\
\hline & & & $\mathrm{pCi} / \mathrm{g}$ & $Q$ & MDA & $\mathrm{pCi} / \mathrm{g}$ & $Q$ & $\mathrm{MDA}$ & $\mathrm{pCi} / \mathrm{g}$ & Q & MDA & $\mathrm{pCi} / \mathrm{g}$ & Q & MDA & $\mathrm{pCi} / \mathrm{g}$ & $Q$ & MDA & $\mathrm{pCi} / \mathrm{g}$ & $Q$ & $\mathrm{MDA}$ \\
\hline SZ Area I AI & $\mathrm{J} 15266$ & $5 / 8 / 07$ & 0.613 & & 0.12 & 0.0586 & $\mathrm{U}$ & 0.25 & 1.64 & $\mathrm{U}$ & 4.2 & 0.469 & & 0.026 & 0.0163 & $\mathrm{U}$ & 0.031 & 0.13 & $\mathrm{U}$ & 0.13 \\
\hline SL Area I A2 & $\mathrm{J} 15267$ & $5 / 8 / 07$ & 0.566 & & 0.12 & 0.0382 & $\mathrm{U}$ & 0.27 & 1.02 & $\mathrm{U}$ & 4.7 & 0.451 & & 0.031 & 0.0148 & $\mathrm{U}$ & 0.038 & 0.13 & $\mathrm{U}$ & 0.13 \\
\hline SZ Areal $1 \mathrm{~A} 3$ & $J 15268$ & $5 / 8 / 07$ & 0.525 & & 0.1 & 0.0767 & $\mathrm{U}$ & 0.24 & 0.369 & $\mathrm{U}$ & 4.4 & 0.494 & & 0.033 & 0.0309 & $\mathrm{U}$ & 0.039 & 0.13 & $\overline{\mathrm{U}}$ & 0.13 \\
\hline SZ Areal $1 \mathrm{~A} 4$ & $J 15269$ & $6 / 20 / 07$ & 0.610 & & 0.132 & 0.079 & $\mathrm{U}$ & 0.334 & 0.457 & $\mathrm{U}$ & 4.08 & 0.903 & & 0.192 & 0.030 & $\mathrm{U}$ & 0.232 & 0.142 & $\mathrm{U}$ & 0.142 \\
\hline
\end{tabular}

\begin{tabular}{|c|c|c|c|}
\hline Attachment & 1 & Sheet No & 4 of 11 \\
\hline Originator & H.M. Sulloway & Date & $09 / 06 / 07$ \\
\hline Checked & J.M. Capron & Date & $09 / 06 / 07$ \\
\hline Calc. No. & $0100 \mathrm{~F}-\mathrm{CA}-\mathrm{V} 0279$ & Rev. No. & 1 \\
\hline
\end{tabular}


Attachment 1. 118-F-1 Verification Sampling Results.

\begin{tabular}{|c|c|c|c|c|c|c|c|c|c|c|c|c|c|c|c|c|c|c|c|c|}
\hline \multirow[t]{2}{*}{ Sample Location } & \multirow{2}{*}{$\begin{array}{c}\text { Sample } \\
\text { Number }\end{array}$} & \multirow{2}{*}{$\begin{array}{c}\text { Sample } \\
\text { Date }\end{array}$} & \multicolumn{3}{|c|}{ Thorium-232 GEA } & \multicolumn{3}{|c|}{$\begin{array}{c}\text { Totalbeta } \\
\text { radiostrontium } \\
\end{array}$} & \multicolumn{3}{|c|}{ Tritium } & \multicolumn{3}{|c|}{ Uranium-233/234 } & \multicolumn{3}{|c|}{ Uranium-235 } & \multicolumn{3}{|c|}{ Uranium-235 GEA } \\
\hline & & & pCigg & $Q$ & MDA & $\mathrm{pCi} / \mathrm{g}$ & $Q$ & $\mathrm{MDA}$ & $\mathrm{pCi} / \mathrm{g}$ & Q & MDA & $\mathrm{pCi} / \mathrm{g}$ & Q & MDA & $\mathrm{pCi} / \mathrm{g}$ & $Q$ & MDA & $\mathrm{pCi} / \mathrm{g}$ & $Q$ & $\mathrm{MDA}$ \\
\hline SZ Areal 2 B5 & $J 15270$ & $6 / 20 / 07$ & 0.649 & & 0.086 & 0.515 & & 0.384 & -0.491 & $\mathrm{U}$ & 4.39 & 0.466 & & 0.188 & 0 & $\mathrm{U}$ & 0.227 & 0.120 & $\mathrm{U}$ & 0.120 \\
\hline SZ Area 2 B6 & J15271 & $5 / 8 / 07$ & 0.599 & & 0.13 & -0.0366 & $\mathrm{U}$ & 0.24 & 1.78 & $\mathrm{U}$ & 4.4 & 0.426 & & 0.046 & 0 & $\mathrm{U}$ & 0.045 & 0.15 & 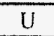 & 0.15 \\
\hline S2 Area 2 B7 & $\mathrm{J} 15272$ & $5 / 8 / 07$ & 0.545 & & 0.10 & 0.213 & U & 0.24 & 1.96 & $\mathrm{U}$ & 5.3 & 0.441 & & 0.032 & 0.0103 & $\mathrm{U}$ & 0.039 & 0.12 & $\mathrm{U}$ & 0.12 \\
\hline Duplicate of 315272 & 115273 & $5 / 8 / 07$ & 0.592 & & 0.14 & -0.0116 & $\mathrm{U}$ & 0.25 & 0.384 & $\mathrm{U}$ & 4.6 & 0.406 & & 0.037 & 0.0117 & U & 0.045 & 0.15 & $U$ & 0.15 \\
\hline Split of J15272 & J152D8 & $5 / 8 / 07$ & & & & 0.0976 & $\mathrm{U}$ & 0.141 & 0.0131 & $\mathrm{U}$ & 0.0366 & 0.208 & & 0.0497 & -0.0007 & $\mathrm{U}$ & 0.0354 & & & \\
\hline SZ Area 2 B8 & $J 15274$ & $5 / 8 / 07$ & 0.585 & & 0.10 & 1.32 & & 0.24 & 1.3 & $\mathrm{U}$ & 4.6 & 0.601 & & 0.038 & 0.0061 & U & 0.046 & 0.12 & $\mathrm{U}$ & 0.12 \\
\hline SZ Arca $3 \mathrm{C} 9$ & .115661 & $6 / 20 / 07$ & 0.538 & & 0.143 & 0.362 & & 0.32 & -0.328 & $\mathrm{U}$ & 4.10 & 0.380 & & 0.171 & 0.027 & $\mathrm{U}$ & 0.207 & 0.154 & $\mathrm{U}$ & 0.154 \\
\hline SZ Areal 3 ClO & $\lcm{15276}$ & $6 / 20 / 07$ & 0.591 & & 0.11 & -0.0608 & $\mathrm{U}$ & 0.27 & 0.0762 & $\mathrm{U}$ & 4.5 & 0.416 & & 0.033 & 0 & $\mathrm{U}$ & 0.040 & 0.13 & 0 & 0.13 \\
\hline$S Z$ Area $3 \mathrm{Cl}$ & $\mathrm{J} 15277$ & $5 / 8 / 07$ & 0.630 & & 0.097 & 0.0956 & $\mathrm{U}$ & 0.31 & 1.19 & $\mathrm{U}$ & 4.4 & 0.496 & & 0.034 & 0.0107 & $\mathrm{U}$ & 0.041 & 0.11 & $\mathrm{U}$ & 0.11 \\
\hline SZ Area $3 \mathrm{C2}$ & $\mathrm{J} 15278$ & $5 / 8 / 07$ & 0.589 & & 0.096 & 0.649 & & 0.26 & 1.56 & $\mathrm{U}$ & 4.6 & 0.464 & & 0.055 & 0.0302 & $\mathrm{U}$ & 0.046 & 0.10 & $\mathrm{U}$ & 0.1 \\
\hline SZ Area 4 D3 & $J 15279$ & $5 / 8 / 07$ & 0.627 & & 0.11 & 0.0690 & $\mathrm{U}$ & 0.24 & -1.59 & $\mathrm{U}$ & 4.3 & 0.565 & & 0.045 & 0.0443 & & 0.038 & 0.11 & $\mathrm{U}$ & 0.11 \\
\hline SZ Area 4 D4 & $\mathrm{J} 15280$ & $5 / 8107$ & 0.692 & & 0.14 & 0.0657 & $\mathrm{U}$ & 0.26 & 0.429 & $\mathrm{U}$ & 5.1 & 0.446 & & 0.039 & 0.0588 & & 0.038 & 0.14 & $U$ & 0.14 \\
\hline SZ Area 4 D5 & $J 15281$ & $5 / 21 / 07$ & 0.639 & & 0.073 & 0.118 & U & 0.317 & 0.887 & $\mathrm{U}$ & 3.74 & 0.320 & & 0.223 & 0.035 & U & 0.27 & 0.069 & $\mathrm{U}$ & 0.069 \\
\hline SZ Area 4 D6 & 515282 & $5 / 21 / 07$ & 0.546 & & 0.137 & 0.566 & & 0.306 & 1.94 & $\mathrm{U}$ & 3.95 & 0.425 & & 0.203 & 0 & U & 0.246 & 0.128 & $\mathrm{U}$ & 0.128 \\
\hline SZ Area 4D7 & J15688 & $6 / 21 / 07$ & 0.700 & & 0.13 & 0.119 & $\mathrm{U}$ & 0.267 & 3.09 & $\mathrm{U}$ & 3.59 & 0.508 & & 0.177 & 0 & $\mathrm{U}$ & 0.214 & 0.126 & $\mathrm{U}$ & 0.126 \\
\hline$O B / B C L A 1$ & $\mathrm{~J} 15249$ & $5 / 2 / 107$ & 0.739 & & 0.12 & 0.0720 & $U$ & 0.32 & -0.0398 & $\mathrm{U}$ & 2.7 & 0.351 & & 0.21 & 0.0327 & U & 0.25 & 0.13 & $\mathrm{U}$ & 0.13 \\
\hline $\mathrm{OB} / \mathrm{BCLA2}$ & $J 15250$ & $5 / 2 / 07$ & 0.692 & & 0.12 & -0.0205 & $\mathrm{U}$ & 0.35 & -0.892 & $\mathrm{U}$ & 2.5 & 0.290 & & 0.20 & 0 & U & 0.24 & 0.12 & $\mathrm{U}$ & 0.12 \\
\hline$O B / B C L A 3$ & $J 1525 !$ & $5 / 2 / 07$ & 0.734 & & 0.12 & 0.150 & $\mathrm{U}$ & 0.31 & -0.802 & $\mathrm{U}$ & 2.8 & 0.537 & & 0.19 & 0.0296 & $\mathrm{U}$ & 0.23 & 0.12 & 0 & 0.12 \\
\hline $\mathrm{OB} / \mathrm{BCL} \mathrm{A} 4$ & 115252 & $5 / 2 / 07$ & 0.817 & & 0.12 & 0.0350 & $\mathrm{U}$ & 0.28 & -0.0379 & $\mathrm{U}$ & 2.5 & 0.342 & & 0.19 & 0 & U & 0.23 & 0.16 & $\mathrm{U}$ & 0.16 \\
\hline OB/BCL B5 & $J 15253$ & $5 / 3 / 07$ & 0.918 & & 0.12 & 0.0657 & $\mathrm{U}$ & 0.30 & -0.464 & $\mathrm{U}$ & 2.8 & 0.673 & & 0.19 & 0.0302 & U & 0.23 & 0.14 & $\mathrm{U}$ & 0.14 \\
\hline $\mathrm{OB} / \mathrm{BCL} \mathrm{B} 6$ & $\mathrm{~J} 15254$ & $5 / 3 / 07$ & 0.703 & & 0.13 & 0.0477 & $\mathrm{U}$ & 0.29 & -1.01 & $\mathrm{U}$ & 2.8 & 0.424 & & 0.22 & 0 & $\mathrm{U}$ & 0.26 & 0.11 & $\mathrm{U}$ & 0.11 \\
\hline $\mathrm{OB} / \mathrm{BCL} \mathrm{B} 7$ & $\mathrm{J15255}$ & $5 / 3 / 07$ & 0.727 & & 0.11 & -0.0738 & $\mathrm{U}$ & 0.29 & -0.925 & $\mathrm{U}$ & 3.3 & 0.385 & & 0.21 & 0 & $\mathrm{U}$ & 0.25 & 0.14 & $\mathrm{U}$ & 0.14 \\
\hline $\mathrm{OB} / \mathrm{BCL} \mathrm{B} 8$ & 315256 & $5 / 3 / 07$ & 0.718 & & 0.12 & 0.0726 & $\mathrm{U}$ & 0.29 & -0.0795 & $U$ & 2.7 & 0.532 & & 0.13 & 0.0604 & $\mathrm{U}$ & 0.15 & 0.15 & $\mathrm{u}$ & 0.15 \\
\hline OB/BCLC9 & $\mathrm{J15257}$ & $5 / 3 / 107$ & 0.571 & & 0.14 & 0.0354 & $\mathrm{U}$ & 0.4 & 0.332 & $\mathrm{U}$ & 2.5 & 0.420 & & 0.12 & 0.0392 & $\mathrm{U}$ & 0.15 & 0.13 & $\mathrm{U}$ & 0.13 \\
\hline $\mathrm{OB} / \mathrm{BCL} \mathrm{Cl}$ & $\mathrm{J15258}$ & $5 / 3 / 07$ & 0.648 & & 0.12 & 0.0206 & $\mathrm{U}$ & 0.24 & -1.17 & $\mathrm{U}$ & 4.9 & 0.712 & & 0.23 & 0 & $u$ & 0.27 & 0.10 & $\mathrm{U}$ & 0.10 \\
\hline $\mathrm{OB} / \mathrm{BCLCl}$ & $\mathrm{J} 15259$ & $5 / 3 / 07$ & 0.719 & & 0.14 & -0.0438 & $\mathrm{U}$ & 0.22 & 2.60 & $\mathrm{U}$ & 5.5 & 0.403 & & 0.16 & 0.103 & $\mathrm{U}$ & 0.2 & 0.16 & $\mathrm{U}$ & 0.16 \\
\hline $\mathrm{OB} / \mathrm{BCL} \mathrm{C} 2$ & $J 15260$ & $5 / 3 / 07$ & 0.702 & & 0.11 & 0.0711 & $\mathrm{U}$ & 0.27 & -1.74 & $u$ & 5.6 & 0.392 & & 0.16 & 0.0499 & $\mathrm{U}$ & 0.19 & 0.15 & $\mathrm{U}$ & 0.15 \\
\hline $\mathrm{OB} / \mathrm{BCL} \mathrm{D} 3$ & $\mathrm{J15261}$ & $5 / 3 / 07$ & 0.721 & & 0.10 & \begin{tabular}{|l|l|}
0.0217 \\
\end{tabular} & $\mathrm{U}$ & 0.24 & 2.55 & $U$ & 6.7 & $0.54 !$ & & 0.15 & 0.0234 & $\mathrm{U}$ & 0.18 & 0.12 & $\mathrm{U}$ & 0.12 \\
\hline Duplicate of J15261 & $\$ 15262$ & $5 / 3 / 07$ & 0.713 & & 0.11 & -0.0069 & $\mathrm{U}$ & 0.24 & 1.12 & $\mathrm{U}$ & 6.1 & 0.350 & & 0.27 & 0 & $\mathrm{U}$ & 0.32 & 0.10 & $\mathrm{U}$ & 0.10 \\
\hline Split of J15201 & $\mathrm{J152D7}$ & $5 / 3 / 07$ & & & & 0.109 & U & 0.126 & 0.0144 & $\mathrm{U}$ & 0.0338 & 0.132 & & 0.0333 & 0.00557 & $\mathrm{U}$ & 0.0333 & & & \\
\hline OB/BCL D4 & $J 15263$ & $5 / 3 / 07$ & 0.654 & & 0.12 & 0.0198 & $\mathrm{U}$ & 0.24 & 0.0212 & $\mathrm{U}$ & 6.4 & 0.572 & & 0.20 & 0 & $\mathrm{U}$ & 0.24 & 0.14 & $U$ & 0.14 \\
\hline OB/BCLDS & $\mathrm{J} 15264$ & $5 / 3 / 07$ & 0.797 & & 0.13 & -0.0433 & $\mathrm{U}$ & 0.24 & 1.58 & $\mathrm{U}$ & 6.3 & 0.430 & & 0.18 & 0.0867 & $\mathrm{U}$ & 0.22 & 0.15 & $\mathrm{U}$ & 0.15 \\
\hline$O B / B C L D 6$ & $\mathrm{~J} 15265$ & $5 / 3 / 07$ & 0.703 & & 0.13 & -0.0547 & $\mathrm{U}$ & 0.27 & 2.31 & $\mathrm{U}$ & 7.3 & 0.292 & & 0.19 & 0.0295 & $\mathrm{U}$ & 0.23 & 0.13 & $\mathrm{U}$ & 0.13 \\
\hline $\mathrm{PTAl}$ & 115283 & $5 / 10 / 07$ & 0.556 & & 0.15 & 0.180 & $\bar{U}$ & 0.25 & 1.58 & $\mathrm{U}$ & 3.9 & 0.558 & & 0.16 & 0.0520 & $\mathrm{U}$ & 0.20 & 0.15 & $\mathrm{U}$ & 0.15 \\
\hline PT A2 & $\mathrm{J} 15284$ & $5 / 10 / 07$ & 0.448 & & 0.093 & 0.176 & $\mathrm{U}$ & 0.22 & 0 & $\mathrm{U}$ & 3.9 & 0.470 & & 0.2 & 0.0316 & $\mathrm{U}$ & 0.24 & 0.11 & U & 0.11 \\
\hline PT A3 & $\mathrm{J15285}$ & $5 / 10 / 07$ & 0.636 & & 0.13 & 0.338 & & 0.23 & 1.18 & $\mathrm{U}$ & 3.9 & 0.588 & & 0.19 & 0.0297 & $\mathrm{U}$ & 0.23 & 0.13 & $\mathrm{U}$ & 0.13 \\
\hline PT A4 & $\mathrm{J15286}$ & $5 / 10 / 07$ & 0.623 & & 0.11 & 0.144 & $\mathrm{U}$ & 0.22 & 0.122 & $U$ & 4.1 & 0.647 & & 0.21 & 0.0326 & $\mathrm{U}$ & 0.25 & 0.12 & $\mathrm{U}$ & 0.12 \\
\hline Duplicate of J15286 & .515287 & $5 / 10 / 07$ & 0.466 & & 0.10 & -0.0949 & $\mathrm{U}$ & 0.29 & 2.24 & $\mathrm{U}$ & 4.0 & 0.592 & & 0.21 & 0.0978 & $\mathrm{U}$ & 0.25 & 0.11 & $\mathrm{U}$ & 0.11 \\
\hline Split of 315286 & $\$ 15209$ & $5 / 10 / 07$ & & & & 0.0458 & & 0.164 & 0.0379 & & 0.0264 & 0.291 & & 0.0297 & 0.0762 & & 0.0297 & & & \\
\hline PrA5 & $\mathrm{J} 15689$ & $6 / 21 / 07$ & 1.02 & & 0.143 & -0.016 & $\mathrm{U}$ & 0.272 & 2.38 & $\mathrm{U}$ & 3.81 & 0.429 & & 0.173 & 0.027 & $\mathrm{U}$ & 0.209 & 0.172 & $U$ & 0.172 \\
\hline
\end{tabular}

Attachment

Sheet No. 5 of 11

Originator H.M. Sulloway

Checked J.M. Capron

Calc. No. $0100 \mathrm{~F}-\mathrm{CA}-\mathrm{V} 0279$ Rev. No. 1 
Attachment 1. 118-F-1 Verification Sampling Results.

\begin{tabular}{|c|c|c|c|c|c|c|c|c|}
\hline \multirow{2}{*}{ Sample Location } & \multirow{2}{*}{$\begin{array}{c}\text { Sample } \\
\text { Number }\end{array}$} & \multirow{2}{*}{$\begin{array}{c}\text { Sample } \\
\text { Date }\end{array}$} & \multicolumn{3}{|c|}{ Uranium-238 } & \multicolumn{3}{|c|}{ Uranium-238 GEA } \\
\hline & & & $\mathrm{pCi} / \mathrm{g}$ & $Q$ & MDA & $\mathrm{pCi} / \mathrm{g}$ & $Q$ & MDA \\
\hline SZ Area $1 \mathrm{Al}$ & $\mathrm{J} 15266$ & $5 / 8 / 07$ & 0.469 & & 0.032 & 3.4 & $\mathrm{U}$ & 3.4 \\
\hline SZ Area 1 A.2 & $J 15267$ & $5 / 8 / 07$ & 0.447 & & 0.031 & 3.7 & $\mathrm{U}$ & 3.7 \\
\hline SZ Area $1 \mathrm{A3}$ & 515268 & $5 / 8 / 07$ & 0.460 & & 0.033 & 3.2 & $U$ & 3.2 \\
\hline SZ Aren 1 A4 & .115269 & $6 / 20 / 07$ & 1.25 & & 0.192 & 3.8 & $\mathrm{U}$ & 3.8 \\
\hline SZ Area 2 B5 & 515270 & $6 / 20 / 07$ & 0.540 & & 0.188 & 3.08 & $\mathrm{U}$ & 3.08 \\
\hline SZ Area 2 BG & $\mathrm{J15271}$ & $5 / 8 / 07$ & 0.436 & & 0.037 & 3.9 & $\mathrm{U}$ & 3.9 \\
\hline SZ Area 2 B7 & $\mathrm{J15272}$ & $5 / 8 / 07$ & 0.496 & & 0.032 & 3.4 & $\mathrm{U}$ & 3.4 \\
\hline Duplicate of J15272 & $\mathrm{J} 15273$ & $5 / 8 / 07$ & 0.411 & & 0.037 & 3.9 & $\mathrm{U}$ & 3.9 \\
\hline Split of J15272 & J152D8 & $5 / 8 / 07$ & 0.191 & & 0.047 & & & \\
\hline SZ Area 2 B8 & $J 15274$ & $5 / 8 / 07$ & 0.546 & & 0.038 & 3.3 & U & 3.3 \\
\hline SZ Area 3C9 & $J 15661$ & $6 / 20107$ & 0.290 & & 0.171 & 3.87 & $\mathrm{U}$ & 3.87 \\
\hline SZ Area $3 \mathrm{ClO}$ & 515276 & $6 / 20 / 07$ & 0.493 & & 0.033 & 3.1 & $\mathrm{u}$ & 3.1 \\
\hline SZ Area 3 Cl & $\mathrm{J15277}$ & $5 / 8 / 07$ & 0.385 & & 0.034 & 3.0 & $\mathrm{U}$ & 3.0 \\
\hline SZ Area 3C2 & $\mathrm{J15278}$ & $5 / 8107$ & 0.419 & & 0.055 & 3.0 & $\mathrm{U}$ & 3.0 \\
\hline SZ Area 4 D3 & $J 15279$ & $5 / 8 / 07$ & 0.557 & & 0.031 & 2.8 & $U$ & 2.8 \\
\hline SZ Arca 4 D4 & 515280 & $5 / 8 / 07$ & 0.332 & & 0.039 & 3.8 & $\mathrm{u}$ & 3.8 \\
\hline SZ Area 4 D5 & 515281 & $5 / 21107$ & 0.524 & & 0.223 & 2.02 & $U$ & 2.02 \\
\hline SZ Area 4 D6 & $\mathrm{J} 15282$ & $5 / 21 / 07$ & 0.478 & & 0.203 & 3.96 & $\mathrm{U}$ & 3.96 \\
\hline SZ Area 4D7 & $\mathrm{J15688}$ & $6 / 21 / 07$ & 0.439 & & 0.177 & 3.59 & $U$ & 3.59 \\
\hline $\mathrm{OB} / \mathrm{BCL} \mathrm{A} 1$ & $J 15249$ & $5 / 2 / 07$ & 0.459 & & 0.21 & 3.6 & U & 3.6 \\
\hline $\mathrm{OB} / \mathrm{BCl} \mathrm{A} 2$ & $\pi 15250$ & $5 / 2 / 107$ & 0.395 & & 0.20 & 3.5 & $\mathrm{U}$ & 3.5 \\
\hline $\mathrm{OB} / \mathrm{BCL} \mathrm{A} 3$ & $J 15251$ & $5 / 2 / 07$ & 0.635 & & 0.19 & 3.3 & $\mathrm{U}$ & 3.3 \\
\hline OB/BCLA4 & .115252 & $5 / 2 / 07$ & 0.367 & & 0.19 & 3.5 & $\mathrm{U}$ & 3.5 \\
\hline $\mathrm{OB} / \mathrm{BCL} \mathrm{B} 5$ & $J 15253$ & $5 / 3 / 107$ & 0.523 & & 0.19 & 3.8 & $\mathrm{U}$ & 3.8 \\
\hline $\mathrm{OB} / \mathrm{BCL} \mathrm{B} 6$ & $\mathrm{~J} 15254$ & $5 / 3 / 07$ & 0.453 & & 0.22 & 3.2 & $\bar{U}$ & 3.2 \\
\hline $\mathrm{OB} / \mathrm{BCL} \mathrm{B} 7$ & $J 15255$ & $5 / 3 / 07$ & 0.412 & & 0.21 & 3.1 & $\mathrm{U}$ & 3.1 \\
\hline $\mathrm{OB} / \mathrm{BCL} \mathrm{B} 8$ & $J 15256$ & $5 / 3 / 07$ & 0.383 & & 0.13 & 3.3 & $\mathrm{U}$ & 3.3 \\
\hline $\mathrm{OB} / \mathrm{BCLC9}$ & $\mathrm{J15257}$ & $5 / 3 / 07$ & 0.469 & & 0.12 & 3.5 & $\mathrm{U}$ & 3.5 \\
\hline $\mathrm{OB} / \mathrm{BCL} \mathrm{Cl} 0$ & $\mathrm{~J} 15258$ & $5 / 3 / 07$ & 0.563 & & 0.23 & 3.3 & $\mathrm{U}$ & 3.3 \\
\hline $\mathrm{OB} / \mathrm{BCLCl}$ & $J 15259$ & $5 / 3 / 07$ & 0.403 & & 0.16 & 4.7 & $\mathrm{U}$ & 4.7 \\
\hline $\mathrm{OB} / \mathrm{BCL} \mathrm{C2}$ & $J 15260$ & $5 / 3 / 07$ & 0.350 & & 0.16 & 3.2 & $\mathrm{U}$ & 3.2 \\
\hline $\mathrm{OB} / \mathrm{BCL} \mathrm{D} 3$ & $J 15261$ & $5 / 3 / 07$ & 0.328 & & 0.15 & 3.2 & $\mathrm{U}$ & 3.2 \\
\hline Duplicate of J15261 & $\mathrm{J15262}$ & $5 / 3 / 07$ & 0.490 & & 0.27 & 3.1 & $\mathrm{u}$ & 3.1 \\
\hline Split of J15261 & $3152 \mathrm{D} 7$ & $5 / 3 / 07$ & 0.167 & & 0.0333 & & & \\
\hline $\mathrm{OB} / \mathrm{BCL} \mathrm{D} 4$ & $\mathrm{J15263}$ & $5 / 3 / 107$ & 0.416 & & 0.20 & 4.2 & $\mathrm{U}$ & 4.2 \\
\hline OB/BCLDS & $\mathrm{J} 15264$ & $5 / 3 / 07$ & 0.454 & & 0.18 & 3.3 & $\mathrm{U}$ & 3.3 \\
\hline $\mathrm{OB} / \mathrm{BCL} \mathrm{D} 6$ & $\mathrm{~J} 15265$ & $5 / 3 / 07$ & 0.511 & & 0.19 & 3.4 & $\mathrm{U}$ & 3.4 \\
\hline $\mathrm{PTAl}$ & $\mathrm{J} 15283$ & $5 / 10 / 07$ & 0.429 & & 0.16 & 4.4 & $\mathrm{U}$ & 4.4 \\
\hline PT A2 & $J 15284$ & $5 / 10 \% 7$ & 0.704 & & 0.20 & 3.3 & $\mathrm{U}$ & 3.3 \\
\hline PT A3 & $\mathrm{J15285}$ & $5 / 10 / 07$ & 0.465 & & 0.19 & 3.2 & $\mathrm{U}$ & 3.2 \\
\hline PT A4 & $\mathrm{J} 15286$ & $5 / 10 / 07$ & 0.297 & & 0.21 & 3.3 & $\mathrm{U}$ & 3.3 \\
\hline Duplicate of J15286 & $\mathrm{J15287}$ & $5 / 10 / 07$ & 0.619 & & 0.21 & 3.3 & $\mathrm{U}$ & 3.3 \\
\hline Split of J15286 & $\mathrm{J} 152 \mathrm{D} 9$ & $5 / 10 / 07$ & 0.273 & & 0.0509 & & & \\
\hline PT AS & J15689 & $6 / 21 / 07$ & 0.406 & U & 0.173 & 4.38 & $U$ & 4.38 \\
\hline
\end{tabular}

Aftachment

Orinator M. Sulloway Sheet Date

$\begin{array}{ll}\text { Checked } & \text { J.M. Capron } \\ \text { Calc. No. } & \text { Date } \\ \text { O100F-CA-V0279 Rev. No. }\end{array}$ 
Attachment 1. 118-F-1 Verification Sampling Results.

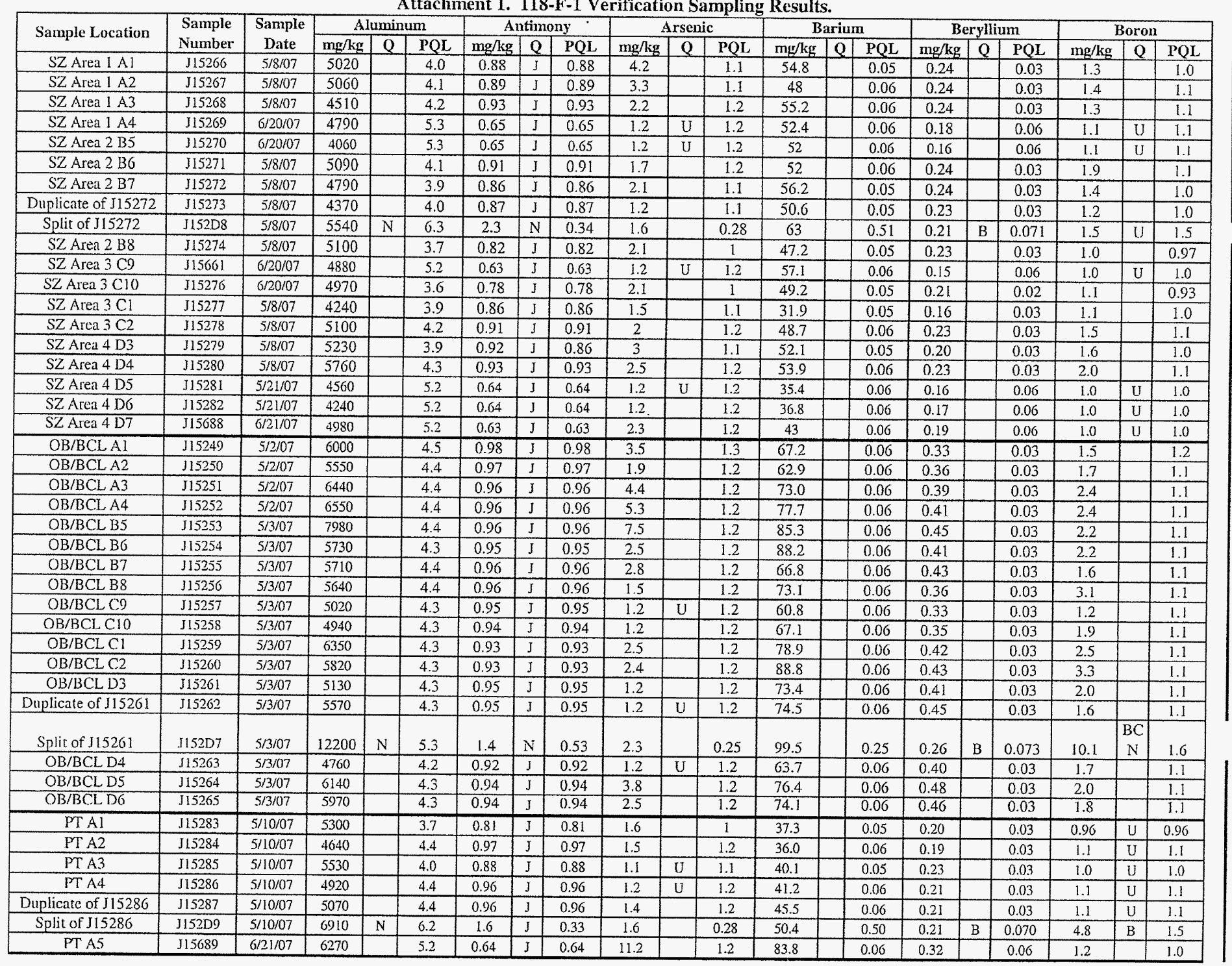

Attachment 1 Sheet No. 7 of 11 Originator H.M. Sulloway Date 09/06/07 $\begin{array}{lll}\text { Checked } & \text { J.M. Capron } & \text { Date } \\ \text { Calc. No. } & \text { 0100F-CA-V0279 Rev. No. } 1\end{array}$ 


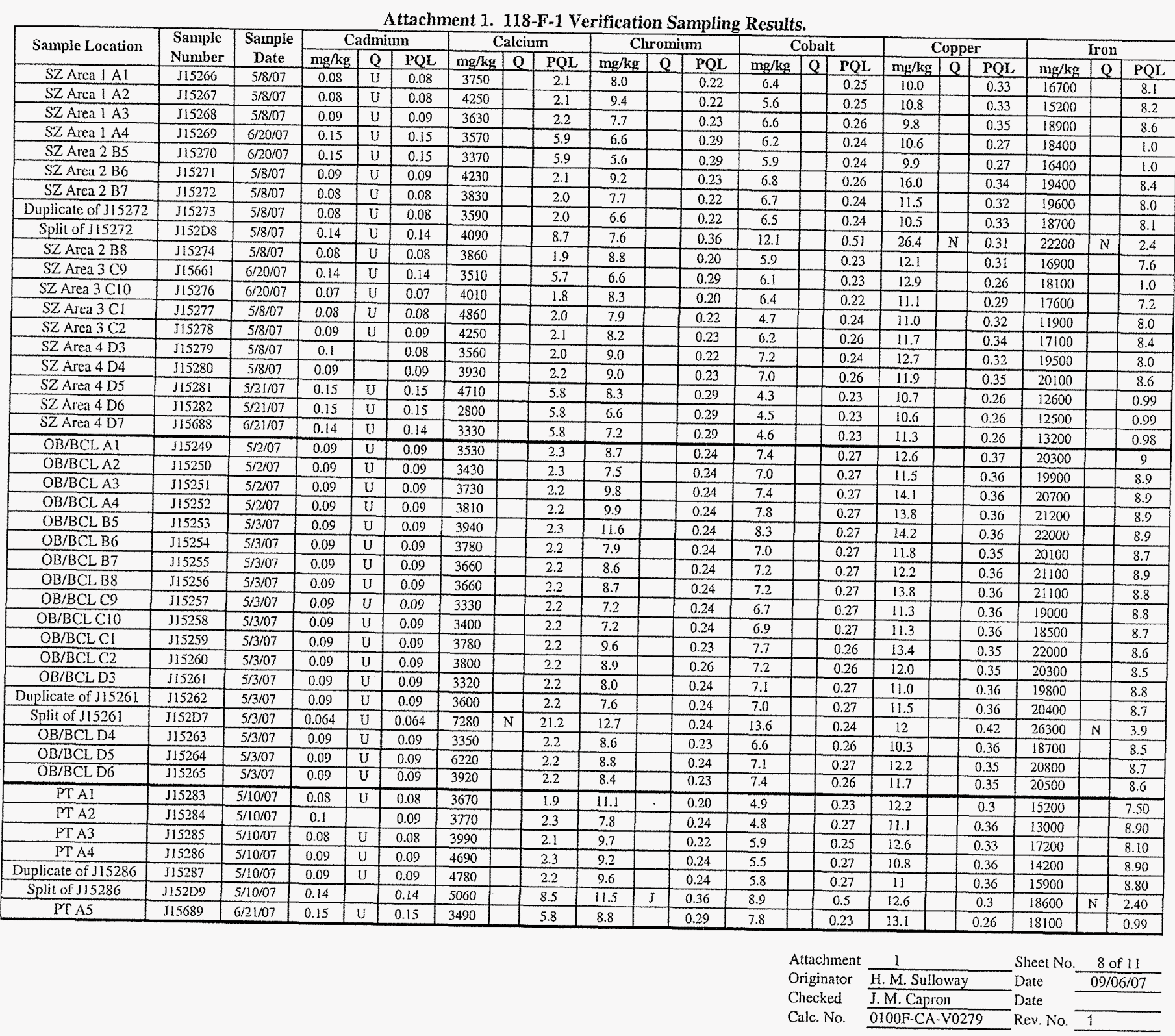




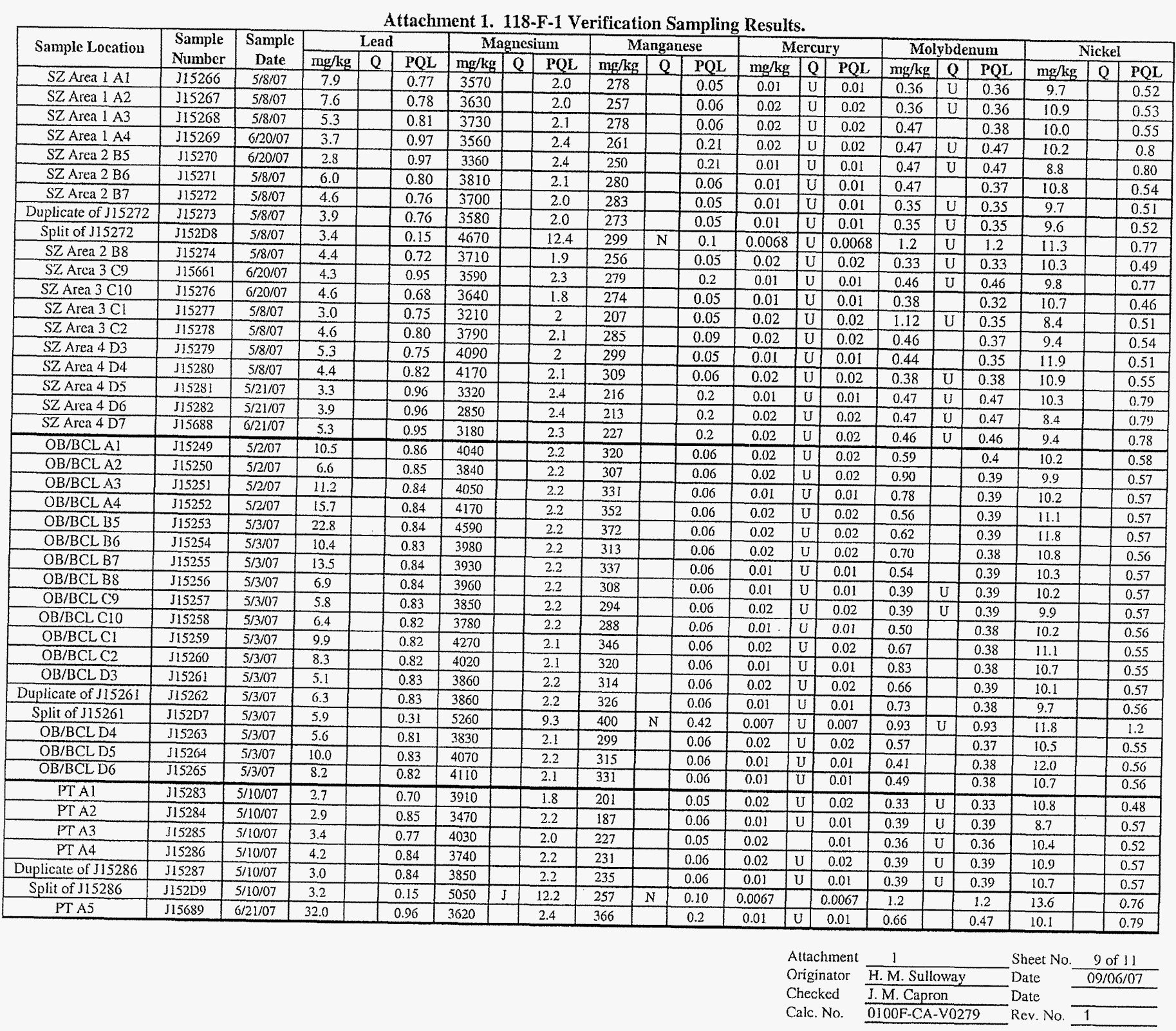




\begin{tabular}{|c|c|c|c|c|c|c|c|c|c|c|c|c|c|c|c|c|c|c|c|c|}
\hline \multirow{2}{*}{ Sample Location } & \multirow{2}{*}{$\begin{array}{c}\text { Sample } \\
\text { Number }\end{array}$} & \multirow{2}{*}{$\begin{array}{c}\text { Sample } \\
\text { Date }\end{array}$} & \multicolumn{3}{|c|}{ Potassium } & \multicolumn{3}{|c|}{ Selenium } & \multicolumn{3}{|c|}{ Silicon } & \multicolumn{3}{|c|}{$\begin{array}{l}\text { Silver } \\
\end{array}$} & \multicolumn{3}{|c|}{ Sodium } & \multicolumn{3}{|c|}{ Vanadium } \\
\hline & & & $\mathrm{mg} / \mathrm{kg}$ & $Q$ & $\mathrm{PQL}$ & $\mathrm{mg} / \mathrm{kg}$ & $Q$ & $\mathrm{PQL}$ & $\mathrm{mg} / \mathrm{kg}$ & $Q$ & PQL & $\mathrm{mg} / \mathrm{kg}$ & $Q$ & $\mathrm{PQL}$ & $\mathrm{mg} / \mathrm{kg}$ & $\mathrm{Q}$ & $\mathrm{PQL}$ & $\mathrm{mg} / \mathrm{kg}$ & $\mathrm{Q}$ & $\mathrm{PQL}$ \\
\hline SZ Area $1 \mathrm{Al}$ & $\mathrm{J} 15266$ & $5 / 8 / 07$ & 812 & & 13.4 & 1.0 & $\mathrm{u}$ & 1.0 & 492 & $\mathrm{~d}$ & 1.2 & 0.25 & $\mathrm{U}$ & 0.25 & \begin{tabular}{|l|}
94.9 \\
\end{tabular} & & 1.2 & 42.0 & & 0.27 \\
\hline SZ Area $1 \mathrm{~A} 2$ & $\mathrm{~J} 15267$ & $5 / 8 / 07$ & 749 & & 13.6 & 1.0 & $\mathrm{U}$ & 1.0 & 540 & $\mathrm{~T}$ & 1.2 & 0.25 & $\mathrm{U}$ & 0.25 & 87.0 & & 1.2 & 35.5 & & 0.28 \\
\hline SZ Area $1 \mathrm{~A} 3$ & J15268 & $5 / 8 / 07$ & 809 & & 14.2 & 1.1 & $\mathrm{U}$ & 1.1 & 449 & $\mathrm{~J}$ & 1.2 & 0.26 & $\mathrm{U}$ & 0.26 & 92.6 & & 1.3 & 50 & & 0.29 \\
\hline SZ Area $1 \mathrm{~A} 4$ & $J 15269$ & $6 / 20 / 07$ & 782 & & 9.4 & 1.3 & $\mathrm{U}$ & 1.3 & 1050 & $\mathrm{~J}$ & 2.5 & 0.27 & $\mathrm{U}$ & 0.27 & 121 & & 4.8 & 46.1 & & 0.24 \\
\hline SZ Aren 2 B5 & $\mathrm{J15270}$ & $6 / 20 / 07$ & 794 & & 9.4 & 1.3 & $\mathrm{U}$ & 1.3 & 922 & $\mathrm{~J}$ & 2.5 & 0.27 & U & 0.27 & 101 & & 4.8 & 40.2 & & 0.24 \\
\hline SZ Area 2 B6 & $J 15271$ & $5 / 8 / 07$ & 849 & & 13.9 & 1.1 & $\mathrm{U}$ & 1.1 & 449 & $\mathrm{~J}$ & 1.2 & 0.26 & $u$ & 0.26 & 110 & & 1.3 & 51.2 & & 0.28 \\
\hline SZ Area 2 B7 & $\mathrm{J15272}$ & $5 / 8 / 07$ & 826 & & 13.2 & 1.0 & $\mathrm{U}$ & 1.0 & 383 & 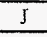 & 1.1 & 0.24 & $U$ & 0.24 & 118 & & 1.2 & 54.2 & & 0.27 \\
\hline Duplicate of J15272 & $J 15273$ & $5 / 8 / 07$ & 798 & & 13.3 & 1.0 & $\mathrm{U}$ & 1.0 & 458 & $\mathrm{~J}$ & 1.1 & 0.24 & U & 0.24 & 88.3 & & 1.2 & 50.7 & & 0.27 \\
\hline Split of J15272 & $3152 \mathrm{DB}$ & $5 / 8 / 07$ & 1180 & & 51 & 0.18 & $\mathrm{U}$ & 0.18 & 259 & $\mathrm{~N}$ & 4.1 & 0.2 & UN & 0.2 & 136 & & 10.2 & 60.3 & & 0.69 \\
\hline SZ Area 2 B8 & $\mathrm{J} 15274$ & $5 / 8 / 07$ & 764 & & 12.5 & 0.95 & $\mathrm{U}$ & 0.95 & 406 & $\mathrm{~T}$ & 1.1 & 0.23 & $\mathrm{U}$ & 0.23 & 101 & & 1.1 & 42.6 & & 0.26 \\
\hline SZ Area $3 \mathrm{C} 9$ & $J 15661$ & $6 / 20107$ & 929 & & 9.2 & 1.2 & $\mathrm{U}$ & 1.2 & 1130 & $I$ & 2.5 & 0.26 & $\mathrm{U}$ & 0.26 & 108 & & 4.7 & 44.2 & & 0.23 \\
\hline SZ Area $3 \mathrm{ClO}$ & .15276 & $6 / 20 / 07$ & 817 & & 11.9 & 0.90 & $\mathrm{U}$ & 0.90 & 428 & $\mathrm{~J}$ & 1 & 0.22 & $\mathrm{U}$ & 0.22 & 90.1 & & 1.1 & 45.3 & & 0.24 \\
\hline SZ Arca $3 \mathrm{Cl}$ & $J 15277$ & $5 / 8107$ & 528 & & 13.1 & 0.99 & $\mathrm{U}$ & 0.99 & 307 & $\mathrm{~J}$ & 1.1 & 0.24 & $\mathrm{U}$ & 0.24 & 104 & & 1.2 & 29.7 & & 0.27 \\
\hline SZ Area $3 \mathrm{C2}$ & $J 15278$ & $5 / 8107$ & 769 & & 13.9 & 1.1 & $\mathrm{U}$ & 1.1 & 392 & $\mathrm{~J}$ & 1.2 & 0.26 & $\mathrm{U}$ & 0.26 & 91.9 & & 1.3 & 43.3 & & 0.28 \\
\hline SZ Area 4 D3 & 315279 & $5 / 8107$ & 872 & & 13.1 & 1.0 & $\mathrm{U}$ & 1.0 & 392 & 3 & 1.1 & 0.24 & $\mathrm{U}$ & 0.24 & 99.5 & & 1.2 & 50.4 & & 0.27 \\
\hline SZ Area 4D4 & $\mathrm{J} 15280$ & $5 / 8 / 07$ & 918 & & 14.2 & 1.1 & $\mathrm{U}$ & 1.1 & 379 & $\mathrm{~J}$ & 1.2 & 0.26 & $\mathrm{U}$ & 0.26 & 110 & & 1.3 & 52.7 & & 0.29 \\
\hline SZ Area 4D5 & $\mathrm{J} 15281$ & $5 / 21 / 07$ & 532 & & 9.3 & 1.3 & U & 1.3 & 713 & $\mathrm{~J}$ & 2.5 & 0.26 & $\mathrm{U}$ & 0.26 & 97.8 & & 4.8 & 27.6 & & 0.23 \\
\hline SZ Area 4D6 & J15282 & $5 / 21 / 07$ & 582 & & 9.3 & 1.3 & $\mathrm{U}$ & 1.3 & 825 & $\mathrm{~J}$ & 2.5 & 0.26 & $\mathrm{U}$ & 0.26 & 83.9 & & 4.8 & 28.6 & & 0.23 \\
\hline SZ Area 4D7 & $J 15688$ & $6 / 21 / 07$ & 697 & & 9.2 & 1.2 & $\mathrm{U}$ & 1.2 & 872 & $\mathrm{~J}$ & 2.5 & 0.26 & 0 & 0.26 & 108 & & 4.7 & 30.6 & & 0.23 \\
\hline OB/BCLAI & J15249 & $5 / 2 / 07$ & 1090 & & 14.9 & 1.1 & $\mathrm{U}$ & 1.1 & 500 & & 1.3 & 0.27 & $\mathrm{U}$ & 0.27 & 91.2 & & 1.3 & 51.0 & & 0.31 \\
\hline $\mathrm{OB} / \mathrm{BCL} \mathrm{A} 2$ & $J 15250$ & $5 / 2107$ & 1000 & & 14.7 & 1.1 & $\mathrm{U}$ & 1.1 & 633 & & 1.3 & 0.27 & $\mathrm{U}$ & 0.27 & 106 & & 1.3 & 51.7 & & 0.30 \\
\hline $\mathrm{OB} / \mathrm{BCL} \mathrm{A} 3$ & 515251 & $5 / 2 / 207$ & 1220 & & 14.6 & 1.1 & $\mathrm{U}$ & 1.1 & 534 & & 1.3 & 0.27 & $\mathrm{U}$ & 0.27 & 113 & & 1.3 & 51.0 & & 0.30 \\
\hline $\mathrm{OB} / \mathrm{BCL} \mathrm{A4}$ & $J 15252$ & $5 / 2 / 07$ & 1180 & & 14.6 & 1.1 & $\mathrm{U}$ & 1.1 & 472 & & 1.3 & 0.27 & $\mathrm{U}$ & 0.27 & 120 & & 1.3 & 53.3 & & 0.30 \\
\hline $\mathrm{OB} / \mathrm{BCL} \mathrm{BS}$ & J15253 & $5 / 3 / 07$ & 1480 & & 14.7 & 1.1 & $\mathrm{U}$ & 1.1 & 373 & & 1.3 & 4.3 & & 0.27 & 135 & & 1.3 & 52.7 & & 0.30 \\
\hline $\mathrm{OB} / \mathrm{BCL} \mathrm{BG}$ & $\mathrm{J15254}$ & $5 / 3 / 07$ & 1100 & & 14.4 & 1.1 & $\mathrm{U}$ & 1.1 & 476 & & 1.2 & 0.27 & $\mathrm{U}$ & 0.27 & 125 & & 1.3 & 53.4 & & 0.30 \\
\hline $\mathrm{OB} / \mathrm{BCL} \mathrm{B} 7$ & J15255 & $5 / 3 / 07$ & 1100 & & 14.6 & 1.3 & & 1.1 & 423 & & 1.3 & 0.27 & U & 0.27 & 104 & & 1.3 & 56.7 & & 0.30 \\
\hline $\mathrm{OB} / \mathrm{BCL} \mathrm{B} 8$ & 515256 & $5 / 3 / 07$ & 1080 & & 14.6 & 1.4 & & 1.1 & 378 & & 1.3 & 0.27 & $\mathrm{U}$ & 0.27 & 139 & & 1.3 & 56.1 & & 0.30 \\
\hline $\mathrm{OB} / \mathrm{BCL} \mathrm{C} 9$ & .15257 & $5 / 3 / 107$ & 944 & & 14.5 & 1.1 & $\mathrm{U}$ & 1.1 & 600 & & 1.2 & 0.27 & $\mathrm{U}$ & 0.27 & 101 & & 1.3 & 48.6 & & 0.30 \\
\hline $\mathrm{OB} / \mathrm{BCL} C 10$ & $\mathrm{J15258}$ & $5 / 3 / 07$ & 923 & & 14.4 & 1.1 & $\mathrm{U}$ & 1.1 & 517 & & 1.2 & 0.27 & $\mathrm{U}$ & 0.27 & 94.5 & & 1.3 & 48.5 & & 0.29 \\
\hline $\mathrm{OB} / \mathrm{BCLCl}$ & $\mathrm{J} 15259$ & $5 / 3 / 107$ & 1220 & & 14.2 & 1.1 & $\mathrm{U}$ & 1.1 & 396 & & 1.2 & 0.26 & $\mathrm{U}$ & 0.26 & 118 & & 1.3 & 57.7 & & 0.29 \\
\hline $\mathrm{OB} / \mathrm{BCLC} 2$ & $\mathrm{~J} 15260$ & $5 / 3 / 07$ & 1210 & & 14.2 & 1.1 & $\mathrm{U}$ & 1.1 & 428 & & 1.2 & 0.26 & $\mathrm{u}$ & 0.26 & 122 & & 1.3 & 54.0 & & 0.29 \\
\hline OB/BCLD3 & $\mathrm{J} 15261$ & $5 / 3 / 07$ & 1050 & & 14.5 & 1.1 & $\mathrm{U}$ & 1.1 & 451 & & 1.3 & 0.27 & $\mathrm{U}$ & 0.27 & 89.9 & & 1.3 & 53.6 & & 0.3 \\
\hline Duplicate of J15261 & $J 15262$ & $5 / 3 / 07$ & 1130 & & 14.4 & 1.3 & & 1.1 & 586 & & 1.2 & 0.27 & $\mathrm{U}$ & 0.27 & 102 & & 1.3 & 54.1 & & 0.3 \\
\hline Split of $J 15261$ & J152D7 & $5 / 3 / 07$ & 1440 & $\mathrm{~N}$ & 153 & 0.46 & $\mathrm{u}$ & 0.46 & 1010 & $\mathrm{CN}$ & 4.2 & 0.38 & UN & 0.38 & 1300 & $\mathrm{~N}$ & 12.5 & 77.1 & $u$ & 0.56 \\
\hline $\mathrm{OB} / \mathrm{BCL} \mathrm{D} 4$ & $\mathrm{J15263}$ & $5 / 3 / 07$ & 874 & & 14.1 & 1.1 & $\bar{U}$ & 1.1 & 540 & & 1.2 & 0.26 & U & 0.26 & 94.1 & & 1.3 & 51.9 & & 0.29 \\
\hline OB/BCLD5 & $J 15264$ & $5 / 3 / 07$ & 1170 & & 14.4 & 1.5 & & 1.1 & 448 & & 1.2 & 0.27 & $\mathrm{u}$ & 0.27 & 118 & & 1.3 & 55.5 & & 0.30 \\
\hline OB/BCL D6 & $J 15265$ & $5 / 3 / 07$ & 1140 & & 14.3 & 1.1 & U & 1.1 & 448 & & 1.2 & 0.26 & U & 0.26 & 125 & & 1.3 & 53.3 & & 0.29 \\
\hline PTAI & $\mathrm{J} 15283$ & $5 / 10 / 07$ & 607 & & 12.3 & 0.93 & U & 0.93 & 621 & $\mathrm{R}$ & 1.1 & 0.23 & $\mathrm{U}$ & 0.23 & 118 & & 1.1 & 36.9 & & 0.25 \\
\hline PT A2 & $J 15284$ & $5 / 10 / 07$ & 534 & & 14.7 & 1.1 & $\mathrm{U}$ & 1.1 & 1130 & $R$ & 1.3 & 0.27 & $\mathrm{U}$ & 0.27 & 147 & & 1.3 & 32.4 & & 0.30 \\
\hline PTA3 & $J 15285$ & $5 / 10 / 07$ & 590 & & 13.4 & 1.0 & $U$ & 1.0 & 562 & $\bar{R}$ & 12 & 0.25 & $\mathrm{U}$ & 0.25 & 138 & & 1.2 & 44.2 & & 0.27 \\
\hline PT A4 & $J 15286$ & $5 / 10 / 07$ & 592 & & 14.7 & 1.1 & $\bar{U}$ & 1.1 & 608 & $\mathrm{R}$ & 1.3 & 0.88 & & 0.27 & 116 & & 1.3 & 36.6 & & 0.30 \\
\hline Duplicate of $J 15286$ & $J 15287$ & $5 / 10 / 07$ & 582 & & 14.6 & 1.1 & $\mathrm{U}$ & 1.1 & 543 & $R$ & 1.3 & 0.27 & $\mathrm{U}$ & 0.27 & 110 & & 1.3 & 38.4 & & 0.30 \\
\hline Split of $J 15286$ & $\mathrm{J152 \textrm {D } 9}$ & $5 / 10 / 07$ & 1030 & & 50.3 & 0.17 & & 0.17 & 490 & $\mathrm{z}$ & 4.0 & 0.20 & & 0.20 & 195 & & 10.1 & 44.8 & & 0.68 \\
\hline PT A5 & $\mathrm{J} 15689$ & $6 / 21 / 07$ & 1330 & & 9.3 & 1.3 & $\mathrm{u}$ & 1.3 & 1240 & $\mathrm{~J}$ & 2.5 & 0.26 & $\mathrm{u}$ & 0.26 & 104 & & 4.8 & 41.1 & & 0.23 \\
\hline
\end{tabular}

Attachment Sheet No. 10 of 11

Originator H.M. Sulloway Date 09/06/07

Checked J.M.Capron 
Attachment 1. 118-F-1 Verification Sampling Results.

\begin{tabular}{|c|c|c|c|c|c|}
\hline \multirow{2}{*}{ Sample Location } & \multirow{2}{*}{$\begin{array}{l}\text { Sample } \\
\text { Number }\end{array}$} & \multirow{2}{*}{$\begin{array}{c}\text { Sample } \\
\text { Date }\end{array}$} & \multicolumn{3}{|c|}{ Zinc } \\
\hline & & & $\mathrm{mg} / \mathrm{kg}$ & $Q$ & $\mathrm{PQL}$ \\
\hline SZ Area $1 \mathrm{Al}$ & $\mathrm{J} 15266$ & $5 / 8 / 07$ & 35.5 & & 0.08 \\
\hline SZ Area 1 A2 & $\mathrm{J} 15267$ & $5 / 8 / 07$ & 33.6 & & 0.08 \\
\hline SZ Area 1 A3 & $\mathrm{J15268}$ & $5 / 8 / 07$ & 38.0 & & 0.09 \\
\hline SZ Arca 1 A4 & $\mathrm{J15269}$ & $6 / 20 / 07$ & 37.1 & & 0.12 \\
\hline SZ Area 2 B5 & $\mathrm{J15270}$ & $6 / 20 / 07$ & 32.7 & & 0.12 \\
\hline SZ Area 2 B6 & $J 15271$ & $5 / 8 / 07$ & 39.7 & & 0.09 \\
\hline SZ Area 2 B7 & $\mathbf{J 1 5 2 7 2}$ & $5 / 3 / 07$ & 38.7 & & 0.08 \\
\hline Duplicate of 115272 & 515273 & $5 / 8 / 07$ & 37.3 & & 0.08 \\
\hline Split of J15272 & $\mathrm{J} 152 \mathrm{D} 8$ & $5 / 8 / 07$ & 37.6 & & 1.4 \\
\hline SZ Area 2 B8 & $\mathrm{J} 15274$ & $5 / 8 / 07$ & 35.4 & & 0.08 \\
\hline SZ Area 3 C9 & $\mathrm{J15661}$ & $6 / 20 / 07$ & 43.0 & & 0.11 \\
\hline SZ Area $3 \mathrm{ClO}$ & $\mathrm{J15276}$ & $6 / 20107$ & 37.0 & & 0.07 \\
\hline SZ Area $3 \mathrm{Cl}$ & $\mathrm{J15277}$ & $5 / 8 / 07$ & 26.2 & & 0.08 \\
\hline SZ Area $3 \mathrm{C} 2$ & $\mathrm{~J} 15278$ & $5 / 8107$ & 37.4 & & 0.09 \\
\hline SZ Area 4D3 & $J 15279$ & $5 / 8 / 07$ & 95.3 & & 0.08 \\
\hline SZ Area 4 D4 & $\mathrm{J} 15280$ & $5 / 8 / 07$ & 39.1 & & 0.09 \\
\hline SZ Area 4 DS & $\mathrm{J} 15281$ & $5 / 21 / 07$ & 28.2 & & 0.12 \\
\hline SZ Area 4 D6 & 315282 & $5 / 21 / 07$ & 28.4 & & 0.12 \\
\hline SZ Area 4 D7 & $J 15688$ & $6 / 21 / 07$ & 31.3 & & 0.12 \\
\hline OB/BCLAI & $\mathrm{J} 15249$ & $5 / 2 / 07$ & 42.0 & & 0.09 \\
\hline $\mathrm{OB} / \mathrm{BCL} \mathrm{A} 2$ & $J 15250$ & $5 / 2 / 07$ & 47.5 & & 0.09 \\
\hline $\mathrm{OB} / \mathrm{BCL} A 3$ & $\mathrm{~J} 15251$ & $5 / 2 / 07$ & 44.1 & & 0.09 \\
\hline $\mathrm{OB} / \mathrm{BCL} \mathrm{A} 4$ & $J 15252$ & $5 / 2 / 07$ & 47.7 & & 0.09 \\
\hline $\mathrm{OB} / \mathrm{BCL} \mathrm{B} 5$ & 515253 & $5 / 3 / 07$ & 46.2 & & 0.09 \\
\hline $\mathrm{OB} / \mathrm{BCL} \mathrm{B} 6$ & $\$ 15254$ & $5 / 3 / 07$ & 43.4 & & 0.09 \\
\hline $\mathrm{OB} / \mathrm{BCL} B \mathrm{BT}$ & $J 15255$ & $5 / 3 / 07$ & 43.4 & & 0.09 \\
\hline $\mathrm{OB} / \mathrm{BCL} \mathrm{B} 8$ & 515256 & $5 / 3 / 07$ & 42.8 & & 0.09 \\
\hline $\mathrm{OB} / \mathrm{BCLC} 9$ & $J 15257$ & $5 / 3 / 07$ & 40.4 & & 0.09 \\
\hline OB/BCLCIO & $J 15258$ & $5 / 3 / 07$ & 40.7 & & 0.09 \\
\hline $\mathrm{OB} / \mathrm{BCLCl}$ & $\mathrm{J} 15259$ & $5 / 3 / 07$ & 45.6 & & 0.09 \\
\hline $\mathrm{OB} / \mathrm{BCLC} 2$ & $\mathrm{~J} 15260$ & $5 / 3 / 07$ & 45.3 & & 0.09 \\
\hline $\mathrm{OB} / \mathrm{BCL} \mathrm{D} 3$ & $J 15261$ & $5 / 3 / 07$ & 42.0 & & 0.09 \\
\hline Duplicate of J15261 & J15262 & $5 / 3 / 07$ & 43.7 & & 0.09 \\
\hline Split of J15261 & $\pi 152 \mathrm{D} 7$ & $5 / 3 / 107$ & 48.2 & & 1.6 \\
\hline OB/BCLD4 & $\mathrm{J} 15263$ & $5 / 3 / 07$ & 41.7 & & 0.09 \\
\hline OB/BCLDS & $\mathrm{J} 15264$ & $5 / 3 / 07$ & 43.7 & & 0.09 \\
\hline $\mathrm{OB} / \mathrm{BCL} \mathrm{D} 6$ & J15265 & $5 / 3 / 07$ & 43.5 & & 0.09 \\
\hline PT AI & 115283 & $5 / 10 / 07$ & 32.9 & & 0.08 \\
\hline PT A2 & $J 15284$ & $5 / 10 / 07$ & 36.4 & & 0.09 \\
\hline PT A3 & $\mathbf{J 1 5 2 8 5}$ & $5 / 10 / 07$ & 39.3 & & 0.08 \\
\hline PT A4 & $\mathrm{J} 15286$ & $5 / 10 / 07$ & 31.9 & & 0.09 \\
\hline Duplicate of J15286 & II15287 & $5 / 10 / 07$ & 33.6 & & 0.09 \\
\hline Split of 315286 & $\mathrm{J152 \textrm {D } 9}$ & $5 / 10 / 07$ & 33.5 & & 1.4 \\
\hline PT A5 & $\mathrm{J} 15689$ & $6 / 21 / 07$ & 40.4 & & 0.12 \\
\hline
\end{tabular}

Attachment

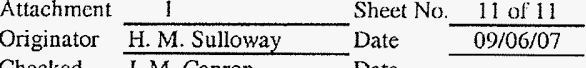

Checked J.M. Capron 
CVP-2007-00001

Rev. 0 


\section{CALCULATION COVER SHEET}

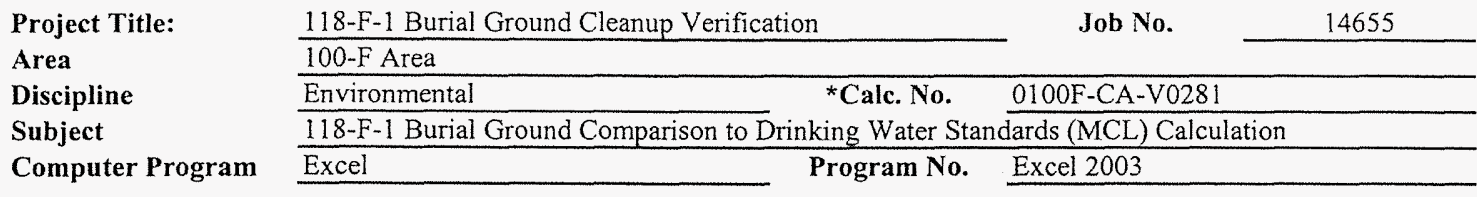

The attached calculations have been generated to document compliance with established cleanup levels.

These calculations should be used in conjunction with other relevant documents in the administrative record.

\section{Committed Calculation $\mathbf{X}$ \\ Preliminary \\ Superseded \\ Voided}

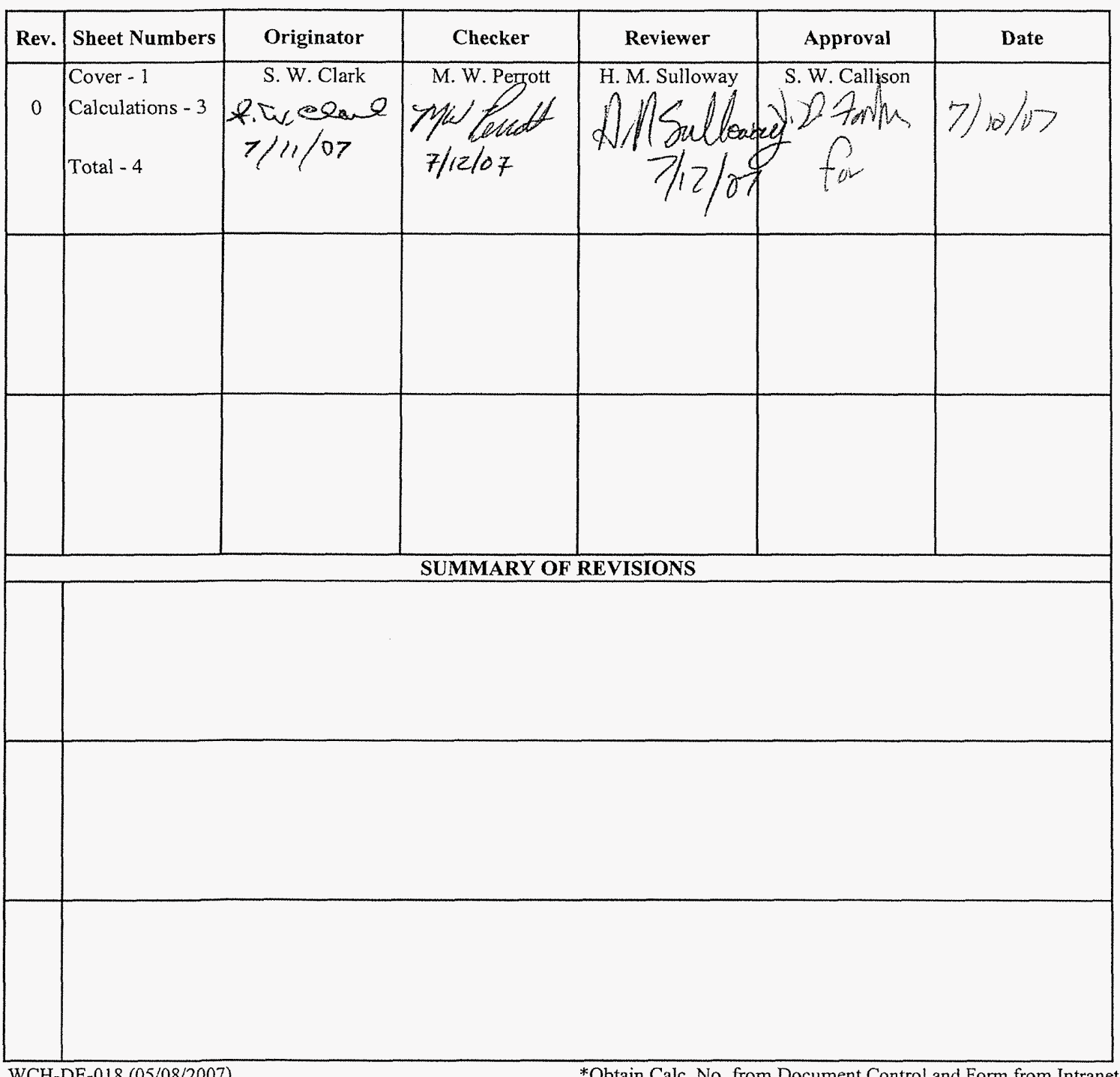


Washington Closure Hanford

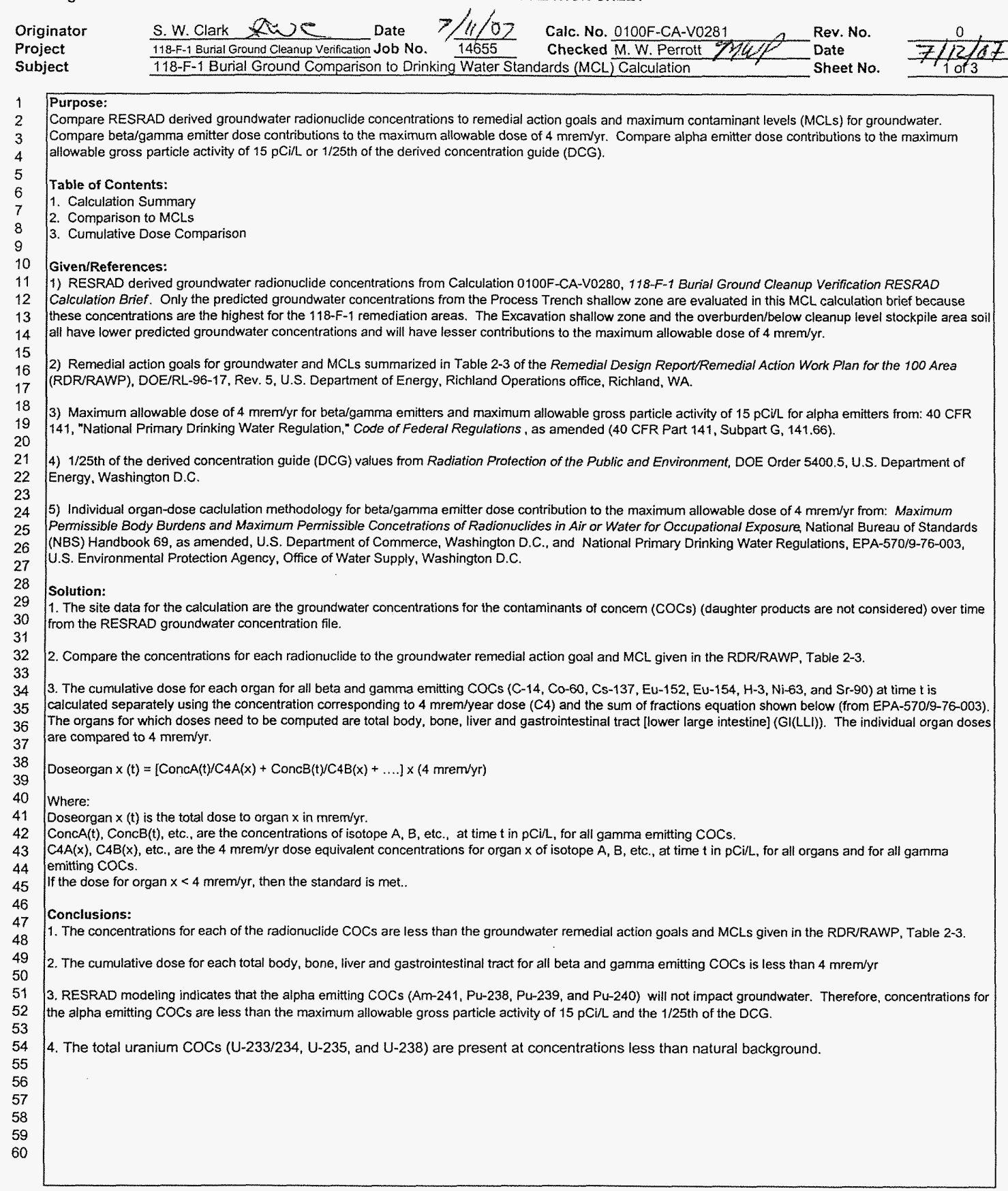


Washington Closure Hanford CALCULATION SHEET

Originator S.W.

S. W. Clark Date $\frac{f}{11 / 1 / \mathrm{F}-1 \text { Burial Ground Cleanup Verification }}$ Calc. No. O100F-CA-V0281

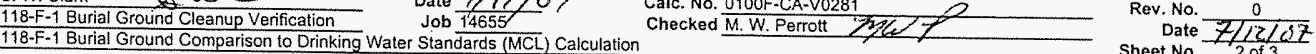

1 Table of Comparisons of the Maximum Concentration of Each Radionuclide to its Groundwater $\mathrm{MCL}$

Data derlved from RESRAD modelling, units are $\mathrm{pCi} / \mathrm{L}$.

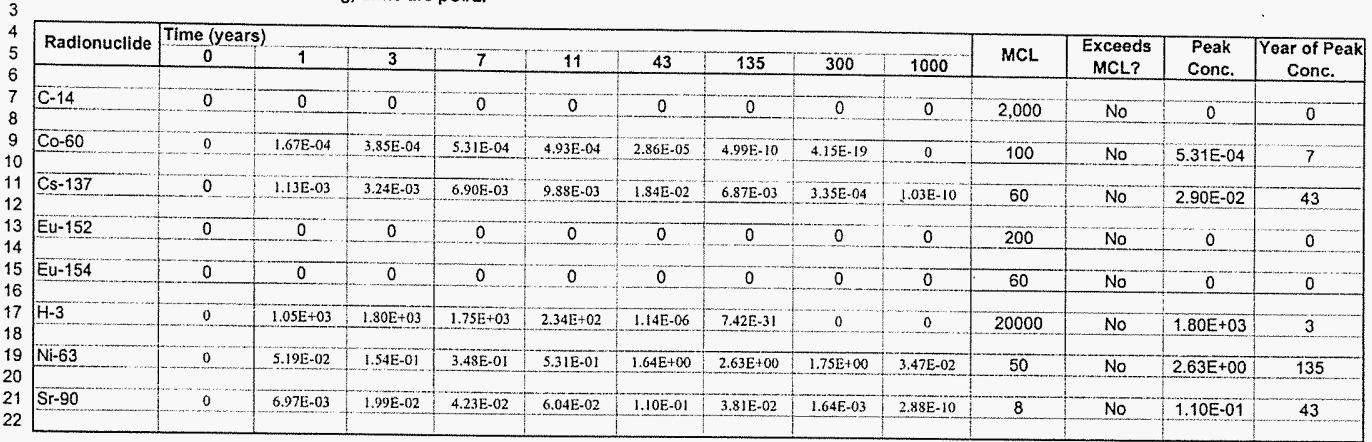




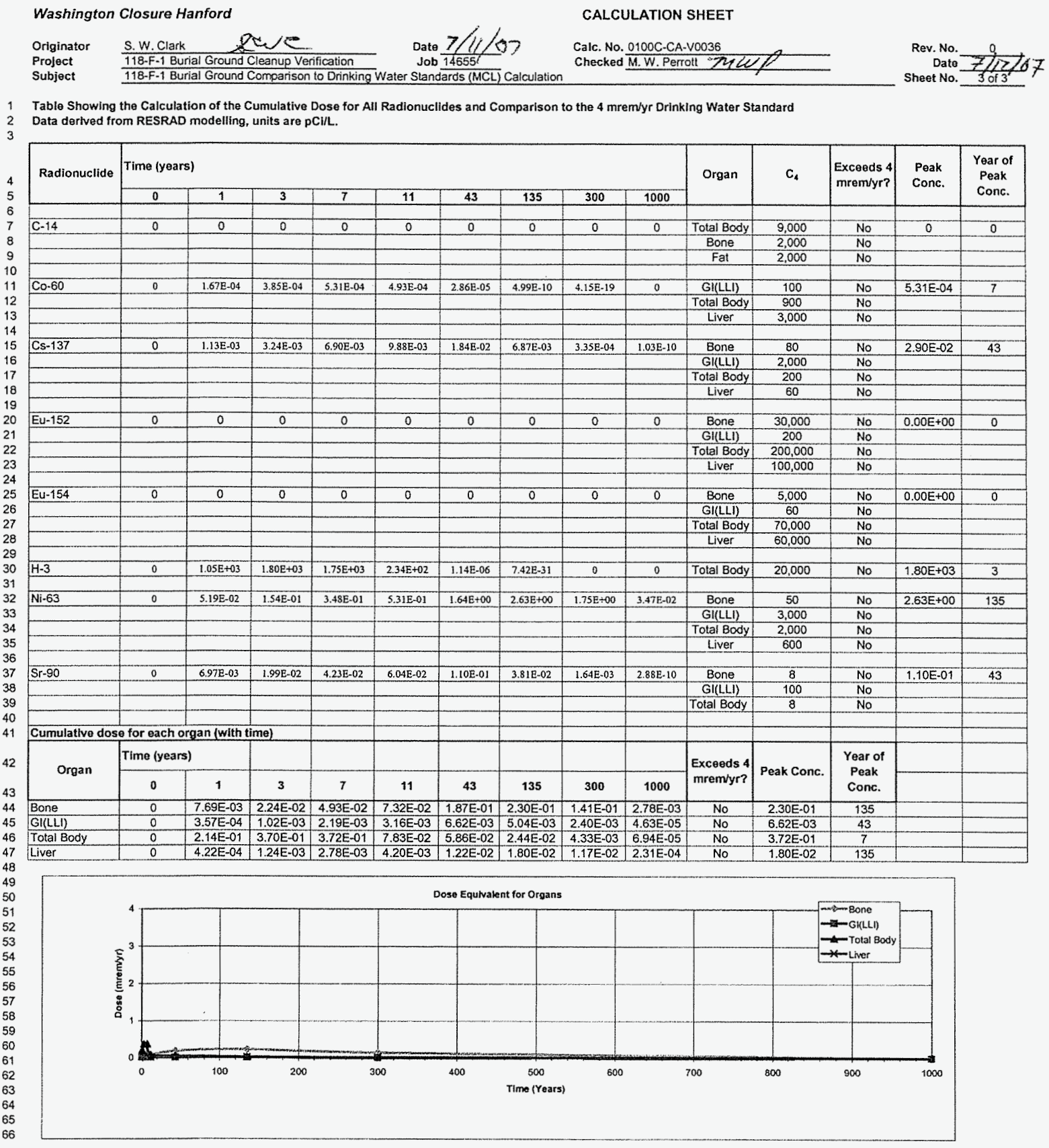




\section{CALCULATION COVER SHEET}

Project Title: 118-F-1 Burial Ground Cleanup Verification Job No:

14655

Area: 100-F Area

Discipline: Environmental

*Calculation No:

0100F-CA-V0280

Subject: 118-F-1 Burial Ground Cleanup Verification RESRAD Calculation Brief Computer Program: RESRAD Program No: Version 6.3

The attached calculations have been generated to document compliance with established cleanup levels. These calculations should be used in conjunction with other relevant documents in the administrative record.

\section{Committed Calculation $\otimes \quad$ Preliminary $\square \quad$ Superseded $\square \quad$ Voided}

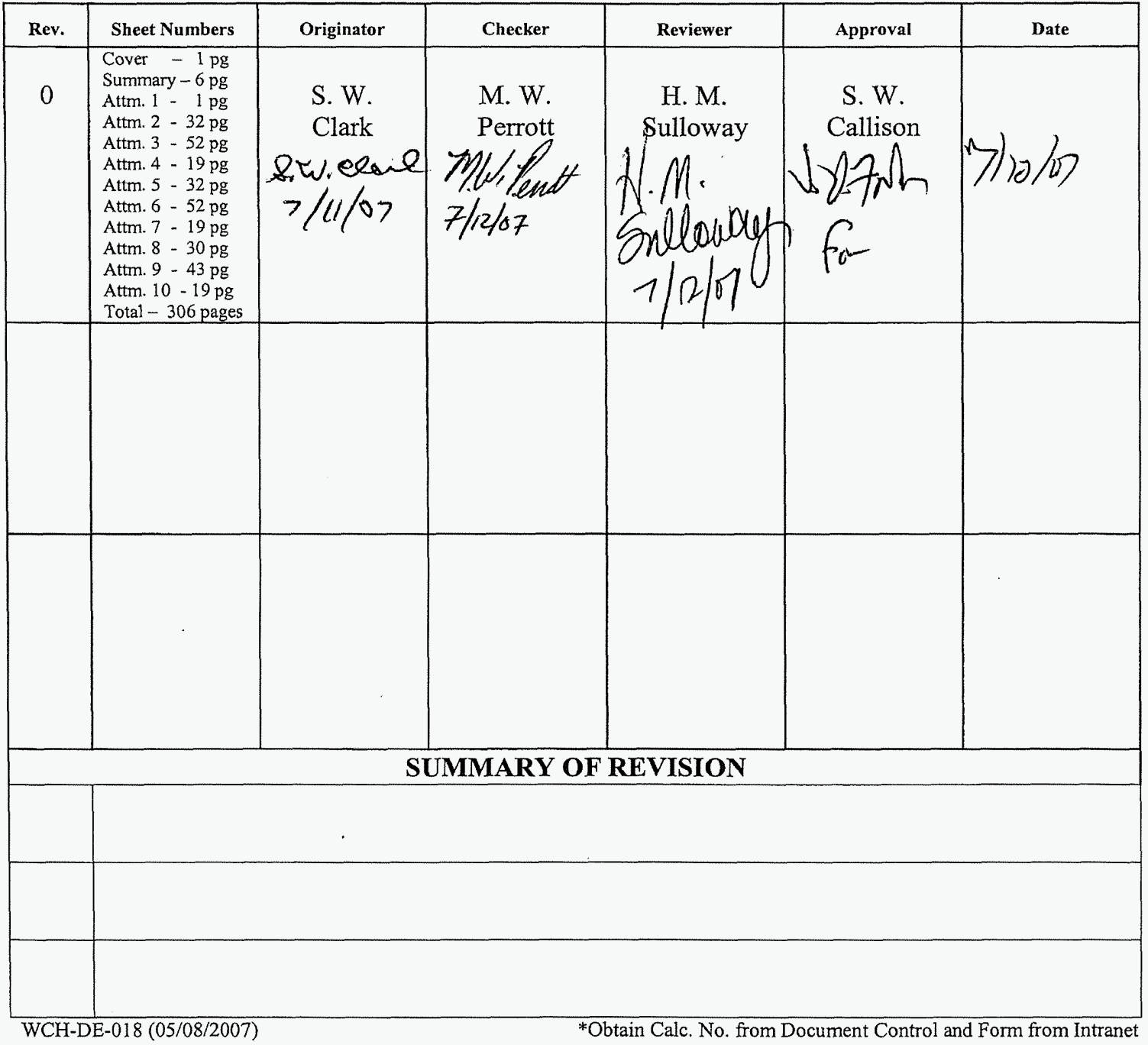




\section{PURPOSE:}

Calculate the soil and groundwater concentrations, dose, and risk contributions from remaining radionuclide contaminants in remediated 118-F-1 Burial Ground areas, in overburden/below cleanup level soil, and in staging pile (stockpile) areas over a period of 1,000 years.

\section{GIVEN/REFERENCES:}

1) Cleanup verification data from 118-F-1 Burial Ground 95\% UCL Calculation, Calculation No. 0100F-CA-V0279, Rev. 0, Washington Closure Hanford, Richland, Washington.

2) Remedial Design Report/Remedial Action Work Plan for the 100 Area (RDR/RAWP), DOE/RL-96-17, Rev. 5, U.S. Department of Energy, Richland Operations Office, Richland, Washington.

3) Radioactive and nonradioactive contaminants of concern from the 100 Area Burial Grounds Remedial Action Sampling and Analysis Plan, DOE/RL-2001-35, Rev. 0, U.S. Department of Energy, Richland Operations Office, Richland, Washington. For the purpose of these RESRAD calculations, the radioactive contaminants of concern (COCs) are americium-241, carbon-14, cesium-137, cobalt-60, europium-152, europium-154, nickel-63, plutonium-238, plutonium-239/240, silver-108m, strontium-90, tritium ( $\mathrm{H}-3)$, and uranium-238. The nonradionuclide contaminants of concern are cadmium, lead, and mercury. Attainment of remedial action goals (RAGs ) by residual concentrations of nonradionuclides is discussed in the 118-F-1 Burial Ground 95\% UCL Calculation. All direct exposure RAGs are met and protection of groundwater and the river can be demonstrated by the results of vertical migration modeling in the 100 Area Analogous Sites RESRAD Calculations, 0100X-CA-V0050, Rev. 0, Bechtel Hanford, Inc., Richland, Washington, which predicts that none of the nonradionuclides will migrate to groundwater (and thus the Columbia River) within 1,000 years.

4) RESidual RADioactivity (RESRAD) computer code, version 6.3, to calculate compliance with residual radioactivity guidelines, developed for the U.S. Department of Energy by the Environmental Assessment Division of Argonne National Laboratory, Argonne, Illinois.

5) Sample design data from the 118-F-1 Burial Ground Sampling Plan, Calculation No. 0100F-CA-V0282, Rev. 0, Washington Closure Hanford, Richland, Washington.

6) Groundwater elevation from Hanford Groundwater Monitoring for Fiscal Year 2006 PNNL-16346, Pacific Northwest National Laboratory, Richland, Washington.

\section{SOLUTION:}

1) Separate RESRAD runs were performed for the 118-F-1 Burial Ground Excavation shallow zone, Process Trench shallow zone, and overburden/below cleanup level stockpile (OB/BCL) material. Table 1 shows the elevations (NAVD88) and thickness of each soil horizon. Attachment 1 shows representative dimensions of soil horizons and contaminant pathways considered for dose, risk, and groundwater protection. Input factors for each run are shown in the "Summary" section of the RESRAD "Mixture Sums and Single Radionuclide Guidelines" printouts in the Attachments to this Calculation Summary. 


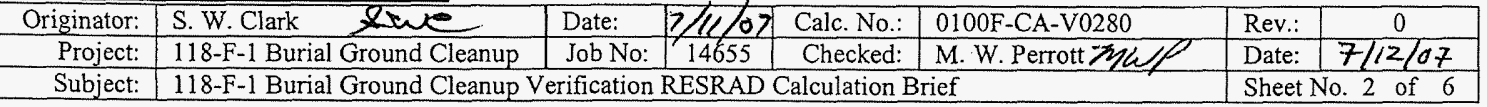

\begin{tabular}{|l|c|c|c|c|}
\hline \multicolumn{7}{|c|}{ Table 1. Waste Site Dimensions for RESRAD Modeling } \\
\hline Parameter & Units & $\begin{array}{c}\text { Excavation } \\
\text { Shallow Zone }\end{array}$ & $\begin{array}{c}\text { Process Trench } \\
\text { Shallow Zone }\end{array}$ & OB/BCL \\
\hline \multicolumn{5}{|c|}{ Contaminated Zone Dimensions } \\
\hline Cover Depth & $\mathrm{m}$ & 0 & 0 & 0 \\
\hline Area of Contaminated Zone (CZ) & $\mathrm{m}^{2}$ & 11,623 & 5,478 & 10,911 \\
\hline Length Parallel to Aquifer Flow & $\mathrm{m}$ & 186 & 164 & 212 \\
\hline \multicolumn{5}{|c|}{ Elevations of Vadose Zone Horizons } \\
\hline Elevation: Surface & $\mathrm{m}$ & 123.0 & 123.0 & 123.0 \\
\hline Elevation: Groundwater & $\mathrm{m}$ & 114.5 & 114.5 & 114.5 \\
\hline Thickness: Contaminated Zone & $\mathrm{m}$ & 8.5 & 8.5 & 8.5 \\
\hline Thickness: Unsaturated Zone & $\mathrm{m}$ & 0 & 0 & 0 \\
\hline OB/BCL= Overburden/Below Cleanup Levels Stockpile Material & \\
\hline
\end{tabular}

2) The year where the peak dose (or concentration) occurs from each individual radionuclide COC and layer is determined by a preliminary run. This year is then added for all horizons for the final RESRAD runs. For the direct exposure pathway (i.e. soil ingestion and inhalation and external radiation), the peak year occurred at year zero (year 2007) for all COCs. For the water pathways (i.e. drinking water and food ingestion) the peak year was year 3 for tritium, year 7 for cobalt-60, year 43 for cesium-137 and strontium-90, and year 135 for nickel-63. The 3-, 7-, 43-, and 135-year time periods were added to all RESRAD runs.

To be conservative, shallow zone evaluations for radionuclides were performed for the 118-F-1 Burial Ground areas assuming that the residual contamination levels from the shallow zone sample data sets extend uniformly from the surface to groundwater (Attachment 1).

\section{METHODOLOGY:}

1) Runs of RESRAD version 6.3 were completed for the 118-F-1 Burial Ground Excavation shallow zone, Process Trench shallow zone, and overburden/below cleanup level stockpile (OB/BCL) material soils using the radionuclide concentrations shown in Table 2. RESRAD numerical output reports for dose, risk, and concentration for the Excavation, Process Trench, and $\mathrm{OB} / \mathrm{BCL}$ material soils are presented in the Attachments to this calculation summary. 
Washington Closure Hanford

CALCULATION SHEET

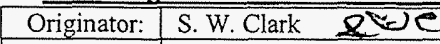

Date: $7 / 11$ or Calc. No.: $0100 \mathrm{~F}-\mathrm{CA}-\mathrm{V} 0280$

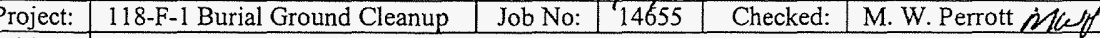

Subject: $118-\mathrm{F}-1$ Burial Ground Cleanup Verification RESRAD Calculation Brief

\begin{tabular}{l|l} 
Date: & $7 / 12 / 07$ \\
\hline
\end{tabular}

Sheet No. 4 of 6

1 overburden/below cleanup level stockpile material soil are, respectively, $4.12 \times 10^{-5}$ and

$21.69 \times 10^{-5}$ which also occur at year zero (2007).

3

Table 4. Radionuclide Excess Lifetime Cancer Risk

\begin{tabular}{|c|c|c|c|c|c|c|c|c|c|c|}
\hline $\begin{array}{c}\text { RESRAD } \\
\text { Run }\end{array}$ & $\begin{array}{c}\text { Vadose Zone } \\
\text { Horizons }\end{array}$ & \multicolumn{8}{|c|}{ Excess Cancer Risk at Each Time Slice (yr) } \\
\cline { 5 - 10 }$y$ & 0 & 1 & 3 & 7 & 11 & 43 & 135 & 300 & 1000 \\
\hline Excavation & Shallow Zone & $4.12 \mathrm{E}-05$ & $3.77 \mathrm{E}-05$ & $3.37 \mathrm{E}-05$ & $2.93 \mathrm{E}-05$ & $2.59 \mathrm{E}-05$ & $1.22 \mathrm{E}-05$ & $2.56 \mathrm{E}-06$ & $6.67 \mathrm{E}-07$ & $1.04 \mathrm{E}-07$ \\
\hline $\begin{array}{c}\text { Process } \\
\text { Trench }\end{array}$ & Shallow Zone & $4.45 \mathrm{E}-05$ & $4.21 \mathrm{E}-05$ & $3.85 \mathrm{E}-05$ & $3.29 \mathrm{E}-05$ & $2.86 \mathrm{E}-05$ & $1.24 \mathrm{E}-05$ & $2.42 \mathrm{E}-06$ & $6.29 \mathrm{E}-07$ & $1.29 \mathrm{E}-07$ \\
\hline OB/BCL & Shallow Zone & $1.69 \mathrm{E}-05$ & $1.15 \mathrm{E}-05$ & $7.00 \mathrm{E}-06$ & $5.05 \mathrm{E}-06$ & $3.99 \mathrm{E}-06$ & $2.21 \mathrm{E}-06$ & $1.29 \mathrm{E}-06$ & $6.54 \mathrm{E}-07$ & $1.62 \mathrm{E}-07$ \\
\hline
\end{tabular}

4

\section{3) Radionuclide Groundwater Protection}

6 The radionuclide concentrations in groundwater calculated by the RESRAD model are

7 summarized in Table 5. Among the radionuclide contaminants of concern only cobalt- 60 ,

8 cesium-137, nickel-63, strontium-90, and tritium are calculated to reach groundwater in the

9 1,000 years of the RESRAD model evaluation. The organ specific dose via the groundwater

10 (and river) pathway is presented in a separate calculation brief [ $118-F-1$ Burial Ground

11 Comparison To Drinking Water Standards (MCL) Calculation, Calculation No. 0100F-CA-

12 V0281, Rev. 0, Washington Closure Hanford, Richland, Washington]. Only concentrations are

13 presented here.

14

Table 5. Predicted Groundwater (Well Water/Drinking Water) Concentrations (2 Pages)

\begin{tabular}{|c|c|c|c|c|c|c|c|c|c|c|c|}
\hline \multirow{2}{*}{$\begin{array}{l}\text { Radio- } \\
\text { nuclides }\end{array}$} & \multirow{2}{*}{$\begin{array}{c}\text { RESRAD } \\
\text { Run }\end{array}$} & \multicolumn{9}{|c|}{ Groundwater Concentrations in $\mathrm{pCi} / \mathrm{L}$ at Each Time Slice (yr) } & \multirow{2}{*}{$\begin{array}{l}\text { RAGs, } \\
\mathrm{pCi} / \mathrm{L}\end{array}$} \\
\hline & & 0 & 1 & 3 & 7 & 11 & 43 & 135 & 300 & 1000 & \\
\hline \multirow[t]{3}{*}{$\mathrm{Co}-60$} & Excavation & 0 & $8.58 \mathrm{E}-05$ & $1.98 \mathrm{E}-04$ & $2.73 \mathrm{E}-04$ & $2.53 \mathrm{E}-04$ & $1.47 \mathrm{E}-05$ & $2.56 \mathrm{E}-10$ & $2.13 \mathrm{E}-19$ & 0 & \multirow[t]{3}{*}{100} \\
\hline & $\begin{array}{c}\text { Process } \\
\text { Trench } \\
\end{array}$ & 0 & $1.67 \mathrm{E}-04$ & $3.85 \mathrm{E}-04$ & $5.31 \mathrm{E}-04$ & 4.93E-04 & $2.86 \mathrm{E}-05$ & $4.99 \mathrm{E}-10$ & 4.15E-19 & 0 & \\
\hline & $\mathrm{OB} / \mathrm{BCL}$ & 0 & $1.69 \mathrm{E}-05$ & $3.90 \mathrm{E}-05$ & $5.38 \mathrm{E}-05$ & $5.00 \mathrm{E}-05$ & $2.90 \mathrm{E}-06$ & $5.05 \mathrm{E}-11$ & $4.21 \mathrm{E}-20$ & 0 & \\
\hline \multirow[t]{3}{*}{ Cs- 137} & Excavation & 0 & $5.28 \mathrm{E}-04$ & $1.51 \mathrm{E}-03$ & $3.22 \mathrm{E}-03$ & 4.61E-03 & $8.59 \mathrm{E}-03$ & $3.21 \mathrm{E}-03$ & $1.56 \mathrm{E}-04$ & $4.78 \mathrm{E}-11$ & \multirow[t]{3}{*}{60} \\
\hline & $\begin{array}{l}\text { Process } \\
\text { Trench } \\
\end{array}$ & 0 & $1.13 \mathrm{E}-03$ & $3.24 \mathrm{E}-03$ & $6.90 \mathrm{E}-03$ & $9.88 \mathrm{E}-03$ & $1.84 \mathrm{E}-02$ & $6.87 \mathrm{E}-03$ & $3.35 \mathrm{E}-04$ & $1.03 \mathrm{E}-10$ & \\
\hline & $\mathrm{OB} / \mathrm{BCL}$ & 0 & 0 & 0 & 0 & 0 & 0 & 0 & 0 & 0 & \\
\hline \multirow[t]{3}{*}{ Tritium (H-3) } & Excavation & 0 & $5.87 \mathrm{E}+02$ & $1.01 \mathrm{E}+03$ & $8.47 \mathrm{E}+02$ & $7.81 \mathrm{E}+01$ & $3.80 \mathrm{E}-07$ & $2.44 \mathrm{E}-31$ & 0 & 0 & \multirow[t]{3}{*}{20,000} \\
\hline & $\begin{array}{c}\text { Process } \\
\text { Trench } \\
\end{array}$ & 0 & $8.38 \mathrm{E}+02$ & $1.44 \mathrm{E}+03$ & $7.76 \mathrm{E}+02$ & $7.15 \mathrm{E}+01$ & $3.47 \mathrm{E}-07$ & $2.21 \mathrm{E}-31$ & 0 & 0 & \\
\hline & $\mathrm{OB} / \mathrm{BCL}$ & 0 & $1.05 E+03$ & $1.80 \mathrm{E}+03$ & $1.75 \mathrm{E}+03$ & $2.34 \mathrm{E}+02$ & $1.14 \mathrm{E}-06$ & $7.42 \mathrm{E}-31$ & 0 & 0 & \\
\hline \multirow[t]{3}{*}{$\mathrm{Ni}-63$} & Excavation & 0 & $2.71 \mathrm{E}-02$ & $8.03 \mathrm{E}-02$ & $1.82 \mathrm{E}-01$ & $2.78 \mathrm{E}-01$ & $8.58 \mathrm{E}-01$ & $1.37 \mathrm{E}+00$ & $9.13 \mathrm{E}-01$ & $1.82 \mathrm{E}-02$ & \multirow[t]{3}{*}{50} \\
\hline & $\begin{array}{c}\text { Process } \\
\text { Trench } \\
\end{array}$ & 0 & $5.19 \mathrm{E}-02$ & $1.54 \mathrm{E}-01$ & $3.48 \mathrm{E}-01$ & $5.31 \mathrm{E}-01$ & $1.64 \mathrm{E}+00$ & $2.63 E+00$ & $1.75 E+00$ & $3.47 \mathrm{E}-02$ & \\
\hline & $\mathrm{OB} / \mathrm{BCL}$ & 0 & $2.95 \mathrm{E}-02$ & $8.72 \mathrm{E}-02$ & $1.98 \mathrm{E}-01$ & $3.02 \mathrm{E}-01$ & $9.33 \mathrm{E}-01$ & $1.49 E+00$ & $9.93 \mathrm{E}-01$ & $1.97 \mathrm{E}-02$ & \\
\hline
\end{tabular}


Washington Closure Hanford

CALCULATION SHEET

\begin{tabular}{|r|l|l|l|l|l|l|l|}
\hline Originator: & S. W. Clark \&ue & Date: & $7 / 11 / 07$ & Calc. No.: & 0100 F-CA-V0280 & Rev.: & 0 \\
\hline Project: & $118-F-1$ Burial Ground Cleanup & Job No: & 14655 & Checked: & M. W. Perrott MW/P & Date: & $7 / 12 / 07$ \\
\hline Subject: & $118-F-1$ Burial Ground Cleanup Verification RESRAD Calculation Brief & Sheet No. 5 of 6 \\
\hline
\end{tabular}

Table 5. Predicted Groundwater (Well Water/Drinking Water) Concentrations (2 Pages)

\begin{tabular}{|c|c|c|c|c|c|c|c|c|c|c|c|}
\hline \multirow{2}{*}{$\begin{array}{l}\text { Radio- } \\
\text { nuclides }\end{array}$} & \multirow{2}{*}{$\begin{array}{l}\text { RESRAD } \\
\text { Run }\end{array}$} & \multicolumn{9}{|c|}{ Groundwater Concentrations in $\mathrm{pCi} / \mathrm{L}$ at Each Time Slice (yr) } & \multirow{2}{*}{$\begin{array}{l}\text { RAGs, } \\
\mathrm{pCi} / \mathrm{L}\end{array}$} \\
\hline & & 0 & 1 & 3 & 7 & 11 & 43 & 135 & 300 & 1000 & \\
\hline \multirow[t]{3}{*}{ Sr-90 } & Excavation & 0 & $6.97 \mathrm{E}-03$ & $1.99 \mathrm{E}-02$ & $4.23 \mathrm{E}-02$ & $6.04 \mathrm{E}-02$ & $1.10 \mathrm{E}-01$ & $3.81 \mathrm{E}-02$ & $1.64 \mathrm{E}-03$ & $2.88 \mathrm{E}-10$ & \multirow[t]{3}{*}{8} \\
\hline & $\begin{array}{l}\text { Process } \\
\text { Trench }\end{array}$ & 0 & $4.04 \mathrm{E}-03$ & $1.15 \mathrm{E}-02$ & $2.45 \mathrm{E}-02$ & $3.50 \mathrm{E}-02$ & $6.35 \mathrm{E}-02$ & $2.21 \mathrm{E}-02$ & 9.47E-04 & $1.45 \mathrm{E}-10$ & \\
\hline & $\mathrm{OB} / \mathrm{BCL}$ & 0 & 0 & 0 & 0 & 0 & 0 & 0 & 0 & 0 & \\
\hline
\end{tabular}

RAGs $=$ Remedial action goals from the 100 Area RDR/RAWP

$\mathrm{OB} / \mathrm{BCL}=$ Overburden/Below Cleanup Levels Stockpile Material

1

2

3

4

5

6

7

8

9

10

11

12

13

14

15

16

17

18

19

20

21

22

\section{CONCLUSIONS:}

- The "all pathways" (maximum) dose rates are shown in Table 3. The maximum all pathways dose rate from the 118-F-1 Burial Ground is $4.59 \mathrm{mrem} / \mathrm{yr}$ at year zero (2007) from the Excavation shallow zone. The maximum all-pathways dose rates from the Process Trench shallow zone and overburden/below cleanup level stockpile material are, respectively, 4.06 and $4.23 \mathrm{mrem} / \mathrm{yr}$ at year zero (2007).

- The radionuclide excess lifetime cancer risk (ELCR) results are shown in Table 4. The maximum ELCR for the 118-F-1 Burial Ground is $4.45 \times 10^{-5}$ at year zero (2007) for the Process Trench shallow zone. The maximum ELCR results for the Excavation shallow zone and overburden/below cleanup level stockpile material soil are, respectively, $4.12 \times 10^{-5}$ and $1.69 \times 10^{-5}$ which also occur at year zero (2007).

- The dominant pathway for the dose rate for the Excavation shallow zone and overburden/ below cleanup level stockpile material soil RESRAD evaluations is the plant ingestion pathway due to carbon-14 (see Attachment 2 and Attachment 8). The dominant pathway for the dose rate for the Process Trench shallow zone is the direct external exposure (external gamma) pathway due to cesium-137 (see Attachment 5). See Table 6, below.

Table 6. Dominant Pathways and Primary Radionuclides for RESRAD Evaluations

\begin{tabular}{|c|c|c|c|c|}
\hline RESRAD Run & Vadose Zone Horizon & Dominant Pathway & Primary Radionuclide & Reference \\
\hline Excavation & Shallow Zone & Plant Ingestion & Carbon-14 & Attachment 2 \\
\hline Process Trench & Shallow Zone & External Gamma & Cesium-137 & Attachment 5 \\
\hline OB/BCL & Shallow Zone & Plant Ingestion & Carbon-14 & Attachment 8 \\
\hline OB/BCL = Overburden/Below Cleanup Levels Stockpile Material & & \\
\hline
\end{tabular}

- None of the site COCs are projected to exceed remedial action goals (RAGs).

- Among the radionuclide contaminants of concern, cesium-137, cobalt-60, nickel-63, strontium-90, and tritium (H-3) are calculated to reach groundwater in the 1,000 years of the 
Washington Closure Hanford CALCULATION SHEET

\begin{tabular}{|c|c|c|c|c|c|c|c|}
\hline Originator: & S. W. Clark & Date: & Di1/a> & Calc. No.: & $0100 \mathrm{~F}-\mathrm{CA}-\mathrm{V} 0280$ & Rev.: & 0 \\
\hline Project: & 118-F-1 Burial Ground Cleanup & Job No: & 14655 & Checked: & M. W. Perrott hafe & Date: & $7 / 12 / 07$ \\
\hline Subject: & \multicolumn{5}{|c|}{ 118-F-1 Burial Ground Cleanup Verification RES } & \multicolumn{2}{|c|}{ Sheet No. 6 of 6} \\
\hline
\end{tabular}

1 RESRAD model run. These radionuclides are predicted to reach groundwater at concentrations significantly below the RAGs.

\section{ATTACHMENTS:}

1. Graphic showing 118-F-1 Cleanup Verification Model (1pages)

2. RESRAD Output: 118-F-1 Excavation Shallow Zone Radionuclides - Mixture Sums and Single Radionuclide Guidelines (32 pages)

3. RESRAD Output: 118-F-1 Excavation Shallow Zone Radionuclides - Intake Quantities and Health Risk Factors (52 pages)

4. RESRAD Output: 118-F-1 Excavation Shallow Zone Radionuclides - Concentration of Radionuclides, (19 pages)

5. RESRAD Output: 118-F-1 Process Trench Shallow Zone Radionuclides - Mixture Sums and Single Radionuclide Guidelines (32 pages)

6. RESRAD Output: 118-F-1 Process Trench Shallow Zone Radionuclides - Intake Quantities and Health Risk Factors (52 pages)

7. RESRAD Output: 118-F-1 Process Trench Shallow Zone Radionuclides - Concentration of Radionuclides (19 pages)

8. RESRAD Output: 118-F-1 Overburden/Below Cleanup Levels Radionuclides - Mixture Sums and Single Radionuclide Guidelines (30 pages)

9. RESRAD Output: 118-F-1 Overburden/Below Cleanup Levels Radionuclides - Intake Quantities and Health Risk Factors (43 pages)

10. RESRAD Output: 118-F-1 Overburden/Below Cleanup Levels Radionuclides Concentration of Radionuclides (19 pages) 
118-F-1 Burial Ground Cleanup Verification Model

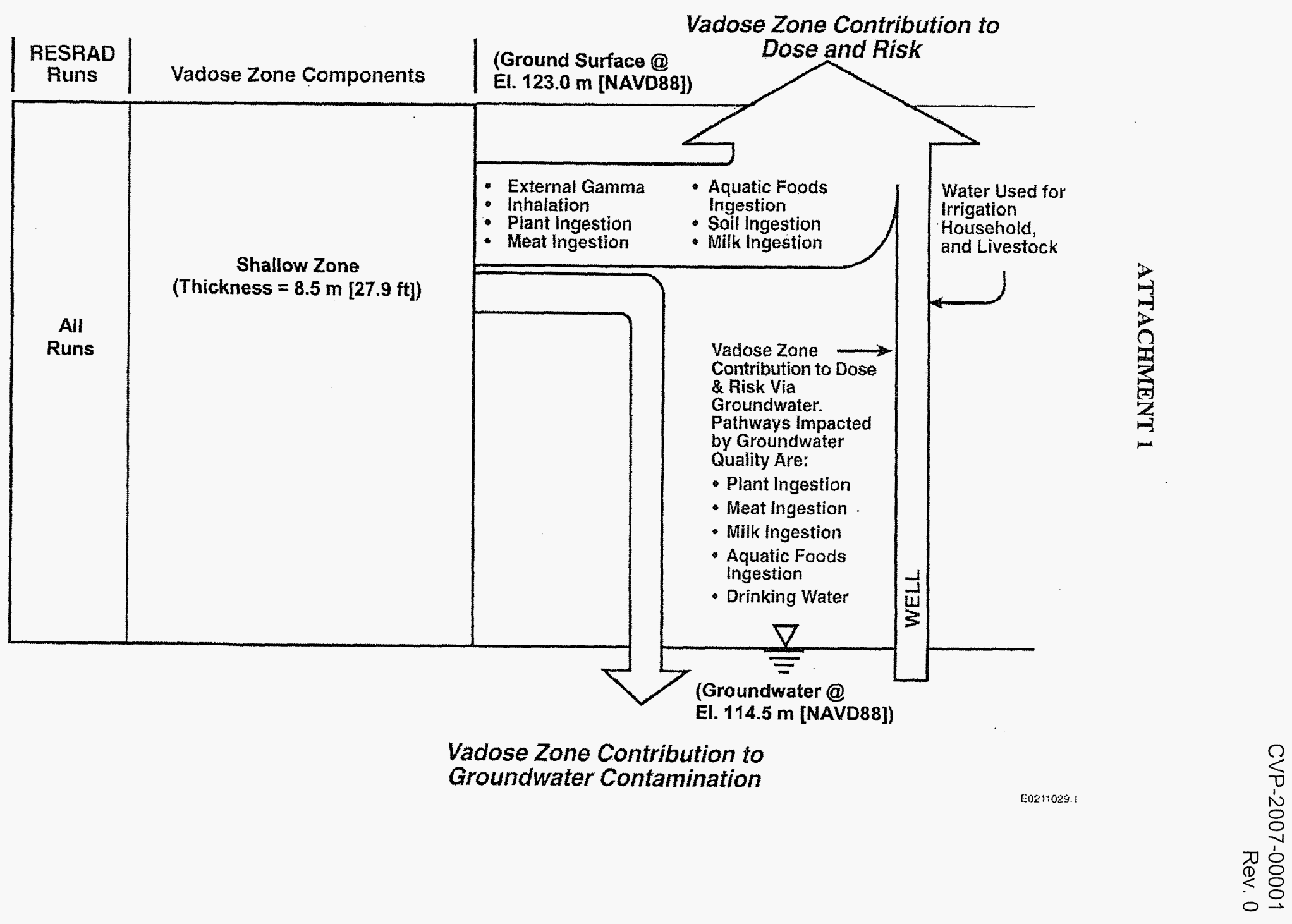




\section{ATTACHMENT 2}

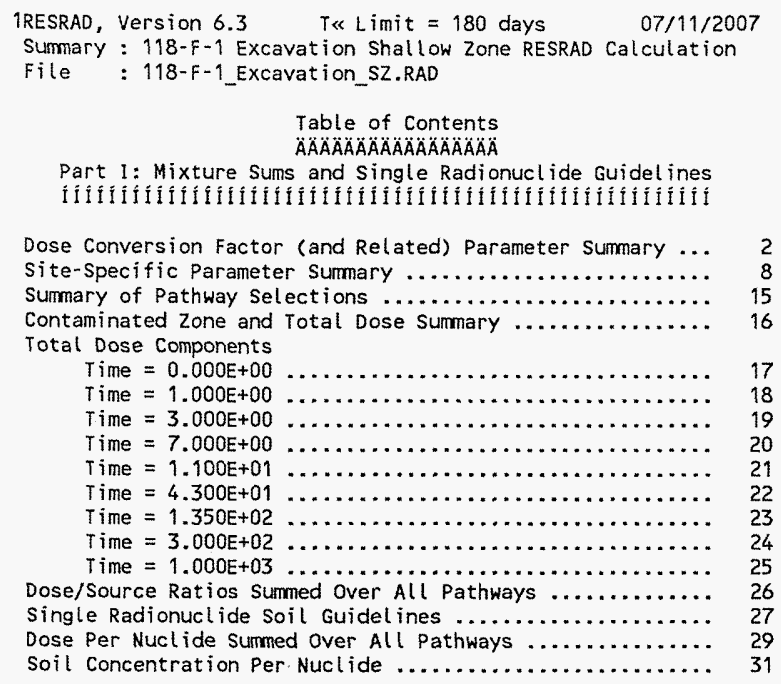

Attachment

Originator: S.W. Clark 2U $\quad$ Sheet No, $1 \frac{1}{11} \% \frac{32}{7}$

Chk'd By M.W. Perrott Tiwi Date 7/12/07

Calc. No. 0100F-CA-V0280

Rev. No. 0 


\section{ATTACHMENT 2}

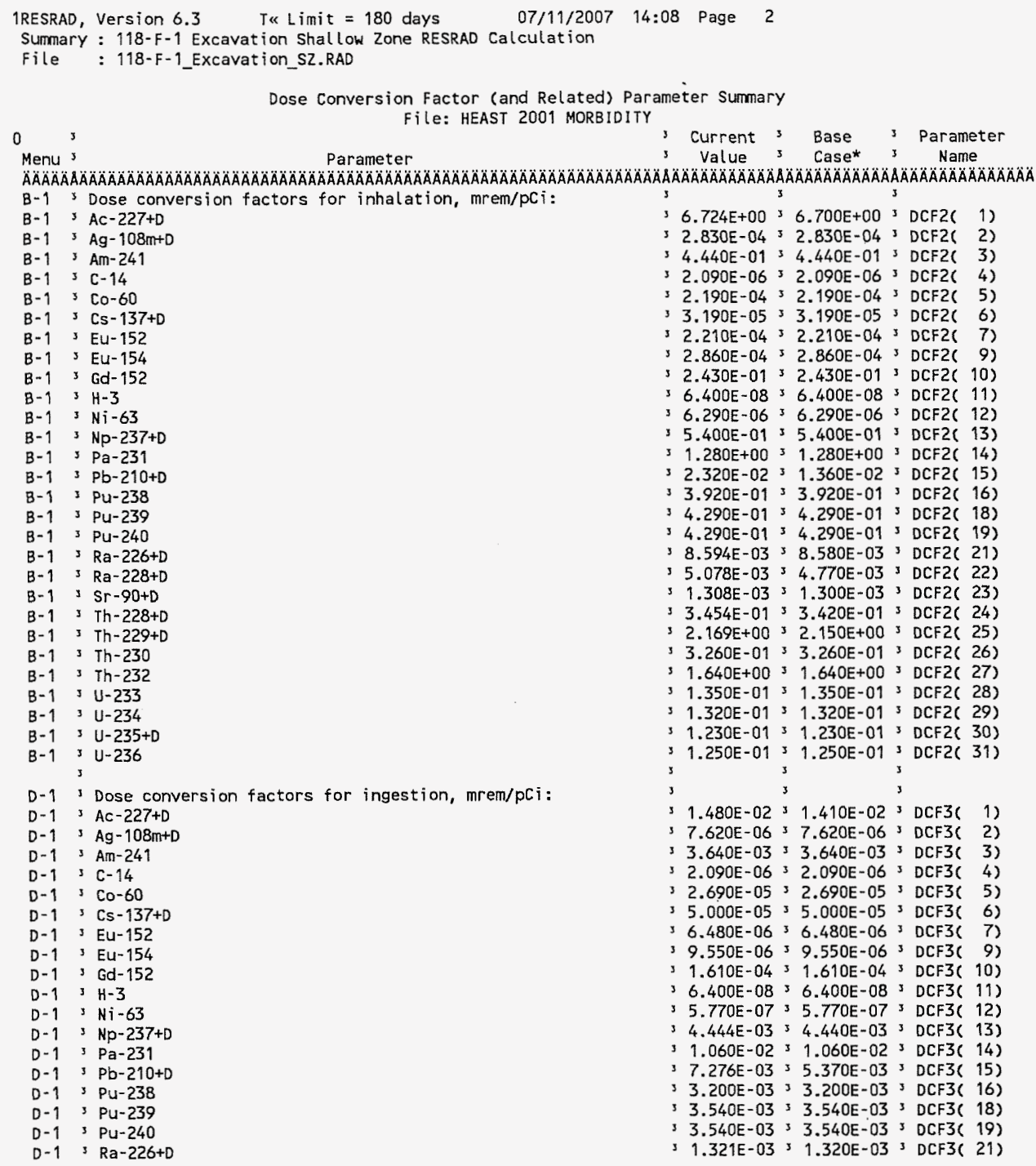

\begin{tabular}{|c|c|}
\hline Attachment & Sheet No. 2 of 32 \\
\hline Originator: S. W. Clark & Date \\
\hline Chk'd By M.W. Perrott & Date \\
\hline $0100 F-C A-V 0280$ & Rev. No. \\
\hline
\end{tabular}


ATTACHMENT 2

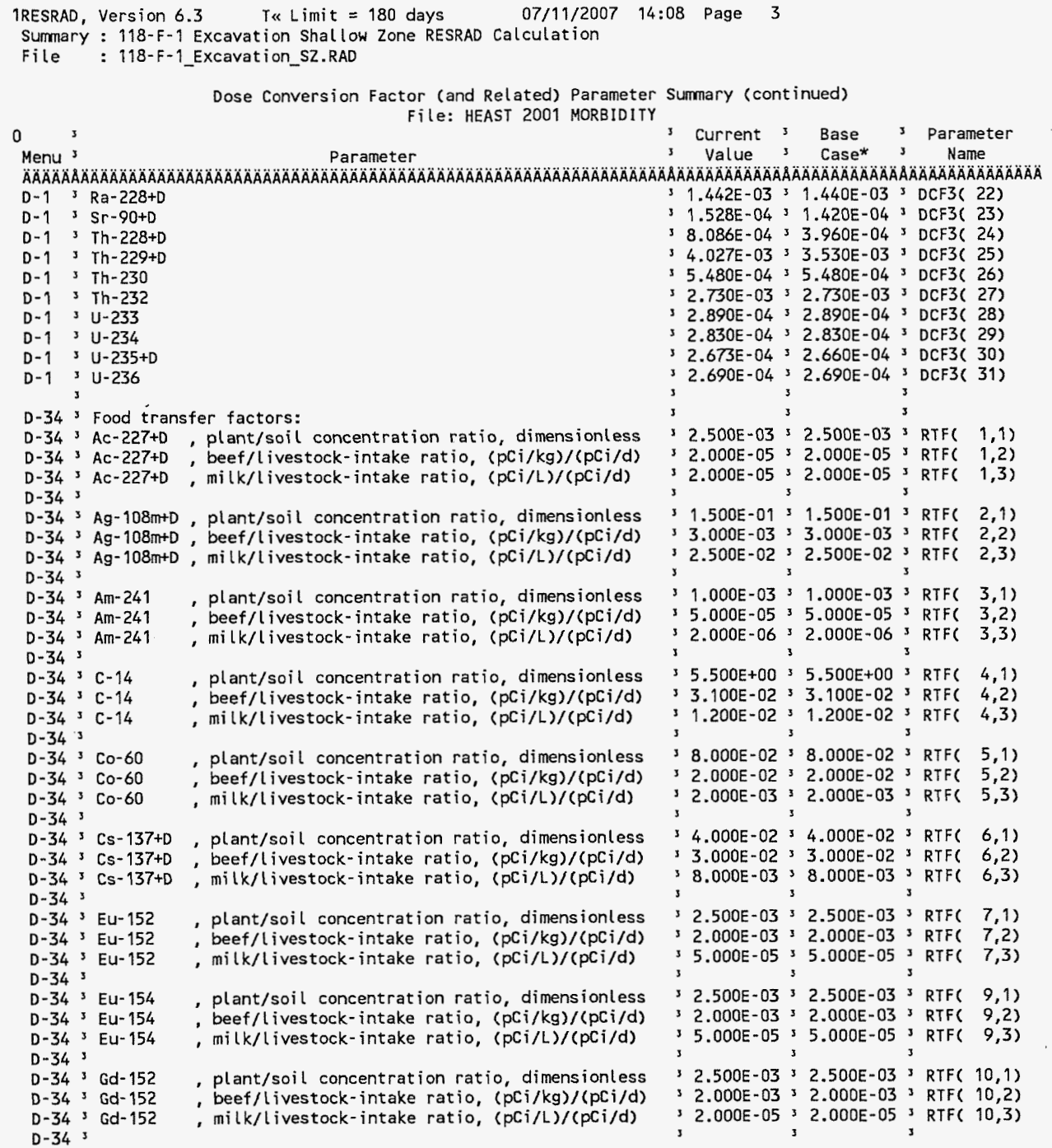

Attachment 2 


\section{ATTACHMENT 2}

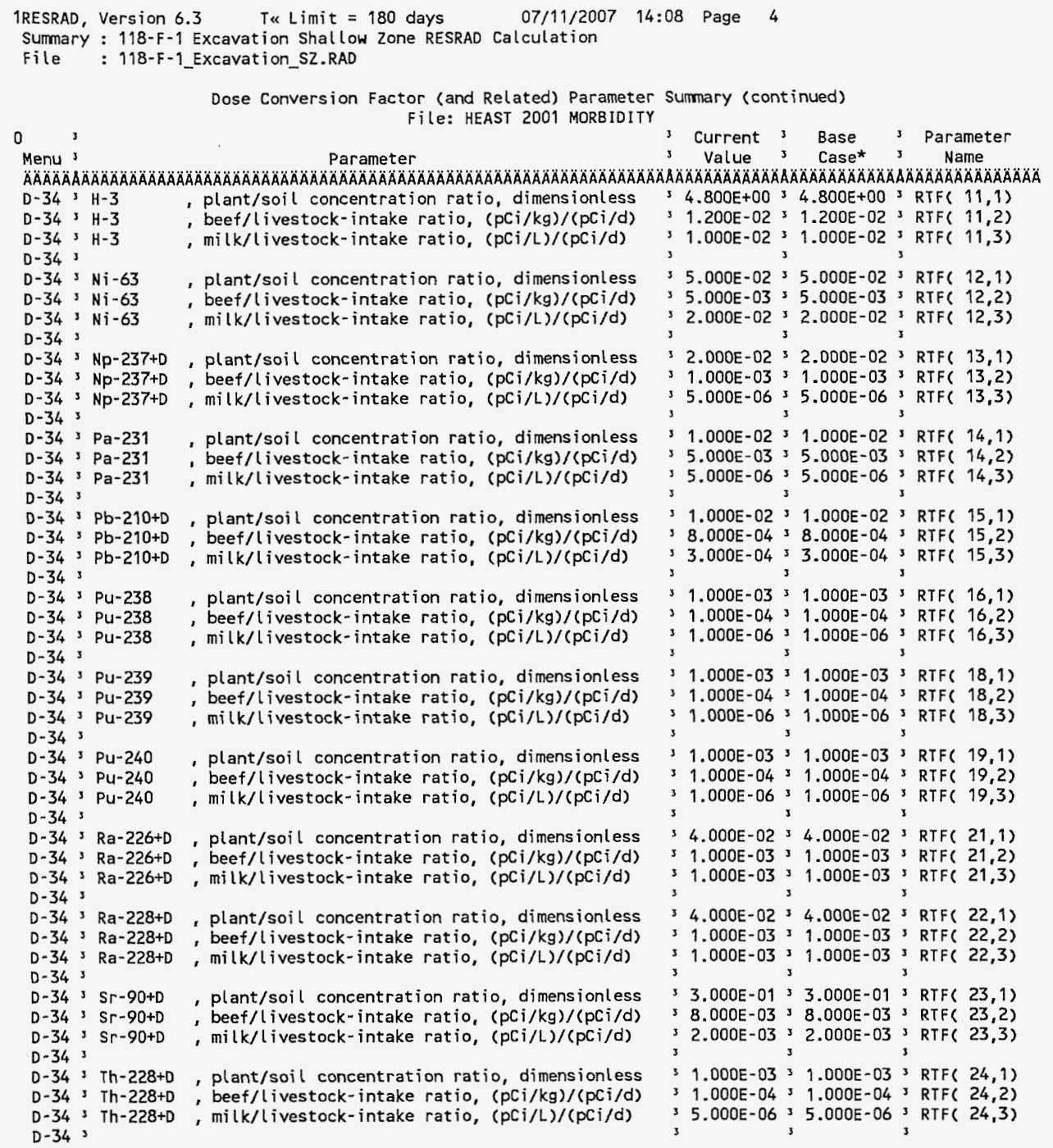

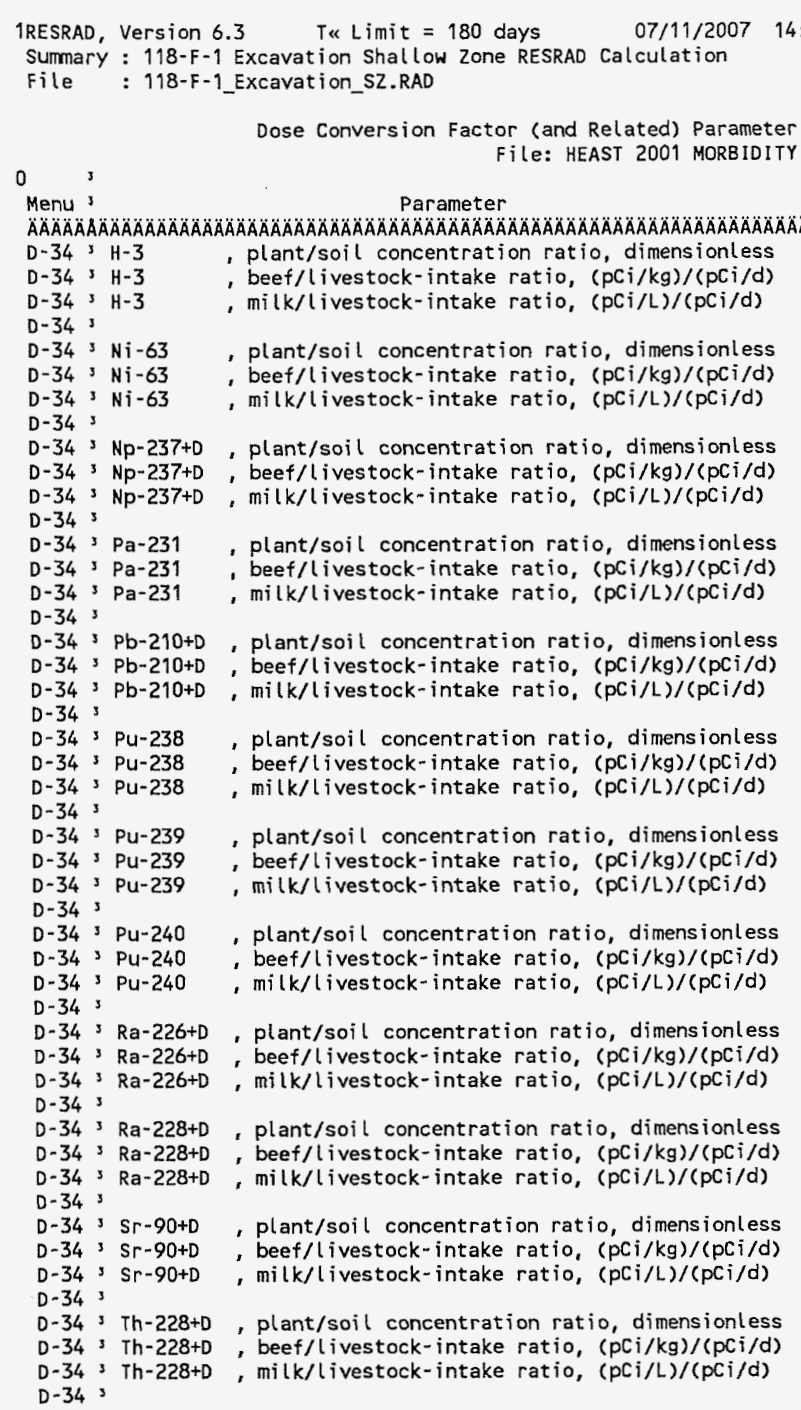

- plant/soil concentration ratio, dimensionless , beef/livestock-intake ratio, $(\mathrm{pCi} / \mathrm{kg}) /(\mathrm{pCi} / \mathrm{d})$

- plant/soil concentration ratio, dimensionles , beef/livestock-intake ratio, (pCi/kg)/(pCi/d)

plant/soil concentration ratio, dimensionles D-34 3 Ra-226+D , beef/livestock-intake ratio, ( $\mathrm{pCi} / \mathrm{kg}) /(\mathrm{pCi} / \mathrm{d})$ D. 34 ,

-34 s $\mathrm{S} r-90+\mathrm{D}$

$\mathrm{D}-34$ 3 Th-228+D, beef/livestock-intake ratio, $(\mathrm{pCi} / \mathrm{kg}) /(\mathrm{pCi} / \mathrm{d})$ D -34 , $24,1)$ $35.000 E-06 ; 5.000 E-063 \operatorname{RTF}(24,3)$ 


\section{ATTACHMENT 2}

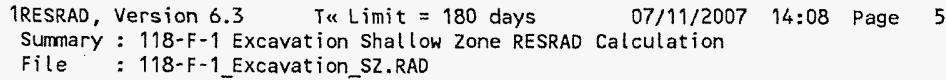

D-5 3
, plant/soil concentration
beef/livestock-intake r
milk/livestock-intake ra
, plant/soil concentration
beef/livestock-intake rat
milk/livestock-intake rat
, plant/soil concentration
beef/livestock-intake
, milk/livestock-intake rat
, plant/soil concentration
beef/livestock-intake rat
milk/livestock-intake rat
ation factors, fresh water
, fish
crustacea and mollusks
fish
crustacea and mollusks
fish
crustacea and mollusks
fish
crustacea and mollusks
fish
crustacea and mollusks
crustacea and mollusks




\section{ATTACHMENT 2}

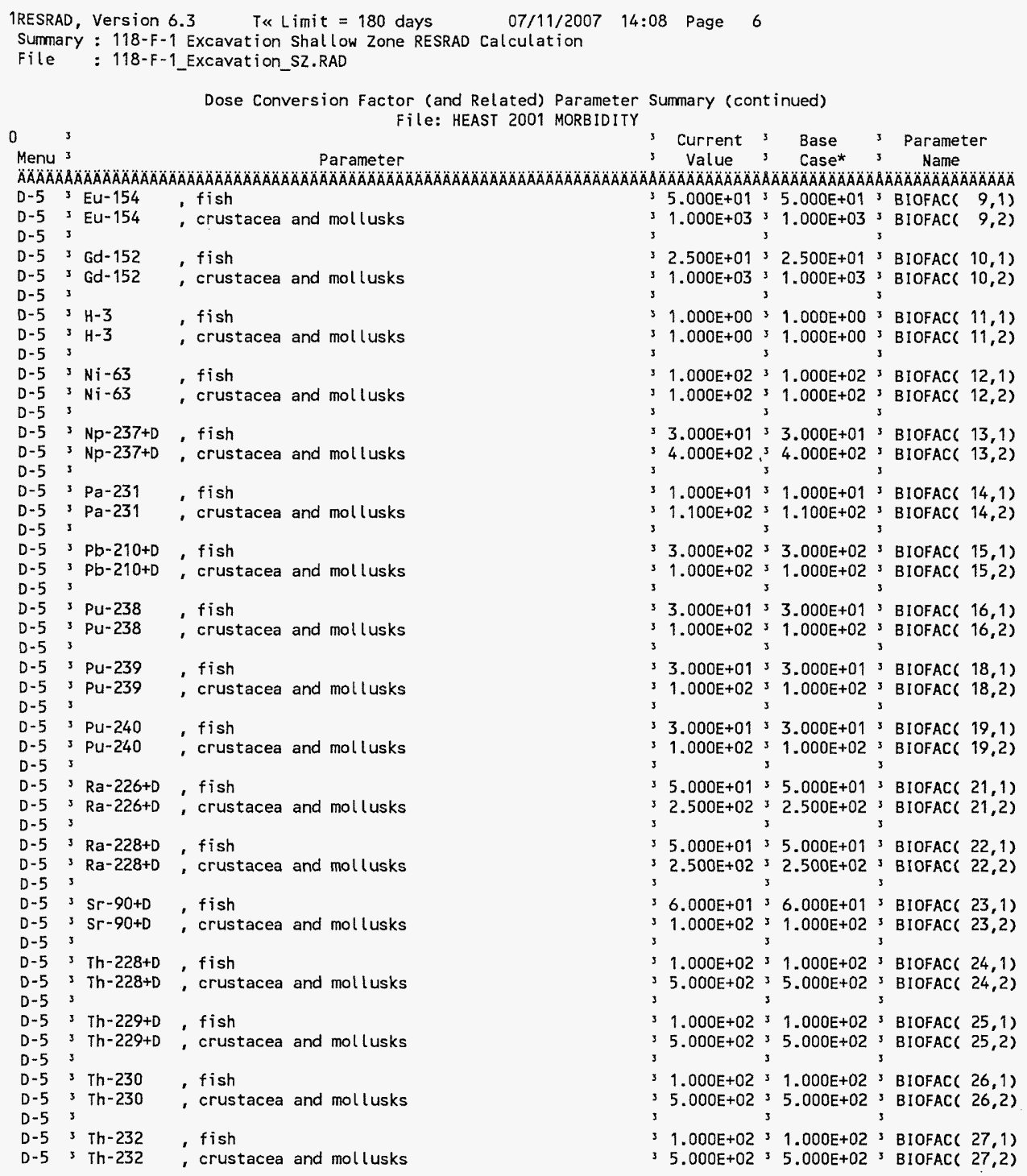

\begin{tabular}{|c|c|}
\hline Attachment & Sheet No. 6 of 32 \\
\hline Originator: S.W. Clark & Date \\
\hline Chk'd By M.W. Perrott & Date \\
\hline Calc. No. $\quad 0100 \mathrm{~F}-\mathrm{CA}-\mathrm{V} 0280$ & Rev. No. \\
\hline
\end{tabular}




\section{ATTACHMENT 2}

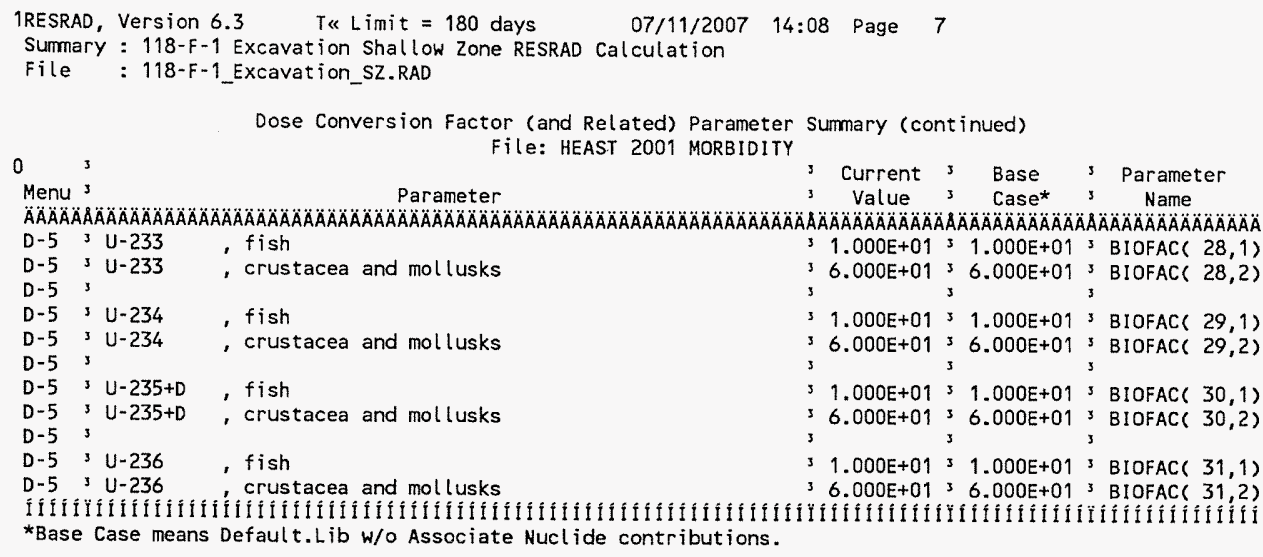

Attachment 


\section{ATTACHMENT 2}

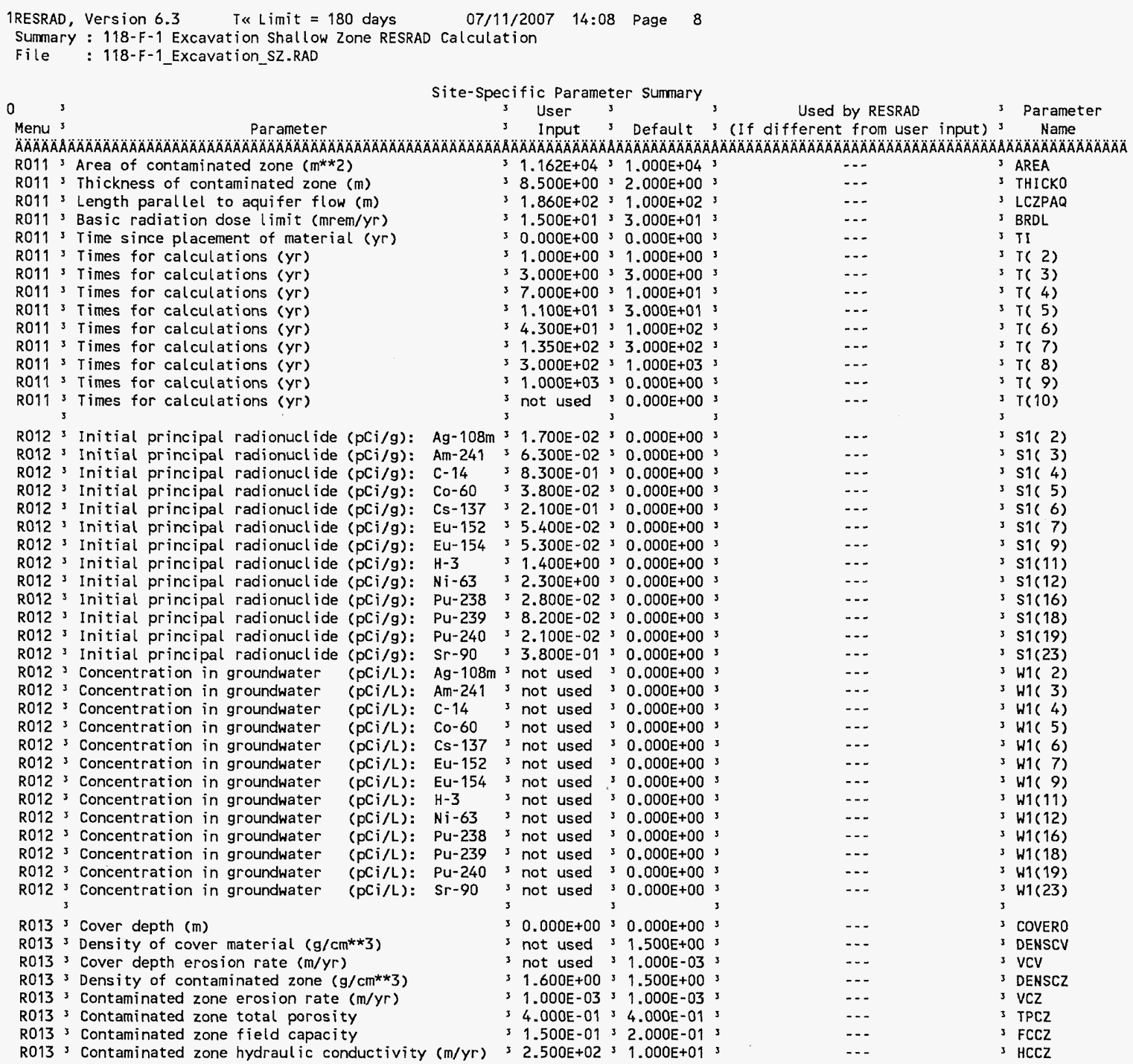

Attachment Originator: S.W. Clark Chk'd By Calc. No.

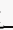

V0280
Sheet No. $\underline{8}$ of $\underline{32}$ Date

Rev. No. 0 


\section{ATTACHMENT 2}

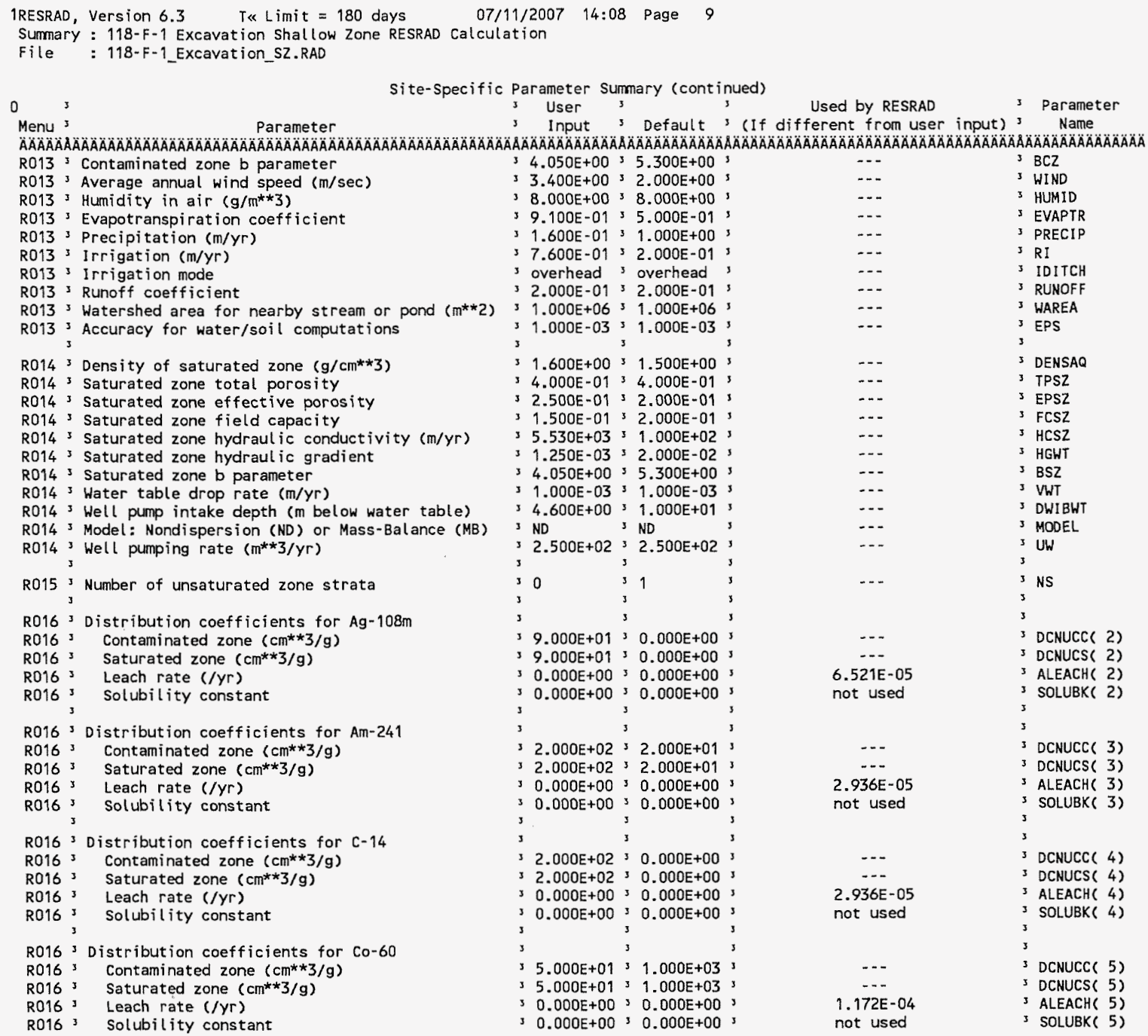

\begin{tabular}{|c|c|}
\hline \multirow{2}{*}{\multicolumn{2}{|c|}{ 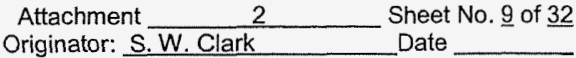 }} \\
\hline & \\
\hline thk'd By M.W. Perrott & \\
\hline $0100 F-C A-V 0280$ & 0 \\
\hline
\end{tabular}




\section{ATTACHMENT 2}

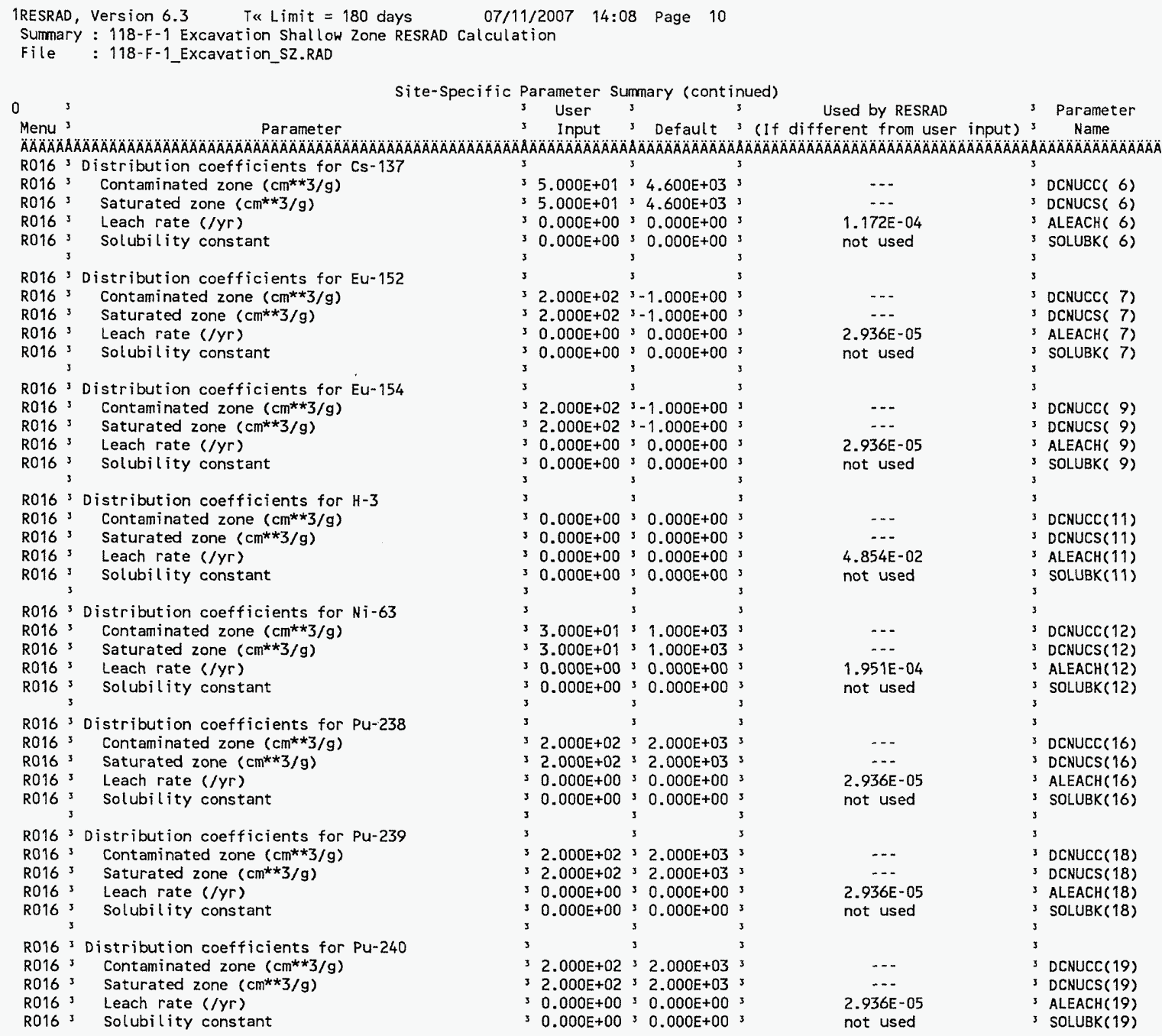

\begin{tabular}{|c|c|}
\hline Attachment & Sheet No. 10 of $\underline{32}$ \\
\hline Originator: S.W. Clark & Date \\
\hline Y. M. Perrott & Date \\
\hline 0100F-CA-V0280 & Rev. No. \\
\hline
\end{tabular}




\section{ATTACHMENT 2}

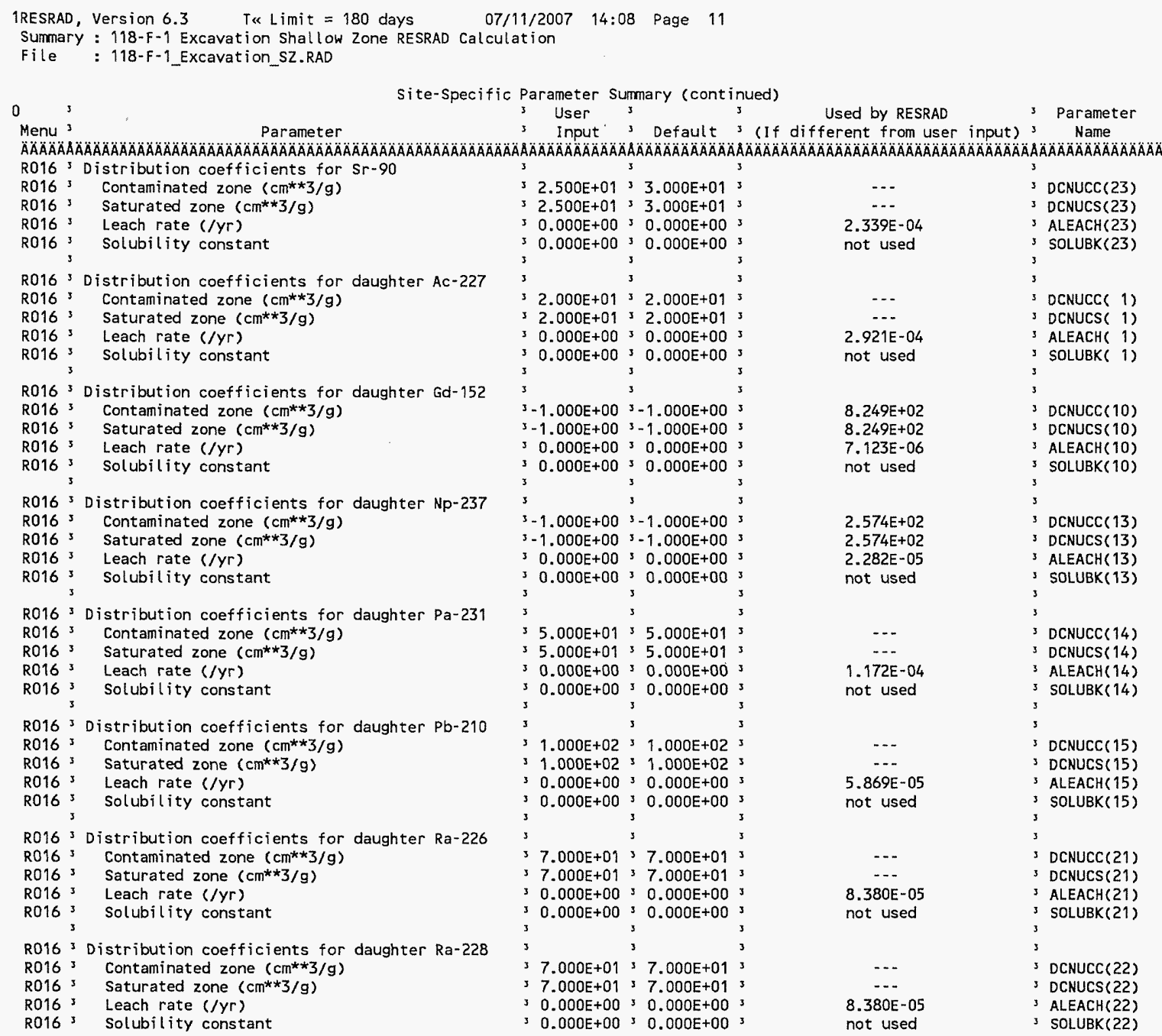




\section{ATTACHMENT 2}

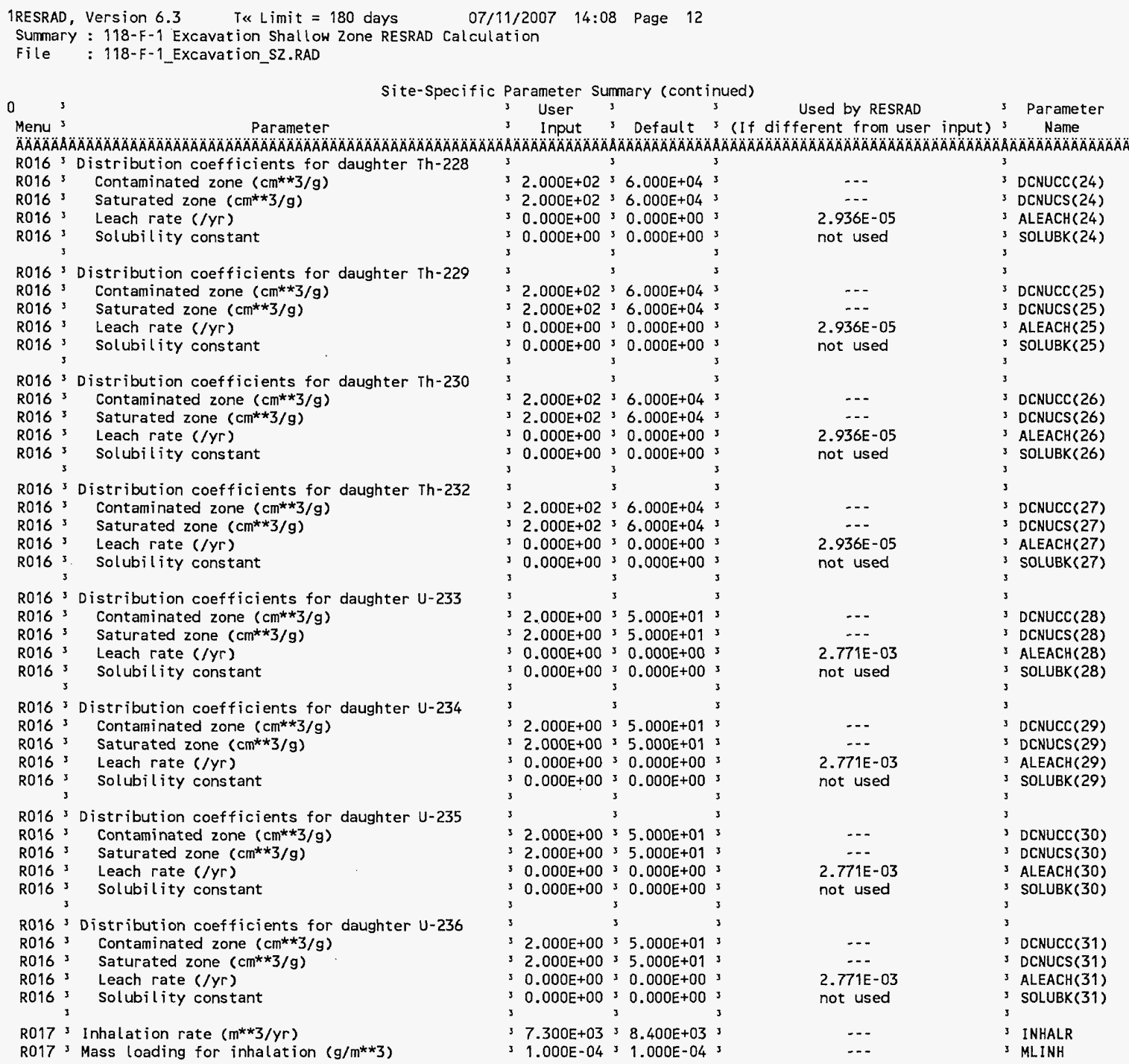

$\begin{array}{ll}\text { Attachment } \frac{2}{\text { S.W. Clark }} & \text { Sheet No. } 12 \text { of } \underline{32} \\ \text { Originator: } & \text { Date } \\ \text { Chk'd By } \frac{\text { M.W. Perrott }}{\text { Date }} & \\ \text { Calc. No. No. } & \text { Rev. No. } \quad 0\end{array}$




\section{ATTACHMENT 2}

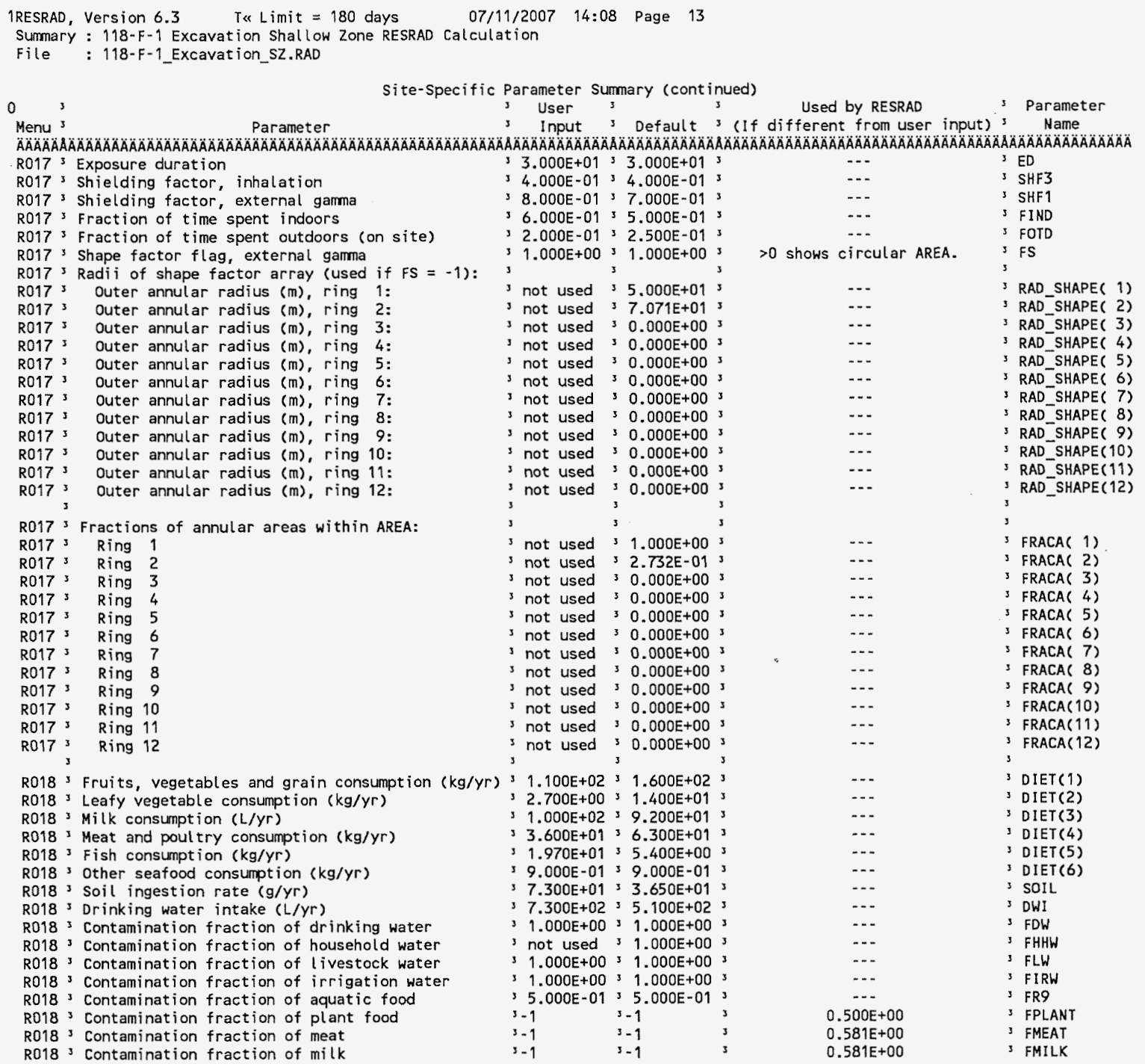

Attachment $2 \quad$ Sheet No. 13 of $\underline{32}$ Originator: S.W. Clark Date

Calc. No. 0100F-CA-V0280 Date 


\section{ATTACHMENT 2}

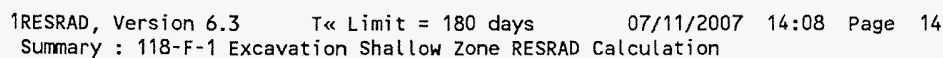

STOR 3 Surface water $6.800 \mathrm{E}+01^{3}, 6.800 \mathrm{E}+01^{3}$

$5.500 E+0135.500 E+01$

3 $1.600 \mathrm{E}+02$, $1.600 \mathrm{E}+02$

3 5.000E-01 3 5.000E-01

$31.000 E-04^{3} 1.000 E-04$

$9.000 E-0139.000 E-01$

$31.000 E+0031.000 E+00$

not used 3 1.000E +00

$31.000 E+0031.000 E+00$ ?

3 7.000E-01 3 7.000E-01

$31.500 E+00$, $1.500 E+00$

$1.100 E+0031.100 E+00$

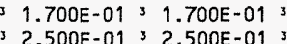

$32.500 \mathrm{E}-0132.500 \mathrm{E}-013$

8.000E-02,8.000E-02

$1.000 \mathrm{E}-0131.000 \mathrm{E}-01$

$2.000 E+01 ; 2.000 E+01$

$2.000 E-05>2.000 E-05$

$3.000 \mathrm{E}-02,3.000 \mathrm{E}-02$

$2.000 E-02 ; 2.000 E-02$

$9.800 \mathrm{E}-0139.800 \mathrm{E}-01$

$3.000 E-0133.000 E-01$

7.000E-07 3 7.000E-07

$1.000 E-10^{3} \quad 1.000 E-10$

8.000 E $-01^{3} 8.000 E-01$

$2.000 E-0132.000 E-01$

$3.894 \mathrm{E}+01>0.000 \mathrm{E}+00$

3

$$
3
$$

$1.400 E+01=1.400 E+01$

$1.000 E+003,1.000 E+00$

$1.000 E+00>1.000 E+00$

$2.000 E+01 ; 2.000 E+01$

$7.000 E+00 ; 7.000 E+00$

$7.000 E+0037.000 E+00$

$1.000 E+00$ > $1.000 E+00$

$31.000 E+0031.000 E+00$

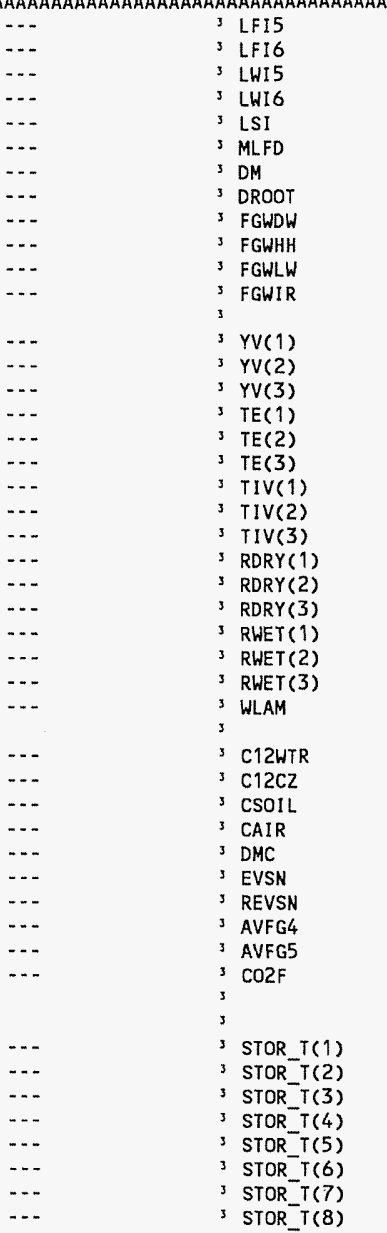

Attachment 


\section{ATTACHMENT 2}

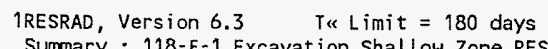

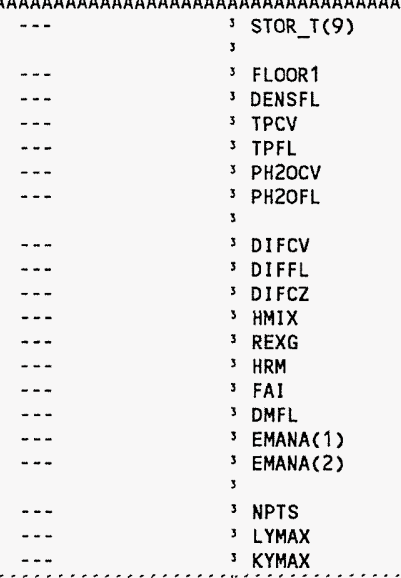

Summary of Pathway selections

Pathway $\quad 3$ User Selection

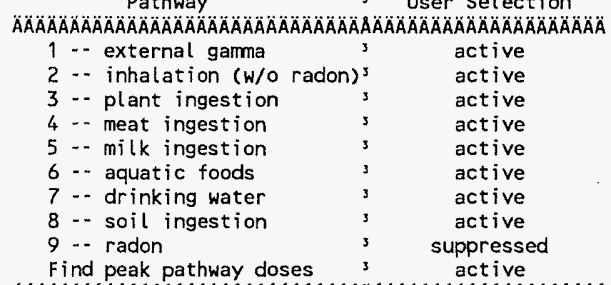

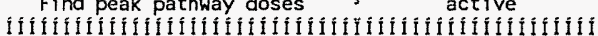

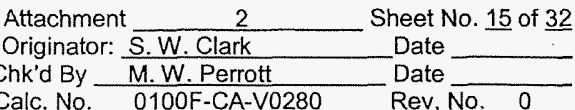


ATTACHMENT 2

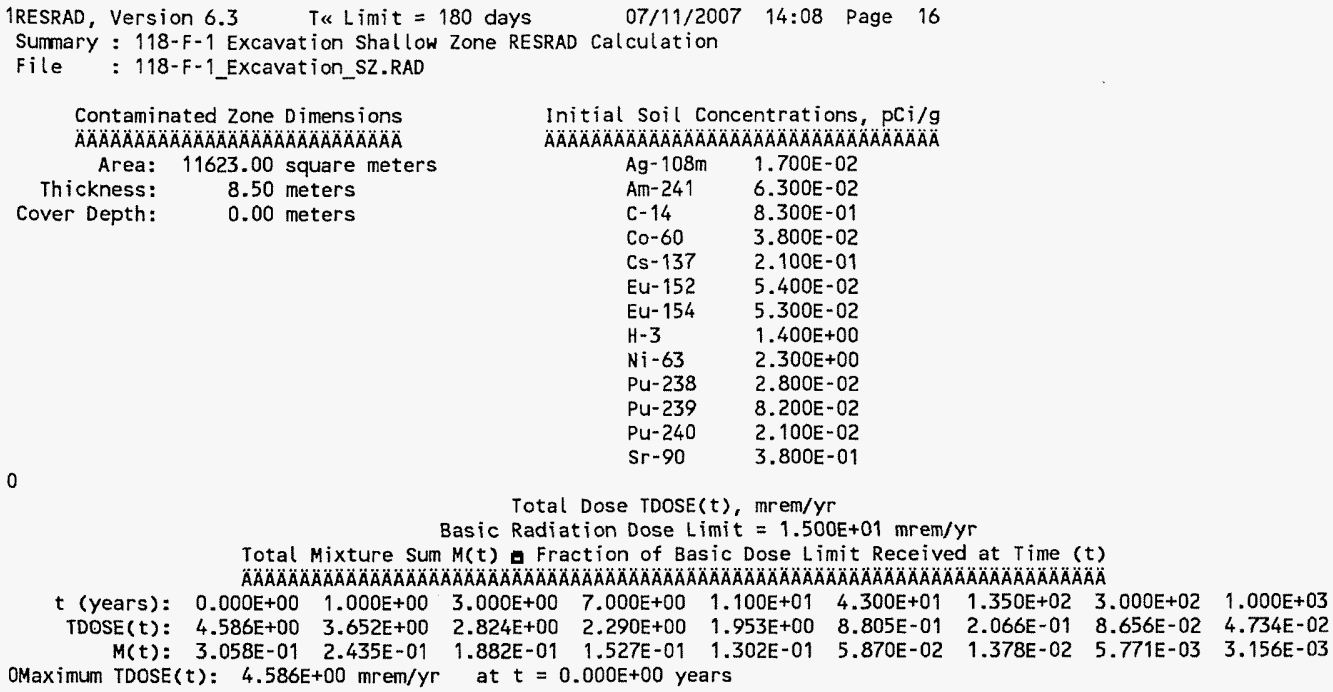

0

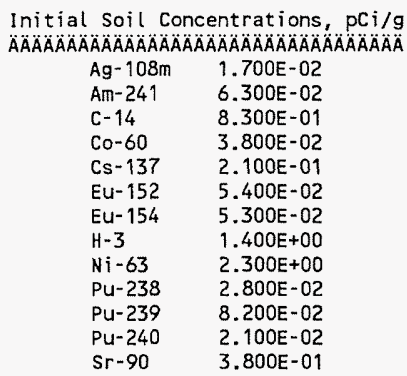

Total Dose TDOSE( $t$ ), mrem/yr Basic Radiation Dose Limit $=1.500 \mathrm{E}+01 \mathrm{mrem} / \mathrm{yr}$

Total Mixture sum $M(t)$. Fraction of Basic Dose Limit Received at Time $(t)$

AOAAA

$t$ (years): $\begin{array}{llllllllll}0.000 E+00 & 1.000 E+00 & 3.000 E+00 & 7.000 E+00 & 1.100 E+01 & 4.300 E+01 & 1.350 E+02 & 3.000 E+02 & 1.000 E+03\end{array}$

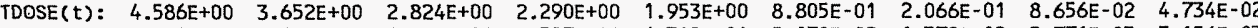
$M(t): 3.058 E-01 \quad 2.435 E-01 \quad 1.882 E-01 \quad 1.527 E-01 \quad 1.302 E-01 \quad 5.870 E-02 \quad 1.378 E-02 \quad 5.771 E-03 \quad 3.156 E-03$ OMaximum $\operatorname{TDOSE}(t): 4.586 \mathrm{E}+00 \mathrm{mrem} / \mathrm{yr}$ at $t=0.000 \mathrm{E}+00$ years

\begin{tabular}{|c|c|}
\hline Attachment & Sheet No. 16 of 32 \\
\hline Originator: S.W. Clark & Date \\
\hline Chk'd By M.W. Perrott & Date \\
\hline 0100 F-CA-V0280 & Rev. No. 0 \\
\hline
\end{tabular}




\section{ATTACHMENT 2}

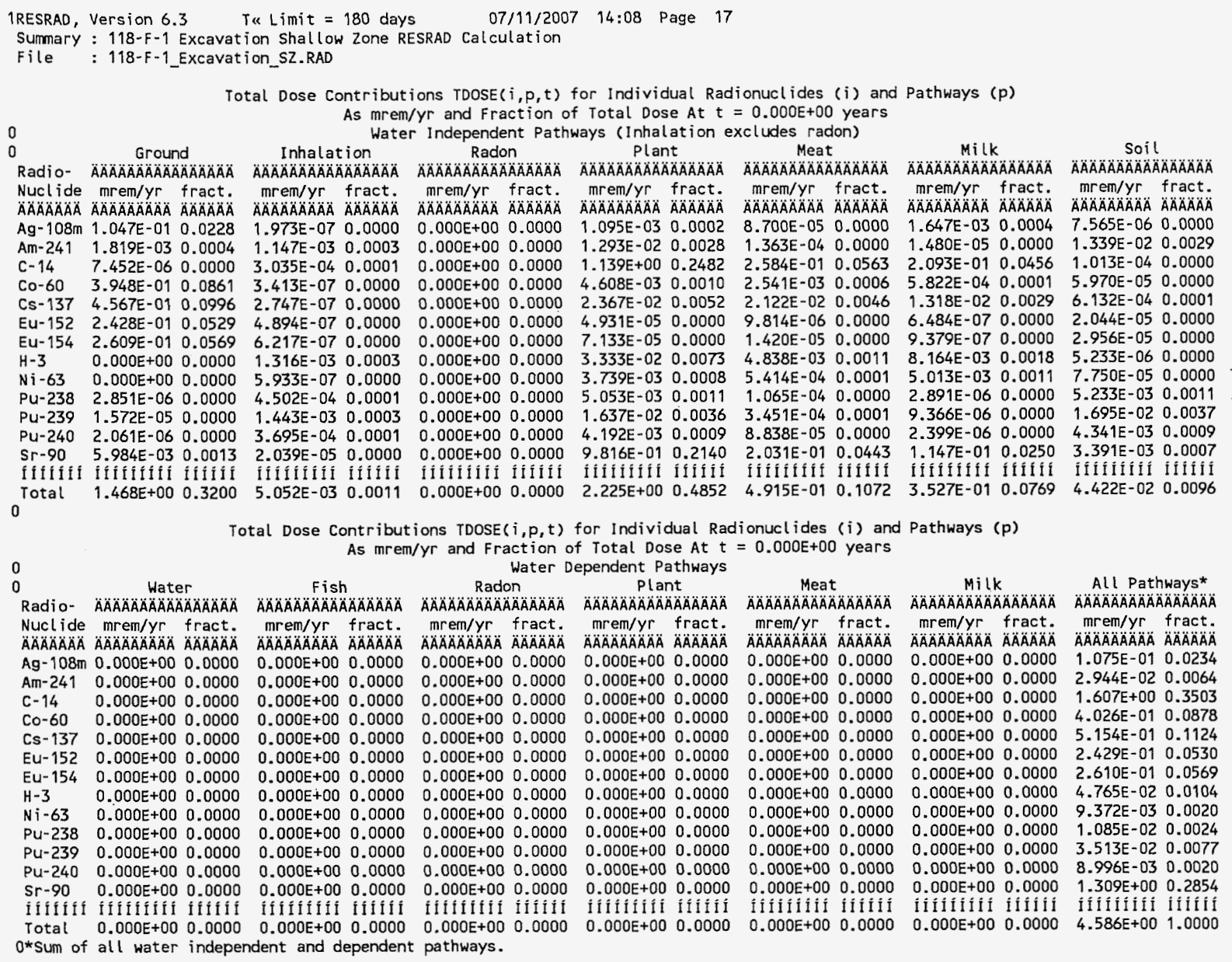

\begin{tabular}{|c|c|}
\hline Attachment & Sheet No. 17 of 32 \\
\hline Originator: S.W. Clark & Date \\
\hline Chk'd By M. W. Perrott & Date \\
\hline $0100 F-C A-V 0280$ & Rev. No. \\
\hline
\end{tabular}




\section{ATTACHMENT 2}

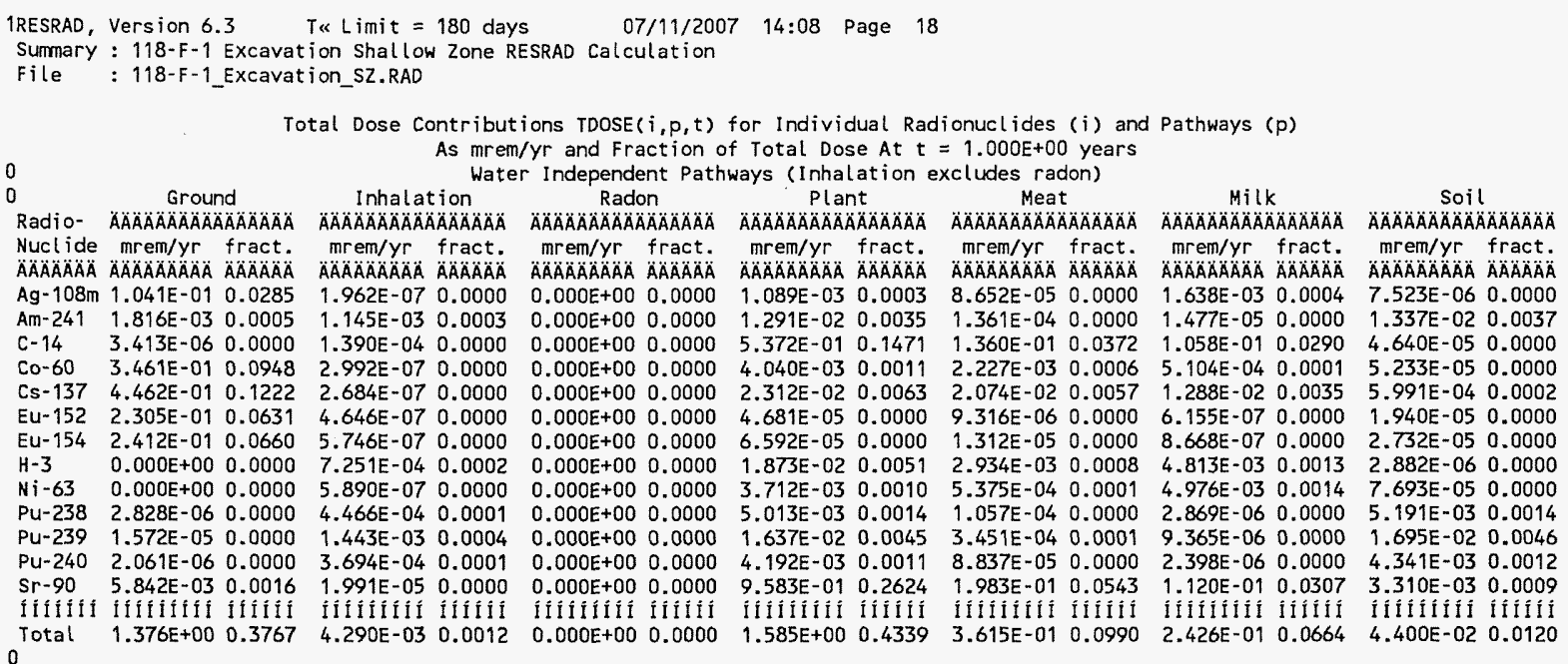

Total Dose Contributions $\operatorname{TDOSE}(i, p, t)$ for Individual Radionuclides (i) and Pathways ( $p$ )

As mrem/yr and Fraction of Total Dose At $t=1.000 E+00$ years

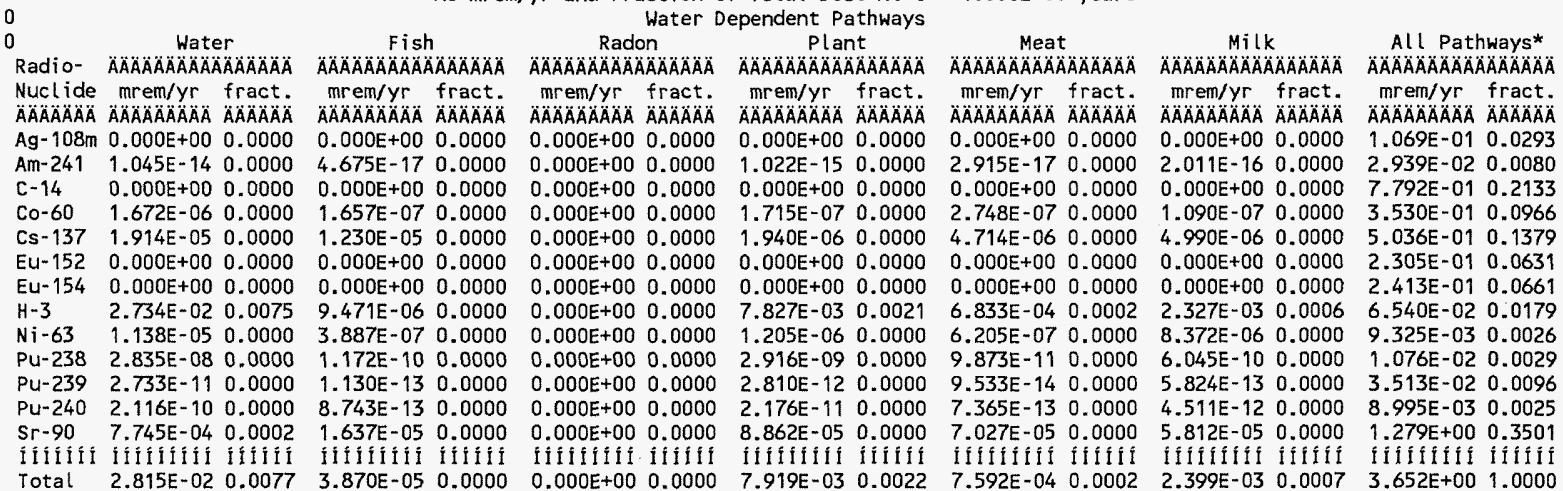

lilil illill $0 *$ Sum of all water independent and dependent pathways.

\begin{tabular}{|c|c|}
\hline \multirow{2}{*}{\multicolumn{2}{|c|}{$\begin{array}{l}\text { Attachment } \frac{2}{\text { S.W. Clark }} \text { Sheet No. } 18 \text { of } \underline{32} \\
\text { Originator: }\end{array}$}} \\
\hline & \\
\hline Chk'd By M. W. Perrott & \\
\hline $0100 F-C A-V 0280$ & Rev. No. \\
\hline
\end{tabular}




\section{ATTACHMENT 2}

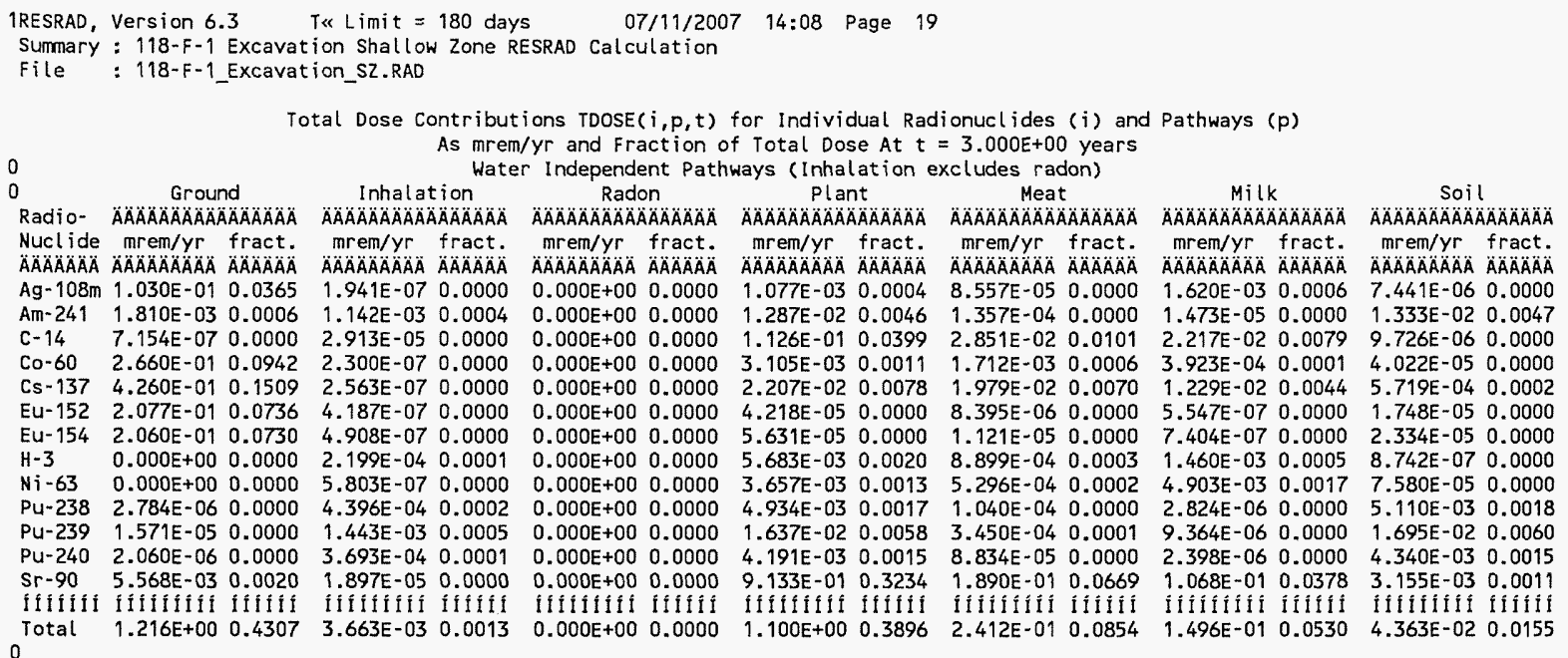

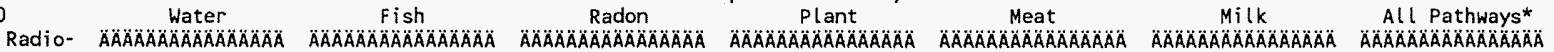

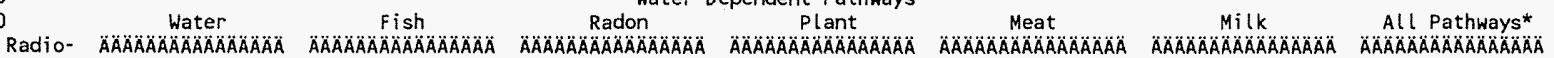

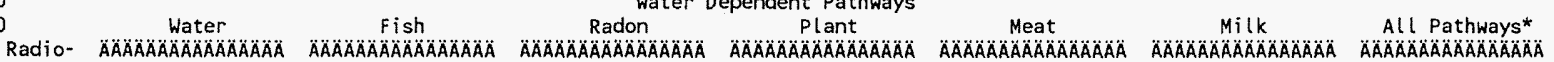

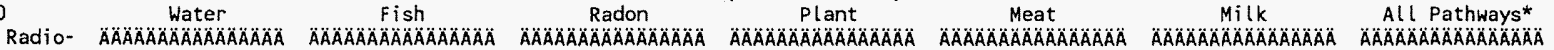

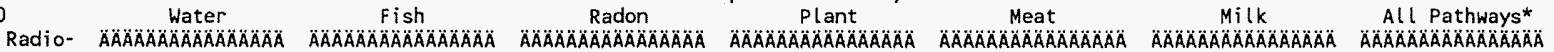

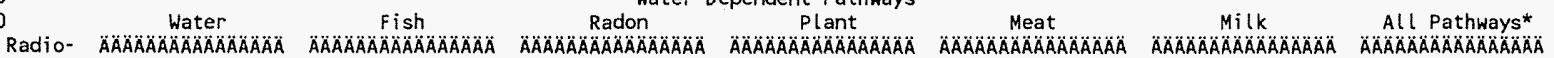
Radio- AAAAAAAAAAAAAAAA AAAAAAAAAAAAAAAA AAAAAAAAAAAAAAAÄ AAAAAAAAAAAAAAAA AAAAAAAAAAAAAAAAA AAAAAAAAAAAAAAAAA AAAAAAAAAAAAAAAAA
Nuclide mrem/yr fract. mrem/yr fract. mrem/yr fract. mrem/yr fract. mrem/yr fract. mrem/yr fract. mrem/yr fract.

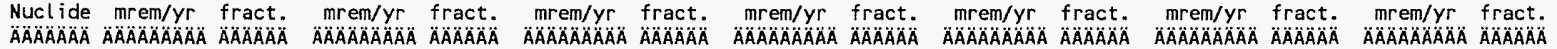

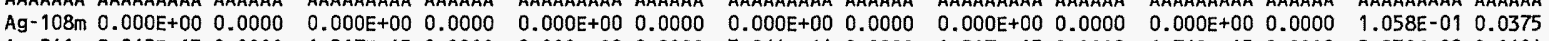

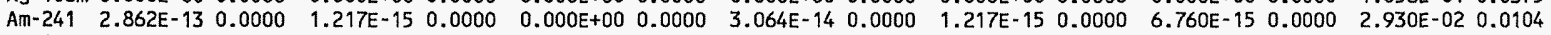
$\begin{array}{lllllllllllllll}C-14 & 0.000 E+00 & 0.0000 & 0.000 E+00 & 0.0000 & 0.000 E+00 & 0.0000 & 0.000 E+00 & 0.0000 & 0.000 E+00 & 0.0000 & 0.000 E+00 & 0.0000 & 1.633 E-01 & 0.0578\end{array}$ $\begin{array}{llllllllllllllll}\text { Co-60 } & 3.874 E-06 & 0.0000 & 3.959 E-07 & 0.0000 & 0.000 E+00 & 0.0000 & 4.248 E-07 & 0.0000 & 9.827 E-07 & 0.0000 & 3.064 E-07 & 0.0000 & 2.713 E-01 & 0.0961\end{array}$ Cs-137 5.509E-05 $0.0000 \quad 3.650 E-05 \quad 0.0000 \quad 0.000 E+00 \quad 0.0000 \quad 5.969 E-06 \quad 0.0000 \quad 2.094 E-05 \quad 0.0000 \quad 1.742 E-05 \quad 0.0000 \quad 4.809 E-01 \quad 0.1703$ 2.078E-01 0.0736 $\begin{array}{lllllllllllllll}E U-154 & 0.000 E+00 & 0.0000 & 0.000 E+00 & 0.0000 & 0.000 E+00 & 0.0000 & 0.000 E+00 & 0.0000 & 0.000 E+00 & 0.0000 & 0.000 E+00 & 0.0000 & 2.061 E-01 & 0.0730\end{array}$

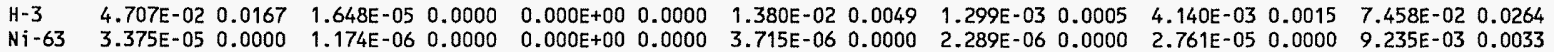

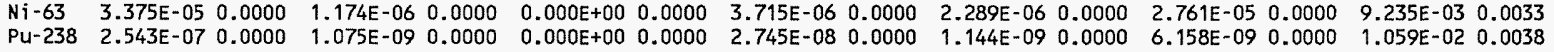

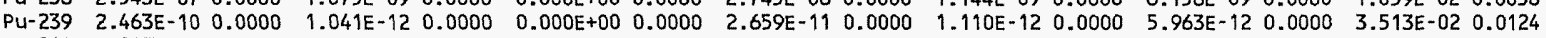

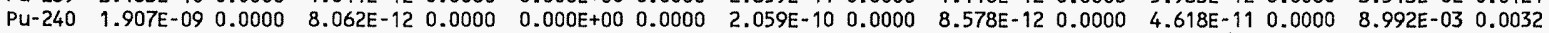

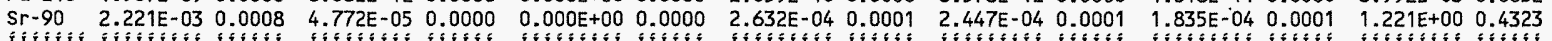

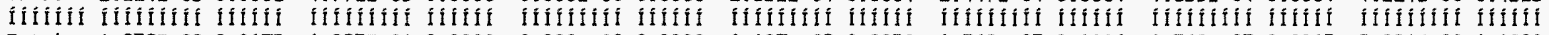

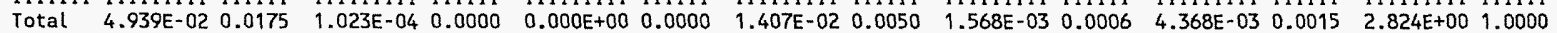
0 * Sum of all water independent and dependent pathways.

\begin{tabular}{|c|c|}
\hline Attachment & Sheet No. 19 of 32 \\
\hline Originator: S.W. Clark & Date \\
\hline Chk'd By M. W. Perrott & Date \\
\hline $0100 F-C A-V 0280$ & Rev. No. \\
\hline
\end{tabular}




\section{ATTACHMENT 2}

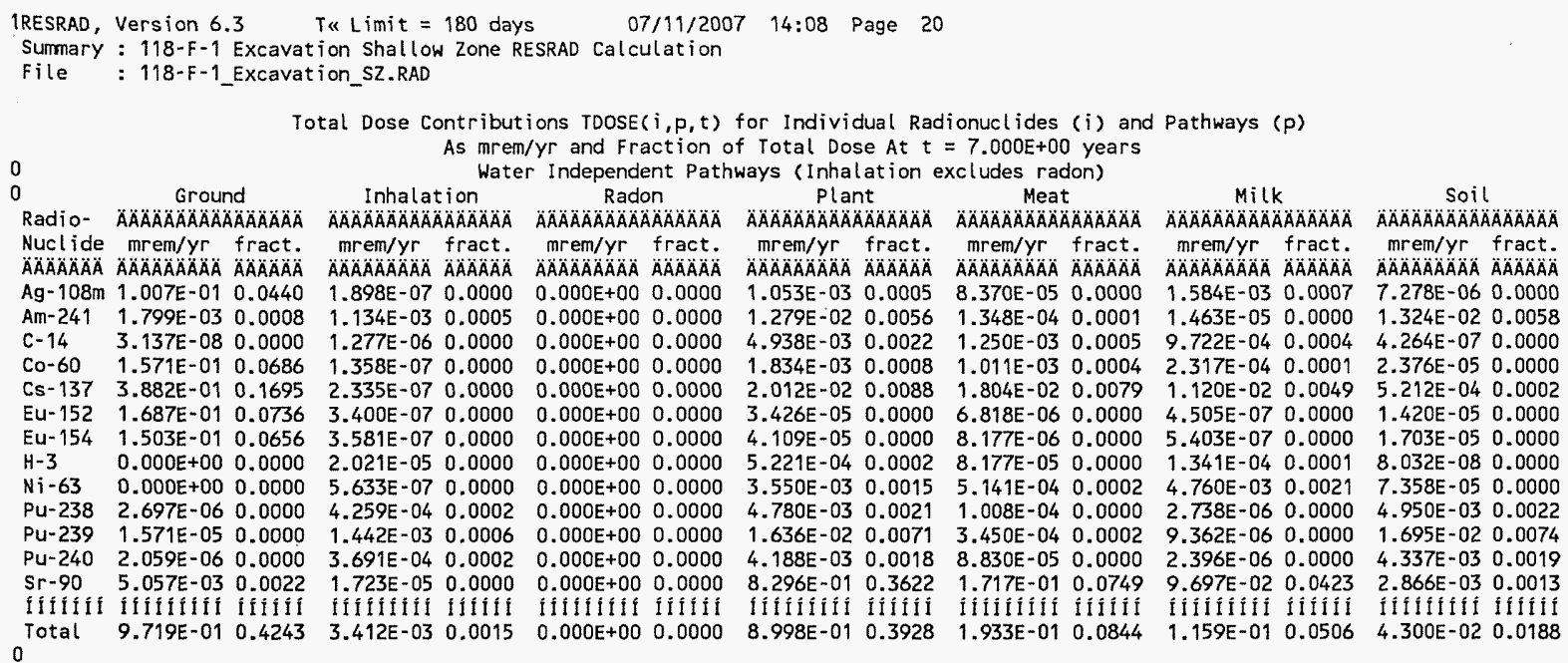

Total Dose Contributions $\operatorname{TDOSE}(i, p, t)$ for Individual Radionuclides (i) and Pathways ( $p$ ) As $\mathrm{mrem} / \mathrm{yr}$ and Fraction of Total Dose At $t=7.000 \mathrm{E}+00$ years

0

$$
\begin{array}{r}
\text { As } \mathrm{mrem} / \mathrm{yr} \text { and Fraction of Total Dose At } t \\
\text { Water Dependent Pathways }
\end{array}
$$

Water Fish Radon Pater Dependent Pathways Plant Meat All Pathways*

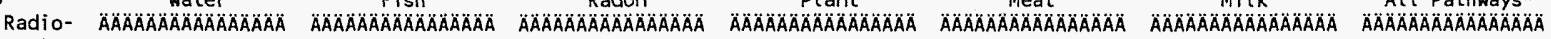
Nuclide $\mathrm{mrem} / \mathrm{yr}$ fract. mrem/yr fract. mrem/yr fract. mrem/yr fract. mrem/yr fract. mrem/yr fract. mrem/yr fract.

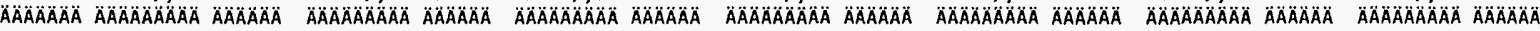

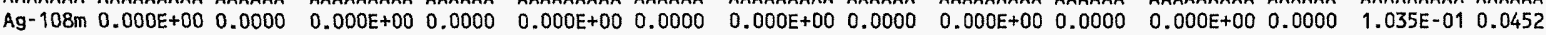

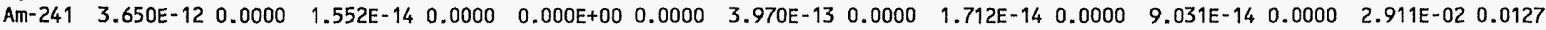
$\begin{array}{lllllllllllllllll}C-14 & 0.000 E+00 & 0.0000 & 0.000 E+00 & 0.0000 & 0.000 E+00 & 0.0000 & 0.000 E+00 & 0.0000 & 0.000 E+00 & 0.0000 & 0.000 E+00 & 0.0000 & 7.162 E-03 & 0.0031\end{array}$

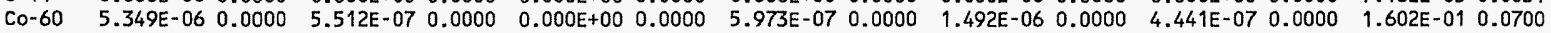

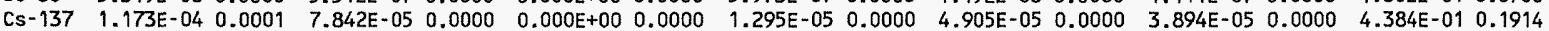

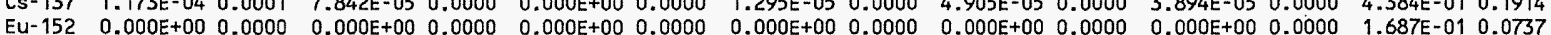

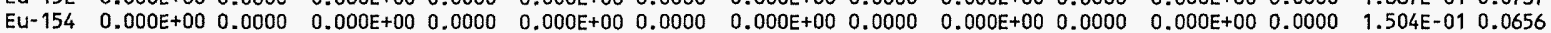

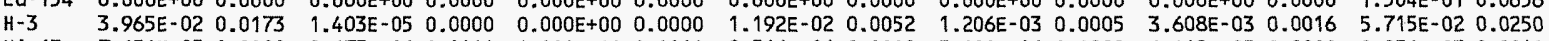

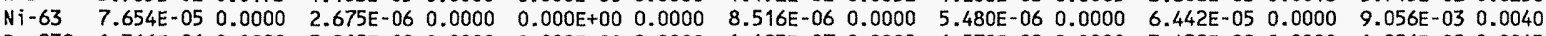

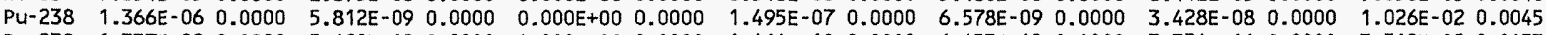

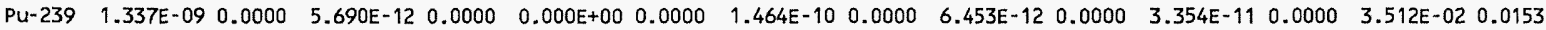

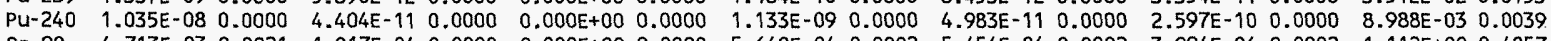

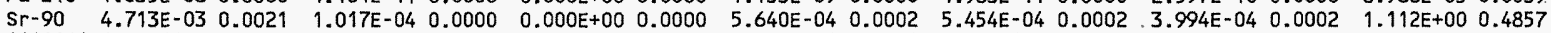

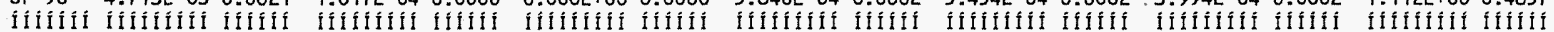

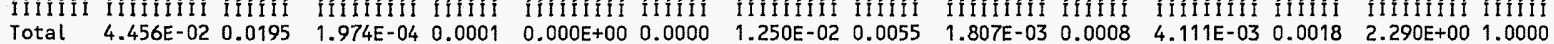
0*Sum of all water independent and dependent pathways.

$\begin{array}{ll}\text { Attachment } \frac{2}{\text { S.W. Clark }} & \text { Sheet No. } \underline{20} \text { of } \underline{32} \\ \text { Originator: } & \text { Date } \\ \text { Chk'd By } & \text { Date } \\ \text { Calc. N. No. Perrott } & \text { Rev. No. } \quad 0\end{array}$




\section{ATTACHMENT 2}

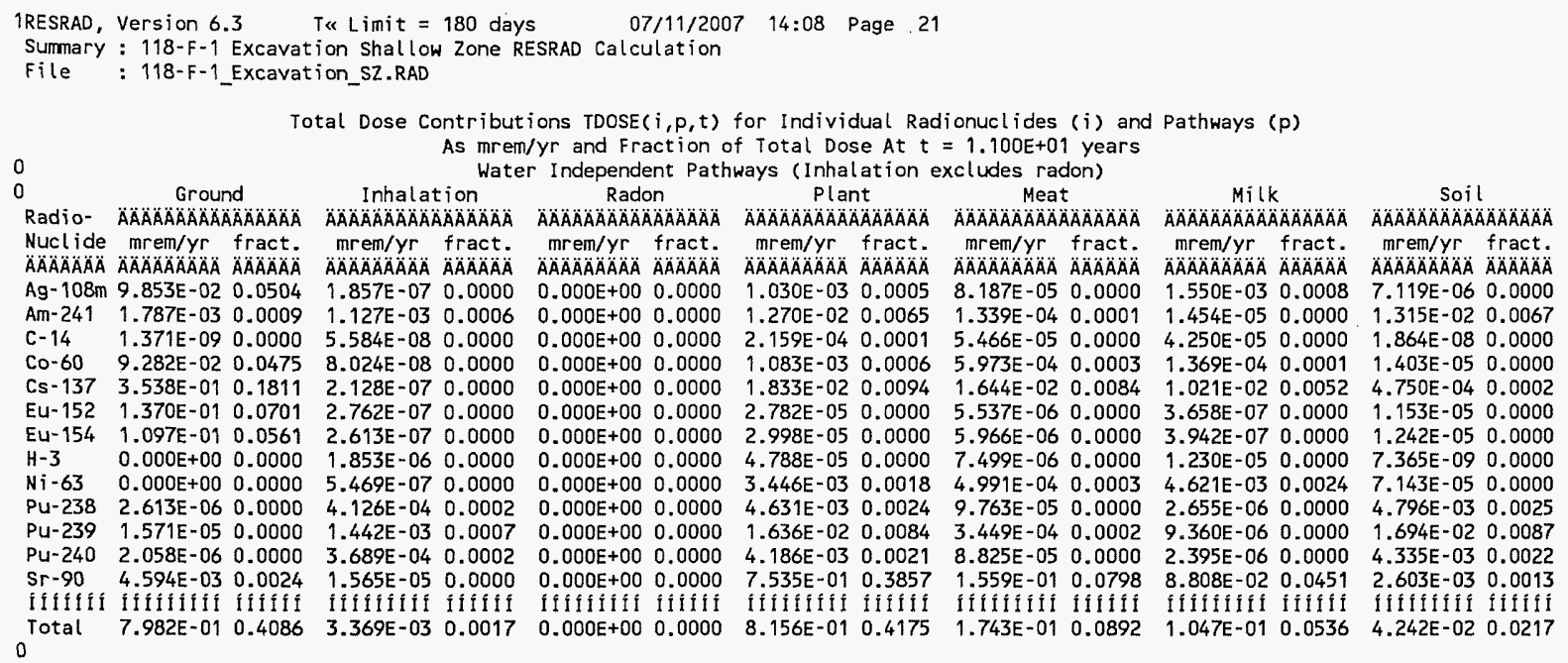

Total Dose Contributions $\operatorname{TDOSE}(i, p, t)$ for Individual Radionuclides ( $i$ ) and Pathways $(p)$ As $\mathrm{mrem} / \mathrm{yr}$ and Fraction of Total Dose At $t=1.100 \mathrm{E}+01$ years

$$
\text { Water Dependent Pathways }
$$

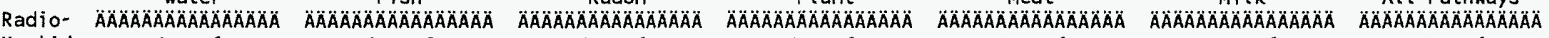
Nuclide $m r e m / y r$ fract. mrem/yr fract. mrem/yr fract. mrem/yr fract. mrem/yr fract. mrem/yr fract. mrem/yr fract.

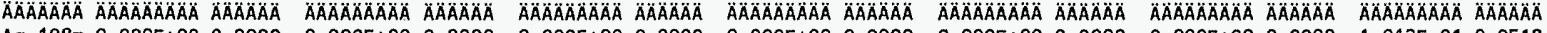
$\begin{array}{lllllllllllllllllllll}\mathrm{Ag}-108 \mathrm{~m} & 0.000 \mathrm{E}+00 & 0.0000 & 0.000 E+00 & 0.0000 & 0.000 E+00 & 0.0000 & 0.000 E+00 & 0.0000 & 0.000 E+00 & 0.0000 & 0.000 E+00 & 0.0000 & 1.012 E-01 & 0.0518\end{array}$

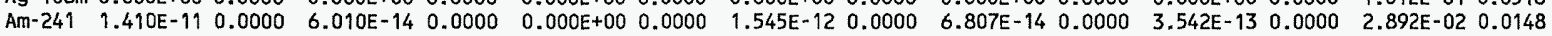
$\begin{array}{lllllllllllllll}c-14 & 0.000 E+00 & 0.0000 & 0.000 E+00 & 0.0000 & 0.000 E+00 & 0.0000 & 0.000 E+00 & 0.0000 & 0.000 E+00 & 0.0000 & 0.000 E+00 & 0.0000 & 3.131 E-04 & 0.0002\end{array}$

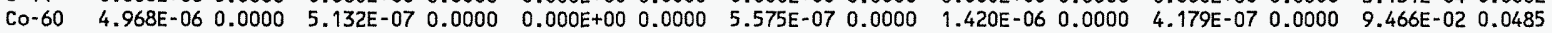

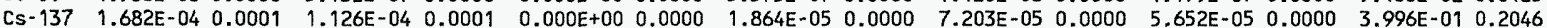
EU-152 $0.000 E+000.0000 \quad 0.000 E+000.0000 \quad 0.00 E+000.00000 .000 E+000.0000 \quad 0.000 E+000.00000 .000 E+000.00001 .370 E-010.0701$ $\begin{array}{lllllllllllllllllll}E & -154 & 0.000 E+00 & 0.0000 & 0.000 E+00 & 0.0000 & 0.000 E+00 & 0.0000 & 0.000 E+00 & 0.0000 & 0.000 E+00 & 0.0000 & 0.000 E+00 & 0.0000 & 1.097 E-01 & 0.0562\end{array}$

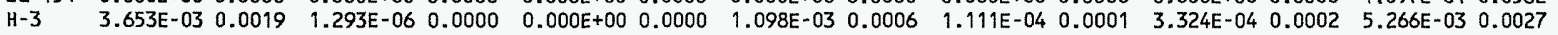

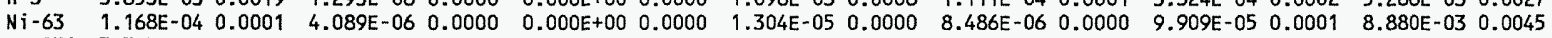
$\begin{array}{lllllllllllllll}\text { Pu-238 } & 3.327 E-06 & 0.0000 & 1.418 E-08 & 0.0000 & 0.000 E+00 & 0.0000 & 3.655 E-07 & 0.0000 & 1.631 E-08 & 0.0000 & 8.429 E-08 & 0.0000 & 9.946 E-03 & 0.0051\end{array}$

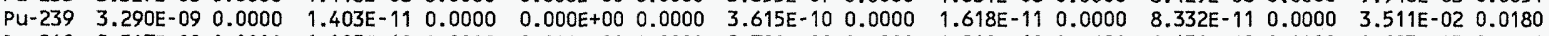

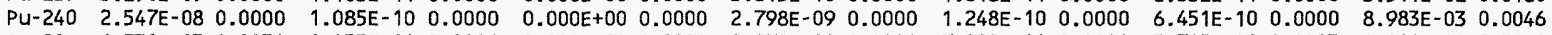
$\begin{array}{lllllllllllllll}\mathrm{Sr}-90 & 6.731 \mathrm{E}-03 & 0.0034 & 1.455 \mathrm{E}-04 & 0.0001 & 0.000 \mathrm{E}+00 & 0.0000 & 8.078 \mathrm{E}-04 & 0.0004 & 7.892 \mathrm{E}-04 & 0.0004 & 5.745 \mathrm{E}-04 & 0.0003 & 1.014 \mathrm{E}+00 & 0.5190\end{array}$

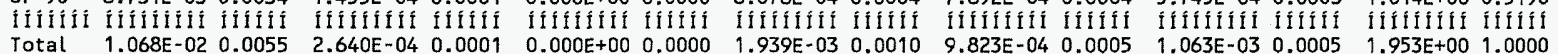
$0 *$ Sum of all water independent and dependent pathways.

\begin{tabular}{|c|c|}
\hline Attachment & Sheet No. 21 of 32 \\
\hline Originator: S.W. Clark & Date \\
\hline Chk'd By M. W. Perrott & Date \\
\hline $0100 \mathrm{~F}-\mathrm{CA}-\mathrm{V} 0280$ & Rev. No. \\
\hline
\end{tabular}




\section{ATTACHMENT 2}

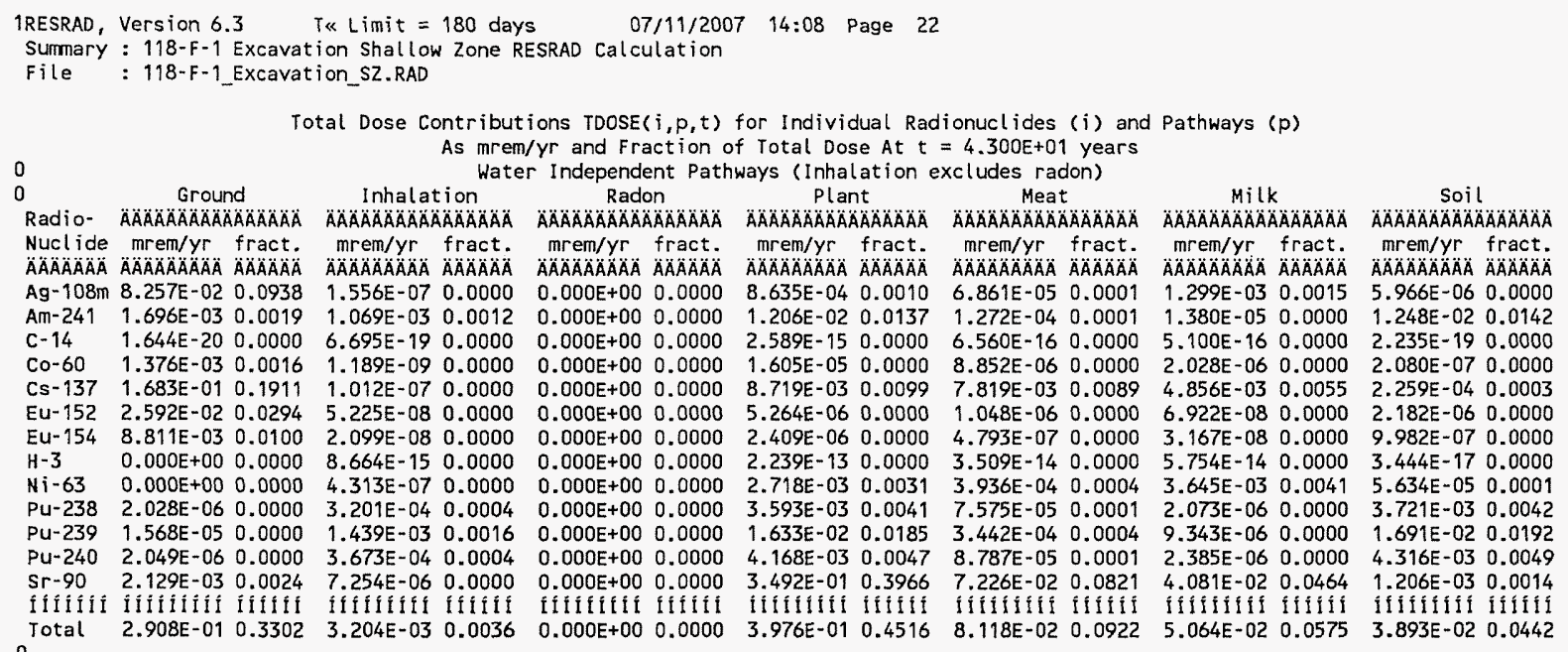
0

Total Dose Contributions TDOSE( $i, p, t)$ for Individual Radionuclides (i) and Pathways ( $p$ ) As mrem/yr and Fraction of Total Dose At $t=4.300 E+01$ years As mrem/yr and Fraction of Total Dose At Nuclide mrem/yr fract. mrem/yr fract. mrem/yr fract. mrem/yr fract. mrem/yr fract. mrem/yr fract. mrem/yr fract.

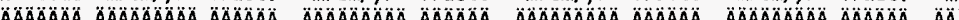

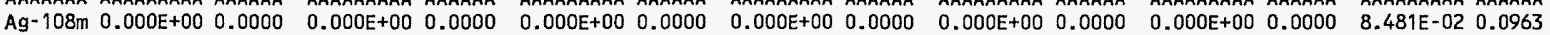

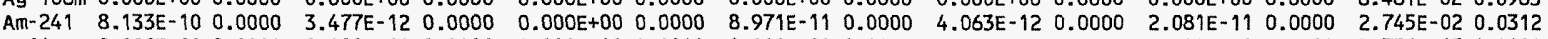
$\begin{array}{lllllllllllllll}C-14 & 0.000 E+00 & 0.0000 & 0.000 E+00 & 0.0000 & 0.000 E+00 & 0.0000 & 0.000 E+00 & 0.0000 & 0.000 E+00 & 0.0000 & 0.000 E+00 & 0.0000 & 3.756 E-15 & 0.0000\end{array}$ $\begin{array}{lllllllllllllll}\text { Co-60 } & 2.886 E-07 & 0.0000 & 2.990 E-08 & 0.0000 & 0.000 E+00 & 0.0000 & 3.259 E-08 & 0.0000 & 8.511 E-08 & 0.0000 & 2.468 E-08 & 0.0000 & 1.403 E-03 & 0.0016\end{array}$

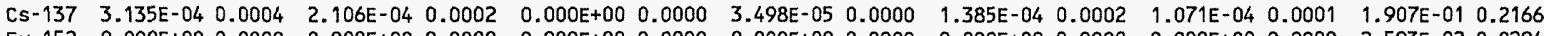
$\begin{array}{llllllllllllllll}E L-152 & 0.000 E+00 & 0.0000 & 0.000 E+00 & 0.0000 & 0.000 E+00 & 0.0000 & 0.000 E+00 & 0.0000 & 0.000 E+00 & 0.0000 & 0.000 E+00 & 0.0000 & 2.593 E-02 & 0.0294\end{array}$ EU-154 $0.000 E+000.0000 \quad 0.000 E+00 \quad 0.0000 \quad 0.000 E+00 \quad 0.0000 \quad 0.000 E+00 \quad 0.0000 \quad 0.000 E+000.0000 \quad 0.000 E+00 \quad 0.0000 \quad 8.815 E-03 \quad 0.0100$

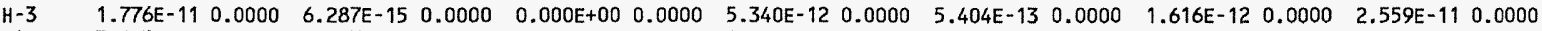
$\begin{array}{lllllllllllllll}\mathrm{Ni}-63 & 3.615 \mathrm{E}-04 & 0.0004 & 1.267 \mathrm{E}-05 & 0.0000 & 0.000 \mathrm{E}+00 & 0.0000 & 4.049 \mathrm{E}-05 & 0.0000 & 2.674 \mathrm{E}-05 & 0.0000 & 3.096 \mathrm{E}-04 & 0.0004 & 7.564 \mathrm{E}-03 & 0.0086 \\ \mathrm{PU}-238 & 4.548 \mathrm{E}-05 & 0.0001 & 1.943 \mathrm{E}-07 & 0.0000 & 0.000 \mathrm{E}+00 & 0.0000 & 5.020 \mathrm{E}-06 & 0.0000 & 2.282 \mathrm{E}-07 & 0.0000 & 1.167 \mathrm{E}-06 & 0.0000 & 7.766 \mathrm{E}-03 & 0.0088\end{array}$

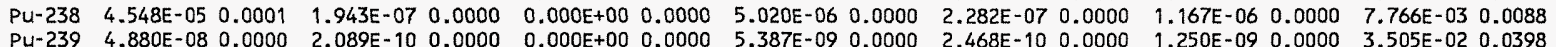

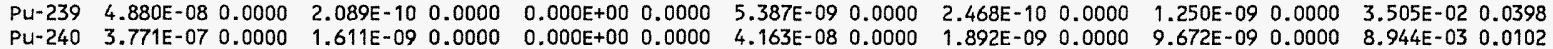

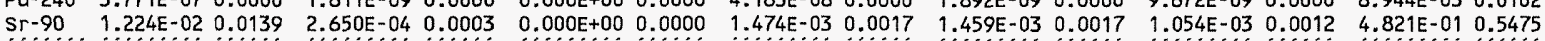

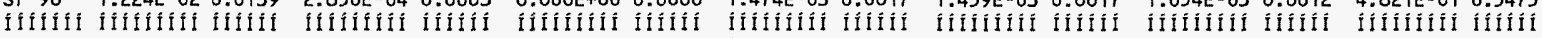
$\begin{array}{lllllllllllllllll}\text { Total } & 1.296 \mathrm{E}-02 & 0.0147 & 4.885 \mathrm{E}-04 & 0.0006 & 0.000 \mathrm{E}+00 & 0.0000 & 1.555 \mathrm{E}-03 & 0.0018 & 1.625 \mathrm{E}-03 & 0.0018 & 1.472 \mathrm{E}-03 & 0.0017 & 8.805 \mathrm{E}-01 & 1.0000\end{array}$ 0 *Sum of all water independent and dependent pathways.

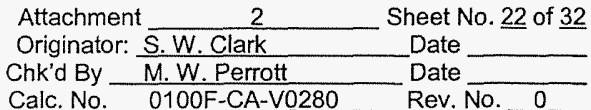




\section{ATTACHMENT 2}

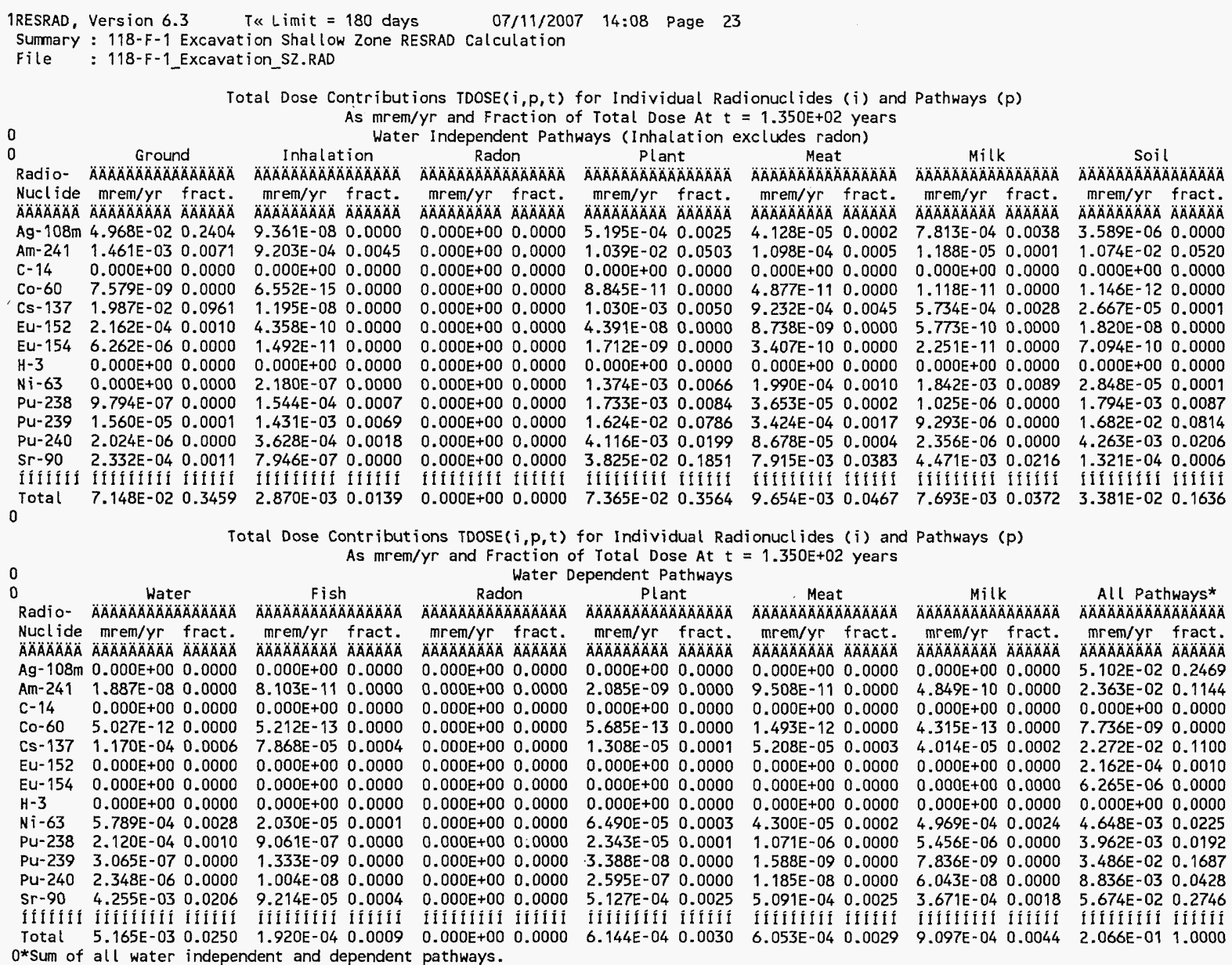
$0 *$ Sum of all water independent and dependent pathways.

\begin{tabular}{|c|c|}
\hline \multirow{2}{*}{\multicolumn{2}{|c|}{$\begin{array}{ll}\text { Attachment } & 2 \\
\text { Originator: S.W. Clark } & \text { Sheet No. } 23 \text { of } 32\end{array}$}} \\
\hline & \\
\hline Chk'd By M.W. Perrott & \\
\hline $0100 F-C A-V 0280$ & Rev. No. \\
\hline
\end{tabular}




\section{ATTACHMENT 2}

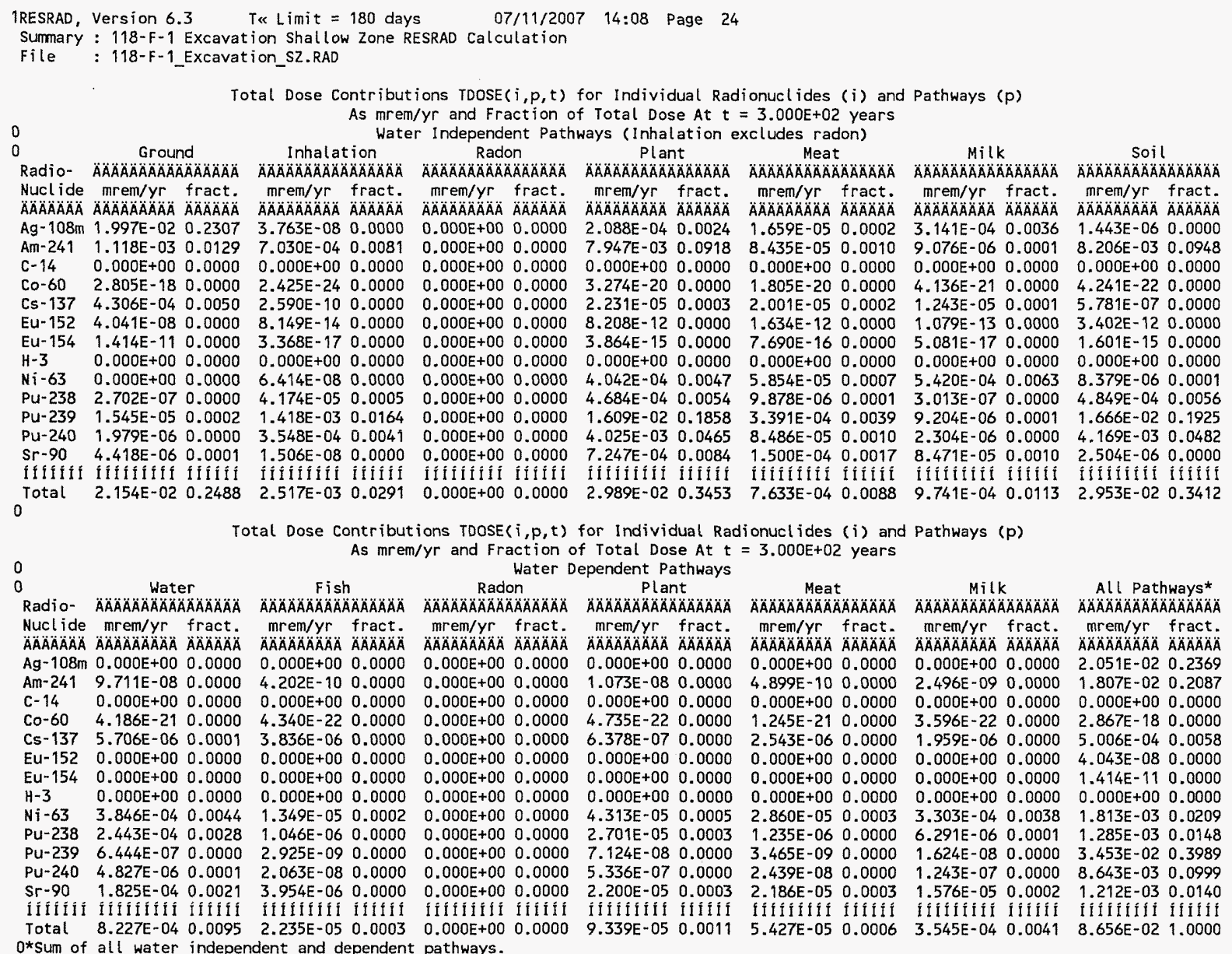

\begin{tabular}{|c|c|}
\hline Attachment $\quad 2$ & Sheet No. 24 of $\underline{32}$ \\
\hline Originator: S.W. Clark & Date \\
\hline Chk'd By M.W. Perrott & Date \\
\hline $0100 F-C A-V 0280$ & Rev. No. \\
\hline
\end{tabular}




\section{ATTACHMENT 2}

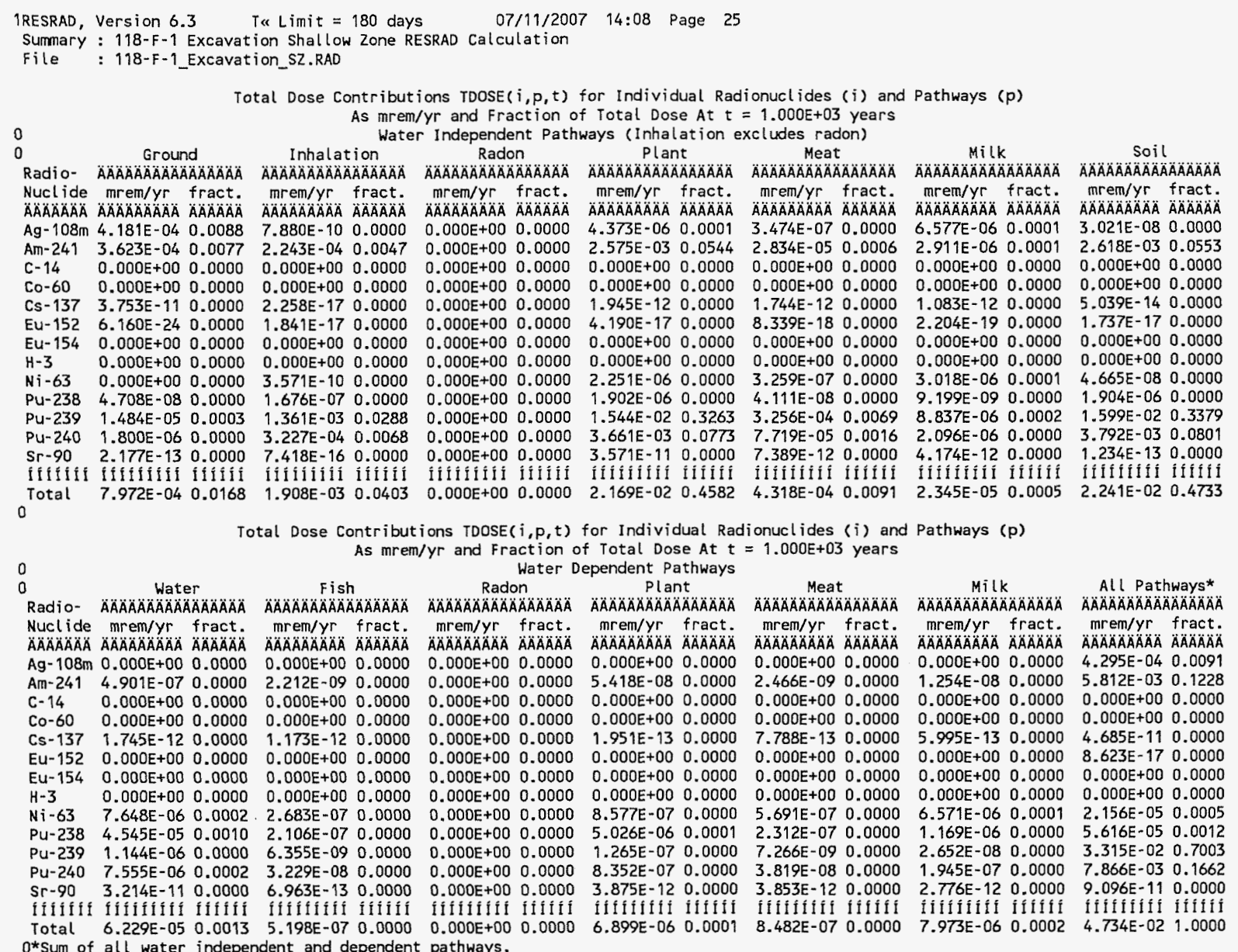

$0 *$ Sum of all water independent and dependent pathways.

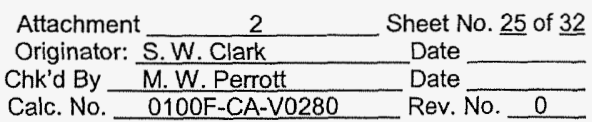




\section{ATTACHMENT 2}

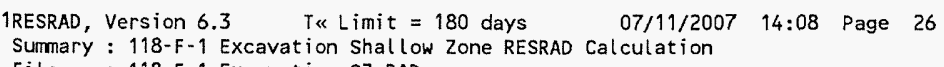

Dose/Source Ratios Surmed Over All Pathways

Parent and Progeny Principal Radionuclide Contributions Indicated

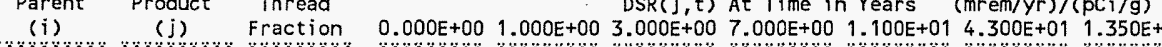

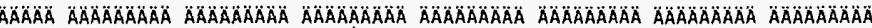
$A g-108 m+D$ Ag-108m+D $1.000 E+00 \quad 6.326 E+00 \quad 6.291 E+00 \quad 6.222 E+00 \quad 6.086 E+00 \quad 5.953 E+00 \quad 4.989 E+00 \quad 3.001 E+00 \quad 1.206 E+00 \quad 2.526 E-02$ OAm-241 Am-241 $\quad 1.000 E+00 \quad 4.673 E-014.666 \mathrm{E}-01 \quad 4.650 \mathrm{E}-01 \quad 4.620 \mathrm{E}-01 \quad 4.590 \mathrm{E}-014.356 \mathrm{E}-013.749 \mathrm{E}-012.863 \mathrm{E}-01$ 9.128E-02 Am-241

Am-241 Th-220+D

Am-249 äDSR(j)

OC -14 C- 14

0Co-60 Co-60

OCs-137+D Cs-137+

OEU-152 Eu-152

OEu-152 Eu-152

Eu-152 Gd-152

Eu-152 äDSR( $j$ )

OEU-154

$\mathrm{OH}-3$

ONi -63

OPu-238 Eu-154

$\mathrm{H}-3$

Pu-238

Pu-238

$\mathrm{U}-234$

Th-230

Pu-238

Pu- 238

$\mathrm{Pu}-238$

$\mathrm{Pu}-238$
$\mathrm{P} u-238$

OPu-239

Pu-239

Pu-239
Pu-239

Pu-239

Ra-
$P b-210+D$

aDSR(j)

Pu-239

U $-235+D$

$\mathrm{Pa}-231$
$\mathrm{AC}-227+\mathrm{D}$

äDSR ( $j)$

Pu-240 $1.000 E+00 \quad 0.000 E+002.521 E-13 \quad 5.677 E-12 \quad 6.876 E-11 \quad 2.623 E-101.487 E-083.437 E-07 \quad 1.766 E-06 \quad 8.867 E-06$

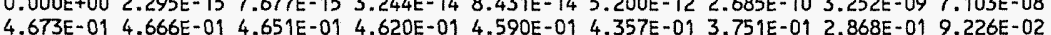
$1.000 \mathrm{E}+00 \quad 1.936 \mathrm{E}+00 \quad 9.388 \mathrm{E}-01 \quad 1.968 \mathrm{E}-01 \quad 8.629 \mathrm{E}-03 \quad 3.772 \mathrm{E}-04 \quad 4.525 \mathrm{E}-15 \quad 0.000 \mathrm{E}+00 \quad 0.000 \mathrm{E}+00 \quad 0.000 \mathrm{E}+00$

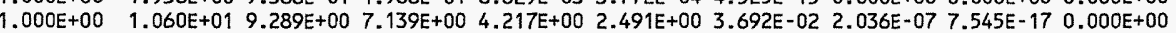

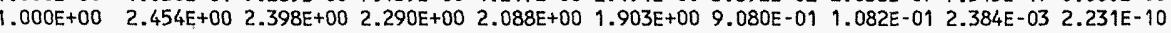

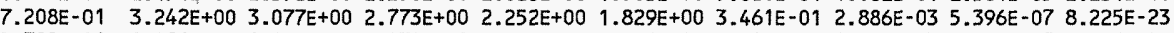
$2.792 E-01 \quad 1.256 E+00 \quad 1.192 E+00 \quad 1.074 E+00 \quad 8.724 E-01 \quad 7.085 E-01 \quad 1.340 E-01 \quad 1.118 E-03 \quad 2.090 E-07 \quad 3.186 E-23$ $2.792 E-01 \quad 0.000 E+00 \quad 8.153 E-17 \quad 2.324 E-16 \quad 4.909 E-16 \quad 7.007 E-16 \quad 1.436 E-15 \quad 1.605 E-15 \quad 1.605 E-15 \quad 1.597 E-15$ $1.256 \mathrm{E}+00 \quad 1.192 \mathrm{E}+00 \quad 1.074 \mathrm{E}+00 \quad 8.724 \mathrm{E}-01 \quad 7.085 \mathrm{E}-01 \quad 1.340 \mathrm{E}-01 \quad 1.118 \mathrm{E}-03 \quad 2.090 \mathrm{E}-07 \quad 1.597 \mathrm{E}-15$ $1.000 \mathrm{E}+00 \quad 4.925 \mathrm{E}+00 \quad 4.552 \mathrm{E}+00 \quad 3.888 \mathrm{E}+002.837 \mathrm{E}+002.070 \mathrm{E}+001.663 \mathrm{E}-011.182 \mathrm{E}-042.668 \mathrm{E}-102.963 \mathrm{E}-34$ $1.000 E+003.404 E-024.671 E-025.327 E-02$ 4.082E-02 $3.761 E-031.828 E-111.173 E-350.000 E+000.000 E+00$ 3. 1.

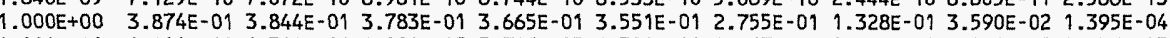

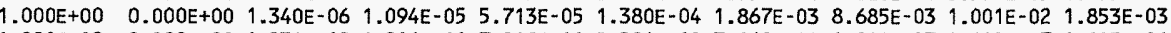
$1.000 \mathrm{E}+00 \quad 0.000 \mathrm{E}+00 \quad 1.234 \mathrm{E}-12 \quad 1.216 \mathrm{E}-11 \quad 7.949 \mathrm{E}-11 \quad 2.291 \mathrm{E}-10 \quad 7.160 \mathrm{E}-09 \quad 1.200 \mathrm{E}-07 \quad 4.602 \mathrm{E}-07 \quad 1.195 \mathrm{E}-06$ $1.000 \mathrm{E}+00 \quad 0.000 \mathrm{E}+00 \quad 2.602 \mathrm{E}-14 \quad 5.493 \mathrm{E}-13 \quad 6.706 \mathrm{E}-12 \quad 2.564 \mathrm{E}-11 \quad 1.549 \mathrm{E}-09 \quad 4.629 \mathrm{E}-08 \quad 3.859 \mathrm{E}-07 \quad 4.134 \mathrm{E}-06$

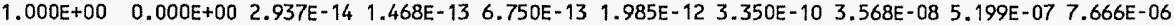
$3.874 \mathrm{E}-013.844 \mathrm{E}-013.783 \mathrm{E}-01$ 3.666E-01 3.552E-01 2.774E-01 1.415E-01 4.591E-02 2.006E-03 $1.000 E+00 \quad 4.285 E-014.285 E-014.284 E-014.283 E-014.282 E-014-274 E-014.251 E-014.211 E-014.043 E-01$

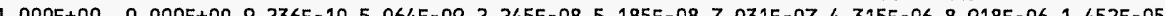

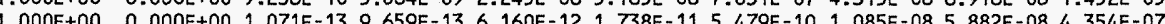

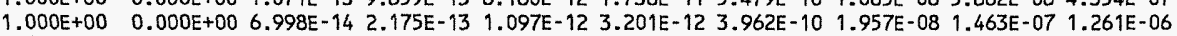
$\begin{array}{lllllllll}0.000 E+00 & 6.998 E-14 & 2.175 E-13 & 1.097 \mathrm{E}-12 & 3.201 \mathrm{E}-12 & 3.962 \mathrm{E}-10 & 1.957 \mathrm{E}-08 & 1.463 \mathrm{E}-07 & 1.261 \mathrm{E}-06 \\ 4.285 \mathrm{E}-01 & 4.285 \mathrm{E}-01 & 4.284 \mathrm{E}-01 & 4.283 \mathrm{E}-01 & 4.282 \mathrm{E}-01 & 4.274 \mathrm{E}-01 & 4.251 \mathrm{E}-01 & 4.211 \mathrm{E}-01 & 4.043 \mathrm{E}-01\end{array}$

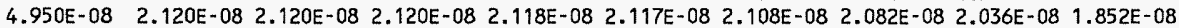

\begin{tabular}{|c|c|}
\hline Attachment & Sheet No. 26 of 32 \\
\hline Originator: S.W. Clark & Date \\
\hline Chk'd By M.W. Perrott & Date \\
\hline $0100 \mathrm{~F}-\mathrm{CA}-\mathrm{V} 0280$ & Rev. No. 0 \\
\hline
\end{tabular}




\section{ATTACHMENT 2}

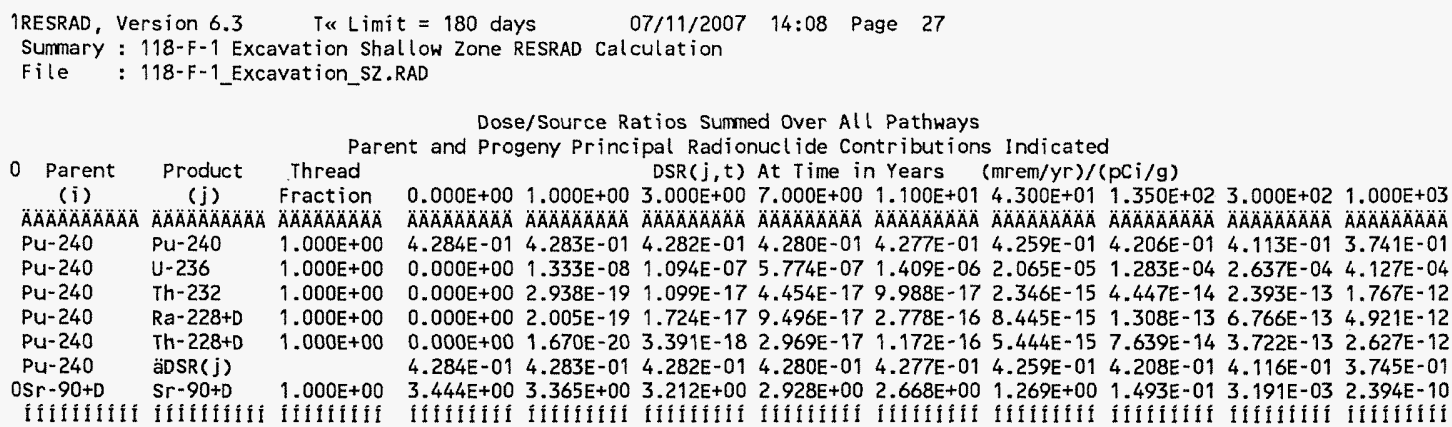

\begin{tabular}{|c|c|c|c|c|}
\hline (i) & $t=0.000 E+00$ & $1.000 E+00$ & $3.000 E+00$ & $7.000 E+00$ \\
\hline$\triangle A A A A A A O A$ & $A \cap A A A A A B A A B$ & AAAOAAAAAAÄÄ & $\triangle A O A A A A A A O A$ & $\triangle A O A O A O A O A ̈ A$ \\
\hline $\mathrm{Ag}-108 \mathrm{~m}$ & $2.371 E+00$ & $2.384 E+00$ & $2.411 \mathrm{E}+00$ & $2.465 \mathrm{E}+00$ \\
\hline$A m-241$ & $3.210 \mathrm{E}+01$ & $3.215 E+01$ & $3.225 E+01$ & $3.247 E+01$ \\
\hline$C-14$ & $7.749 E+00$ & $1.598 E+01$ & $7.622 E+01$ & $1.738 E+03$ \\
\hline Co-60 & $1.416 E+00$ & $1.615 E+00$ & $2.101 E+00$ & $3.557 E+00$ \\
\hline Cs-137 & $6.112 E+00$ & $6.255 E+00$ & $6.551 E+00$ & $7.186 E+00$ \\
\hline Eu-152 & $3.335 E+00$ & $3.513 E+00$ & $3.899 E+00$ & $4.801 E+00$ \\
\hline Eu-154 & $3.046 E+00$ & $3.295 \mathrm{E}+00$ & $3.858 E+00$ & $5.287 E+00$ \\
\hline$H-3$ & $4.407 E+02$ & $3.211 \mathrm{E}+02$ & $2.816 E+02$ & $3.675 E+02$ \\
\hline $\mathrm{Ni}-63$ & $3.681 E+03$ & $3.700 E+03$ & $3.736 E+03$ & $3.810 E+03$ \\
\hline $\mathrm{Pu}-238$ & $3.872 E+01$ & $3.903 E+01$ & $3.965 E+01$ & $4.092 \mathrm{E}+01$ \\
\hline Pu-239 & $3.501 E+01$ & $3.501 E+01$ & $3.501 E+01$ & $3.502 \mathrm{E}+01$ \\
\hline Pu-240 & $3.502 E+01$ & $3.502 E+01$ & $3.503 E+01$ & $3.505 \mathrm{E}+01$ \\
\hline & $4.355 E+00$ & $4.457 E+00$ & $4.669 \mathrm{E}+00$ & $5.124 E+00$ \\
\hline & & & IIII & \\
\hline
\end{tabular}

$1.100 E+01$
$A A B A O A O A O A O A$
$2.520 E+00$
$3.268 E+01$
$3.976 E+04$
$6.022 E+00$
$7.882 E+00$
$5.911 E+00$
$7.246 E+00$
$3.988 E+03$
$3.885 E+03$
$4.223 E+01$
$3.503 E+01$
$3.507 E+01$
$5.622 E+00$
II I I I I I I I I

$4.300 \mathrm{E}+01$

AAAAAAAAA

$3.007 \mathrm{E}+00$

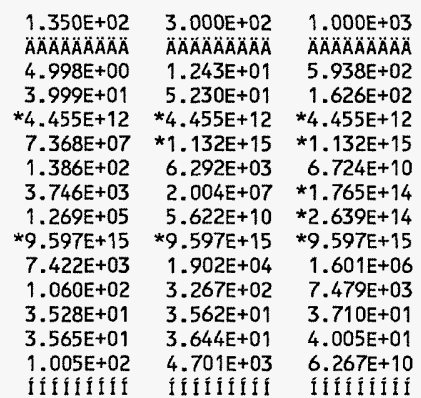

$3.443 \mathrm{E}+0$

$4.455 E+1$

$4.062 E+0$

$1.652 E+0$

$3.124 E+01$

$9.019 E+01$

$8.206 \mathrm{E}+11$

4.561E+03

$5.408 \mathrm{E}+01$

$3.510 E+01$

$3.522 \mathrm{E}+0$

$1.182 \mathrm{E}+0$

filfifí

iffifífít

Ítílifíl

IIfIIIII

\begin{tabular}{|c|c|c|}
\hline \multirow{2}{*}{\multicolumn{3}{|c|}{$\begin{array}{ll}\text { Attachment } & \frac{2}{\text { Sheet No. } 27} \text { of } \underline{32} \\
\text { Originator: S.W. Clark } & \text { Date }\end{array}$}} \\
\hline & & \\
\hline Chk'd By & M.W. Perrott & _Date \\
\hline Calc. No. & $0100 F-C A-V 0280$ & Rev. No. \\
\hline
\end{tabular}


ATTACHMENT 2

\begin{tabular}{|c|c|c|c|c|c|c|}
\hline \multirow[t]{2}{*}{$\begin{array}{l}\text { 1RESRAD, } \\
\text { Summary } \\
\text { File }\end{array}$} & $\begin{array}{l}\text { Version } 6 \\
: 118-F-1 \\
: 118-F-1\end{array}$ & $\begin{array}{l}3 \quad \text { T\& Limit }= \\
\text { Excavation Shallow } \\
\text { Excavation_SZ.RAD }\end{array}$ & $\begin{array}{l}180 \text { days } \\
\text { W Zone RESRAL }\end{array}$ & $\begin{array}{r}07 / 11 / \\
\text { Calculati }\end{array}$ & $\begin{array}{l}\text { l2007 } 14: 08 \\
\text { ion }\end{array}$ & \multirow[t]{2}{*}{ Page 28} \\
\hline & \multicolumn{5}{|c|}{$\begin{array}{l}\text { Summed Dose/Source Ratios DSR }(i, t) \text { in }(m r e m / y r) /(p C i / g) \\
\text { and Single Radionuclide Soil Guidel ines } G(i, t) \text { in } p C i / g\end{array}$} & \\
\hline $\begin{array}{l}\text { ONucl ide } \\
\text { (i) }\end{array}$ & $\begin{array}{l}\text { Initial } \\
(\mathrm{pci} i \mathrm{~g})\end{array}$ & $\begin{array}{l}\operatorname{tmin} \\
\text { (years) }\end{array}$ & $\operatorname{DSR}(i, \mathrm{tmin})$ & $\begin{array}{l}G(i, t \min ) \\
(p C i / g)\end{array}$ & DSR $(i, t \max )$ & $\begin{array}{l}G(i, \operatorname{tmax}) \\
(p C i / g)\end{array}$ \\
\hline ÄAAAAAÄÄ & $\triangle A A A A A O A O A O A O A$ & 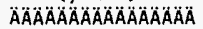 & $\triangle A A A A A A O A O A$ & AAAAAAAAAA & ÄÄÄÄÄÄÄ & AAOAAAAAAAOÄA \\
\hline $\mathrm{Ag}-108 \mathrm{~m}$ & $1.700 \mathrm{E}-02$ & $0.000 E+00$ & $6.326 E+00$ & $2.371 \mathrm{E}+00$ & $6.326 E+00$ & $2.371 E+00$ \\
\hline Am-241 & $6.300 E-02$ & $0.000 E+00$ & 4.673E-01 & $3.210 E+01$ & 4.673E-01 & $3.210 E+01$ \\
\hline$c-14$ & $8.300 E-01$ & $0.000 E+00$ & $1.936 E+00$ & $7.749 E+00$ & $1.936 E+00$ & $7.749 E+00$ \\
\hline & $3.800 E-02$ & 0.0 & & $1.416 \mathrm{E}$ & 1.06 & $416 E+00$ \\
\hline Cs- & $2.100 E-01$ & $0.000 E+00$ & $2.454 E+00$ & $6.112 E+00$ & $2.454 E+00$ & $6.112 E+00$ \\
\hline $\mathrm{Eu}$ & $5.400 E-02$ & $0.000 E+00$ & $4.497 E+00$ & $3.335 E+00$ & $4.497 \mathrm{E}+00$ & $3.335 E+00$ \\
\hline Eu & $5.300 E-02$ & $0.000 \mathrm{E}+00$ & & $3.046 \mathrm{E}+00$ & $4.925 E+00$ & $3.046 E+00$ \\
\hline $\mathrm{H}-3$ & $1.400 \mathrm{E}+00$ & $3.115 \tilde{n} 0.006$ & $5.328 \mathrm{E}-02$ & $2.815 \mathrm{E}+02$ & $3.404 E-02$ & $4.407 E+02$ \\
\hline $\mathrm{Ni}-63$ & $2.300 E+00$ & $0.000 E+00$ & $4.075 E-03$ & $3.681 E+03$ & $4.075 E-03$ & $3.681 E+03$ \\
\hline & $2.800 E-02$ & $0.000 E+00$ & & $3.872 E+01$ & $3.874 E-01$ & $3.872 E+01$ \\
\hline Pu-239 & $8.200 \mathrm{E}-02$ & $0.000 E+00$ & $4.285 E-01$ & $3.501 \mathrm{E}+01$ & $4.285 \mathrm{E}-01$ & $3.501 E+01$ \\
\hline Pu-240 & $2.100 E-02$ & $0.000 E+00$ & $4.284 E-01$ & $3.502 E+01$ & $4.284 E-01$ & $3.502 E+01$ \\
\hline & $3.800 E-01$ & $0.000 E+00$ & $3.444 E+00$ & $4.355 E+00$ & $3.444 E+00$ & $4.355 E+00$ \\
\hline & & fiffifitififit & & Iffiffili & fIIfIIII & Iffiffifi \\
\hline
\end{tabular}


CVP-2007-00001

Rev. 0

\section{ATTACHMENT 2}

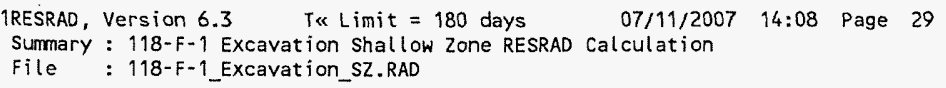

ONuclide Parent THF(i) (j) AAAAÄÄÄ ÄÄÄÄÄÄ ÄÄÄÄAAÄÄ $\mathrm{Ag}-108 \mathrm{~m}$ Ag- $108 \mathrm{~m} 1.000 \mathrm{E}+00$ AAm-241 Am-241, $1.000 E+00$ ONP -237 Am-241, $1.000 \mathrm{E}+00$ $\begin{array}{lll}\mathrm{OU}-233 & \mathrm{Am}-241 & 1.000 \mathrm{E}+00\end{array}$ OTh-220 Am-241, 1.000E+00 OC- $14 \quad \mathrm{C}-14 \quad 1.000 \mathrm{E}+00$ OCO-60 CO-60 1 .OOOE +00 OCs-137 Cs-137 $1.000 \mathrm{E}+00$ OEU-152 EU-152 7.208E-01 7.208E-01 Eu-152 Eu-152 2.792E-01 Eu-152 äDOSE ( $j)$

OGd-152 Eu-152 2.792E-01 OEU-154 EU-154 1.000E+00 $\mathrm{OH}-3 \quad \mathrm{H}-3$ 1.00OE+00 ONi-63 Ni-63 1.000E+00 OPu-238 Pu-238 1.840E-09 Pu-238 PU-238 $1.000 E+00$ Pu-238 äDOSE $(j)$

OU-234 PU-238 1.000E+00 OTh-230 PU-238 $1.000 E+00$ $\begin{array}{lll}O T h-230 & \text { PU }-238 & 1.000 E+00 \\ O R a-226 & \mathrm{PU}-238 & 1.000 \mathrm{E}+00\end{array}$ $\begin{array}{lll}\mathrm{ORa}-226 & \mathrm{PU}-238 & 1.000 \mathrm{E}+00 \\ \mathrm{OPb}-210 & \mathrm{Pu}-238 & 1.000 \mathrm{E}+00\end{array}$ $\mathrm{OPb}-210$ Pu-238 $1.000 \mathrm{E}+00$ OPu-239 Pu-239 1.000E +00 OU-235 Pu-239 $1.000 E+00$ $\mathrm{OPa}-231$ Pu-239 $1.000 \mathrm{E}+00$ OAC-227 PU-239 $1.000 E+00$ OPu-240 Pu-240 4.950E-08

$$
\operatorname{DOSE}(j, t), \mathrm{mrem} / \mathrm{yr}
$$

$t=0.000 E+001,000 E+003,000 E+007.000 E+001.100 E+014300 E+011,350 E+023.000 E+021.000 E+03$

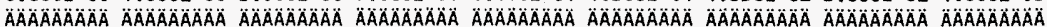

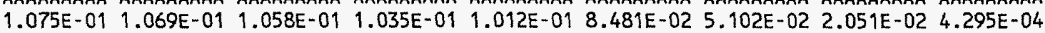
$2.944 \mathrm{E}-02 \quad 2.939 \mathrm{E}-02 \quad 2.930 \mathrm{E}-02 \quad 2.911 \mathrm{E}-02 \quad 2.892 \mathrm{E}-02 \quad 2.745 \mathrm{E}-02 \quad 2.362 \mathrm{E}-02 \quad 1.804 \mathrm{E}-02 \quad 5.750 \mathrm{E}-03$ $0.000 \mathrm{E}+00 \quad 1.217 \mathrm{E}-07$ 3.729E-07 8.726E-07 1.369E-06 5.224E-06 $1.523 \mathrm{E}-05$ 2.976E-05 $6.117 \mathrm{E}-05$ $0.000 E+00 \quad 1.588 E-14 \quad 3.577 E-13 \quad 4.332 E-12 \quad 1.652 E-11 \quad 9.369 E-10 \quad 2.165 E-08 \quad 1.113 E-07 \quad 5.586 E-07$ $0.000 \mathrm{E}+00 \quad 1.446 \mathrm{E}-16 \quad 4.836 \mathrm{E}-16 \quad 2.043 \mathrm{E}-15 \quad 5.312 \mathrm{E}-15 \quad 3.276 \mathrm{E}-13 \quad 1.692 \mathrm{E}-11 \quad 2.049 \mathrm{E}-10 \quad 4.475 \mathrm{E}-09$

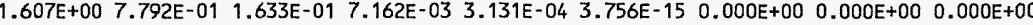
4.026E-01 3.530E-01 2.713E-01 1.602E-01 9.466E-02 1.403E-03 7.736E-09 2.867E-18 $0.000 E+00$ $5.154 \mathrm{E}-01$ 5.036E-01 4.809E-01 4.384E-01 3.996E-01 1.907E-01 2.272E-02 5.006E-04 4.685E-11 $1.750 E-011.662 E-011.498 E-011.216 E-019.877 E-021.869 E-021.559 E-04$ 2.914E-08 $4.441 E-24$ 6.750E-01 $1.662 E-01$ 1.498E-01 1.216E-01 9.877E-02 1.86EE-02 1.559E-04 2.914E-08 4.441E-2 6.780E-02 6.437E-02 5.801E-02 4.7T1E-02 3.826E-02 7.238E-03 6.037E-05 1.129E-0B 1.720E-24 $\begin{array}{lllllllll}2.429 \mathrm{E}-01 & 2.305 \mathrm{E}-01 & 2.078 \mathrm{E}-01 & 1.687 \mathrm{E}-01 & 1.370 \mathrm{E}-01 & 2.593 \mathrm{E}-02 & 2.162 \mathrm{E}-04 & 4.043 \mathrm{E}-08 & 6.162 \mathrm{E}-24\end{array}$

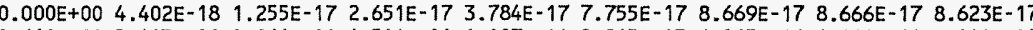

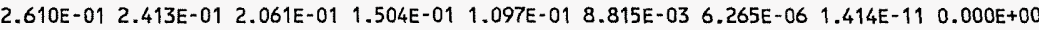

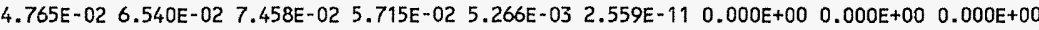

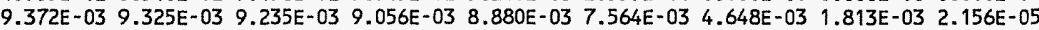

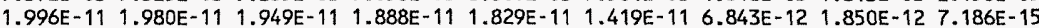

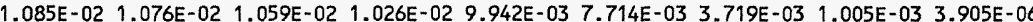
$1.085 \mathrm{E}-02 \quad 1.076 \mathrm{E}-02 \quad 1.059 \mathrm{E}-02 \quad 1.026 \mathrm{E}-02 \quad 9.942 \mathrm{E}-03 \quad 7.714 \mathrm{E}-03 \quad 3.719 \mathrm{E}-03 \quad 1.005 \mathrm{E}-03 \quad 3.905 \mathrm{E}-06$ . $0.000 E+003.454 E-143.404 E-13$ 2.226E-12 6.415E-12 2.005E-10 3.360E-09 1.289E-08 3.346E-08 $0.000 \mathrm{E}+00 \quad 7.285 \mathrm{E}-16 \quad 1.538 \mathrm{E}-14 \quad 1.878 \mathrm{E}-13$ 7.179E-13 $4.336 \mathrm{E}-11$ 1.296E-09 $1.081 \mathrm{E}-08$ 1.157E-07 $0.000 \mathrm{E}+00 \quad 8.224 \mathrm{E}-16 \quad 4.110 \mathrm{E}-15 \quad 1.890 \mathrm{E}-14 \quad 5.559 \mathrm{E}-14 \quad 9.379 \mathrm{E}-12 \quad 9.991 \mathrm{E}-10 \quad 1.456 \mathrm{E}-08 \quad 2.146 \mathrm{E}-07$ 3.513E-02 3.513E-02 3.513E-02 3.512E-02 3.511E-02 3.505E-02 3.486E-02 3.453E-02 3.315E-02 $0.000 E+00 \quad 7.574 E-11 \quad 4.152 E-10 \quad 1.841 E-09 \quad 4.252 E-09 \quad 5.765 E-08 \quad 3.538 E-07 \quad 7.312 E-07 \quad 1.191 E-06$ $0.000 \mathrm{E}+00 \quad 8.785 \mathrm{E}-15 \quad 7.921 \mathrm{E}-14 \quad 5.051 \mathrm{E}-13 \quad 1.425 \mathrm{E}-12 \quad 4.493 \mathrm{E}-11 \quad 8.894 \mathrm{E}-10 \quad 4.823 \mathrm{E}-09 \quad 3.571 \mathrm{E}-08$

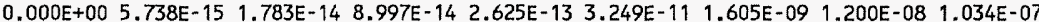
$4.453 E-10 \quad 4.452 E-10 \quad 4.451 E-10 \quad 4.449 E-10 \quad 4.446 E-10 \quad 4.427 E-10 \quad 4.372 E-10 \quad 4.276 E-10 \quad 3.889 E-10$

\begin{tabular}{|c|c|}
\hline Attachment & Sheet No. 29 of 32 \\
\hline Originator: S.W. Clark & Date \\
\hline Chk'd By M.W. Perrott & Date \\
\hline Calc. No. $0100 \mathrm{~F}-\mathrm{CA}-\mathrm{V} 0280$ & Rev. No. \\
\hline
\end{tabular}




\section{ATTACHMENT 2}

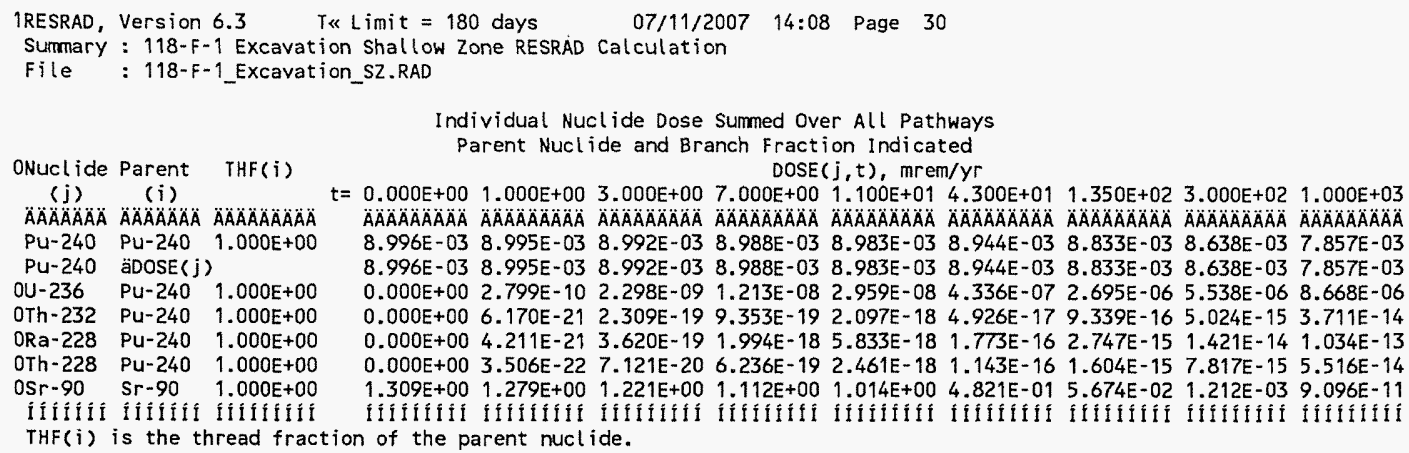

$t=0.000 E+00 \quad 1.000 E+003.000 E+007.000 E+001,0001.000 E+03$

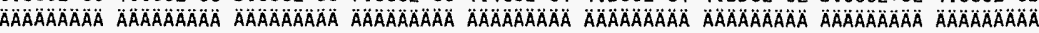
$8.996 \mathrm{E}-03$
$8.995 \mathrm{E}-03$ 8.996E-03 8.995E-03 8.992E-03 8.988E-03 8.983E-03 8.944E-03 8.833E-03 8.638E-03 $7.857 E-03$ $0.000 \mathrm{E}+00 \quad 2.799 \mathrm{E}-10 \quad 2.298 \mathrm{E}-09 \quad 1.213 \mathrm{E}-08 \quad 2.959 \mathrm{E}-08 \quad 4.336 \mathrm{E}-07 \quad 2.695 \mathrm{E}-06 \quad 5.538 \mathrm{E}-06 \quad 8.668 \mathrm{E}-06$ $0.000 E+00 \quad 6.170 E-21 \quad 2.309 E-19$ 9.353E-19 2.097E-18 $4.926 \mathrm{E}-17 \quad 9.339 \mathrm{E}-16 \quad 5.024 \mathrm{E}-15 \quad 3.711 \mathrm{E}-14$ $0.000 \mathrm{E}+00 \quad 4.211 \mathrm{E}-21 \quad 3.620 \mathrm{E}-19 \quad 1.994 \mathrm{E}-18 \quad 5.833 \mathrm{E}-18 \quad 1.773 \mathrm{E}-16 \quad 2.747 \mathrm{E}-15 \quad 1.421 \mathrm{E}-141.034 \mathrm{E}-13$ $0.000 E+00 \quad 3.506 E-22 \quad 7.121 E-20 \quad 6.236 E-19 \quad 2.461 E-18 \quad 1.143 E-16 \quad 1.604 E-15 \quad 7.817 E-15 \quad 5.516 E-14$

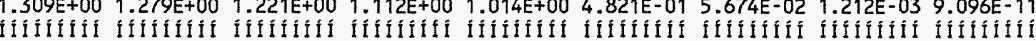

\begin{tabular}{|c|c|}
\hline Attachment & Sheet No. 30 of 32 \\
\hline Originator: S.W. Clark & Date \\
\hline Chk'd By M.W.Perrott & Date \\
\hline $0100 F-C A-V 0280$ & Rev. No. \\
\hline
\end{tabular}




\section{ATTACHMENT 2}

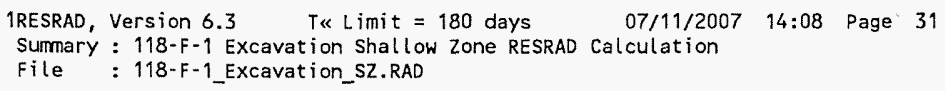

ONuclide Parent THF(i) (j) (i)

ÄÄÄÄÄÄA A ÄÄÄÄÄÄ ÄÄÄÄÄÄÄÄ Ag-108m Ag-108m 1.000E+00 AAm-241 Am-241 1.000E+00 ONp-237 Am-241 1.000E+00 OU-233 Am-241 1.000E+00 0Th-229 Am-241 $1.000 \mathrm{E}+00$ OC $-14 \quad C-14 \quad 1.000 E+00$ OCO-60 Co-60 $1.000 \mathrm{E}+00$ CO-60 CO-60 $1.000 E+00$ Cs -137 Cs $-137 \quad 1.000 \mathrm{E}+00$ Eu-152 Eu-152 7.208E-01 Eu-152 Eu-152 2.792E-01 $\mathrm{Eu}-152$ äs( $j)$ : OGd-152 EU-152 2.792E-01 OEU-154 EU-154 1.000E+00 $\mathrm{OH}-3 \mathrm{H}-3 \quad 1.000 \mathrm{E}+0 \mathrm{O}$ ONi-63 Ni-63 $1.000 \mathrm{E}+\mathrm{OO}$ OPU-238 PU-238 $1.840 E-09$ PU 238 1.840E-09 Pu-238 Pu-238 $1.000 E+00$ Pu-238 äs( $\mathrm{j})$ :

OU-234 PU-238 $1.000 E+00$ Th-230 PU-238 $1.000 \mathrm{E}+00$ ORa-226 PU-238 1.000E+00 OPb-210 Pu-238 $1.000 \mathrm{E}+00$ OPu-239 Pu-239 $1.000 E+00$ OU-235 PU-239 $1.000 E+00$ OPa-231 Pu-239 $1.000 E+00$ OPC-231 PU-239 1 .000E+00 $\begin{array}{lll}\text { OAC-227 } & \text { Pu }-239 & 1.000 E+00 \\ \text { OPU-240 } & \text { Pu-240 } & 4.950 E-08\end{array}$

$$
\mathrm{S}(\mathrm{j}, \mathrm{t}), \mathrm{pCi} / \mathrm{g}
$$

$t=0.000 E+001.000 E+003.000 E+007.000 E+00,1.100 E+014300 E+011.350 E+023.000 E+021.000 E+03$

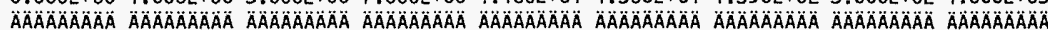

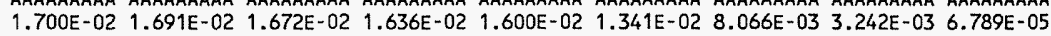
6.300E-02 6.290E-02 6.269E-02 6.228E-02 6.188E-02 5.873E-02 5.053E-02 3.860E-02 1.230 -02 $0.000 E+00 \quad 2.039 E-08 \quad 6.107 E-08 \quad 1.420 E-07 \quad 2.224 E-07 \quad 8.469 E-07 \quad 2.468 E-06 \quad 4.822 E-06 \quad 9.909 E-06$

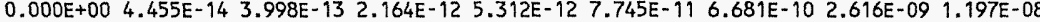
$0.000 \mathrm{E}+00 \quad 1.403 \mathrm{E}-18 \quad 3.779 \mathrm{E}-17 \quad 4.779 \mathrm{E}-16 \quad 1.846 \mathrm{E}-15 \quad 1.064 \mathrm{E}-13 \quad 2.970 \mathrm{E}-12 \quad 2.726 \mathrm{E}-11 \quad 5.086 \mathrm{E}-10$ $8.300 \mathrm{E}-013.801 \mathrm{E}-01 \quad 7.968 \mathrm{E}-02 \quad 3.494 \mathrm{E}-03 \quad 1.527 \mathrm{E}-04 \quad 1.831 \mathrm{E}-15 \quad 0.000 \mathrm{E}+00 \quad 0.000 \mathrm{E}+00 \quad 0.000 \mathrm{E}+00$ $3.800 E-023.331 E-022.560 E-02$ 1.512E-02 $8.933 E-03 \quad 1.324 E-047.294 E-102.700 E-190.000 E+00$ 3.800E-02 3.331E-02 2.560E-02 $1.512 E-02$ 8.933E-03 1.324E-04 7.294E-10 2.700E-19 0.000E+00 2.100E-01 2.052EE 1 1. $3.892 E-02$ 3.695E-02 3.330E-02 2.704E-02 2.196E-02 4.155E-03 3.466E-05 6.479E-09 9.876E-25 1.508E-02 1.431E-02 1.290E-02 1.047E-02 8.507E-03 1.610E-03 1.342E-05 2.510E-09 3.825E-25

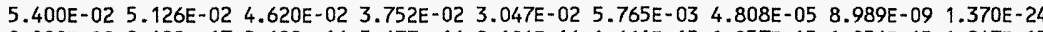

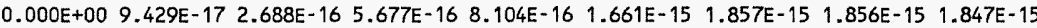
5.300E-02 4.898E-02 4.184E-02 3.053E-02 2.228E-02 $1.790 \mathrm{E}-03 \quad 1.272 \mathrm{E}-06 \quad 2.871 \mathrm{E}-12 \quad 3.188 \mathrm{E}-36$

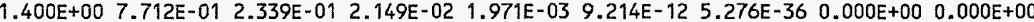

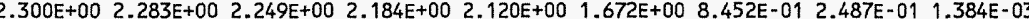
152E-11 5 .111E-11 5.031E-114.874E-11 4.722E-11 3.664E-11 $1.766 \mathrm{E}-11$ 4.774 E-12 $1.855 \mathrm{E}-14$ . 2.800E-02 $2.778 E-02$ 2.734E-02 2.649E-02 $2.566 E-02$ 1.991E-02 $9.600 E-03$ 2.594E-03 $1.008 E-05$ .

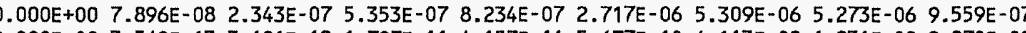
$0.000 E+00 \quad 3.560 E-13 \quad 3.181 E-12 \quad 1.707 E-11 \quad 4.157 E-11 \quad 5.677 E-10 \quad 4.113 E-09$ 1.231E-08 2.870E-08

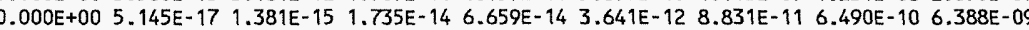
$0.000 \mathrm{E}+00 \quad 3.975 \mathrm{E}-19 \quad 3.166 \mathrm{E}-17 \quad 9.076 \mathrm{E}-16 \quad 5.354 \mathrm{E}-15 \quad 9.708 \mathrm{E}-13 \quad 5.028 \mathrm{E}-11$ 5.070E-10 $6.082 \mathrm{E}-09$ 8.200E-02 8.200E-02 8.199E-02 8.197E-02 8.195E-02 8.180E-02 8.136E-02 8.058E-02 7.737E-02 $0.000 \mathrm{E}+00 \quad 8.064 \mathrm{E}-11 \quad 2.413 \mathrm{E}-10 \quad 5.598 \mathrm{E}-10 \quad 8.747 \mathrm{E}-10 \quad 3.270 \mathrm{E}-09 \quad 9.058 \mathrm{E}-09 \quad 1.629 \mathrm{E}-08 \quad 2.623 \mathrm{E}-08$

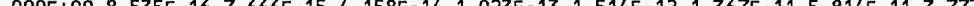
$\begin{array}{lllllllll}0.000 E+00 & 8.987 E-18 & 2.385 E-16 & 2.927 E-15 & 1.098 E-14 & 5.101 E-13 & 8.879 E-12 & 4.795 E-11 & 3.588 E-10 \\ 1.039 E-09 & 1.039 E-09 & 1.039 E-09 & 1.039 E-09 & 1.038 E-09 & 1.033 E-09 & 1.021 E-09 & 9.981 E-10 & 9.079 E-10\end{array}$

\begin{tabular}{|c|c|}
\hline Attachment & Sheet No. 31 of 32 \\
\hline Originator: S.W. Clark & Date \\
\hline Chk'd By M. W. Perrott & Date \\
\hline 0100F-CA-V0280 & Rev. No. \\
\hline
\end{tabular}




\section{ATTACHMENT 2}

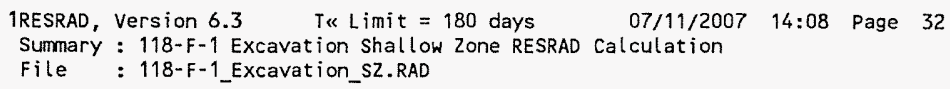

Individual Nuclide Soil Concentration

ONuclide Parent THF(i) (j) (i)

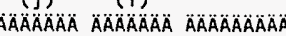

$\begin{array}{lll}\text { PU-240 PU-240 } 1.000 E+00 & \end{array}$

Pu-240 äs $(j)$ :

OU-236 PU-240 1.000E+00

OTh-232 PU-240 1.000E+00

Ra-228 PU-240 $1.000 E+00$

TTh-228 PU-240 1.000E+00

OS -90 Sr-90 $1.000 E+00$

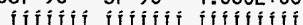

IIIIII IIIIIII IIIfIIII

THF( $i$ ) is the thread fraction
ORESCALC.EXE execution time =
Parent Nuclide and Branch Fraction Indicated

$t=0.000 E+001.000 E+003.000 E+00 \quad 7.000 E+001.100 E+01 \quad 4.300 E+011.350 E+02 \quad 3.000 E+02 \quad 1.000 E+03$

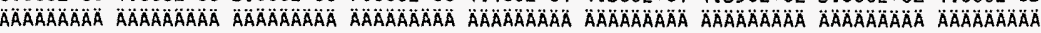

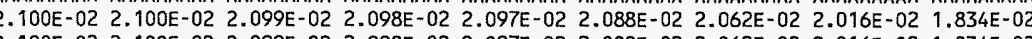

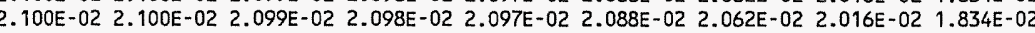
$0.000 E+00 \quad 6.208 E-10 \quad 1.857 E-09 \quad 4.308 E-09 \quad 6.730 E-09 \quad 2.513 E-08$ 6.934E-08 $1.238 E-07 \quad 1.913 E-07$ $0.000 E+00 \quad 1.532 E-20 \quad 1.376 E-19 \quad 7.463 E-19 \quad 1.836 E-18 \quad 2.720 E-17 \quad 2.458 E-16 \quad 1.047 E-15 \quad 6.866 E-15$

$0.000 \mathrm{E}+00 \quad 5.976 \mathrm{E}-22 \quad 1.520 \mathrm{E}-20 \quad 1.724 \mathrm{E}-19 \quad 6.017 \mathrm{E}-19 \quad 1.880 \mathrm{E}-17 \quad 2.188 \mathrm{E}-16 \quad 9.969 \mathrm{E}-16 \quad 6.785 \mathrm{E}-15$ $0.000 E+00 \quad 5.073 E-23 \quad 3.426 E-21 \quad 7.296 E-20 \quad 3.319 E-19 \quad 1.623 E-17 \quad 2.100 E-16 \quad 9.805 E-16 \quad 6.759 E-15$ $3.800 \mathrm{E}-013.710 \mathrm{E}-013.536 \mathrm{E}-013.212 \mathrm{E}-01$ 2 $317 \mathrm{E}-01$ 1.352E-01 1.481E-02 2.806E-04 $1.382 \mathrm{E}-11$

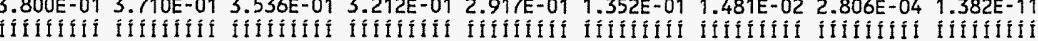
of the parent nuclide. 21.45 seconds

$\begin{array}{ll}\text { Attachment } \frac{2}{\text { S.W. Clark }} & \text { Sheet No. } \underline{32} \text { of } \underline{32} \\ \text { Originator: } & \text { Date } \\ \text { Chk'd By } & \text { Date } \\ \text { Calc. No. Perrott } & \text { Rev. No. } \quad 0\end{array}$




\section{ATTACHMENT 3}

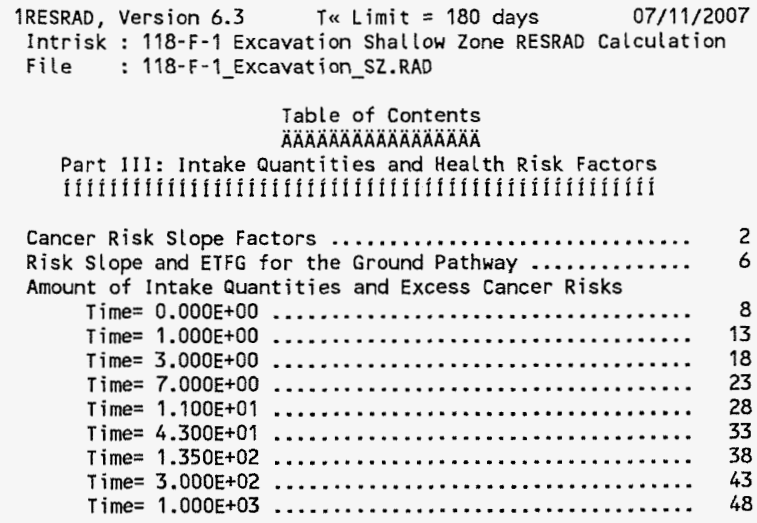

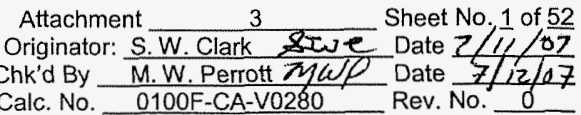




\section{ATTACHMENT 3}

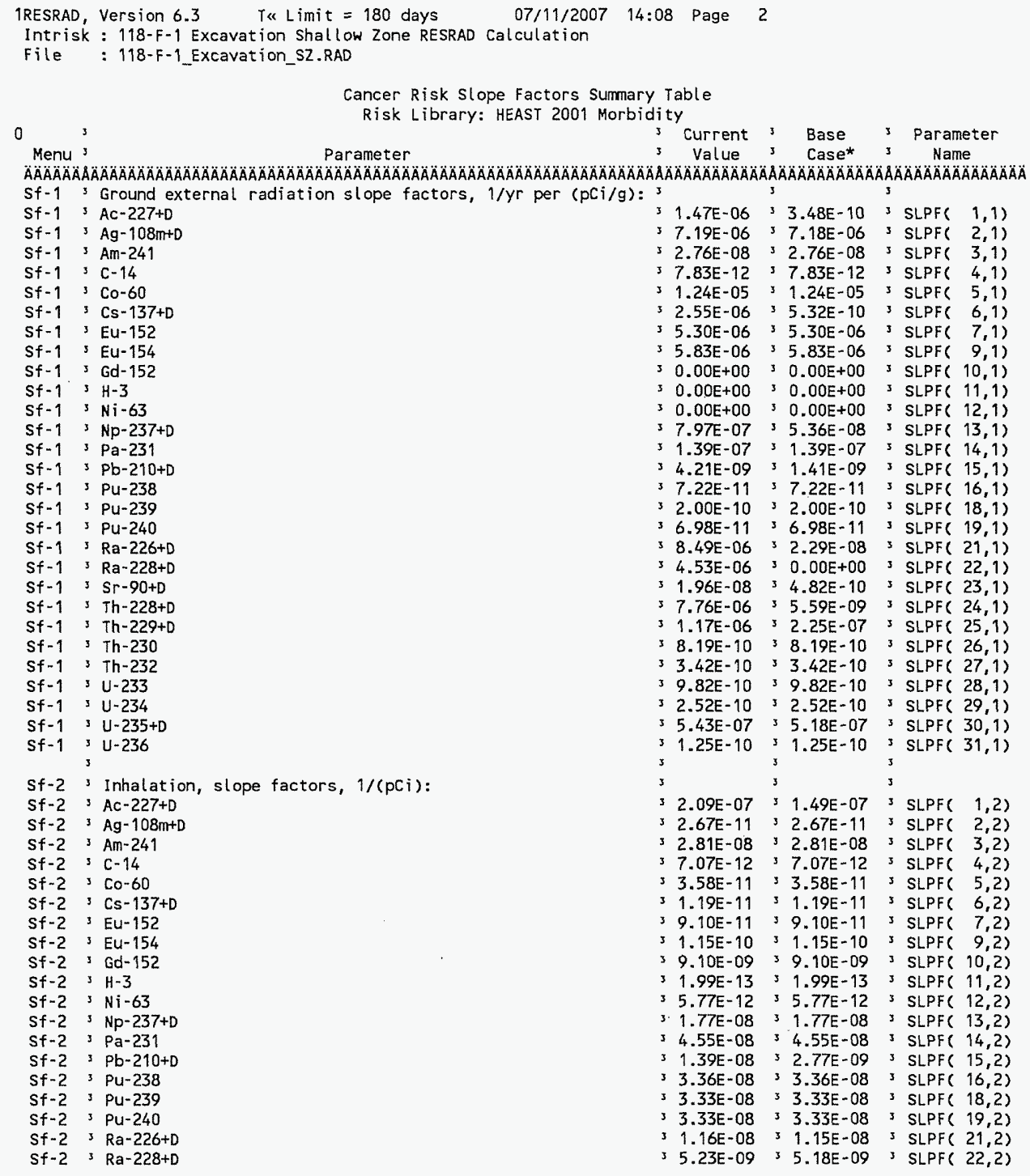




\section{ATTACHMENT 3}

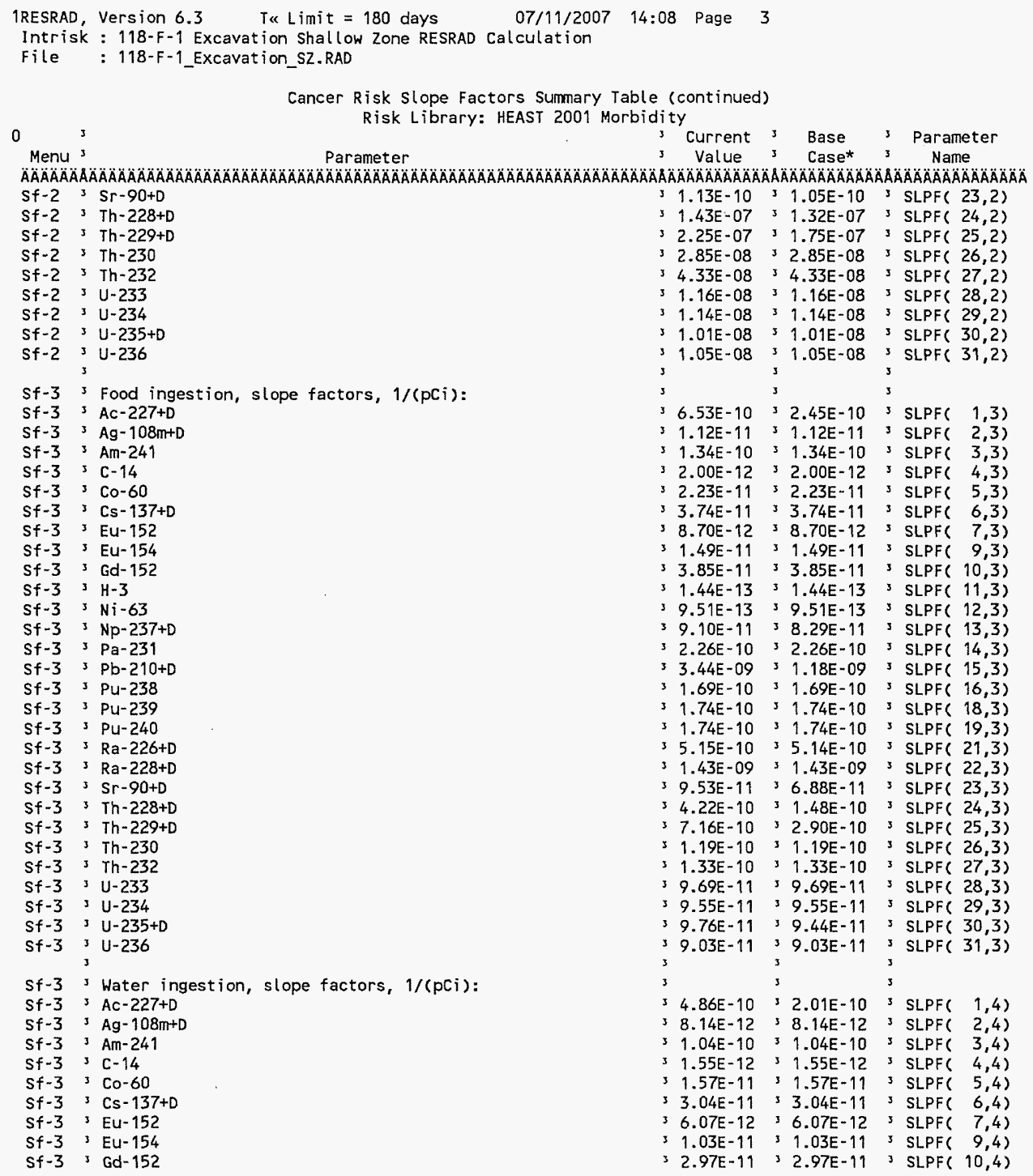

\begin{tabular}{|c|c|}
\hline Attachment & Sheet No. 3 of 52 \\
\hline Originator: S.W. Clark & Date \\
\hline M. W. Perrott & Date \\
\hline $0100 \mathrm{~F}-\mathrm{CA}-\mathrm{V} 0280$ & Rev. No. \\
\hline
\end{tabular}




\section{ATTACHMENT 3}

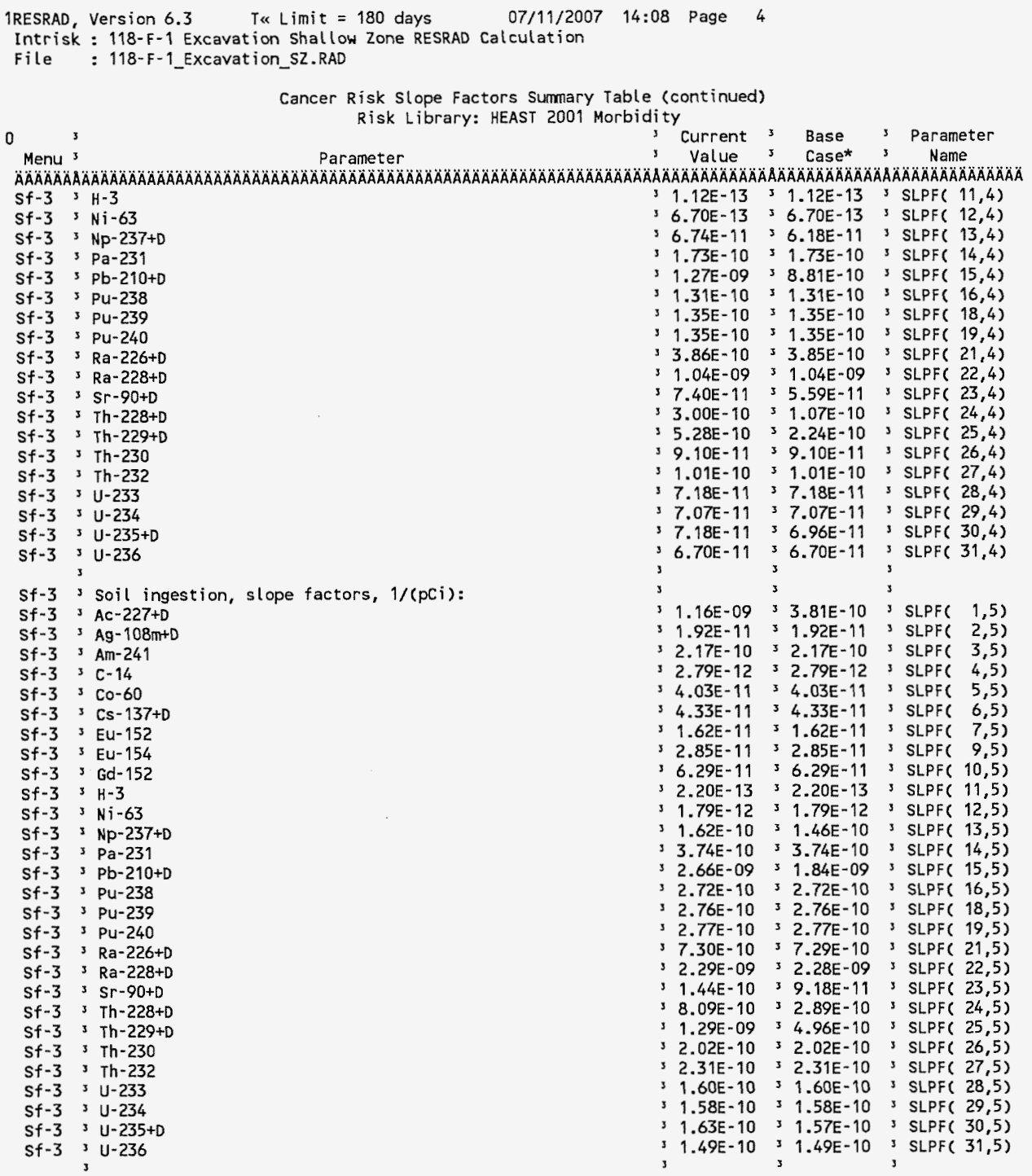

\begin{tabular}{|c|c|}
\hline \multirow{2}{*}{\multicolumn{2}{|c|}{ 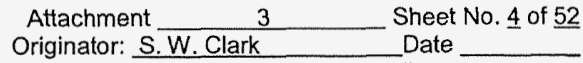 }} \\
\hline & \\
\hline Chk'd By M.W. Perrott & Date \\
\hline $0100 \mathrm{~F}-\mathrm{CA}-\mathrm{V} 0280$ & Rev. No. \\
\hline
\end{tabular}




\section{ATTACHMENT 3}

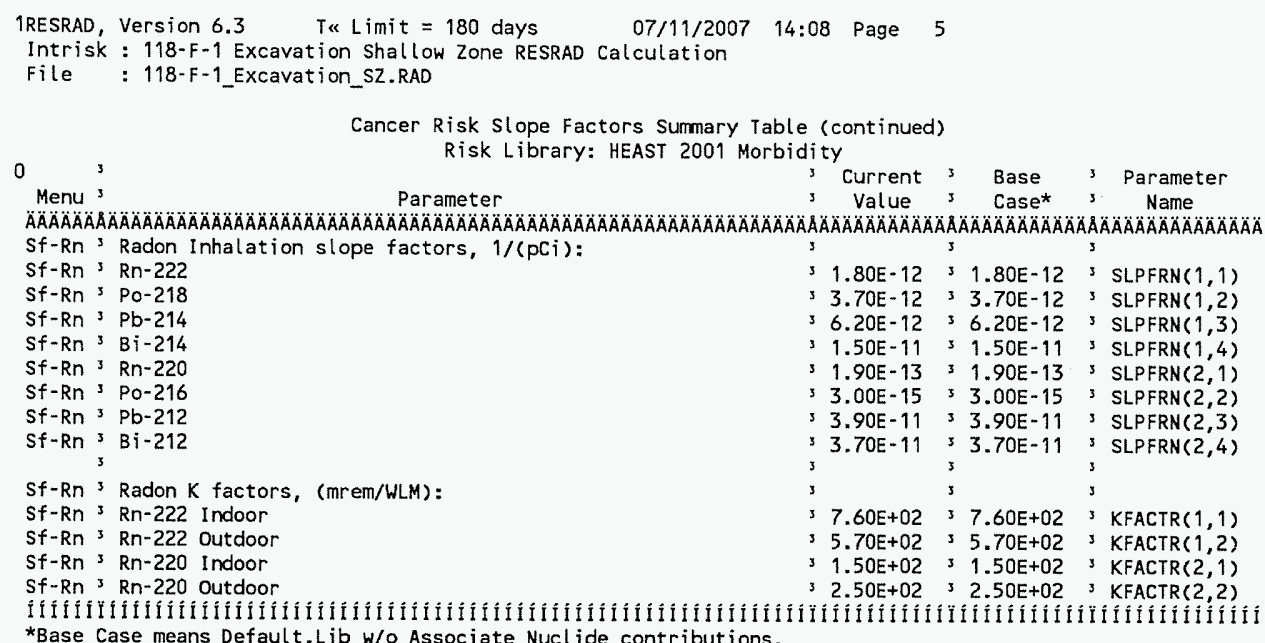

Attachment

3 Sheet No. $\underline{5}$ of $\underline{52}$

Originator: S.W. Clark

Date

Ca. W. Perrott

Rev. No. 0 


\section{ATTACHMENT 3}

\begin{tabular}{|c|c|c|c|c|c|c|c|c|c|c|}
\hline $\begin{array}{l}\text { 1RESRAD, } \\
\text { Intrisk } \\
\text { File }\end{array}$ & $\begin{array}{l}\text { Version } 6.3 \\
: 118-F-1 \text { Ex } \\
: 118-F-1 \text { Ex }\end{array}$ & vation_s & $A D$ & & $\begin{array}{l}7 / 11 / 2007 \\
\text { ulation }\end{array}$ & $4: 08$ & 0 & & & \\
\hline Nucl ide & slope $(i)^{*}$ & & & ETFG( & & & & & & \\
\hline & & $0.000 E+00$ & $1.000 E+00$ & $3.000 E+00$ & $7.000 E+00$ & $1.100 E+01$ & $4.300 E+01$ & $1.350 E+02$ & $3.000 E+02$ & $1.000 E+03$ \\
\hline$\triangle A A A A A A O A$ & $\triangle A A A A O A A A O A$ & $\triangle A A A A A A B A B$ & $\triangle A A A A A A A A A O A$ & $\triangle A A A A B A A A A A$ & $\triangle A A A A A A B A O A O A$ & $\triangle A O A A A O A O A O A O A$ & $\triangle A A A A B A A A$ & $\triangle A A A A A B A A A A B$ & $\triangle A A A A A O A B A B A$ & $\triangle A A B A A A B A A$ \\
\hline$A c-225$ & $4.500 E-08$ & $6.506 \mathrm{E}-01$ & $6.506 \mathrm{E}-01$ & $6.506 E-01$ & $6.506 E-01$ & & $6.506 \mathrm{E}-01$ & $6.506 \mathrm{E}-01$ & $6.506 E-01$ & $6.506 \mathrm{E}-01$ \\
\hline & $3.480 E-10$ & $6.515 \mathrm{E}-01$ & $6.515 \mathrm{E}-01$ & $6.515 \mathrm{E}-01$ & $6.515 \mathrm{E}-01$ & & $6.515 \mathrm{E}-01$ & $6.515 E-01$ & $6.515 E-01$ & $.515 E-01$ \\
\hline & EE-06 & $.413 E-01$ & $3 E-01$ & $6.413 E-01$ & $6.413 E-01$ & & $6.413 E-01$ & & $6.413 E-01$ & $6.413 E-01$ \\
\hline $\mathrm{Ag}-$ & & $.381 E-01$ & $1 E-01$ & $6.381 E-01$ & $6.381 E-01$ & 6.381E-01 & $6.381 E-01$ & $6.381 E-01$ & $6.381 E-01$ & $6.381 E-01$ \\
\hline Ag- & OE-06 & $6.383 E-01$ & $6.383 E-01$ & $6.383 E-01$ & $383 E-01$ & $6.383 E-01$ & 6.383E-01 & $6.383 E-01$ & $6.383 E-01$ & $383 E-01$ \\
\hline & & $.606 \mathrm{E}-01$ & $6 E-01$ & $6.606 E-01$ & $6.606 E-01$ & $6.606 \mathrm{E}-01$ & $6.606 E-01$ & $6.606 E-01$ & $6.606 \mathrm{E}-01$ & $6 \mathrm{E}-01$ \\
\hline & $E-09$ & $.401 \mathrm{E}-01$ & $1 E-01$ & $6.401 E-01$ & $6.401 E-01$ & $6.401 E-01$ & $6.401 E-01$ & $6.401 \mathrm{E}-01$ & $6.401 E-01$ & $1 E-01$ \\
\hline & $E-09$ & $6.605 E-01$ & 5E-01 & $6.605 E-01$ & $6.605 E-01$ & $6.605 E-01$ & $6.605 \mathrm{E}-01$ & $6.605 E-01$ & $6.605 E-01$ & $E-01$ \\
\hline & & $75 E-01$ & 6.3 & $6.375 \mathrm{E}-01$ & $E-01$ & $6.375 E-01$ & E-01 & $E-01$ & $E-01$ & $E-01$ \\
\hline & & & & $6.436 \mathrm{E}-01$ & $E-01$ & & & & & $E-01$ \\
\hline & 1.8 & $6.438 \mathrm{E}-01$ & $8 E-01$ & $6.438 E-01$ & $6.438 \mathrm{E}-01$ & & & & & $8 E-01$ \\
\hline & & $.386 E-01$ & $E-01$ & $6.386 E-01$ & $E-01$ & $6.386 E-$ & -01 & $E-01$ & & $E-01$ \\
\hline & & & & $6.410 E-01$ & $=-01$ & & & & & $E-01$ \\
\hline $\mathrm{Bi}$ & 7.4 & & 6.4 & J2E-01 & $E-01$ & & & & & E- 01 \\
\hline C- & & & 6.6 & $E-01$ & -01 & 6.6 & 6.6 & & -01 & $=01$ \\
\hline & & & & $E-01$ & & & & & & $=01$ \\
\hline & & & 6.4 & $6.471 E-01$ & -01 & & & & & $=-01$ \\
\hline & & -01 & 6.4 & $\mathrm{E}-01$ & -01 & 6.4 & & & & $E-01$ \\
\hline & & & & $E-01$ & & & & & & \\
\hline & & $1 E-01$ & 6.4 & $E-01$ & -01 & & & E-01 & & $E-01$ \\
\hline & 07 & & 6.4 & $E-01$ & -01 & $1 E-01$ & 6.2. & $=-01$ & & -01 \\
\hline & & & & $E+00$ & +00 & $O E+C O$ & & & & \\
\hline$H-$ & & & & $E-01$ & -01 & & & & & $=-01$ \\
\hline & & & & $E+\infty 0$ & +00 & 0.0 & & & & +00 \\
\hline & & $30 E-01$ & 6.5 & $E-01$ & -01 & $6.530 \mathrm{E}-$ & 6.53 & & & -01 \\
\hline & & & & -01 & & & & -01 & & $=-01$ \\
\hline & & & & & & & & & & \\
\hline & & & & & & & & & & \\
\hline & & & & & & & & & & \\
\hline & & & & & & & & & & \\
\hline & & & 6.4 & $E-01$ & & & & & & \\
\hline & & & 6.4 & & & & & & & -01 \\
\hline & & & & & & & & & & \\
\hline & & & & & & & & & & \\
\hline & & & & & & & & & & \\
\hline & & & & & & & & & & \\
\hline & & & & & & & & & & \\
\hline & & & & & & & & & & \\
\hline & & & & & & & & & & \\
\hline & & & & & & & & & & \\
\hline & & & & & & & & & & \\
\hline & & & & $6.494 E-01$ & & $6.494 E-0$ & & & & $4 E-0$ \\
\hline & & & & & & & & & & \\
\hline & & & & & & & & & & \\
\hline & $3.720 E-08$ & $6.470 \mathrm{E}-0$ & & $6.470 E-01$ & $6.470 E-01$ & $6.470 \mathrm{E}-0$ & $6.470 E-01$ & $6.470 E-01$ & $6.470 E-01$ & $6.470 E-0$ \\
\hline & & & & & & & & & & \\
\hline & & & & & & & & & & \\
\hline & $0.000 E+00$ & $0.000 E+00$ & $0.000 E+00$ & $0.000 E+00$ & $0.000 E+00$ & $0.000 E+00$ & $0.000 E+00$ & $0.000 E+00$ & $0.000 E+00$ & $0.000 E+00$ \\
\hline & & & & & & & & & & \\
\hline & 1.700E-09 & $3 E-01$ & & & $6.383 E-01$ & & & $6.383 E-01$ & $6.383 E-01$ & \\
\hline
\end{tabular}

\begin{tabular}{|c|c|}
\hline Attachment & Sheet No. 6 of 52 \\
\hline Originator: S. W. Clark & Date \\
\hline Chk'd By M. W. Perrott & Date \\
\hline $0100 \mathrm{~F}-\mathrm{CA}-\mathrm{V} 0280$ & Rev. No. \\
\hline
\end{tabular}




\section{ATTACHMENT 3}

\begin{tabular}{|c|c|c|c|c|c|c|c|c|c|c|}
\hline $\begin{array}{l}\text { 1RESRAD, } \\
\text { Intrisk } \\
\text { File }\end{array}$ & $\begin{array}{l}\text { Version } 6.3 \\
: 118-F-1 \text { Exc } \\
: 118-F-1 \text { Exc }\end{array}$ & $\begin{array}{l}\text { T\& } L \\
\text { cavation } \\
\text { cavation_s }\end{array}$ & $\begin{array}{l}t=180 \mathrm{c} \\
\text { llow Zone } \\
\text { RAD }\end{array}$ & SRAD Calc & $\begin{array}{l}7 / 11 / 2007 \\
\text { ulation }\end{array}$ & $14: 08$ & 7 & & & \\
\hline ONucl ide & Slope(i)* & $R$ is & & $\begin{array}{r}\text { ir ronmental } \\
\text { ETFG( }\end{array}$ & & & $\begin{array}{l}\text { the Ground } \\
\text { (dimension }\end{array}$ & $\begin{array}{l}\text { Pathway } \\
\text { (ess) }\end{array}$ & & \\
\hline (i) & $t=$ & $0.000 E+00$ & $1.000 E+00$ & $3.000 E+00$ & $7.000 E+00$ & $1.100 E+01$ & $4.300 E+01$ & $1.350 E+02$ & $3.000 E+02$ & $1.000 E+03$ \\
\hline$\triangle A A A A B A A$ & A & $\triangle A A A A A B A A A B$ & $\triangle A O A A A A A A B A$ & $\triangle A A B A A A A A O A$ & $\triangle A A B A A A A A B A$ & $\triangle A A A A A A A A A$ & $\triangle A B A A A A A A A$ & $\triangle A B A A A A A A B A$ & $\triangle A A A O A A A B A A$ & $\triangle A A A A A A A A O A$ \\
\hline$R n-222$ & $1.740 \mathrm{E}-09$ & $6.383 E-01$ & $6.383 \mathrm{E}-01$ & $6.383 E-01$ & $6.383 \mathrm{E}-01$ & $6.383 E-01$ & $6.383 E-01$ & $6.383 \mathrm{E}-01$ & $6.383 \mathrm{E}-01$ & $6.383 E-01$ \\
\hline $\mathrm{Sr}-90$ & $4.820 E-10$ & $6.483 E-01$ & $6.483 \mathrm{E}-01$ & $6.483 E-01$ & $6.483 E-01$ & $6.483 E-01$ & $6.483 E-01$ & $6.483 E-01$ & $6.483 E-01$ & $6.483 E-01$ \\
\hline Th-22 & $3.780 E-07$ & $6.475 E-01$ & $6.475 \mathrm{E}-01$ & $6.475 E-01$ & $6.475 E-01$ & $6.475 E-01$ & $6.475 E-01$ & $6.475 E-01$ & $6.475 \mathrm{E}-01$ & $6.475 E-01$ \\
\hline & $5.590 \mathrm{E}-09$ & $6.504 E-01$ & $6.504 E-01$ & $6.504 E-01$ & $6.504 E-01$ & $6.504 E-01$ & $6.504 E-01$ & $6.504 \mathrm{E}-01$ & $6.504 E-01$ & $6.504 E-01$ \\
\hline Th-229 & $2.250 E-07$ & $6.513 E-01$ & $6.513 E-01$ & $6.513 E-01$ & $6.513 E-01$ & $6.513 E-01$ & $6.513 E-01$ & $6.513 E-01$ & $6.513 E-01$ & $6.513 E-01$ \\
\hline Th -23 & $8.190 E-10$ & $6.528 E-01$ & 6.52 & $6.528 E-01$ & $6.528 E-01$ & $6.528 E-01$ & $6.528 E-01$ & $28 E-01$ & $28 \mathrm{E}-01$ & $28 E-01$ \\
\hline Th- & $2.450 E-08$ & $6.536 \mathrm{E}-01$ & 6.5 & $6.536 E-01$ & $6 E-01$ & $6.536 \mathrm{E}-01$ & $6.536 \mathrm{E}-01$ & $6 \mathrm{E}-01$ & $6.536 \mathrm{E}-01$ & $36 E-01$ \\
\hline Th-232 & $3.420 E-10$ & $6.561 E-01$ & $6.561 E-01$ & $6.561 E-01$ & $6.561 E-01$ & $6.561 E-01$ & $6.561 E-01$ & $6.561 E-01$ & $6.561 E-01$ & $6.561 \mathrm{E}-01$ \\
\hline$T l-20 T$ & $1.520 E-08$ & 6.4 & & $E-01$ & -01 & $6.404 E-01$ & 6.4 & 01 & $=-01$ & $E-01$ \\
\hline$T L-2$ & $1.760 E-05$ & $6.418 E-01$ & $6.418 \mathrm{E}-$ & $6.418 E-01$ & $6.418 E-01$ & $6.418 E-01$ & $6.418 E-01$ & $6.418 E-01$ & $6.418 E-01$ & $6.418 E-01$ \\
\hline$T L-209$ & $9.830 \mathrm{E}-06$ & $6.417 E-01$ & $6.417 E-01$ & $6.417 E-01$ & $6.417 E-01$ & $6.417 E-01$ & $6.417 E-01$ & $6.417 E-01$ & $6.417 \mathrm{E}-01$ & $6.417 \mathrm{E}-01$ \\
\hline & $0.000 \mathrm{E}+00$ & $6.800 E-01$ & $6.800 \mathrm{E}$ & $6.800 E-01$ & & $6.800 E-01$ & & & & $0 E-01$ \\
\hline & $9.820 E-10$ & $6.497 E-01$ & $6.497 \mathrm{E}-01$ & $6.497 E-01$ & $6.497 E-01$ & $6.497 E-01$ & $6.497 E-01$ & $6.497 \mathrm{E}-01$ & $6.497 \mathrm{E}-01$ & $6.497 E-01$ \\
\hline$U-234$ & $2.520 E-10$ & $6.565 E-01$ & $6.565 \mathrm{E}-01$ & $6.565 E-01$ & $6.565 E-01$ & $6.565 E-01$ & $6.565 E-01$ & $6.565 E-01$ & $6.565 \mathrm{E}-01$ & $6.565 E-01$ \\
\hline & $5.180 E-07$ & $6.483 E-01$ & $6.483 \mathrm{E}-01$ & $6.483 E-01$ & $6.483 E-01$ & $6.483 E-01$ & $6.483 E-01$ & $6.483 \mathrm{E}-01$ & $6.483 \mathrm{E}-01$ & $6.483 E-01$ \\
\hline & $1.250 E-10$ & 4 & $6.617 \mathrm{E}-01$ & $6.617 \mathrm{E}-01$ & 6.617E-01 & $6.617 \mathrm{E}-01$ & $6.617 \mathrm{E}-01$ & $6.617 \mathrm{E}-01$ & $6.617 \mathrm{E}-01$ & $6.617 E-01$ \\
\hline & $1.910 E-08$ & $6.395 E-01$ & $6.395 \mathrm{E}-01$ & $6.395 E-01$ & 6.395E-01 & $6.395 E-01$ & $6.395 \mathrm{E}-01$ & $6.395 E-01$ & $6.395 \mathrm{E}-01$ & $6.395 \mathrm{E}-01$ \\
\hline & Iffitílí & iffififit & LAtifítít & 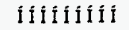 & Itiffitio & tiffifíti & fiffitifi & IfIfifif & fififitit & EIfififif \\
\hline
\end{tabular}

Attachment 3 Sheet No. 7 of $\underline{52}$ Originator: S.W. Clark Date

Chk'd By $\frac{\text { M.W. Perrott }}{\text { Calc. No. }}$
0100F-CA-V0280 Rev. No. 0 


\section{ATTACHMENT 3}

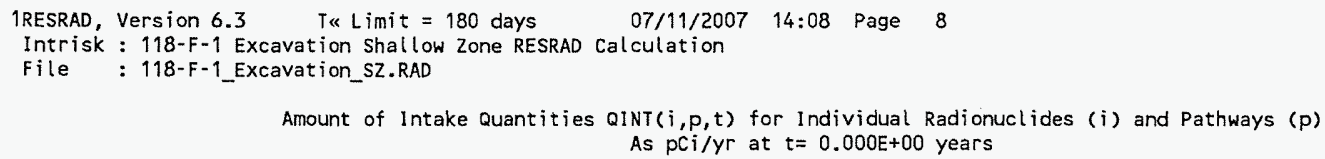

Water-ind. $=$ = Water-independent Water-dep. $==$ Water-dependent

\begin{tabular}{ll} 
Attachment $\frac{3}{1}$ & Sheet No. $\underline{8}$ of $\underline{52}$ \\
Originator: S.W. Clark & Date \\
Chk'd By & Date \\
Calc. No. N. Perrott & Rev. No. \\
\hline O100F-CA-V0280 & Rev
\end{tabular}




\section{ATTACHMENT 3}

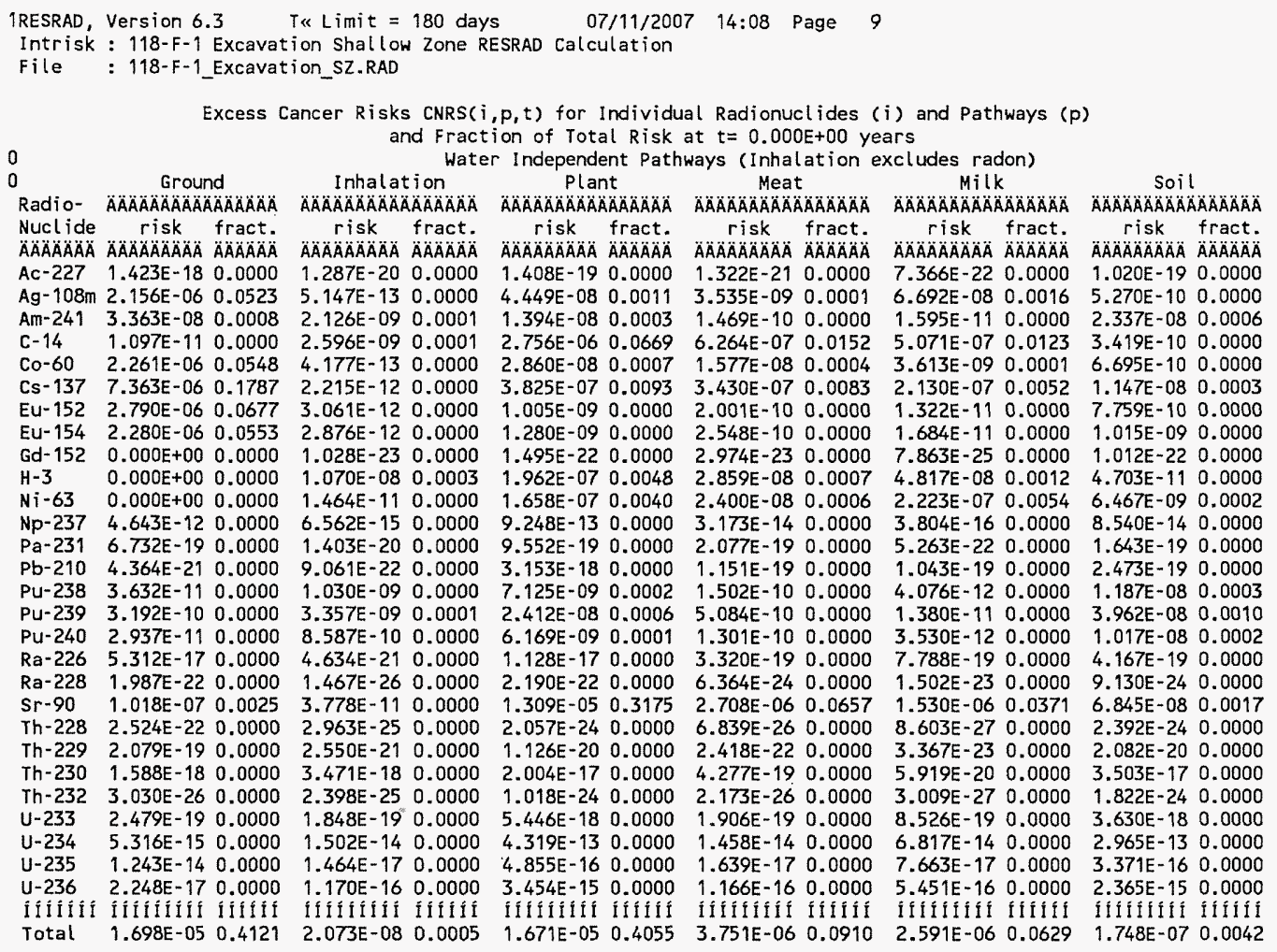

Attachment

Originator: S.W. Clark

3
Sheet No. $\underline{9}$ of $\underline{52}$ Chk'd By M. W. Perrott Date Calc. No 


\section{ATTACHMENT 3}

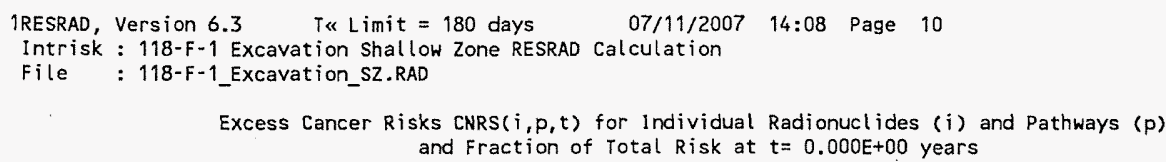

Water Dependent Pathways

\begin{tabular}{|c|c|c|c|c|c|c|c|c|c|c|c|c|}
\hline \multirow{2}{*}{$\begin{array}{l}\text { Radio- } \\
\text { Nucl ide } \\
\text { ÄÄÄÄÄÄÄ }\end{array}$} & \multicolumn{2}{|c|}{$\begin{array}{c}\text { Water } \\
\text { Wo }\end{array}$} & \multicolumn{2}{|c|}{ Fish } & \multicolumn{2}{|c|}{ Plant } & \multicolumn{2}{|c|}{ Meat } & \multicolumn{2}{|l|}{ Milk } & \multicolumn{2}{|c|}{ All Pathways ${ }^{\star *}$} \\
\hline & $\begin{array}{c}\text { risk } \\
\text { AOAAAOAOAAA }\end{array}$ & $\begin{array}{l}\text { fract. } \\
\triangle A A B A A B A\end{array}$ & $\begin{array}{c}\text { risk } \\
\triangle A A B A ̈ A ̈ A B A A\end{array}$ & $\begin{array}{l}\text { fract. } \\
\because A O A B A A A B A\end{array}$ & 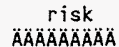 & $\begin{array}{l}\text { fract. } \\
\triangle A A B A B A A\end{array}$ & $\begin{array}{c}\text { risk } \\
\triangle A A O A B A O A B A B\end{array}$ & 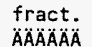 & $\begin{array}{c}\text { risk } \\
\triangle A A A A O A A A O A B\end{array}$ & $\begin{array}{l}\text { fract. } \\
\triangle A O A O A O A B\end{array}$ & $\begin{array}{c}\text { risk } \\
\triangle A A A B A A A A A B\end{array}$ & $\begin{array}{l}\text { fract. } \\
\text { ÄAAAAAAA }\end{array}$ \\
\hline $\mathrm{Ac}-227$ & $1.455 E-18$ & 0.0000 & $3.976 E-20$ & 0.0000 & $2.162 E-19$ & 0.0000 & $1.301 \mathrm{E}-21$ & 0.0000 & $1.668 \mathrm{E}-21$ & 0.0000 & $3.395 E-18$ & 0.0000 \\
\hline$g-108 m$ & $0.000 E+00$ & 0.0000 & $0.000 E+00$ & 0.0000 & $0.000 E+00$ & 0.0000 & $0.000 E+00$ & 0.0000 & $0.000 E+00$ & 0.0000 & $2.272 E-06$ & 0.0551 \\
\hline & $0.000 E+00$ & 0.0000 & $0.000 E+00$ & 0.0000 & $0.000 E+00$ & 0.0000 & $0.000 E+00$ & 0.0000 & $0.000 E+00$ & 0.0000 & $7.323 \mathrm{E}-08$ & \\
\hline & $0.000 E+00$ & 0.0000 & $0.000 E+00$ & 0.0000 & $0.000 E+00$ & 0.0000 & $0.000 E+00$ & 0.0000 & $0.000 E+00$ & 0.0000 & & \\
\hline-60 & $5.770 E-11$ & 0.0000 & $8.463 E-12$ & 0.0000 & $9.191 \mathrm{E}-12$ & 0.0000 & $2.337 E-11$ & 0.0000 & $6.883 \mathrm{E}-12$ & 0.0000 & $2.309 E-06$ & 0.0560 \\
\hline & $3.443 E-09$ & 0.0001 & $2.841 E-09$ & 0.0001 & $4.708 E-10$ & 0.0000 & $1.835 E-09$ & 0.0000 & $1.432 E-09$ & 0.0000 & & \\
\hline & & 0.0000 & & 0.0000 & $0.000 E+00$ & 0.0000 & & & & & & \\
\hline Eu-154 & $0.000 E+00$ & 0.0000 & $0.000 E+00$ & 0.0000 & $0.000 E+00$ & 0.0000 & $0.000 E+00$ & 0.0000 & $0.000 E+00$ & 0.0000 & $82 E-06$ & 0.0554 \\
\hline$y-152$ & $0.000 E+00$ & 0.0000 & $0.000 E+00$ & 0.0000 & $0.000 E+00$ & 0.0000 & $0.000 E+00$ & 0.0000 & $0.000 E+00$ & 0.0000 & $E-22$ & .0000 \\
\hline & & & & & & 0.0049 & & 0.0005 & & 015 & & \\
\hline & $5.204 E-09$ & 0.0001 & $2.587 E-10$ & 0.0000 & $8.255 E-10$ & 0.0000 & 5.40 & 0.0000 & $90 \mathrm{E}-09$ & 0.0002 & & 0.0105 \\
\hline-237 & $0.000 E+00$ & 0.0000 & $0.000 E+00$ & 0.0000 & $0.000 \mathrm{E}+00$ & 0.0000 & $0.000 E+00$ & 0.0000 & $0.000 E+00$ & 0.0000 & $E-12$ & .0000 \\
\hline & & & $7.871 E-21$ & 0.0000 & & 0.0000 & & 0.0000 & $E-22$ & 000 & & 000 \\
\hline & & & & 0.0000 & $2.396 E-$ & 0.0000 & & 0.0000 & & 000 & & \\
\hline$u-2$ & $0.000 E+00$ & 0 & $0.000 E+00$ & 0.0000 & $0.000 E+00$ & 0 & $0.000 \mathrm{E}+00$ & 0.0000 & $0.000 E+00$ & 0.0000 & $322 E-08$ & 005 \\
\hline & $0.000 E+0$ & 0.0000 & $0.000 E+00$ & 0.0000 & $0.000 E+00$ & 0.0000 & $0.000 E+00$ & 0.0000 & $0.000 \mathrm{E}+00$ & 0.0000 & $793 E-08$ & .0016 \\
\hline & $0.000 \mathrm{E}+0$ & 0.0000 & $0.000 E+00$ & 0.0000 & $0.000 E+$ & 0.0000 & $E+00$ & 0.0 & $100 E+00$ & 0.0000 & & \\
\hline & & & $5.137 E-20$ & & & 0.0 & -20 & 0.0000 & $E-19$ & .0000 & $E-17$ & \\
\hline & & 0.0000 & $1.964 E-24$ & 0.0000 & $1 E-23$ & 0.0000 & & 0.0000 & $E-24$ & 0.0000 & $E-22$ & 0.0000 \\
\hline & $1.091 E-$ & 0.0026 & $3.039 E-09$ & 0.0001 & $1.689 \mathrm{E}-08$ & 0.0004 & 1.657 & 0.0004 & 203E-08 & 0.0003 & $55 E-05$ & 0.4283 \\
\hline & & & & & & & & & & & $E-22$ & \\
\hline & $3.345 E-20$ & 0.0000 & $1.851 E-21$ & 0.0000 & & 0.0000 & $2.792 E-$ & 0.0 & $5.283 E-23$ & 0.0000 & $53 E-19$ & 0.0000 \\
\hline Th-230 & $5.984 E-17$ & 0.0000 & $3.190 \mathrm{E}-18$ & 0.0000 & $1.204 E-17$ & 0.0000 & $5.051 \mathrm{E}-19$ & 0.0000 & $9.601 E-20$ & 0.0000 & $1.363 E-16$ & 0.0000 \\
\hline & & & & & & & & & $5.185 E-27$ & & $7 E-24$ & 000 \\
\hline & & 0.0000 & & 30.0000 & $7.807 E-17$ & 0.0000 & $3.506 E-18$ & 0.0000 & $1.805 E-17$ & 0.0000 & $389 E-16$ & 0.0000 \\
\hline$U-234$ & $5.940 E-11$ & 0.0000 & $3.424 E-13$ & 0.0000 & $8.840 \mathrm{E}-12$ & 0.0000 & $3.989 E-13$ & 0.0000 & $2.048 E-12$ & 0.0000 & $7.186 \mathrm{E}-11$ & 0.0000 \\
\hline & & & $3.5125-10$ & & $9.737 E-15$ & & & & & 0.0000 & $9.118 E-14$ & 0.0000 \\
\hline & & & $2.684 E-15$ & & $6.928 E-14$ & & $3.125 E-15$ & & $1.605 E-14$ & 0.0000 & $5.644 E-13$ & \\
\hline f f f I I I I I I & Lifififi & & 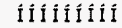 & Î́îî́ & Iitifitio & Ifíî́ & 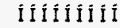 & Iíîín & IIIXIIIA & fífifí & Ifiliffít & II I I I i i \\
\hline$T=1$ & $6.359 E-07$ & 0.0154 & $6.383 E-09$ & 0.0002 & $2.184 E-07$ & 0.0053 & $3.923 E-08$ & 30.0010 & $8.037 \mathrm{E}-08$ & 0.0020 & 4.121E-05 & 1.0000 \\
\hline
\end{tabular}

** Sum of water independent ground, inhalation, plant, meat, milk, soil

and water dependent water, fish, plant, meat, milk pathways

\begin{tabular}{|c|c|}
\hline Attachment & Sheet No. 10 of 52 \\
\hline Originator: S.W. Clark & Date \\
\hline Chk'd By M. W. Perrott & Date \\
\hline Calc. No. $0100 \mathrm{~F}-\mathrm{CA}-\mathrm{V} 0280$ & Rev. No. \\
\hline
\end{tabular}


Rev. 0

\section{ATTACHMENT 3}

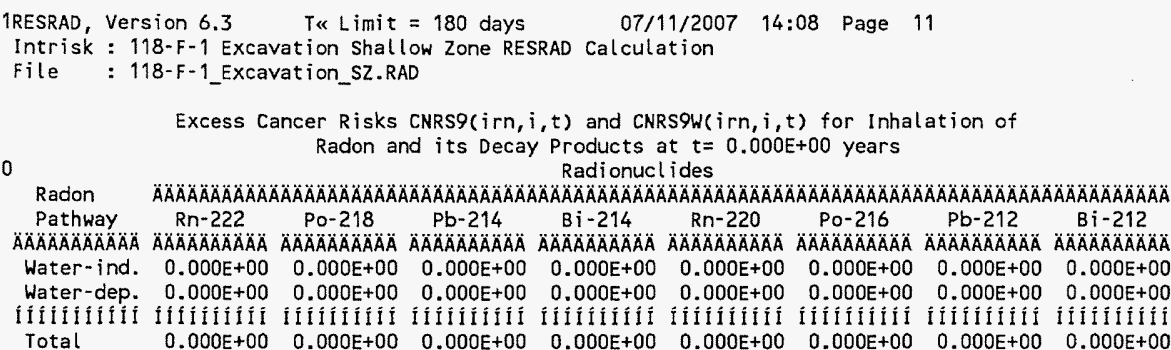

\begin{tabular}{|c|c|}
\hline Attachment $\quad 3$ & Sheet No. 11 of 52 \\
\hline Originator: S.W. Clark & Date \\
\hline M. W. Perrott & Date \\
\hline $0100 \mathrm{~F}-\mathrm{CA}-\mathrm{V} 0280$ & Rev. No. \\
\hline
\end{tabular}




\section{ATTACHMENT 3}

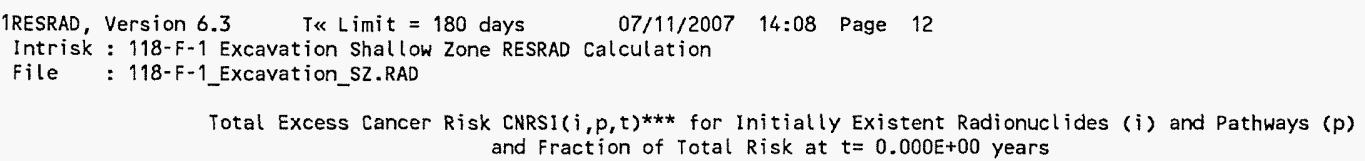

Water Dependent Pathways

\begin{tabular}{|c|c|c|c|c|c|c|c|c|c|c|c|c|c|c|}
\hline \multirow{2}{*}{ 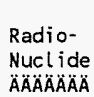 } & \multicolumn{2}{|c|}{ Water } & \multicolumn{2}{|c|}{ Fish } & \multicolumn{2}{|c|}{ Radon } & \multicolumn{2}{|c|}{ Plant } & \multicolumn{2}{|l|}{ Meat } & \multicolumn{2}{|c|}{ 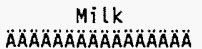 } & \multicolumn{2}{|c|}{ 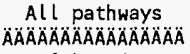 } \\
\hline & & & $\begin{array}{c}\text { risk } \\
\triangle A B A B A B A B A\end{array}$ & $\begin{array}{l}\text { fract. } \\
\text { ÄÄABÄA }\end{array}$ & risk & fract. & risk & fract. & risk & $\begin{array}{l}\text { fract. } \\
\text { ÄÄÄÄÄA }\end{array}$ & risk & 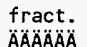 & risk & $\begin{array}{l}\text { fract. } \\
\triangle A A A A A B A\end{array}$ \\
\hline $\mathrm{Ag}-108 \mathrm{~m}$ & & 0.0000 & $.000 E+00$ & & $.000 E+00$ & & $0.000 \mathrm{E}+00$ & & & 0.0000 & $0.000 E+00$ & & $2.272 E-06$ & 0.0551 \\
\hline$m-241$ & $5.257 E-16$ & 0.0000 & $3.027 E-18$ & 0.0000 & $0.000 \mathrm{E}+00$ & 0.0000 & $7.807 E-17$ & 0.0000 & $3.506 E-18$ & 0.0000 & $1.805 E-17$ & 0.0000 & $7.323 E-08$ & 0.0018 \\
\hline & & & $000 E+00$ & & $0 E+00$ & 0.0000 & $0.000 E+00$ & 0.0000 & $0 E+00$ & 0. & $E+\infty$ & 0000 & & \\
\hline & & & & & & 0.0000 & $9.191 \mathrm{E}-12$ & & & & & & & \\
\hline & $3.443 E-09$ & 0.0001 & $2.841 \mathrm{E}-09$ & 0.0001 & $0.000 E+00$ & 0.0000 & $4.708 E-10$ & & & 0.0 & & .0000 & & 019 \\
\hline & 0.00 & 0.0000 & $E+00$ & 0.0 & $E+00$ & & $O E+00$ & & $+\infty 0$ & & $E+00$ & & & 677 \\
\hline & 0.00 & 0.00 & $E+00$ & 0.0000 & 0.00 & 0.0000 & $0.000 E+00$ & 0.0000 & -00 & 0.0000 & $0.000 E+00$ & .0000 & -06 & 554 \\
\hline $1-3$ & 5.18 & 0.0126 & $E-10$ & 0.0000 & $0.000 E+00$ & 0.0000 & -07 & 0.0049 & & 0.0005 & 6. & 15 & & \\
\hline & & & & & & & -10 & & & & & & & \\
\hline & & & & & $0.000 E+00$ & 0.0000 & 8.8 & 0. & & & & & & 005 \\
\hline Pu-239 & $6.501 E-14$ & 0.0000 & $3.772 E-16$ & 0.0000 & $0.000 E+00$ & 0.0000 & $9.738 E-15$ & 0.0000 & 4.3 & 0.0 & $2.256 E-15$ & 0.0000 & $73 E-08$ & 0.0016 \\
\hline & & & & & & & & & & & & & & \\
\hline $\begin{array}{l}\text { Sr-9 } \\
\text { í íi }\end{array}$ & $\begin{array}{l}1.09 \\
\text { IIII }\end{array}$ & & $\begin{array}{l}3.039 E-09 \\
\text { IIfffifi }\end{array}$ & $\begin{array}{l}0.0001 \\
\text { IfIfII }\end{array}$ & $\begin{array}{l}0.000 E+C \\
\text { ifififil }\end{array}$ & $\begin{array}{l}0.0000 \\
\text { iffíti }\end{array}$ & $\begin{array}{l}1.689 \mathrm{E}- \\
\text { IIIfII }\end{array}$ & $\begin{array}{l}0.0004 \\
\text { IIIfII }\end{array}$ & $\begin{array}{l}1.657 E-08 \\
\text { Iilfiffi }\end{array}$ & $\begin{array}{l}0.0004 \\
\text { Ififí }\end{array}$ & 1.20 & 0003 & & $\begin{array}{l}0.4283 \\
\text { If Í II I }\end{array}$ \\
\hline Total & $6.359 \mathrm{E}-07$ & 0.0154 & $6.383 \mathrm{E}-09$ & 0.0002 & $0.000 E+00$ & 0.0000 & $2.184 \mathrm{E}-07$ & 0.0053 & $3.923 E-08$ & 0.0010 & $8.037 \mathrm{E}-08$ & 0.0020 & 4.121E-05 & 1.0000 \\
\hline
\end{tabular}

***CNRSI $(i, p, t)$ includes contribution from decay daughter radionuclides

\begin{tabular}{|c|c|}
\hline Attachment $\quad 3$ & Sheet No. 12 of $\underline{52}$ \\
\hline Originator: S.W. Clark & Date \\
\hline Chk'd By M.W. Perrott & Date \\
\hline $0100 \mathrm{~F}-\mathrm{CA}-\mathrm{V} 0280$ & Rev. No. \\
\hline
\end{tabular}




\section{ATTACHMENT 3}

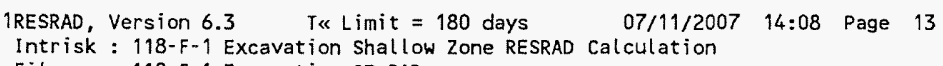
Radionucl ides

\begin{tabular}{|c|c|c|c|c|c|c|c|c|}
\hline \multirow{2}{*}{$\begin{array}{l}\text { Radon } \\
\text { Pathway } \\
\text { ÄÄÄÄÄÄÄÄÄ }\end{array}$} & \multicolumn{8}{|c|}{ 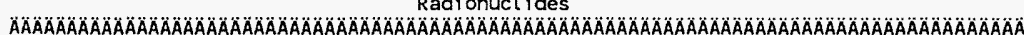 } \\
\hline & $\begin{array}{c}R n-222 \\
\text { RAABABABAA }\end{array}$ & $\begin{array}{c}\text { PO-218 } \\
\text { A A AOA }\end{array}$ & $\begin{array}{c}\mathrm{Pb}-214 \\
A B A B A B A A B A\end{array}$ & $\begin{array}{c}B i-214 \\
A B A B A B A B A A\end{array}$ & $\begin{array}{c}R n-220 \\
R A B A B A\end{array}$ & $\begin{array}{c}P 0-216 \\
P O A A A A\end{array}$ & $\begin{array}{c}P b-212 \\
P B A B A\end{array}$ & $\begin{array}{c}B i-212 \\
\end{array}$ \\
\hline Water-ind. & $0.000 E+00$ & $0.000 E+00$ & $0.000 E+00$ & $0.000 E+00$ & $\begin{array}{r}\text { ARAAAAAAAA } \\
0.000 \mathrm{E}+00\end{array}$ & $0.000 \mathrm{E}+00$ & $\begin{array}{r}0.000 E+00 \\
0\end{array}$ & $\begin{array}{r}\text { AAAAAAAAAA } \\
0.000 \mathrm{E}+00\end{array}$ \\
\hline Water-dep. & $0.000 E+00$ & $0.000 E+00$ & $0.000 E+00$ & $0.000 E+00$ & $0.000 E+00$ & $0.000 \mathrm{E}+00$ & $0.000 E+00$ & $0.000 E+00$ \\
\hline Total & $0.000 E+00$ & $0.000 E+00$ & $0.000 E+00$ & $0.000 E+00$ & $0.000 E+00$ & $0.000 E+00$ & $0.000 E+00$ & $0.000 E+00$ \\
\hline
\end{tabular}

Water - ind. $=$ Water-independent Water-dep. $==$ Water-dependent

\begin{tabular}{|c|c|}
\hline Attachment & Sheet No. 13 of 52 \\
\hline Originator: S.W. Clark & Date \\
\hline Chk'd By M. W. Perrott & Date \\
\hline Calc. No. $0100 \mathrm{~F}-\mathrm{CA}-\mathrm{V} 0280$ & Rev. No. \\
\hline
\end{tabular}




\section{ATTACHMENT 3}

\begin{tabular}{|c|c|c|c|c|c|c|c|c|c|}
\hline \multirow[t]{2}{*}{$\begin{array}{l}\text { 1RESRAD, } \\
\text { Intrisk } \\
\text { File }\end{array}$} & $\begin{array}{l}\text { version } \\
: 118-\mathrm{F}- \\
: 118-\mathrm{F}-\end{array}$ & EXcav & in SZallow & Tone & $\begin{array}{r}07 / 11 / 200 \\
\text { RAD Calculation }\end{array}$ & & age & & \\
\hline & \multirow{2}{*}{\multicolumn{2}{|c|}{ Excess }} & \multicolumn{7}{|c|}{$\begin{array}{c}\text { Cancer Risks CNRS }(i, p, t) \text { for Individual Radionuclides }(i) \text { and Pathways }(p) \\
\text { and Fraction of Total Risk at } t=1.000 E+00 \text { years }\end{array}$} \\
\hline 0 & & & & & & & & & \\
\hline 0 & & & Inhalat & tion & Plant & Mea & & Milk & Soil \\
\hline & & $\triangle A O A A A O A O A$ & $\triangle A O A A A A A A A A A$ & $\triangle A ̈ A ̈ A ̈ A ̈ A ̈$ & 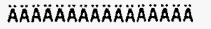 & $\triangle A A A A A A A A O A$ & $\triangle A A A A A A A O A$ & 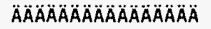 & $\triangle A A A A A A A A A A A A A A A A A B A$ \\
\hline $\begin{array}{l}\text { Nuclide } \\
\text { ÄÄÄÄÄÄÄ }\end{array}$ & $\begin{array}{l}k \\
k \\
A ̈ A O A ̈\end{array}$ & $\begin{array}{l}\text { fract. } \\
\text { ÄÄÄÄÄ }\end{array}$ & $\begin{array}{c}\text { risk } \\
\text { AAAAAAAOAOÄ }\end{array}$ & & 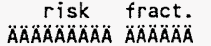 & $\begin{array}{l}\text { sk } \\
A ̈ A ̈ A ̈ A\end{array}$ & & 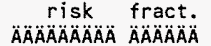 & 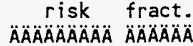 \\
\hline & & 0.0000 & & & $1.595 E-190.0000$ & & 0.0000 & $8.344 E-220.0000$ & $1.156 \mathrm{E}-190.0000$ \\
\hline & & & & & $5 E-08 \quad 0.0$ & & 0.0001 & $5 E-08 \quad 0.0018$ & $E-100$. \\
\hline & & & & & $2 E-080.0$ & & 0.0 & 110. & .080 \\
\hline & & & & & OE-06 $\quad 0.0$ & & 70.0 & 070.0 & -100 \\
\hline & & & & & $7 \varepsilon-08 \quad 0.0$ & & & 090.0 & -100 \\
\hline & & & & & $7 E-07 \quad 0.0$ & & & 070.1 & \\
\hline & & 0.07 & & & $4 E-100$. & & 0. & 110.0 & 10 \\
\hline & & 0.0 & & & 090. & & & 110. & 10 \\
\hline & & 0.0 & & & -220. & & & 250 & \\
\hline & & 0.00 & & & $=-070$. & & & 080. & \\
\hline & & 0.0 & & & $E-070$ & & & 170 & 02 \\
\hline & & 0.0 & & & -130 & & & 160. & 14 \\
\hline & & 0.0 & & & -180 & & & 220. & 19 \\
\hline & & 0.0 & & & 180 & & & & \\
\hline & & & & & & & & 120. & \\
\hline & & 0.0 & & & -080. & & & 110. & 08 \\
\hline & & 0.0 & & & $=-090$ & & & & \\
\hline & & & & & -170. & & & 190. & 190 \\
\hline & & 0.0 & & 0.0 & $2.458 \mathrm{E}-22 \quad 0.0$ & & & 230. & .230 \\
\hline & & & & & & & & & \\
\hline & & & & & $2.321 \mathrm{E}-240.0$ & & & 270. & 24 \\
\hline & $2.368 \mathrm{E}-19$ & 0.0000 & & 0.00 & $1.282 \mathrm{E}-20 \quad 0.00$ & & 20.0 & $=-230.0$ & -200. \\
\hline & 1.74 & 0.0 & & & $4 E-170.0$ & & & & \\
\hline & 3.34 & & & & $3 E-24 \quad 0.0$ & & & -270.0 & \\
\hline & $2.732 \mathrm{E}-19$ & 0.0000 & 2.03 & 0.0000 & $5.998 E-18 \quad 0.0000$ & $6 E-19$ & 90.0000 & $E-190.0$ & $E-18 \quad 0.0000$ \\
\hline & & & & & & & & $E-14 \quad 0.0$ & -130.0000 \\
\hline & & & & & $5.174 \mathrm{E}-16 \quad 0.0000$ & & & E-170 0 & -160.0000 \\
\hline & & & & & $3.680 E-15 \quad 0.0000$ & & & $9 E-16 \quad 0.0$ & $E-15 \quad 0.0000$ \\
\hline & & & & & 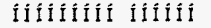 & Ilififiti & & & Dififilí títít \\
\hline 10Lat & $1.621 \mathrm{E}-05$ & 0.4300 & $1.450 E-08$ & 0.0004 & $1.485 E-05 \quad 0.3938$ & $3.368 \mathrm{E}-06$ & 60.0893 & $2.276 \mathrm{E}-06 \quad 0.0604$ & $1.723 E-07 \quad 0.0046$ \\
\hline
\end{tabular}

Attachment Sheet No. 14 of $\underline{52}$ Originator: $\frac{\text { S.W. Clark }}{\text { M.W. Perrot }}$ Date

Calc. No. 0100F-CA-V0280 Rev. No 0 


\title{
ATTACHMENT 3
}

\author{
IRESRAD, Version 6.3 T\& Limit $=180$ days $\quad 07 / 11 / 2007 \quad 14: 08$ Page 15 \\ Intrisk : 118-F-1 Excavation Shallow Zone RESRAD Calculation \\ File: 118-F-1 Excavation SZ.RAD \\ Excess Cancer Risks CNRS( $i, p, t)$ for Individual Radionuclides (i) and Pathways ( $p$ ) \\ and Fraction of Total Risk at $t=1.000 E+00$ years
}

Water Dependent Pathways

\begin{tabular}{|c|c|c|c|c|c|c|c|c|c|c|c|c|}
\hline & $\begin{array}{r}\text { water } \\
\text { ÄÄÄÄÄÄÄA }\end{array}$ & 范 & 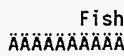 & $\begin{array}{l}h \\
\text { ÄÄÄÄÄÄÄ }\end{array}$ & $\begin{array}{r}P L \\
\triangle A A O A A A O A O\end{array}$ & 同 & $\begin{array}{r}\text { Meat } \\
\text { AAAABAOABABA }\end{array}$ & 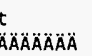 & 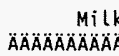 & $A ̈ A ̈ A ̈ A O A O A$ & $\begin{array}{r}\text { All Path } \\
A A B A B A B A A B A\end{array}$ & ays* \\
\hline $\begin{array}{l}\text { Iclide } \\
\ddot{A} A \ddot{A} \ddot{A} \ddot{A}\end{array}$ & $\begin{array}{c}\text { risk } \\
\triangle A A A A B A B A O A\end{array}$ & 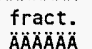 & $\begin{array}{c}\text { risk } \\
\text { AÄAAAAOA }\end{array}$ & $\begin{array}{l}\text { fract. } \\
\text { ÄÄÄAOABA }\end{array}$ & $\begin{array}{c}\text { risk } \\
\text { ÄÄÄABAOÄA }\end{array}$ & $\begin{array}{l}\text { fract. } \\
\ddot{A} \ddot{A} \ddot{A} \ddot{A} \ddot{A} \ddot{A}\end{array}$ & $\begin{array}{c}\text { risk } \\
A B ̈ A B A B A B A\end{array}$ & fract. & $\begin{array}{c}\text { risk } \\
\text { OABAOAO }\end{array}$ & & $\begin{array}{l}\text { risk } \\
\text { AAAAAA }\end{array}$ & \\
\hline & & & & & & & & & & & & \\
\hline & & & & & & & & & & & & \\
\hline & $0.000 E+00$ & & $10 E+00$ & 0.0000 & $.000 E+00$ & & $O O E+D O$ & & & & & \\
\hline & & & & & $+\infty$ & & & & & & & \\
\hline & & & & & & & & & & & & \\
\hline & & & & & & & & & & & & \\
\hline & & & & & & & & & & & & \\
\hline & & & & & & & & & & & & \\
\hline & & & & & & & & & & & & \\
\hline 3 & & & & & & & & & & & & \\
\hline & & & & & & & & & & & & \\
\hline & & & & & & & & & & & & \\
\hline & & & & & & & & & & & & \\
\hline & & & & & & & & & & & & \\
\hline & & & & & & & & & & & & \\
\hline & & & & & & & & & & & & \\
\hline & & & & & & & & & & & & \\
\hline & & & & & & & & & & & & \\
\hline & & & & & & & & & & & & \\
\hline & & & & & & & & & & & & \\
\hline & & & & & & & & & & & & \\
\hline & & & & & & & & & & & & \\
\hline & & & & & & & & & & & & \\
\hline & & & & & & & & & & & & \\
\hline & & & & & & & & & & & & \\
\hline & & & & & & & & & & & & \\
\hline & 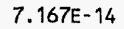 & & 5 & & & & & & & & & \\
\hline & & & & & & & & & & & & \\
\hline & & & & & & & & & & & & \\
\hline & & & & & & & & & & & & \\
\hline
\end{tabular}

** Sum of water independent ground, inhalation, plant, meat, milk, soil

and water dependent water, fish, plant, meat, milk pathways

\begin{tabular}{|c|c|}
\hline Attachment & Sheet No. 15 of 52 \\
\hline Originator: S.W. Clark & Date \\
\hline Chk'd By M. W. Perrott & Date \\
\hline $0100 F-C A-V 0280$ & Rev. No. \\
\hline
\end{tabular}




\section{ATTACHMENT 3}

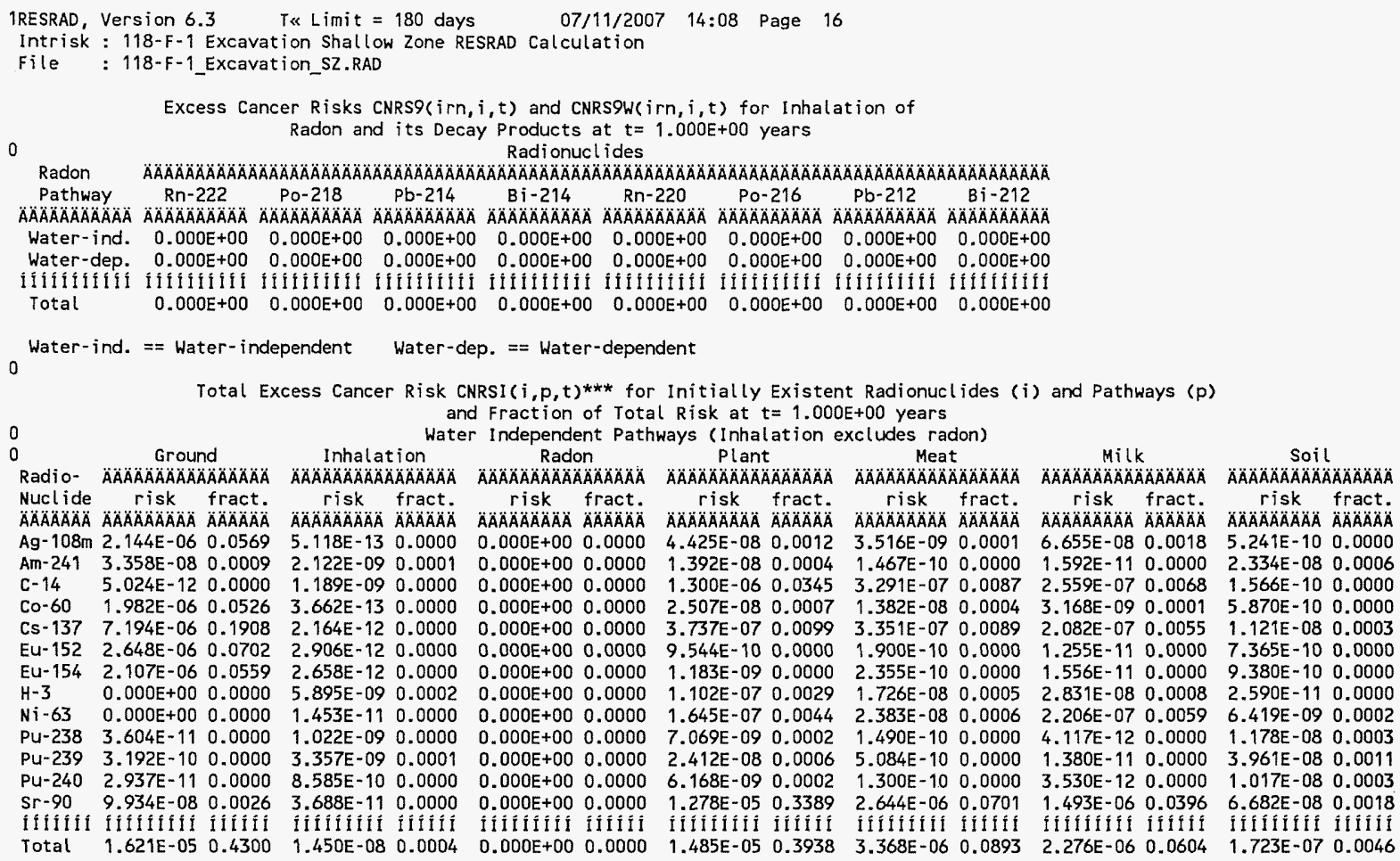

\begin{tabular}{|c|c|}
\hline Attachment & Sheet No. 16 of $\underline{52}$ \\
\hline Originator: S.W. Clark & Date \\
\hline Chk'd By M.W. Perrott & Date \\
\hline 0100F-CA-V0280 & Rev. No. \\
\hline
\end{tabular}




\title{
ATTACHMENT 3
}

\begin{abstract}
1RESRAD, Version $6.3 \quad T \ll$ Limit $=180$ days 07/11/2007 14:08 Page 17
\end{abstract}

Intrisk : 118-F-1 Excavation Shallow Zone RESRAD Calculation

File: :118-F-1_Excavation_SZ.RAD

Total Excess Cancer Risk CNRSI $(i, p, t)^{* * *}$ for Initially Existent Radionuclides (i) and Pathways ( $p$ ) and Fraction of Total Risk at $t=1.000 E+00$ years

Water Dependent Pathways

\begin{tabular}{|c|c|c|c|c|c|c|c|c|c|c|c|c|c|}
\hline \multirow{2}{*}{$\begin{array}{l}\text { Radio- } \\
\text { Nuclide } \\
\text { AAAAABA }\end{array}$} & \multicolumn{2}{|c|}{$\begin{array}{c}\text { Water } \\
\text { AAÄAOAOAOAOAOÄÄÄÄ }\end{array}$} & \multicolumn{2}{|c|}{$\begin{array}{c}\text { Fish } \\
\text { ÄÄÄAAAAOAOAAÄÄÄ }\end{array}$} & \multicolumn{2}{|c|}{$\begin{array}{c}\text { Radon } \\
\text { ÁÄAÄÄÄÄÄÄÄÄÄÄ }\end{array}$} & \multicolumn{2}{|c|}{ Plant } & \multicolumn{2}{|c|}{ Meat } & \multicolumn{2}{|c|}{ Milk } & 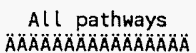 \\
\hline & & & $\begin{array}{c}\text { risk } \\
\text { ÄÄÄÄÄÄÄ̈ }\end{array}$ & $\begin{array}{l}\text { fract. } \\
\text { ÄÄÄÄÄA }\end{array}$ & $\begin{array}{c}\text { risk } \\
\triangle A \cap A ̈ A ̈ A B A ̈ A ̈\end{array}$ & $\begin{array}{l}\text { fract. } \\
\text { ÄÄÄÄÄA }\end{array}$ & $\begin{array}{c}\text { risk } \\
\text { RÄÄAOAOÄA }\end{array}$ & & $\begin{array}{c}\text { risk } \\
\triangle A B A O A B A B A\end{array}$ & & $\begin{array}{c}\text { risk } \\
\text { ÄÄÄÄÄÄA }\end{array}$ & & \\
\hline & & & & & & & & & & & & & \\
\hline & & & & & & & & & & & & & \\
\hline & & & & & & & & & & & & & \\
\hline & & & & & & & & & & & & & \\
\hline & & & & & & & & & & & & & \\
\hline & & & & & & & & & & & & & \\
\hline & & & & & & & & & & & & & \\
\hline & & & & & & & & & & & & & \\
\hline & & & & & & & & & & & & & 08 \\
\hline & & & & & & & & & & & & & \\
\hline & & & & & & & & & & & & & \\
\hline & & & & & & & & & & & & & \\
\hline & & & & & & & & & & & & & \\
\hline & & & & & & & & & & & & & \\
\hline & & & & & & & & & & & & & \\
\hline
\end{tabular}

$\star * *$ CNRSI $(i, p, t)$ includes contribution from decay daughter radionuclides

$\begin{array}{ll}\text { Attachment } \frac{3}{\text { S.W. Clark }} & \text { Sheet No. } 17 \text { of } \underline{52} \\ \text { Originator: } \frac{\text { S.Wate }}{\text { M.W. Perrott }} & \text { Date } \\ \text { Chk'd By } & \text { Rev. No. } 0 \\ \text { Calc. No. } 0100 \text { F-CA-V0280 } & \text { Rever. }\end{array}$




\section{ATTACHMENT 3}

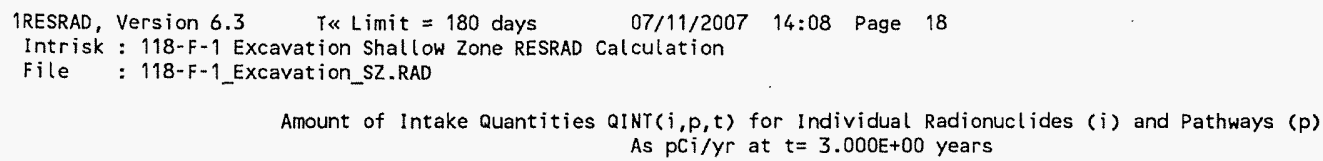

\begin{tabular}{|c|c|}
\hline \multirow{2}{*}{\multicolumn{2}{|c|}{$\begin{array}{ll}\text { Attachment } & 3 \\
\text { Originator: S.W. Slark } & \text { Sheet No. } 18 \text { of } \underline{52}\end{array}$}} \\
\hline & \\
\hline Chk'd By M.W. Perrott & Date \\
\hline $0100 \mathrm{~F}-\mathrm{CA}-\mathrm{V} 0280$ & Rev. No. \\
\hline
\end{tabular}




\section{ATTACHMENT 3}

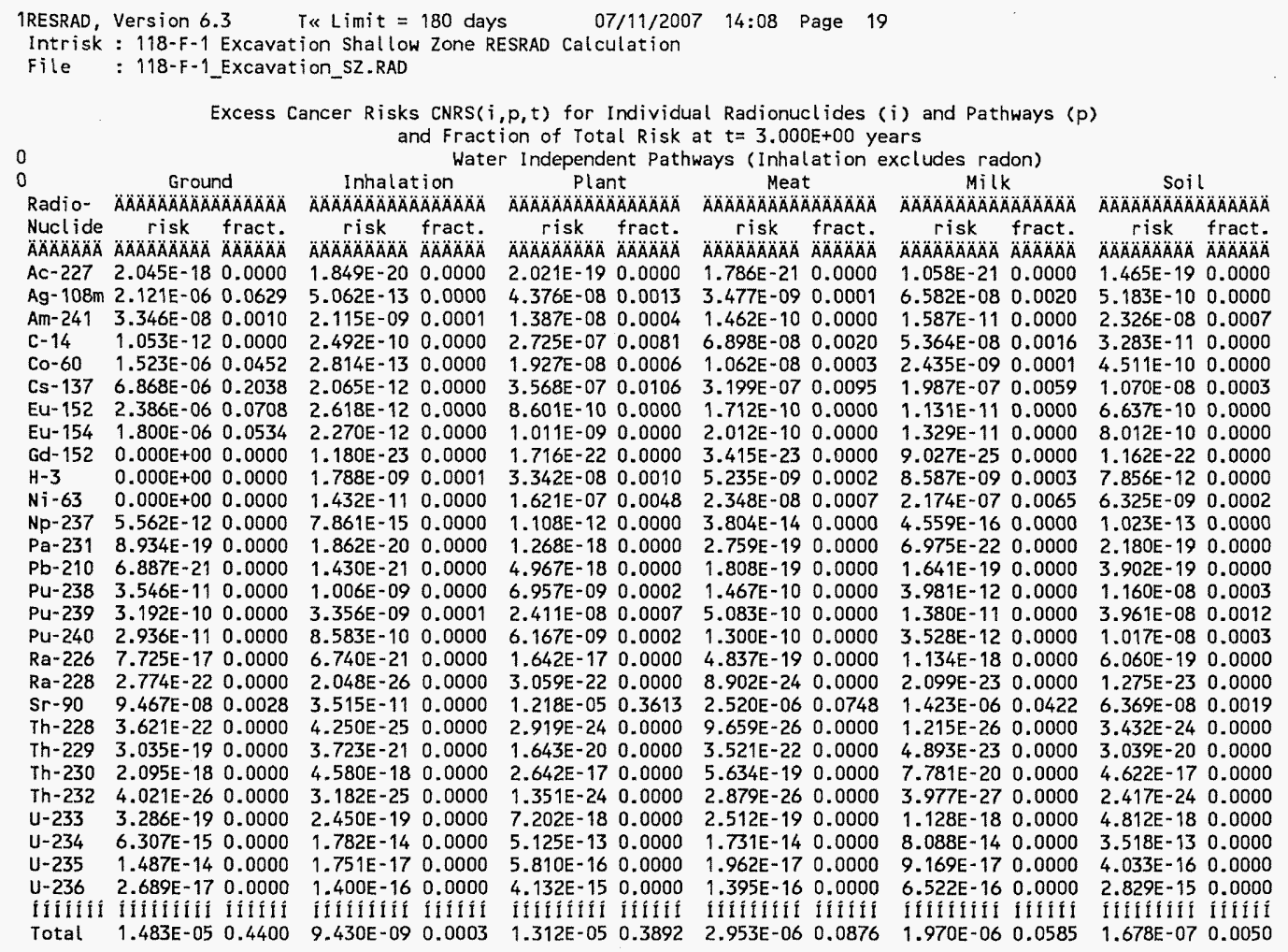

\footnotetext{
Attachment
} 3 


\section{ATTACHMENT 3}

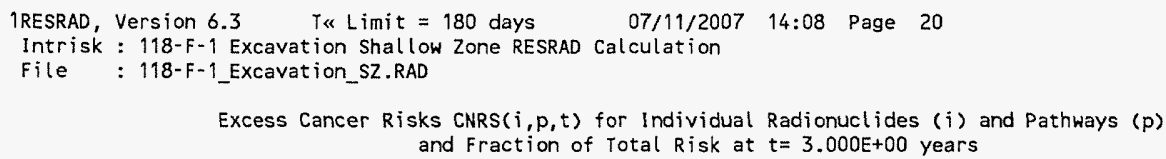

Water Dependent Pathways

\begin{tabular}{|c|c|c|c|c|c|c|c|c|c|c|c|c|}
\hline \multirow[b]{2}{*}{$\begin{array}{l}\text { Nuclide } \\
\text { AAAAAOABÄ }\end{array}$} & \multicolumn{2}{|c|}{ 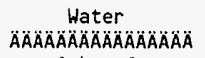 } & \multicolumn{2}{|c|}{ 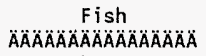 } & \multicolumn{2}{|c|}{ 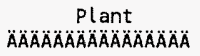 } & \multicolumn{2}{|c|}{ 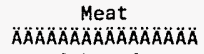 } & \multicolumn{2}{|c|}{$\begin{array}{c}M i l k \\
\triangle A A A A A A B A A O A A A A A O A\end{array}$} & \multicolumn{2}{|c|}{ 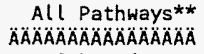 } \\
\hline & $\begin{aligned} r 1 S K \\
\triangle A O A O A O A O A B A\end{aligned}$ & $\begin{array}{l}\text { tract. } \\
\triangle A A B A B A\end{array}$ & $\begin{array}{c}r i s k \\
\dddot{A} A ̈ A ̈ A ̈ A ̈ A ̈ A ̈ A ̈\end{array}$ & 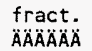 & $\begin{array}{c}\text { risk } \\
\text { ÄÄÄÄÄÄÄÄÄ }\end{array}$ & $\begin{array}{l}\text { fract. } \\
\text { ÄÄÄÄÄ }\end{array}$ & $\begin{array}{c}r i s k \\
\triangle A O A A O A O A O A B A\end{array}$ & $\begin{array}{l}\text { fract. } \\
\text { ÄÄÄÄÄA }\end{array}$ & $\begin{array}{c}\text { risk } \\
\triangle A A A O A B A B A O A B\end{array}$ & $\begin{array}{l}\text { fract. } \\
\triangle A ̈ A ̈ A ̈ A O A\end{array}$ & $\begin{array}{c}\text { risk } \\
\triangle A B A O A O A B A B A\end{array}$ & $\begin{array}{l}\text { tract. } \\
\text { ÄÄÄÄ̈̈̈̈ }\end{array}$ \\
\hline & $2.280 E-18$ & 0.0000 & $6.210 E-20$ & 0.0000 & & 0.0000 & $1.932 E-21$ & 0.0000 & $2.609 E-21$ & 0.0000 & & \\
\hline & $0.000 \mathrm{E}+00$ & 0.0000 & $.000 E+00$ & & $0.000 E+00$ & 0.0000 & $0.000 E+00$ & 0.0000 & $0.000 E+00$ & 0.0000 & & \\
\hline & $0.000 E+00$ & & $.000 E+00$ & & & & & & & & & \\
\hline & & & $.000 E+00$ & 0.0000 & & 0.0000 & $0.000 E+00$ & & & & & \\
\hline & & & $190 \mathrm{E}-12$ & & & 0.0000 & $2.257 \mathrm{E}-11$ & 0.0000 & & & & \\
\hline & & & & & & & & & & & & \\
\hline & & & $.000 E+00$ & & & & $E+00$ & & & & & \\
\hline & $0.000 E+00$ & & $O E+O D$ & & $E+00$ & & $E+00$ & & $E+\infty$ & & & \\
\hline & 0.00 & & 700 & & & & $D O E+00$ & & $+\infty 0$ & & & \\
\hline & & & & & & & & & & & & \\
\hline & 6.1 & & & & & & & & & & & \\
\hline & 0.0 & & $E+00$ & & & & $E+\infty$ & & +00 & & & \\
\hline & & & & & & & & & & & & \\
\hline & & & & & & & & & & & & \\
\hline & 0.0 & & $E+00$ & & $E+00$ & 1000 & $E+00$ & & $0 E+00$ & & & \\
\hline & & & & & & & & & & & & \\
\hline & 0.0 & & & & & & & & & & & \\
\hline & & & -20 & & & & & & & & & \\
\hline & & & & & & & & & & & & \\
\hline & 1.2 & & & & & & & & & & & \\
\hline & 7.50 & & $E-25$ & & & & -26 & & & & & \\
\hline & & & & & & & & & & & & \\
\hline & & & & & & & & & & & & \\
\hline & & & $E-25$ & & & & & & & & & \\
\hline & & & & & & & & & & & & \\
\hline & $7.839 E-11$ & 0.0000 & $4.519 E-13$ & 0.0000 & $1.167 E-11$ & 0.0000 & $5.272 E-13$ & 0.0000 & $2.705 E-12$ & 0.00 & $9.473 E-11$ & 0.00 \\
\hline & & & & & & & & & & & & \\
\hline & & & & & & & & & & & & \\
\hline & fiffiffis & & ilfiliff & & fifififi & & 111ถ & & 111MII & & liftifiti & \\
\hline & $4.274 E-07$ & 0.0127 & $7.167 E-09$ & 0.0002 & $1.319 \mathrm{E}-07$ & 0.0039 & $3.242 E-08$ & 0.0010 & $5.626 E-08$ & 0.0017 & $3.370 E-05$ & \\
\hline
\end{tabular}

** Sum of water independent ground, inhalation, plant, meat, milk, soil

and water dependent water, fish, plant, meat, milk pathways

\begin{tabular}{|c|c|}
\hline Attachment & Sheet No. 20 of 52 \\
\hline Originator: S.W. Clark & Date \\
\hline Chk'd By M.W. Perrott & Date \\
\hline $0100 \mathrm{~F}-\mathrm{CA}-\mathrm{V} 0280$ & Rev. No. \\
\hline
\end{tabular}




\section{ATTACHMENT 3}

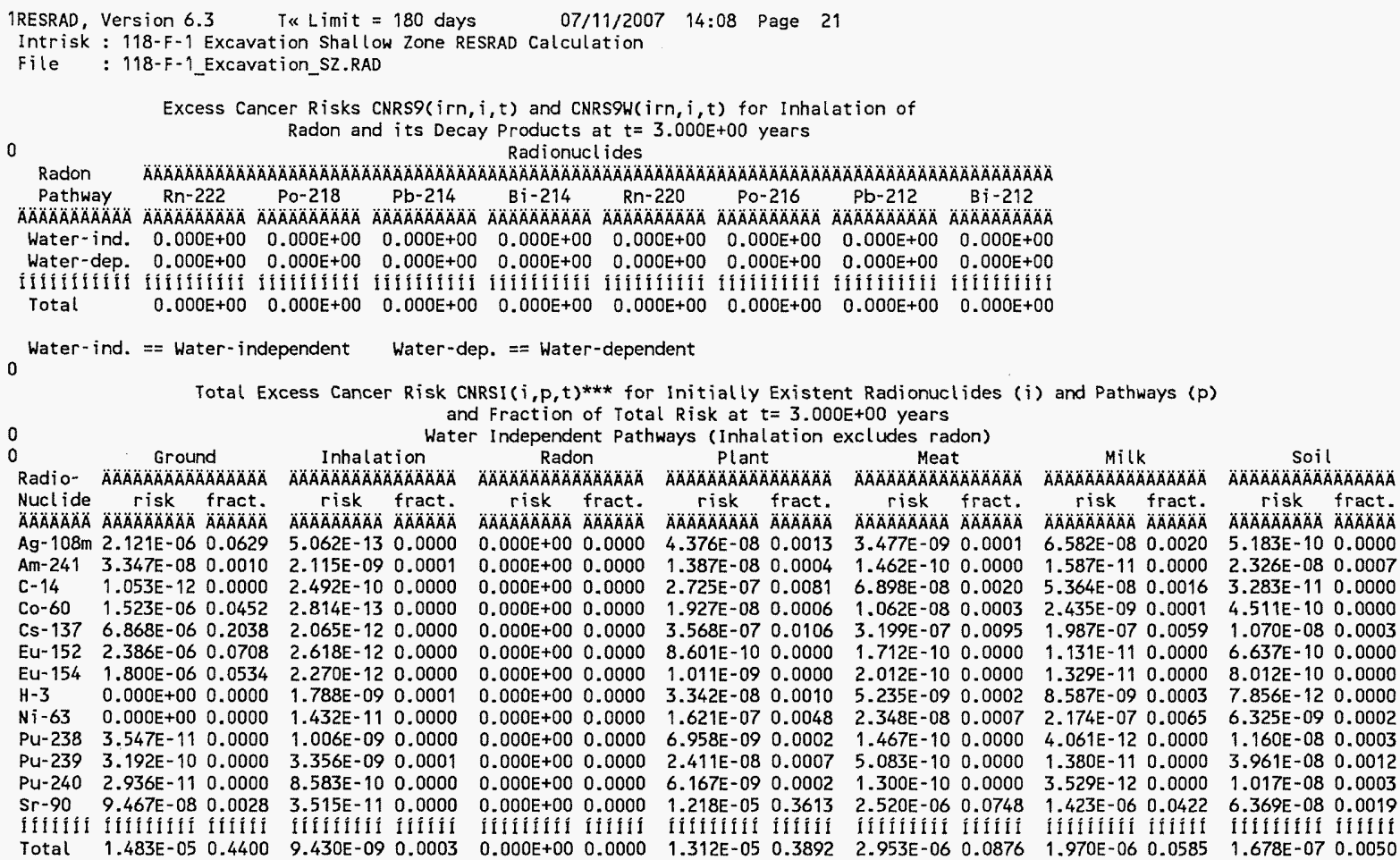




\section{ATTACHMENT 3}

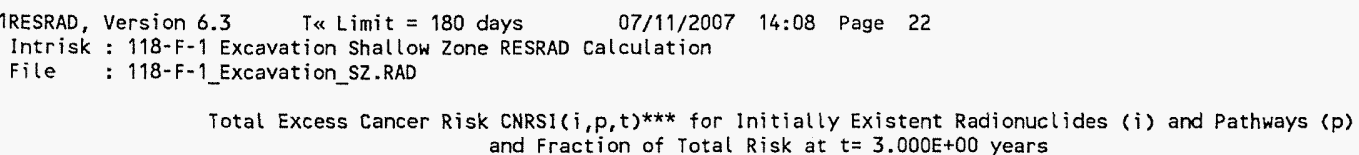

Water Dependent Pathways

\begin{tabular}{|c|c|c|c|c|c|c|c|c|c|c|c|c|c|c|}
\hline \multirow{2}{*}{$\begin{array}{l}\text { Radio- } \\
\text { Nucl ide } \\
\text { ÄÄÄÄÄÄÄ }\end{array}$} & \multicolumn{2}{|c|}{ Water } & \multicolumn{2}{|c|}{ Fish } & \multicolumn{2}{|c|}{ Radon } & \multicolumn{2}{|c|}{ Plant } & \multicolumn{2}{|c|}{ Meat } & \multicolumn{2}{|c|}{ Milk } & \multicolumn{2}{|c|}{$\begin{array}{c}\text { All pathways } \\
A A A B A A A A B A A A B A A A A B A\end{array}$} \\
\hline & 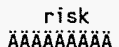 & fract. & sk & fract. & $\begin{array}{l}\text { risk } \\
\text { ASAAAAA }\end{array}$ & fract. & $\begin{array}{l}\text { risk } \\
\text { AÄÄAAAA }\end{array}$ & $\begin{array}{l}\text { fract. } \\
A A B A A B\end{array}$ & $\begin{array}{l}\text { risk } \\
\text { CAABAAOA }\end{array}$ & & $\begin{array}{l}\text { risk } \\
\text { AABAAAOA }\end{array}$ & & $\begin{array}{c}\text { risk } \\
\text { AAAAAAOA }\end{array}$ & \\
\hline & & & & & & & & & & & & & & \\
\hline & & & & & & & & & & & & & & \\
\hline & & & & & & & & & & & & & & \\
\hline & & & & & & & & & & & & & & \\
\hline & & & & & & & & & & & & & & \\
\hline & & & & & & & & & & & & & & \\
\hline & & & & & & & & & & & & & & \\
\hline & & & & & & & & & & & & & & \\
\hline & & & & & & & & & & & & & & \\
\hline & & & & & & & & & & & & & & \\
\hline & & & & & & & & & & & & & & \\
\hline $1=7+2+$ & & & & & $0.000 \mathrm{E}+00$ & & & & & & & & & \\
\hline & & & & & & & & & & & & & & \\
\hline & & & & & & & & & & & & & & \\
\hline & $4 \mathrm{HE}-\mathrm{Ur}$ & & $T=-0 Y$ & 0.0002 & DUOUt+00 & 0.0000 & $\begin{array}{l}.3190-01 \\
0\end{array}$ & 0.0039 & $3 . \angle 4 \angle E-08$ & & $3.020 \mathrm{E}-08$ & 0.0017 & $3.370 E-05$ & \\
\hline
\end{tabular}

***CNRSI $(i, p, t)$ includes contribution from decay daughter radionuclides

\begin{tabular}{|c|c|}
\hline Attachment & Sheet No. 22 of 52 \\
\hline Originator: S.W. Clark & Date \\
\hline hk'd By M.W.Perrott & Date \\
\hline $0100 F-C A-V 0280$ & Rev. No. \\
\hline
\end{tabular}




\section{ATTACHMENT 3}

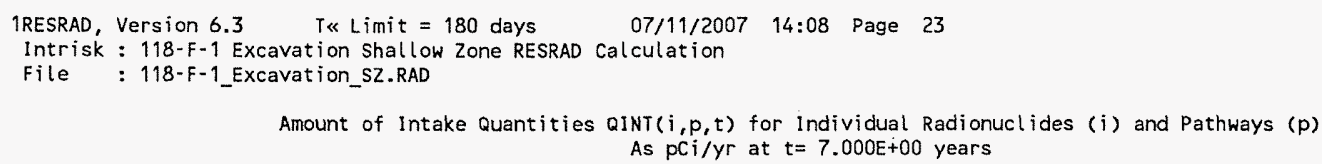

Water Independent Pathways (Inhalation w/o radon)

Water Dependent Pathways

\begin{tabular}{|c|c|c|c|c|c|c|c|c|c|c|c|}
\hline & & & & & & & & & & & \\
\hline & Inhalation & Plant & Meat & Milk & Soil & Water & Fish & $P \operatorname{lant}$ & Meat & Milk & Ingestion* \\
\hline & ÄÄÄÄÄÄÄ & $\triangle A A A A O A O A O A$ & $\triangle A O A A A O A O A ̈ A ̈$ & $\triangle A O A A A A O A O A$ & ÄÄÄÄÄÄÄÄ & $A A A A A B A A B A$ & $\triangle A O A A A B A A B$ & $\triangle A B A A A A A A A ̈$ & I $\triangle A O A O A ̈ A ̈ A ̈ A ̈ A ̈$ & 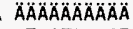 & 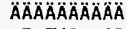 \\
\hline & $1.200 E-16$ & $4.332 E-13$ & $9.504 E-15$ & $2.243 E-15$ & $1.709 E-13$ & $4.606 E-12$ & $8.815 E-14$ & $4.512 E-13$ & $4.165 E-15$ & $3.478 E-15$ & $5.769 E-12$ \\
\hline & $6.708 E-04$ & $1.382 E+02$ & $1.098 E+01$ & $2.079 E+02$ & $9.551 \mathrm{E}-01$ & $0.000 E+00$ & $0.000 E+00$ & $0.000 \mathrm{E}+00$ & $0.000 E+00$ & $0.000 E+00$ & $3.581 E+02$ \\
\hline & $2.554 E-03$ & $3.512 E+00$ & $3.702 E-02$ & $4.019 E-03$ & $3.637 E+00$ & $0.000 E+00$ & $0.000 E+00$ & $0.000 E+00$ & $0.000 E+00$ & $0.000 E+00$ & $7.191 \mathrm{E}+00$ \\
\hline & & & $5.982 E+02$ & $4.651 E+02$ & $2.040 E-01$ & $0.000 E+00$ & $0.000 E+00$ & $0.000 E+00$ & & & \\
\hline & $13 E-04$ & $6.818 E+01$ & $3.759 \mathrm{E}+01$ & $8.614 E+00$ & $8.832 E-01$ & $1.988 \mathrm{E}-01$ & 2.049E-02 & $2.220 \mathrm{E}-02$ & $5.548 \mathrm{E}-02$ & $1.651 E-02$ & $1.156 E+02$ \\
\hline & -03 & $4.023 E+02$ & $3.608 \mathrm{E}+02$ & $2.241 E+02$ & $1.042 E+01$ & $2.347 E+00$ & $1.568 E+00$ & $2.589 E-01$ & $9.811 \mathrm{E}-01$ & $7.788 E-01$ & $1.004 E+03$ \\
\hline & & $5.287 E+00$ & $2 E+00$ & 6.952E-02 & 2. $191 E+00$ & $0.000 E+00$ & $0.000 E+00$ & $0.000 E+00$ & & & \\
\hline & 1.25 & $4.302 E+00$ & $8.562 E-01$ & 5.657E-02 & $1.783 E+00$ & $0.000 E+00$ & $0.000 E+00$ & $0.000 E+00$ & $0.000 E+00$ & $0.000 E+00$ & $998 \mathrm{E}+00$ \\
\hline & 2.32 & $8.000 E-14$ & $92 E-14$ & 4.210E-16 & $3.315 E-14$ & $0.000 \mathrm{E}+00$ & $0.000 E+00$ & $0.000 E+00$ & $0.000 E+00$ & $0.000 E+00$ & $5 E-13$ \\
\hline & & & & & & $6.195 E+05$ & & & & & \\
\hline & & $3 E+03$ & $E+02$ & $49 E+03$ & $1.275 E+02$ & $1.327 E+02$ & $\mathrm{SE}+00$ & $1.476 E+01$ & $8 E+00$ & $E+02$ & +04 \\
\hline & 5.8 & $1.592 E-04$ & $8 E-06$ & $6.526 \mathrm{E}-08$ & $94 E-06$ & $0.000 E+00$ & $O E+D O$ & $0.000 E+00$ & $=+\infty 0$ & $E+00$ & -04 \\
\hline & & $2.324 E-11$ & $\mathrm{DE}-12$ & ?E-14 & 2.4 & $3 E-11$ & E-14 & $1.765 \mathrm{E}-12$ & & $E-14$ & \\
\hline & $2 E-17$ & $5.450 E-13$ & $29 E-14$ & $1.861 \mathrm{E}-14$ & $5.301 E-14$ & $1.555 E-12$ & $3 E-13$ & $7 E-13$ & $=-14$ & $=-14$ & \\
\hline & 1.08 & $1.494 E+00$ & $49 E-02$ & $8.547 E-04$ & $E+\infty$ & $0.000 E+00$ & $E+00$ & $0 E+00$ & $E+00$ & $E+00$ & $E+\infty 0$ \\
\hline & & $4.622 E+00$ & E-02 & E-03 & 4.7 & $0.000 E+00$ & $D E+\infty 0$ & $0.000 E+00$ & $E+\infty$ & $E+00$ & \\
\hline & $5 E-04$ & $1.183 E+00$ & $4 \varepsilon-02$ & $6.769 \mathrm{E}-04$ & $1.225 E+00$ & $0.000 E+00$ & $0.000 E+00$ & $0.000 \mathrm{E}+00$ & $0 E+00$ & $0.000 E+00$ & \\
\hline & 7.1 & 3.8 & $4 E-12$ & $3 E-12$ & 1.0 & $E-12$ & $E-14$ & 4.7 & & $=-13$ & \\
\hline & $7.071 E-21$ & $E-16$ & $1 E-17$ & E-17 & $1.007 E-17$ & $4.150 E-16$ & $3 E-18$ & $4 \mathrm{E}-17$ & $E-18$ & $1.904 E-17$ & \\
\hline & & $9 E+03$ & $1.123 E+03$ & $6.346 E+02$ & $1.876 \mathrm{E}+01$ & $3.084 E+01$ & BE-01 & $1 E+00$ & $9 \mathrm{E}+00$ & $4 E+00$ & \\
\hline & & 9.13 & $15 E-19$ & 4.16 & 4.26 & & & & & & \\
\hline & $1.960 E-17$ & $E-14$ & $6.204 E-16$ & $1 E-17$ & $2.791 \mathrm{E}-14$ & $2.741 E-13$ & $6 E-14$ & $1 E-14$ & $B E-16$ & $1 E-16$ & $8 E-13$ \\
\hline & $7.003 E-13$ & $9.781 E-10$ & $2.136 E-11$ & $3.059 E-12$ & $9.972 E-10$ & $1.247 E-09$ & $4.971 E-11$ & $3.002 E-10$ & $2.001 \mathrm{E}-11$ & $4.022 E-12$ & $3.621 \mathrm{E}-09$ \\
\hline & & $4.275 E-17$ & $9.338 \mathrm{E}-19$ & $1.338 \mathrm{E}-19$ & $4.358 \mathrm{E}-17$ & $1.979 \mathrm{E}-16$ & $8.146 E-18$ & $2.937 \mathrm{E}-17$ & $1.088 \mathrm{E}-18$ & & \\
\hline & $8.875 E-14$ & $3.278 E-10$ & $09 E-11$ & $5.060 \mathrm{E}-11$ & $1.264 E-10$ & $1.262 E-08$ & $4 E-11$ & $1.373 E-09$ & $5.922 E-11$ & $3.125 E-10$ & \\
\hline & & $7.520 \mathrm{E}-05$ & $2.531 E-06$ & $1.187 \mathrm{E}-05$ & $3.126 E-05$ & $4.828 \mathrm{E}-03$ & $2.054 E-05$ & $5.284 E-04$ & $2.324 E-05$ & $1.211 \mathrm{E}-04$ & S \\
\hline & & & $2.646 E-09$ & $1.241 E-08$ & $3.269 E-08$ & $5.001 E-06$ & $2.127 E-08$ & & $2.407 E-08$ & & \\
\hline & & $6.051 E-07$ & $2.036 E-08$ & $9.553 \mathrm{E}-08$ & $2.516 E-07$ & $3.849 \mathrm{E}-05$ & 1.63 E-U? & $4.212 E-06$ & $1852 \mathrm{~F}-0$ & $9.655 \mathrm{E}-07$ & \\
\hline
\end{tabular}

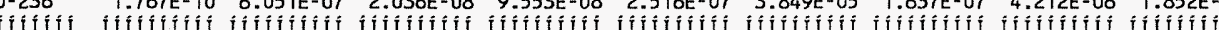

* Sum of all ingestion pathways, i.e. water independent plant, meat, milk, soil and water-dependent water, $f i$ sh, plant, meat, milk pathways

Amount of Intake Quantities QINTP(irn, $i, t)$ and $\operatorname{QINTSW}(i r n, i, t)$ for Inhalation of Radon and $i$ ts Decay Products as $p C i / y r$ at $t=7.000 E+00$ year Radionucl ides

\begin{tabular}{|c|c|c|c|c|c|c|c|c|}
\hline Radon & 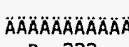 & $\triangle A A A A A A A A A A A A$ & $\triangle A A A A A A A A A A A O A$ & 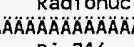 & 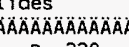 & $\triangle A \cap A B A A A A A A A A$ & $\triangle A A A A A A A A A A A A$ & $\triangle A \cap A O A A A A A A A A A ̈$ \\
\hline Pathway & $R n-222$ & Po-218 & $\mathrm{Pb}-214$ & $\mathrm{Bi}-214$ & $R n-220$ & Po-216 & $\mathrm{Pb}-212$ & Bi-212 \\
\hline A AOAAOAAAAAAA & $\triangle A A A A B A O A O A A$ & $\triangle A A A A A A A A B A B$ & $\triangle A A A A A A A B A B A$ & $\triangle \triangle A O A O A B A B A B A$ & $A O A O A B A A A A A$ & $\triangle A A B A O A A A A A A$ & $\triangle A A A A A A B A B A B$ & 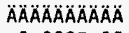 \\
\hline Water-ind. & $0.000 E+00$ & $0.000 E+00$ & $0.000 \mathrm{E}+00$ & $0.000 E+00$ & $0.000 E+00$ & $0.000 E+00$ & $0.000 \mathrm{E}+00$ & $0.000 E+00$ \\
\hline Water-dep. & $0.000 \mathrm{E}+00$ & $0.000 E+00$ & $0.000 E+00$ & $0.000 E+00$ & $0.000 E+00$ & $0.000 \mathrm{E}+00$ & $0.000 E+00$ & $0.000 \mathrm{E}+$ \\
\hline Iflififíti & fílifítif & 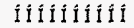 & lifitifiti & fiffiftili & 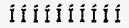 & 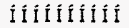 & litilitiolit & İíílílín \\
\hline Total & $0.000 \mathrm{E}+00$ & $0.000 E+00$ & $0.000 E+00$ & $0.000 E+00$ & $0.000 E+00$ & $0.000 E+00$ & $0.000 E+00$ & $0.000 E+00$ \\
\hline
\end{tabular}

Water-ind. = Water-independent Water-dep. == Water-dependent

\begin{tabular}{|c|c|}
\hline Attachment & Sheet No. 23 of $\underline{52}$ \\
\hline Originator: S.W. Clark & Date \\
\hline Chk'd By M.W. Perrott & Date \\
\hline $0100 F-C A-V 0280$ & Rev. No. \\
\hline
\end{tabular}




\section{ATTACHMENT 3}

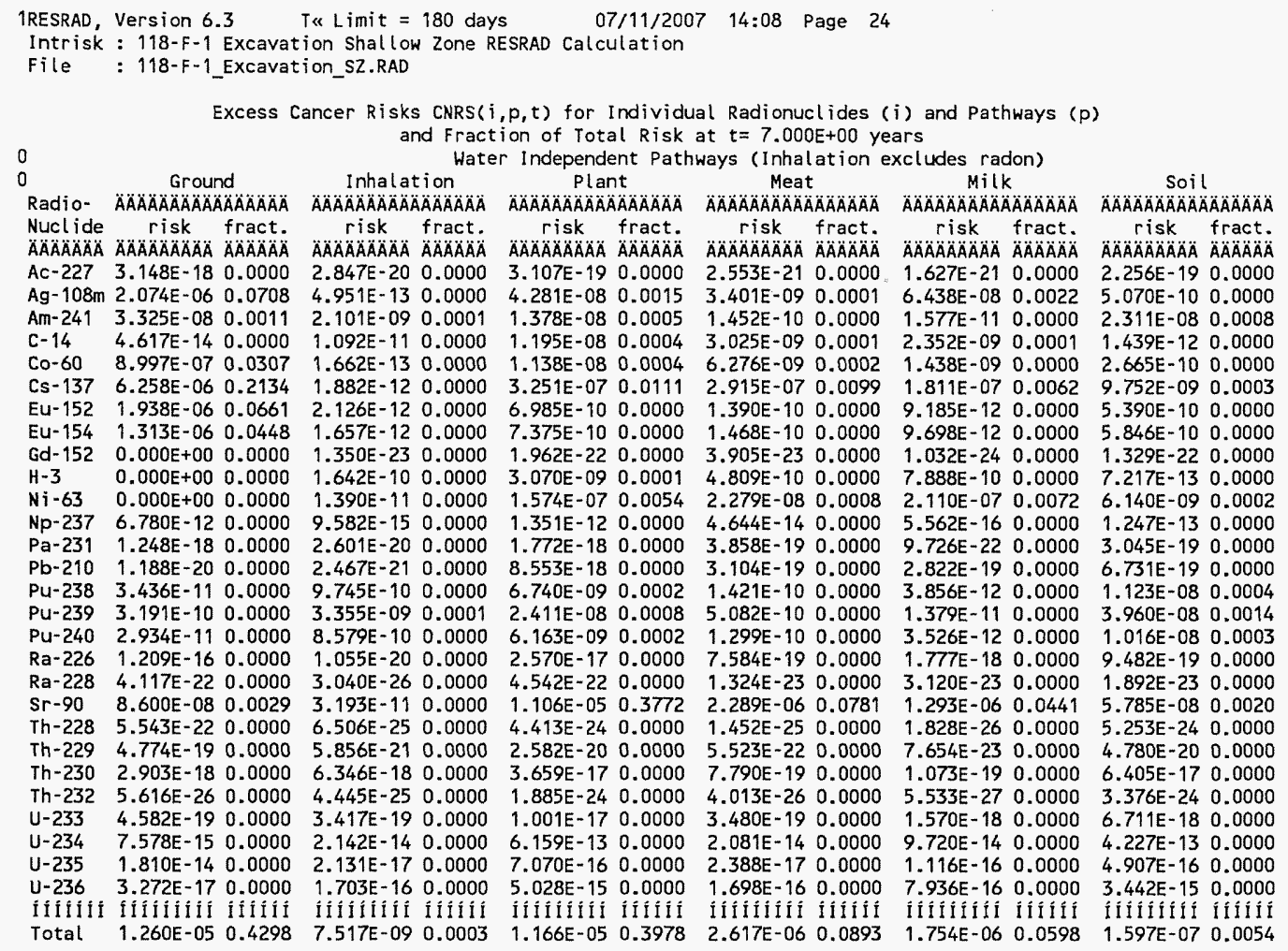

Attachment 3 Originator: S.W. Clark Sheet No. 24 of $\underline{52}$ Chk'd By M W Perrott Date

Calc. No. 0100F-CA-V0280 Rev. No. 0 


\title{
ATTACHMENT 3
}

\author{
1RESRAD, Version 6.3 T« Limit $=180$ days $\quad 07 / 11 / 2007 \quad 14: 08$ Page 25 \\ Intrisk : 118-F-1 Excavation Shallow Zone RESRAD Calculation \\ File: 118-F-1_Excavation_SZ.RAD \\ Excess Cancer Risks CNRS( $i, p, t)$ for Individual Radionuclides (i) and Pathways ( $p$ ) \\ and Fraction of Total Risk at $t=7.000 E+00$ years
}

Water Dependent Pathways

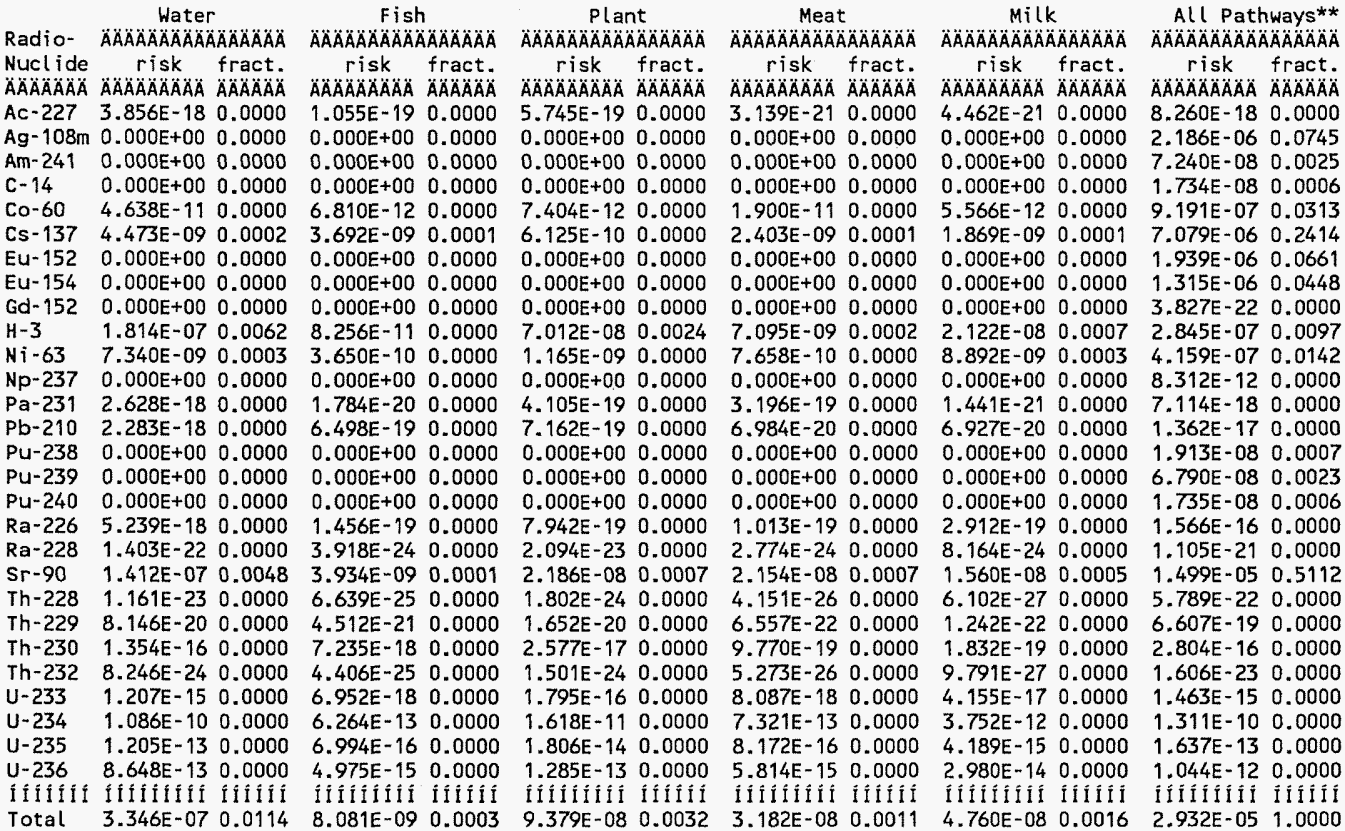

** Sum of water independent ground, inhalation, plant, meat, milk, soil

and water dependent water, fish, plant, meat, milk pathways

\begin{tabular}{|c|c|}
\hline Attachment & Sheet No. 25 of 52 \\
\hline Originator: S.W. Clark & Date ___ \\
\hline Chk'd By M. W. Perrott & Date \\
\hline Calc. No. $\quad 0100 \mathrm{~F}-\mathrm{CA}-\mathrm{V} 0280$ & Rev. No. \\
\hline
\end{tabular}




\section{ATTACHMENT 3}

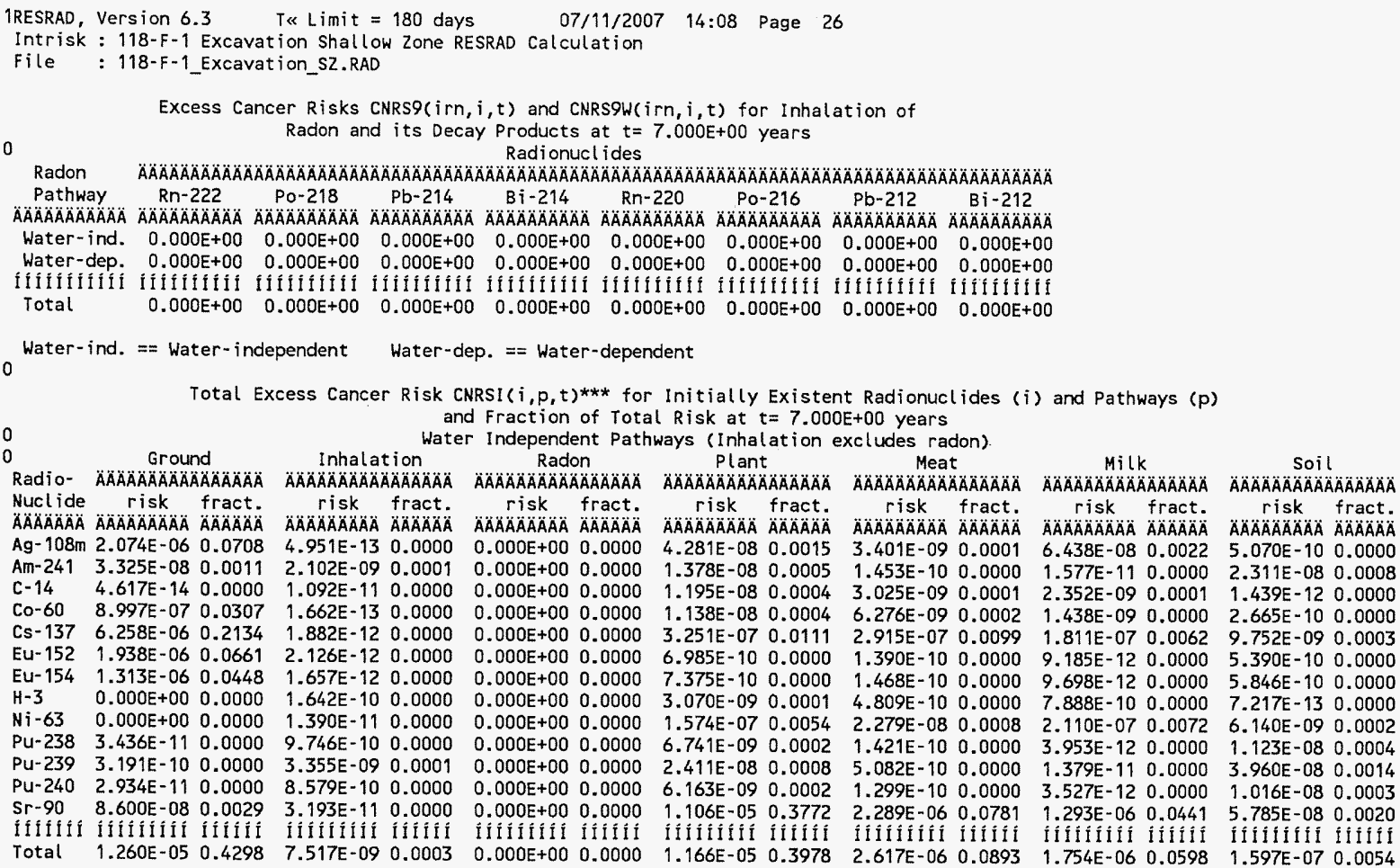

\begin{tabular}{|c|c|}
\hline Attachment & Sheet No. 26 of 52 \\
\hline Originator: $\overline{S . W . \text { Clark }}$ & Date \\
\hline Chk'd By M.W. Perrott & Date \\
\hline $0100 \mathrm{~F}-\mathrm{CA}-\mathrm{V} 0280$ & Rev. No. \\
\hline
\end{tabular}




\section{ATTACHMENT 3}

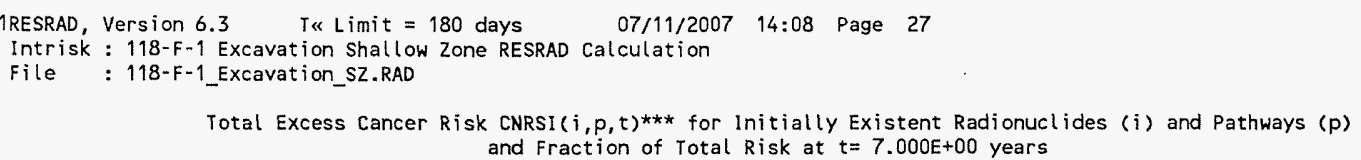

Water Dependent Pathways

\begin{tabular}{|c|c|c|c|c|c|c|c|c|c|c|c|c|c|c|}
\hline \multirow{2}{*}{$\begin{array}{l}\text { Radio- } \\
\text { Nuclide } \\
\text { ÄÄÄÄÄÄÄA }\end{array}$} & \multicolumn{2}{|c|}{ Water } & \multicolumn{2}{|l|}{ Fish } & \multicolumn{2}{|c|}{ Radon } & \multicolumn{2}{|l|}{$P$ lant } & \multicolumn{2}{|l|}{ Meat } & \multicolumn{2}{|l|}{ Milk } & \multicolumn{2}{|c|}{ 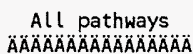 } \\
\hline & risk & $\begin{array}{l}\text { fract. } \\
A B A B A O A O A B\end{array}$ & $\begin{array}{c}\text { risk } \\
\text { AÄÄÄÄÄ }\end{array}$ & $\begin{array}{l}\text { fract. } \\
A B A B A A\end{array}$ & $\begin{array}{c}\text { risK } \\
\text { ÄÄÄAOAAA }\end{array}$ & $\begin{array}{l}\text { fract. } \\
A B A A A A\end{array}$ & $\begin{array}{c}\text { risk } \\
\text { AAAOAAAOAOA }\end{array}$ & $\begin{array}{l}\text { fract. } \\
\text { ÄÄAOAOA }\end{array}$ & $\begin{array}{c}\text { risk } \\
\text { AAÄÄÄÄÄ }\end{array}$ & $\begin{array}{l}\text { frac } \\
A B A A A\end{array}$ & $\begin{array}{c}\text { risk } \\
\text { AAAAAAÄA }\end{array}$ & & $\begin{array}{c}\text { risk } \\
\text { AAAAAAAOÄA }\end{array}$ & \\
\hline$A g-108 m$ & & & & & & & & & & & & & & \\
\hline & & & & & & & & & & & & & & \\
\hline & & & & & & & & & & & & & & \\
\hline & & & & & & & & & & & & & & \\
\hline & 4.4 & & & & & & & & & & & & & \\
\hline & & & & & & & & & & & & & & \\
\hline & & & & & & & & & & & & & & \\
\hline & & & & & & & & & & & & & & \\
\hline & & & & & & & & & & & & & & \\
\hline & $1.086 E-10$ & & & & & & & & & & & & & \\
\hline & & & & & & & & & & & & & & \\
\hline & & & & & & & & & & & & & & \\
\hline & & & & & & & & & & & & & & \\
\hline & & & & & & & & & & & & & & \\
\hline & & & & & & & & & & & & & & \\
\hline
\end{tabular}

$* * * \operatorname{CNRSI}(i, p, t)$ includes contribution from decay daughter radionuclides

Attachment Originator: S.W. Clark Chk'd By M.W. Perrott Calc. No. 0100F-CA-V0280
Sheet No. $\underline{27}$ of $\underline{52}$ Date Date Rev. No. 


\section{ATTACHMENT 3}

\begin{tabular}{|c|c|c|c|c|c|c|c|c|c|c|c|}
\hline \multirow[t]{2}{*}{$\begin{array}{l}\text { 1RESRAD, } \\
\text { Intrisk } \\
\text { file }\end{array}$} & $\begin{array}{l}\text { Version } 6 . \\
: 118-\mathrm{F}-1 \\
: 118-\mathrm{F}-1\end{array}$ & $\begin{array}{l}.3 \\
\text { Excavat } \\
\text { Excavat }\end{array}$ & $\begin{array}{l}\text { T\& Limit = } \\
\text { ion Shallow } \\
\text { ion_SZ.RAD }\end{array}$ & $\begin{array}{l}180 \mathrm{de} \\
\text { Zone }\end{array}$ & RAD Cal & $\begin{array}{l}11 / 200 \\
\text { ation }\end{array}$ & $14: 08$ & Page & & & \\
\hline & \multicolumn{2}{|r|}{ Excess } & \multicolumn{9}{|c|}{$\begin{array}{c}\text { Cancer Risks CNRS }(i, p, t) \text { for Individual Radionuclides }(i) \text { and Pathways }(p) \\
\text { and Fraction of Total Risk at } t=1.100 E+01 \text { years }\end{array}$} \\
\hline & Groun & & Inhalat & tion & Plar & & Mea & & $M i l k$ & & Soil \\
\hline & ÄÄÄÄÄÄÄÄ & ÄÄÄÄÄÄ & $\triangle A O A O A ̈ A ̈ A A A O A$ & AÄÄÄÄÄ & $\triangle A A A A A B A A A$ & $\triangle A ̈ A ̈ A ̈ A ̈ A ̈$ & $\triangle A O A O A ̈ A ̈ A ̈ A ̈$ & AÄÄAAÄÄ & $\triangle A A A A B A A A A A$ & AAÄÄÄÄÄ & $\triangle A A O A A A A B A A A A A A A B A$ \\
\hline $\begin{array}{l}\text { Nuclide } \\
\text { ÄÄÄÄÄÄÄ }\end{array}$ & & $\begin{array}{l}\text { fract. } \\
\not A B A ̈ A ̈ A B A\end{array}$ & 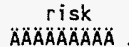 & & & & $\begin{array}{c}\text { risk } \\
A \ddot{A} A B A B A B A\end{array}$ & $\begin{array}{l}\text { fract. } \\
\text { ÄÄÄÄÄÄ }\end{array}$ & $\begin{array}{c}\text { risk } \\
\triangle A ̈ A ̈ A ̈ A B A O A\end{array}$ & $\begin{array}{l}\text { fract. } \\
\ddot{A} A \ddot{A} A \ddot{A} A \dot{A}\end{array}$ & 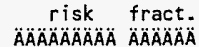 \\
\hline & & 0.0000 & & 0.0000 & & 0.0000 & $3.498 E-21$ & 0.0000 & $2.380 E-21$ & 0.0000 & $3.305 E-190.0$ \\
\hline Ag- & & 0.0783 & & 0.0000 & $7 E-08$ & 0.0016 & $E-09$ & 0.0001 & $8 E-08$ & 0.0024 & $-10 \quad 0.0000$ \\
\hline$A m-2$ & & 0.0013 & -09 & 0.0001 & $9 E-08$ & 0.0005 & 1.44 & 0.0000 & -11 & 0.0000 & -080.0009 \\
\hline$c-14$ & & 0.0000 & & & $2 E-10$ & & & 0.0000 & & 0.0 & 140 \\
\hline $\mathrm{Co}-\mathrm{t}$ & & & 14 & 0.0000 & & 0.0003 & $=-09$ & 0.0001 & 10 & 0.00 & 100.0000 \\
\hline Cs- & & 0.2199 & 12 & 0.0000 & $3 E-07$ & 0.0 & 2.6 & 0.0 & 07 & 0.0 & -090.0 \\
\hline & & 0.0607 & & 0.0 & & 0.0000 & 1.1 & 0.0000 & 12 & 0.0 & -100. \\
\hline & & & & 0.0 & & 0000 & -10 & 0.0000 & 12 & 0.0000 & -100.0 \\
\hline Gd- & & 0.0 & & & & & & 0.00 & 24 & & \\
\hline $\mathrm{H}-3$ & & 0.00 & & & & & 4.4 & 0.0 & 110 & 0. & -140 \\
\hline & & 0.00 & & 0.0000 & & 0.0 & & 0.0009 & $07 \mathrm{c}$ & 0.0 & 090.0002 \\
\hline $\mathrm{Np}-$ & & & & & & & & & & & \\
\hline $\mathrm{Pa}-$ & & 0.0 & & 0.00 & $3 E-18$ & & 5.1 & 0.0000 & -210 & 0 & 190 \\
\hline & & & & & & & & 0.0 & 190 & 00 & 180.0000 \\
\hline Pu- & & & & & & & & & & & \\
\hline & & 0.00 & & 0.00 & -08 & 009 & 5.0 & 0.0000 & 110 & 0 & 080 \\
\hline $\mathrm{Pu}^{-2}$ & & & & 0.0 & & 02 & & 0.0000 & -120 & 0.0 & .080 .0004 \\
\hline & & 0.00 & & & & & & 0.0 & & & 180. \\
\hline Ra- & & & & 0.00 & $6.422 E-22$ & & 1.8 & 0.0 & $=-23 c$ & 0.0 & \\
\hline & & & & 0.00 & $1.005 E-05$ & 74 & & 0.0 & $.06 \mathrm{c}-2 \mathrm{c}-\mathrm{s}$ & 0.0 & .080 .0020 \\
\hline Th-228 & $8.046 \mathrm{E}-$ & & & 0.0000 & $6.339 E-24$ & 0.0000 & & 0.0000 & $2.614 \mathrm{E}$ & 0.0 & .240. \\
\hline & & & & & $E-20$ & & 8.2 & & $E-22$ & 0.00 & \\
\hline & & & & & $57 E-17$ & & & & $1.420 \mathrm{E}-19$ & 0.0 & -170.0 \\
\hline Th-232 & $7.521 \mathrm{E}-26$ & 0.0000 & $5.952 E-25$ & 0.0000 & $2.524 E-24$ & 0.0000 & $5.367 \mathrm{E}-26$ & 0.0000 & $7.382 E-27$ & 0.0000 & $4.522 E-24 \quad 0.0000$ \\
\hline & & & & & $1.336 E-17$ & & & & $2.096 \mathrm{E}-18$ & & $8.972 E-18 \quad 0.0000$ \\
\hline & & & & & $7.148 E-13$ & & & & $1.128 \mathrm{E}-13$ & 0.00 & 130.0 \\
\hline$u-235$ & $2.128 E-14$ & 0.0000 & $2.506 E-17$ & 0.0000 & $8.316 E-16$ & 0.0000 & $O E-17$ & 0.0000 & $1.312 E-16$ & 0.0000 & $5.771 E-16 \quad 0.0000$ \\
\hline & & & & & & & & & & & \\
\hline & & & & & & & & 111 & İ́líl & & Iffif ififíl \\
\hline & $1.091 \mathrm{E}-05$ & 0.4207 & $7.307 \mathrm{E}-09$ & 0.0003 & $1.060 E-05$ & 0.4086 & $2.375 \mathrm{E}-06$ & 0.0916 & $1.608 \mathrm{E}-06$ & 0.0620 & $1.525 \mathrm{E}-07 \quad 0.0059$ \\
\hline
\end{tabular}

\begin{tabular}{|c|c|}
\hline Attachment $\quad 3$ & Sheet No. $\underline{29}$ of $\underline{52}$ \\
\hline Originator: S.W. Clark & Date \\
\hline M. W. Perrott & Date \\
\hline $0100 F-C A-V 0280$ & Rev. No. \\
\hline
\end{tabular}




\section{ATTACHMENT 3}

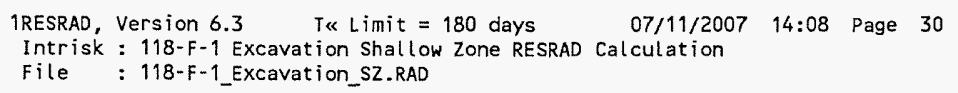

Water Dependent Pathways

\begin{tabular}{|c|c|c|c|c|c|c|c|c|c|c|c|c|}
\hline \multirow{2}{*}{ 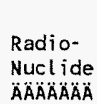 } & \multicolumn{2}{|c|}{ 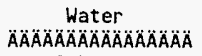 } & \multicolumn{2}{|c|}{ 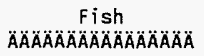 } & \multicolumn{2}{|c|}{$\begin{array}{c}P \text { lant } \\
\text { A } \\
\text { A }\end{array}$} & \multicolumn{2}{|c|}{$\begin{array}{c}\text { Meat } \\
\text { ÄÄÄÄÄÄÄÄÄÄÄÄ }\end{array}$} & \multicolumn{2}{|c|}{ 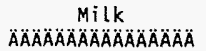 } & \multicolumn{2}{|c|}{ 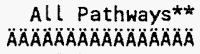 } \\
\hline & $\triangle A A B A A B A B A A O A$ & $\begin{array}{l}\text { fract. } \\
\triangle A O A O A O A B A\end{array}$ & 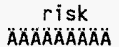 & $\begin{array}{l}\text { fract. } \\
\ddot{A} \ddot{A} \ddot{A} A \ddot{A} \bar{A}\end{array}$ & $\begin{array}{c}\text { risk } \\
\text { ÄÄÄÄÄÄÄÄ }\end{array}$ & $\begin{array}{l}\text { fract. } \\
\text { ÄÄÄÄÄ }\end{array}$ & $\begin{array}{c}r i s k \\
\triangle A \cap A O A O A B A A O A \\
\end{array}$ & 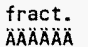 & $\begin{array}{c}\text { risk } \\
\triangle A \cap A O A O A B A ̈ A ̈ A ̈\end{array}$ & 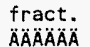 & $\begin{array}{c}\text { risk } \\
\triangle A B A A O A O A B A\end{array}$ & 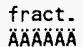 \\
\hline Ac -227 & & 0.0000 & $1.734 \mathrm{E}-19$ & 0.0000 & $9.378 \mathrm{E}-19$ & 0.0000 & $4.823 \mathrm{E}-21$ & 0.0000 & & 0.0000 & & 0.0000 \\
\hline$g-108 m$ & $0.000 E+00$ & 0.0000 & $0.000 E+00$ & 0.0000 & $0.000 E+00$ & 0.0000 & $0.000 E+00$ & 0.0000 & $0.000 E+00$ & 0.0000 & $2.138 \mathrm{E}-06$ & 0.0824 \\
\hline & & & $0.000 E+00$ & 0.0000 & $0.000 E+00$ & 0.0000 & $0.000 E+00$ & 0.0000 & $0.000 E+00$ & 0.0000 & $7.193 \mathrm{E}-08$ & 0.0028 \\
\hline & & 0.0000 & $0.000 E+00$ & 0.0000 & $.000 E+00$ & 0.0000 & $0.000 E+00$ & 0.0000 & $0.000 E+00$ & 0.0000 & $7.578 E-10$ & 0.0000 \\
\hline & & 0.0000 & $5.188 E-12$ & 0.0000 & $5.645 E-12$ & 0.0000 & $1.457 \mathrm{E}-11$ & 0.0000 & $4.254 E-12$ & 0.0000 & $5.429 \mathrm{E}-07$ & 0.0209 \\
\hline & & & 4.0328 & 0.0002 & $6.690 \mathrm{E}-10$ & 0.0000 & $2.632 E-09$ & 0.0001 & $E-09$ & 0.0001 & & 0.2489 \\
\hline & & & & & $.000 E+00$ & 0.0000 & $0.000 E+00$ & 0.0000 & & 0000 & & \\
\hline & $0.000 E+00$ & 0.0000 & $0.000 E+00$ & 0.0000 & $0.000 E+00$ & 0.0000 & $0.000 E+00$ & 0.0000 & $0.000 E+00$ & 0.0000 & $E-07$ & 0.0370 \\
\hline & $E+00$ & & $0.000 \mathrm{E}+00$ & 0.0000 & $0.000 \mathrm{E}+00$ & 0000 & $0.000 E+00$ & 0.0000 & $0.000 E+00$ & .0000 & -22 & 0.0000 \\
\hline$y-3$ & & & & & & .0002 & & & & & & 0.0010 \\
\hline & 8.4 & & 4.2 & & 1.34 & 0.0001 & & & & & IE-07 & 0.0157 \\
\hline$p-237$ & $E+00$ & 0.0 & $0.000 E+00$ & 0. & $0.000 E+00$ & 0000 & $0.000 E+00$ & 0.0000 & $0.000 \mathrm{E}+00$ & 000 & 9.796 & .0000 \\
\hline & & & & & & 000 & & & & & & 1000 \\
\hline & & & 1.1 & & & & & & & & -17 & 0000 \\
\hline$u-238$ & $E+00$ & 0.0000 & $0.000 E+00$ & 0.0000 & $0.000 E+00$ & 0000 & $0.000 E+00$ & .0000 & $0.000 E+00$ & 000 & $3 E-08$ & 0007 \\
\hline & & & $+\infty$ & & $.000 E+00$ & 0000 & $E+00$ & 1000 & $0.000 E+00$ & 0000 & .08 & .0026 \\
\hline & & & & & 0.00 & & $E+\infty 0$ & & +00 & & & 007 \\
\hline & & & & & $7 E-18$ & 000 & 1. & & & 000 & & 000 \\
\hline & & & & & & 1000 & & & & & & 1000 \\
\hline $\mathrm{sr}-90$ & 1.53 & 0.0 & 4.28 & 0.0 & 2.38 & 109 & $=-08$ & 0.0009 & $E-08$ & 0.0007 & -05 & 0.5265 \\
\hline & $1.475 E-23$ & & & & 2.29 & & 5. & & $=-27$ & & & 000 \\
\hline & & 0.0000 & $E-21$ & & $2.602 E-20$ & 0.0000 & & & $E-22$ & & & 0.0000 \\
\hline Th-230 & & 0.0000 & $1.075 E-17$ & 0.0000 & $3.730 \mathrm{E}-17$ & 0.0000 & $1.341 E-18$ & 0.0000 & $2.494 \mathrm{E}-19$ & 0.0000 & $3.978 E-16$ & 0.0000 \\
\hline & & & $6.002 E-25$ & & $2.049 E-24$ & & $7.089 E-26$ & & $1.310 \mathrm{E}-26$ & & & 0.0000 \\
\hline & & & $1.040 \mathrm{E}-17$ & & & 0000 & & & $24 E-17$ & & $6 E-15$ & 0.0000 \\
\hline$U-234$ & $1.443 E-10$ & & $8.321 \mathrm{E}-13$ & 0.0000 & $2.150 E-11$ & 0.0000 & $9.740 E-13$ & 0.0000 & $4.988 E-12$ & 0.0000 & $1.739 \mathrm{E}-10$ & 0.0000 \\
\hline & & & $9.368 E-16$ & & $2.420 \mathrm{E}-14$ & & $1.096 \mathrm{E}-15$ & & $5.615 E-15$ & & & 0.0000 \\
\hline & & & & & $1.721 E-13$ & & & & $3.994 \mathrm{E}-14$ & & & 0.0000 \\
\hline & 11日月⿺ & & Iffifiti & IIIII & IfIEAlfít & fififi & fififift & $M \Pi \Pi$ & Ifififfí & IIIfif & IIYIXYYî̉î & ffifif \\
\hline Total & $1.839 E-07$ & 0.0071 & $8.749 \mathrm{E}-09$ & 0.0003 & $3.231 \mathrm{E}-08$ & 0.0012 & $2.768 E-08$ & 0.0011 & $3.127 \mathrm{E}-08$ & 0.0012 & $2.593 E-05$ & 1.0000 \\
\hline
\end{tabular}

** Sum of water independent ground, inhalation, plant, meat, milk, soil

and water dependent water, fish, plant, meat, milk pathways

\begin{tabular}{|c|c|}
\hline Attachment & Sheet No. $\underline{30}$ of $\underline{52}$ \\
\hline Originator: S.W. Clark & Date \\
\hline Chk'd By M.W. Perrott & Date \\
\hline $0100 F-C A-V 0280$ & Rev. No. \\
\hline
\end{tabular}




\section{ATTACHMENT 3}

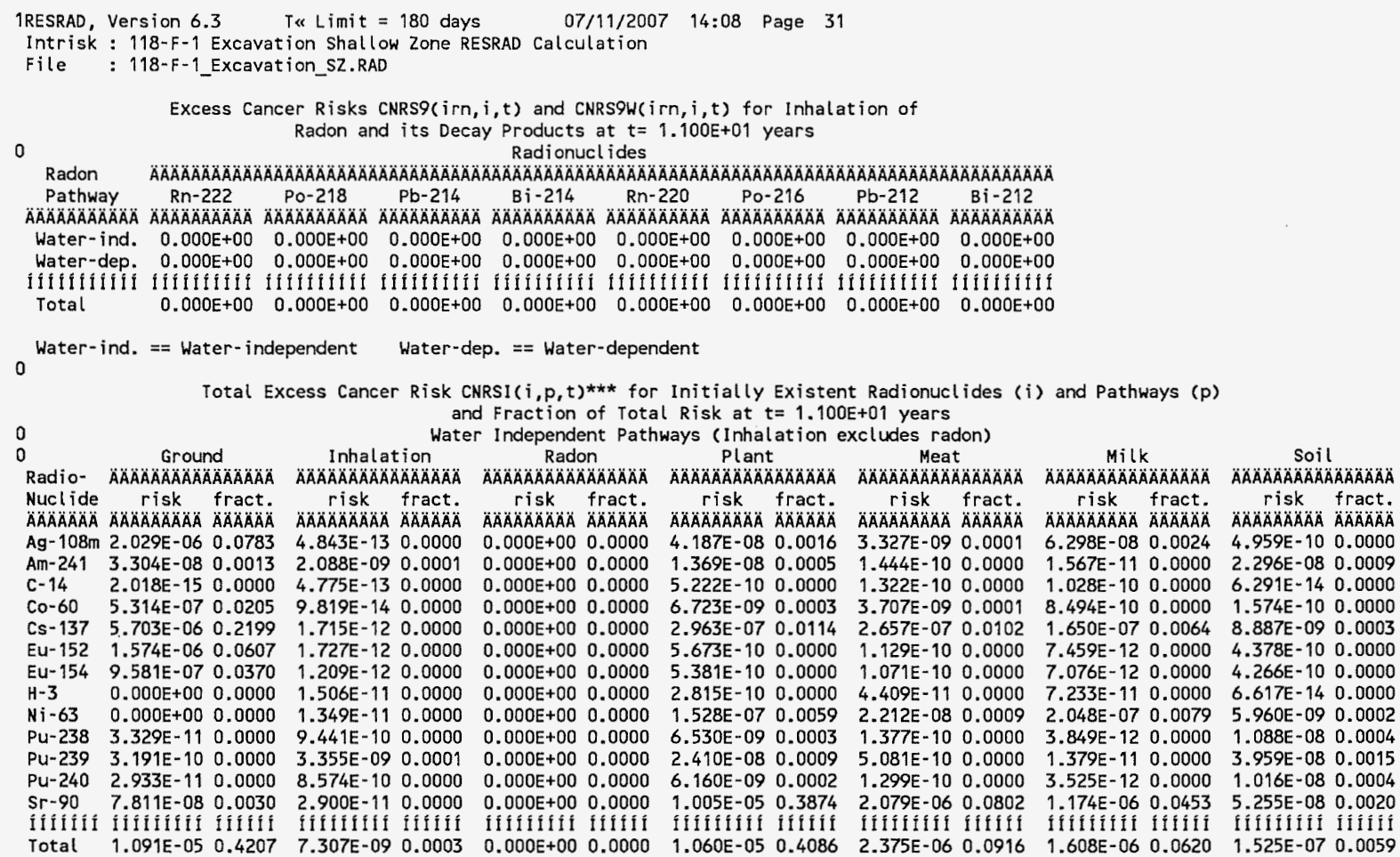

\begin{tabular}{|c|c|}
\hline \multirow{2}{*}{\multicolumn{2}{|c|}{$\begin{array}{l}\text { Attachment } \frac{3}{\text { Originator: S.W. Clark }} \text { Sheet No. } 31 \text { of } \underline{52} \\
\text { Date }\end{array}$}} \\
\hline & \\
\hline Chk'd By M.W. Perrott & Date \\
\hline $0100 F-C A-V 0280$ & Rev. No. \\
\hline
\end{tabular}




\section{ATTACHMENT 3}

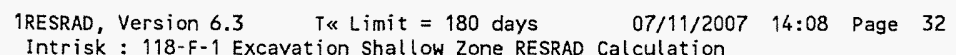

Water Dependent Pathways

\begin{tabular}{|c|c|c|c|c|c|c|c|c|c|c|c|c|c|}
\hline & $\begin{array}{r}\text { Wate } \\
\text { ÄÄÄÄÄÄÄÄ }\end{array}$ & $\triangle A ̈ A ̈ A \cap A ̈ A ̈$ & $\begin{aligned} F i s ! \\
A A A A A ̈ A ̈ A ̈ A\end{aligned}$ & A & 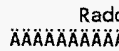 & ÄÄAOAAOA & $\begin{array}{r}\text { Plan } \\
\text { ÄAAOÄÄÄÄ }\end{array}$ & A & $\begin{array}{r}\mathrm{Mea} \\
\text { ÄAÄAÄÄ̈ }\end{array}$ & AAOAAAOAOA & $\begin{array}{r}M i l \\
\text { MÄÄÄÄÄÄ }\end{array}$ & 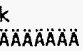 & $\begin{array}{c}\text { All pathways } \\
\text { ÄAAAAAAAAAAAAAAAOA }\end{array}$ \\
\hline $\begin{array}{l}\text { UCl ide } \\
\ddot{A} A ̈ A ̈ A ̈ A ̈ A ̈ A\end{array}$ & $\begin{array}{c}r i s K \\
\triangle A \cap A O A B A B A B A B\end{array}$ & & $\begin{array}{c}r i s k \\
\triangle A B A B A O A O A O A\end{array}$ & 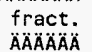 & $\begin{array}{c}\text { risk } \\
\text { ÁÄÄÄÄÄA }\end{array}$ & & $\begin{array}{c}\text { risk } \\
\triangle A B A B A ̈ A B A B A\end{array}$ & & 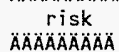 & & $\begin{array}{c}r i s k \\
M A O A B A O A O A O A\end{array}$ & & 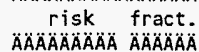 \\
\hline & & & & & & & & & & & & & \\
\hline & & & & & & & & & & & & & \\
\hline & & & & & & & & & & & & & \\
\hline & & & & & & & & & & & & & \\
\hline & & & & & & & & & & & & & \\
\hline & 0.0 & & & & & & & & & & & & \\
\hline & & & & & & & & & & & & & \\
\hline & & & & & & & & & & & & & \\
\hline & & & & & & & & & & & & & \\
\hline & & & & & & & & & & & & & \\
\hline & & & & & 00 & & & & & & & & \\
\hline & & & & & & & & & & & & & \\
\hline & & & & & & & & & & & & & \\
\hline & & & & & & & & & & & & & \\
\hline & & & $8.749 \mathrm{E}-09$ & & $0.000 E+00$ & & $3.2315-00$ & & $2.100 c-00$ & & $3.127 \mathrm{E}-08$ & 0.0012 & \\
\hline
\end{tabular}

***CNRSI $(i, p, t)$ includes contribution from decay daughter radionuclides

$\begin{array}{ll}\text { Attachment } \frac{3}{\text { S.W. Clark }} & \text { Sheet No. } \underline{32} \text { of } \underline{52} \\ \text { Originator: } & \text { Date } \\ \text { Chk'd By } & \text { Date } \\ \text { Calc. No. N. Perrott } & \text { Rev. No. } \frac{0}{0100 \text { F-CA-V0280 }}\end{array}$




\section{ATTACHMENT 3}

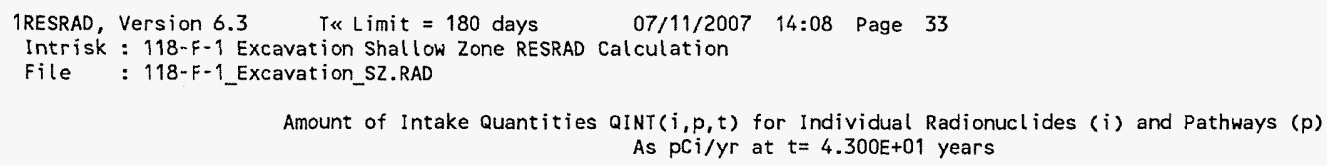
Radionuclides

\begin{tabular}{|c|c|c|c|c|c|c|c|c|}
\hline & & & & & & & & \\
\hline & & & & & & & -212 & \\
\hline 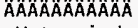 & 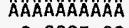 & $\triangle A O A O A ̈ A ̈ A A A O A$ & ÄÄÄÄÄÄÄ & ÄÄÄÄÄÄÄÄ & ÄÄÄÄÄÄÄÄ & $\triangle A A B A A A A A A A A B$ & $\triangle A O A A A B A A A B A ̈$ & $A ̈ A \cap A ̈ A$ \\
\hline Water-ind. & $0.000 E+00$ & $0.000 E+00$ & $0.000 E+00$ & $0.000 E+00$ & $0.000 E+00$ & $O E+00$ & $0.000 E \div 00$ & 0.0 \\
\hline $\begin{array}{l}\text { Water-d } \\
\text { Iif iffif }\end{array}$ & $\begin{array}{r}0.000 E+00 \\
\text { Sîlifiti }\end{array}$ & $\begin{array}{r}0.000 E+00 \\
\text { Ifififitit }\end{array}$ & 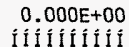 & $\begin{array}{r}0.000 E+00 \\
\text { IIIIIIIIII }\end{array}$ & 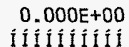 & $\begin{array}{r}0.000 E+00 \\
\text { IIIIIIIII }\end{array}$ & $\begin{array}{r}0.000 E+00 \\
\text { IIIIIIIII }\end{array}$ & $\begin{array}{l}0.000 E+00 \\
\text { Iitifitit }\end{array}$ \\
\hline & $0.000 E+00$ & $0.000 E+00$ & $0.000 E+00$ & $0.000 E+00$ & $0.000 E+00$ & $0.000 \mathrm{E}+00$ & $0.000 \mathrm{E}+00$ & $0.000 \mathrm{E}$ \\
\hline
\end{tabular}

Water-ind. == Water-independent Water-dep. == Water-dependent

$\begin{array}{ll}\text { Attachment } \frac{3}{\text { S.W. Clark }} & \text { Sheet No. } \underline{33} \text { of } \underline{52} \\ \text { Originator: } & \text { Date } \\ \text { Chk'd By } & \text { Date } \\ \text { Calc. No. Nerrott } & \text { Rev. No. } \quad 0\end{array}$


Rev. 0

\section{ATTACHMENT 3}

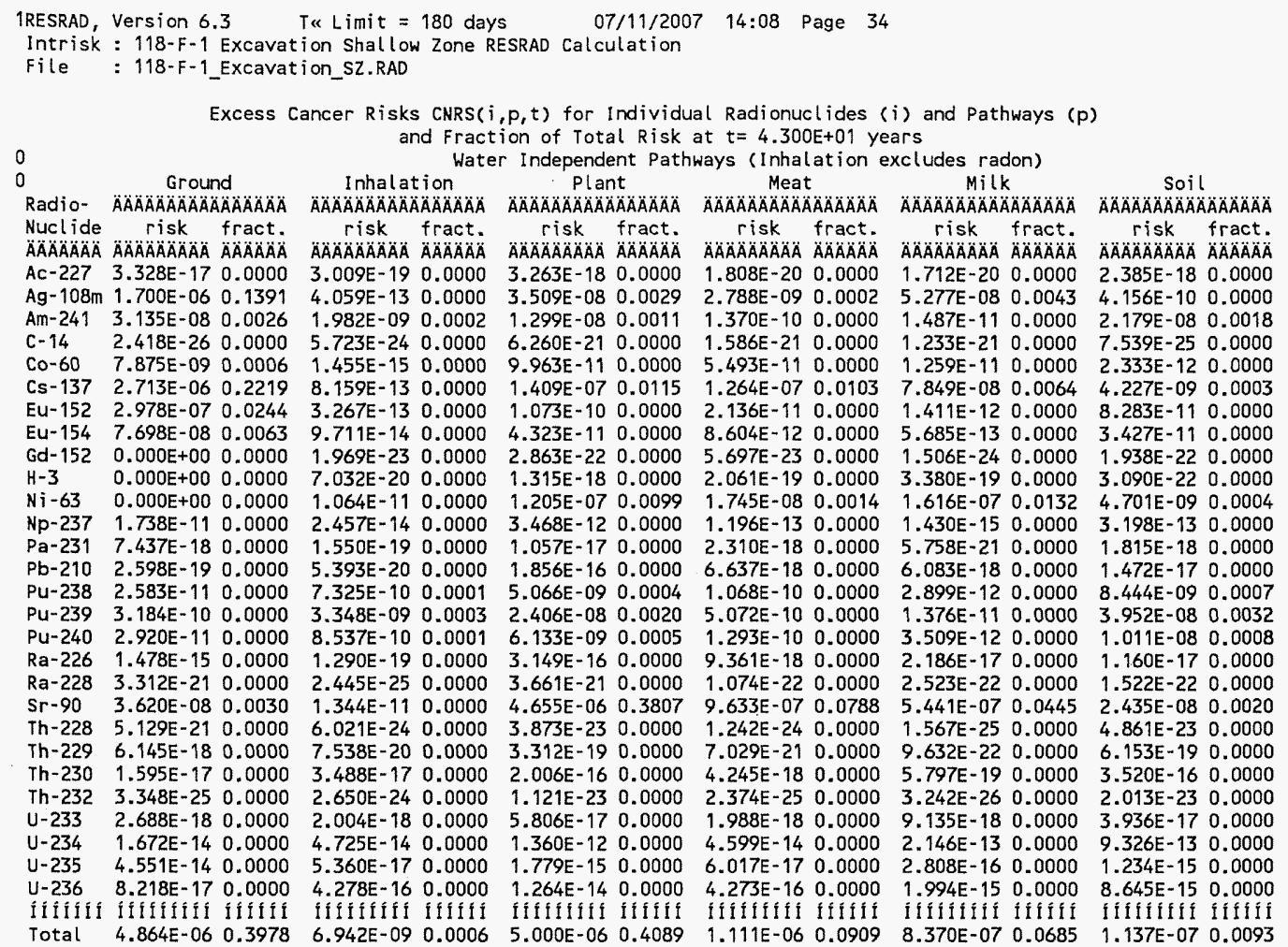




\section{ATTACHMENT 3}

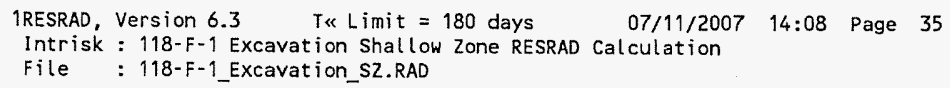

Water Dependent Pathways

\begin{tabular}{|c|c|c|c|c|c|c|c|c|c|c|c|c|}
\hline & $\begin{array}{r}\text { Water } \\
\text { ÄAOAAAOAOAOAO }\end{array}$ & ÖÄÄÄÄÄÄ & $\begin{array}{r}F i s h \\
\text { ÄÄAAAAÄÄÄ }\end{array}$ & $\triangle A B A B A O A B$ & 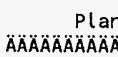 & 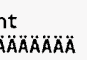 & $\begin{array}{r}\text { Mea } \\
\triangle A \cap A O A A A A A A A\end{array}$ & ÄÄÄÄÄA & $\begin{array}{r}M i l k \\
\text { ÄÄAAAAOÄÄA }\end{array}$ & $\triangle A A A A O A O A B$ & $\begin{array}{r}\text { All Path } \\
A A B A A A B A B A B A\end{array}$ & $\begin{array}{l}\text { hways*** } \\
A B A A A O A B A\end{array}$ \\
\hline $\begin{array}{l}\text { Nucl ide } \\
A \text { ÄAAAOÄÄ }\end{array}$ & $\begin{array}{c}\text { risk } \\
A A A A A A A A A\end{array}$ & 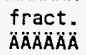 & $\begin{array}{c}\text { risk } \\
\triangle A \cap A ̈ A ̈ A ̈ A ̈ A ̈ A\end{array}$ & $\begin{array}{l}\text { fract. } \\
A B A B A B A B\end{array}$ & $\begin{array}{c}\text { risk } \\
A A B A A A A A A\end{array}$ & fract. & $\begin{array}{c}\text { risk } \\
\text { AAÄAAÄÄÄ }\end{array}$ & $\begin{array}{l}\text { fract. } \\
A O A O A O A O\end{array}$ & $\begin{array}{c}\text { risk } \\
\text { ÄAAAAAAAB }\end{array}$ & $\begin{array}{l}\text { fract. } \\
\text { ÄAAAAÄ }\end{array}$ & $\begin{array}{c}r \text { ISK } \\
\text { ÄÄÄÄÄÄÄ }\end{array}$ & $\begin{array}{l}\text { fract. } \\
A O A A A B A\end{array}$ \\
\hline$A c-227$ & $8.731 \mathrm{E}-17$ & 0.0000 & $2.385 E-18$ & 0.0000 & $1.295 E-17$ & 0.0000 & $5.307 \mathrm{E}-20$ & 0.0000 & $1.002 E-19$ & 0.0000 & $1.421 \mathrm{E}-16$ & 0.0000 \\
\hline & & & $0.000 E+00$ & 0.0000 & $0.000 E+00$ & 0.0000 & $0.000 E+00$ & 0.0000 & $0.000 E+00$ & 0.0000 & $1.791 \mathrm{E}-06$ & 0.1465 \\
\hline & $0.000 \mathrm{E}+00$ & 0.0000 & $0.000 E+00$ & 0.0000 & $.000 E+00$ & 0.0000 & $0.000 E+00$ & 0.0000 & $0.000 E+00$ & 0.0000 & & 0.0056 \\
\hline & $0.000 E+00$ & 0.0000 & $0.000 E+00$ & 0.0000 & $.000 E+00$ & 0.0000 & $0.000 E+00$ & 0.0000 & $0.000 E+00$ & 0.0000 & & 0000 \\
\hline & & 0.0000 & $E-13$ & 0.0000 & $348 E-13$ & 0.0000 & $6.139 E-13$ & 0.0000 & $1.779 E-13$ & 0.0000 & $8.047 \mathrm{E}-09$ & 0.0007 \\
\hline & & & & 0.0004 & $411 E-10$ & 0.0001 & $2.940 E-09$ & 0.0002 & $2.272 E-09$ & 0.0002 & $3.078 E-06$ & 0.2518 \\
\hline & & & & & & & & & $0.000 E+00$ & 0.0000 & & \\
\hline $1-1$ & $000 E+00$ & 0.0000 & $0,000 E+00$ & 0.0000 & $0.000 \mathrm{E}+00$ & 0.0000 & $0.000 E+00$ & 0.0000 & $0.000 E+00$ & 0.0000 & & \\
\hline & $O E+0 O$ & 0.0000 & $0.000 E+00$ & 0.0000 & $.000 \mathrm{E}+00$ & 0.0000 & $0.000 E+00$ & 0000 & $0.000 E+00$ & 0.0000 & -22 & \\
\hline & & & & & & 0.0000 & $E-18$ & 0.0000 & $9.497 E-18$ & 0.0000 & -16 & 0000 \\
\hline & $E-08$ & & & & & 002 & & & & 015 & & \\
\hline 237 & $.000 E+00$ & 0.0000 & $0.000 E+00$ & 0.0000 & $0.000 E+00$ & 0.0000 & $E+\infty$ & & $E+00$ & 000 & & \\
\hline & & & 2.2 & 0.0 & & 0.0000 & & & 1.37 & 000 & & \\
\hline & & & & & & & & & & 000 & & \\
\hline $1-238$ & $.000 E+00$ & 0.0000 & $0.000 E+00$ & 0.0000 & $0 E+00$ & 0.0000 & & & $E+00$ & 0.0000 & $E-08$ & 0.0012 \\
\hline & & 0.0 & $0.000 E+00$ & 0.0000 & $.000 E+00$ & 0.0000 & $0.000 E+00$ & 0. & $E+00$ & 000 & & 555 \\
\hline & & & & & +00 & 000 & $+\infty$ & 0.0 & -00 & 0.0000 & -08 & 001 \\
\hline & & & & & & & & 0.0 & $76 E-18$ & 0.0000 & -15 & 0.0000 \\
\hline & $E-2$ & & $5 E-23$ & 0.0000 & $4 E-22$ & 000 & -23 & & & & & 0 \\
\hline & & 0.0 & -09 & 0.0004 & & 0.0021 & -08 & 0.0 & $E-08$ & 015 & & \\
\hline & & & $E-24$ & 0.0 & $83 E-23$ & & & 0.0 & & 000 & & 0000 \\
\hline & -18 & 0.00 & $4 E-19$ & & E-19 & & & 0.0 & $E-21$ & 0.0000 & $7 E-18$ & 000 \\
\hline & $=-15$ & 0.0000 & $4 E-17$ & 0.0 & $707 E-16$ & & -18 & & & & & \\
\hline & & & DE-24 & 0.0 & $490 E-23$ & & & & & & & \\
\hline & $E-1$ & & & 0.0000 & & 0.0000 & $1.051 \mathrm{E}-16$ & & $5.373 E-16$ & 0.0000 & & 0.0000 \\
\hline & & & $430 \mathrm{E}-12$ & & 1 & & & & & & $7.138 E-10$ & 0.0001 \\
\hline & & & & & & & & & & & & \\
\hline & & & & & & & & & & & & \\
\hline & & & & & & & & 11111 & fílififífí & 11111 & 111101 & 11111 \\
\hline & & & & & & & & & & & & \\
\hline
\end{tabular}

** Sum of water independent ground, inhalation, plant, meat, milk, soil

and water dependent water, fish, plant, meat, milk pathways

\begin{tabular}{|c|c|}
\hline Attachment $\quad 3$ & Sheet No. $\underline{35}$ of $\underline{52}$ \\
\hline Originator: S.W. Clark & Date \\
\hline Chk'd By M.W.Perrott & Date \\
\hline 0100F-CA-V0280 & Rev. No. \\
\hline
\end{tabular}




\section{ATTACHMENT 3}

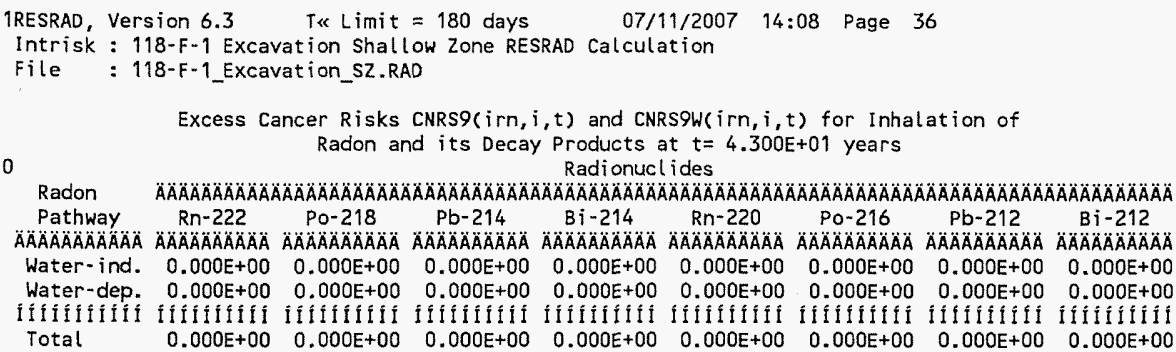

\begin{tabular}{|c|c|}
\hline \multicolumn{2}{|c|}{ Attachment $\frac{3}{2}$ Sheet No. $\underline{36}$ of $\underline{52}$} \\
\hline Originator: S.W. Clark & \\
\hline Chk'd By M.W. Perrott & Date \\
\hline $0100 F-C A-V 0280$ & Rev. No. \\
\hline
\end{tabular}




\section{ATTACHMENT 3}

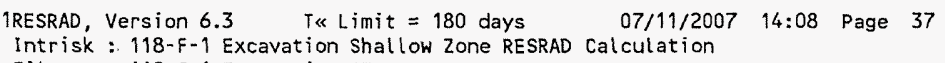

Total Excess Cancer Risk CNRSI $(i, p, t)^{* * *}$ for Initially Existent Radionuclides $(i)$ and Pathways $(p)$ and Fraction of Total Risk at $t=4.300 E+01$ years

Water Dependent Pathways

\begin{tabular}{|c|c|c|c|c|c|c|c|c|c|c|c|c|c|c|}
\hline \multirow{2}{*}{$\begin{array}{l}\text { Radio- } \\
\text { Nucl ide } \\
\text { AÄÄÄÄÄÄ }\end{array}$} & \multicolumn{2}{|c|}{ Water } & \multicolumn{2}{|c|}{ Fish } & \multicolumn{2}{|c|}{ Radon } & \multicolumn{2}{|c|}{ Plant } & \multicolumn{2}{|c|}{ Meat } & \multicolumn{2}{|c|}{ Milk } & \multicolumn{2}{|c|}{$\begin{array}{l}\text { All pathways } \\
A A A A A A A A A A B A B A A A\end{array}$} \\
\hline & risk & 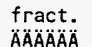 & $\begin{array}{l}\text { risk } \\
\text { ÄÄAOAOAA }\end{array}$ & $\begin{array}{l}\text { fract. } \\
\ddot{A A O A B A B A}\end{array}$ & $\begin{array}{c}\text { risk } \\
\triangle A B A B A B A A B A\end{array}$ & $\begin{array}{l}\text { fract. } \\
\triangle A O A B A B A\end{array}$ & $\begin{array}{c}\text { risk } \\
\triangle A B A B A B A\end{array}$ & $\begin{array}{l}\text { fract. } \\
\triangle A O A B A B A B\end{array}$ & $\begin{array}{c}\text { risk } \\
\text { YAAAOÄÄA }\end{array}$ & $\begin{array}{l}\text { fract. } \\
\triangle A O A O A O A B\end{array}$ & $\begin{array}{c}\text { risk } \\
\triangle A B A A B A B A O A\end{array}$ & & $\begin{array}{c}\text { risk } \\
\triangle A A B O A B A O A B A\end{array}$ & \\
\hline & & & & & & & & & & & & & & \\
\hline & & & & & & & & & & & & & & \\
\hline & & & & & & & & & & & & & & \\
\hline & & & & & & & & & & & & & & \\
\hline & & & & & & & & & & & & & & \\
\hline & & & & & & & & & & & & & & \\
\hline & & & & & & & & & & & & & & \\
\hline & & & & & & & & & & & & & & \\
\hline & & & & & & & & & & & & & & \\
\hline & & & & & & & & & & & & & & \\
\hline & & & & & & & & & & & & & & \\
\hline & & & $75-14$ & & $0.000 E+00$ & & & & & & $5 E-13$ & & & \\
\hline & & & & & & & & & & & & & & \\
\hline & & & & & & & & & & & & & & \\
\hline & & & & 008 & +40 & & & & & & & & & \\
\hline
\end{tabular}

$* * * \operatorname{CNRSI}(i, p, t)$ includes contribution from decay daughter radionuclides

\begin{tabular}{|c|c|}
\hline Attachment $\quad 3$ & Sheet No. $\underline{37}$ of $\underline{52}$ \\
\hline Originator: S.W. Clark & Date \\
\hline Chk'd By M.W.Perrott & Date \\
\hline $0100 F-C A-V 0280$ & Rev. No. \\
\hline
\end{tabular}




\section{ATTACHMENT 3}

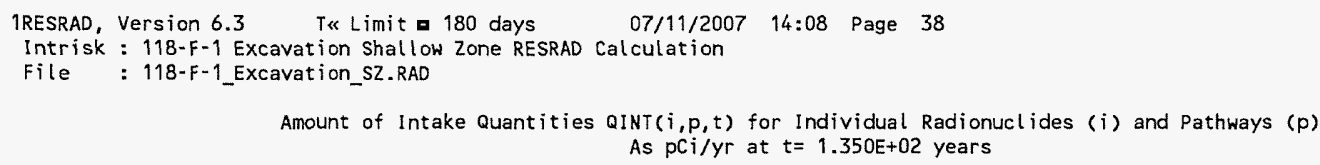
Radionuclides

\begin{tabular}{|c|c|c|c|c|c|c|c|c|}
\hline Radon & & ARAAAA & AAAAAA & AAAAAAAAA & AAAAAAAAAAA & AOÄÄAAAAAAAA & $\triangle A O A A A O A O A O A A$ & $\triangle A A A A A A A A A O A-$ \\
\hline Pathway & $R n-222$ & Po-218 & $\mathrm{Pb}-214$ & $\mathrm{Bi}-214$ & $R n-220$ & Po-216 & $\mathrm{Pb}-212$ & Bi-212 \\
\hline$\triangle A A A A A A A A A A A$ & $\triangle A A A A B A B A O A O A$ & $\triangle A \triangle A O A A A O A A A$ & $\triangle A A A O A A A A A A$ & $\triangle A A A A A A A A A A$ & $\triangle A A B A A A B A A A A$ & A & 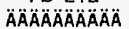 & 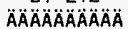 \\
\hline Water-ind. & $0.000 E+00$ & $0.000 E+00$ & $0.000 E+00$ & $0.000 E+00$ & $0.000 E+00$ & $0.000 E+00$ & $0.000 E+00$ & $0.000 E+00$ \\
\hline Water-dep. & $0.000 E+00$ & $0.000 E+00$ & $0.000 E+00$ & $0.000 E+00$ & $0.000 E+00$ & $0.000 E+00$ & $0.000 \mathrm{E}+00$ & $0.000 E+00$ \\
\hline iffififte & 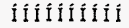 & 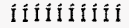 & î́ílítîi & 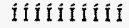 & 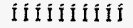 & 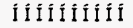 & tifilifili & 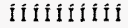 \\
\hline Total & $0.000 E+00$ & $0.000 E+00$ & $0.000 E+00$ & $0.000 E+00$ & $0.000 E+00$ & $0.000 E+00$ & $0.000 E+00$ & $0.000 E+00$ \\
\hline
\end{tabular}

Water-ind. $=$ Water-independent $\quad$ Water-dep. $==$ Water-dependent

\begin{tabular}{|c|c|}
\hline Attachment $\quad 3$ & Sheet No. 38 of 52 \\
\hline Originator: S.W. Clark & Date \\
\hline Chk'd By M.W. Perrott & Date \\
\hline Calc. No. $0100 \mathrm{~F}-\mathrm{CA}-\mathrm{V} 0280$ & Rev. No. 0 \\
\hline
\end{tabular}




\section{ATTACHMENT 3}

\begin{tabular}{|c|c|c|c|c|c|c|c|c|c|c|c|c|}
\hline $\begin{array}{l}\text { 1RESRAD, } \\
\text { Intrisk } \\
\text { File }\end{array}$ & $\begin{array}{l}\text { Version } 6 \\
: 118-F-1 \\
: 118-F-1\end{array}$ & $\begin{array}{l}\text { Excava } \\
\text { Excava }\end{array}$ & $\begin{array}{l}\text { T\& Limit }= \\
\text { ion Shallow } \\
\text { ion_Sz.RAD }\end{array}$ & $\begin{array}{l}180 \text { days } \\
\text { Zone } R E\end{array}$ & RAD Calcu & ulation & $14: 08$ & age & \multicolumn{4}{|c|}{39} \\
\hline \multicolumn{13}{|c|}{$\begin{array}{c}\text { Excess Cancer Risks CNRS }(i, p, t) \text { for Individual Radionuclides (i) and Pathways }(p) \\
\text { and Fraction of Total Risk at } t=1.350 E+02 \text { years }\end{array}$} \\
\hline & Groun & & Inhalat & ion & Plan & & Mea & & Mill & & Soil & \\
\hline & & $\triangle A A A A O A O A B$ & $\triangle A A A A A O A O A A B$ & $\triangle A A O A O A O A B$ & $\triangle A O A A A A A A B A$ & A ÄÄÄÄÄ & $\triangle A A A O A A O A O A O A$ & $\triangle A O A O A O A A A ̈ A$ & $\triangle A A A A A A A A A$ & $A A A A O A O A B$ & $\triangle A O A A A A A A A B$ & AAAOAAAAOA \\
\hline $\begin{array}{l}\text { Nuclide } \\
\text { ÄAAAAOAOA }\end{array}$ & $\begin{array}{l}\text { risk } \\
A ̈ A B A O A O A\end{array}$ & $\begin{array}{l}\text { fract. } \\
A B A O A B A\end{array}$ & $\begin{array}{c}\text { risk } \\
\triangle A A A A A A A B A B\end{array}$ & & $\begin{array}{c}\text { risk } \\
A A B A B A A A ̈\end{array}$ & & $\begin{array}{c}\text { risk } \\
\text { AAAAAAAAOÄÄ }\end{array}$ & $\begin{array}{l}\text { fract. } \\
\text { ÄÄÄÄÄ }\end{array}$ & $\begin{array}{c}\text { risk } \\
\text { AAAAAAAAÄ }\end{array}$ & $\begin{array}{l}\text { fract. } \\
A A A A A B A\end{array}$ & $\begin{array}{c}\text { risk } \\
\text { ÄÄÄÄÄÄÄ }\end{array}$ & $\begin{array}{l}\text { fract. } \\
\triangle A O A B A O A B\end{array}$ \\
\hline & & 0.0000 & & 0.0000 & $3.138 \varepsilon-17$ & 0000 & $2 E-19$ & 0.0000 & & & $2.301 \mathrm{E}-17$ & 0.0000 \\
\hline & & & & & & & & & & & -10 & \\
\hline & & 0.0106 & 090 & 0007 & $18 E-08$ & 0.0 & $1.178 E-10$ & 0.0000 & -11 & & & \\
\hline & & & & & & & & 000 & & & +00 & 000 \\
\hline & & 0.0000 & & & $O E-16$ & & & & & & & 1000 \\
\hline & & 0.1253 & & & $4 E-08$ & & -08 & & & & & \\
\hline & & & & & & & & & & & & \\
\hline & & 0.00 & & & & & & & & & & \\
\hline & & & & & & & & & & & & \\
\hline & & & & & & & & & & & & \\
\hline & & & & & & & & & & & & \\
\hline & & & & & & & & & & & & \\
\hline & & & & & & & & & & & & \\
\hline & & & & & & & & & & & & \\
\hline & & & & & & & & & & & & \\
\hline & & & & & & & & & & & & \\
\hline & & & & & & & & & & & & \\
\hline & & & & & & & & & & & & \\
\hline & & & & & & & & & & & & \\
\hline & & & & & & & & & & & & \\
\hline & & & & & & & & & & & & \\
\hline & & & & & & & & & & & & \\
\hline & & & & & $9.752 E-16$ & & $E-17$ & & & & -15 & 0.0000 \\
\hline & & & & & $6.755 E-23$ & & & & & & -22 & \\
\hline & & & & & & & & & & & & \\
\hline & $2.710 E-14$ & & $7.661 \mathrm{E}-14$ & & $2.205 E-12$ & 0.0000 & $7.460 \mathrm{E}-14$ & 40.0000 & $3.479 E-13$ & 0.0000 & 1. $512 E-12$ & 0.0000 \\
\hline & & & & & 10700 & & & & & & & \\
\hline & & & & & & & & & & & $1.969 \mathrm{E}-14$ & \\
\hline İIIIIII & & & & & MMIII & iffifi & Difífífí & f́ffílí & fIXIfífí & Ifíi İí & fiflififi & filifil \\
\hline Total & $1.377 E-06$ & 0.5389 & $6.239 E-09$ & 0.0024 & $6.522 \mathrm{E}-07$ & 0.2552 & $1.317 \mathrm{E}-07$ & 70.0516 & $1.823 E-07$ & 0.0713 & $7.791 E-08$ & 0.0305 \\
\hline
\end{tabular}

\begin{tabular}{|c|c|}
\hline Attachment $\quad 3$ & Sheet No. $\underline{39}$ of $\underline{52}$ \\
\hline Originator: S. W. Clark & _Date \\
\hline Chk'd By M.W.Perrott & Date \\
\hline $0100 \mathrm{~F}-\mathrm{CA}-\mathrm{V} 0280$ & Rev. No. \\
\hline
\end{tabular}


Rev. 0

\section{ATTACHMENT 3}

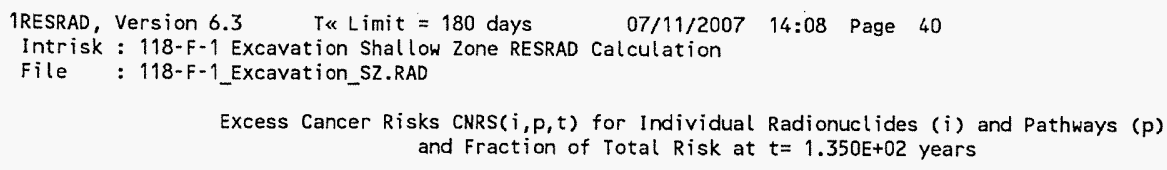

Water Dependent Pathways

\begin{tabular}{|c|c|c|c|c|c|c|c|c|c|c|c|c|}
\hline & $\begin{array}{r}\text { Wate } \\
\text { AaÄAAAOÄÄ }\end{array}$ & OÄÄÄÄÄ & $\begin{array}{r}F i s h \\
A \cap A A A A B A O A B\end{array}$ & h & $\begin{array}{r}P l a r \\
\text { ÄÄÄAOAOAOÁ }\end{array}$ & nt & $\begin{array}{r}\text { Mea } \\
\text { ÄÄÄÄÄÄÄA }\end{array}$ & It & $\begin{array}{r}M i l l \\
\text { AOAAOAAOAOAOA }\end{array}$ & $A ̈ A ̈ A ̈ A A ̈ A ̈$ & $\begin{array}{r}\text { All Path } \\
\text { AAAAAAAAAA }\end{array}$ & $\begin{array}{l}\text { hways*** } \\
\text { ÄÄÄÄÄÄÄ }\end{array}$ \\
\hline $\begin{array}{l}\text { Nucl ide } \\
\text { ÄÄÄÄÄÄÄ }\end{array}$ & $\begin{array}{c}\text { risk } \\
A A B A A A B A B A\end{array}$ & $\begin{array}{l}\text { fract. } \\
\triangle A B A A A O A B\end{array}$ & $\begin{array}{c}\text { risk } \\
A B A A A A A A B\end{array}$ & $\begin{array}{l}\text { fract. } \\
A O A O A B A B\end{array}$ & $\begin{array}{c}\text { risk } \\
\text { AAAAAAAAAA }\end{array}$ & $\begin{array}{l}\text { fract. } \\
\triangle A A A B A B A\end{array}$ & $\begin{array}{c}\text { risk } \\
\triangle A A A A A A A A B\end{array}$ & 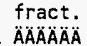 & $\begin{array}{c}\text { risk } \\
\text { ÄÄÄÄÄÄÄÄ }\end{array}$ & 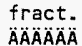 & $\begin{array}{c}\text { risk } \\
\text { ÄÄ̈̈ÄÄÄAOA }\end{array}$ & $\begin{array}{l}\text { fract. } \\
\triangle A A A B A A B A\end{array}$ \\
\hline & $1.856 \mathrm{E}-15$ & 0.0000 & $5.070 \mathrm{E}-17$ & 0.0000 & $2.753 E-16$ & 0.0000 & $9.446 E-19$ & 0.0000 & $2.134 \mathrm{E}-18$ & 0.0000 & $2.564 E-15$ & 0.0000 \\
\hline & & 0.0000 & $0 E+00$ & 0.0000 & $.000 E+00$ & 0.0000 & $0.000 \mathrm{E}+00$ & 0.0000 & $0.000 E+00$ & 0.0000 & $1.078 E-06$ & 0.4217 \\
\hline & $O O E+00$ & 0.0000 & $.000 E+00$ & 0.0000 & $.000 E+00$ & 0.0000 & $0.000 E+00$ & 0.0000 & $0.000 E+00$ & 0.0000 & & 0.0230 \\
\hline & $O E+0 O$ & 0.0000 & $.000 E+00$ & 0.0000 & $0.000 E+00$ & 0.0000 & $0.000 \mathrm{E}+00$ & 0.0000 & $0.000 E+00$ & 0.0000 & & \\
\hline & 57 & 0.0000 & $11 E-18$ & 0.0000 & $.710 E-18$ & 0.0000 & $9.744 E-18$ & 0.0000 & 2. $816 E-18$ & 0.0000 & $4.437 E-14$ & 0.0000 \\
\hline & & & $8 E-09$ & 0.0 & $.324 E-10$ & 0.0001 & $9.256 E-10$ & 0.0004 & $.134 E-10$ & 0.0003 & $3.666 \mathrm{E}-07$ & .1434 \\
\hline & & & & & & & & & $0.000 E+00$ & & & UTU \\
\hline & $0.000 E+00$ & 0.0000 & $0.000 \mathrm{E}+00$ & 0.0000 & $0.000 \mathrm{E}+00$ & 0.0000 & $0.000 \mathrm{E}+00$ & 0.0000 & $0.000 E+00$ & 1000 & & \\
\hline & $0.000 \mathrm{E}+00$ & 0.0000 & $0.000 E+00$ & 0.0000 & $0.000 \mathrm{E}+00$ & 0.0000 & $0.000 E+00$ & 0.0000 & $0.000 E+00$ & 000 & & \\
\hline & & & & & $0 O E+00$ & & $O E+00$ & 0.0000 & $0.000 E+00$ & 0.0000 & $E+00$ & .0000 \\
\hline & 2.0 & & & & $90 E-09$ & 0.0 & & & & & & 800 \\
\hline & $0.000 E+00$ & 0.0000 & $0 E+00$ & 0. & $0.000 \mathrm{E}+00$ & 0.0 & & & 0.0 & & & \\
\hline & & & & & $4 E-17$ & 0.0000 & 4.1 & 0.0 & $E-19$ & 200 & -16 & 00 \\
\hline & & & & & & & & & & & & 000 \\
\hline & $0.000 \mathrm{E}+\mathrm{C}$ & 0.0000 & $O E+00$ & & $\mathrm{E}+00$ & & & & $0.000 E+00$ & 0.0000 & $E-09$ & 0.0027 \\
\hline & 0.0 & & $O E+00$ & 0.0000 & DOE +00 & 0.0000 & $O E+00$ & & $0.000 \mathrm{E}+00$ & & $E-08$ & \\
\hline & 0.0 & & & & $=+\infty$ & & & 0.0000 & & & $E-08$ & \\
\hline & 3.8 & & E-16 & & 16 & & & 0.0000 & $E-16$ & 0.0000 & $E-14$ & 0.0000 \\
\hline & 2.65 & & $E-22$ & & F-21 & & & & & & & \\
\hline & 4.8 & & & 0. & SE-09 & & & 0.0029 & $5.382 E-09$ & & $E-07$ & \\
\hline & 2.5 & & 1.4 & 0.0000 & $86 \mathrm{E}-22$ & 0.0000 & $E-24$ & 0. & $1.274 E-24$ & & $E-20$ & 000 \\
\hline & .03 & & & & $.684 E-18$ & & $E-19$ & 0. & $3.258 E-20$ & 0.0000 & $E-16$ & 0.0000 \\
\hline & 1.6 & & & & $.441 E-15$ & & & & & & $E-14$ & \\
\hline & & & & & & & & & & & $E-21$ & 000 \\
\hline & $1.796 \mathrm{E}-$ & & $1.036 E-15$ & & $2.678 E-14$ & & $1.222 E-15$ & 0.0000 & $6.232 \mathrm{E}-15$ & 0.0000 & $2.155 E-13$ & 0.0000 \\
\hline & & & & & $514 E-10$ & & & & & & & \\
\hline & & & & & & & & & $E-14$ & & $E-12$ & \\
\hline & & & & & & & & 0.00 & 6.81 & & 2.3 & 0.0 \\
\hline & & & & & & & & & & & & \\
\hline & 7.18 & & & 0.0015 & -08 & & & & $3.058 E-08$ & & $255<5$ & \\
\hline
\end{tabular}

** Sum of water independent ground, inhalation, plant, meat, milk, soil

and water dependent water, fish, plant, meat, milk pathways

\begin{tabular}{|c|c|}
\hline Attachment $\quad 3$ & Sheet No. $\underline{40}$ of $\underline{52}$ \\
\hline Originator: S.W. Clark & Date \\
\hline Chk'd By M.W. Perrott & Date \\
\hline $0100 \mathrm{~F}-\mathrm{CA}-\mathrm{V} 0280$ & Rev. No. \\
\hline
\end{tabular}




\section{ATTACHMENT 3}

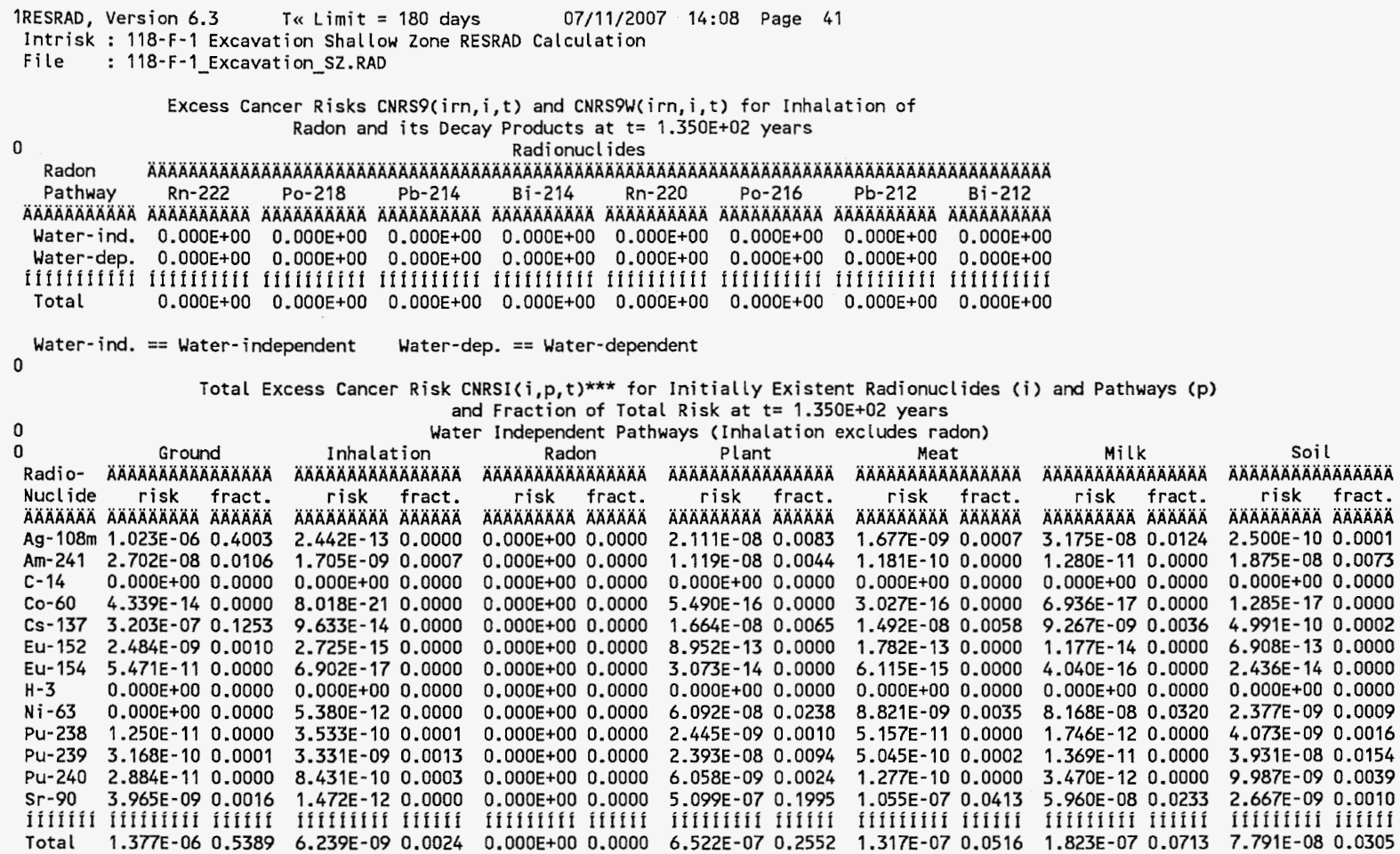

\begin{tabular}{|c|c|}
\hline Attachment & Sheet No. 41 of 52 \\
\hline Originator: S.W. Clark & Date \\
\hline Chk'd By M.W. Perrott & Date \\
\hline $0100 F-C A-V 0280$ & Rev. No. \\
\hline
\end{tabular}




\section{ATTACHMENT 3}

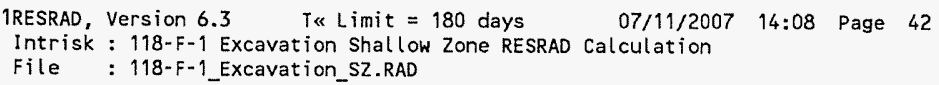

Water Dependent Pathways

\begin{tabular}{|c|c|c|c|c|c|c|c|c|c|c|c|c|c|c|}
\hline \multirow{2}{*}{$\begin{array}{l}\text { Radio- } \\
\text { Nuclide } \\
\text { ÄÄÄÄÄÄÄ }\end{array}$} & 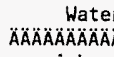 & Water & 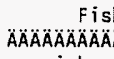 & Fish & Radon & On & \multicolumn{2}{|c|}{ 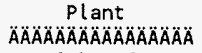 } & \multicolumn{2}{|c|}{ 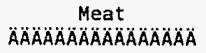 } & \multicolumn{2}{|c|}{ 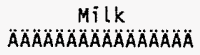 } & \multicolumn{2}{|c|}{$\begin{array}{c}\text { All pathways } \\
\text { AAAAAAAAAAAAOAAAAAA }\end{array}$} \\
\hline & $\begin{array}{c}r i s k \\
A A A O A O A A A B A\end{array}$ & $\begin{array}{l}\text { fract. } \\
\triangle A A B A A B A\end{array}$ & $\begin{array}{c}\text { risk } \\
\text { AAAAAAAOAOA }\end{array}$ & $\begin{array}{l}\text { fract. } \\
\text { ÄÄÄÄÄA }\end{array}$ & $\begin{array}{c}\text { risk } \\
\triangle A O A A B A B A B A B\end{array}$ & 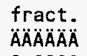 & $\begin{array}{c}\text { risk } \\
\text { ÄAAAAAAAAOA }\end{array}$ & $\begin{array}{l}\text { fract. } \\
\ddot{A B A ̈ A ̈ A ̈ A ̈}\end{array}$ & $\begin{array}{c}\text { risk } \\
\text { ÄAAAAÄÄÄ }\end{array}$ & $\begin{array}{l}\text { fract. } \\
\text { ÄÄÄÄÄ }\end{array}$ & $\begin{array}{c}\text { risk } \\
\text { ÄÄÄÄÄÄÄÄ }\end{array}$ & $\begin{array}{l}\text { fract. } \\
\text { ÄÄÄÄÄA }\end{array}$ & $\begin{array}{c}\text { risk } \\
\text { ÄÄÄÄÄÄÄ }\end{array}$ & $\begin{array}{l}\text { fract. } \\
\text { ÄAAAAA }\end{array}$ \\
\hline & $0.000 E+00$ & 0.0000 & $0.000 E+00$ & 0.0000 & & 0000 & $0.000 E+00$ & 00 & 0.000 & 00 & $10 E+00$ & & & \\
\hline & & 0.0000 & & & & & & & & & & & & \\
\hline & $E+00$ & & $E+\infty 0$ & & $.000 E+00$ & 0000 & $E+00$ & & & & $+\infty$ & & & \\
\hline & & & & & $000 E+00$ & 0000 & -18 & & 18 & & & & & \\
\hline & & & & & & & & & & & -10 & 003 & & \\
\hline & $E+00$ & & 0.00 & & 00 & 000 & & & 00 & & $+\infty 0$ & & & \\
\hline & $E+00$ & 0.0000 & $0.000 E+00$ & 0000 & $.000 E+00$ & 0000 & +00 & & 0.00 & & & & & \\
\hline & & & & & & 000 & & & 0.00 & & & & & \\
\hline & 2.00 & & -10 & & $=00$ & 0.0000 & -09 & 0. & & & & & & \\
\hline & & & & & $=+\infty$ & & & & & & & & & \\
\hline & & & & & $0.000 E+00$ & & $E-13$ & & & & 9 & & & \\
\hline & & & $1.131 E-13$ & 0.0000 & $0.000 E+00$ & & & & & & & & & \\
\hline & $\begin{array}{l}4.843 \\
\text { \{III }\end{array}$ & & $\begin{array}{l}1.351 \text { E-09 } \\
\text { IIITISII }\end{array}$ & 0.0005 & $\begin{array}{l}0.000 E+00 \\
\text { iftititíl }\end{array}$ & 0.0000 & & & & & & & & \\
\hline & $.187 E-08$ & 0.0281 & $3.756 \mathrm{E}-09$ & 0.0015 & $0.000 E+00$ & 0.0000 & $1.119 E-08$ & 0.0044 & $1.052 E-08$ & 0.0041 & $3.058 E-08$ & 0.0120 & $2.556 E-06$ & 1.000 \\
\hline
\end{tabular}

***CNRSI $(i, p, t)$ includes contribution from decay daughter radionuclides

\begin{tabular}{|c|c|}
\hline \multirow{2}{*}{\multicolumn{2}{|c|}{$\begin{array}{l}\text { Attachment } \frac{3}{\text { Originator: } \mathrm{S.W} \text {. Clark }} \quad \text { Sheet No. } 42 \text { of } 52 \\
\text { Date }\end{array}$}} \\
\hline & \\
\hline Chk'd By M. W. Perrott & Date \\
\hline $0100 F-C A-V 0280$ & Rev. No. \\
\hline
\end{tabular}




\section{ATTACHMENT 3}

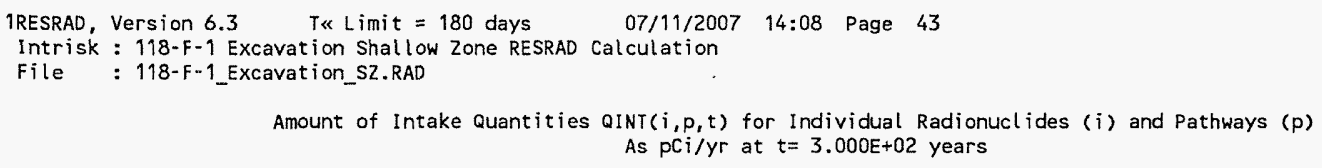

Water-ind. == Water-independent Water-dep. $==$ Water-dependent

\begin{tabular}{|c|c|}
\hline Attachment $\quad 3$ & Sheet No. $\underline{43}$ of $\underline{52}$ \\
\hline Originator: S.W. Clark & Date. \\
\hline Chk'd By M. W. Perrott & Date \\
\hline Calc. No. $\quad 0100 F-C A-V 0280$ & Rev. No. \\
\hline
\end{tabular}




\section{ATTACHMENT 3}

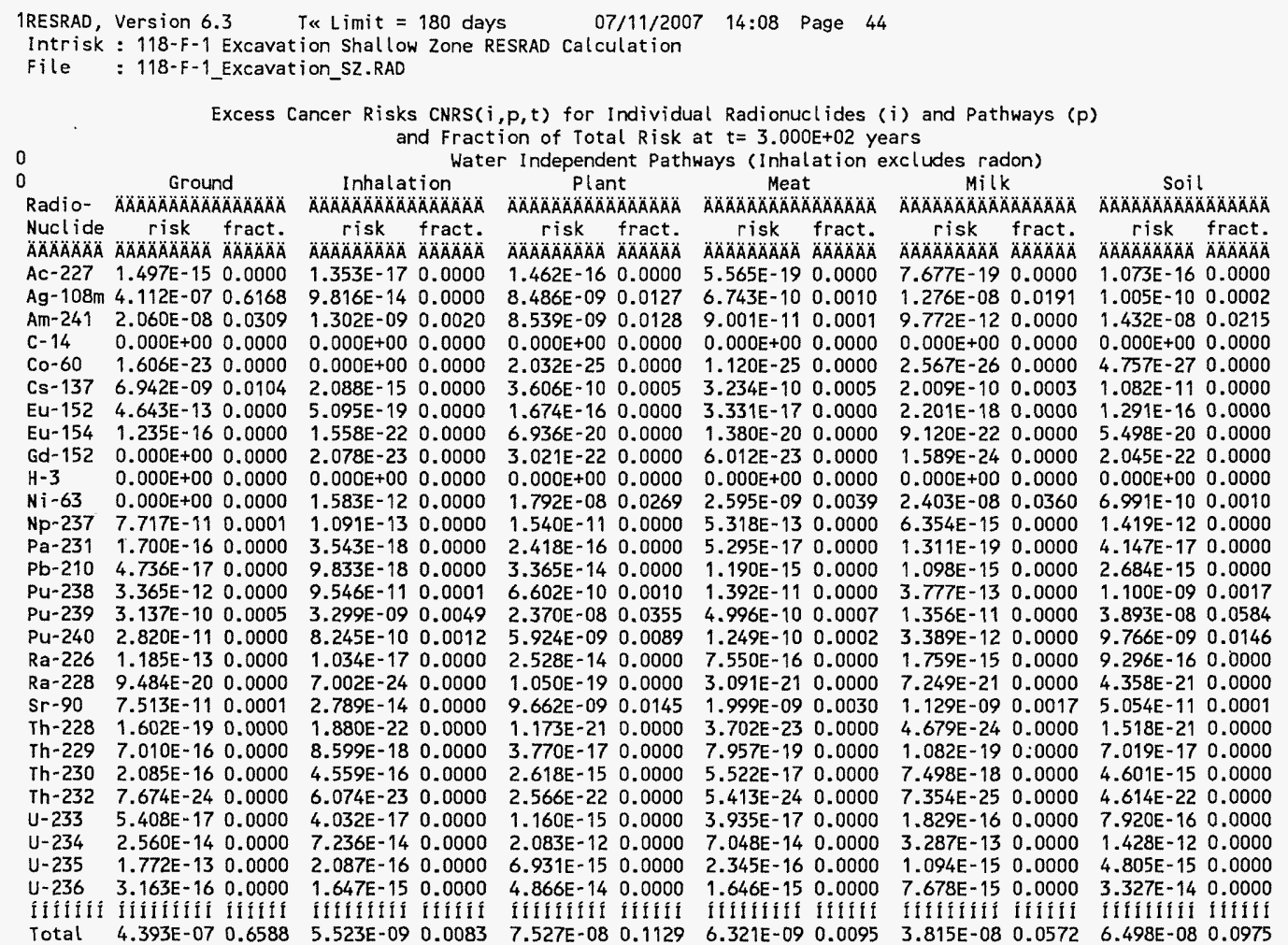

$\begin{array}{ll}\text { Attachment } \frac{3}{\text { S.W. Clark }} & \text { Sheet No. } 44 \text { of } \underline{52} \\ \text { Originator: } & \text { Date } \\ \text { Chk'd By } & \text { Date } \\ \text { M.W. Perrott } & \text { Rev. No. } 0\end{array}$




\section{ATTACHMENT 3}

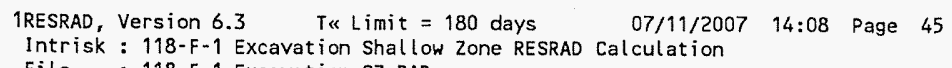

Water Dependent Pathways

\begin{tabular}{|c|c|c|c|c|c|c|c|c|c|c|c|c|}
\hline \multirow{2}{*}{$\begin{array}{l}\text { Radio- } \\
\text { Nucl ide } \\
\text { AOAOAAAOÄA }\end{array}$} & \multicolumn{2}{|c|}{ Water } & \multicolumn{2}{|c|}{ Fish } & \multicolumn{2}{|c|}{ Plant } & \multicolumn{2}{|c|}{ Meat } & \multicolumn{2}{|c|}{ 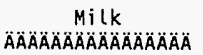 } & \multicolumn{2}{|c|}{$\begin{array}{r}\text { All Pathways** } \\
\text { AAAAAAAAOAOAAAAAAA }\end{array}$} \\
\hline & $\begin{array}{c}\text { risk } \\
\text { ÄÄÄÄÄÄÄÄA }\end{array}$ & 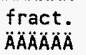 & $\begin{array}{c}\text { risk } \\
\text { ÄAAAAAAAAOA }\end{array}$ & $\begin{array}{l}\text { fract. } \\
\text { Ä̈̈Ä̈̈̈̈̈ }\end{array}$ & $\begin{array}{c}\text { risk } \\
\text { AAAAAAAÄÄA }\end{array}$ & $\begin{array}{l}\text { fract. } \\
\text { ÄÄAAÄA }\end{array}$ & $\begin{array}{c}\text { risk } \\
\triangle A A A A A A A A O A B A\end{array}$ & $\begin{array}{l}\text { fract. } \\
\ddot{A} A \ddot{A} A \ddot{A} A \ddot{A}\end{array}$ & $\begin{array}{c}r i s k \\
\triangle A A B A O A B A ̈ A ̈\end{array}$ & $\begin{array}{l}\text { fract. } \\
A A O A A A O A\end{array}$ & $\begin{array}{c}\text { risk } \\
\triangle A A A A O A B A B A ̈\end{array}$ & 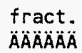 \\
\hline & & 0.0000 & $3.118 \mathrm{E}-16$ & 0.0000 & $1.693 \mathrm{E}-15$ & 0.0000 & $5.513 E-18$ & 0.0000 & $1.313 E-17$ & 0.0000 & $1.520 E-14$ & 0.0000 \\
\hline & & & $O E+O O$ & 1000 & $10 E+00$ & 0.0000 & $.000 E+00$ & 0.0000 & $0.000 E+00$ & 0.0000 & $4.333 E-07$ & 0.6498 \\
\hline & & & $0.000 E+00$ & 0.0000 & $0.000 E+00$ & & $0.000 E+00$ & 0.0000 & $.000 E+00$ & 0.0000 & $4.486 E-08$ & 1073 \\
\hline & & & $0.000 E+00$ & 0.0000 & $0.000 \mathrm{E}+00$ & 0.0000 & $0.000 E+00$ & 0.0000 & & 0.0000 & & \\
\hline & & & $7 E-27$ & & $3.002 E-27$ & 0.0000 & $7.898 E-27$ & 0.0000 & & 000 & $1.644 E-23$ & 0.0000 \\
\hline & & & & & $77 E-11$ & 0.0000 & -11 & 0.0001 & -11 & 1000 & $8.068 \mathrm{E}-09$ & 0121 \\
\hline & & & & & & & & & & & & 000 \\
\hline & $0.000 E+00$ & 0.0 & +00 & & $0 E+00$ & & & & $.000 E+00$ & & & \\
\hline & $\mathrm{OE}+00$ & 0.0 & $O E+00$ & 0. & $0.000 E+00$ & 0.0 & $0.000 E+00$ & 000 & $0 O E+00$ & & & \\
\hline & & & & & & & $O O E+00$ & 300 & $0.000 E+00$ & 000 & $0.000 E+00$ & 000 \\
\hline & 1.2 & & & & & & & & & & .08 & \\
\hline & $0.000 \mathrm{E}+00$ & 0.0000 & $0 E+00$ & & $E+00$ & & +00 & & & & & \\
\hline & & & & & & & & & & & -15 & \\
\hline & & & & & & & & & & & 1.3 & 0 \\
\hline$d-2$ & 0.00 & & $\mathrm{BE}+00$ & & +00 & & & & $10 E+00$ & & 1.87 & \\
\hline & & & $0 E+00$ & 0.0000 & $10 \mathrm{E}+00$ & 0.0000 & $0.000 \mathrm{E}+00$ & & & & -08 & \\
\hline & & & & & & & & 0. & & & & \\
\hline & & & & & & & & & & & & \\
\hline & & & -21 & & & & & & & & & \\
\hline & & & & & & & & & & & 1.5 & 256 \\
\hline & & & & & & & & & & & & \\
\hline & & & $E-17$ & & 9 & & -18 & & & & & \\
\hline & & & $E-15$ & & & & & & & & & \\
\hline & & & & & & & & & & & & \\
\hline & $7.882 \mathrm{E}-1$ & & & & & & & & $2.738 \mathrm{E}-1$ & & $9.454 \mathrm{E}-13$ & \\
\hline & & & & & 2 & & & & & & $2.157 \mathrm{E}-09$ & 0.0032 \\
\hline & & & & & & & & & & & & \\
\hline & & & & & & & & & & & & \\
\hline & & & & & & & & & 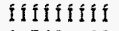 & Iffifif & iffififit & 11111 \\
\hline & & 0.0248 & $E-10$ & & $2.600 \mathrm{E}-09$ & & $1.691 \mathrm{E}-09$ & & $1.569 \mathrm{E}-08$ & 0.0235 & $6.668 \mathrm{E}-07$ & 1.0000 \\
\hline
\end{tabular}

** Sum of water independent ground, inhalation, plant, meat, milk, soil

and water dependent water, fish, plant, meat, milk pathways

\begin{tabular}{|c|c|}
\hline Attachment $\quad 3$ & Sheet No. $\underline{45}$ of $\underline{52}$ \\
\hline Originator: S.W. Clark & Date \\
\hline Chk'd By M.W.Perrott & Date \\
\hline $0100 \mathrm{~F}-\mathrm{CA}-\mathrm{V} 0280$ & Rev. No. \\
\hline
\end{tabular}




\section{ATTACHMENT 3}

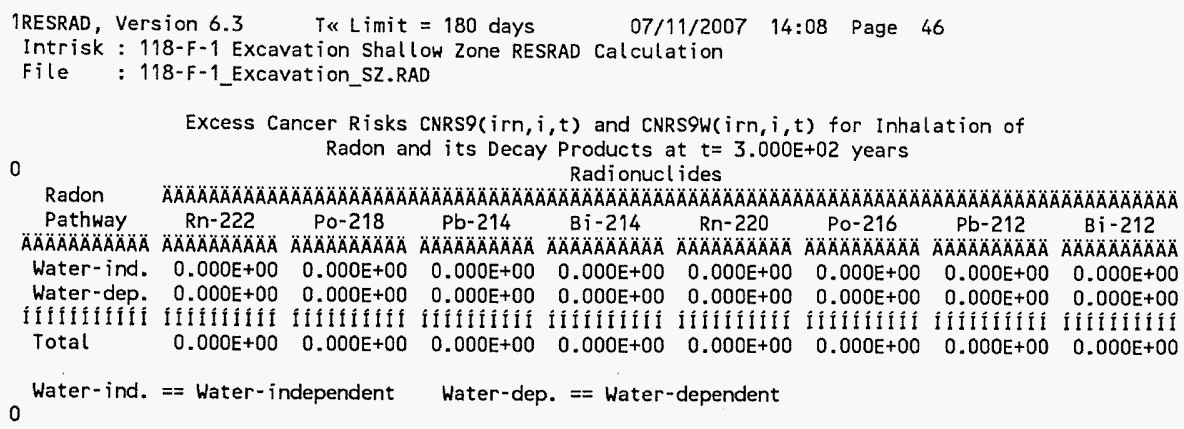

\begin{tabular}{|c|c|}
\hline Attachment $\quad 3$ & Sheet No. $\underline{46}$ of $\underline{52}$ \\
\hline Originator: S. W. Clark & Date \\
\hline Chk'd By M.W. Perrott & Date \\
\hline $0100 F-C A-V 0280$ & Rev. No. \\
\hline
\end{tabular}




\section{ATTACHMENT 3}

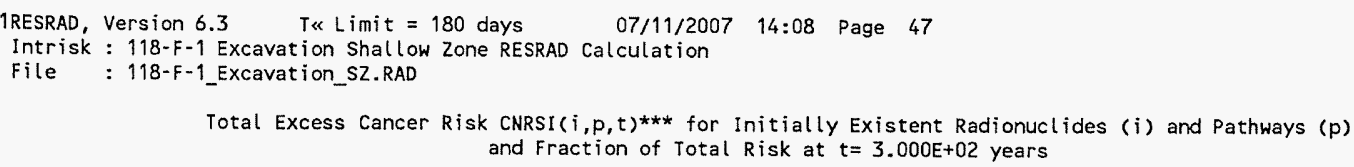

Water Dependent Pathways

\begin{tabular}{|c|c|c|c|c|c|c|c|c|c|c|c|c|c|c|}
\hline \multirow{2}{*}{$\begin{array}{l}\text { Radio- } \\
\text { Nucl ide }\end{array}$} & $\begin{aligned} \text { Water } & \\
\text { ÄÄABÄÄÄÄÄA } & \end{aligned}$ & ÄÄÄÄÄÄ & \multicolumn{2}{|c|}{ Fish } & \multicolumn{2}{|c|}{ Radon } & \multicolumn{2}{|l|}{ Plant } & \multicolumn{2}{|l|}{ Meat } & \multicolumn{2}{|l|}{ Milk } & \multicolumn{2}{|c|}{ 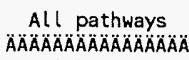 } \\
\hline & $\begin{array}{c}\text { risk } \\
\triangle A A A A A B A A B\end{array}$ & $\begin{array}{l}\text { fract. } \\
\because R A B A B A B A\end{array}$ & $\begin{array}{c}\text { risk } \\
\triangle A O A B A O A B A B\end{array}$ & $\begin{array}{l}\text { fract. } \\
\text { ÄÄÄÄÄ }\end{array}$ & $\begin{array}{c}\text { risk } \\
\text { ABAAAAAOA }\end{array}$ & fract. & $\begin{array}{c}\text { risk } \\
\text { AAAAAAAOÄ }\end{array}$ & $\begin{array}{l}\text { fract. } \\
A B A B A B\end{array}$ & $\begin{array}{c}\text { risk } \\
\text { AAAAAABA }\end{array}$ & fract. & risk & & $\begin{array}{c}\text { risk } \\
\text { ABAAOAOA }\end{array}$ & \\
\hline & $0.000 E+00$ & 0.0000 & $.000 E+00$ & 0.0000 & $0.000 E+00$ & 0.0000 & $0.000 \mathrm{E}+00$ & $\begin{array}{l}\text { AAAAAA } \\
0.0000\end{array}$ & $0.000 \mathrm{E}+00$ & 0.0000 & $0.000 \mathrm{E}+00$ & 0.0000 & $4.333 \mathrm{E}-07$ & 0.6498 \\
\hline & $7.888 E-13$ & 0.0000 & & 0.0000 & $0.000 E+00$ & 0.0000 & 1. $177 \mathrm{E}-13$ & 0.0000 & $5.373 E-15$ & 0.0000 & $2.738 \mathrm{E}-14$ & 0.0000 & 4.496E-08 & 0.0674 \\
\hline & & & & 0.0000 & & & & 0.0000 & & 0.0000 & $0.000 \mathrm{E}+00$ & 0.0000 & $=+00$ & 0.0000 \\
\hline & $872 E-26$ & 0.0000 & -27 & 0.0000 & $0.000 E+00$ & 0.0000 & $3.002 \mathrm{E}$ & 0.0000 & $E-27$ & 0.0000 & $80 E-27$ & 0. & & 0000 \\
\hline & $.835 \mathrm{E}-11$ & 0.0001 & $.481 E-11$ & 0.0001 & $0.000 E+00$ & 0.0000 & $1.077 \mathrm{E}-11$ & 0.0000 & $=-11$ & & & & & \\
\hline & & & & 0.0 & $E+00$ & 0.0000 & $0.000 E+00$ & 0.0000 & $0.000 E+00$ & 0.0000 & $0.000 E+00$ & 0.0000 & & 0000 \\
\hline & bo & & $E+\infty 0$ & & $E+00$ & 0.0000 & $O O E+00$ & 0.0000 & $000 E+00$ & 0.0000 & $0.000 E+00$ & 0.0000 & & .0000 \\
\hline & $0.000 E+00$ & 0.0000 & $.000 E+00$ & 0.0000 & $0.000 E+00$ & & $0.000 E+$ & & -00 & 000 & $0.000 E+00$ & 0.0000 & $D E+00$ & 0.0000 \\
\hline & & & & 0.0009 & $0.000 E+00$ & 0.0000 & -09 & 0.0030 & $E-09$ & & $E-08$ & & & \\
\hline & & 0.0027 & & 0.0000 & $0.000 E+00$ & 0.0000 & & & & 000 & $6.258 E-11$ & 0.00 & & 0.0060 \\
\hline & $71 \mathrm{E}-12$ & & 3 & & $0.000 E+00$ & 0.0000 & & 0.0000 & $3.632 E-14$ & 0.0000 & $1.841 E-13$ & 0.0000 & & 0.1001 \\
\hline & & & & & $E+00$ & & -12 & & $40 E-13$ & & $1.294 \mathrm{E}-12$ & & & \\
\hline & & & & & & & & & & & & & & \\
\hline & & & & & \$it & Iffifí & & & iffififif & & & & & \\
\hline & & & & & & & & & & & & & & \\
\hline
\end{tabular}

***CNRSI $(i, p, t)$ includes contribution from decay daughter radionuclides

\begin{tabular}{|c|c|}
\hline Attachment & Sheet No. 47 of 52 \\
\hline Originator: S.W. Clark & Date \\
\hline Chk'd By M. W. Perrott & Date \\
\hline $0100 F-C A-V 0280$ & Rev. No. \\
\hline
\end{tabular}




\section{ATTACHMENT 3}

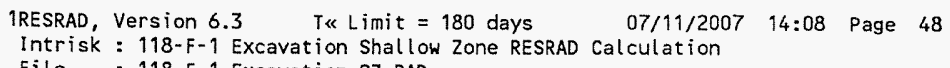

\begin{tabular}{|c|c|}
\hline Attachment & Sheet No. 48 of 52 \\
\hline Originator: S. W. Clark & Date \\
\hline Chk'd By M. W. Perrott & Date \\
\hline $0100 F-C A-V 0280$ & Rev. No. \\
\hline
\end{tabular}




\section{ATTACHMENT 3}

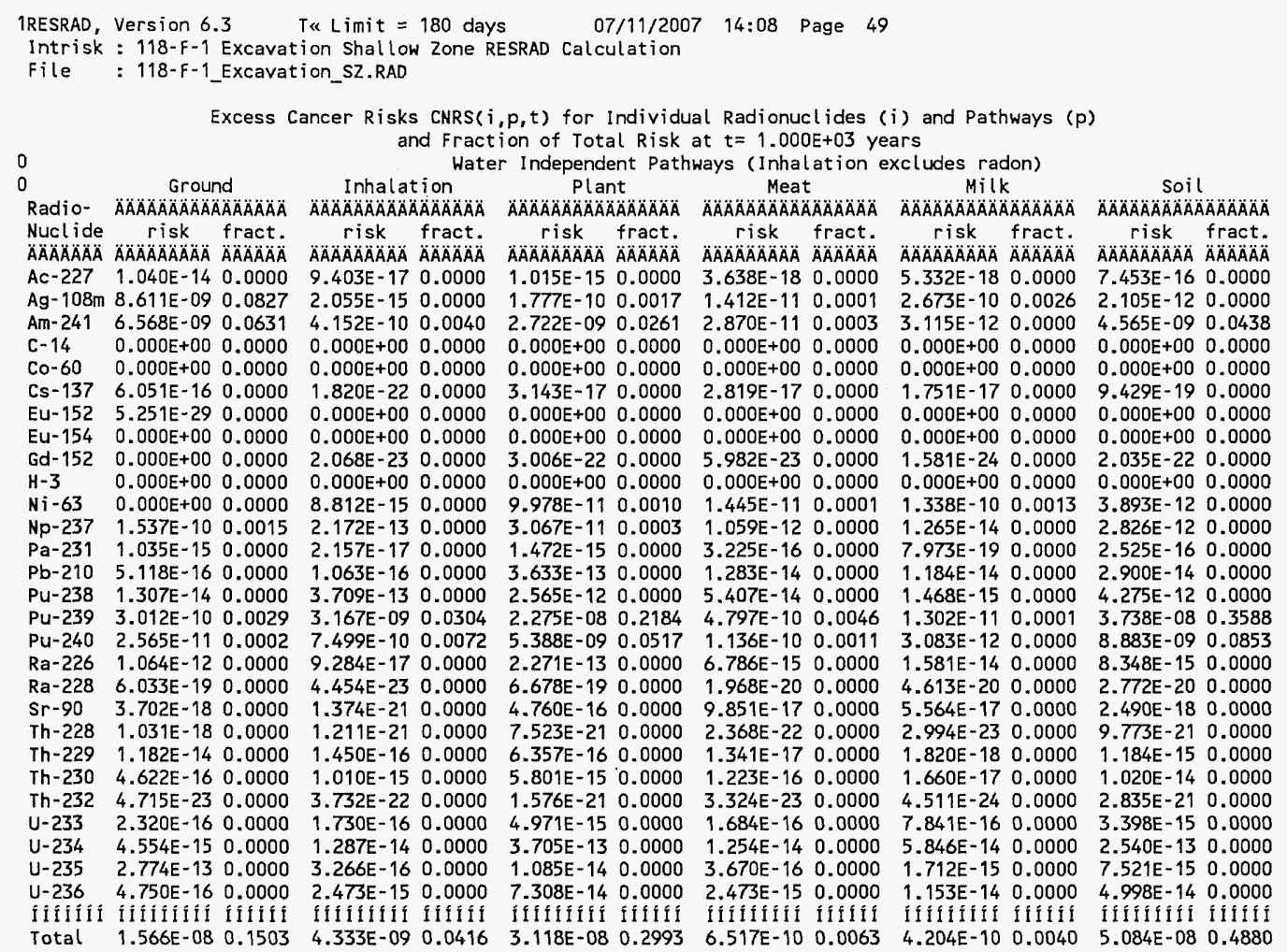

\begin{tabular}{|c|c|}
\hline Attachment & Sheet No. 49 of $\underline{52}$ \\
\hline Originator: S.W. Clark & Date \\
\hline M. W. Perrott & Date \\
\hline $0100 F-C A-V 0280$ & Rev. No. \\
\hline
\end{tabular}




\section{ATTACHMENT 3}

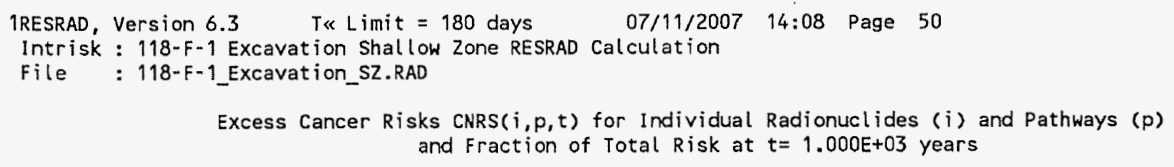

Water Dependent Pathways

\begin{tabular}{|c|c|c|c|c|c|c|c|c|c|c|c|c|}
\hline & $\begin{array}{r}\text { Water } \\
\text { AOAOAAAOAAABA }\end{array}$ & С̆ÄÄÄÄÄ & $\begin{array}{r}F i s h \\
\text { ÄAAिÄÄÄÄÄA }\end{array}$ & $A ̈ A A B A A A$ & $\begin{array}{r}P l a n \\
\triangle A O A A A A A A A O A\end{array}$ & it & $\begin{array}{r}\text { Meat } \\
\text { AAAAAAAAAAAA }\end{array}$ & ÄÄAAAOA & $\begin{array}{r}M i l k \\
\triangle A A O A O A O A O A O A B\end{array}$ & ÄÄÄÄÄ & $\begin{array}{r}\text { All Path } \\
A A A A B A A A A B A\end{array}$ & Ways*** \\
\hline $\begin{array}{l}\text { Ucl ide } \\
\triangle 1 \text { A }\end{array}$ & $\begin{array}{l}\text { risk } \\
\text { AAAABAOÄ }\end{array}$ & fract. & $\begin{array}{c}\text { risk } \\
\text { AOAAAAAAA }\end{array}$ & fract. & $\begin{array}{c}\text { risk } \\
\text { A }\end{array}$ & $\begin{array}{l}\text { fract. } \\
\text { AAAAAAA }\end{array}$ & $\begin{array}{c}\text { risk } \\
\text { AAAAAAAAA }\end{array}$ & $\begin{array}{l}\text { fract. } \\
A B A A A A\end{array}$ & $\begin{array}{c}\text { risk } \\
A O A B A A B A O A\end{array}$ & $\begin{array}{l}\text { fract. } \\
\text { AABAAA }\end{array}$ & $\begin{array}{c}\text { risk } \\
\text { AAAAAAABÄ }\end{array}$ & $\begin{array}{l}\text { fract. } \\
\triangle A B A A B A\end{array}$ \\
\hline & $9.060 \mathrm{E}-14$ & 0.0000 & $2.475 E-15$ & & $1.344 E-14$ & 0.0000 & $4.274 E-17$ & 0.0000 & $1.042 E-16$ & 0.0000 & $1.189 E-13$ & 0.0000 \\
\hline & & 0.0000 & $000 E+00$ & 0.0000 & $000 E+00$ & 0.0000 & $0.000 E+00$ & 0.0000 & $0.000 E+00$ & 0.0000 & $9.072 E-09$ & .0871 \\
\hline$A m-241$ & $0.000 E+00$ & 0.0000 & $0.000 E+00$ & 0.0000 & $0.000 E+00$ & 0.0000 & $0.000 E+00$ & 0.0000 & $0.000 E+00$ & 0.0000 & $1.430 \mathrm{E}-08$ & .1373 \\
\hline & $0.000 E+00$ & 0.0000 & $0.000 E+00$ & 0.0000 & $0.000 E+00$ & & $0.000 E+00$ & 0.0000 & $0.000 E+00$ & & & \\
\hline & & & $D O E+00$ & & $0.000 E+00$ & 0.0000 & $0.000 E+00$ & 000 & $0.000 E+00$ & 0.0000 & & 000 \\
\hline & $2.325 \mathrm{E}-$ & 0.0000 & $1.924 E-17$ & 0.0000 & $3.198 E-18$ & 0.0000 & $277 \mathrm{E}-17$ & 0.0000 & $828 E-18$ & 000 & & .0000 \\
\hline & $0.000 \mathrm{E}+00$ & 0.0000 & $1 O E+00$ & 0.0000 & $0.000 E+00$ & 000 & $E+00$ & 0.0000 & $000 E+00$ & & & \\
\hline & $0.000 E+00$ & & $10 E+00$ & 0.0000 & $O E E+00$ & & $E+00$ & & $10 E+00$ & & & 000 \\
\hline & $0.000 E+00$ & 0.0000 & $0.000 E+00$ & 0.0000 & $0.000 E+00$ & 000 & $0.000 E+00$ & 0.0 & $0.000 E+00$ & 0.0000 & $E-22$ & 0000 \\
\hline-3 & $0.000 E \div 00$ & & $10 E+00$ & 0.0000 & $0 E+00$ & 0.0000 & $00 E+00$ & 0.0 & $0.000 E+00$ & 0.0000 & & \\
\hline & & & & & & & & & & & & \\
\hline & $0.000 E+$ & & $O E+00$ & & $E+\infty$ & & & & $E+00$ & 000 & -10 & 018 \\
\hline & $1.369 \mathrm{E}-1$ & & $a E-17$ & 0.00 & $1.984 E-15$ & 0.0000 & $1.334 \mathrm{E}-15$ & 0.0000 & & & & \\
\hline & $8.008 \mathrm{E}-$ & & EE-13 & & & & & & $E-14$ & & -12 & 000 \\
\hline & & & & & $E+00$ & & & & $E+00$ & & -12 & \\
\hline & 0.0 & & $O E+00$ & 0.0000 & $0.000 E+00$ & 0.0 & $0 E+00$ & & $0.000 E+00$ & 0.0000 & $9 E-08$ & 153 \\
\hline & 0.0 & 000 & $O E+00$ & 0.0000 & $E+00$ & 0.0000 & $0 E+00$ & 000 & $O O E+00$ & 1000 & -08 & \\
\hline & & & & & & & & & & & & \\
\hline & & & 2.7 & & 1.5 & & $E-20$ & & $8 E-20$ & 00 & -18 & 0 \\
\hline & & 0.0000 & $9.281 \mathrm{E}-18$ & 0.0000 & $E-17$ & 0.0000 & $E-17$ & 000 & $E-17$ & 0.0000 & $8 E-15$ & 0.0000 \\
\hline & $9.851 \mathrm{E}$. & 0.0000 & $5.728 \mathrm{E}-$ & 0.0000 & 1.5 & & & & $E-23$ & 000 & $E-18$ & 000 \\
\hline & & & $7.203 E-16$ & & & & $E-17$ & & ;9E-18 & & $E-14$ & 00 \\
\hline & & & $7.297 \mathrm{E}-15$ & & & 0.0000 & $4 E-16$ & & $3.844 \mathrm{E}-17$ & 00 & $E-13$ & 0.0000 \\
\hline & $3.380 E-2$ & & $1.834 \mathrm{E}-21$ & 0.0000 & $4.939 E-21$ & 0.0000 & $6.860 \mathrm{E}-23$ & & $1.004 \mathrm{E}-23$ & 1000 & $2 E-20$ & 0.0000 \\
\hline & & & & & & & & & & & & \\
\hline & & & $1.878 \mathrm{E}-12$ & & $4.857 E-11$ & 0.0005 & $2.221 \mathrm{E}-12$ & & $1.131 \mathrm{E}-11$ & 0.0001 & $E-10$ & 0.0037 \\
\hline & $8.279 E^{-}$ & & $4.811 \mathrm{E}-14$ & 0.0000 & $1.244 E-12$ & 0.0000 & $5.690 E-14$ & 0.0000 & $2.899 \mathrm{E}-13$ & 0.0000 & $1.022 E-11$ & 0.0001 \\
\hline & & & & & & & & & & & & \\
\hline & & & & & & & & & & & & \\
\hline otal & & .0061 & & .0001 & 9.7 & 0.0009 & $E=11$ & 003 & $=-70$ & 0.0030 & & \\
\hline
\end{tabular}

** Sum of water independent ground, inhalation, plant, meat, milk, soil

and water dependent water, fish, plant, meat, milk pathways

\begin{tabular}{|c|c|}
\hline Attachment & Sheet No. 50 of 52 \\
\hline Originator: S.W. Clark & Date \\
\hline Chk'd By M.W. Perrott & Date \\
\hline $0100 F-C A-V 0280$ & Rev. No. \\
\hline
\end{tabular}




\section{ATTACHMENT 3}

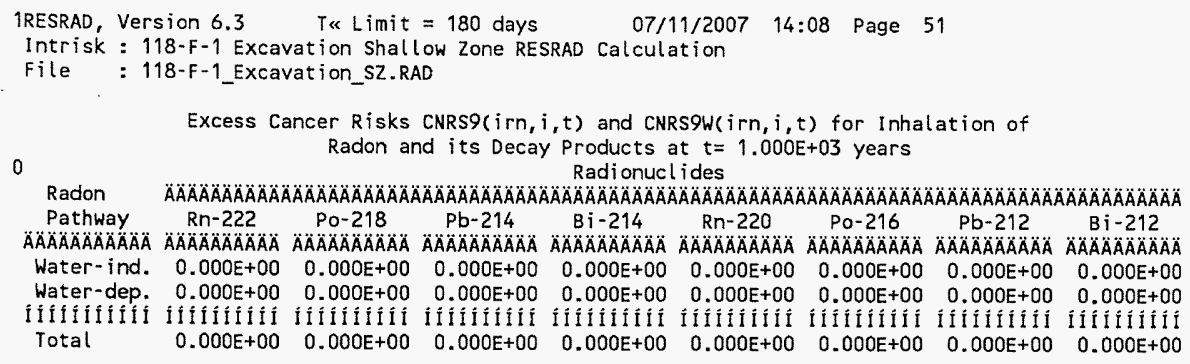

\begin{tabular}{|c|c|}
\hline Attachment $\quad 3$ & Sheet No. $\underline{51}$ of $\underline{52}$ \\
\hline Originator: S.W. Clark & Date \\
\hline Chk'd By M.W. Perrott & Date \\
\hline $0100 F-C A-V 0280$ & Rev. No. \\
\hline
\end{tabular}




\title{
ATTACHMENT 3
}

\begin{abstract}
1RESRAD, Version $6.3 \quad T$ Limit $=180$ days $07 / 11 / 2007 \quad 14: 08$ Page 52
\end{abstract}

Intrisk : 118-F-1 Excavation Shallow Zone RESRAD Calculation

File : 118-F-1_Excavation_SZ.RAD

Total Excess Cancer Risk CNRSI $(i, p, t)^{* * *}$ for Initially Existent Radionuclides $(i)$ and Pathways $(p)$ and Fraction of Total Risk at $t=1.000 E+03$ years

Water Dependent Pathways

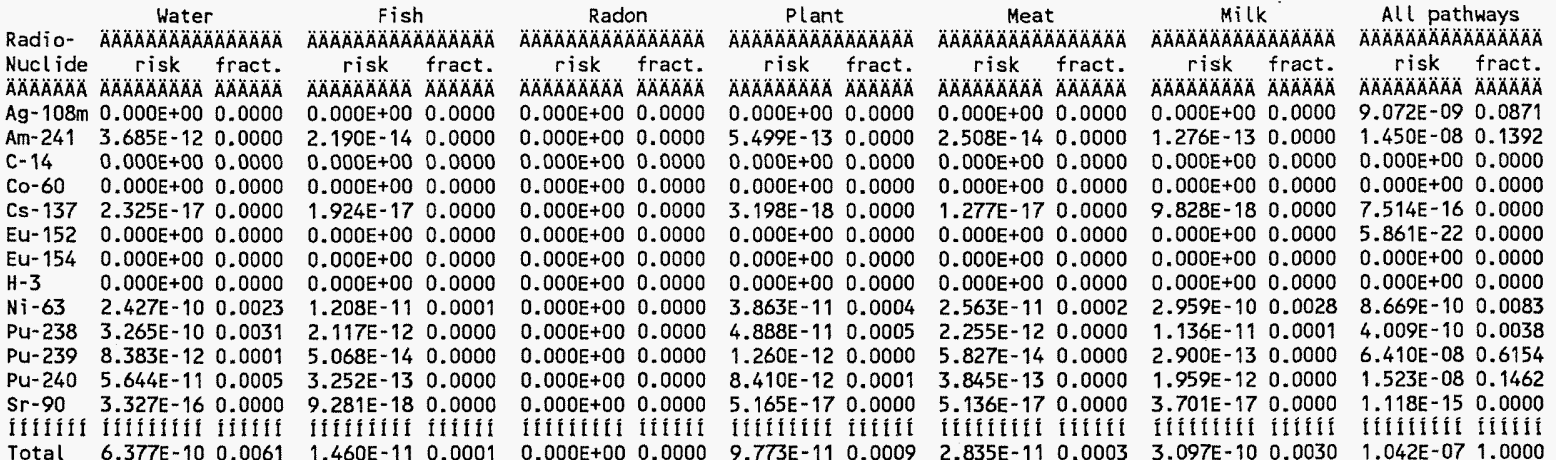

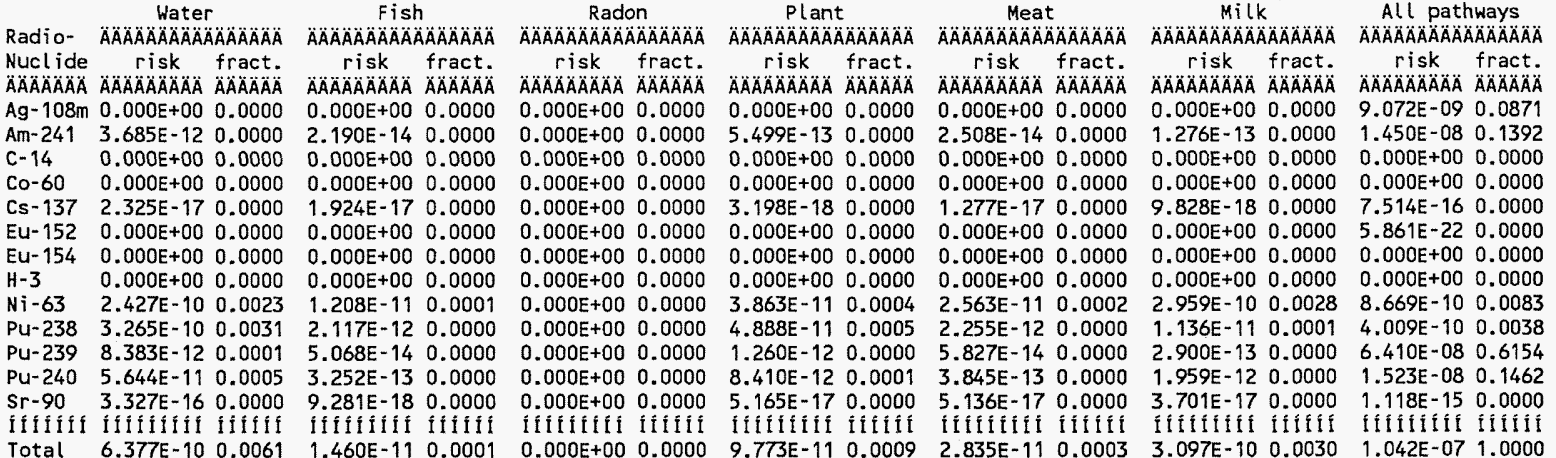

***CNRSI $(i, p, t)$ includes contribution from decay daughter radionuclides

\begin{tabular}{|c|c|}
\hline Attachment $\quad 3$ & Sheet No. $\underline{52}$ of $\underline{52}$ \\
\hline Originator: S.W. Clark & Date \\
\hline Chk'd By M.W. Perrott & Date \\
\hline Calc. No. $0100 F-C A-V 0280$ & Rev. No. 0 \\
\hline
\end{tabular}




\section{ATTACHMENT 4}

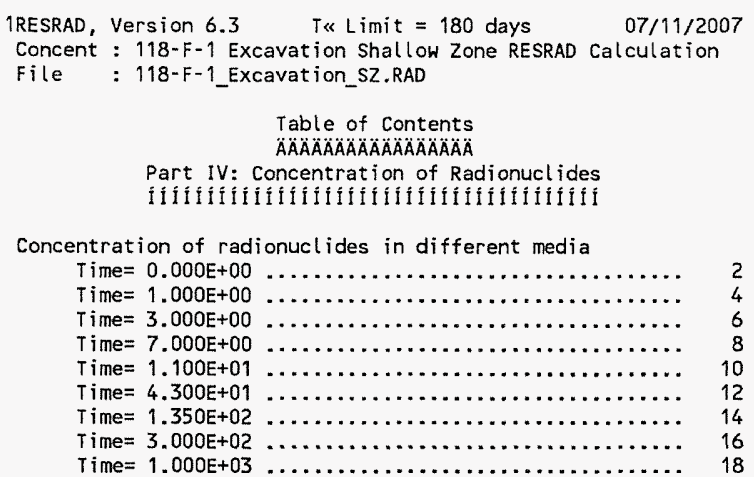

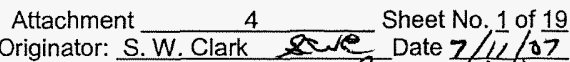

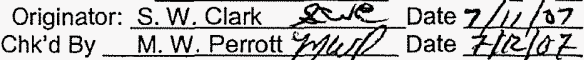

Calc. No. 0100 F-CA-V0280 Rev. No. 0 


\section{ATTACHMENT 4}

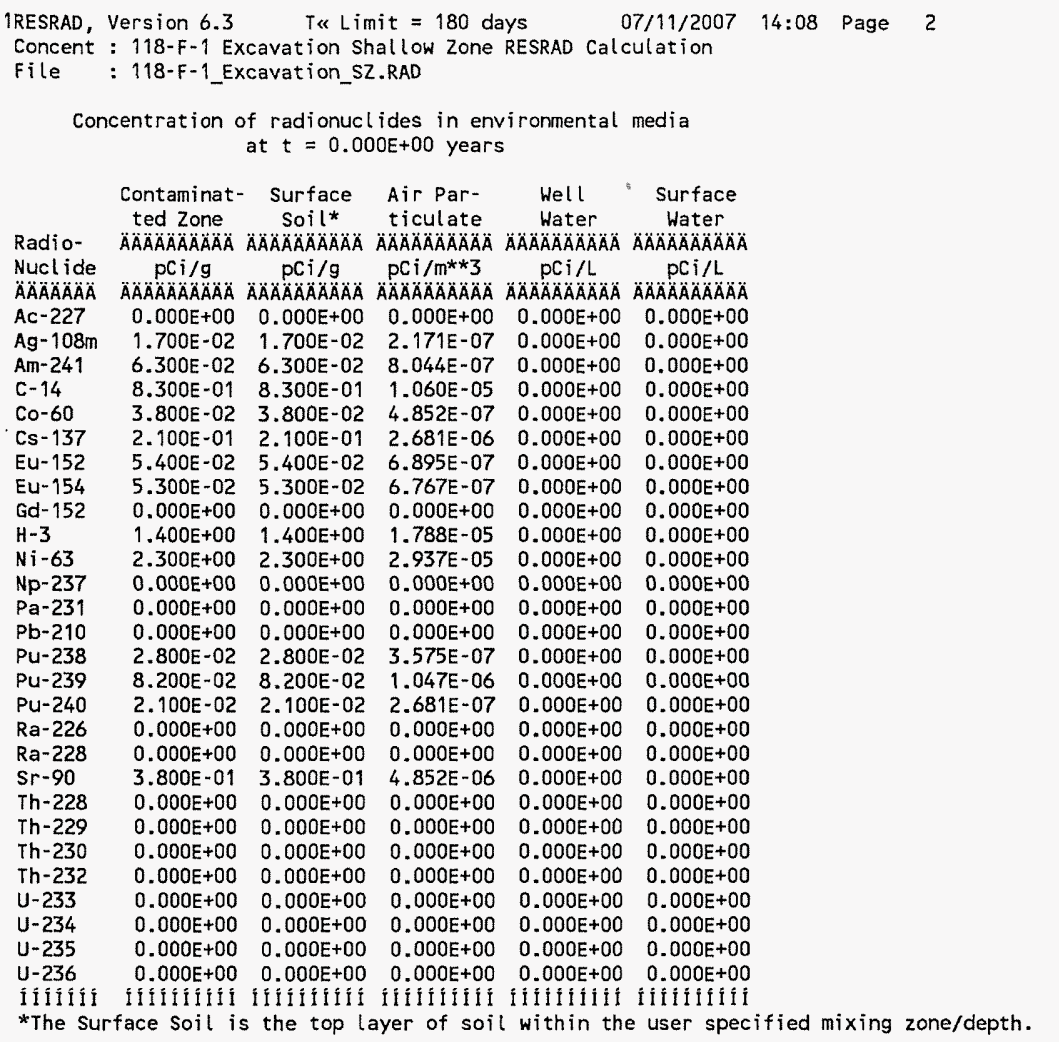

Concentrations in the media occurring in pathways that are suppressed are calculated using the current input parameters, i.e. using parameters appearing in the input screen when the pathways are active.

Concentration of $\mathrm{H}-3$ in soil moisture $=1.156 \mathrm{E}+01 \mathrm{pCi} / \mathrm{ml}$

Concentration of gaseous $\mathrm{H}-3$ in air $=2.348 \mathrm{E}+00 \mathrm{pCi} / \mathrm{m}^{\star *} 3$

Concentration of gaseous $\mathrm{C}-14$ in air $=4.421 \mathrm{E}+00 \mathrm{pCi} / \mathrm{m} \star * 3$

\begin{tabular}{ll} 
Attachment $\frac{4}{1}$ & Sheet No. 2 of 19 \\
Originator: S.W. Clark & Date \\
Chk'd By & Date \\
Calc. No. Perrott & Rev. No. $\quad 0$ \\
\hline O100F-CA-V0280 & Rev.
\end{tabular}




\title{
ATT ACHMENT 4
}

\begin{abstract}
IRESRAD, Version $6.3 \quad T \ll$ Limit $=180$ days
Concent : $118-F-1$ Excavat ion Shallow Zone RESRA
07/11/2007 14:08 Page 3
\end{abstract}

File: 118-F-1_Excavation_SZ.RAD

Concentration of radionuclides in foodstuff media at $t=0.000 E+00$ years*

\begin{tabular}{|c|c|c|c|c|c|c|c|c|c|}
\hline & $\begin{array}{c}\text { Drinking } \\
\text { Water }\end{array}$ & $\begin{array}{l}\text { Nonleafy } \\
\text { Vegetable }\end{array}$ & $\begin{array}{c}\text { Leafy } \\
\text { Vegetable }\end{array}$ & $\begin{array}{l}\text { Fodder } \\
\text { Meat }\end{array}$ & $\begin{array}{l}\text { Fodder } \\
\text { Milk }\end{array}$ & 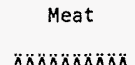 & 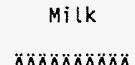 & 00000000000 & Crustacea \\
\hline & $A \cap A B A A A A O A O A$ & $\triangle A A O A O A Z A ̈ A ̈ A ̈ A$ & $\triangle A A A A O A O A Z A Z A ̈ A$ & $\triangle A O A O A O A A O A O A O A$ & $\triangle A O A O A A O A A O A O A$ & 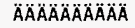 & A AOAAAAAOAAÄÄ & $\triangle A O A A O A O A A A B A ̈$ & $\triangle A O A B A A A A B A$ \\
\hline & $\begin{array}{c}\mathrm{PCi} / \mathrm{L} \\
A A A A B A A B A B A\end{array}$ & & $\begin{array}{c}\mathrm{pCi} / \mathrm{kg} \\
A A B A A A A A A B\end{array}$ & $p C i / k g$ & $\begin{array}{c}\mathrm{pCi} / \mathrm{kg} \\
A A A B A A A B A A\end{array}$ & ÄÄÄAAAAOAOA & $\mathrm{pCi} / \mathrm{L}$ & $\mathrm{pci} / \mathrm{kg}$ & $\mathrm{pCi} / \mathrm{kg}$ \\
\hline & $0.000 \mathrm{E}+00$ & $0.000 \mathrm{E}+00$ & $0.000 \mathrm{E}+00$ & $0.000 \mathrm{E}+00$ & $0.000 E+00$ & $0.000 E+00$ & $0.000 E+00$ & $0.000 E+00$ & $0.000 E+00$ \\
\hline & $0.000 E+00$ & $2.550 \mathrm{E}+00$ & & & & & $3.719 E+00$ & $0.000 E+00$ & $.000 E+00$ \\
\hline & & & & & & & & $0.000 E+00$ & \\
\hline & $0.000 E+00$ & $0 E+03$ & $E+03$ & & $E+03$ & & & $J O E+00$ & $E+00$ \\
\hline & $E+00$ & $+\infty 0$ & 3.0 & & & & & $+\infty 0$ & \\
\hline & & & & & & & & & \\
\hline & 0.0 & & & & & & & +00 & $E+00$ \\
\hline & 0.0 & & & & & & & +00 & +00 \\
\hline & & & & & & & & & \\
\hline & & & & & & & & $+\infty 0$ & $+\infty$ \\
\hline & & & & & & & & .00 & \\
\hline & & & & & & & & & \\
\hline & +00 & & & & & & & $+\infty 0$ & $+\infty$ \\
\hline & & & & & & & & & \\
\hline & & & & & & & & & \\
\hline & +00 & & & & & & & & $+\infty$ \\
\hline & & & & & & & & & +00 \\
\hline & +00 & & & & & & & $+\infty$ & $+\infty$ \\
\hline & +00 & & & & $+\infty 0$ & & & $+\infty 0$ & $E+00$ \\
\hline & & & & & & & & & \\
\hline & & & & & & & & $+\infty$ & $+\infty$ \\
\hline & $0.000 E+00$ & +00 & 0.0 & $E+\infty$ & $E+00$ & $+\infty 0$ & $+\infty$ & $+\infty 0$ & $=00$ \\
\hline & & & & & & & & & $+\infty 0$ \\
\hline & $0.000 E+00$ & & & & & & & & \\
\hline & $0.000 E+00$ & $0.000 E+00$ & 0.00 & 0.0 & $O E+00$ & & & $+\infty 0$ & $E+\infty$ \\
\hline & & $0.000 E+00$ & & & $0.000 E+00$ & & & $E+00$ & $0.000 \mathrm{E}+00$ \\
\hline & & & & & & & & & \\
\hline & & & & & & & & +00 & $E+00$ \\
\hline & & & & & & & & & \\
\hline
\end{tabular}

* Concentrations are at consumption time and include radioactive decay and ingrowth during storage time.

For livestock fodder, consumption time is $t$ minus meat or milk storage time.

Concentrations in the media occurring in pathways that are suppressed are calculated using the current input parameters, i.e. using parameters appearing in the input screen when the pathways are active.

\begin{tabular}{|c|c|}
\hline Attachment $\quad 4$ & Sheet No. $\underline{3}$ of 19 \\
\hline Originator: $S$. W. Clark & Date \\
\hline Chk'd By M.W. Perrott & Date \\
\hline Calc. No. $0100 \mathrm{~F}$-CA-V0280 & Rev. No. \\
\hline
\end{tabular}




\section{ATTACHMENT 4}

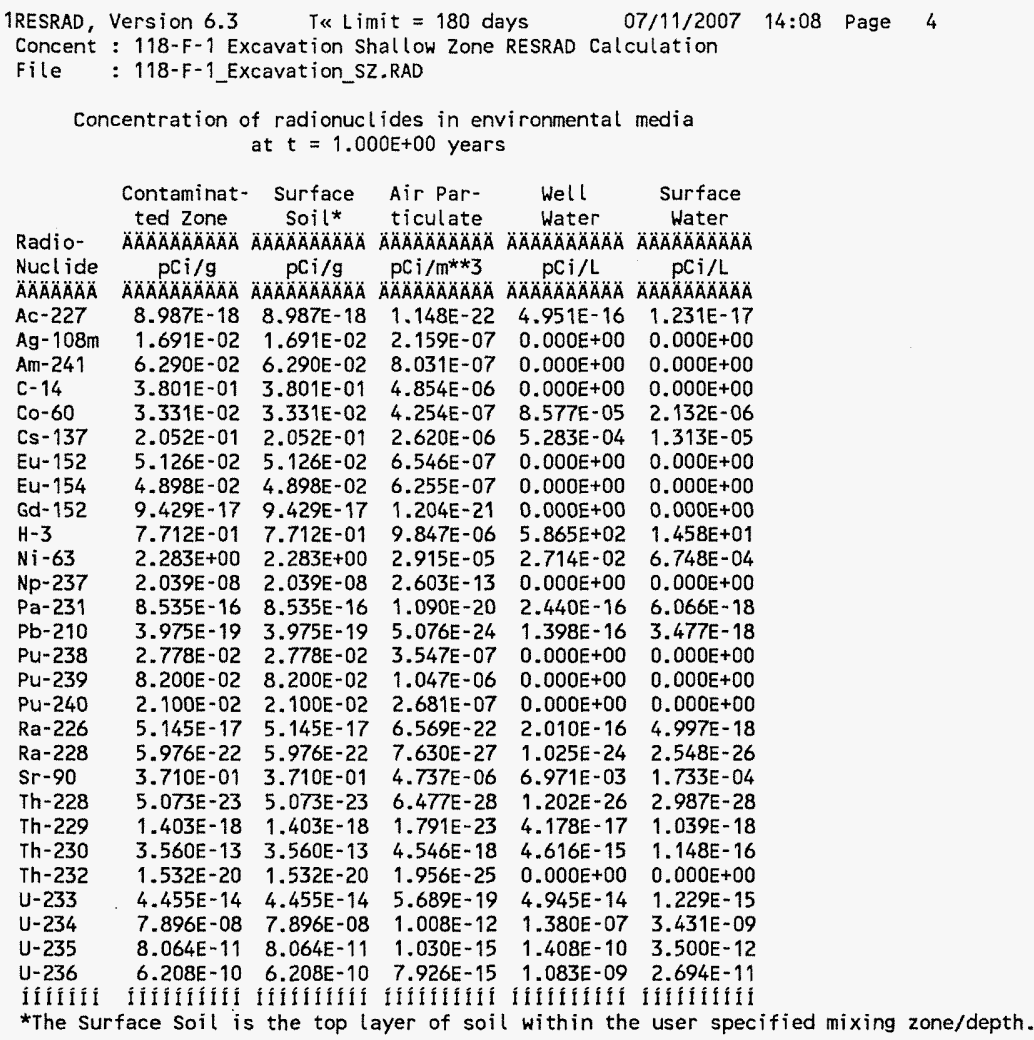

Concentrations in the media occurring in pathways that are suppressed are calculated using the current input parameters, i.e. using parameters appearing in the input screen when the pathways are active.

Concentration of $\mathrm{H}-3$ in soil moisture $=6.369 \mathrm{E}+00 \mathrm{pCi} / \mathrm{mL}$

Concentration of gaseous $\mathrm{H}-3$ in air $=1.293 \mathrm{E}+00 \mathrm{pCi} / \mathrm{m}^{* * 3}$

Concentration of gaseous $\mathrm{C}-14$ in air $=2.025 \mathrm{E}+00 \mathrm{pCi} / \mathrm{m}^{* * 3}$

$\begin{array}{ll}\text { Attachment } \frac{4}{1} & \text { Sheet No. } 4 \text { of } 19 \\ \text { Originator: S.W. Clark } & \text { Date } \\ \text { Chk'd By } & \text { Date } \\ \text { Calc. No. Nerrott } & \text { Rev. No. } \_ \text {O100F-CA-V0280 }\end{array}$




\section{ATTACHMENT 4}

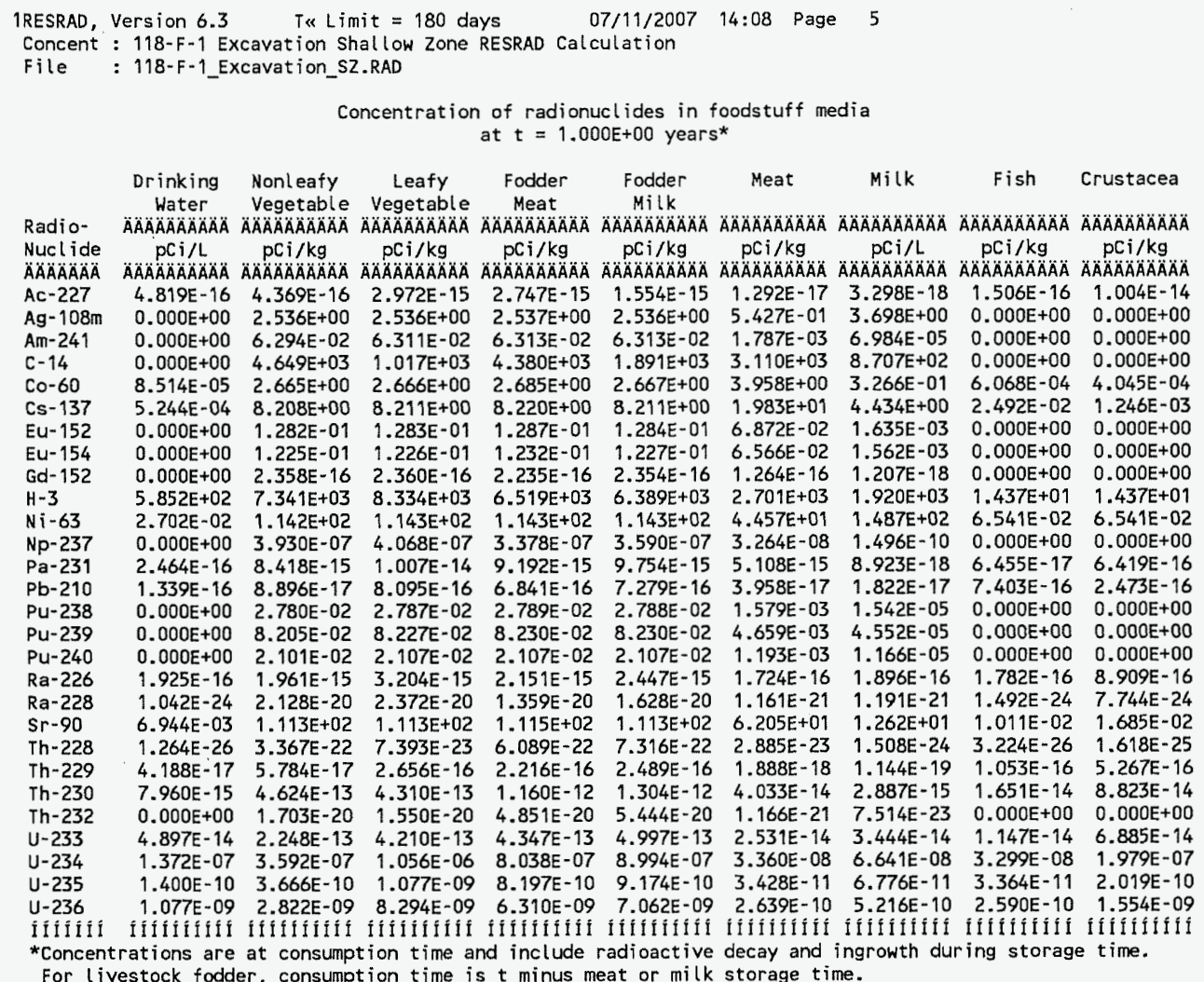

Concentrations in the media occurring in pathways that are suppressed are calculated using the current input parameters, i.e. using parameters appearing in the input screen when the pathways are active.

$\begin{array}{ll}\text { Attachment } \frac{4}{\text { S. Clark }} & \text { Sheet No. } \underline{5} \text { of } 19 \\ \text { Originator: } \frac{\text { S.W. }}{\text { M.W. Perrott }} & \text { Date } \\ \text { Chk'd By } & \text { Rev. No. } \underline{0} \\ \text { Calc. No. } & \text { O100F-CA-V0280 }\end{array}$




\section{ATTACHMENT 4}

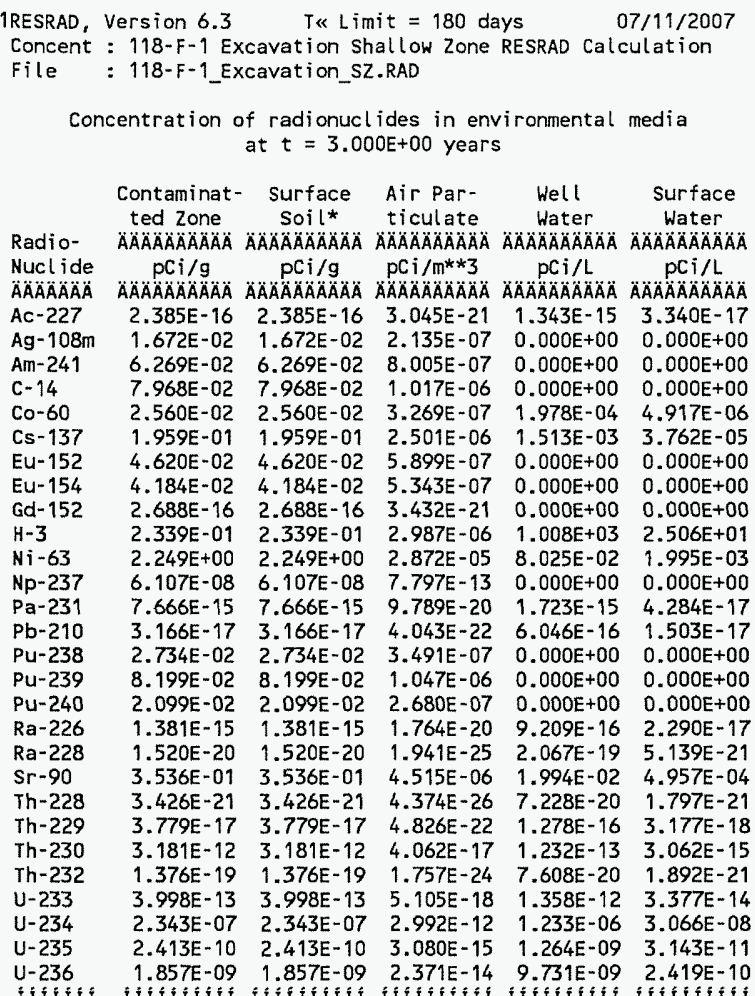

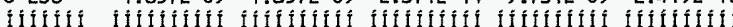

*The Surface Soil is the top layer of soil within the user specified mixing zone/depth.

Concentrations in the media occurring in pathways that are suppressed are calculated using the current input parameters, i.e. using parameters appearing in the input screen when the pathways are active.

Concentration of $\mathrm{H}-3$ in soil moisture $=1.932 \mathrm{E}+00 \mathrm{pCi} / \mathrm{ml}$

Concentration of gaseous $\mathrm{H}-3$ in air $=3.923 \mathrm{E}-01 \mathrm{pCi} / \mathrm{m}^{\star * 3}$

Concentration of gaseous $\mathrm{C}-14$ in air $=4.245 \mathrm{E}-01 \mathrm{pCi} / \mathrm{m}^{\star * 3}$

Attachment 4 


\section{ATTACHMENT 4}

\begin{tabular}{|c|c|c|c|c|c|c|c|c|c|}
\hline $\begin{array}{l}\text { IRESRAD, } \\
\text { Concent } \\
\text { File }\end{array}$ & $\begin{array}{l}\text { Version } 6.3 \\
: 118-F-1 \text { EX } \\
: 118-F-1 \text { EX }\end{array}$ & $\begin{array}{l}\text { T\& L } \\
\text { xcavation } \\
\text { xcavation_ }\end{array}$ & $\begin{array}{l}t=180 \\
\text { llow Zon } \\
\text { RAD }\end{array}$ & $\begin{array}{l}\text { lays } \\
\text { RESRAD Calo }\end{array}$ & $\begin{array}{l}07 / 11 / 2007 \\
\text { culation }\end{array}$ & $14: 08$ & 7 & & \\
\hline & & & oncentrat & at $t \square 3$ & ides ir & & & & \\
\hline & $\begin{array}{l}\text { Drinking } \\
\text { Water }\end{array}$ & $\begin{array}{l}\text { Nonleafy } \\
\text { Vegetable }\end{array}$ & $\begin{array}{c}\text { Leafy } \\
\text { Vegetable }\end{array}$ & $\begin{array}{l}\text { Fodder } \\
\text { Meat }\end{array}$ & $\begin{array}{l}\text { Fodder } \\
\text { Milk }\end{array}$ & Meat & Milk & Fish & Crustacea \\
\hline & 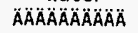 & ÄÄÄÄÄAAÄ & 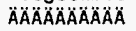 & 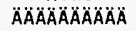 & 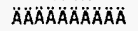 & $\triangle A O A O A O A A O A O A$ & $\triangle A O A A A O A A A O A ̈$ & $\triangle A A A B A A B A A O A A$ & $\triangle A A A A A B A O A B A ̈$ \\
\hline & $\mathrm{pCi} / \mathrm{L}$ & & $\mathrm{pCi} / \mathrm{kg}$ & $\mathrm{pCi} / \mathrm{kg}$ & $\mathrm{pCi} / \mathrm{kg}$ & $p c i / k g$ & pCi/L & $\mathrm{pci} / \mathrm{kg}$ & $\mathrm{pCi} / \mathrm{kg}$ \\
\hline & $\triangle A A A A O A O A A A$ & & AAAOAOAAOAOAAÄ & AAAAAAAAAAAAOA & $\triangle A A A A A A A A A A A$ & A AOAAAAAOAOÄ & $\triangle A B A A A A A A A B A$ & AAAAAAAAAAAÄ & AOAAAAAAAAAOA \\
\hline & $353 E-15$ & $2.570 E-15$ & 9.17 & $6 E-14$ & $8.899 E-15$ & $1.104 E-16$ & $1.653 E-17$ & $1 E-16$ & $99 E-14$ \\
\hline & OOOE +00 & & 2.50 & $E+00$ & & $5.368 \mathrm{E}-01$ & $3.658 E+00$ & $0.000 E+00$ & $00 E+00$ \\
\hline & & & 6.2 & & & $1.781 \mathrm{E}-03$ & & $E+00$ & $E+00$ \\
\hline & & & 2.1 & $E+02$ & & $6.520 \mathrm{E}+$ & 1.82 & $+\infty$ & $E+\infty$ \\
\hline & & & 2.0 & & & $3.044 E+$ & 2.51 & OE- 03 & E-04 \\
\hline & .03 & & 7.8 & & & $1.894 \mathrm{E}+$ & 4.2 & & $=-03$ \\
\hline & & & & & & 6.1 & & & +00 \\
\hline & & & & & & & & & $=+\infty$ \\
\hline & 00 & & 6.7 & & & & 3.4 & & $=+\infty$ \\
\hline & & 3 & & 3. & & 1. & & +01 & $E+01$ \\
\hline & & & & & & & & & \\
\hline & & & 1.2 & $i$. & & $33 E-07$ & 4.7 & $+\infty$ & $=+\infty$ \\
\hline & & & & & & $4 E-14$ & & -16 & $=-15$ \\
\hline & & & & & & & & & \\
\hline & & & 2.7 & & & 1. & & $+\infty$ & $E+00$ \\
\hline & $E+\infty$ & & 8.2 & 8.2 & & 4.659E-03 & & $+\infty 0$ & $=+\infty$ \\
\hline & $+\infty$ & & 2.1 & & & & & & \\
\hline & -16 & & & & & 4.2 & & & -15 \\
\hline & $=-19$ & & 1.8 & & & $1.332 E-19$ & & -19 & $E-18$ \\
\hline & -02 & & & & & & & & \\
\hline & -20 & & 4.4 & 4.9 & & 6.3 & & & -19 \\
\hline & $E-16$ & $E-16$ & $4 E-16$ & $=-16$ & & $15 E-18$ & & -16 & $=-15$ \\
\hline & $E-13$ & & & & & 3.6 & & & \\
\hline & $=-20$ & 2.5 & 6.22 & 9.7 & -19 & $E-20$ & 1.1 & & -19 \\
\hline & $1.355 \mathrm{E}-12$ & $2.893 \mathrm{E}-12$ & & 9.26 & $E-12$ & $3.275 E-13$ & & $E-13$ & $E-12$ \\
\hline & $E-06$ & & $8.317 \mathrm{E}-06$ & $8.048 \mathrm{E}-06$ & $8.344 E-06$ & $2.456 \mathrm{E}-07$ & & & $E-06$ \\
\hline & E-09 & $2.212 \mathrm{E}-09$ & $8.529 \mathrm{E}-09$ & $8.250 E-09$ & & $2.519 \mathrm{E}-10$ & & & 1.8 \\
\hline & $9.713 \mathrm{E}-09$ & & & 50E-08 & & & & & $33 E-08$ \\
\hline & & & & & & & & & \\
\hline & & & & & & & & & \\
\hline
\end{tabular}

Concentrations in the media occurring in pathways that are suppressed are calculated using the current input parameters, i.e. using parameters appearing in the input screen when the pathways are active.

\begin{tabular}{|c|c|c|}
\hline \multirow{2}{*}{\multicolumn{3}{|c|}{$\begin{array}{cc}\text { Attachment } & 4 \\
\text { Originator: } S \text {. W. Clark } & \text { Sheet No. } I \text { of } 19\end{array}$}} \\
\hline & & \\
\hline Chk'd By & M.W. Perrott & Date \\
\hline Calc. & $0100 F-C A-V 0280$ & Rev. No. \\
\hline
\end{tabular}




\section{ATTACHMENT 4}

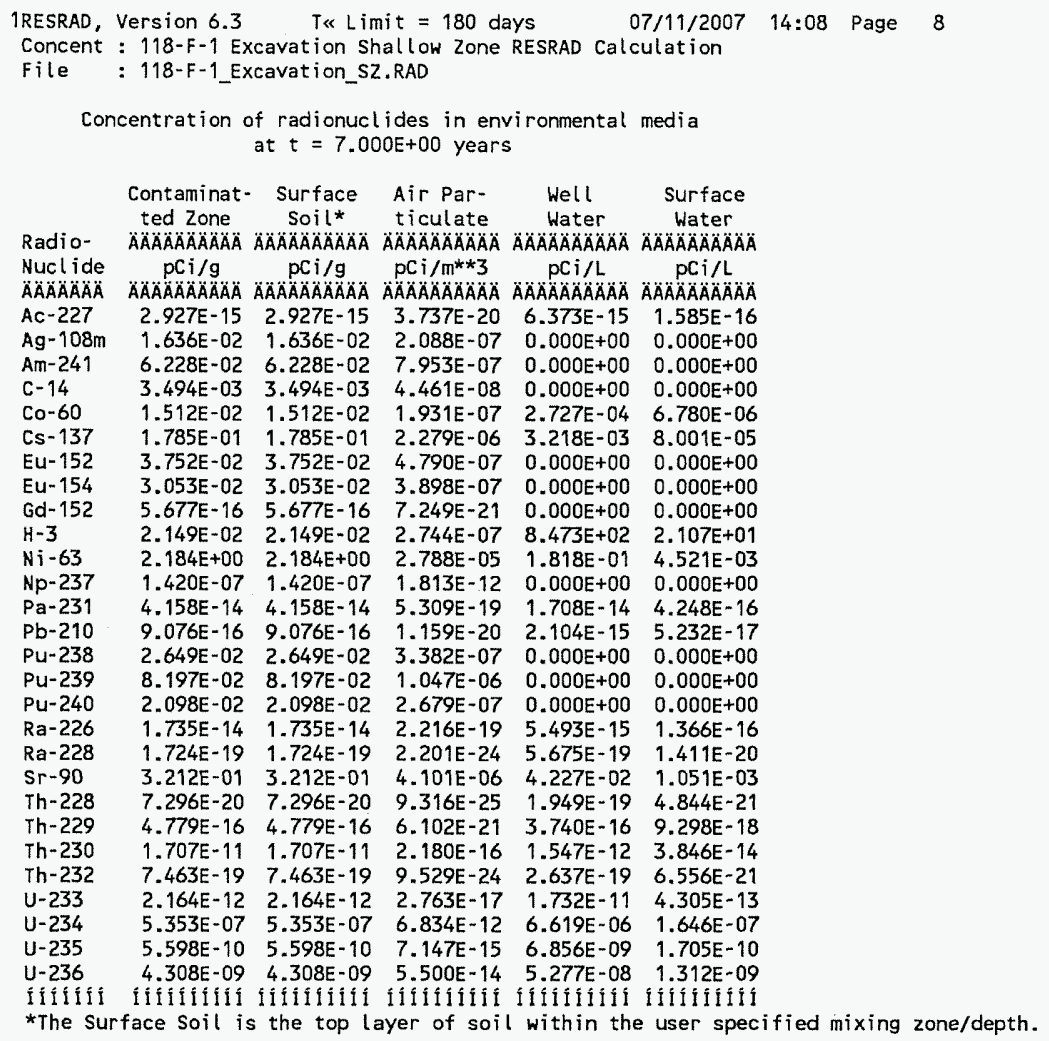

Concentrations in the media occurring in pathways that are suppressed are calculated using the current input parameters, i.e. using parameters appearing in the input screen when the pathways are active.

Concentration of $\mathrm{H}-3$ in soil moisture $=1.775 \mathrm{E}-01 \mathrm{pCi} / \mathrm{ml}$

Concentration of gaseous $\mathrm{H}-3$ in air $=3.604 \mathrm{E}-02 \mathrm{pCi} / \mathrm{m}^{* * 3}$

Concentration of gaseous $\mathrm{C}-14$ in air $=1.861 \mathrm{E}-02 \mathrm{pCi} / \mathrm{m}^{* * 3}$

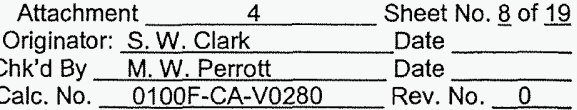




\section{ATTACHMENT 4}

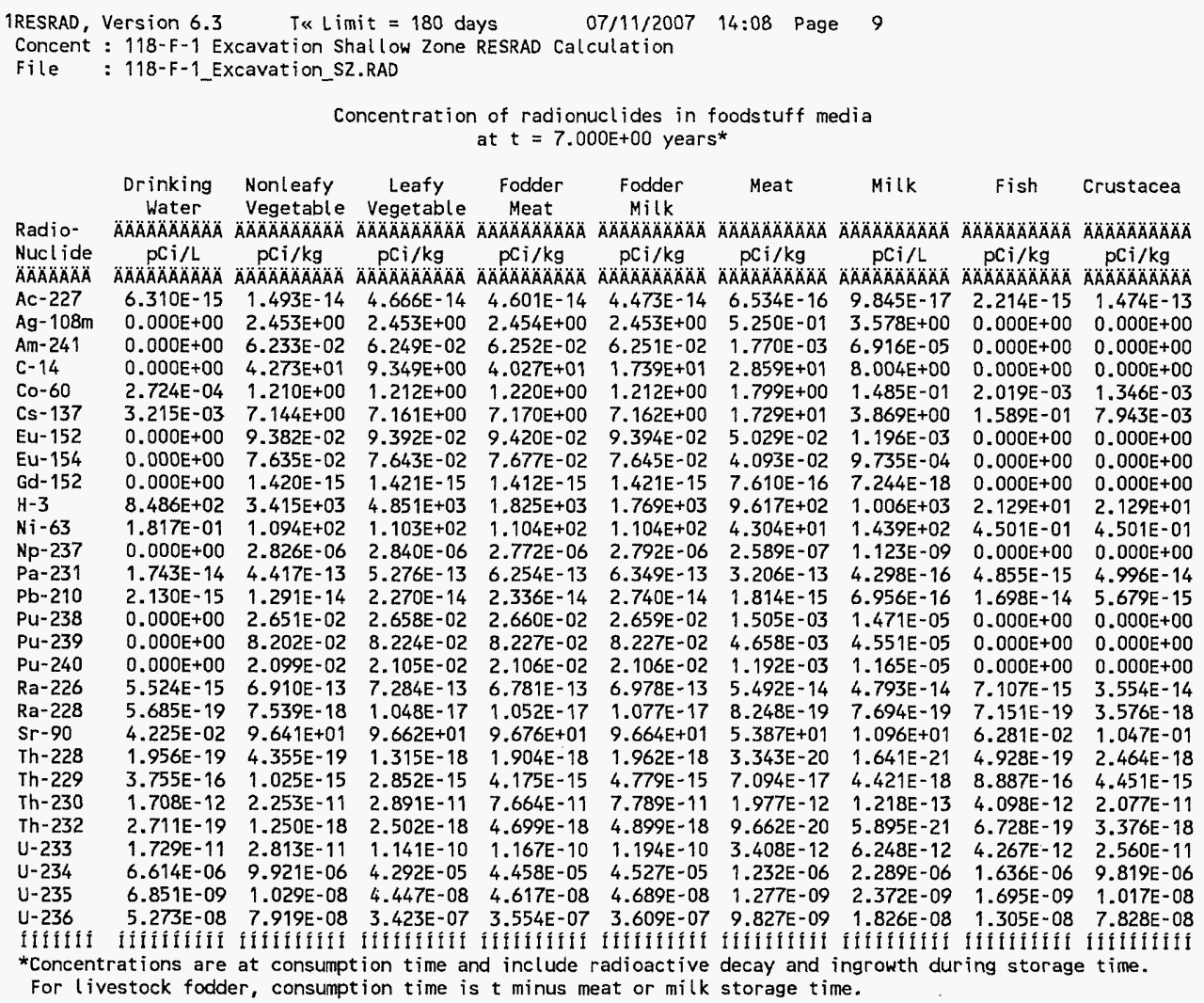

Concentrations in the media occurring in pathways that are suppressed are calculated using the current input parameters, i.e. using parameters appearing in the input screen when the pathways are active.

Attachment Originator: $S$. W. Clark Chk'd By M.W. Perrott Calc. No. 0100F-CA-V0280
Sheet No. $\underline{9}$ of 19 Date Date Rev No 0 


\section{ATTACHMENT 4}

\begin{tabular}{|c|c|c|c|c|c|c|}
\hline $\begin{array}{l}\text { 1RESRAD, } \\
\text { Concent } \\
\text { File }\end{array}$ & $\begin{array}{l}\text { Version } 6.3 \\
: 118-F-1 \text { EX } \\
: 118-F-1 \text { EX }\end{array}$ & $\begin{array}{r}\text { T« Lim } \\
\text { xcavation Sh } \\
\text { xcavation_Sz }\end{array}$ & $\begin{array}{l}\text { mit }=180 \text { da } \\
\text { hallow Zone } \\
\text { Z. RAD }\end{array}$ & $\begin{array}{l}\text { ays } \\
\text { RESRAD Calc }\end{array}$ & $\begin{array}{l}07 / 11 / 2007 \\
\text { culation }\end{array}$ & $14: 08$ Page \\
\hline & centration & $\begin{array}{l}\text { of radionucl } \\
\text { at } t=1.10\end{array}$ & $\begin{array}{l}\text { lides in env } \\
O O E+01 \text { years }\end{array}$ & $\begin{array}{l}\text { vironmental } \\
\text { s }\end{array}$ & media & \\
\hline & $\begin{array}{l}\text { Contaminat- } \\
\text { ted Zone }\end{array}$ & $\begin{array}{l}\text { Surface } \\
\text { Soil* }\end{array}$ & $\begin{array}{l}\text { Air Par- } \\
\text { ticulate }\end{array}$ & $\begin{array}{l}\text { Well } \\
\text { Water }\end{array}$ & $\begin{array}{l}\text { Surface } \\
\text { Water }\end{array}$ & \\
\hline Radio- & A ÄAAAAÄÄÄ & ÄÄÄÄÄÄÄÄÄÄ & ÄÄÄÄAAÄÄÄ & ÄÄÄÄÄÄÄÄ & $\triangle A A O A A A O A O A ̈$ & \\
\hline $\begin{array}{l}\text { Nuclide } \\
\text { ÄÄÄÄÄÄÄ }\end{array}$ & $\begin{array}{c}p C i / g \\
A A A A B A O A O A O A\end{array}$ & $\begin{array}{c}p C i / g \\
\triangle A A A A B A O A O A O A\end{array}$ & 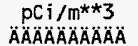 & 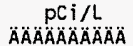 & $\begin{array}{c}\mathrm{pCi} / \mathrm{L} \\
\text { AAAÄÄÄÄÄÄÄA }\end{array}$ & \\
\hline$A C-227$ & $1.098 \mathrm{E}-14$ & $1.098 E-14$ & $1.402 E-19$ & $1.725 E-14$ & $4.290 E-16$ & \\
\hline $\mathrm{Ag}-108 \mathrm{~m}$ & $1.600 \mathrm{E}-02$ & $1.600 \mathrm{E}-02$ & $2.043 E-07$ & $0.000 E+00$ & $0.000 E+00$ & \\
\hline Am-241 & $6.188 \mathrm{E}-02$ & $6.188 E-02$ & $7.901 E-07$ & $0.000 E+00$ & $0.000 E+00$ & \\
\hline$c-14$ & $1.527 E-04$ & $1.527 E-04$ & $1.950 \mathrm{E}-09$ & $0.000 E+00$ & $0.000 E+00$ & \\
\hline Co- 60 & 8.933E-03 & $8.933 E-03$ & $1.141 E-07$ & $2.532 E-04$ & $6.295 E-06$ & \\
\hline Cs-137 & $1.627 E-01$ & $1.627 E-01$ & $2.077 E-06$ & $4.610 E-03$ & $1.146 E-04$ & \\
\hline Eu- 152 & $3.047 \mathrm{E}-02$ & $3.047 E-02$ & $3.890 \mathrm{E}-07$ & $0.000 E+00$ & $0.000 E+00$ & \\
\hline Eu-154 & $2.228 \mathrm{E}-02$ & $2.228 \mathrm{E}-02$ & $2.844 \mathrm{E}-07$ & $0.000 E+00$ & $0.000 E+00$ & \\
\hline Gd-152 & $8.104 E-16$ & $8.104 E-16$ & $1.035 E-20$ & $0.000 E+00$ & $0.000 E+00$ & \\
\hline$H-3$ & $1.971 \mathrm{E}-03$ & 1.971E-03 & $2.516 E-08$ & $7.808 E+01$ & $1.941 E+00$ & \\
\hline $\mathrm{Ni}-63$ & $2.120 E+00$ & $2.120 \mathrm{E}+00$ & $2.707 E-05$ & $2.775 E-01$ & $6.899 E-03$ & \\
\hline $\mathrm{Np}-237$ & $2.224 \mathrm{E}-07$ & $2.224 E-07$ & $2.840 E-12$ & $0.000 E+00$ & $0.000 E+00$ & \\
\hline $\mathrm{Pa}-231$ & 1.023E-13 & $1.023 E-13$ & $1.306 E-18$ & $6.125 E-14$ & $1.523 E-15$ & \\
\hline $\mathrm{Pb}-210$ & $5.354 E-15$ & $5.354 E-15$ & $6.837 E-20$ & $4.173 E-15$ & $1.037 E-16$ & \\
\hline Pu-238 & $2.566 \mathrm{E}-02$ & $2.566 \mathrm{E}-02$ & $3.277 \mathrm{E}-07$ & $0.000 E+00$ & $0.000 E+00$ & \\
\hline Pu-239 & 8.195E-02 & $8.195 \mathrm{E}-02$ & $1.046 E-06$ & $0.000 E+00$ & $0.000 E+00$ & \\
\hline Pu-240 & 2.097E-02 & $2.097 \mathrm{E}-02$ & $2.677 \mathrm{E}-07$ & $0.000 E+00$ & $0.000 E+00$ & \\
\hline $\mathrm{Ra}-226$ & $6.659 \mathrm{E}-14$ & $6.659 \mathrm{E}-14$ & $8.502 E-19$ & $1.687 E-14$ & 4.194E-16 & \\
\hline $\mathrm{Ra}-228$ & $6.017 E-19$ & $6.017 E-19$ & $7.683 E-24$ & $1.078 \mathrm{E}-18$ & $2.680 E-20$ & \\
\hline $5 r-90$ & $2.917 E-01$ & $2.917 E-01$ & $3.725 E-06$ & $6.037 E-02$ & $1.501 E-03$ & \\
\hline Th-228 & $3.319 E-19$ & $3.319 E-19$ & $4.238 E-24$ & $3.458 E-19$ & $8.597 E-21$ & \\
\hline Th-229 & $1.846 E-15$ & $1.846 E-15$ & $2.357 E-20$ & $6.561 E-16$ & $1.631 E-17$ & \\
\hline Th-230 & $4.157 E-11$ & $4.157 \mathrm{E}-11$ & $5.308 E-16$ & $5.939 E-12$ & $1.477 \mathrm{E}-13$ & \\
\hline Th-232 & $1.836 E-18$ & $1.836 E-18$ & $2.344 E-23$ & $5.604 E-19$ & $1.393 E-20$ & \\
\hline U-233 & $5.312 E-12$ & $5.312 E-12$ & $6.783 E-17$ & $6.689 E-11$ & $1.663 E-12$ & \\
\hline$U-234$ & $8.234 E-07$ & $8.234 E-07$ & $1.051 E-11$ & $1.611 E-05$ & 4.006E-07 & \\
\hline$U-235$ & $8.747 \mathrm{E}-10$ & $8.747 E-10$ & $1.117 \mathrm{E}-14$ & $1.686 E-08$ & 4. $193 E-10$ & \\
\hline $4-236$ & $6.730 \mathrm{E}-09$ & $6.730 \mathrm{E}-09$ & $8.593 \mathrm{E}-14$ & $1.298 \mathrm{E}-07$ & 3.227E-09 & \\
\hline fillílí & ffifififi & fiflififfí & fiffifítín & flifitifi & 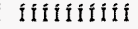 & \\
\hline
\end{tabular}

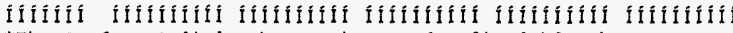

*The Surface Soil is the top layer of soil within the user specified mixing zone/depth.

Concentrations in the media occurring in pathways that are suppressed are calculated using the current input parameters, i.e. using parameters appearing in the input screen when the pathways are active.

Concentration of $\mathrm{H}-3$ in soil moisture $=1.628 \mathrm{E}-02 \mathrm{pCi} / \mathrm{ml}$

Concentration of gaseous $\mathrm{H}-3$ in air $=3.305 \mathrm{E}-03 \mathrm{pCi} / \mathrm{m}^{* * 3}$

Concentration of gaseous $\mathrm{C}-14$ in air $=8.136 \mathrm{E}-04 \mathrm{pCi} / \mathrm{m}^{* * 3}$

Attachment 


\section{ATTACHMENT 4}

\begin{tabular}{|c|c|c|c|c|c|c|c|c|c|}
\hline \multirow[t]{2}{*}{$\begin{array}{l}\text { 1RESRAD, } \\
\text { Concent } \\
\text { File : }\end{array}$} & $\begin{array}{l}\text { Version } 6.3 \\
: 118-F-1 \text { Ex } \\
: 118-F-1 \text { Ex }\end{array}$ & $\begin{array}{l}\text { T* Lim } \\
\text { cavation Sh } \\
\text { cavation_Sz }\end{array}$ & $\begin{array}{l}\text { nit }=180 \text { da } \\
\text { hallow Zone } \\
\text { 2.RAD } \\
\text { oncentration }\end{array}$ & $\begin{array}{l}n \text { of radions } \\
\text { at } t=1.10\end{array}$ & $\begin{array}{l}\text { uclides in } f \\
00 E+01 \text { years }\end{array}$ & $\begin{array}{l}\text { foodstuff me } \\
s^{*}\end{array}$ & edia & & \\
\hline & $\begin{array}{l}\text { Drinking } \\
\text { Water }\end{array}$ & $\begin{array}{l}\text { Nonleafy } \\
\text { Vegetable }\end{array}$ & $\begin{array}{c}\text { Leafy } \\
\text { Vegetable }\end{array}$ & $\begin{array}{l}\text { Fodder } \\
\text { Meat }\end{array}$ & $\begin{array}{l}\text { Fodder } \\
\text { Milk }\end{array}$ & Meat & Milk & Fish & Crustacea \\
\hline Radio- & ÄÄÄÄÄÄÄÄ & ÄÄÄÄÄÄÄÄÄ & $\triangle A A A A A B A A B A$ & $\triangle A \cap A ̈ A ̈ A ̈ A ̈ A ̈ A ̈ A ̈$ & 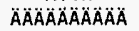 & 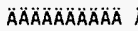 & ÄÄÄÄÄÄÄÄÄ & ÄÄÄÄÄÄÄÄ & $\triangle A \triangle A O A O A ̈ A ̈ A ̈ A ̈$ \\
\hline $\begin{array}{l}\text { Nucl ide } \\
\text { ÄÄÄÄÄÄ }\end{array}$ & $\begin{array}{c}\mathrm{PCI} / \mathrm{L} \\
\triangle A A A B A A A B A B\end{array}$ & $\begin{array}{c}p C i / k g \\
A A A A A B A A A B\end{array}$ & $\begin{array}{c}\mathrm{pCi} / \mathrm{kg} \\
A A A B A A B A A\end{array}$ & $\begin{array}{c}\mathrm{pCI} / \mathrm{kg} \\
\triangle A A B A B A A O A\end{array}$ & $\begin{array}{c}\mathrm{pCi} / \mathrm{kg} \\
A B A A B A B A B\end{array}$ & $\begin{array}{c}\mathrm{pCi} / \mathrm{kg} \\
A A B A B A B A A B\end{array}$ & $\begin{array}{c}\text { pCi } / L \\
A B A B A B A O\end{array}$ & $\begin{array}{l}\mathrm{pCi} / \mathrm{kg} \\
\mathrm{A}\end{array}$ & $\begin{array}{c}\mathrm{pCi} / \mathrm{kg} \\
\text { AAAAAAAAOAO }\end{array}$ \\
\hline$A C-227$ & $1.727 \mathrm{E}-14$ & $5.134 E-14$ & $1.363 \mathrm{E}-13$ & $1.347 \mathrm{E}-13$ & $1.478 E-13$ & $1.781 E-15$ & $3.277 \mathrm{E}-16$ & $6.472 E-15$ & $\begin{array}{l}\text { AAAAAAAAAAA } \\
4.309 E-13\end{array}$ \\
\hline $\mathrm{Ag}-108 \mathrm{~m}$ & $0.000 E+00$ & & $2.400 \mathrm{E}+00$ & $2.400 E+00$ & $2.400 \mathrm{E}+00$ & $5.136 \mathrm{E}-01$ & $3.500 E \div 00$ & $0.000 E+00$ & $0.000 \mathrm{E}+00$ \\
\hline & $0.000 E+00$ & $6.192 E-02$ & $6.209 E-02$ & $6.211 \mathrm{E}-02$ & & $1.758 E-03$ & $6.871 \mathrm{E}-05$ & $0.000 E+00$ & $0.000 E+00$ \\
\hline$c-14$ & $O E+00$ & $1.868 \mathrm{E}+00$ & 4.087E-01 & $1.761 E+00$ & $7.601 E-01$ & $1.250 \mathrm{E}+00$ & $3.499 \mathrm{E}-01$ & $0.000 E+00$ & $0.000 E+00$ \\
\hline Co- 60 & $2.530 E-04$ & $7.150 E-01$ & 7.163E-01 & 7.216E-01 & $7.167 E-01$ & $1.064 E+00$ & $8.782 E-02$ & $1.880 E-03$ & $1.253 \mathrm{E}-03$ \\
\hline & $4.607 E-03$ & $6.513 E+00$ & $6.536 \mathrm{E}+00$ & $6.546 E+00$ & $E+00$ & $1.578 E+01$ & $3.533 E+00$ & $2.282 E-01$ & $+1 E-02$ \\
\hline & $E+\infty$ & 7.619 & $7.627 \mathrm{E}$ & $7.650 \mathrm{E}-02$ & 7.6 & $4.084 E-02$ & $9.715 E-04$ & $0.000 E+00$ & $O O E+00$ \\
\hline Eu-1 & $0.000 E+00$ & $5.571 \mathrm{E}-02$ & $5.577 \mathrm{E}-02$ & $5.601 \mathrm{E}-02$ & $5.579 E-02$ & $2.986 E-02$ & $7.103 \mathrm{E}-04$ & $O O E+00$ & $O E+00$ \\
\hline & $O E+00$ & $2.027 E-15$ & $2.029 E-15$ & $2.022 \mathrm{E}-15$ & $2.029 E-15$ & $1.086 \mathrm{E}-15$ & $1.034 \mathrm{E}-17$ & $0.000 E+00$ & $10 E+00$ \\
\hline $\mathrm{H}-3$ & $7.819 E+01$ & $3.146 E+02$ & $4.469 E+02$ & $1.681 E+02$ & $1.630 E+02$ & $8.859 E+01$ & $9.268 E+01$ & $1.962 E+00$ & $1.962 E+00$ \\
\hline $\mathrm{Ni}-63$ & $2.774 E-01$ & $1.064 E+02$ & $1.078 E+02$ & $1.079 E+02$ & $1.079 \mathrm{E}+02$ & $4.204 E+01$ & $1.408 \mathrm{E}+02$ & $6.880 E-01$ & $6.880 E-01$ \\
\hline & +00 & & 4.44 & $4.381 E-06$ & 4,40 & 4.086E-07 & $1.766 \mathrm{E}-09$ & $D O E+0 D$ & $E+00$ \\
\hline & $6.219 E-14$ & $1.116 \mathrm{E}-12$ & $1.420 \mathrm{E}-12$ & $1.692 \mathrm{E}-12$ & $1.716 \mathrm{E}-12$ & $8.472 E-13$ & $1.107 \mathrm{E}-15$ & $1.686 E-14$ & $1.770 E-13$ \\
\hline & $4.242 E-15$ & $6.268 \mathrm{E}-14$ & $8.088 E-14$ & $9.747 \mathrm{E}-14$ & & $7.977 \mathrm{E}-15$ & $2.698 \mathrm{E}-15$ & $5 E-14$ & $1.161 \mathrm{E}-14$ \\
\hline & $D E+00$ & $2.568 \mathrm{E}-02$ & $2.575 E-$ & $2.577 E-02$ & $2.576 E-$ & $1.458 \mathrm{E}-03$ & $1.425 \mathrm{E}-05$ & $0.000 E+00$ & $0.000 E+00$ \\
\hline & $0.000 E+00$ & $8.200 E-02$ & $8.222 E-02$ & $8.225 \mathrm{E}-02$ & $8.225 E-02$ & $4.657 \mathrm{E}-03$ & $4.550 \mathrm{E}-05$ & $0.000 E+00$ & $0.000 E+00$ \\
\hline & $0.000 E+00$ & $2.098 \mathrm{E}-02$ & $2.104 E-02$ & $05 \mathrm{E}-02$ & & $1.192 \mathrm{E}-03$ & 1.1 & $E+00$ & $E+\infty$ \\
\hline & $E-14$ & & 2.77 & $2.700 E-12$ & 2.75 & $2.176 \mathrm{E}-13$ & $1.877 \mathrm{E}-13$ & $2.308 E-14$ & $1.154 E-13$ \\
\hline & $1.081 E-18$ & $2.523 \mathrm{E}-17$ & $3.090 E-17$ & $3.026 \mathrm{E}-17$ & $3.053 E-17$ & $2.396 E-18$ & $2.152 E-18$ & $1.368 \mathrm{E}-18$ & $6.839 E-18$ \\
\hline & $6.035 E-02$ & $8.760 \mathrm{E}+01$ & $8.791 E+01$ & $8.804 E+01$ & 8.79 & $4.902 E+01$ & $9.983 \mathrm{E}$ & $8.983 \mathrm{E}-02$ & $97 \mathrm{E}-01$ \\
\hline & $3.477 E-19$ & $1.140 E-18$ & $2.556 E-18$ & $3.962 E-18$ & $3.967 \mathrm{E}-$ & $9.141 \mathrm{E}-2$ & $4.331 \mathrm{E}$ & $8.830 E-19$ & $4.415 \mathrm{E}-18$ \\
\hline & $6.757 E-16$ & $3.101 \mathrm{E}-15$ & $6.229 E-15$ & $1.201 \mathrm{E}-14$ & $1.099 E-14$ & $2.409 E-16$ & $1.417 \mathrm{E}-17$ & $1.698 \mathrm{E}-15$ & $8.522 E-15$ \\
\hline & $6.332 E-12$ & $5.749 \mathrm{E}-11$ & $8.404 E-11$ & $2.034 E-10$ & $2.056 \mathrm{E}-10$ & $4.922 E-12$ & $2.995 E-13$ & $1.538 \mathrm{E}-11$ & $7.758 \mathrm{E}-11$ \\
\hline & $5.789 E-19$ & $2.951 E-18$ & $5.602 E-18$ & $1.111 \mathrm{E}-17$ & $1.118 \mathrm{E}-17$ & $2.334 E-19$ & $1.405 \mathrm{E}-20$ & $1.441 \mathrm{E}-18$ & $7.235 \mathrm{E}-18$ \\
\hline$U-233$ & $6.685 \mathrm{E}-11$ & $1.008 \mathrm{E}-10$ & $4.337 E-10$ & $4.537 E-10$ & $4.601 E-10$ & $1.260 \mathrm{E}-11$ & $2.319 E-11$ & $1.655 \mathrm{E}-11$ & $9.929 E-11$ \\
\hline & $1.611 \mathrm{E}-05$ & $2.305 E-05$ & 1.034 E- 04 & $1.095 \mathrm{E}-04$ & $1.105 \mathrm{E}-04$ & $2.942 E-06$ & $5.440 \mathrm{E}-06$ & $3.992 \mathrm{E}-06$ & $2.395 \mathrm{E}-05$ \\
\hline$u-235$ & $1.686 \mathrm{E}-08$ & $2.416 E-08$ & $1.082 E-07$ & $1.145 \mathrm{E}-07$ & $1.157 \mathrm{E}-07$ & $3.080 E-09$ & $5.697 \mathrm{E}-09$ & $4.178 E-09$ & $2.507 \mathrm{E}-08$ \\
\hline & $1.297 \mathrm{E}-07$ & $1.859 E-07$ & $8.327 \mathrm{E}-07$ & $8.815 E-07$ & $8.901 \mathrm{E}-07$ & $2.370 E-08$ & $4.384 \mathrm{E}-08$ & $3.215 E-08$ & $3 \quad 1.929 \mathrm{E}-07$ \\
\hline & & & & & & & & & 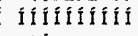 \\
\hline
\end{tabular}

For livestock fodder, consumption time is $t$ minus meat or milk storage time.

Concentrations in the media occurring in pathways that are suppressed are calculated using the current input parameters, i.e. using parameters appearing in the input screen when the pathways are active.

\begin{tabular}{ll} 
Attachment & \multicolumn{1}{c}{$\begin{array}{c}4 \\
\text { Originator: }\end{array} \frac{\text { S.W. W. Clark }}{\text { Sheet No. } 11 \text { of } 19}$} \\
Chk'd By & Date \\
Calc. No. Perrott & Date \\
Caldo N-CA-V0280 & Rev. No. $\quad 0$ \\
\hline
\end{tabular}




\section{ATTACHMENT 4}

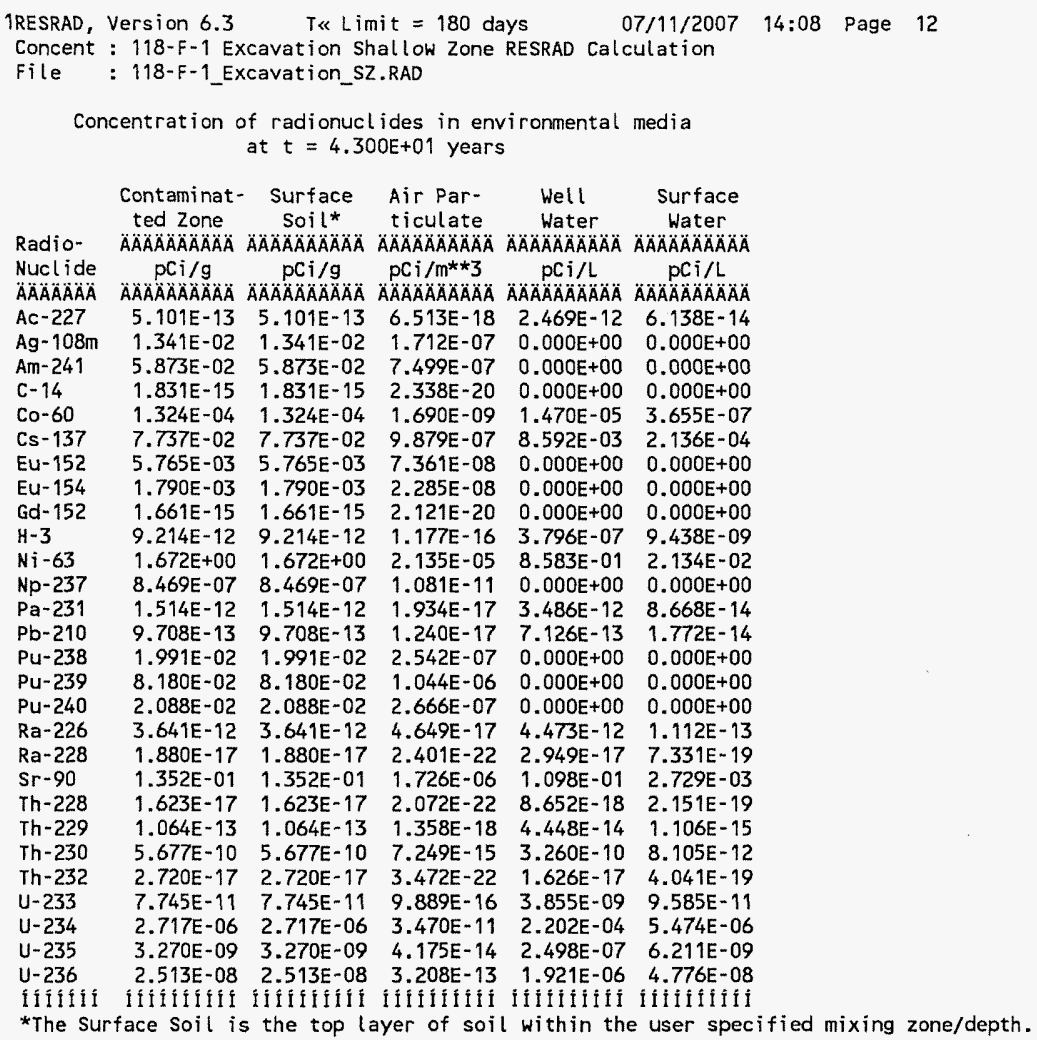

Concentrations in the media occurring in pathways that are suppressed are calculated using the current input parameters, i.e. using parameters appearing in the input screen when the pathways are active.

Concentration of $\mathrm{H}-3$ in soil moisture $=7.610 \mathrm{E}-11 \mathrm{pCi} / \mathrm{ml}$

Concentration of gaseous $\mathrm{H}-3$ in air $=1.545 \mathrm{E}-11 \mathrm{pCi} / \mathrm{m}^{* * 3}$

\begin{tabular}{|c|c|}
\hline Attachment & Sheet No. 12 of 19 \\
\hline Originator: S.W. Clark & Date \\
\hline Chk'd By M.W. Perrott & Date \\
\hline $0100 F-C A-V 0280$ & Rev. No. 0 \\
\hline
\end{tabular}




\section{ATTACHMENT 4}

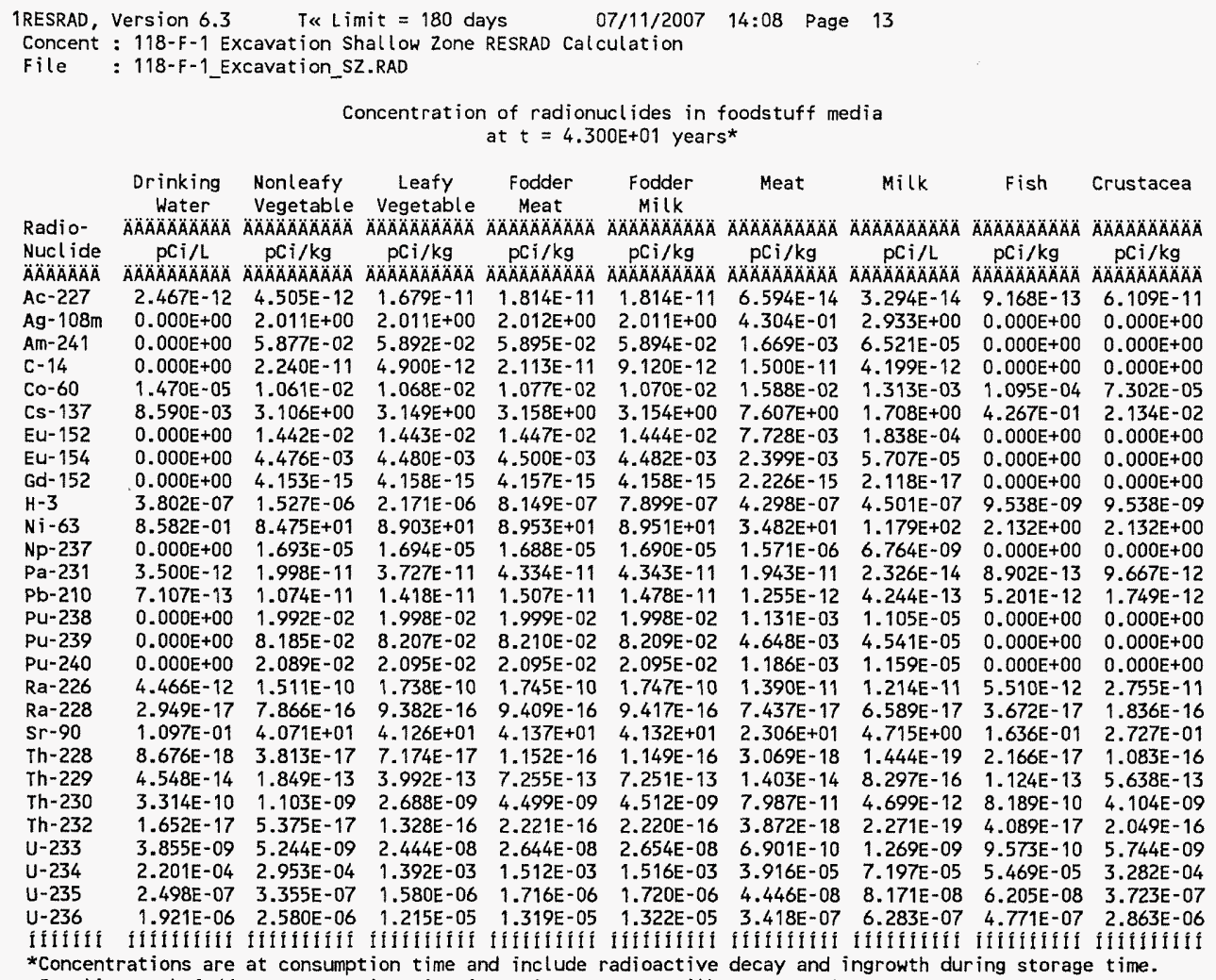

*Concentrations are at consumption time and include radioactive decay and ingrowth during storage time.

For livestock fodder, consumption time is $t$ minus meat or milk storage time.

Concentrations in the media occurring in pathways that are suppressed are calculated using the current input parameters, i.e. using parameters appearing in the input screen when the pathways are active.

\begin{tabular}{|c|c|}
\hline Attachment & Sheet No. 13 of 19 \\
\hline Originator: S.W. Clark & Date \\
\hline Chk'd By M. W. Perrott & Date \\
\hline $0100 F-C A-V 0280$ & Rev. No. \\
\hline
\end{tabular}




\section{ATTACHMENT 4}

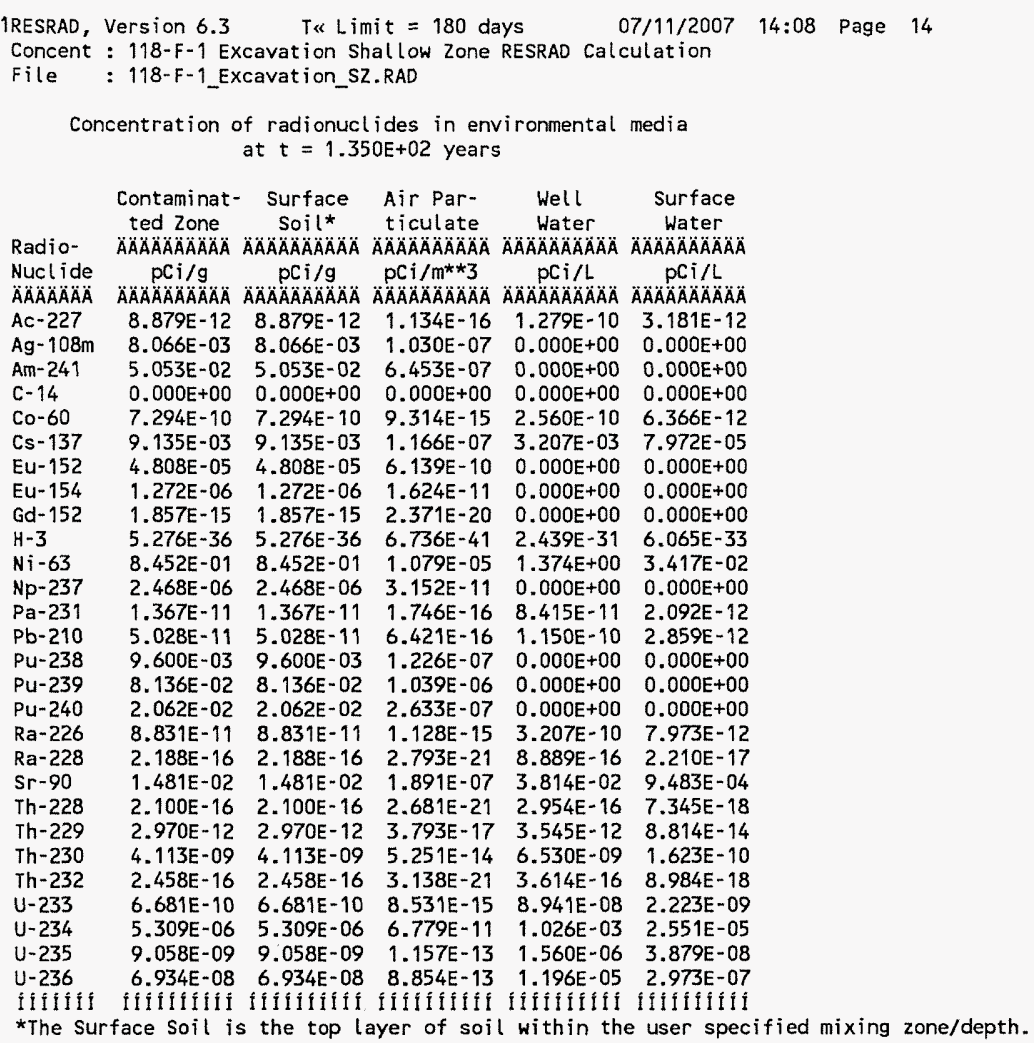

Concentrations in the media occurring in pathways that are suppressed are calculated using the current input parameters, i.e. using parameters appearing in the input screen when the pathways are active.

Concentration of $\mathrm{H}-3$ in soil moisture $=4.357 \mathrm{E}-35 \mathrm{pCi} / \mathrm{ml}$

Concentration of gaseous $\mathrm{H}-3$ in air $=8.848 \mathrm{E}-36 \mathrm{pCi} / \mathrm{m}^{\star *}$

Concentration of gaseous $\mathrm{C}-14$ in air $=0.000 \mathrm{E}+00 \mathrm{pCi} / \mathrm{m}^{* * 3}$

\begin{tabular}{|c|c|}
\hline \multirow{2}{*}{\multicolumn{2}{|c|}{ 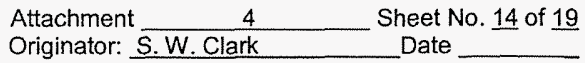 }} \\
\hline & \\
\hline Chk'd By M. W. Perrott & Date \\
\hline $0100 F-C A-V 0280$ & Rev. No. \\
\hline
\end{tabular}




\section{ATTACHMENT 4}

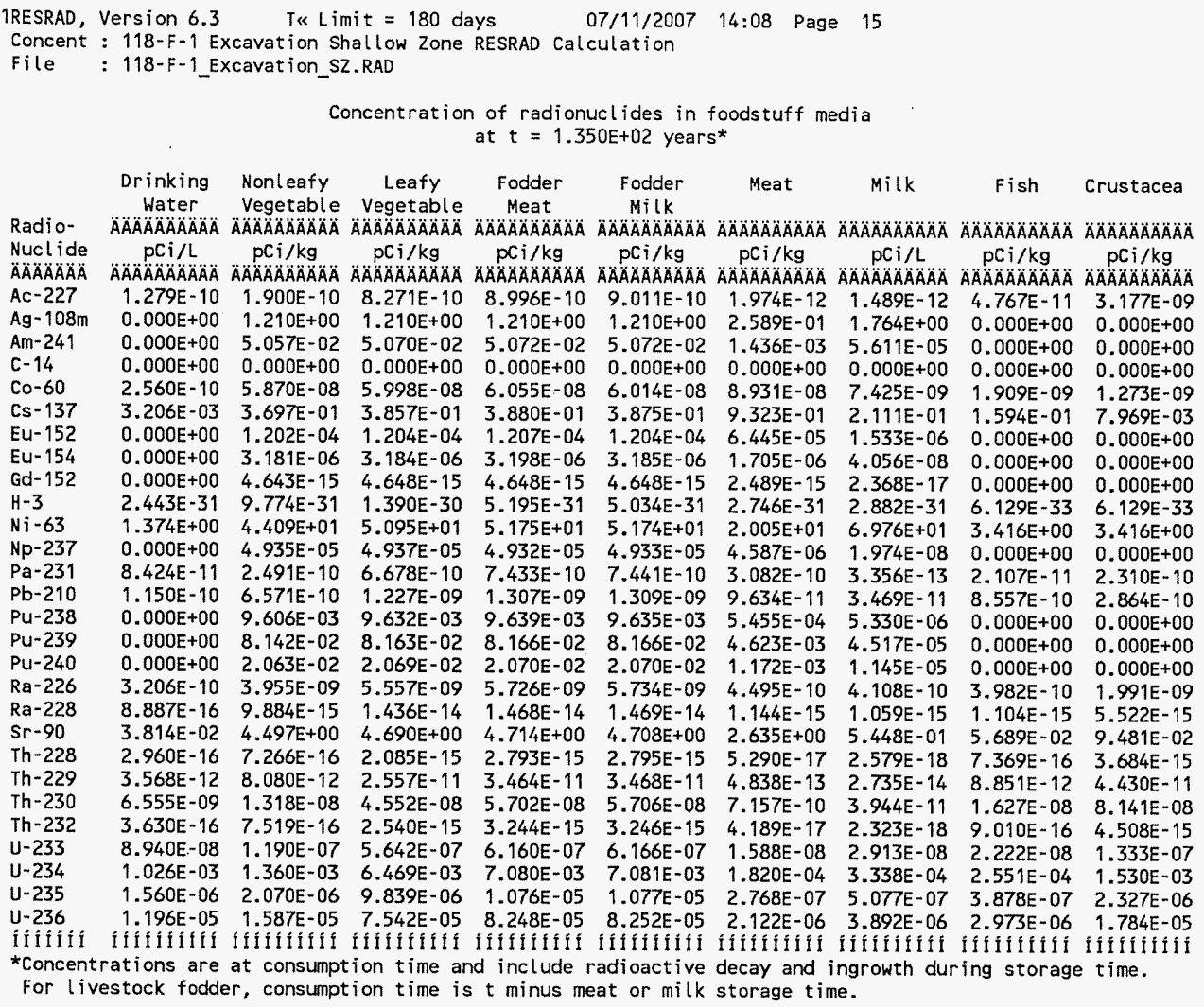

Concentrations in the media occurring in pathways that are suppressed are calculated using the current input parameters, i.e. using parameters appearing in the input screen when the pathways are active.

\begin{tabular}{|c|c|}
\hline Attachment & Sheet No. 15 of 19 \\
\hline Originator: S.W. Clark & Date \\
\hline Chk'd By M.W. Perrott & Date \\
\hline $0100 \mathrm{~F}-\mathrm{CA}-\mathrm{V} 0280$ & Rev. No. \\
\hline
\end{tabular}




\section{ATTACHMENT 4}

\begin{tabular}{|c|c|c|c|c|c|}
\hline $\begin{array}{l}\text { 1RESRAD, } \\
\text { Concent } \\
\text { File }\end{array}$ & $\begin{array}{l}\text { Version } 6.3 \\
: 118-F-1 \text { Ex } \\
: 118-F-1 \text { Ex }\end{array}$ & $\begin{array}{l}\text { T\& Lin } \\
\text { xcavation Sh } \\
\text { xcavation_Sz }\end{array}$ & $\begin{array}{l}\text { nit }=180 \text { da } \\
\text { hall ow Zone } \\
\text { 2.RAD }\end{array}$ & $\begin{array}{l}\text { lays } \\
\text { RESRAD Cal }\end{array}$ & $\begin{array}{l}07 / 11 / 2007 \\
\text { culation }\end{array}$ \\
\hline & & $\begin{array}{l}\text { of radiont } \\
\text { at } t=3\end{array}$ & $\begin{array}{l}\text { lides in } \\
\text { DOE }+02 \text { yea }\end{array}$ & & media \\
\hline & $\begin{array}{l}\text { Contaminat- } \\
\text { ted Zone }\end{array}$ & $\begin{array}{l}\text { Surface } \\
\text { Soil** }\end{array}$ & $\begin{array}{l}\text { Air Par- } \\
\text { ticulate }\end{array}$ & $\begin{array}{l}\text { Well } \\
\text { Water }\end{array}$ & $\begin{array}{l}\text { Surface } \\
\text { Water }\end{array}$ \\
\hline Radio- & ÄÄÄÄÄÄÄ & AAAAAOAAAOÄ & $\triangle A A A A B A B A O A$ & A ÄAAAAÄÄÄ & A ÄÄÄÄÄÄ \\
\hline ide & $\mathrm{pCi} / \mathrm{g}$ & $\mathrm{pCi} / \mathrm{g}$ & $\mathrm{pCi} / \mathrm{m}^{* * 3}$ & $\mathrm{pCi} / \mathrm{L}$ & $p C i / L$ \\
\hline ÄÄÄÄA & 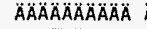 & $A A A B A A A A A A A B$ & $\triangle A A B A A A O A A O A O A$ & $\triangle A A A A A A A A B A B$ & $\triangle A A A A A A B A O A O A$ \\
\hline$A C-227$ & $4.795 E-11$ & 4.795E-11 & $6.123 E-16$ & $9.636 \mathrm{E}-10$ & $2.396 E-11$ \\
\hline $08 \mathrm{~m}$ & $3.242 E-03$ & $3.242 E-03$ & $4.140 E-08$ & $0.000 E+00$ & $0.000 E+00$ \\
\hline 41 & $3.860 E-02$ & $3.860 E-02$ & $4.928 \mathrm{E}-07$ & $0.000 E+00$ & $0.000 E+00$ \\
\hline$C-14$ & $0.000 E+00$ & $0.000 E+00$ & $0.000 E+00$ & $0.000 \mathrm{E}+00$ & $0.000 \mathrm{E}+00$ \\
\hline$C 0-60$ & $2.700 E-19$ & $2.700 \mathrm{E}-19$ & $3.447 E-24$ & $2.132 E-19$ & $5.300 E-21$ \\
\hline & $1.980 E-04$ & $1.980 E-04$ & $2.528 \mathrm{E}-09$ & $1.563 E-04$ & $3.886 E-06$ \\
\hline Eu-152 & $8.989 E-09$ & $8.989 E-09$ & $1.148 E-13$ & $0.000 \mathrm{E}+00$ & $0.000 \mathrm{E}+00$ \\
\hline Eu- & $2.871 E-12$ & $2.871 E-12$ & $3.666 \mathrm{E}-17$ & $0.000 \mathrm{E}+00$ & $0.000 E+00$ \\
\hline Gd-1 & $1.856 E-15$ & $1.856 E-15$ & $2.370 E-20$ & $0.000 E+00$ & $0.000 E+00$ \\
\hline $\mathrm{H}-3$ & $0.000 E+00$ & $0.000 E+00$ & $0.000 \mathrm{E}+00$ & $0.000 E+00$ & $0.000 \mathrm{E}+00$ \\
\hline $\mathrm{Ni}-63$ & $2.487 E-01$ & $2.487 E-01$ & $3.175 E-06$ & $9.132 E-01$ & 2.270E-02 \\
\hline & $4.822 E-06$ & $4.822 \mathrm{E}-06$ & $6.157 E-11$ & $0.000 E+00$ & $0.000 E+00$ \\
\hline & $5.814 \mathrm{E}-11$ & $5.814 E=11$ & $7.424 E-16$ & $4.717 E-10$ & $1.173 E-11$ \\
\hline $\mathrm{Pb}-$ & $5.070 E-10$ & $5.070 E-10$ & $6.473 E-15$ & $1.841 \mathrm{E}-09$ & $4.578 E-11$ \\
\hline $\mathrm{Pu}^{-}$ & $2.594 E-03$ & $2.594 E-03$ & $3.313 E-08$ & $0.000 E+00$ & $0.000 E+00$ \\
\hline Pu- & $8.058 E-02$ & $8.058 E-02$ & $1.029 E-06$ & $0.000 E+00$ & $0.000 E+00$ \\
\hline Pu- & $2.016 E-02$ & $2.016 \mathrm{E}-02$ & $2.575 E-07$ & $0.000 E+00$ & $0.000 \varepsilon+00$ \\
\hline Ra- & $6.490 E-10$ & $6.490 E-10$ & $8.287 E-15$ & $3.471 E-09$ & $8.629 E-11$ \\
\hline & $9.969 E-16$ & $9.969 \mathrm{E}-16$ & $1.273 E-20$ & $5.399 E-15$ & $1.342 E-16$ \\
\hline & $2.806 \mathrm{E}-04$ & $2.806 \mathrm{E}-04$ & 3.582E-09 & $1.636 \mathrm{E}-03$ & 4.069E-05 \\
\hline Th-? & $9.805 E-16$ & $9.805 E-16$ & $1.252 \mathrm{E}-20$ & $1.857 E-15$ & $4.616 \mathrm{E}-17$ \\
\hline Th-229 & $2.726 E-11$ & $2.726 E-11$ & $3.481 E-16$ & $4.740 E-11$ & $1.178 \mathrm{E}-12$ \\
\hline & $1.231 E-08$ & $1.231 E-08$ & $1.571 E-13$ & 2.579E-08 & $6.411 E-10$ \\
\hline & $1.047 \mathrm{E}-15$ & $1.047 \mathrm{E}-15$ & $1.337 E-20$ & $2.003 E-15$ & $4.979 E-17$ \\
\hline & 2.616E-09 & $2.616 \mathrm{E}-09$ & $3.340 \mathrm{E}-14$ & 4.596E-07 & $1.143 E-08$ \\
\hline & $5.273 E-06$ & $5.273 E-06$ & $6733=-11$ & $1.182 E-03$ & 2.939E-05 \\
\hline$U-235$ & $1.629 E-08$ & $1.629 E-08$ & $2.080 E-13$ & $3.230 E-06$ & $8.031 E-08$ \\
\hline$U-236$ & $1.238 E-07$ & $1.238 \mathrm{E}-07$ & $1.580 \mathrm{E}-12$ & $2.458 E-05$ & $6.111 \mathrm{E}-07$ \\
\hline & IIfIfififi & 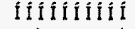 & IIIIIIIfít & 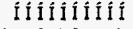 & 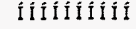 \\
\hline
\end{tabular}

*The Surface Soil is the top layer of soil within the user specified mixing zone/depth.

Concentrations in the media occurring in pathways that are suppressed are calculated using the current input parameters, i.e. using parameters appearing in the input screen when the pathways are active.

Concentration of $\mathrm{H}-3$ in soil moisture $=0.000 \mathrm{E}+00 \mathrm{pCi} / \mathrm{ml}$

Concentration of gaseous $\mathrm{H}-3$ in air $=0.000 \mathrm{E}+00 \mathrm{pCi} / \mathrm{m}^{\star *} 3$

Concentration of gaseous $\mathrm{C}-14$ in air $=0.000 \mathrm{E}+00 \mathrm{pCi} / \mathrm{m}^{* * 3}$

Attachment $4 \quad$ Sheet No. 16 of 19 Originator: S.W. Clark Date

Chk'd By M.W. Perrott Date

Calc. No. 0100F-CA-V0280 Rev No. O 


\section{ATTACHMENT 4}

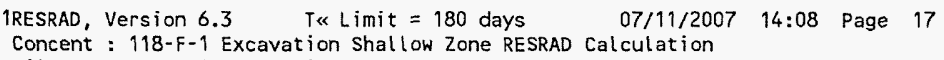

Concentrations in the media occurring in pathways that are suppressed are calculated using the current input parameters, i.e. using parameters appearing in the input screen when the pathways are active.

\begin{tabular}{|c|c|c|}
\hline \multicolumn{2}{|c|}{ Attachment $\quad 4$} & \multirow{2}{*}{$\begin{array}{l}\text { Sheet No. } 17 \text { of } 19 \\
\text { Date }\end{array}$} \\
\hline Originator: & S.W. Clark & \\
\hline & M. W. Perrott & Date \\
\hline & $0100 F-C A-V 0280$ & Rev. No. \\
\hline
\end{tabular}




\section{ATTACHMENT 4}

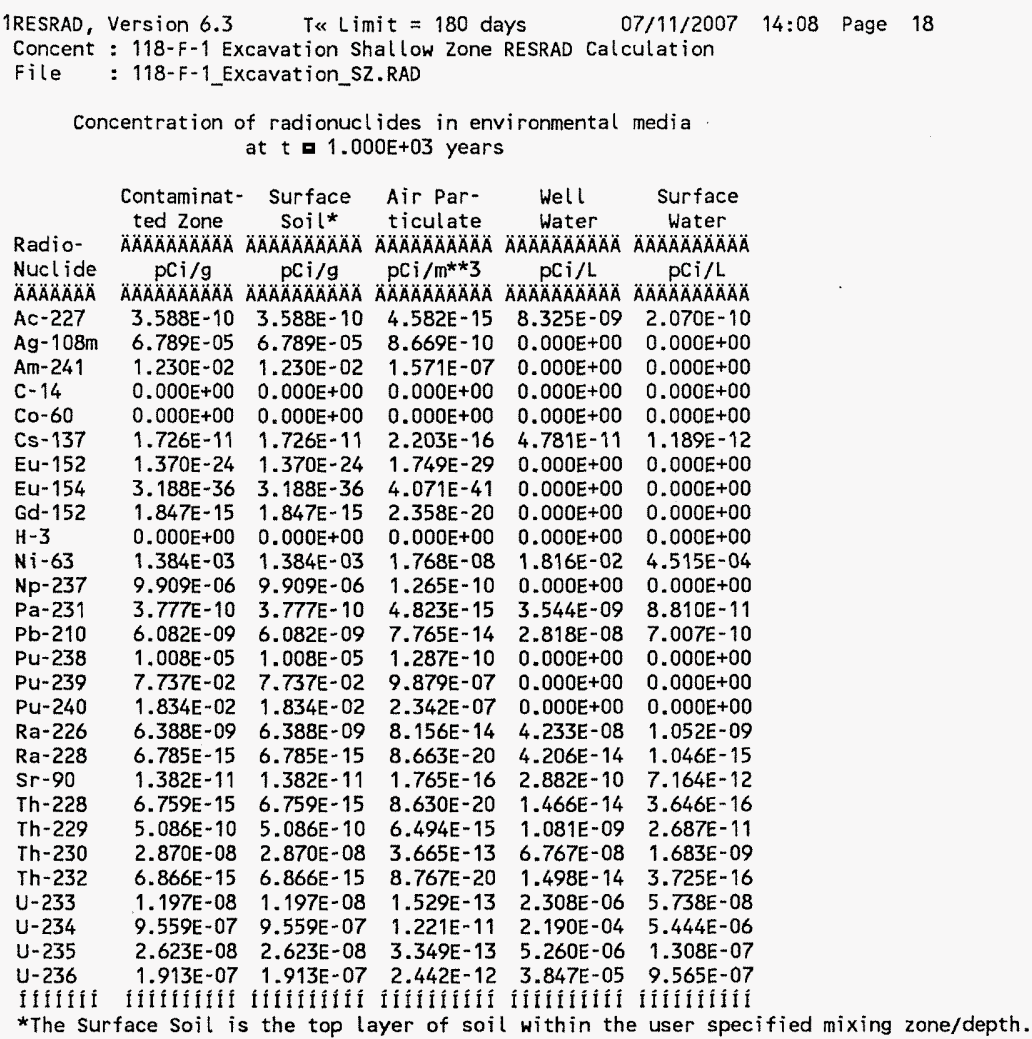

Concentrations in the media occurring in pathways that are suppressed are calculated using the current input parameters, i.e. using parameters appearing in the input screen when the pathways are active.

Concentration of $\mathrm{H}-3$ in soil moisture $=0.000 \mathrm{E}+00 \mathrm{pCi} / \mathrm{ml}$

Concentration of gaseous $\mathrm{H}-3$ in air $=0.000 \mathrm{E}+00 \mathrm{pCi} / \mathrm{m}^{\star * 3}$

Concentration of gaseous $\mathrm{c}-14$ in air $=0.000 \mathrm{E}+00 \mathrm{pCi} / \mathrm{m}^{* * 3}$

\begin{tabular}{|c|c|}
\hline Attachment $\quad 4$ & Sheet No. 18 of $\underline{19}$ \\
\hline Originator: S.W. Clark & Date __ \\
\hline Chk'd By M.W. Perrott & Date \\
\hline $0100 F-C A-V 0280$ & Rev. No. \\
\hline
\end{tabular}




\section{ATTACHMENT 4}

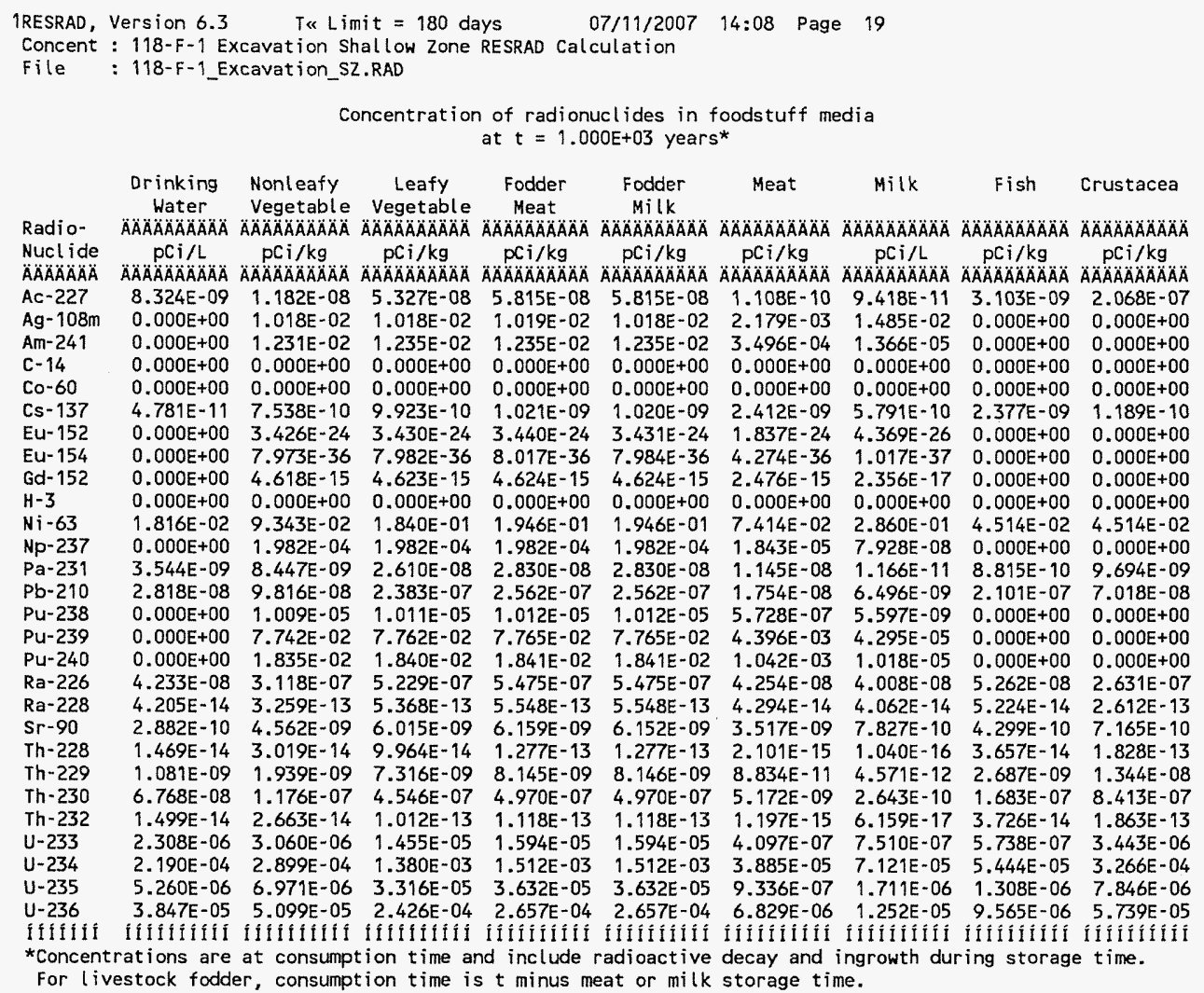

Concentrations in the media occurring in pathways that are suppressed are calculated using the current input parameters, i.e. using parameters appearing in the input screen when the pathways are active.

\begin{tabular}{|c|c|}
\hline Attachment & Sheet No. 19 of 19 \\
\hline Originator: S.W. Clark & Date \\
\hline Shk'd By M. W. Perrott & Date \\
\hline $0100 F-C A-V 0280$ & Rev. No. 0 \\
\hline
\end{tabular}


ATTACHMENT 5

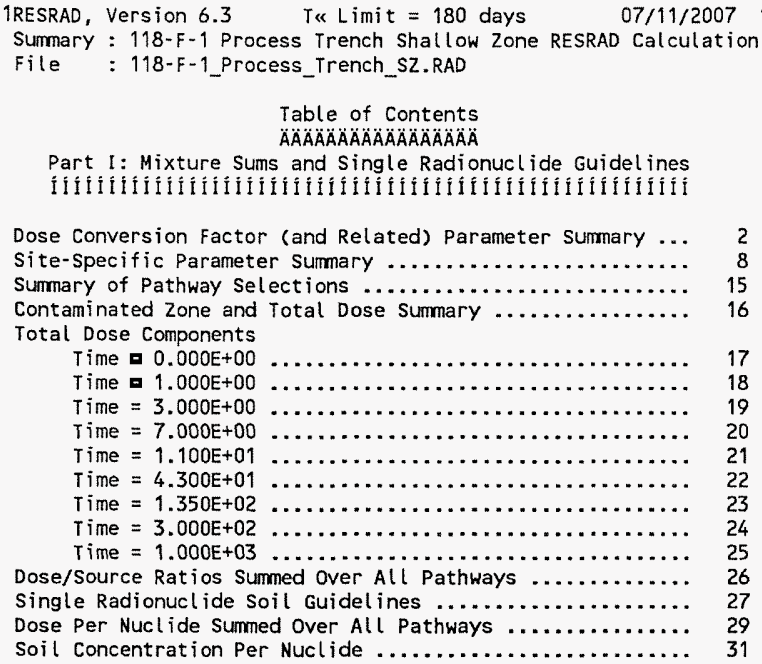




\section{ATTACHMENT 5}

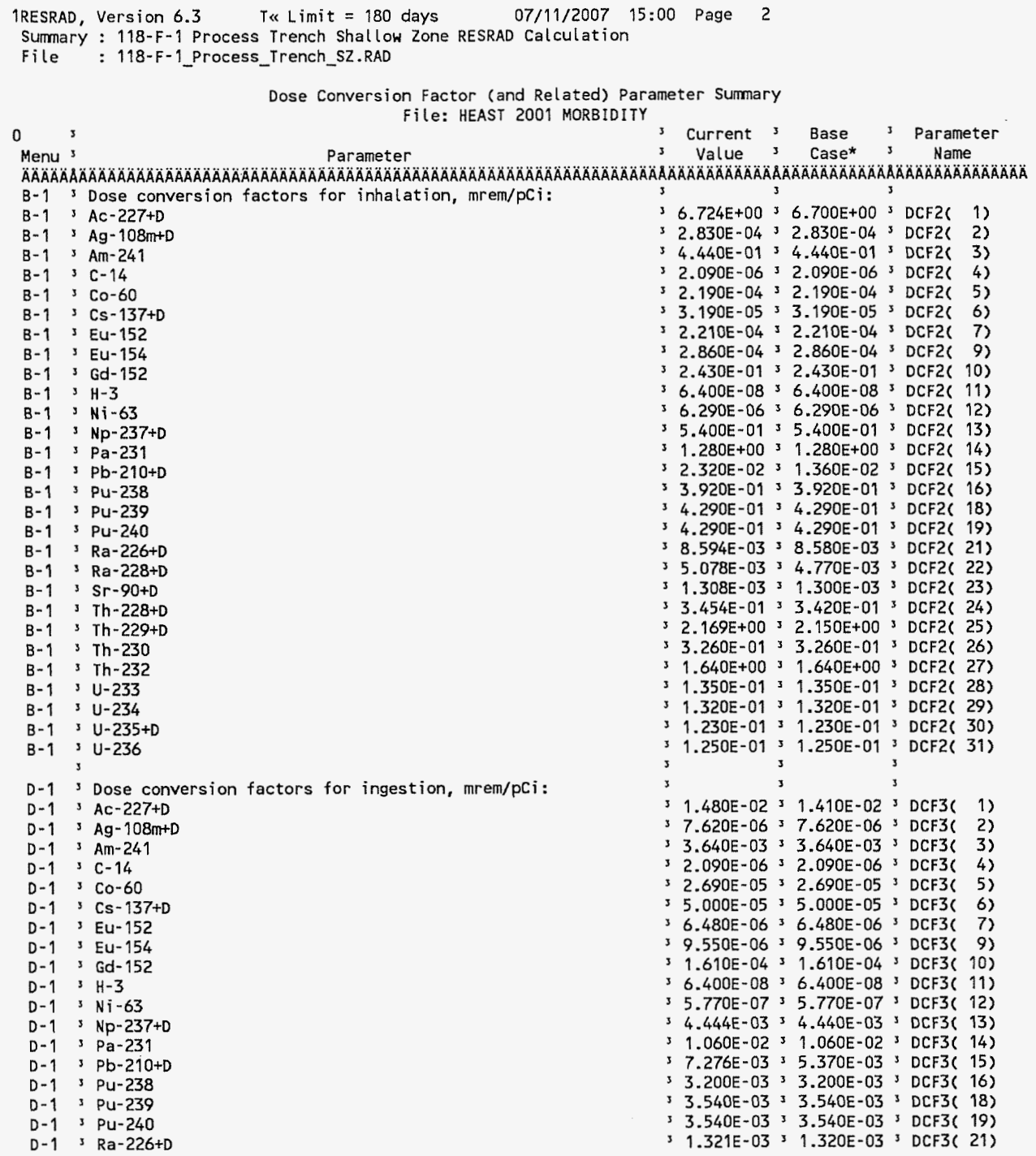

Attachment 5 


\section{ATTACHMENT 5}

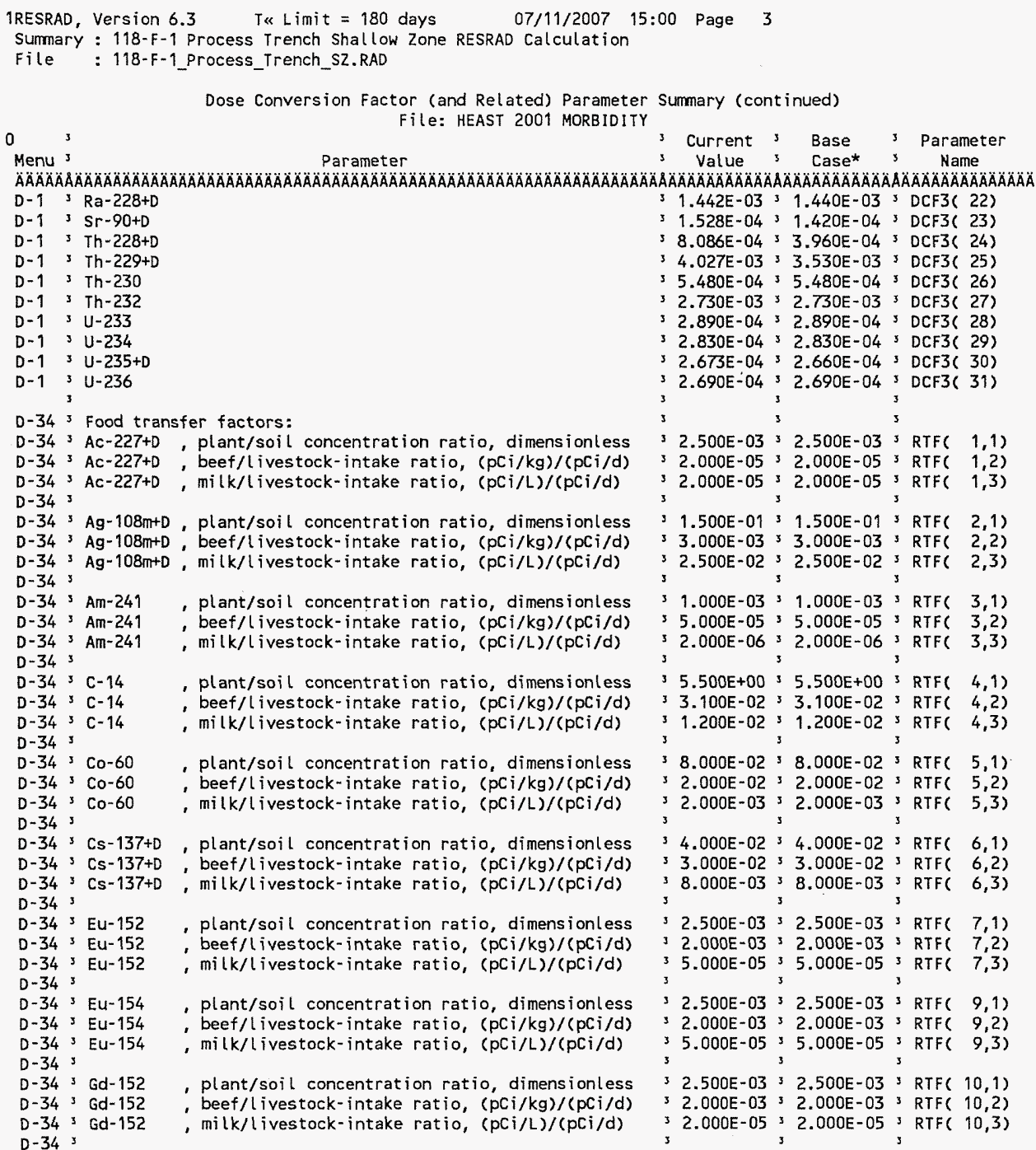

Attachment 


\section{ATTACHMENT 5}

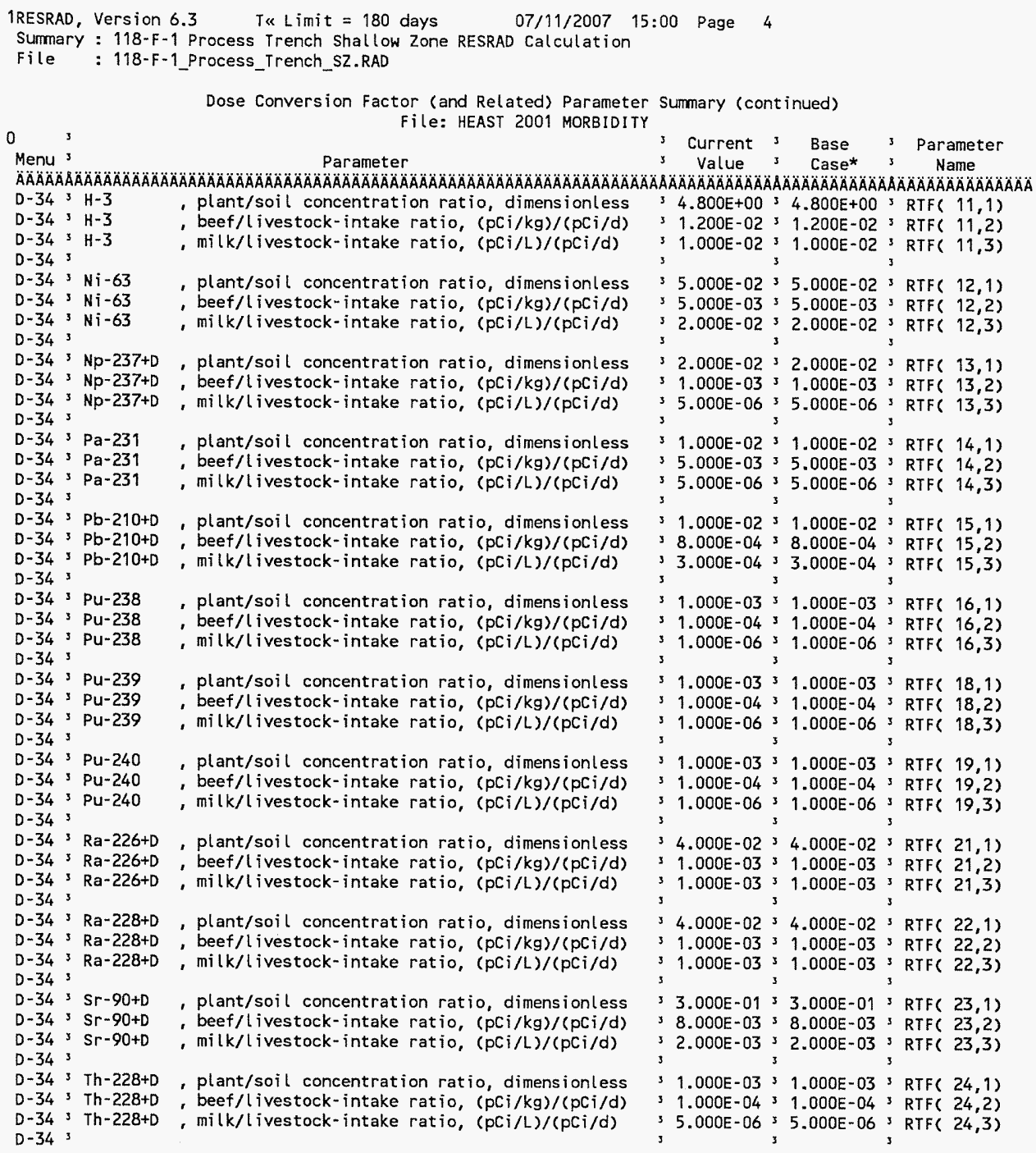

\begin{tabular}{|c|c|}
\hline Attachment $\quad 5$ & Sheet No. 4 of 32 \\
\hline Originator: S.W. Clark & Date \\
\hline Chk'd By M.W. Perrott & Date \\
\hline $0100 F-C A-V 0280$ & Rev. No. \\
\hline
\end{tabular}




\section{ATTACHMENT 5}

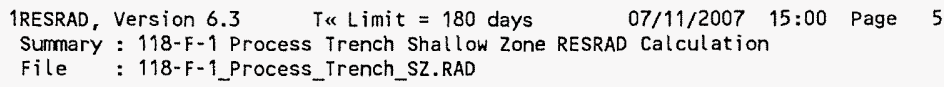




\section{ATTACHMENT 5}

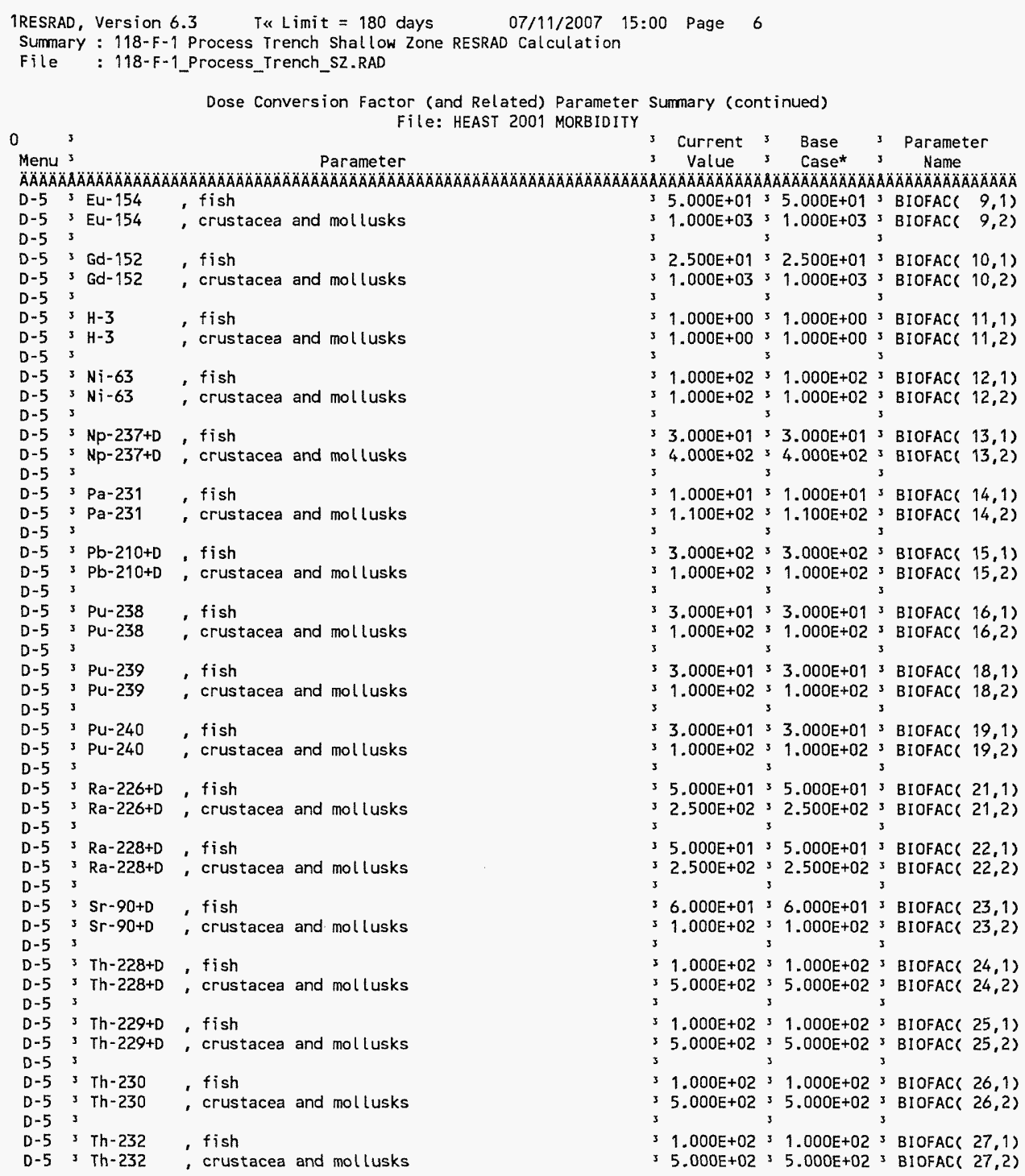

$\begin{array}{ll}\text { Attachment } \frac{5}{1} & \text { Sheet No. } \underline{6} \text { of } \underline{32} \\ \text { Originator: } \frac{\text { S.W. Clark }}{\text { D.W.Perrott }} & \text { Date } \\ \text { Chk'd By } & \text { Rev. No. } \frac{0}{0100 \text { F-CA-V0280 }}\end{array}$




\section{ATTACHMENT 5}

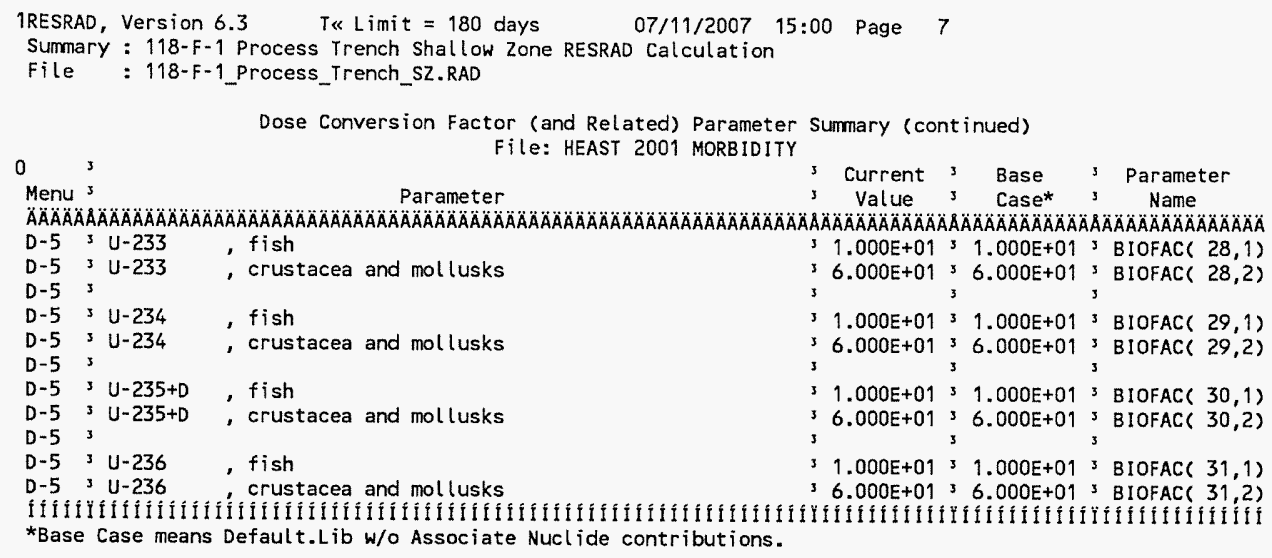

Attachment 


\title{
ATTACHMENT 5
}

\begin{abstract}
IRESRAD, Version $6.3 \quad T \ll$ Limit $=180$ days 07/11/2007 15:00 Page 8

Summary : 118-F-1 Process Trench Shallow Zone RESRAD Calculation
\end{abstract}

File : 118-F-1_Process_Trench_SZ.RAD

\section{$0_{\text {Menu }}^{3}$} R011; Area of Cont aminated zone $\left(m^{* * 2}\right.$ R011 3 Thickn of contaminated zone $\left(m^{* * 2}\right)$ R011 Thickness of contaminated zone (m) R0113 Basic radiation dose limit (mrem/yr) R011 Basic radiation dose limit (mrem/yr)
R011' Time since placement of material (yr) R011 Time since placement of mate
R011 Times for calculations (yr) R011'Times for calculations (yr) R011 'Times for calculations (yr) R011' Times for calculations (yr) R011' Times for calculations (yr) R011' Times for calculations (yr) R011' Times for calculations (yr) R011' Times for calculations (yr) R011' Times for calculations (yr) 3 Site-Specific Parameter Summary, input 3 Default 3 Used by RESRAD 3 Parameter A $5.478 E+03 ; 1.000 E+043$ $3.500 \mathrm{E}+0032.000 \mathrm{E}+00$ $31.640 E+0231.000 E+02$ $1.500 E+01,3.000+02$ $1.500 E+013.000 E+01$ $0.000 E+0030.000 E+00$ $31.000 \mathrm{E}+00=1.000 \mathrm{E}+00$ $3.000 E+0033.000 E+00$ $>7.000 E+00>1.000 E+01$ $31.100 E+0133.000 E+01$ $34.300 E+0131.000 E+02$ $31.350 E+0233.000 E+02$ $3.000 E+02,1.000 E+03$ \begin{tabular}{ll}
3 & $0.000 \mathrm{E}+00$ \\
\hline
\end{tabular} 3 not used $30.000 E+00^{3}$

R012 I Initial principal radionuclide $(\mathrm{pCi} / \mathrm{g})$ : Ag-108m, $1.300 \mathrm{E}-02,0.000 \mathrm{E}+00$ R012 I Initial principal radionuclide $(\mathrm{pCi} / \mathrm{g})$ : Am-241, $8.900 \mathrm{E}-02,0.000 \mathrm{E}+00$ R012, Initial principal radionuclide $(\mathrm{pCi} / \mathrm{g}): \mathrm{C}-14,3,200 \mathrm{E}-01,0.000 \mathrm{E}+00$ R012 3 Initial principal radionuclide $(\mathrm{pCi} / \mathrm{g})$ : $\mathrm{Co}-60$, $7.400 \mathrm{E}-02$ > $0.00 \mathrm{E}+00$ R012 3 Initial principal radionuclide (pCi/g): $\mathrm{Cs}-137,4,500 E-0130.000 E+00$ R012 3 Initial principal radionuclide (pCi/g): Eu-152, $31.400 \mathrm{E}-0130.000 \mathrm{E}+00$ R012 3 Initial principal radionuclide ( $\mathrm{PCi} / \mathrm{g})$ : Eu-154 3 6.300E-02 s $0.000 \mathrm{E}+00$

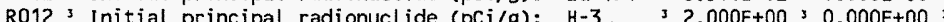
R012 3 Initial principal radionuclide $(\mathrm{pCi} / \mathrm{g}): \mathrm{Ni}-63$, $4.400 \mathrm{E}+00,0.000 \mathrm{E}+00$ R012 3 Initial principal radionuclide (pCi/g): $\mathrm{Pu}-238,1.000 \mathrm{E}-0130.000 \mathrm{E}+00$ R012 s Initial principal radionuclide $(\mathrm{pCi} / \mathrm{g})$ : $\mathrm{Pu}-239,1.050 \mathrm{E}-0130.000 \mathrm{E}+00$ R012 3 Initial principal radionuclide $(\mathrm{pCi} / \mathrm{g})$ : $R 0123$ Initial principal radionuclide $(\mathrm{pCi} / \mathrm{g})$ : $\mathrm{Sr}-90$ 3 $2.200 \mathrm{E}-013 \mathrm{O}$. DOOE+00 R012 3 Concentration in groundwater (PCi/L): Ag-108m ${ }^{3}$ not used $30.000 E+00$ $\mathrm{R} 012$, Concentration in groundwater (PCi/L): Am-241, not used $30.000 E+00$ R012 3 Cncentration in groundwater (PCi/L): Am-241, not used $3.000+00$ R012 3 Concentration in groundwater (pCi/L): $C 0-60$ s not used $30.000 E+00$ R012 3 Concentration in groundwater $(\mathrm{pCi} / \mathrm{L})$ : $\mathrm{Cs}-1373$ not used $30.000 \mathrm{E}+00$ R012 Concentration in groundwater (PCi/L): Eu-152 s not used $30.000 E+00$ R012 s Concentration in groundwater (pCi/L): Eu-154; not used $30.000 E+00$ R012 S Concentration in groundwater ( $\mathrm{pCi} / \mathrm{L}): \mathrm{H}-3$, s not used $30.000 \mathrm{E}+00$ R012 3 Concentration in groundwater (PCi/L): $\mathrm{Ni}-63$ s not used $30.000 \mathrm{E}+0 \mathrm{O}^{3}$ R012 3 Concentration in groundwater (PCi/L): Pu-238 s not used $30.000 E+00{ }^{3}$ R012 3 Concentration in groundwater (PCi/L): $\mathrm{Pu}-239$, not used $30.000 \mathrm{E}+00$

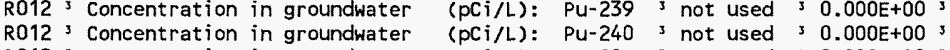
R012 Concentration in groundwater ( $\mathrm{PCi} / \mathrm{L}): \mathrm{Sr}_{3}-90$; not used $30.000 \mathrm{E}+00$ s 013 S Cover depth (m)

R013 Density of cover material $\left(\mathrm{g} / \mathrm{cm}^{* * 3}\right)$ R013 3 Cover depth erosion rate (m/yr) R013 3 Density of contaminated zone $\left(\mathrm{g} / \mathrm{cm}^{* * 3}\right)$

RO13 Contaminated zone erosion rate $(\mathrm{m} / \mathrm{yr})$

R013 ' Contaminated zone total porosity $0.000 \mathrm{E}+00^{3} 0.000 \mathrm{E}+00^{3}$ 3 not used $31.500 E+00$ ? 3 not used 3 1.000E-03 3 $31.600 E+0031.500 E+00^{3}$ $31.000 E-03,1.000 E-03$, s.000E-01 $3.000 \mathrm{E}-01^{3}$ 3 , $1.000 \mathrm{E}-0132.000 \mathrm{E}-013$

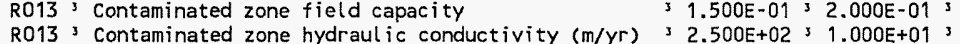

\begin{tabular}{|c|c|}
\hline - & 3 AREA \\
\hline - & S THICKO \\
\hline$\cdots$ & 3 LCZPAQ \\
\hline-- & BRDL \\
\hline$\cdots$ & S TI \\
\hline$\cdots$ & ${ }^{3} T(2)$ \\
\hline - & $3 T(3)$ \\
\hline$\cdots$ & $3 T(4)$ \\
\hline$\cdots$ & ${ }^{3} T(5)$ \\
\hline$\cdots$ & $3 T(6)$ \\
\hline$\ldots$ & ${ }^{3} \mathrm{~T}(7)$ \\
\hline- & $3 T(8)$ \\
\hline & $3 T(9)$ \\
\hline & $3 T(10)$ \\
\hline & 3 \\
\hline & $31(2)$ \\
\hline -- & $51(3)$ \\
\hline & ${ }^{3} 51(4)$ \\
\hline & $3 \operatorname{sic}(5)$ \\
\hline- & $3 \operatorname{sic} 6)$ \\
\hline & $3 \operatorname{sic}(7)$ \\
\hline & $3 \operatorname{sic} 9)$ \\
\hline -- & 's1(11) \\
\hline & $3 \mathrm{~s} 1(12)$ \\
\hline & $s 1(16)$ \\
\hline 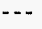 & $3 s 1(18)$ \\
\hline & 3 s1(19) \\
\hline & $=51(23)$ \\
\hline & Wi( 2) \\
\hline & ${ }^{3}$ W1 ( 3) \\
\hline & "W1( 4) \\
\hline & 3 W1 ( 5) \\
\hline & 3 WI (6) \\
\hline & $31(7)$ \\
\hline & J1( 9) \\
\hline & ${ }^{3} W 1(11)$ \\
\hline & W1(12) \\
\hline & 3 W1 (16) \\
\hline & H1(18) \\
\hline & $\therefore$ W1 (19) \\
\hline & 3 W1(23) \\
\hline & 3 \\
\hline & 3 COVERO \\
\hline & DENSCV \\
\hline & 3 VCV \\
\hline & ${ }^{3}$ DENSCZ \\
\hline & ${ }^{3}$ VCZ \\
\hline & TPCZ \\
\hline & ${ }^{3} \mathrm{FCCZ}$ \\
\hline & $\mathrm{HCCZ}$ \\
\hline
\end{tabular}

\begin{tabular}{|c|c|}
\hline \multirow{2}{*}{\multicolumn{2}{|c|}{$\begin{array}{ll}\text { Attachment } & 5 \\
\text { Originator: S.W. Clark } & \text { Sheet No. } 8 \text { of } 32\end{array}$}} \\
\hline & \\
\hline Shk'd By M.W. Perrott & \\
\hline $0100 F-C A-V 0280$ & Rev. No. \\
\hline
\end{tabular}




\section{ATTACHMENT 5}

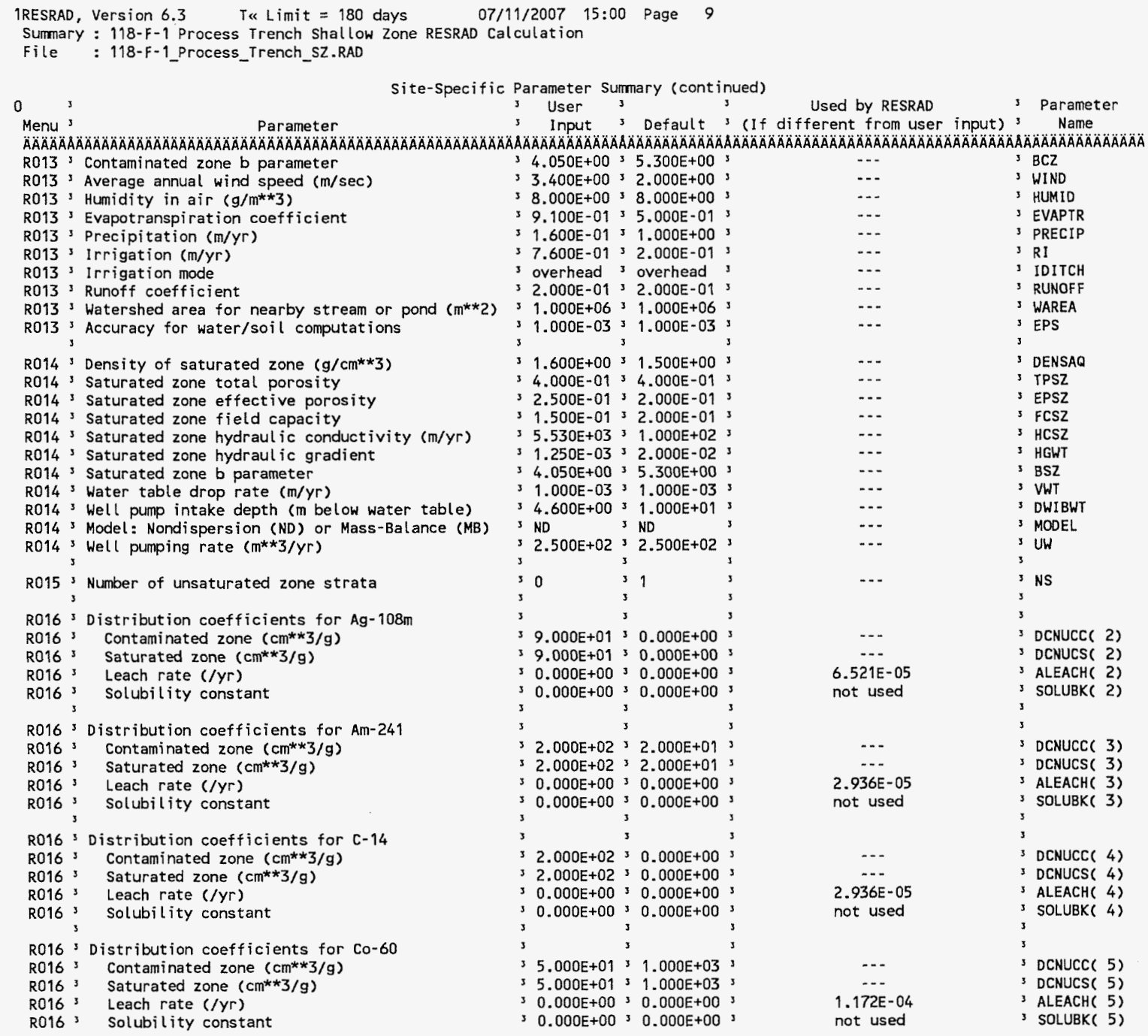

Attachment Originator: S.W. Clark

Chk'd By M.W. Perrott

Calc. No. 0100F-CA-V0280
Sheet No. $\underline{9}$ of 32 Date

Rev. No. 0 


\section{ATTACHMENT 5}

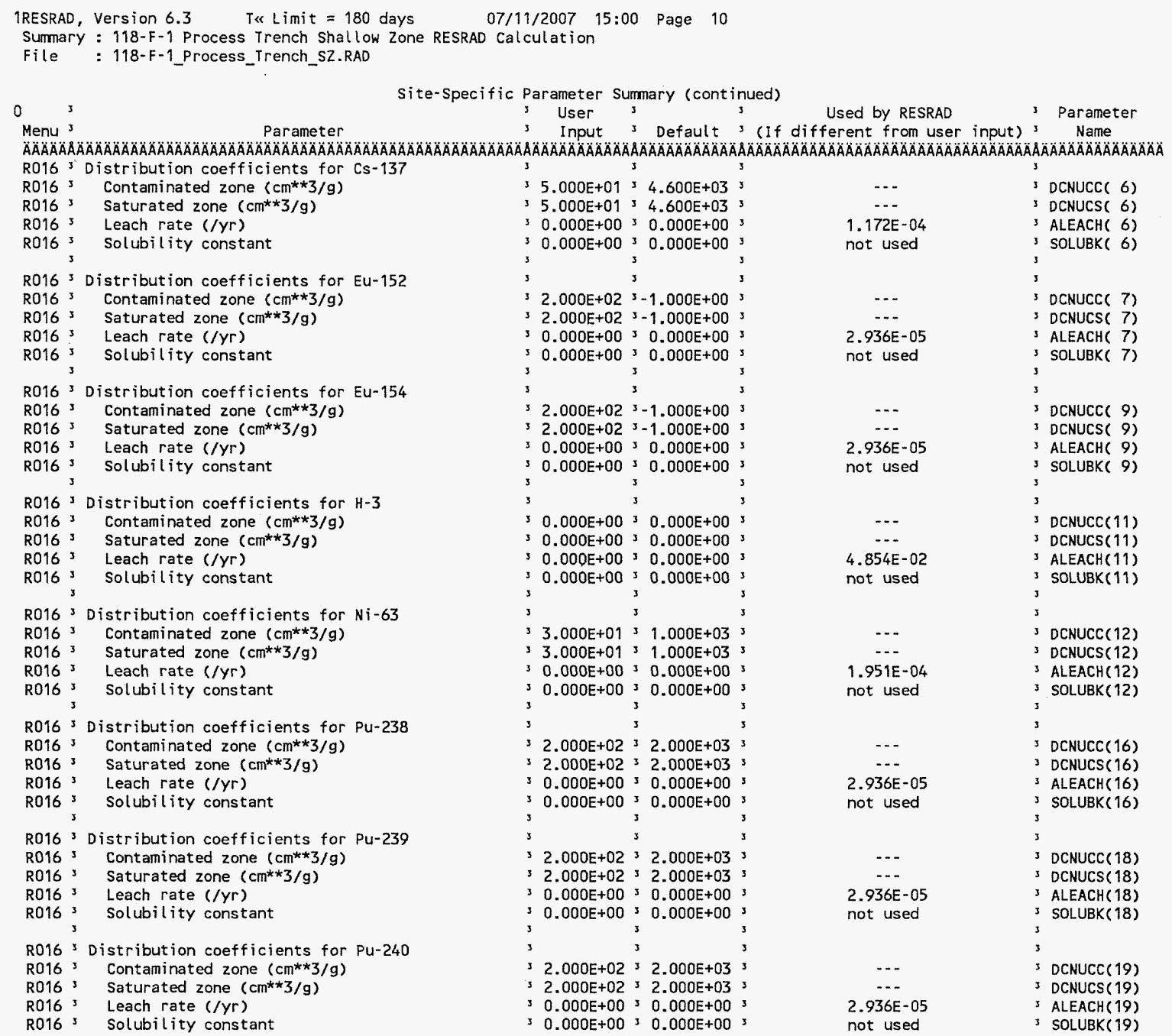

\begin{tabular}{|c|c|}
\hline Attachment & Sheet No. 10 of 32 \\
\hline Originator: S. W. Clark & _Date \\
\hline By M. W. Perrott & Date \\
\hline $0100 F-C A-V 0280$ & Rev. No. \\
\hline
\end{tabular}




\section{ATTACHMENT 5}

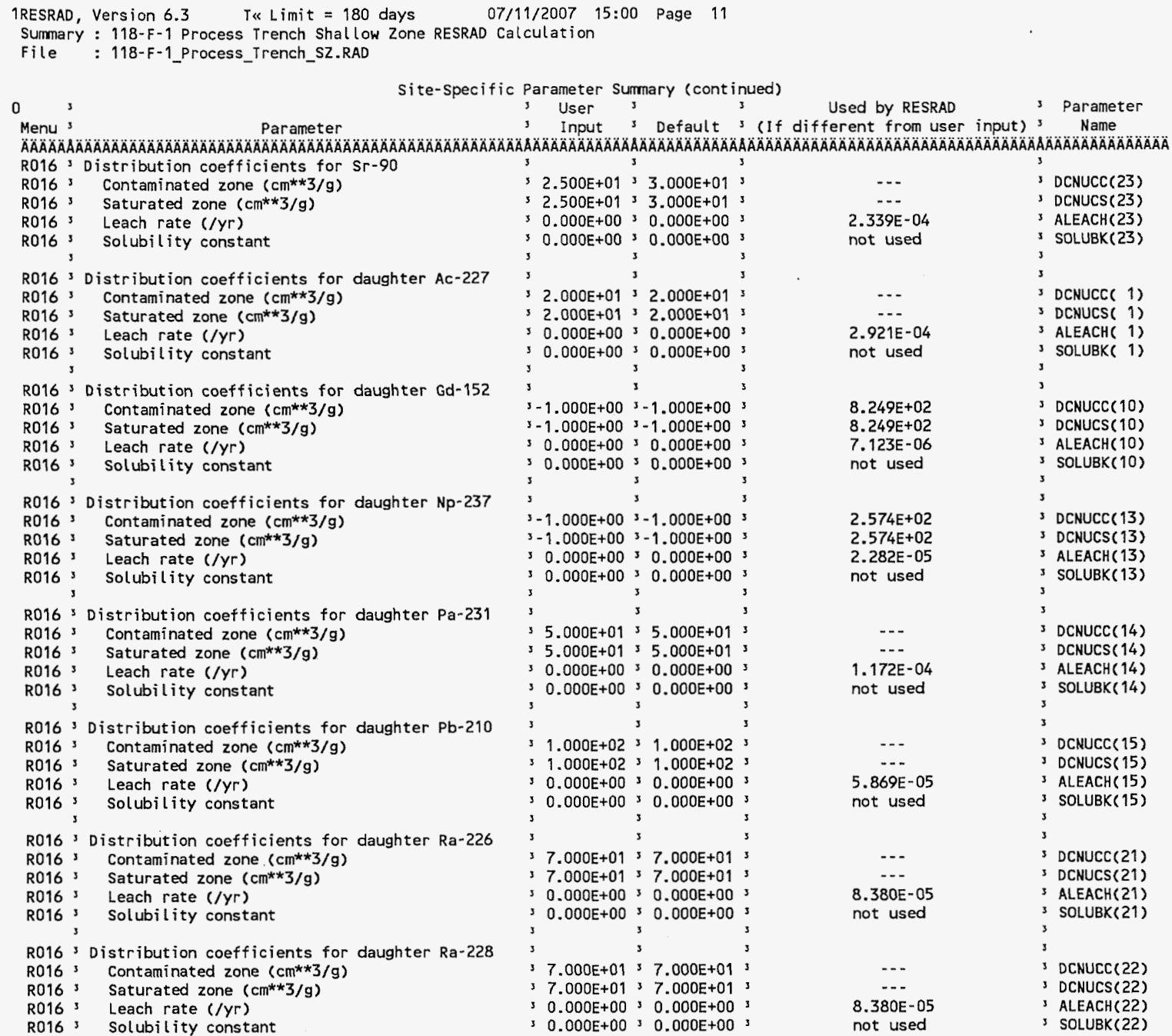

$\begin{array}{ll}\text { Attachment } \frac{5}{\text { Originator: }} \frac{5 . \text { W. Clark }}{\text { S.W. Perrott }} & \text { Sheet No. } 11 \text { of } 32 \\ \text { Date } & \text { Date } \\ \text { Chk'd By } & \text { Rev. No. } 0 \\ \text { Calc. No. No100F-CA-V0280 } & \text { Rev. No }\end{array}$




\section{ATTACHMENT 5}

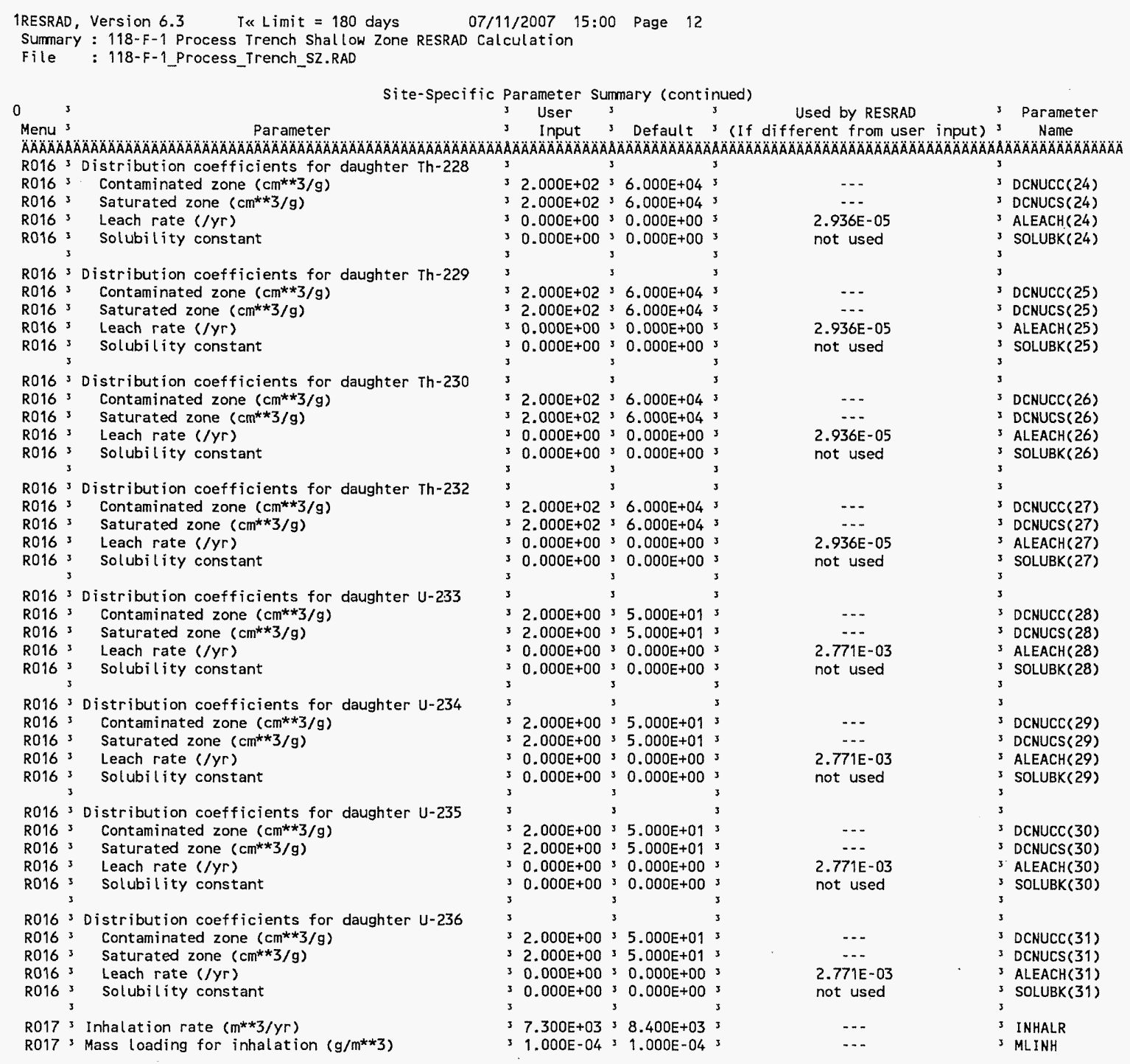

$\begin{array}{ll}\text { Attachment } \frac{5}{\text { S.W. Clark }} & \text { Sheet No. } 12 \text { of } 32 \\ \text { Originator: } & \text { Date } \\ \text { Chk'd By } & \text { Date } \\ \text { Calc. No. W. Perrott } & \text { Rev. No. } \quad 0\end{array}$




\section{ATTACHMENT 5}

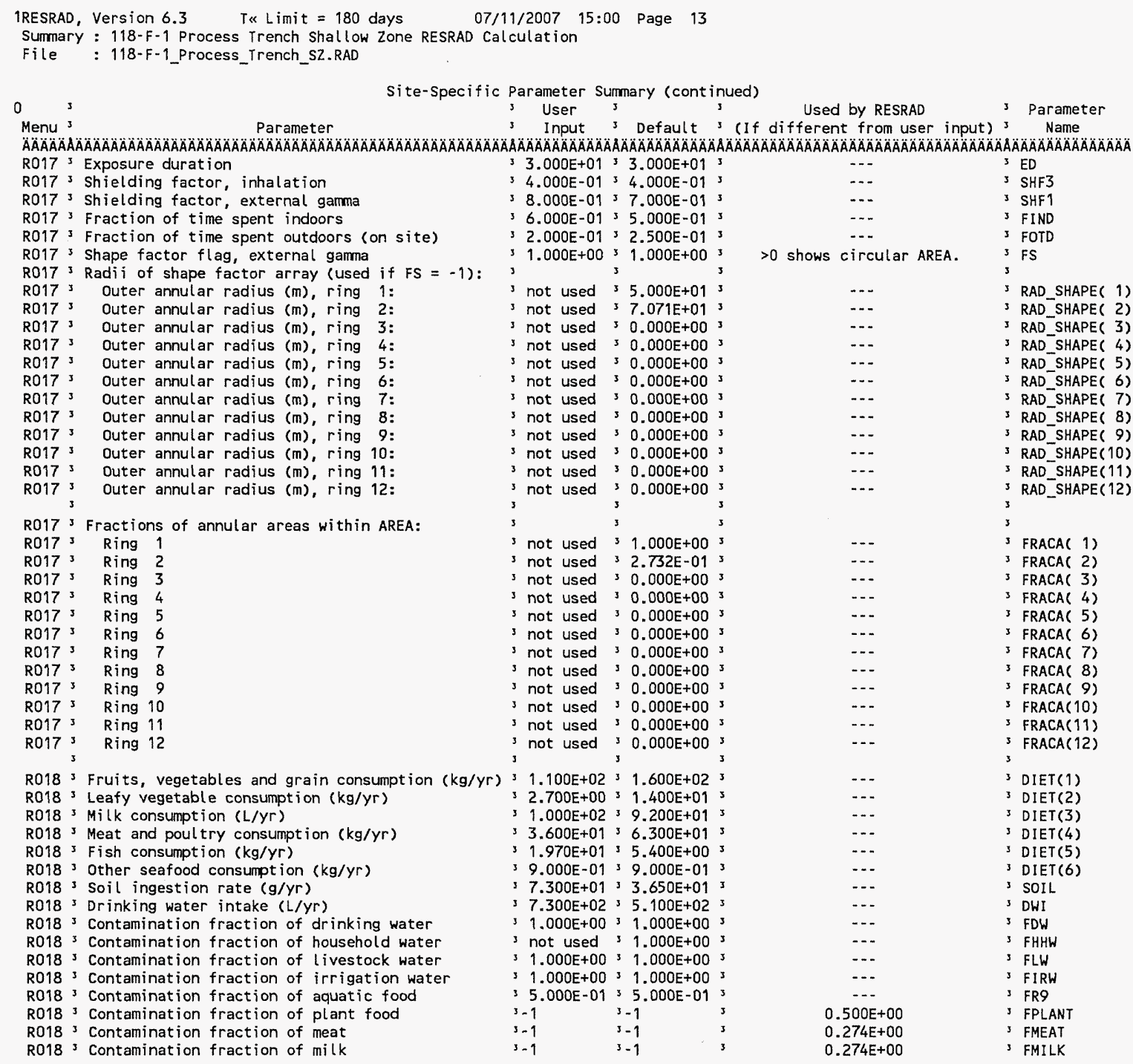

Attachment

5 Sheet No. 13 of $\underline{32}$ Originator: S.W. Clark Date

$\begin{array}{ll}\text { Calc. No. } & \text { Date } \\ \text { C100F-CA-V0280 Rev. No. } 0 & \end{array}$ 


\section{ATTACHMENT 5}

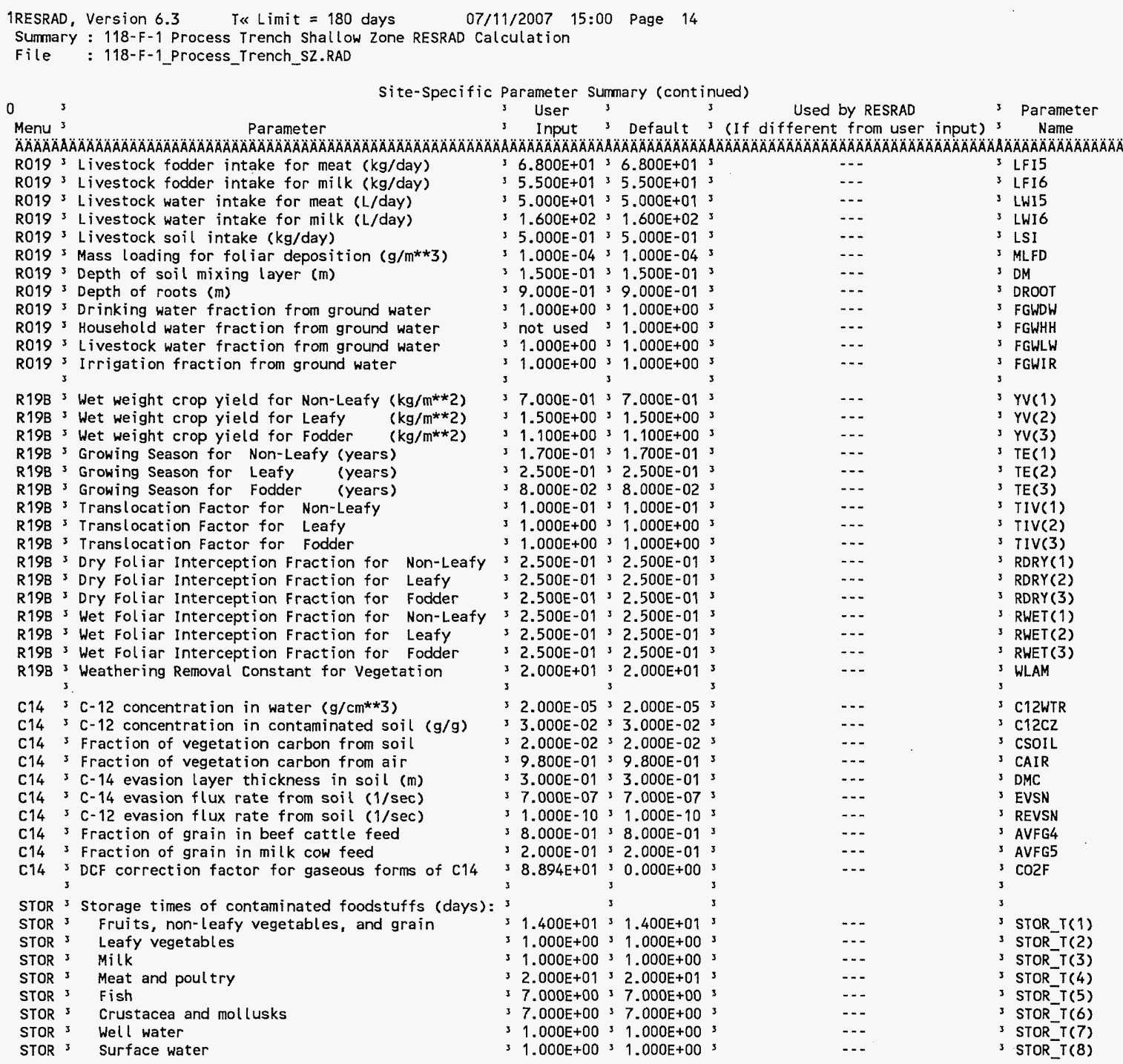

Attachment 


\section{ATTACHMENT 5}

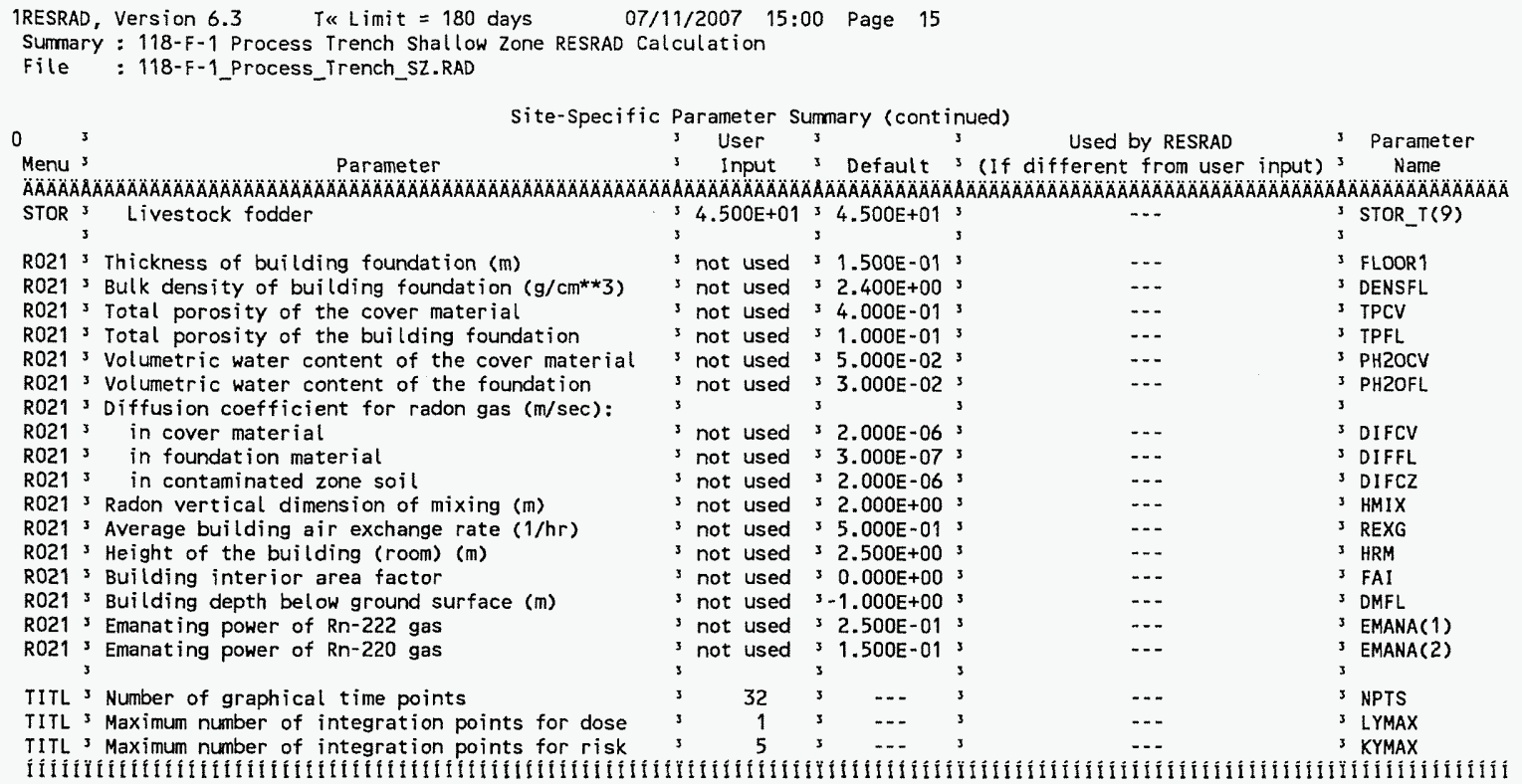

Summary of Pathway Selections

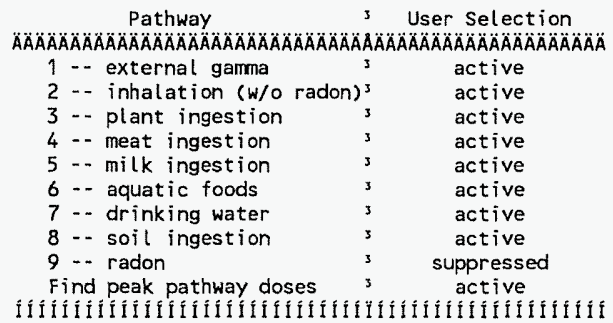

\begin{tabular}{|c|c|}
\hline Attachment & Sheet No. 15 of $\underline{32}$ \\
\hline Originator: S.W. Clark & Date \\
\hline M. W. Perrott & Date \\
\hline $0100 F-C A-V 0280$ & Rev. No. \\
\hline
\end{tabular}




\section{ATTACHMENT 5}

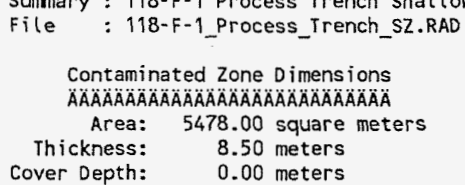

0

Total Dose TDOSE( $t$ ) mrem/yr

Basic Radiation Dose Limit $=1.500 E+01 \mathrm{mrem} / \mathrm{yr}$ Total Mixture Sum $M(t)=$ Fraction of Basic Dose Limit Received at Time $(t)$

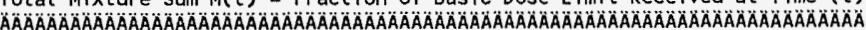

t (years): $\begin{array}{llllllllll}0.000 E+00 & 1.000 E+00 & 3.000 E+00 & 7.000 E+00 & 1.100 E+01 & 4.300 E+01 & 1.350 E+02 & 3.000 E+02 & 1.000 E+03\end{array}$

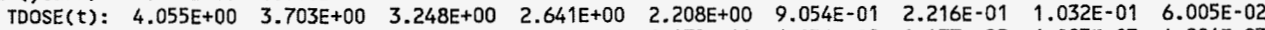
$M(t): \quad 2.703 E-01 \quad 2.469 E-01 \quad 2.166 E-01 \quad 1.761 E-01 \quad 1.472 E-01 \quad 6.036 E-02 \quad 1.477 E-02 \quad 6.883 E-03 \quad 4.004 E-03$ OMaximum TDOSE( $t): 4.055 E+00 \mathrm{mrem} / \mathrm{yr}$ at $t=0.000 E+00$ years

Attachment 


\section{ATTACHMENT 5}

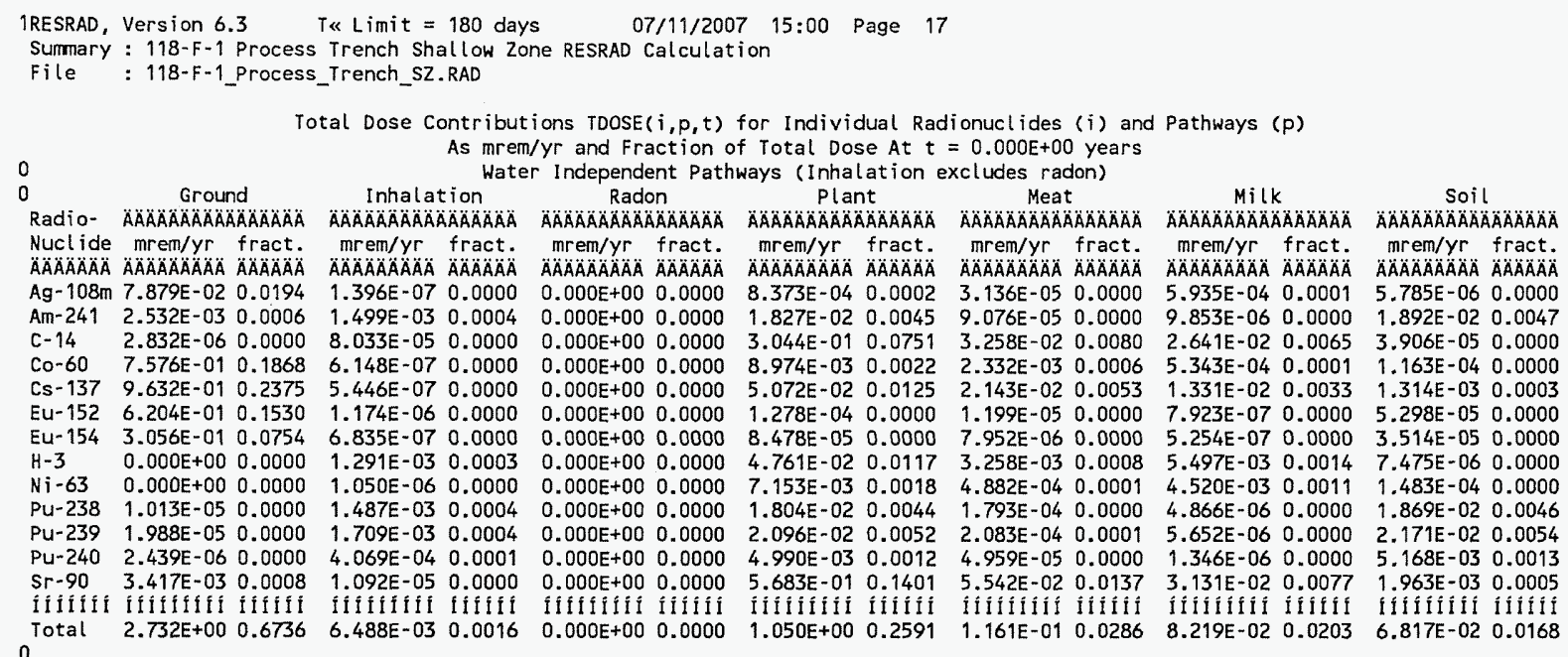
0

Total Dose Contributions $\operatorname{TDOSE}(i, p, t)$ for Individual Radionuclides (i) and Pathways ( $p$ )

As mrem/yr and Fraction of Total Dose At $t=0.000 E+00$ years

0

As $\mathrm{mrem} / \mathrm{yr}$ and Fraction of Total Dose At $t$
Water Dependent Pathways

Water Fish Radon Plant Matl Pathways*

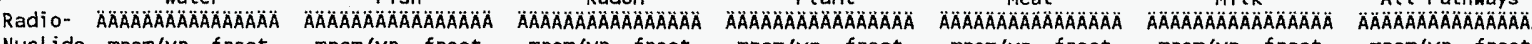
Nuclide $m r e m / y r$ fract. mrem/yr fract. mrem/yr fract. mrem/yr fract. mrem/yr fract. mrem/yr fract. $\mathrm{mrem} / \mathrm{yr}$ fract.

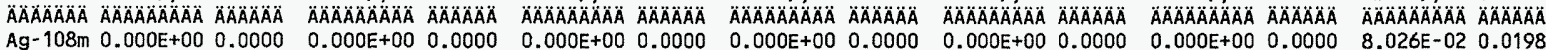
$\begin{array}{llllllllllllllll}A \mathrm{Am}-241 & 0.000 E+00 & 0.0000 & 0.000 E+00 & 0.0000 & 0.000 E+00 & 0.0000 & 0.000 E+00 & 0.0000 & 0.000 E+00 & 0.0000 & 0.000 E+00 & 0.0000 & 4.132 E-02 & 0.0102\end{array}$ $\begin{array}{lllllllllllllllll}C-14 & 0.000 E+00 & 0.0000 & 0.000 E+00 & 0.0000 & 0.000 E+00 & 0.0000 & 0.000 E+00 & 0.0000 & 0.000 E+00 & 0.0000 & 0.000 E+00 & 0.0000 & 3.636 E-01 & 0.0897\end{array}$

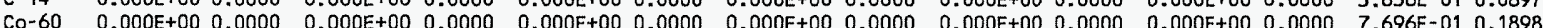
(.650 0.1898 $\begin{array}{llllllllllllllll}C s-137 & 0.000 E+00 & 0.0000 & 0.000 E+00 & 0.0000 & 0.000 E+00 & 0.0000 & 0.000 E+00 & 0.0000 & 0.000 E+00 & 0.0000 & 0.000 E+00 & 0.0000 & 1.050 E+00 & 0.2589\end{array}$

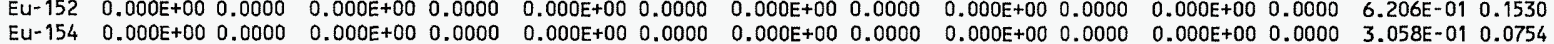

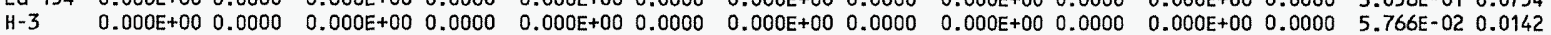

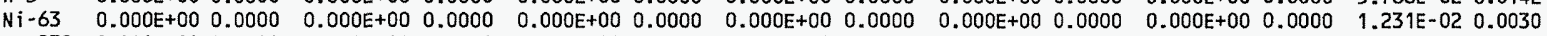
$\begin{array}{llllllllllllllll}\text { Pu-238 } & 0.000 E+00 & 0.0000 & 0.000 E+00 & 0.0000 & 0.000 E+00 & 0.0000 & 0.000 E+00 & 0.0000 & 0.000 E+00 & 0.0000 & 0.000 E+00 & 0.0000 & 3.841 E-02 & 0.0095\end{array}$ $\begin{array}{lllllllllllllll}\text { PU-239 } & 0.000 E+00 & 0.0000 & 0.000 E+00 & 0.0000 & 0.000 E+00 & 0.0000 & 0.000 E+00 & 0.0000 & 0.000 E+00 & 0.0000 & 0.000 E+00 & 0.0000 & 4.461 E-02 & 0.0110\end{array}$ $\begin{array}{lllllllllllllllll}\text { Pu-240 } & 0.000 E+00 & 0.0000 & 0.000 E+00 & 0.0000 & 0.000 E+00 & 0.0000 & 0.000 E+00 & 0.0000 & 0.000 E+00 & 0.0000 & 0.000 E+00 & 0.0000 & 1.062 E-02 & 0.0026\end{array}$

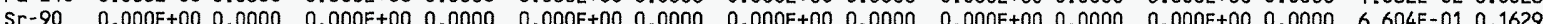

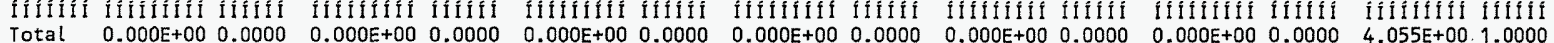
$0 *$ Sum of all water independent and dependent pathways.

\begin{tabular}{|c|c|}
\hline Attachment $\quad 5$ & Sheet No. 17 of 32 \\
\hline Originator: S. W. Clark & Date \\
\hline Chk'd By M.W. Perrott & Date. \\
\hline $0100 F-C A-V 0280$ & Rev. No. \\
\hline
\end{tabular}




\section{ATTACHMENT 5}

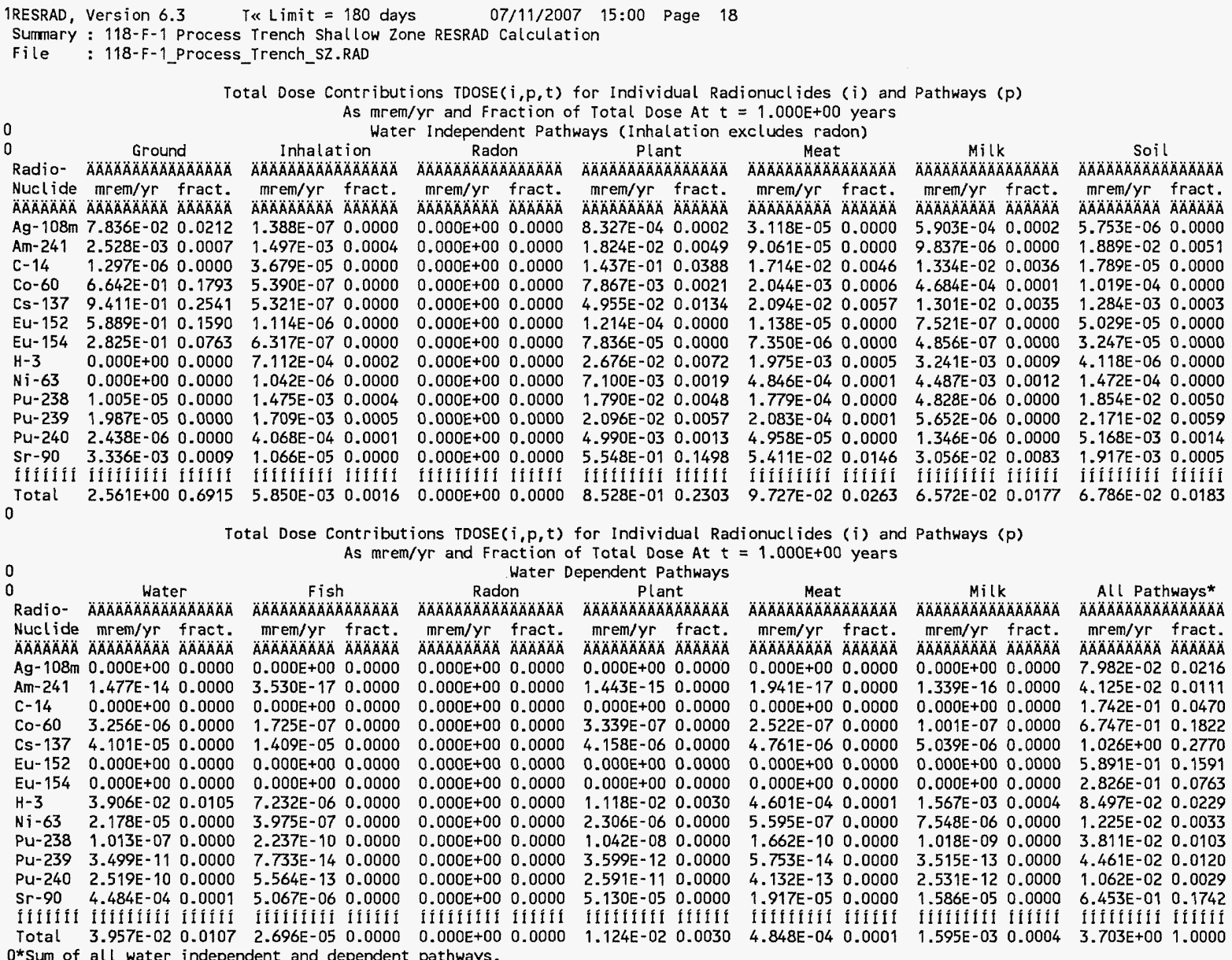
$0 *$ Sum of all water independent and dependent pathways.

\begin{tabular}{|c|c|}
\hline \multirow{2}{*}{\multicolumn{2}{|c|}{$\begin{array}{l}\text { Attachment } \frac{5}{\text { S.W. Clark }} \text { Sheet No. } 18 \text { of } 32 \\
\text { Originator: }\end{array}$}} \\
\hline & \\
\hline Chk'd By M. W. Perrott & Date \\
\hline $0100 F-C A-V 0280$ & Rev. No. \\
\hline
\end{tabular}




\section{ATTACHMENT 5}

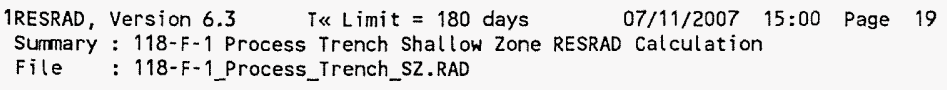

\begin{tabular}{|c|c|}
\hline Attachment $\quad 5$ & Sheet No. 19 of 32 \\
\hline Originator: S. W. Clark & Date \\
\hline Chk'd By M.W. Perrott & Date \\
\hline $0100 F-C A-V 0280$ & Rev. No. \\
\hline
\end{tabular}




\section{ATTACHMENT 5}

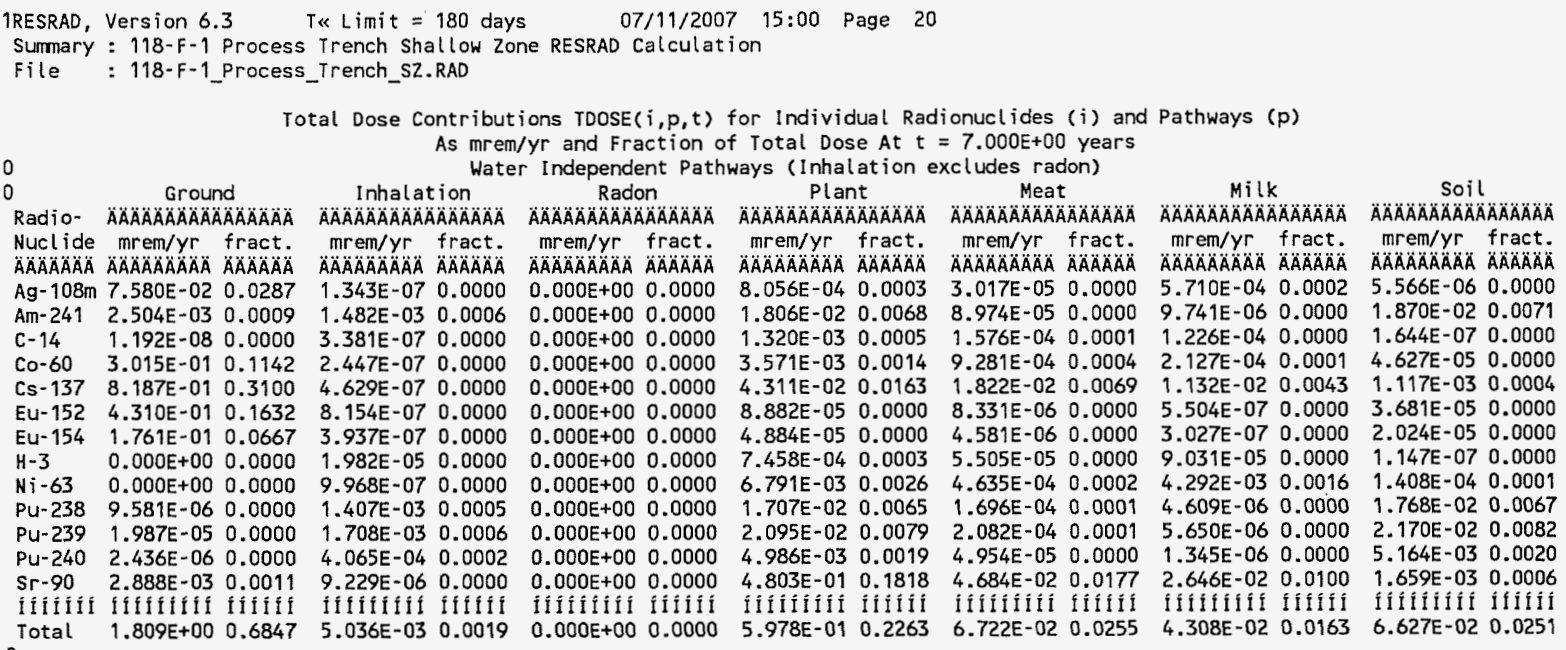
0

Total Dose Contributions TDOSE$(i, p, t)$ for Individual Radionuclides (i) and Pathways ( $p$ ) As mrem/yr and Fraction of Total Dose At $t=7.000 E+00$ years

\begin{tabular}{|c|c|c|c|c|c|c|c|c|c|c|c|c|c|}
\hline \\
\hline & & & Fish & & Rado & on & $P !$ & & Meat & & & & $\begin{array}{l}\text { All Pathways* } \\
\text { AAAAAAAAAAAAAAA }\end{array}$ \\
\hline $\begin{array}{l}\text { Nucl ide } \\
\triangle A A A A B A A\end{array}$ & & $\begin{array}{l}\text { fract. } \\
A B A O A O A B\end{array}$ & & act. & & & & & & & & & \\
\hline & $0.000 E+00$ & 0.0000 & $0.000 E+00$ & 0.0000 & $0.000 E+00$ & 0.0000 & +00 & & 0.0 & 0.0000 & & & $7.722 E-02 \quad 0.0292$ \\
\hline & $5.156 E-12$ & & & & & & & & & & & & $=020.0$ \\
\hline & & & & & & & & & & & +00 & & 3 \\
\hline & & & & & & & & & & & & & \\
\hline & & & & & & & & & & & & & \\
\hline & & & & & & & & & & & & & \\
\hline & & & & & & & & & & & & & \\
\hline & & & & & & & & & & & & & 02 \\
\hline-63 & & & & & & & & & & & & & \\
\hline & & & & & & & & & & & & & \\
\hline & & & & & & & & & & & $E-11$ & & 020. \\
\hline & 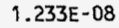 & 0.00 & & & & & & & & & & & \\
\hline & & & & & & & & & & & & & \\
\hline & & & & & & & If & & fiftifit & & fifififi & & 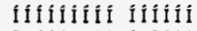 \\
\hline & $+2 E-0<$ & & 7.515E- 04 & 0.0000 & $0.000 E+00$ & 0.0000 & $1.129 \mathrm{E}-02$ & 0.0043 & $7.252 E-04$ & 0.0003 & $1.764 E-03$ & 0.0007 & $2.641 E+00 \quad 1.000$ \\
\hline
\end{tabular}
$0 *$ Sum of all water independent and dependent pathways.

$\begin{array}{ll}\text { Attachment } \frac{5}{\text { S.W. Clark }} & \text { Sheet No. } 20 \text { of } \underline{32} \\ \text { Originator: } & \text { Date } \\ \text { Chk'd By } & \text { Date } \\ \text { Calc. No. } \ldots \text {. Perrott } & \text { Rev. No. No } \quad 0\end{array}$




\section{ATTACHMENT 5}

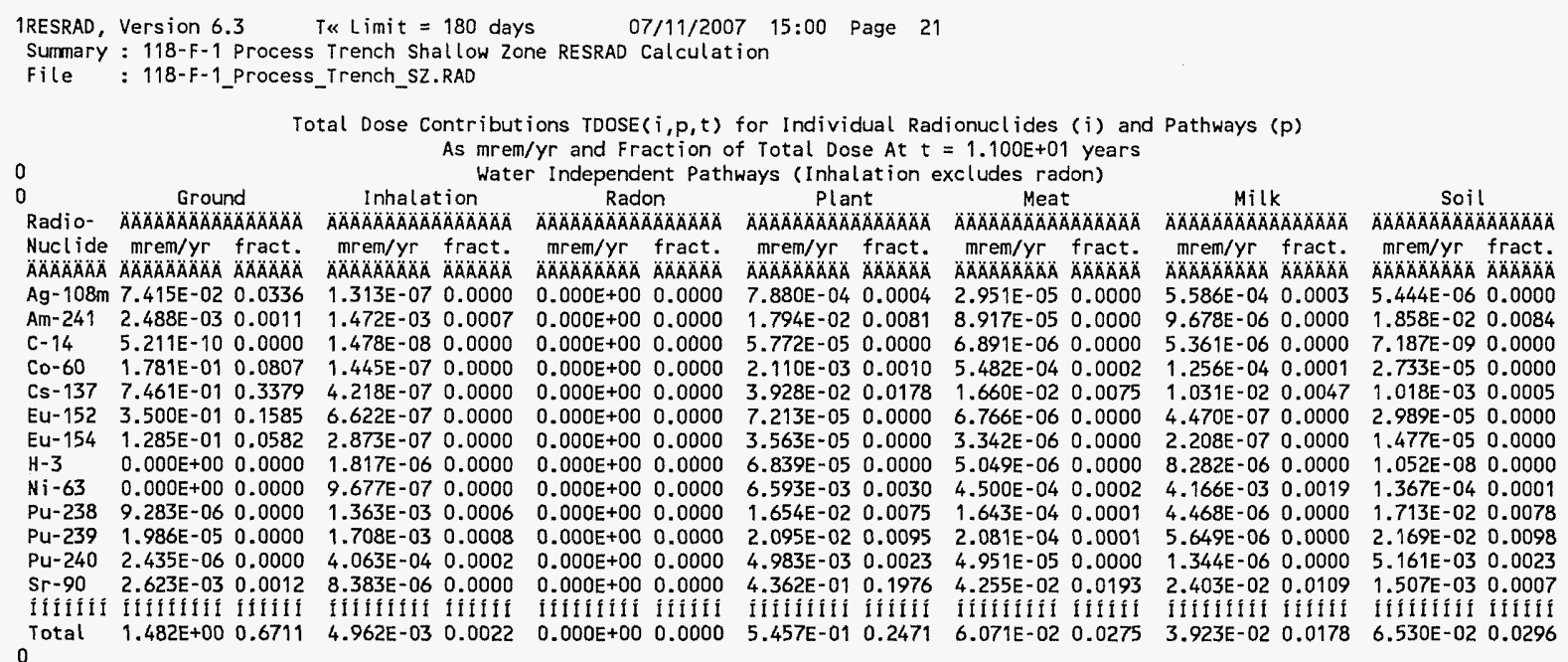

Total Dose Contributions $\operatorname{TDOSE}(i, p, t)$ for Individual Radionuclides ( $i$ ) and Pathways $(p)$

As mrem/yr and Fraction of Total Dose At $t=1.100 E+01$ years

$$
\begin{array}{r}
\text { As mrem/yr and Fraction of Total Dose At } t \\
\text { Water Dependent Pathways }
\end{array}
$$

Water Fish Radon Plant Mat Pathways*

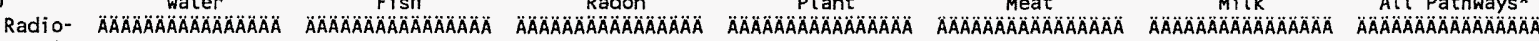
Nucl ide mrem/yr fract. mrem/yr fract. mrem/yr fract. mrem/yr fract. mrem/yr fract. mrem/yr fract. mrem/yr fract.

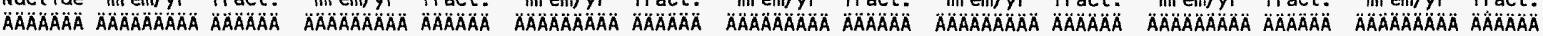
$\begin{array}{lllllllllllllllll}\mathrm{Ag}-108 \mathrm{~m} & 0.000 \mathrm{E}+00 & 0.0000 & 0.000 \mathrm{E}+00 & 0.0000 & 0.000 \mathrm{E}+00 & 0.0000 & 0.000 \mathrm{E}+00 & 0.0000 & 0.000 \mathrm{E}+00 & 0.0000 & 0.000 \mathrm{E}+00 & 0.0000 & 7.553 \mathrm{E}-02 & 0.0342\end{array}$

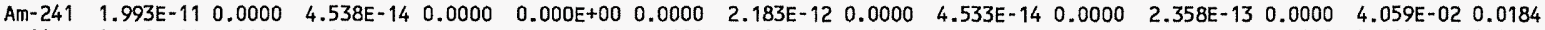
$\begin{array}{lllllllllllllllll}C-14 & 0.000 E+00 & 0.0000 & 0.000 E+00 & 0.0000 & 0.000 E+00 & 0.0000 & 0.000 E+00 & 0.0000 & 0.000 E+00 & 0.0000 & 0.000 E+00 & 0.0000 & 7.000 E-05 & 0.0000\end{array}$ Co-60 $9.675 \mathrm{E}-06 \quad 0.0000 \quad 5.342 \mathrm{E}-07 \quad 0.0000 \quad 0.000 \mathrm{E}+00 \quad 0.0000 \quad 1.086 \mathrm{E}-06 \quad 0.0000 \quad 1.304 \mathrm{E}-06 \quad 0.0000 \quad 3.835 \mathrm{E}-07 \quad 0.0000 \quad 1.809 \mathrm{E}-01 \quad 0.0819$ CS-137 3.603E-04 $0.00021 .290 E-040.00010 .000 E+000.00003 .995 E-050.00007 .275 E-050.00005 .709 E-050.0000 \quad 8.139 E-010.3686$ $\begin{array}{llll}-05 & 0.0000 & 8.139 E-01 & 0.3686\end{array}$

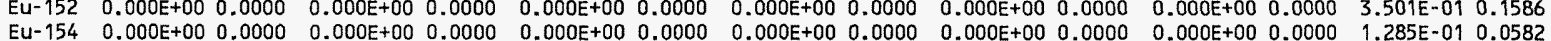

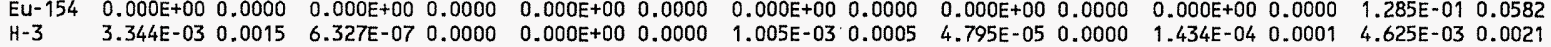

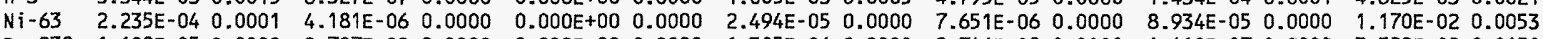

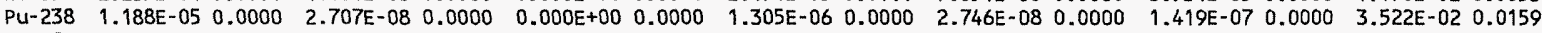
$\begin{array}{lllllllllllllll}\text { Pu-239 } & 4.213 E-09 & 0.0000 & 9.600 E-12 & 0.0000 & 0.000 E+00 & 0.0000 & 4.628 E-10 & 0.0000 & 9.763 E-12 & 0.0000 & 5.028 E-11 & 0.0000 & 4.458 E-02 & 0.0202\end{array}$ $\begin{array}{lllllllllllllll}\text { Pu-240 } & 3.032 E-08 & 0.0000 & 6.907 E-11 & 0.0000 & 0.000 E+00 & 0.0000 & 3.331 E-09 & 0.0000 & 7.003 E-11 & 0.0000 & 3.620 E-10 & 0.0000 & 1.060 E-02 & 0.0048\end{array}$

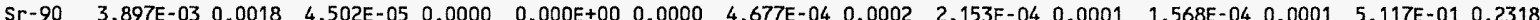

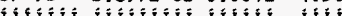

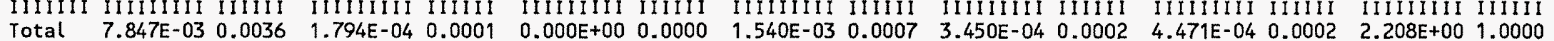
$0 *$ Sum of all water independent and dependent pathways.

$\begin{array}{ll}\text { Attachment } \frac{5}{\text { O. W. Clark }} & \text { Sheet No. } 21 \text { of } \underline{32} \\ \text { Originator: } & \text { Date } \\ \text { Chk'd By } & \text { Date } \\ \text { Calc. No. Norrott } & \text { Rev. No. } \quad \text { O100F-CA-V0280 }\end{array}$




\section{ATTACHMENT 5}

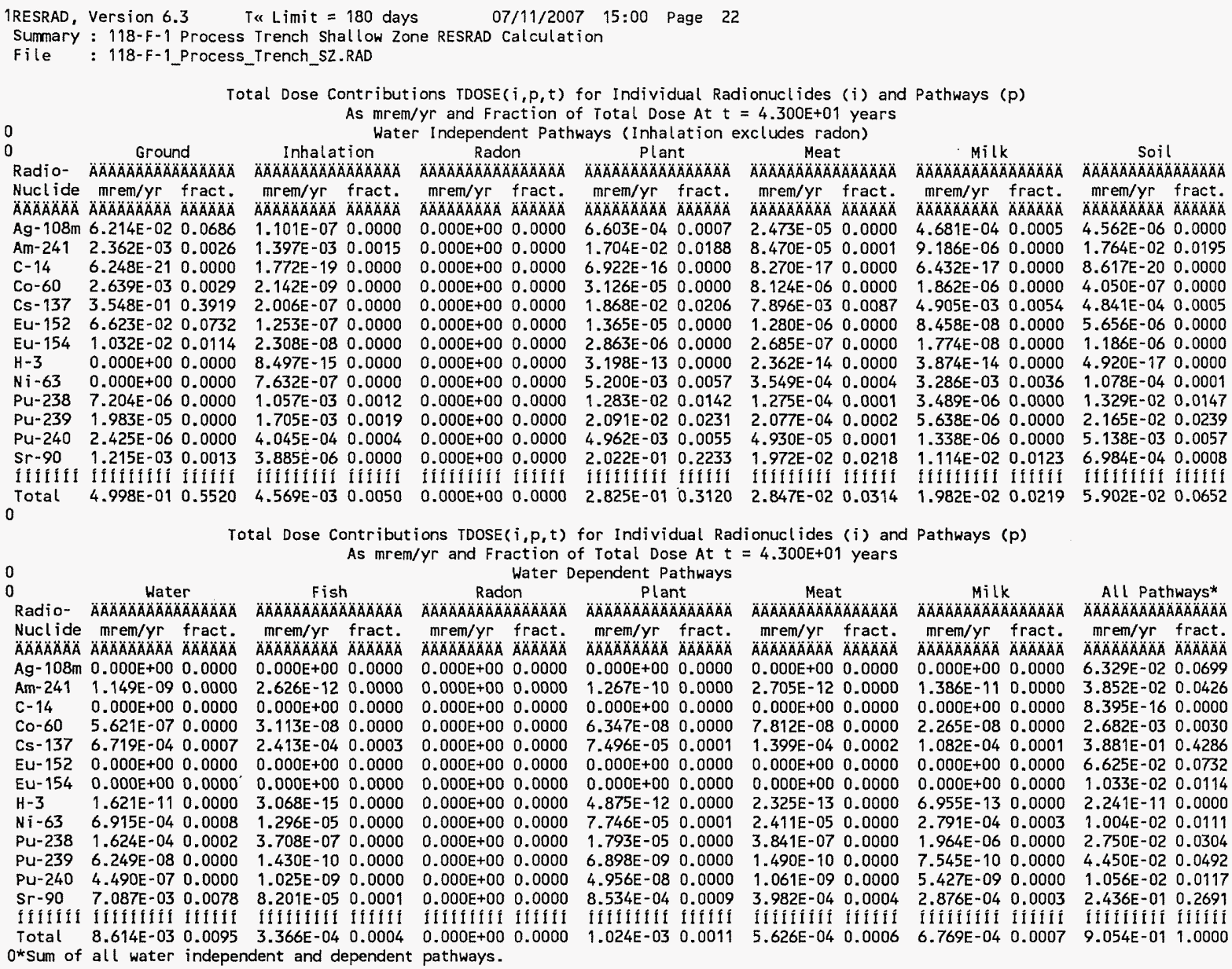

\begin{tabular}{|c|c|c|}
\hline \multirow{2}{*}{\multicolumn{3}{|c|}{$\begin{array}{ll}\text { Attachment } & 5 \\
\text { Originator: S.W. Clark Sheet No. } \underline{22} \text { of } \underline{32}\end{array}$}} \\
\hline & & \\
\hline & M. W. Perrott & _ Date \\
\hline & $0100 F-C A-V 0280$ & Rev. No. \\
\hline
\end{tabular}




\section{ATTACHMENT 5}

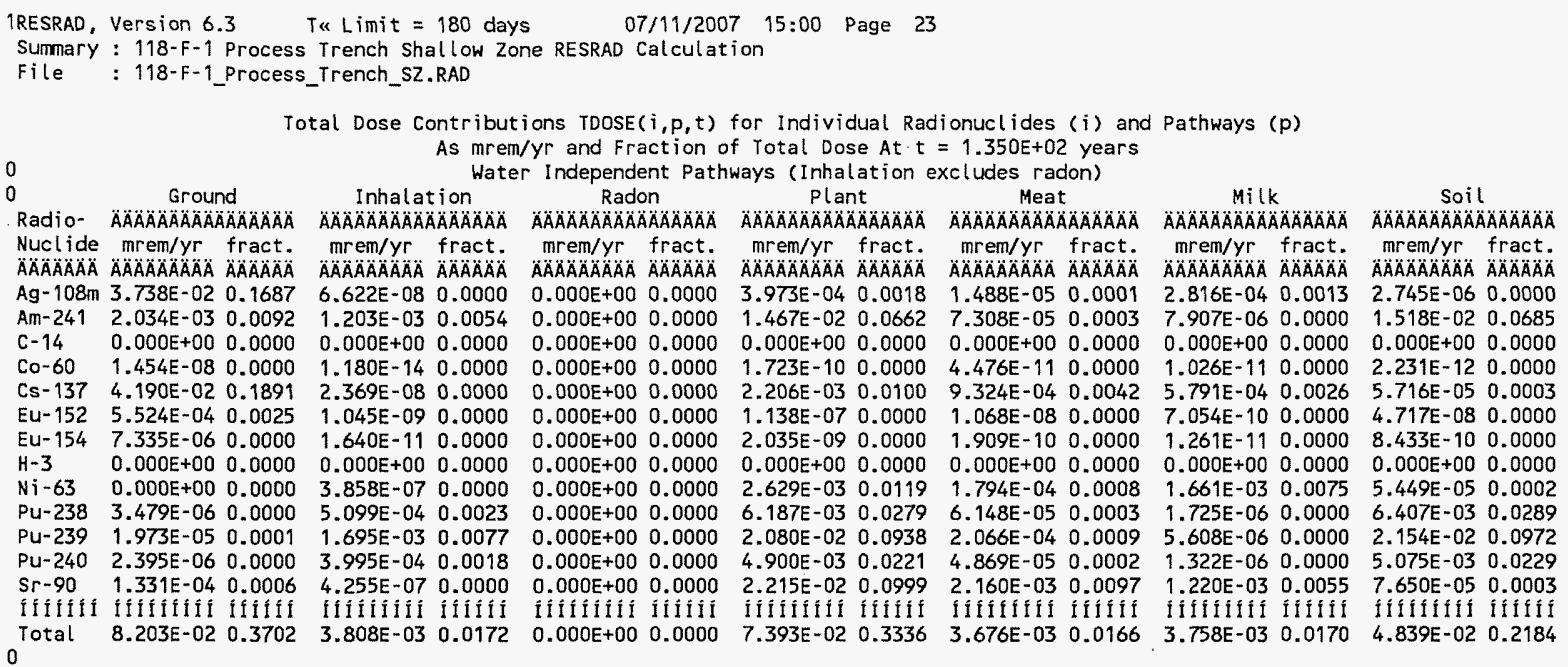

Total Dose Contributions TDOSE $(i, p, t)$ for Individual Radionuclides (i) and Pathways ( $p$ )

As $m r e m / y r$ and Fraction of Total Dose At $t=1.350 E+02$ years

$$
\text { Water Dependent Pathways }
$$

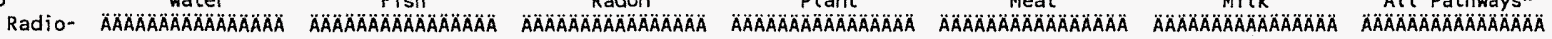
Nuclide mrem/yr fract. mrem/yr fract. mrem/yr fract. mrem/yr fract. mrem/yr fract. mrem/yr fract. mrem/yr fract.

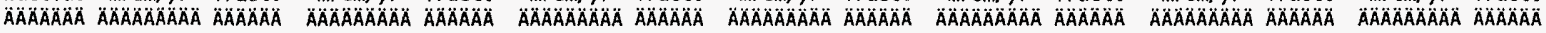
$\begin{array}{llllllllllllllllll}A g-108 m & 0.000 E+00 & 0.0000 & 0.000 E+00 & 0.0000 & 0.000 E+00 & 0.0000 & 0.000 E+00 & 0.0000 & 0.000 E+00 & 0.0000 & 0.000 E+00 & 0.0000 & 3.808 E-02 & 0.1718\end{array}$

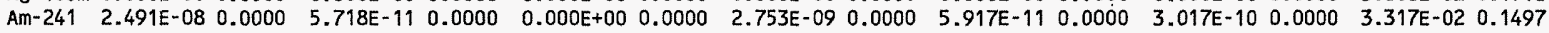
$\begin{array}{lllllllllllllllllllll}C-14 & 0.000 E+00 & 0.0000 & 0.000 E+00 & 0.0000 & 0.000 E+00 & 0.0000 & 0.000 E+00 & 0.0000 & 0.000 E+00 & 0.0000 & 0.000 E+00 & 0.0000 & 0.000 E+00 & 0.0000\end{array}$

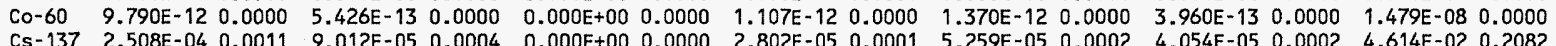

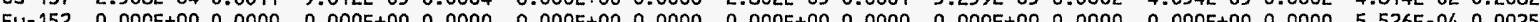

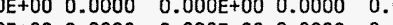

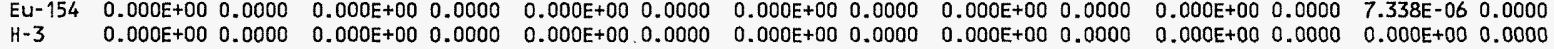
$\begin{array}{lllllllllllllll}\mathrm{Ni}-63 & 1.107 \mathrm{E}-03 & 0.0050 & 2.076 \mathrm{E}-05 & 0.0001 & 0.000 \mathrm{E}+00 & 0.0000 & 1.242 \mathrm{E}-04 & 0.0006 & 3.877 \mathrm{E}-05 & 0.0002 & 4.480 \mathrm{E}-04 & 0.0020 & 6.263 \mathrm{E}-03 & 0.0283\end{array}$

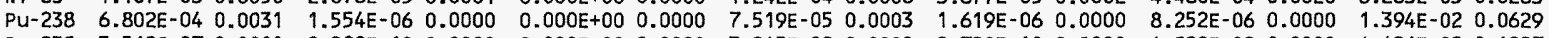
$\begin{array}{lllllllllllllll}\text { PU-239 } & 3.569 E-07 & 0.0000 & 8.299 E-10 & 0.0000 & 0.000 E+00 & 0.0000 & 3.945 E-08 & 0.0000 & 8.720 E-10 & 0.0000 & 4.299 E-09 & 0.0000 & 4.426 E-02 & 0.1997\end{array}$ $\begin{array}{llllllllllllllll}\text { Pu-240 } & 2.541 E-06 & 0.0000 & 5.805 E-09 & 0.0000 & 0.000 E+00 & 0.0000 & 2.809 E-07 & 0.0000 & 6.045 E-09 & 0.0000 & 3.082 E-08 & 0.0000 & 1.043 E-02 & 0.0471\end{array}$

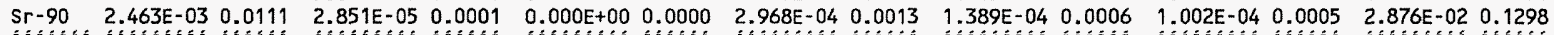

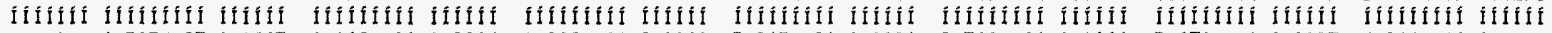

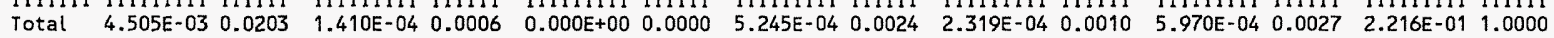
$0 *$ Sum of all water independent and dependent pathways.

\begin{tabular}{ll} 
Attachment $\frac{5}{\text { S.W. Clark }}$ & Sheet No. 23 of $\underline{32}$ \\
Originator: & Date \\
Chk'd By & Date \\
Calc. N. No. Perrott & Rev. No. $\quad 0$ \\
\hline O100F-CA-V0280 & Rev.
\end{tabular}




\section{ATTACHMENT 5}

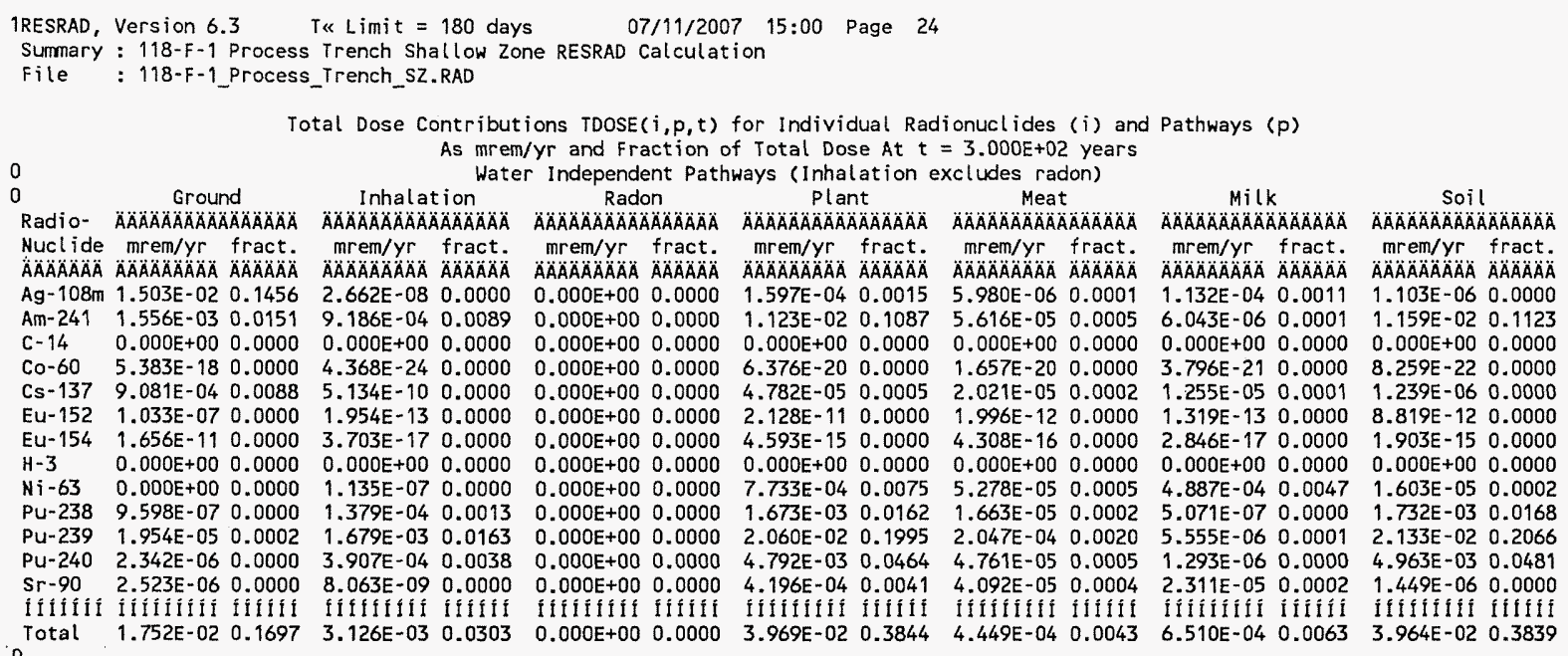
o

Total Dose Contributions $\operatorname{TDOSE}(i, p, t)$ for Individual Radionuclides (i) and Pathways $(p)$ As mrem/yr and Fraction of Total Dose At $t=3.000 E+02$ years

0 As $\mathrm{mrem} / \mathrm{yr}$ and Fraction of Total Dose At $t$
Water Dependent Pathways

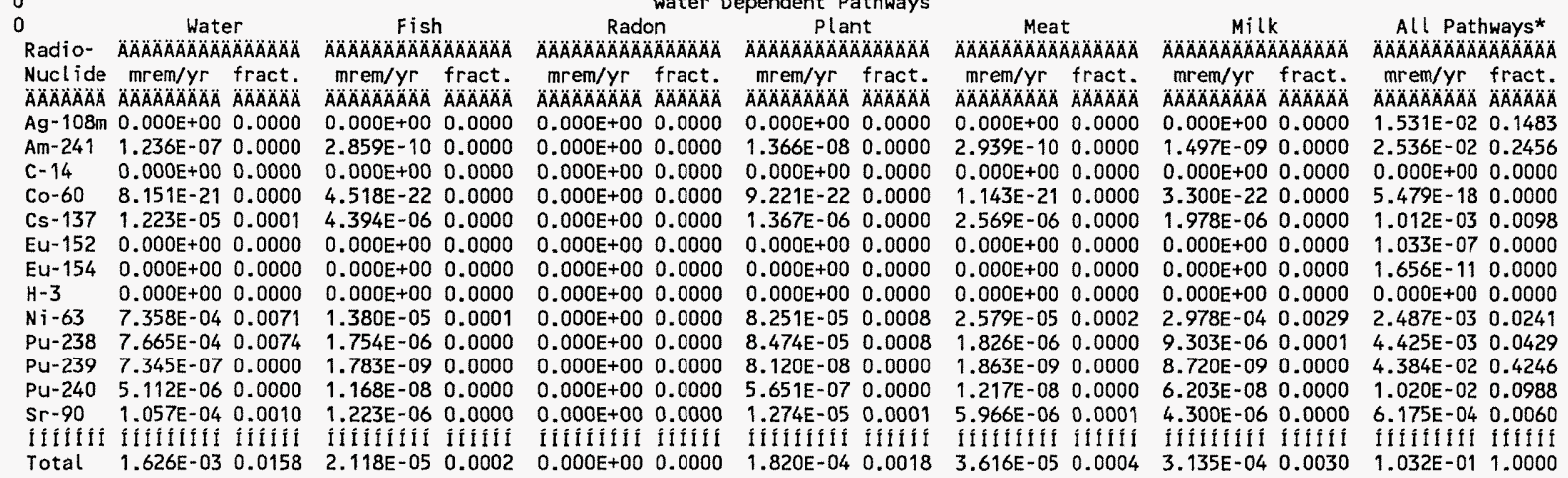
$0 *$ Sum of all water independent and dependent pathways.

\begin{tabular}{|c|c|}
\hline Attachment $\quad 5$ & Sheet No. $\underline{24}$ of $\underline{32}$ \\
\hline Originator: S.W. Clark & Date \\
\hline Chk'd By M. W. Perrott & Date \\
\hline Calc. No. $0100 F-C A-V 0280$ & Rev. No. \\
\hline
\end{tabular}




\section{ATTACHMENT 5}

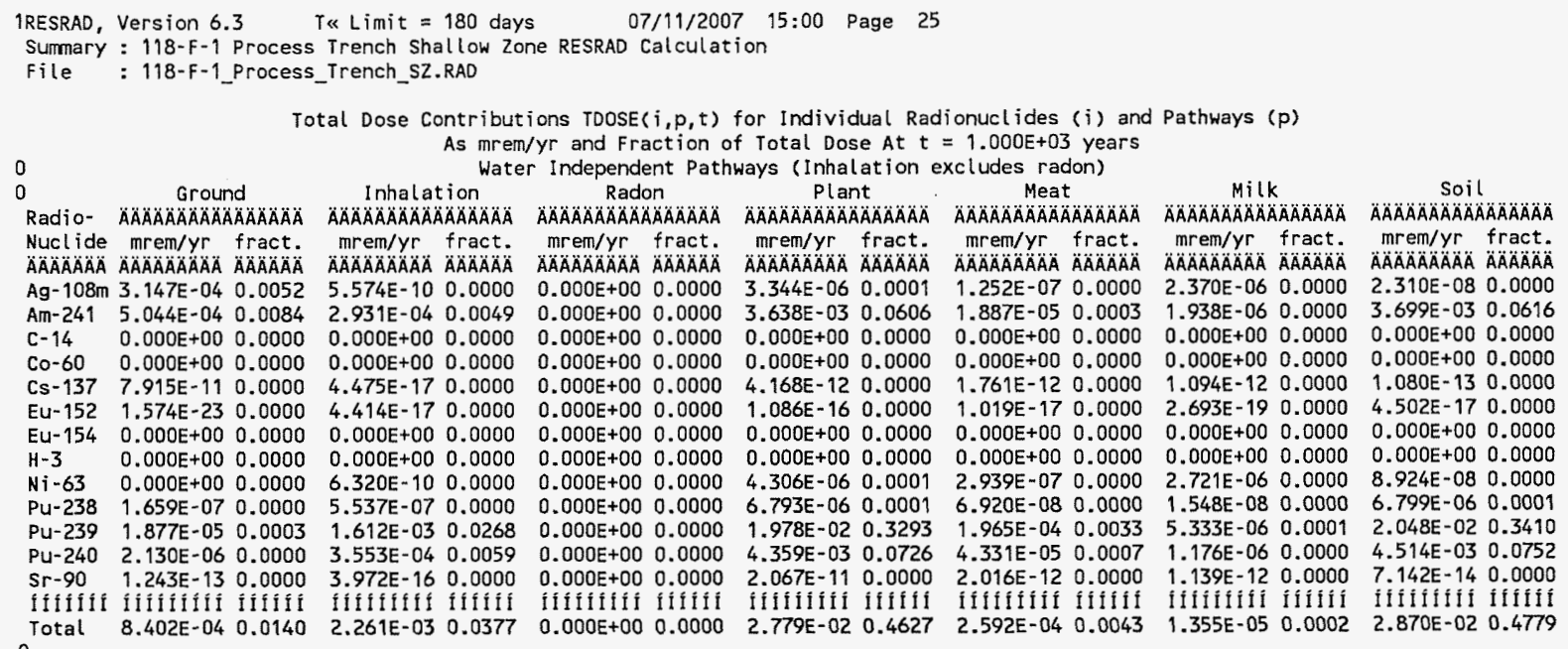
0

Total Dose Contributions $\operatorname{TDOSE}(i, p, t)$ for Individual Radionuclides (i) and Pathways ( $p$ ) As $\mathrm{mrem} / \mathrm{yr}$ and Fraction of Total Dose At $t \quad 1.000 \mathrm{E}+03$ years

\begin{tabular}{|c|c|c|c|c|c|c|c|c|c|c|c|c|c|}
\hline & \\
\hline & & & Fish & & Rado & & & & & & Milk & & All Pathways* \\
\hline & & & & & & 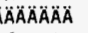 & 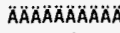 & 0000000 & & $\triangle O O A O A O$ & 0000000000 & 00000 & $\triangle A A A A A B A A A A A A A A A A A B$ \\
\hline & & & & & & & & & & & & $\begin{array}{l}\text { fract. } \\
A B A A A O A B\end{array}$ & $\begin{array}{l}\text { m/yr fract. } \\
A A B A A B A A B A A B A\end{array}$ \\
\hline & 0.000 & & $E+00$ & & & & $0.000 \mathrm{E}+00$ & & & & $0.000 E+00$ & 0.0000 & -040. \\
\hline & & & & & $E+\infty$ & & $B E-08$ & & & & & & \\
\hline & $+\infty 0$ & & & & & & & & & & & & \\
\hline & & & & & & & & & & & & & 000 \\
\hline & & & & & & & & & & & & & 110 \\
\hline & & & & & & & & & & & & & 000 \\
\hline & & & & & +00 & & $+\infty$ & & & & & & \\
\hline $\mathrm{H}-3$ & & & & & & & & & & & & & 000 \\
\hline & & & & & & & & & & & & & 050. \\
\hline & & & & & & & -05 & & & & & & \\
\hline & & & & & & & & & & & & & \\
\hline & & & & & & & & & & & & & $=-03 \quad 0.1546$ \\
\hline & & & & & & & & & & & & & \\
\hline & & & & & & & & & & & & & \\
\hline & & & & & & 0.0000 & & 0.0003 & & & $7.139 E^{-06}$ & 0.0001 & C \\
\hline
\end{tabular}
Total $1.661 E-040.0028 \quad 6.490 E-070.0000 \quad 0.000 E+00$
$0 *$ Sum of all water independent and dependent pathways.

\begin{tabular}{|c|c|}
\hline \multirow{2}{*}{\multicolumn{2}{|c|}{$\begin{array}{l}\text { Attachment } \frac{5}{\text { O.W. Clark }} \text { Sheet No. } 25 \text { of } 32 \\
\text { Originator: }\end{array}$}} \\
\hline & \\
\hline Chk'd By M.W. Perrott & \\
\hline $0100 F-C A-V 0280$ & Rev. No. \\
\hline
\end{tabular}




\section{ATTACHMENT 5}

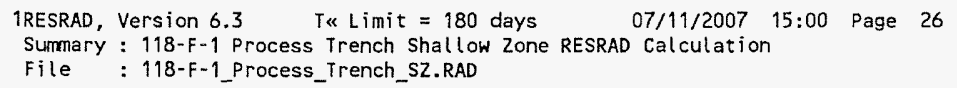

\begin{tabular}{|c|c|}
\hline Attachment & Sheet No. 26 of $\underline{32}$ \\
\hline Originator: S.W. Clark & Date \\
\hline Chk'd By M.W.Perrott & Date \\
\hline $0100 F-C A-V 0280$ & Rev. No. \\
\hline
\end{tabular}




\section{ATTACHMENT 5}

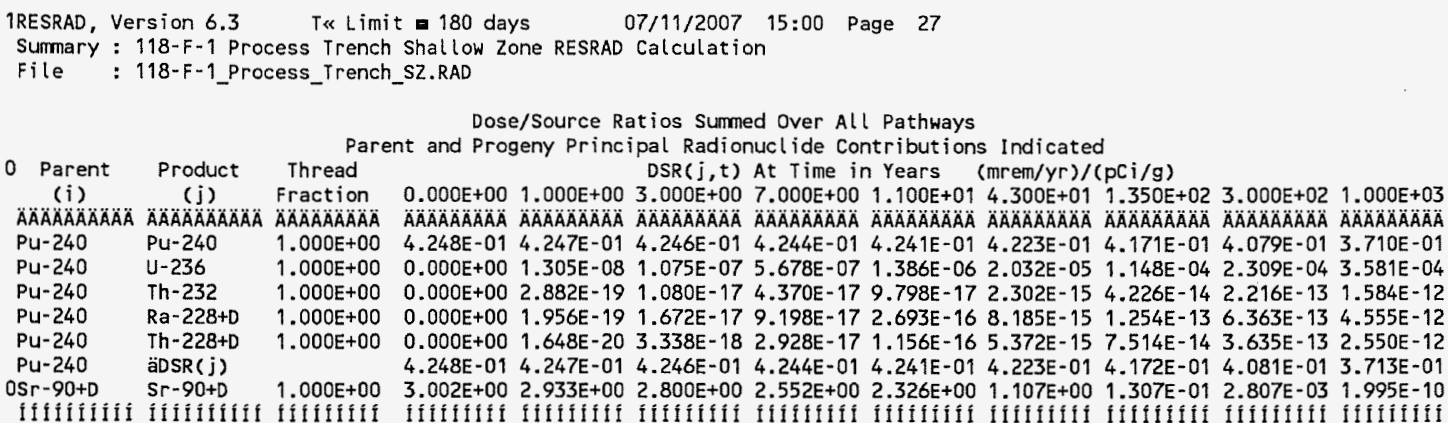
The DSR includes contributions from associated (half-life ó 180 days) daughters.

ONucl ide

\begin{tabular}{|c|c|c|}
\hline (i) & $t=0.000 E+00$ & 1. $000 E+00$ \\
\hline ÄÄÄÄÄÄ & ÄÄÄÄÄÄÄÄ & 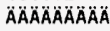 \\
\hline $\mathrm{Ag}-108 \mathrm{~m}$ & $2.430 E+00$ & $2.443 E+00$ \\
\hline$A m-241$ & $3.231 E+01$ & $3.236 E+01$ \\
\hline$c-14$ & $1.320 E+01$ & $2.756 E+01$ \\
\hline Co-60 & $1.442 E+00$ & $1.645 \mathrm{E} \div 00$ \\
\hline$C s-137$ & $6.429 E+00$ & $6.579 E+00$ \\
\hline Eu- 152 & $3.384 E+00$ & $3.565 E+00$ \\
\hline Eu-154 & $3.091 E+00$ & $3.344 E+00$ \\
\hline$H-3$ & $5.203 E+02$ & $3.531 E+02$ \\
\hline Ni-63 & $5.361 E+03$ & $5.387 E+03$ \\
\hline Pu-238 & $3.905 E+01$ & $3.936 E+01$ \\
\hline Pu-239 & $3.531 E+01$ & $3.531 \mathrm{E}+01$ \\
\hline Pu-240 & $3.531 E+01$ & $3.532 E+01$ \\
\hline sr-90 & $4.997 E+00$ & $5.114 E+00$ \\
\hline Iflifif & fiffifiti & IIIIIIIII \\
\hline
\end{tabular}

*At specific activity limit
Single Radionuclide Soil Guidelines $G(i, t)$ in $\mathrm{pCi} / \mathrm{g}$ Basic Radiation Dose Limit $=1.500 \mathrm{E}+01 \mathrm{mrem} / \mathrm{yr}$

\begin{tabular}{|c|c|c|c|c|c|c|}
\hline $\begin{array}{l}3.000 E+00 \\
A A A A A A A A A A\end{array}$ & $\begin{array}{l}7.000 E+00 \\
A B A A A A A A A\end{array}$ & $\begin{array}{l}1.100 E+01 \\
A A A A A B A A A\end{array}$ & $\begin{array}{l}4.300 E+01 \\
\triangle A A A O A B A O A\end{array}$ & $\begin{array}{l}1.350 E+02 \\
\triangle A B A A B A A B A A\end{array}$ & $\begin{array}{l}3.000 E+02 \\
\triangle A B A A A A A B A\end{array}$ & $\begin{array}{l}1.000 E+03 \\
A B A A A A A B A\end{array}$ \\
\hline $2.470 E+00$ & $2.525 E+00$ & $2.582 E+00$ & $3.081 E+00$ & $5.121 E+00$ & 1. $274 E+01$ & $6.084 E+02$ \\
\hline 3. $247 E+01$ & $3.268 E+01$ & $3.289 E+01$ & $3.465 E+01$ & $4.025 E+01$ & $5.265 \mathrm{E}+01$ & $1.637 \mathrm{E}+02$ \\
\hline & $2.998 \mathrm{E}+03$ & $6.858 E+04$ & $* 4.455 \mathrm{E}+12$ & $*_{4} .455 E+12$ & & \\
\hline $2.141 E+00$ & $3.624 E+00$ & $6.135 E+00$ & $4.139 E+02$ & $7.507 E+07$ & $\star 1.132 E+15$ & $* 1.132 E+15$ \\
\hline $1 E+00$ & $7.560 E+00$ & $8.293 E+00$ & $9 E+01$ & $1.463 E+02$ & $6.667 E+03$ & $7.244 E+10$ \\
\hline $.956 \mathrm{E}+00$ & $4.871 E+00$ & $5.998 \mathrm{E}+00$ & $0 E+01$ & $3.800 E+03$ & $2.033 E+07$ & $* 1.765 E+14$ \\
\hline$=+\infty$ & $65 \mathrm{E}+00$ & $7.353 E+00$ & $9.152 E+01$ & $1.288 E+05$ & $5.705 E+10$ & $* 2.639 E+14$ \\
\hline$E+02$ & $4 E+02$ & $6.486 E+03$ & & $* 9.597 \mathrm{E}+15$ & $97 E+15$ & $* 9.597 E+15$ \\
\hline & $5.538 E+03$ & $5.643 E+03$ & $6.577 E+03$ & $1.054 E+04$ & $2.654 E+04$ & $2.171 E+06$ \\
\hline & $4.127 E+01$ & $4.259 E+01$ & $5.455 E+01$ & $1.076 E+02$ & $3.390 E+02$ & $8.616 E+03$ \\
\hline & $3.532 E+01$ & $3.533 E+01$ & & $3.558 \mathrm{E}+01$ & $3.593 E+01$ & $3.742 E+01$ \\
\hline & & & & & $76 E+01$ & \\
\hline & $5.877 E+00$ & $6.448 E+00$ & $1.355 \mathrm{E}+01$ & & $5.344 \mathrm{E}+03$ & $7.517 E+10$ \\
\hline CHABIIII & Ififlifi & lílíílí & iffififit & fliffífíl & fífififif & flififlit \\
\hline
\end{tabular}

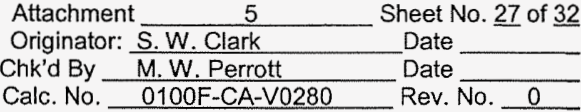




\section{ATTACHMENT 5}

\begin{tabular}{|c|c|c|c|c|c|c|}
\hline $\begin{array}{l}\text { 1RESRAD, } \\
\text { Sumnary } \\
\text { File }\end{array}$ & $\begin{array}{l}\text { Version } 6 \\
: 118-F-1 \\
: 118-F-1\end{array}$ & $\begin{array}{l}\text { T\& Limit }= \\
\text { rocess Trench Sha } \\
\text { rocess_Trench_s2. }\end{array}$ & $\begin{array}{l}180 \text { days } \\
\text { allow Zone RE } \\
\text { RAD }\end{array}$ & $\begin{array}{r}07 / 11 / \\
\text { ESRAD Calcu }\end{array}$ & $\begin{array}{l}2007 \quad 15: 00 \\
\text { dlation }\end{array}$ & Page \\
\hline & $\begin{array}{l}\text { Summed } \\
\text { and Sir } \\
\text { at } t \text { min = } \\
\text { at } t \max \text { 口 }\end{array}$ & $\begin{array}{l}\text { Dose/Source Ratio } \\
\text { igle Radionuclide } \\
\text { time of minimum s } \\
\text { time of maximum }\end{array}$ & $\begin{array}{l}\text { Soil Guidel } \\
\text { single radion } \\
\text { total dose - }\end{array}$ & $0.000 E+00$ & $\begin{array}{l}\text { in } p c i / g \\
\text { il guideline } \\
\text { years }\end{array}$ & \\
\hline $\begin{array}{l}\text { ONuclide } \\
\text { (i) }\end{array}$ & Initial & tmin & DSR $(i, \operatorname{tmin})$ & $G(i, t \min )$ & $\operatorname{DSR}(i, \operatorname{tmax})$ & $\begin{array}{c}G(i, t \operatorname{tmax}) \\
(p C i / g)\end{array}$ \\
\hline$\ddot{A} A \ddot{A} A A A B A$ & $\triangle A A A O A A O A A O A B A$ & $\triangle A B A A A A A O A O A O A O A O A O A O A$ & $\triangle A O A A O A A O A O A$ & $\triangle A A A B A A B A A$ & $\triangle A ̈ A ̈ A ̈ A ̈ A A O A ̈$ & A A AOA \\
\hline $\mathrm{Ag}-108 \mathrm{~m}$ & $1.300 \mathrm{E}-02$ & $0.000 E+00$ & $6.174 E+00$ & $2.430 E+00$ & $6.174 E+00$ & $2.430 E+00$ \\
\hline Am- 241 & $8.900 E-02$ & $0.000 E+00$ & $4.643 \mathrm{E}-01$ & $3.231 E+01$ & $4.643 \mathrm{E}-01$ & $3.231 E+01$ \\
\hline$c-14$ & $3.200 \mathrm{E}-01$ & $0.000 E+00$ & $1.136 \mathrm{E}+00$ & $1.320 E+01$ & $1.136 E+00$ & $1.320 E+01$ \\
\hline $\cos 60$ & $7.400 \mathrm{E}-02$ & $0.000 E+00$ & $1.040 E+01$ & $1.442 E+00$ & $1.040 \mathrm{E}+01$ & $1.442 E+00$ \\
\hline-137 & $4.500 E-01$ & $0.000 E+00$ & $2.333 E+00$ & $6.429 E+00$ & $2.333 E+00$ & $6.429 E+00$ \\
\hline Eu- 152 & $1.400 E=01$ & $0.000 E+00$ & $4.433 E+00$ & $3.384 E+00$ & $4.433 E+00$ & $3.384 E+00$ \\
\hline Eu-154 & $6.300 E-02$ & $0.000 E+00$ & $4.853 E+00$ & $3.091 E+00$ & $4.853 E+00$ & $3.091 \mathrm{E}+00$ \\
\hline$H-3$ & $2.000 E+00$ & 3.321 ก 0.007 & $5.037 \mathrm{E}-02$ & $2.978 E+02$ & $2.883 E-02$ & $5.203 E+02$ \\
\hline $\mathrm{Ni}-63$ & $4.400 E+00$ & $0.000 \mathrm{E}+00$ & $2.798 \mathrm{E}-03$ & $5.361 E+03$ & $2.798 \mathrm{E}-03$ & $5.361 E+03$ \\
\hline & $1.000 E-01$ & $0.000 E+00$ & $3.841 \mathrm{E}-01$ & $3.905 E+01$ & $3.841 E-01$ & $3.905 E+01$ \\
\hline & $1.050 \mathrm{E}-01$ & $0.000 E+00$ & $4.249 \mathrm{E}-01$ & $3.531 E+01$ & $4.249 E-01$ & $3.531 E+01$ \\
\hline & $2.500 \mathrm{E}-02$ & $0.000 E+00$ & $4.248 \mathrm{E}-01$ & $3.531 E+01$ & $4.248 E-01$ & $3.531 E+01$ \\
\hline & 2.200E-01 & $0.000 E+00$ & $3.002 E+00$ & $4.997 \mathrm{E}+00$ & $3.002 E+00$ & $4.997 \mathrm{E}+00$ \\
\hline f́lítî́ & Î́ítît & fliftulififite & IIIIFIIII & ffilitift & Ififfifi & ffilifif \\
\hline
\end{tabular}

Attachment Sheet No. 28 of 32 Originator: S.W. Clark Date

Calc. No. 0100F-CA-V0280 Date 


\section{ATTACHMENT 5}

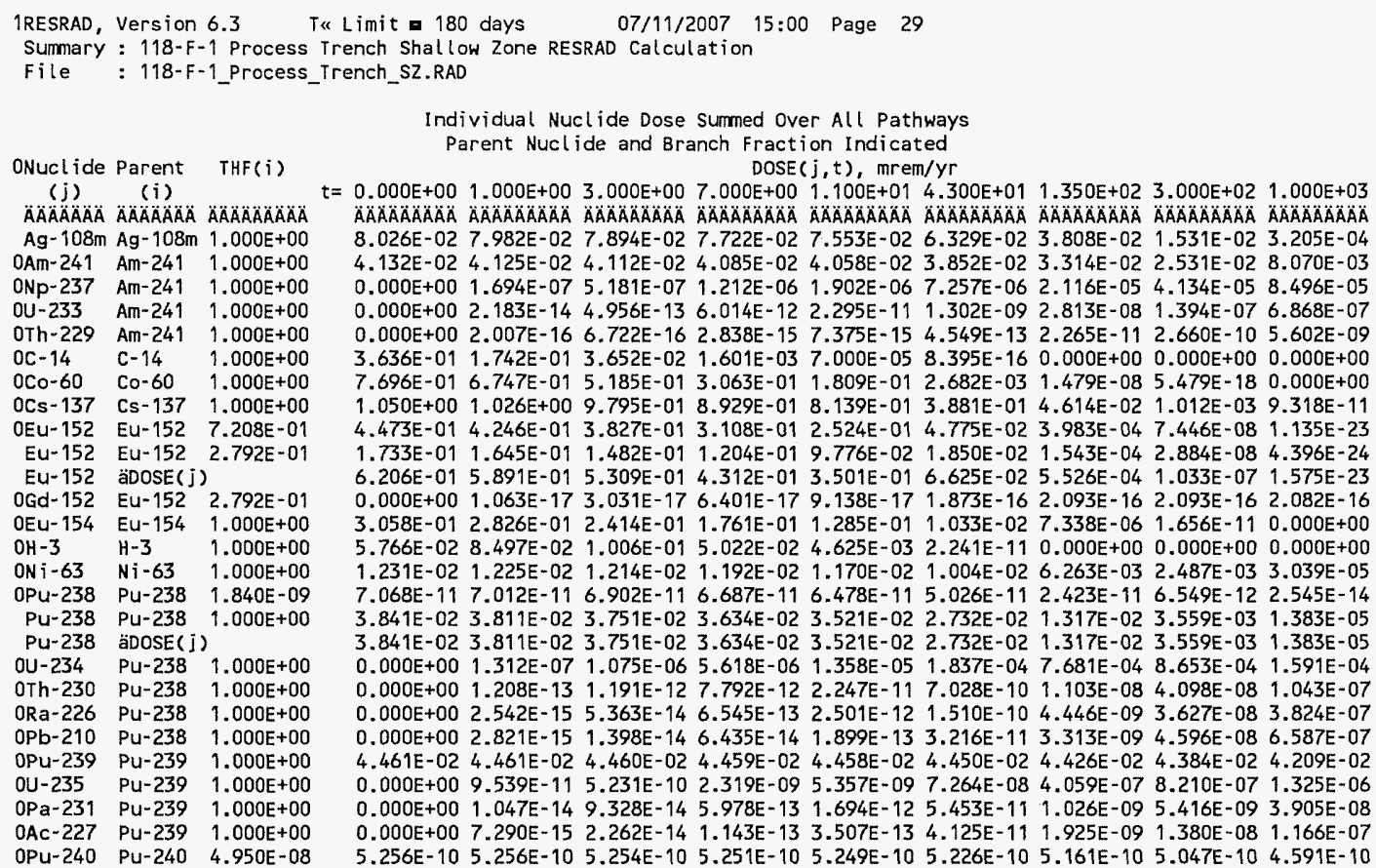

Attachment Sheet No. 29 of $\underline{32}$ Originator: S.W. Clark Date

Chk'd By M.W. Perrot Date

Calc. No. 0100F-CA-V0280 


\section{ATTACHMENT 5}

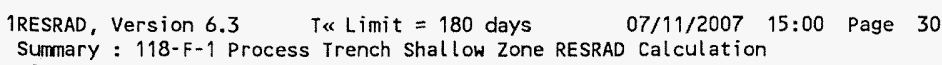

$t=0.000 E+00 \quad 1.000 E+00 \quad 3.000 E+00 \quad 7.000 E+001.100 E+01 \quad 4.300 E+011.350 E+02 \quad 3.000 E+02 \quad 1.000 E+03$

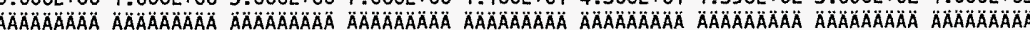

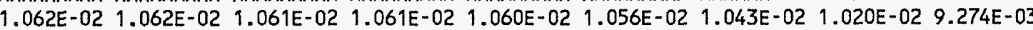

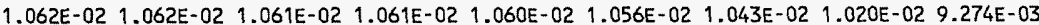
$0.000 E+003.264 E-102.688 E-091.419 E-08 \quad 3.465 E-08$ 5.079E-07 2.870E-06 5 .772E-06 8.953E-06 . $0.000 E+007.204 E-212.700 E-19$ 1.093E-18 2.450E-18 $5.756 E-171.057 E-15$ 5.541E-15 $3.959 E-14$ $0.000 E+00$ 4.889E-21 4.181E-19 2.299E-18 6.732E-18 2.046E-16 3.134E-15 1.591E-14 $1.139 E-13$

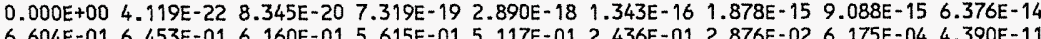

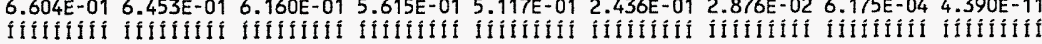
PU-240 PU-240 $1.000 E+00$

PU-240 äDOSE(j)

OU-236 PU-240 $1.000 E+$

OTh-232 PU-240 $1.000 E+00$

ORa-228 PU-240 $1.000 E+00$

OTh-228 PU-240 $1.000 E+00$

$0 S r-90 \quad S r-90 \quad 1.000 E+00$ THF( $i$ ) is the thread fraction of the parent nuclide.

\begin{tabular}{ll} 
Attachment $\frac{5}{S . \text { W. Clark }}$ & Sheet No. 30 of 32 \\
Originator: & Date \\
Chk'd By & Date \\
Calc. No. Perrott & Rev. No. $\quad 0$ \\
\hline O100F-CA-V0280 & Rev. No
\end{tabular}




\section{ATTACHMENT 5}

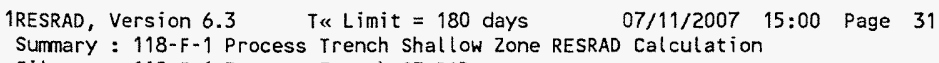

ONuclide Parent THF(i)

(j) (i)

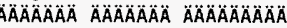

$\mathrm{Ag}-108 \mathrm{~m} \mathrm{Ag}-108 \mathrm{~m} 1.000 \mathrm{E}+00$

OAm-241 Am-241 1.000E+00

ONP-237 Am-241 1.000E+00

OU -233 Am-241 $1.000 E+00$

OTh-229 Am-241 $1.000 E+00$

$\begin{array}{lll}0 \mathrm{C}-14 & \mathrm{C}-14 & 1.000 \mathrm{E}+00\end{array}$

$0 \mathrm{CO}-60$ Co-60 1.000E+00

OCs -137 Cs-137 1.000E+00

OEU-152 Eu-152 7.208E-01

Eu-152 Eu-152 2.792E-01

Eu-152 äs(j):

OGd-152 EU-152 2.792E-01

OEU-154 EU-154 $1.000 E+00$

$\mathrm{OH}-3$ H -3 1.00OE+0O

ONi $-63 \quad \mathrm{Ni}-63 \quad 1.000 \mathrm{E}+00$

PU-238 PU-238 $1.840 E-09$

Pu-238 Pu-238 $1.000 E+00$

Pu-238 äs $(j)$ :

OU-234 Pu-238 1.000E+00

OTh-230 PU-238 $1.000 E+00$

ORa-226 Pu-238 $1.000 E+00$

ORA-226 PU-238 1.00OE+OD

OPb-210 PU-238 $1.000 E+00$

OPu-239 Pu-239 1.000E+00

OU-235 PU-239 $1.000 E+00$

OPa-231 PU-239 $1.000 \mathrm{E}+00$

$0 A C-227 \quad \mathrm{Pu}-239 \quad 1.000 \mathrm{E}+00$

$\mathrm{OPu}-240 \quad \mathrm{Pu}-240,4.950 \mathrm{E}-08$

\section{Parent Nuclide and Branch Fraction Indicated
$\mathrm{S}(\mathrm{j}, \mathrm{t}), \mathrm{pCi} / \mathrm{g}$}

$t=0.000 E+00 \quad 1.000 E+00 \quad 3.000 E+00 \quad 7.000 E+00 \quad 1.100 E+01 \quad 4.300 E+01 \quad 1.350 E+02 \quad 3.000 E+02 \quad 1.000 E+03$

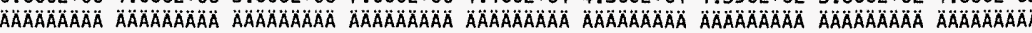
1.300E-02 1.293E-02 1.279E-02 1.251E-02 1.223E-02 $1.025 E-02 \quad 6.168 E-03 \quad 2.479 E-03 \quad 5.192 E-05$ 8.900E-02 8.885E-02 8.857E-02 8.799E-02 8.742E-02 8.296E-02 7.139E-02 5.453E-02 $1.738 E-02$ .

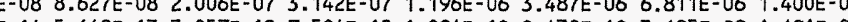
$0.000 E+000.294 \mathrm{E}-145.64$ 0.000E 00 1. $.982 E-18$ 5.339E-17 $6.752 E-16$ 2.608E-15 1.503E-13 4.196E-12 3.85 EE-11 7. $785 E-10$

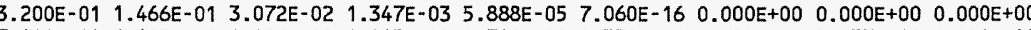
7.400E-02 6.487E-02 4.986E-02 2.945E-02 $1.740 \mathrm{E}-02 \quad 2.578 \mathrm{E}-04 \quad 1.420 \mathrm{E}-09 \quad 5.257 \mathrm{E}-19$ 0.000E+00 4.500E-01 4.397E-01 4.197E-01 3.825E-01 3.486E-01 1.658E-01 1.958E-02 4.243E-04 3.698E-11 1.009E-01 9.580E-02 8.633E-02 7.011E-02 5.694E-02 $1.077 E-02 \quad 8.985 E-05 \quad 1.680 E-082.560 E-24$ 3.909E-02 3.711E-02 3.344E-02 2.716E-02 2.205E-02 4.173E-03 3.480E-05 6.507E-09 9.917E-25 $1.400 \mathrm{E}-01 \quad 1.329 \mathrm{E}-01 \quad 1.198 \mathrm{E}-01 \quad 9.727 \mathrm{E}-02 \quad 7.899 \mathrm{E}-02 \quad 1.495 \mathrm{E}-02 \quad 1.247 \mathrm{E}-04 \quad 2.330 \mathrm{E}-08 \quad 3.552 \mathrm{E}-24$ 1600 . (1) . .

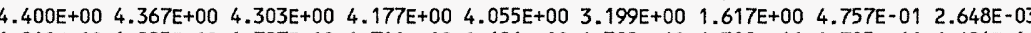

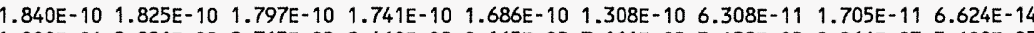
1.000E-01 9.921E-02 9.765E-02 9.460E-02 9.165E-02 $7.111 \mathrm{E}-02 \quad 3.428 \mathrm{E}-02 \quad 9.266 \mathrm{E}-03 \quad 3.600 \mathrm{E}-05$ 1.000E-01 9.921E-02 9.765E-02 9.460E-02 9.165E-02 7.111E-02 3.428E-02 9.266E-03 3.600E-05

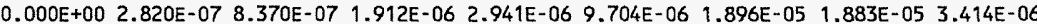
$0.000 \mathrm{E}+00 \quad 1.271 \mathrm{E}-12 \quad 1.136 \mathrm{E}-11 \quad 6.098 \mathrm{E}-11 \quad 1.485 \mathrm{E}-10 \quad 2.028 \mathrm{E}-09 \quad 1.469 \mathrm{E}-08 \quad 4.395 \mathrm{E}-08 \quad 1.025 \mathrm{E}-07$

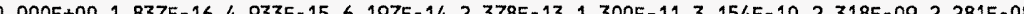
. $0.00 E+001.420 E-1811.131 E-163.242 E-15$ 1.912E-14 3.467E-12 $1.796 E-10$ 1.BTIE-09 2. $172 E-08$

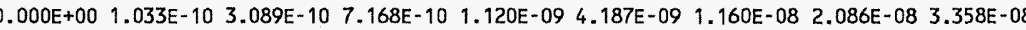
$0.000 E+00 \quad 1.093 E-15 \quad 9.817 E-15 \quad 5.324 E-14 \quad 1.309 E-13 \quad 1.939 E-12 \quad 1.751 E-11 \quad 7.445 E-11 \quad 4.837 E-10$ $0.000 \mathrm{E}+00 \quad 1.151 \mathrm{E}-17 \quad 3.054 \mathrm{E}-16 \quad 3.748 \mathrm{E}-15 \quad 1.406 \mathrm{E}-14 \quad 6.531 \mathrm{E}-13 \quad 1.137 \mathrm{E}-11 \quad 6.140 \mathrm{E}-11 \quad 4.595 \mathrm{E}-10$ 1.237E-09 1.237E-09 1.237E-09 1.236E-09 1.236E-09 1.230E-09 $1.215 E-09$ 1.188E-09 $1.081 E-09$
Attachment Originator:

Chk'd By Calc. No.

$$
\text { r: } \mathrm{S} \text {. }
$$
0100F-CA-V0280
Sheet No. 31 of 32 Date

Date

Rev. No. 0 


\section{ATTACHMENT 5}

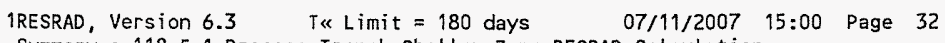

\section{(i)}

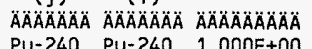
PU-240 äS(j):

OU $-236 \quad$ PU $-240 \quad 1.000 E+00$

OTh-235 Pu-240 1.00

OTh-232 PU 240 1.000E+00

ORa-228 Pu-240 1.000E+00

OTh-228 Pu-240 $1.000 \mathrm{E}+00$

$\begin{array}{lll}0 \mathrm{Sr}-90 & \mathrm{Sr}-90 & 1.000 \mathrm{E}+00\end{array}$

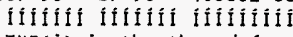

THF(i) is the thread fraction THF(i) is the thread fraction of the parent nuclide
ORESCALC.EXE execution time $=7.61$ seconds

$t=0.000 E+00 \quad 1.000 E+00 \quad 3.000 E+00 \quad 7.000 E+001.100 E+01 \quad 4.300 E+01 \quad 1.350 E+02 \quad 3.000 E+02 \quad 1.000 E+03$

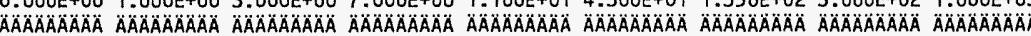

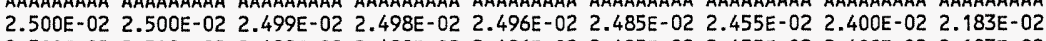

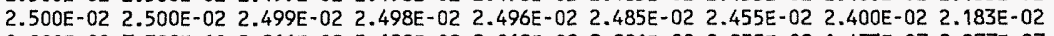

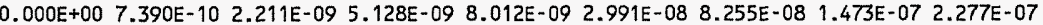

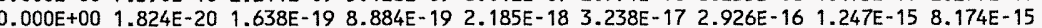

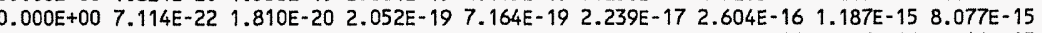
$0.000 \mathrm{E}+00 \quad 6.039 \mathrm{E}-23 \quad 4.078 \mathrm{E}-21 \quad 8.686 \mathrm{E}-20 \quad 3.951 \mathrm{E}-19 \quad 1.932 \mathrm{E}-17 \quad 2.500 \mathrm{E}-16 \quad 1.167 \mathrm{E}-15 \quad 8.046 \mathrm{E}-15$

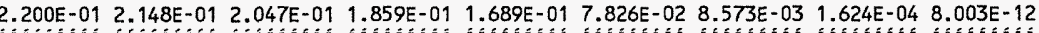

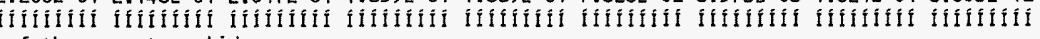

\begin{tabular}{|c|c|}
\hline Attachment $\quad 5$ & Sheet No. 32 of 32 \\
\hline Originator: S.W. Clark & Date \\
\hline Chk'd By M.W. Perrott & Date \\
\hline $0100 \mathrm{~F}-\mathrm{CA}-\mathrm{V} 0280$ & Rev. No. \\
\hline
\end{tabular}




\section{ATTACHMENT 6}

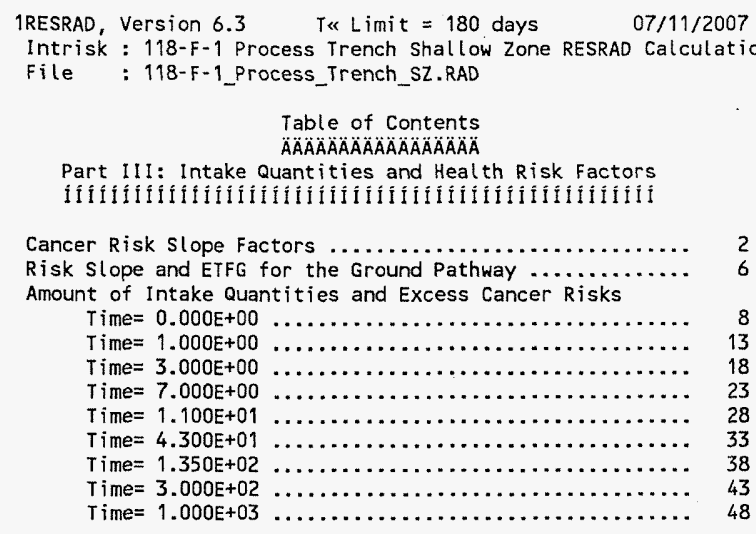

Attachment 6 Sheet No. 1 of 52 Originator: S.W. Clark Sune Date $2 / 11 \% 6$ Chk'd By M.W. Perrott Mulf Date $7 / 12 / 07$ Calc. No. 0100F-CA-V0280 Rev. No. 0 


\section{ATTACHMENT 6}

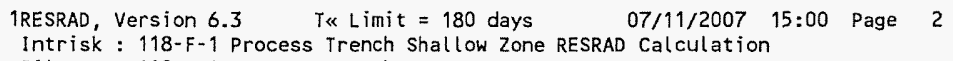




\section{ATTACHMENT 6}

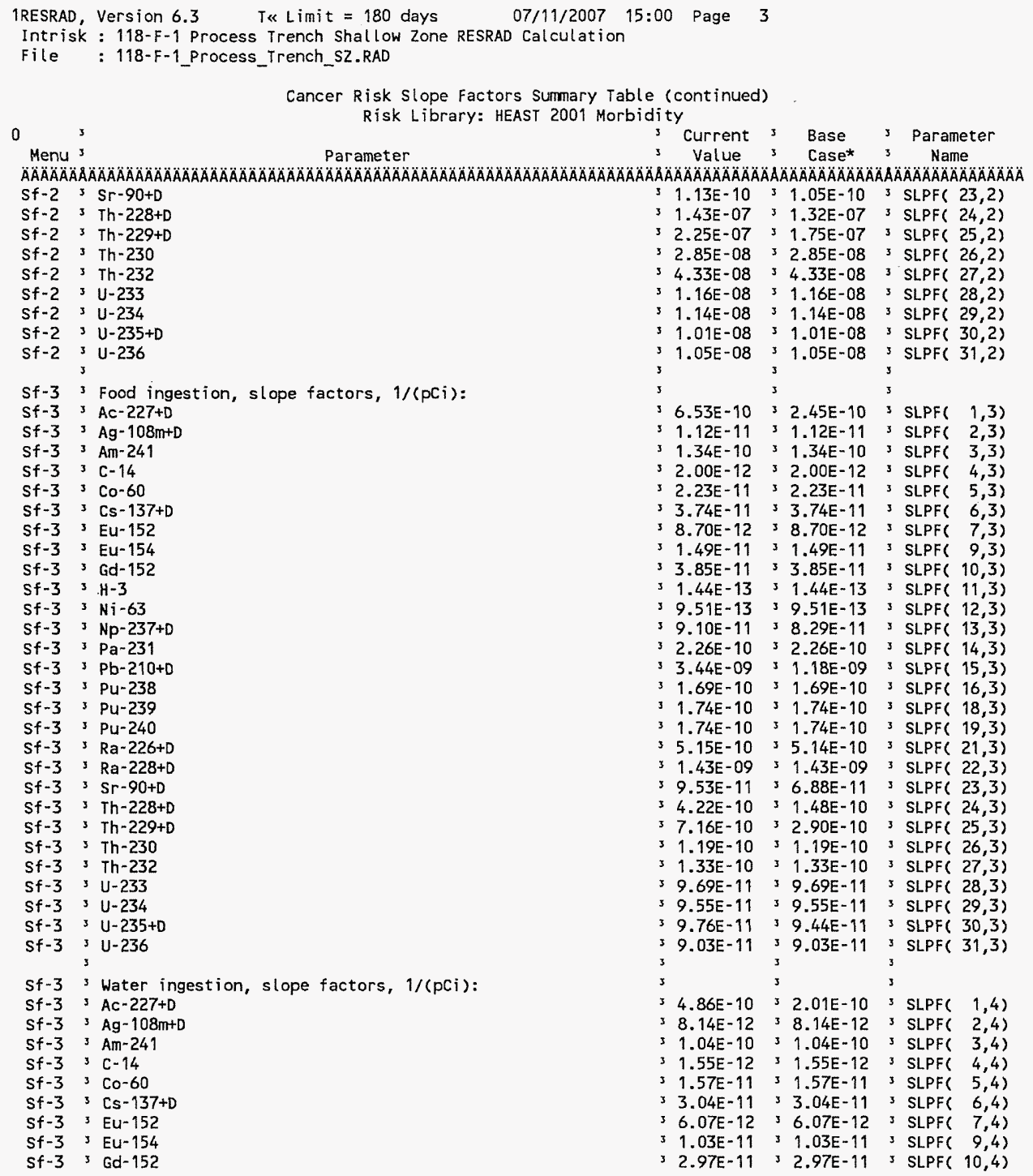

$\begin{array}{ll}\text { Attachment } \frac{6}{6} & \text { Sheet No. } \underline{3} \text { of } \underline{52} \\ \text { Originator: } \frac{\text { S.W. Clark }}{\text { M.W. Perrott }} & \text { Date } \\ \text { Chk'd By } & \text { Date } \\ \text { Calc. No. } \quad \text { O100F-CA-V0280 } & \text { Rev. No. } 0\end{array}$




\section{ATTACHMENT 6}

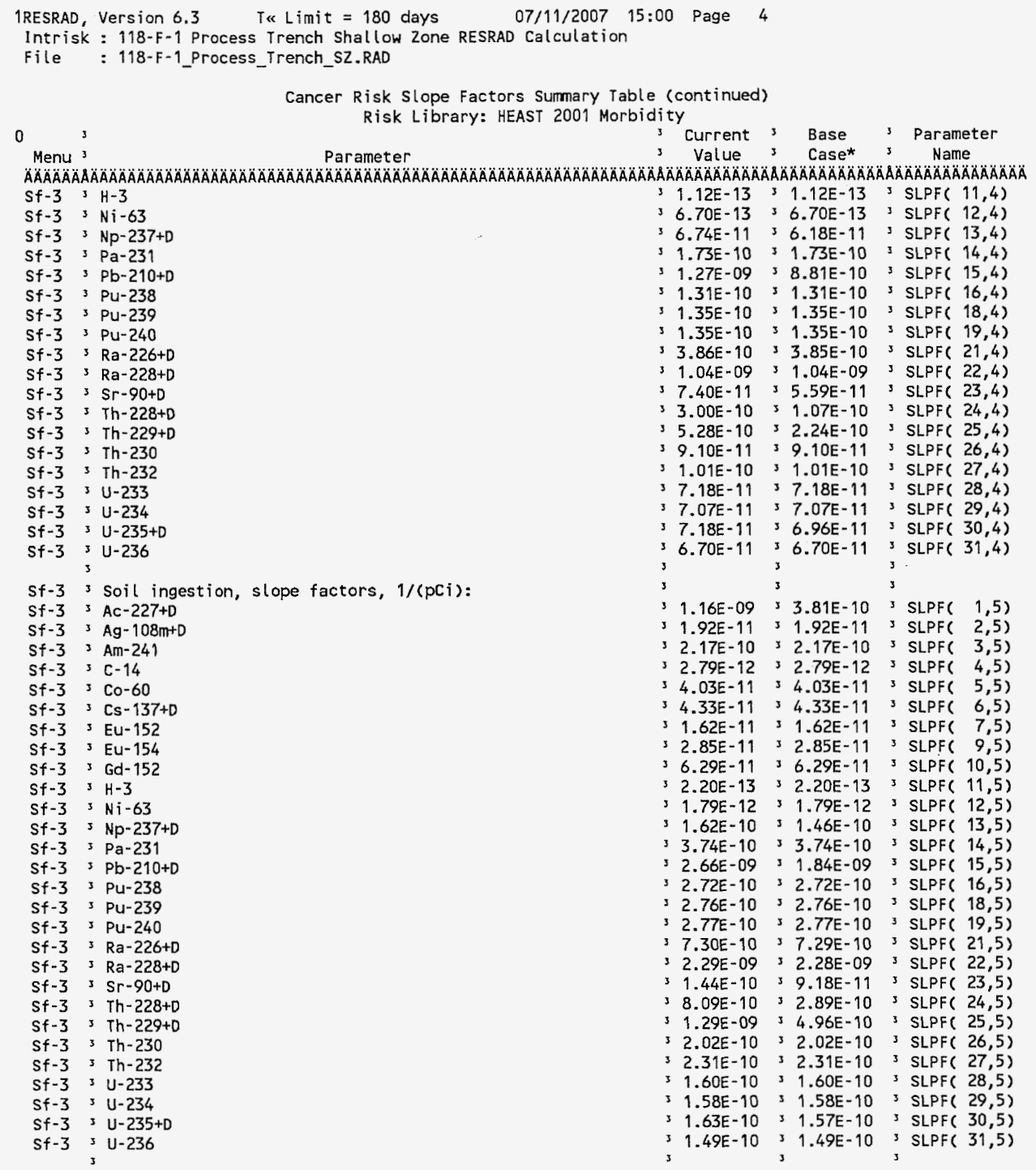

\begin{tabular}{|c|c|}
\hline Attachment & Sheet No. 4 of $\underline{52}$ \\
\hline Originator: $\mathrm{S} . \mathrm{W}$. Clark & Date _ _ \\
\hline Chk'd By M.W. Perrott & Date \\
\hline $0100 \mathrm{~F}-\mathrm{CA}-\mathrm{V} 0280$ & Rev. No. $\quad 0$ \\
\hline
\end{tabular}


ATTACHMENT 6

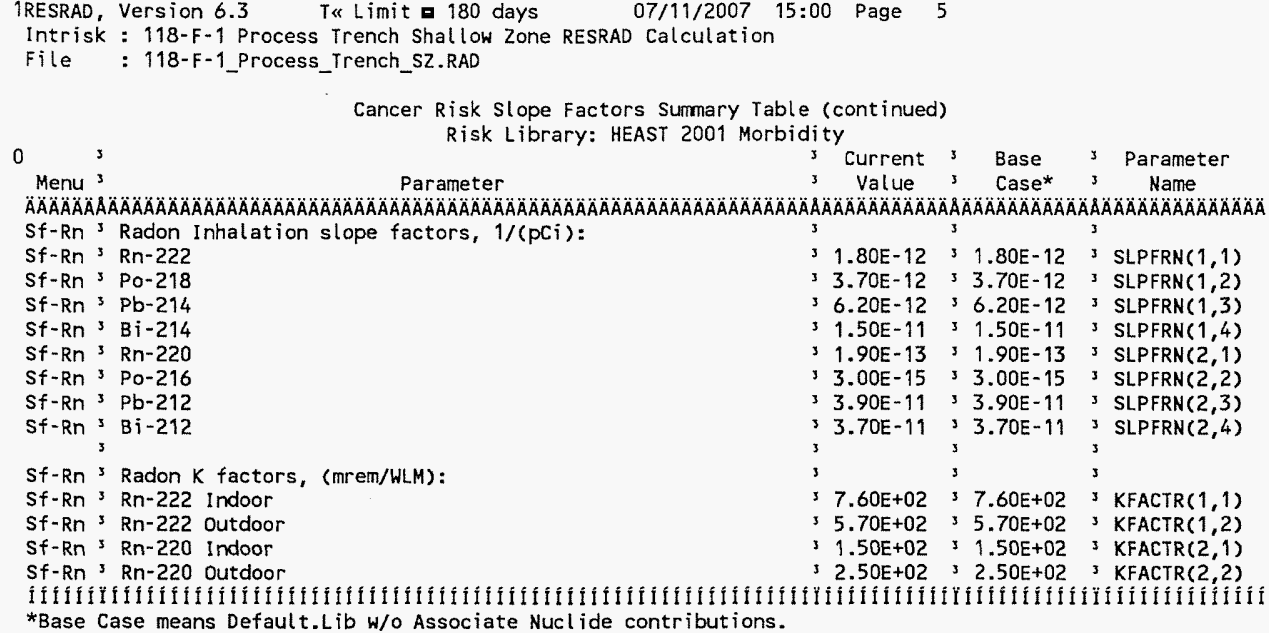

$\begin{array}{ll}\text { Attachment } \frac{6}{\text { S.W. Clark }} & \text { Sheet No. } \underline{5} \text { of } \underline{52} \\ \text { Originator: } & \text { Date } \\ \text { Chk'd By } & \text { Date } \\ \text { Calc. No. Nerrott } & \text { Rev. No. N } \quad 0\end{array}$




\section{ATTACHMENT 6}

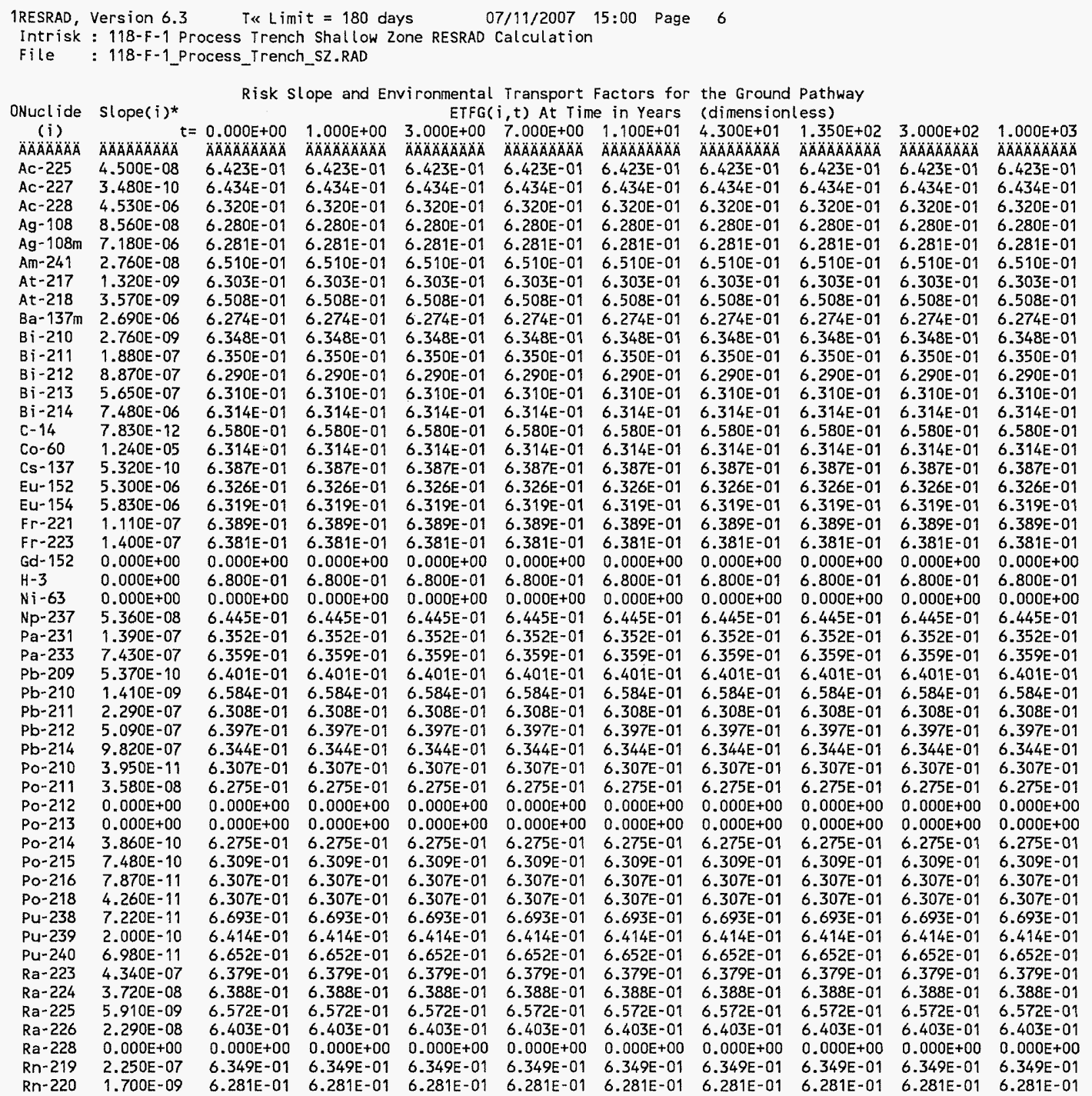

$\begin{array}{ll}\text { Attachment } \frac{6}{2} & \text { Sheet No. } \underline{6} \text { of } \underline{52} \\ \text { Originator: S.W. Clark } & \text { Date } \\ \text { Chk'd By } & \text { Date } \\ \text { Calc. No. N. Perrott } & \text { Rev. No. } \quad \text { O100F-CA-V0280 }\end{array}$




\section{ATTACHMENT 6}

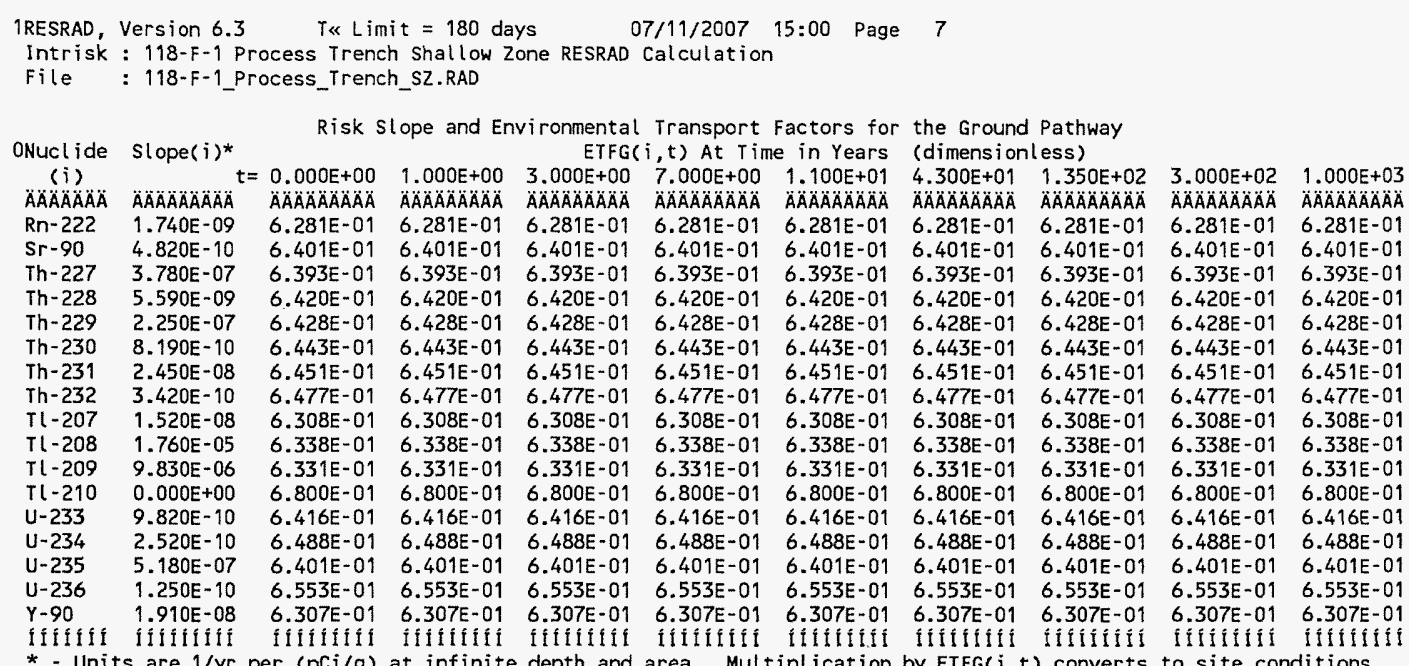

* - Units are $1 / \mathrm{yr}$ per $(\mathrm{pC} / \mathrm{g})$ at infinite depth and area. Mutiplication by eTfG(i,t) converts to site conditions.

Attachment 


\section{ATTACHMENT 6}

IRESRAD, Version $6.3 \quad$ T\& Limit $=180$ days $\quad 07 / 11 / 2007 \quad 15: 00$ Page 8

Intrisk : $118-F-1$ Process Trench Shallow Zone RESRAD Calculation

file : 118-F-1_Process_Trench_SZ.RAD

Amount of Intake Quantities QINT(i,p,t) for Individual Radionuclides (i) and Pathways ( $p$ )

As $\mathrm{pCi} / \mathrm{yr}$ at $\mathrm{t}=0.000 \mathrm{E}+00$ years

\begin{tabular}{|c|c|c|c|c|c|c|c|c|c|c|c|}
\hline \multirow{4}{*}{$\begin{array}{l}\text { Radio- } \\
\text { Nucl ide } \\
\text { AAAAAAAA }\end{array}$} & \multicolumn{5}{|c|}{ Water Independent Pathways (Inhalation w/o radon) } & \multicolumn{6}{|c|}{ Water Dependent Pathways } \\
\hline & & & & & $\triangle A \cap A O A A O A O A ̈$ & & & & & & Total \\
\hline & & & Meat & Milk & Soil & Water & Fish & Plant & Meat & & ingestion* \\
\hline & & A ÄÄAÄÄÄÄÄ & ÄÄÄÄÄÄÄÄÄA & ÄÄÄÄÄÄÄÄÄ & ÄÄÄÄÄÄÄÄÄÄ & ÄÄÄÄÄÄÄÄÄ & ÄÄÄÄÄÄÄÄ & ÄÄÄÄÄÄÄ & ÄÄÄÄÄÄÄA & A ÄÄÄÄÄÄÄA & \\
\hline & & & & & $O O E+00$ & & & & $000 E+00$ & $0.000 E+00$ & $0.000 E+00$ \\
\hline & & & & & $2 E-01$ & & $000 E+00$ & $00 E+00$ & $0.000 \mathrm{E}+00$ & $0.000 E+00$ & \\
\hline & & $E+00$ & $E-02$ & $7 E-03$ & $E+\infty$ & & & & $00 E+00$ & & \\
\hline & & & & & & & & & $O E+00$ & $00 \mathrm{E}+00$ & $E+05$ \\
\hline & & & & & $E+00$ & & & $=00$ & $O E+00$ & & \\
\hline & & & +02 & & $\mathrm{EE}+01$ & & & & $E+\infty 0$ & & \\
\hline & & & & & & & & & & & \\
\hline & & & & & $E+00$ & & $\mathrm{E}+00$ & & $E+\infty$ & & \\
\hline & & & $\$+00$ & & $E+\infty 0$ & & & & & & \\
\hline & & & & & & & & & $E+\infty$ & & \\
\hline & & & & & $E+02$ & & & & $=+00$ & & \\
\hline & & & +00 & & $E+00$ & & & & & & \\
\hline & & & & & & & & & & & \\
\hline & & & & & & & & & $=+\infty$ & +00 & \\
\hline & & & & & & & & & +00 & & \\
\hline & & & & & & & & & & & \\
\hline & & & & & & & & & $E+00$ & & \\
\hline & & & +00 & & & & & & & & +00 \\
\hline & & & $=00$ & & & & & & & & \\
\hline & & & $=2$ & & & & & & $=+\infty$ & & \\
\hline & & & $=00$ & & & & 0.0 & & & & $+\infty$ \\
\hline & & & $E+\infty$ & $E+00$ & $O E E+O D$ & & $0.000 E+00$ & & $E+00$ & & \\
\hline & & & $E+00$ & & & & & & $E+00$ & & \\
\hline & & & & & $E+\infty$ & & 0.000 & & $E+00$ & $E+00$ & $E+00$ \\
\hline & & & $0.000 E+00$ & $E+\infty$ & $0.000 \mathrm{E}+00$ & $0.000 E+00$ & $0.000 E+00$ & $E+C O$ & $E+00$ & & \\
\hline-2004 & $O E+00$ & $0.000 E+00$ & $0.000 \mathrm{E}+00$ & & & & & & $E+00$ & & \\
\hline & & & & & & & & & $E+00$ & & $0 E+00$ \\
\hline & & & & & & & & & & & \\
\hline & & & & & & & & & & & \\
\hline
\end{tabular}

and water-dependent water, fish, plant, meat, milk pathways

Amount of Intake Quantities QINTS(irn, $i, t)$ and QINTQW(irn, $i, t)$ for Inhalation of

Radon and its Decay Products as $p C i / y r$ at $t=0.000 E+00$ years

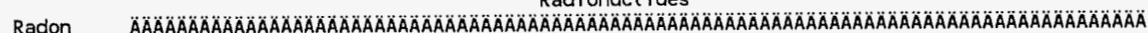

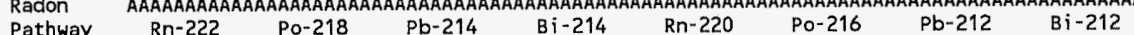

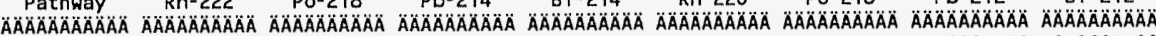

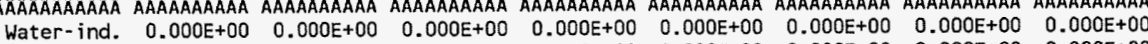
Water-dep. $\quad \begin{array}{llllllll}0.000 E+00 & 0.000 E+00 & 0.000 E+00 & 0.000 E+00 & 0.000 E+00 & 0.000 E+00 & 0.000 E+00 & 0.000 E+00\end{array}$

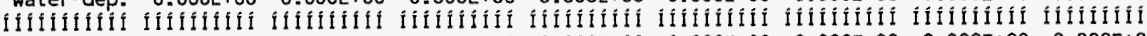

$\begin{array}{lllllllll}\text { Total } & 0.000 E+00 & 0.000 E+00 & 0.000 E+00 & 0.000 E+00 & 0.000 E+00 & 0.000 E+00 & 0.000 E+00 & 0.000 E+00\end{array}$

Water-ind. $==$ Water-independent Water-dep. $==$ Water-dependent

\begin{tabular}{|c|c|}
\hline Attachment & Sheet No. 8 of 52 \\
\hline Originator: S.W. Clark & Date \\
\hline Chk'd By M. W. Perrott & Date \\
\hline $0100 \mathrm{~F}-\mathrm{CA}-\mathrm{V} 0280$ & Rev. No. \\
\hline
\end{tabular}




\section{ATTACHMENT 6}

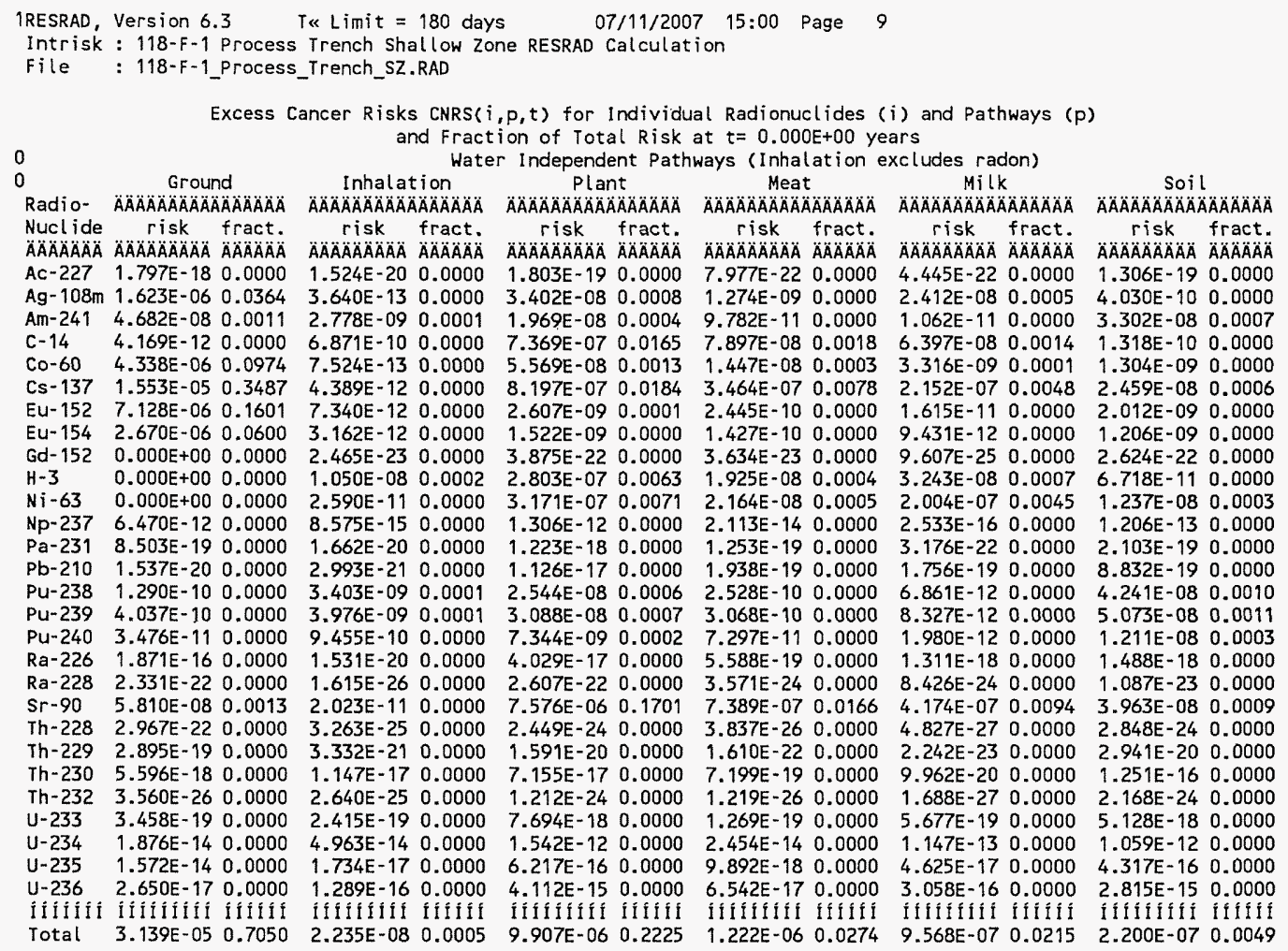

$\begin{array}{ll}\text { Attachment } \frac{6}{6} & \text { Sheet No. } \underline{9} \text { of } \underline{52} \\ \text { Originator: } \frac{\text { S.W.Clark }}{M . W . P e r r o t t} & \text { Date } \\ \text { Chk'd By } & \text { Date } \\ \text { Calc. No. } & \text { Rev. No. } 0100 \text { F-CA-V0280 }\end{array}$




\section{ATTACHMENT 6}

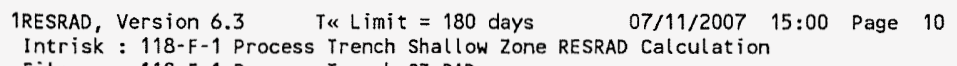

Excess Cancer Risks CNRS $(i, p, t)$ for Individual Radionuclides (i) and Pathways $(p)$ and Fraction of Total Risk at $t=0.000 E+00$ years

Water Dependent Pathways

\begin{tabular}{|c|c|c|c|c|c|c|c|c|c|c|c|c|}
\hline & $\begin{array}{r}\text { Water } \\
\text { ÄÄÄÄÄÄÄ }\end{array}$ & A & 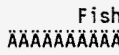 & AĀÄÄÄA & $\begin{array}{r}\text { Plar } \\
\triangle A A A A A A B A B A\end{array}$ & it & $\begin{array}{r}\text { Meat } \\
\text { AAAAAOAOABAOA }\end{array}$ & Ä̈ÄÄÄÄÄ & 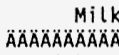 & ÄÄÄÄÄÄ & $\begin{array}{l}\text { All Path } \\
A A A A A A A B A\end{array}$ & $\begin{array}{l}\text { TWays* } \\
\text { ẄÄÄÄÄ }\end{array}$ \\
\hline $\begin{array}{l}\text { clide } \\
A B A B A B A\end{array}$ & $\begin{array}{c}\text { risk } \\
A A B A A B A O A B\end{array}$ & $\begin{array}{l}\text { fract. } \\
\ddot{A} \ddot{A} \ddot{A} \ddot{A} \ddot{A}\end{array}$ & $\begin{array}{c}\text { risk } \\
A \triangle A B A B A B A\end{array}$ & $\begin{array}{l}\text { fract. } \\
\qquad \ddot{A} A \ddot{A} \ddot{A} \ddot{A}\end{array}$ & $\begin{array}{c}\text { risk } \\
\triangle A B A O A B A B A B\end{array}$ & $\begin{array}{l}\text { fract. } \\
\triangle A B A O A B A\end{array}$ & 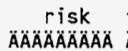 & $\begin{array}{l}\text { fract. } \\
\triangle A A A B A A B A\end{array}$ & $\begin{array}{c}\text { risk } \\
\triangle A B A O A B A B A B A\end{array}$ & $\begin{array}{l}\text { fract. } \\
\text { ÄÄÄÄÄ }\end{array}$ & $\begin{array}{c}\text { risk } \\
\triangle A ̈ A O A O A ̈ A ̈ A ̈ A\end{array}$ & \\
\hline & & & & & & & & & & & & \\
\hline & & & & & & & & & & & & \\
\hline & $0.000 E+00$ & & $0.000 E+00$ & & $.000 E+00$ & & $.000 E+00$ & & $00 \mathrm{E}+00$ & & & \\
\hline & & & & & & & & & & & & \\
\hline & & & & & & & & & & & & \\
\hline & & & & & & & & & & & & \\
\hline & & & +00 & & & & & & & & & \\
\hline & & & & & & & & & & & & \\
\hline & & & & & & & & & & & & \\
\hline & & & & & & & & & & & & \\
\hline & & & & & & & & & & & & \\
\hline & & & & & & & & & & & & \\
\hline & & & & & & & & & & & & \\
\hline & & & & & & & & & & & & \\
\hline & & & & & & & & & & & & \\
\hline & & & & & & & & & & & & \\
\hline & & & +00 & & & & & & +00 & & & \\
\hline & & & & & & & & & & & & \\
\hline & & & & & & & & & & & & \\
\hline & & & & & & & & & -09 & & & \\
\hline & & & & & & & & & & & & \\
\hline & & & & & & & & & -23 & & & \\
\hline & & & & & & & & & -19 & & & \\
\hline & & & & & & & & & & & & \\
\hline & & & & & & & & & $32 E-17$ & & & \\
\hline & & & & & & & & & & & & \\
\hline & & & & & & & & & & & & \\
\hline & & & & & & & & & & & & \\
\hline & & & & & & & & & & & & \\
\hline & & & & & & & & & & & & \\
\hline
\end{tabular}

** Sum of water independent ground, inhalation, plant, meat, milk, soil

and water dependent water, fish, plant, meat, milk pathways

\begin{tabular}{|c|c|}
\hline Attachment & Sheet No. 10 of 52 \\
\hline Originator: S.W. Clark & Date \\
\hline By M.W. Perrott & Date \\
\hline $0100 F-C A-V 0280$ & Rev. No. \\
\hline
\end{tabular}




\section{ATTACHMENT 6}

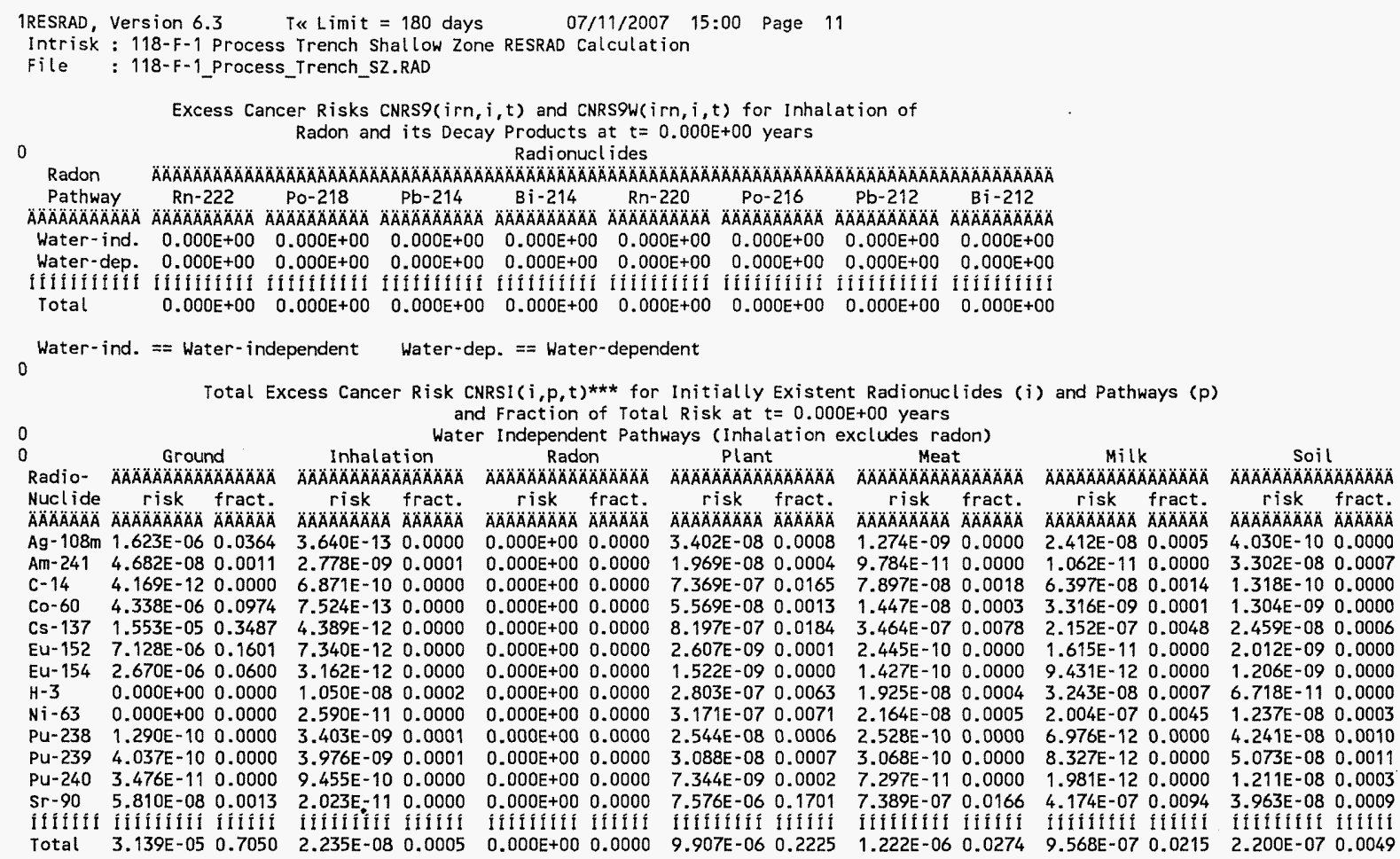

\begin{tabular}{|c|c|}
\hline Attachment $\quad 6$ & Sheet No. 11 of 52 \\
\hline Originator: S.W. Clark & Date \\
\hline Shk'd By M.W.Perrott & Date \\
\hline $0100 F-C A-V 0280$ & Rev. No. 0 \\
\hline
\end{tabular}




\section{ATTACHMENT 6}

IRESRAD, Version 6.3 T\& Limit $=180$ days $07 / 11 / 2007 \quad 15: 00$ Page 12

Intrisk : 118-F-1 Process Trench Shallow Zone RESRAD Calculation

File : 118-F-1_Process_Trench_SZ.RAD

Total Excess Cancer Risk CNRSI $(i, p, t) * \star *$ for Initially Existent Radionuclides $(i)$ and Pathways $(p)$ and Fraction of Total Risk at $t=0.000 E+00$ years

Water Dependent Pathways

\begin{tabular}{|c|c|c|c|c|c|c|c|c|c|c|c|c|c|c|}
\hline \multirow{2}{*}{ 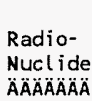 } & \multicolumn{2}{|c|}{ Water } & \multicolumn{2}{|c|}{ Fish } & \multicolumn{2}{|c|}{ Radon } & \multicolumn{2}{|c|}{$P$ lant } & \multicolumn{2}{|c|}{ Meat } & \multicolumn{2}{|c|}{ Milk } & \multicolumn{2}{|c|}{$\begin{array}{c}\text { All pathways } \\
A A A A B A A B A A A A A A A\end{array}$} \\
\hline & risk & 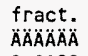 & $\begin{array}{c}\text { risk } \\
\triangle A ̈ A ̈ A O A ̈ A ̈ A O A\end{array}$ & $\begin{array}{l}\text { fract. } \\
\triangle A \cap A ̈ A ̈ A ̈ A\end{array}$ & $\begin{array}{c}\text { risk } \\
A \cap A \cap A ̈ A ̈ A B A\end{array}$ & $\begin{array}{l}\text { fract. } \\
\text { ÄÄÄÄÄÄ }\end{array}$ & 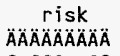 & 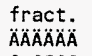 & $\begin{array}{c}\text { risk } \\
\text { ÄÄÄÄÄÄA }\end{array}$ & & $\begin{array}{c}\text { risk } \\
\triangle A \cap A O A B A A B A\end{array}$ & & $\begin{array}{c}r i s k \\
\triangle A ̈ A ̈ A ̈ A ̈ A ̈ A ̈ A\end{array}$ & \\
\hline & & & & & & & & & & & & & & \\
\hline & & & & & & & & & & & & & & \\
\hline & & & & & & & & & & & & & & \\
\hline & & & & & & & & & & & & & & \\
\hline & & & & & & & & & & & & & & \\
\hline & & & & & & & & & & & & & & \\
\hline & & & & & & & & & & & & & & \\
\hline & & & & & & & & & & & & & & \\
\hline & & & & & & & & & & & & & & \\
\hline & & & & & & & & & & & & & & \\
\hline & & & & & & & & & & & & & & \\
\hline & & & & & & & & & & & & & & \\
\hline & & & & & & & & & & & & & & \\
\hline & & & & & & & & & & & & & 111111 & \\
\hline & $5.552 E-07$ & 0.0125 & $4.2045-U Y$ & 0.0001 & $0.000 \mathrm{E}+00$ & 0.0000 & $1.958 E-07$ & 0.0044 & 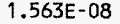 & 0.0004 & $3.657 E-08$ & 0.0008 & $4.453 E-05$ & 1.000 \\
\hline
\end{tabular}

***CNRSI $(i, p, t)$ includes contribution from decay daughter radionuclides

\begin{tabular}{|c|c|c|}
\hline \multirow{2}{*}{\multicolumn{3}{|c|}{ 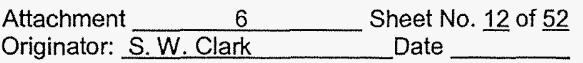 }} \\
\hline & & \\
\hline & M.W. Perrott & Date \\
\hline & $0100 F-C A-V 0280$ & Rev. No. \\
\hline
\end{tabular}




\section{ATTACHMENT 6}

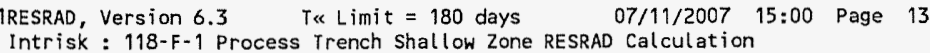

Water-ind. $==$ Water-independent $\quad$ Water-dep. $==$ Water-dependent 


\section{ATTACHMENT 6}

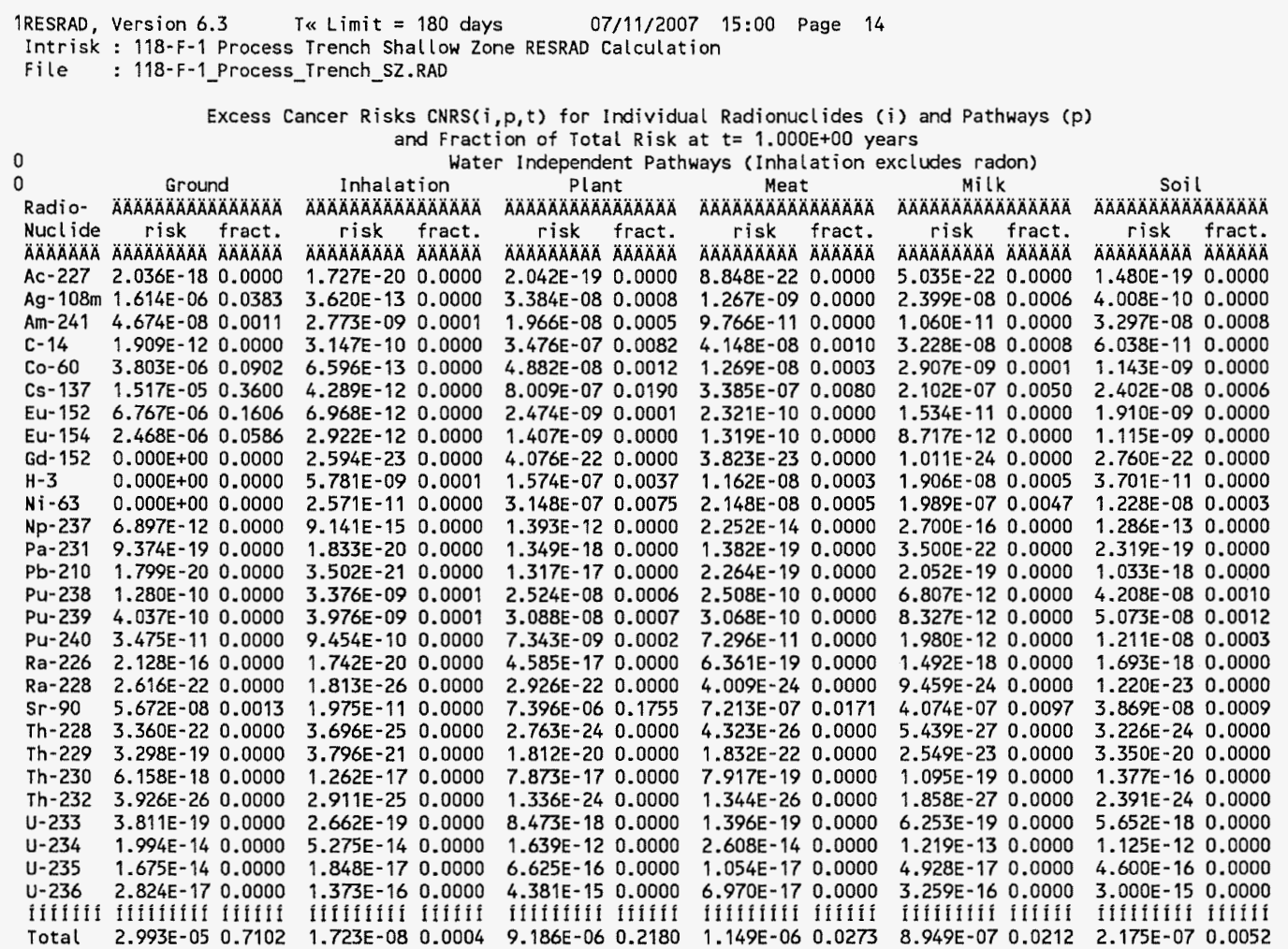

\begin{tabular}{|c|c|}
\hline Attachment & Sheet No. 14 of 52 \\
\hline Originator: S.W. Clark & Date \\
\hline Chk'd By M.W.Perrott & Date \\
\hline $0100 F-C A-V 0280$ & Rev. No. \\
\hline
\end{tabular}




\section{ATTACHMENT 6}

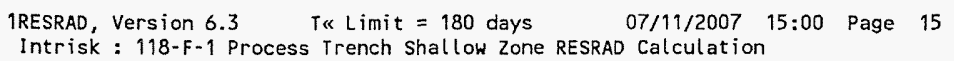

Water Dependent Pathways

\begin{tabular}{|c|c|c|c|c|c|c|c|c|c|c|c|c|}
\hline & 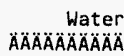 & AÄÄÄÄA & $\begin{array}{r}\text { Fish } \\
\text { AÄÄÄÄAAAAA }\end{array}$ & AAAAAAÄÄ & $\begin{array}{r}\text { Plan } \\
\text { ÄÄAिÄÄÄÄÄA }\end{array}$ & AT & 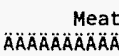 & ÄÄÄÄÁA & $\begin{array}{r}M i l K \\
\text { ÄÄÄAAÄÄÄA }\end{array}$ & ÄÄÄÄÄÄ & $\begin{array}{r}\text { All Path } \\
A A O A B A A B A B A\end{array}$ & 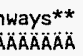 \\
\hline $\begin{array}{l}\text { Nucl ide } \\
\text { ÄABAOA }\end{array}$ & $\begin{array}{c}\text { risk } \\
\text { AABAAB̈AO }\end{array}$ & fract. & $\begin{array}{c}\text { risk } \\
\text { A }\end{array}$ & fract. & $\begin{array}{c}\text { risk } \\
\text { AAAAABAAA }\end{array}$ & fract. & $\begin{array}{c}\text { risk } \\
\text { ABAABAAOA }\end{array}$ & fract. & $\begin{array}{c}\text { risk } \\
\text { AAABABABA }\end{array}$ & fract. & $\begin{array}{c}\text { risk } \\
\text { ABÄABAOA }\end{array}$ & $\begin{array}{l}\text { fract. } \\
A B A B A B\end{array}$ \\
\hline$A C-227$ & $2.196 \mathrm{E}-18$ & 0.0000 & $3.199 \mathrm{E}-20$ & 0.0000 & $3.248 E-19$ & 0.0000 & $8.992 \mathrm{E}-22$ & 0.0000 & $1.185 \mathrm{E}-21$ & 0.0000 & $4.962 E-18$ & \\
\hline & $0 O E+00$ & 0.0000 & $000 E+00$ & 0.0000 & $0.000 E+00$ & 0.0000 & $000 E+00$ & 0000 & $0.000 \mathrm{E}+00$ & 0.0000 & $1.673 \mathrm{E}-06$ & 0.0397 \\
\hline $\mathrm{m}-241$ & $0.000 E+00$ & 0.0000 & $0.000 \mathrm{E}+00$ & 0.0000 & $0.000 E+00$ & 0.0000 & $0.000 E+00$ & .0000 & $0.000 \mathrm{E}+00$ & 0.0000 & $1.022 \mathrm{E}-07$ & 0.0024 \\
\hline & & & $.000 E+00$ & & $.000 E+00$ & & $.000 E+00$ & & & & & \\
\hline $\mathrm{Co}-6$ & $1.128 E-10$ & 0.0000 & $.833 E-12$ & 0.0000 & $1.792 E-11$ & 0.0000 & $.123 \mathrm{E}-11$ & 0.0000 & $6.296 \mathrm{E}-12$ & 0.0000 & $3.868 \mathrm{E}$ & 918 \\
\hline & $E-09$ & 0.0002 & $.418 \mathrm{E}-09$ & 0001 & $1.060 \mathrm{E}-09$ & 0000 & $.944 E-09$ & .0000 & $1.519 \mathrm{E}-09$ & 1000 & $1.656 E-05$ & 0.3930 \\
\hline & $0.000 \mathrm{E}+00$ & 0.0000 & $.000 E+00$ & 0.0000 & $.000 E+00$ & 0.0000 & $.000 E+00$ & 100 & $0.000 E+00$ & 00 & 6.77 & \\
\hline & & & $.000 E+00$ & 0.0000 & $.000 E+00$ & 0.0000 & $.000 \mathrm{E}+00$ & & $0.000 \mathrm{E}+00$ & & & \\
\hline Gd-152 & $0.000 E+00$ & 0.0000 & $0.000 E+00$ & 0000 & $0.000 E+00$ & 0.0000 & $0.000 E+00$ & 0.0000 & $0.000 \mathrm{E}+00$ & .0000 & $E-22$ & 000 \\
\hline$H-$ & 4.3 & & -10 & 0.0 & $9 E-07$ & & 7 & 002 & $2.323 \mathrm{E}-08$ & 006 & & \\
\hline & & & & & & & & & & & & \\
\hline $\mathrm{Np}-2$ & 0.00 & & $O E+0 O$ & 0.0 & $E+00$ & & $10 E+00$ & 000 & $000 E+00$ & 000 & -12 & 000 \\
\hline & 1.68 & & $E-21$ & 0.0000 & $E-19$ & 0.0000 & $E-20$ & .0000 & $8 E-22$ & 000 & & .0000 \\
\hline & & & $E-19$ & & 19 & & $109 \mathrm{E}-20$ & & & & & \\
\hline $\mathrm{Pu}-\mathrm{Z}$ & 0.00 & & $E+00$ & 0.0 & $0.000 E+00$ & 0. & $0 E+00$ & 0.0000 & $=+\infty$ & 000 & -08 & 017 \\
\hline $\mathrm{Pu}-239$ & $0.000 E+00$ & 0.0000 & $.000 E+00$ & 0.0000 & $0.000 E+00$ & 0.0000 & $0.000 E+00$ & 0.0000 & $0.000 E+00$ & 0.0000 & $8.630 E-08$ & 0.0020 \\
\hline & & & $+\infty$ & 0.0000 & $+\infty 0$ & 0.0000 & $O E+00$ & .0000 & $+\infty$ & 0.0000 & & \\
\hline & & & -19 & & & & $=-20$ & & & & & \\
\hline Ra- & & & $7 E-24$ & 0.0000 & $6 E-23$ & 0.0000 & $0 E-25$ & 0.0000 & $12 E-24$ & 0.0000 & $E-22$ & 0.0000 \\
\hline $\mathrm{Sr}-90$ & $6.635 E-08$ & 0.0016 & $.877 \mathrm{E}-10$ & 0.0000 & $1.026 E-08$ & 0.0002 & $6 E-09$ & 0.0001 & $E-09$ & 0.0001 & $E-06$ & 0. \\
\hline & & & 25 & & BE-24 & & $=-20$ & & 1.8 & & -22 & \\
\hline & $5.304 E-20$ & & $.578 E-21$ & & $\mathrm{E}-20$ & & $E-22$ & 000 & $E-23$ & 000 & & 0.0000 \\
\hline & & 0.0000 & $925 E-18$ & 0.0000 & $2 E-17$ & 0.0000 & $2 E-19$ & 0.0000 & $E-19$ & 0.0000 & -16 & 000 \\
\hline & & & & 0.0000 & $1.014 E-24$ & & BE-26 & & $3.211 \mathrm{E}-27$ & 00 & & \\
\hline & & & $.603 E-18$ & & $1.256 E-16$ & & $2.661 \mathrm{E}-18$ & & 1.3 & & & \\
\hline & & & & 0.0000 & $3.475 E-11$ & 0.0000 & $7303 \mathrm{E}-13$ & 0.0000 & & 3000 & $E-10$ & 0.0000 \\
\hline & & & $x=10$ & & $1.375 E-14$ & & & & $1.501 \mathrm{E}-15$ & & & 0.0000 \\
\hline & & & & & & & & & & & & \\
\hline & & & & & & & & & & & & \\
\hline & & & & & & & & & & & & \\
\hline
\end{tabular}

** Sum of water independent ground, inhalation, plant, meat, milk, soil

and water dependent water, fish, plant, meat, milk pathways

$\begin{array}{ll}\text { Attachment } \frac{6}{\text { S.W. Clark }} & \text { Sheet No. } 15 \text { of } \underline{52} \\ \text { Originator: } & \text { Date } \\ \text { Chk'd By } & \text { Date } \\ \text { Calc. No. Perrott } & \text { Rev. No. } \quad 0\end{array}$




\section{ATTACHMENT 6}

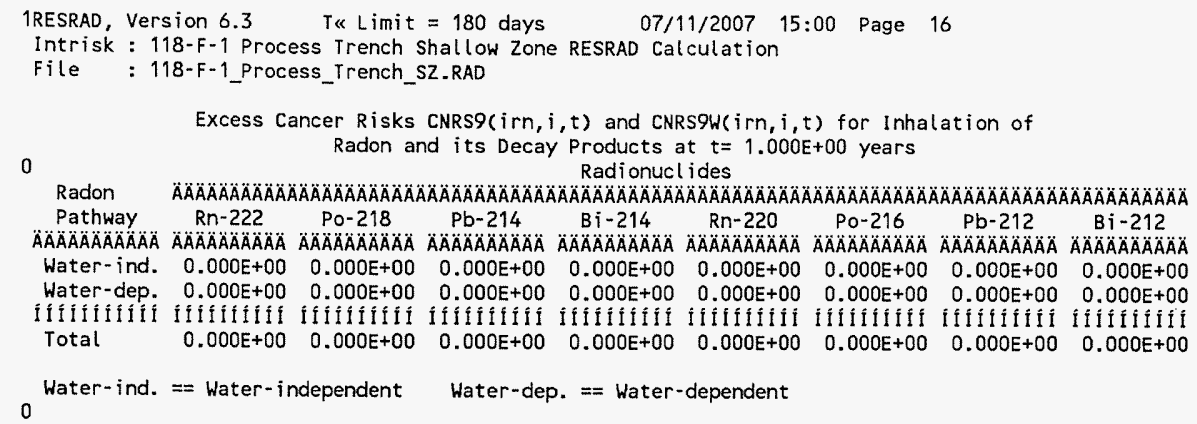

\begin{tabular}{|c|c|}
\hline Attachment & Sheet No. 16 of 52 \\
\hline Originator: S.W.Clark & Date \\
\hline Chk'd By M. W. Perrott & Date \\
\hline $0100 F-C A-V 0280$ & Rev. No. \\
\hline
\end{tabular}




\section{ATTACHMENT 6}

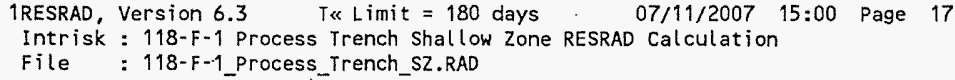

Water Dependent Pathways

\begin{tabular}{|c|c|c|c|c|c|c|c|c|c|c|c|c|c|c|}
\hline \multirow{2}{*}{$\begin{array}{l}\text { Radio- } \\
\text { Nucl ide } \\
\text { ÄÄÄÄÄÄA }\end{array}$} & \multicolumn{2}{|c|}{ Water } & $\begin{aligned} F i s h \\
\text { ÄÄAAAAAOAOÄ }\end{aligned}$ & ÄÄÄÄÄÄ & $\begin{aligned} & \text { Rado } \\
& \text { ÄÄAAAOAOÄÄA }\end{aligned}$ & On & \multicolumn{2}{|c|}{ Plant } & \multicolumn{2}{|c|}{ Meat } & \multicolumn{2}{|c|}{ Milk } & \multicolumn{2}{|c|}{$\begin{array}{c}\text { All pathways } \\
\text { AAAAAAAAOAOAOAOAAAAOA }\end{array}$} \\
\hline & $\begin{array}{c}r i s k \\
\triangle A O A O A B A ̈ A A O A\end{array}$ & $\begin{array}{l}\text { fract. } \\
\not A B A A B A A ̈\end{array}$ & $\begin{array}{c}\text { risk } \\
\text { ÄÄÄAOAOABA }\end{array}$ & $\begin{array}{l}\text { fract. } \\
\text { ÄÄAAAAA }\end{array}$ & $\begin{array}{c}\text { risk } \\
\text { ÄAAAABÄÄÄ }\end{array}$ & $\begin{array}{l}\text { fract. } \\
\because A A B A ̈ A B A\end{array}$ & $\begin{array}{c}r i s k \\
\triangle A B A B A B A B A B A\end{array}$ & $\begin{array}{l}\text { fract: } \\
\text { AAAAABA }\end{array}$ & $\begin{array}{c}\text { risk } \\
\text { ÄÄÄÄÄÄA }\end{array}$ & $\begin{array}{l}\text { fract. } \\
\text { ÄÄÄAB }\end{array}$ & $\begin{array}{c}\text { risk } \\
\text { ÄAÄÄAOÄ }\end{array}$ & $\begin{array}{l}\text { fract. } \\
\text { AAAAOABA }\end{array}$ & $\begin{array}{c}\text { risk } \\
\text { ÄÄAAAOAOÄ }\end{array}$ & $\begin{array}{l}\text { fract. } \\
A B A A B A B\end{array}$ \\
\hline $\mathrm{Ag}-108 \mathrm{~m}$ & $.000 \mathrm{E}+00$ & 0.0000 & $0.000 \mathrm{E}+00$ & 0.0000 & $0.000 E+00$ & 0.0000 & $0.000 E+00$ & 0.0000 & $0.000 E+00$ & 0.0000 & $0.000 E+00$ & 0.0000 & $1.673 \mathrm{E}-06$ & 0.0397 \\
\hline & 8 & & $2.604 E-18$ & 0.0000 & $0.000 E+00$ & 0.0000 & $1.257 E-16$ & 0.0000 & $2.661 \mathrm{E}-18$ & 0.0000 & $1.370 E-17$ & 0.0000 & & \\
\hline & & & $.000 E+00$ & 0.0000 & $0.000 E+00$ & 0.0000 & $0.000 E+00$ & 0.0000 & $0.000 E+00$ & 0.0000 & $000 E+00$ & 0.0000 & $4.217 \mathrm{E}-07$ & 0.0100 \\
\hline ;o & $1.128 E-10$ & 0.0000 & $8.833 E-12$ & 0.0000 & $0.000 E+00$ & 0.0000 & $1.792 \mathrm{E}-11$ & 0.0000 & $2.123 E-11$ & 0.0000 & $6.296 E-12$ & 0.0000 & $3.868 E-06$ & .0918 \\
\hline 137 & $7.753 E-09$ & 0.0002 & $3.418 E-09$ & 0.0001 & $0.000 E+00$ & 0.0000 & $1.060 \mathrm{E}-09$ & 0.0000 & $1.944 \mathrm{E}-09$ & 0.0000 & $1.519 E-09$ & 0.0000 & $1.656 E-05$ & 3930 \\
\hline & & 0.0000 & $.000 E+00$ & 0.0000 & $0.000 E+00$ & 0.0000 & $0.000 \mathrm{E}+00$ & 0.0000 & $0.000 \mathrm{E}+00$ & 0.0000 & $0.000 E+00$ & 0.0000 & 6.77 & 1607 \\
\hline Eu-154 & $0.000 E+00$ & 0.0000 & $0.000 E+00$ & 0.0000 & $0.000 E+00$ & 0.0000 & $0.000 E+00$ & 0.0000 & $0.000 E+00$ & 0.0000 & $0.000 E+00$ & 000 & & \\
\hline$H-3$ & $.323 \mathrm{E}$ & 0.0 & $.043 E-10$ & 0.0 & $0.000 E+00$ & 0.0000 & $1.639 \mathrm{E}-07$ & 039 & 7.405 & 002 & $2.323 E-08$ & 0006 & -07 & 0195 \\
\hline $\mathrm{Ni}-63$ & $1.057 E-08$ & 0.0003 & $2.808 E-10$ & 0.0000 & $0.000 E+00$ & 0.0000 & $1.676 \mathrm{E}-09$ & 0.0000 & $5.171 \mathrm{E}$ & 0.0000 & $6.018 \mathrm{E}-09$ & 0.0001 & 5.66 & .0134 \\
\hline Pu- & $.335 E-10$ & 0.0000 & $194 E-13$ & 0.0000 & $0.000 E+00$ & 0.0000 & $3.475 E-11$ & 0.0000 & $7.393 \mathrm{E}-13$ & 0.0000 & $95 E-12$ & 0.0000 & -08 & 0.001 \\
\hline & & & & & & & & & & & $E-15$ & & & 020 \\
\hline Pu-240 & $124 E-13$ & 0.0000 & $.883 E-15$ & 0.0000 & $0.000 E+00$ & 0.0000 & $9.094 \mathrm{E}-14$ & 0.0000 & $E-15$ & 0.0000 & OE-15 & 0.0000 & 2.05 & .0005 \\
\hline & & & $9.877 E-10$ & 0.0000 & $0.000 E+00$ & 0.0000 & $1.026 \mathrm{E}-08$ & 0.0002 & $4.746 \mathrm{E}-$ & 0.0001 & $3.446 E-09$ & 0.0001 & & 0.2066 \\
\hline & & & & & & & & & & & & & & fi I I I I i i \\
\hline Total & $5.173 \mathrm{E}-07$ & 0.0123 & $4.800 E-09$ & 0.0001 & $0.000 E+00$ & 0.0000 & $1.770 \mathrm{E}-07$ & 0.0042 & $1.463 E-08$ & 0.0003 & $3.422 E-08$ & 0.0008 & $4.214 \mathrm{E}-05$ & 1.0000 \\
\hline
\end{tabular}

***CNRSI $(i, p, t)$ includes contribution from decay daughter radionuclides

\begin{tabular}{|c|c|}
\hline Attachment & Sheet No. 17 of $\underline{52}$ \\
\hline Originator: S.W. Clark & Date \\
\hline Chk'd By M. W. Perrott & Date \\
\hline $0100 \mathrm{~F}-\mathrm{CA}-\mathrm{V} 0280$ & Rev. No. \\
\hline
\end{tabular}




\section{ATTACHMENT 6}

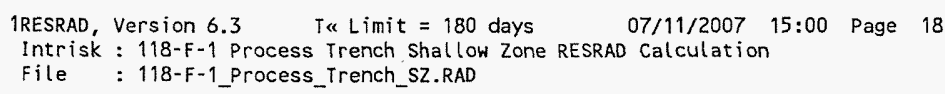

Water-ind. $=$ Water-independent Water-dep. $==$ Water-dependent

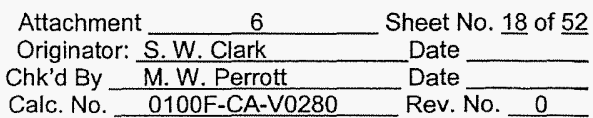


Rev. 0

\section{ATTACHMENT 6}

\begin{tabular}{|c|c|c|c|c|c|c|c|c|c|c|}
\hline & $\begin{array}{l}\text { Version } \\
: 118-F- \\
: 118-F-\end{array}$ & Process & \multicolumn{2}{|c|}{$\begin{array}{l}\text { T« Limit }=180 \text { days } \\
\text { Irench Shallow Zone } \\
\text { _Trench_SZ.RAD }\end{array}$} & \multicolumn{3}{|c|}{$\begin{array}{l}07 / 11 / 2007 \quad 15: 00 \\
\text { Calculation }\end{array}$} & Page 19 & & \\
\hline & \multicolumn{2}{|r|}{ Excess } & \multicolumn{8}{|c|}{$\begin{array}{c}\text { Cancer Risks CNRS }(i, p, t) \text { for Individual Radionuclides }(i) \text { and Pathways }(p) \\
\text { and Fraction of Total Risk at } t=3.000 E+00 \text { years }\end{array}$} \\
\hline 0 & Gro & & Inhalat & tion & Pla & & Mea & & Milk & Soil \\
\hline & $\triangle A ̈ A \cap A ̈ A ̈ A ̈$ & $\because \ddot{A} A ̈ A ̈ A ̈ A ̈ A$ & ÄÄÄÄÄÄÄÄ & $\triangle A \ddot{A} A ̈ A O A$ & $\triangle A \cap A \cap A \cap A \cap A A$ & $\triangle A ̈ A ̈ A ̈ A ̈ A ̈ A$ & $\triangle A \cap A ̈ A O A A A$ & ÄÄÄÄĂÄĂ & ÄÄÄÄÄÄÄÄÄÄÄÄA & ÄÄÄÄÄAAÄÄÄÄÄÄA \\
\hline $\begin{array}{l}\text { Nuclide } \\
\text { ÄÄÄÄÄÄÄA }\end{array}$ & $\begin{array}{c}\text { risk } \\
\text { AOAAAAAAAAÄ }\end{array}$ & $\begin{array}{l}\text { fract. } \\
\text { ÄÄÄÄÄ }\end{array}$ & $\begin{array}{c}\text { risk } \\
\text { ÄÄÄÄÄÄÄ }\end{array}$ & $\begin{array}{l}\text { fract. } \\
\text { ÄÄÄÄÄA }\end{array}$ & $\begin{array}{c}r i s k \\
\text { ÄÄÄÄÄÄÄÄ }\end{array}$ & $\begin{array}{l}\text { fract. } \\
\triangle A A A A O A B A\end{array}$ & $\begin{array}{c}\text { risk } \\
\text { ÄAAAAAAAAAA }\end{array}$ & $\begin{array}{l}\text { fract. } \\
\text { AAAAAAOA }\end{array}$ & $\begin{array}{l}\text { risk fract. } \\
\text { ÄAAAAAAAAB ÄAAAAAA }\end{array}$ & $\begin{array}{r}\text { risk fract. } \\
\text { AAAAAAAAA AAAAAA }\end{array}$ \\
\hline & & 0.0000 & $2.190 \mathrm{E}-20$ & 0.0000 & $2.588 \mathrm{E}-19$ & 0.0000 & $1.078 E-21$ & 0.0000 & $6.382 E-220.0000$ & $1.876 \mathrm{E}-190.0000$ \\
\hline & & 0.0415 & & 0.0000 & $3.347 E-08$ & 0.0009 & $1.253 \mathrm{E}-09$ & 0.0000 & $2.372 E-08 \quad 0.0006$ & $3.964 E-100.0000$ \\
\hline & & 0.0012 & & 0.0001 & -08 & 0.0005 & $9.734 \mathrm{E}-11$ & 0.0000 & $1.057 E-110.0000$ & $86 E-080.0009$ \\
\hline & & & & & & & 8.696 & & 090.0002 & -110.0000 \\
\hline Co & & & & 0.0000 & $=-08$ & 0.0010 & $9.751 \mathrm{E}-09$ & 0.0003 & $2.234 E-090.00$ & -100.0000 \\
\hline & 1 & 0.3763 & 12 & 0.0000 & & & $3.231 \mathrm{E}-07$ & 0.0084 & $2.007 \mathrm{E}-07 \quad 0.0052$ & $3 E-08 \quad 0.0006$ \\
\hline & & 0.1584 & & 0.0000 & -09 & 0. & 2.092 & 0.0000 & $=-110.0000$ & $=-090.0000$ \\
\hline & & 0.0548 & & & & 0000 & 1.127 & 0.0000 & 120.0000 & $E-100$. \\
\hline & & 0.0 & & & -22 & 0.0 & 4.173 & 0.0000 & -240.0 & 220. \\
\hline$H-3$ & 00 & 0.0000 & & & & & 3.524 & 0.0001 & -090.0002 & $E-11 \quad 0.0000$ \\
\hline & & 0.0000 & & 0.0000 & & & -08 & 0.0005 & 070.0051 & -080.0 \\
\hline & & & & & & & 2.5 & 0.0000 & $\begin{array}{ll}-16 & 0.000\end{array}$ & 130 \\
\hline $\mathrm{Pa}-$ & & 0.0000 & & 0.0000 & & & 1.665 & 0.0000 & $-22 \quad 0.00$ & 190. \\
\hline $\mathrm{Pb}-$ & & 0.0 & & & & & 3.6 & 0.0000 & 190.0000 & $E-18 \quad 0.0000$ \\
\hline & & & & & & & & & 120.0 & 4.1 \\
\hline & & & & 0.0001 & -08 & & & & $E-12 \quad 0.000$ & $E-08 \quad 0.0013$ \\
\hline & & & & 0.0000 & & & & 0.0000 & $E-12 \quad 0.0000$ & $E-08 \quad 0.0003$ \\
\hline & & & & & & & 8.14 & 0.0000 & $=-18 \quad 0.0000$ & $2.164 \mathrm{E}-18 \quad 0.0000$ \\
\hline & & & & & & & & & -230.0 & \\
\hline & & 0.0014 & & 0.0000 & & & & & $3.883 E-07 \quad 0.0101$ & $7 E-08 \quad 0.0010$ \\
\hline & & & & 0.0000 & $E-24$ & 0.0000 & $5.419 \mathrm{E}-$ & 0.0000 & $6.817 E-27 \quad 0.0000$ & $4.085 \mathrm{E}-24 \quad 0.0000$ \\
\hline & & & & & & & $2.344 E-22$ & 0.0000 & $3.258 E-23 \quad 0.0000$ & $4.294 E-20 \quad 0.0000$ \\
\hline & & & & & & & & & -190.0000 & $1 E-160$. \\
\hline Th-232 & & 0.0000 & $3.504 E-25$ & 0.0000 & $1.608 \mathrm{E}-24$ & & $1.615 E-26$ & & $2.231 E-27 \quad 0.0000$ & $78 \mathrm{E}-240.0000$ \\
\hline $0-2$ & & 0.0000 & $3.201 \mathrm{E}-19$ & 0.0000 & $1.017 E-17$ & 0.0000 & $1.673 \mathrm{E}-19$ & 0.0000 & $7.512 E-19 \quad 0.0000$ & $6.798 \mathrm{E}-18 \quad 0.0000$ \\
\hline & & & & 0.00 & $O E-12$ & 0.0000 & $2.913 E-14$ & 0.0000 & $1.361 E-13 \quad 0.0000$ & $1.256 \mathrm{E}-12 \quad 0.0000$ \\
\hline & & & & & & & & & $5.533 E-17 \quad 0.0000$ & $5.164 E-16 \quad 0.0000$ \\
\hline & & & & & & & & & $3.659 \mathrm{E}-16 \quad 0.0000$ & $3.368 \mathrm{E}-15 \quad 0.0000$ \\
\hline & & & & Iftî́n & 1111111 & fíîî́ & IfffIIIII & Ififif́ & 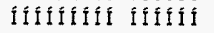 & filitifítíli \\
\hline Total & $7315=0$ & 0.7095 & $1.288 \mathrm{E}-08$ & 0.0003 & $8.401 E-06$ & 0.2183 & $1.056 \mathrm{E}-06$ & 0.0274 & $8.235 E-07 \quad 0.0214$ & ¿. TSUE-Ur \\
\hline
\end{tabular}

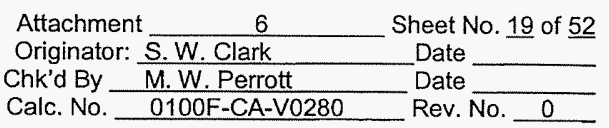




\section{ATTACHMENT 6}

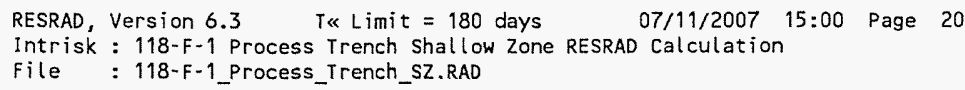

Water Dependent Pathways

\begin{tabular}{|c|c|c|c|c|c|c|c|c|c|c|c|c|}
\hline & $\begin{array}{r}\text { Water } \\
\text { ÄÄÄÄÄÄA }\end{array}$ & ÄÄĂAัÄÄÄ & 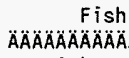 & ÄÄÄÄÄÄ & 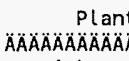 & $\triangle A B A A O A O A B A$ & 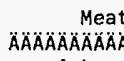 & ÄĂÄÄÄ & $\begin{array}{r}M i l k \\
\text { ÄÄÄÄÄÄÄÄÄ }\end{array}$ & ÄÄÄÄÄÄÄ & 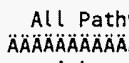 & $\begin{array}{l}\text { Ways } \\
\text { ÄÄÄÄÄÄ }\end{array}$ \\
\hline $\begin{array}{l}\text { Nucl ide } \\
\text { AÄÄÄÄÄA }\end{array}$ & $\begin{array}{c}r i s k \\
\text { ÄAAAAAOAOAOA }\end{array}$ & $\begin{array}{l}\text { fract. } \\
A ̈ A ̈ A O A O A\end{array}$ & $\begin{array}{c}\text { risk } \\
\triangle A A A B A A O A B A\end{array}$ & 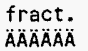 & $\begin{array}{c}\text { risk } \\
\text { AAAAAÄÄÄÄ }\end{array}$ & $\begin{array}{l}\text { fract. } \\
\text { ÄÄAAÄA }\end{array}$ & $\begin{array}{c}\text { risk } \\
\text { AAAAAAAOÄÄ }\end{array}$ & $\begin{array}{l}\text { fract. } \\
\text { ÄÄÄÄÄA }\end{array}$ & $\begin{array}{c}\text { risk } \\
\text { ÄAAAAAOAAOA }\end{array}$ & 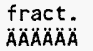 & $\begin{array}{c}\text { risk } \\
A A B A A B A B A ̈\end{array}$ & $\begin{array}{l}\text { fract. } \\
A \ddot{A B A O A B}\end{array}$ \\
\hline & & & & & $4.307 E-19$ & 0.0000 & $1.166 E-21$ & 0.0000 & $1.574 E-21$ & 0.0000 & $6.437 E-18$ & 0.0000 \\
\hline $88 m$ & & 0.0000 & & & $.000 \mathrm{E}+00$ & 0.0000 & $.000 E+00$ & & $0.000 E+00$ & & & \\
\hline & $0.000 E+00$ & 0.0000 & $0.000 E+00$ & 0.0000 & $0.000 E+00$ & 0.0000 & $0.000 E+00$ & 0.0000 & $.000 E+00$ & 0.0000 & $1.019 \mathrm{E}-07$ & \\
\hline & & 000 & $E+00$ & 0.0 & $00 E+00$ & 000 & $0.000 E+00$ & & $0 E+00$ & & & \\
\hline & & & & & & & & & & & & \\
\hline & & & & & & & & & & & & \\
\hline & $0.000 E+00$ & & $0 E+00$ & & $0.000 E+00$ & 000 & $0 E+00$ & 00 & $=00$ & & & \\
\hline & 0.00 & 0.0 & $E+00$ & 0.0 & $=+00$ & 0.0000 & $10 E+00$ & 00 & $E+00$ & & & \\
\hline & 0.0 & & & & & & & & & & & \\
\hline & & & & & & & & & & & & \\
\hline & 1.1 & & & & & & 10 & & & & & \\
\hline & 0.0 & & $+\infty 0$ & & $E+00$ & 0.0 & $D E+\infty 0$ & & +00 & & & \\
\hline & 2.1 & & & & & & & & & & & \\
\hline & & & & & & & & & & & & \\
\hline & & & & & & & $=+\infty$ & & 100 & & & \\
\hline & 0.0 & & & & & & $E+00$ & & $=+00$ & & & \\
\hline & & & & & & & $+\infty$ & & & & & \\
\hline & & & & & & & -20 & & & & & \\
\hline & & & & & & & & & & & & \\
\hline & & & & & & & -09 & & -09 & & & \\
\hline & & & -25 & & & & $=-26$ & & $=-27$ & & & \\
\hline & $=-20$ & & & & $E-20$ & & $=-22$ & & $=-23$ & & & 300 \\
\hline & & & -18 & & & & & & & & & 00 \\
\hline & & & $E-25$ & & & & & & $=-27$ & & & \\
\hline & & & $E-18$ & & & & & & $57 E-17$ & & & 000 \\
\hline & $2.799 E-10$ & & $8.627 E-13$ & & $4.168 E-11$ & 0.0000 & E-13 & & $4.553 E-12$ & & $3 E-10$ & 0.0000 \\
\hline & & & $3.427 E-16$ & & $1.655 E-14$ & & $4 E-16$ & & $1.808 E-15$ & & & 0.0000 \\
\hline & & & & & & & & & & & & \\
\hline & & & & & & & & & & & & \\
\hline & $4.663 \mathrm{E}-07$ & & & & $1.558 E-07$ & 0.0040 & $1.428 \mathrm{E}-08$ & 0.0004 & J.210L 80 & 0.0008 & & 1.0000 \\
\hline
\end{tabular}

** Sum of water independent ground, inhalation, plant, meat, milk, soil

and water dependent water, fish, plant, meat, milk pathways

\begin{tabular}{|c|c|}
\hline Attachment $\quad 6$ & Sheet No. 20 of $\underline{52}$ \\
\hline Originator: S.W. Clark & Date \\
\hline Chk'd By M.W. Perrott & Date \\
\hline $0100 F-C A-V 0280$ & Rev. No. \\
\hline
\end{tabular}




\section{ATTACHMENT 6}

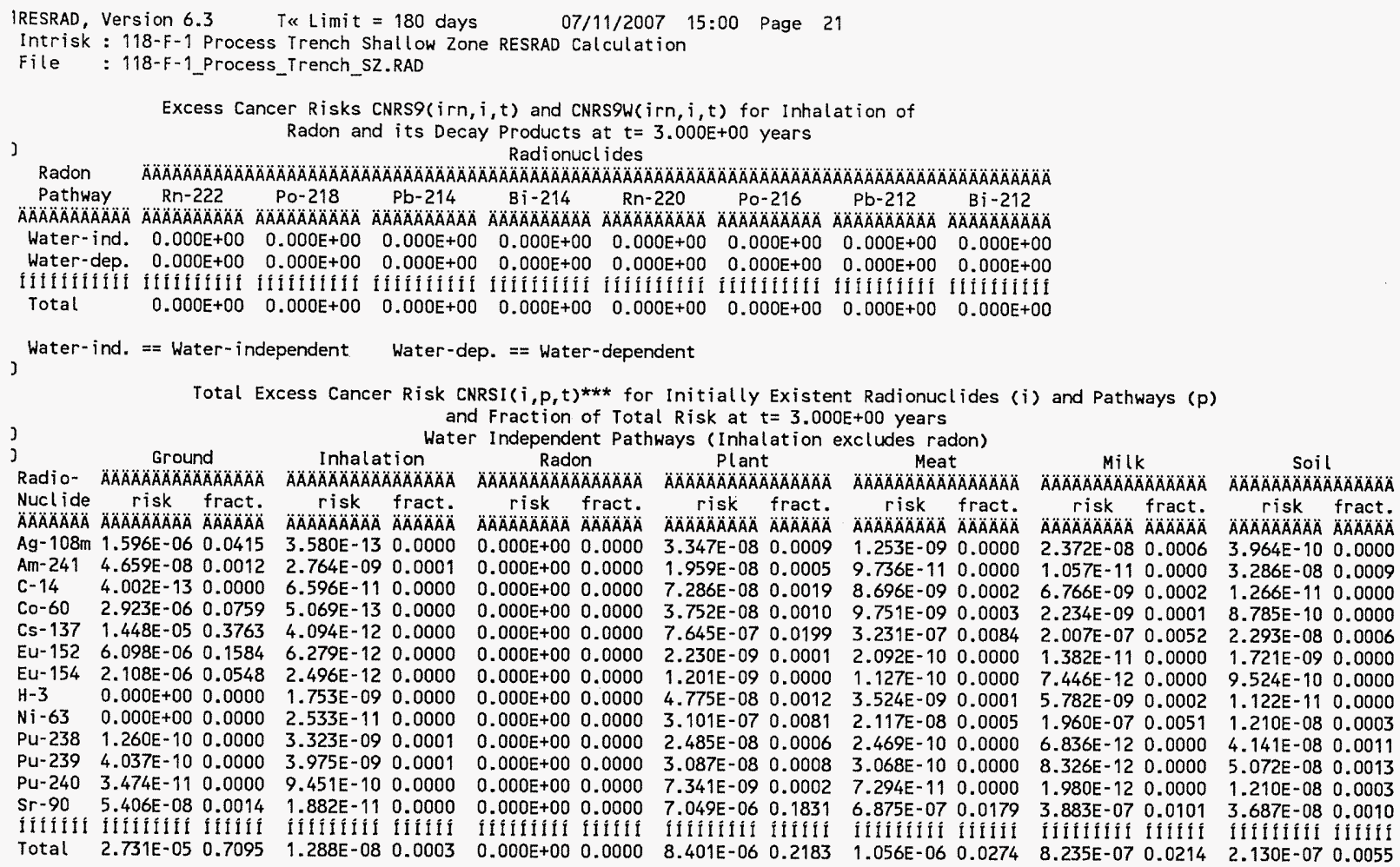

\begin{tabular}{|c|c|}
\hline Attachment $\quad 6$ & Sheet No. 21 of $\underline{52}$ \\
\hline Originator: S.W. Clark & Date \\
\hline M. W. Perrott & Date \\
\hline $0100 \mathrm{~F}-\mathrm{CA}-\mathrm{V} 0280$ & v. No. \\
\hline
\end{tabular}




\section{ATTACHMENT 6}

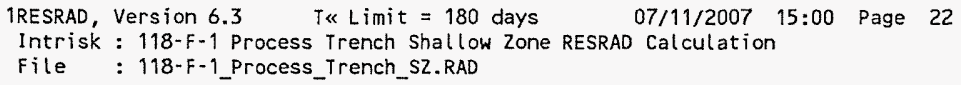

Water Dependent Pathways

\begin{tabular}{|c|c|c|c|c|c|c|c|c|c|c|c|c|c|}
\hline & Water & $\begin{aligned} &F i s\} \\
& A \\
& A\end{aligned}$ & Fish & Radon & on & Plant & $\begin{array}{l}t \\
A\end{array}$ & $\begin{array}{r}\text { Mea } \\
\text { ÄÄÄAÄÄÄÁ }\end{array}$ & $\triangle A ̈ A ̈ A O A B A ̈$ & \multicolumn{2}{|c|}{ 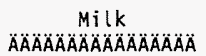 } & \multicolumn{2}{|c|}{$\begin{array}{c}\text { All pathways } \\
\text { AAAAAAAAAAAAAAAAAAA }\end{array}$} \\
\hline $\begin{array}{l}\text { uclide } \\
A B A B A B A B\end{array}$ & $\begin{array}{r}\text { risk fract. } \\
\triangle A A A A B A B A B A \\
A B A B A B A O A\end{array}$ & $\begin{array}{c}r i s k \\
A \cap A ̈ A ̈ A ̈ A B A ̈\end{array}$ & $\begin{array}{l}\text { fract. } \\
\text { ÄÄÄÄÄÄ }\end{array}$ & $\begin{array}{c}\text { risk } \\
\triangle A A A A A B A B A ̈ A\end{array}$ & $\begin{array}{l}\text { fract. } \\
\text { ÄÄÄÄÄA }\end{array}$ & $\begin{array}{c}r i s k \\
A \cap A ̈ A \cap A B A B A B A\end{array}$ & $\begin{array}{l}\text { fract. } \\
\ddot{A} A ̈ A ̈ A ̈ A ̈ A ̈\end{array}$ & $\begin{array}{c}\text { risk } \\
\text { ÄAAAAAÄÄÄ }\end{array}$ & $\begin{array}{l}\text { fract. } \\
\text { ÄÄÄÄÄA }\end{array}$ & $\begin{array}{c}\text { risk } \\
\triangle A A A A O A O A O A\end{array}$ & $\begin{array}{l}\text { fract. } \\
\text { ÄÄÄÄÄA }\end{array}$ & $\begin{array}{c}\text { risk } \\
\text { A } \\
\text { A }\end{array}$ & \\
\hline & $0.000 E+00 \quad 0.0000$ & & 0.0000 & $0.000 E+00$ & 0.0000 & $0.000 E+00$ & & & 0.0000 & $0.000 E+00$ & & & 0.0430 \\
\hline$n-241$ & $1.085 \mathrm{E}-150.0000$ & & 0.0000 & $0.000 E+00$ & 0.0000 & & 0.0000 & & 0.0000 & & & -07 & 0.0026 \\
\hline & $+\infty 0$ & $+\infty$ & 0.0000 & $E+00$ & & & & +00 & 000 & $=+00$ & & & \\
\hline & & & & & & & & & & & & & 772 \\
\hline & & & 0.0 & $0.000 E+00$ & 000 & & 0.0 & & 0.0001 & $=-09$ & & & 108 \\
\hline & $0.000 E+00 \quad 0.0000$ & $0.000 E+00$ & 0.0 & $0.000 E+00$ & & & & & & $E+00$ & & & \\
\hline & +000. & $E+00$ & & $E+00$ & & 00 & & & & $E+00$ & & & \\
\hline & & & & $E+\infty 0$ & & & & & & -08 & & & \\
\hline & 1.176E - & $3.126 E-10$ & 0.00 & $0.000 E+00$ & 0.0000 & & 0.0000 & & 0.0 & -09 & & & \\
\hline & & & & & & & & & & & & & \\
\hline & & & & $.000 E+00$ & & & & & & $E-15$ & & & 022 \\
\hline$P u-240$ & $7.372 E-13 \quad 0.0000$ & $2.266 E-15$ & 0.0000 & $0.000 E+00$ & 0.0000 & $E-13$ & 0.0000 & & & $1.196 E-14$ & & -08 & 0.0005 \\
\hline & & & & & 0.0000 & & 0.0003 & & 0.0001 & & & & \\
\hline That & $63 \mathrm{E}-070.0$ & $\cdot \angle U O E-U\rangle$ & 0.07 & $0.000 t+00$ & 000 & E-Ur & 0.0040 & $20 t-60$ & 04 & $3.218 E-08$ & 0.0008 & $3.0^{2}+4$ & 1.0000 \\
\hline
\end{tabular}

***CNRSI $(i, p, t)$ includes contribution from decay daughter radionuclides

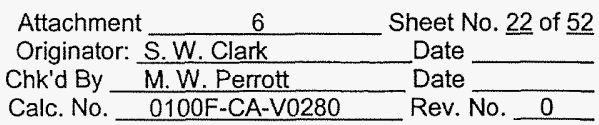




\section{ATTACHMENT 6}

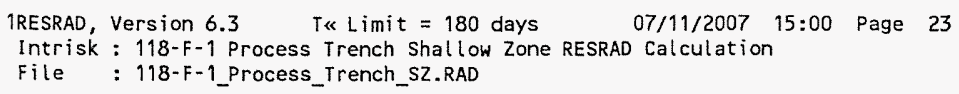
Radionuclides

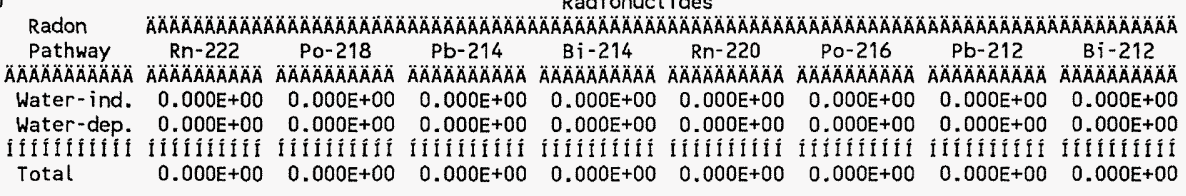

\begin{tabular}{|c|c|}
\hline Attachment & Sheet No. 23 of 52 \\
\hline Originator: S.W. Clark & Date \\
\hline Chk'd By M. W. Perrott & Date \\
\hline $0100 F-C A-V 0280$ & Rev. No. 0 \\
\hline
\end{tabular}


Rev. 0

\section{ATTACHMENT 6}

RESRAD, Version $6.3 \quad T \ll L$ Limit $=180$ days $\quad 07 / 11 / 2007 \quad 15: 00$ Page 24
Intrisk : $118-F-1$ Process Trench Shallow Zone RESRAD Calculation

File : 118-F-1_Process_Trench_SZ.RAD

Excess Cancer Risks CNRS $(i, p, t)$ for Individual Radionuclides (i) and Pathways ( $p$ ) and Fraction of Total Risk at $t=7.000 E+00$ years

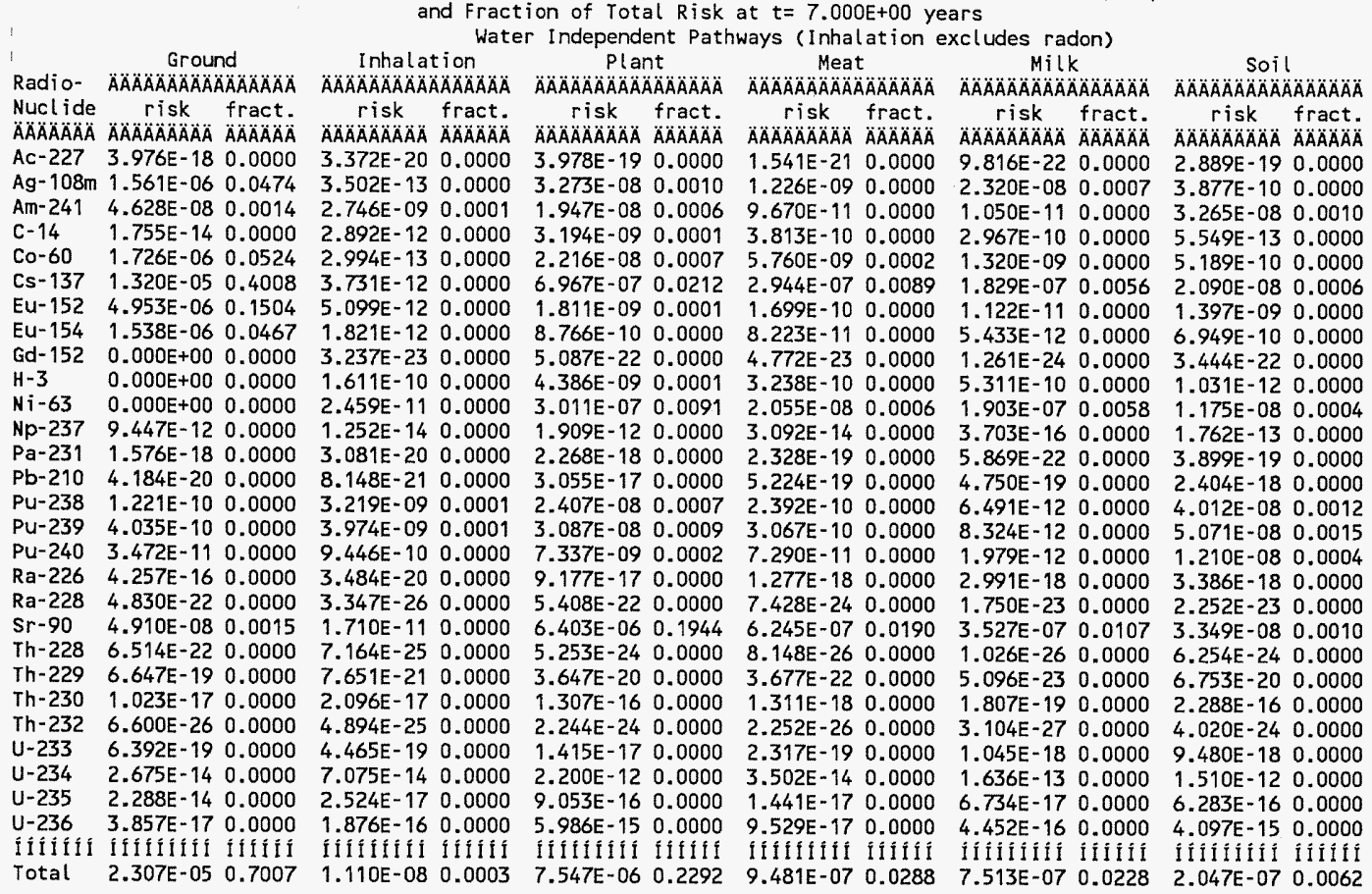

\begin{tabular}{|c|c|}
\hline Attachment $\quad 6$ & Sheet No. $\underline{24}$ of 52 \\
\hline Originator: S.W. Clark & Date \\
\hline Chk'd By M. W. Perrott & Date \\
\hline $0100 F-C A-V 0280$ & Rev. No. \\
\hline
\end{tabular}




\section{ATTACHMENT 6}

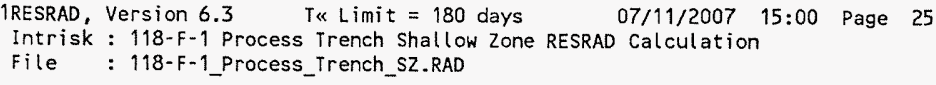

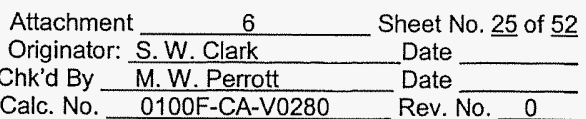




\section{ATTACHMENT 6}

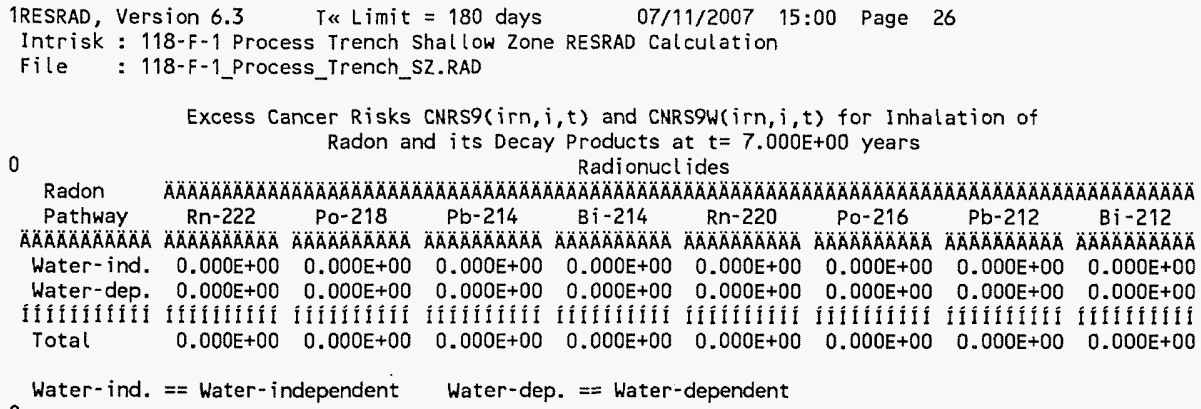

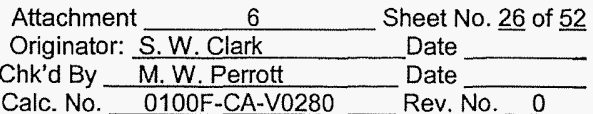




\section{ATTACHMENT 6}

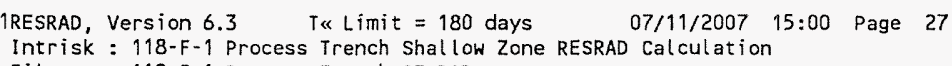

Total Excess Cancer Risk CNRSI $(i, p, t) * * *$ for Initially Existent Radionuclides ( $i$ ) and Pathways $(p)$ and Fraction of Total Risk at $t=7.000 E+00$ years

Water Dependent Pathways

\begin{tabular}{|c|c|c|c|c|c|c|c|c|c|c|c|c|c|c|}
\hline \multirow{2}{*}{$\begin{array}{l}\text { Radio- } \\
\text { Nucl ide } \\
\text { ÄÄÄÄÄÄÄ }\end{array}$} & \multicolumn{2}{|c|}{$\begin{array}{c}\text { Water } \\
\text { AÄÄÄÄÄÄÄÄAAAAÄ }\end{array}$} & \multicolumn{2}{|c|}{ Fish } & \multicolumn{2}{|c|}{ Radon } & \multicolumn{2}{|c|}{ Plant } & \multicolumn{2}{|c|}{ Meat } & \multicolumn{2}{|c|}{ Milk } & \multicolumn{2}{|c|}{$\begin{array}{c}\text { All pathways } \\
A A A A A A A B A A A A A A A A A B A\end{array}$} \\
\hline & 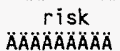 & $\begin{array}{l}\text { fract. } \\
\triangle A O A B A B A B A\end{array}$ & $\begin{array}{c}\text { risk } \\
\because A \cap A ̈ A ̈ A ̈ A ̈ A ̈ A ̈\end{array}$ & $\begin{array}{l}\text { fract. } \\
\because A B A ̈ A ̈ A ̈\end{array}$ & 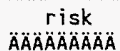 & $\begin{array}{l}\text { fract. } \\
\text { ÄÄÄÄÄA }\end{array}$ & $\begin{array}{c}\text { risk } \\
\triangle A \cap A O A B A O A O A\end{array}$ & $\begin{array}{l}\text { fract. } \\
\triangle A B A ̈ A B A B\end{array}$ & $\begin{array}{c}\text { risk } \\
\text { ÄÄÄAAAOAAA }\end{array}$ & $\begin{array}{l}\text { fract. } \\
\ddot{A} \ddot{A} A \ddot{A} A \ddot{A} A\end{array}$ & $\begin{array}{c}\text { risk } \\
\text { ÄÄÄÄÄÄÄÄ }\end{array}$ & 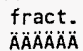 & $\begin{array}{c}\text { risk } \\
\text { ÁAÄÄÄÄÄÄ }\end{array}$ & $\begin{array}{l}\text { fract. } \\
\triangle A B A B A B A B\end{array}$ \\
\hline $\mathrm{Ag}-108 \mathrm{~m}$ & $0.000 E+00$ & 0.0000 & $0.000 E+00$ & 0.0000 & $0.000 \mathrm{E}+00$ & 0.0000 & $0.000 E+00$ & 0.0000 & $0.000 E+00$ & 0.0000 & $0.000 E+00$ & 0.0000 & $1.619 \mathrm{E}-06$ & .0492 \\
\hline & $1.706 E-15$ & 0.0000 & $5.253 E-18$ & 0.0000 & $0.000 E+00$ & 0.0000 & $2.535 E-16$ & 0.0000 & $5.385 E-18$ & 0.0000 & $2.766 E-17$ & Ju & & \\
\hline & & 0.0000 & $300 E+00$ & 0.0000 & $0.000 E+00$ & 0.0000 & & 000 & $.000 E+00$ & 0000 & & & & \\
\hline & & 0.0000 & $7.088 \mathrm{E}-12$ & 0.0000 & $0.000 E+00$ & 0.0000 & $1.442 E-11$ & 0.0000 & $1.744 \mathrm{E}-11$ & 0.0000 & $5.108 \mathrm{E}-12$ & 000 & 06 & 0533 \\
\hline & 09 & 0.0 & $4.229 \mathrm{E}-09$ & 0.0 & $0.000 E+00$ & & $E-09$ & 0.0 & $7 E-09$ & & PE-09 & & & 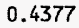 \\
\hline & $0.000 E+00$ & 0.0000 & $0.000 E+00$ & 0.0000 & $0.000 E+00$ & 0.0000 & $0.000 E+00$ & 0.0000 & $0.000 E+00$ & 0.0000 & & 0000 & & \\
\hline & $D E+00$ & 0.0000 & $O E+\infty O$ & 0.0000 & $0.000 E+00$ & 0.0000 & & 0000 & $0.000 E+00$ & 0.0000 & $0.000 E+00$ & 0.0 & & 0.046 \\
\hline & & 0.0050 & $E-11$ & & $\mathrm{E}+00$ & 1000 & & & & & & & & \\
\hline & $404 E-08$ & 0.00 & $733 E-10$ & & $0.000 \mathrm{E}+00$ & 0.0000 & & & $E-10$ & 300 & -09 & 002 & 07 & \\
\hline & & 0.0000 & $1.196 E-12$ & 0.0000 & $0.000 \mathrm{E}+00$ & 0.0000 & & 0.0000 & $1.232 E-12$ & 0.0000 & -12 & & & \\
\hline Pu-2 & & 0.0000 & $4.788 E-16$ & 0.0000 & $0.000 E+00$ & 0.0000 & $2.313 E-14$ & 0.0000 & $4.934 E-16$ & 0.0000 & $3 E-15$ & 000 & -08 & \\
\hline & & & & & & & & & & & & & & \\
\hline & & & & & & & & & & & & & & \\
\hline & & & & & Ifififilit & & fiffifiti & & fillifílít & & ifififiti & & & \\
\hline Total & $2.720 E-07$ & 0.0083 & $5.869 E-09$ & 0.0002 & $0.000 E+00$ & 0.0000 & $8.049 E-08$ & 0.0024 & $1.207 \mathrm{E}-08$ & 0.0004 & $2.333 E-08$ & 0.0007 & $3.293 \mathrm{E}-05$ & 180 \\
\hline
\end{tabular}

***CNRSI $(i, p, t)$ includes contribution from decay daughter radionuclides

\begin{tabular}{|c|c|}
\hline Attachment $\quad 6$ & Sheet No. 27 of $\underline{52}$ \\
\hline Originator: S.W. Clark & Date \\
\hline Chk'd By M. W. Perrott & Date \\
\hline $0100 F-C A-V 0280$ & Rev. No. \\
\hline
\end{tabular}




\section{ATTACHMENT 6}

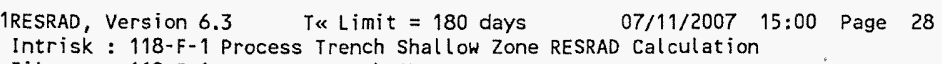

0

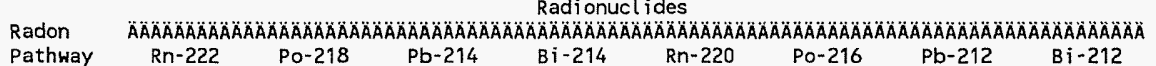

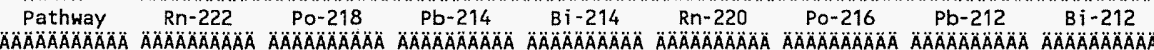
$\begin{array}{lllllllll}\text { Water-ind. } & 0.000 E+00 & 0.000 \mathrm{E}+00 & 0.000 \mathrm{E}+00 & 0.000 \mathrm{E}+00 & 0.000 \mathrm{E}+00 & 0.000 \mathrm{E}+00 & 0.000 \mathrm{E}+00 & 0.000 \mathrm{E}+00\end{array}$ Water-dep. $0.000 E+00 \quad 0.000 E+00 \quad 0.000 E+00 \quad 0.000 E+00 \quad 0.000 E+00 \quad 0.000 E+00 \quad 0.000 E+00 \quad 0.000 E+00$

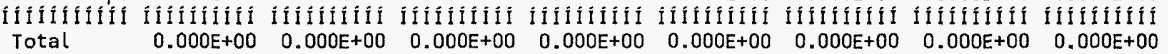

Water-ind. = Water-independent Water-dep. $==$ Water-dependent

\begin{tabular}{|c|c|}
\hline Attachment $\quad 6$ & Sheet No. 28 of 52 \\
\hline Originator: S.W. Clark & Date \\
\hline Chk'd By M. W. Perrott & Date \\
\hline Calc. No. $\quad 0100 F-C A-V 0280$ & Rev. No. \\
\hline
\end{tabular}


Rev. 0

\section{ATTACHMENT 6}

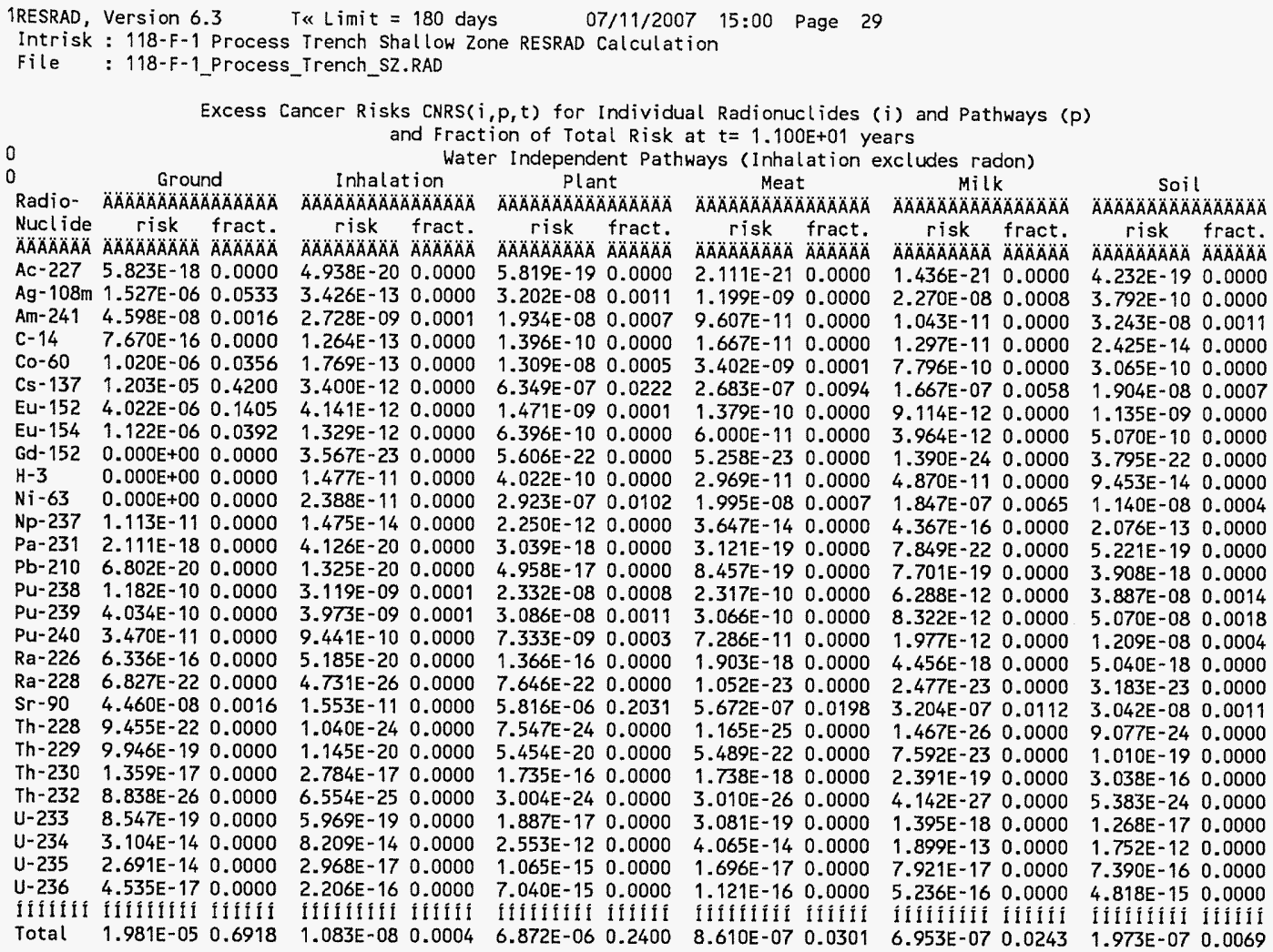

Attachment 6 


\section{ATTACHMENT 6}

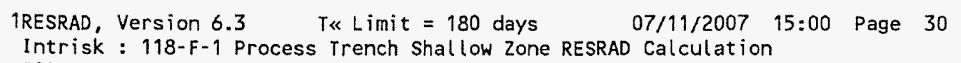

Water Dependent Pathways

\begin{tabular}{|c|c|c|c|c|c|c|c|c|c|c|c|c|}
\hline & \multicolumn{2}{|c|}{ Water } & \multicolumn{2}{|c|}{ Fish } & \multicolumn{2}{|c|}{$P$ lant } & \multicolumn{2}{|c|}{ Meat } & \multicolumn{2}{|c|}{ Milk } & \multicolumn{2}{|c|}{ 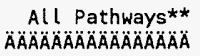 } \\
\hline AOAAOÄ & $\begin{array}{c}\text { risk } \\
\text { AAAAAAAAAAA }\end{array}$ & & $\begin{array}{c}r i s k \\
A A O A B A B A B A B\end{array}$ & $\begin{array}{l}\text { fract. } \\
\triangle A O A A A A A A\end{array}$ & $\begin{array}{c}\text { risk } \\
\triangle A O A O A B A B A B A\end{array}$ & $\begin{array}{l}\text { fract. } \\
\text { ÄÄ̈̈̈̈̈̈̈̈̈̈ }\end{array}$ & $\begin{array}{c}r i s k \\
\triangle A \cap A B A ̈ A O A B A ̈ A\end{array}$ & & 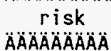 & 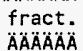 & $\begin{array}{c}\text { risk } \\
\triangle A B A B A B A B A ̈\end{array}$ & \\
\hline & & & & & & & & & & & & \\
\hline & & & $\mathrm{EE}+00$ & & & & & & $000 E+00$ & & & \\
\hline & & & & & & & & & $000 E+00$ & & & \\
\hline & & & & & & & & & & & & \\
\hline & & & & & & & & & & & & \\
\hline & & & & & & & & & & & & \\
\hline & & & & & & & & & & & & \\
\hline & & & & & & & & & & & & \\
\hline & & & & & & & & & & & & \\
\hline & & & & & & & & & & & & \\
\hline & & & & & & & & & & & & \\
\hline & & & & & & & & & & & & \\
\hline & & & & & & & & & & & & \\
\hline & & & & & & & & & & & & \\
\hline & & & & & & & & & & & & \\
\hline & & & & & & & & & & & & \\
\hline & & & & & & & & & & & & \\
\hline & & & & & & & & & & & & \\
\hline & & & & & & & & & & & & \\
\hline & & & & & & & & & & & & \\
\hline & & & & & & & & & & & & \\
\hline & & & & & & & & & & & & \\
\hline & & & $E-17$ & & $E-16$ & & EE-18 & & $4.199 E-19$ & & $E-15$ & \\
\hline & & & & & & & & & & & & \\
\hline & & & & & & & & & & & & \\
\hline & $153 E-10$ & & $1.589 \mathrm{E}-12$ & & $7.677 \mathrm{E}-11$ & & $1.640 \mathrm{E}-12$ & & $8.397 E-12$ & & $E-10$ & \\
\hline & & & & & & & & & & & & \\
\hline & & & & & & & & & & & & \\
\hline & Ifítîf & & & & liffifiti & & IIIIIII & & ППМП & & I I I I I & \\
\hline & $1.2130-\mathrm{U} / \mathrm{T}$ & 0.0040 & $0.384 t-U 4$ & 0.0002 & $2.379 E-08$ & 0.0008 & $1.010 \mathrm{t}-08$ & 0.0004 & $1.081 \mathrm{t}-08$ & 0.0006 & $2.805 E_{-O S}$ & \\
\hline
\end{tabular}

** Sum of water independent ground, inhalation, plant, meat, milk, soil and water dependent water, fish, plant, meat, milk pathways

\begin{tabular}{|c|c|c|}
\hline \multirow{2}{*}{\multicolumn{3}{|c|}{$\begin{array}{l}\text { Attachment } \frac{6}{\text { S.W. Clark }} \text { Sheet No. } \underline{30} \text { of } \underline{52} \\
\text { Originator: }\end{array}$}} \\
\hline & & \\
\hline Chk'd By & M. W. Perrott & Date \\
\hline & 0100F-CA-V0280 & Rev. No. \\
\hline
\end{tabular}




\section{ATTACHMENT 6}

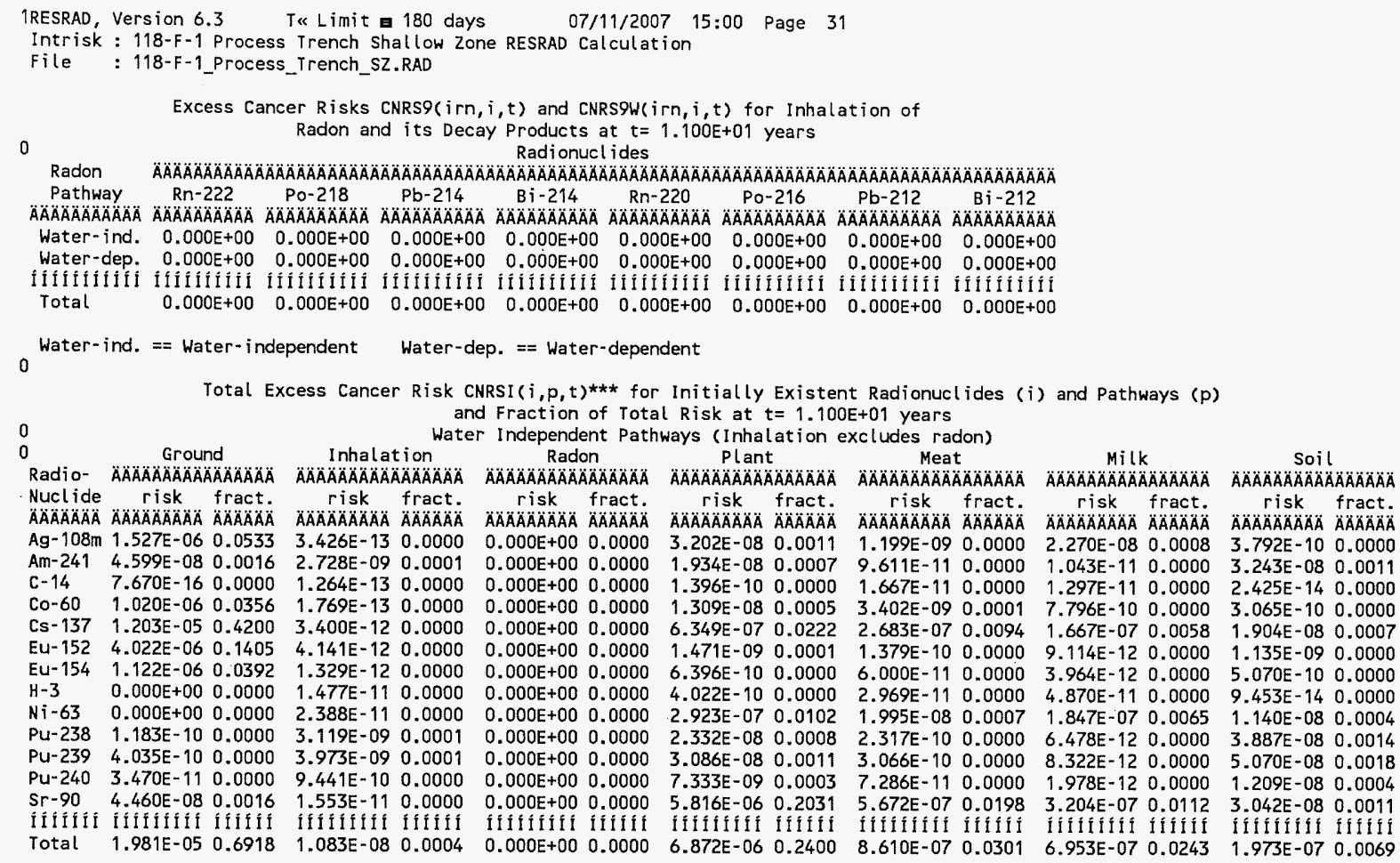

\begin{tabular}{|c|c|}
\hline \multirow{2}{*}{\multicolumn{2}{|c|}{$\begin{array}{lll}\text { Attachment } & 6 & \text { Sheet No. } 31 \text { of } \underline{52} \\
\text { Originator: } & \text { S.W. Clark } & \text { Date }\end{array}$}} \\
\hline & \\
\hline Chk'd By M.W. Perrott & Date \\
\hline $0100 F-C A-V 0280$ & Rev. No. \\
\hline
\end{tabular}




\title{
ATTACHMENT 6
}

\begin{abstract}
IRESRAD, Version $6.3 \quad$ T« Limit $=180$ days
\end{abstract}
File : 118-F-1_Process_Trench_SZ.RAD

Total Excess Cancer Risk CNRSI $(i, p, t) \star \star \star$ for Initially Existent Radionuclides $(i)$ and Pathways $(p)$ and Fraction of Total Risk at $t=1.100 E+01$ years

Water Dependent Pathways

\begin{tabular}{|c|c|c|c|c|c|c|c|c|c|c|c|c|c|c|}
\hline \multirow{2}{*}{$\begin{array}{l}\text { Radio- } \\
\text { Nucl ide } \\
\text { ÄÄÄÄÄÄ }\end{array}$} & \multicolumn{2}{|c|}{ Water } & \multicolumn{2}{|c|}{ Fish } & \multicolumn{2}{|c|}{ Radon } & \multicolumn{2}{|c|}{ Plant } & \multicolumn{2}{|c|}{ Meat } & \multicolumn{2}{|c|}{ Milk } & \multicolumn{2}{|c|}{ All pathways } \\
\hline & risk & $\begin{array}{l}\text { fract. } \\
A B A B A B\end{array}$ & $\begin{array}{c}\text { risk } \\
\text { AAAAAAÄ }\end{array}$ & $\begin{array}{l}\text { fract. } \\
\text { ÄABABA }\end{array}$ & $\begin{array}{c}\text { risk } \\
\text { ABÄÄAAABAA }\end{array}$ & fract. & $\begin{array}{c}r i s k \\
\triangle A B A B A B A O\end{array}$ & $\begin{array}{l}\text { fract. } \\
\because A O A B A B A\end{array}$ & $\begin{array}{c}\text { risk } \\
\triangle A A B A O A B A O A\end{array}$ & & $\begin{array}{c}\text { risk } \\
\text { AAAAAABA }\end{array}$ & $\begin{array}{l}\text { fract. } \\
A B A B A B A\end{array}$ & $\begin{array}{c}\text { risk } \\
\text { AAABAAAOÄ }\end{array}$ & fract. \\
\hline & & & & & & & & & & & & & & \\
\hline & & & & & & & & & & & & & & \\
\hline & & & & & & & & & & & & & & \\
\hline & & & & & & & & & & & & & & \\
\hline & & & & & & & & & & & & & & \\
\hline & & & & & & & & & & & & & & \\
\hline & & & & & & & & & & & & & & \\
\hline & & & & & & & & & & & & & & \\
\hline & & & & & & & & & & & & & & \\
\hline & & & & & & & & & & & & & & \\
\hline & & & & & & & & & & & & & & \\
\hline 4 & & & $E-15$ & 0.00 & $E+00$ & & & & & & & & & \\
\hline & & & & & & & & & & & & & & \\
\hline & & & & & & & & & & & & & & \\
\hline & & & & & & & & & & & & & & \\
\hline
\end{tabular}

$* * *$ CNRSI $(i, p, t)$ includes contribution from decay daughter radionuclides

\begin{tabular}{|c|c|}
\hline Attachment $\quad 6$ & Sheet No. 32 of $\underline{52}$ \\
\hline Originator: S.W. Clark & Date \\
\hline Chk'd By M.W. Perrott & Date \\
\hline $0100 F-C A-V 0280$ & Rev. No. \\
\hline
\end{tabular}




\section{ATTACHMENT 6}

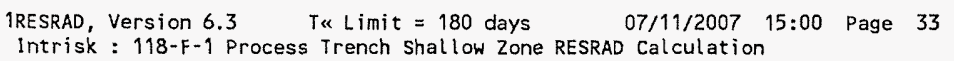

\begin{tabular}{|c|c|}
\hline Attachment & Sheet No. $\underline{33}$ of $\underline{52}$ \\
\hline Originator: S.W. Clark & Date \\
\hline M. W. Perrott & Date \\
\hline 0100F-CA-V0280 & Rev. No. \\
\hline
\end{tabular}




\section{ATTACHMENT 6}

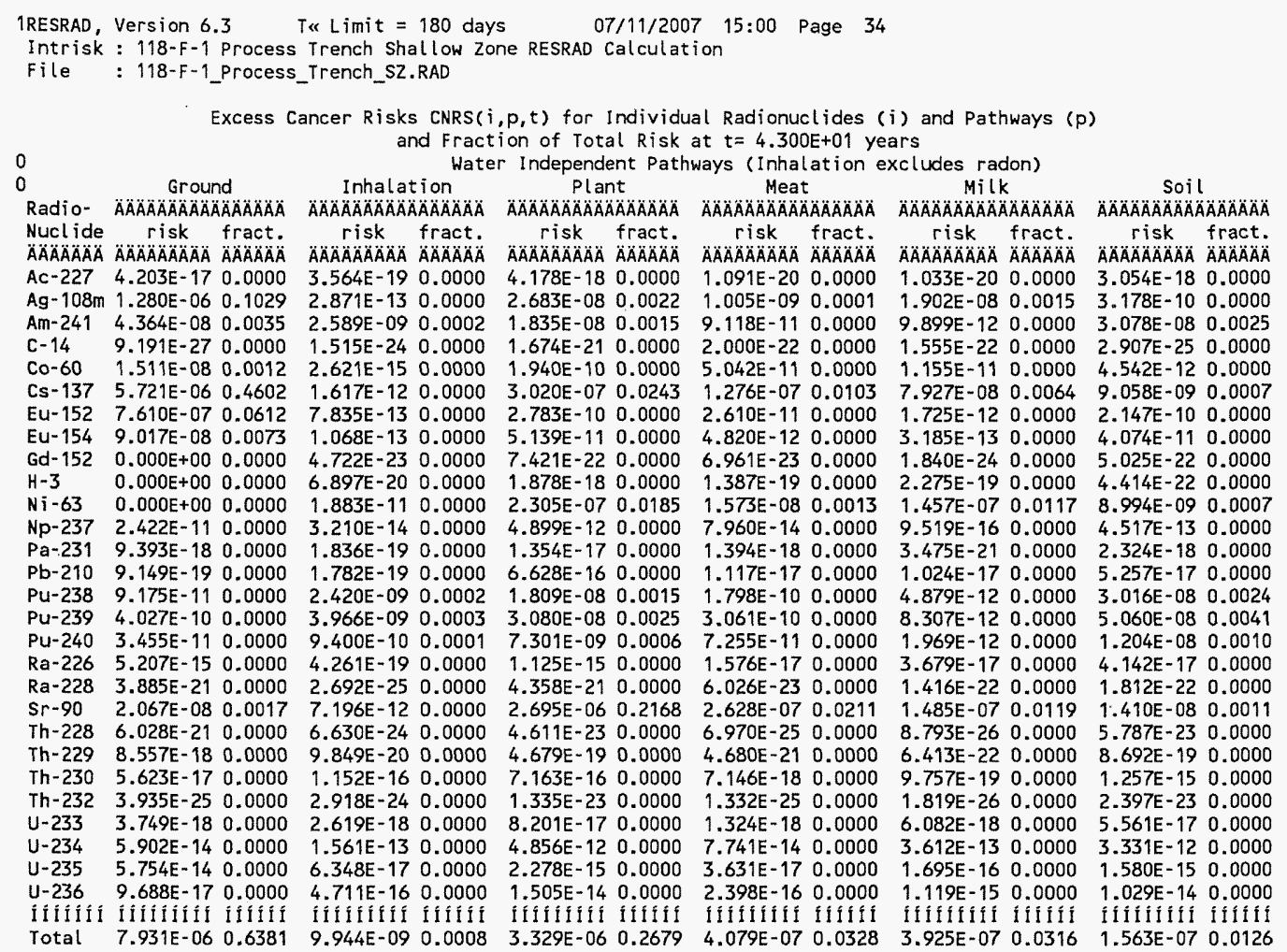

Attachment

Originator: S.W. Clark

Chk'd By M.W. Perrott

Calc. No. $\frac{\text { M. W. Perrott }}{0100 \text {-CA-V0280 }}$
Sheet No. 34 of 52 Date Date Rev. No. 0 


\section{ATTACHMENT 6}

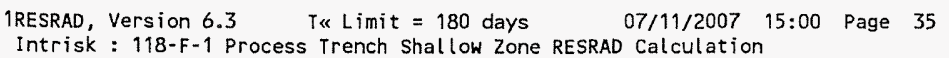

Water Dependent Pathways

\begin{tabular}{|c|c|c|c|c|c|c|c|c|c|c|c|c|}
\hline \multirow{2}{*}{$\begin{array}{l}\text { Radio- } \\
\text { Nuclide } \\
\text { ÄÄÄÄÄÄA }\end{array}$} & \multicolumn{2}{|l|}{ Water } & \multicolumn{2}{|c|}{ Fish } & \multicolumn{2}{|c|}{ Plant } & \multicolumn{2}{|c|}{ Meat } & \multicolumn{2}{|c|}{ Milk } & \multicolumn{2}{|c|}{ Al! Pathways** } \\
\hline & $\begin{array}{c}\text { risk } \\
A A ̈ A A A B A\end{array}$ & $\begin{array}{l}\text { fract. } \\
\triangle A A B A B A B\end{array}$ & $\begin{array}{c}\text { risk } \\
A B A A B A A A A\end{array}$ & $\begin{array}{l}\text { fract. } \\
\text { ÄAÄAOAÄ }\end{array}$ & $\begin{array}{c}\text { risk } \\
A B A B A A A A\end{array}$ & $\begin{array}{l}\text { fract. } \\
\triangle A B A B A B A B\end{array}$ & $\begin{array}{c}\text { risk } \\
\text { ABAAAAAAB }\end{array}$ & fract. & $\begin{array}{c}\text { risk } \\
\text { AAAOAABABA }\end{array}$ & fract. & $\begin{array}{c}\text { risk } \\
\text { AABAAABAO }\end{array}$ & $\begin{array}{l}\text { fract. } \\
A B A B A B\end{array}$ \\
\hline$A c-227$ & $.118 E-16$ & 0.0000 & $1.631 \mathrm{E}-18$ & 0.0000 & $1.657 \mathrm{E}-17$ & 0.0000 & $3.194 \mathrm{E}-20$ & 0.0000 & $6.037 \mathrm{E}-20$ & 0.0000 & & \\
\hline & $0.000 E+00$ & 0.0000 & $000 E+00$ & 0.0000 & $0.000 E+00$ & 0.0000 & $0.000 \mathrm{E}+00$ & 0.0000 & $100 E+00$ & 0.0000 & & \\
\hline$A m-241$ & $0.000 E+00$ & 0.0000 & $0.000 E+00$ & 0.0000 & $0.000 \mathrm{E}+00$ & 0.0000 & $0.000 E+00$ & 0.0000 & $0.000 E+00$ & 0.0000 & $9.547 E-08$ & 0.0077 \\
\hline & $.000 E+00$ & 0.0000 & $000 E+00$ & 0.0000 & $.000 E+00$ & 0.0000 & $0.000 E+00$ & 0.0000 & $0.000 E+00$ & 0.0000 & $2.031 E-21$ & .0000 \\
\hline & & & & & & & & & & & & \\
\hline & -08 & & $=-09$ & & BE-09 & 0.0001 & 7OE-09 & 0.0002 & $E-09$ & 0.0002 & $=-06$ & .5038 \\
\hline & $0.000 E+00$ & 0.0000 & $E E+00$ & 0.0000 & $E+\infty 0$ & 0.0000 & $0 E+00$ & 0.0000 & $E+00$ & 000 & -07 & 613 \\
\hline & $0.000 E+00$ & & $.000 E+00$ & & & & $0.000 E+00$ & & & & & \\
\hline & $0.000 \mathrm{E}+00$ & 0.0000 & $0.000 E+00$ & 0.0000 & $0.000 E+00$ & 0.0000 & $0.000 E+00$ & 0.0000 & $0.000 E+00$ & 0.0000 & & .0000 \\
\hline$H-3$ & $E-17$ & & $E-20$ & & & & $E-18$ & 000 & E-18 & & & 300 \\
\hline & & & & & & & & & & & & \\
\hline & $0.000 E+00$ & 0.0000 & $E+00$ & 0.0000 & $=+\infty$ & 0.0000 & $E+00$ & 0.0000 & $0 E+00$ & 200 & & 000 \\
\hline & 4.35 & & -19 & & -18 & 1000 & -18 & 300 & -21 & & 17 & 000 \\
\hline & & & -17 & & & 0.0000 & & 0.0 & $=-18$ & & & 000 \\
\hline & & & $E+\infty$ & 1000 & DOOE +00 & 0.0000 & $E+00$ & 0.0000 & $E+00$ & 0.0000 & & 0041 \\
\hline & +00 & & $+\infty$ & & $=+00$ & & $2+00$ & & $E+00$ & & & 069 \\
\hline & $E+00$ & & $+\infty 0$ & & & 0.0000 & $+\infty 0$ & 0.0000 & $D E+00$ & 000 & & \\
\hline & & & & & & 0.0000 & & 0.0000 & $E-17$ & 0.0000 & & 000 \\
\hline & $2.186 E-21$ & & -23 & & -22 & & $E-23$ & & $E-23$ & & & \\
\hline & & & -09 & & & 0.0012 & $E-09$ & 006 & E-09 & 004 & .06 & 627 \\
\hline Th-228 & $1.949 E-22$ & 0.0000 & $6.053 E-24$ & 0.0000 & $3.111 \mathrm{E}-23$ & 0.0000 & $3.270 E-25$ & 0.0000 & $4.723 E-26$ & 0.0000 & -21 & 0.0000 \\
\hline & & & $7.993 \mathrm{E}-20$ & & & & & & $1.227 \mathrm{E}-21$ & & & \\
\hline & & & $1.671 E-16$ & & $9.608 E-16$ & & $E-17$ & & $2.089 E-18$ & & & \\
\hline & $1.071 E-22$ & 0.0000 & $3.096 E-24$ & 0.0000 & $1.781 \mathrm{E}-23$ & 0.0000 & $2.206 \mathrm{E}-25$ & 0.0000 & $3.888 E-26$ & 0.0000 & $1.691 \mathrm{E}-22$ & 0.0000 \\
\hline & & & & & & 0.0000 & & & & & & \\
\hline & & & $6.428 E-12$ & & $3.109 E-10$ & 0.0000 & $6.675 E-12$ & & $3.408 \mathrm{E}-11$ & & & \\
\hline & $7.0110-1$ & 0.0000 & $2.798 \mathrm{E}-15$ & 0.0000 & 1. & 0.0000 & $904 \mathrm{E}-15$ & 0.0000 & $1.483 E-14$ & 0.0000 & 1. & 0.0000 \\
\hline & & & & & & 0.0000 & $1.919 E-14$ & & 08005 & & & \\
\hline & & & & & & & & & & & & \\
\hline & & & & & & & & & & & & \\
\hline
\end{tabular}

** Sum of water independent ground, inhalation, plant, meat, milk, soil

and water dependent water, fish, plant, meat, milk pathways

\begin{tabular}{|c|c|}
\hline Attachment & Sheet No. 35 of 52 \\
\hline Originator: $\mathrm{S.W.Clark}$ & Date \\
\hline hk'd By M. W. Perrott & Date \\
\hline $0100 \mathrm{~F}-\mathrm{CA}-\mathrm{V} 0280$ & Rev. No. \\
\hline
\end{tabular}




\section{ATTACHMENT 6}

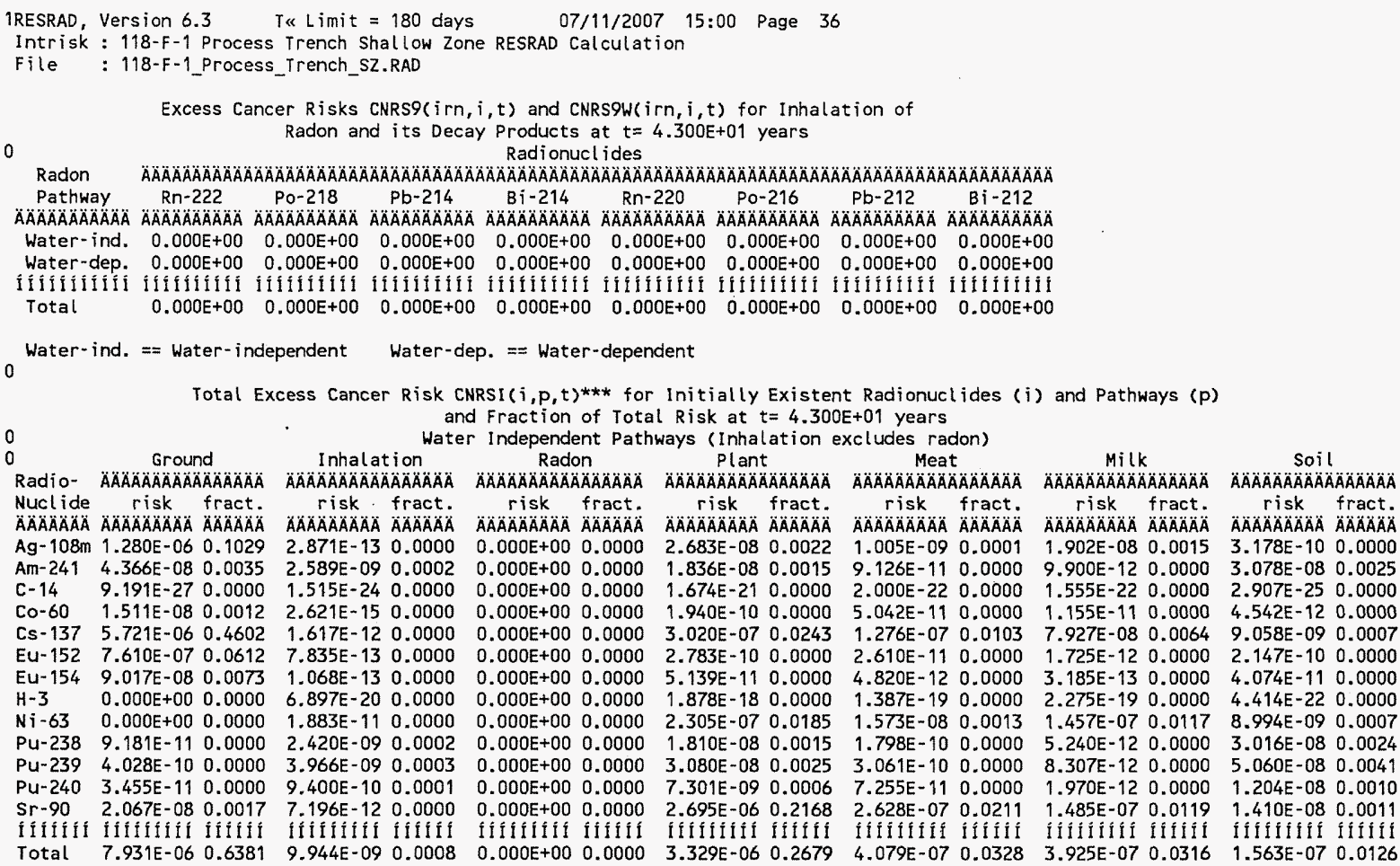

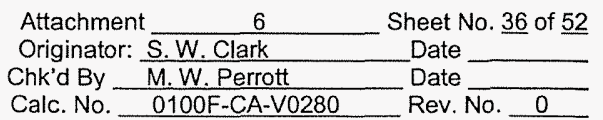




\section{ATTACHMENT 6}

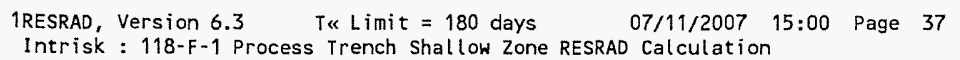

Water Dependent Pathways

\begin{tabular}{|c|c|c|c|c|c|c|c|c|c|c|c|c|c|c|}
\hline \multirow{2}{*}{$\begin{array}{l}\text { Radio- } \\
\text { Nucl ide } \\
\text { ÄAAAAAAAA }\end{array}$} & \multicolumn{2}{|c|}{$\begin{array}{c}\text { Water } \\
\text { ÄÄÄÄÄÄÄÄÄÄÄÄÄÄA }\end{array}$} & \multicolumn{2}{|c|}{ Fish } & \multicolumn{2}{|c|}{ Radon } & \multicolumn{2}{|c|}{ Plant } & \multicolumn{2}{|c|}{ Meat } & \multicolumn{2}{|c|}{ Milk } & \multicolumn{2}{|c|}{ 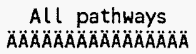 } \\
\hline & $\begin{array}{c}\text { risk } \\
\triangle A A A B A B A A B A\end{array}$ & $\begin{array}{l}\text { fract. } \\
\text { AAAAABÄÄ }\end{array}$ & $\begin{array}{c}\text { risk } \\
\text { ARAAÄÄÄÄ }\end{array}$ & & $\begin{array}{c}\text { risk } \\
\triangle A ̈ A ̈ A ̈ A B A ̈ A\end{array}$ & & $\begin{array}{c}\text { risk } \\
\text { ÄÄÄÄÄÄ }\end{array}$ & & $\begin{array}{c}\text { risk } \\
\text { ÄÄÄÄÄÄÄA }\end{array}$ & $\begin{array}{l}\text { fract. } \\
\text { ÄÄÄÄÄA }\end{array}$ & $\begin{array}{c}\text { risk } \\
A \cap A ̈ A ̈ A ̈ A ̈ A ̈\end{array}$ & & $\begin{array}{c}r i s k \\
A B A A A B A B A\end{array}$ & \\
\hline & $0.000 \mathrm{E}+00$ & & & & & & & & & & & & & \\
\hline & & & & & & & & & & & & & & \\
\hline & & & & & & & & & & & & & & \\
\hline & & & & & & & & & & & & & & \\
\hline & & & & & & & & & & & & & & \\
\hline & & & & & & & & & & & & & & \\
\hline & & & & & & & & & & & & & & \\
\hline & & & & & & & & & & & & & & \\
\hline & & & & & & & & & & & & & & \\
\hline & 2.084 & & & & & & & & & & & & & \\
\hline & & & & & & & & & & & & & & \\
\hline & & & (8) & & 10 & & & & & & & & & \\
\hline & & & & & & & & & & & & & & \\
\hline & & & & & & & & & & & & & & \\
\hline & & & & & & & & & & & & & & \\
\hline
\end{tabular}

$* * *$ CNRSI $(i, p, t)$ includes contribution from decay daughter radionuclides

\begin{tabular}{|c|c|}
\hline Attachment & Sheet No. 37 o \\
\hline Originator: S.W. Clark & Date \\
\hline Chk'd By M.W. Perrott & Date \\
\hline Calc. No. 0100F-CA-V0280 & Rev. No. \\
\hline
\end{tabular}




\section{ATTACHMENT 6}

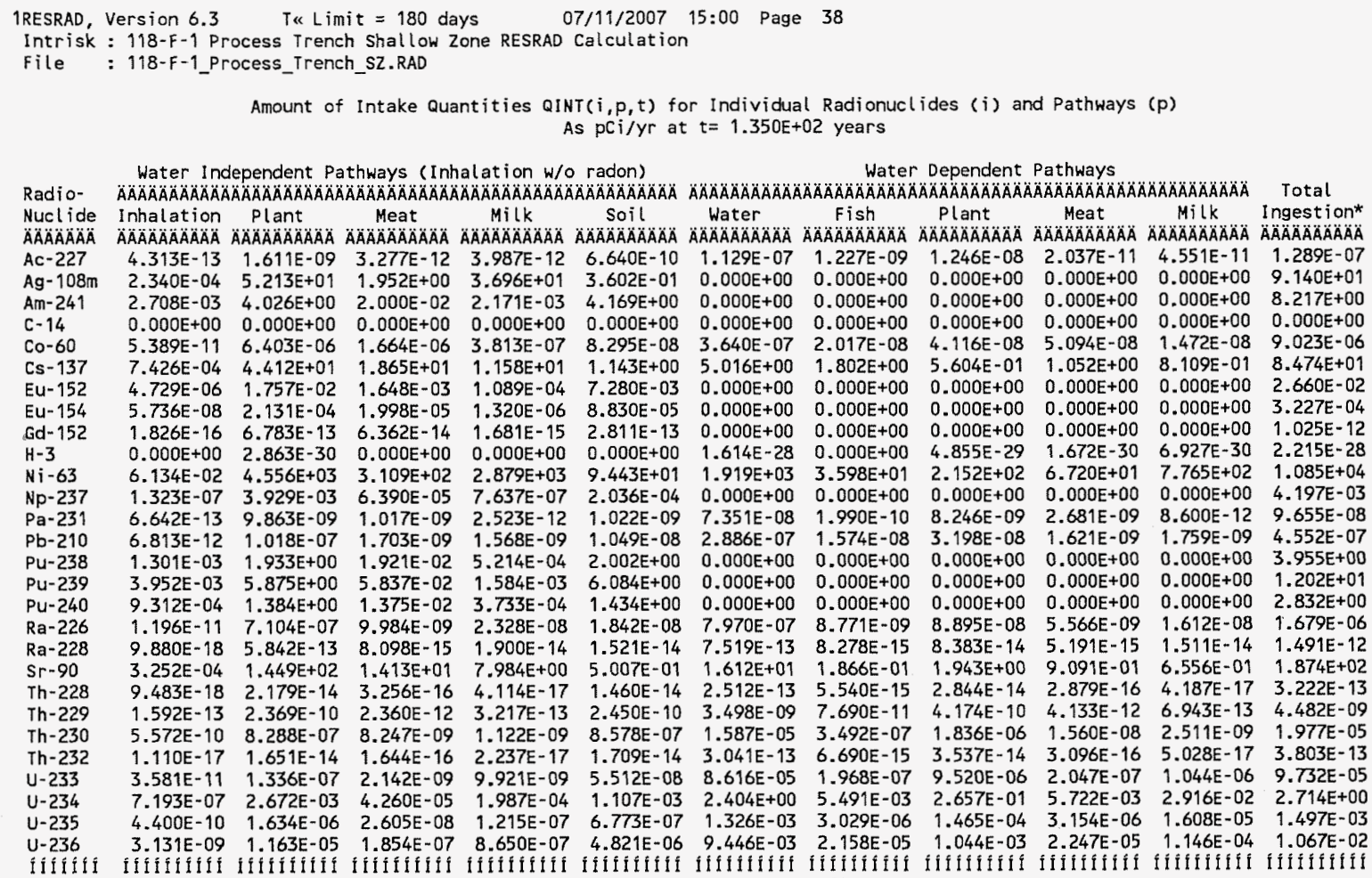

* sum of all ingestion pathways, i.e. water independent plant, meat, milk, soil Sum of all ingestion pathways, i.e. Water independent plant,
and water-dependent water, fish, plant, meat, milk pathways

Amount of Intake Quantities QINT9(irn, $i, t)$ and QINTOW $(i r n, i, t)$ for Inhalation of

0 Radon and $i$ ts Decay Products as pCi/yr at $t=1.350 E+02$ years

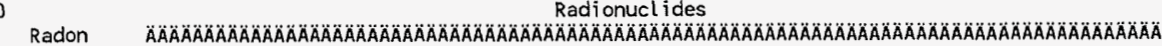

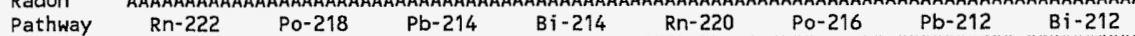

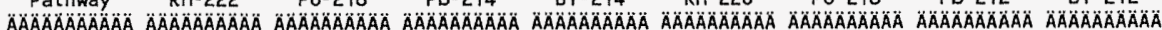

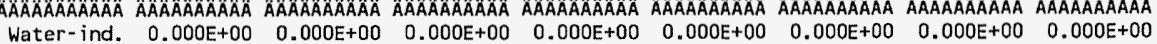
$\begin{array}{lllllllll}\text { Water-ind. } & 0.000 E+00 & 0.000 E+00 & 0.000 E+00 & 0.000 E+00 & 0.000 E+00 & 0.000 E+00 & 0.000 E+00 & 0.000 E+00 \\ \text { Water-dep. } & 0.000 E+00 & 0.000 E+00 & 0.000 E+00 & 0.000 E+00 & 0.000 E+00 & 0.000 E+00 & 0.000 E+00 & 0.000 E+00\end{array}$

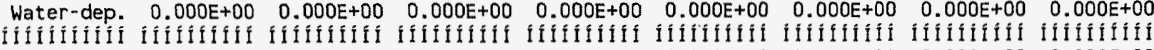

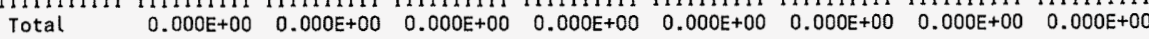

Water-ind. == Water-independent Water-dep. == Water-dependent

\begin{tabular}{ll} 
Attachment $\frac{6}{\text { S.W. Clakk }}$ & Sheet No. 38 of $\underline{52}$ \\
Originator: & Date \\
Chk'd By & Date \\
Calc. No. Perrott & Rev. No. 0 \\
\hline O100F-CA-V0280 & Rev. No
\end{tabular}




\section{ATTACHMENT 6}

\begin{tabular}{|c|c|c|c|c|c|c|c|c|c|c|c|c|}
\hline $\begin{array}{l}\text { 1RESRAD, } \\
\text { Intrisk } \\
\text { File }\end{array}$ & $\begin{array}{l}\text { Version } 6 \\
: 118-F-1 \\
: 118-F-1\end{array}$ & $\begin{array}{l}\text { Process } \\
\text { Process }\end{array}$ & \multicolumn{2}{|c|}{$\begin{array}{l}\text { T« Limit }=180 \text { days } \\
\text { Trench Shallow Zone } \\
\text { _Trench_SZ.RAD }\end{array}$} & \multicolumn{3}{|c|}{$07 / 11 / 2007 \quad 15: 00$} & Page 3 & \\
\hline 0 & \multicolumn{12}{|c|}{$\begin{array}{c}\text { Excess Cancer Risks CNRS }(i, p, t) \text { for Individual Radionuclides ( } i) \text { and Pathways }(p) \\
\text { and Fraction of Total Risk at } t=1.350 E+02 \text { years }\end{array}$} \\
\hline 0 & \multirow{2}{*}{\multicolumn{2}{|c|}{$\begin{array}{c}\text { Ground } \\
\text { AOAAAAAAAOAOAOAAAABA }\end{array}$}} & \multicolumn{2}{|c|}{ Inhalation } & \multicolumn{2}{|c|}{ Plant } & \multirow{2}{*}{\multicolumn{2}{|c|}{$\begin{array}{r}\text { Meat } \\
\triangle A B A O A B A O A\end{array}$}} & \multirow{2}{*}{\multicolumn{2}{|c|}{$\begin{array}{c}M i l k \\
\triangle A \cap A O A O A O A O A B A B A O A O A O A\end{array}$}} & \multicolumn{2}{|c|}{ Soil } \\
\hline Radio- & & & ÄÄÄAAAÄÄÄ & $\triangle A O A A O A O A B$ & $\triangle A \triangle A ̈ A ̈ A ̈ A ̈ A ̈$ & ÄÄÄÄÄÄÄ & & & & & $\triangle A O A A O A O A A A O A$ & ÄÄÄÄÄ \\
\hline $\begin{array}{l}\text { Nuclide } \\
\text { ÄÄÄÄÄÄA }\end{array}$ & $\begin{array}{c}\text { risk } \\
\text { ÄÄÄÄÄÄAOA }\end{array}$ & $\begin{array}{l}\text { fract. } \\
\text { ÄÄÄÄÄA }\end{array}$ & $\begin{array}{c}\text { risk } \\
\triangle A ̈ A ̈ A ̈ A ̈ A B A ̈\end{array}$ & & $\begin{array}{c}\text { risk } \\
\triangle A ̈ A ̈ A ̈ A ̈ A ̈ A ̈\end{array}$ & $\begin{array}{l}\text { fract. } \\
\ddot{A} A \ddot{A} \ddot{A} A \ddot{A}\end{array}$ & $\begin{array}{l}\text { risk } \\
A ̈ A B A B A O A B\end{array}$ & $\begin{array}{l}\text { fract. } \\
\text { ÄAÄÄÄÄ }\end{array}$ & $\begin{array}{c}\text { risk } \\
\triangle A A B A B A O A B A O A\end{array}$ & $\begin{array}{l}\text { fract. } \\
A O A B A O A B A\end{array}$ & $\begin{array}{c}\text { risk } \\
\triangle A A B A ̈ A ̈ A B A O A ̈\end{array}$ & $\begin{array}{l}\text { fract. } \\
\triangle A A A A O A O A\end{array}$ \\
\hline$A C-227$ & & 0.0000 & $E-18$ & .0000 & & 0.0000 & & 0.0000 & $9.946 \mathrm{E}-20$ & 0.0000 & & 000 \\
\hline Ag- $108 m$ & & 0.3181 & & .0000 & & & & 0.0002 & & 0.0047 & $E-10$ & 001 \\
\hline & & & .09 & 0.0009 & .08 & & & & & & -08 & \\
\hline & & & & & & & & & & & & \\
\hline & & & & 0.0000 & & 0.0 & & 0.0 & & 0.0000 & -17 & 000 \\
\hline & & & & & & & & & & & & \\
\hline & & & & & & & & & & & & \\
\hline & & 0.0000 & & .0000 & 3.6 & 0.0 & & 0.0000 & & 0.0 & -14 & 000 \\
\hline & & 0.0 & & & & & & & & & & \\
\hline & & & & & & & & & & & & \\
\hline & & & & & & & & 0.0033 & & 0.0 & & 019 \\
\hline & & & & & & & & & & & & \\
\hline & & & & & & & & & & & & \\
\hline & 2.0 & & & 000 & -14 & 0.0 & & 0.0 & & 0. & & 000 \\
\hline & & & & & & & & & & & & \\
\hline & & & & & & & & & & & & \\
\hline & 3.4 & & & & & & & 0.0 & & & & 049 \\
\hline & & & & & & & & & & & & \\
\hline & & & & & & & & & & & & \\
\hline & 2.2 & & & 0.0000 & -07 & 0.1220 & & 0.0 & & 0. & & \\
\hline & & & & & & & & & & & & \\
\hline & & & & & & & & & & & & \\
\hline & $2.737 \mathrm{E}$ & 0.0000 & 5.6 & 0.0000 & $3 E-15$ & 0.0000 & $3.465 E-17$ & 70.0000 & & & & 000 \\
\hline & & 0.00 & & & & & & & & & & \\
\hline & & & & & & & & & & & & \\
\hline & & & & 0.0000 & & & & 0.00 & & & & 0.0000 \\
\hline & & 0.0000 & $1.451 \mathrm{E}-16$ & 0.0000 & & 0.0000 & & 0.0000 & $3.876 E-16$ & 0.0000 & $3.614 E-15$ & 0.0000 \\
\hline & & & & & & & & & & & & \\
\hline & & & & & & & & & & & & \\
\hline Total & $1.492 E-06$ & 0.6166 & $8.279 E-09$ & 0.0034 & $5.259 E-07$ & 0.2173 & $5.296 E-08$ & 30.0219 & $1.107 \mathrm{E}-07$ & 0.0458 & $1.106 E-07$ & 0.0457 \\
\hline
\end{tabular}

Attachment Originator: S.W. Clark Chk'd By M.W. Perrott Calc. No.

$\frac{\text { M. W. Perrott }}{0100 \text { F-CA-V0280 }}$

Sheet No. 39 of 52 Date Date Rev. No. 0 


\section{ATTACHMENT 6}

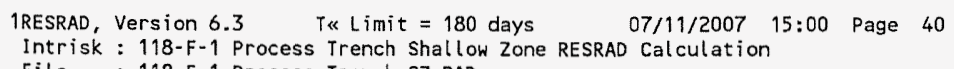

Water Dependent Pathways

\begin{tabular}{|c|c|c|c|c|c|c|c|c|c|c|c|c|}
\hline & $\begin{array}{r}\text { Water } \\
\text { ÄÄAिÄÄÄÄAB }\end{array}$ & ÄÄÄÄÄÄ & $\begin{array}{r}\text { Fish } \\
\text { ÄÄÄÄÄÄÄÄA }\end{array}$ & AAAAAAAAÄ & 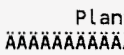 & It & $\begin{array}{r}\text { Meat } \\
\text { A AAAAAAAAAA }\end{array}$ & $A \cap A \cap A A A O A$ & $\begin{array}{r}M i l k \\
\triangle A A O A A O A O A O A B A\end{array}$ & $\triangle A \cap A O A O A B A$ & $\begin{array}{r}\text { All Path } \\
A B A A A B A A B A B\end{array}$ & $\begin{array}{l}\text { hways*** } \\
\text { ÄÄÄÄÄÄÄ }\end{array}$ \\
\hline $\begin{array}{l}\text { Nuclide } \\
\because A B A B A O A O A\end{array}$ & $\begin{array}{c}\text { risk } \\
\text { AAAAAAAA }\end{array}$ & $\begin{array}{l}\text { fract. } \\
\triangle A B A B A B A\end{array}$ & $\begin{array}{c}\text { risk } \\
\text { AAAABAAO }\end{array}$ & fract. & $\begin{array}{c}\text { risk } \\
\text { AAAAAABABA }\end{array}$ & $\begin{array}{l}\text { fract. } \\
\text { ÁAB̈A }\end{array}$ & $\begin{array}{c}\text { risk } \\
\text { AAAAOABAB }\end{array}$ & fract. & $\begin{array}{c}\text { risk } \\
\text { PAABAB }\end{array}$ & fract. & $\begin{array}{c}\text { risk } \\
\text { risa }\end{array}$ & fract. \\
\hline$A C-227$ & 2.226E-15 & & $3.251 \mathrm{E}-17$ & & $3.302 E-16$ & 0.0000 & & 0.0000 & $1.206 E-18$ & 0.0000 & $3.069 \mathrm{E}-15$ & 0.0000 \\
\hline & $O E E+00$ & 0.0000 & $0 E+00$ & 0.0000 & $100 E+00$ & 0.0000 & $0 O E+00$ & & $00 E+00$ & & & \\
\hline $1-241$ & $0.000 E+00$ & 0.0000 & $.000 E+00$ & 0.0000 & $0.000 E+00$ & 0.0000 & $0.000 E+00$ & 0.0000 & $0.000 E+00$ & 0.0000 & $8.215 E-08$ & 0.0339 \\
\hline & & 0.0000 & $0 E+00$ & 00 & $.000 E+00$ & 0.0000 & $0.000 E+00$ & 0.0000 & $0.000 E+00$ & 0.0000 & $E+00$ & 0.0000 \\
\hline & & & & & & & & & & & & \\
\hline & $3.622 \mathrm{E}-09$ & 0.0015 & $.601 \mathrm{E}-09$ & 0.0007 & $.979 E-10$ & 0.0002 & $\varepsilon-10$ & 0.0004 & $E-10$ & 0.0003 & & 3074 \\
\hline & 0.0 & 0.0000 & $E+00$ & 0.0000 & $D E+00$ & 0.0000 & $=+00$ & 0.0000 & $O E+00$ & 0.0000 & & \\
\hline & & & & & $.000 E+00$ & & & & & & & \\
\hline & $0.000 E+00$ & 0.0000 & $.000 E+00$ & 0.0000 & $.000 E+00$ & 0.0000 & $O E+00$ & 0.0000 & $0.000 E+00$ & 0.0000 & & 0.0000 \\
\hline-3 & $0.000 E+00$ & 0.0 & $E+\infty$ & 0.0 & $O E+00$ & 000 & $E+00$ & 0.0 & $E+00$ & & & 000 \\
\hline & & & & & $E-09$ & & & & & & & \\
\hline & $0.000 E+00$ & 0.0 & & & $E+00$ & 0.0000 & & 0.0 & $E+00$ & 0.0000 & & 0. \\
\hline$a-$ & $4.878 E-16$ & 0.0 & -18 & & -17 & & & & -20 & & & \\
\hline & 1.67 & & & & -15 & 000 & & & & & & \\
\hline & 0.00 & & & & $E+00$ & 0000 & $=+00$ & 0.0 & $E+00$ & 000 & & 0.0102 \\
\hline & 0.00 & 0.0 & $+\infty$ & & $+\infty$ & & & & & & & \\
\hline & 0.000 & 0.0000 & $0 E+00$ & & $D E+\infty O$ & 1000 & $=00$ & 0.0 & $O E+00$ & 100 & & \\
\hline & & 0.0 & & & -15 & & & 0.0 & & 0.0 & & \\
\hline & & & & & $=-21$ & & & & & & & \\
\hline & $2.804 E-08$ & & $E-10$ & & $E-09$ & & $=-09$ & & & & & \\
\hline & & & $D E-23$ & & $E-22$ & & $=-24$ & & $E-25$ & & & \\
\hline & 8.04 & & & & $E-17$ & & & 0.0 & $E-20$ & 0.0 & -16 & 0.0000 \\
\hline & & & $1.537 \mathrm{E}-15$ & & $\bar{E}-15$ & & & & & & & \\
\hline & & & & & $\mathrm{EE}-22$ & & & & & & & \\
\hline & & & $7.255 E-16$ & 0.0000 & $3.510 E-14$ & & $7.548 E-16$ & 0.0000 & $3.850 E-15$ & 0.0 & $2.767 E-13$ & 0.0000 \\
\hline & & & $1.659 E-11$ & & $8.029 E-10$ & & & & & & & \\
\hline & & & & & & & & & & & & \\
\hline & & & & & $3.152 E-1$ & & $0.180 \mathrm{E}-$ & 100 & $3.459 \mathrm{E}$ & & & \\
\hline & & & & & & & & & & & & \\
\hline & & & & & & & & & & & & \\
\hline
\end{tabular}

** Sum of water independent ground, inhalation, plant, meat, milk, soil

and water dependent water, fish, plant, meat, milk pathways

\begin{tabular}{|c|c|}
\hline Attachment $\quad 6$ & Sheet No. $\underline{40}$ of $\underline{52}$ \\
\hline Originator: $\overline{\mathrm{S} . \mathrm{W}}$. Clark & Date \\
\hline Chk'd By M.W. Perrott & Date \\
\hline $0100 \mathrm{~F}-\mathrm{CA}-\mathrm{V} 0280$ & Rey \\
\hline
\end{tabular}




\section{ATTACHMENT 6}

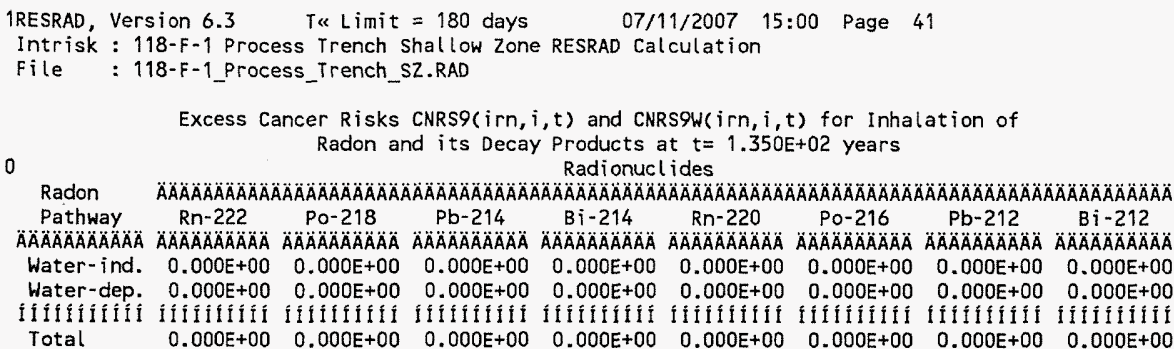

\begin{tabular}{|c|c|}
\hline Attachment & Sheet No. 41 of 52 \\
\hline Originator: S.W. Clark & Date \\
\hline Chk'd By M.W. Perrott & Date \\
\hline $0100 \mathrm{~F}-\mathrm{CA}-\mathrm{V} 0280$ & Rev. No. \\
\hline
\end{tabular}




\section{ATTACHMENT 6}

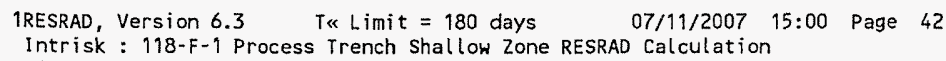

Total Excess Cancer Risk CNRSI $(i, p, t)^{* * *}$ for Initially Existent Radionuclides $(i)$ and Pathways $(p)$ and Fraction of Total Risk at $t=1.350 E+02$ years

Water Dependent Pathways

\begin{tabular}{|c|c|c|c|c|c|c|c|c|c|c|c|c|c|c|}
\hline \multirow[b]{2}{*}{ 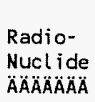 } & \multicolumn{2}{|c|}{ Water } & \multicolumn{2}{|l|}{ Fish } & \multicolumn{2}{|c|}{ Radon } & \multicolumn{2}{|c|}{ Plant } & \multicolumn{2}{|c|}{ Meat } & \multicolumn{2}{|c|}{$\begin{array}{c}\text { Milk } \\
\text { ÄAOAOÄÄÄÄÄÄÄAOÄÄ }\end{array}$} & \multicolumn{2}{|c|}{$\begin{array}{c}\text { All pathways } \\
\text { AAAAAAAAOAOAOAOAOAOAA }\end{array}$} \\
\hline & $\begin{array}{c}\text { risk } \\
\text { AAAAAOAOAOAOA }\end{array}$ & $\begin{array}{l}\text { fract. } \\
\ddot{A} A \ddot{A} A \ddot{A} \ddot{A} \bar{A}\end{array}$ & 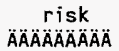 & $\begin{array}{l}\text { fract. } \\
\not A A ̈ A B A ̈ A\end{array}$ & $\begin{array}{c}\text { risk } \\
\text { ÄÄÄÄÄÄÄÄ }\end{array}$ & $\begin{array}{l}\text { fract. } \\
\triangle A A A O A O A\end{array}$ & $\begin{array}{c}\text { risk } \\
\text { ÄÄÄÄÄÄÄÄ }\end{array}$ & $\begin{array}{l}\text { fract. } \\
\text { ÄÄÄÄÄA }\end{array}$ & $\begin{array}{c}\text { risk } \\
\text { AAAOAOAAAAAOA }\end{array}$ & $\begin{array}{l}\text { fract. } \\
\text { ÄÄÄÄÄA }\end{array}$ & $\begin{array}{c}\text { risk } \\
\text { ÄAAOAOAOAOAOA }\end{array}$ & $\begin{array}{l}\text { fract. } \\
\text { ÄAAAOAOA }\end{array}$ & $\begin{array}{c}\text { risk } \\
\text { AAAAAABÄÄÄ }\end{array}$ & $\begin{array}{l}\text { fract. } \\
\text { ÄABAAA }\end{array}$ \\
\hline $\mathrm{Ag}-108 \mathrm{~m}$ & $0.000 E+00$ & 0.0000 & $0.000 E+00$ & 0.0000 & $0.000 E+00$ & 0.0000 & $0.000 E+00$ & 0.0000 & $0.000 E+00$ & 0.0000 & $0.000 E+00$ & 0.0000 & $7.982 E-07$ & 0.3298 \\
\hline & $2.354 E-13$ & 0.0000 & $7.279 E-16$ & 0.0000 & $0.000 E+00$ & 0.0000 & $3.511 \mathrm{E}-14$ & 0.0000 & $7.550 E-16$ & 0.0000 & $3.850 E-15$ & 0.0000 & $8.222 E-08$ & 0.0340 \\
\hline & & & & & $.000 E+00$ & 0.0000 & & & & & $E+00$ & & & \\
\hline 50 & $4.498 E-17$ & 0.0000 & & 0.0000 & $0.000 E+00$ & 0.0000 & $E-18$ & 0.0000 & -18 & 0.0000 & $E-18$ & 0.0000 & & 300 \\
\hline & 3.622 & & & 0.0007 & $0.000 E+00$ & 0.0000 & $E-10$ & 0.0 & -10 & 104 & -10 & 03 & .07 & 074 \\
\hline & $E+00$ & 0.0000 & $+\infty 0$ & 0.0000 & $E+00$ & 0.0000 & $\mathrm{EE}+00$ & 0.0000 & $E+00$ & 0000 & +00 & 000 & & 0026 \\
\hline u- 154 & $0.000 E+00$ & 0.0000 & $E+00$ & 0.0000 & $0.000 E+00$ & 0.0000 & $0.000 E+00$ & 0.0000 & $0.000 E+00$ & 0.0000 & $0.000 E+00$ & 0.0000 & & .0000 \\
\hline 3 & $0.000 E+00$ & & & & & & & & & & & & & \\
\hline$i-6$ & 3.83 & 0.0158 & -09 & 0.0004 & $E+00$ & 0.0000 & $6.102 E-09$ & 0.0025 & -09 & 0.0008 & $E-08$ & 0.0 & 2.72 & 0.1124 \\
\hline Pu-238 & $5.377 E-09$ & 0.0022 & $1.660 E-11$ & 0.0000 & $0.000 E+00$ & 0.0000 & $8.029 E-10$ & 0.0003 & 1.725 & 0.0000 & $E-11$ & 0.0000 & .08 & 0.0128 \\
\hline & & & & & & & & & & & & & & \\
\hline & $2.116 E-11$ & 0.0000 & $6.515 E-14$ & 0.0000 & $0.000 E+00$ & 0.0000 & $3.152 E-12$ & 0.0000 & $E-14$ & 0.0000 & & 0.0000 & & 0.0083 \\
\hline & & & $4.180 E-10$ & 0.0002 & $0.000 E+00$ & 0.0000 & $4.351 \mathrm{E}-\mathrm{C}$ & 0.0018 & $037 E-09$ & 0.0008 & & & & 0.1572 \\
\hline & & & & & & & & & & & & & & \\
\hline & $7.541 E-08$ & 0.0312 & $3.056 \mathrm{E}-09$ & 0.0013 & $0.000 \mathrm{E}+00$ & 0.0000 & $1.176 \mathrm{E}-08$ & 0.0049 & 4.895 & 0.0020 & 2.430 & 0.0100 & -06 & 1.000 \\
\hline
\end{tabular}

***CNRSI $(i, p, t)$ includes contribution from decay daughter radionuclides

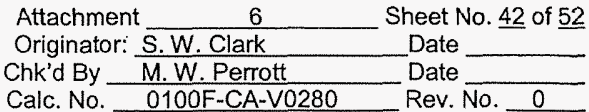




\section{ATTACHMENT 6}

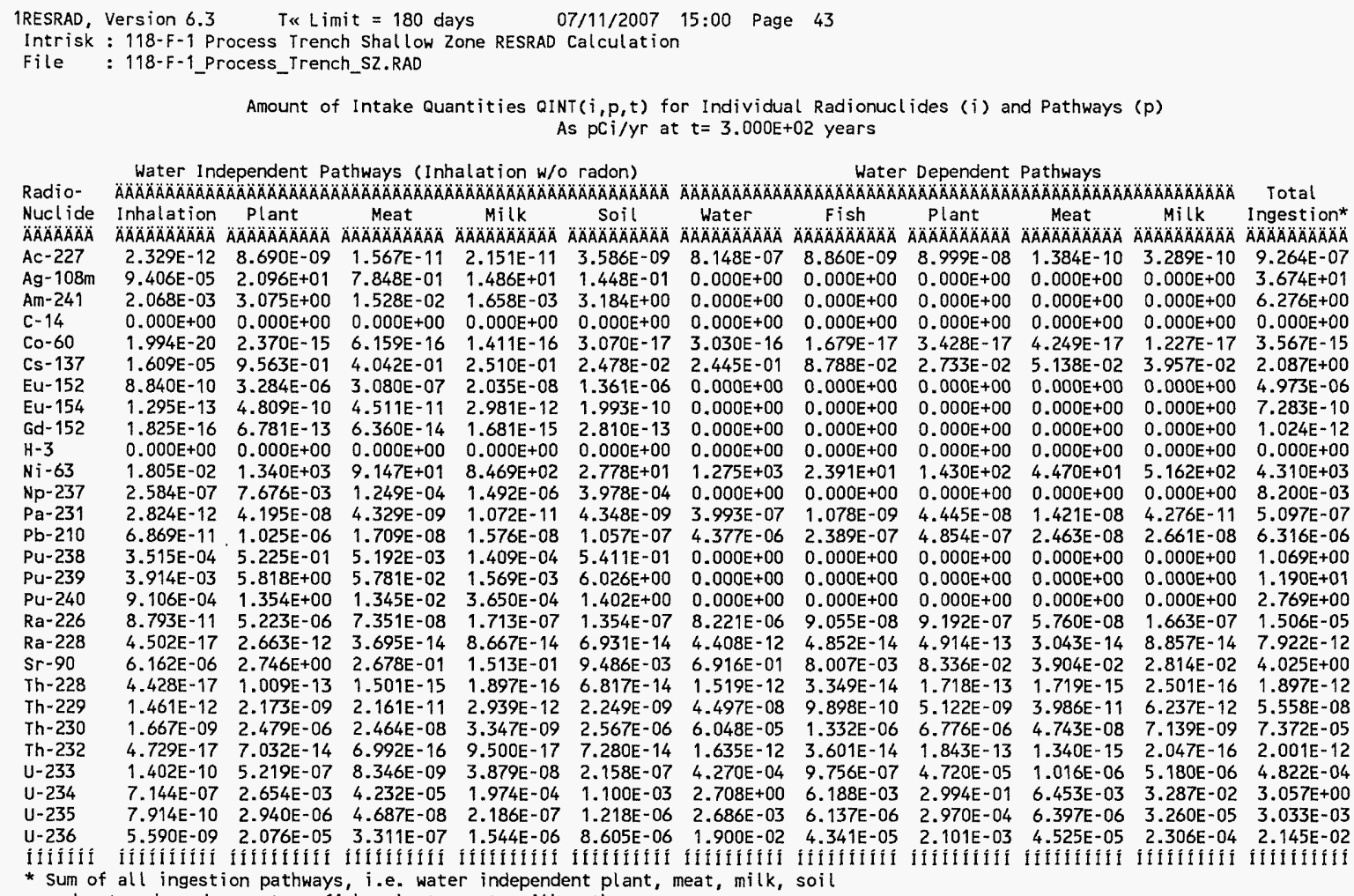
0 and water-dependent water, fish, plant, meat, milk pathways

\footnotetext{
Radon and its Decay Products as $p C i / y r$ at $t=3.000 E+02$ years Radi onucl ides

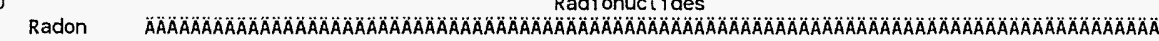

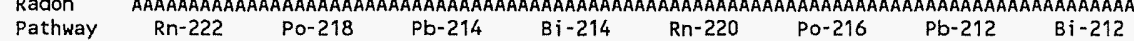

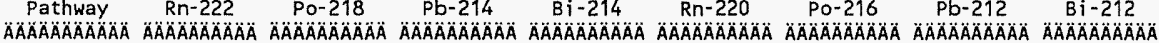

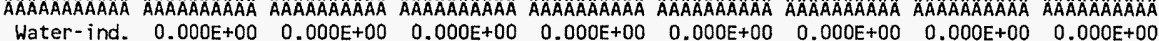
$\begin{array}{lllllllll}\text { Water-ind. } & 0.000 E+00 & 0.000 E+00 & 0.000 E+00 & 0.000 E+00 & 0.000 E+00 & 0.000 E+00 & 0.000 E+00 & 0.000 E+00 \\ \text { water-dep. } & 0.000 E+00 & 0.000 E+00 & 0.000 E+00 & 0.000 E+00 & 0.000 E+00 & 0.000 E+00 & 0.000 E+00 & 0.000 E+00\end{array}$

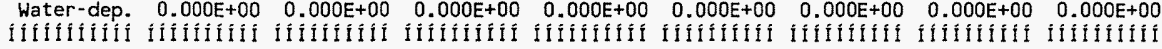

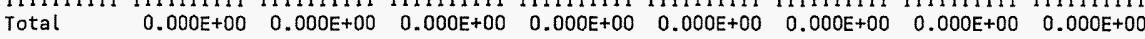

Amount of Intake Quantities QINT9 $(i r n, i, t)$ and QINTQW(irn, $i, t)$ for Inhalation of

0

Water-ind. $==$ Water-independent Water-dep. $==$ Water-dependent

\begin{tabular}{|c|c|}
\hline Attachment & Sheet No. $\underline{43}$ of $\underline{52}$ \\
\hline Originator: S.W. Clark & Date \\
\hline M. W. Perrott & Date \\
\hline $0100 \mathrm{~F}-\mathrm{CA}-\mathrm{V} 0280$ & Rev. No. \\
\hline
\end{tabular}




\section{ATTACHMENT 6}

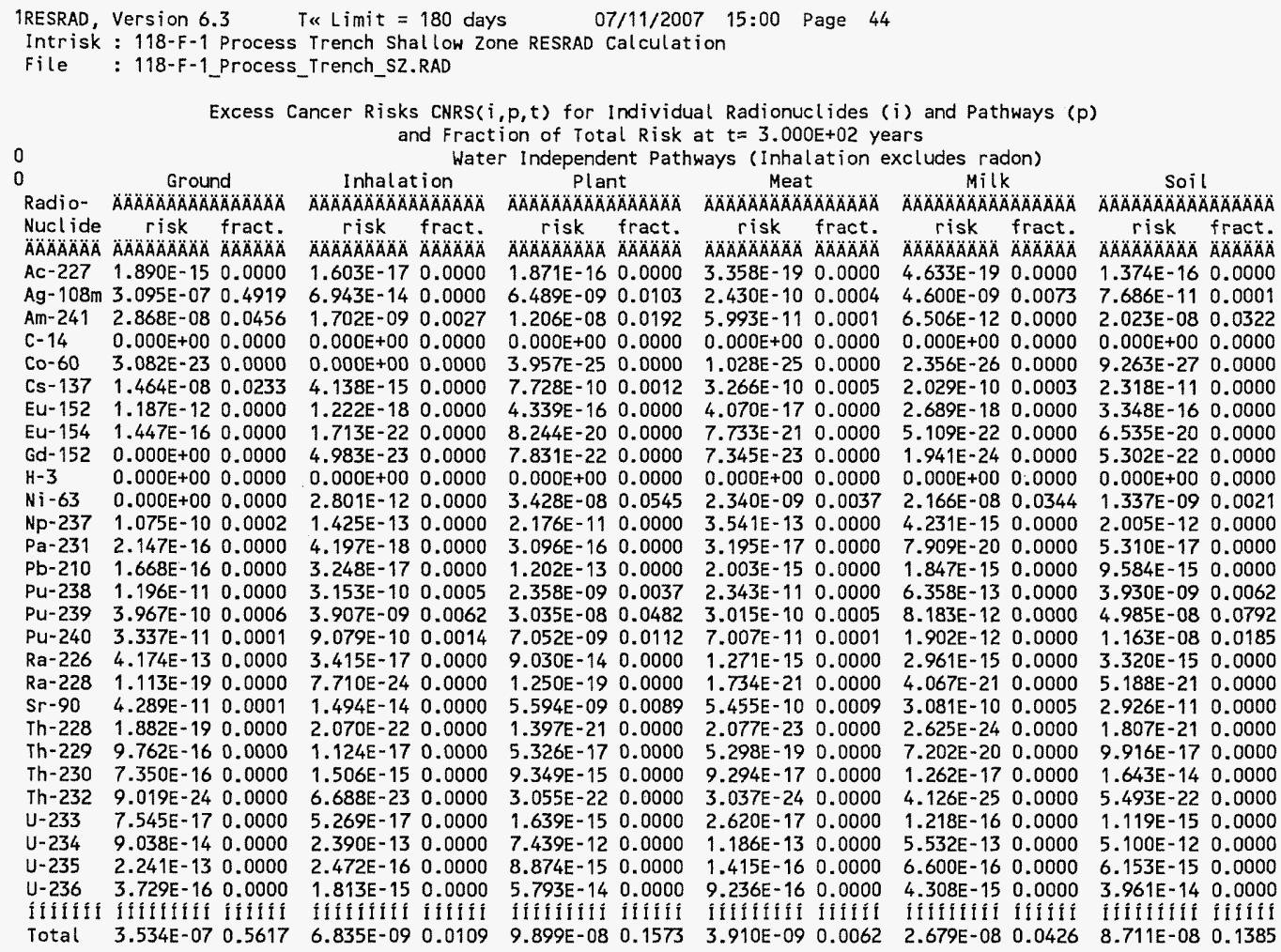

\begin{tabular}{|c|c|}
\hline Attachment & Sheet No. $\underline{44}$ of $\underline{52}$ \\
\hline Originator: S.W. Clark & Date \\
\hline Chk'd By M.W. Perrott & Date \\
\hline $0100 \mathrm{~F}-\mathrm{CA}-\mathrm{V} 0280$ & Rev. No. \\
\hline
\end{tabular}


Rev. 0

\section{ATTACHMENT 6}

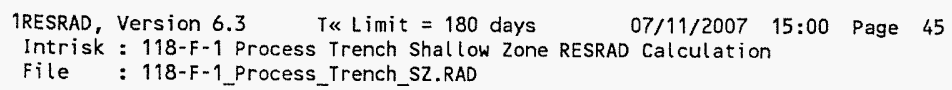

Excess Cancer Risks CNRS $(i, p, t)$ for Individual Radionuclides ( $i$ ) and Pathways $(p)$ and Fraction of Total $R$ isk at $t=3.000 E+02$ years

Water Dependent Pathways

\begin{tabular}{|c|c|c|c|c|c|c|c|c|c|c|c|c|}
\hline & $\begin{array}{r}\text { Water } \\
\text { AAAAAAAAAA }\end{array}$ & ÄAAAAAOA & $\begin{aligned} F i \text { sh } \\
\text { ÄÄÄÄÄÄÄÄA }\end{aligned}$ & 角 & $\begin{array}{r}\text { Plan } \\
\text { ÄÄĀÄÄÄÄĂ }\end{array}$ & nt & $\begin{array}{r}\text { Mea } \\
\text { ÄÄÄÄÄÄA }\end{array}$ & I & $\begin{array}{r}M i l k \\
\text { ÄÄÄÄÄÄÄA }\end{array}$ & $\triangle A A A A O A A$ & $\begin{array}{l}\text { All Path } \\
\text { AAAAAAAAAAAB }\end{array}$ & $\begin{array}{l}\text { hways }{ }^{\star \star} \\
A \mathscr{A} A A A A A ̈\end{array}$ \\
\hline $\begin{array}{l}\text { Nuclide } \\
A \mathscr{A} A ̈ A O A B A\end{array}$ & $\begin{array}{c}\text { risk } \\
A A B A A A B A B\end{array}$ & $\begin{array}{l}\text { fract. } \\
A \cap A O A B A B\end{array}$ & $\begin{array}{c}\text { risk } \\
\text { AAÄÄÄÄÄ }\end{array}$ & $\begin{array}{l}\text { fract. } \\
\triangle A B A O A B A B\end{array}$ & $\begin{array}{c}\text { risk } \\
\triangle A A ̈ A ̈ A ̈ A ̈ A ̈ A ̈\end{array}$ & $\begin{array}{l}\text { fract. } \\
A B A O A B A\end{array}$ & $\begin{array}{c}\text { risk } \\
\triangle A B A O A B A O A B A\end{array}$ & $\begin{array}{l}\text { fract. } \\
\triangle A B A A B A B A\end{array}$ & $\begin{array}{c}\text { risk } \\
\triangle A ̈ A A B A O A B A O A\end{array}$ & $\begin{array}{l}\text { fract. } \\
\triangle A A B A A B A\end{array}$ & $\begin{array}{c}\text { risk } \\
A B A A B A B A O\end{array}$ & $\begin{array}{l}\text { fract. } \\
\text { A } A A O A O A B\end{array}$ \\
\hline דבר & $1.320 E-14$ & 0.0000 & $1.928 \mathrm{E}-16$ & 0.0000 & $1.958 \mathrm{E}-15$ & 0.0000 & $3.003 E-18$ & 0.0000 & 7.157E-18 & 0.0000 & $1.759 E-14$ & 0.0000 \\
\hline & $0.000 E+00$ & 0.0000 & $0.000 E+00$ & 0.0000 & $0.000 \mathrm{E}+00$ & 0.0000 & $0.000 E+00$ & 0.0000 & $0.000 E+00$ & 0.0000 & $3.209 E-07$ & 0.5100 \\
\hline & $30 E+00$ & 0.0000 & $0.000 E+00$ & 0.0000 & $.000 \mathrm{E}+00$ & 0.0000 & $0.000 E+00$ & 0.0000 & $0.000 E+00$ & 0.0000 & $6.274 \mathrm{E}-08$ & 0.0997 \\
\hline & & & $O E E+O O$ & 0.0000 & $.000 E+00$ & 0.0000 & $0.000 E+00$ & & $0.000 E+00$ & 0000 & +00 & 0000 \\
\hline & & 000 & $O E-27$ & 0.0000 & $.856 E-27$ & 0.0000 & $7.249 \mathrm{E}-27$ & 0.0000 & $2.093 E-27$ & 0.0000 & $E-23$ & 0.0000 \\
\hline & & 003 & $7.423 E-11$ & 0.0001 & $2.309 E-11$ & 0.0000 & 4.3 & 0.0001 & $3.343 E-11$ & 0.0001 & $1.631 \mathrm{E}-08$ & 2259 \\
\hline & & & & & $.000 E+00$ & 0.0000 & $0.000 E+00$ & 0.0000 & $0.000 E+00$ & 0.0000 & 12 & 0000 \\
\hline & 0.00 & & DEE+00 & 0.0000 & $0.000 E+00$ & 0.0000 & & & $E+00$ & & & \\
\hline & $0.000 E+00$ & 0.0000 & $0.000 \mathrm{E}+00$ & 0.0000 & $0.000 E+00$ & 0.0000 & $0.000 E+00$ & 0.0000 & $O O E+00$ & & 1.4 & 000 \\
\hline & & & $O E+00$ & 0.0000 & $0.000 E+00$ & 0.0000 & $0.000 \mathrm{E}+00$ & 0.0000 & $0.000 E+00$ & 0000 & $000 E+00$ & 0000 \\
\hline & & & & & & & & 0.0 & $1.386 E-08$ & 0.0220 & $1.033 \mathrm{E}-07$ & 0.1642 \\
\hline 237 & $0.000 E+00$ & 0.0000 & $0 E+00$ & 0.0000 & $0.000 E+00$ & & & & & & & \\
\hline & & & $=-18$ & 0.0 & $E-16$ & 0000 & 1.05 & 0. & & & & \\
\hline & & & & & & 000 & 2.9 & 0.0000 & -15 & & & \\
\hline 23 & $0.000 E+00$ & & $0 E+00$ & & & & & & & & & 106 \\
\hline & $0.000 E+00$ & 0.0000 & $0.000 E+00$ & 0.0000 & $0.000 E+00$ & 0000 & 0.000 & & & & & \\
\hline & & & +00 & & $E+00$ & 0.0000 & $0.000 E+00$ & 0.0000 & $00 E+00$ & & & \\
\hline & & & & & -14 & & & & & & & 0.0000 \\
\hline & 1.5 & & $=-21$ & & $32 E-20$ & & & & & & & 1000 \\
\hline & & & $1.7 \mathrm{C}$ & 0.0000 & $1.776 E-10$ & 0.0003 & $=-11$ & 0.0001 & & & & \\
\hline & 1.5 & & & & & 0.0000 & & 0. & & 000 & & 0.0000 \\
\hline & & & & & $1.264 E-16$ & & 9.73 & 0.0 & $1.519 E-19$ & & $E-15$ & 0.0000 \\
\hline & & & 5.0 & & 5E-14 & & & & & & $:-13$ & 0.0000 \\
\hline & & & & & $.053 E-22$ & 0.0000 & 5.814 & & & & & \\
\hline & & & $3.088 E-15$ & 0.0000 & $1.494 \mathrm{E}-13$ & 0.0000 & $3.218 \mathrm{E}-$ & & & & & 0000 \\
\hline & & & $1 E-11$ & & $8.424 E-10$ & & $1.816 \mathrm{E}-11$ & 0.0 & & & $6.625 \mathrm{E}-09$ & 0.0105 \\
\hline & FE- & & & & & & $E-14$ & & & & & \\
\hline & & & & & & & & & & & & \\
\hline & & & & & & Ififlif & Iffiftifit & & fifififi & & 111111 & tififi \\
\hline & TKL & & 1.509E-10 & 0.0012 & $4.890 E-09$ & 0.0078 & $1.345 E-09$ & & $1.405 E-08$ & 0.0223 & $6.292 \mathrm{E}-07$ & 1.0000 \\
\hline
\end{tabular}

** Sum of water independent ground, inhalation, plant, meat, milk, soil

and water dependent water, fish, plant, meat, milk pathways

$\begin{array}{ll}\text { Attachment } \frac{6}{\text { S.W. Clark }} & \text { Sheet No. } \underline{45} \text { of } \underline{52} \\ \text { Originator: } \frac{\text { S.W. }}{\text { M.W. Perrott }} & \text { Date } \\ \text { Chk'd By } & \text { Rev. No. } 0 \\ \text { Calc. No. } 0100 \text { F-CA-V0280 } & \text { Rev. No }\end{array}$




\section{ATTACHMENT 6}

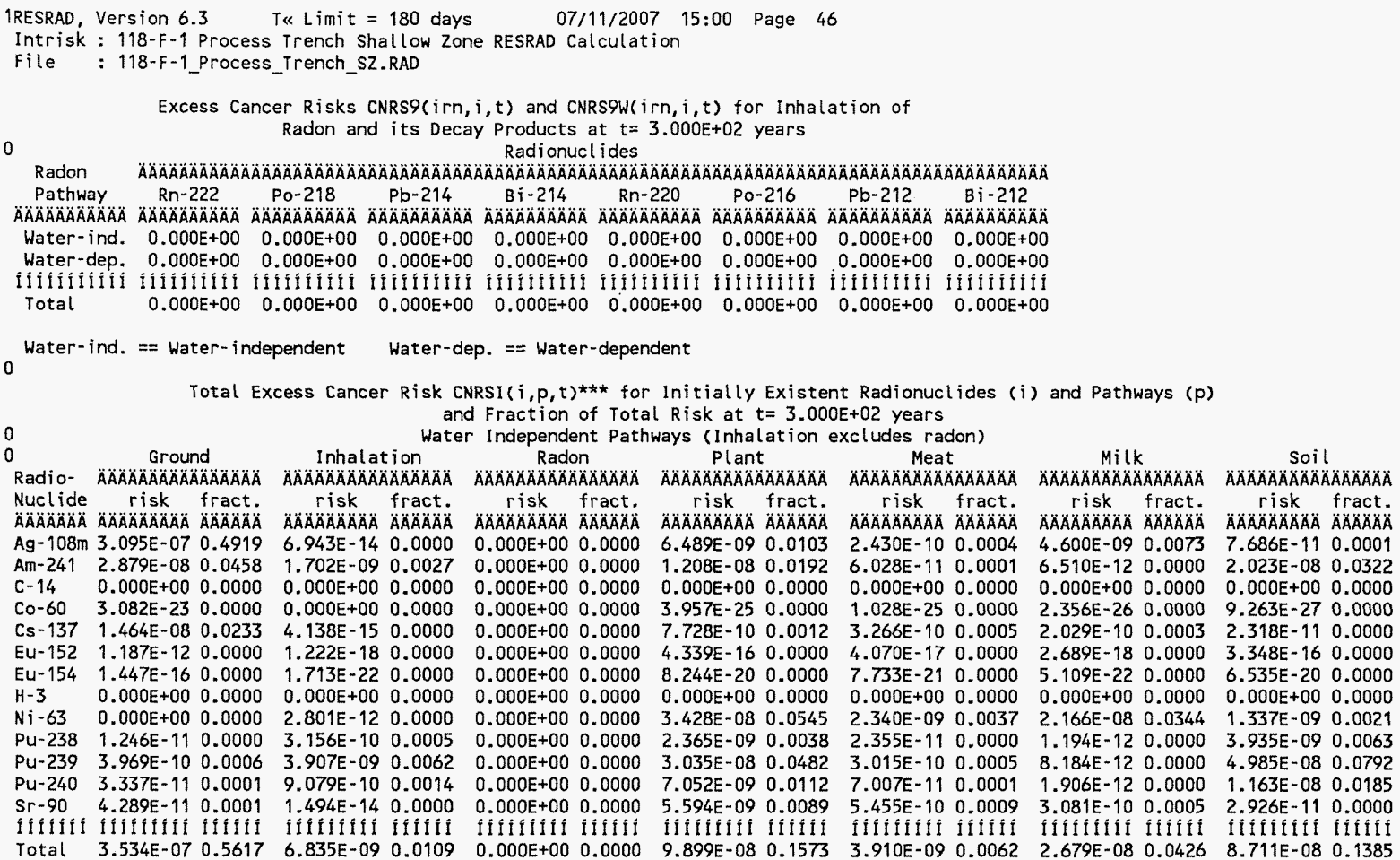




\section{ATTACHMENT 6}

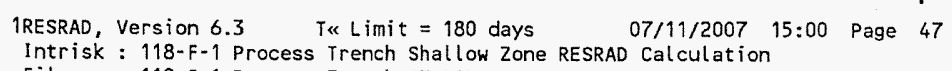

Water Dependent Pathways

\begin{tabular}{|c|c|c|c|c|c|c|c|c|c|c|c|c|c|c|}
\hline & $\begin{array}{r}\text { Water } \\
\text { ÄÄÄÄÄÄÄÄA }\end{array}$ & ÄA & $\begin{array}{r}F i s \zeta \\
A B A A A A A B A\end{array}$ & ÄÄÄÄÄÄÄ & $\begin{array}{r}\text { Rad } \\
\text { ÄÄÄÂÄÄÄÄ }\end{array}$ & on & 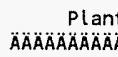 & t & $\begin{array}{r}M e \\
A \cap A O A O A ̈ A ̈\end{array}$ & $\triangle A \cap A \cap A \cap A ̈ A ̈ A$ & $\begin{array}{r}M i l K \\
\text { MAOAOAOÄÄÄÁ }\end{array}$ & $\triangle A O A O A O A B A$ & 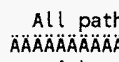 & $\begin{array}{l}\text { hways } \\
A A B A O A O A\end{array}$ \\
\hline $\begin{array}{l}\text { le } \\
\ddot{A}\end{array}$ & risk & & $\begin{array}{c}\text { risk } \\
\text { AिAिÄÄÄÄA }\end{array}$ & $\begin{array}{l}\text { fract. } \\
\text { ÄÄÄÄÄA }\end{array}$ & $\begin{array}{c}\text { risk } \\
\triangle A A A A A A A A A\end{array}$ & $\begin{array}{l}\text { fract. } \\
A B A A A B A\end{array}$ & $\begin{array}{c}\text { risk } \\
\text { AAAAAAAAAA }\end{array}$ & $\begin{array}{l}\text { fract. } \\
\text { ÄÄÄÄÄA }\end{array}$ & $\begin{array}{c}\text { risk } \\
\text { AAAAAÄÄÄA }\end{array}$ & & $\begin{array}{c}\text { risk } \\
\text { ÄAÄÄÄÄÄ }\end{array}$ & & $\begin{array}{c}\text { risk } \\
A \cap A B A A B A B A\end{array}$ & \\
\hline & & & & & $E+00$ & .0000 & $000 E+00$ & & & & $0.000 \mathrm{E}+00$ & & & \\
\hline & & & & & & & & & & & & & & \\
\hline & & & & & & & & & & & & & & \\
\hline & & & & & & & & & & & & & & \\
\hline & & & & & & & & & & & & & & \\
\hline & & & & & & & & & & & & & & \\
\hline & & & & & & & & & & & & & & \\
\hline & & & & & & & & & & & & & & \\
\hline & & & & & & & & & & & & & & \\
\hline & & & & & & & & & & & & & & \\
\hline & & & & & & & & & & & & & & \\
\hline & & & & & & & & & & & & & & \\
\hline & & & & & & & & & & & & & & \\
\hline & & & & & & & & & & & & & & \\
\hline & & & & & & & & & & & & & & \\
\hline
\end{tabular}

***CNRSI $(i, p, t)$ includes contribution from decay daughter radionuclides

\begin{tabular}{|c|c|}
\hline Attachment & Sheet No. 47 of $\underline{52}$ \\
\hline Originator: S.W. Clark & Date \\
\hline Chk'd By M.W. Perrott & Date \\
\hline Calc. No. $0100 F-C A-V 0280$ & Rev. No. \\
\hline
\end{tabular}




\section{ATTACHMENT 6}

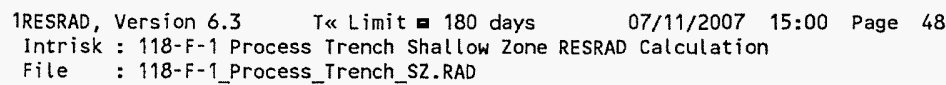

Water-ind. $=$ Water-independent $\quad$ Water-dep. $==$ Water-dependent

\begin{tabular}{|c|c|}
\hline Attachment & Sheet No. $\underline{48}$ of $\underline{52}$ \\
\hline Originator: S.W. Clark & Date \\
\hline Chk'd By M. W. Perrott & Date. \\
\hline $0100 \mathrm{~F}-\mathrm{CA}-\mathrm{V} 0280$ & Rev. No. \\
\hline
\end{tabular}




\section{ATTACHMENT 6}

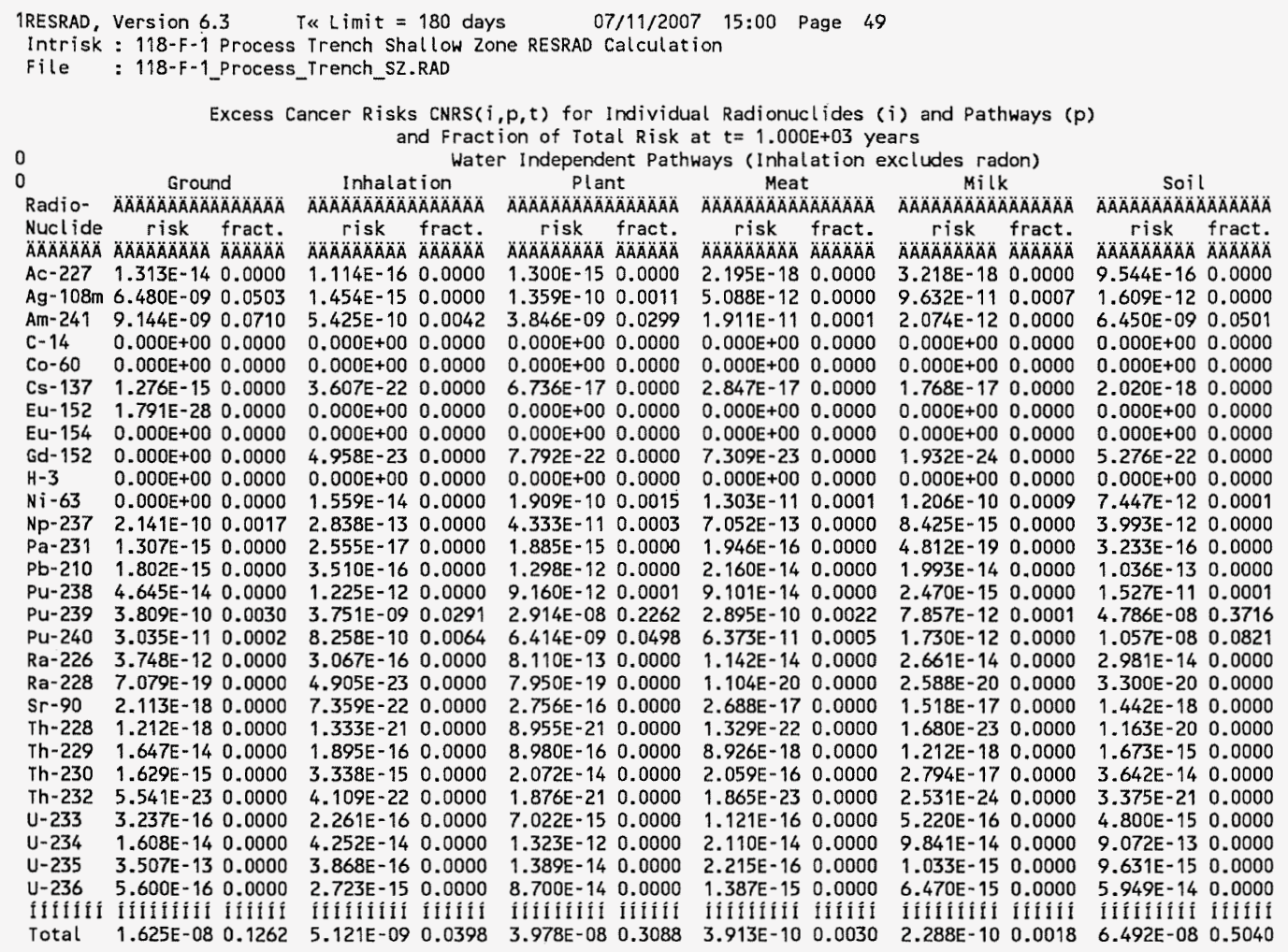

\begin{tabular}{|c|c|}
\hline Attachment & Sheet No. 49 of 52 \\
\hline Originator: S.W. Clark & Date \\
\hline Chik'd By M. W. Perrott & Date \\
\hline 0100F-CA-V0280 & Rev. No. \\
\hline
\end{tabular}




\section{ATTACHMENT 6}

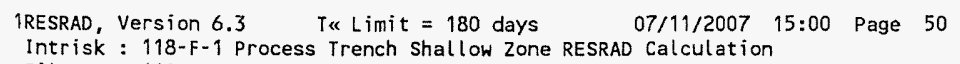

Water Dependent Pathways

\begin{tabular}{|c|c|c|c|c|c|c|c|c|c|c|c|c|}
\hline & \multicolumn{2}{|c|}{ Water } & \multicolumn{2}{|c|}{ Fish } & \multicolumn{2}{|c|}{ Plant } & \multicolumn{2}{|c|}{ Meat } & \multicolumn{2}{|c|}{ Milk } & \multicolumn{2}{|c|}{ All Pathways** } \\
\hline $\begin{array}{l}\text { Nuclide } \\
\triangle A O A O A O A O A O A\end{array}$ & $\begin{array}{c}\text { risk } \\
\triangle A B A B A A O A B\end{array}$ & $\begin{array}{l}\text { fract. } \\
\dddot{A} \ddot{A} \ddot{A} \ddot{A} \ddot{A} A\end{array}$ & 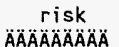 & $\begin{array}{l}\text { fract. } \\
\triangle A O A B A O A B\end{array}$ & $\begin{array}{c}\text { risk } \\
\triangle A O A B A O A O A O A\end{array}$ & $\begin{array}{l}\text { fract. } \\
\dddot{A} A \ddot{A} \ddot{A} \ddot{A} \ddot{A}\end{array}$ & $\begin{array}{c}\text { risk } \\
\triangle A \cap A ̈ A ̈ A O A B A ̈\end{array}$ & $\begin{array}{l}\text { fract. } \\
\triangle A A B A B A B A\end{array}$ & $\begin{array}{c}\text { risk } \\
\triangle A \triangle A B A O A O A O A O\end{array}$ & $\begin{array}{l}\text { fract. } \\
\triangle A A A A A O A\end{array}$ & $\begin{array}{c}\text { risk } \\
\text { ÄAAAOAOAOAOA }\end{array}$ & $\begin{array}{l}\text { fract. } \\
\qquad A \cap A C A A B A\end{array}$ \\
\hline & $1.028 \mathrm{E}-13$ & 0.0000 & $1.502 E-15$ & 0.0000 & $1.526 E-14$ & 0.0000 & $2.284 E-17$ & 0.0000 & & & & \\
\hline$-108 m$ & $0.000 E+00$ & 0.0000 & $0.000 E+00$ & 0.0000 & $0.000 E+00$ & 0.0000 & $0.000 E+00$ & 0.0000 & $0.000 E+00$ & 0.0000 & $6.719 E-09$ & 0.0522 \\
\hline & $0.000 E+00$ & 0.0000 & $0.000 E+00$ & 0.0000 & $.000 E+00$ & 0.0000 & $.000 E+00$ & 0.0000 & $0.000 E+00$ & 0.0000 & $2.000 E-08$ & \\
\hline & & & & & $.000 E+00$ & & $.000 E+00$ & 0.0000 & $.000 E+00$ & & & \\
\hline 50 & $O O E+00$ & 0.0000 & $0.000 E+00$ & 0.0000 & $.000 E+00$ & 0.0000 & $0.000 E+00$ & 0.0000 & $0.000 E+00$ & 0.0000 & $0.000 E+00$ & 0.0000 \\
\hline & & 0.0000 & $3 E-17$ & 0.0000 & $6.854 E-18$ & 0.0000 & $.289 E-17$ & 0.0000 & $9.925 E-18$ & 0.0000 & $1.493 E-15$ & 0000 \\
\hline & & & & & & & & & $D O E+0 O$ & & & \\
\hline & $0.000 E+00$ & 0.0000 & $0.000 E+00$ & 0.0000 & $.000 E+00$ & 0.0000 & $0.000 E+00$ & 0.0000 & $300 E+00$ & 2000 & $E+00$ & 0000 \\
\hline & $E+00$ & 0.0 & $0.000 \mathrm{E}+00$ & 0.0000 & $0.000 E+00$ & 000 & $0.000 E+00$ & 0000 & $O O E+00$ & 00 & -21 & 0000 \\
\hline & & & $E+00$ & & $+\infty$ & & $E+00$ & & & & & \\
\hline & $4.642 \mathrm{E}$ & 0.00 & $6 E-11$ & 0.0001 & $=-11$ & & & & $58 E-10$ & & & 0091 \\
\hline$p-2$ & $O E+00$ & & $E+00$ & & $0 E+00$ & & $.000 E+00$ & & $D O E+00$ & 100 & -10 & 3020 \\
\hline & & & & & & & $2 E-16$ & & $E-18$ & & & \\
\hline & 2.5 & 0.0000 & & & & & $E-14$ & & $=-14$ & & & .0000 \\
\hline & 0.0 & 0.0000 & $\mathrm{E}+00$ & & $+\infty$ & & $E+00$ & & $E+\infty$ & & & 002 \\
\hline & & & $0 E+00$ & & $E+\infty$ & 000 & $0 E+00$ & & $0 E+00$ & 000 & & 322 \\
\hline & 0.0 & 0.0000 & $0.000 E+00$ & 0.0000 & $O E+00$ & 0.0000 & $0.000 E+00$ & 0.0000 & $0.000 E+00$ & 000 & -08 & 0.1390 \\
\hline & & & -14 & & & & $E-14$ & & E-14 & & & \\
\hline & & & & & -10 & & -20 & & $42 E-20$ & & & 000 \\
\hline $\mathrm{sr}-90$ & $1.673 \mathrm{E}-1$ & 0.0000 & $2.495 E-18$ & 0.0000 & $E-17$ & 0.0000 & $8 E-17$ & 0.0000 & $8.772 E-18$ & 0.0000 & & 0.0000 \\
\hline & $1.072 \mathrm{E}-$ & & & & & & $1 E-22$ & & & & & \\
\hline & $1.601 \mathrm{E}-$ & & & & $6-11$ & & $E-17$ & & $E-18$ & & & \\
\hline Th-2 & $4.256 E-13$ & 0.0000 & $1.226 \mathrm{E}-14$ & 0.0000 & $6.155 E-14$ & 0.0000 & $3.931 E-16$ & 0.0000 & $5.693 E-17$ & 0.0 & $E-13$ & 0.0000 \\
\hline & & & & & & & & & & & & \\
\hline & & & & & 4 & & $1.475 E-14$ & & $7.513 \mathrm{E}-14$. & & & \\
\hline & $1.013 E-C$ & & $3.127 \mathrm{E}-12$ & & $13 E-10$ & 0.0012 & $3.262 E-12$ & 0.0000 & $1.662 E-11$ & 0.0001 & & 0.0092 \\
\hline & & 0.0001 & $2.904 E-14$ & 0.0000 & $1.405 E-12$ & 0.0000 & $3.028 E-14$ & 0.0000 & $1.543 E-13$ & 0.0000 & & 0.0001 \\
\hline & & & & & & & & & & & & \\
\hline ifiliti & & & Lutiffít & & & & & & fulftift & & & IIffi \\
\hline Total & $1.555 \mathrm{E}-09$ & 0.0121 & $1.612 E-11$ & 0.0001 & $2.372 E-10$ & 0.0018 & $2.666 \mathrm{E}-11$ & 0.0002 & $2.847 \mathrm{E}-10$ & 0.0022 & & 1.0000 \\
\hline
\end{tabular}

** Sum of water independent ground, inhalation, plant, meat, milk, soil

and water dependent water, fish, plant, meat, milk pathways

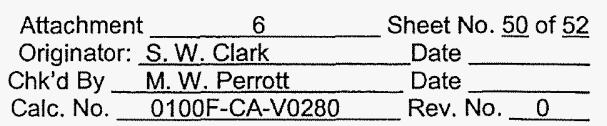




\section{ATTACHMENT 6}

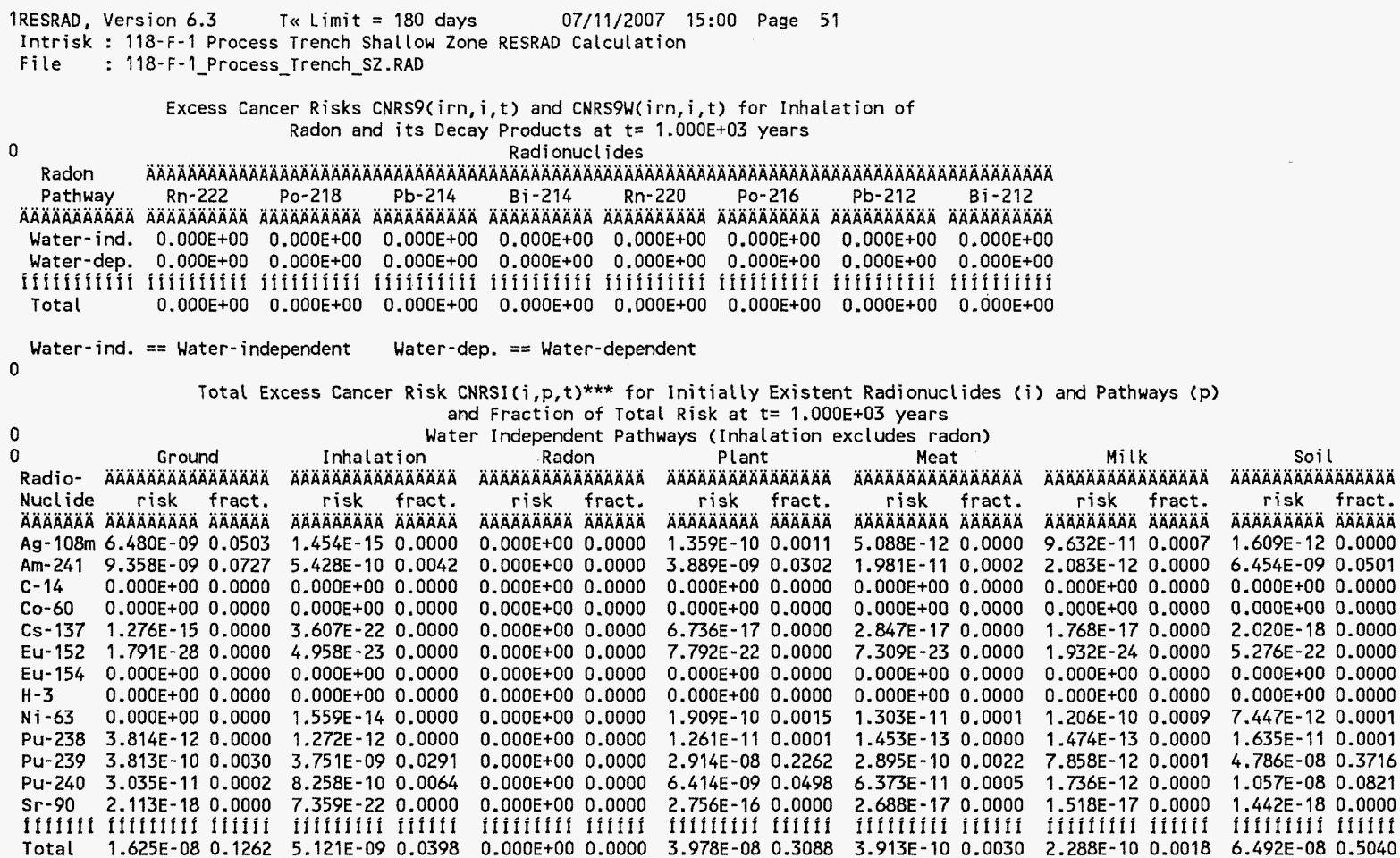

\begin{tabular}{|c|c|}
\hline Attachment $\quad 6$ & Sheet No. $\underline{51}$ of $\underline{52}$ \\
\hline Originator: S.W. Clark & Date \\
\hline M. W. Perrott & Date \\
\hline $0100 F-C A-V 0280$ & Rev. No. \\
\hline
\end{tabular}


Rev. 0

\title{
ATTACHMENT 6
}

\begin{abstract}
1RESRAD, Version 6.3
T\& Limit $=180$ days

07/11/2007 15:00 Page 52
\end{abstract}

Intrisk : 118-F-1 Process Trench Shallow Zone RESRAD Calculation

File : 118-F-1_Process_Trench_SZ.RAD

Total Excess Cancer Risk CNRSI $(i, p, t) * * *$ for Initially Existent Radionuclides (i) and Pathways $(p)$ and Fraction of Total Risk at $t=1.000 E+03$ years

Water Dependent Pathways

\begin{tabular}{|c|c|c|c|c|c|c|c|c|c|c|c|c|c|c|}
\hline & $\begin{array}{r}\text { Water } \\
\text { ÄÄÄÄÄÄÄA }\end{array}$ & С̈ÄÄÄÄÄ & 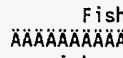 & $\begin{array}{l}\text { L } \\
\text { ÄÄĀÄÄĂ }\end{array}$ & $\begin{array}{r}\text { Rado } \\
\text { ÄÄÄÄÄÄÄA }\end{array}$ & On & $\begin{array}{r}P l \text { an } \\
\triangle A O A A O A O A O A A\end{array}$ & ÄÄÄÄÄA & $\begin{array}{r}\text { Meat } \\
\text { ÄÄAAAÄÄÄA }\end{array}$ & AÄÄÄÄÄ & AMAOAOÄÄÄ & $\triangle A O A ̈ A ̈ A ̈ A ̈ A ̈ A$ & $\begin{array}{r}\text { All pa } \\
\text { ÄÄÄÄÄÄÄA }\end{array}$ & $\begin{array}{l}\text { Ways } \\
A B A A A B A B\end{array}$ \\
\hline & & & $\begin{array}{c}\text { risk } \\
A B A A B A A A\end{array}$ & 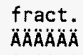 & $\begin{array}{c}\text { risk } \\
\text { ÁAAAAAAB }\end{array}$ & & $\begin{array}{c}\text { risk } \\
\text { AOÄÄAAAAA }\end{array}$ & & $\begin{array}{c}\text { risk } \\
A A A A A A A B A\end{array}$ & & $\begin{array}{c}\text { risk } \\
\text { ÄAAAAAAAA }\end{array}$ & & $\begin{array}{c}\text { risk } \\
\text { AAAAAAAAÄA }\end{array}$ & \\
\hline & & & & & $+\infty 0$ & & & & & & & & & \\
\hline & & & & & & & & & & & & & & \\
\hline & & & & & & & & & & & & & & \\
\hline & & & & & & & & & & & & & & \\
\hline & & & & & & & & & & & & & & \\
\hline & & & & & & & & & & & +00 & & & \\
\hline & & & & & & & & & & & & & & \\
\hline & & & & & & & & & & & & & & \\
\hline & & & & & & & & & & & & & & \\
\hline & & & & & & & & & & & & & & \\
\hline & & & & & & & & & & & & & & \\
\hline & & & & & & & & & & & & & & \\
\hline & & & & & & & & & & & & & & \\
\hline & & & & & & & & & & & & & & \\
\hline & & & & & & & & & & & & & & \\
\hline
\end{tabular}

$\star \star \star$ CNRSI $(i, p, t)$ includes contribution from decay daughter radionuclides

\begin{tabular}{|c|c|}
\hline Attachment & Sheet No. 52 of $\underline{52}$ \\
\hline Originator: S.W. Clark & Date \\
\hline Chk'd By M. W. Perrott & Date \\
\hline Calc. No. $\quad 0100 \mathrm{~F}-\mathrm{CA}-\mathrm{V} 0280$ & Rev. No. \\
\hline
\end{tabular}




\section{ATTACHMENT 7}

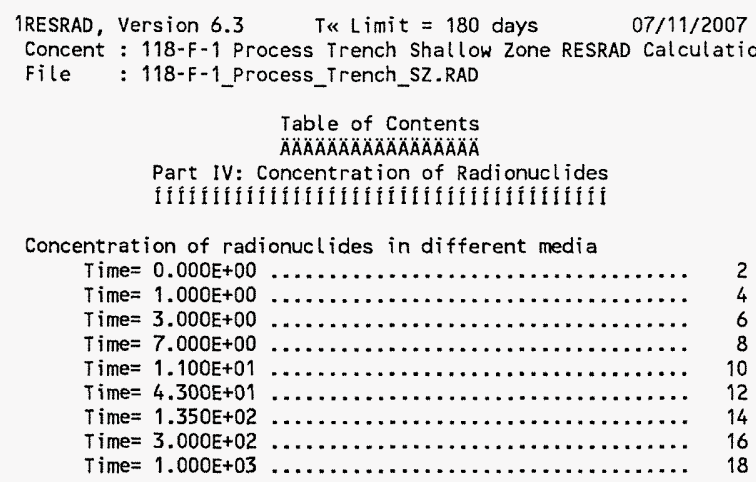




\section{ATTACHMENT 7}

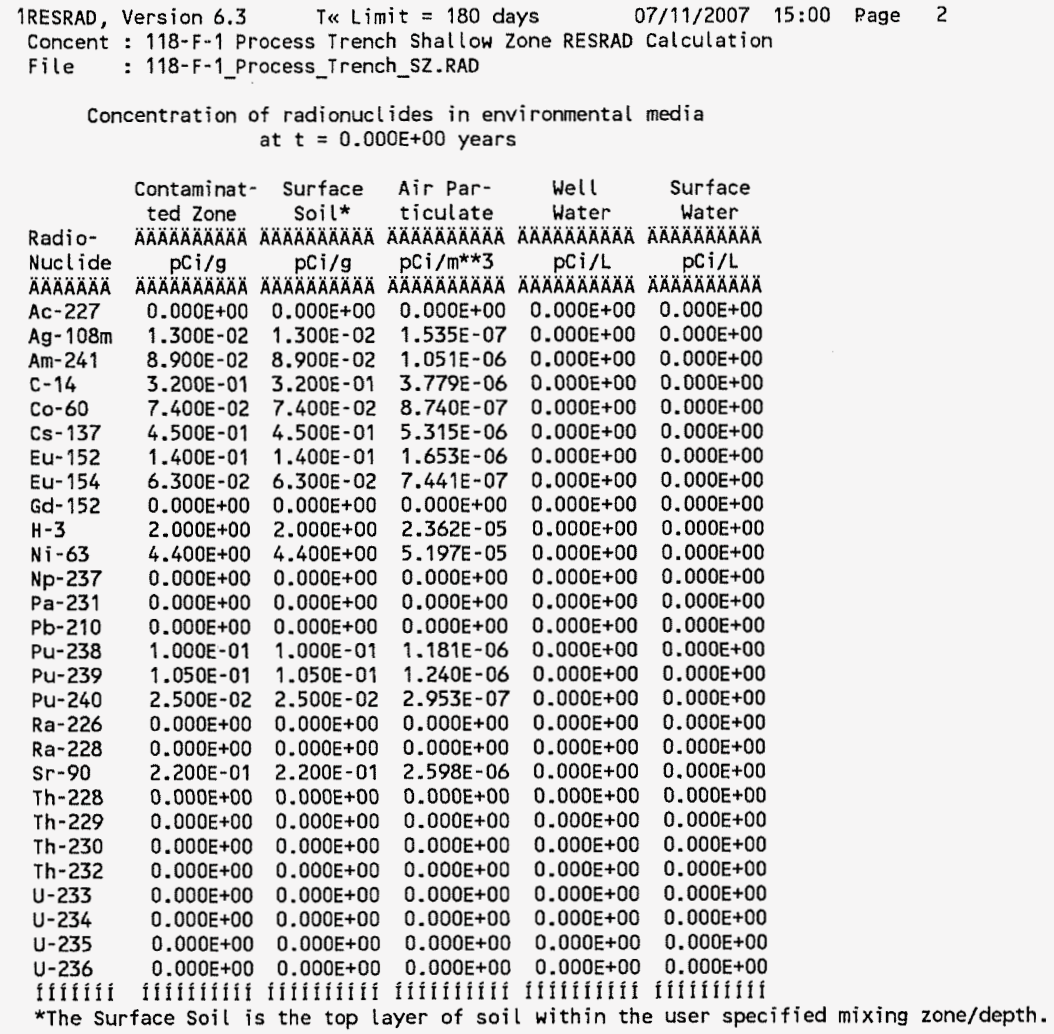

Concentrations in the media occurring in pathways that are suppressed are calculated using the current input parameters, i.e. using parameters appearing in the input screen when the pathways are active.

Concentration of $\mathrm{H}-3$ in soil moisture $=1.652 \mathrm{E}+01 \mathrm{pCi} / \mathrm{mL}$

Concentration of gaseous $\mathrm{H}-3$ in air $=2.303 \mathrm{E}+00 \mathrm{pCi} / \mathrm{m}^{* * 3}$

Concentration of gaseous $\mathrm{C}-14$ in air $=1.170 \mathrm{E}+00 \mathrm{pCi} / \mathrm{m}^{\star *} 3$

Attachment Originator: S.W. Clark 7 Chk'd By M.W. Perrott Calc. No. 0100F-CA-V0280 Sheet No. 2 of 19 Date Date 


\section{ATTACHMENT 7}

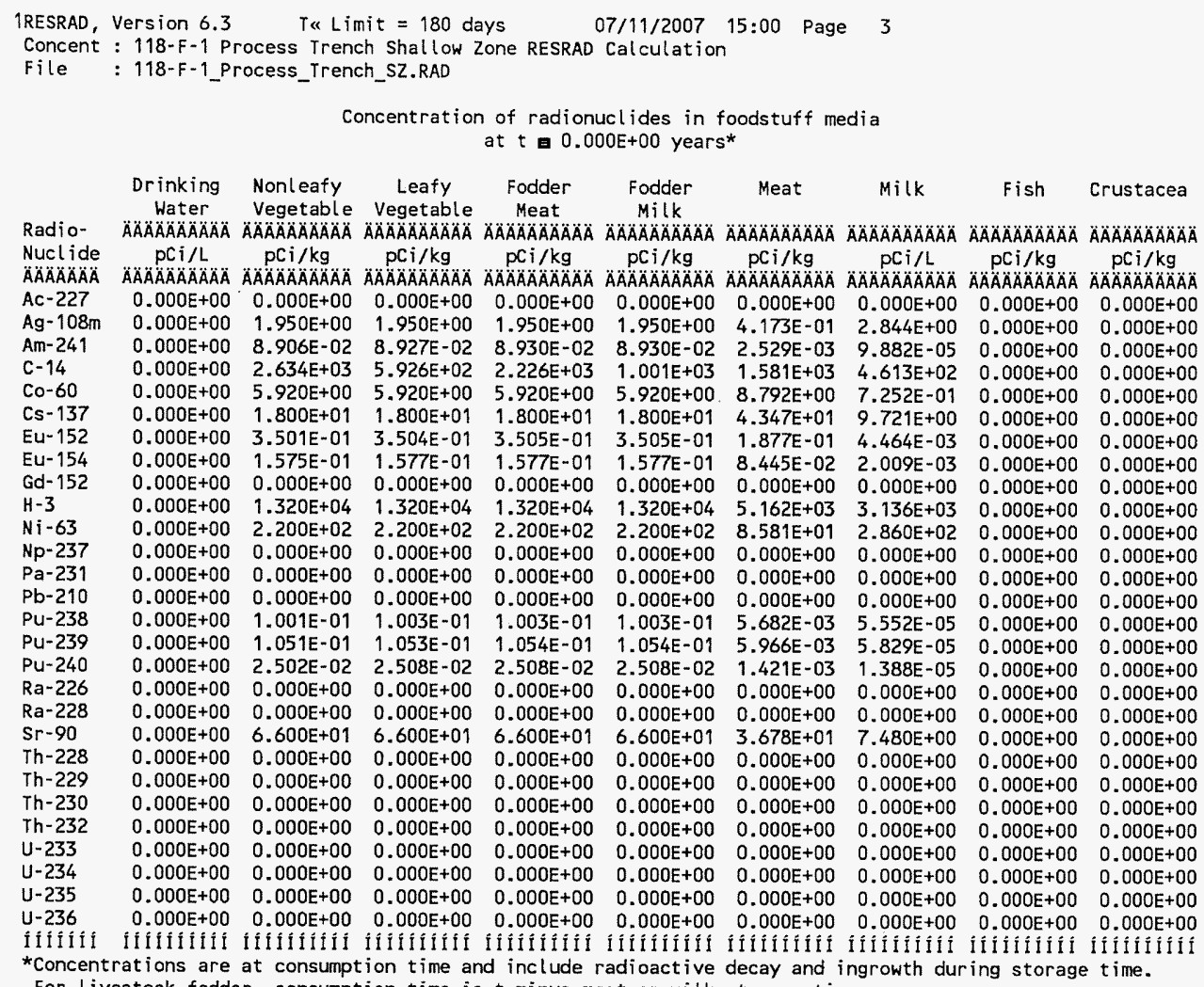

For livestock fodder, consumption time is $t$ minus meat or milk storage time.

Concentrations in the media occurring in pathways that are suppressed are calculated using the current input parameters, i.e. using parameters appearing in the input screen when the pathways are active.

$\begin{array}{ll}\text { Attachment } \frac{7}{\text { W. Clark }} & \text { Sheet No. } 3 \text { of } 19 \\ \text { Originator: } \frac{\text { S.W. }}{\text { M. W. Perrott }} & \text { Date } \\ \text { Chk'd By } \frac{\text { Date }}{\text { O100F-CA-V0280 }} \text { Rev. No. } \quad \text { R } & \text { Ralc. No. }\end{array}$




\section{ATTACHMENT 7}

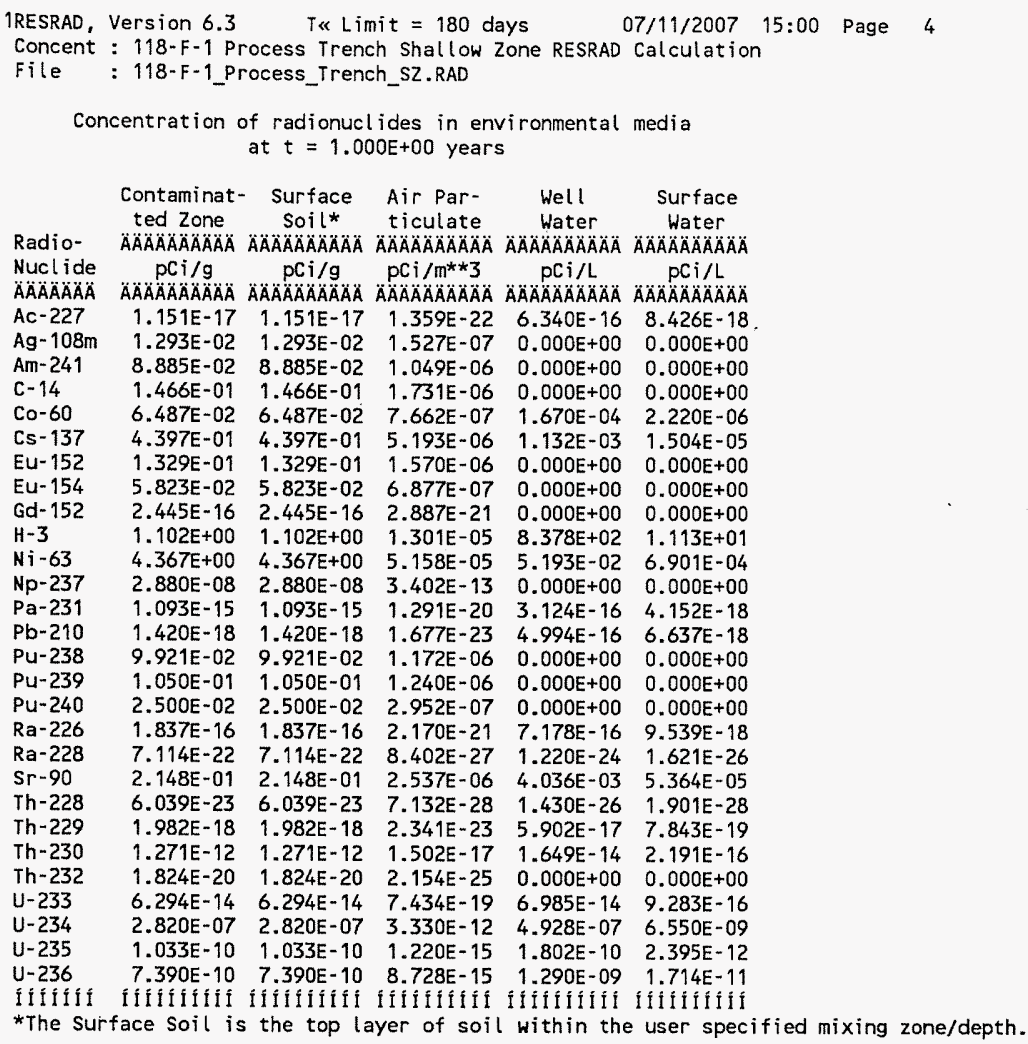

Concentrations in the media occurring in pathways that are suppressed are calculated using the current input parameters, i.e. using parameters appearing in the input screen when the pathways are active. Concentration of $\mathrm{H}-3$ in soil moisture $=9.099 \mathrm{E}+00 \mathrm{pCi} / \mathrm{ml}$

Concentration of gaseous $\mathrm{H}-3$ in air $=1.268 \mathrm{E}+00 \mathrm{pCi} / \mathrm{m} * * 3$

Concentration of gaseous $\mathrm{H}-3$ in air $=1.268 \mathrm{E}+00 \mathrm{pCi} / \mathrm{m}^{* * 3}$
Concentration of gaseous $\mathrm{C}-14$ in air $=5.360 \mathrm{E}-01 \mathrm{pCi} / \mathrm{m}^{\star * 3}$

Attachment

Rev. No. 0




\section{ATTACHMENT 7}

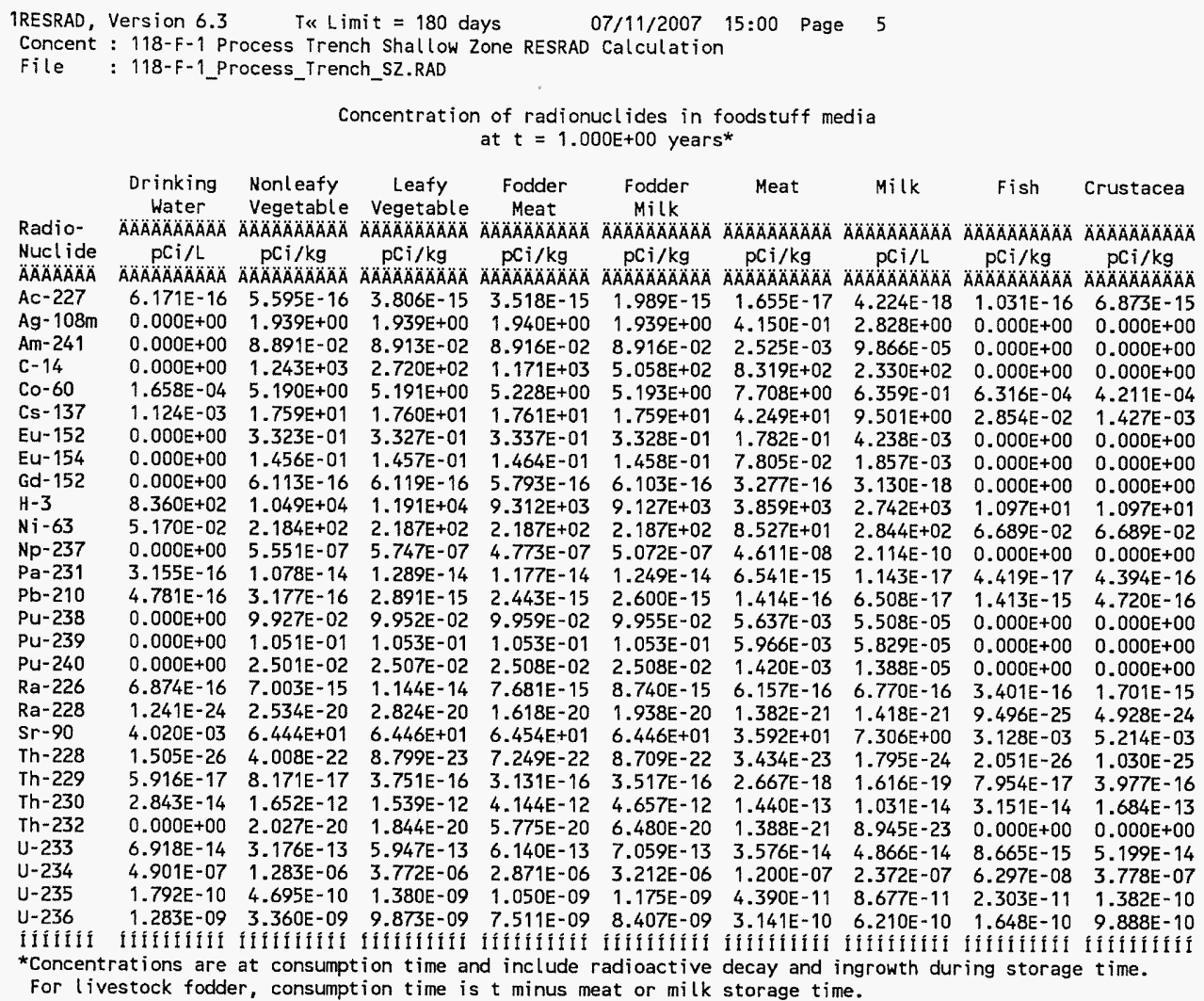

For livestock fodder, consumption time is $t$ minus meat or milk storage time.

Concentrations in the media occurring in pathways that are suppressed are calculated using the current input parameters, i.e. using parameters appearing in the input screen when the pathways are active.

\begin{tabular}{|c|c|}
\hline \multirow{2}{*}{$\begin{array}{l}\text { Attachment } \\
\text { Originator: S. W. Clark }\end{array}$} & Sheet No. 5 of 19 \\
\hline & Date \\
\hline Chk'd By M.W. Perrott & Date \\
\hline 0100F-CA-V0280 & Rev. No. \\
\hline
\end{tabular}




\section{ATTACHMENT 7}

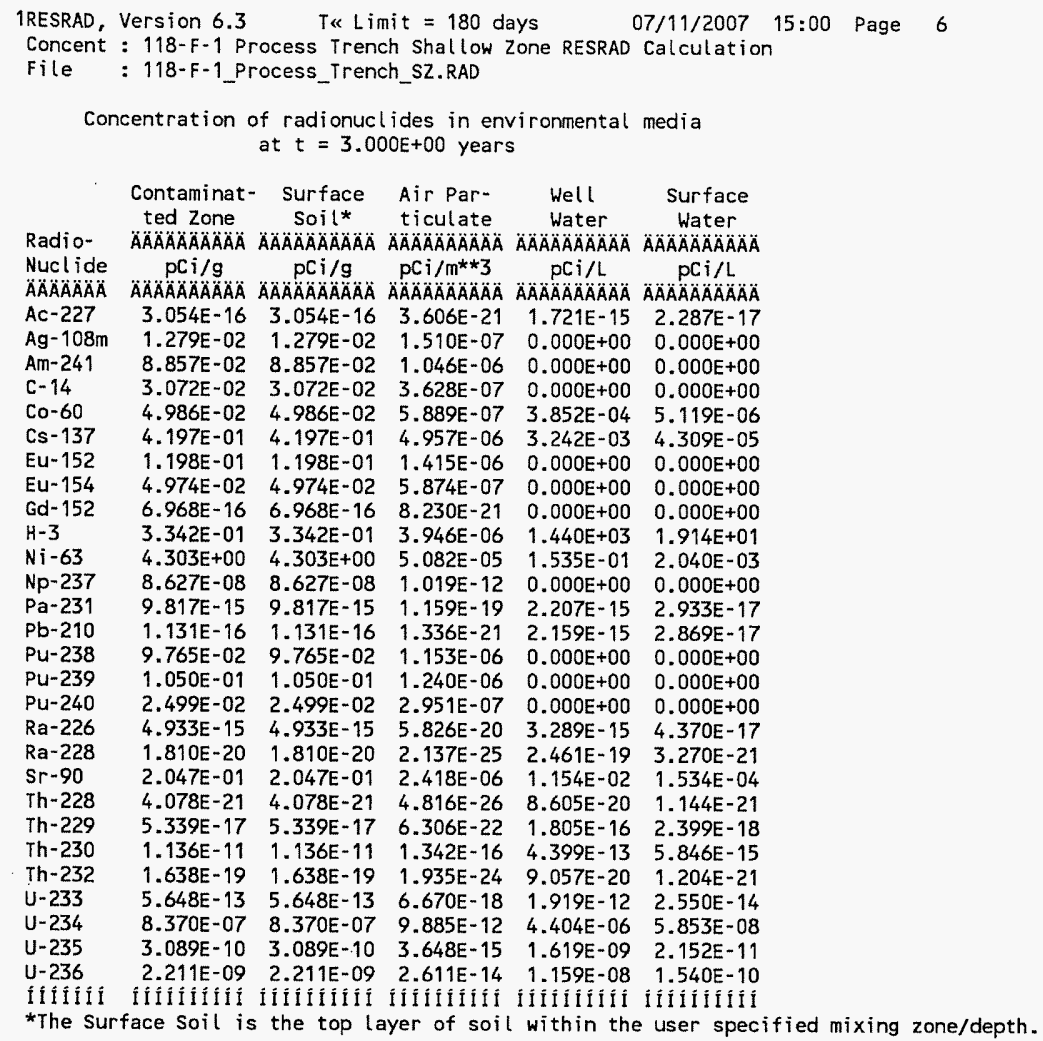

Concentrations in the media occurring in pathways that are suppressed are calculated using the current input parameters, i.e. using parameters appearing in the input screen when the pathways are active.

Concentration of $\mathrm{H}-3$ in soil moisture $=2.760 \mathrm{E}+00 \mathrm{pCi} / \mathrm{ml}$

Concentration of gaseous $\mathrm{H}-3$ in air $=3.848 \mathrm{E}-01 \mathrm{pCi} / \mathrm{m}^{* * 3}$
Concentration of gaseous $\mathrm{C}-14$ in air $=1.123 \mathrm{E}-01 \mathrm{pCi} / \mathrm{m}^{\star *} 3$

Attachment

$7 \quad$ Sheet No. $\underline{6}$ of $\underline{19}$

Originator: S.W. Clark

Date

Chk'd By M.W. Perrott

Date

Calc. No. $0100 F-C A-V 0280$ 


\section{ATTACHMENT 7}

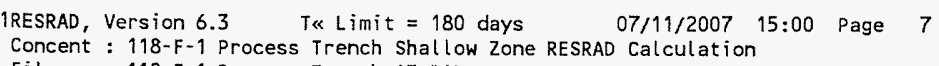

Concentration of radionuclides in foodstuff media at $\mathrm{t}=3.000 \mathrm{E}+00$ years*

\begin{tabular}{|c|c|c|c|c|c|c|c|c|c|}
\hline & $\begin{array}{l}\text { Drinking } \\
\text { Water }\end{array}$ & $\begin{array}{l}\text { Nonleafy } \\
\text { Vegetable }\end{array}$ & $\begin{array}{c}\text { Leafy } \\
\text { Vegetable }\end{array}$ & $\begin{array}{l}\text { Fodder } \\
\text { Meat }\end{array}$ & $\begin{array}{l}\text { Fodder } \\
\text { Milk }\end{array}$ & Meat & Milk & Fish & Crustacea \\
\hline & $\triangle A O A A A A O A A A B A$ & $\triangle A O A A A A A A A B A$ & $\triangle A A A A A A A A A A$ & $\triangle A B A O A A A A A B$ & $\triangle A A O A A A A A A B$ & $\triangle A B A A A B A A A$ & ÄÄÄAAAAÄÄ & $\triangle A A A A A A A A A B$ & $\triangle A A ̈ A ̈ A ̈ A ̈ A O A ̈$ \\
\hline & & $\mathrm{pCi} / \mathrm{kg}$ & $\mathrm{pCi} / \mathrm{kg}$ & $\mathrm{pCi} / \mathrm{kg}$ & $\mathrm{pCi} / \mathrm{kg}$ & $\mathrm{pCi} / \mathrm{kg}$ & $\mathrm{pCi} / \mathrm{L}$ & $\mathrm{pCi} / \mathrm{kg}$ & $\mathrm{pCi} / \mathrm{kg}$ \\
\hline & 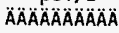 & 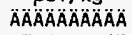 & $\triangle A \cap A O A A A O A A A B A$ & $\triangle A \cap A \cap A A A A A B A$ & $\triangle A A A A A A A A B$ & $\triangle A \cap A ̈ A ̈ A ̈ A ̈ A ̈ A ̈$ & $\triangle A \triangle A ̈ A ̈ A ̈ A ̈ A ̈ A ̈ A$ & 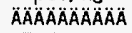 & $\triangle A \cap A \cap A A A B A A A B A$ \\
\hline$c-227$ & $1.734 E-15$ & $3.292 E-15$ & $1.176 E-14$ & $1.327 \mathrm{E}-14$ & $1.140 E-14$ & $1.414 \mathrm{E}-16$ & $2.118 \mathrm{E}-17$ & $3.596 \mathrm{E}-16$ & $2.396 \mathrm{E}-14$ \\
\hline & $0.000 E+00$ & $1.918 E+00$ & $1.918 E+00$ & $1.919 E+00$ & $1.918 E+00$ & 4.105E-01 & $2.797 \mathrm{E}+00$ & $0.000 E+00$ & $0.000 \mathrm{E}+00$ \\
\hline & $0.000 E+00$ & $8.862 E-02$ & $8.884 E-02$ & 8.887E-02 & $8.887 E-02$ & $2.516 \mathrm{E}-03$ & $9.834 \mathrm{E}-05$ & $0.000 E+00$ & $0.000 \mathrm{E}+00$ \\
\hline & $0.000 \mathrm{E}+00$ & $2.606 \mathrm{E}+02$ & $5.702 E+01$ & $2.455 \mathrm{E}+02$ & $1.060 E+02$ & $1.744 E+02$ & $4.885 E+01$ & $0.000 E+00$ & $0.000 E+00$ \\
\hline & $3.842 E-04$ & $3.989 E+00$ & $3.991 \mathrm{E}+00$ & $4.020 E+00$ & $3.993 E+00$ & $5.927 E+00$ & 4.890E-01 & 1.509E-03 & $1.006 \mathrm{E}-03$ \\
\hline & $3.234 E-03$ & $1.679 E+01$ & $1.681 E+01$ & $1.683 E+01$ & $1.681 E+01$ & $4.059 \mathrm{E}+01$ & $9.079 E+00$ & $8.470 E-02$ & $4.235 E-03$ \\
\hline & $0.000 E+00$ & -01 & & 3.0 & & $1.605 \mathrm{E}-01$ & $3.819 \mathrm{E}-03$ & $0.000 E+00$ & $0.000 E+00$ \\
\hline & $0.000 E+00$ & $E-01$ & $5 E-01$ & OE- 01 & $5 E-01$ & $6.667 \mathrm{E}-02$ & $1.586 \mathrm{E}-03$ & $0.000 E+00$ & $30 E+00$ \\
\hline$y-152$ & $0.000 \mathrm{E}+00$ & $1.742 E-15$ & $1.744 \mathrm{E}-15$ & E- 15 & $3 E-15$ & $E-16$ & $8.898 E-18$ & $0.000 E+00$ & $0.000 E+00$ \\
\hline & $1.439 E+03$ & 7.6 & $\equiv+04$ & $4.942 E+03$ & $4.880 E+03$ & $2.336 E+03$ & 2. $151 E+03$ & $9 E+01$ & $19 E+01$ \\
\hline & $1.533 E-01$ & $E+02$ & $E+02$ & $E+02$ & $E+02$ & $E+01$ & $E+02$ & & $E-01$ \\
\hline - & $0.000 E+00$ & 1.7 & & 1.6 & E-06 & $E-07$ & $2 E-10$ & $0 E+00$ & $E+00$ \\
\hline & $2.301 E-15$ & 1.01 & E-13 & $1.286 \mathrm{E}-13$ & $5 E-13$ & $E-14$ & $9.806 E-17$ & $E-16$ & -15 \\
\hline & -15 & & & 1.6 & $E-14$ & $=-15$ & 3.6 & 8.3 & -15 \\
\hline & 0.00 & -02 & & 9.8 & $E-02$ & -03 & $E-05$ & $10 E+00$ & $E+00$ \\
\hline $1-2$ & $0.000 E+00$ & $E-01$ & $E-01$ & 1.053 & $E-01$ & -03 & & $+\infty$ & $=+00$ \\
\hline & 0.00 & -02 & -02 & 2.50 & $E-02$ & E-03 & 1.3 & $E+\infty$ & $=+00$ \\
\hline & 3.27 & -13 & -13 & 1.88 & $E-13$ & $E-14$ & $E-14$ & $2.140 E-15$ & $E-14$ \\
\hline & 2.430 & 9.6 & 2.2 & 2.0 & 2.0 & & $E-19$ & 1.49 & $7.490 E-19$ \\
\hline & 1.153 & 6.1 & 6.14 & $6.156 E+01$ & $E \div 01$ & $E+01$ & 6.9 & & \\
\hline & $8.515 E-20$ & SE-19 & $E-19$ & $5 E-19$ & FE-19 & $E-21$ & $E-22$ & 1.0 & -19 \\
\hline & $1.782 E-16$ & 2.70 & $E-15$ & $8 E-16$ & $2.172 \mathrm{E}-15$ & $1.228 \mathrm{E}-17$ & $1.080 E-18$ & $2.164 \mathrm{E}-16$ & $1.083 E-15$ \\
\hline & $5.471 \mathrm{E}-13$ & 1.44 & & $4.512 E-11$ & $4.683 E-11$ & $1.289 E-12$ & $8.247 E-14$ & & $E-12$ \\
\hline & $9.105 E-20$ & 3.00 & 7.406 & $1.157 E-18$ & $1.162 E-18$ & 2.2 & 1.3 & $O E-19$ & $E-19$ \\
\hline & $1.914 E-12$ & $4.087 \mathrm{E}-12$ & $1.345 E-1$ & $1.308 \mathrm{E}-11$ & $1.387 E-11$ & $4.626 \mathrm{E}-13$ & 8.10 & & \\
\hline & $4.396 \mathrm{E}-06$ & $7.699 \mathrm{E}-06$ & $2.970 E-05$ & $2.874 E-05$ & $2.980 \mathrm{E}-05$ & $8.771 \mathrm{E}-07$ & $1.655 \mathrm{E}-0$ & $5.777 \mathrm{E}-07$ & $3.466 \mathrm{E}-06$ \\
\hline & & & & & & $3.226 \mathrm{E}-10$ & & & $1.274 \mathrm{E}-09$ \\
\hline & & $2.027 \mathrm{E}-08$ & $7.816 \mathrm{E}-08$ & $7.560 E-08$ & 7.8 & & & & \\
\hline & 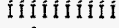 & 18 & & & & & & & \\
\hline
\end{tabular}

trations are at consumption time and include radioactive decay and ingrowth during storage time.

For livestock fodder, consumption time is $t$ minus meat or milk storage time.

Concentrations in the media occurring in pathways that are suppressed are calculated using the current input parameters, i.e. using parameters appearing in the input screen when the pathways are active.

$\begin{array}{ll}\text { Attachment } \frac{7}{\text { W. Clark }} & \text { Sheet No. } \underline{I} \text { of } 19 \\ \text { Originator: } \frac{\text { S.Wate }}{\text { M.W. Perrott }} & \text { Date } \\ \text { Chk'd By } & \text { Rev. No. } \quad \text { O }\end{array}$




\section{ATTACHMENT 7}

\begin{tabular}{|c|c|c|c|c|c|}
\hline $\begin{array}{l}\text { 1RESRAD, } \\
\text { Concent } \\
\text { File }\end{array}$ & $\begin{array}{l}\text { Version } 6.3 \\
: 118-\mathrm{F}-1 \mathrm{Pr} \\
: 118-\mathrm{F}-1 \mathrm{Pr}\end{array}$ & $\begin{array}{r}\text { T\& Lif } \\
\text { rocess Trenc } \\
\text { rocess_Treno }\end{array}$ & $\begin{array}{l}\text { nit }=180 \text { da } \\
\text { ch Shallow Z } \\
\text { ch_SZ.RAD }\end{array}$ & lays ${ }^{0}{ }^{0}$ & $\begin{array}{l}07 / 11 / 2007 \\
\text { Calculation }\end{array}$ \\
\hline \multicolumn{6}{|c|}{$\begin{array}{c}\text { Concentration of radionuclides in environmental media } \\
\text { at } t=7.000 E+00 \text { years }\end{array}$} \\
\hline & $\begin{array}{l}\text { Contaminat- } \\
\text { ted Zone }\end{array}$ & $\begin{array}{l}\text { Surface } \\
\text { Soil** }\end{array}$ & $\begin{array}{l}\text { Air Par- } \\
\text { ticulate }\end{array}$ & $\begin{array}{l}\text { Well } \\
\text { Water }\end{array}$ & $\begin{array}{l}\text { Surface } \\
\text { Water }\end{array}$ \\
\hline Radio- & 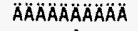 & $\triangle A \cap A ̈ A ̈ A ̈ A ̈ A ̈ A ̈ A ̈ A ̈$ & ÄAिAिÄÄÄA & A A AAAAAAÄ & $\triangle A A A A A A A A A A A$ \\
\hline $\begin{array}{l}\text { Nuclide } \\
A A B A B A B A\end{array}$ & $\begin{array}{c}p C i / g \\
A B A B A B A B A\end{array}$ & $p C i / g$ & $\mathrm{pCi} / \mathrm{m}^{* * 3}$ & $p C i / L$ & $p C i / L$ \\
\hline & $\begin{array}{r}\text { AAAAAAAAAA } \\
3.748 E-15\end{array}$ & $\begin{array}{r}\text { AAAAAAAAAAA } \\
3.748 E-15\end{array}$ & $\begin{array}{r}\text { AAAAAAAAAAA } \\
4.427 E-20\end{array}$ & $\begin{array}{l}\text { AAAAAAAAAA } \\
8.178 E-15\end{array}$ & $\begin{array}{r}\text { AAAAAAAAAAA } \\
1.087 E-16\end{array}$ \\
\hline $08 m$ & $1.251 \mathrm{E}-02$ & $1.251 \mathrm{E}-02$ & $1.477 \mathrm{E}-07$ & $0.000 E+00$ & $0.000 E+00$ \\
\hline & $8.799 E-02$ & $8.799 E-02$ & $E-06$ & $0.000 E+00$ & $0.000 \mathrm{E}+00$ \\
\hline$c-1$ & $7 E-03$ & $1.347 \mathrm{E}-03$ & $1 E-08$ & $0.000 E+00$ & $0.000 E+00$ \\
\hline $\mathrm{Co}-6$ & $2.945 E-02$ & $2.945 E-02$ & $3.478 E-07$ & $5.310 E-04$ & $7.057 E-06$ \\
\hline & -01 & $3.825 E-01$ & $E-06$ & $6.896 \mathrm{E}-03$ & $9.165 E-05$ \\
\hline & E-02 & $9.727 E-02$ & 1.1 & $0.000 E+00$ & $0 E+00$ \\
\hline & $3.629 \mathrm{E}-02$ & $3.629 E-02$ & 4.286E-07 & $0.000 E+00$ & $0.000 E+00$ \\
\hline & $E-15$ & $1.472 E-15$ & $3 E-20$ & $0.000 E+00$ & $0.000 E+00$ \\
\hline $\mathrm{H}-\mathrm{T}$ & & $3.070 \mathrm{E}-$ & 3.6 & $7.760 E+02$ & $E+01$ \\
\hline $\mathrm{Ni}$ & $4.177 E+00$ & $4.177 E+00$ & $4.934 E-05$ & $3.479 \mathrm{E}-01$ & $4.623 \mathrm{E}-03$ \\
\hline & $E-07$ & 07 & 2.36 & $0.000 E+00$ & $100 E+00$ \\
\hline & $E-14$ & .324 & $=-19$ & $8 E-14$ & -16 \\
\hline & $3.242 E-15$ & $3.242 \mathrm{E}$ & 3.8 & $7.512 E-15$ & $9.984 E-17$ \\
\hline & $E-02$ & 9.460 & $E-06$ & $0.000 E+00$ & $0.000 \mathrm{E}+00$ \\
\hline & $E-01$ & $1.050 E-01$ & 1.24 & $0.000 E+00$ & $E+00$ \\
\hline & & $2.498 \mathrm{E}-02$ & $2.950 E-07$ & $0.000 E+00$ & $0.000 E+00$ \\
\hline & $6.197 E-14$ & $6.197 E-14$ & $7.319 E-19$ & $1.961 E-14$ & $2.606 E-16$ \\
\hline & $2.052 E-19$ & $2.052 E-19$ & & $6.756 E-19$ & $8.979 E-21$ \\
\hline & $1.859 \mathrm{E}-01$ & $1.859 E-01$ & $2.196 E-06$ & $2.447 E-02$ & $3.253 E-04$ \\
\hline & $8.686 E-20$ & $8.686 \mathrm{E}-20$ & $1.026 E-24$ & $2.320 E-19$ & $3.083 E-21$ \\
\hline & $6.752 E-16$ & $6.752 E-16$ & $7.974 E-21$ & $5.283 E-16$ & $7.020 E-18$ \\
\hline & $6.098 \mathrm{E}-11$ & $6.098 E-11$ & $7.202 E-16$ & $5.525 E-12$ & $7.342 E-14$ \\
\hline & $8.884 E-19$ & $8.884 E-19$ & $1.049 E-23$ & $3.139 E-19$ & $4.172 E-21$ \\
\hline & $3.057 E-12$ & $3.057 E-12$ & $3.610 E-17$ & $2.446 E-11$ & $3.251 E-13$ \\
\hline & $1.912 E-06$ & $1.912 E-06$ & $2.258 E-11$ & $2.364 E-05$ & $3.142 E-07$ \\
\hline$U-235$ & $7.168 \mathrm{E}-10$ & $7.168 \mathrm{E}-10$ & $8.465 E-15$ & $8.780 E-09$ & $1.167 E-10$ \\
\hline & & $3: 1<05-4$ & 0.03619 & $6.282 E-08$ & $8.349 E-10$ \\
\hline & & & & & \\
\hline
\end{tabular}

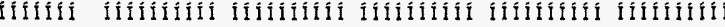

*The Surface Soil is the top layer of soil within the user specified mixing zone/depth.

Concentrations in the media occurring in pathways that are suppressed are calculated using the current input parameters, i.e. using parameters appearing in the input screen when the pathways are active.

Concentration of $\mathrm{H}-3$ in soil moisture $=2.536 \mathrm{E}-01 \mathrm{pCi} / \mathrm{mL}$

Concentration of gaseous $\mathrm{H}-3$ in air $=3.535 \mathrm{E}-02 \mathrm{pCi} / \mathrm{m}^{* * 3}$
Concentration of gaseous $\mathrm{C}-14$ in air $\quad 4.926 \mathrm{E}-03 \mathrm{pCi} / \mathrm{m}^{* * 3}$

\begin{tabular}{ll} 
Attachment $\frac{7}{\text { S. Clark }}$ & Sheet No. $\underline{8}$ of $\underline{19}$ \\
Originator: & Date \\
Chk'd By & Date \\
Calc. No. Perrott & Rev. No. 0 \\
\hline
\end{tabular}




\section{ATTACHMENT 7}

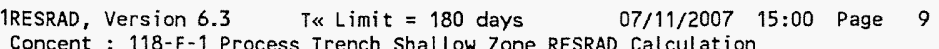

Concentrations in the media occurring in pathways that are suppressed are calculated using the current input parameters, i.e. using parameters appearing in the input screen when the pathways are active.

$\begin{array}{ll}\text { Attachment } \frac{7}{19} & \text { Sheet No. } \underline{9} \text { of } 19 \\ \text { Originator: } \frac{\text { S.W. Clark }}{\text { W.W.Perrott }} & \text { Date } \\ \text { Chk'd By } & \text { Date } \\ \text { Calc. No. } & \text { Rev. No. No0F-CA-V0280 }\end{array}$




\section{ATTACHMENT 7}

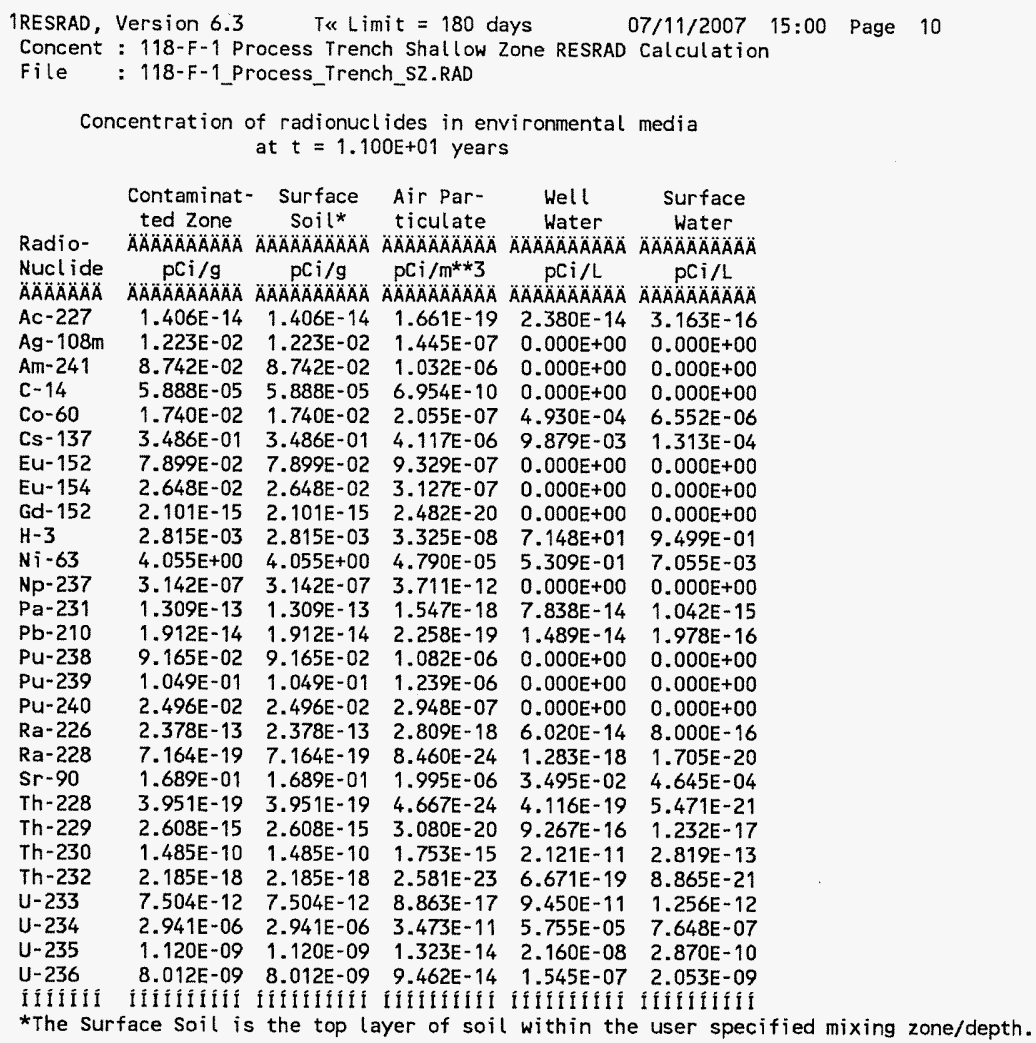

Concentrations in the media occurring in pathways that are suppressed are calculated using the current input parameters, i.e. using parameters appearing in the input screen when the pathways are active.

concentration of $\mathrm{H}-3$ in soil moisture $=2.325 \mathrm{E}-02 \mathrm{pCi} / \mathrm{ml}$

Concentration of gaseous $\mathrm{H}-3$ in air $=3.241 \mathrm{E}-03 \mathrm{pCi} / \mathrm{m}^{* * 3}$

Concentration of gaseous $\mathrm{C}-14$ in air $=2.153 \mathrm{E}-04 \mathrm{pCi} / \mathrm{m}^{* * 3}$

\begin{tabular}{|c|c|}
\hline Attachment & Sheet No. 10 of 19 \\
\hline Originator: S.W. Clark & Date \\
\hline M.W. Perrott & Date \\
\hline $0100 F-C A-V 0280$ & Rev. No. \\
\hline
\end{tabular}




\section{ATTACHMENT 7}

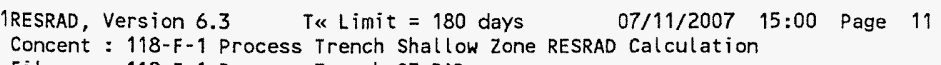

Drinking Nonleafy Leafy Fodder Fodder Meat Milk Fish crustacea Water Vegetable Vegetable Meat MilK

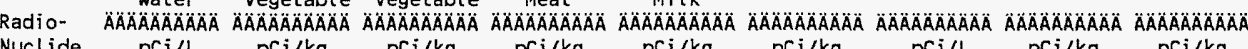

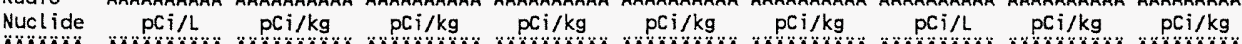

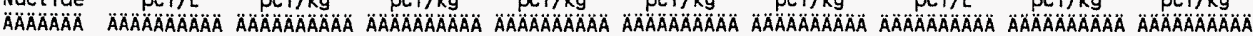
$\begin{array}{llllllllll}\mathrm{AC}-227 & 2.372 \mathrm{E}-14 & 6.616 \mathrm{E}-14 & 1.840 \mathrm{E}-13 & 1.727 \mathrm{E}-13 & 1.890 \mathrm{E}-13 & 2.281 \mathrm{E}-15 & 4.241 \mathrm{E}-16 & 4.630 \mathrm{E}-15 & 3.083 \mathrm{E}-13\end{array}$ $\begin{array}{lllllllllll}\mathrm{Ag}-108 \mathrm{~m} & 0.000 \mathrm{E}+00 & 1.835 \mathrm{E}+00 & 1.835 \mathrm{E}+00 & 1.836 \mathrm{E}+00 & 1.835 \mathrm{E}+00 & 3.927 \mathrm{E}-01 & 2.676 \mathrm{E}+00 & 0.000 \mathrm{E}+00 & 0.000 \mathrm{E}+00\end{array}$ $\begin{array}{llllllllll}A m-241 & 0.000 E+00 & 8.747 E-02 & 8.769 E-02 & 8.772 E-02 & 8.771 E-02 & 2.484 E-03 & 9.706 E-05 & 0.000 E+00 & 0.000 E+00\end{array}$ $\begin{array}{llllllllll}\mathrm{C}-14 & 0.000 \mathrm{E}+00 & 4.995 \mathrm{E}-01 & 1.093 \mathrm{E}-01 & 4.708 \mathrm{E}-01 & 2.033 \mathrm{E}-01 & 3.344 \mathrm{E}-01 & 9.365 \mathrm{E}-02 & 0.000 \mathrm{E}+00 & 0.000 \mathrm{E}+00\end{array}$ $\begin{array}{llllllllll}\text { Co-60 } & 4.927 E-04 & 1.392 E+00 & 1.395 E+00 & 1.405 E+00 & 1.396 E+00 & 2.072 E+00 & 1.710 E-01 & 1.957 E-03 & 1.304 E-03\end{array}$

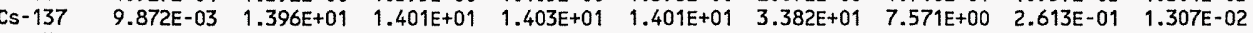
$\begin{array}{llllllllll}\text { Eu-152 } & 0.000 E+00 & 1.975 E-01 & 1.977 E-01 & 1.983 E-01 & 1.978 E-01 & 1.059 E-01 & 2.519 E-03 & 0.000 E+00 & 0.000 E+00\end{array}$ $\begin{array}{llllllllll}\text { EU-154 } & 0.000 E+00 & 6.622 E-02 & 6.628 E-02 & 6.658 E-02 & 6.630 E-02 & 3.550 E-02 & 8.443 E-04 & 0.000 E+00 & 0.000 E+00\end{array}$ Gd-152 $0.000 E+00 \quad 5.254 E-15 \quad 5.259 E-15 \quad 5.241 E-15 \quad 5.259 E-15 \quad 2.816 E-15 \quad 2.680 E-17 \quad 0.000 E+00 \quad 0.000 E+00$ 8.398E+01 8.655E+01 $9.599 \mathrm{E}-01 \quad 9.599 \mathrm{E}-01$ $\begin{array}{llllllllll}\mathrm{Ni}-63 & 5.307 \mathrm{E}-01 & 2.035 \mathrm{E}+02 & 2.061 \mathrm{E}+02 & 2.064 \mathrm{E}+02 & 2.064 \mathrm{E}+02 & 8.043 \mathrm{E}+01 & 2.693 \mathrm{E}+02 & 7.035 \mathrm{E}-01 & 7.035 \mathrm{E}-01 \\ \mathrm{~Np}-237 & 0.000 \mathrm{E}+00 & 6.264 \mathrm{E}-06 & 6.284 \mathrm{E}-06 & 6.188 \mathrm{E}-06 & 6.218 \mathrm{E}-06 & 5.772 \mathrm{E}-07 & 2.495 \mathrm{E}-09 & 0.000 \mathrm{E}+00 & 0.000 \mathrm{E}+00\end{array}$ $\begin{array}{llllllllll}\mathrm{Np}-237 & 0.000 \mathrm{E}+00 & 6.264 \mathrm{E}-06 & 6.284 \mathrm{E}-06 & 6.188 \mathrm{E}-06 & 6.218 \mathrm{E}-06 & 5.772 \mathrm{E}-07 & 2.495 \mathrm{E}-09 & 0.000 \mathrm{E}+00 & 0.000 \mathrm{E}+00 \\ \mathrm{~Pa}-231 & 7.958 \mathrm{E}-14 & 1.429 \mathrm{E}-12 & 1.818 \mathrm{E}-12 & 2.166 \mathrm{E}-12 & 2.197 \mathrm{E}-12 & 1.085 \mathrm{E}-12 & 1.418 \mathrm{E}-15 & 1.153 \mathrm{E}-14 & 1.211 \mathrm{E}-13\end{array}$ $\begin{array}{llllllllll}\mathrm{Pb}-210 & 1.514 \mathrm{E}-14 & 2.239 \mathrm{E}-13 & 2.888 \mathrm{E}-13 & 3.479 \mathrm{E}-13 & 3.623 \mathrm{E}-13 & 2.848 \mathrm{E}-14 & 9.639 \mathrm{E}-15 & 6.622 \mathrm{E}-14 & 2.220 \mathrm{E}-14\end{array}$ $\begin{array}{llllllllll}\text { Pu-238 } & 0.000 E+00 & 9.171 E-02 & 9.193 E-02 & 9.200 E-02 & 9.196 E-02 & 5.208 E-03 & 5.088 E-05 & 0.000 E+00 & 0.000 E+00\end{array}$

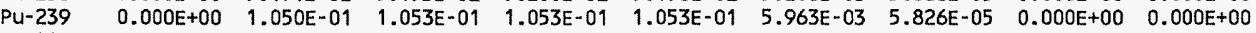
$\begin{array}{llllllllll}\mathrm{PU}-240 & 0.000 \mathrm{E}+00 & 2.498 \mathrm{E}-02 & 2.504 \mathrm{E}-02 & 2.505 \mathrm{E}-02 & 2.505 \mathrm{E}-02 & 1.418 \mathrm{E}-03 & 1.386 \mathrm{E}-05 & 0.000 \mathrm{E}+00 & 0.000 \mathrm{E}+00\end{array}$ $\begin{array}{llllllllll}R a-226 & 6.104 E-14 & 9.514 E-12 & 9.897 E-12 & 9.642 E-12 & 9.846 E-12 & 7.770 E-13 & 6.702 E-13 & 4.403 E-14 & 2.202 E-13\end{array}$ $\begin{array}{llllllllll}R a-228 & 1.287 E-18 & 3.003 E-17 & 3.678 E-17 & 3.602 E-17 & 3.634 E-17 & 2.852 E-18 & 2.562 E-18 & 8.704 E-19 & 4.352 E-18\end{array}$

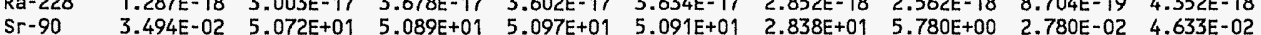
$\begin{array}{llllllllll}\mathrm{Sr}-90 & 3.494 \mathrm{E}-02 & 5.072 \mathrm{E}+01 & 5.089 \mathrm{E}+01 & 5.097 \mathrm{E}+01 & 5.091 \mathrm{E}+01 & 2.838 \mathrm{E}+01 & 5.780 \mathrm{E}+00 & 2.780 \mathrm{E}-02 & 4.633 \mathrm{E}-02 \\ \mathrm{Th}-228 & 4.139 \mathrm{E}-19 & 1.358 \mathrm{E}-18 & 3.042 \mathrm{E}-18 & 4.717 \mathrm{E}-18 & 4.722 \mathrm{E}-18 & 1.088 \mathrm{E}-19 & 5.156 \mathrm{E}-21 & 5.618 \mathrm{E}-19 & 2.809 \mathrm{E}-18\end{array}$

$\begin{array}{llllllllll}\text { Th-229 } & 9.544 \mathrm{E}-16 & 4.380 \mathrm{E}-15 & 8.798 \mathrm{E}-15 & 1.696 \mathrm{E}-14 & 1.552 \mathrm{E}-14 & 3.403 \mathrm{E}-16 & 2.002 \mathrm{E}-17 & 1.282 \mathrm{E}-15 & 6.434 \mathrm{E}-15\end{array}$

$\begin{array}{llllllllll}\text { Th-230 } & 2.261 \mathrm{E}-11 & 2.053 \mathrm{E}-10 & 3.001 \mathrm{E}-10 & 7.262 \mathrm{E}-10 & 7.341 \mathrm{E}-10 & 1.758 \mathrm{E}-11 & 1.070 \mathrm{E}-12 & 2.936 \mathrm{E}-11 & 1.481 \mathrm{E}-10\end{array}$

$\begin{array}{llllllllll}\text { Th-232 } & 6.892 E-19 & 3.513 E-18 & 6.668 E-18 & 1.322 E-17 & 1.331 E-17 & 2.778 E-19 & 1.672 E-20 & 9.169 E-19 & 4.604 E-18\end{array}$

$\begin{array}{lllllllllll}U-233 & 9.443 E-11 & 1.424 E-10 & 6.126 E-10 & 6.409 E-10 & 6.500 E-10 & 1.780 E-11 & 3.276 E-11 & 1.250 E-11 & 7.497 E-11\end{array}$

$\begin{array}{llllllllll}\text { U-234 } & 5.752 E-05 & 8.233 E-05 & 3.691 E-04 & 3.910 E-04 & 3.947 E-04 & 1.051 E-05 & 1.943 E-05 & 7.622 E-06 & 4.573 E-05\end{array}$

$\begin{array}{llllllllll}U-235 & 2.158 E-08 & 3.093 E-08 & 1.385 E-07 & 1.467 E-07 & 1.481 E-07 & 3.944 E-09 & 7.295 E-09 & 2.860 E-09 & 1.716 E-08\end{array}$

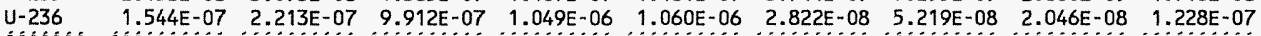

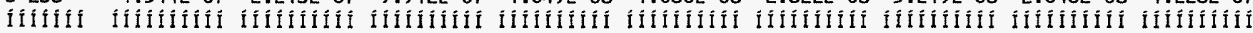

*Concentrations are at consumption time and include radioactive decay and ingrowth during storage time.

For livestock fodder, consumption time is $t$ minus meat or milk storage time.

Concentrations in the media occurring in pathways that are suppressed are calculated using the current input parameters, i.e. using parameters appearing in the input screen when the pathways are active.

Attachment

Originator: S.W. Clark

Chk'd By M.W. Perrott

Calc. No. 0100F-CA-V0280
Sheet No. 11 of 19

Rev. No. 0 


\section{ATTACHMENT 7}

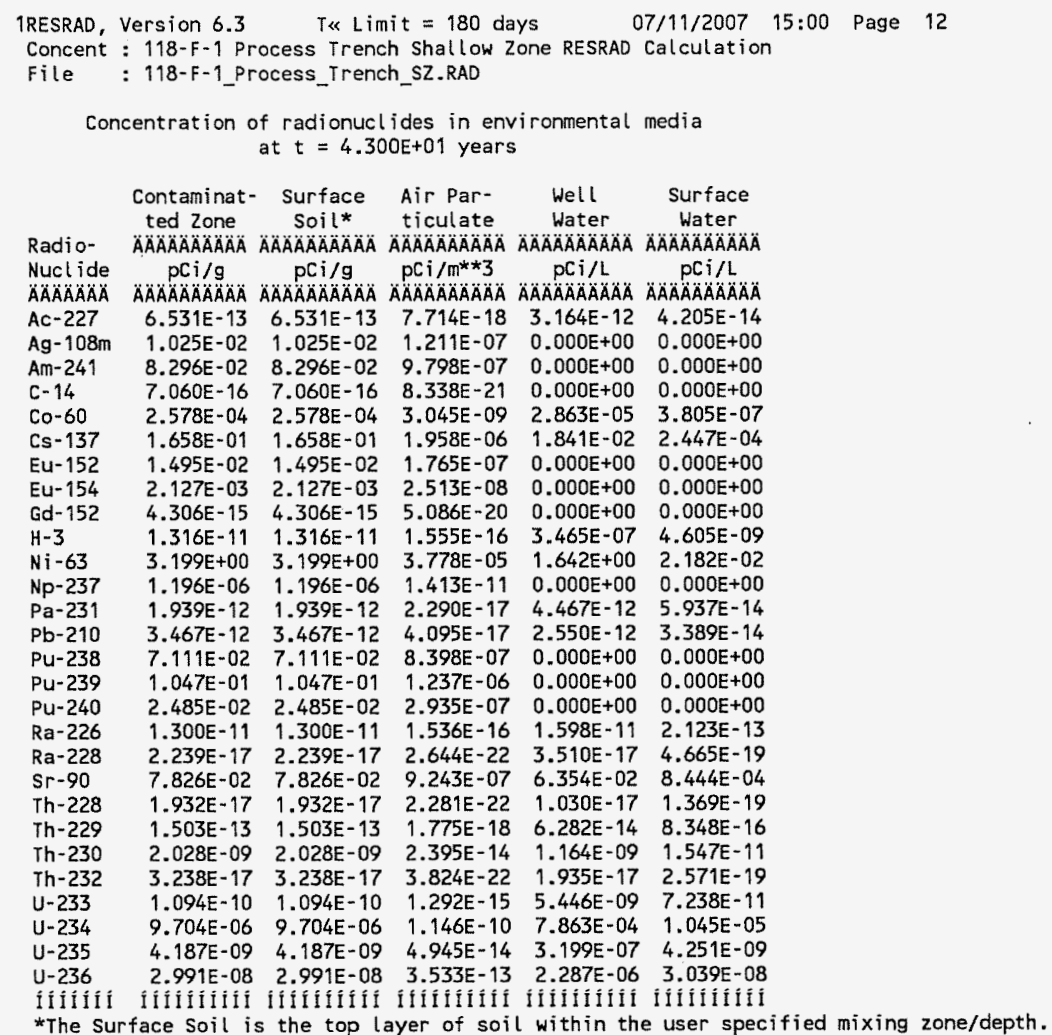

Concentrations in the media occurring in pathways that are suppressed are calculated using the current input parameters, i e. using parameters appearing in the input screen when the pathways are active.

Concentration of $\mathrm{H}-3$ in soil moisture $=1.087 \mathrm{E}-10 \mathrm{pCi} / \mathrm{ml}$

Concentration of gaseous $\mathrm{H}-3$ in air $=1.516 \mathrm{E}-11 \mathrm{pCi} / \mathrm{m}^{* * 3}$

Concentration of gaseous $\mathrm{C}-14$ in air $=2.582 \mathrm{E}-15 \mathrm{pCi} / \mathrm{m}^{\star * 3}$

$\begin{array}{ll}\text { Attachment } \frac{7}{\text { S.W. Clark }} & \text { Sheet No. } 12 \text { of } 19 \\ \text { Originator: } & \text { Date } \\ \text { Chk'd By } \frac{\text { M. W. Perrott }}{0100 \text { F-CA-V0280 }} & \text { Date } \\ \text { Calc. No. } & \text { Rev. No. } \quad 0\end{array}$




\section{ATTACHMENT 7}

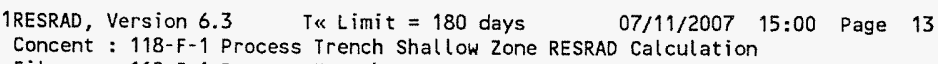

Concentrations in the media occurring in pathways that are suppressed are calculated using the current input parameters, i.e. using parameters appearing in the input screen when the pathways are active.

\begin{tabular}{|c|c|}
\hline Attachment $\quad 7$ & Sheet No. 13 of 19 \\
\hline Originator: S.W. Clark & Date \\
\hline Chk'd By M. W. Perrott & Date \\
\hline $0100 F-C A-V 0280$ & Rev. No. \\
\hline
\end{tabular}




\section{ATTACHMENT 7}

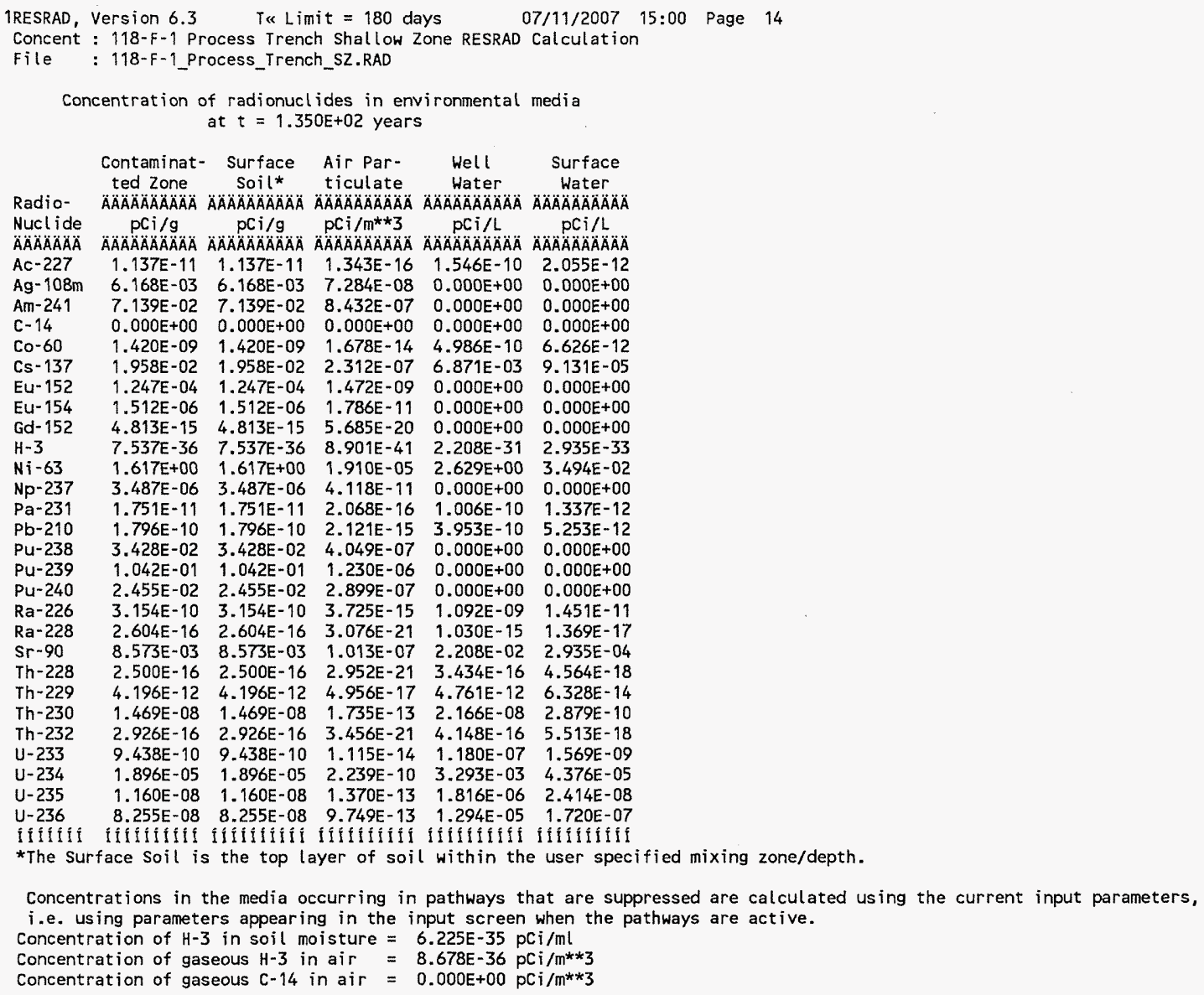

Attachment 


\section{ATTACHMENT 7}

1RESRAD, Version 6.3 T\& Limit $=180$ days 07/11/2007 15:00 Page 15

Concent : 118-F-1 Process Trench Shallow Zone RESRAD Calculation

File : 118-F-1_Process_Trench_SZ.RAD

Concentration of radionuclides in foodstuff media at $t=1.350 \mathrm{E}+02$ years*

\begin{tabular}{|c|c|c|c|c|c|c|c|c|c|}
\hline & $\begin{array}{l}\text { Drinking } \\
\text { Water }\end{array}$ & $\begin{array}{l}\text { Nonleafy } \\
\text { Vegetable }\end{array}$ & $\begin{array}{c}\text { Leafy } \\
\text { Vegetable }\end{array}$ & $\begin{array}{l}\text { Fodder } \\
\text { Meat }\end{array}$ & $\begin{array}{l}\text { Fodder } \\
\text { Milk }\end{array}$ & Meat & Milk & Fish & Crustacea \\
\hline dio- & $\triangle A \cap A ̈ A \cap A B A A A A A A$ & $\triangle A \cap A \cap A A A B A A B A$ & 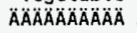 & 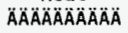 & $\triangle A \cap A \cap A \cap A \cap A \cap A B A$ & 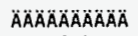 & $\triangle A A O A A A O A A A A O A$ & $\triangle A A A A A A A A A O A B$ & 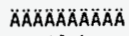 \\
\hline & $\begin{array}{c}P C I / L \\
\text { AAAAAAAAOAOAOA }\end{array}$ & $\begin{array}{c}\mathrm{pCi} / \mathrm{kg} \\
\text { AÄAAOAOAAAOA }\end{array}$ & $\begin{array}{c}\mathrm{pCi} / \mathrm{kg} \\
A A A A A A A A A B A\end{array}$ & $\begin{array}{c}p C i / \mathrm{kg} \\
A A A B A O A O A B A ̈\end{array}$ & $\begin{array}{c}\mathrm{pCi} / \mathrm{kg} \\
\text { AAOAOAAOAOAAA }\end{array}$ & $\begin{array}{c}p C i / \mathrm{kg} \\
\triangle A A A O A O A O A O A O A O A\end{array}$ & $\begin{array}{c}P C i / L \\
A O A B A A A A A B A\end{array}$ & $\begin{array}{c}\mathrm{pCi} / \mathrm{kg} \\
\triangle A \cap A B A A A A B A\end{array}$ & $\begin{array}{c}\mathrm{pCi} / \mathrm{kg} \\
\triangle A O A B A O A O A B A\end{array}$ \\
\hline & $\begin{array}{r}1.546 \mathrm{E}-10 \\
0\end{array}$ & $\begin{array}{r}2.313 E-10\end{array}$ & $1.001 \mathrm{E}-09$ & $\begin{array}{r}1.089 E-09 \\
\end{array}$ & $\begin{array}{r}1.090 \mathrm{E}-09 \\
\end{array}$ & $2.399 E-12$ & $\begin{array}{r}1.807 \mathrm{E}-12 \\
\end{array}$ & $\begin{array}{r}3.080 E-11 \\
3\end{array}$ & $\begin{array}{r}2.053 \mathrm{E}-09 \\
\end{array}$ \\
\hline & $0.000 \mathrm{E}+00$ & $.252 \mathrm{E}-01$ & $9.252 \mathrm{E}-01$ & $9.255 \mathrm{E}-01$ & $9.252 \mathrm{E}-01$ & $1.980 \mathrm{E}-01$ & $1.349 E+00$ & $0.000 E+00$ & \\
\hline & $0.000 E+00$ & $7.144 \mathrm{E}-02$ & $7.161 \mathrm{E}-02$ & $7.164 E-02$ & $7.163 \mathrm{E}-02$ & $28 E-03$ & $7.927 \mathrm{E}-05$ & $0.000 E+00$ & $0.000 E+00$ \\
\hline & $0.000 \mathrm{E}+00$ & $0.000 \mathrm{E}+00$ & $0.000 E+00$ & $0.000 E+00$ & $0.000 E+00$ & $0.000 E+00$ & $0.000 E+00$ & $0.000 E+00$ & $100 E+00$ \\
\hline & $4.986 E-10$ & $1.143 E-07$ & $1.168 \mathrm{E}-07$ & $1.179 E-07$ & $1.171 \mathrm{E}-07$ & $1.739 \mathrm{E}-07$ & $1.446 E-08$ & $1.987 E-09$ & $25 E-09$ \\
\hline & & $1 E-01$ & 8.2 & $14 E-01$ & $4 E-01$ & $1.998 \mathrm{E}+00$ & $25 E-01$ & $E-01$ & $8 E-03$ \\
\hline & $0.000 E+00$ & $7 E-04$ & $3.120 E-04$ & $3.130 \mathrm{E}-04$ & $3.121 E-04$ & $1.671 E-04$ & $75 E-06$ & $O E+00$ & $0 E+00$ \\
\hline & $E+00$ & $E-06$ & $5 E-06$ & $3.801 \mathrm{E}-06$ & $3.786 E-06$ & $2.027 E-06$ & $E-08$ & $D E+O 0$ & $0 E+00$ \\
\hline & $E+\infty$ & & $E-14$ & $E-14$ & $E-14$ & & -17 & $=+\infty$ & $E+00$ \\
\hline & $E=31$ & $4 E-31$ & $77 E-30$ & $15 E-31$ & $3 E-31$ & $4 E-31$ & $E-31$ & $E-33$ & $E-33$ \\
\hline & 2.6 & $5 E+01$ & $P E+01$ & $1 E+01$ & $E+01$ & $E+01$ & $E+02$ & $E+00$ & $E+00$ \\
\hline & 0.0 & 6.9 & E- 05 & $6.967 E-05$ & E- 05 & -06 & 2.7 & $E+D$ & $E+\infty$ \\
\hline & $E-10$ & 3.0 & $8.098 E-10$ & $8.993 E-10$ & $E-10$ & -10 & $E-13$ & $E-11$ & $E-10$ \\
\hline & 3.9 & -09 & $E-09$ & $9 E-09$ & -09 & -10 & $=-10$ & $E-09$ & $=-10$ \\
\hline & $E+00$ & 3.4 & $E-02$ & $2 E-02$ & -02 & & -05 & $E+\infty$ & $=+\infty$ \\
\hline & $0.000 \mathrm{E}+00$ & 1.04 & E-01 & $5 E-01$ & $E-01$ & -03 & & $=+\infty$ & $E+00$ \\
\hline & 0.00 & 2.4 & -02 & $=-02$ & -02 & -03 & -05 & $\mathrm{DE}+00$ & $E+00$ \\
\hline & 1.05 & 1.40 & $E-08$ & $E-08$ & -08 & -09 & $=-09$ & $9 E-10$ & $E-09$ \\
\hline & 1.03 & 1.17 & $2 E-14$ & $8 E-14$ & $E-14$ & -15 & $E-15$ & $=-16$ & $E-15$ \\
\hline & 2.20 & 2.6 & 2.7 & $E+00$ & $+\infty$ & & $E-01$ & $O E-02$ & $2.934 E-02$ \\
\hline & 3.44 & 8.53 & $E-15$ & $3.260 \mathrm{E}-15$ & 3.2 & $E-17$ & $E-18$ & $4.578 E-16$ & $2.289 E-15$ \\
\hline & 4.79 & $5 E-11$ & $3.455 E-11$ & $4.655 \mathrm{E}-11$ & $4.663 E-11$ & $E-13$ & $O E-14$ & $54 E-12$ & $3.180 E-11$ \\
\hline & $2.174 \mathrm{E}-08$ & 4.4 & 1.52 & $1.894 E-07$ & E-07 & & $E-10$ & SE-08 & $1.444 \mathrm{E}-07$ \\
\hline & $4.166 E-16$ & 8.7 & $E-15$ & $3.701 \mathrm{E}-15$ & 3.7 & $E-17$ & $E-18$ & $5.528 E-16$ & $2.766 E-15$ \\
\hline & $1.180 \mathrm{E}-07$ & 1.572 & OE-07 & $8.135 E-07$ & $E-07$ & $2.097 \mathrm{E}-08$ & $3.848 E-08$ & $1.568 E-08$ & $9.408 E-08$ \\
\hline & $3.293 \mathrm{E}-03$ & $4.370 E-03$ & $2.076 \mathrm{E}-02$ & $2.273 E-02$ & $2.273 E-02$ & & $1.072 \varepsilon-03$ & $4.375 E-04$ & $2.625 \mathrm{E}-03$ \\
\hline & $1.816 \mathrm{E}-06$ & $2.413 E-06$ & $1.146 E-05$ & $1.253 E-05$ & $1.253 E-05$ & $3.225 \mathrm{E}-07$ & $5.915 E-07$ & $2.413 E-07$ & $1.448 E-06$ \\
\hline & & & & & & & 4.21 & $1.719 E-06$ & $1.032 E-05$ \\
\hline & & & & & & & & & \\
\hline
\end{tabular}

Concentrations in the media occurring in pathways that are suppressed are calculated using the current input parameters, i.e. using parameters appearing in the input screen when the pathways are active.

\begin{tabular}{|c|c|}
\hline Attachment & Sheet No. 15 of 19 \\
\hline Originator: S.W. Clark & Date _. \\
\hline M.W. Perrott & Date \\
\hline $0100 F-C A-V 0280$ & Rev. No. \\
\hline
\end{tabular}




\section{ATTACHMENT 7}

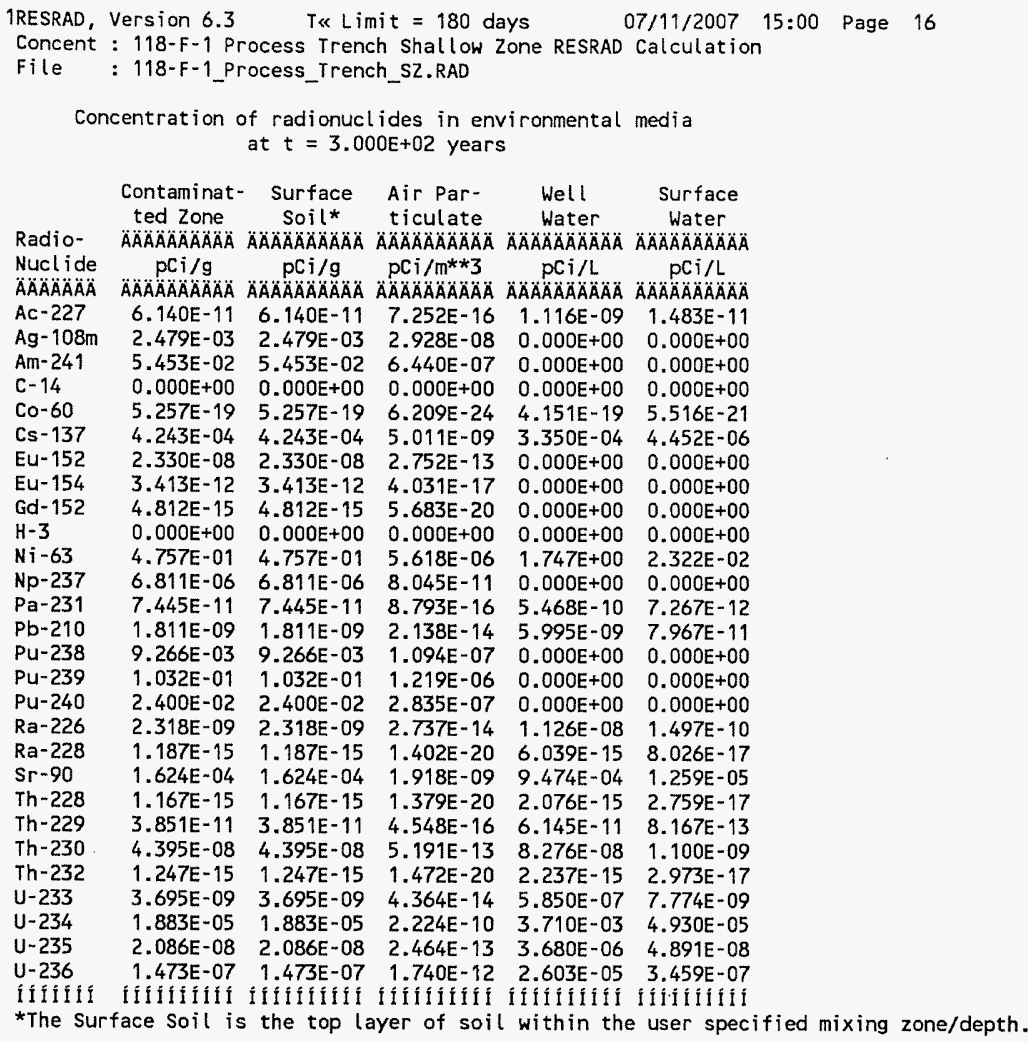

Concentrations in the media occurring in pathways that are suppressed are calculated using the current input parameters, i.e. using parameters appearing in the input screen when the pathways are active.

Concentration of $\mathrm{H}-3$ in soil moisture $=0.000 \mathrm{E}+00 \mathrm{pCi} / \mathrm{ml}$

Concentration of gaseous $\mathrm{H}-3$ in air $=0.000 \mathrm{E}+00 \mathrm{pCi} / \mathrm{m}^{\star * 3}$

Concentration of gaseous $\mathrm{C}-14$ in air $=0.000 \mathrm{E}+00 \mathrm{pCi} / \mathrm{m}^{\star * 3}$

$\begin{array}{ll}\text { Attachment } \frac{7}{\text { S.W. Clark }} & \text { Sheet No. } 16 \text { of } 19 \\ \text { Originator: } & \text { Date } \\ \text { Chk'd By } & \text { Date } \\ \text { Calc. No. Perrott } & \text { Rev. No. } \quad \text { O100F-CA-V0280 }\end{array}$




\section{ATTACHMENT 7}

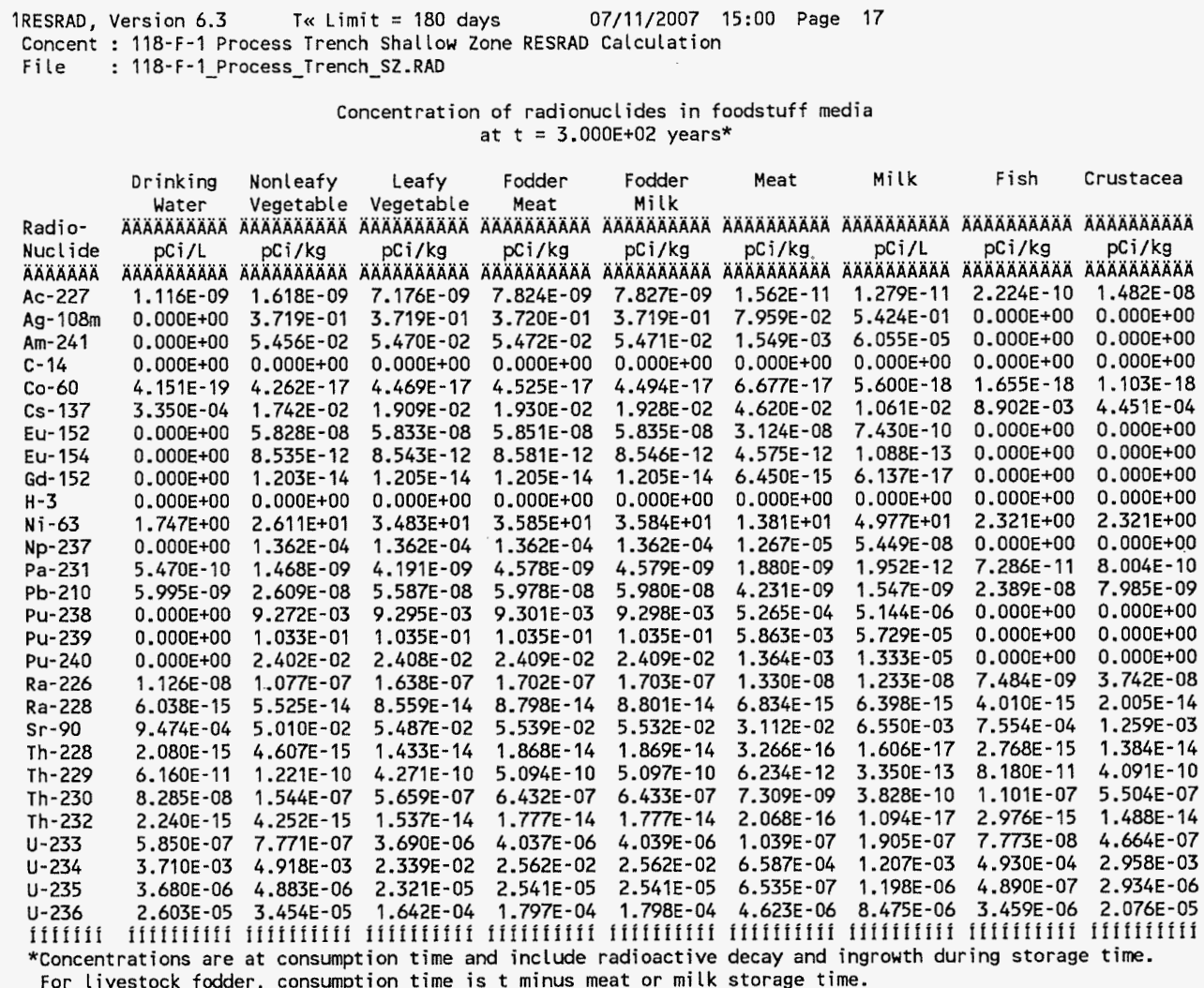

Concentrations in the media occurring in pathways that are suppressed are calculated using the current input parameters, i.e. using parameters appearing in the input screen when the pathways are active.

\begin{tabular}{|c|c|}
\hline Attachment & Sheet No. 17 of 19 \\
\hline Originator: S.W. Clark & __ate ___ \\
\hline M. W. Perrott & Date \\
\hline $0100 \mathrm{~F}-\mathrm{CA}-\mathrm{V} 0280$ & Rev. No. \\
\hline
\end{tabular}




\section{ATTACHMENT 7}

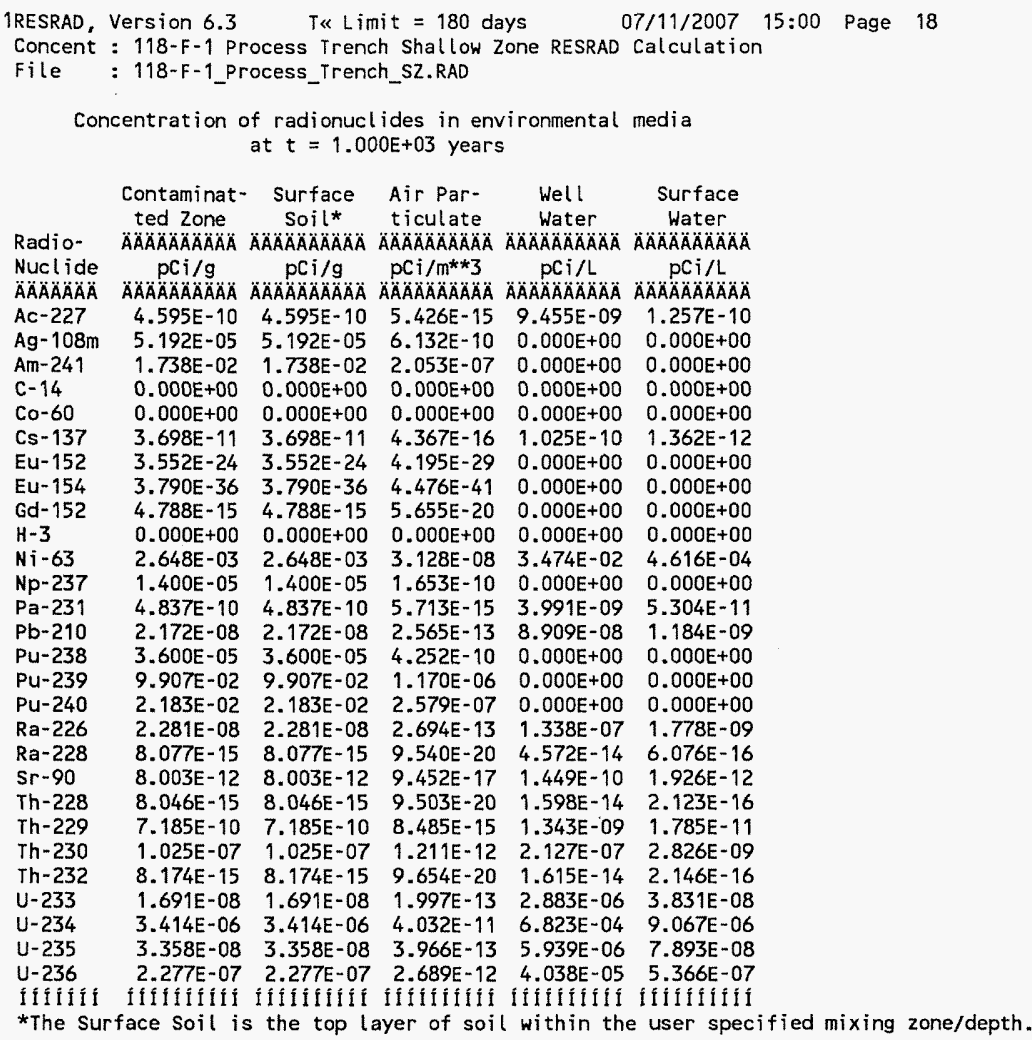

Concentrations in the media occurring in pathways that are suppressed are calculated using the current input parameters, i.e. using parameters appearing in the input screen when the pathways are active.

Concentration of $\mathrm{H}-3$ in soil moisture $=0.000 \mathrm{E}+00 \mathrm{pCi} / \mathrm{ml}$

Concentration of gaseous $\mathrm{H}-3$ in air $=0.000 \mathrm{E}+00 \mathrm{pCi} / \mathrm{m}^{\star * 3}$

Concentration of gaseous $\mathrm{C}-14$ in air $=0.000 \mathrm{E}+00 \mathrm{pCi} / \mathrm{m}^{* * 3}$

\begin{tabular}{|c|c|}
\hline Attachment & Sheet No. 18 of 19 \\
\hline Originator: S.W. Clark & Date \\
\hline Chk'd By M. W. Perrott & Date \\
\hline 0100F-CA-V0280 & Rev. No. \\
\hline
\end{tabular}




\section{ATTACHMENT 7}

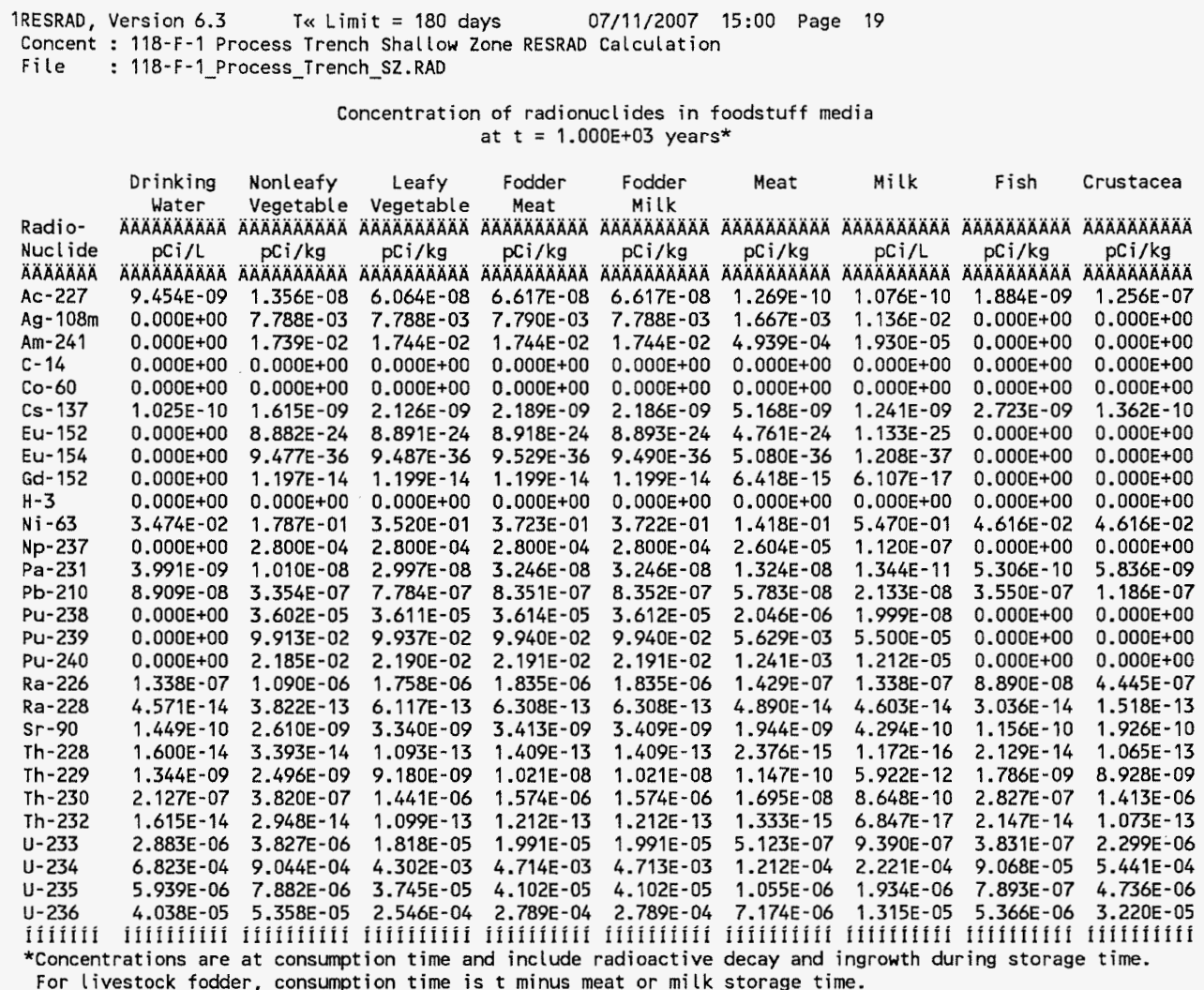

Concentrations in the media occurring in pathways that are suppressed are calculated using the current input parameters, i.e. using parameters appearing in the input screen when the pathways are active.

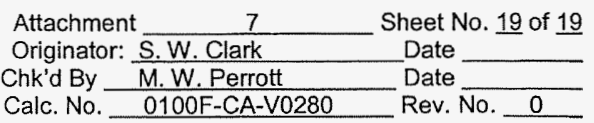




\section{ATTACHMENT 8}

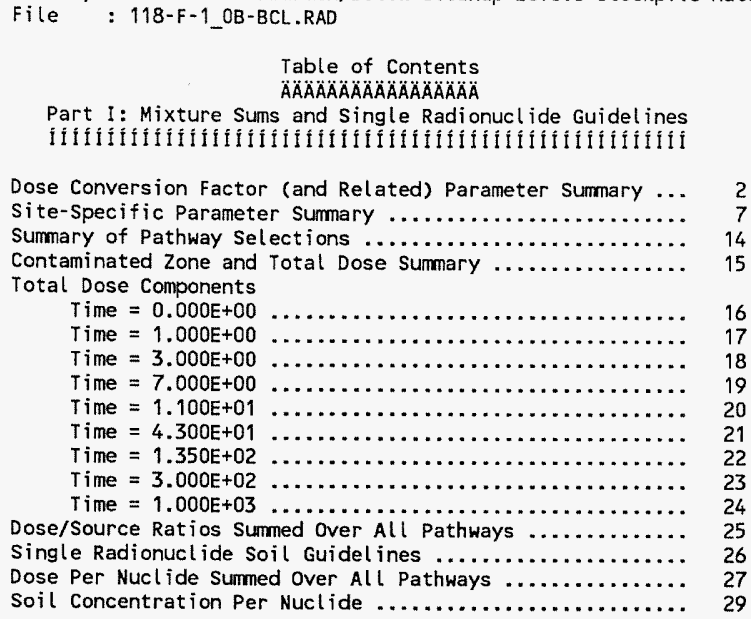




\section{ATTACHMENT 8}

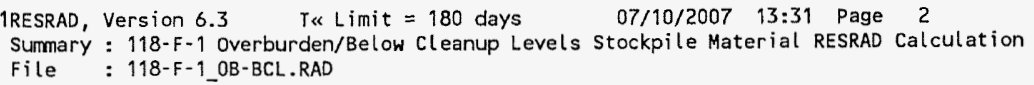

$34.027 E-03$, $3.530 E-03$, DCF3( 23)

Attachment

8

Sheet No. 2 of 30 


\section{ATTACHMENT 8}

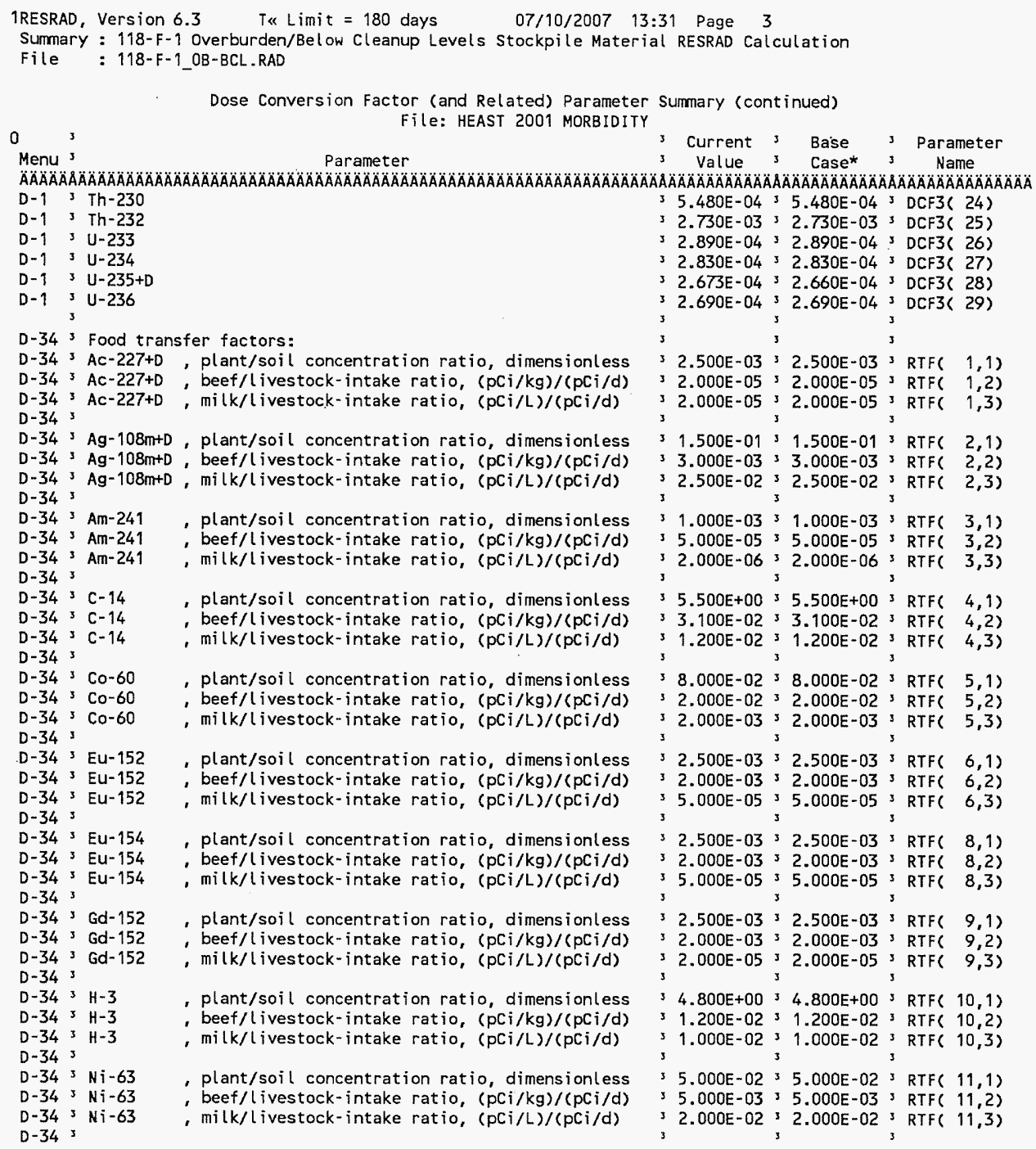

$\begin{array}{ll}\text { Attachment } \frac{8}{\text { W. Clark }} & \text { Sheet No. } \underline{3} \text { of } \underline{30} \\ \text { Originator: } \frac{\text { S.W. Wate }}{\text { M.W. Perrott }} & \text { Date } \\ \text { Chk'd By } & \text { Rev. No. } 0 \\ \text { Calc. No. } 0100 \text { F-CA-V0280 } & \text { Rev }\end{array}$




\section{ATTACHMENT 8}

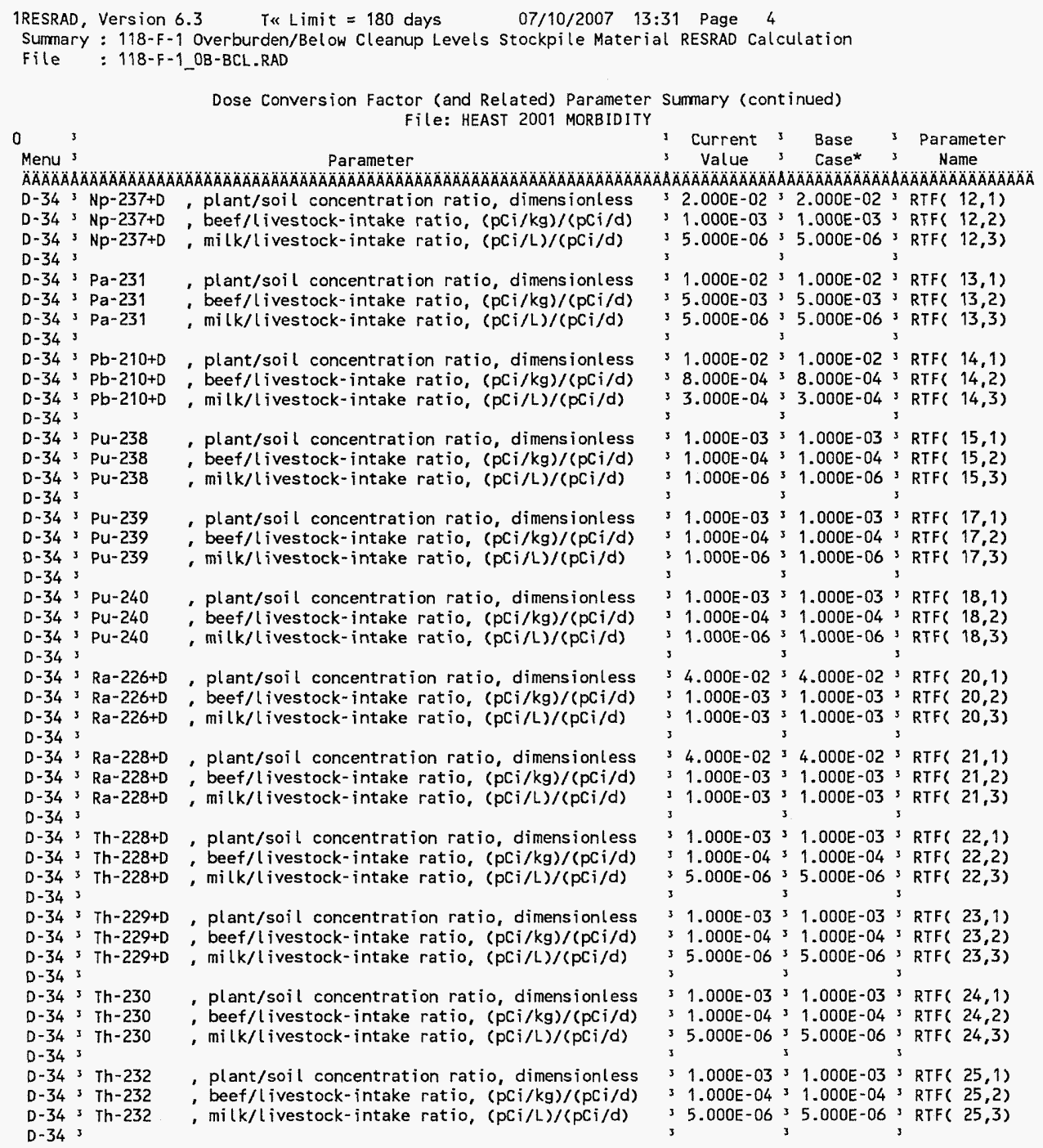




\section{ATTACHMENT 8}

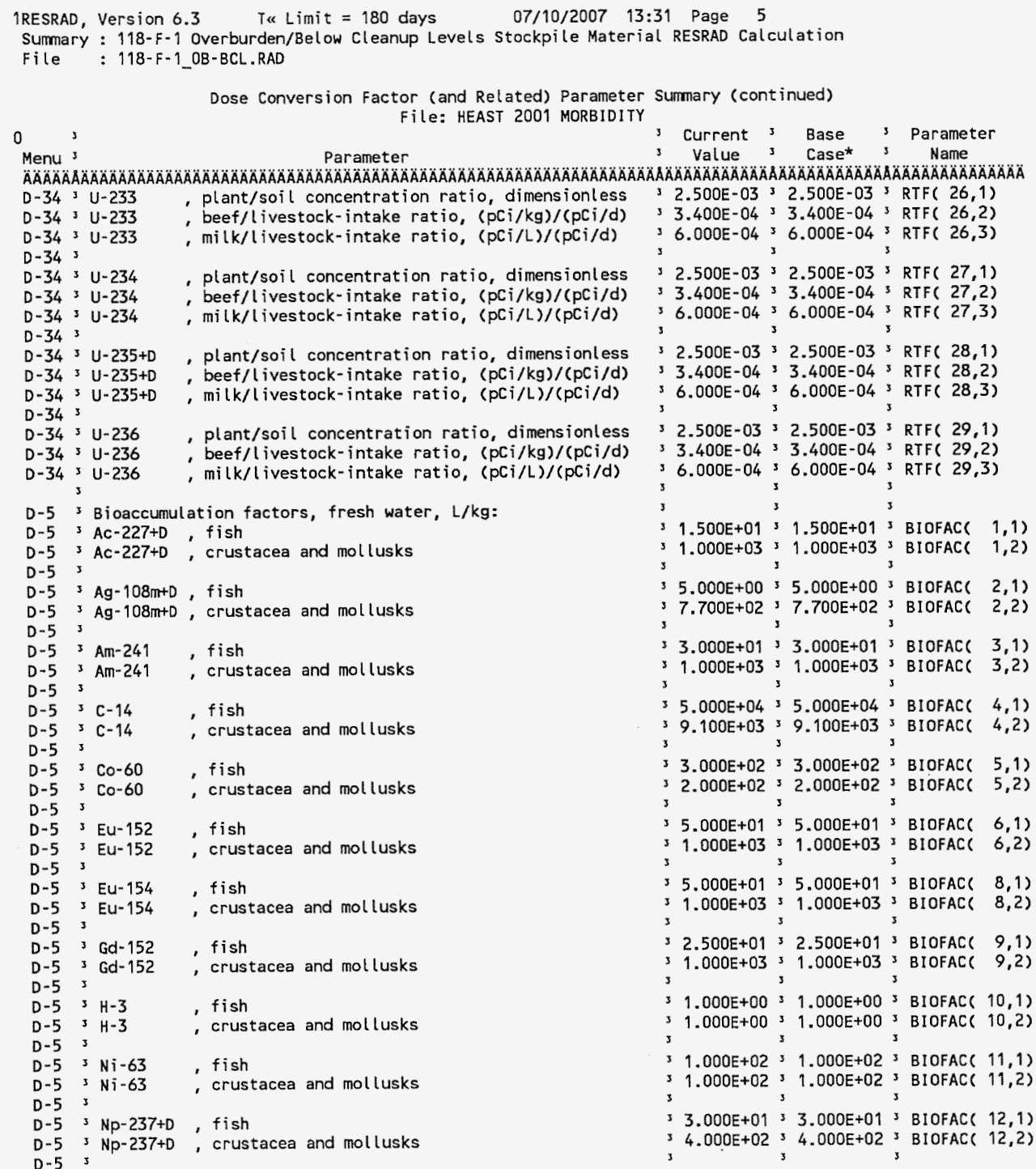

Attachment 8 


\section{ATTACHMENT 8}

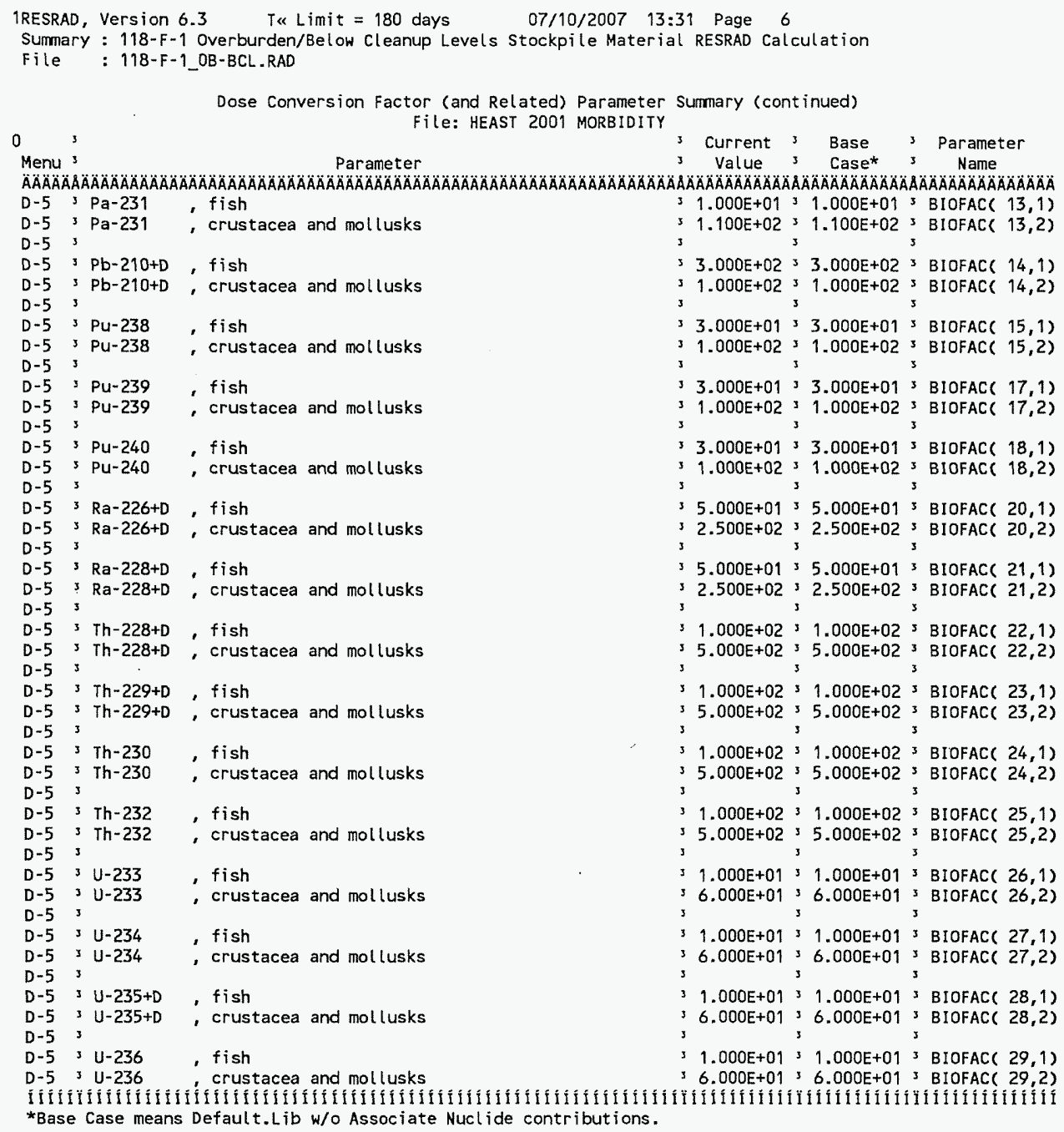

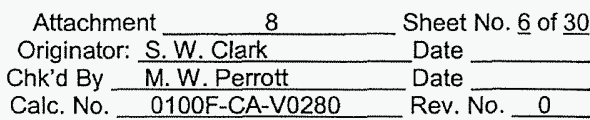




\title{
ATTACHMENT 8
}

\begin{abstract}
1RESRAD, Version 6.3 T\& Limit $=180$ days $\quad 07 / 10 / 2007 \quad 13: 31$ Page 7
\end{abstract} Sumary : 118-F-1 Overburden/Below Cleanup Levels Stockpile Material RESRAD Calculation File : 118-F-1_OB-BCL.RAD

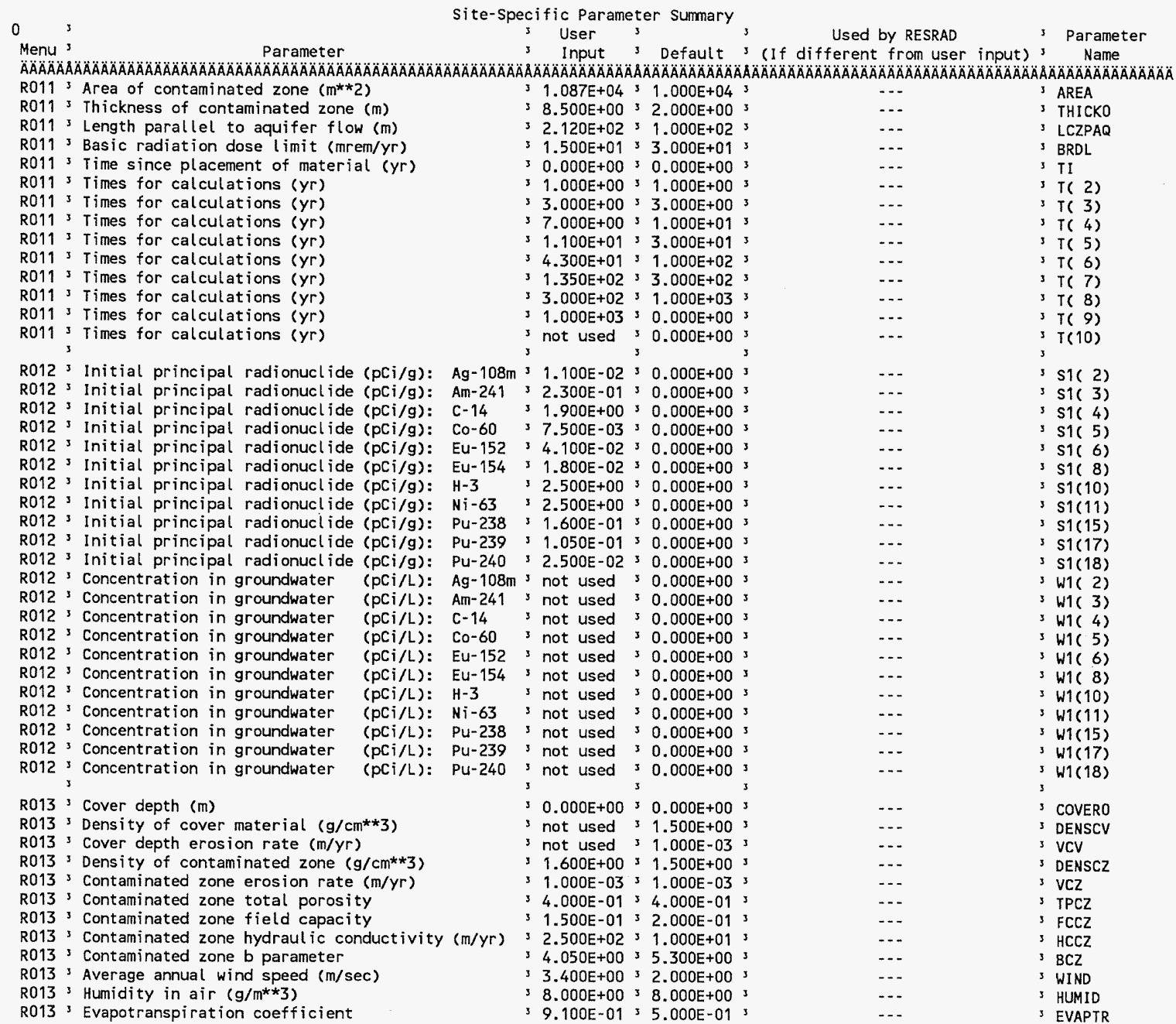

\begin{tabular}{|c|c|}
\hline Attachment $\quad 8$ & Sheet No. 7 of 30 \\
\hline Originator: S.W. Clark & Date \\
\hline Chk'd By M. W. Perrott & Date \\
\hline $0100 F-C A-V 0280$ & Rev. No. \\
\hline
\end{tabular}




\section{ATTACHMENT 8}

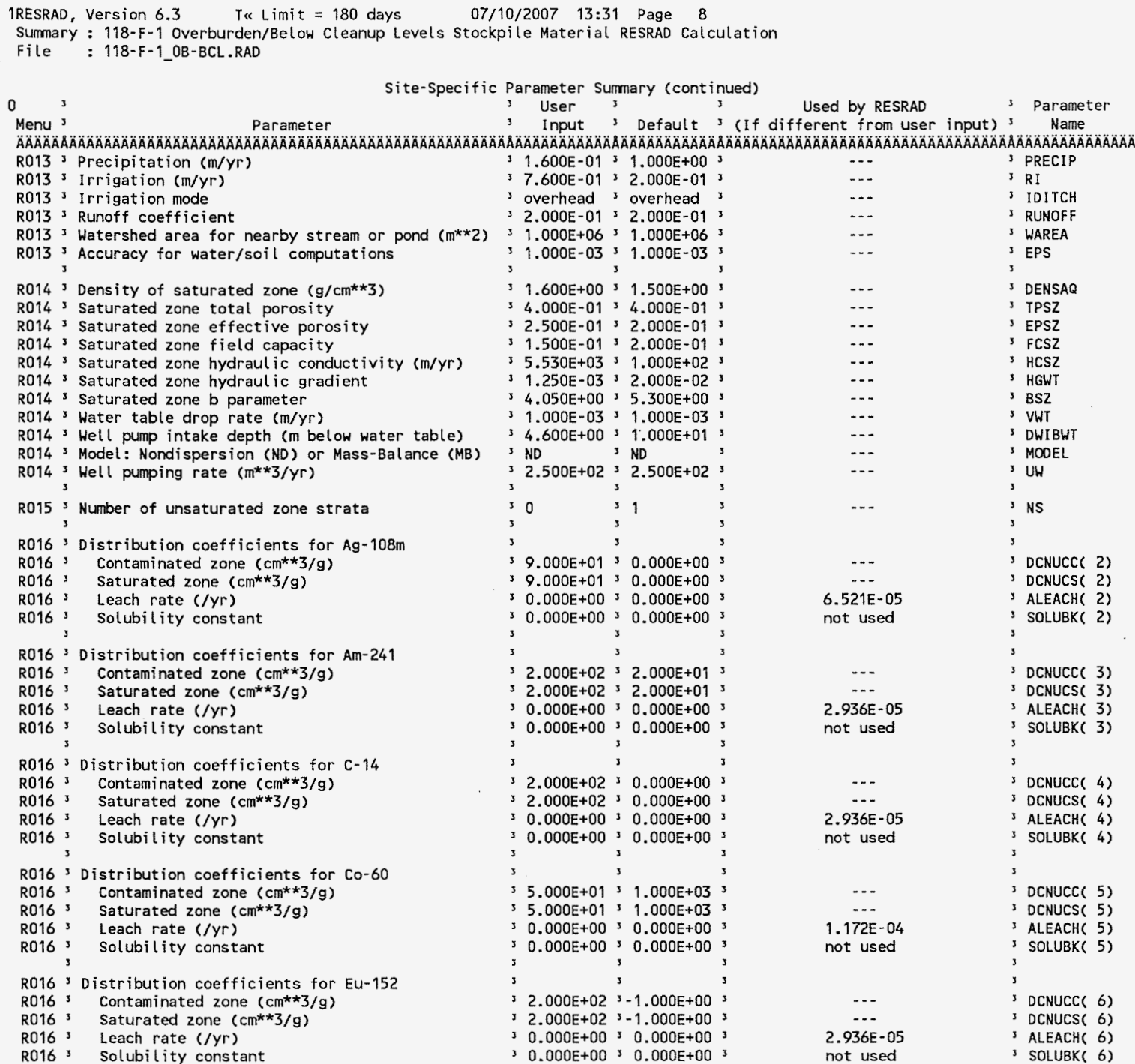

\begin{tabular}{|c|c|c|}
\hline \multirow{2}{*}{\multicolumn{3}{|c|}{ 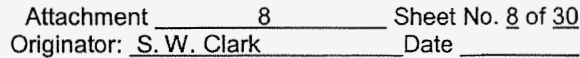 }} \\
\hline & & \\
\hline Chk'd By & M. W. Perrott & Date \\
\hline Calc. No. & $0100 F-C A-V 0280$ & Rev. No. \\
\hline
\end{tabular}




\section{ATTACHMENT 8}

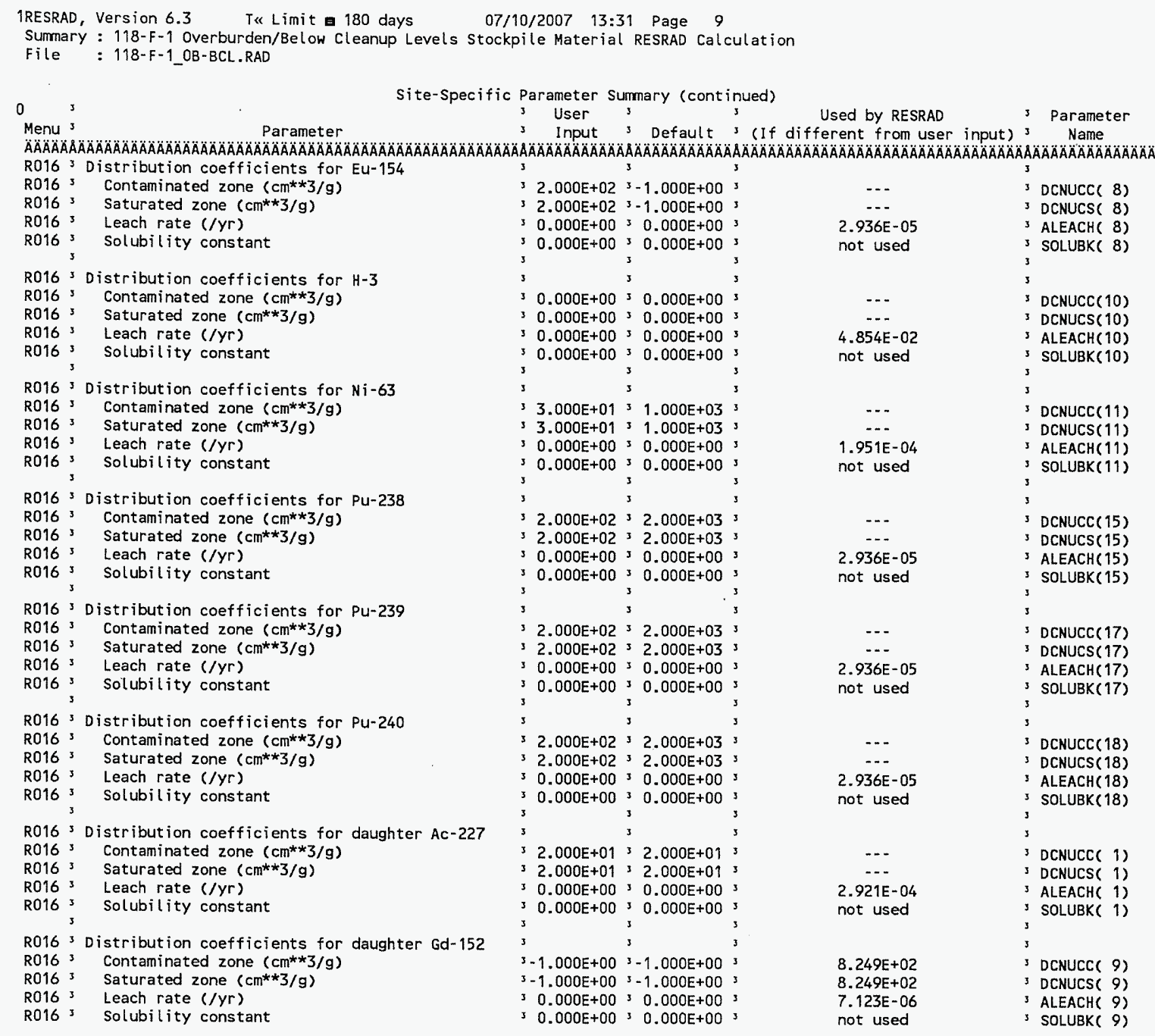

$\begin{array}{ll}\text { Attachment } \frac{8}{\text { W. Clark }} & \text { Sheet No. } \underline{9} \text { of } 30 \\ \text { Originator: } \frac{\text { S.W. }}{\text { M.W. Perrott }} & \text { Date } \\ \text { Chk'd By } & \text { Rev. No. } 0 \\ \text { Calc. No. } 0100 \text { F-CA-V0280 } & \text { Rev. No }\end{array}$




\section{ATTACHMENT 8}

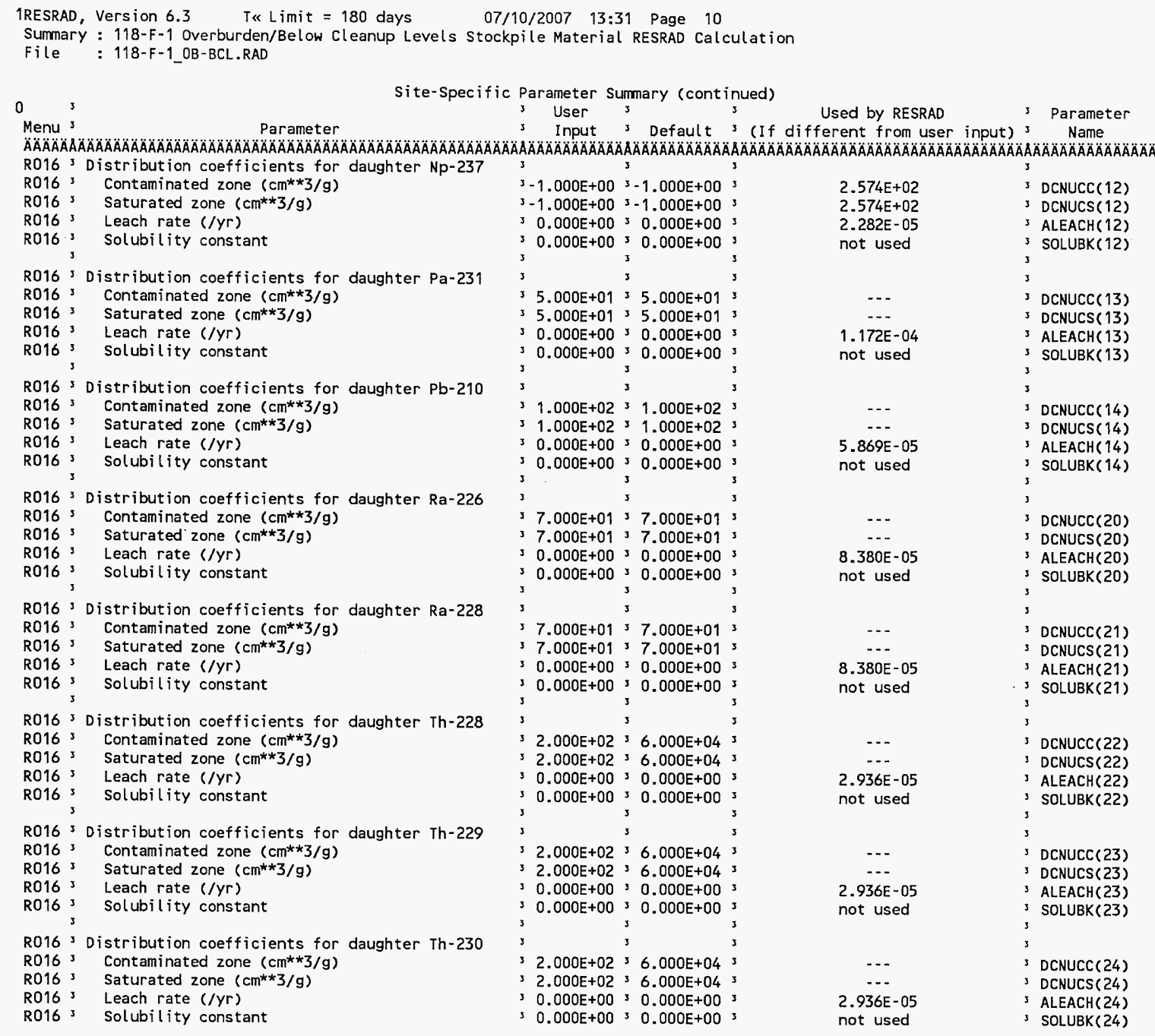

Attachment

8 


\section{ATTACHMENT 8}

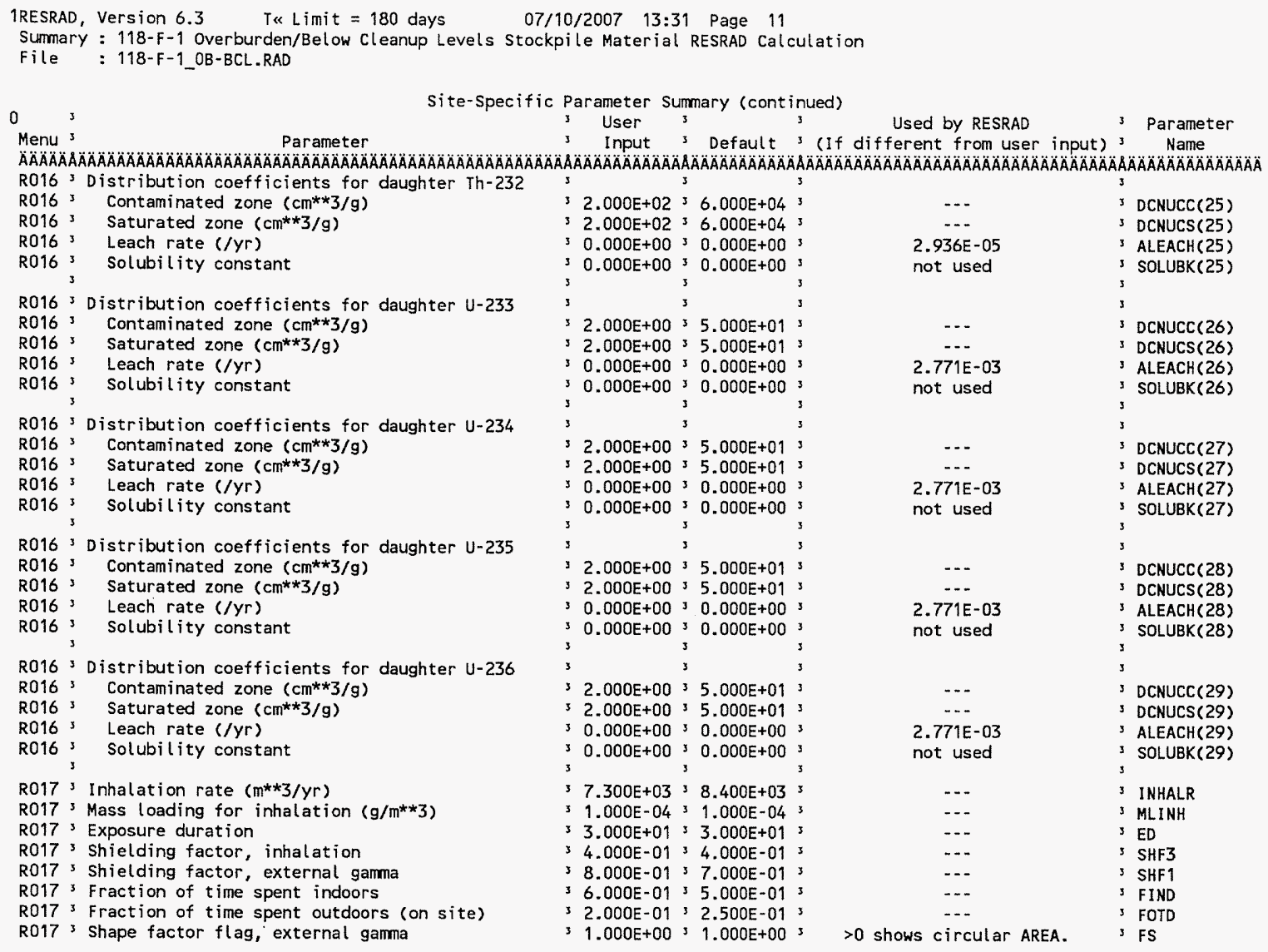

\begin{tabular}{|c|c|}
\hline Attachment & Sheet No. 11 of 30 \\
\hline Originator: $\overline{\mathrm{S.W} . \text { Clark }}$ & Date \\
\hline hk'd By M.W. Perrott & Date \\
\hline $0100 F-C A-V 0280$ & Rev. No. \\
\hline
\end{tabular}




\section{ATTACHMENT 8}

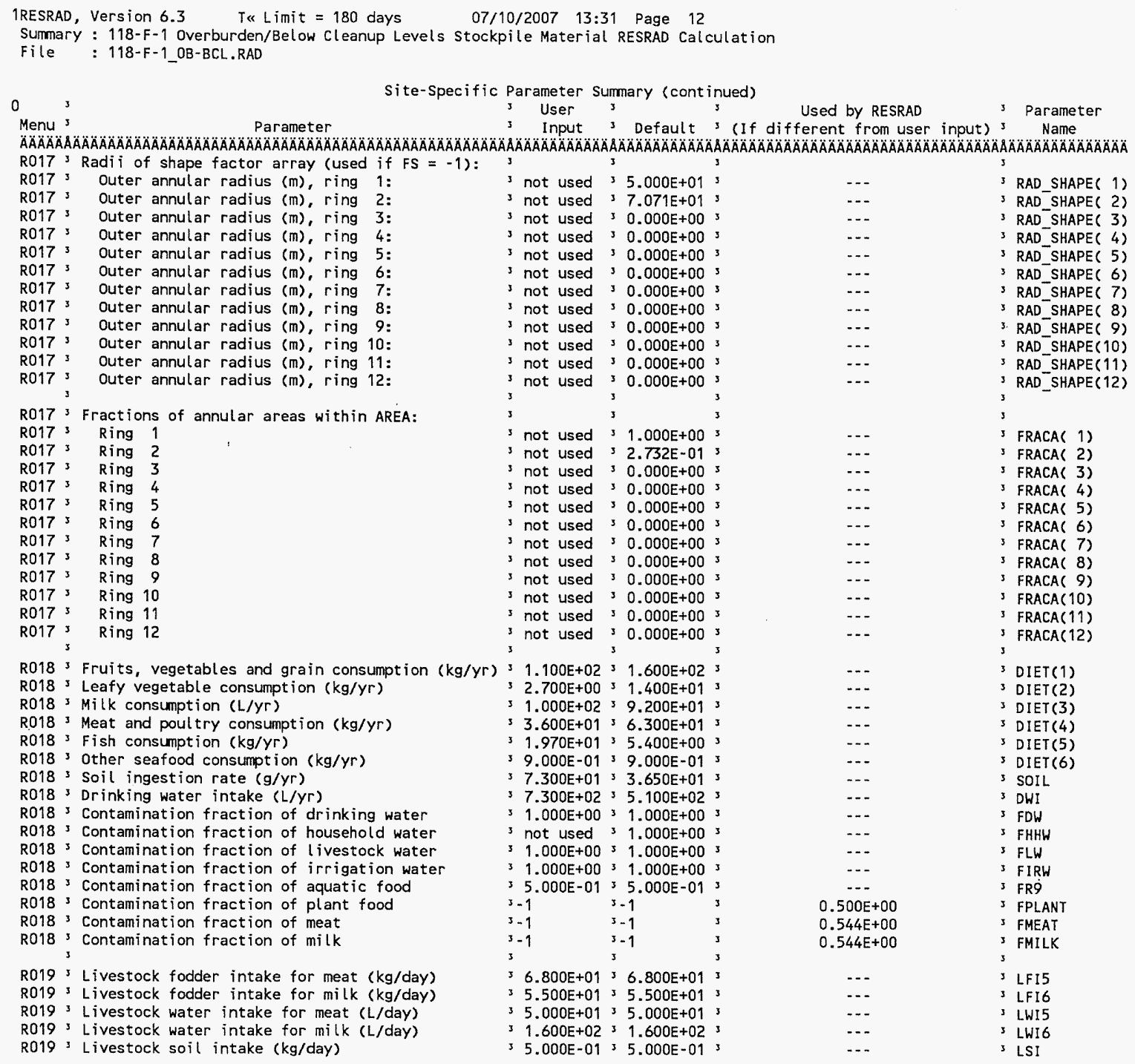

Attachment

8 


\section{ATTACHMENT 8}

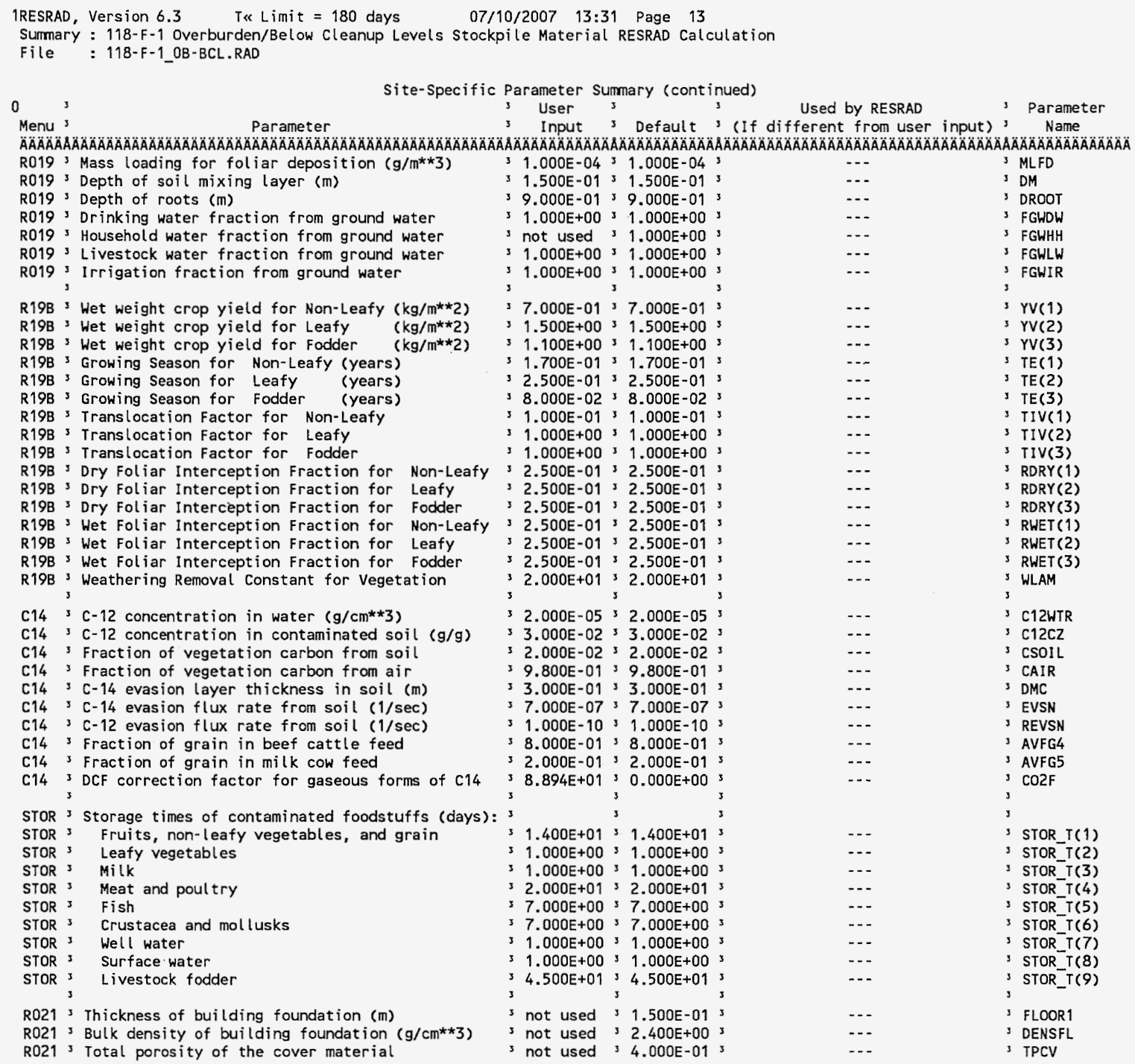




\section{ATTACHMENT 8}

1RESRAD, Version 6.3 T\& Limit $=180$ days $\quad 07 / 10 / 2007 \quad 13: 31$ Page 14

Summary : 118-F-1 Overburden/Below Cleanup Levels Stockpile Material RESRAD Calculation

File : 118-F-1_OB-BCL.RAD

\begin{tabular}{|c|c|c|c|c|c|c|c|c|c|c|}
\hline \multirow{3}{*}{$\begin{array}{l}0_{\text {Menu }} \\
\text { Men }\end{array}$} & \multicolumn{4}{|c|}{ Site-Specific Parameter $S$} & \multicolumn{3}{|c|}{ Summary (cont inued) } & & \multirow{3}{*}{3} & \multirow[b]{2}{*}{ Parameter } \\
\hline & & 3 & & ser & 3 & & & Used by RESRAD & & \\
\hline & Parameter & 3 & & aput & 3 & Default & ${ }^{3}$ (If & different from user input) & & Name \\
\hline ÄÄÄÄ & 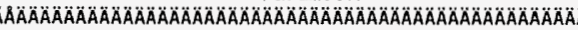 & ÄĂ̈ & $A A ̈ A ̈ A$ & $\triangle A ̈ A O A O A$ & & & AA ÄÄÄÄ & 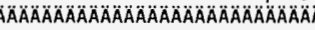 & & $\triangle A O A O A O A O A O A O A O A O A$ \\
\hline$R 021$ & 3 Total porosity of the building foundation & 3 & not & used & 3 & $1.000 E-01$ & 3 & $\ldots$ & 3 & TPFL \\
\hline$R 021$ & 3 Volumetric water content of the cover material & 3 & not & used & s & $5.000 \mathrm{E}-02$ & 3 & ... & 3 & PH2OCV \\
\hline $\mathrm{R} 021$ & Volumetric water content of the foundation & 3 & not & used & s & $3.000 \mathrm{E}-02$ & : & $\cdots$ & 3 & PH2OFL \\
\hline$R 021$ & ${ }^{3}$ Diffusion coefficient for radon gas $(\mathrm{m} / \mathrm{sec})$ : & 3 & & & 3 & & 3 & & 3 & \\
\hline R021 & 3 in cover material & 3 & not & used & 3 & $2.000 E-06$ & 3 & $\cdots$ & 3 & DIFCV \\
\hline R021 & in foundation material & 3 & not & used & s & $3.000 E-07$ & 3 & -. & 3 & DIFFL \\
\hline R021 & in contaminated zone soil & 3 & not & used & s & $2.000 E-06$ & 3 & ... & 3 & DIFCZ \\
\hline R021 & 3 Radon vertical dimension of mixing $(m)$ & 3 & not & used & 3 & $2.000 \mathrm{E}+00$ & 3 & $\cdots$ & s & HMIX \\
\hline R021 & ${ }^{3}$ Average building air exchange rate $(1 / \mathrm{hr})$ & 3 & not & used & 3 & $5.000 E-01$ & 3 & ... & 3 & REXG \\
\hline R021 & 3 Height of the building (room) (m) & 3 & not & used & s & $2.500 E+00$ & 3 & -.. & 3 & HRM \\
\hline R021 & Building interior area factor & 3 & not & used & 3 & $0.000 E+00$ & s &.-- & 3 & FAI \\
\hline$R 021$ & 3 Building depth below ground surface (m) & 3 & not & used & & $-1.000 E+00$ & 3 & $\cdots$ & 3 & DMFL \\
\hline$R 021$ & 3 Emanating power of $\mathrm{Rn}-222$ gas & 3 & not & used & 3 & $2.500 E-01$ & s & $\cdots$ & 3 & EMANA(1) \\
\hline $\mathrm{R} 021$ & Emanating power of $\mathrm{Rn}-220$ gas & 3 & not & used & 3 & $1.500 E-01$ & 3 & $\cdots$ & 3 & EMANA(2) \\
\hline TITL & 3 Number of graphical time points & 3 & & 32 & s & -.. & 3 & ..- & 3 & NPTS \\
\hline TITL & ${ }^{3}$ Maximum number of integration points for dose & 3 & & 1 & s & -.. & 3 & 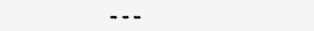 & 3 & LYMAX \\
\hline TITL & Maximum number of integration points for risk & s & & 5 & 3 & ..- & 3 & -.. & 3 & KYMAX \\
\hline
\end{tabular}

Summary of Pathway Selections

\begin{tabular}{|c|c|c|c|c|}
\hline \\
\hline & & & & \\
\hline & \multicolumn{4}{|c|}{ 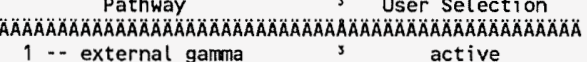 } \\
\hline \multicolumn{3}{|c|}{ 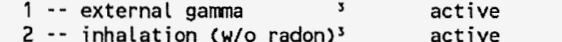 } & \multicolumn{2}{|c|}{ inhalation (w/o radon $)^{3}$} \\
\hline \multicolumn{5}{|c|}{$\begin{array}{ll}3 \text { - plant ingestion } & \text { active } \\
\end{array}$} \\
\hline \multicolumn{5}{|c|}{4 .. meat ingestion 3 active } \\
\hline \multirow{2}{*}{\multicolumn{5}{|c|}{$\begin{array}{lll}5 & -\mathrm{mi} & \mathrm{mi} \\
6 & --\mathrm{ac}\end{array}$}} \\
\hline & & & 3 & \\
\hline \multirow{2}{*}{\multicolumn{5}{|c|}{$\begin{array}{l}7 \cdots d \\
8 \cdots s\end{array}$}} \\
\hline & & & & \\
\hline \multicolumn{5}{|c|}{$\begin{array}{l}9 \text {-- radon } \\
\text { Find peak pathway doses }\end{array}$} \\
\hline \multicolumn{5}{|c|}{ 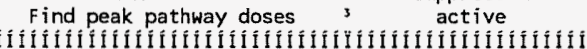 } \\
\hline
\end{tabular}

\begin{tabular}{|c|c|}
\hline Attachment $\quad 8$ & Sheet No. 14 of $\underline{30}$ \\
\hline Originator: S.W. Clark & Date - - \\
\hline Chk'd By M. W. Perrott & Date \\
\hline $0100 \mathrm{~F}-\mathrm{CA}-\mathrm{V} 0280$ & Rev. No. \\
\hline
\end{tabular}




\section{ATTACHMENT 8}

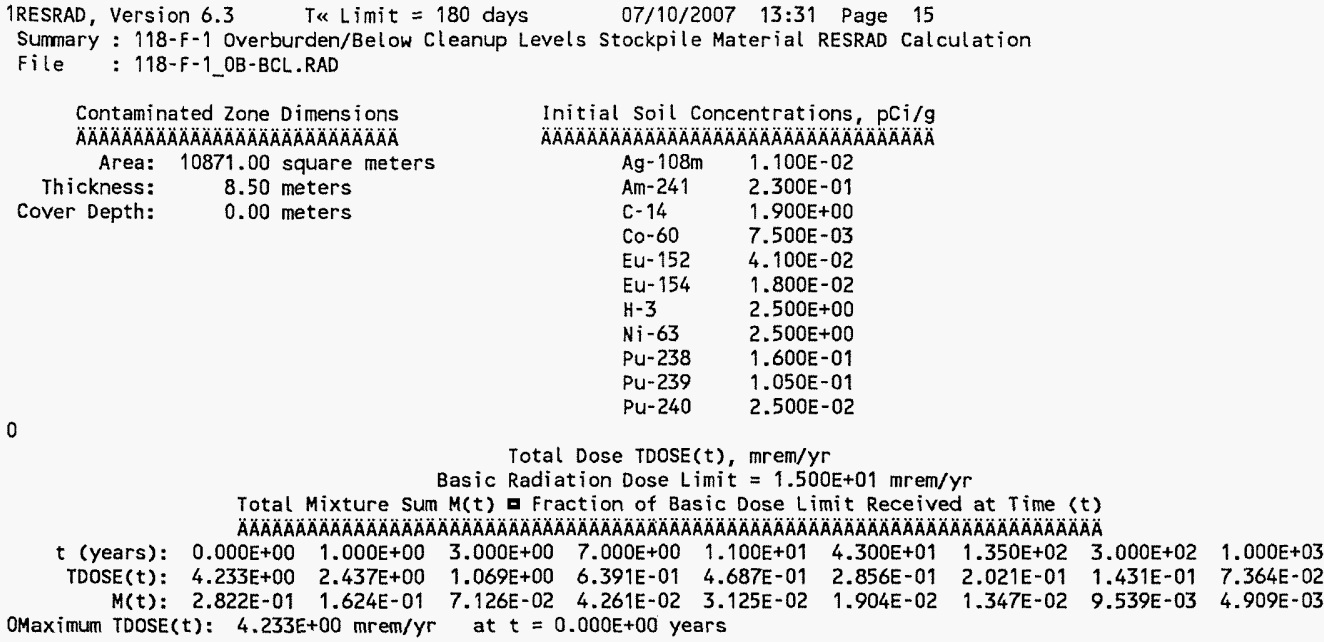

Total Dose TDOSE( $t)$, mrem/yr Basic Radiation Dose Limit $=1500 \mathrm{E}+01 \mathrm{mrem} / \mathrm{yr}$

Total Mixture Sum M(t) a Fraction of Basic Dose Limit Received at Time $(t)$

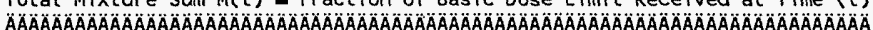

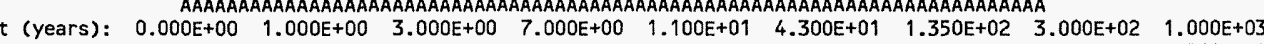

$\operatorname{TDOSE}(t): \quad 4.233 E+00 \quad 2.437 \mathrm{E}+00 \quad 1.069 \mathrm{E}+00 \quad 6.391 \mathrm{E}-01 \quad 4.687 \mathrm{E}-01 \quad 2.856 \mathrm{E}-01 \quad 2.021 \mathrm{E}-01 \quad 1.431 \mathrm{E}-01 \quad 7.364 \mathrm{E}-02$ $M(t): \quad 2.822 E-01 \quad 1.624 E-01 \quad 7.126 E-02 \quad 4.261 E-02 \quad 3.125 E-02 \quad 1.904 E-02 \quad 1.347 E-02 \quad 9.539 E-03 \quad 4.909 E-03$ OMaximum $\operatorname{TDOSE}(t): 4.233 E+00 \mathrm{mrem} / \mathrm{yr}$ at $t=0.000 E+00$ years

$\begin{array}{ll}\text { Attachment } \frac{8}{\text { S.W.Clark }} & \text { Sheet No. } 15 \text { of } 30 \\ \text { Originator: } & \text { Date } \\ \text { Chk'd By } \frac{\text { M.W. Perrott }}{\text { Date }} & \\ \text { Calc. No. } & \text { Rev. No. } 0\end{array}$


Rev. 0

\section{ATTACHMENT 8}

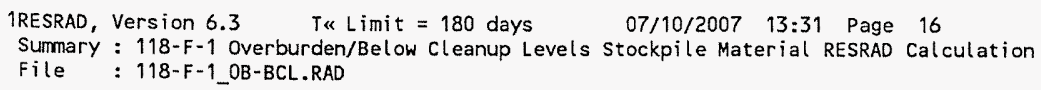

Total Dose Contributions $\operatorname{TDOSE}(i, p, t)$ for Individual Radionuclides (i) and Pathways ( $p$ ) As $\mathrm{mrem} / \mathrm{yr}$ and Fraction of Total Dose At $t=0.000 E+00$ years

0 Water $r$ and Fraction of rotal Dose At $t=0.000 \mathrm{E}+00$ years Plant Meat Nuclide mrem/yr fract. mrem/yr fract. mrem/yr fract. mrem/yr fract. mrem/yr fract. mrem/yr fract. mrem/yr fract.

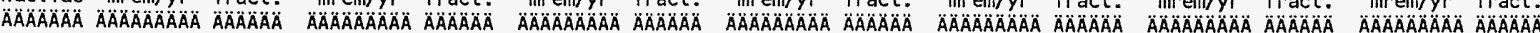

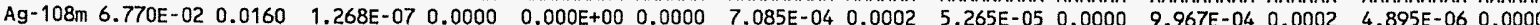

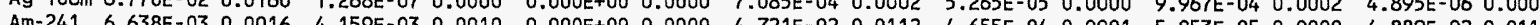

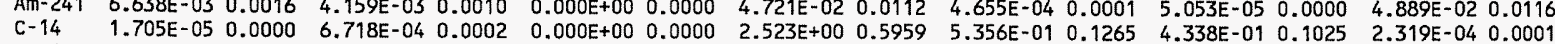

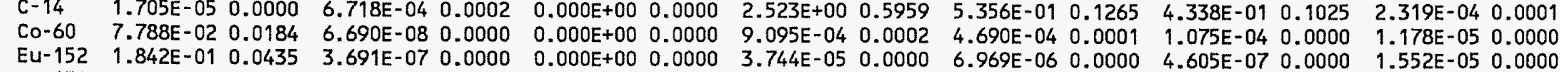

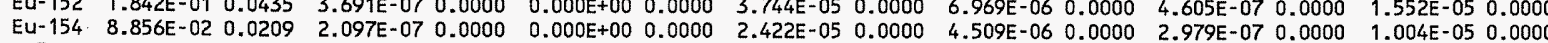

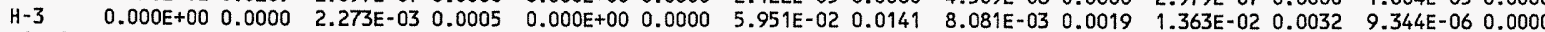
$\begin{array}{lllllllllllllllll}\mathrm{Ni}-63 & 0.000 \mathrm{E}+00 & 0.0000 & 6.405 \mathrm{E}-07 & 0.0000 & 0.000 \mathrm{E}+00 & 0.0000 & 4.064 \mathrm{E}-03 & 0.0010 & 5.505 \mathrm{E}-04 & 0.0001 & 5.097 \mathrm{E}-03 & 0.0012 & 8.424 \mathrm{E}-05 & 0.0000\end{array}$ PU-238 1.629E-05 $0.0000 \quad 2.555 E-03 \quad 0.0006 \quad 0.000 E+00 \quad 0.0000 \quad 2.887 E-02 \quad 0.0068 \quad 5.693 E-04 \quad 0.0001 \quad 1.545 E-05 \quad 0.0000 \quad 2.990 E-020.0071$ PU-239 2.011E-05 0.0000 $1.835 E-030.0004$.

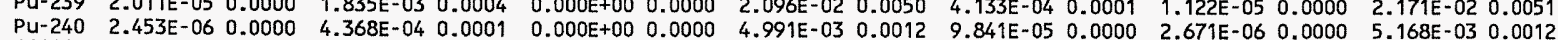

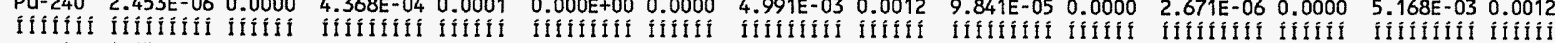
$\begin{array}{llllllllllllllllll}\text { Total } & 4.250 E-01 & 0.1004 & 1.193 E-02 & 0.0028 & 0.000 E+00 & 0.0000 & 2.690 E+00 & 0.6355 & 5.463 E-01 & 0.1291 & 4.537 E-01 & 0.1072 & 1.060 E-01 & 0.0251\end{array}$

Total Dose Contributions $\operatorname{TDOSE}(i, p, t)$ for Individual Radionuclides (i) and Pathways ( $p$ )

As $\mathrm{mrem} / \mathrm{yr}$ and Fraction of Total Dose At $t=0.000 \mathrm{E}+00$ years
Water Dependent Pathways

0

$$
\begin{array}{r}
\text { As } \mathrm{mrem} / \mathrm{yr} \text { and Fraction of Total Dose At } t \\
\text { Water Dependent Pathways }
\end{array}
$$
Nuclide mrem/yr fract. mrem/yr fract. mrem/yr fract. mrem/yr fract. mrem/yr fract. mrem/yr fract. mrem/yr fract.

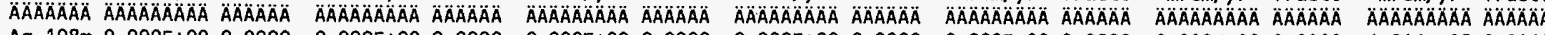
$\begin{array}{llllllllllllllllll}A g-108 m & 0.000 E+00 & 0.0000 & 0.000 E+00 & 0.0000 & 0.000 E+00 & 0.0000 & 0.000 E+00 & 0.0000 & 0.000 E+00 & 0.0000 & 0.000 E+00 & 0.0000 & 6.946 E-02 & 0.0164\end{array}$

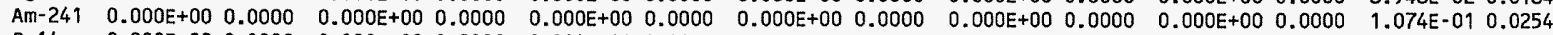
$\begin{array}{lllllllllllllllllll}C-14 & 0.000 E+00 & 0.0000 & 0.000 E+00 & 0.0000 & 0.000 E+00 & 0.0000 & 0.000 E+00 & 0.0000 & 0.000 E+00 & 0.0000 & 0.000 E+00 & 0.0000 & 3.493 E+00 & 0.8252\end{array}$

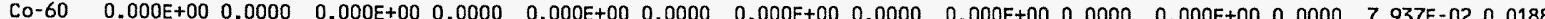
EU-152 0.000E+00 0.0000 0.000E+00 0.0000 0.000E+00 0.0000 0.000E+00 0.0000 0.000E+00 0.0000 $0.000 E+000.0000 \quad 1.843 E-010.0435$

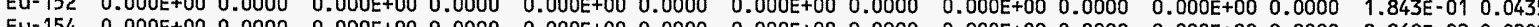

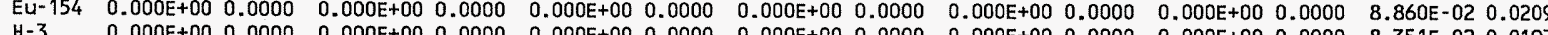

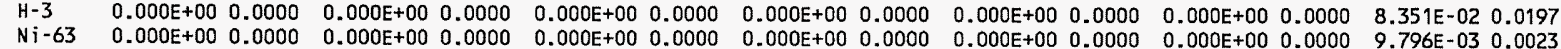
$\begin{array}{llllllllllllllll}\mathrm{Pu}-238 & 0.000 \mathrm{E}+00 & 0.0000 & 0.000 E+00 & 0.0000 & 0.000 E+00 & 0.0000 & 0.000 E+00 & 0.0000 & 0.000 E+00 & 0.0000 & 0.000 E+00 & 0.0000 & 9.796 E-03 & 0.0023\end{array}$ $\begin{array}{lllllllllllllll}\text { PU-239 } & 0.000 E+00 & 0.0000 & 0.000 E+00 & 0.0000 & 0.000 E+00 & 0.0000 & 0.000 E+00 & 0.0000 & 0.000 E+00 & 0.0000 & 0.000 E+00 & 0.0000 & 4.495 E-02 & 0.0106\end{array}$

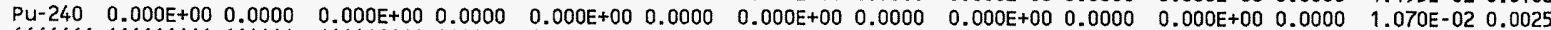

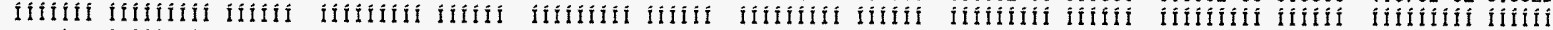
$\begin{array}{lllllllllllllllllll}\text { Total } & 0.000 E+00 & 0.0000 & 0.000 E+00 & 0.0000 & 0.000 E+00 & 0.0000 & 0.000 E+00 & 0.0000 & 0.000 E+00 & 0.0000 & 0.000 E+00 & 0.0000 & 4.233 E+00 & 1.0000\end{array}$ $0 *$ Sum of all water independent and dependent pathways.

\begin{tabular}{|c|c|}
\hline Attachment & Sheet No. 16 of 30 \\
\hline Originator: S.W. Clark & Date \\
\hline Chk'd By M.W. Perrott & Date \\
\hline $0100 F-C A-V 0280$ & Rev. No. \\
\hline
\end{tabular}




\section{ATTACHMENT 8}

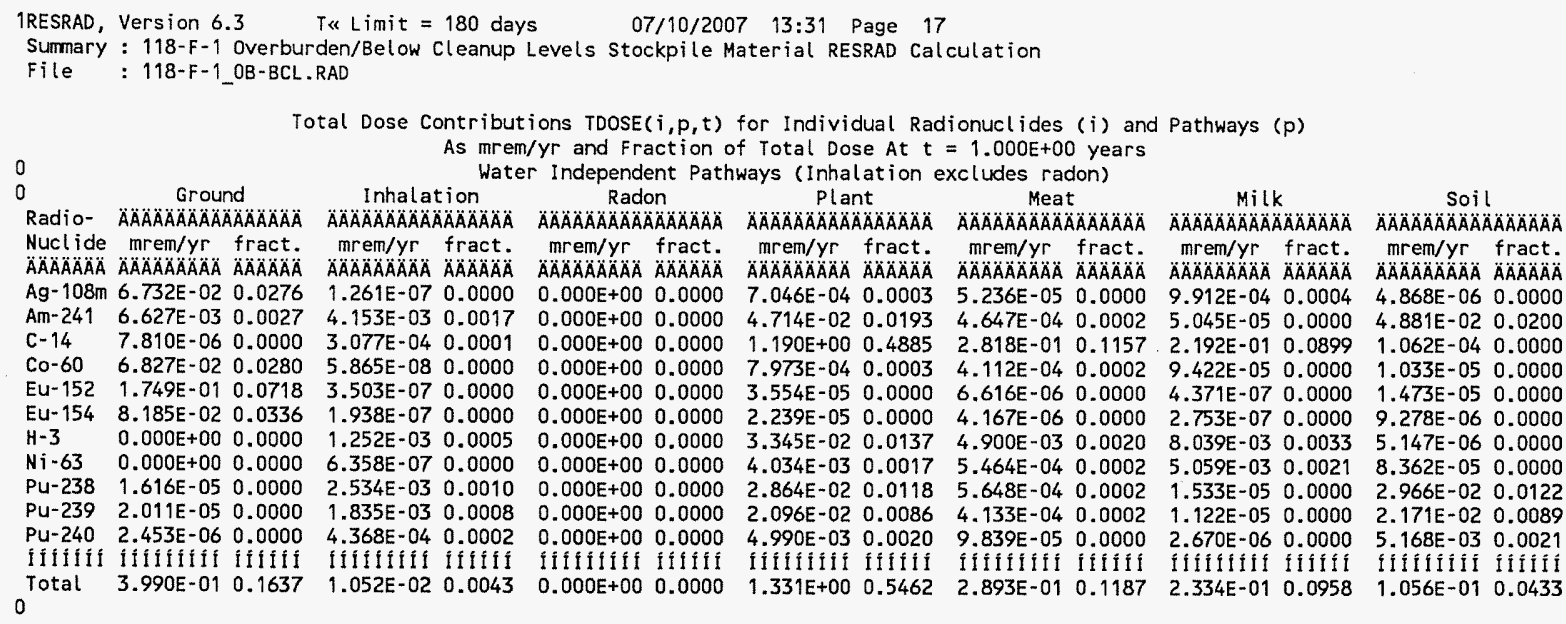

Total Dose Contributions $\operatorname{TDOSE}(i, p, t)$ for Individual Radionuclides (i) and Pathways ( $p$ )

As mrem/yr and Fraction of Total Dose At $t=1.000 E+00$ years

0

$$
\begin{array}{r}
\text { As mrem/yr and Fraction of Total Dose At } t \\
\text { Water Dependent Pathways }
\end{array}
$$

0 Water Fish Radon Plant Mependent Pathways Milk Pathways*

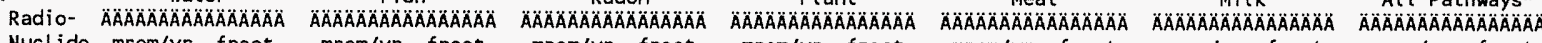
Nuclide $m r e m / y r$ fract. $m r e m / y r$ fract. mrem/yr fract. mrem/yr fract. mrem/yr fract. mrem/yr fract. mrem/yr fract.

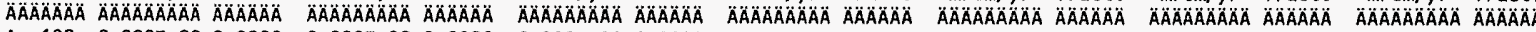
$\begin{array}{lllllllllllllll}\mathrm{Ag}-108 \mathrm{~m} & 0.000 \mathrm{E}+00 & 0.0000 & 0.000 \mathrm{E}+00 & 0.0000 & 0.000 \mathrm{E}+00 & 0.0000 & 0.000 \mathrm{E}+00 & 0.0000 & 0.000 \mathrm{E}+00 & 0.0000 & 0.000 \mathrm{E}+00 & 0.0000 & 6.908 E-02 & 0.0283\end{array}$

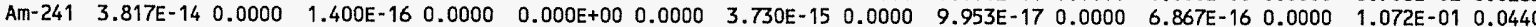
C-14 $\quad 0.000 E+00 \quad 0.0000 \quad 0.000 E+00 \quad 0.0000 \quad 0.000 E+00 \quad 0.0000 \quad 0.000 E+00 \quad 0.0000 \quad 0.000 E+000.0000 \quad 0.000 E+000.0000 \quad 1.692 E+00 \quad 0.6942$ CO-60 3.300E-07 0.0000 2.683E-08 0.0000 0.000E+00 0.0000 3.385E-08 0.0000 5.073E-08 0.0000 $2.013 E-080.0000 \quad 6.959 E-020.0286$ CO-60 $3.300 E-070.0000$ 2.683E-08 $0.0000 \quad 0.000 E+000.00003 .385 E-080.0000$ $\begin{array}{llllllllllllllll}E & \text { Eu-152 } & 0.000 E+00 & 0.0000 & 0.000 E+00 & 0.0000 & 0.000 E+00 & 0.0000 & 0.000 E+00 & 0.0000 & 0.000 E+00 & 0.0000 & 0.000 E+00 & 0.0000 & 1.749 E-01 & 0.0718\end{array}$

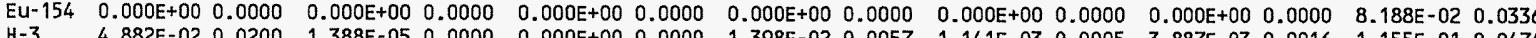

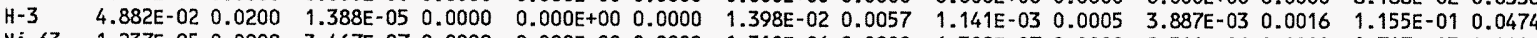
$\begin{array}{lllllllllllllll}\mathrm{Ni}-63 & 1.237 \mathrm{E}-05 & 0.0000 & 3.467 \mathrm{E}-07 & 0.0000 & 0.000 \mathrm{E}+00 & 0.0000 & 1.310 \mathrm{E}-06 & 0.0000 & 6.308 \mathrm{E}-07 & 0.0000 & 8.511 \mathrm{E}-06 & 0.0000 & 9.747 \mathrm{E}-03 & 0.0040\end{array}$

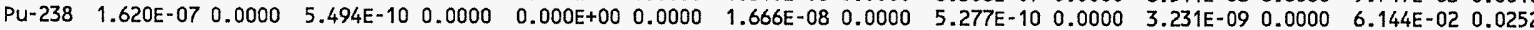

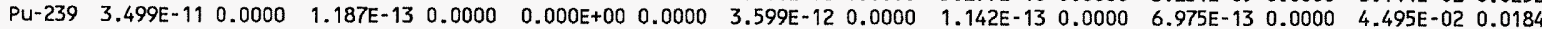
$\begin{array}{llllllllllllllllllllll}\text { Pu-240 } & 2.519 E-10 & 0.0000 & 8.541 E-13 & 0.0000 & 0.000 E+00 & 0.0000 & 2.591 E-11 & 0.0000 & 8.201 E-13 & 0.0000 & 5.022 E-12 & 0.0000 & 1.070 E-02 & 0.0044\end{array}$

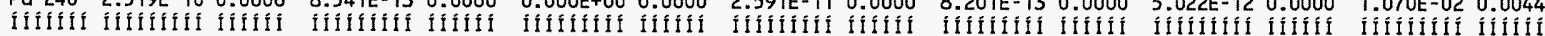

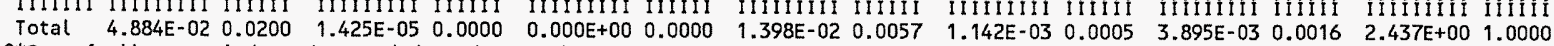
$0 *$ Sum of all water independent and dependent pathways.

\begin{tabular}{|c|c|}
\hline \multirow{2}{*}{\multicolumn{2}{|c|}{$\begin{array}{ll}\text { Attachment } & 8 \\
\text { Originator: S.W. Clark } & \text { Sheet No. } 17 \text { of } 30 \\
\end{array}$}} \\
\hline & \\
\hline Chk'd By M.W. Perrott & Date \\
\hline $0100 F-C A-V 0280$ & Rev. No. \\
\hline
\end{tabular}




\section{ATTACHMENT 8}

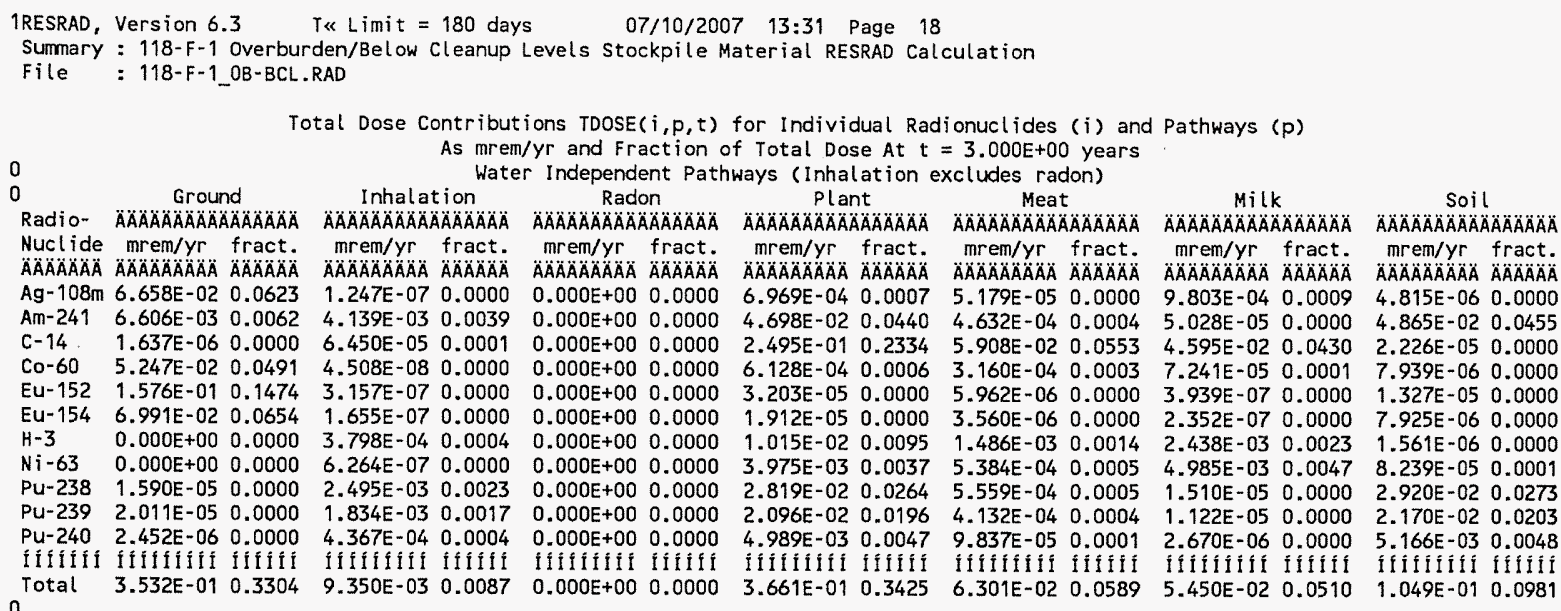

$\begin{array}{ll}\text { Attachment } & \frac{8}{\text { Originator: }} \begin{array}{c}\text { S.W. Clark } \\ \text { Sheet No. } 18 \text { of } 30 \\ \text { Date }\end{array} \\ \text { Chk'd By } & \text { Date } \\ \text { Calc. No. Nerrott } & \text { Rev. No. } \quad 0\end{array}$




\section{ATTACHMENT 8}

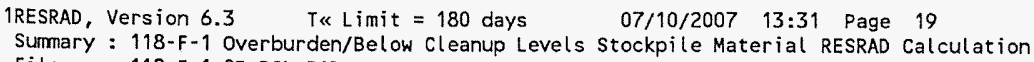

Total Dose Contributions TDOSE (i,p,t) for Individual Radionuclides (i) and Pathways ( $p$ )

As mrem/yr and Fraction of Total Dose At $t=7.000 E+00$ years

0

Water Dependent Pathways

Water Fish Radon Plant Meat Milk All Pathways*

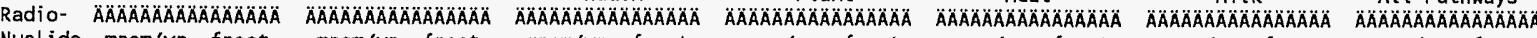
Nuclide mrem/yr fract. mrem/yr fract. mrem/yr fract. mrem/yr fract. mrem/yr fract. mrem/yr fract. mrem/yr fract.

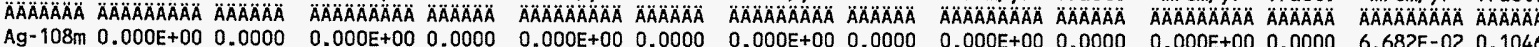
Am-241 $1.332 \mathrm{E}-11 \quad 0.0000 \quad 4.649 \mathrm{E}-140.0000 \quad 0.000 \mathrm{E}+000.00001 .44$ $\begin{array}{lllllllll}1.449 E-12 & 0.0000 & 5.845 E-14 & 0.0000 & 3.084 E-13 & 0.0000 & 1.062 E-01 & 0.166\end{array}$ $\begin{array}{lllllllllllllll} & 0.000 E+00 & 0.0000 & 0.000 E+00 & 0.0000 & 1.555 E-02 & 0.0243\end{array}$ $\begin{array}{lllllllllllllll}C 0-60 & 1.056 E-06 & 0.0000 & 8.928 E-08 & 0.0000 & 0.000 E+00 & 0.0000 & 1.179 E-07 & 0.0000 & 2.755 E-07 & 0.0000 & 8.199 E-08 & 0.0000 & 3.159 E-02 & 0.0494\end{array}$ $\begin{array}{llllllllllllllll}\text { Eu- } 152 & 0.000 E+00 & 0.0000 & 0.000 E+00 & 0.0000 & 0.000 E+00 & 0.0000 & 0.000 E+00 & 0.0000 & 0.000 E+00 & 0.0000 & 0.000 E+00 & 0.0000 & 1.280 E-01 & 0.2003\end{array}$ $\begin{array}{llllllllllllllll}\text { EU- } 154 & 0.000 E+00 & 0.0000 & 0.000 E+00 & 0.0000 & 0.000 E+00 & 0.0000 & 0.000 E+00 & 0.0000 & 0.000 E+00 & 0.0000 & 0.000 E+00 & 0.0000 & 5.104 E-02 & 0.0798\end{array}$ $\begin{array}{lllllllllllllll}H-3 & 8.186 E-02 & 0.1281 & 2.356 E-05 & 0.0000 & 0.000 E+00 & 0.0000 & 2.411 E-02 & 0.0377 & 2.152 E-03 & 0.0034 & 6.775 E-03 & 0.0106 & 1.162 E-01 & 0.1819\end{array}$

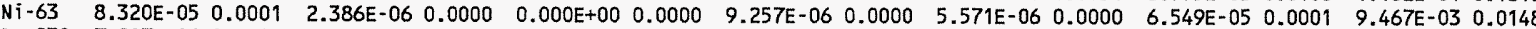
$\begin{array}{llllllllllllllll}\text { PU-238 } & 7.807 E-06 & 0.0000 & 2.725 E-08 & 0.0000 & 0.000 E+00 & 0.0000 & 8.545 E-07 & 0.0000 & 3.516 E-08 & 0.0000 & 1.832 E-07 & 0.0000 & 5.859 E-02 & 0.0917\end{array}$ Pu-239 $1.712 \mathrm{E}-090.0000 \quad 5.978 E-12 \quad 0.0000 \quad 0.000 E+00 \quad 0.0000 \quad 1.874 E-10 \quad 0.00007 .728 E-120.0000 \quad 4.017 F-110.0000 \quad 4.493 E-02 \quad 0.0703$

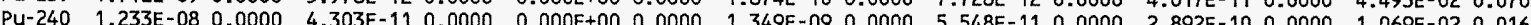

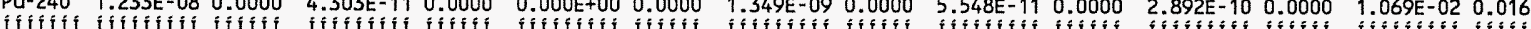

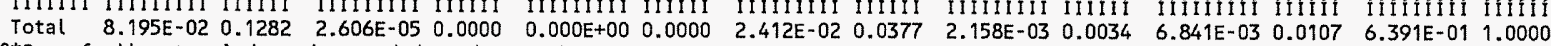
$0 *$ Sum of all water independent and dependent pathways.

\begin{tabular}{|c|c|}
\hline Attachment & Sheet No. 19 of 30 \\
\hline Originator: S.W. Clark & Date \\
\hline Chk'd By M.W. Perrott & Date \\
\hline $0100 \mathrm{~F}-\mathrm{CA}-\mathrm{V} 0280$ & Rev. No. \\
\hline
\end{tabular}




\section{ATTACHMENT 8}

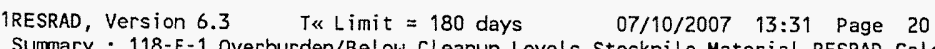

Milk

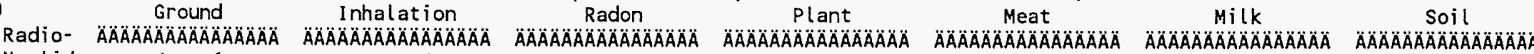
Nuclide mrem/yr fract mrem/yr fract. mrem/yr fract. mrem/yr fract. mrem/yr fract. mrem/yr fract. mren/yr fract. Ä

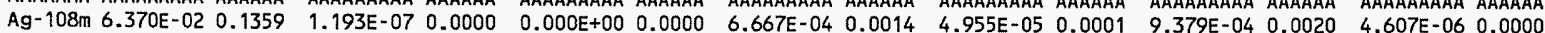
$\begin{array}{lllllllllllllll}A m-241 & 6.520 E-03 & 0.0139 & 4.085 E-03 & 0.0087 & 0.000 E+00 & 0.0000 & 4.638 E-02 & 0.0989 & 4.573 E-04 & 0.0010 & 4.963 E-05 & 0.0001 & 4.802 E-02 & 0.1025\end{array}$

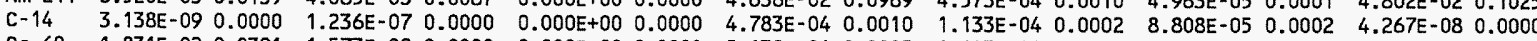
$\begin{array}{lllllllllllllllllll}\text { Co-60 } & 1.831 E-02 & 0.0391 & 1.573 E-08 & 0.0000 & 0.000 E+00 & 0.0000 & 2.138 E-04 & 0.0005 & 1.103 E-04 & 0.0002 & 2.527 E-05 & 0.0001 & 2.770 E-06 & 0.0000\end{array}$

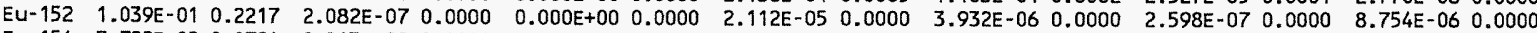

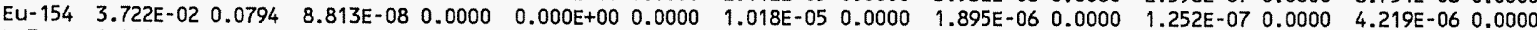

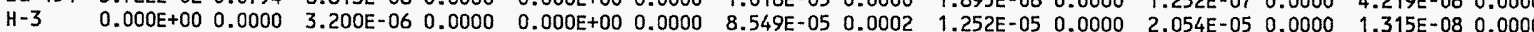

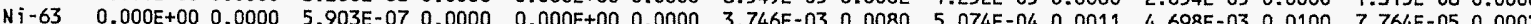

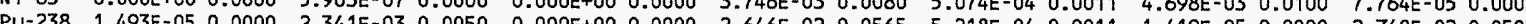
$\begin{array}{lllllll} & \end{array}$

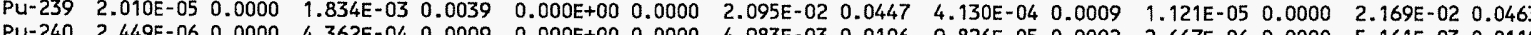

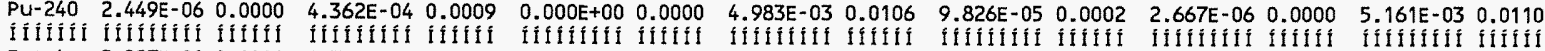
$\begin{array}{lllllllllllllllllll}\text { Total } & 2.297 \mathrm{E}-01 & 0.4901 & 8.701 \mathrm{E}-03 & 0.0186 & 0.000 \mathrm{E}+00 & 0.0000 & 1.040 \mathrm{E}-01 & 0.2219 & 2.289 \mathrm{E}-03 & 0.0049 & 5.848 \mathrm{E}-03 & 0.0125 & 1.024 \mathrm{E}-01 & 0.2184\end{array}$

Total Dose Contributions $\operatorname{TDOSE}(i, p, t)$ for Individual Radionuclides (i) and Pathways $(p)$ As $\mathrm{mrem} / \mathrm{yr}$ and Fraction of Total Dose At $t=1.100 \mathrm{E}+01$ years

Water Dependent Pathways

Water Fish Radon Plant Meat All Pathways*

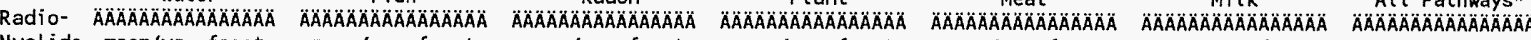
Nuclide $m r e m / y r$ fract. $m r e m / y r$ fract. mrem/yr fract. mrem/yr fract. mrem/yr fract. mrem/yr fract. mrem/yr fract.

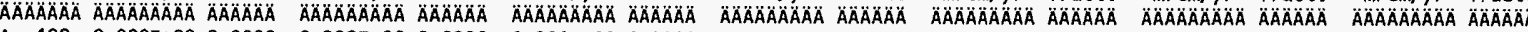

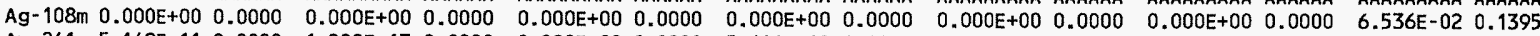

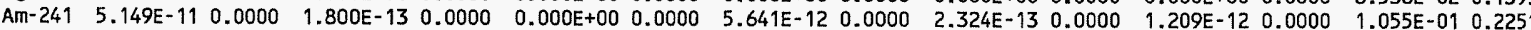

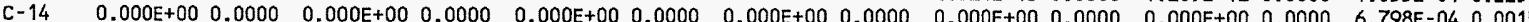

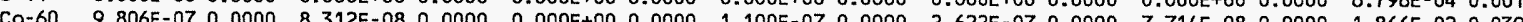

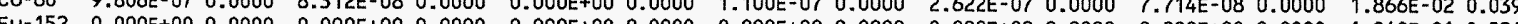

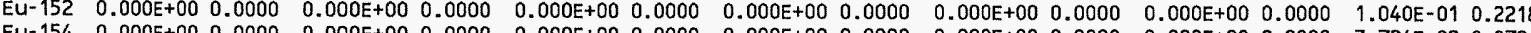

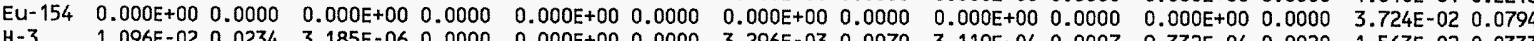
$\begin{array}{lllllllllllllll}H-3 & 1.096 E-02 & 0.0234 & 3.185 E-06 & 0.0000 & 0.000 E+00 & 0.0000 & 3.296 E-03 & 0.0070 & 3.119 E-04 & 0.0007 & 9.332 E-04 & 0.0020 & 1.563 E-02 & 0.0333\end{array}$ $\begin{array}{lllllllllllllll}\mathrm{Ni}-63 & 1.270 \mathrm{E}-04 & 0.0003 & 3.647 \mathrm{E}-06 & 0.0000 & 0.000 \mathrm{E}+00 & 0.0000 & 1.417 \mathrm{E}-05 & 0.0000 & 8.627 \mathrm{E}-06 & 0.0000 & 1.007 \mathrm{E}-04 & 0.0002 & 9.283 \mathrm{E}-03 & 0.0198\end{array}$

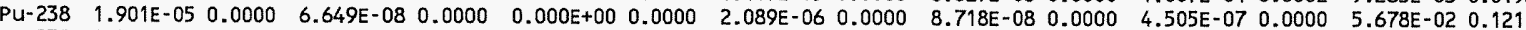

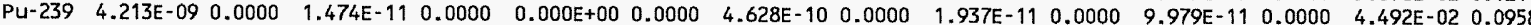
Pu-240 3.032E-08 $0.0000 \quad 1.060 E-10 \quad 0.0000 \quad 0.000 E+00 \quad 0.0000 \quad 3.331 E-090.0000 \quad 1.390 E-100.00007 .183 E-100.0000 \quad 1.068 E-020.0228$

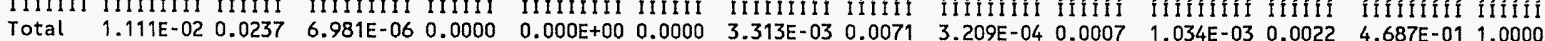
$0 *$ Sum of all water independent and dependent pathways.

\begin{tabular}{ll} 
Attachment & $\frac{8}{\text { Sheet No. } 20 \text { of } \underline{30}}$ \\
Originator: $\frac{\text { S.W. Clark }}{\text { M.W. Perrott }}$ & Date \\
Chk'd By & Date \\
Calc. No. 0100 F-CA-V0280 & Rev. No. 0 \\
\hline
\end{tabular}




\section{ATTACHMENT 8}

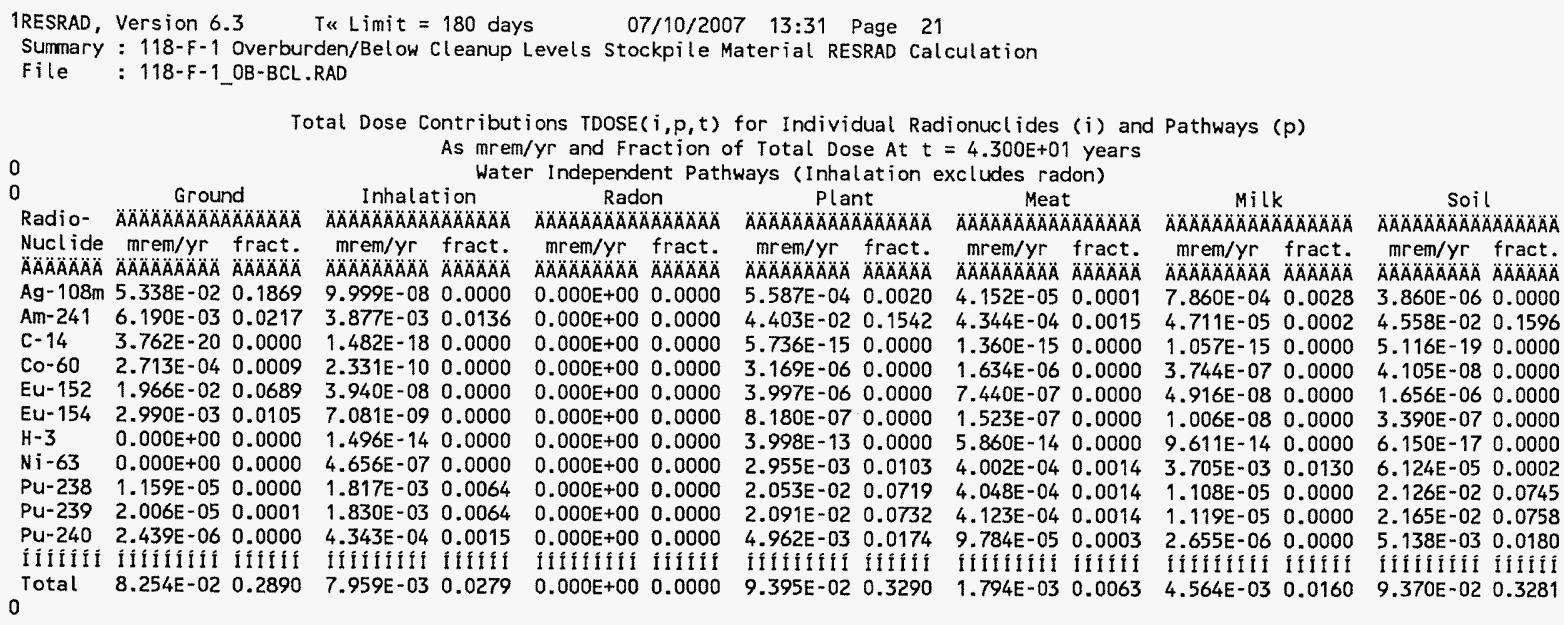

\begin{tabular}{|c|c|}
\hline Attachment $\quad 8$ & Sheet No. 21 of 30 \\
\hline Originator: S.W. Clark & Date \\
\hline Chk'd By M.W. Perrott & Date \\
\hline $0100 \mathrm{~F}-\mathrm{CA}-\mathrm{V} 0280$ & Rev. No. \\
\hline
\end{tabular}




\section{ATTACHMENT 8}

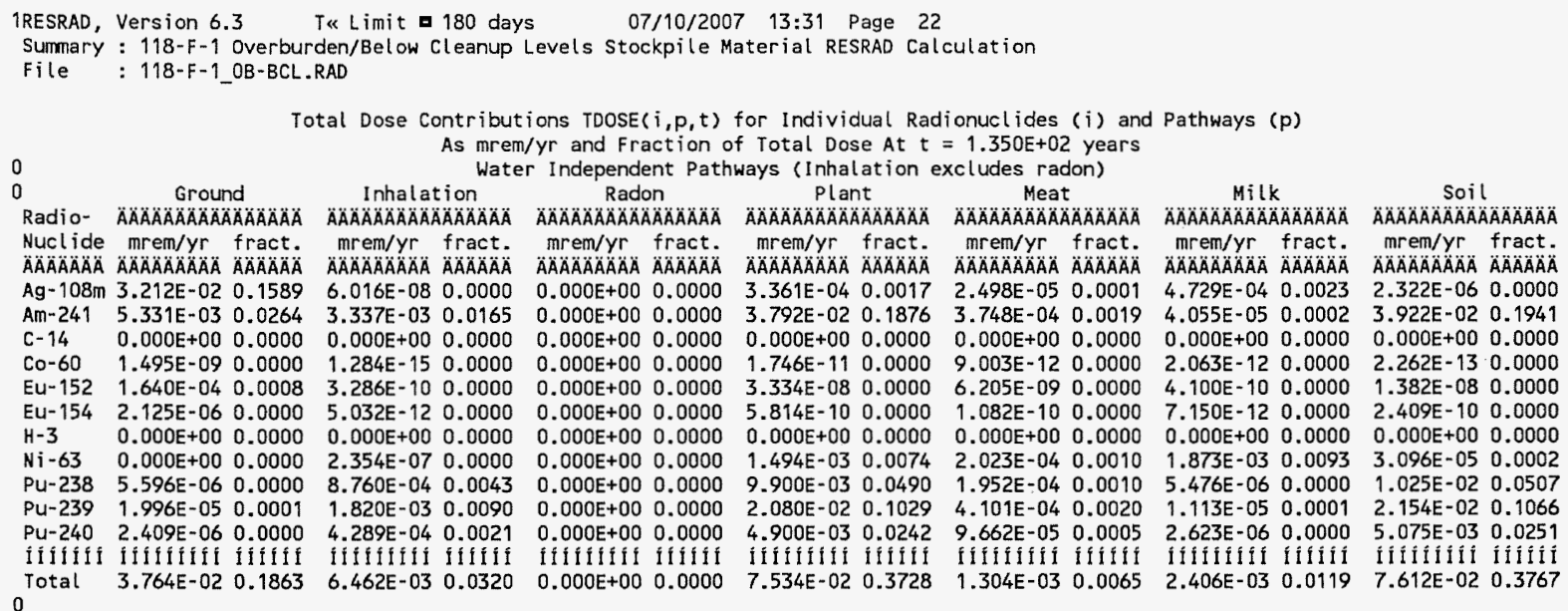

Total Dose Contributions $\operatorname{TDOSE}(i, p, t)$ for Individual Radionuclides (i) and Pathways ( $p$ )

As $\mathrm{mrem} / \mathrm{yr}$ and Fraction of Total Dose At $t=1.350 \mathrm{E}+02$ years

$$
\begin{array}{r}
\text { As } \mathrm{mrem} / \mathrm{yr} \text { and Fraction of Total Dose At } t \\
\text { Water Dependent Pathways }
\end{array}
$$

Water Fish Radon Plant Math Pathways*

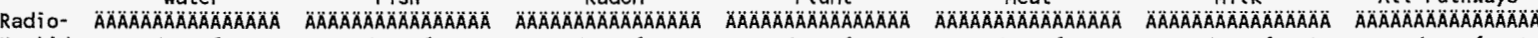
Nuclide 1 rem/yr fract. mrem/yr fract. mrem/yr fract. mrem/yr fract. mrem/yr fract. mrem/yr fract. mrem/yr fract.

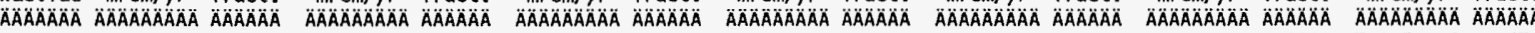
$\begin{array}{llllllllllllllllll}\mathrm{Ag}-108 \mathrm{~m} & 0.000 \mathrm{E}+00 & 0.0000 & 0.000 \mathrm{E}+00 & 0.0000 & 0.000 \mathrm{E}+00 & 0.0000 & 0.000 \mathrm{E}+00 & 0.0000 & 0.000 \mathrm{E}+00 & 0.0000 & 0.000 \mathrm{E}+00 & 0.0000 & 3.295 \mathrm{E}-02 & 0.1631\end{array}$

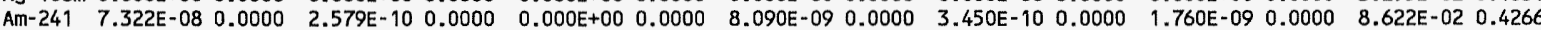
$\begin{array}{llllllllllllllll}c-14 & 0.000 E+00 & 0.0000 & 0.000 E+00 & 0.0000 & 0.000 E+00 & 0.0000 & 0.000 E+00 & 0.0000 & 0.000 E+00 & 0.0000 & 0.000 E+00 & 0.0000 & 0.000 E+00 & 0.0000\end{array}$ C0-60 $9.923 E-130.0000 \quad 8.442 E-140.0000 \quad 0.000 E+00 \quad 0.0000 \quad 1.122 E-130.00002 .756 E-130.00007 .965 E-14 \quad 0.0000 \quad 1.525 E-090.0000$

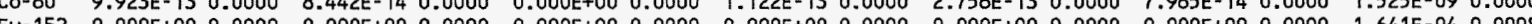
$\begin{array}{llllllllll} & 0.0008\end{array}$

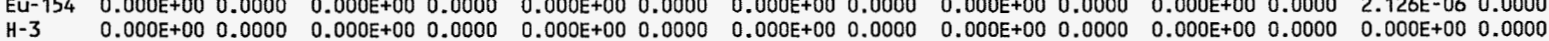

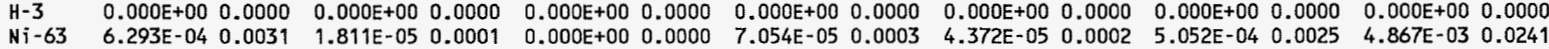
$\begin{array}{llllllllllllllll}\mathrm{Pu}-238 & 1.347 \mathrm{E}-03 & 0.0067 & 4.724 \mathrm{E}-06 & 0.0000 & 0.000 E+00 & 0.0000 & 1.489 \mathrm{E}-04 & 0.0007 & 6.361 \mathrm{E}-06 & 0.0000 & 3.242 \mathrm{E}-05 & 0.0002 & 2.277 \mathrm{E}-02 & 0.1127\end{array}$ $\begin{array}{lllllllllllllll}\text { Pu-239 } & 4.305 E-07 & 0.0000 & 1.535 E-09 & 0.0000 & 0.000 E+00 & 0.0000 & 4.759 E-08 & 0.0000 & 2.084 E-09 & 0.0000 & 1.030 E-08 & 0.0000 & 4.460 E-02 & 0.2207\end{array}$ $\begin{array}{lllllllllllllllll}\text { PU-240 } & 3.068 E-06 & 0.0000 & 1.076 E-08 & 0.0000 & 0.000 E+00 & 0.0000 & 3.391 E-07 & 0.0000 & 1.448 E-08 & 0.0000 & 7.383 E-08 & 0.0000 & 1.051 E-02 & 0.0520\end{array}$

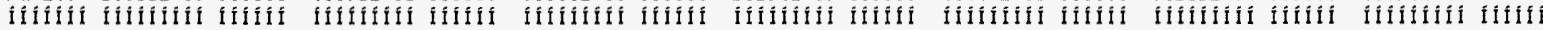
$\begin{array}{lllllllllllllll}\text { Total } & 1.979 E-03 & 0.0098 & 2.285 E-05 & 0.0001 & 0.000 E+00 & 0.0000 & 2.198 E-04 & 0.0011 & 5.010 E-05 & 0.0002 & 5.377 E-04 & 0.0027 & 2.021 E-01 & 1.0000\end{array}$ $0^{*}$ Sum of all water independent and dependent pathways.

\begin{tabular}{|c|c|}
\hline Attachment & Sheet No. 22 of 30 \\
\hline Originator: S.W. Clark & Date \\
\hline Shk'd By M.W. Perrott & Date \\
\hline $0100 F-C A-V 0280$ & Rev. No. \\
\hline
\end{tabular}




\section{ATTACHMENT 8}

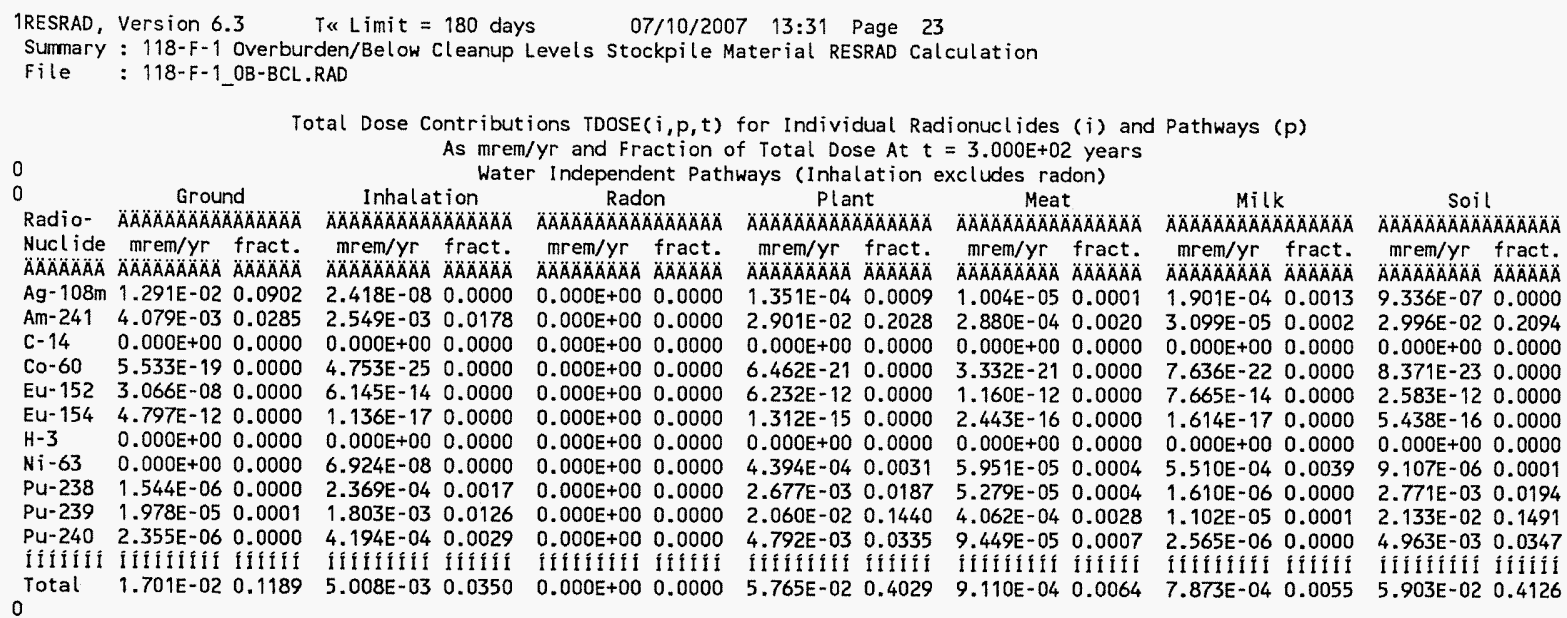

Total Dose Contributions $\operatorname{TDOSE}(i, p, t)$ for Individual Radionuclides (i) and Pathways ( $p$ )

As $\mathrm{mrem} / \mathrm{yr}$ and Fraction of Total Dose At $t=3.000 \mathrm{E}+02$ years

0

As $\mathrm{mrem} / \mathrm{yr}$ and Fraction of Total Dose At

0 Water Fish Radon Plant Meat All Pathways*

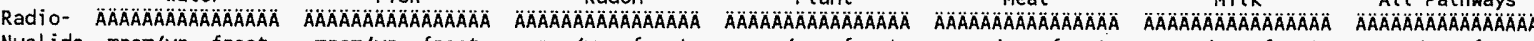
Nuclide mrem/yr fract. mrem/yr fract. mrem/yr fract. mrem/yr fract. mrem/yr fract. mrem/yr fract. mrem/yr fract.

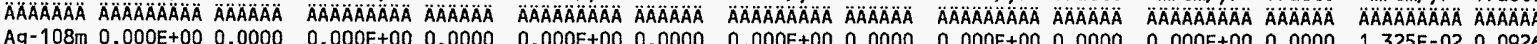
Am-241 3.938E-07 $0.0000 \quad 1.398 E-090.0000 \quad 0.000 E+00 \quad 0.0000 \quad 4.353 E$

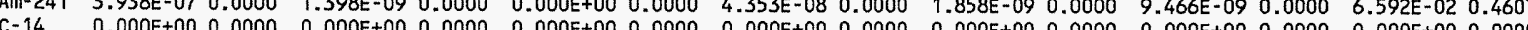

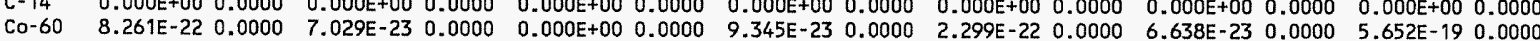
$\begin{array}{lllllllllllllll}C O-60 & 8.261 E-22 & 0.0000 & 7.029 E-23 & 0.0000 & 0.000 E+00 & 0.0000 & 9.345 E-23 & 0.0000 & 2.299 E-22 & 0.0000 & 6.638 E-23 & 0.0000 & 5.652 E-19 & 0.0000 \\ \text { Eu-152 } & 0.0000 E+00 & 0.0000 & 0.000 E+00 & 0.0000 & 0.000 E+00 & 0.0000 & 0.000 E+00 & 0.0000 & 0.000 E+00 & 0.0000 & 0.000 E+00 & 0.0000 & 3.067 E-08 & 0.0000\end{array}$ $\begin{array}{lllllllllllllll}E U-152 & 0.000 E+00 & 0.0000 & 0.000 E+00 & 0.0000 & 0.000 E+00 & 0.0000 & 0.000 E+00 & 0.0000 & 0.000 E+00 & 0.0000 & 0.000 E+00 & 0.0000 & 3.067 E-08 & 0.0000 \\ \text { Eu-154 } & 0.000 E+00 & 0.0000 & 0.000 E+00 & 0.0000 & 0.000 E+00 & 0.0000 & 0.000 E+00 & 0.0000 & 0.000 E+00 & 0.0000 & 0.000 E+00 & 0.0000 & 4.800 E-12 & 0.0000\end{array}$ $\begin{array}{lllllllllllllllll}H-3 & 0.000 E+00 & 0.0000 & 0.000 E+00 & 0.0000 & 0.000 E+00 & 0.0000 & 0.000 E+00 & 0.0000 & 0.000 E+00 & 0.0000 & 0.000 E+00 & 0.0000 & 0.000 E+00 & 0.0000\end{array}$

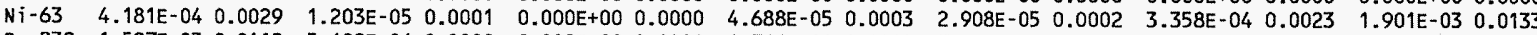
$\begin{array}{llllllllllllllll}\text { Pu-238 } & 1.597 E-03 & 0.0112 & 5.609 E-06 & 0.0000 & 0.000 E+00 & 0.0000 & 1.766 E-04 & 0.0012 & 7.553 E-06 & 0.0001 & 3.847 E-05 & 0.0003 & 7.566 E-03 & 0.0529\end{array}$ Pu-239 9.307E-07 $0.0000 \quad 3.472 E-09 \quad 0.0000 \quad 0.000 E+00 \quad 0.0000 \quad 1.029 E-07 \quad 0.0000 \quad 4.671 E-09 \quad 0.0000 \quad 2.193 E-08 \quad 0.0000 \quad 4.417 E-02 \quad 0.3087$ $\begin{array}{llllllllllllllllll}\text { Pu-240 } & 6.479 E-06 & 0.0000 & 2.272 E-08 & 0.0000 & 0.000 E+00 & 0.0000 & 7.163 E-07 & 0.0000 & 3.062 E-08 & 0.0000 & 1.560 E-07 & 0.0000 & 1.028 E-02 & 0.0719\end{array}$

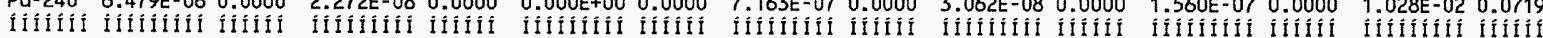

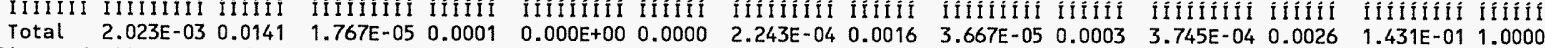
$0 *$ Sum of all water independent and dependent pathways.

\begin{tabular}{ll} 
Attachment $\frac{8}{\text { S.W. Clark }}$ & Sheet No. 23 of $\underline{30}$ \\
Originator: & Date \\
Chk'd By & Date \\
Calc. No. W. Perrott & Rev. No. ${ }_{0} 0$ \\
\hline
\end{tabular}




\section{ATTACHMENT 8}

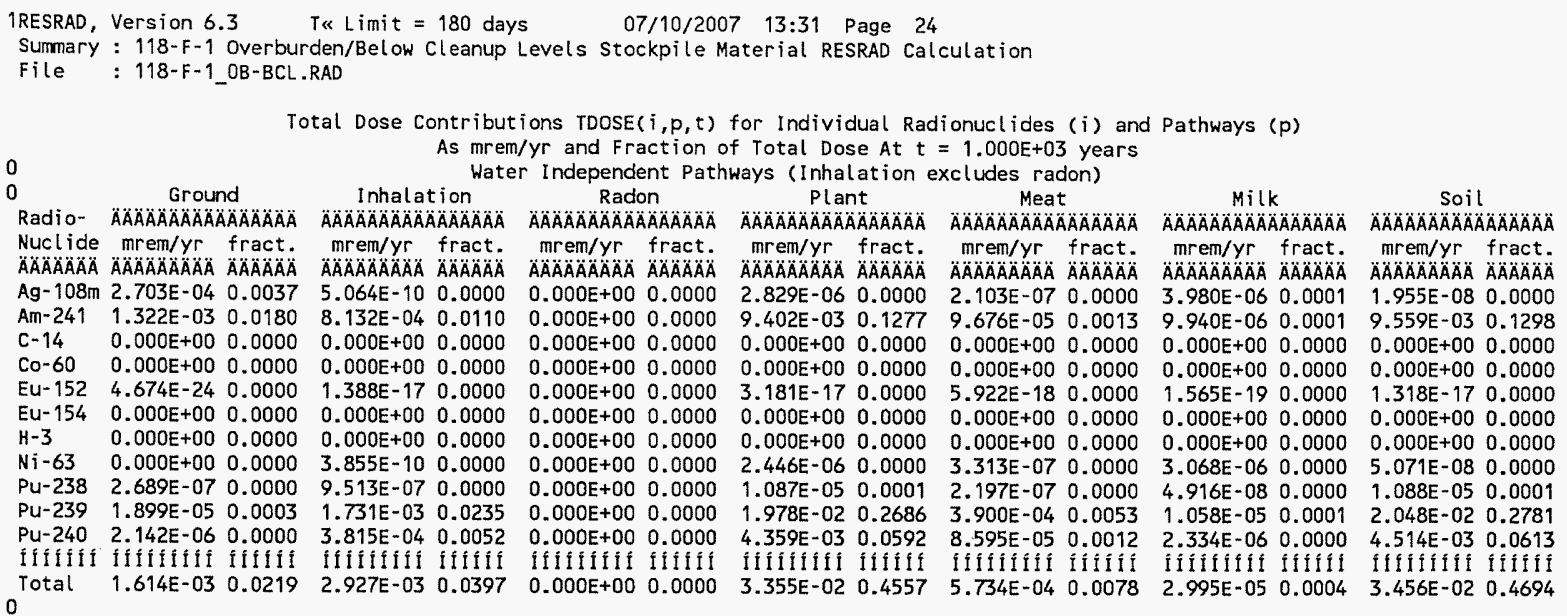

Total Dose Contributions TDOSE $(i, p, t)$ for Individual Radionuclides (i) and Path
As mrem/yr and Fraction of Total Dose At $t=1.000 E+03$ years

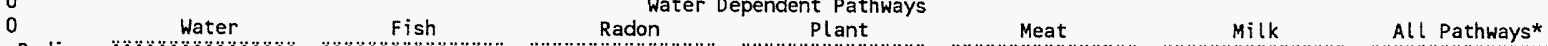

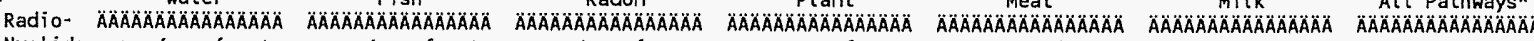
Nuclide mrem/yr fract. mrem/yr fract. mrem/yr fract. mrem/yr fract. mrem/yr fract. mrem/yr fract. mrem/yr fract.

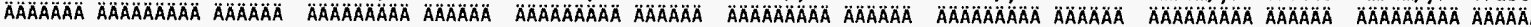

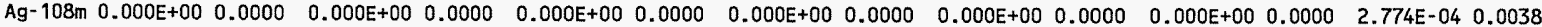

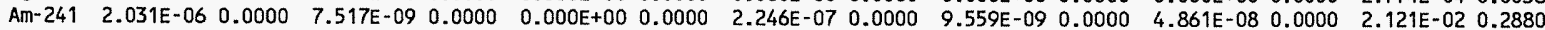

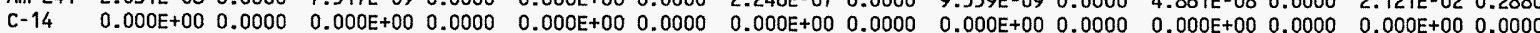

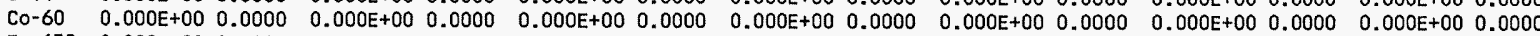

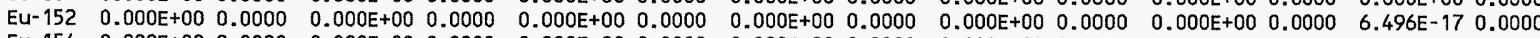
$\begin{array}{lllllllllllllllllll}\text { Eu- } 154 & 0.000 E+00 & 0.0000 & 0.000 E+00 & 0.0000 & 0.000 E+00 & 0.0000 & 0.000 E+00 & 0.0000 & 0.000 E+00 & 0.0000 & 0.000 E+00 & 0.0000 & 0.000 E+00 & 0.0000\end{array}$ $\begin{array}{llllllllllllllllll}H-3 & 0.000 E+00 & 0.0000 & 0.000 E+00 & 0.0000 & 0.000 E+00 & 0.0000 & 0.000 E+00 & 0.0000 & 0.000 E+00 & 0.0000 & 0.000 E+00 & 0.0000 & 0.000 E+00 & 0.0000\end{array}$ $\begin{array}{llllllllllllllllll}\mathrm{Ni}-63 & 8.313 \mathrm{E}-06 & 0.0001 & 2.393 \mathrm{E}-07 & 0.0000 & 0.000 \mathrm{E}+00 & 0.0000 & 9.323 \mathrm{E}-07 & 0.0000 & 5.786 \mathrm{E}-07 & 0.0000 & 6.680 \mathrm{E}-06 & 0.0001 & 2.264 \mathrm{E}-05 & 0.0003\end{array}$ $\begin{array}{llllllllllllllll}\text { Pu-238 2.997E-04 } & 0.0041 & 1.138 E-06 & 0.0000 & 0.000 E+00 & 0.0000 & 3.314 E-05 & 0.0005 & 1.426 E-06 & 0.0000 & 7.209 E-06 & 0.0001 & 3.659 E-04 & 0.0050\end{array}$ $\begin{array}{lllllllllllllllll}\text { Pu-239 } & 1.667 E-06 & 0.0000 & 7.591 E-09 & 0.0000 & 0.000 E+00 & 0.0000 & 1.843 E-07 & 0.0000 & 9 & 881 E-09 & 0.0000 & 3.618 E-08 & 0.0000 & 4.241 E-02 & 0.5759\end{array}$

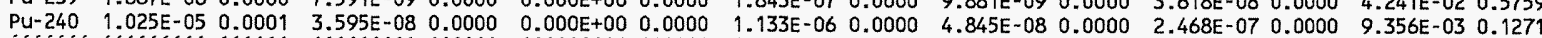

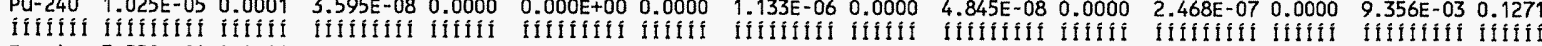
$\begin{array}{lllllllllllllllllllllll}\text { Total } & 3.220 E-04 & 0.0044 & 1.429 E-06 & 0.0000 & 0.000 E+00 & 0.0000 & 3.561 E-05 & 0.0005 & 2.072 E-06 & 0.0000 & 1.422 E-05 & 0.0002 & 7.364 E-02 & 1.0000\end{array}$ $0 *$ Sum of all water independent and dependent pathways.

\begin{tabular}{|c|c|c|}
\hline \multirow{2}{*}{\multicolumn{3}{|c|}{ 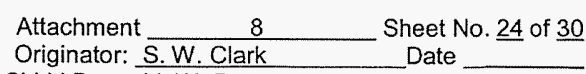 }} \\
\hline & & \\
\hline & M. W. Perrott & Date \\
\hline & 0100F-CA-V0280 & 0 \\
\hline
\end{tabular}




\section{ATTACHMENT 8}

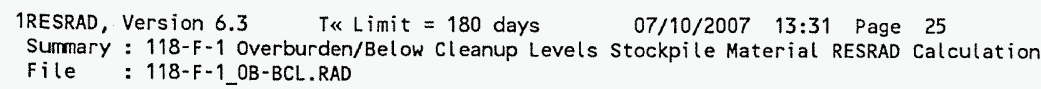

\begin{tabular}{|c|c|}
\hline Attachment $\quad 8$ & Sheet No. 25 of 30 \\
\hline Originator: S.W. Clark & Date \\
\hline Chk'd By M. W. Perrott & Date \\
\hline Calc. No. $0100 F-C A-V 0280$ & Rev. No. 0 \\
\hline
\end{tabular}




\section{ATTACHMENT 8}

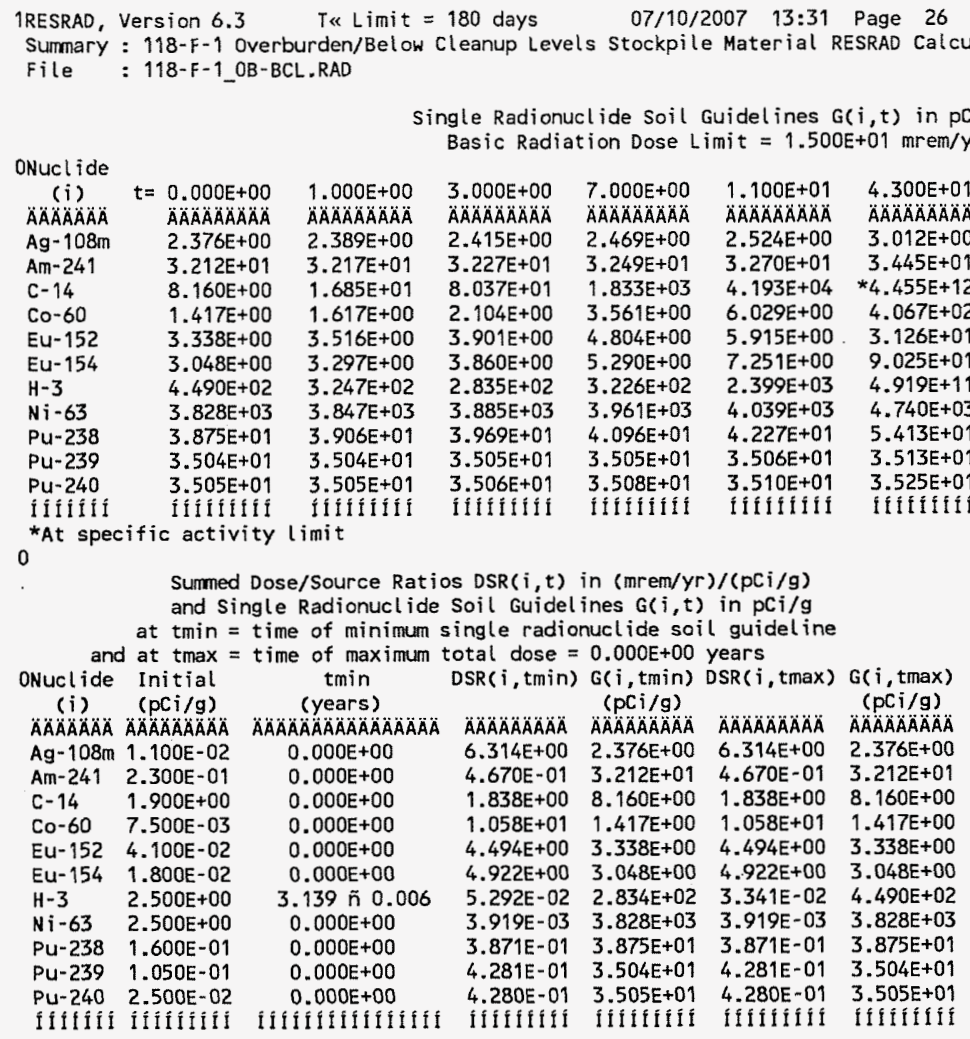

Attachment Sheet No. 26 of 30 Originator: $\frac{\text { S.W. Clark }}{\text { M.W. Perrott }}$ Date Calc. No. 0100 F-CA-V0280

Rev. No. 0




\section{ATTACHMENT 8}

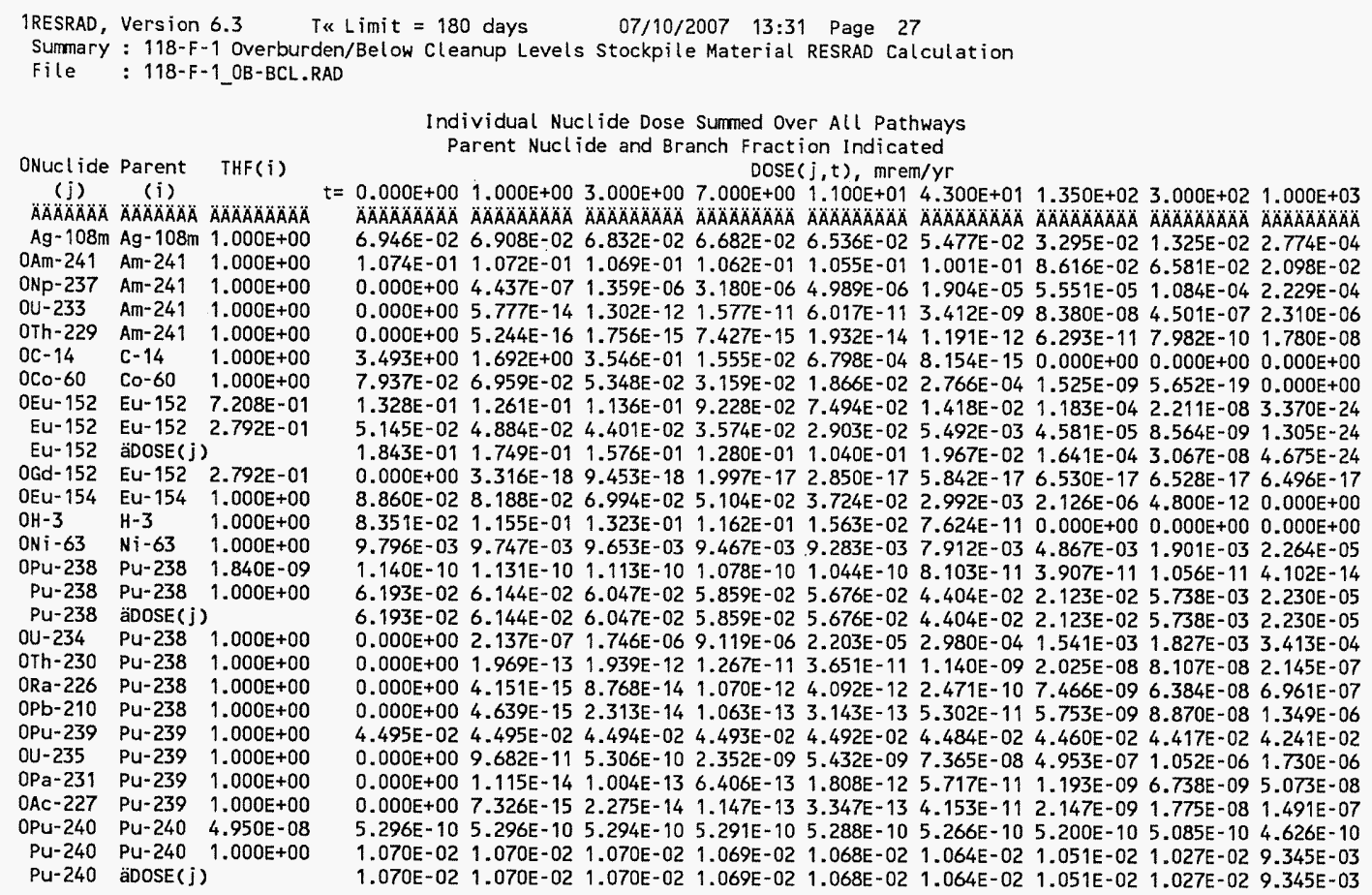

\begin{tabular}{|c|c|}
\hline Attachment & Sheet No. $\underline{27}$ of $\underline{30}$ \\
\hline Originator: S.W. Clark & Date \\
\hline M. W. Perrott & Date \\
\hline $0100 F-C A-V 0280$ & Rev. No. \\
\hline
\end{tabular}




\title{
ATTACHMENT 8
}

\begin{abstract}
1RESRAD, Version 6.3 T\& Limit $=180$ days $\quad 07 / 10 / 2007 \quad 13: 31$ Page 28
Summary : 118-F-1 Overburden/Below Cleanup Levels Stockpile Material RESRAD Calculation

File: $118-F-1$ OB-BCL.RAD

Individual Nuclide Dose Summed Over All Pathways

Parent Nuclide and Branch Fraction Indicated

ONuctide Parent THF(i)

(j) (i) DOSE $(j, t), m r e m / y r$

AAAAAAA AAAAAAA ÄAAAAAAAAÄ

U-236 PU-240 1.000E+00

$t=0.000 E+00 \quad 1.000 E+00 \quad 3.000 E+00 \quad 7.000 E+00 \quad 1.100 E+01 \quad 4.300 E+01 \quad 1.350 E+02 \quad 3.000 E+02 \quad 1.000 E+03$

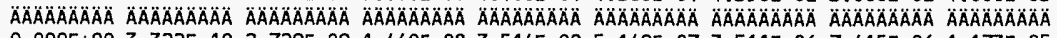

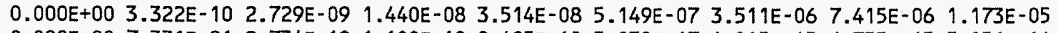
$0.000 \mathrm{E}+00 \quad 7.331 \mathrm{E}-21 \quad 2.734 \mathrm{E}-19 \quad 1.108 \mathrm{E}-18 \quad 2.485 \mathrm{E}-18 \quad 5.832 \mathrm{E}-17 \quad 1.205 \mathrm{E}-15 \quad 6.755 \mathrm{E}-15 \quad 5.056 \mathrm{E}-14$

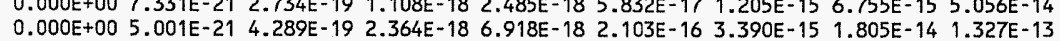

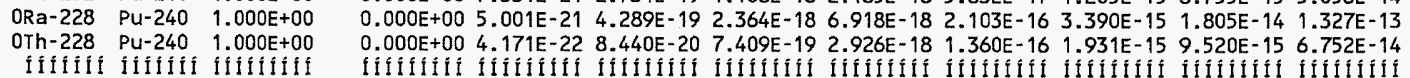
fífiliti ilififítififilit

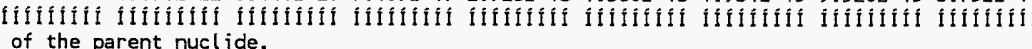
THF(i) is the thread fraction of the parent nuclide.
\end{abstract}

\begin{tabular}{|c|c|}
\hline \multicolumn{2}{|l|}{ Attachment $\quad 8$} \\
\hline Originator: $\mathrm{S} . \mathrm{W}$. Clark & Date \\
\hline Chk'd By M.W. Perrott & Date \\
\hline Calc. No. $\quad 0100 F-C A-V 0280$ & Rev. No. \\
\hline
\end{tabular}




\section{ATTACHMENT 8}

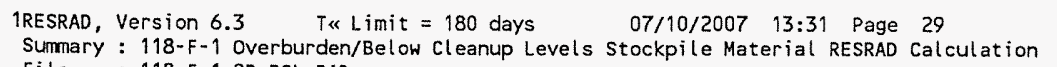

$t=0.000 E+00 \quad 1.000 E+00 \quad 3.000 E+00 \quad 7.000 E+00 \quad 1.100 E+01 \quad 4.300 E+01 \quad 1.350 E+02 \quad 3.000 E+02 \quad 1.000 E+03$

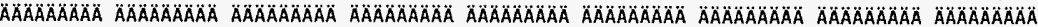

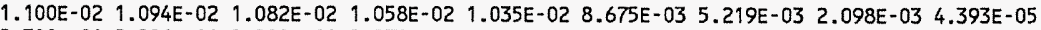
2.300E-01 2.296E-01 2.289E-01 2.274E-01 2.259E-01 2.144E-01 $1.845 E-01 \quad 1.409 E-01 \quad 4.492 E-02$ $0.000 E+00 \quad 7.444 E-08 \quad 2.229 E-07 \quad 5.185 E-07 \quad 8.120 E-07 \quad 3.092 E-06 \quad 9.011 E-06 \quad 1.760 E-05 \quad 3.618 E-05$

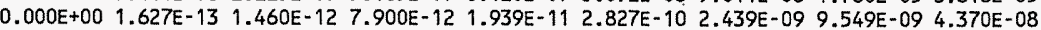
$0.000 E+00 \quad 5.122 E-18 \quad 1.380 E-16 \quad 1.745 E-15 \quad 6.740 E-15 \quad 3.883 E-13 \quad 1.084 E-11 \quad 9.952 E-111.857 E-09$

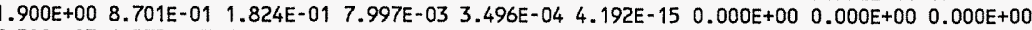

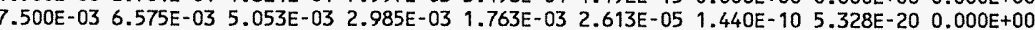
2.955E-02 2.805E-02 2.528E-02 2.053E-02 1.667E-02 3.155E-03 2.631E-05 $4.919 E-09 \quad 7.498 E-25$ 1.145E-02 1.087E-02 9.793E-03 7.953E-03 6.459E-03 $1.222 \mathrm{E}-03 \quad 1.019 \mathrm{E}-05 \quad 1.905 \mathrm{E}-092.904 \mathrm{E}-25$

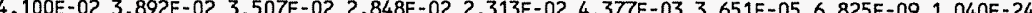

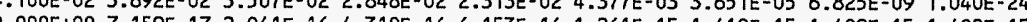
(1.402E-15 1.800E-02 1.664E-02 1.421E-02 1.037E-02 7.566E-03 6.078E-04 4.320E-07 9.751E-13 1.083E-36

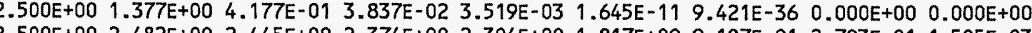

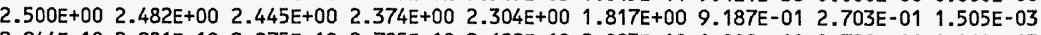
$2.944 E-10 \quad 2.921 E-10 \quad 2.875 E-10 \quad 2.785 E-10 \quad 2.698 E-10 \quad 2.093 E-10 \quad 1.009 E-10 \quad 2.728 E-11 \quad 1.060 E-13$ 1.600E-01 1.587E-01 1.562E-01 1.514E-01 1.466E-01 1.138E-01 5.486E-02 1.483E-02 5.760E-05 1.600E-01 1.587E-01 1.562E-01 1.514E-01 1.466E-01 1.138E-01 5.486E-02 1.483E-02 5.760E-05 $0.000 \mathrm{E}+00 \quad 4.512 \mathrm{E}-07 \quad 1.339 \mathrm{E}-06 \quad 3.059 \mathrm{E}-06 \quad 4.705 \mathrm{E}-06 \quad 1.553 \mathrm{E}-05 \quad 3.034 \mathrm{E}-05 \quad 3.013 \mathrm{E}-05 \quad 5.462 \mathrm{E}-06$ 0.

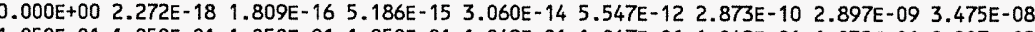

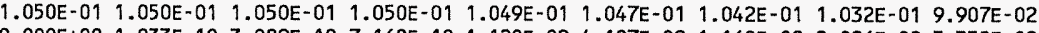

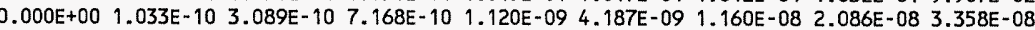
$0.000 \mathrm{E}+00 \quad 1.093 \mathrm{E}-15 \quad 9.817 \mathrm{E}-15 \quad 5.324 \mathrm{E}-14 \quad 1.309 \mathrm{E}-13 \quad 1.939 \mathrm{E}-12 \quad 1.751 \mathrm{E}-11 \quad 7.445 \mathrm{E}-11 \quad 4.837 \mathrm{E}-10$ $0.000 \mathrm{E}+00 \quad 1.151 \mathrm{E}-17 \quad 3.054 \mathrm{E}-16 \quad 3.748 \mathrm{E}-15 \quad 1.406 \mathrm{E}-14 \quad 6.531 \mathrm{E}-13 \quad 1.137 \mathrm{E}-11 \quad 6.140 \mathrm{E}-11 \quad 4.595 \mathrm{E}-10$ $1.237 \mathrm{E}-09 \quad 1.237 \mathrm{E}-09 \quad 1.237 \mathrm{E}-09 \quad 1.236 \mathrm{E}-09$ 1.236E-09 $1.230 \mathrm{E}-09 \quad 1.215 \mathrm{E}-09 \quad 1.188 \mathrm{E}-09 \quad 1.081 \mathrm{E}-09$ 2.500E-02 2.500E-02 2.499E-02 2.498E-02 2.496E-02 2.485E-02 2.455E-02 2.400E-02 2.183E-02

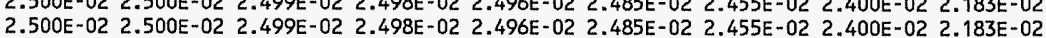

\begin{tabular}{ll} 
Attachment $\frac{8}{\text { O.W. Clark }}$ & Sheet No. 29 of 30 \\
Originator: & Date \\
Chk'd By & Date \\
Calc. No. Perrott & Rev. No. $\quad 0$ \\
\hline O100F-CA-V0280 & Rev. No
\end{tabular}




\section{ATTACHMENT 8}

1RESRAD, Version $6.3 \quad$ T\& Limit $=180$ days
Surmary $: 118-F-1$ Overburden/Below cleanup Levels
Stockpile Material RESRAD Calculation

File: $118-F-1$ OB-BCL.RAD

Individual Nuclide Soil Concentration Parent Nuclide and Branch Fraction Indicated

ONuclide Parent THF(i) (j) (i) ) ÄÄÄÄÄÄ ÄÄÄÄÄÄ ÄÄÄÄÄÄÄÄ $\begin{array}{ccc}U-236 & \text { PU-240 } & 1.000 E+00 \\ 0 T h-232 & \text { PU }-240 & 1.000 E+00\end{array}$ OR ORa-228 PU-240 1.000E+00 OTh-228 Pu-240 $1.000 \mathrm{E}+00$

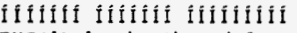

THF( $i$ ) is the thread fraction of the parent nuclide.
ORESCALC.EXE execution time $=14.42$ seconds

$t=0.000 E+00 \quad 1.000 E+003.000 E+00 \quad 7.000 E+00 \quad 1.100 E+014.300 E+01 \quad 1.350 E+02 \quad 3.000 E+02 \quad 1.000 E+03$

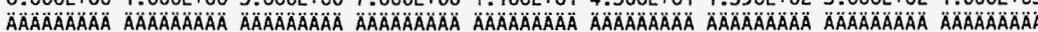
$0.000 \mathrm{E}+00 \quad 7.390 \mathrm{E}-10 \quad 2.211 \mathrm{E}-09$ 5.128E-09 8.012E-09 2.991E-08 8.255E-08 1.473E-07 $2.277 \mathrm{E}-07$ .

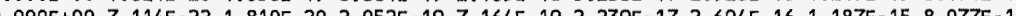
(16) 作

\begin{tabular}{|c|c|}
\hline Attachment & Sheet No. $\underline{30}$ of 30 \\
\hline Originator: S.W. Clark & Date \\
\hline Chk'd By M. W. Perrott & Date \\
\hline Calc. No. $\quad 0100 \mathrm{~F}-\mathrm{CA}-\mathrm{V} 0280$ & Rev. No. \\
\hline
\end{tabular}




\section{ATTACHMENT 9}

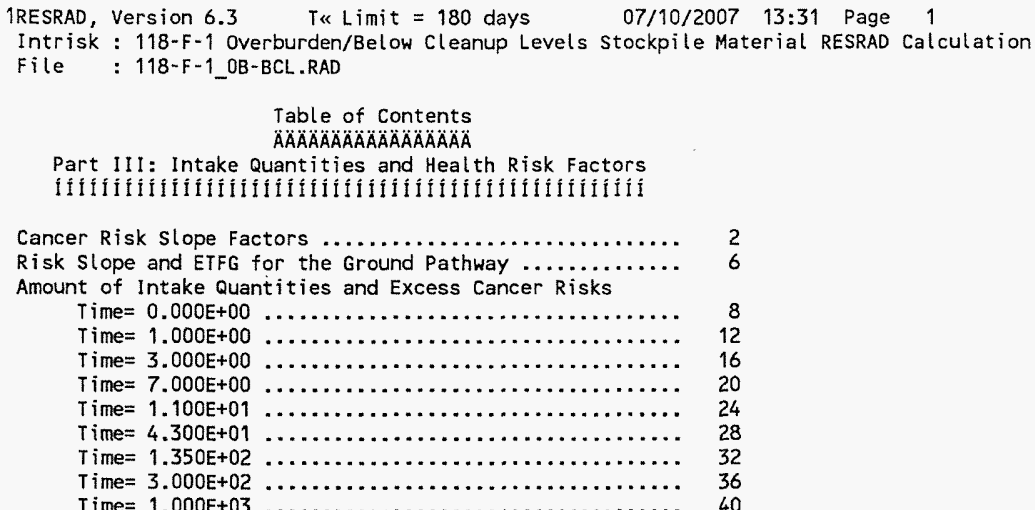




\section{ATTACHMENT 9}

1RESRAD, Version $6.3 \quad$ T« Limit $=180$ days $07 / 10 / 2007 \quad 13: 31$ Page 2
Intrisk : $118-F-1$ Overburden/Below Cleanup Levels Stockpile Material RESRAD Calculation File : 118-F-1_OB-BCL.RAD

$0 \quad 3$

Cancer Risk Slope Factors Sumary Table

Risk Library: HEAST 2001 Morbidity

Menu

Parameter

3 Current 3 Base 3 Parameter

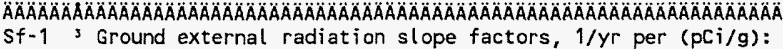

Sf -1 , 3 AC-227+D

Sf-1, $A C-227+D$

Sf-1 Ag-108m+D

$\begin{array}{lll}\mathrm{Sf}-1 & \mathrm{Am}-241 \\ \mathrm{sf}-1 & 3 \mathrm{C}-14\end{array}$

$\begin{array}{lll}S f-1 & 3 & C-14 \\ S f-1 & 3 & C O-60\end{array}$

$\begin{array}{lll}S f-1 & 3 & \text { Co }-60 \\ s f-1 & 3 & \text { Eu }-152\end{array}$

Sf-1, Eu-154

$S f-1$, Gd -152

$\mathrm{Sf}-1, \mathrm{H}-3$

$\mathrm{Sf}-1$, $\mathrm{Ni}-63$

Sf-1 $3 \mathrm{~Np}-237+\mathrm{D}$

$\mathrm{Sf}-1$; $\mathrm{Pa}-231$

$\mathrm{Sf}-1$, $\mathrm{Pb}-210+\mathrm{D}$

$\mathrm{Sf}-1, \mathrm{Pu}-238$

Sf-1 3 Pu-239

Sf-1 3 Pu-240

$S f-1 ; R a-226+D$

$S f-1 \quad 3$ Ra-228+D

Sf -1 Th $-228+D$

$\mathrm{Sf}-1 \quad 3 \quad \mathrm{Th}-229+\mathrm{D}$

Sf-1 3 Th-230

$S f-1$; Th-232

$S f-1 \quad 3 \quad U-233$

$S f-1 \quad 3 \quad U-234$

$S f-1 \quad 3 \quad U-235+D$

Sf-1 $>$ U-236

Sf-2 3 Inhalation, slope factors, $1 /(\mathrm{pC} i)$ :

Sf-2 $3 \mathrm{AC}-227+D$

$\mathrm{Sf}-\mathrm{s}$, AG-108m+D

$\mathrm{Sf}-2$; Am-241

$\mathrm{sf}-2 \times \mathrm{C}-14$

$\mathrm{Sf}-2 \times \mathrm{CO}-60$

Sf-2 3 Eu-152

Sf-2 3 Eu- 154

Sf-2 3 Gd-15

Sf -2 s

$\mathrm{Sf}-2>\mathrm{Ni}-63$

$\mathrm{Sf}-2,3 \mathrm{~Np}-237+\mathrm{D}$

Sf -2 ? $\mathrm{Pa}-231$

$\mathrm{Sf}-2 \times \mathrm{Pb}-210+\mathrm{D}$

Sf-2 3 Pu-238

sf-2 3 Pu-239

$S f-23$ Pu-240

Sf- 2 I Ra-226+D

Sf-5 s Ra- $528+0$

Sf-S Ra-228+D

Sf-2 3 Th-228+D

$\begin{array}{lll}\text { Sf }-2 & 3 & \text { Th }-229+0 \\ \text { sf }-2 & 3 & \text { Th }-230\end{array}$

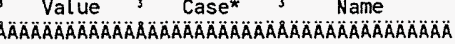

1.47E-06 $33.48 E-10 \quad 3 \operatorname{SLPF}(1,1)$

$3.19 E-06 ; 7.18 E-06$ 3 $\operatorname{SLPF}(2,1)$

$2.76 E-08$ 3 $2.76 \mathrm{E}-08$ S SLPF( 3,1$)$

$7.83 E-12$ 3 $7.83 E-12$ s SLPF 4,1$)$

$1.24 E-05$ 3 $1.24 E-05$ 3 SLPF 5,1$)$

$5.30 E-06>5.30 E-063 \operatorname{SLPF}(6,1)$

5.83E-06 $35.83 E-06$ S SLPF( 8,1)

$0.00 E+00$ 3 $0.00 E+00$ SLPF 9,1$)$

$0.00 E+00$ 3 $0.00 E+00$ S SLPF $(10,1)$

$0.00 E+0030.00 E+$

$7.07 E-07,5.36 \mathrm{E}-\mathrm{C}$

7.97E-07 $5.36 E-08$ SLPF $(12,1)$

$1.39 E-07$ 1.39E-07 $3 \operatorname{SLPF}(13,1)$

-09 3 SLPF $(14,1)$

$7.22 E-11$ 3.22E-11 $3 \operatorname{SLPF}(15,1)$

2.00E-10 3 2.00E-10 $3 \operatorname{SLPF}(17,1)$

6.98E-11 3 $6.98 \mathrm{E}-11$ 3 $\operatorname{SLPF}(18,1)$

3 8.49E-06 3 2.29E-08 $3 \operatorname{SLPF}(20,1)$

4.53E-06 3 $0.00 E+00$ 3 $\operatorname{SLPF}(21,1)$

$7.76 E-06$ 3 $5.59 E-09$ s SLPF( 22,1$)$

$1.17 E-06$ 3 $2.25 E-07$ SLPF( 23,1$)$

$1.17 E-06,2.25 E-07$ SLPF $(23,1)$

$\operatorname{SLPF}(24,1)$

$\operatorname{SLPF}(25,1)$

$9.82 E-10 \quad 39.82 E-10$ 3 $\operatorname{SLPF}(26,1)$

$32.52 E-10$ 3 $2.52 E-10$ \SLPF( 27,1)

3 5.43E-07 3 5.18E-07 3 $\operatorname{SLPF}(28,1)$

3.25E-10 $31.25 E-10$ SLPF( 29,1)

$3.09 E-07 \quad 3 \quad 1.49 E-07 \quad 3 \operatorname{SLPF}(1,2)$

$2.09 E-11 ; 2.67 E-11 ; \operatorname{SLPF}(2,2)$

$32.81 \mathrm{E}-08 ; 2.81 \mathrm{E}-08 ; \operatorname{SLPF}(3,2)$

3.07E-12, $3.07 E-12, \operatorname{SLPF}(4,2)$

$3.58 \mathrm{E}-11,3.58 \mathrm{E}-11,3 \operatorname{SLPF}(5,2)$

$39.10 E-11 ; 9.10 \mathrm{E}-113 \operatorname{SLPF}(6,2)$

$1.15 E-10$ 3 $1.15 E-10$ 3 SLPF 8,2$)$

$39.10 E-0939.10 E-093 \operatorname{SLPF}(9,2)$

$5.77 E-12$ s $5.77 E-12$ S SLPF( 11,2$)$

$1.77 E-0 B \sim 1.77 E-08$ SLPF 11,2$)$

$4.75 E-08$ अ $4.55 E-08$ J SLPF $(13,2)$

08 SLPF $(13,2)$

1.39E-08 3 2.77E-09 $3 \operatorname{SLPF}(14,2)$

$3.36 E-08$ 3 3.36E-08 3 SLPF( 15,2$)$

$3.33 E-08$ 3 3.33E-08 $3 \operatorname{SLPF}(17,2)$

$3.33 E-08$ 3 3.33E-08 3 $\operatorname{SLPF}(18,2)$

$31.16 \mathrm{E}-08$ 3 $1.15 \mathrm{E}-08$ 3 $\operatorname{SLPF}(20,2)$

$3.16 E-08$ 3 $5.18 E-09$ S SLPF( 21,2$)$

$1.43 E-07,1.32 E-07$ S SLPF( 22,2$)$

$1.43 E-07,1.32 E-07$ SLPF( 22,2$)$

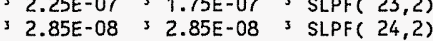

$\begin{array}{ll}\text { Attachment } \frac{9}{\text { S.W. Clark }} & \text { Sheet No. } 2 \text { of } \underline{43} \\ \text { Originator: } & \text { Date } \\ \text { Chk'd By } & \frac{\text { M. W. Perrott }}{\text { Date }} \\ \text { Calc. No. } & \text { Rev. No. } 0\end{array}$




\section{ATTACHMENT 9}

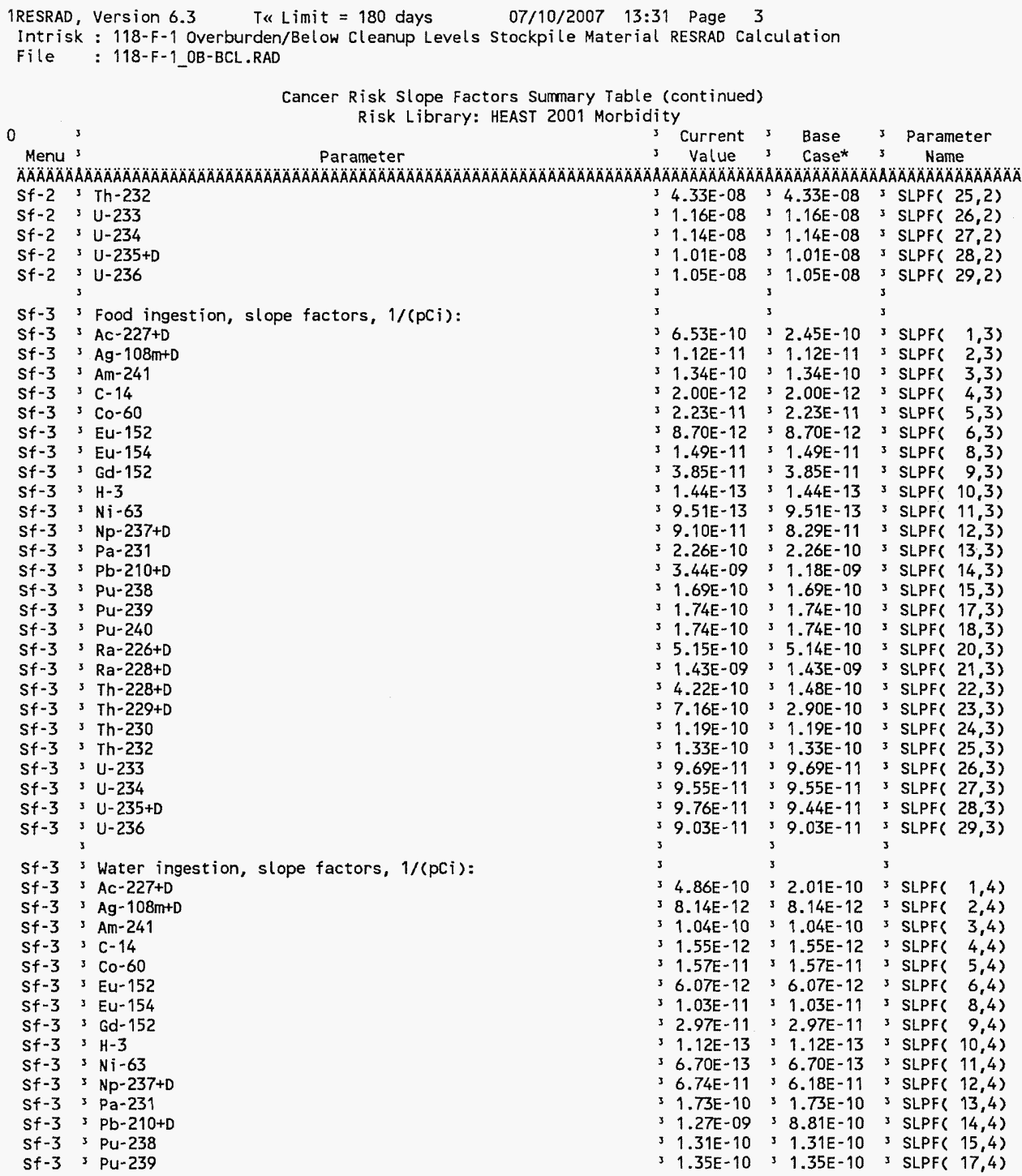

Attachment 


\section{ATTACHMENT 9}

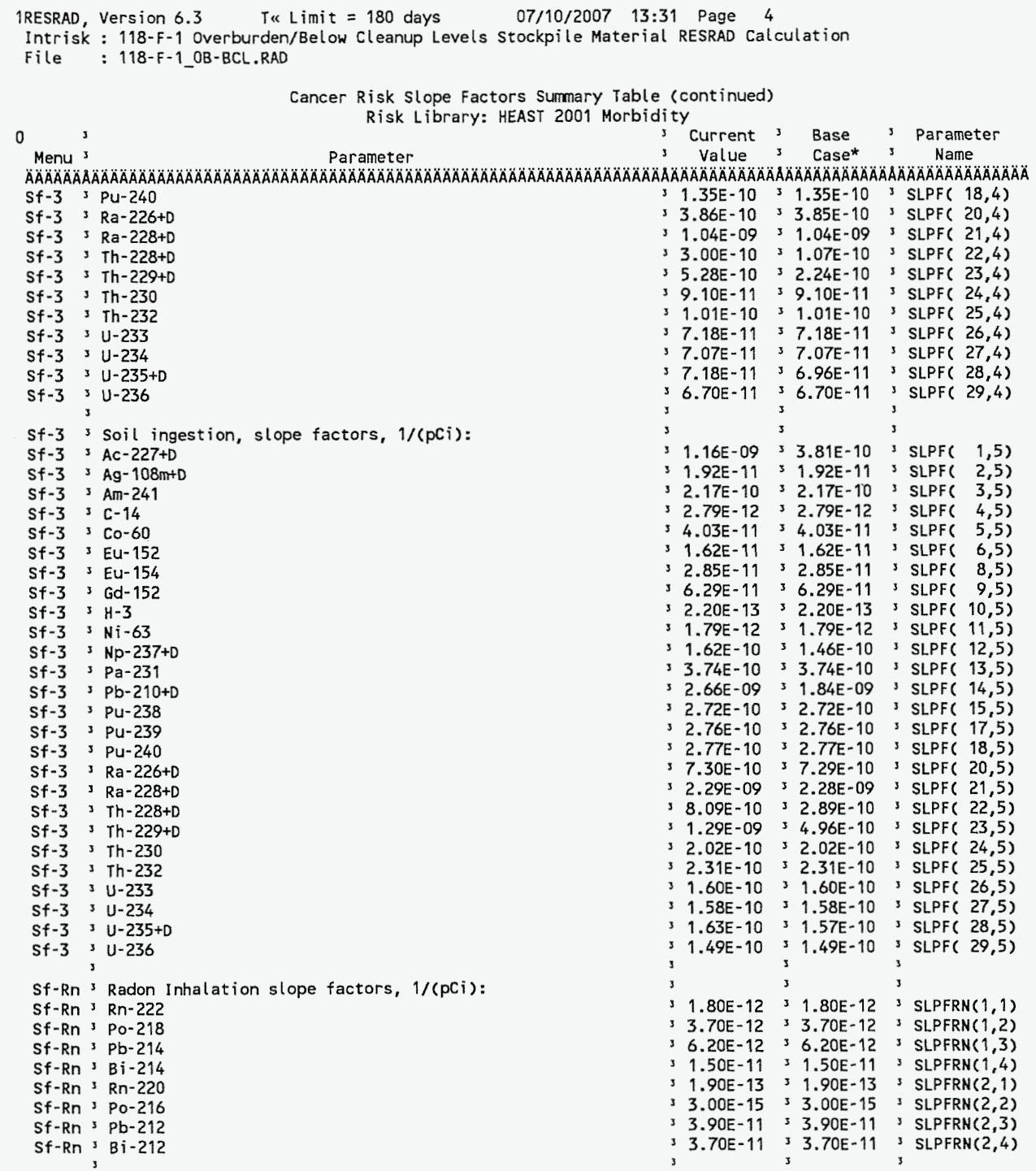

\begin{tabular}{|c|c|}
\hline Attachment & Sheet No. 4 of 43 \\
\hline Originator: S.W. Clark & Date \\
\hline Chk'd By M.W. Perrott & Date \\
\hline Calc. No. $0100 \mathrm{~F}-\mathrm{CA}-\mathrm{V} 0280$ & Rev. No. \\
\hline
\end{tabular}




\section{ATTACHMENT 9}

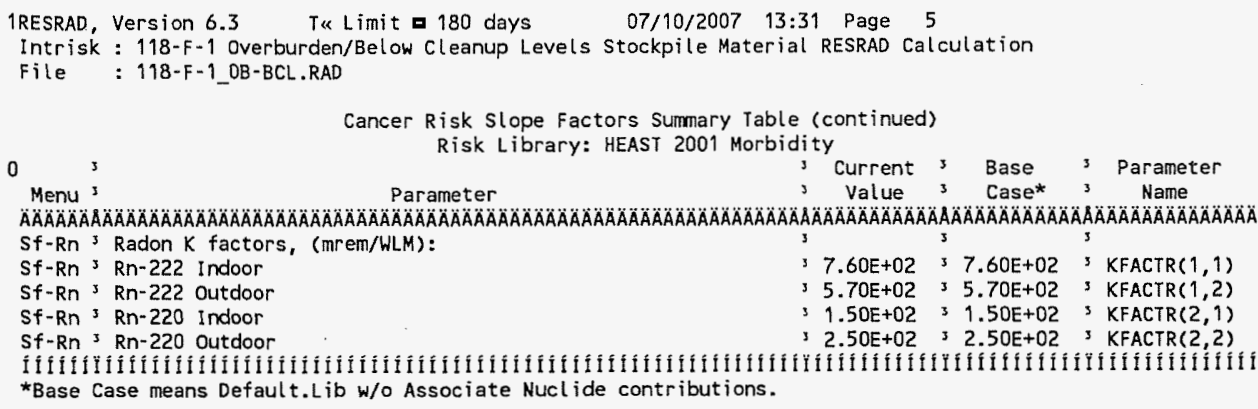

Attachment 


\section{ATTACHMENT 9}

1RESRAD, Version $6.3 \quad$ T « Limit $=180$ days 07/10/2007 13:31 Page 6

Intrisk : 118-F-1 Overburden/Below Cleanup Levels Stockpile Material RESRAD Calculation

File : 118-F-1_OB-BCL.RAD

ONuclide Slope(i)* (i) ÄÄÄÄÄÄ ÄÄÄÄÄÄÄÄ AC-225 4.500E-08 AC- $227 \quad 3.480 E-10$

AC- $228 \quad 4.530 E-06$

Am-241 2.760E-08

At $-217 \quad 1.320 \mathrm{E}-09$

At $-218 \quad 3.570 E-09$

Bi-210 2.760E-09

$8 \mathrm{i}-211 \quad 1.880 \mathrm{E}-07$

Bi-212 8.870E-07

$\mathrm{Bi}-213 \quad 5.650 \mathrm{E}-07$

Bi-214 7.480E-06

C-14 $7.830 \mathrm{E}-12$

CO-60 1.240E-05

EU-152 5.300E-06

Eu-154 5.830E-06

Fr-221 1.110E-07

$\mathrm{Fr}-223 \quad 1.400 \mathrm{E}-07$

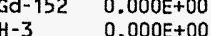

$\mathrm{Ni}-63 \quad 0.000 \mathrm{E}+00$

Np-237 $5.360 \mathrm{E}-08$

Pa-231 1.390E-07

Pa-233 7.430E-07

Pb-209 5.370E-10

Pb-210 1.410E-09

Pb-211 2.290E-07

$\mathrm{Pb}-212 \quad 5.090 \mathrm{E}-07$

Pb-214 9.820E-07

3.950E-11

3.950E-11

$\begin{array}{ll}\mathrm{PO}-211 & 3.580 \mathrm{E}-08 \\ \mathrm{PO}-212 & 0.000 \mathrm{E}+00\end{array}$

$\mathrm{PO}-213 \quad 0.000 \mathrm{E}+00$

PO- 214 3.860E-10

Po-215 7.480E-10

Po-216 7.870E-11

Po-218 4.260E-11

PU-238 $7.220 E-11$

PU-238 7.220E-11

Pu-239 2.000E-10

Pu-240 6.980E-11

Ra-223 4.340E-07

Ra-224 3.720E-08

Ra-225 5.910E-09

Ra-226 2.290E - 08

Ra-228 $0.000 E+00$

Rn-219 2.250E-07

$\mathrm{Rn}-220 \quad 1.700 \mathrm{E}-09$

$1.740 E-09$

$\begin{array}{ll}R n-222 & 1.740 E-09 \\ T h-227 & 3.780 E-07\end{array}$
Risk Slope and Environmental Transport Factors for the Ground Pathway ETFG( $i, t)$ At Time in Years (dimensionless)

$\begin{array}{llllllllll}0.000 E+00 & 1.000 E+00 & 3.000 E+00 & 7.000 E+00 & 1.100 E+01 & 4.300 E+01 & 1.350 E+02 & 3.000 E+02 & 1.000 E+03\end{array}$ A $\begin{array}{lllllllll}6.502 E-01 & 6.502 E-01 & 6.502 E-01 & 6.502 E-01 & 6.502 E-01 & 6.502 E-01 & 6.502 E-01 & 6.502 E-01 & 6.502 E-01\end{array}$

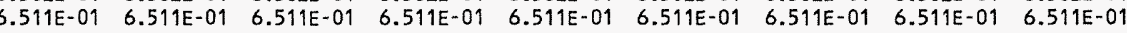
$\begin{array}{lllllllll}6.408 E-01 & 6.408 E-01 & 6.408 E-01 & 6.408 E-01 & 6.408 E-01 & 6.408 E-01 & 6.408 E-01 & 6.408 E-01 & 6.408 E-01\end{array}$ $\begin{array}{lllllllll}6.376 E-01 & 6.376 E-01 & 6.376 E-01 & 6.376 E-01 & 6.376 E-01 & 6.376 E-01 & 6.376 E-01 & 6.376 E-01 & 6.376 E-01\end{array}$ $\begin{array}{lllllllll}6.376 E-01 & 6.376 E-01 & 6.376 E-01 & 6.376 E-01 & 6.376 E-01 & 6.376 E-01 & 6.376 E-01 & 6.376 E-01 & 6.376 E-01 \\ 6.378 E-01 & 6.378 E-01 & 6.378 E-01 & 6.378 E-01 & 6.378 E-01 & 6.378 E-01 & 6.378 E-01 & 6.378 E-01 & 6.378 E-01\end{array}$ $\begin{array}{llllllllll}6.378 E-01 & 6.378 E-01 & 6.378 E-01 & 6.378 E-01 & 6.378 E-01 & 6.378 E-01 & 6.378 E-01 & 6.378 E-01 & 6.378 E-01 \\ 6.603 E-01 & 6.603 E-01 & 6.603 E-01 & 6.603 E-01 & 6.603 E-01 & 6.603 E-01 & 6.603 E-01 & 6.603 E-01 & 6.603 E-01\end{array}$ $\begin{array}{llllllllll}6.603 \mathrm{E}-01 & 6.603 \mathrm{E}-01 & 6.603 \mathrm{E}-01 & 6.603 \mathrm{E}-01 & 6.603 \mathrm{E}-01 & 6.603 \mathrm{E}-01 & 6.603 \mathrm{E}-01 & 6.603 \mathrm{E}-01 & 6.603 \mathrm{E}-01 \\ 6.396 \mathrm{E}-01 & 6.396 \mathrm{E}-01 & 6.396 \mathrm{E}-01 & 6.396 \mathrm{E}-01 & 6.396 \mathrm{E}-01 & 6.396 \mathrm{E}-01 & 6.396 \mathrm{E}-01 & 6.396 \mathrm{E}-01 & 6.396 \mathrm{E}-01\end{array}$ $\begin{array}{lllllllll}6.396 \mathrm{E}-01 & 6.396 \mathrm{E}-01 & 6.396 \mathrm{E}-01 & 6.396 \mathrm{E}-01 & 6.396 \mathrm{E}-01 & 6.396 \mathrm{E}-01 & 6.396 \mathrm{E}-01 & 6.396 \mathrm{E}-01 & 6.396 \mathrm{E}-01 \\ 6.601 \mathrm{E}-01 & 6.601 \mathrm{E}-01 & 6.601 \mathrm{E}-01 & 6.601 \mathrm{E}-01 & 6.601 \mathrm{E}-01 & 6.601 \mathrm{E}-01 & 6.601 \mathrm{E}-01 & 6.601 \mathrm{E}-01 & 6.601 \mathrm{E}-01\end{array}$

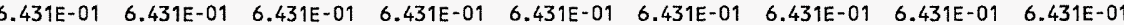
$\begin{array}{lllllllll}6.433 E-01 & 6.433 E-01 & 6.433 E-01 & 6.433 E-01 & 6.433 E-01 & 6.433 E-01 & 6.433 E-01 & 6.433 E-01 & 6.433 E-01\end{array}$

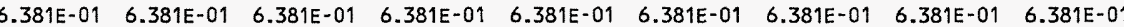
$6.405 \mathrm{E}-01$ 6.405E-01 $6.405 \mathrm{E}-01$ 6.405E-01 $6.405 \mathrm{E}-01 \quad 6.405 \mathrm{E}-01 \quad 6.405 \mathrm{E}-01 \quad 6.405 \mathrm{E}-01 \quad 6.405 \mathrm{E}-01$ 6. $\begin{array}{lllllllll}6.398 E-01 & 6.398 \mathrm{E}-01 & 6.398 \mathrm{E}-01 & 6.398 \mathrm{E}-01 & 6.398 \mathrm{E}-01 & 6.398 \mathrm{E}-01 & 6.398 \mathrm{E}-01 & 6.398 \mathrm{E}-01 & 6.398 \mathrm{E}-01\end{array}$ $\begin{array}{lllllllll}6.673 \mathrm{E}-01 & 6.673 \mathrm{E}-01 & 6.673 \mathrm{E}-01 & 6.673 \mathrm{E}-01 & 6.673 \mathrm{E}-01 & 6.673 \mathrm{E}-01 & 6.673 \mathrm{E}-01 & 6.673 \mathrm{E}-01 & 6.673 \mathrm{E}-0\end{array}$ $\begin{array}{llllllllll}6.404 \mathrm{E}-01 & 6.404 \mathrm{E}-01 & 6.404 \mathrm{E}-01 & 6.404 \mathrm{E}-01 & 6.404 \mathrm{E}-01 & 6.404 \mathrm{E}-01 & 6.404 \mathrm{E}-01 & 6.404 \mathrm{E}-01 & 6.404 \mathrm{E}-01 \\ 6.414 \mathrm{E}-01 & 6.414 \mathrm{E}-01 & 6.414 \mathrm{E}-01 & 6.414 \mathrm{E}-01 & 6.414 \mathrm{E}-01 & 6.414 \mathrm{E}-01 & 6.414 \mathrm{E}-01 & 6.414 \mathrm{E}-01 & 6.414 \mathrm{E}-01\end{array}$ $\begin{array}{cccccccccc}6.414 \mathrm{E}-01 & 6.414 \mathrm{E}-01 & 6.414 \mathrm{E}-01 & 6.414 \mathrm{E}-01 & 6.414 \mathrm{E}-01 & 6.414 \mathrm{E}-01 & 6.414 \mathrm{E}-01 & 6.414 \mathrm{E}-01 & 6.414 \mathrm{E}-01 \\ 6.408 \mathrm{E}-01 & 6.408 \mathrm{E}-01 & 6.408 \mathrm{E}-01 & 6.408 \mathrm{E}-01 & 6.408 \mathrm{E}-01 & 6.408 \mathrm{E}-01 & 6.408 \mathrm{E}-01 & 6.408 \mathrm{E}-01 & 6.408 \mathrm{E}-01\end{array}$ $\begin{array}{llllllllll}6.408 E-01 & 6.408 E-01 & 6.408 E-01 & 6.408 E-01 & 6.408 E-01 & 6.408 E-01 & 6.408 E-01 & 6.408 E-01 & 6.408 E-01 \\ 6.467 E-01 & 6.467 E-01 & 6.467 E-01 & 6.467 E-01 & 6.467 E-01 & 6.467 E-01 & 6.467 E-01 & 6.467 E-01 & 6.467 E-01\end{array}$ $\begin{array}{lllllllll}6.466 E-01 & 6.466 E-01 & 6.466 E-01 & 6.466 E-01 & 6.466 E-01 & 6.466 E-01 & 6.466 E-01 & 6.466 E-01 & 6.466 E-01\end{array}$ $\begin{array}{lllllllll}0.000 E+00 & 0.000 E+00 & 0.000 E+00 & 0.000 E+00 & 0.000 E+00 & 0.000 E+00 & 0.000 E+00 & 0.000 E+00 & 0.000 E+00\end{array}$ $6.800 \mathrm{E}-01 \quad 6.800 \mathrm{E}-01 \quad 6.800 \mathrm{E}-01 \quad 6.800 \mathrm{E}-01 \quad 6.800 \mathrm{E}-01 \quad 6.800 \mathrm{E}-01 \quad 6.800 \mathrm{E}-01 \quad 6.800 \mathrm{E}-01 \quad 6.800 \mathrm{E}-01$ $\begin{array}{lllllllll}0.000 E+00 & 0.000 E+00 & 0.000 E+00 & 0.000 E+00 & 0.000 E+00 & 0.000 E+00 & 0.000 E+00 & 0.000 E+00 & 0.000 E+00\end{array}$ $\begin{array}{lllllllll}6.526 \mathrm{E}-01 & 6.526 \mathrm{E}-01 & 6.526 \mathrm{E}-01 & 6.526 \mathrm{E}-01 & 6.526 \mathrm{E}-01 & 6.526 \mathrm{E}-01 & 6.526 \mathrm{E}-01 & 6.526 \mathrm{E}-01 & 6.526 \mathrm{E}-01\end{array}$

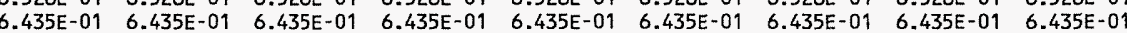
$\begin{array}{lllllllll}6.443 E-01 & 6.443 E-01 & 6.443 E-01 & 6.443 E-01 & 6.443 E-01 & 6.443 E-01 & 6.443 E-01 & 6.443 E-01 & 6.443 E-01\end{array}$ $\begin{array}{lllllllll}6.479 E-01 & 6.479 E-01 & 6.479 E-01 & 6.479 E-01 & 6.479 E-01 & 6.479 E-01 & 6.479 E-01 & 6.479 E-01 & 6.479 E-01\end{array}$ 6.676E-01 6.676E-01 6.676E-01 6.676E-01 6.676E-01 6.676E-01 $6.676 E-01 \quad 6.676 E-01 \quad 6.676 E-01$

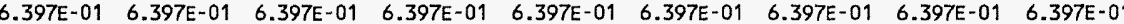
$\begin{array}{lllllllll}6.475 E-01 & 6.475 E-01 & 6.475 E-01 & 6.475 E-01 & 6.475 E-01 & 6.475 E-01 & 6.475 E-01 & 6.475 E-01 & 6.475 E-01\end{array}$ $6.429 \mathrm{E}-01$ 6.429E-01 6.429E-01 6.429E-01 6.429E-01 6.429E-01 6.472E-01 6. 629E-01 6.429E-01 $6.329 E 016.429 E-016.429 E-01$ 6.429E-01 6.429E-01 6.429E-01 $6.429 E-01$ 6.429E-01 6.429E-01 $\begin{array}{lllllllll}6.391 \mathrm{E}-01 & 6.391 \mathrm{E}-01 & 6.391 \mathrm{E}-01 & 6.391 \mathrm{E}-01 & 6.391 \mathrm{E}-01 & 6.391 \mathrm{E}-01 & 6.391 \mathrm{E}-01 & 6.391 \mathrm{E}-01 & 6.391 \mathrm{E}-0\end{array}$ $\begin{array}{llllllllll}6.371 E-01 & 6.371 E-01 & 6.371 E-01 & 6.371 E-01 & 6.371 E-01 & 6.371 E-01 & 6.371 E-01 & 6.371 E-01 & 6.371 E-01 \\ 0.000 E+00 & 0.000 E+00 & 0.000 E+00 & 0.000 E+00 & 0.000 E+00 & 0.000 E+00 & 0.000 E+00 & 0.000 E+00 & 0.000 E+00\end{array}$ $\begin{array}{lllllllll}0.000 E+00 & 0.000 E+00 & 0.000 E+00 & 0.000 E+00 & 0.000 E+00 & 0.000 E+00 & 0.000 E+00 & 0.000 E+00 & 0.000 E+00 \\ 0.000 E+00 & 0.000 E+00 & 0.000 E+00 & 0.000 E+00 & 0.000 E+00 & 0.000 E+00 & 0.000 E+00 & 0.000 E+00 & 0.000 E+00\end{array}$ $\begin{array}{lllllllll}0.000 E+00 & 0.000 E+00 & 0.000 E+00 & 0.000 E+00 & 0.000 E+00 & 0.000 E+00 & 0.000 E+00 & 0.000 E+00 & 0.000 E+00 \\ 6.371 E-01 & 6.371 E-01 & 6.371 E-01 & 6.371 E-01 & 6.371 E-01 & 6.371 E-01 & 6.371 E-01 & 6.371 E-01 & 6.371 E-01\end{array}$

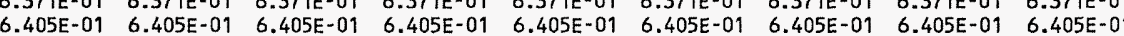

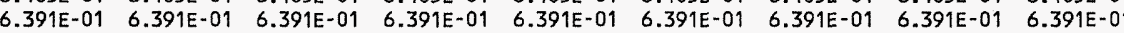
$\begin{array}{llllllllll}6.391 \mathrm{E}-01 & 6.391 \mathrm{E}-01 & 6.391 \mathrm{E}-01 & 6.391 \mathrm{E}-01 & 6.391 \mathrm{E}-01 & 6.391 \mathrm{E}-01 & 6.391 \mathrm{E}-01 & 6.391 \mathrm{E}-01 & 6.391 \mathrm{E}-01\end{array}$ $6.728 \mathrm{E}-01$ 6.728E-01 6.728E-01 6.728E-01 6.728E-01 6.728E-01 6.728E-01 6.728E-01 6.728E-01 . $\begin{array}{lllllllll}6.490 E-01 & 6.490 E-01 & 6.490 E-01 & 6.490 E-01 & 6.490 E-01 & 6.490 E-01 & 6.490 E-01 & 6.490 E-01 & 6.490 E-01\end{array}$ $\begin{array}{lllllllll}6.691 \mathrm{E}-01 & 6.691 \mathrm{E}-01 & 6.691 \mathrm{E}-01 & 6.691 \mathrm{E}-01 & 6.691 \mathrm{E}-01 & 6.691 \mathrm{E}-01 & 6.691 \mathrm{E}-01 & 6.691 \mathrm{E}-01 & 6.691 \mathrm{E}-01\end{array}$ $\begin{array}{lllllllll}6.463 E-01 & 6.463 E-01 & 6.463 E-01 & 6.463 E-01 & 6.463 E-01 & 6.463 E-01 & 6.463 E-01 & 6.463 E-01 & 6.463 E-01\end{array}$ $\begin{array}{lllllllll}6.466 \mathrm{E}-01 & 6.466 \mathrm{E}-01 & 6.466 \mathrm{E}-01 & 6.466 \mathrm{E}-01 & 6.466 \mathrm{E}-01 & 6.466 \mathrm{E}-01 & 6.466 \mathrm{E}-01 & 6.466 \mathrm{E}-01 & 6.466 \mathrm{E}-01\end{array}$ $\begin{array}{lllllllll}6.664 \mathrm{E}-01 & 6.664 \mathrm{E}-01 & 6.664 \mathrm{E}-01 & 6.664 \mathrm{E}-01 & 6.664 \mathrm{E}-01 & 6.664 \mathrm{E}-01 & 6.664 \mathrm{E}-01 & 6.664 \mathrm{E}-01 & 6.664 \mathrm{E}-01\end{array}$ 6.481E-01 6.481E-01 6.481E-01 $\quad 6.481 E-01 \quad 6.481 E-01 \quad 6.481 E-01 \quad 6.481 E-01 \quad 6.481 E-01 \quad 6.481 E-01$ $\begin{array}{llllllllll}0.000 E+00 & 0.000 E+00 & 0.000 E+00 & 0.000 E+00 & 0.000 E+00 & 0.000 E+00 & 0.000 E+00 & 0.000 E+00 & 0.000 E+00\end{array}$ $\begin{array}{lllllllll}6.433 E-01 & 6.433 E-01 & 6.433 E-01 & 6.433 E-01 & 6.433 E-01 & 6.433 E-01 & 6.433 E-01 & 6.433 E-01 & 6.433 E-01\end{array}$ $6.378 \mathrm{E}-01 \quad 6.378 \mathrm{E}-01 \quad 6.378 \mathrm{E}-01 \quad 6.378 \mathrm{E}-01 \quad 6.378 \mathrm{E}-01 \quad 6.378 \mathrm{E}-01 \quad 6.378 \mathrm{E}-01 \quad 6.378 \mathrm{E}-01 \quad 6.378 \mathrm{E}-01$ $6.378 \mathrm{E}-016.378 \mathrm{E}-016.378 \mathrm{E}-01$ 6.378E-01 6.378E-01 6.378E-01 $6.378 \mathrm{E}-01$ 6.378E-01 $6.378 \mathrm{E}-01$ $\begin{array}{lllllllll}6.378 E-01 & 6.378 E-01 & 6.378 E-01 & 6.378 E-01 & 6.378 E-01 & 6.378 E-01 & 6.378 E-01 & 6.378 E-01 & 6.378 E-01 \\ 6.471 E-01 & 6.471 E-01 & 6.471 E-01 & 6.471 E-01 & 6.471 E-01 & 6.471 E-01 & 6.471 E-01 & 6.471 E-01 & 6.471 E-01\end{array}$

$\begin{array}{ll}\text { Attachment } \frac{9}{\text { S.W. Clark }} & \text { Sheet No. } \underline{6} \text { of } \underline{43} \\ \text { Originator: } \frac{\text { S.Wate }}{\text { M.W. Perrott }} & \text { Date } \\ \text { Chk'd By } & \text { Rev. No. } 0 \\ \text { Calc. No. } & 0100 \text { F-CA-V0280 }\end{array}$




\section{ATTACHMENT 9}

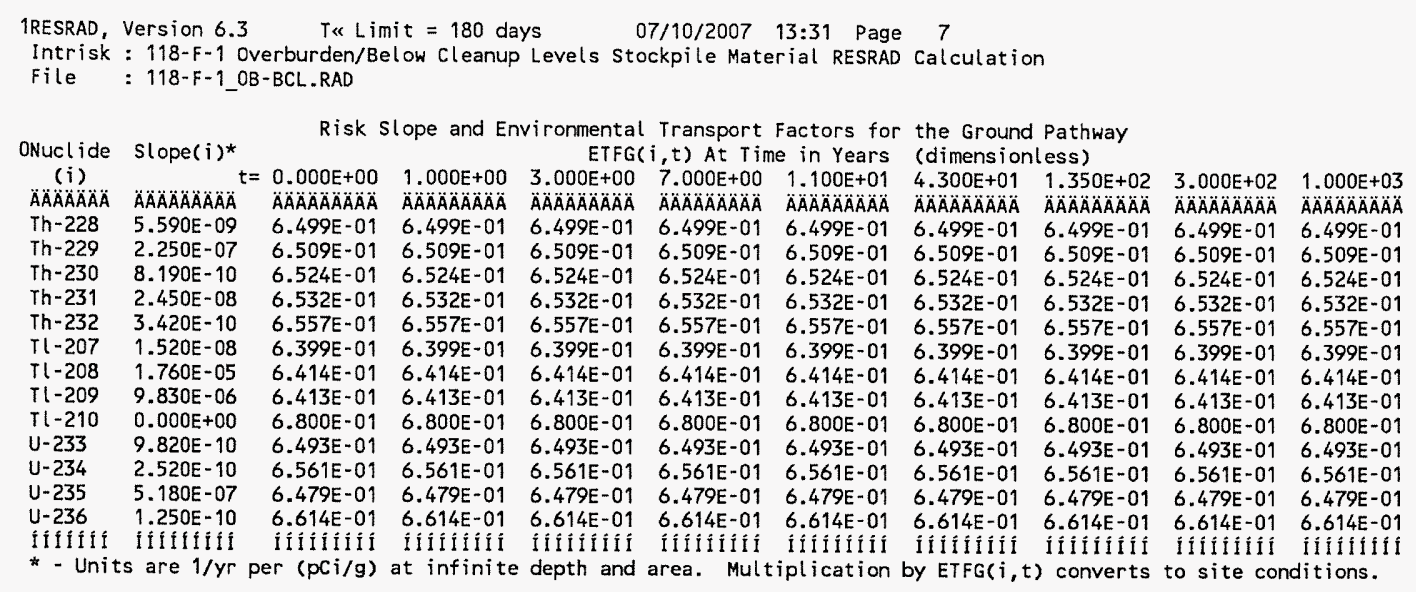

$\begin{array}{ll}\text { Attachment } \frac{9}{\text { S. Clark }} & \text { Sheet No. } \underline{7} \text { of } \underline{43} \\ \text { Originator: } & \text { Date } \\ \text { Chk'd By } & \text { Date } \\ \text { Calc. No. Perrott } & \text { Rev. No. } \quad 0\end{array}$




\section{ATTACHMENT 9}

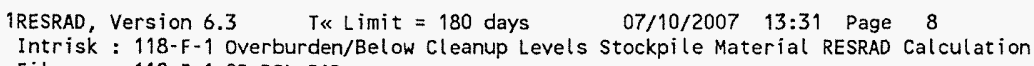

$\begin{array}{ll}\text { Attachment } \frac{9}{\text { S. Clark }} & \text { Sheet No. } \underline{8} \text { of } \underline{43} \\ \text { Originator: } & \text { Date } \\ \text { Chk'd By } & \text { Date } \\ \text { Calc. No. Perrott } & \text { Rev. No. No0 } 0\end{array}$




\section{ATTACHMENT 9}

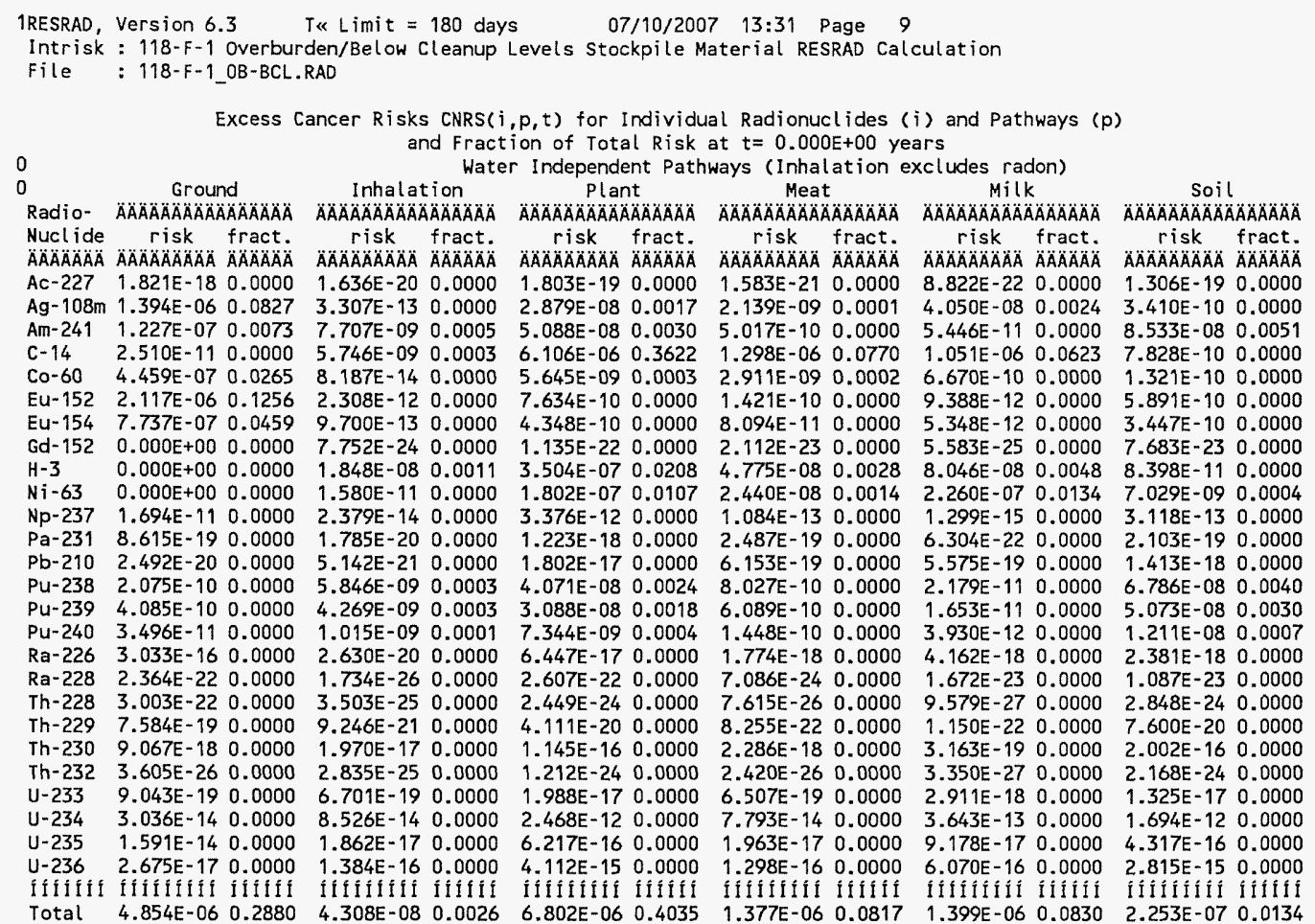

$\begin{array}{ll}\text { Attachment } \frac{9}{\text { S. Clark }} & \text { Sheet No. } 9 \text { of } 43 \\ \text { Originator: } \frac{\text { S.W. }}{\text { M.W. Perrott }} & \text { Date } \\ \text { Chk'd By } \frac{\text { D.W. }}{\text { O100F-CA-V0280 }} \text { Rev. No. } \quad \text { O } & \end{array}$




\section{ATTACHMENT 9}

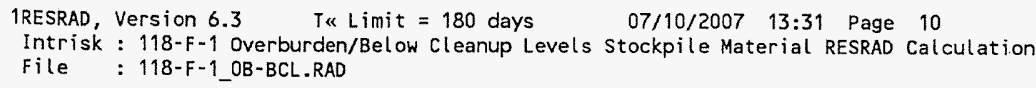

Water Dependent Pathways

\begin{tabular}{|c|c|c|c|c|c|c|c|c|c|c|c|c|}
\hline & $\begin{array}{r}\text { Water } \\
\text { AAAAAAAAAOAOA }\end{array}$ & A & $\begin{array}{r}F \text { is } \\
\triangle A \cap A ̈ A ̈ A O A O A ̈ A ̈\end{array}$ & A & $\begin{array}{r}P l a n \\
A \not A O A A O A O A O A B\end{array}$ & $\begin{array}{l}n t \\
G A M A Z A ̈ A ̈ A ̈ A\end{array}$ & $\begin{array}{r}\text { Meat } \\
\text { ÄÄÄÄÄÄÄÄÁ }\end{array}$ & t & $\begin{array}{r}M i l l \\
\text { ÄÄAAAOÄÄA }\end{array}$ & $\begin{array}{l}k \\
\ddot{A} A ̈ A ̈ A ̈ A B A ̈\end{array}$ & $\begin{array}{r}\text { All Path } \\
A A A A A A A O A A A\end{array}$ & $\begin{array}{l}\text { hwways ** } \\
\text { ÄAAAAAÄ }\end{array}$ \\
\hline $\begin{array}{l}\text { IClide } \\
\text { ÄÄÄÄÄ }\end{array}$ & $\begin{array}{c}\text { risk } \\
\text { AAAAÄÄÄA }\end{array}$ & 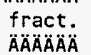 & $\begin{array}{c}\text { risk } \\
\text { ÄÄÄÄÄÄÄ }\end{array}$ & $\begin{array}{l}\text { fract. } \\
\text { ÄABAOAOA }\end{array}$ & $\begin{array}{c}\text { risk } \\
\text { ABÄÄÄÄÄ }\end{array}$ & $\begin{array}{l}\text { fract. } \\
\text { ÄÄÄÄÄ }\end{array}$ & $\begin{array}{c}\text { risk } \\
\text { AूÄÄÄÄÄÄÄ }\end{array}$ & $\begin{array}{l}\text { fract. } \\
\text { ÄÄÄÄÄA }\end{array}$ & 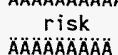 & $\begin{array}{l}\text { fract. } \\
\text { fract. } \\
\text { AOAAOAOA }\end{array}$ & $\begin{array}{c}\text { AAAAAAAAA } \\
\text { riSk } \\
\text { ÄAAOAOAOAOAA }\end{array}$ & $\begin{array}{l}\text { ARAACA. } \\
\text { fract. } \\
\text { ÄAOAOAB }\end{array}$ \\
\hline & $1.863 E-18$ & 0.0000 & $4.171 \mathrm{E}-20$ & 0.0000 & $2.762 E-19$ & 0.0000 & $1.561 \mathrm{E}-21$ & 0.0000 & $2.008 E-21$ & 0.0000 & $4.335 E-18$ & 0.0000 \\
\hline & & 0.0000 & $0.000 E+00$ & 0.0000 & $.000 \mathrm{E}+00$ & 0.0000 & $0.000 E+00$ & 0.0000 & $0.000 \mathrm{E}+00$ & 0.0000 & $1.466 \mathrm{E}-06$ & 0.0870 \\
\hline & $0.000 \mathrm{E}+00$ & 0.0000 & $0.000 E+00$ & & $.000 E+00$ & 0.0000 & $.000 E+00$ & 0.0000 & $0.000 E+00$ & 0.0000 & & 0.0159 \\
\hline & $0.000 \mathrm{E}+00$ & 0.0000 & $0 E+00$ & & & 0.0000 & $0.000 E+00$ & 0.0000 & $0.000 E+00$ & 0.0000 & & \\
\hline & $139 E-11$ & 0.0000 & $E-12$ & 0.0000 & 12 & 0.0000 & $4.313 E-12$ & 0.0000 & $1.271 \mathrm{E}-12$ & 000 & & 0.0270 \\
\hline & & & $O E+00$ & 00 & $O E+0 D$ & 0000 & $0.000 E+00$ & 0.0000 & $0.000 E+00$ & 0000 & & \\
\hline & & & & & $E+00$ & & & & & & & \\
\hline & $0.000 \mathrm{E}+00$ & 0.0 & $E+\infty$ & & $E+00$ & & & & $E+\infty$ & 000 & & 000 \\
\hline & 1. & & $=-10$ & 00 & -07 & 317 & -08 & 0.0 & & & & \\
\hline & & & & & & & & 000 & $E-09$ & 0.0 & & \\
\hline & 0.00 & & & & & & & 0.0 & & 000 & & \\
\hline & 8 & 0.0 & $E-21$ & 0.0 & -19 & & & & & & & \\
\hline & & & & & & 000 & -19 & & & & & \\
\hline & & & & & $O E+00$ & & & & & & & \\
\hline $1-2$ & $0.000 E+00$ & 0.0 & $E+00$ & & $+\infty$ & & & & $000 E+00$ & 0.0000 & & 0.0052 \\
\hline & & & $E+\infty$ & 00 & $\mathrm{~F}+00$ & & $+\infty$ & & & & & \\
\hline & & & & & & & & & & 0.0 & & \\
\hline & 8.21 & & 1.5 & & 1.2 & & -24 & 0.0000 & $E-24$ & 0.0 & & 1000 \\
\hline & & & & & & & & & -27 & 100 & & 1000 \\
\hline & & & & & $=-20$ & & -22 & & $=-22$ & & & \\
\hline & & 0.0000 & 1.45 & & $.879 E-17$ & & & & & & & \\
\hline & 4 & & $E-25$ & & & & $3.093 E-26$ & & $5.773 E-27$ & 0.0000 & $9.671 E-24$ & 0.0000 \\
\hline & & & & & & & & & & & & \\
\hline & & & & & & & & & & & & \\
\hline & & & & 0.0000 & $1.247 E-14$ & & $5.261 \mathrm{E}-16$ & 0.0000 & $2.701 E-15$ & 0.0000 & $1.164 E-13$ & 0.0000 \\
\hline & & & & & & & & & & & & \\
\hline & & & & & & & & & & & & \\
\hline & $O E-00$ & & & & & & & & $=-0 r$ & 0.0093 & -03 & \\
\hline
\end{tabular}

\footnotetext{
* Sum of water independent ground, inhalation, plant, meat, milk, soil
} and water dependent water, fish, plant, meat, milk pathways

Excess Cancer Risks CNRS9 $(i \mathrm{rn}, i, t)$ and CNRSPW( $i r n, i, t)$ for Inhalation of Radon and its Decay Products at $t=0.000 \mathrm{E}+00$ years

Radionucl ides

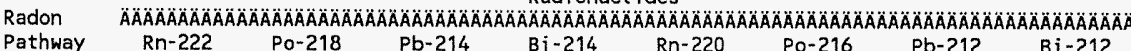

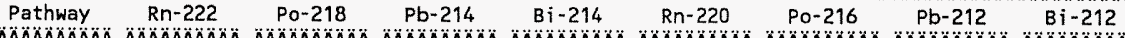

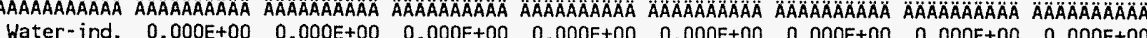

Water-dep. $\begin{array}{lllllllll}0.000 E+00 & 0.000 E+00 & 0.000 E+00 & 0.000 E+00 & 0.000 E+00 & 0.000 E+00 & 0.000 E+00 & 0.000 E+00\end{array}$

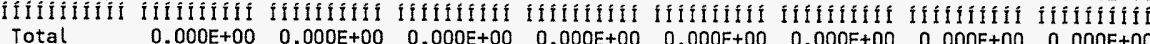

Water - ind. $==$ Water - independent Water-dep. $==$ Water-dependent

\begin{tabular}{|c|c|}
\hline \multirow{2}{*}{\multicolumn{2}{|c|}{$\begin{array}{l}\text { Attachment } \frac{9}{\text { S.W. Clark }} \text { Sheet No. } 10 \text { of } \underline{43} \text { Date } \\
\text { Originator: }\end{array}$}} \\
\hline & \\
\hline Chk'd By M. W. Perrott & Date \\
\hline $0100 F-C A-V 0280$ & Rev. No. \\
\hline
\end{tabular}




\section{ATTACHMENT 9}

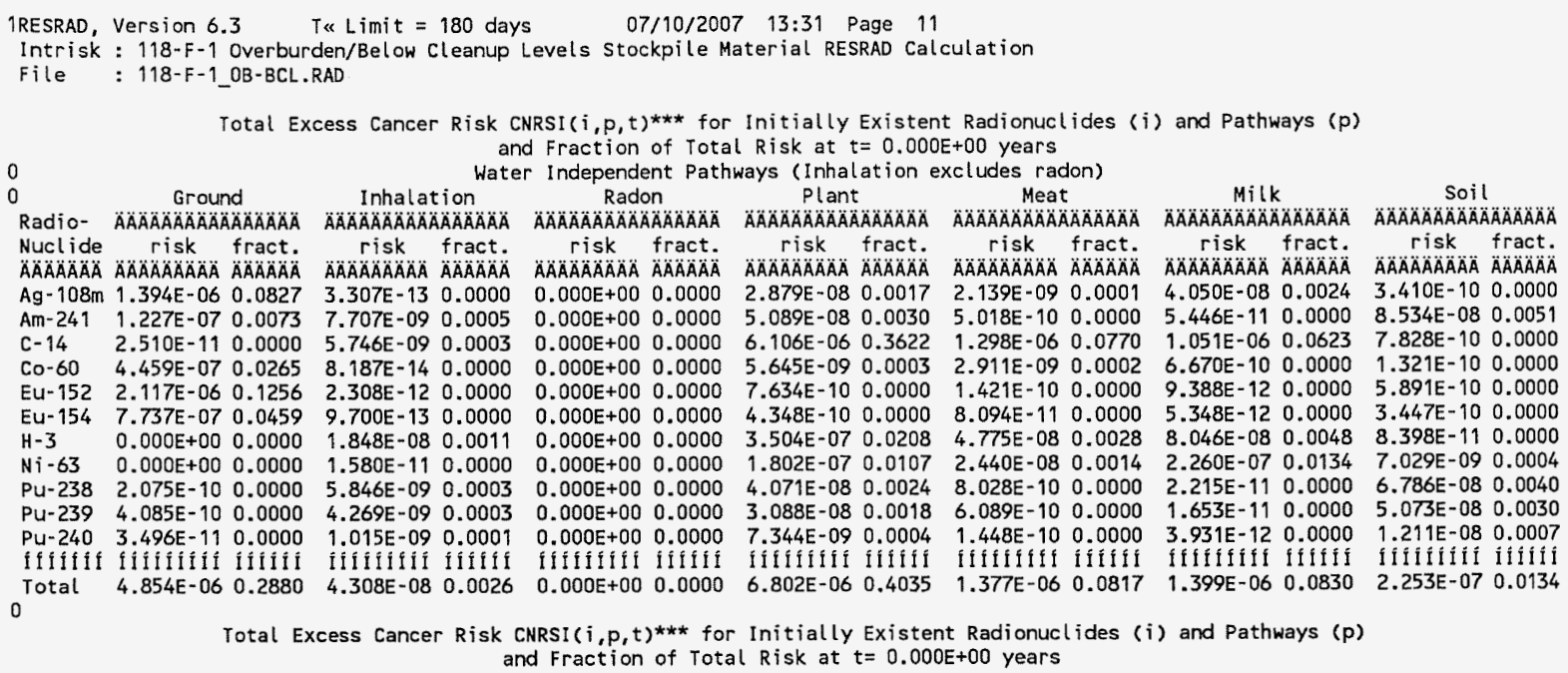

Total Excess Cancer Risk CNRSI $(i, p, t) * * *$ for Initially Existent Radionuclides $(i)$ and Pathways $(p)$ and Fraction of Total Risk at $t=0.000 E+00$ years

Water Dependent Pathways

\begin{tabular}{|c|c|c|c|c|c|c|c|c|c|c|c|c|c|}
\hline \multirow{2}{*}{$\begin{array}{l}\text { Radio- } \\
\text { Nuclide } \\
\text { ÄÄÄÄÄÄ }\end{array}$} & \multicolumn{2}{|c|}{$\begin{array}{c}\text { Water } \\
\text { ÄAAAAAAAOAAAAAOAOA }\end{array}$} & \multicolumn{2}{|c|}{ 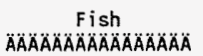 } & \multicolumn{2}{|c|}{$\begin{array}{c}\text { Radion } \\
\text { AAAAAAAAAAAAAAOAAA }\end{array}$} & \multicolumn{2}{|c|}{$\begin{array}{c}\text { Plant } \\
\text { AAAAAAAAOAAAAAOAOAOAOA }\end{array}$} & \multicolumn{2}{|c|}{ 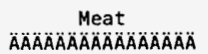 } & \multicolumn{2}{|c|}{$\begin{array}{c}M i l k \\
\text { ÄAAAAAAAAAAAOÄÄÄÄ }\end{array}$} & $\begin{array}{c}\text { All pathways } \\
A A A A A A A B A A B A A B A A\end{array}$ \\
\hline & risk & $\begin{array}{l}\text { fract. } \\
\text { AिAABAAAB }\end{array}$ & $\begin{array}{c}\text { risk } \\
\triangle A A A B A A O A A\end{array}$ & $\begin{array}{l}\text { fract. } \\
\text { AAAAAAA }\end{array}$ & $\begin{array}{c}\text { risk } \\
\text { AAAAAAAAAAA }\end{array}$ & $\begin{array}{l}\text { fract. } \\
A B A B A O A O A\end{array}$ & 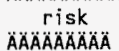 & 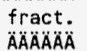 & $\begin{array}{c}\text { risk } \\
\text { ÄÄÄÄÄÄÄÄ }\end{array}$ & & risk & & $\begin{array}{l}\text { risk fract. } \\
\triangle A O A O A B A B A B A B A B A B A\end{array}$ \\
\hline & & & & & & & & & & & & & \\
\hline & & & & & & & & & & & & & \\
\hline & & & & & & & & & & & & & \\
\hline & & & & & & & & & & & & & \\
\hline & & & & & & & & & & & & & \\
\hline & & & & & & & & & & & & & \\
\hline & & & & & & & & & & & & & \\
\hline & & & & & & & & & & & & & \\
\hline & & & & & & & & & & & & & \\
\hline & & & & & & & & & & & & & \\
\hline & & & & & & & & & & & & & \\
\hline & & & & & & & & & If & & & & $\Lambda \Omega$ \\
\hline & & & -10 & & $.000 E+00$ & .0000 & 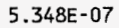 & & $E-08$ & & $\because 007$ & 0.0093 & us \\
\hline
\end{tabular}

***CNRSI $(i, p, t)$ includes contribution from decay daughter radionuclides

\begin{tabular}{ll} 
Attachment $\frac{9}{\text { S.W. Clark }}$ & Sheet No. 11 of 43 \\
Originator: & Date \\
Chk'd By & Date \\
Calc. No. Perrott & Rev. No. \\
\hline C100F-CA-V0280 & Rev. No
\end{tabular}




\section{ATTACHMENT 9}

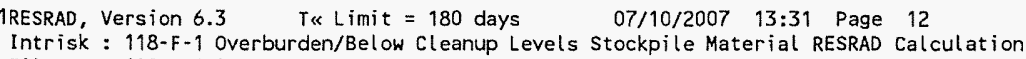

$\begin{array}{ll}\text { Attachment } \frac{9}{\text { S.W. Clark }} & \text { Sheet No. } 12 \text { of } \underline{43} \\ \text { Originator: } & \text { Date } \\ \text { Chk'd By } & \text { Date } \\ \text { Calc. No. N. Perrott } & \text { Rev. No. } \quad 0\end{array}$




\section{ATTACHMENT 9}

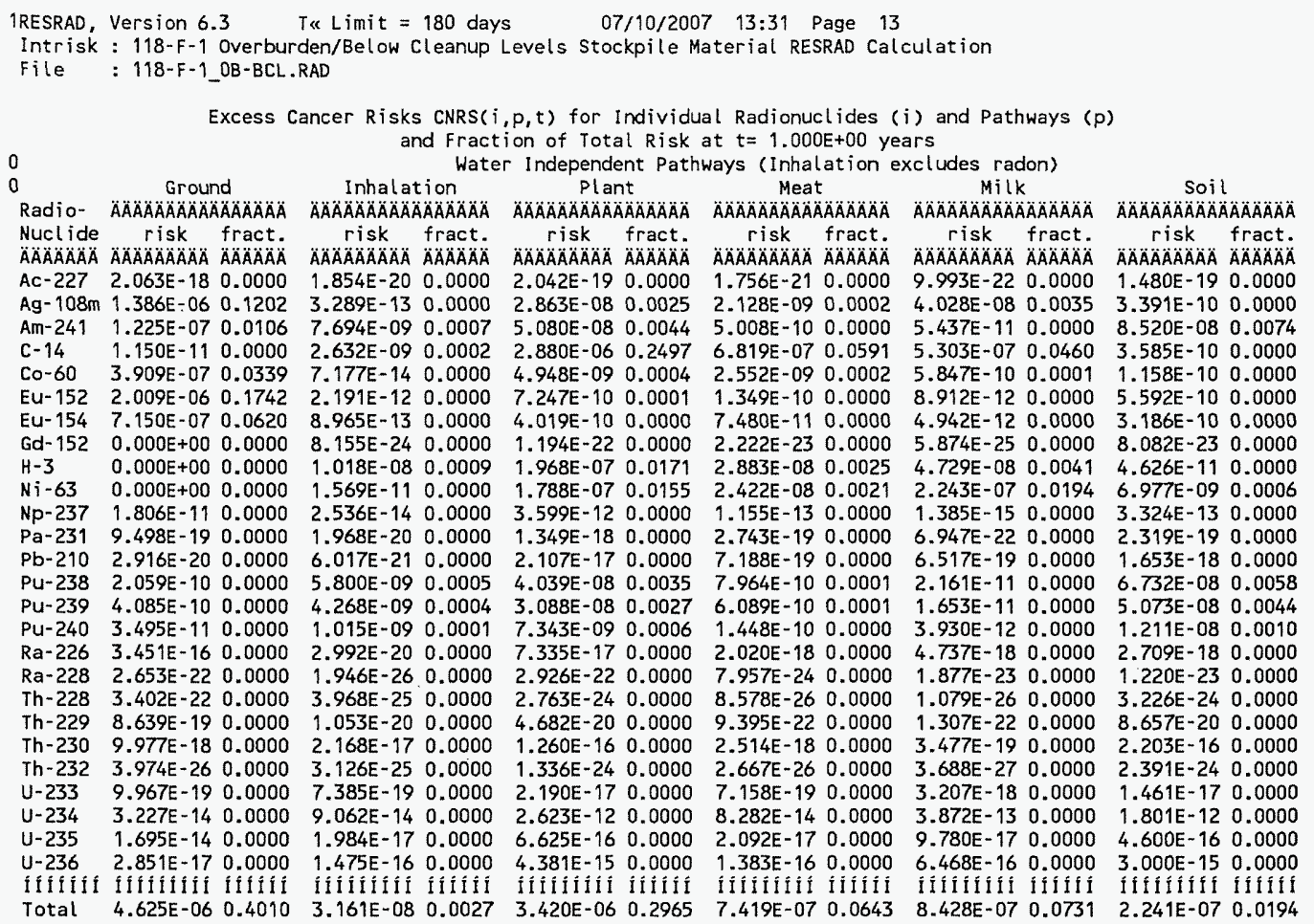

$\begin{array}{ll}\text { Attachment } \frac{9}{\text { S.W. Clark }} & \text { Sheet No. } \underline{13} \text { of } \underline{43} \\ \text { Originator: } & \text { Date } \\ \text { Chk'd By } & \text { Date } \\ \text { Calc. No. Perrott } & \text { Rev. No. } \quad 0\end{array}$




\section{ATTACHMENT 9}

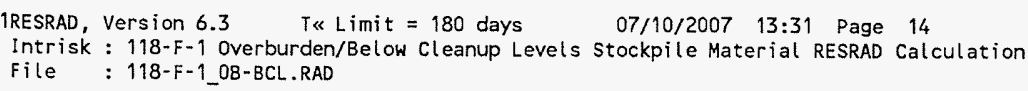

Water Dependent Pathways

\begin{tabular}{|c|c|c|c|c|c|c|c|c|c|c|c|c|}
\hline & $\begin{array}{r}\text { Wate } \\
\text { AAAAOÄÄÄA }\end{array}$ & ÄÄÄÄÄÄ & 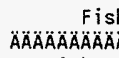 & H & $\begin{array}{r}P l a r \\
A D A O A O A O A B A B\end{array}$ & $\triangle A O A O A O A O A O A$ & $\begin{array}{r}\text { Mea } \\
\text { ÄÄAAAAAOA }\end{array}$ & $\triangle A A B A A A B A$ & $\begin{array}{r}M i l \\
A \cap A ̈ A ̈ A ̈ A ̈ A ̈ A B\end{array}$ & ÄÄÄÄÄ & 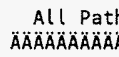 & 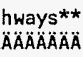 \\
\hline $\begin{array}{l}\text { Nuclide } \\
\text { ÄAOAOAOAOABA }\end{array}$ & $\begin{array}{c}\text { risk } \\
A A A B A A A B A\end{array}$ & $\begin{array}{l}\text { fract. } \\
\triangle A A B A A B A\end{array}$ & $\begin{array}{c}\text { risk } \\
\triangle A A A B A A B A B\end{array}$ & $\begin{array}{l}\text { fract. } \\
A B A A A B A\end{array}$ & $\begin{array}{c}\text { risk } \\
\triangle A A A B A O A B A O\end{array}$ & $\begin{array}{l}\text { fract. } \\
\triangle A B A A A B A\end{array}$ & $\begin{array}{c}\text { risk } \\
A A B A A B A O A O A\end{array}$ & 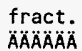 & $\begin{array}{c}r i s k \\
\text { ÄÄÄAAAOÄÄA }\end{array}$ & $\begin{array}{l}\text { fract. } \\
\triangle A B A A A A A B\end{array}$ & $\begin{array}{c}r i s k \\
\text { ÄÄÄÄAOAOÄ }\end{array}$ & $\begin{array}{l}\text { fract. } \\
\because A ̈ A ̈ A B A B A\end{array}$ \\
\hline$=-227$ & $2.188 \mathrm{E}-18$ & 0.0000 & $4.885 E-20$ & 0.0000 & $3.226 \mathrm{E}-19$ & 0.0000 & $1.781 \mathrm{E}-21$ & 0.0000 & $2.347 \mathrm{E}-21$ & 0.0000 & $5.000 E-18$ & 0.0000 \\
\hline & $0.000 \mathrm{E}+00$ & 0.0000 & $.000 E+00$ & 0.0000 & $0.000 E+00$ & 0.0000 & $0.000 E+00$ & 0.0000 & $0.000 E+00$ & 0.0000 & $1.458 E-06$ & 0.1264 \\
\hline & $0.000 E+00$ & 0.0000 & $.000 E+00$ & 0.0000 & $0.000 \mathrm{E}+00$ & 0.0000 & $0.000 E \div 00$ & 0.0000 & $0.000 E+00$ & 0.0000 & & \\
\hline & $0.000 E+00$ & 0.0000 & $.000 E+00$ & 0.0000 & $0.000 \mathrm{E}+00$ & 0.0000 & $0.000 E+00$ & 0.0000 & $0.000 E+00$ & 0.0000 & & \\
\hline 0 & $1.143 \mathrm{E}-11$ & 0.0000 & $.374 E-12$ & 0.0000 & $1.816 E-12$ & 0.0000 & $4.270 E-12$ & 0.0000 & $1.266 E-12$ & 0.0000 & $3.991 E-07$ & 0.0346 \\
\hline & $0.000 E+00$ & 0.0000 & $0.000 \mathrm{E}+00$ & 0.0000 & $0.000 E+00$ & 0.0000 & $0.000 E+00$ & 0.0000 & $0.000 \mathrm{E}+00$ & 0.0000 & $2.011 E-06$ & 1743 \\
\hline & $0.000 E+00$ & & $0.000 \mathrm{E}+00$ & 0.0000 & $0.000 E+00$ & 0.0000 & & & $0.000 \mathrm{E}+00$ & 0.0000 & $E-07$ & \\
\hline 52 & $0.000 E+00$ & 0.0000 & $.000 E+00$ & 0.0000 & $D O E+00$ & 0.0000 & & & $0.000 E+00$ & 0.0000 & $E-22$ & \\
\hline & 1.0 & 0.0928 & $.979 E-10$ & 0.0000 & 4.097E-07 & 0.0355 & $3.775 E-08$ & 0.0033 & SE-07 & 0.0100 & $=-06$ & 662 \\
\hline & & & & & & 0.0001 & & & $E-09$ & 0.0006 & E-07 & 9 \\
\hline-2 & $0.000 E+00$ & 0.0 & & 0.0 & & & & 0.0000 & $0.000 E+00$ & 0.0000 & -11 & 000 \\
\hline 231 & $1.682 E-18$ & 0.0000 & $.415 E-21$ & 0.0000 & $2.659 E-19$ & 0.0000 & 1.9 & & & 0.0000 & & \\
\hline & & & & 0.0000 & & 0.0000 & & 0000 & $1.790 \mathrm{E}-19$ & .0000 & -17 & \\
\hline 38 & $0.000 E+00$ & & & & $E+00$ & 0.0000 & $E+00$ & 0.0000 & $0.000 \mathrm{E}+00$ & 0.0000 & $E-07$ & 099 \\
\hline $1-239$ & $0.000 E+00$ & 0.0000 & $0.000 E+00$ & 0.0000 & $0.000 E+00$ & 0.0000 & 0.0 & & $E+00$ & 000 & $E-08$ & \\
\hline & & & $E+00$ & 0.0000 & $0.000 E+00$ & 0.0000 & $0.000 \mathrm{E}+00$ & 000 & $\mathrm{E}+00$ & 000 & $E-08$ & 018 \\
\hline & 1.2 & & 19 & 0.0000 & & 0.0000 & 2.3 & 0.0 & $E-19$ & 0.0000 & $E-16$ & 000 \\
\hline & 9.1 & & & & & & & & $E-24$ & 0.0000 & $E-22$ & .0000 \\
\hline & $86 E-24$ & & $E-25$ & 0.0000 & $1.214 \mathrm{E}-24$ & 0.0000 & 2.58 & & & & $E-22$ & \\
\hline & & & -21 & 0.0000 & & 0.0000 & & & & 1000 & $7 E-18$ & 000 \\
\hline & $888 \mathrm{E}-16$ & & $E-17$ & 0.00 & $48 E-17$ & 0.0000 & & 0.0 & $5.681 E-19$ & 0.0000 & $8.677 E-16$ & 0.0000 \\
\hline & $53 F-? 4$ & & $11 E-25$ & & & & & & & & & \\
\hline & & & & & & & & & & & & \\
\hline & & & $1.767 \mathrm{E}-12$ & & $5.560 E-11$ & 0.0000 & $.347 E-12$ & & $1 . \angle U O E-1$ & 1000 & $03 E-10$ & 0000 \\
\hline & $77 E-14$ & & $.370 E-16$ & & $1375=-1$ & & & & & & $1.277 E-13$ & 0.0000 \\
\hline & & & & & $9.094 \mathrm{E}-14$ & & & & & & & \\
\hline & & & fitififif & IIIfíí & iftiftifi & Iffift & 1 & & & & & \\
\hline & $1.077 \mathrm{E}-06$ & 0.0933 & $6.460 \mathrm{E}-10$ & 0.0001 & $4.107 E-07$ & 0.0356 & $=-00$ & & & & & \\
\hline
\end{tabular}

** Sum of water independent ground, inhalation, plant, meat, milk, soil

0

and water dependent water, fish, plant, meat, milk pathways

Excess Cancer Risks CNRS9(irn, $i, t$ ) and CNRSPW( $i r n, j, t$ ) for Inhalat ion of Radon and its Decay Products at $t=1,000 \mathrm{E}+00$ years Radionucl ides

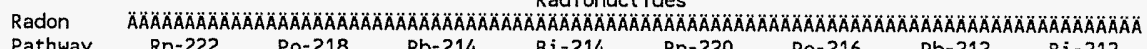

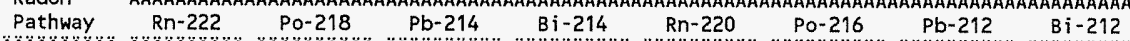

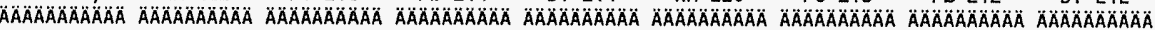

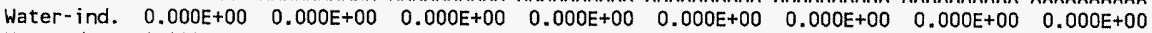

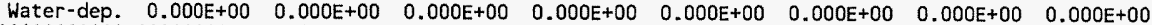

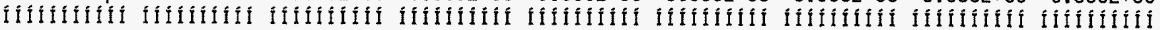

$\begin{array}{lllllllll}\text { Total } & 0.000 E+00 & 0.000 E+00 & 0.000 E+00 & 0.000 E+00 & 0.000 E+00 & 0.000 E+00 & 0.000 E+00 & 0.000 E+00\end{array}$

Water-ind. == Water-independent Water-dep. $==$ Water-dependent

\begin{tabular}{|c|c|}
\hline Attachment & Sheet No. 14 of 43 \\
\hline Originator: S.W.Clark & Date ___ \\
\hline Chk'd By M.W. Perrott & Date \\
\hline $0100 \mathrm{~F}-\mathrm{CA}-\mathrm{V} 0280$ & Rev. No. \\
\hline
\end{tabular}




\section{ATTACHMENT 9}

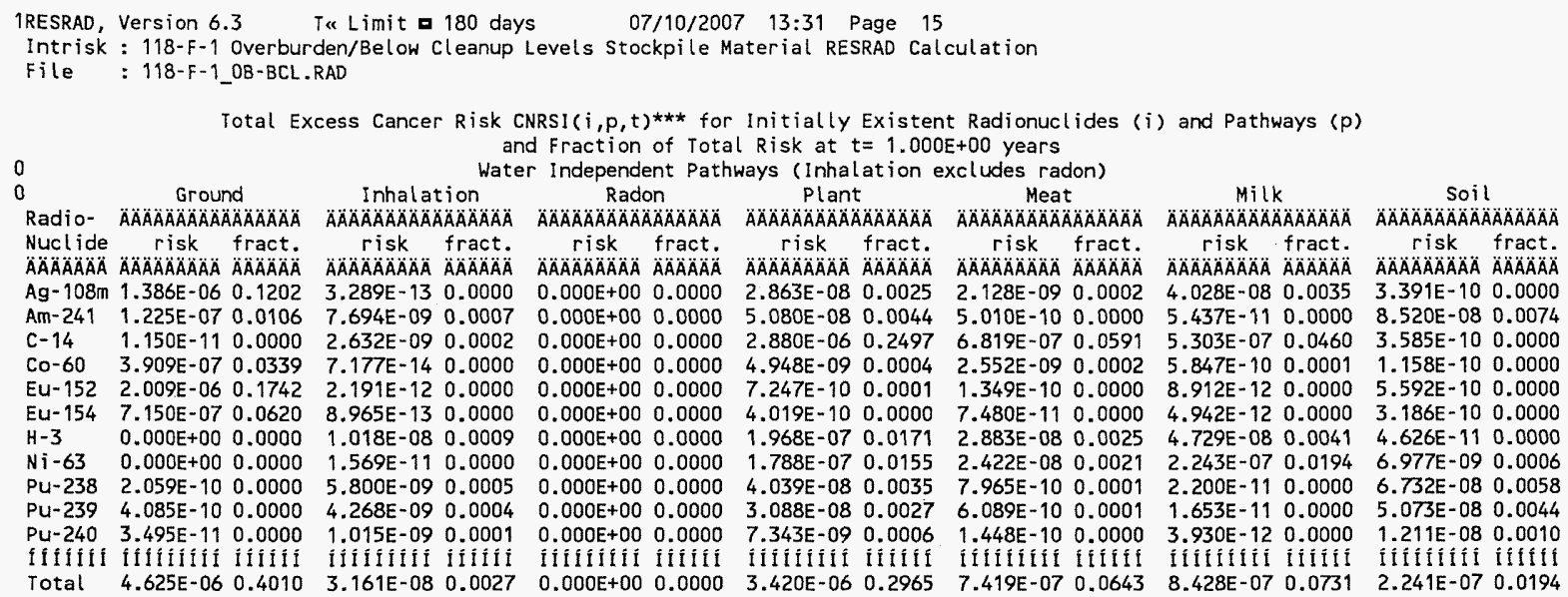

Total Excess Cancer Risk CNRSI $(i, p, t)^{* * *}$ for Initially Existent Radionuclides (i) and Pathways $(p)$ and Fraction of Total Risk at $t=1.000 E+00$ years

Water Dependent Pathways

\begin{tabular}{|c|c|c|c|c|c|c|c|c|c|c|c|c|c|c|}
\hline \multirow{2}{*}{$\begin{array}{l}\text { Radio- } \\
\text { Nuclide } \\
\text { ÄÄÄÄÄÄA }\end{array}$} & \multicolumn{2}{|c|}{ Water } & 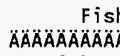 & 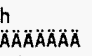 & \multicolumn{2}{|c|}{ Radon } & \multicolumn{2}{|c|}{$P$ lant } & \multicolumn{2}{|c|}{ Meat } & \multicolumn{2}{|c|}{ Milk } & \multicolumn{2}{|c|}{$\begin{array}{c}\text { All pathways } \\
\text { ALÄAAAOAAAAAAAAOAOA}\end{array}$} \\
\hline & risk & $\begin{array}{l}\text { fract. } \\
\triangle A B A B A A B A\end{array}$ & $\begin{array}{c}\text { risk } \\
\triangle A \cap A ̈ A B A ̈ A ̈ A\end{array}$ & $\begin{array}{l}\text { fract. } \\
\not \triangle A ̈ A B A A B A\end{array}$ & $\begin{array}{c}\text { risk } \\
\triangle A O A B A O A B A A A\end{array}$ & $\begin{array}{l}\text { fract. } \\
\triangle A O A A O A B A\end{array}$ & $\begin{array}{c}\text { risk } \\
\triangle A \cap A ̈ A B A B A B A\end{array}$ & $\begin{array}{l}\text { fract. } \\
\triangle A A B A A A B A\end{array}$ & $\begin{array}{c}\text { risk } \\
\triangle A B A O A O A B A B A B\end{array}$ & & $\begin{array}{c}\text { risk } \\
\triangle A O A O A B A O A O A\end{array}$ & & $\begin{array}{c}\text { risk } \\
\triangle A ̈ A ̈ A ̈ A O A O A B A\end{array}$ & \\
\hline & 100 & & & & & & & & & & & & & \\
\hline & & & & & & & & & & & & & & \\
\hline & & & & & & & & & & & & & & \\
\hline & & & & & & & & & & & & & & \\
\hline & & & & & & & & & & & & & & \\
\hline & & & & & & & & & & & & & & \\
\hline & & & & & & & & & & & & & & \\
\hline & & & & & & & & & & & & & & \\
\hline & & & & & & & & & & & & & & \\
\hline & & & & & & & & & & & & & & \\
\hline & & & & & & & & & & & & & & \\
\hline & & & & & & & & & & & & & & \\
\hline & & & & & & & & & $=-00$ & & & & & \\
\hline
\end{tabular}

***CNRSI $(i, p, t)$ includes contribution from decay daughter radionuclides

$\begin{array}{ll}\text { Attachment } \frac{9}{\text { S.W. Clark }} & \text { Sheet No. } \underline{15} \text { of } \underline{43} \\ \text { Originator: } & \text { Date } \\ \text { Chk'd By } & \text { Date } \\ \text { Calc. No. Nerrott } & \text { Rev. No. No } 0\end{array}$




\section{ATTACHMENT 9}

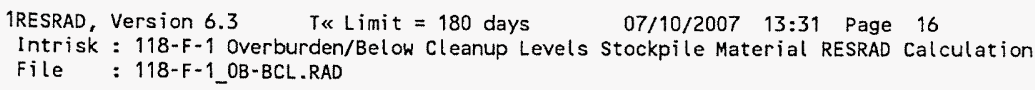

Water-ind. $==$ Water-independent Water-dep. $==$ Wate $r$-dependent

\begin{tabular}{|c|c|}
\hline Attachment & Sheet No. 16 of 43 \\
\hline Originator: $\overline{S . W . ~ C l a r k ~}$ & Date \\
\hline Chk'd By M.W.Perrott & Date \\
\hline Calc. No. $0100 \mathrm{~F}-\mathrm{CA}-\mathrm{V} 0280$ & Rev. No. \\
\hline
\end{tabular}




\section{ATTACHMENT 9}

\begin{tabular}{|c|c|c|c|c|c|c|c|c|c|c|c|c|}
\hline $\begin{array}{l}\text { 1RESRAD } \\
\text { Intrisk } \\
\text { File }\end{array}$ & \multicolumn{4}{|c|}{$\begin{array}{l}\text { Version } 6.3 \quad \text { T\& Limit }=180 \text { day } \\
: 118-F-1 \text { Overburden/Below Cleanup } \\
: 118-F-1 \text { OB-BCL. RAD }\end{array}$} & \multicolumn{6}{|c|}{$\begin{array}{l}713: 31 \text { Page } 17 \\
\text { aterial RESRAD Calculation }\end{array}$} & & \\
\hline 0 & \multicolumn{12}{|c|}{$\begin{array}{c}\text { Excess Cancer Risks CNRS }(i, p, t) \text { for Individual Radionuclides }(i) \text { and Pathways }(p) \\
\text { and Fraction of Total Risk at } t=3.000 E+00 \text { years }\end{array}$} \\
\hline 0 & \multirow{2}{*}{\multicolumn{2}{|c|}{ 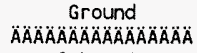 }} & \multirow{2}{*}{\multicolumn{2}{|c|}{$\begin{array}{l}\text { Inhalation } \\
\text { ÄÄAAAAAAAAAAAOÄA }\end{array}$}} & \multirow{2}{*}{\multicolumn{2}{|c|}{ 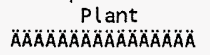 }} & \multirow{2}{*}{\multicolumn{2}{|c|}{$\begin{array}{l}\text { Meat } \\
\text { AAAAAAAAAAAAÄ }\end{array}$}} & \multirow{2}{*}{\multicolumn{2}{|c|}{$\begin{array}{l}\text { MilK } \\
\text { AÄÄÄÄÄÄAAÄ }\end{array}$}} & \multicolumn{2}{|c|}{ Soil } \\
\hline & & & & & & & & & & & $\triangle A B A O A A A B A O A$ & $\triangle A ̈ A O A O A ̈$ \\
\hline $\begin{array}{l}\text { Nucl ide } \\
\text { ÄÄÄAAAA }\end{array}$ & $\begin{array}{c}\text { risk } \\
\text { AAAAAAAAÄÄ }\end{array}$ & $\begin{array}{l}\text { fract. } \\
A B A A A B A\end{array}$ & $\begin{array}{c}\text { risk } \\
\triangle A ̈ A ̈ A ̈ A B A B A\end{array}$ & $\begin{array}{l}\text { fract. } \\
\triangle A \not A B A B A B\end{array}$ & $\begin{array}{l}\text { sk } \\
\triangle A O A ̈ A ̈\end{array}$ & $\begin{array}{l}\text { fract. } \\
\text { ÄÄÄÄÄÄ }\end{array}$ & $\begin{array}{c}\text { risk } \\
\text { М̈ÄÄÄÄÄ }\end{array}$ & $\begin{array}{l}\text { fract. } \\
\text { ÄÄÄÄÄA }\end{array}$ & $\begin{array}{c}\text { risk } \\
\triangle A ̈ A ̈ A ̈ A ̈ A ̈ A ̈\end{array}$ & $\begin{array}{l}\text { fract. } \\
\text { ÄÄÄÄÄÄ }\end{array}$ & $\begin{array}{c}\text { risk } \\
\text { XOÄÄÄÄÄ }\end{array}$ & \\
\hline & -18 & 0.0000 & & .0000 & & 000 & & 0.0000 & & 0.00 & $=-19$ & 000 \\
\hline & & 0.1958 & & .0000 & & & & 0.0003 & -08 & 0.0 & & \\
\hline & & 0.0 & & & & & & 0.0 & & 0.0 & -08 & \\
\hline & & 0.0000 & & & & & & & & & & \\
\hline & & 0.0429 & & & & & & 0.0003 & -10 & 0.0 & -11 & 1000 \\
\hline & & & & & & & & & & & & \\
\hline & & & & & & & & & & & & \\
\hline & & 0.0000 & & 000 & & & & 0.0000 & & 0.0 & & 000 \\
\hline & & & & & & & & & & & & \\
\hline & & & & & & & & & & & & \\
\hline & & 0.0 & & & & & & 0.0 & & 0.0 & -13 & \\
\hline & & & & & & & & & & & & \\
\hline & & & & & & & & & & & & \\
\hline & & & & & & & 7. & 0. & & 0. & 08 & 1095 \\
\hline & & & & & & & & & & & & \\
\hline & & & & & & & & & & & & \\
\hline & & & & 0.0 & & & & 0.0 & & 0. & & \\
\hline & & & & & & & & & & & & \\
\hline & & & & & & & & & & & & \\
\hline & & 0.0000 & 1.3 & 0.0 & & & & 0.0000 & & & & \\
\hline & & & & & & & & & & & & \\
\hline & & & 3.7 & & 1.6 & & & & & & & \\
\hline & & & & & & & & & & & & \\
\hline & & 0.0000 & & 0.0000 & & & & I & & & & \\
\hline & & & & & & & & & & & & \\
\hline & & & & & & & & & & 0.0000 & & \\
\hline & & & & & & & 1110111 & 11111 & fliftititi & 11011 & Ifitifitîn & ilifif \\
\hline & $4.216 E-06$ & 0.6020 & $2.232 \mathrm{E}-08$ & 0.0032 & $1.001 \mathrm{E}-06$ & 0.1430 & $1.818 E-07$ & 0.0260 & $3.869 \mathrm{E}-07$ & 0.0552 & 2.222E-07 & 0.0317 \\
\hline
\end{tabular}

$\begin{array}{ll}\text { Attachment } \frac{9}{\text { S.W. Clark }} & \text { Sheet No. } 17 \text { of } \underline{43} \\ \text { Originator: } & \text { Date } \\ \text { Chk'd By } \frac{\text { M.W. Perrott }}{\text { M.W. }} & \text { Date } \\ \text { Calc. No. } & \text { O100F-CA-V0280 Nev. No. } \quad \text { Re }\end{array}$




\section{ATTACHMENT 9}

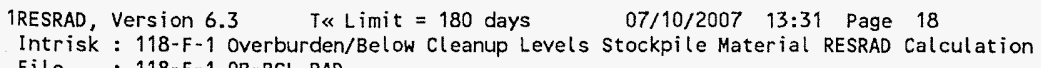

Water Dependent Pathways

\begin{tabular}{|c|c|c|c|c|c|c|c|c|c|c|c|c|}
\hline & $\begin{array}{r}\text { Wat } \\
\text { ÄÄÄÄÄA }\end{array}$ & $\triangle A O A O A O A B A$ & $\begin{array}{r}F i s h \\
\triangle A A A A B A A A ̈ A\end{array}$ & 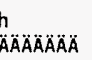 & $\begin{array}{r}P l a r \\
A \cap A B A O A O A O A O A\end{array}$ & 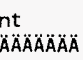 & $\begin{array}{r}\text { Meat } \\
\triangle A A O A A B A O A O A\end{array}$ & $\triangle A O A A O A A$ & $\begin{array}{r}M i l l \\
\triangle A ̈ A ̈ A ̈ A ̈ A ̈ A ̈ A ̈\end{array}$ & $\triangle A O A O A O A O A ̈ A$ & 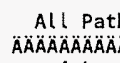 & $\begin{array}{l}\text { ays** } \\
\text { ÄÄÄÄ }\end{array}$ \\
\hline $\begin{array}{l}\text { JClide } \\
\text { NÄAOAOA }\end{array}$ & $\begin{array}{c}\text { risk } \\
\text { ÄAAAAAAÄA }\end{array}$ & $\begin{array}{l}\text { fract. } \\
\triangle A A A B A B A\end{array}$ & $\begin{array}{c}\text { risk } \\
\text { A AAAAÄAAAOA }\end{array}$ & $\begin{array}{l}\text { fract. } \\
\triangle A A B A B A B A\end{array}$ & $\begin{array}{c}\text { risk } \\
\text { AAAAAAOAAAOA }\end{array}$ & $\begin{array}{l}\text { fract. } \\
A O A A B A O A\end{array}$ & $\begin{array}{c}\text { risk } \\
\text { AिAAAAOAOAOA }\end{array}$ & $\begin{array}{l}\text { fract. } \\
\text { AAAAAAAA }\end{array}$ & $\begin{array}{c}\text { risk } \\
\text { AAAAAAAAAA }\end{array}$ & & $\begin{array}{c}\text { risk } \\
\text { AAAAAAAAAA }\end{array}$ & \\
\hline & & & & & $4.348 E-19$ & 0.0000 & & & & & & \\
\hline & & & & & & & & & & & & \\
\hline & & & & & & & & & & & & \\
\hline & & & & & & & & & & & & \\
\hline & & & & & & & & & & & & \\
\hline & & & & & & & & & & & & \\
\hline & & & & & & & & & & & & \\
\hline & & & & & & & & & & & & \\
\hline & & & & & & & & & & & & \\
\hline & & & & & & & & & & & & \\
\hline & & & & & & & & & & & & \\
\hline & & & & & & & & & & & & \\
\hline & & & & & & & & & & & & \\
\hline & & & & & & & & & & & & \\
\hline & & & & & & & & & & & & \\
\hline & & & & & & & & & & & & \\
\hline & & & & & & & & & & & & \\
\hline & & & & & & & & & & & & \\
\hline & & & & & & & & & & & & \\
\hline & & & & & & & & & & & & \\
\hline & & & & & & & & & & & & \\
\hline & & & & & & & & & & & $37 E-23$ & \\
\hline & & & & & & & & & & & & \\
\hline & & & & & & & & & & & & \\
\hline 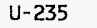 & & & & & $1.655 E-14$ & & 6.99 & & $8 E-15$ & & $1.523 E-13$ & \\
\hline & & & & & & & & & & & & \\
\hline & & & & & & & & & & & & \\
\hline & & & & & $S E-U R$ & & & & & 0.0107 & & \\
\hline
\end{tabular}

** Sum of water independent ground, inhalation, plant, meat, milk, soil

0 and water dependent water, fish, plant, meat, milk pathways Excess Cancer Risks CNRS9(irn, $i, t)$ and CNRSPW( $i r n, i, t)$ for Inhalation of Radon and its Decay Products at $t=3.000 E+00$ years

\begin{tabular}{|c|c|c|c|c|c|c|c|c|}
\hline Radon & $A A A A$ & $\triangle A A A A A A A A A A$ & AAAAAAAAAAAA & $A O A O A O A O A O A B$ & $\triangle A O A O A A A B A O A$ & $A ̈ A ̈ A B A A A A A B A$ & A A A A A A A A A & AAAAAAAAAAA \\
\hline Pathway & $R n-222$ & Po-218 & $\mathrm{Pb}-214$ & $8 i-214$ & $R n-220$ & $P o-216$ & $\mathrm{~Pb}-212$ & $8 j-212$ \\
\hline$\triangle A A A A A A A A O A B$ & ÄÄÄÄÄÄÄÄ & ÄÄÄÄÄÄÄÄÄ & ÄÄÄÄÄÄÄÄÄ & ÄÄÄÄÄÄÄ & $\triangle A ̈ A ̈ A ̈ A ̈ A ̈ A ̈ A ̈$ & ÄÄÄÄÄÄÄ & ÄÄÄÄÄÄÄÄ & ÄÄÄÄÄÄÄ \\
\hline Water-ind. & $0.000 \mathrm{E}+00$ & $0.000 E+00$ & $0.000 E+00$ & $0.000 E+00$ & $0.000 E+00$ & $0.000 E+00$ & $0.000 \mathrm{E}+00$ & $0.000 E+00$ \\
\hline $\begin{array}{l}\text { Water-dep. } \\
\text { Ifififififí }\end{array}$ & $\begin{array}{r}0.000 E+00 \\
\text { itififiti }\end{array}$ & $\begin{array}{r}0.000 E+00 \\
\text { iftififí }\end{array}$ & $\begin{array}{r}0.000 E+00 \\
\text { ififififi }\end{array}$ & $\begin{array}{r}0.000 E+00 \\
\text { iffififit }\end{array}$ & $\begin{array}{l}0.000 E+00 \\
\text { iffititit }\end{array}$ & $\begin{array}{r}0.000 E+00 \\
\text { fiffififí }\end{array}$ & $\begin{array}{l}0.000 \mathrm{E}+00 \\
\text { tifititit }\end{array}$ & 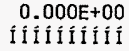 \\
\hline Total & $0.000 E+00$ & $0.000 E+00$ & $0.000 E+00$ & $0.000 E+00$ & $0.000 E+00$ & $0.000 E+00$ & $0.000 E+00$ & $0.000 E+00$ \\
\hline
\end{tabular}

Water-ind. $==$ Water-independent Water-dep. $==$ Water-dependent

\begin{tabular}{|c|c|}
\hline Attachment & Sheet No. 18 of 43 \\
\hline Originator: $\overline{\text { S.W. Clark }}$ & Date \\
\hline Chk'd By M.W. Perrott & Date. \\
\hline $0100 F-C A-V 0280$ & Rev. No. \\
\hline
\end{tabular}




\section{ATTACHMENT 9}

\begin{tabular}{|c|c|c|c|c|c|c|c|c|c|c|}
\hline $\begin{array}{l}\text { 1RESRAD, } \\
\text { Intrisk } \\
\text { File }\end{array}$ & \multicolumn{3}{|c|}{$\begin{array}{l}\text { T\& Limit = } \\
\text { rden/Below } \\
\text { RAD }\end{array}$} & \multicolumn{5}{|c|}{$\begin{array}{l}\text { 07/10/2007 } 13: 31 \text { Page } 19 \\
\text { Stockpile Material RESRAD calculation }\end{array}$} & & \\
\hline & \multirow{2}{*}{\multicolumn{10}{|c|}{$\begin{array}{c}\text { Total Excess Cancer Risk CNRSI }(i, p, t) * * * \text { for Initially Existent Radionuclides }(i) \text { and Pathways }(p) \\
\text { and Fraction of Total Risk at } t=3.000 E+00 \text { years } \\
\text { Water Independent Pathways (Inhalation excludes radon) }\end{array}$}} \\
\hline 0 & & & & & & & & & & \\
\hline Radio- & $\begin{array}{l}\text { GroUn } \\
\text { AOAAOAOAOAOAOA }\end{array}$ & ÄÄÄÄÄĂ & $\begin{aligned} \text { Inhalat } \\
\text { AOAAOAOAAOAOA }\end{aligned}$ & $\begin{array}{l}\text { tion } \\
\text { ÄÄÄÄÄÄA }\end{array}$ & $\begin{array}{r}\text { Rad } \\
\text { ÄÄAAAÄÄÄ }\end{array}$ & on & $\begin{array}{c}\text { Plant } \\
\triangle A B A A A A A A A A A A A A A A\end{array}$ & $\begin{array}{c}\text { Meat } \\
\text { AAAAAAAAAAAAOAOAOAOA }\end{array}$ & $\begin{array}{c}M i l k \\
\text { AAAAAAAAOAOAOÄAOÄ }\end{array}$ & $\begin{array}{c}\text { SoI } \\
\text { ÄÄÄÄÄÄÄÄÄÄÄ }\end{array}$ \\
\hline $\begin{array}{l}\text { Nuclide } \\
\triangle A C A B A B A O A B\end{array}$ & $\begin{array}{c}\text { risk } \\
\triangle A O A A O A B A O A O A ̈\end{array}$ & $\begin{array}{l}\text { fract. } \\
\text { ÄÄÄÄÄÄ }\end{array}$ & $\begin{array}{c}\text { risk } \\
\triangle A A A A A B A A A A \\
\end{array}$ & 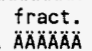 & $\begin{array}{c}\text { risk } \\
\triangle A B A A B A B A B A B\end{array}$ & $\begin{array}{l}\text { fract. } \\
\ddot{A} \ddot{A} \ddot{A} \ddot{A} \ddot{A}\end{array}$ & $\begin{array}{r}\text { risk fract. } \\
\triangle A A B A B A B A B A \\
A B A O A B A B\end{array}$ & 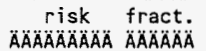 & 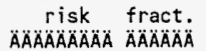 & $\begin{array}{r}\text { risk fract. } \\
\text { AAAAAAAOAOA } A A A A A O A\end{array}$ \\
\hline $\mathrm{Ag}-108 \mathrm{~m}$ & $1.371 \mathrm{E}-06$ & 0.1958 & $3.253 \mathrm{E}-13$ & 0.0000 & $0.000 E+00$ & 0.0000 & $2.832 E-08 \quad 0.0040$ & $2.104 \mathrm{E}-090.0003$ & $3.983 E-08 \quad 0.0057$ & $3.354 E-10 \quad 0.0000$ \\
\hline Am-241 & $1.221 \mathrm{E}-07$ & 0.0174 & $7.669 E-09$ & 0.0011 & $0.000 E+00$ & 0.0000 & 5.064E-08 0.0072 & $4.993 E-10 \quad 0.0001$ & $5.420 \mathrm{E}-11 \quad 0.0000$ & $\begin{array}{lll}8.492 E-08 & 0.0121\end{array}$ \\
\hline$c-14$ & $2.410 \mathrm{E}$ & 0.0000 & $6 E-10$ & 0.0001 & $0.000 E+00$ & 0.0000 & $6.037 \mathrm{E}-07 \quad 0.0862$ & $1.429 E-07 \quad 0.0204$ & $1.112 E-07 \quad 0.0159$ & $7.514 E-110.0000$ \\
\hline Co-60 & $3.004 \mathrm{E}$ & 0.0429 & $5.516 \mathrm{E}-14$ & 0.0000 & $0.000 E+00$ & 0.0000 & $3.803 \mathrm{E}-09 \quad 0.0005$ & $1.961 \mathrm{E}-09 \quad 0.0003$ & $4.494 E-10 \quad 0.0001$ & $8.904 E-110.0000$ \\
\hline Eu-152 & $1.811 \mathrm{E}-06$ & 0.2585 & $1.974 \mathrm{E}-12$ & 0.0000 & $0.000 E+00$ & 0.0000 & $6.531 E-10 \quad 0.0001$ & $1.216 E-10 \quad 0.0000$ & $8.032 E-12 \quad 0.0000$ & $5.040 E-10 \quad 0.0001$ \\
\hline Eu-154 & $6.108 E-07$ & 0.0872 & $7.658 E-13$ & 0.0000 & $0.000 E+00$ & 0.0000 & $3.433 E-10 \quad 0.0000$ & $6.390 E-11 \quad 0.0000$ & $4.222 E-120.0000$ & $2.721 E-10 \quad 0.0000$ \\
\hline $\mathrm{H}-3$ & $0.000 E+00$ & 0.0000 & $3.088 E-09$ & 0.0004 & $0.000 E+C 0$ & 0.0000 & $5.969 E-08 \quad 0.0085$ & $8.743 E-09 \quad 0.0012$ & $1.434 E-08 \quad 0.0020$ & $1.403 E-11 \quad 0.0000$ \\
\hline $\mathrm{Ni}-63$ & $0.000 E+00$ & 0.0000 & $1.546 E-11$ & 0.0000 & $0.000 E+00$ & 0.0000 & $1.762 E-07 \quad 0.0252$ & $2.387 E-08 \quad 0.0034$ & $2.210 \mathrm{E}-07 \quad 0.0316$ & $6.875 E-090.0010$ \\
\hline Pu-238 & $2.027 E-10$ & 0.0000 & & 0.0008 & $0.000 E+00$ & 0.0000 & $3.976 \mathrm{E}-08 \quad 0.0057$ & $7.840 \mathrm{E}-10 \quad 0.0001$ & $2.171 E-110.0000$ & $6.626 \mathrm{E}-08 \quad 0.0095$ \\
\hline Pu-239 & $4.085 E-10$ & 0.0001 & $4.268 E-09$ & 0.0006 & $0.000 \mathrm{E}+00$ & 0.0000 & $3.088 E=08 \quad 0.0044$ & $6.088 E-10 \quad 0.0001$ & $1.652 \mathrm{E}-11 \quad 0.0000$ & $5.072 E-08 \quad 0.0072$ \\
\hline & $3.494 \mathrm{E}-$ & 0.0000 & $1.015 \mathrm{E}-09$ & 0.0001 & $0.000 E+00$ & 0.0000 & $7.341 \mathrm{E}-090.0010$ & $1.448 \mathrm{E}-100.0000$ & $3.929 \mathrm{E}-120.0000$ & 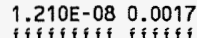 \\
\hline & & & & & & & Iffifilit iffifi & & Ififfífítífíf & \\
\hline Total & $4.216 E-06$ & 0.6020 & $2.232 E-08$ & 0.0032 & $0.000 E+00$ & 0.0000 & $1.001 \mathrm{E}-06 \quad 0.1430$ & $1.818 E-07 \quad 0.0260$ & $3.869 E-07 \quad 0.0552$ & $2.222 E-07 \quad 0.0317$ \\
\hline
\end{tabular}

Total Excess Cancer Risk CNRSI $(i, p, t)^{* * *}$ for Initially Existent Radionuclides (i) and Pathways ( $p$ ) and Fraction of Total Risk at $t=3.000 E+00$ years

Water Dependent Pathways

\begin{tabular}{|c|c|c|c|c|c|c|c|c|c|c|c|c|c|c|}
\hline \multirow{2}{*}{$\begin{array}{l}\text { Radio- } \\
\text { Nucl ide } \\
\text { ÄÄÄÄÄÄA }\end{array}$} & \multicolumn{2}{|c|}{$\begin{array}{c}\text { Water } \\
\text { AAAAAAAOAOAOÄÄÄÄAAA }\end{array}$} & \multicolumn{2}{|c|}{$\begin{array}{c}F i s h \\
\text { A } \\
\text { A }\end{array}$} & \multicolumn{2}{|c|}{$\begin{array}{c}\text { Radon } \\
\text { AAAAAAAOÄÄÄÄÄÄAA }\end{array}$} & \multicolumn{2}{|c|}{ 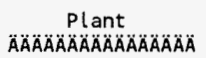 } & \multicolumn{2}{|c|}{$\begin{array}{c}\text { Meat } \\
\text { AAAAAXÄÄÄÄÄÄÄÄÄ }\end{array}$} & \multicolumn{2}{|c|}{$\begin{array}{c}\text { MilK } \\
\text { ÄÄÄÄÄÄÄÄÄÄÄÄÄ }\end{array}$} & \multicolumn{2}{|c|}{$\begin{array}{c}\text { A! L pathways } \\
\text { AAAAAAAAOAOAOAOAAAOAOA }\end{array}$} \\
\hline & $\begin{array}{c}\text { risk } \\
\text { ÂAAAAÄÄÄ }\end{array}$ & $\begin{array}{l}\text { fract. } \\
\text { ÄÄÄÄÄA }\end{array}$ & $\begin{array}{c}\text { risk } \\
\text { ĀÄÄÄÄÄÄA }\end{array}$ & & $\begin{array}{c}\text { risk } \\
\text { AAAAAAAOAAA }\end{array}$ & & $\begin{array}{c}\text { risk } \\
\text { AAAAAAAAAA }\end{array}$ & & $\begin{array}{c}\text { risk } \\
\text { ÄAAAAAOÄÄÄ }\end{array}$ & & $\begin{array}{c}\text { risk } \\
\text { ÄAAAAAAOÄÄ }\end{array}$ & & $\begin{array}{c}\text { risk } \\
A \text { ÁÄÄÄABA }\end{array}$ & \\
\hline $\mathrm{Ag}-108 \mathrm{~m}$ & & & & & & & & & & & & & & \\
\hline & & & & & & & & & & & & & & \\
\hline & & & & & & & & & & & & & & \\
\hline & & & & & & & & & & & & & & \\
\hline & & & & & & & & & & & & & & \\
\hline & & & & & & & & & & & & & & \\
\hline & & & & & & & & & & & & & & \\
\hline & & & & & & & & & & & & & & \\
\hline & & & & & & & & & & & & & & \\
\hline & & & & & & & & & & & & & & \\
\hline & & & & & & & & & & & & & & \\
\hline & & & & & & & & & & & & & & \\
\hline & & & & & 0.0000 T & & & & & & & & & \\
\hline
\end{tabular}

***CNRSI $(i, p, t)$ includes contribution from decay daughter radionuclides

\begin{tabular}{|c|c|c|}
\hline \multicolumn{2}{|c|}{ Attachment $\quad 9$} & \multirow{2}{*}{$\begin{array}{l}\text { Sheet No. } 19 \text { of } 43 \\
\text { Date }\end{array}$} \\
\hline Originator: & S. W. Clark & \\
\hline & M. W. Perrott & Date \\
\hline Calc. No. & 0100F-CA-V0280 & Rev. No. \\
\hline
\end{tabular}




\section{ATTACHMENT 9}

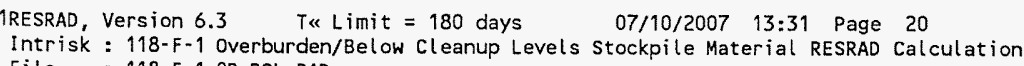

Water-ind. = Water-independent Water-dep. $==$ Water-dependent

\begin{tabular}{|c|c|}
\hline Attachment $\quad 9$ & Sheet No. 20 of $\underline{43}$ \\
\hline Originator: S.W. Clark & Date \\
\hline Chk'd By M.W.Perrott & Date \\
\hline Calc. No. $0100 F-C A-V 0280$ & Rev. No. $\quad 0$ \\
\hline
\end{tabular}




\section{ATTACHMENT 9}

\begin{tabular}{|c|c|c|c|c|c|c|c|c|c|c|c|c|}
\hline \multirow[t]{2}{*}{$\begin{array}{l}\text { 1RESRAD, } \\
\text { Intrisk } \\
\text { File }\end{array}$} & $\begin{array}{l}\text { Version } 6 \\
: 118-F-1 \\
: 118-F-1\end{array}$ & $\begin{array}{l}.3 \\
\text { Overt } \\
\text { OB }-B C\end{array}$ & en/Below & $\begin{array}{l}180 \mathrm{da} \\
\text { leanup }\end{array}$ & is St & cpile & $\begin{array}{l}13: 31 \\
\text { terial RE }\end{array}$ & $\begin{array}{l}\text { Page } \\
\text { SRAD C }\end{array}$ & ulation & & & \\
\hline & \multicolumn{2}{|r|}{ Excess } & \multicolumn{10}{|c|}{$\begin{array}{l}\text { for Individual Radionuclides }(i) \text { and Pathways }(p) \\
\text { Total Risk at } t=7.000 E+00 \text { years } \\
\text { ependent Pathways (Inhalation excludes radon) }\end{array}$} \\
\hline 0 & Grour & & Inhala & tion & Pla & & & & Mil & & Soi & \\
\hline & 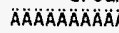 & $\because A ̈ A \cap A ̈ A O A O A$ & ÄÄÄÄ & ÄÄÄÄÄ & $\triangle \triangle A ̈ A ̈ A ̈ A \cap A ̈ A ̈ A$ & ÄÄÄÄÄ & ÄĂÄÄÄÄÄÄ & 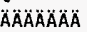 & ӒÄÄĂÄÄÄĂ & ÄÄÄÄÄA & 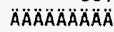 & $A O A A A A B A$ \\
\hline $\begin{array}{l}\text { Nucl ide } \\
\text { ÄÄÄÄÄÄ }\end{array}$ & & $\begin{array}{l}\text { fract. } \\
A B A A A A A A\end{array}$ & $\begin{array}{c}r i s k \\
\triangle A A A A B A A A A\end{array}$ & $\begin{array}{l}\text { fract. } \\
\text { ÄAAAAÄÄ }\end{array}$ & 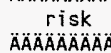 & & $\begin{array}{c}r i s k \\
\triangle A B A O A B A O A B A\end{array}$ & & $\begin{array}{c}r i s k \\
\triangle A B A O A O A ̈ A ̈ A M A\end{array}$ & & $\begin{array}{c}r i s k \\
A A A A B A B A B A\end{array}$ & \\
\hline & & .0000 & $3.620 E-20$ & 0.0000 & $3.978 E-19$ & 0.0000 & & 0.0000 & $1.948 E-21$ & 0.0000 & $2.889 E-19$ & 0.0000 \\
\hline & & & & 0.0000 & $2.770 E-08$ & & & & & & $E-10$ & 0.0001 \\
\hline & & 0.02 & & 0.00 & $E-08$ & 0.0100 & & 0.0 & & & & \\
\hline & & & & & & & & & & 0.0 & & 1000 \\
\hline & & & & & & & & & & & & 000 \\
\hline & & & & & & & & & & & & 001 \\
\hline & & & & & & & & 0.0 & -12 & 0.0 & & \\
\hline & & 0.0 & & & & & & & -25 & 0.0 & & 0000 \\
\hline & & & & & & & & & & & & \\
\hline & & & & & & & & 0.0 & & 0. & & \\
\hline & & & & & & & & & & 0.0 & & 0.0000 \\
\hline & & & & & & & & & & & & \\
\hline & & & & & & & & & & & & 0 \\
\hline & & & & & & & & 0.0 & 11 & 0. & & 127 \\
\hline & & & .2 & & & & & & & & & \\
\hline & & & & & & & & & & & & \\
\hline & & & & & & & & & & 0.0 & & 0.0000 \\
\hline & & & & & & & & & & 0.00 & -23 & 0.0000 \\
\hline & & & & & & & & & & & & \\
\hline & & & & 0.0 & & & & 0.0000 & & & & \\
\hline & & & & & & & & 0.0000 & $5.737 E-19$ & 0.0000 & $3.660 \mathrm{E}-16$ & 0.0000 \\
\hline & & & & & & & & & & & & \\
\hline & & & & 0.0000 & & & & & & & & \\
\hline & & 0.0000 & & & $3.519 E-12$ & 0.0000 & $1.112 E-13$ & 0.0000 & $5.195 E-13$ & 0.0000 & $2.415 E-12$ & 0.0000 \\
\hline & & & & 00 & & & $2.860 \mathrm{E}-17$ & 0.0000 & & 0.0000 & $6.283 E-16$ & 0.0000 \\
\hline $\begin{array}{l}\text { U-2 } \\
\text { Ii î }\end{array}$ & & 0.0000 & 2.0 & 00 & 5.98 & & & 0.0000 & $8936=-16$ & 0.0000 & & \\
\hline & $3.557 E-06$ & 0.7040 & $1.876 \mathrm{E}-08$ & 0.0037 & $3.608 E-07$ & & & & & & & \\
\hline
\end{tabular}

$\begin{array}{ll}\text { Attachment } & \frac{9}{\text { Sheet No. } 21 \text { of } 43} \\ \text { Originator: } \frac{\text { S.W. Clark }}{\text { M.W. Perrott }} & \text { Date } \\ \text { Chk'd By } & \text { Date } \\ \text { Calc. No. } & \text { Rev. No. } \quad 0100 \text { F-CA-V0280 }\end{array}$




\title{
ATTACHMENT 9
}

\begin{abstract}
1RESRAD, Version $6.3 \quad$ T « Limit $=180$ days $\quad 07 / 10 / 2007 \quad 13: 31$ Page 22
Intrisk : 118-F-1 Overburden/Below Cleanup Levels Stockpile Material RESRAD Calculation
\end{abstract}

file : 118-F-1_OB-BCL.RAD

Excess Cancer Risks CNRS( $i, p, t)$ for Individual Radionuclides (i) and Pathways $(p)$ and Fraction of Total Risk at $t=7.000 E+00$ years

Water Dependent Pathways

\begin{tabular}{|c|c|c|c|c|c|c|c|c|c|c|c|c|}
\hline & $\begin{array}{r}\text { Water } \\
\text { AaAAAAOAOAOABA }\end{array}$ & ÄAAAAAOÄ & $\begin{array}{r}F i s h \\
\text { AAAAAAAOAOÄ }\end{array}$ & $A A O A A A A A B$ & $\begin{array}{r}\text { Plar } \\
\text { AAAAAAAAÄA }\end{array}$ & AT & $\begin{array}{r}\text { Meat } \\
\triangle A ̈ A O A A B A A A A\end{array}$ & ÄÄÄÄÄÄ & 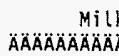 & ÄÄÄÄÄÄ & $\begin{array}{r}A l l P a \\
A B A B A B A O A\end{array}$ & ays** \\
\hline IA & $\begin{array}{l}\text { risk } \\
A A B A B A\end{array}$ & $\begin{array}{l}\text { fract. } \\
\text { AAAAAAA }\end{array}$ & $\begin{array}{c}\text { risk } \\
\text { ÄÄÄÄÄA }\end{array}$ & $\begin{array}{l}\text { fract. } \\
\triangle A B A O A B A\end{array}$ & $\begin{array}{c}\text { risk } \\
A B A B A A B A\end{array}$ & $\begin{array}{l}\text { fract. } \\
A B A B A A B\end{array}$ & $\begin{array}{c}\text { risk } \\
\text { AAAAAOAOÄ }\end{array}$ & & $\begin{array}{c}\text { risk } \\
\text { AAABABAO }\end{array}$ & & risk & \\
\hline & & & & & & & & & & & & \\
\hline & & & & & & & & & & & & \\
\hline & & & $E+00$ & & $10 E+00$ & & $E+00$ & & $E+00$ & & & \\
\hline & & & & & & & & & & & & \\
\hline & & & & & & & & & & & & \\
\hline & & & & & & & & & & & & \\
\hline & & & & & & & & & & & & \\
\hline & & & & & & & & & & & & \\
\hline & & & & & & & & & & & & \\
\hline & & & & & & & & & & & & \\
\hline & & & & & & & & & & & & \\
\hline & & & & & & & & & & & & \\
\hline & & & & & & & & & & & & \\
\hline & & & & & & & & & & & & \\
\hline & & & & & & & & & & & & \\
\hline & & & & & & & & & & & & \\
\hline & & & & & & & & & & & & \\
\hline & & & & & & & & & & & & \\
\hline & & & & & & & & & & & & \\
\hline & & & & & & & & & & & & \\
\hline & & & & & & & & & & & & \\
\hline & & & & & & & & & & & & \\
\hline & & & & & & & & & & & & \\
\hline & & & & & & & & & & & & \\
\hline & & & & & $2.313 E-14$ & & & & $5.017 E-15$ & 0.0000 & $2.090 E-13$ & \\
\hline & & & & & & & & & & & & \\
\hline & & & & & & & & & & & & \\
\hline & & & 10 & & 1 & & 1.37 & & & 0.0099 & & \\
\hline
\end{tabular}

** Sum of water independent ground, inhalation, plant, meat, milk, soil

and water dependent water, fish, plant, meat, milk pathways

Excess Cancer Risks CNRS9 $i \mathrm{rn}, i, t$ ) and CNRSPW( $i r n, i, t)$ for Inhalation of

Radon and its Decay Products at $t=7.000 E+00$ years Radionuclides

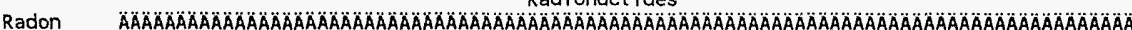

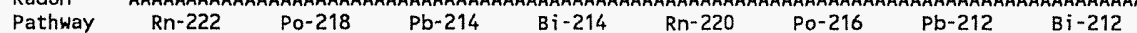

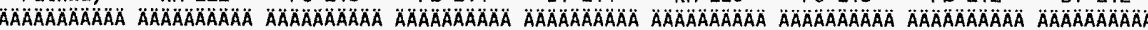

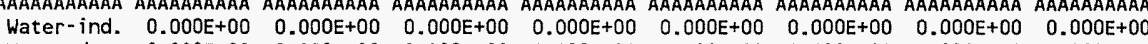

$\begin{array}{lllllllll}\text { Water-dep. } & 0.000 E+00 & 0.000 E+00 & 0.000 E+00 & 0.000 E+00 & 0.000 E+00 & 0.000 E+00 & 0.000 E+00 & 0.000 E+00\end{array}$

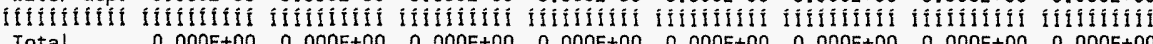

Water-ind. =- Water-independent - Water-dep. $=0$ Water-dependent

$\begin{array}{ll}\text { Attachment } \frac{9}{\text { S.W. Clark }} & \text { Sheet No. } 22 \text { of } \underline{43} \\ \text { Originator: } & \text { Date } \\ \text { Chk'd By } & \text { Date } \\ \text { Calc. No. Perrott } & \text { Rev. No. } \frac{0}{0100 \text { F-CA-V0280 }}\end{array}$




\section{ATTACHMENT 9}

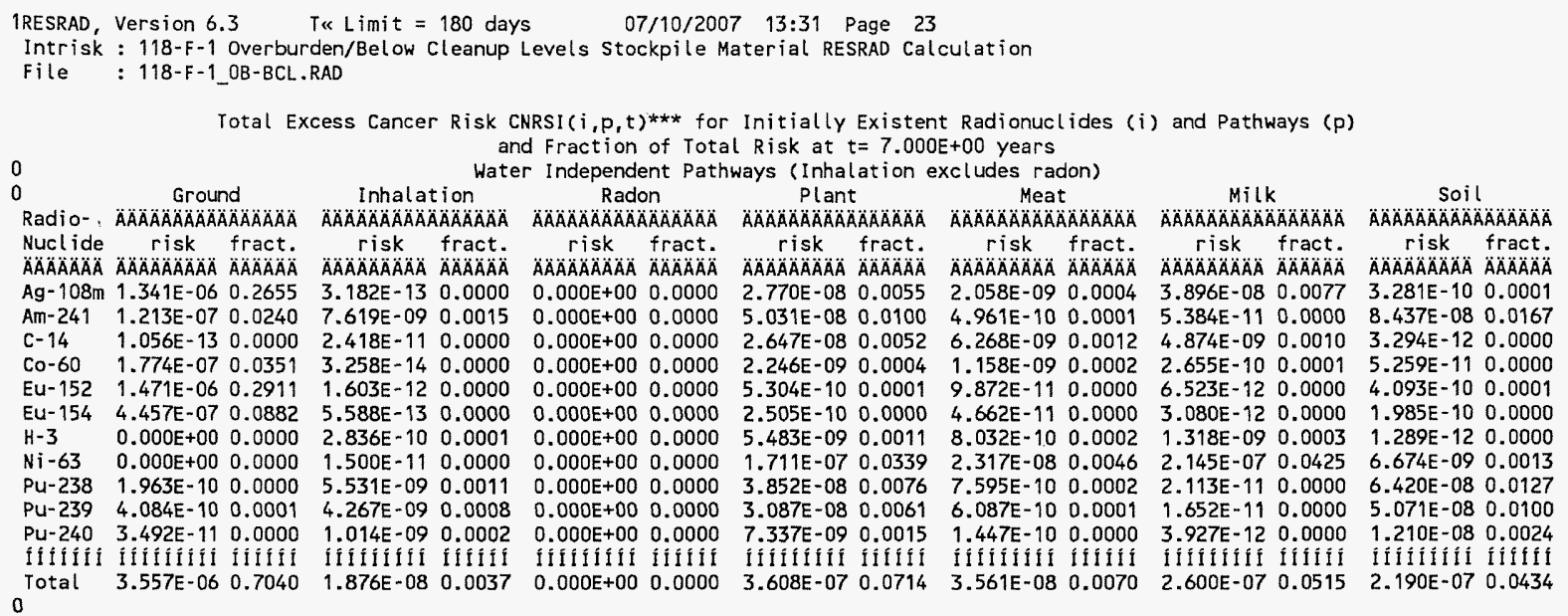

Total Excess Cancer Risk CNRSI $(i, p, t) * * *$ for Initially Existent Radionuclides (i) and Pathways $(p)$ and Fraction of Total Risk at $t=7.000 E+00$ years

Water Dependent Pathways

\begin{tabular}{|c|c|c|c|c|c|c|c|c|c|c|c|c|c|}
\hline \multirow[b]{2}{*}{\begin{tabular}{l} 
Nucl ide \\
\hdashline$A O A B A A B A$
\end{tabular}} & \multicolumn{2}{|c|}{ 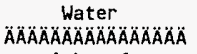 } & \multicolumn{2}{|c|}{ 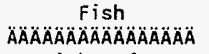 } & \multicolumn{2}{|c|}{$\begin{array}{l}\text { Radon } \\
\text { AAAAAAOÄÄÄÄÄAAAOÄ }\end{array}$} & \multicolumn{2}{|c|}{ 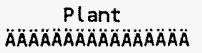 } & \multicolumn{2}{|c|}{ 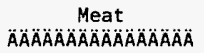 } & \multicolumn{2}{|c|}{$\begin{array}{c}M i l k \\
\text { AOAAAAAAAAAOAOAOAOÄA }\end{array}$} & 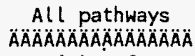 \\
\hline & risk & $\begin{array}{l}\text { fract. } \\
\text { ÄÄÄÄ }\end{array}$ & $\begin{array}{c}\text { risk } \\
\text { AAÄÄÄÄÄÄÄ }\end{array}$ & $\begin{array}{l}\text { fract. } \\
\not A ̈ A ̈ A ̈ A ̈ A ̈\end{array}$ & $\begin{array}{c}\text { risk } \\
\text { ÄÄÄAOAAAOA }\end{array}$ & & risk & & $\begin{array}{c}\text { risk } \\
\text { ÄÄÄÄÄÄÄÄ }\end{array}$ & & risk & & risk fract. \\
\hline & & & & & & & & & & & & & \\
\hline & & & & & & & & & & & & & \\
\hline & & & & & & & & & & & & & \\
\hline & & & & & & & & & & & & & \\
\hline & & & & & & & & & & & & & \\
\hline & & & & & & & & & & & & & \\
\hline & & & & & & & & & & & & & \\
\hline & & & & & & & & & & & & & 070 \\
\hline & & & & & & & & & & & & & \\
\hline & & & & & & & & & & & & & \\
\hline & & & 4.8 & & & & & & & & & & \\
\hline & & & & & & & & & & & & & \\
\hline & & & $4.711 E-10$ & 0.0001 & $0.0002 \cdot 0$ & & & & $1.36 / \mathrm{E}-08$ & 0.0027 & $4.979 E-08$ & 0.0099 & 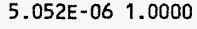 \\
\hline
\end{tabular}

***CNRSI $(i, p, t)$ includes contribution from decay daughter radionuclides

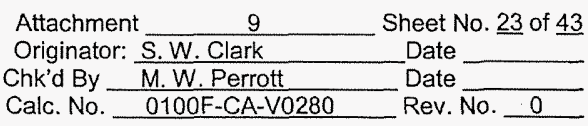




\section{ATTACHMENT 9}

1RESRAD, Version 6.3 T\& Limit $=180$ days $\quad 07 / 10 / 2007 \quad 13: 31$ Page 24

Intrisk : 118-F-1 Overburden/Below Cleanup Levels Stockpile Material RESRAD Calculation

File : 118-F-1_OB-BCL.RAD

Amount of Intake Quantities QINT(i,p,t) for Individual Radionuclides (i) and Pathways ( $p$ ) As $\mathrm{pCi} / \mathrm{yr}$ at $\mathrm{t}=1.100 \mathrm{E}+01$ years

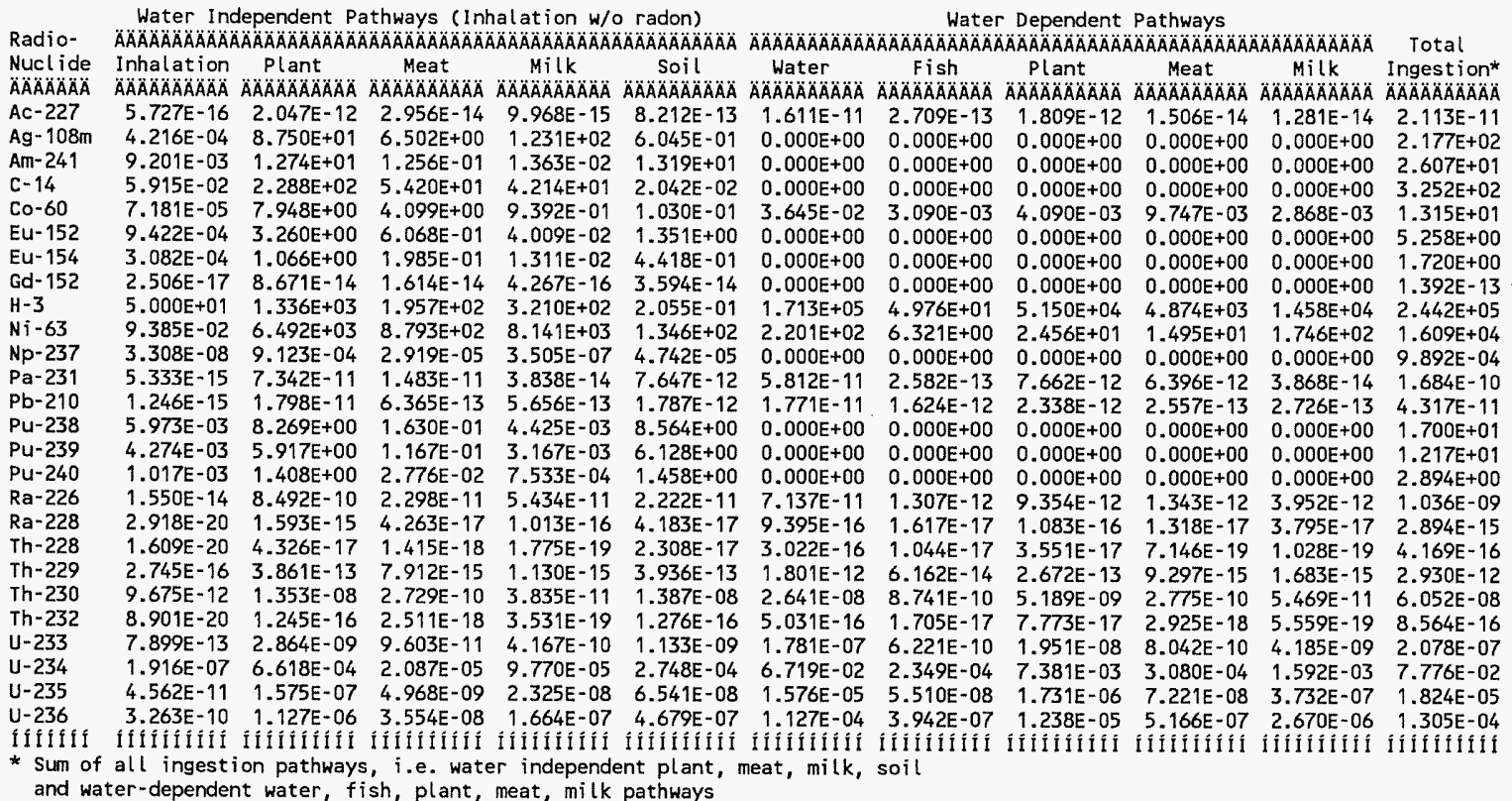

0

Amount of Intake Quantities QINTP(irn, $i, t)$ and QINTSW(irn, $i, t)$ for Inhalation of

0 Radon and $i t s$ Decay Products as $p C i / y r$ at $t=1.100 E+01$ years

\begin{tabular}{|c|c|c|c|c|c|c|c|c|}
\hline Radon & ÄÄÄÄÄÄÄÄ & AOAAAAAAAAAAÄ & ÄÄÄÄÄÄÄÄÄ & ÄÄÄÄÄÄÄÄÄÄA & ÄÄÄÄÄÄÄÄÄ & ÄAAÄÄÄAOÄ & AOAAAAAAAAAAAA & ÄÄÄÄ \\
\hline Pathway & $R n-222$ & Po- 218 & $\mathrm{~Pb}-214$ & $8 i-214$ & $R n-220$ & Po-216 & $\mathrm{Pb}-212$ & \\
\hline$\triangle A A O A O A A A O A O A$ & $\triangle A O A O A O A O A O A O A Z A ̈$ & $\triangle A \cap A A A B A A B A A A$ & $\triangle A A A A A A A B A B A$ & $\triangle A A A A A A A A A A A$ & $\triangle A A A A A A A A A A B$ & 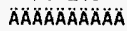 & $\triangle A A A A A A B A O A O A$ & $\triangle A A A A A A A A A B A ̈$ \\
\hline er-ind. & $0.000 E+00$ & $0.000 E+00$ & $0.000 \mathrm{E}+00$ & $0.000 E+00$ & $0.000 E+00$ & $0.000 E+00$ & $0.000 E+00$ & $O E+00$ \\
\hline -dep. & $0.000 E+00$ & $0.000 \mathrm{E}+00$ & $0.000 E+00$ & $0.000 \mathrm{E}+00$ & $0.000 \mathrm{E}+00$ & $0.000 E+00$ & $0.000 \mathrm{E}+00$ & $0.000 E+00$ \\
\hline & IIIIIIIIII & fillitifit & flitifilit & fitifitifl & IIIIIIIIII & Iififififí & IIIfitiolify & Iifififiti \\
\hline Tot & $0.000 E+00$ & $0.000 E+00$ & $0.000 E+00$ & $0.000 E+00$ & $0.000 E+00$ & $0.000 E+00$ & $0.000 \mathrm{E}+00$ & $0.000 E+00$ \\
\hline
\end{tabular}

Water-ind. $=$ Water-independent Water-dep. $==$ Water-dependent

\begin{tabular}{|c|c|}
\hline Attachment & Sheet No. 24 of 43 \\
\hline Originator: $\overline{\mathrm{S.W} \text {. Clark }}$ & Date \\
\hline Chk'd By M. W. Perrott & Date \\
\hline $0100 F-C A-V 0280$ & Rev. No. \\
\hline
\end{tabular}




\section{ATTACHMENT 9}

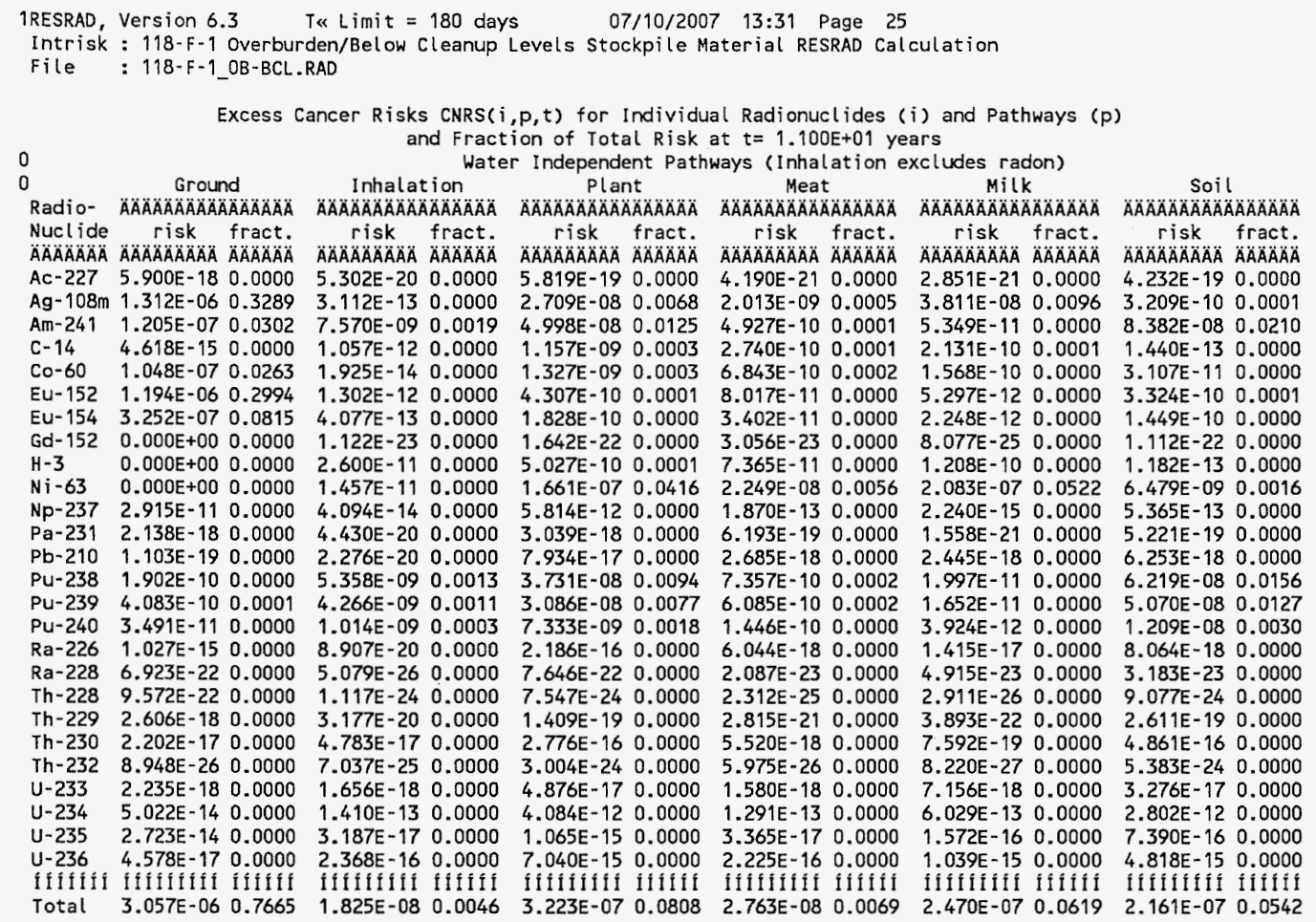

\begin{tabular}{|c|c|}
\hline \multirow{2}{*}{\multicolumn{2}{|c|}{$\begin{array}{l}\text { Attachment } \frac{9}{\text { Originator: S.W. Clark }} \\
\text { S. W }\end{array}$}} \\
\hline & \\
\hline Chk'd By M.W. Perrott & Date \\
\hline $0100 F-C A-V 0280$ & Rev. No. \\
\hline
\end{tabular}


Rev. 0

\section{ATTACHMENT 9}

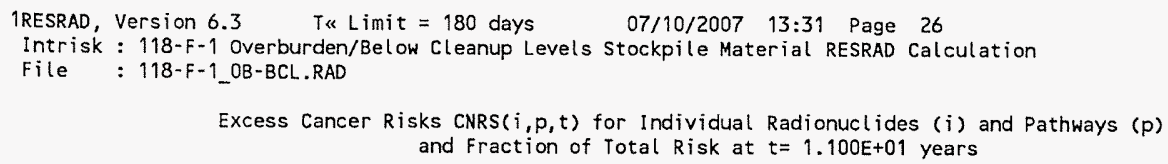

Water Dependent Pathways

\begin{tabular}{|c|c|c|c|c|c|c|c|c|c|c|c|c|}
\hline & $\begin{array}{r}\text { Water } \\
\text { ÄAOAAAAAAOAO }\end{array}$ & A & $\begin{aligned} & F i s h \text { ish } \\
& \text { ÄÄÄÄÄÄÄÄ }\end{aligned}$ & 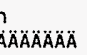 & $\begin{array}{r}P l a n \\
\text { ÄÄÄÄÄÄÄÄA }\end{array}$ & 证 & $\begin{array}{r}\text { Mea } \\
\text { ÄÄAAAAAOAOA }\end{array}$ & $\stackrel{t}{Z A O A O A O A ̈ A ̈ A}$ & 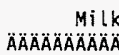 & $\triangle A O A O A Z A Z A ̈$ & $\begin{array}{r}\text { All Path } \\
A A A B A B A B A B A B A\end{array}$ & $\begin{array}{l}\text { hways*** } \\
A ̈ A ̈ A ̈ A ̈ A O A\end{array}$ \\
\hline $\begin{array}{l}\text { Nucl ide } \\
\ddot{A} A \ddot{A} A \ddot{A} \ddot{A} \ddot{A}\end{array}$ & $\begin{array}{c}\text { risk } \\
\dddot{A} \text { ÄÄÄÄÄÄÄ }\end{array}$ & $\begin{array}{l}\text { fract. } \\
\because \ddot{A ̈ A ̈ A ̈ A ̈ A ̈}\end{array}$ & $\begin{array}{c}r i s k \\
\text { ÄÄÄÄÄÄÄ }\end{array}$ & $\begin{array}{l}\text { fract. } \\
A A A A B A ̈ A\end{array}$ & $\begin{array}{c}\text { risk } \\
\text { ÄÄÄÄÄÄÄÄ }\end{array}$ & 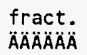 & $\begin{array}{c}\text { risk } \\
\text { AAAAAAAAAOA }\end{array}$ & $\begin{array}{l}\text { fract. } \\
A O A B A B A B\end{array}$ & $\begin{array}{c}\text { risk } \\
\text { AAAAAAAAAAÄ }\end{array}$ & $\begin{array}{l}\text { fract. } \\
A \cap A B A B A B\end{array}$ & $\begin{array}{c}\text { risk } \\
\text { AAAÄÄÄÄÄ }\end{array}$ & $\begin{array}{l}\text { fract. } \\
A ̈ A B A O A B\end{array}$ \\
\hline Ac- -227 & $8.163 E-18$ & 0.0000 & $1.824 E-19$ & 0.0000 & $1.205 E-18$ & 0.0000 & $5.773 E-21$ & 0.0000 & $8.710 E-21$ & 0.0000 & $1.653 \mathrm{E}-17$ & 0.0000 \\
\hline$-108 m$ & $.000 E+00$ & 0.0000 & $0.000 E+00$ & 0.0000 & $0.000 E+00$ & 0.0000 & $0.000 E+00$ & 0.0000 & $0.000 \mathrm{E}+00$ & 0.0000 & $1.379 E-06$ & 0.3458 \\
\hline & $0.000 E+00$ & 0.0000 & $0.000 E+00$ & 0.0000 & $0.000 E+00$ & 0.0000 & $0.000 E+00$ & 0.0000 & $0.000 E+00$ & 0.0000 & $2.624 E-07$ & 0.0658 \\
\hline & $0.000 E+00$ & 0.0000 & $0.000 E+00$ & 0.0000 & $0.000 E+00$ & 0.0000 & $0.000 E+00$ & 0.0000 & $0.000 E+00$ & 0.0000 & $645 E-09$ & 0.0004 \\
\hline & $6.968 \mathrm{E}-12$ & 0.0000 & $8.402 E-13$ & 0.0000 & $1.114 E-12$ & 0.0000 & $2.689 E-12$ & 0.0000 & $7.852 E-13$ & 0.0000 & $1.070 \mathrm{E}-07$ & 0.0268 \\
\hline & $0.000 \mathrm{E}+00$ & 0.0000 & $0.000 E+00$ & 0.0000 & $0.000 E+00$ & 0.0000 & $0.000 \varepsilon+00$ & 0.0000 & $0.000 E+00$ & 0.0000 & $1.195 E-06$ & \\
\hline & & & $0.000 E+00$ & & $0.000 E+00$ & 0.0000 & $0.000 E+00$ & 0.0000 & $0.000 \mathrm{E}+00$ & 0.0000 & $3.255 E-07$ & 0.081 \\
\hline & $0.000 E+00$ & 0.0000 & $0.000 E+00$ & 0.0000 & $0.000 E+00$ & 0.0000 & $0.000 E+00$ & 0.0000 & $0.000 E+00$ & 0.0000 & $E-22$ & 0000 \\
\hline 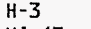 & $5.017 E-08$ & 0.0126 & $1.873 E-11$ & 0.0000 & $1.939 E-08$ & 0.0049 & $1.835 \mathrm{E}-09$ & 0.0005 & $5.490 \mathrm{E}-09$ & 0.0014 & $7.763 E-08$ & 0.0195 \\
\hline & & 0.0023 & $2 E-10$ & 0.0001 & $1.460 \mathrm{E}-09$ & 0.0004 & $8.988 \mathrm{E}-10$ & 0.0002 & $1.043 E-08$ & 0.0026 & $7 E-07$ & 1067 \\
\hline & $0.000 E+00$ & 0.0000 & $0.000 E+00$ & & $0.000 E+00$ & 0.0000 & $0.000 E+00$ & 0.0000 & $0.000 E+00$ & 0.0000 & 3.573 & 0.0000 \\
\hline-231 & $5.074 E-18$ & 0.0000 & $2.809 E-20$ & 0.0000 & $7.821 \mathrm{E}-19$ & 0.0000 & $5.599 E-19$ & 0.0000 & $2.455 \mathrm{E}-21$ & 0.0000 & $1.281 \mathrm{E}-17$ & 0.0000 \\
\hline & $2.241 \mathrm{E}-17$ & 0.0000 & $5.243 E-18$ & 0.0000 & $7.101 \mathrm{E}-18$ & 0.0000 & $6.866 \mathrm{E}-19$ & 0.0000 & -19 & & & \\
\hline & & & $E+00$ & & $0 E+00$ & 0.0000 & $0.000 E+00$ & 0.0000 & $0.000 E+00$ & 0.0000 & 07 & 026 \\
\hline $1-2$ & $0.000 E+00$ & 0.0000 & $\mathrm{E}+00$ & 0.00 & $0.000 E+00$ & 0000 & $0.000 \mathrm{E}+00$ & 0.0000 & $0.000 E+00$ & 0.0000 & $8.686 \mathrm{E}-08$ & 0.0218 \\
\hline $1-240$ & $0.000 E+00$ & 0.0000 & $0.000 E+00$ & 0.0000 & $0.000 E+00$ & 0.0000 & $0.000 E+00$ & 0.0 & $0.000 E+00$ & 000 & & 0052 \\
\hline & & 00 & $E-18$ & 0.0000 & $7.428 \mathrm{E}-18$ & 0.0000 & $9.045 E-19$ & 0.0000 & $2.702 E-18$ & 0000 & $E-15$ & 0000 \\
\hline & $2.181 \mathrm{E}-22$ & & $E-24$ & 0.0000 & $3.325 E-23$ & 0.0000 & $32 E-24$ & 0.0000 & $81 E-23$ & 0.0000 & $1.831 \mathrm{E}-21$ & 0.0000 \\
\hline & $1.756 E-23$ & 0.0000 & $8.237 E-25$ & & $2.728 E-24$ & & $E-26$ & 0.0000 & -27 & 0.0000 & $9.964 \mathrm{E}-22$ & 0.0000 \\
\hline & $4.777 \mathrm{E}-19$ & 0.0000 & $2.184 E-20$ & 0.0000 & $9.575 E-20$ & 0.0000 & $3.408 E-21$ & 0.0000 & $6.423 E-22$ & 000 & & \\
\hline & $1.149 E-15$ & 0.0000 & $E-17$ & 0.0000 & $132 E-16$ & 0.0000 & $7.165 E-18$ & 0.0000 & $1.333 E-18$ & 000 & & 0000 \\
\hline & $.324 E-23$ & & $4 E-25$ & 0.0000 & $2.440 E-24$ & 0.0000 & $7.893 E-26$ & 0.0000 & $1.458 E-26$ & 0.0000 & $2.561 E-23$ & 0.0000 \\
\hline & $6.595 E-15$ & & 3. $117 \mathrm{E}-17$ & & $.807 E-16$ & & $4.140 \mathrm{E}-17$ & & $2.125 E-16$ & & $7.955 E-15$ & 0.0000 \\
\hline & $2 / 5 \mathrm{~F}-1$ & & $3.902 E-12$ & 0.0000 & $1.228 E-10$ & 0.0000 & $5.206 \mathrm{E}-12$ & & $2.666 \mathrm{E}-11$ & & & \\
\hline & $2.066 E-13$ & 0.0000 & $9.843 \mathrm{E}-16$ & 0.0000 & $3.099 E-14$ & 0.0000 & $1.313 E-15$ & 0.0000 & $6.725 E-15$ & 0.0000 & & 0.0000 \\
\hline & & & & & & & & & $4.447 \mathrm{E}-14$ & 0.0000 & $1.657 \mathrm{E}-12$ & 0.0000 \\
\hline & & & & & & & & & & & & \\
\hline & & 0.0151 & $3.987 E-10$ & 0.0001 & $2.098 \mathrm{E}-08$ & 0.0053 & $2.742 E-09$ & 0.0007 & $1.594 \mathrm{E}-08$ & 0.0040 & $3.989 E-06$ & 1.0000 \\
\hline
\end{tabular}

** Sum of water independent ground, inhalation, plant, meat, milk, soil and water dependent water, fish, plant, meat, mi lk pathways Excess Cancer Risks CNRS9(irn, $i, t)$ and CNRSPW(irn, $i, t$ ) for Inhalation of

0 Radon Radionucl ides

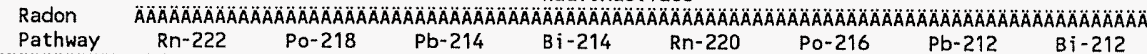

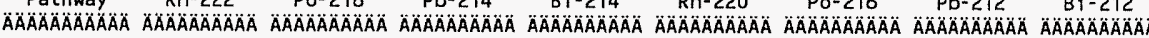

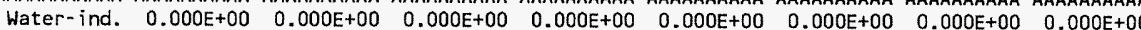
Water-deP $0.000 E+00$ 0.000E+00 $0.000 E+00$ 0.000E+00 $0.000 E+00$ 0.000E+00 $0.000 E+00 \quad 0.000 E+00$

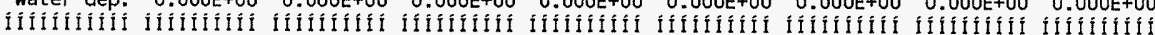

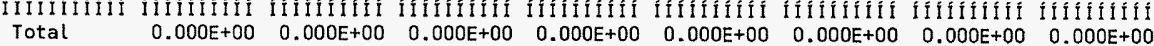

Water-ind. = Water-independent Water-dep. == Water-dependent

$\begin{array}{ll}\text { Attachment } \frac{9}{\text { S.W. Clark }} & \text { Sheet No. } 26 \text { of } 43 \\ \text { Originator: } & \text { Date } \\ \text { Chk'd By } & \text { Date } \\ \text { Calc. No. N. Perrott } & \text { Rev. No. } \quad 0\end{array}$




\section{ATTACHMENT 9}

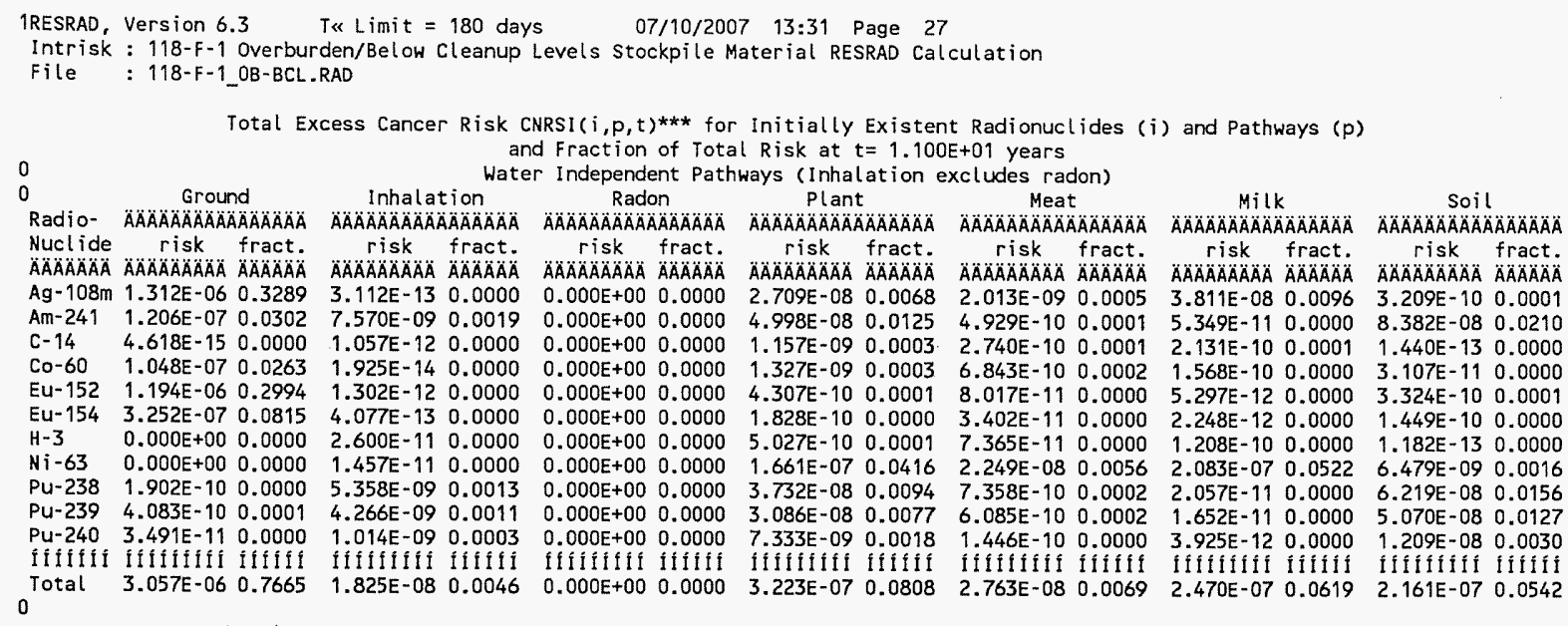

Total Excess Cancer Risk CNRSI $i, p, t)^{* * \star}$ for Initially Existent Radionuclides $(i)$ and Pathways (p) and Fraction of Total $R$ isk at $t=1.100 E+01$ years

Water Dependent Pathways

\begin{tabular}{|c|c|c|c|c|c|c|c|c|c|c|c|c|c|}
\hline \multirow{2}{*}{ 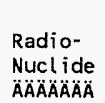 } & $\begin{array}{c}\text { Water } \\
\text { ÄÄAAAAAOAOAOAOÄÄÄ }\end{array}$ & \multicolumn{2}{|c|}{ 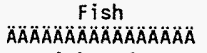 } & \multicolumn{2}{|c|}{$\begin{array}{c}\text { Radon } \\
\text { AAÄÄAOAOÄÄÄÄÄÄÄÄ }\end{array}$} & \multicolumn{2}{|c|}{ 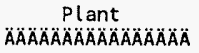 } & \multicolumn{2}{|c|}{ 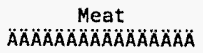 } & \multicolumn{2}{|c|}{$\begin{array}{c}M i l k \\
\text { AMAOAAAAOAOAOAOAOAOAOA }\end{array}$} & \multicolumn{2}{|c|}{$\begin{array}{l}\text { All pathways } \\
\text { AÄÄÄÄAOAAAOAAAOAAAAA }\end{array}$} \\
\hline & 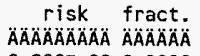 & 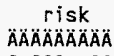 & $\begin{array}{l}\text { fract. } \\
\dddot{A} A \ddot{A} \ddot{A} \ddot{A} \ddot{A} \dot{A}\end{array}$ & $\begin{array}{c}\text { risk } \\
\text { AAAAAAAOAOAOA }\end{array}$ & $\begin{array}{l}\text { fract. } \\
\text { ÄÄÄÄÄÄ }\end{array}$ & $\begin{array}{c}\text { risk } \\
\triangle A A A B A A A B A\end{array}$ & $\begin{array}{l}\text { fract. } \\
\text { ÄÄÄÄÄÄ }\end{array}$ & $\begin{array}{c}\text { risk } \\
\text { ÄAAAAAAAÄÄ }\end{array}$ & $\begin{array}{l}\text { fract. } \\
\text { ÄÄÄÄA }\end{array}$ & $\begin{array}{c}\text { risk } \\
\triangle A \cap A ̈ A ̈ A ̈ A ̈ A Z A ̈ A\end{array}$ & $\begin{array}{l}\text { fract. } \\
\text { ÄAAAAAOA }\end{array}$ & $\begin{array}{c}\text { risk } \\
\triangle A A A A A A A A A B\end{array}$ & $\begin{array}{l}\text { fract. } \\
\text { ÄAÄAÄA }\end{array}$ \\
\hline $\mathrm{Ag}-108 \mathrm{~m}$ & $0.000 \mathrm{E}+00 \quad 0.0000$ & $0.000 E+00$ & 0.0000 & $0.000 E+00$ & 0.0000 & $0.000 E+00$ & 0.0000 & $0.000 E+00$ & 0.0000 & $0.000 E+00$ & 0.0000 & $1.379 E-06$ & 0.3458 \\
\hline Am- 241 & $6.595 \mathrm{E}-15 \quad 0.0000$ & $3.119 E-17$ & 0.0000 & $0.000 E+00$ & 0.0000 & $9.808 E-16$ & 0.0000 & $4.140 \mathrm{E}-17$ & 0.0000 & $2.125 \mathrm{E}-16$ & 0.0000 & & 0.0658 \\
\hline$c-14$ & $0.000 E+00 \quad 0.0000$ & $0.000 E+00$ & 0.0000 & $0.000 E+00$ & 0.0000 & $0.000 E+00$ & 0.0000 & $0.000 E+00$ & 0.0000 & $0.000 \mathrm{E}+00$ & 0.0000 & 1.645 & 0.0004 \\
\hline Co- 60 & $6.968 \mathrm{E}-12 \quad 0.0000$ & $8.402 E-13$ & 0.0000 & $0.000 E+00$ & 0.0000 & $1.114 E-12$ & 0.0000 & $2.689 \mathrm{E}-12$ & 0.0000 & -13 & 0.0000 & 070E-07 & 0.0268 \\
\hline & $0.000 E+00 \quad 0.0000$ & $0.000 E+00$ & 0.0000 & $0.000 \mathrm{E}+00$ & 0.0000 & $0.000 E+00$ & 0.0000 & $0.000 E+00$ & 0.0000 & $0.000 E+00$ & 0.0000 & E-06 & 2996 \\
\hline Eu- 154 & $0.000 E+00 \quad 0.0000$ & $0.000 E+00$ & 0.0000 & $0.000 E+00$ & 0.0000 & $0.000 E+00$ & 0.0000 & $0.000 E+00$ & 0.0000 & $0.000 E+00$ & 0.0000 & -07 & 0.0816 \\
\hline $\mathrm{H}-3$ & $5.017 \mathrm{E}-08 \quad 0.0126$ & $1.873 E-11$ & 0.0000 & $0.000 E+00$ & 0000 & $1.939 \mathrm{E}-08$ & 0.0049 & $1.835 \mathrm{E}-09$ & 0.0005 & $5.490 E-09$ & 0.0014 & $E-08$ & 0.0195 \\
\hline & $93 E-090.0023$ & $3.752 E-10$ & 0.0001 & $0.000 E+00$ & 0.0000 & $50 E-09$ & 0.0004 & & 0.0002 & & & & \\
\hline Pu-238 & $8.245 E-10 \quad 0.0002$ & $3.902 E-12$ & 0.0000 & $0.000 E+00$ & 0.0000 & $1.228 E-10$ & 0.0000 & $5.206 \mathrm{E}-12$ & 0.0000 & $2.666 \mathrm{E}-11$ & 0.0000 & $1.068 \mathrm{E}-07$ & 0.0268 \\
\hline & $2.067 \mathrm{E}-13 \quad 0.0000$ & $9.846 \mathrm{E}-16$ & 0.0000 & $0.000 E+00$ & 0.0000 & $3.099 E-14$ & 0.0000 & $1.313 E-15$ & 0.0000 & $6.725 E-15$ & 0.0000 & $8.686 E-08$ & 0.0218 \\
\hline & $-12 \quad 0 . c$ & $E-15$ & 0.0000 & $0.000 E+00$ & & & & & & $4.447 \mathrm{E}-14$ & 0.0000 & $2.062 E-08$ & 0.0052 \\
\hline & & $0=7$ & Iffiti & 1111111 & & & & & & & & & \\
\hline & $19 E-08 \quad 0.0151$ & $87 E-10$ & 0.0001 & $0.000 E+00$ & 0.0000 & $2.098 E-08$ & 0.0053 & $2.742 \mathrm{E}-09$ & 0.0007 & $1.594 E-08$ & 0.0040 & $3.989 E-06$ & 1.0000 \\
\hline
\end{tabular}

***CNRSI $(i, p, t)$ includes contribution from decay daughter radionuclides

\begin{tabular}{|c|c|}
\hline \multirow{2}{*}{\multicolumn{2}{|c|}{$\begin{array}{ll}\text { Attachment } & 9 \\
\text { Originator: } \underline{\text { S.W. Clark }} \quad \text { Sheet No. } 27 \text { of } \underline{43} \\
\text { Date }\end{array}$}} \\
\hline & \\
\hline Chk'd By M. W. Perrott & Date \\
\hline $0100 F-C A-V 0280$ & Rev. No. \\
\hline
\end{tabular}




\section{ATTACHMENT 9}

1RESRAD, Version $6.3 \quad$ Tu Limit $=180$ days $\quad 07 / 10 / 2007 \quad 13: 31$ Page 28
Intrisk : $118-\mathrm{F}-1$ Overburden/Below cleanup Levels Stockpile Material RESRAD Calculation

File: $118-F-1$ OB-BCL.RAD

Amount of Intake Quantities QINT(i,p,t) for Individual Radionuclides (i) and Pathways $(p)$ As $\mathrm{pCi} / \mathrm{yr}$ at $\mathrm{t}=4.300 \mathrm{E}+01$ years

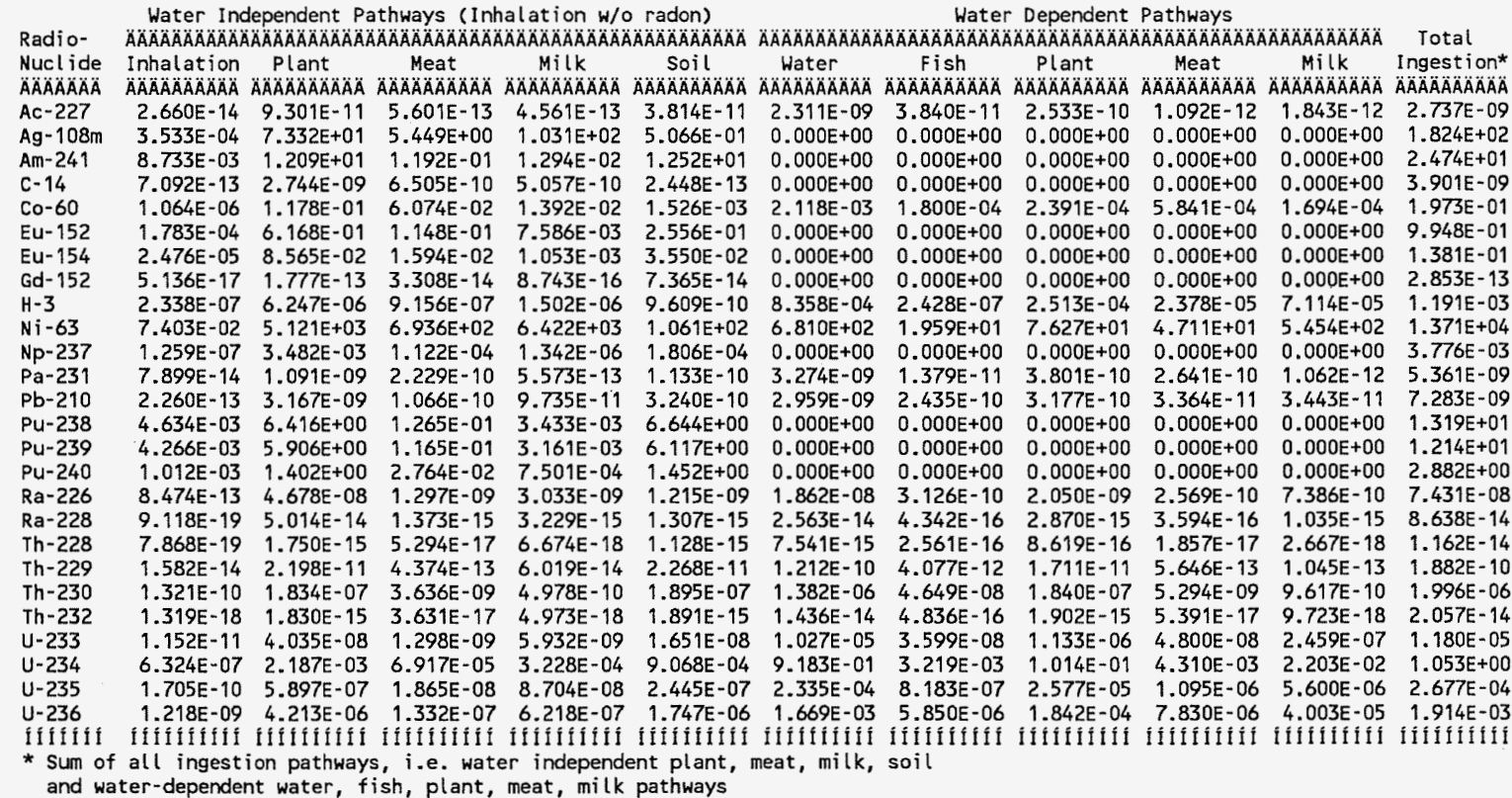

0

Amount of Intake Quantities QINTS(irn, i, t) and QINTOW(irn, $i, t)$ for Inhalation of

0 Radon and its Decay Products as $\mathrm{pCi} / \mathrm{yr}$ at $\mathrm{t}=4.300 \mathrm{E}+01$ years

Radon Radionuclides

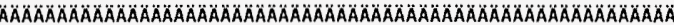

Pathway Rn-222 Po-218 Pb-214 Bi-214 Rn-220 $\quad$ Po-216 $\quad$ Pb-212 $\quad B i-212$

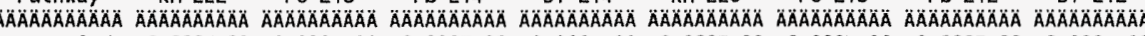

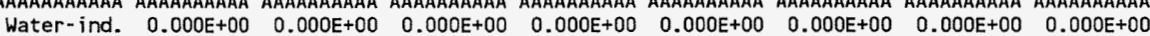

$\begin{array}{llllllllll}\text { Water-dep. } & 0.000 E+00 & 0.000 E+00 & 0.000 E+00 & 0.000 E+00 & 0.000 E+00 & 0.000 E+00 & 0.000 E+00 & 0.000 E+00\end{array}$

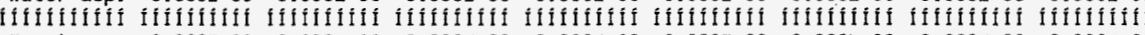

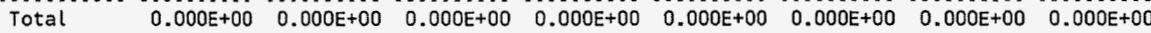

Water-ind. $==$ Water-independent Water-dep. $==$ Water-dependent

$\begin{array}{ll}\text { Attachment } \frac{9}{\text { S.W. Clark }} & \text { Sheet No. } 28 \text { of } 43 \\ \text { Originator: } & \text { Date } \\ \text { Chk'd By } & \text { Date } \\ \text { Calc. No. W. Perrott } & \text { Rev. No. } 0\end{array}$




\section{ATTACHMENT 9}

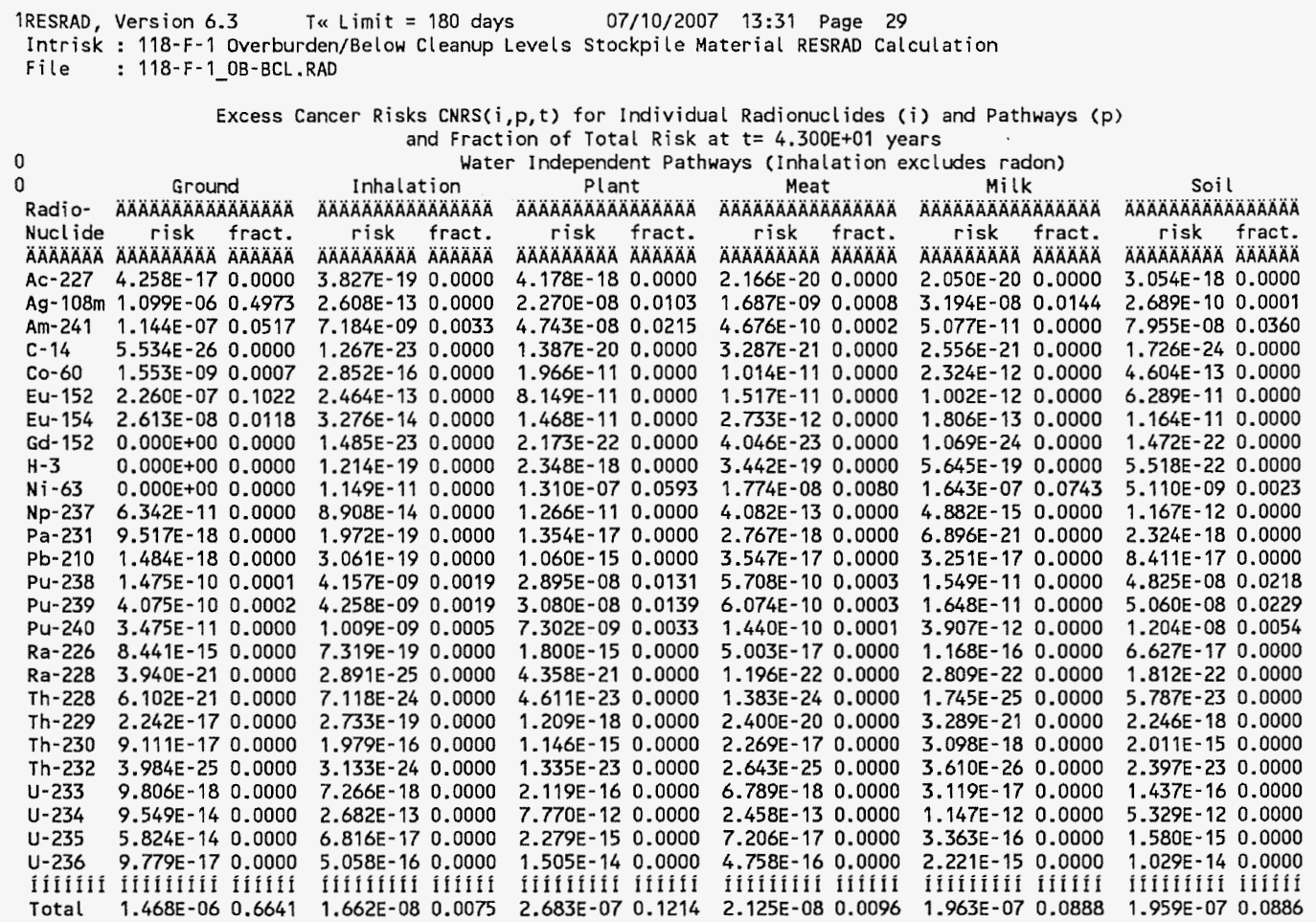

\begin{tabular}{|c|c|c|}
\hline \multicolumn{2}{|c|}{ Attachment $\quad 9$} & \multirow{2}{*}{$\begin{array}{l}\text { Sheet No. } 29 \text { of } 43 \\
\text { Date }\end{array}$} \\
\hline Originator: & S.W. Clark & \\
\hline Chk & M. W. Perrott & Date \\
\hline Calc & $0100 F-C A-V 0280$ & Rev. No. \\
\hline
\end{tabular}




\section{ATTACHMENT 9}

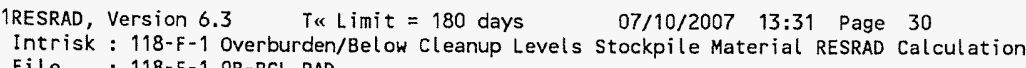

File : 118-F-1_OB-BCL.RAD

Excess Cancer Risks CNRS $(i, p, t)$ for Individual Radionuclides (i) and Pathways $(p)$ and Fraction of Total Risk at $t=4.300 E+01$ years

Water Dependent Pathways

\begin{tabular}{|c|c|c|c|c|c|c|c|c|c|c|c|c|}
\hline & \multicolumn{2}{|c|}{$\begin{array}{l}\text { Water } \\
\text { AOAOAOAOA }\end{array}$} & \multicolumn{2}{|c|}{ Fish } & \multicolumn{2}{|c|}{$P$ lant } & \multicolumn{2}{|c|}{ Meat } & \multicolumn{2}{|c|}{$\mathrm{Milk}$} & \multicolumn{2}{|c|}{$\begin{array}{r}\text { All Pathways** } \\
\text { AAAAAAAAAAAAAAAAA }\end{array}$} \\
\hline 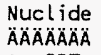 & $\begin{array}{l}\text { risk } \\
A B A B A B A\end{array}$ & 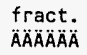 & $\begin{array}{c}\text { risk } \\
\text { ÄÄÄÄÄÄÄÄ }\end{array}$ & 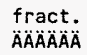 & $\begin{array}{c}\text { risk } \\
\text { ÄAAAAAAAA }\end{array}$ & $\begin{array}{l}\text { fract. } \\
\text { ÄÄÄÄÄÄ }\end{array}$ & $\begin{array}{c}\text { risk } \\
\text { AAAAAAAAÄ }\end{array}$ & $\begin{array}{l}\text { fract. } \\
\text { ÄÄÄÄÄ }\end{array}$ & $\begin{array}{c}\text { risk } \\
\text { AAAAÄÄ̈ÄÄÄ }\end{array}$ & $\begin{array}{l}\text { fract. } \\
\text { AAAAAAABA }\end{array}$ & $\begin{array}{c}r i s k \\
\text { ÄÄÄÄÄÄÄÄ }\end{array}$ & $\begin{array}{l}\text { fract. } \\
\text { ÄÄÄÄÄ }\end{array}$ \\
\hline & & & $2.507 E-18$ & 0.0000 & $1.659 \mathrm{E}-17$ & 0.0000 & $6.357 E-20$ & 0.0000 & $1.201 E-19$ & 0.0000 & $1.814 E-16$ & 0.0000 \\
\hline & & & $0.000 E+00$ & 0.0000 & $.000 E+00$ & 0.0000 & $.000 E+00$ & 0.0000 & & 0.0000 & & \\
\hline & $000 E+00$ & 0.0000 & $0.000 E+00$ & 0.0000 & $.000 E+00$ & 0.0000 & $0.000 E+00$ & 0.0000 & $0.000 E+00$ & 0.0000 & $2.491 \mathrm{E}-07$ & 0.1127 \\
\hline & $O O E+$ & & $0.000 E+00$ & 0.0000 & $0.000 E+00$ & 0.0000 & $0.000 E+00$ & 0.0000 & $0.000 E+00$ & 0.0000 & $1.973 \mathrm{E}-20$ & 0.0000 \\
\hline & & & $3.489 E-14$ & & $4.634 E-14$ & 0.0000 & $.133 E-13$ & 0.0000 & $34 E-14$ & 0.0000 & & 0007 \\
\hline & 0.0 & 0.0000 & $0.000 E+00$ & 0.0000 & $0.000 E+00$ & 0.0000 & $0.000 E+00$ & 0.0000 & $E+\infty$ & 0.0000 & & 023 \\
\hline & $0.000 E+00$ & 0.0000 & $0.000 E+00$ & 0.0000 & $O E+00$ & 0.0 & OOE +00 & 0.0000 & $0.000 E+00$ & 0.0000 & & 0.0118 \\
\hline & & & $O E+00$ & 0.0000 & $E E+00$ & 0.0000 & $0.000 E+00$ & 0.0000 & $0.000 E+00$ & 0.0000 & 4.209E-22 & 0.0000 \\
\hline & & & & & & & & 0.0 & & 000 & & .0000 \\
\hline$i-6$ & $1.642 E-08$ & 0.0074 & $6.706 E-10$ & 0.0 & -09 & & & & & & & 1620 \\
\hline & 0.0 & 0.0000 & $0.000 E+00$ & 0.0000 & $O E E+00$ & 0.0000 & $0.000 E+00$ & 0.0000 & $0 E+00$ & 000 & 7. & 000 \\
\hline & & & & & & & & 0.0000 & & 000 & 8.3 & 1000 \\
\hline 10 & 5.27 & & $E-16$ & & & & & & -17 & 0.0000 & -15 & 0.0000 \\
\hline & $E+00$ & & $0.000 E+00$ & 0.0000 & $0 \mathrm{E}+00$ & 0.0000 & $O O E+0 O$ & & $=+00$ & & & \\
\hline & & & $=+00$ & & $E+00$ & 0.0000 & $+\infty 0$ & 0.0000 & $\$+00$ & 0.0000 & & 392 \\
\hline & 0.00 & & +00 & & $\varepsilon+00$ & 0.0 & $E+00$ & 0.0000 & $0.000 E+00$ & 0.0000 & 2. & 1093 \\
\hline & & & 1.74 & 0. & 1. & & & & $E-17$ & & & \\
\hline & & & & & & & & & & 0000 & & 000 \\
\hline & $1.928 E-22$ & & 9.2 & & $=-23$ & 0.0000 & -25 & 0.0000 & E-26 & 0.0000 & -21 & 0.0000 \\
\hline & $6.964 E-18$ & & 3.1 & & & & & & & & -17 & 0000 \\
\hline & $9.370 E-15$ & & $27 E-16$ & & $F-15$ & 0.0 & & & & & & \\
\hline & $1.065 E-22$ & & $26 E-24$ & & $E-23$ & 0.0 & & & & 00 & $E-22$ & 0000 \\
\hline & $5.672 E-14$ & & $=-16$ & & $8.448 E-15$ & 0.0 & $3.589 E-16$ & & $1.836 E-15$ & 0.0000 & $6.804 \mathrm{E}-14$ & 0.0000 \\
\hline & & & & & & & & & & & & 0.0018 \\
\hline 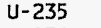 & $198 E-13$ & 0.0000 & $.384 E-15$ & 0.0000 & 政 & 0.0000 & & & & & 1. & 000 \\
\hline & & & & & & & & & & & & 0.0000 \\
\hline & & & & & & & & & & & & \\
\hline & & 0.0090 & $6.868 E-10$ & 0.0003 & $3.122 E-09$ & 0.0014 & $1.637 E-09$ & 0.0007 & $1.06 \pi-00$ & 0.0085 & $2.211 \mathrm{E}-06$ & 1.0000 \\
\hline
\end{tabular}

** Sum of water independent ground, inhalation, plant, meat, milk, soil

and water dependent water, fish, plant, meat, milk pathways

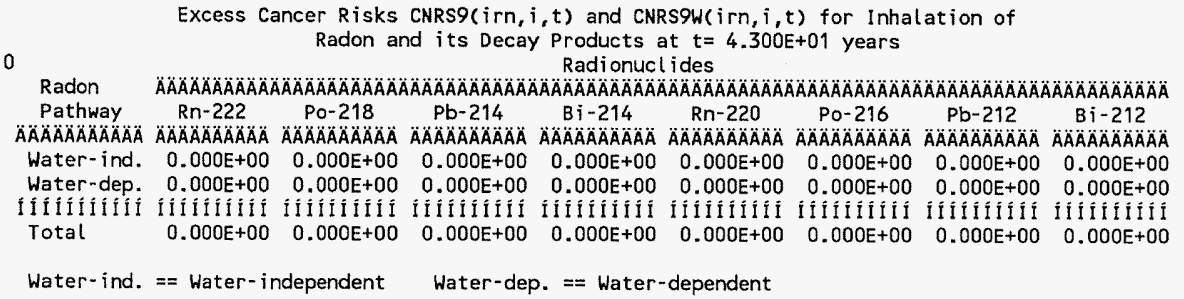

\begin{tabular}{|c|c|}
\hline \multirow{2}{*}{\multicolumn{2}{|c|}{$\begin{array}{l}\text { Attachment } \frac{9}{\text { Sriginator: S.W. Clark }} \quad \text { Sheet No. } 30 \text { of } 43 \\
\text { Date }\end{array}$}} \\
\hline & \\
\hline Chk'd By M. W. Perrott & Date \\
\hline $0100 F-C A-V 0280$ & Rev. No. \\
\hline
\end{tabular}




\section{ATTACHMENT 9}

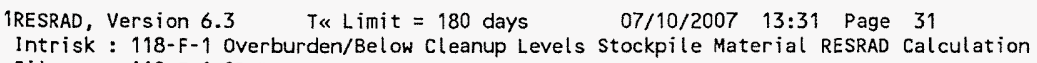

Total Excess Cancer Risk CNRSI $(i, p, t)^{* * *}$ for Initially Existent Radionuclides (i) and Pathways ( $p$ ) and Fraction of Total Risk at $t=4.300 E+01$ years

Water Dependent Pathways

\begin{tabular}{|c|c|c|c|c|c|c|c|c|c|c|c|c|c|c|}
\hline \multirow{2}{*}{ 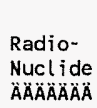 } & \multicolumn{2}{|c|}{$\begin{array}{c}\text { Water } \\
\text { ÄÄÄÄÄÄÄÄÄÄÄÄÄÄ }\end{array}$} & \multicolumn{2}{|c|}{$\begin{array}{c}\text { Fish } \\
\text { ÄÄAAAAAAAAAOAOAAAAOA }\end{array}$} & \multicolumn{2}{|c|}{$\begin{array}{c}\text { Radon } \\
\text { AAAAAAAAAAAAAAAAAAAAAAAA }\end{array}$} & \multicolumn{2}{|c|}{ 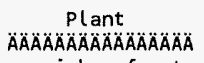 } & \multicolumn{2}{|c|}{$\begin{array}{c}\text { Meat } \\
\text { AÄAAAAAAOÄÄÄÄÄÄÄ }\end{array}$} & \multicolumn{2}{|c|}{$\begin{array}{c}\text { Milk } \\
\text { AAAAAAAOAOAOAOAOAOAAA }\end{array}$} & \multicolumn{2}{|c|}{ 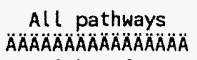 } \\
\hline & $\begin{array}{c}\text { risk } \\
\text { AAAAAOAAOAOA }\end{array}$ & $\begin{array}{l}\text { fract. } \\
A A B A O A O A\end{array}$ & $\begin{array}{c}\text { risk } \\
\text { ÄAAAAAAAAAA }\end{array}$ & $\begin{array}{l}\text { fract. } \\
A B A A O A B A\end{array}$ & ÄÄÄÄÄÁÄÄ & & $\begin{array}{c}\text { risk } \\
\text { ÄÄÄÄÄAOAO }\end{array}$ & & $\begin{array}{c}\text { risk } \\
\triangle A A B A A A A O A A B\end{array}$ & & $\begin{array}{c}\text { risk } \\
\text { ĀAAAAAAAAAÄ }\end{array}$ & & $\begin{array}{c}\text { risk } \\
A B A A A A A A A\end{array}$ & \\
\hline & & & & & & & & & & & & & & \\
\hline & & & & & & & & & & & & & & \\
\hline & & & & & & & & & & & & & & \\
\hline & & & & & & & & & & & & & & \\
\hline & & & & & & & & & & & & & & \\
\hline & & & & & & & & & & & & & & \\
\hline $1-$ & & & & & & & & & & & & & & \\
\hline & & & & & & & & & & & & & & \\
\hline & & & & & & & & & & & & & & \\
\hline & & & & & & & & & & & & & & \\
\hline & & & & & & & & & & & & & & \\
\hline & & & & & & & & & & & & & & \\
\hline & & & & & $0005++00$ & & & & & & & & & \\
\hline
\end{tabular}

***CNRSI $(i, p, t)$ includes contribution from decay daughter radionuclides

\begin{tabular}{ll} 
Attachment $\frac{9}{\text { S.W. Clark }}$ & Sheet No. $\underline{31}$ of $\underline{43}$ \\
Originator: & Date \\
Chk'd By & Date \\
Calc. No. N. Perrott & Rev. No. $\quad 0$ \\
\hline 0100 F-CA-V0280 & Reve
\end{tabular}




\section{ATTACHMENT 9}

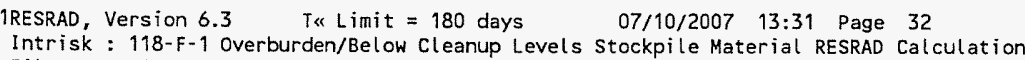

Water-ind. == Water-independent Water-dep. = = Water-dependent

\begin{tabular}{|c|c|}
\hline \multirow{2}{*}{\multicolumn{2}{|c|}{ 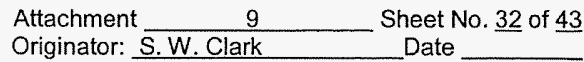 }} \\
\hline & \\
\hline Chk'd By M.W. Perrott & Date \\
\hline $0100 F-C A-V 0280$ & Rev. No. 0 \\
\hline
\end{tabular}




\section{ATTACHMENT 9}

\begin{tabular}{|c|c|c|c|c|c|c|c|c|c|c|c|c|}
\hline $\begin{array}{l}\text { 1RESRAD, } \\
\text { Intrisk } \\
\text { File }\end{array}$ & \multicolumn{4}{|c|}{$\begin{array}{l}\text { Version } 6.3 \quad \text { T\& Limit }=180 \text { day } \\
: 118-F-1 \text { Overburden/Below Cleanup } \\
: 118-F-1 \text { OB-BCL.RAD }\end{array}$} & \multicolumn{6}{|c|}{$\begin{array}{l}\text { 07/10/2007 13:31 Page } 33 \\
\text { Stockpile Material RESRAD Calculation }\end{array}$} & & \\
\hline & \multicolumn{12}{|c|}{$\begin{array}{c}\text { Excess Cancer Risks CNRS }(i, p, t) \text { for Individual Radionuclides }(i) \text { and Pathways }(p) \\
\text { and Fraction of Total Risk at } t=1.350 E+02 \text { years }\end{array}$} \\
\hline & \multirow{2}{*}{\multicolumn{2}{|c|}{$\begin{array}{c}\text { Ground } \\
\text { AÄÄAOAOAAOAAÄÄÄÄA }\end{array}$}} & \multirow{2}{*}{\multicolumn{2}{|c|}{ 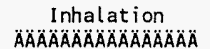 }} & \multirow{2}{*}{\multicolumn{2}{|c|}{$\begin{array}{l}\text { Plant } \\
\text { ÄAAAAAAAAAAAAAA }\end{array}$}} & \multirow{2}{*}{\multicolumn{2}{|c|}{$\begin{array}{c}\text { Meat } \\
\text { AEAABAAAAAAA }\end{array}$}} & \multicolumn{2}{|c|}{ Milk } & \multicolumn{2}{|l|}{ soil } \\
\hline & & & & & & & & & $\triangle \triangle A ั A ̈ A ̈ A ̈ A ̈ A ̈ A ̈$ & $\because ̈ A ̈ A ̈ A O A O A$ & ÄAAÄAOÄÄA & ÄÄÄÄÄÄ \\
\hline $\begin{array}{l}\text { Nucl ide } \\
\triangle A O A B A ̈ A ̈ A ̈ A\end{array}$ & $\begin{array}{c}\text { risk } \\
\text { ÄÄÄÄÄÄAOÄ }\end{array}$ & $\begin{array}{l}\text { fract. } \\
\text { AAAAAA }\end{array}$ & $\begin{array}{c}r \text { risk } \\
\text { ÄÄÄÄÄÄÄA }\end{array}$ & $\begin{array}{l}\text { fract. } \\
\ddot{A} \ddot{A} A \ddot{A} A \ddot{A} \ddot{A}\end{array}$ & $\begin{array}{l}\text { isk } \\
\text { ÄÄÄÄA }\end{array}$ & $\begin{array}{l}\text { fract. } \\
\text { ÄAAAAAA }\end{array}$ & 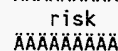 & & $\begin{array}{c}\text { risK } \\
\text { AAAAÄAAAA }\end{array}$ & fract. & $\begin{array}{l}\text { risk } \\
\text { AAAOAAOAOA }\end{array}$ & \\
\hline & & 0.0000 & & & & & & 0.0000 & & & & \\
\hline & & & & & & & & 0.0008 & & & -10 & 001 \\
\hline & & & & & & & & & & & & \\
\hline & & & & & & & & & & & & \\
\hline & & & & & & & & & & & & \\
\hline & & & & & & & & & & & & \\
\hline & & & & & & & & & & & & \\
\hline & & & & & & & & & & & & \\
\hline $\mathrm{H}-\mathrm{C}-\mathrm{Ca}-\mathrm{C}$ & & & & & & & & & & & & \\
\hline & & & & & & & & & & & & \\
\hline & & & & & & & & & & & & \\
\hline & & & & & & & & & & & & \\
\hline & & & & & & & & & & & & \\
\hline & & & & & & & & & & & & \\
\hline & & & & & & & & & & & & \\
\hline & & & & & & & & & & & & \\
\hline & & & & & $E-14$ & & & & & & & \\
\hline & & & & & & & & & & & & \\
\hline & & & & & & & & & & & & \\
\hline & & & & & $E-17$ & & & & & & & \\
\hline & & & & & & & & & & & & \\
\hline & & & & & 8 & & & & & & & \\
\hline & & & & & & & & & & & & \\
\hline & & & & & $50 E-11$ & & & 0.0000 & & 000 & 8. & 0.0000 \\
\hline & & & & & & & & & & & & \\
\hline & & & & & & & & & & & & \\
\hline & & & & & 111111 & & & & & & & \\
\hline Total & & & $1.343 E-08$ & 0.0104 & T. $/ 25 \mathrm{EE}-0 /$ & 0.1343 & $1.141 \mathrm{E}-08$ & 5.0085 & $1.0 \angle 3 E=U /$ & 0.0196 & 1.56rE-Or & 0.1220 \\
\hline
\end{tabular}

\begin{tabular}{|c|c|}
\hline Attachment & Sheet No. $\underline{33}$ of 43 \\
\hline Originator: S.W. Clark & Date \\
\hline Chk'd By _ M. W. Perrott & Date \\
\hline $0100 F-C A-V 0280$ & Rev. No. \\
\hline
\end{tabular}




\section{ATTACHMENT 9}

1RESRAD, Version $6.3 \quad$ T $\ll$ Limit $=180$ days $\quad 07 / 10 / 2007 \quad 13: 31$ Page 34
Intrisk : $118-F-1$ Overburden/Below Cleanup Levels stockpile Material RESRAD Calculation

File : $118-F-1$ OB-BCL.RAD

Excess Cancer Risks CNRS $(i, p, t)$ for Individual Radionuclides (i) and Pathways $(p)$ and Fraction of Total Risk at $t=1.350 E+02$ years

Water Dependent Pathways

\begin{tabular}{|c|c|c|c|c|c|c|c|c|c|c|c|c|}
\hline & $\begin{array}{r}\text { Water } \\
\text { ÄÄÄÄÄÄÄÄA }\end{array}$ & P & $\begin{array}{r}\text { Fish } \\
\triangle A O A O A A O A B A O A\end{array}$ & ÄÄÄÄÄ & $\begin{array}{r}P l a n \\
A \text { ÁÄÄÄÄÄÄÄÄ }\end{array}$ & İ & $\begin{array}{r}\text { Meat } \\
\text { AिÄÄÄÄÄÄÄA }\end{array}$ & ÄÄÄÄÄ & $\begin{array}{r}M i l k \\
\triangle A A O A A O A A B A O A\end{array}$ & GÄĀÄÄÄÄ & $\begin{array}{r}\text { All Pat } \\
\text { ÄAAAOAAAAAA }\end{array}$ & $\begin{array}{l}\text { Ways *** } \\
\text { ÄÄÄÄÄA }\end{array}$ \\
\hline $\begin{array}{l}\text { Jclide } \\
\qquad \ddot{A B A B A B A ̈}\end{array}$ & $\begin{array}{c}\text { risk } \\
\text { ÄÄÄÄÄÄA }\end{array}$ & $\begin{array}{l}\text { fract. } \\
\triangle A B A ̈ A ̈ A ̈ A\end{array}$ & $\begin{array}{c}\text { risk } \\
\text { ÄÄÄÄAAÄÄ }\end{array}$ & $\begin{array}{l}\text { fract. } \\
A B A A A B A\end{array}$ & $\begin{array}{c}\text { risk } \\
\text { ÄÄÄÄÄÄÄÄ }\end{array}$ & $\begin{array}{l}\text { fract. } \\
\text { ÄÄÄÄÄÄ }\end{array}$ & $\begin{array}{c}\text { risk } \\
\text { ÄÄÄÄÄÄÄÄ }\end{array}$ & $\begin{array}{l}\text { fract. } \\
A \not A A A A A O A\end{array}$ & $\begin{array}{c}\text { risk } \\
\text { ÄAAAAAAAAÄ }\end{array}$ & $\begin{array}{l}\text { fract. } \\
\text { ÄÄÄÄÄ }\end{array}$ & $\begin{array}{c}\text { risk } \\
\text { AिÄÄÄÄÄA }\end{array}$ & $\begin{array}{l}\text { fract. } \\
\text { ÄÄÄÄÄA }\end{array}$ \\
\hline & & & $5.648 E-17$ & 0.0000 & & 0.0000 & $1.202 E-18$ & 0.0000 & $2.709 E-18$ & 0.0000 & $3.439 E-15$ & 0.0000 \\
\hline & & & $0.000 E+00$ & 0.0000 & $.000 E+00$ & 0.0000 & $0.000 \mathrm{E}+00$ & & & & & \\
\hline & $0.000 E+00$ & 0.0000 & $0.000 E+00$ & 0.0000 & $.000 E+00$ & 0.0000 & $0.000 E+00$ & 0.0000 & $0.000 E+00$ & 0.0000 & $2.143 E-07$ & 1668 \\
\hline & & & $0 E+00$ & 0.0000 & $E E+00$ & 0.0000 & $.000 E+00$ & 0.0000 & $0.000 E+00$ & 0.0000 & $0.000 E+00$ & 0.0000 \\
\hline & & & & & & & $.799 E-18$ & & $8 E-19$ & 0.0000 & & \\
\hline & $0.000 E+00$ & & $.000 E+00$ & & $0 E+00$ & & $D O E+00$ & & & & & \\
\hline & $E+00$ & & $D O E+00$ & 0.0 & $O E+00$ & 0.0000 & $0.000 E+00$ & 0.0000 & $D O E+00$ & & & \\
\hline & $E+00$ & & $D O E+00$ & 0.0000 & $O E+O O$ & 0.0000 & $.000 E+00$ & 0.0000 & $0.000 E+00$ & 0.0000 & & 000 \\
\hline & & & & & & & $.000 E+00$ & & & & & \\
\hline - & 2.1 & & $=-10$ & & & & $=-09$ & & & & & \\
\hline & $E+00$ & & $O E+00$ & 0.0000 & $\mathrm{BE}+00$ & & $0.000 E+00$ & & $D E+00$ & & & \\
\hline & & & & & -17 & & -17 & 0.0 & & & & \\
\hline & 2.9 & & & & & & & & -16 & 0.0000 & & \\
\hline & $E+00$ & & $O E+00$ & 0.0 & $\mathrm{E}+00$ & & $E+00$ & & +00 & & & \\
\hline & & & $E+00$ & 0.0 & $+\infty$ & & +00 & & $=+\infty$ & & & \\
\hline & & & $+\infty 0$ & & $:+\infty$ & 0.0 & +00 & 0.0000 & $E+00$ & 0.0000 & & \\
\hline & 2.32 & & -16 & & -15 & & & & & & & \\
\hline & & & & & -21 & & -22 & & & & & \\
\hline & & & & & $E-22$ & & & & & & & \\
\hline & 2.299 & & & & $=-17$ & & & & $E-19$ & 0.0000 & & 1000 \\
\hline & & & & & SE-14 & & & & & & & \\
\hline & & & & & $1 E-22$ & & & & & & & \\
\hline & $7.027 \mathrm{E}-1$ & & & 0.0000 & $1.048 E-13$ & 0.0000 & $4.472 E-15$ & 0.0000 & $2.281 E-14$ & 0.0 & $8.405 E$ & \\
\hline & & & & & & & & & & & & \\
\hline & & & & & & & & & & & & \\
\hline & & & & & & & & & & & & \\
\hline & & & & & & & & & & & & \\
\hline & & & & & & & & & & & & \\
\hline
\end{tabular}

** Sum of water independent ground, inhalation, plant, meat, milk, soil

and water dependent water, fish, plant, meat, milk pathways

Excess Cancer Risks CNRS9(irn, $i, t)$ and CNRSPW(irn, $i, t)$ for Inhalation of

Radon and $i$ ts Decay Products at $t=1.350 E+02$ years Radionucl ides

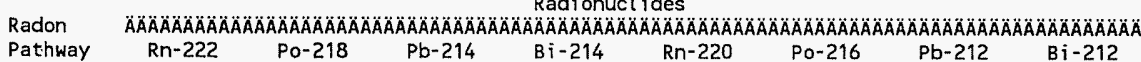

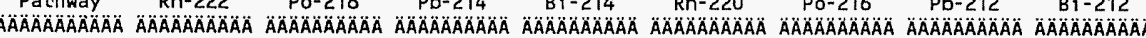

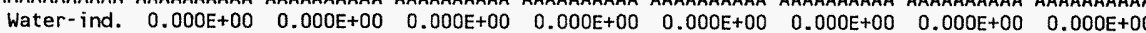

$\begin{array}{llllllllll}\text { Water-dep, } 0.000 E+00 & 0.000 E+00 & 0.000 E+00 & 0.000 E+00 & 0.000 E+00 & 0.000 E+00 & 0.000 E+00 & 0.000 E+00\end{array}$

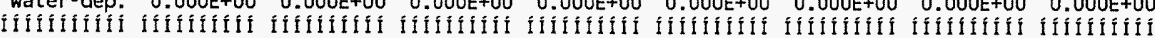

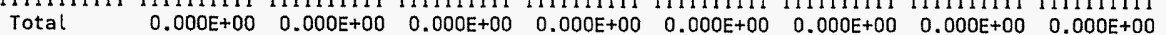

Water - ind. $==$ Water - independent Water-dep. $==$ Water-dependent

$\begin{array}{ll}\text { Attachment } \frac{9}{\text { O.W. Clark }} & \text { Sheet No. } \underline{34} \text { of } \underline{43} \\ \text { Originator: } & \text { Date } \\ \text { Chk'd By } & \text { Date } \\ \text { Calc. No. N. Perrott } & \text { Rev. No. } \quad 0\end{array}$




\section{ATTACHMENT 9}

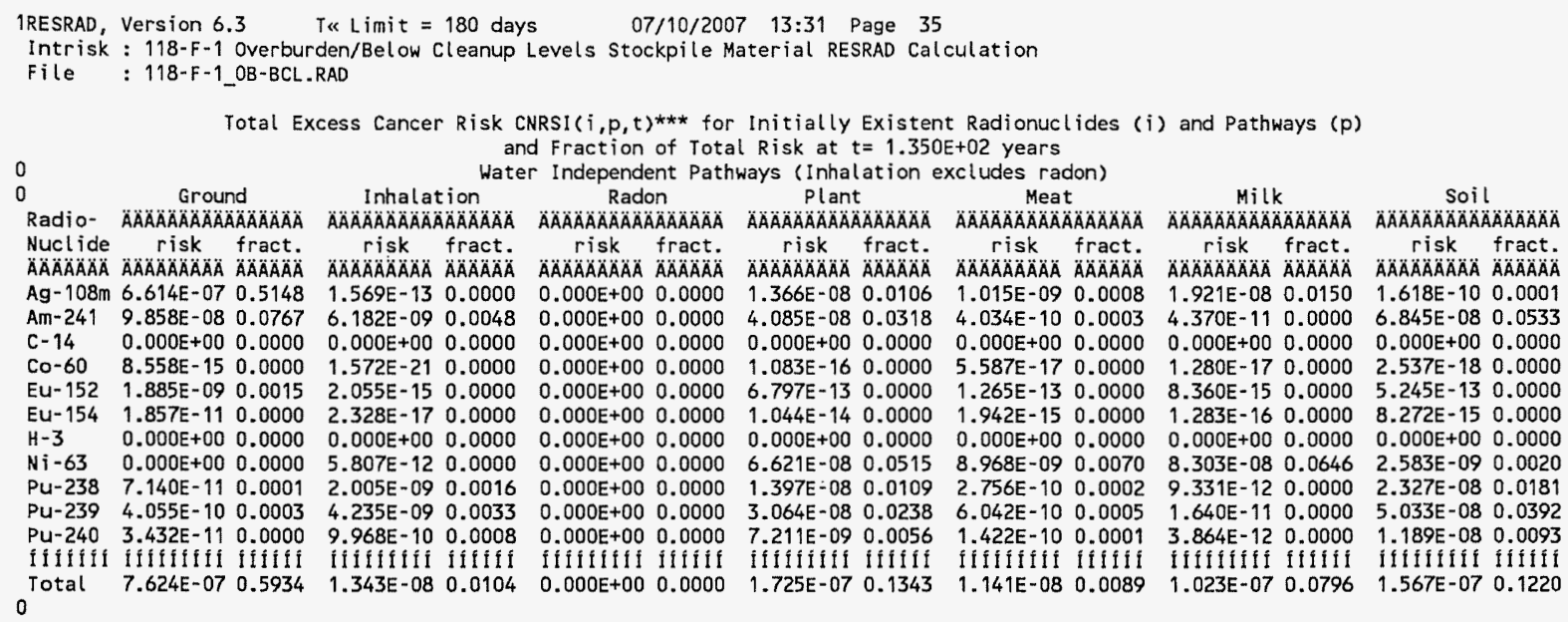

Total Excess Cancer Risk CNRSI $(i, p, t)^{\star \star *}$ for Initially Existent Radionuclides (i) and Pathways $(p)$ and Fraction of Total $R$ isk at $t=1.350 E+02$ years

Water Dependent Pathways

\begin{tabular}{|c|c|c|c|c|c|c|c|c|c|c|c|c|c|c|}
\hline \multirow{2}{*}{$\begin{array}{l}\text { Radio- } \\
\text { Nucl ide }\end{array}$} & \multicolumn{2}{|c|}{$\begin{array}{c}\text { Water } \\
\text { AÄÄÄÄÄÄÄÄÄAAÄA }\end{array}$} & \multicolumn{2}{|c|}{$\begin{array}{c}F i s h \\
\text { AAÄÄÄÄAOAOAOAOAOÄ }\end{array}$} & \multicolumn{2}{|c|}{$\begin{array}{c}\text { Radon } \\
\text { AAAOAAOAÄÄAOAOAAAAAA }\end{array}$} & \multicolumn{2}{|c|}{ 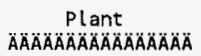 } & \multicolumn{2}{|c|}{$\begin{array}{c}\text { Meat } \\
\text { AAAAAAAOAOAOAAAAAAOA }\end{array}$} & \multicolumn{2}{|c|}{ 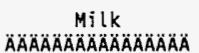 } & \multicolumn{2}{|c|}{$\begin{array}{c}A ! L \text { pathways } \\
A A A B A A A A B A O A B A A A A A\end{array}$} \\
\hline & $\begin{array}{c}\text { risk } \\
\text { ÄÄÄÄÄÄÄA }\end{array}$ & $\begin{array}{l}\text { fract. } \\
A \cap A B A B A\end{array}$ & $\begin{array}{c}\text { risk } \\
A A B A A A A B A\end{array}$ & $\begin{array}{l}\text { fract. } \\
\text { ÄÄÄÄÄA }\end{array}$ & $\begin{array}{c}\text { risk } \\
\text { ÄÄÄÄÄÄÄA }\end{array}$ & & $\begin{array}{c}\text { risk } \\
\text { ÄÄÄÄÄÄĀA }\end{array}$ & & $\begin{array}{c}\text { risk } \\
\text { ÂAAÄÄÄÄ }\end{array}$ & & $\begin{array}{c}\text { risk } \\
\text { ÄÄÄÄÄÄÄ }\end{array}$ & & $\begin{array}{c}\text { risk } \\
\text { ÄÄÄÄÄÄÄ }\end{array}$ & fract. \\
\hline & & & & & & & & & & & & & & \\
\hline & & & & & & & & & & & & & & \\
\hline & & & & & & & & & & & & & & \\
\hline & & & & & & & & & & & & & & \\
\hline & & & & & & & & & & & & & & \\
\hline & & & & & & & & & & & & & & \\
\hline & & & & & & & & & & & & & & \\
\hline & & & & & & & & & & & & & & \\
\hline & & & & & & & & & & & & & & \\
\hline & & & & & & & & & & & & & & \\
\hline & & & & & & & & & & & & & & \\
\hline & & & & & & & & & & & & & & \\
\hline & & & $9.412 E-10$ & & 0.0001 t UU & & $3.010 \mathrm{C}-\mathrm{U}$ & & & & C.210E-00 & & & \\
\hline
\end{tabular}

***CNRSI $(i, p, t)$ includes contribution from decay daughter radionuclides

\begin{tabular}{|c|c|}
\hline Attachment & Sheet No. $\underline{35}$ of $\underline{43}$ \\
\hline Originator: S.W. Clark & Date \\
\hline M. W. Perrott & Date \\
\hline $0100 F-C A-V 0280$ & Rev. No. \\
\hline
\end{tabular}




\section{ATTACHMENT 9}

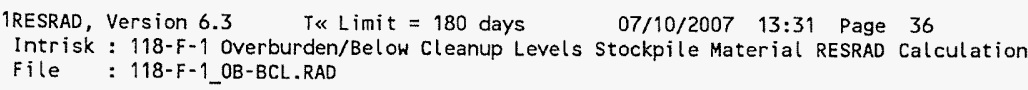

Water-ind. = $=$ Water-independent $\quad$ Water-dep. $==$ Water-dependent

\begin{tabular}{|c|c|}
\hline Attachment & Sheet No. $\underline{36}$ of $\underline{43}$ \\
\hline Originator: S.W. Clark & Date \\
\hline Chk'd By M. W. Perrott & Date \\
\hline $0100 F-C A-V 0280$ & Rev. No. \\
\hline
\end{tabular}




\section{ATTACHMENT 9}

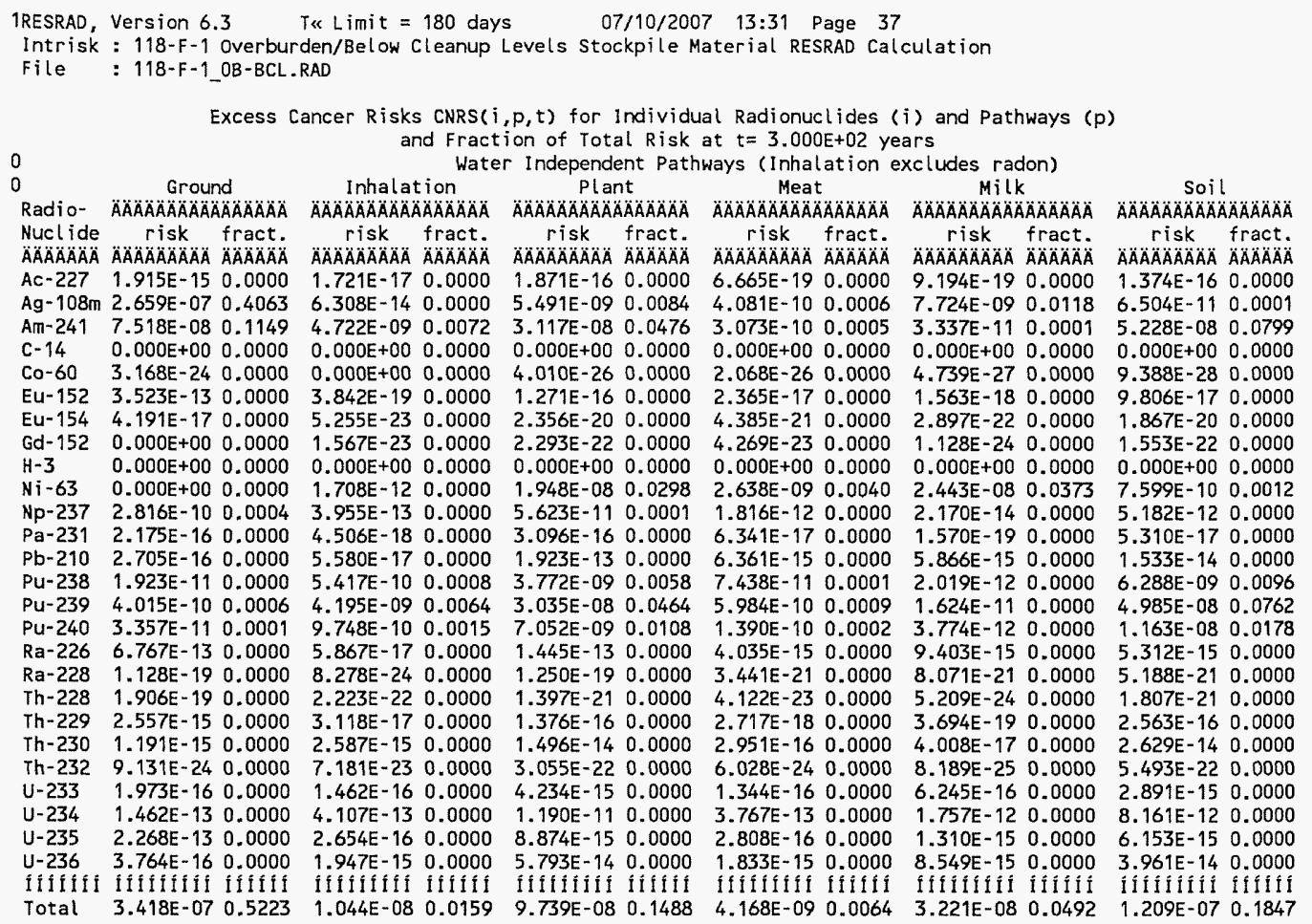




\section{ATTACHMENT 9}

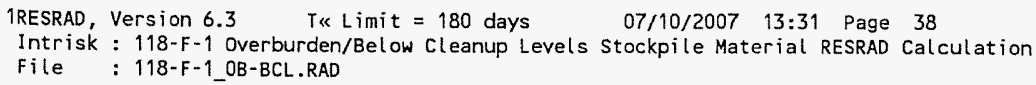

Water Dependent Pathways

\begin{tabular}{|c|c|c|c|c|c|c|c|c|c|c|c|c|}
\hline \multirow{2}{*}{$\begin{array}{l}\text { Radio- } \\
\text { Nucl ide } \\
A \text { ÄÄÄÄÄA }\end{array}$} & \multicolumn{2}{|c|}{ Water } & \multicolumn{2}{|c|}{ Fish } & $P$ lant & nt & $\begin{array}{r}\text { Meat } \\
\text { AXÄĀÄÄÄÄÁ }\end{array}$ & A & \multicolumn{2}{|c|}{ Milk } & \multicolumn{2}{|c|}{$\begin{array}{r}\text { All Pathways** } \\
\text { AAAAAAAAAAAAAAAAA }\end{array}$} \\
\hline & $\begin{array}{c}\text { risk } \\
\text { ÄÄÄÄÄÄÄA }\end{array}$ & $\begin{array}{l}\text { fract. } \\
\dddot{A} A \ddot{A} \ddot{A} \ddot{A} \ddot{A}\end{array}$ & $\begin{array}{c}\text { risk } \\
\triangle A A B A A B A\end{array}$ & $\begin{array}{l}\text { fract. } \\
A B A B A O A\end{array}$ & $\begin{array}{c}\text { risk } \\
\text { ÄÄÄÄÄÄ }\end{array}$ & fract. & $\begin{array}{c}\text { risk } \\
\text { AABÄÄÄÄ }\end{array}$ & fract. & $\begin{array}{c}\text { risk } \\
\text { ABAAABA }\end{array}$ & fract. & $\begin{array}{l}\text { risk } \\
\text { a }\end{array}$ & fract. \\
\hline & $1.626 \mathrm{E}-14$ & 0.0000 & & 0.0000 & $.412 E-15$ & 0.0000 & $7.339 E-18$ & 0.0000 & $749 \mathrm{E}-17$ & $\begin{array}{l}A \bar{A} \bar{A} \\
000\end{array}$ & AAAAAAAAA & \\
\hline & & & & 0.0000 & $.000 E+00$ & 0.0000 & $0.000 E+00$ & 0.0000 & $000 E+00$ & & & \\
\hline & $00 E+00$ & 0.0000 & $0.000 E+00$ & 0.0000 & $0.000 E+00$ & 0.0000 & $.000 E+00$ & 0.0000 & $0.000 E+00$ & 0.0000 & $1.637 \mathrm{E}-07$ & 0.2501 \\
\hline & & & $30 E+00$ & 0.0000 & $.000 E+00$ & 0.0000 & $.000 E+00$ & 0.0000 & $.000 E+00$ & 0.0000 & $0.000 E+00$ & 0.0000 \\
\hline & & & & & $.841 E-28$ & & $1.456 E-27$ & & $089 \mathrm{E}-28$ & & & .0000 \\
\hline & 0.00 & 0.0000 & $0.000 E+00$ & 0.0000 & $.000 E+00$ & & $0.000 E+00$ & & $.000 E+00$ & & & \\
\hline & $000 E+00$ & 0.0000 & $0.000 E+00$ & 0.0000 & $0.000 E+00$ & 0.0000 & $0.000 \mathrm{E}+00$ & & $0.000 E+00$ & & & \\
\hline & & & & & $.000 E+00$ & & $000 E+00$ & 0.0000 & $000 E+00$ & & 22 & 000 \\
\hline & & & $0 E+00$ & & $000 E+00$ & 0.0000 & $000 E+00$ & & & & & \\
\hline & $.371 \mathrm{E}$ & 0.0 & $E-10$ & 0.0 & $E-09$ & 0.0033 & -09 & & & & & \\
\hline & & & $+\infty$ & 0.0000 & $.000 E+00$ & 0.0000 & $0.000 E+00$ & 0.0 & & & & 005 \\
\hline & & & & & & & & & & & & 000 \\
\hline & 3 & & & & & & & & 14 & & & \\
\hline & +0 & & $E+00$ & 0.0 & $0.000 E+00$ & 0. & $\varepsilon+\infty$ & & +00 & & & \\
\hline & & & +00 & & $=+\infty$ & 0.0000 & +00 & 0.0 & & & $.08>-2$ & 305 \\
\hline & & & & & & & & 0.0000 & & & & 303 \\
\hline & 13 & & $.749 \mathrm{E}-15$ & & $=-14$ & & & & 14 & & & 0000 \\
\hline & & & & & $E-20$ & 0. & & & & & & \\
\hline & & & -22 & 0.0 & $2.969 E-21$ & 0.0000 & -23 & 0.0000 & & & & \\
\hline & & & & & $26 E-16$ & 0.0 & & 0.0 & 19 & 000 & -15 & 0.0000 \\
\hline & & & $O E-14$ & & $E-14$ & & & & & & & \\
\hline & & & $2.987 E-22$ & & $9.952 E-22$ & & & & & & & \\
\hline & & & $1.515 E-14$ & 0.0000 & $4.776 E-13$ & 0.0000 & $2.041 \mathrm{E}-14$ & 0.0000 & $1.040 E-13$ & & & 000 \\
\hline & & & & & $1.758 E-09$ & & & 0.00 & & 0.0006 & $1.407 \mathrm{E}-08$ & 0.0215 \\
\hline & & & & & $1.142 E-12$ & & & & & & & \\
\hline & & & & & & 0.0000 & & & & & & \\
\hline & & & & & & & 11111111 & & iffififif & 11111 & 1111111 & flifif \\
\hline & $34 E-00$ & & $6.162 E-10$ & 0.0009 & $.949 E-09$ & 0.0060 & $1.429 E-09$ & 0.0022 & $1.601 \mathrm{E}-08$ & 0.0245 & $6.544 E-07$ & 1.0000 \\
\hline
\end{tabular}

** Sum of water independent ground, inhalation, plant, meat, milk, soil

and water dependent water, fish, plant, meat, milk pathways

0

Excess Cancer Risks CNRS9( $i r n, i, t)$ and CNRSPW( $i r n, i, t)$ for Inhalation of Radon and its Decay Products at $t=3.000 E+02$ years

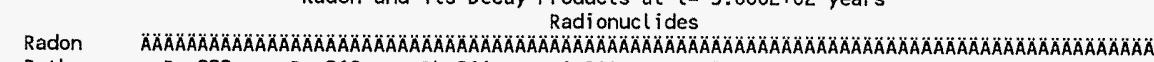
$\begin{array}{lllllll}\text { Pathway Rn-222 Po-218 Pb-214 } & \text { Bi-214 Rn-220 Po-216 Pb-212 Bi-212 }\end{array}$

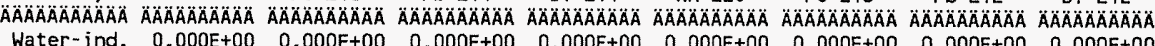

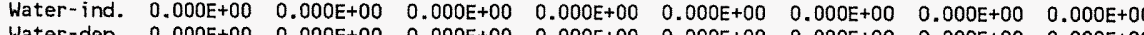
Water-dep. $\quad \begin{array}{llllllll}0.000 E+00 & 0.000 E+00 & 0.000 E+00 & 0.000 E+00 & 0.000 E+00 & 0.000 E+00 & 0.000 E+00 & 0.000 E+00\end{array}$

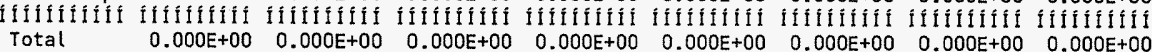

Water-ind. = Water - independent Water-dep. $==$ Water-dependent

$\begin{array}{ll}\text { Attachment } \frac{9}{\text { S.W. Clark }} & \text { Sheet No. } 38 \text { of } 43 \\ \text { Originator: } & \text { Date } \\ \text { Chk'd By } & \text { Date } \\ \text { Calc. N. Perrott } & \text { Rev. No. } \frac{0}{\text { O100F-CA-V0280 }}\end{array}$




\section{ATTACHMENT 9}

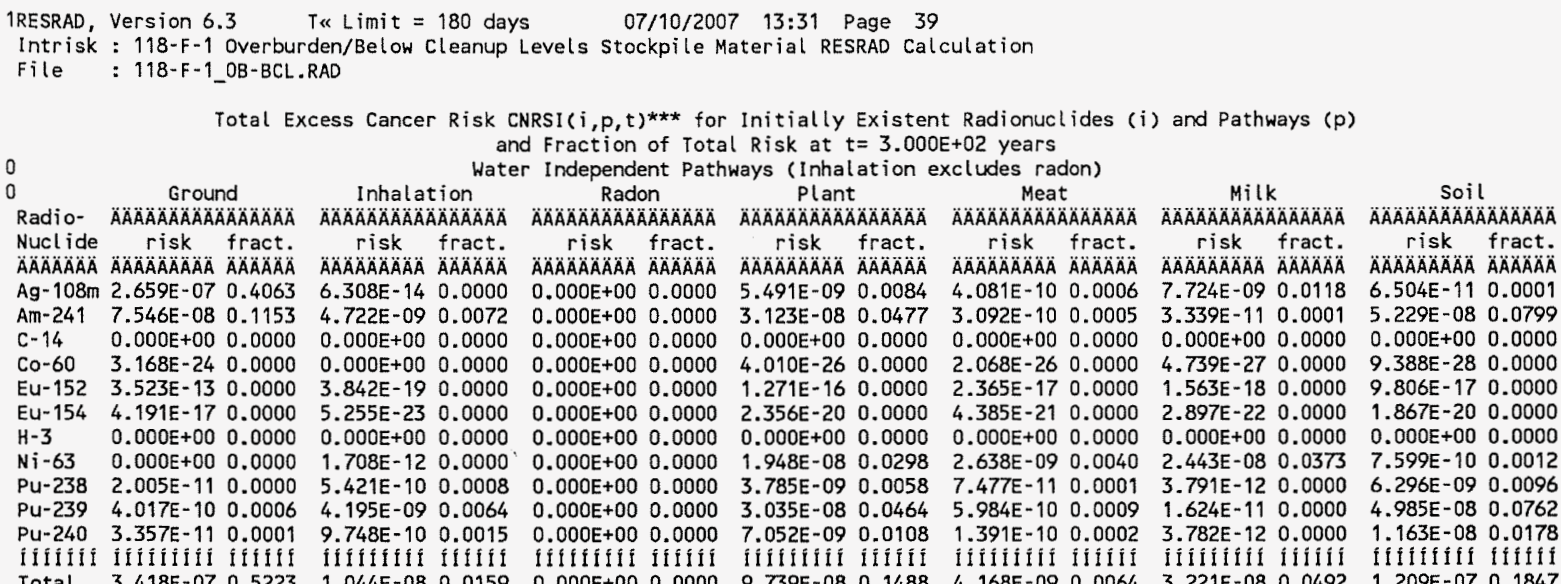

Total Excess Cancer Risk CNRSI $(i, p, t)^{* * *}$ for Initially Existent Radionuclides (i) and Pathways ( $p$ ) and Fraction of Total Risk at $t=3.000 E+02$ years

Water Dependent Pathways

\begin{tabular}{|c|c|c|c|c|c|c|c|c|c|c|c|c|c|c|}
\hline \multirow{2}{*}{$\begin{array}{l}\text { Radio- } \\
\text { Nucl ide } \\
\text { ÄAAAAAAAA }\end{array}$} & \multicolumn{2}{|c|}{ 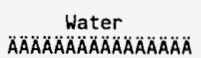 } & \multicolumn{2}{|c|}{ 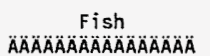 } & \multicolumn{2}{|c|}{ 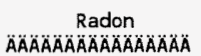 } & \multicolumn{2}{|c|}{$\begin{array}{c}\text { Plant } \\
\text { ANÄAAAOAOAOAOAOAOAOAOA }\end{array}$} & \multicolumn{2}{|c|}{$\begin{array}{c}\text { Meat } \\
\triangle A B A A B A B A A B A A B A A B A\end{array}$} & \multicolumn{2}{|c|}{$\begin{array}{c}M i L k \\
\text { AAAAAAAAAAOAOAOAOAOA }\end{array}$} & \multicolumn{2}{|c|}{ 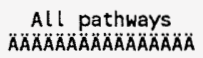 } \\
\hline & & $\begin{array}{l}\text { fract. } \\
\triangle A A B A B A B A\end{array}$ & risk & $\begin{array}{l}\text { fract. } \\
\triangle A B A A A A B\end{array}$ & risk & $\begin{array}{l}\text { fract. } \\
\text { ÄÄÄÄÄA }\end{array}$ & 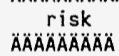 & & $\begin{array}{c}\text { risk } \\
A A B A A B A A B\end{array}$ & & $\begin{array}{c}\text { risk } \\
\text { AAAAAOAAOA }\end{array}$ & & $\begin{array}{c}\text { risk } \\
\triangle A ̈ A ̈ A ̈ A ̈ A ̈ A O A O A\end{array}$ & \\
\hline & & & & & & & & & & & & & & \\
\hline & & & & & & & & & & & & & & \\
\hline & & & & & & & & & & & & & & \\
\hline & & & & & & & & & & & & & & \\
\hline & & & & & & & & & & & & & & \\
\hline & & & & & & & & & & & & & & \\
\hline & & & & & & & & & & & & & & \\
\hline & & & & & & & & & & & & & & \\
\hline & & & & & & & & & & & & & & \\
\hline & & & & & & & & & & & & & & \\
\hline & & & & & & & & & & & & & & \\
\hline & & & & & & & & & & & & & & \\
\hline & & & & & & & $E-09$ & & & & $1.601 \mathrm{E}-08$ & 0.0245 & $4 t E-U /$ & \\
\hline
\end{tabular}

***CNRSI $(i, p, t)$ includes contribution from decay daughter radionuclides

\begin{tabular}{|c|c|c|}
\hline \multicolumn{2}{|c|}{ Attachment $\quad 9$} & \multirow{2}{*}{$\begin{array}{l}\text { Sheet No. } \underline{39} \text { of } \underline{43} \\
\text { Date }\end{array}$} \\
\hline Originator: & S.W. Clark & \\
\hline Chk'd By & M. W. Perrott & Date \\
\hline Calc. No. & $0100 F-C A-V 0280$ & Rev. No. \\
\hline
\end{tabular}




\section{ATTACHMENT 9}
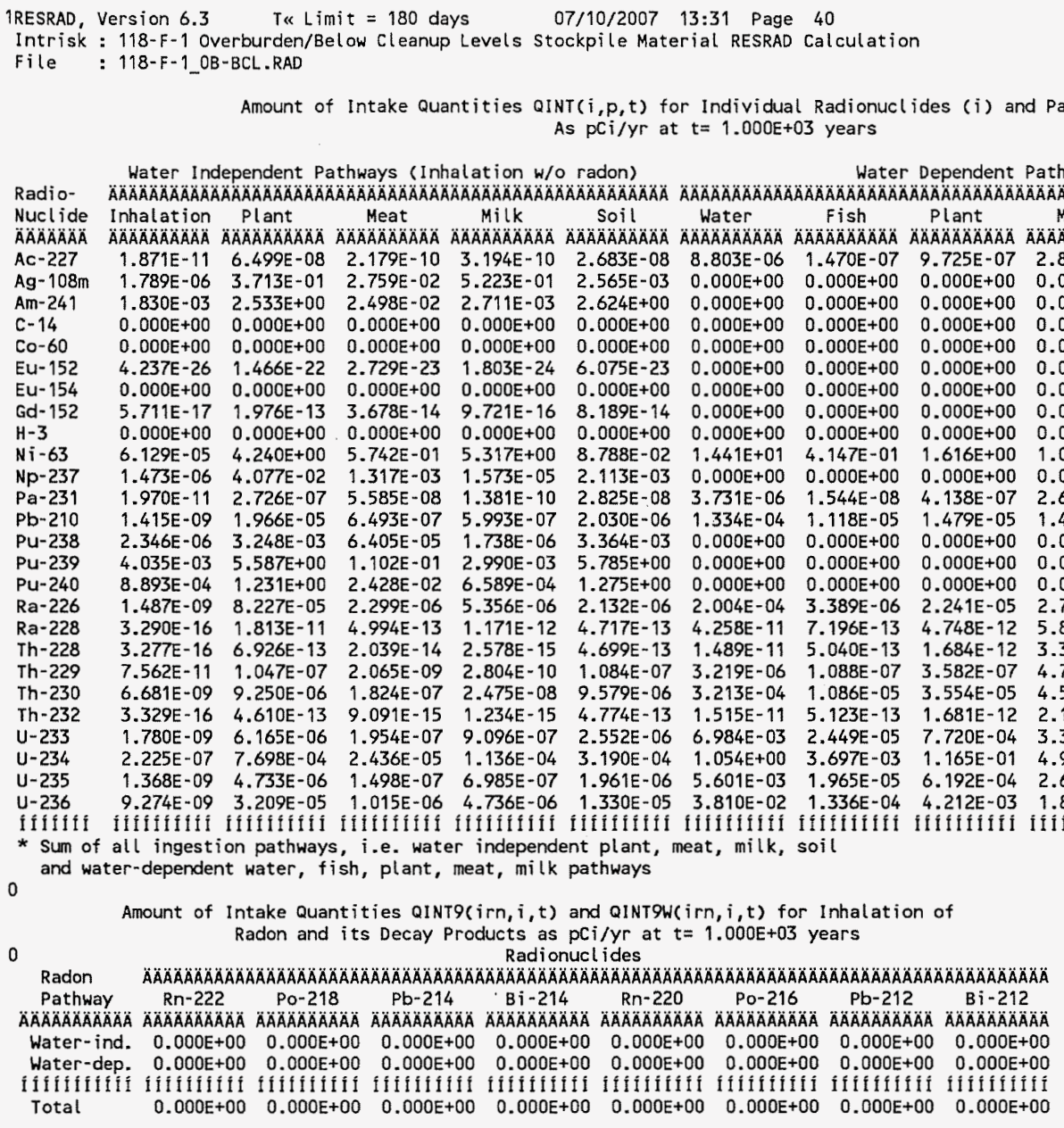

Water-ind. = Water-independent Water-dep. == Water-dependent

\begin{tabular}{|c|c|}
\hline Attachment & Sheet No. $\underline{40}$ of $\underline{43}$ \\
\hline Originator: $\mathrm{S} . \mathrm{W}$. Clark & Date \\
\hline Chk'd By M.W. Perrott & Date \\
\hline 0100F-CA-V0280 & Rev. No. \\
\hline
\end{tabular}




\section{ATT ACHMENT 9}

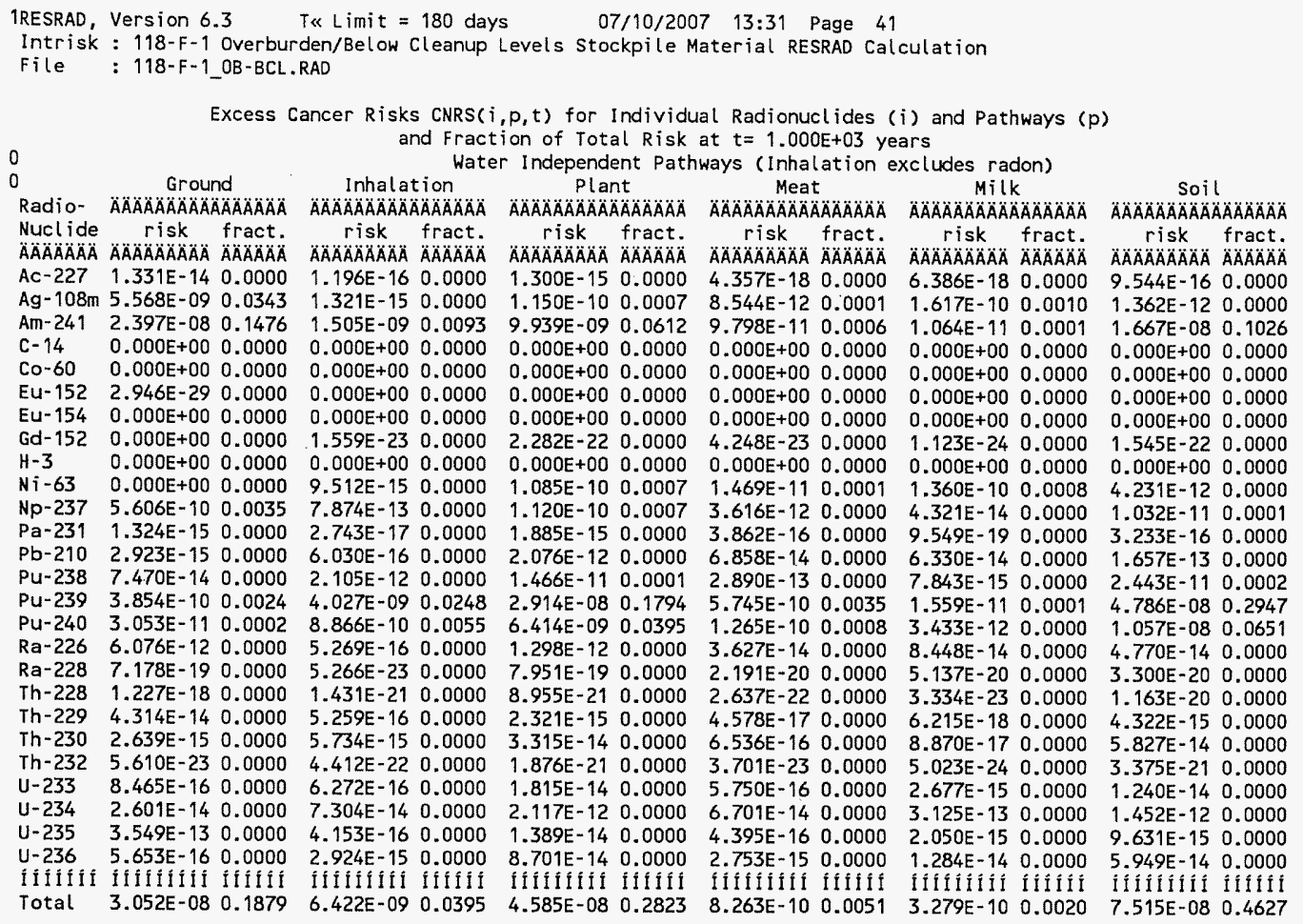

\begin{tabular}{|c|c|}
\hline Attachment & Sheet No. 41 of 43 \\
\hline Originator: S.W. Clark & Date \\
\hline Chk'd By M.W. Perrott & Date \\
\hline $0100 F-C A-V 0280$ & Rev. No. \\
\hline
\end{tabular}




\section{ATTACHMENT 9}

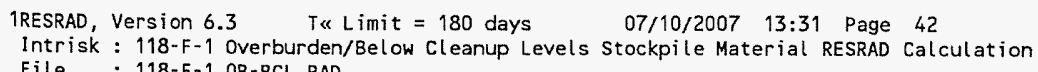

Water Dependent Pathways

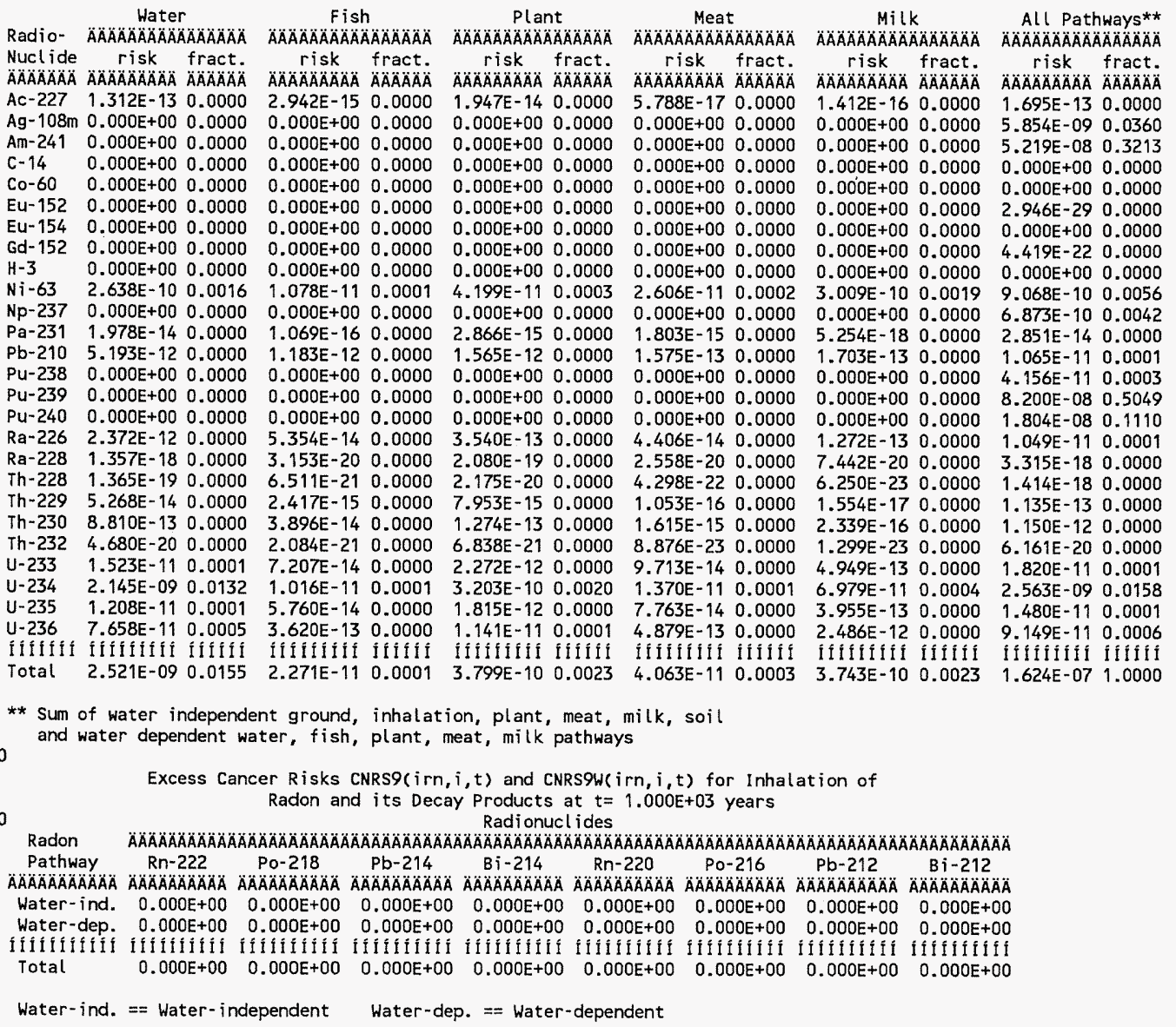

\begin{tabular}{|c|c|}
\hline Attachment & Sheet No. 42 of 43 \\
\hline Originator: S.W. Clark & Date \\
\hline Chk'd By M. W. Perrott & Date \\
\hline $0100 F-C A-V 0280$ & Rev. No. \\
\hline
\end{tabular}




\section{ATTACHMENT 9}

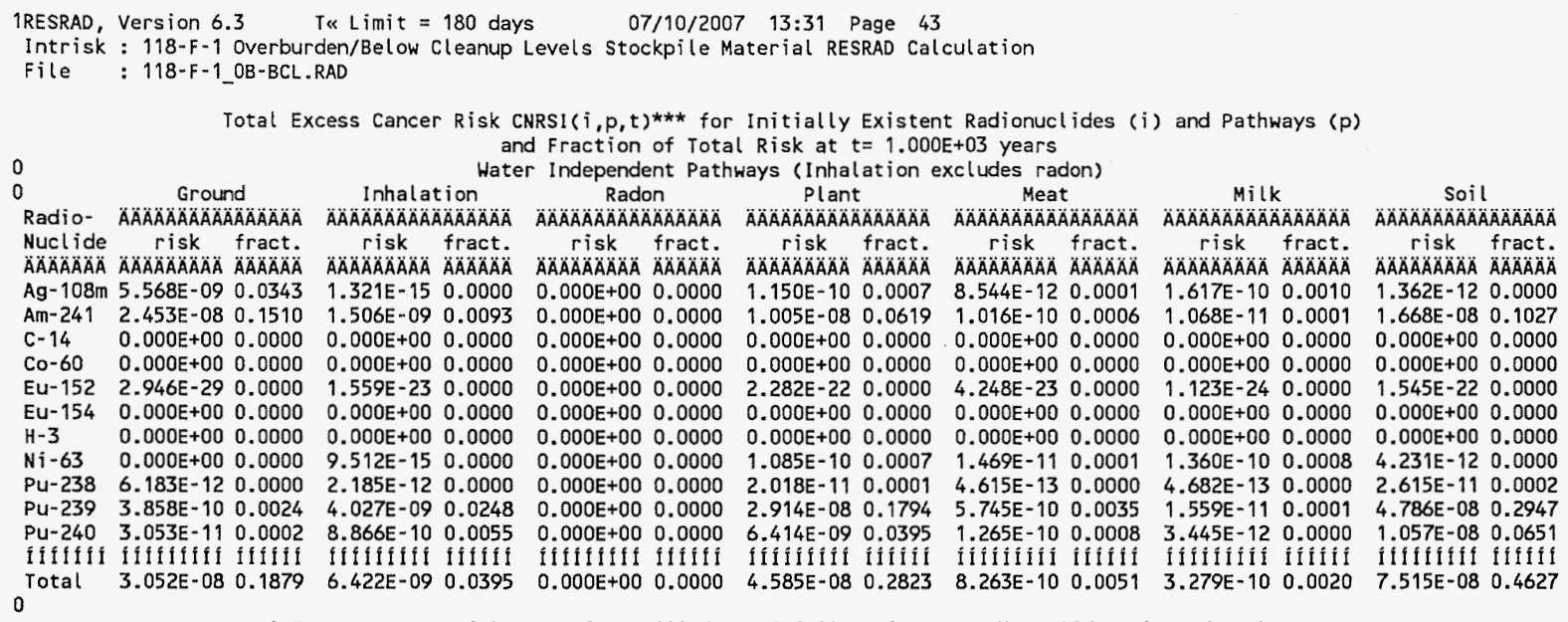
Total Excess Cancer Risk CNRSI $(i, p, t) * * *$ for Initially Existent Radionuclides $(i)$ and Pathways $(p)$
and Fraction of Total Risk at $t=1.000 E+03$ years

Water Dependent Pathways

\begin{tabular}{|c|c|c|c|c|c|c|c|c|c|c|c|c|c|c|}
\hline \multirow{2}{*}{$\begin{array}{l}\text { Radio- } \\
\text { Nuclide } \\
\ddot{A} \ddot{A} \ddot{A} \ddot{A} \ddot{A} A \ddot{A} A\end{array}$} & \multicolumn{2}{|c|}{$\begin{array}{c}\text { Water } \\
\text { AAAAAAAAAAOAOAOAOÄÄÄ }\end{array}$} & \multicolumn{2}{|c|}{$\begin{array}{c}\text { Fish } \\
\text { AisÄÄÄÄAOAOAOAOÄ }\end{array}$} & \multicolumn{2}{|c|}{$\begin{array}{c}\text { Radon } \\
\text { AAAOAOAOAOAOAOAOAOAOAOA }\end{array}$} & \multicolumn{2}{|c|}{ 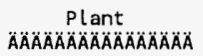 } & \multicolumn{2}{|c|}{ 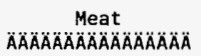 } & \multicolumn{2}{|c|}{ 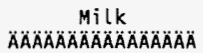 } & \multicolumn{2}{|c|}{ 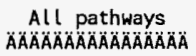 } \\
\hline & risk. & $\begin{array}{l}\text { fract. } \\
A B A B A B A B\end{array}$ & $\begin{array}{c}\text { risk } \\
\text { ÄÄÄÄÄÄÄÄ }\end{array}$ & $\begin{array}{l}\text { fract. } \\
A B A A A B A B\end{array}$ & risk & & $\begin{array}{c}\text { risk } \\
\text { ÄÄÄÄÄÄÄ }\end{array}$ & & $\begin{array}{c}\text { risk } \\
\text { ÄÄÄÄÄÄA }\end{array}$ & & $\begin{array}{c}\text { risk } \\
\text { ÄAAAAAAAA }\end{array}$ & & & \\
\hline & & & & & & & & & & & & & & \\
\hline & & & & & & & & & & & & & & \\
\hline & & & & & & & & & & & & & & \\
\hline & & & & & & & & & & & & & & \\
\hline & & & & & & & & & & & & & & \\
\hline & & & & & & & & & & & & & & \\
\hline & & & & & & & & & & & & & & \\
\hline & & & & & & & & & & & & & & \\
\hline & & & & & & & & & & & & & & \\
\hline & & & & & & & & & & & & & & \\
\hline & & & & & & & & & & & & & & \\
\hline & & & & & & & & & & & & & & \\
\hline & & & & & $0.000 E+00$ & & $3.1995-10$ & & $4.0000 \%$ & & $3.74 J 5-10$ & $0.00<3$ & & \\
\hline
\end{tabular}

***CNRSI $(i, p, t)$ includes contribution from decay daughter radionuclides

\begin{tabular}{|c|c|}
\hline Attachment & Sheet No. 43 of 43 \\
\hline Originator: S.W. Clark & Date \\
\hline Chk'd By M. W. Perrott & Date \\
\hline $0100 F-C A-V 0280$ & Rev. No. \\
\hline
\end{tabular}




\section{ATTACHMENT 10}

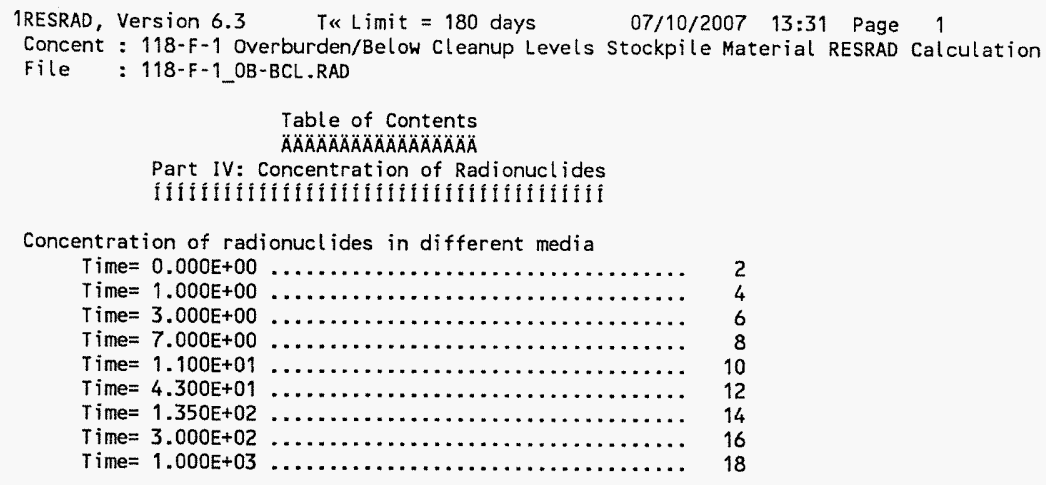

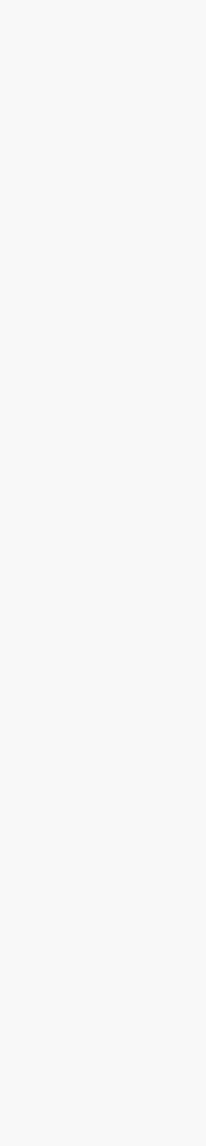

Attachment $\frac{10}{\text { Originator: S.W. Clark }}$ Sheet No. 1 of 19
Chk'd By

Calc. No. 0100F-CA-V0280 Rev. No. 0 


\section{ATTACHMENT 10}

\begin{tabular}{|c|c|c|c|c|c|c|}
\hline $\begin{array}{l}\text { RESRAD, } \\
\text { Concent } \\
\text { File }\end{array}$ & $\begin{array}{l}\text { Version } 6.3 \\
: 118-F-1 \text { OV } \\
: 118-F-1 / O B\end{array}$ & $\begin{array}{l}\text { T\& Lim } \\
\text { verburden/Be } \\
\text { B-BCL.RAD }\end{array}$ & $\begin{array}{l}\text { nit }=180 \text { da } \\
\text { elow Cleanup }\end{array}$ & $\begin{array}{l}\text { ays } \\
\text { P Levels Stc }\end{array}$ & \multicolumn{2}{|c|}{$\begin{array}{l}\text { 07/10/2007 13:31 Page } 2 \\
\text { stockpile Material RESRAD Calculation }\end{array}$} \\
\hline \multicolumn{7}{|c|}{$\begin{array}{c}\text { Concentration of radionuclides in environmental media } \\
\text { at } t=0.000 E+00 \text { years }\end{array}$} \\
\hline & $\begin{array}{l}\text { Contaminat- } \\
\text { ted Zone }\end{array}$ & $\begin{array}{c}\text { Surface } \\
\text { Soil* }\end{array}$ & $\begin{array}{l}\text { Air Par- } \\
\text { ticulate }\end{array}$ & $\begin{array}{l}\text { Well } \\
\text { Water }\end{array}$ & $\begin{array}{l}\text { Surface } \\
\text { Water }\end{array}$ & \\
\hline Radio- & $\triangle A O A A A A B A A O A$ & $\triangle A A A O A O A O A O A A A$ & $A A A A A A A A A B A$ & $A A A O A A A A A O A B$ & A $A A A A O A A A B A Z A ̈$ & \\
\hline Nucl ide & $p C i / g$ & $\mathrm{pCi} / \mathrm{g}$ & $\mathrm{pCi} / \mathrm{m}^{\star * 3}$ & $\mathrm{pCi} / \mathrm{L}$ & $\mathrm{pCi} / \mathrm{L}$ & \\
\hline$\triangle A A A A A A A ̈$ & $\triangle A A B A A A A O A O A$ & $\triangle A A A A A A A A B A A A$ & $\triangle A A A A A A A A A A A O A$ & $\triangle A A A A A A A A A A$ & $\triangle \triangle A A A A A A A B A O A B$ & \\
\hline$A c-227$ & $0.000 E+00$ & $0.000 E+00$ & $0.000 \mathrm{E}+00$ & $0.000 E+00$ & $0.000 E+00$ & \\
\hline $\mathrm{Ag}-108 \mathrm{~m}$ & $1.100 \mathrm{E}-02$ & $1.100 \mathrm{E}-02$ & $1.395 \mathrm{E}-07$ & $0.000 E+00$ & $0.000 E+00$ & \\
\hline$A m-241$ & $2.300 E-01$ & $2.300 E-01$ & $2.917 \mathrm{E}-06$ & $0.000 E+00$ & $0.000 E+00$ & \\
\hline$c-14$ & $1.900 \mathrm{E}+00$ & $1.900 \mathrm{E}+00$ & $2.409 E-05$ & $0.000 \mathrm{E}+00$ & $0.000 E+00$ & \\
\hline $\mathrm{Co}-60$ & $7.500 \mathrm{E}-03$ & $7.500 \mathrm{E}-03$ & $9.511 E-08$ & $0.000 E+00$ & $0.000 E+00$ & \\
\hline Eu-152 & 4.100E-02 & $4.100 E-02$ & 5.199E- 07 & $0.000 E+00$ & $0.000 E+00$ & \\
\hline Eu-154 & $1.800 \mathrm{E}-02$ & $1.800 E-02$ & $2.283 E-07$ & $0.000 \mathrm{E}+00$ & $0.000 E+00$ & \\
\hline Gd-152 & $0.000 E+00$ & $0.000 E+00$ & $0.000 E+00$ & $0.000 E+00$ & $0.000 \mathrm{E}+00$ & \\
\hline$H-3$ & $2.500 E+00$ & $2.500 E+00$ & $3.170 E-05$ & $0.000 E+00$ & $0.000 E+00$ & \\
\hline $\mathrm{Ni}-63$ & $2.500 \mathrm{E}+00$ & $2.500 E+00$ & $3.170 E-05$ & $0.000 E+00$ & $0.000 E+00$ & \\
\hline$N p-237$ & $0.000 E+00$ & $0.000 E+00$ & $0.000 E+00$ & $0.000 E+00$ & $0.000 E+00$ & \\
\hline$P a-231$ & $0.000 E+00$ & $0.000 \mathrm{E}+00$ & $0.000 E+00$ & $0.000 E+00$ & $0.000 \mathrm{E}+00$ & \\
\hline $\mathrm{Pb}-210$ & $0.000 E+00$ & $0.000 E+00$ & $0.000 \mathrm{E}+00$ & $0.000 \mathrm{E}+00$ & $0.000 E+00$ & \\
\hline Pu-238 & $1.600 \mathrm{E}-01$ & $1.600 E-01$ & $2.029 E-06$ & $0.000 E+00$ & $0.000 E+00$ & \\
\hline Pu-239 & $1.050 \mathrm{E}-01$ & $1.050 \mathrm{E}-01$ & $1.331 E-06$ & $0.000 \mathrm{E}+00$ & $0.000 E+00$ & \\
\hline Pu-240 & $2.500 \mathrm{E}-02$ & $2.500 E-02$ & $3.170 E-07$ & $0.000 E+00$ & $0.000 \mathrm{E}+00$ & \\
\hline $\mathrm{Ra}-226$ & $0.000 E+00$ & $0.000 E+00$ & $0.000 E+00$ & $0.000 E+00$ & $0.000 E+00$ & \\
\hline$R a-228$ & $0.000 E+00$ & $0.000 \mathrm{E}+00$ & $0.000 E+00$ & $0.000 E+00$ & $0.000 E+00$ & \\
\hline Th-228 & $0.000 E+00$ & $0.000 E+00$ & $0.000 E+00$ & $0.000 E+00$ & $0.000 E+00$ & \\
\hline Th-229 & $0.000 E+00$ & $0.000 E+00$ & $0.000 E+00$ & $0.000 E+00$ & $0.000 E+00$ & \\
\hline Th -230 & $0.000 \mathrm{E}+00$ & $0.000 E+00$ & $0.000 \mathrm{E}+00$ & $0.000 E+00$ & $0.000 E+00$ & \\
\hline Th-232 & $0.000 E+00$ & $0.000 E+00$ & $0.000 \mathrm{E}+00$ & $0.000 \mathrm{E}+00$ & $0.000 E+00$ & \\
\hline$U-233$ & $0.000 E+00$ & $0.000 E+00$ & $0.000 E+00$ & $0.000 \mathrm{E}+00$ & $0.000 E+00$ & \\
\hline$U-234$ & $0.000 E+00$ & $0.000 E+00$ & $0.000 E+00$ & $0.000 \mathrm{E}+00$ & $0.000 E+00$ & \\
\hline$U-235$ & $0.000 E+00$ & $0.000 E+00$ & $0.000 \mathrm{E}+00$ & $0.000 \mathrm{E}+00$ & $0.000 E+00$ & \\
\hline$U-236$ & $0.000 E+00$ & $0.000 E+00$ & $0.000 E+00$ & $0.000 E+00$ & $0.000 E+00$ & \\
\hline f f f fîi & AOAOA & OA & 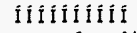 & 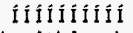 & Iَ1 & \\
\hline
\end{tabular}

*The Surface Soil is the top layer of soil within the user specified mixing zone/depth.

Concentrations in the media occurring in pathways that are suppressed are calculated using the current input parameters, i.e. using parameters appearing in the input screen when the pathways are active.

Concentration of $\mathrm{H}-3$ in soil moisture $=2.065 \mathrm{E}+01 \mathrm{pCi} / \mathrm{ml}$

Concentration of gaseous $\mathrm{H}-3$ in air $=4.055 \mathrm{E}+00 \mathrm{pCi} / \mathrm{m} * * 3$

Concentration of gaseous $\mathrm{C}-14$ in air $=9.789 \mathrm{E}+00 \mathrm{pCi} / \mathrm{m} * * 3$

\begin{tabular}{ll} 
Attachment $\frac{10}{\text { S. W. Clark }}$ & Sheet No. 2 of 19 \\
Originator: & Date \\
Chk'd By & Date \\
Calc. No. Nerrott & Rev. No. 0 \\
\hline
\end{tabular}




\section{ATTACHMENT 10}

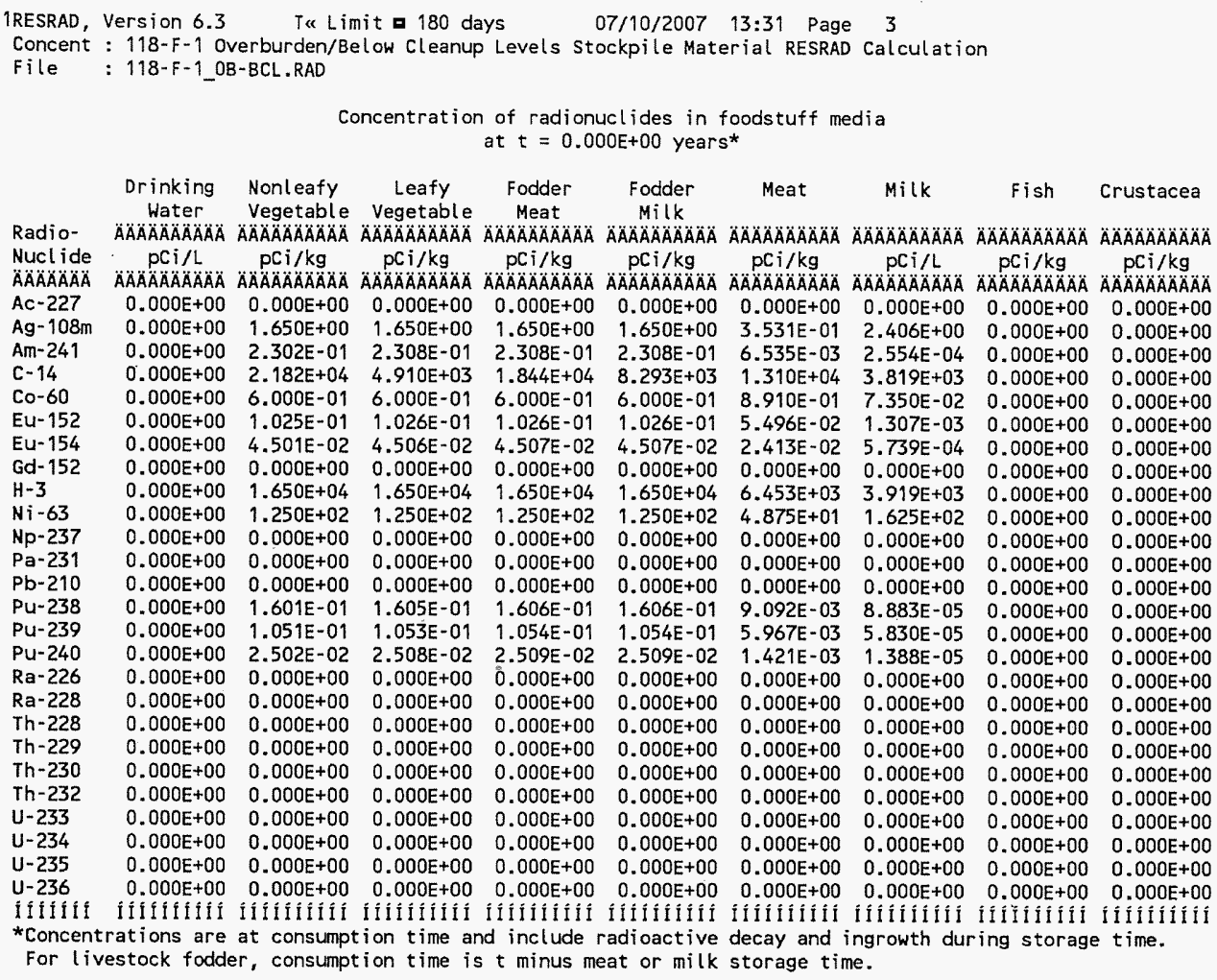

\begin{tabular}{|c|c|}
\hline \multirow{2}{*}{\multicolumn{2}{|c|}{$\begin{array}{l}\text { Attachment } \frac{10}{\text { Oriqinator: }} \text { S.W. Clark }\end{array}$}} \\
\hline & \\
\hline Chk'd By M. W. Perrott & Date \\
\hline $0100 F-C A-V 0280$ & Rev. No. \\
\hline
\end{tabular}




\section{ATTACHMENT 10}

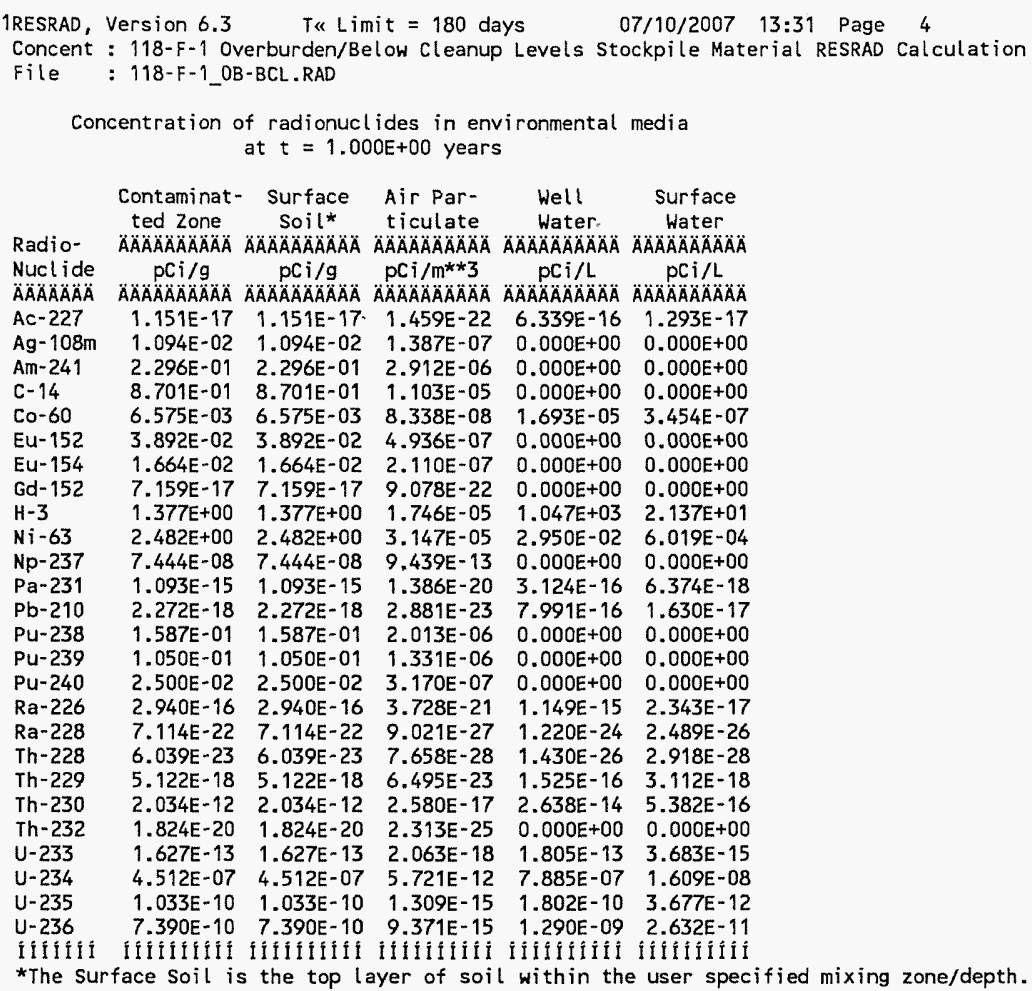

Concentrations in the media occurring in pathways that are suppressed are calculated using the current input parameters, i.e. using parameters appearing in the input screen when the pathways are active.

Concentration of $\mathrm{H}-3$ in soil moisture $=1.137 \mathrm{E}+01 \mathrm{pCi} / \mathrm{mL}$

Concentration of gaseous $\mathrm{H}-3$ in air $=2.234 \mathrm{E}+00 \mathrm{pCi} / \mathrm{m}^{* * 3}$

Concentration of gaseous $\mathrm{C}-14$ in air $=4.483 \mathrm{E}+00 \mathrm{pCi} / \mathrm{m}^{* * 3}$

\begin{tabular}{|c|c|}
\hline Attachment $\quad 10$ & Sheet No. 4 of 19 \\
\hline Originator: S.W. Clark & Date \\
\hline Shk'd By M. W. Perrott & Date \\
\hline $0100 F-C A-V 0280$ & Rev. No. \\
\hline
\end{tabular}




\section{ATTACHMENT 10}

IRESRAD, Version $6.3 \quad T \ll$ Limit $=180$ days $07 / 10 / 2007 \quad 13: 31$ Page 5

Concent : 118-F-1 Overburden/Below Cleanup Levels Stockpile Material RESRAD Calculation

File : 118-F-1 OB-BCL.RAD

Concentration of radionuclides in foodstuff media

at $t=1.000 E+00$ years*

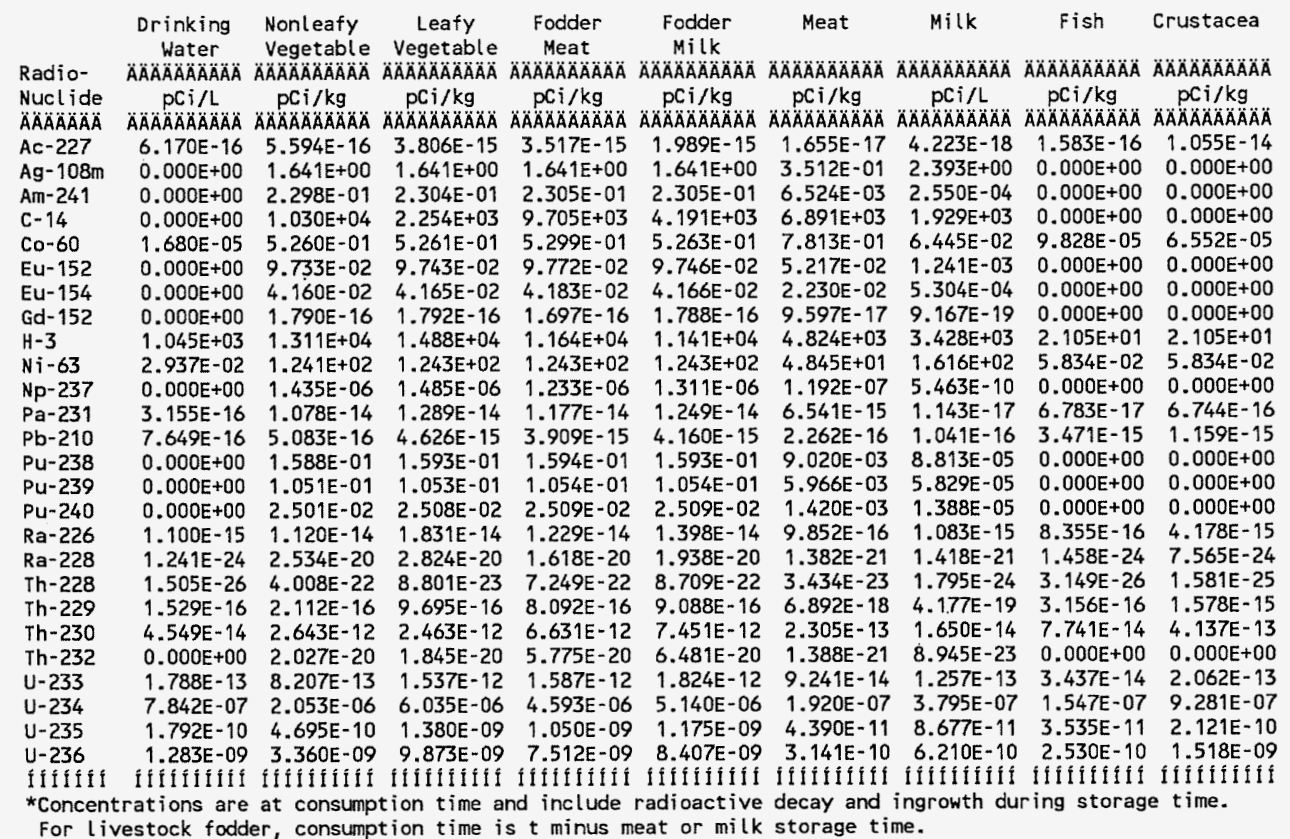

For livestock fodder, consumption time is $t$ minus meat or milk storage time.

Concentrations in the media occurring in pathways that are suppressed are calculated using the current input parameters, i.e. using parameters appearing in the input screen when the pathways are active.

\begin{tabular}{|c|c|}
\hline Attachment & Sheet No. 5 of 19 \\
\hline Originator: S.W. Clark & Date \\
\hline Chk'd By M.W. Perrott & Date \\
\hline $0100 F-C A-V 0280$ & Rev. No. \\
\hline
\end{tabular}




\section{ATTACHMENT 10}

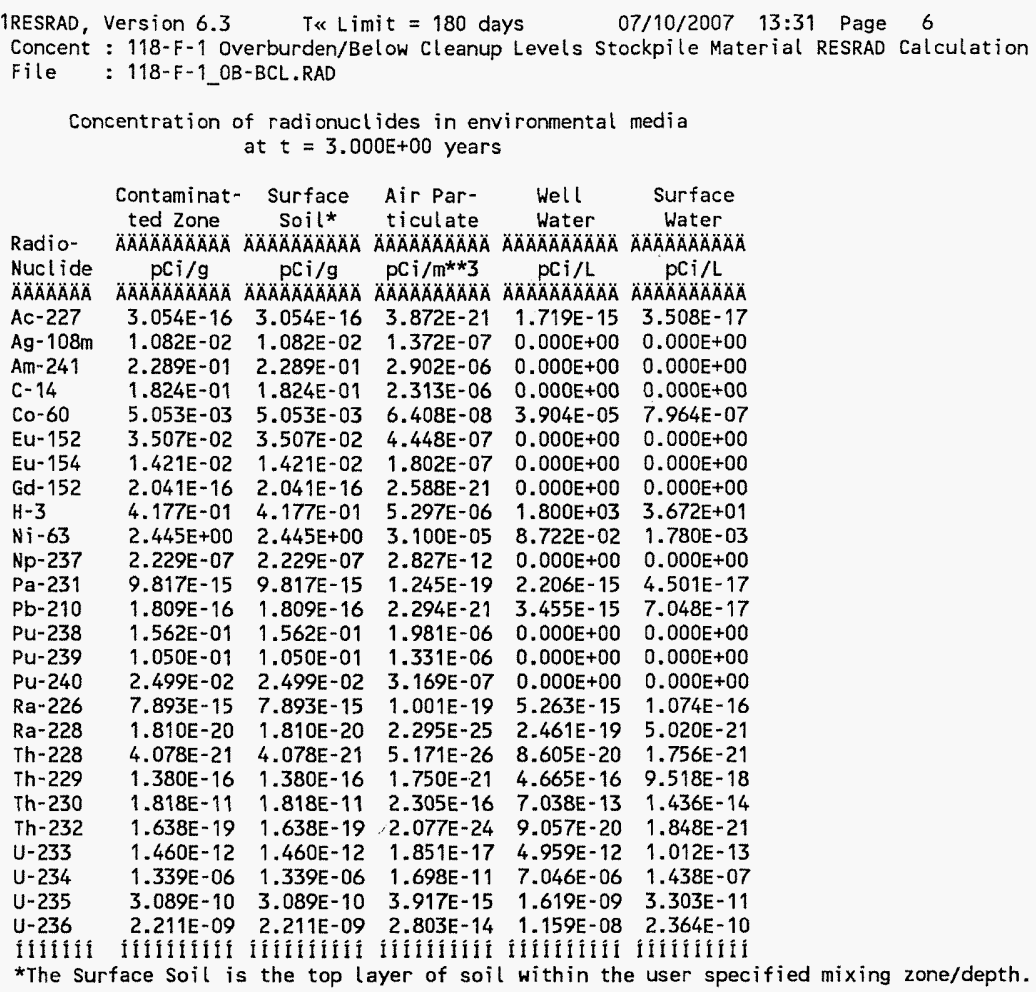

*The Surface Soil is the top layer of soil within the user specified mixing zone/depth.

Concentrations in the media occurring in pathways that are suppressed are calculated using the current input parameters, i.e. using parameters appearing in the input screen when the pathways are active.

Concentration of $\mathrm{H}-3$ in soil moisture $=3.450 \mathrm{E}+00 \mathrm{pCi} / \mathrm{mL}$

Concentration of gaseous $\mathrm{H}-3$ in air $=6.775 \mathrm{E}-01 \mathrm{pCi} / \mathrm{m}^{* * 3}$

Attachment

Sheet No. $\underline{6}$ of 19

Originator: S.W. Clark Date

Chk'd By M.W. Perrott Date

Calc. No. 0100F-CA-V0280

Rev No 0




\section{ATTACHMENT 10}

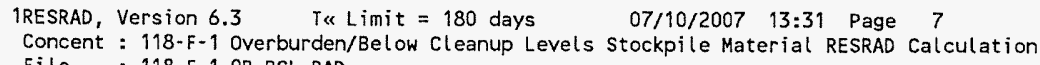

Concentrations in the media occurring in pathways that are suppressed are calculated using the current input parameters, i.e. using parameters appearing in the input screen when the pathways are active.

\begin{tabular}{|c|c|}
\hline \multirow{2}{*}{\multicolumn{2}{|c|}{$\begin{array}{ll}\text { Attachment } & \frac{10}{\text { S.W. Clark }} \quad \text { Sheet No. } \underline{7} \text { of } 19 \\
\text { Originator: } & \text { Date }\end{array}$}} \\
\hline & \\
\hline Chk'd By _ M. W. Perrott & Date \\
\hline $0100 F-C A-V 0280$ & Rev. No. \\
\hline
\end{tabular}




\section{ATTACHMENT 10}

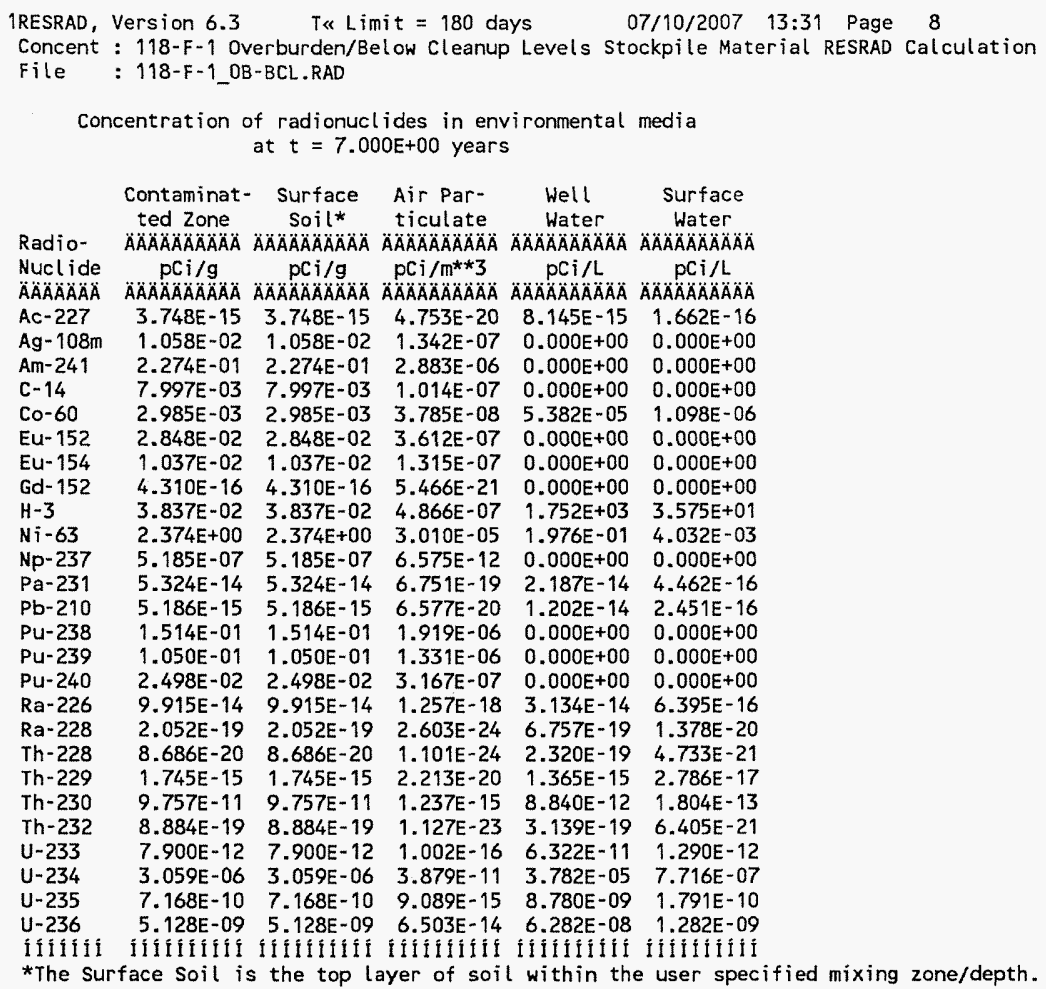

*The Surface Soil is the top layer of soil within the user specified mixing zone/depth.

Concentrations in the media occurring in pathways that are suppressed are calculated using the current input parameters, i.e. using parameters appearing in the input screen when the pathways are active.

Concentration of $\mathrm{H}-3$ in soil moisture $=3.169 \mathrm{E}-01 \mathrm{pCi} / \mathrm{ml}$

Concentration of gaseous $\mathrm{H}-3$ in air $=6.224 \mathrm{E}-02 \mathrm{pCi} / \mathrm{m}^{* * 3}$
Concentration of gaseous $\mathrm{C}-14$ in air $=4.120 \mathrm{E}-02 \mathrm{pCi} / \mathrm{m}^{* * 3}$

\begin{tabular}{|c|c|}
\hline Attachment & Sheet No. $\underline{8}$ of 19 \\
\hline Originator: S.W. Clark & Date \\
\hline hk'd By M. W. Perrott & Date \\
\hline $0100 F-C A-V 0280$ & Rev. No. \\
\hline
\end{tabular}


CVP-2007-00001

Rev. 0

\section{ATTACHMENT 10}

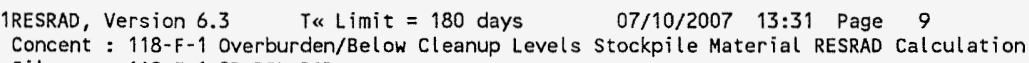

Drinking Nonleafy Leafy Fodder Fodder Meat Milk Fish Crustacea Water Vegetable Vegetable Meat Mil

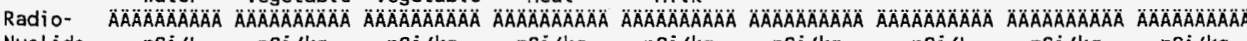

Nuclide $\mathrm{pCi} / \mathrm{L} p \mathrm{pci} / \mathrm{kg} p \mathrm{pi} / \mathrm{kg} p C i / \mathrm{kg} p C i / \mathrm{kg} p C i / \mathrm{kg} p \mathrm{pCi} / \mathrm{L} p \mathrm{pCi} / \mathrm{kg} \quad \mathrm{pCi} / \mathrm{kg}$

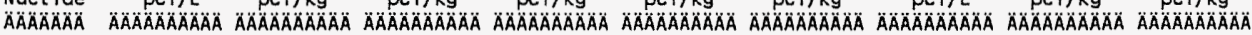

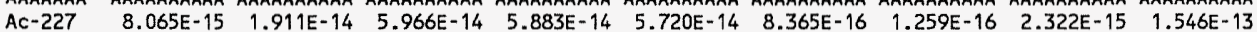

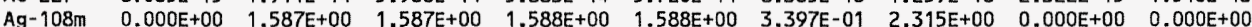

$\begin{array}{llllllllll}A m-241 & 0.000 E+00 & 2.275 E-01 & 2.281 E-01 & 2.282 E-01 & 2.282 E-01 & 6.461 E-03 & 2.525 E-04 & 0.000 E+00 & 0.000 E+00\end{array}$

$\begin{array}{llllllllll}\mathrm{C}-14 & 0.000 \mathrm{E}+00 & 9.466 \mathrm{E}+01 & 2.071 \mathrm{E}+01 & 8.921 \mathrm{E}+01 & 3.852 \mathrm{E}+01 & 6.335 \mathrm{E}+01 & 1.773 \mathrm{E}+01 & 0.000 \mathrm{E}+00 & 0.000 \mathrm{E}+00\end{array}$

$\begin{array}{llllllllll}C 0-60 & 5.376 E-05 & 2.389 E-01 & 2.391 E-01 & 2.409 E-01 & 2.392 E-01 & 3.552 E-01 & 2.931 E-02 & 3.270 E-04 & 2.180 E-04\end{array}$

$\begin{array}{llllllllll}\text { Eu-152 } & 0.000 E+00 & 7.123 E-02 & 7.131 E-02 & 7.152 E-02 & 7.133 E-02 & 3.818 E-02 & 9.082 E-04 & 0.000 E+00 & 0.000 E+00\end{array}$

$\begin{array}{llllllllll}\text { Eu-154 } & 0.000 E+00 & 2.593 E-02 & 2.596 E-02 & 2.607 E-02 & 2.597 E-02 & 1.390 E-02 & 3.306 E-04 & 0.000 E+00 & 0.000 E+00\end{array}$

$\begin{array}{llllllllll}\text { Gd-152 } & 0.000 E+00 & 1.078 E-15 & 1.079 E-15 & 1.072 E-15 & 1.079 E-15 & 5.778 E-16 & 5.500 E-18 & 0.000 E+00 & 0.000 E+00\end{array}$

$\begin{array}{llllllllll}H-3 & 1.752 E+03 & 6.869 E+03 & 9.961 E+03 & 3.401 E+03 & 3.386 E+03 & 1.827 E+03 & 2.012 E+03 & 3.574 E+01 & 3.574 E+01\end{array}$

$\begin{array}{llllllllll}\mathrm{Ni}-63 & 1.975 \mathrm{E}-01 & 1.189 \mathrm{E}+02 & 1.199 \mathrm{E}+02 & 1.200 \mathrm{E}+02 & 1.200 \mathrm{E}+02 & 4.678 \mathrm{E}+01 & 1.564 \mathrm{E}+02 & 4.015 \mathrm{E}-01 & 4.015 \mathrm{E}-01\end{array}$

$\begin{array}{lllllllllll}\mathrm{Np}-237 & 0.000 E+00 & 1.032 E-05 & 1.037 E-05 & 1.012 E-05 & 1.019 E-05 & 9.454 E-07 & 4.099 E-09 & 0.000 E+00 & 0.000 E+00\end{array}$

$\begin{array}{lllllllllll}\text { Pa-231 } & 2.232 E-14 & 5.656 \mathrm{E}-13 & 6.756 E-13 & 8.008 \mathrm{E}-13 & 8.129 \mathrm{E}-13 & 4.105 \mathrm{E}-13 & 5.503 \mathrm{E}-16 & 5.100 \mathrm{E}-15 & 5.249 \mathrm{E}-14\end{array}$

$\begin{array}{llllllllll}\mathrm{Pb}-210 & 1.215 \mathrm{E}-14 & 7.359 \mathrm{E}-14 & 1.295 \mathrm{E}-13 & 1.335 \mathrm{E}-13 & 1.567 \mathrm{E}-13 & 1.036 \mathrm{E}-14 & 3.974 \mathrm{E}-15 & 7.913 \mathrm{E}-14 & 2.647 \mathrm{E}-14\end{array}$

$\begin{array}{lllllllllll}\text { Pu-238 } & 0.000 E+00 & 1.515 E-01 & 1.519 E-01 & 1.520 E-01 & 1.519 E-01 & 8.601 E-03 & 8.404 E-05 & 0.000 E+00 & 0.000 E+00\end{array}$

$\begin{array}{lllllllllll}\text { Pu-239 } 0.000 E+00 & 1.050 E-01 & 1.053 E-01 & 1.053 E-01 & 1.053 E-01 & 5.964 E-03 & 5.827 E-05 & 0.000 E+00 & 0.000 E+00\end{array}$

$\begin{array}{llllllllll}\text { Pu-240 } & 0.000 E+00 & 2.499 E-02 & 2.506 E-02 & 2.507 E-02 & 2.507 E-02 & 1.419 E-03 & 1.387 E-05 & 0.000 E+00 & 0.000 E+00\end{array}$

$\begin{array}{lllllllllll}R a-226 & 3.151 E-14 & 3.948 E-12 & 4.162 E-12 & 3.875 E-12 & 3.987 E-12 & 3.138 E-13 & 2.739 E-13 & 3.320 E-14 & 1.660 E-13\end{array}$

$\begin{array}{llllllllll}\text { Ra-228 } & 6.769 E-19 & 8.975 E-18 & 1.248 E-17 & 1.253 E-17 & 1.282 E-17 & 9.819 E-19 & 9.159 E-19 & 6.986 E-19 & 3.493 E-18\end{array}$

$\begin{array}{llllllllll}\text { Th-228 } & 2.329 \mathrm{E}-19 & 5.185 \mathrm{E}-19 & 1.566 \mathrm{E}-18 & 2.267 \mathrm{E}-18 & 2.336 \mathrm{E}-18 & 3.979 \mathrm{E}-20 & 1.953 \mathrm{E}-21 & 4.814 \mathrm{E}-19 & 2.407 \mathrm{E}-18\end{array}$

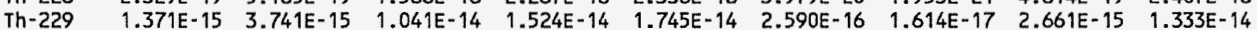

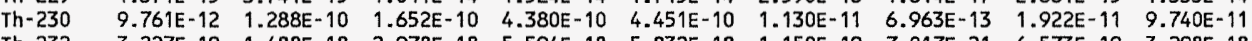

$\begin{array}{llllllllll}\text { Th-232 } & 3.227 \mathrm{E}-19 & 1.488 \mathrm{E}-18 & 2.978 \mathrm{E}-18 & 5.594 \mathrm{E}-18 & 5.832 \mathrm{E}-18 & 1.150 \mathrm{E}-19 & 7.017 \mathrm{E}-21 & 6.573 \mathrm{E}-19 & 3.298 \mathrm{E}-18\end{array}$

$\begin{array}{lllllllllll}\mathrm{U}-233 & 6.314 \mathrm{E}-11 & 1.027 \mathrm{E}-10 & 4.166 \mathrm{E}-10 & 4.259 \mathrm{E}-10 & 4.360 \mathrm{E}-10 & 1.244 \mathrm{E}-11 & 2.281 \mathrm{E}-11 & 1.278 \mathrm{E}-11 & 7.669 \mathrm{E}-11\end{array}$

$\begin{array}{llllllllll}\text { U-234 } & 3.779 E-05 & 5.669 E-05 & 2.453 E-04 & 2.548 E-04 & 2.587 E-04 & 7.040 E-06 & 1.308 E-05 & 7.674 E-06 & 4.604 E-05\end{array}$

$\begin{array}{lllllllllll}U-235 & 8.773 E-09 & 1.318 E-08 & 5.695 E-08 & 5.913 E-08 & 6.004 E-08 & 1.635 E-09 & 3.038 E-09 & 1.781 E-09 & 1.069 E-08\end{array}$

$\begin{array}{lllllllllll}\text { U-236 } & 6.277 E-08 & 9.427 E-08 & 4.075 E-07 & 4.231 E-07 & 4.296 E-07 & 1.170 E-08 & 2.174 E-08 & 1.274 E-08 & 7.647 E-08\end{array}$

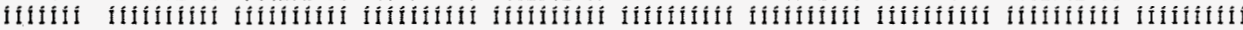

* Concentrations are at consumption time and include radioactive decay and ingrowth during storage time.

for livestock fodder, consumption time is $t$ minus meat or milk storage time.

Concentrations in the media occurring in pathways that are suppressed are calculated using the current input parameters, i.e. using parameters appearing in the inout screen when the pathways are active.

\begin{tabular}{|c|c|}
\hline \multirow{2}{*}{\multicolumn{2}{|c|}{$\begin{array}{ll}\text { Attachment } & 10 \\
\text { Originator: S.W. Clark } & \text { Sheet No. } \underline{9} \text { of } \underline{19} \\
\text { Date }\end{array}$}} \\
\hline & \\
\hline Chk'd By M.W. Perrott & Date \\
\hline $0100 F-C A-V 0280$ & Rev. No. \\
\hline
\end{tabular}




\section{ATTACHMENT 10}

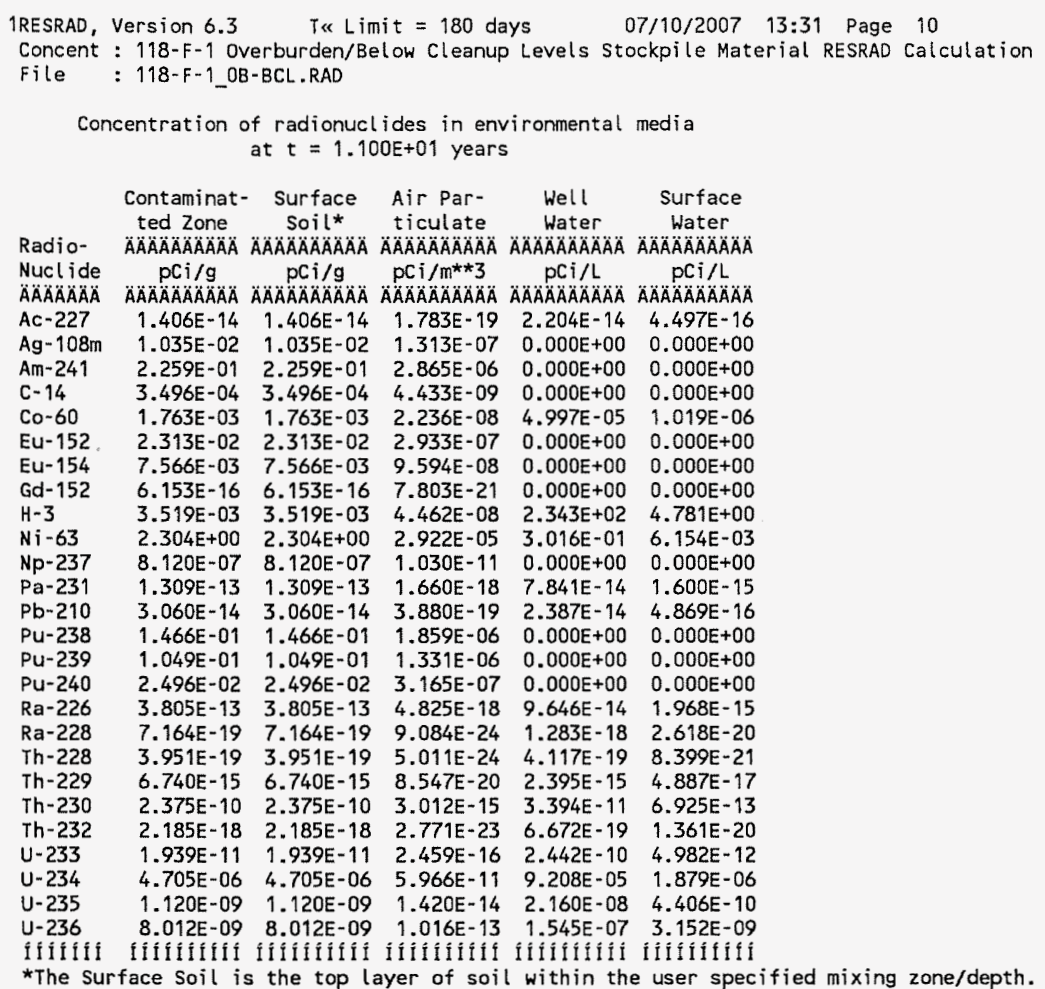

Concentrations in the media occurring in pathways that are suppressed are calculated using the current input parameters, i.e. using parameters appearing in the input screen when the pathways are active.

Concentration of $\mathrm{H}-3$ in soil moisture $=2.906 \mathrm{E}-02 \mathrm{pCi} / \mathrm{mL}$

Concentration of gaseous $\mathrm{H}-3$ in air $=5.708 \mathrm{E}-03 \mathrm{pCi} / \mathrm{m}^{* *} 3$

Concentration of gaseous $\mathrm{C}-14$ in air $=1.801 \mathrm{E}-03 \mathrm{pCi} / \mathrm{m}^{\star * 3}$

\begin{tabular}{|c|c|}
\hline \multirow{2}{*}{\multicolumn{2}{|c|}{$\begin{array}{c}\text { Attachment } \\
\text { Originator: S.W. Clark }\end{array}$}} \\
\hline & \\
\hline Chk'd By M.W. Perrott & Date \\
\hline $0100 F-C A-V 0280$ & Rev. No. \\
\hline
\end{tabular}




\section{ATTACHMENT 10}

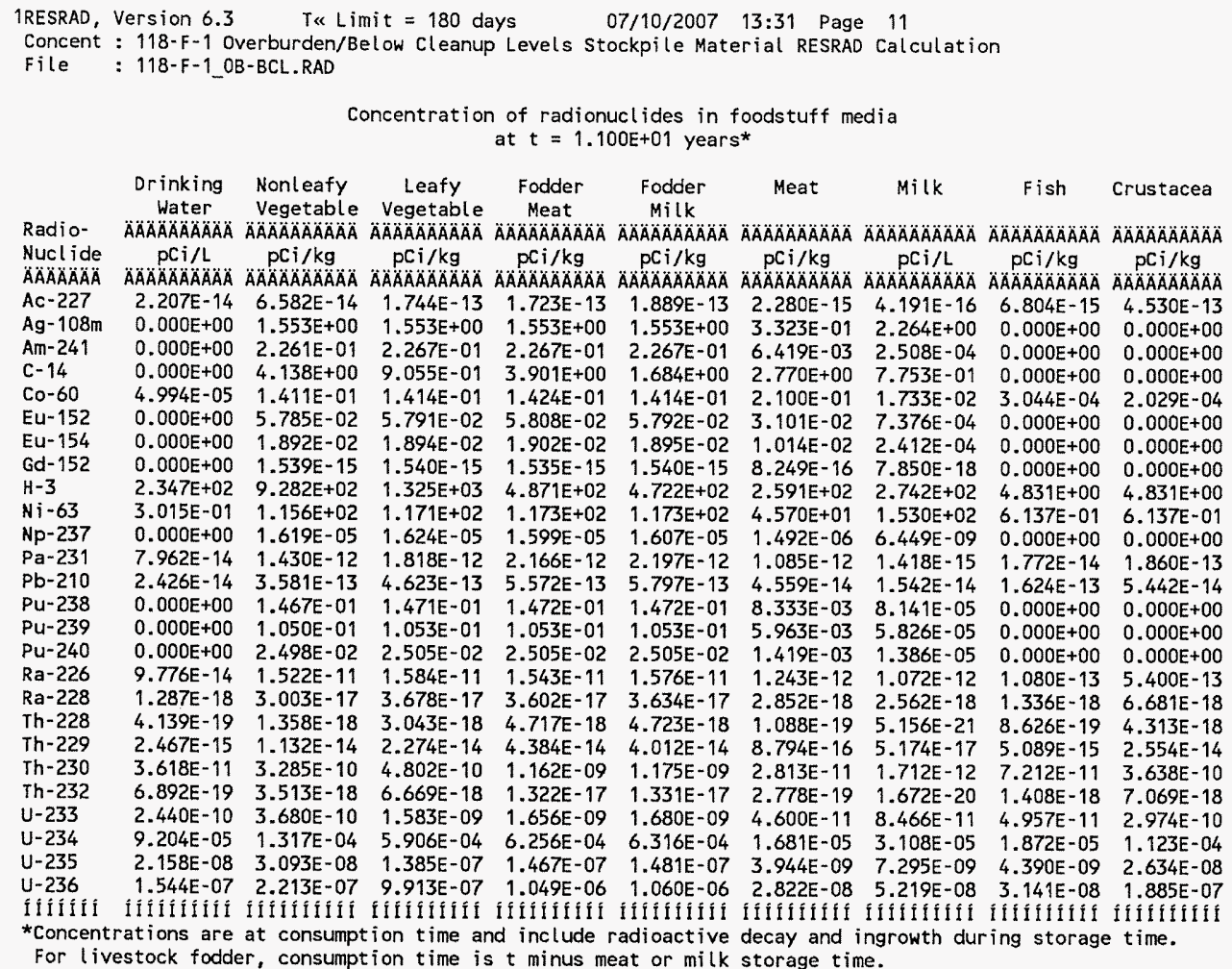

For livestock fodder, consumption time is $t$ minus meat or milk storage time.

Concentrations in the media occurring in pathways that are suppressed are calculated using the current input parameters, i.e. using parameters appearing in the input screen when the pathways are active.

\begin{tabular}{|c|c|c|}
\hline Attachment & 10 & Sheet No. 11 of 19 \\
\hline Originator & S.W. Clark & Date \\
\hline Chk'd By & M. W. Perrott & Date \\
\hline Calc. No. & 0100F-CA-V0280 & Rev. No. \\
\hline
\end{tabular}




\section{ATTACHMENT 10}

\begin{tabular}{|c|c|c|c|c|c|c|}
\hline \multicolumn{7}{|c|}{$\begin{array}{c}\text { Concentration of radionuc } l \text { ides in environmental media } \\
\text { at } t=4.300 E+01 \text { years }\end{array}$} \\
\hline & $\begin{array}{l}\text { Contaminat- } \\
\text { ted Zone }\end{array}$ & $\begin{array}{l}\text { Surface } \\
\text { Soil l* }\end{array}$ & $\begin{array}{l}\text { Air Par- } \\
\text { ticulate }\end{array}$ & $\begin{array}{l}\text { Well } \\
\text { Water }\end{array}$ & $\begin{array}{c}\text { Surface } \\
\text { Water }\end{array}$ & \\
\hline Radio- & ÄÄÄÄÄÄÄÄÄ & ÄÄÄÄÄÄÄÄÄA & ÄÄÄÄÄÄÄÄÄÄ & ÄÄÄÄÄAOÄÄ & AAAAAAAAAAAOA & \\
\hline Nucl ide & $\mathrm{pCi} / \mathrm{g}$ & $\mathrm{pCi} / \mathrm{g}$ & $\mathrm{pCi} / \mathrm{m}^{* * 3}$ & $\mathrm{pCi} / \mathrm{L}$ & $\mathrm{pCi} / \mathrm{L}$ & \\
\hline AAÄAOAÄÄ & ÄÄAÄAOAOAAOA & $\triangle A A A A A A A B A B A$ & $\triangle A A B A A A A A O A O A$ & $\triangle A A A A A A A A A A$ & AAAAAAAAAAAR & \\
\hline$A C-227$ & $6.531 E-13$ & $6.531 \mathrm{E}-13$ & $8.282 E-18$ & $3.168 E-12$ & $6.463 E-14$ & \\
\hline $\mathrm{Ag}-108 \mathrm{~m}$ & $8.675 E-03$ & $8.675 E-03$ & $1.100 \mathrm{E}-07$ & $0.000 E+00$ & $0.000 E+00$ & \\
\hline$A m-241$ & $2.144 \mathrm{E}-01$ & $2.144 \mathrm{E}-01$ & $2.719 E-06$ & $0.000 E+00$ & $0.000 E+00$ & \\
\hline$c-14$ & $4.192 E-15$ & 4.192E-15 & $5.315 \mathrm{E}-20$ & $0.000 E+00$ & $0.000 E+00$ & \\
\hline Co- 60 & $2.613 E-05$ & $2.613 E-05$ & $3.313 E-10$ & $2.902 \mathrm{E}-06$ & $5.920 E-08$ & \\
\hline Eu- 152 & $4.377 \mathrm{E}-03$ & $4.377 \mathrm{E}-03$ & $5.550 E-08$ & $0.000 E+00$ & $0.000 E+00$ & \\
\hline Eu- 154 & $6.078 E-04$ & $6.078 \mathrm{E}-04$ & $7.708 \mathrm{E}-09$ & $0.000 E+00$ & $0.000 E+00$ & \\
\hline Gd-152 & $1.261 \mathrm{E}-15$ & $1.261 \mathrm{E}-15$ & $1.599 \mathrm{E}-20$ & $0.000 E+00$ & $0.000 E+00$ & \\
\hline $\mathrm{H}-3$ & $1.645 E-11$ & $1.645 \mathrm{E}-11$ & $2.086 E-16$ & $1.143 E-06$ & $2.332 E-08$ & \\
\hline $\mathrm{Ni}-63$ & $1.817 \mathrm{E}+00$ & $1.817 E+00$ & $2.305 E-05$ & $9.329 \mathrm{E}-01$ & $1.903 E-02$ & \\
\hline $\mathrm{Np}-237$ & $3.092 \mathrm{E}-06$ & $3.092 \mathrm{E}-06$ & $3.921 \mathrm{E}-11$ & $0.000 E+00$ & $0.000 E+00$ & \\
\hline $\mathrm{Pa}-231$ & $1.939 E-12$ & $1.939 \mathrm{E}-12$ & $2.459 E-17$ & $4.468 \mathrm{E}-12$ & $9.116 E-14$ & \\
\hline $\mathrm{Pb}-210$ & $5.547 \mathrm{E}-12$ & $5.547 \mathrm{E}-12$ & $7.035 E-17$ & $4.063 \mathrm{E}-12$ & $8.290 E-14$ & \\
\hline Pu-238 & $1.138 \mathrm{E}-01$ & $1.138 \mathrm{E}-01$ & $1.443 E-06$ & $0.000 E+00$ & $0.000 E+00$ & \\
\hline $\mathrm{Pu}-239$ & $1.047 \mathrm{E}-01$ & $1.047 \mathrm{E}-01$ & $1.328 \mathrm{E}-06$ & $0.000 E+00$ & $0.000 E+00$ & \\
\hline Pu-240 & $2.485 E-02$ & $2.485 E-02$ & $3.152 E-07$ & $0.000 E+00$ & $0.000 E+00$ & \\
\hline$R a-226$ & $2.081 \mathrm{E}-11$ & $2.081 \mathrm{E}-11$ & $2.638 E-16$ & $2.555 \mathrm{E}-11$ & $5.212 E-13$ & \\
\hline $\mathrm{Ra}-228$ & $2.239 \mathrm{E}-17$ & $2.239 E-17$ & $2.839 E-22$ & $3.511 \mathrm{E}-17$ & $7.163 E-19$ & \\
\hline Th- -228 & $1.932 \mathrm{E}-17$ & $1.932 \mathrm{E}-17$ & $2.450 E-22$ & $1.030 \mathrm{E}-17$ & $2.102 E-19$ & \\
\hline Th-229 & $3.883 \mathrm{E}-13$ & $3.883 E-13$ & $4.924 E-18$ & $1.623 E-13$ & $3.311 E-15$ & \\
\hline Th-230 & $3.244 \mathrm{E}-09$ & $3.244 \mathrm{E}-09$ & $4.114 E-14$ & $1.863 \mathrm{E}-09$ & $3.801 \mathrm{E}-11$ & \\
\hline Th-232 & $3.238 \mathrm{E}-17$ & $3.238 \mathrm{E}-17$ & $4.105 E-22$ & $1.935 \mathrm{E}-17$ & $3.949 \mathrm{E}-19$ & \\
\hline$U-233$ & $2.827 \mathrm{E}-10$ & $2.827 \mathrm{E}-10$ & $3.585 E-15$ & $1.408 E-08$ & $2.872 E-10$ & \\
\hline$U-234$ & $1.553 \mathrm{E}-05$ & $1.553 \mathrm{E}-05$ & $1.969 E-10$ & $1.258 \mathrm{E}-03$ & $2.567 \mathrm{E}-05$ & \\
\hline$U-235$ & 4.187E-09 & $4.187 \mathrm{E}-09$ & $5.309 \mathrm{E}-14$ & $3.199 \mathrm{E}-07$ & $6.526 \mathrm{E}-09$ & \\
\hline$u-236$ & $2.991 \mathrm{E}-08$ & $2.991 \mathrm{E}-08$ & $3.793 E-13$ & $2.287 E-06$ & $4.665 \mathrm{E}-08$ & \\
\hline IfIfIf & bitifitif & IIIIIIIIII İ & 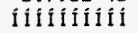 & ififitifil & fififílíi & \\
\hline
\end{tabular}

*The Surface Soil is the top layer of soil within the user specified mixing zone/depth.

Concentrations in the media occurring in pathways that are suppressed are calculated using the current input parameters, i.e. using parameters appearing in the input screen when the pathways are active.

Concentration of $\mathrm{H}-3$ in soil moisture $=1.359 \mathrm{E}-10 \mathrm{pCi} / \mathrm{ml}$

Concentration of gaseous $\mathrm{H}-3$ in air $=2.669 \mathrm{E}-11 \mathrm{pCi} / \mathrm{m}^{* * 3}$

Concentration of gaseous $\mathrm{C}-14$ in air $=2.160 \mathrm{E}-14 \mathrm{pCi} / \mathrm{m}^{* * 3}$

\begin{tabular}{|c|c|c|}
\hline \multirow{2}{*}{\multicolumn{3}{|c|}{ 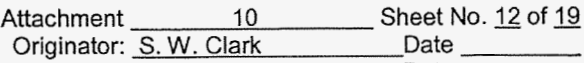 }} \\
\hline & & \\
\hline Chk'd By & M.W. Perrott & Date \\
\hline Calc. No. & $0100 F-C A-V 0280$ & Rev. No. \\
\hline
\end{tabular}




\section{ATTACHMENT 10}

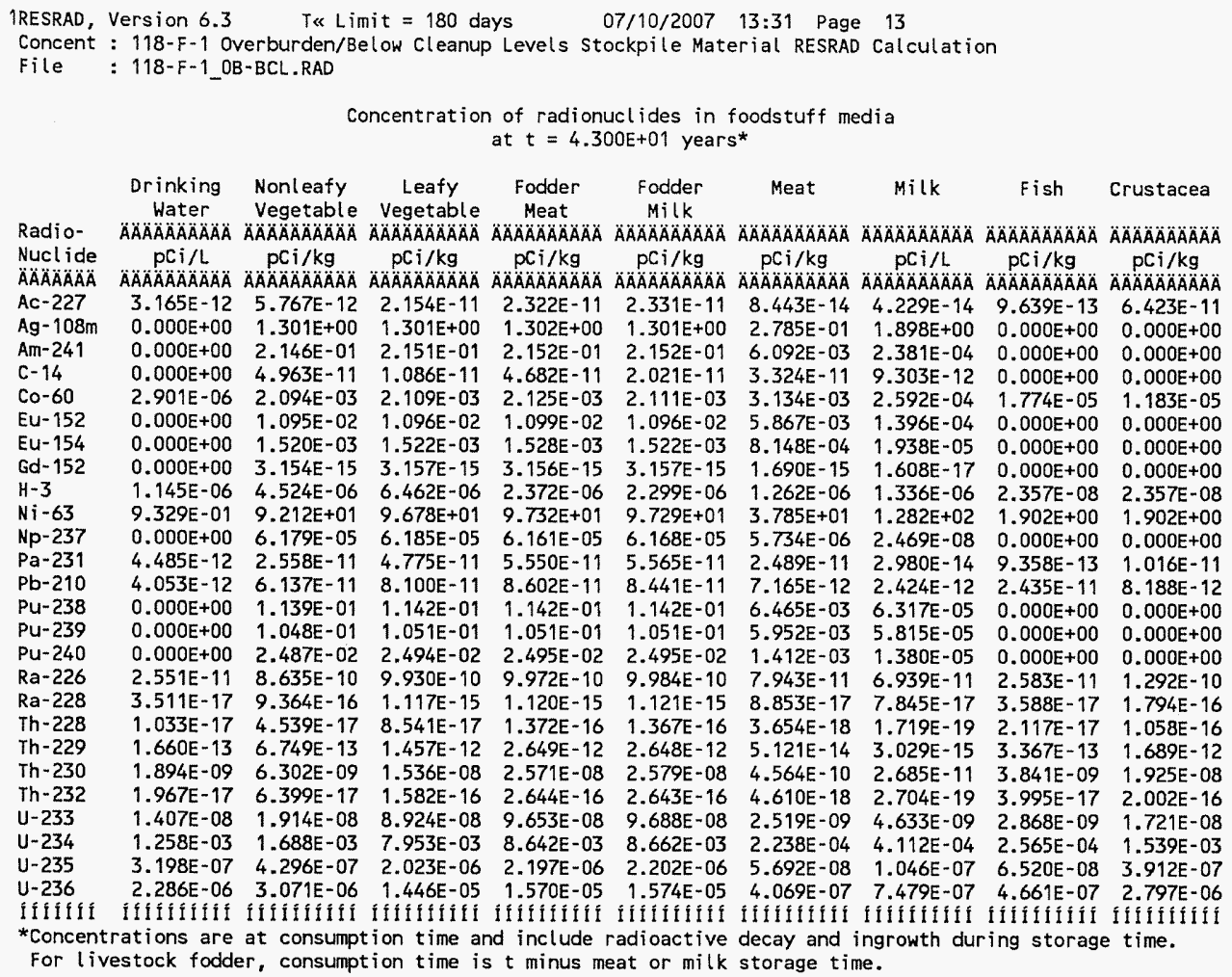

For livestock fodder, consumption time is $t$ minus meat or milk storage time.

Concentrations in the media occurring in pathways that are suppressed are calculated using the current input parameters, i.e. using parameters appearing in the input screen when the pathways are active.

\begin{tabular}{|c|c|c|}
\hline Attachment & 10 & Sheet No. 13 of 19 \\
\hline Originator: & S.W. Clark & Date \\
\hline Chk'd By & M. W. Perrott & Date \\
\hline Calc. No. & $0100 \mathrm{~F}-\mathrm{CA}-\mathrm{V} 0280$ & Rev. No. \\
\hline
\end{tabular}


CVP-2007-00001

Rev. 0

\section{ATTACHMENT 10}

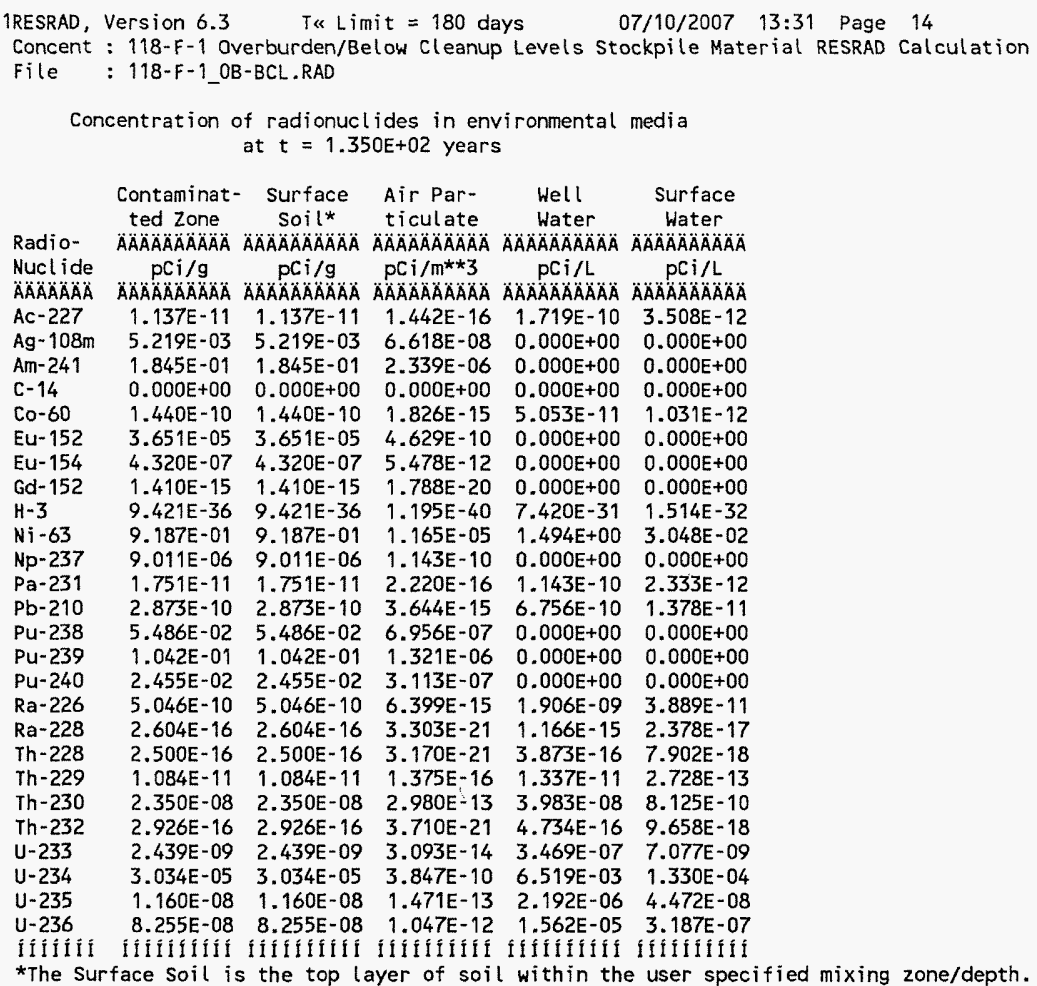

*The Surface Soil is the top layer of soil within the user specified mixing zone/depth.

Concentrations in the media occurring in pathways that are suppressed are calculated using the current input parameters, i.e. Using parameters appearing in the input screen when the pathways are active.

Concentration of $\mathrm{H}-3$ in soil moisture $=7.781 \mathrm{E}-35 \mathrm{pCi} / \mathrm{ml}$

Concentration of gaseous $\mathrm{H}-3$ in air $=1.528 \mathrm{E}-35 \mathrm{pCi} / \mathrm{m}^{* * 3}$
Concentration of gaseous $\mathrm{C}-14$ in air $=0.000 \mathrm{E}+00 \mathrm{pCi} / \mathrm{m}^{* * 3}$

\begin{tabular}{|c|c|}
\hline Attachment & Sheet No. 14 of 19 \\
\hline Originator: S.W. Clark & Date \\
\hline Chk'd By M. W. Perrott & Date \\
\hline $0100 \mathrm{~F}-\mathrm{CA}-\mathrm{V} 0280$ & Rev. No. \\
\hline
\end{tabular}


CVP-2007-00001

Rev. 0

\title{
ATTACHMENT 10
}

\begin{abstract}
1RESRAD, Version $6.3 \quad$ Ta Limit $=180$ days 07/10/2007 13:31 Page 15
Concent : 118 F-1 Overburden/Below Cleanup Levels Stockpile Material RESRAD Calculation
\end{abstract}

File : 118-F-1 OB-BCL.RAD

Concentration of radionuclides in foodstuff media at $\mathrm{t}=1.350 \mathrm{E}+02$ years*

\begin{tabular}{|c|c|c|c|c|c|c|c|c|c|}
\hline & $\begin{array}{c}\text { Drinking } \\
\text { Water }\end{array}$ & $\begin{array}{l}\text { Nonl eafy } \\
\text { Vegetable }\end{array}$ & $\begin{array}{c}\text { Leafy } \\
\text { Vegetable }\end{array}$ & $\begin{array}{c}\text { Fodder } \\
\text { Meat }\end{array}$ & $\begin{array}{l}\text { Fodder } \\
\text { Milk }\end{array}$ & Meat & Milk & Fish & Crustacea \\
\hline Radio- & A ÄÄÄAAAAÄÄ & 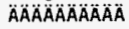 & 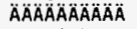 & 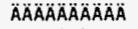 & ÁÂÄÂÂÄÄ & $A \cap A A A A R A A B A$ & ÄAिÄAAAÄ & $A \cap A A A B A A B A$ & A ÄÄÄÄÄÄ \\
\hline $\begin{array}{l}\text { Nuclide } \\
\text { ÄÄÄÄÄÄÄ }\end{array}$ & $\begin{array}{c}p C i / L \\
A A A A A A B A B A\end{array}$ & $\begin{array}{c}\mathrm{pci} / \mathrm{kg} \\
A B A A A A B A A B\end{array}$ & $\mathrm{pCi} / \mathrm{kg}$ & $p C i / \mathrm{kg}$ & $\begin{array}{c}\mathrm{pci} / \mathrm{kg} \\
\end{array}$ & $\begin{array}{c}\mathrm{pCi} / \mathrm{kg} \\
\end{array}$ & $\begin{array}{c}p C i / L \\
\end{array}$ & $\mathrm{pCi} / \mathrm{kg}$ & $\mathrm{pCi} / \mathrm{kg}$ \\
\hline AC-227 & $\begin{array}{r}\text { AAAAAAAAAA } \\
1.719 \mathrm{E}-10\end{array}$ & $\begin{array}{r}\text { AAAAAAAAAA } \\
2.541 \mathrm{E}-10\end{array}$ & $\begin{array}{r}\text { ARAAAAAAAA } \\
1.110 \mathrm{E}-09\end{array}$ & $\begin{array}{r}\text { AAAAAAAAAA } \\
1.208 \mathrm{E}-09\end{array}$ & $\begin{array}{r}\text { AAAAAAAAAAA } \\
1.210 E-09\end{array}$ & $\begin{array}{r}2.644 E-12 \\
\end{array}$ & $\begin{array}{r}1.994 \mathrm{E}-12 \\
\end{array}$ & $\begin{array}{r}5.258 \mathrm{E}-11 \\
\end{array}$ & $\begin{array}{l}\text { AAAAAAAAAAA } \\
3.504 E-09\end{array}$ \\
\hline $\mathrm{Ag}-108 \mathrm{~m}$ & $0.000 E+00$ & $7.828 E-01$ & $7.828 \mathrm{E}-01$ & $7.831 E-01$ & $7.829 E-01$ & $1.675 \mathrm{E}-01$ & $1.142 E+00$ & $0.000 E+00$ & $0.000 E+00$ \\
\hline & $0.000 E+00$ & $1.846 \mathrm{E}-01$ & $1.851 E-01$ & $1.852 \mathrm{E}-01$ & $1.852 E-01$ & $5.242 E-03$ & $2.049 E-04$ & $0.000 E+00$ & $0.000 E+00$ \\
\hline$c-14$ & $0.000 E+00$ & $0.000 E+00$ & $0.000 E+00$ & $0.000 E+00$ & $0.000 E+00$ & $0.000 E+00$ & $0.000 E+00$ & $0.000 E+00$ & $0.000 E+00$ \\
\hline Co- 60 & $5.053 E-11$ & 1.159E-08 & $1.184 E-08$ & 1.195E-08 & $1.187 E-08$ & $1.763 \mathrm{E}-08$ & $1.465 E-09$ & $3.092 E-10$ & $2.061 E-10$ \\
\hline & $0.000 E+00$ & $9.129 E-05$ & $9.139 E-05$ & $9.166 E-05$ & $9.141 E-05$ & 4.894E-05 & $1.164 E-06$ & $0.000 E+00$ & $0.000 E+00$ \\
\hline$u-154$ & $0.000 E+00$ & 1.080E-06 & $1.081 \mathrm{E}-06$ & $1.086 \mathrm{E}-06$ & $1.082 E-06$ & 5.791E-07 & $1.377 E-08$ & $0.000 E+00$ & $0.000 E+00$ \\
\hline Gd-152 & $0.000 E+00$ & $3.525 E-15$ & $3.529 E-15$ & $3.529 E-15$ & $3.529 E-15$ & $1.890 \mathrm{E}-15$ & $1.798 \mathrm{E}-17$ & $0.000 E+00$ & $0.000 E+00$ \\
\hline $\mathrm{H}-3$ & $7.431 E-31$ & $2.928 E-30$ & $4.186 \mathrm{E}-30$ & $1.532 E-30$ & $1.484 E-30$ & $8.164 E-31$ & $8.655 E-31$ & $1.530 E-32$ & $1.530 E-32$ \\
\hline 63 & $1.494 E+00$ & $4.793 E+01$ & $5.538 \mathrm{E}+01$ & $5.625 E+01$ & $5.624 E+01$ & $2.179 E+01$ & $7.583 E+01$ & $3.047 E+00$ & $3.047 E+00$ \\
\hline $\mathrm{Np}-$ & $0.000 E+00$ & $1.802 E-04$ & $1.802 E-04$ & $1.800 \mathrm{E}-04$ & $1.801 E-04$ & $1.675 \mathrm{E}-05$ & $7.206 E-08$ & $0.000 \mathrm{E}+00$ & $0.000 E+00$ \\
\hline $\mathrm{Pa}-231$ & $1.145 E-10$ & $3.279 E-10$ & $8.967 E-10$ & $1.001 \mathrm{E}-09$ & $1.002 E-09$ & $4.130 \mathrm{E}-10$ & $4.521 E-13$ & $2.350 E-11$ & $2.576 E-10$ \\
\hline $\mathrm{Pb}-210$ & $6.755 E-10$ & $3.779 \mathrm{E}-09$ & $7.129 \mathrm{E}-09$ & $7.595 E-09$ & $7.610 \mathrm{E}-09$ & $5.583 E-10$ & $E-10$ & $4.125 \mathrm{E}-09$ & $E-09$ \\
\hline Pu- & $0.000 E+00$ & 5.48 & $E-02$ & $8 E-02$ & 5.506E-02 & $3.117 E-03$ & $3.046 E-05$ & $0.000 E+00$ & $0.000 \mathrm{E}+00$ \\
\hline Pu-235 & $0.000 E+00$ & 1.043E-01 & $1.045 \mathrm{E}-01$ & $1.046 \mathrm{E}-01$ & $1.046 \mathrm{E}-01$ & $5.920 \mathrm{E}-03$ & $5.784 E-05$ & $0.000 E+00$ & $0.000 E+00$ \\
\hline Pu-24 & $0.000 \mathrm{E}+00$ & $2.456 E-02$ & $2.463 E-02$ & $2.464 \mathrm{E}-02$ & $2.464 \mathrm{E}-02$ & $1.395 \mathrm{E}-03$ & $1.363 \mathrm{E}$ & $0.000 E+00$ & $E+00$ \\
\hline Ra- & $6 \mathrm{E}-09$ & 2.27 & 3.22 & $3 E-08$ & $3.328 E-08$ & 2.607E-09 & $2.387 E-09$ & $1.942 E-09$ & $9.712 \mathrm{E}-09$ \\
\hline & $1.165 E-15$ & $1.191 \mathrm{E}-14$ & $1.777 \mathrm{E}-14$ & $1.820 E-14$ & $1.822 E-14$ & $1.417 E-15$ & $1.318 E-15$ & $1.188 E-15$ & $5.941 E-15$ \\
\hline Th -228 & $3.881 \mathrm{E}-16$ & $9.132 E-16$ & $2.707 E-15$ & $3.592 E-15$ & $3.594 E-15$ & $6.602 E-17$ & $3.229 E-18$ & $7.928 E-16$ & $3.964 E-15$ \\
\hline & $1.346 \mathrm{E}-11$ & $3.016 \mathrm{E}-11$ & $E-11$ & $1 E-10$ & $1.313 E-10$ & $1.818 E-12$ & $1.032 E-13$ & $2.739 E-11$ & $1.371 E-10$ \\
\hline & $3.998 \mathrm{E}-08$ & $7.892 E-08$ & $2.761 E-07$ & $3.482 E-07$ & $3.485 E-07$ & 4.311E-09 & $2.388 E-10$ & $8.145 E-08$ & $4.075 \mathrm{E}-07$ \\
\hline Th-23 & $4.755 E-16$ & $9.555 E-16$ & $3.298 E-15$ & 4.219E-15 & 4.222E- 15 & $5.317 E-17$ & $2.959 E-18$ & $9.686 \mathrm{E}-16$ & $4.846 E-15$ \\
\hline & $3.469 \mathrm{E}-07$ & $4.612 E-07$ & $2.189 \mathrm{E}-06$ & $2.390 \mathrm{E}-06$ & $2.392 \mathrm{E}-06$ & $6.155 \mathrm{E}-08$ & $1.130 E-07$ & $7.075 E-08$ & $4.245 E-07$ \\
\hline & $6.518 \mathrm{E}-03$ & $8.632 E-03$ & 4.109E-02 & 4.497E-02 & $4.498 \mathrm{E}-02$ & 1. 156E-03 & 2.119E-03 & $1.330 \mathrm{E}-03$ & $7.979 \mathrm{E}-03$ \\
\hline & $2.192 E-06$ & $2.906 \mathrm{E}-06$ & $1.382 E-05$ & $1.511 E-05$ & $1.512 E-05$ & $3.887 E-07$ & $7.129 \mathrm{E}-07$ & $4.471 E-07$ & $2.683 E-06$ \\
\hline & $1.562 E-05$ & & & & & & & $3.187 \mathrm{E}-06$ & $1.912 \mathrm{E}-05$ \\
\hline & & & & & & & & & \\
\hline For & 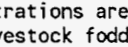 & & & & & & & & \\
\hline
\end{tabular}

Concentrations in the media occurring in pathways that are suppressed are calculated using the current input parameters, i.e. using parameters appearing in the input screen when the pathways are active.

\begin{tabular}{|c|c|}
\hline Attachment $\quad 10$ & Sheet No. 15 of 19 \\
\hline Originator: S.W. Clark & Date \\
\hline Chk'd By M.W. Perrott & Date \\
\hline $0100 \mathrm{~F}-\mathrm{CA}-\mathrm{V} 0280$ & Rev. No. \\
\hline
\end{tabular}




\section{ATTACHMENT 10}

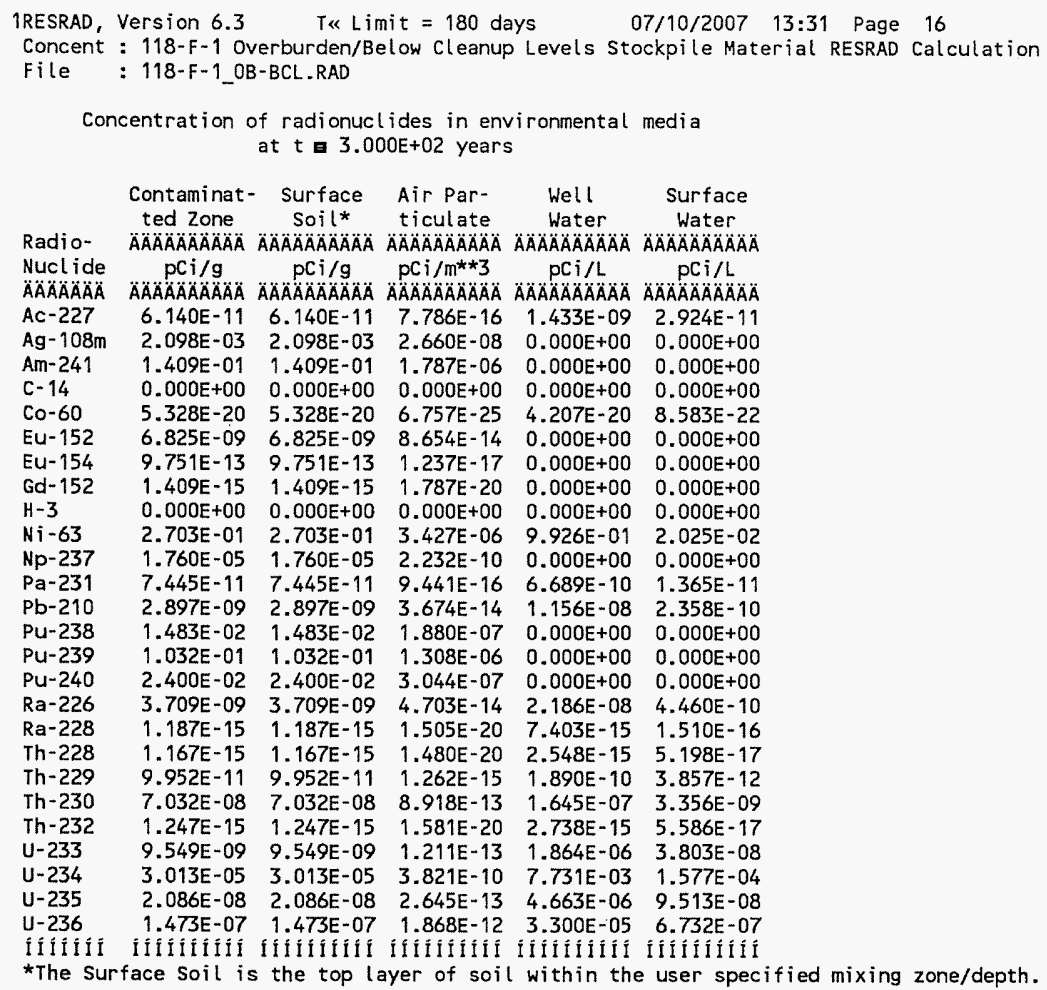

Concentrations in the media occurring in pathways that are suppressed are calculated using the current input parameters, i.e. using parameters appearing in the input screen when the pathways are active. Concentration of $\mathrm{H}-3$ in soil moisture $=0.000 \mathrm{E}+00 \mathrm{pCi} / \mathrm{mL}$

Concentration of gaseous $\mathrm{H}-3$ in air $=0.000 \mathrm{E}+00 \mathrm{pCi} / \mathrm{m}^{* * 3}$
Concentration of gaseous $\mathrm{C}-14$ in air $=0.000 \mathrm{E}+00 \mathrm{pCi} / \mathrm{m}^{* * 3}$

\begin{tabular}{|c|c|c|}
\hline Attachment & 10 & Sheet No. 16 of 19 \\
\hline Originator & S.W. Clark & Date \\
\hline Chk'd By & M. W. Perrott & Date \\
\hline Calc. No. & $0100 \mathrm{~F}-\mathrm{CA}-\mathrm{V} 0280$ & Rev. No. \\
\hline
\end{tabular}




\section{ATTACHMENT 10}

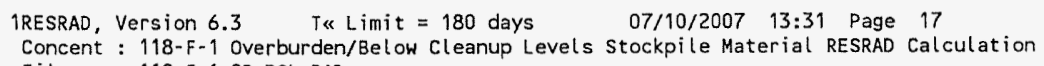

Drinking Nonleafy Leafy Fodder Fodder Meat Milk Fish Crustacea Water Vegetable Vegetable Meat Mil

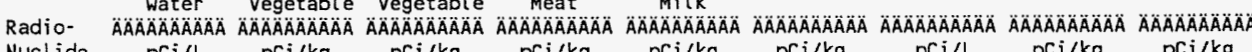
Nuclide $\mathrm{pCi} / \mathrm{L} \mathrm{pCi} / \mathrm{kg} \quad \mathrm{pCi} / \mathrm{kg} p \mathrm{pCi} / \mathrm{kg} \quad \mathrm{pCi} / \mathrm{kg} \quad \mathrm{pCi} / \mathrm{kg} \quad \mathrm{pCi} / \mathrm{L} \quad \mathrm{pCi} / \mathrm{kg} \quad \mathrm{pCi} / \mathrm{kg}$

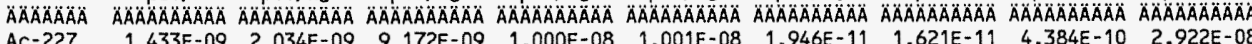
$\begin{array}{llllllllll}A C-227 & 1.433 E-09 & 2.034 E-09 & 9.172 E-09 & 1.000 E-08 & 1.001 E-08 & 1.946 E-11 & 1.621 E-11 & 4.384 E-10 & 2.922 E-08\end{array}$ $\begin{array}{llllllllll}\mathrm{Ag}-108 \mathrm{~m} & 0.000 \mathrm{E}+00 & 3.147 \mathrm{E}-01 & 3.147 \mathrm{E}-01 & 3.148 \mathrm{E}-01 & 3.147 \mathrm{E}-01 & 6.735 \mathrm{E}-02 & 4.589 \mathrm{E}-01 & 0.000 \mathrm{E}+00 & 0.000 \mathrm{E}+00\end{array}$ $\begin{array}{lllllllllll}\text { Am-2 } & 0.000 \mathrm{E}+00 & 1.410 \mathrm{E}-01 & 1.414 \mathrm{E}-01 & 1.414 \mathrm{E}-01 & 1.414 \mathrm{E}-01 & 4.004 \mathrm{E}-03 & 1.565 \mathrm{E}-04 & 0.000 \mathrm{E}+00 & 0.000 \mathrm{E}+00\end{array}$ $\begin{array}{llllllllll}\mathrm{C}-14 & 0.000 \mathrm{E}+\mathrm{CO} & 0.000 \mathrm{E}+00 & 0.000 \mathrm{E}+00 & 0.000 \mathrm{E}+00 & 0.000 \mathrm{E}+00 & 0.000 \mathrm{E}+00 & 0.000 \mathrm{E}+00 & 0.000 \mathrm{E}+00 & 0.000 \mathrm{E}+00\end{array}$ $\begin{array}{lllllllllll}\text { Co-60 } & 4.207 E-20 & 4.319 E-18 & 4.530 E-18 & 4.586 E-18 & 4.555 E-18 & 6.767 E-18 & 5.676 E-19 & 2.575 E-19 & 1.716 E-19\end{array}$ $\begin{array}{lllllllllll}\text { EU-152 } & 0.000 E+00 & 1.707 E-08 & 1.708 E-08 & 1.714 E-08 & 1.709 E-08 & 9.149 E-09 & 2.176 E-10 & 0.000 E+00 & 0.000 E+00 \\ \text { EU-154 } & 0.000 E+00 & 2.438 E-12 & 2.441 E-12 & 2.452 E-12 & 2.442 E-12 & 1.307 E-12 & 3.109 E-14 & 0.000 E+00 & 0.000 E+00\end{array}$ $\begin{array}{llllllllll} & \end{array}$

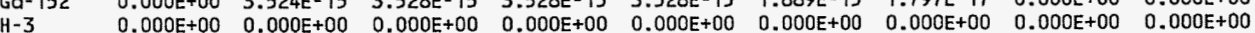
$\mathrm{Ni}-63 \quad 9.926 \mathrm{E}-01 \quad 1.484 \mathrm{E}+01 \quad 1.979 \mathrm{E}+012.037 \mathrm{E}+012.036 \mathrm{E}+01 \quad 7.846 \mathrm{E}+002.828 \mathrm{E}+012.025 \mathrm{E}+002.025 \mathrm{E}+00$ Ni.63 9.926E-01 1.484E+01 1.972 Np-237 $0.000 E+00-3.520 E-04 \quad 3.521 E-04 \quad 3.520 E-04 \quad 3.520 E-04 \quad 3.273 E-05$ 1.408E-07 $0.000 E+00$ 0.000E+00 $\begin{array}{llllllllll}\mathrm{Pa}-231 & 6.692 \mathrm{E}-10 & 1.630 \mathrm{E}-09 & 4.960 \mathrm{E}-09 & 5.436 \mathrm{E}-09 & 5.438 \mathrm{E}-09 & 2.202 \mathrm{E}-09 & 2.305 \mathrm{E}-12 & 1.368 \mathrm{E}-10 & 1.503 \mathrm{E}-09\end{array}$

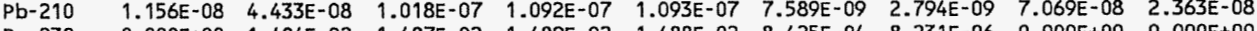
$\begin{array}{lllllllllll}\mathrm{Pu}-238 & 0.000 \mathrm{E}+00 & 1.484 \mathrm{E}-02 & 1.487 \mathrm{E}-02 & 1.489 \mathrm{E}-02 & 1.488 \mathrm{E}-02 & 8.425 \mathrm{E}-04 & 8.231 \mathrm{E}-06 & 0.000 \mathrm{E}+00 & 0.000 \mathrm{E}+00\end{array}$ $\begin{array}{llllllllll}\text { Pu-239 } & 0.000 E+00 & 1.033 E-01 & 1.035 E-01 & 1.036 E-01 & 1.036 E-01 & 5.863 E-03 & 5.729 E-05 & 0.000 E+00 & 0.000 E+00\end{array}$ $\begin{array}{llllllllll}\text { Pu-240 } & 0.000 E+00 & 2.402 E-02 & 2.408 E-02 & 2.409 E-02 & 2.409 E-02 & 1.364 E-03 & 1.333 E-05 & 0.000 E+00 & 0.000 E+00\end{array}$

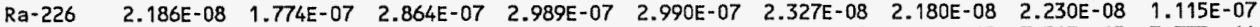
$\begin{array}{llllllllll}\mathrm{Ra}-228 & 7.402 \mathrm{E}-15 & 5.706 \mathrm{E}-14 & 9.420 \mathrm{E}-14 & 9.730 \mathrm{E}-14 & 9.733 \mathrm{E}-14 & 7.531 \mathrm{E}-15 & 7.129 \mathrm{E}-15 & 7.547 \mathrm{E}-15 & 3.773 \mathrm{E}-14\end{array}$ $\begin{array}{llllllllll}\text { Th-228 } & 2.553 \mathrm{E}-15 & 5.243 \mathrm{E}-15 & 1.731 \mathrm{E}-14 & 2.220 \mathrm{E}-14 & 2.221 \mathrm{E}-14 & 3.661 \mathrm{E}-16 & 1.813 \mathrm{E}-17 & 5.214 \mathrm{E}-15 & 2.607 \mathrm{E}-14\end{array}$

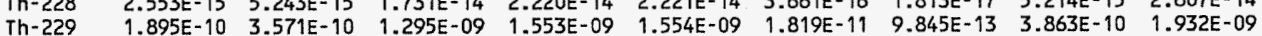

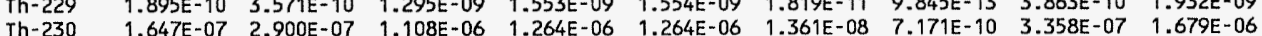
$\begin{array}{llllllllll}\text { Th-232 } & 2.742 \mathrm{E}-15 & 4.928 \mathrm{E}-15 & 1.853 \mathrm{E}-14 & 2.152 \mathrm{E}-14 & 2.152 \mathrm{E}-14 & 2.381 \mathrm{E}-16 & 1.268 \mathrm{E}-17 & 5.592 \mathrm{E}-15 & 2.797 \mathrm{E}-14\end{array}$ $\begin{array}{llllllllll}U-233 & 1.864 E-06 & 2.471 E-06 & 1.175 E-05 & 1.286 E-05 & 1.286 E-05 & 3.306 E-07 & 6.063 E-07 & 3.802 E-07 & 2.281 E-06\end{array}$

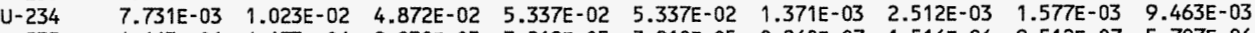
$\begin{array}{llllllllll}U-235 & 4.663 E-06 & 6.173 E-06 & 2.939 E-05 & 3.218 E-05 & 3.218 E-05 & 8.268 E-07 & 1.516 E-06 & 9.512 E-07 & 5.707 E-06\end{array}$ $\begin{array}{llllllllll}U-236 & 3.299 E-05 & 4.368 E-05 & 2.080 E-04 & 2.277 E-04 & 2.2777 E-04 & 5.851 E-06 & 1.073 E-05 & 6.731 E-06 & 4.039 E-05\end{array}$

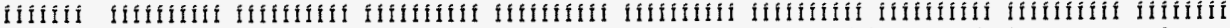

* Concentrations are at consumption time and include radioactive decay and ingrowth during storage time.

For livestock fodder, consumption time is $t$ minus meat or milk storage time.

Concentrations in the media occurring in pathways that are suppressed are calculated using the current input parameters, i.e. using parameters appearing in the input screen when the pathways are active.

\begin{tabular}{|c|c|}
\hline Attachment & Sheet No. 17 of 19 \\
\hline Originator: S.W. Clark & Date \\
\hline Chk'd By M. W. Perrott & Date \\
\hline $0100 \mathrm{~F}-\mathrm{CA}-\mathrm{V} 0280$ & Rev. No. \\
\hline
\end{tabular}




\section{ATTACHMENT 10}

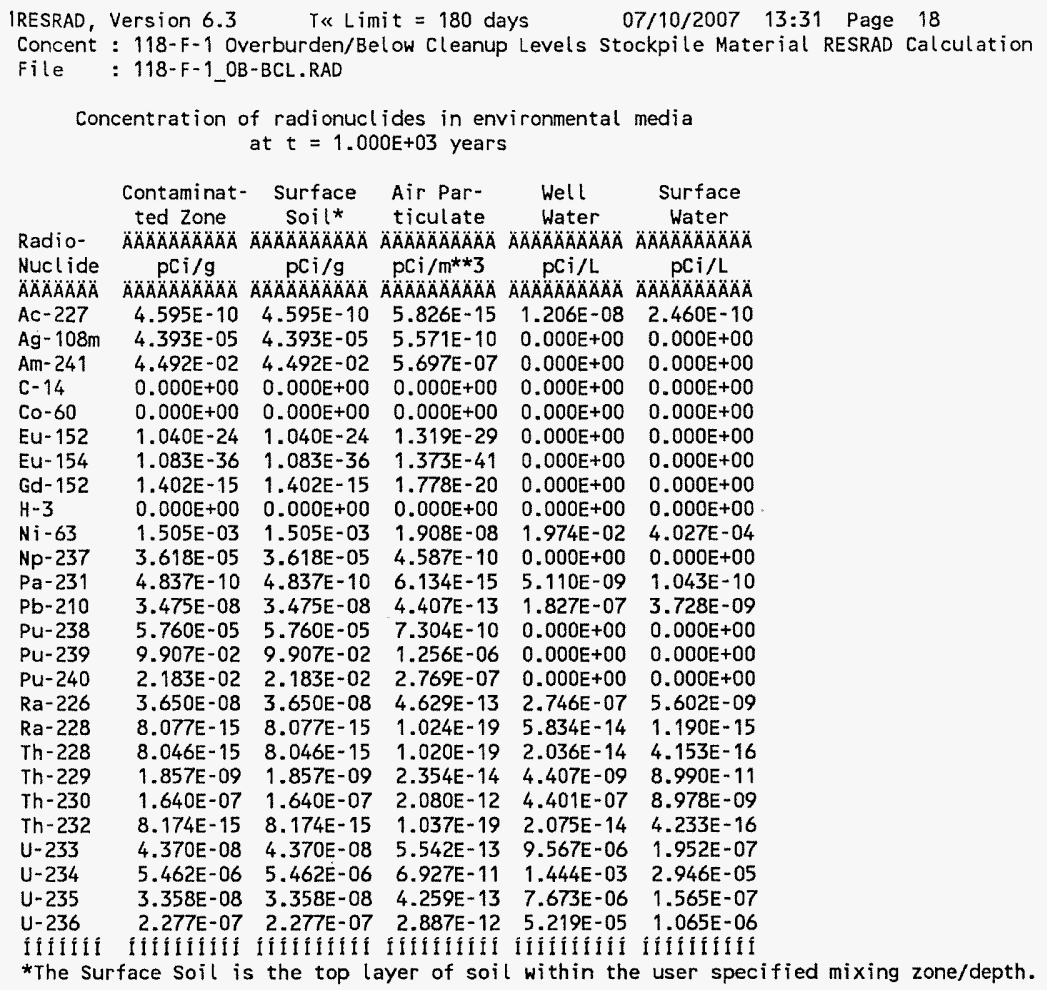

Concentrations in the media occurring in pathways that are suppressed are calculated using the current input parameters, i.e. using parameters appearing in the input screen when the pathways are active.

Concentration of $\mathrm{H}-3$ in soil moisture $=0.000 \mathrm{E}+00 \mathrm{pci} / \mathrm{ml}$

Concentration of gaseous $\mathrm{H}-3$ in air $=0.000 \mathrm{E}+00 \mathrm{pCi} / \mathrm{m}^{\star *} 3$

Concentration of gaseous $\mathrm{C}-14$ in air $=0.000 \mathrm{E}+00 \mathrm{pCi} / \mathrm{m}^{* * 3}$

\begin{tabular}{|c|c|c|}
\hline Attachment & 10 & Sheet No. 18 of 19 \\
\hline Originator: & S. W. Clark & _Date \\
\hline Chk'd By & M.W. Perrott & Date \\
\hline Calc. No. & $0100 F-C A-V 0280$ & Rev, No. \\
\hline
\end{tabular}




\section{ATTACHMENT 10}

IRESRAD, Version $6.3 \quad$ T« Limit a 180 days $07 / 10 / 2007 \quad 13: 31$ Page 19

Concent : $118-\mathrm{F}-1$ Overburden/Below Cleanup Levels Stockpile Material RESRAD Calculation

File : 118-F-1_OB-BCL.RAD

Concentration of radionuclides in foodstuff media at $t$ 田 $1.000 E+03$ years*

\begin{tabular}{|c|c|c|c|c|c|c|c|c|c|}
\hline & $\begin{array}{l}\text { Drinking } \\
\text { Water }\end{array}$ & $\begin{array}{l}\text { Nonleafy } \\
\text { Vegetable }\end{array}$ & $\begin{array}{l}\text { Leafy } \\
\text { Vegetable }\end{array}$ & $\begin{array}{l}\text { Fodder } \\
\text { Meat }\end{array}$ & $\begin{array}{l}\text { Fodder } \\
\text { Milk }\end{array}$ & Meat & Milk & Fish & Crustacea \\
\hline Radio- & $A \cap A O A A A A A ̈ A$ & $\triangle A A B A A A A A B$ & ÄÄÄÄÄÄÄÄÄ & AAAAAOAAAÄ & AAAAAAAAAAAAÄ & $\widetilde{A} \ddot{A} \ddot{A} A \ddot{A} \ddot{A} \ddot{A} A \ddot{A} \ddot{A}$ & ÄÄÄAAÄÄÄ & 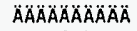 & $\triangle A O A A O A B A ̈ A ̈$ \\
\hline $\begin{array}{l}\text { Nuclide } \\
\text { ÄÄÄÄÄÄÄ }\end{array}$ & $\begin{array}{c}p C i / L \\
A \cap A A A A O A O A O A\end{array}$ & 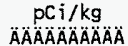 & $\begin{array}{c}\mathrm{pCi} / \mathrm{kg} \\
\triangle A \cap A \not A A O A A O A O A\end{array}$ & $\begin{array}{c}\mathrm{pCi} / \mathrm{kg} \\
\triangle A ̈ A ̈ A ̈ A ̈ A ̈ A ̈ A ̈ A ̈\end{array}$ & $\begin{array}{c}\mathrm{pCi} / \mathrm{kg} \\
\text { AÄÄÄÄÄÄÄÄA }\end{array}$ & 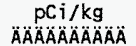 & $\begin{array}{c}P C I / L \\
A O A A B A B A A A B A\end{array}$ & $\mathrm{pCi} / \mathrm{kg}$ & $\mathrm{pci} / \mathrm{kg}$ \\
\hline$A C-227$ & $1.206 \mathrm{E}-08$ & $1.697 \mathrm{E}-08$ & $7.702 E-08$ & $8.408 E-08$ & $8.408 E-08$ & $1.589 \mathrm{E}-10$ & $1.357 E-10$ & $3.689 E-09$ & $\begin{array}{r}2.459 E-07 \\
\end{array}$ \\
\hline Ag-108m & $0.000 E+00$ & $6.590 E-03$ & $6.590 E-03$ & $6.592 E-03$ & $6.590 E-03$ & $1.410 E-03$ & $9.610 E-03$ & $0.000 E+00$ & $0.000 E+00$ \\
\hline & $0.000 E+00$ & $4.495 \mathrm{E}-02$ & $4.507 \mathrm{E}-02$ & $4.509 E-02$ & 4.509E-02 & $1.276 E-03$ & $4.988 \mathrm{E}-05$ & $0.000 E+00$ & $0.000 E+00$ \\
\hline & $0.000 E+00$ & $0.000 E+00$ & $0.000 \mathrm{E}+00$ & $0.000 E+00$ & $0.000 E+00$ & $0.000 E+00$ & $0.000 E+00$ & $0.000 E+00$ & $0.000 E+00$ \\
\hline Co- 60 & $0.000 E+00$ & $0.000 E+00$ & $0.000 E+00$ & $0.000 E+00$ & $0.000 E+00$ & $0.000 E+00$ & $0.000 E+00$ & $0.000 E+00$ & $0.000 E+00$ \\
\hline & $0.000 E+00$ & $2.601 E-24$ & $2.604 E-24$ & $2.612 E-24$ & $2.605 E-24$ & $1.394 E-24$ & $3.317 E-26$ & $0.000 E+00$ & $0.000 E+00$ \\
\hline & $0.000 E+00$ & $2.708 E-36$ & $2.711 \mathrm{E}-36$ & $2.723 E-36$ & $2.712 E-36$ & $1.452 E-36$ & $3.453 E-38$ & $0.000 E+00$ & $O O E+00$ \\
\hline Gd-152 & $0.000 E+00$ & $3.507 E-15$ & $3.510 E-15$ & $3.511 E-15$ & $3.511 E-15$ & $1.880 E-15$ & $1.788 E-17$ & $0.000 E+00$ & $0.000 E+00$ \\
\hline $\mathrm{H}-3$ & $0.000 E+00$ & $0.000 E+00$ & $0.000 E+00$ & $0.000 E+00$ & $0.000 \mathrm{E}+00$ & $0.000 \mathrm{E}+00$ & $0.000 \mathrm{E}+00$ & $0.000 \mathrm{E}+00$ & $0.000 E+00$ \\
\hline $\mathrm{Ni}-63$ & $1.974 E-02$ & $1.016 \mathrm{E}-01$ & $2.000 E-01$ & $2.115 \mathrm{E}-01$ & $2.115 E-01$ & 8.059E-02 & $3.108 \mathrm{E}-01$ & $27 E-02$ & $7 E-02$ \\
\hline & $0.000 E+00$ & $7.235 E-04$ & $7.236 \mathrm{E}-04$ & $7.236 \mathrm{E}-04$ & $7.236 \mathrm{E}-04$ & $6.729 \mathrm{E}-05$ & $2.894 E-07$ & $0.000 E+00$ & $0.000 E+00$ \\
\hline $\mathrm{Pa}$ & DE-09 & $E-08$ & $3.702 E-08$ & OE- 08 & $21 E-08$ & SE-08 & $50 E-11$ & $43 E-09$ & $7 E-08$ \\
\hline & $1.827 \mathrm{E}-07$ & $5.895 \mathrm{E}-07$ & $1.499 \mathrm{E}-06$ & $1.614 \mathrm{E}-06$ & $1.614 \mathrm{E}-06$ & $1.093 E-07$ & $4.063 \mathrm{E}-08$ & $8 E-06$ & $3.734 E-07$ \\
\hline & $0.000 \mathrm{E}+00$ & $5.764 \mathrm{E}-05$ & $5.779 E-05$ & $5.784 E-05$ & $5.781 E-05$ & $3.273 E-06$ & $3.198 \mathrm{E}-08$ & $0.000 E+00$ & $0.000 E+00$ \\
\hline Pu-239 & $0.000 E+00$ & $9.914 E-02$ & $9.940 E-02$ & $9.943 E-02$ & $43 E-02$ & DE-03 & DE-05 & $E+00$ & $E+\infty 0$ \\
\hline & $0.000 E+00$ & 2.18 & $2.191 E-02$ & 2.191E-02 & $2.191 E-02$ & $1 E-03$ & $1.212 E-05$ & $0.000 E+00$ & $0.000 E+00$ \\
\hline $\mathrm{Ra}-2$ & $2.746 \mathrm{E}-07$ & 1.82 & $3.194 \mathrm{E}-06$ & $3.354 E-06$ & $3.354 E-06$ & $2.600 \mathrm{E}-07$ & $2.467 E-07$ & $2.801 \mathrm{E}-07$ & $1.400 E-06$ \\
\hline Ra-228 & $5.832 \mathrm{E}-14$ & $3.989 E-13$ & $6.913 E-13$ & $7.170 \mathrm{E}-13$ & $7.170 \mathrm{E}-13$ & $5.535 E-14$ & $79 E-14$ & $5.947 E-14$ & $3 E-13$ \\
\hline & $2.039 E-14$ & $3.985 E-14$ & $1.369 E-13$ & $1.736 E-13$ & $E-13$ & $E-15$ & $E-16$ & $E-14$ & $2.083 E-13$ \\
\hline & $4.409 \mathrm{E}-09$ & $7.689 E-09$ & $2.962 E-08$ & $3.301 E-08$ & $3.301 E-08$ & $3.481 E-10$ & $1.805 E-11$ & $8.993 \mathrm{E}-09$ & $4.497 E-08$ \\
\hline Th-230 & $4.401 \mathrm{E}-07$ & $7.423 E-07$ & $2.934 \mathrm{E}-06$ & $3.209 E-06$ & $3.209 \mathrm{E}-06$ & $3.235 E-08$ & $1.656 \mathrm{E}-09$ & $8.979 E-07$ & $4.489 E-06$ \\
\hline & $2.076 E-14$ & $3.555 E-14$ & $1.388 \mathrm{E}-13$ & $1.534 E-13$ & $1.534 E-13$ & $1.581 E-15$ & $8.153 E-17$ & $4.234 E-14$ & $2.117 E-13$ \\
\hline$U-233$ & $9.567 E-06$ & $1.267 \mathrm{E}-05$ & $6.030 \mathrm{E}-05$ & $6.604 E-05$ & $6.605 E-05$ & $1.697 \mathrm{E}-06$ & $3.111 \mathrm{E}-06$ & $1.952 E-06$ & $1.171 E-05$ \\
\hline$U-234$ & $1.444 E-03$ & $1.910 \mathrm{E}-03$ & $9.100 \mathrm{E}-03$ & $9.972 E-03$ & $9.971 E-03$ & $2.560 \mathrm{E}-04$ & $4.693 \mathrm{E}-04$ & $2.946 \mathrm{E}-04$ & $1.768 E-03$ \\
\hline & $7.673 E-06$ & $1.016 \mathrm{E}-05$ & $4.836 \mathrm{E}-0$ & $5.297 E-05$ & $5.297 \mathrm{E}-05$ & $1.361 \mathrm{E}-06$ & $2.495 E-06$ & $1.565 \mathrm{E}-06$ & $9.392 E-06$ \\
\hline & & $6.909 E-05$ & & $3.603 \mathrm{E}-04$ & & & & $1.065 \mathrm{E}-05$ & $6.389 \mathrm{E}-05$ \\
\hline ifififi & & & & & & & & & Ifî́t \\
\hline & & & & & & & & & \\
\hline
\end{tabular}

Concentrations in the media occurring in pathways that are suppressed are calculate

$\begin{array}{ll}\text { Attachment } & \frac{10}{\text { Shiginator: }} \begin{array}{c}\text { S.W. Clark } \\ \text { Origeet No. } 19 \text { of } 19 \\ \text { Date }\end{array} \\ \text { Chk'd By } & \text { Date } \\ \text { Calc. No. Perrott } & \text { Rev. No. } 0\end{array}$




\section{APPENDIX C}

\section{GPERS RADIOLOGICAL SURVEY GAMMA TRACK MAPS}


CVP-2007-00001

Rev. 0

C-ii 


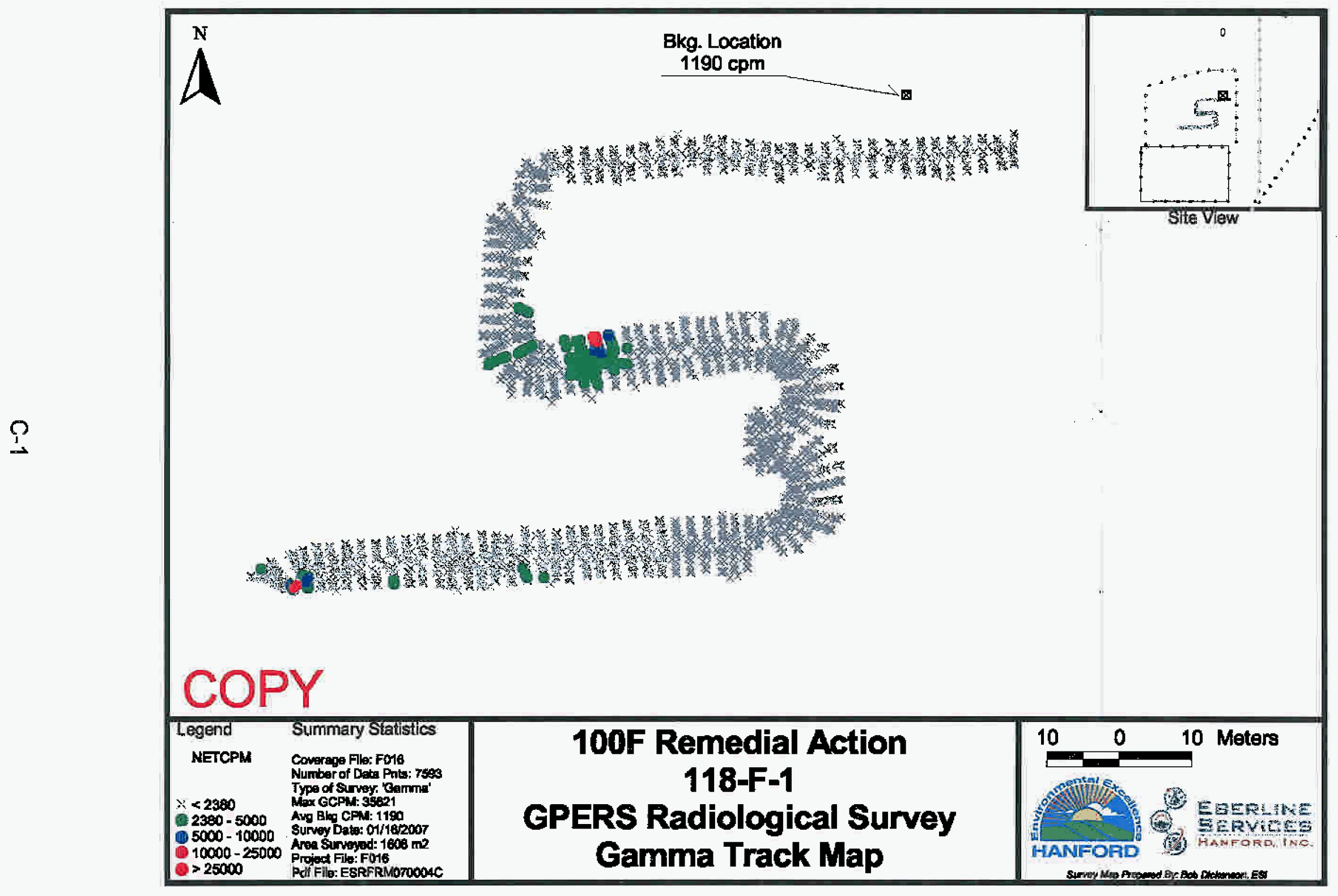

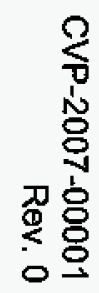




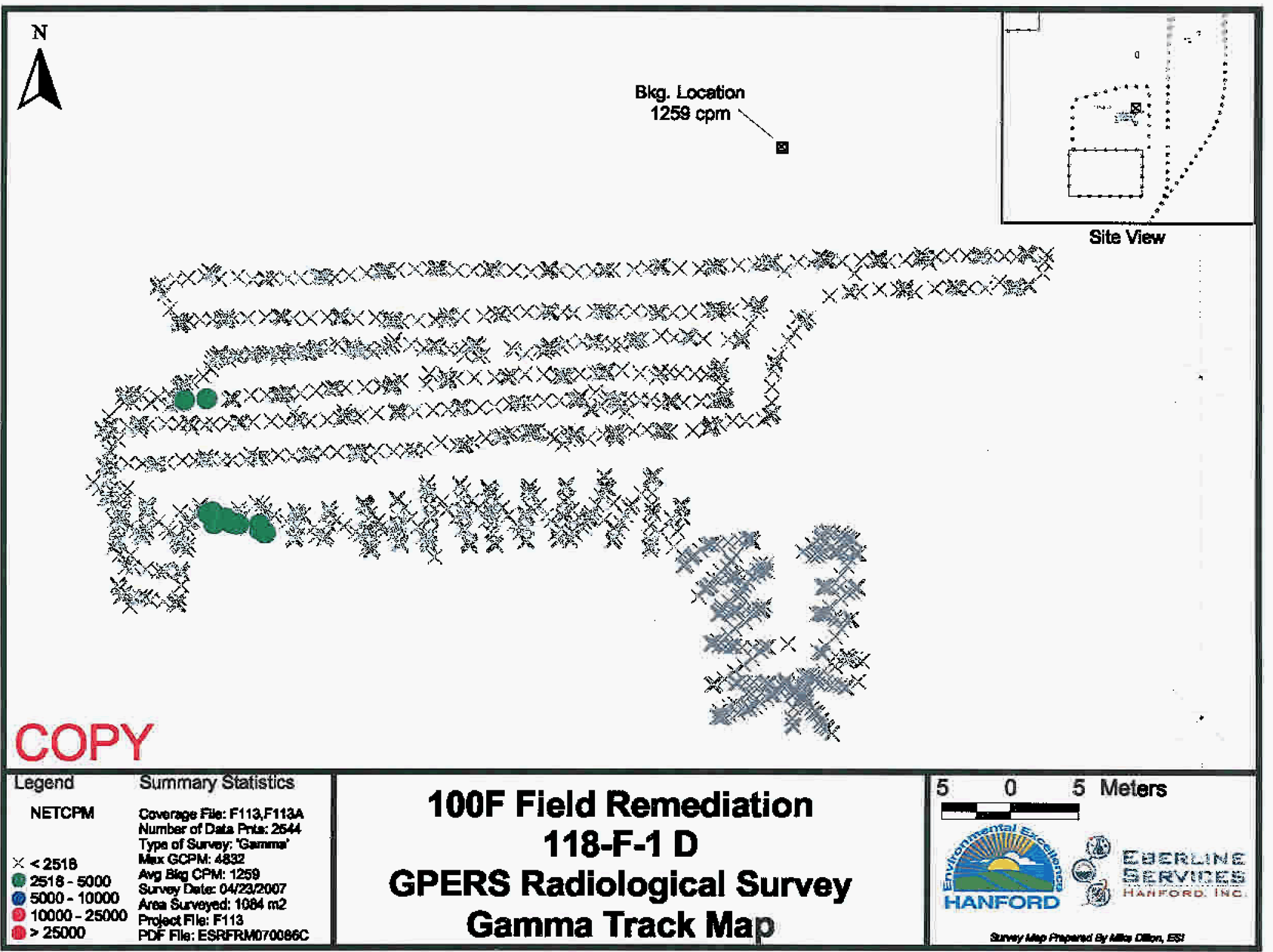

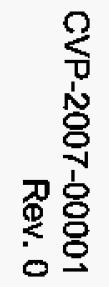




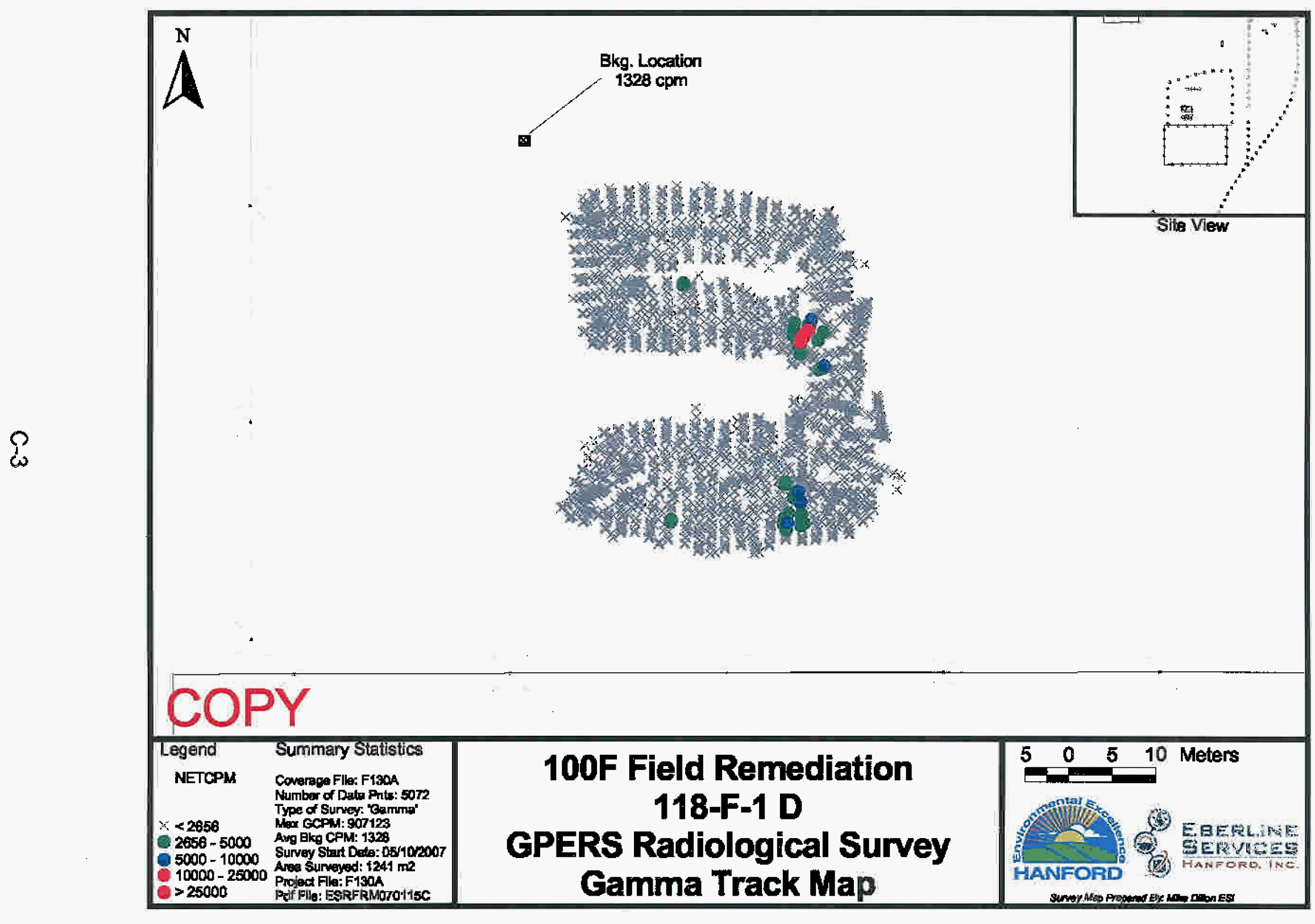

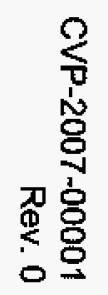




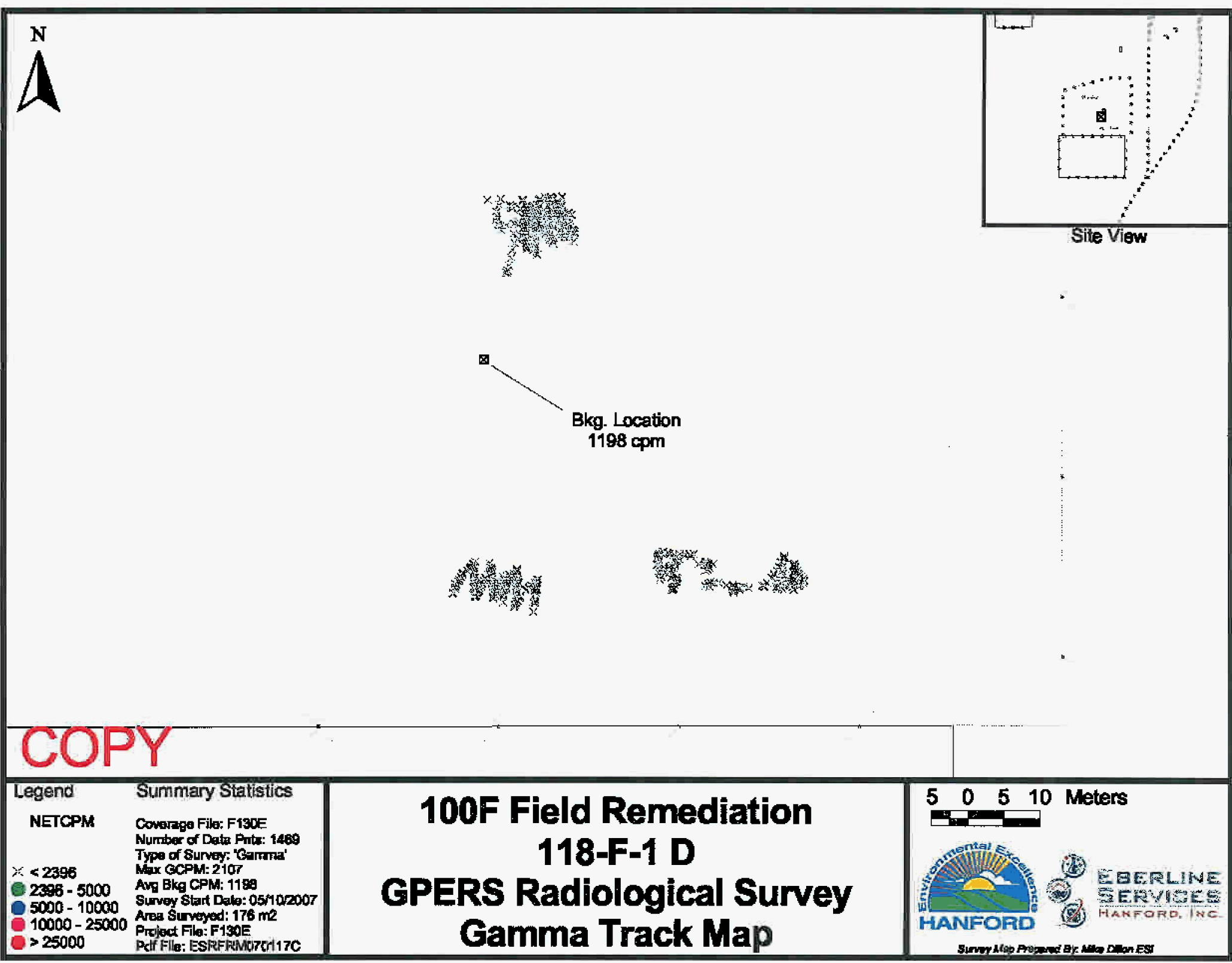




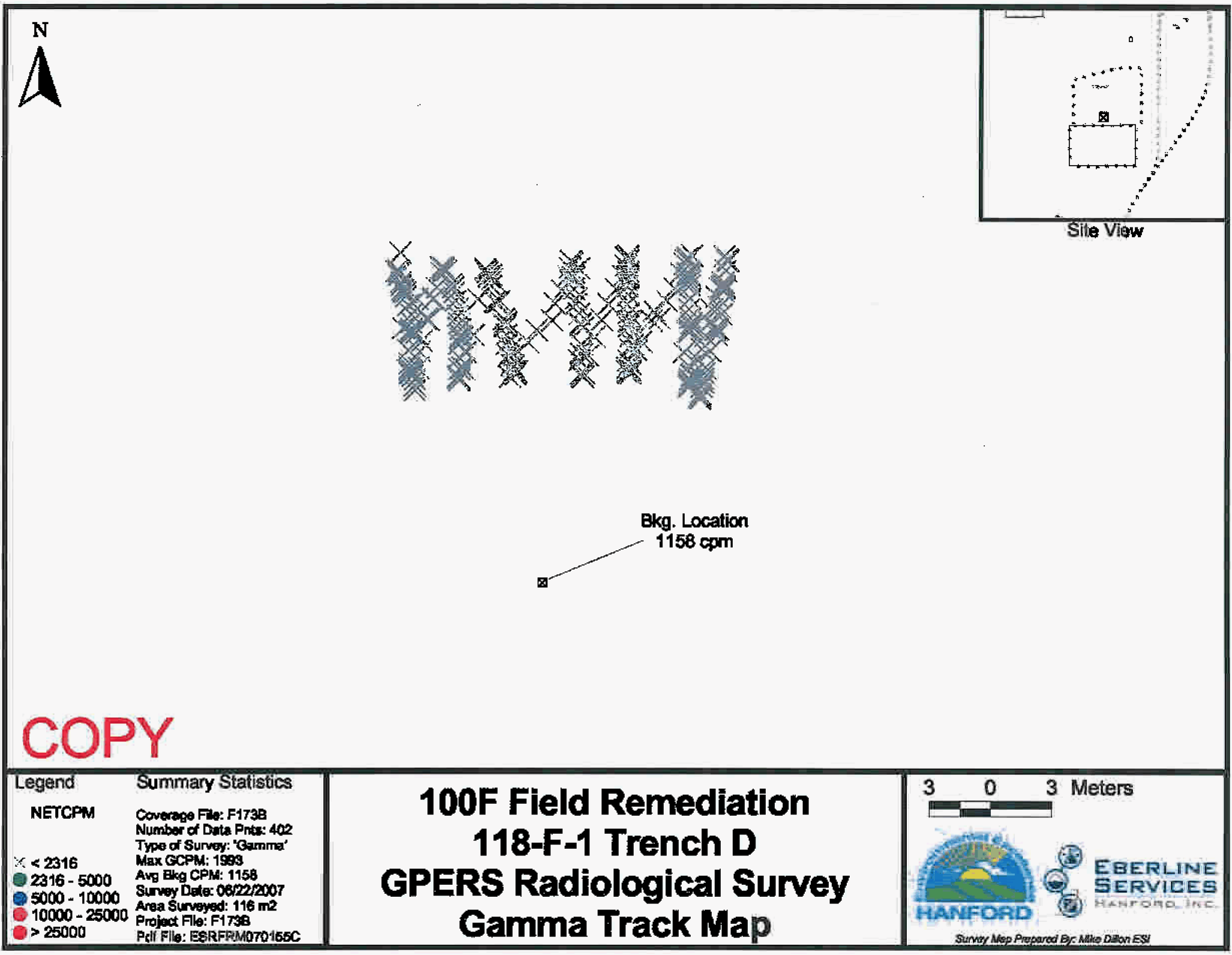

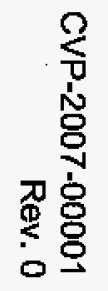




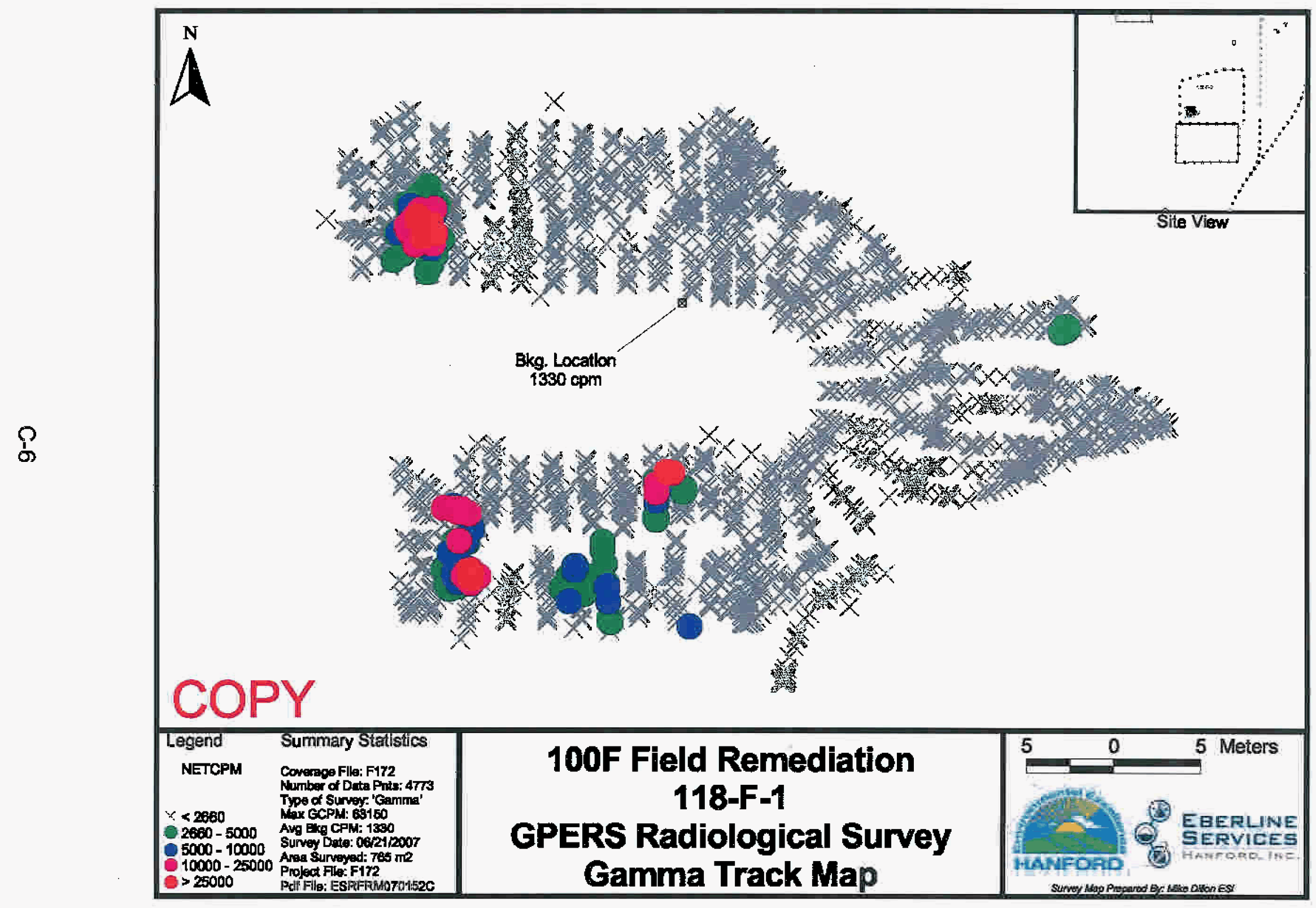

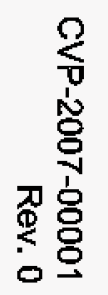




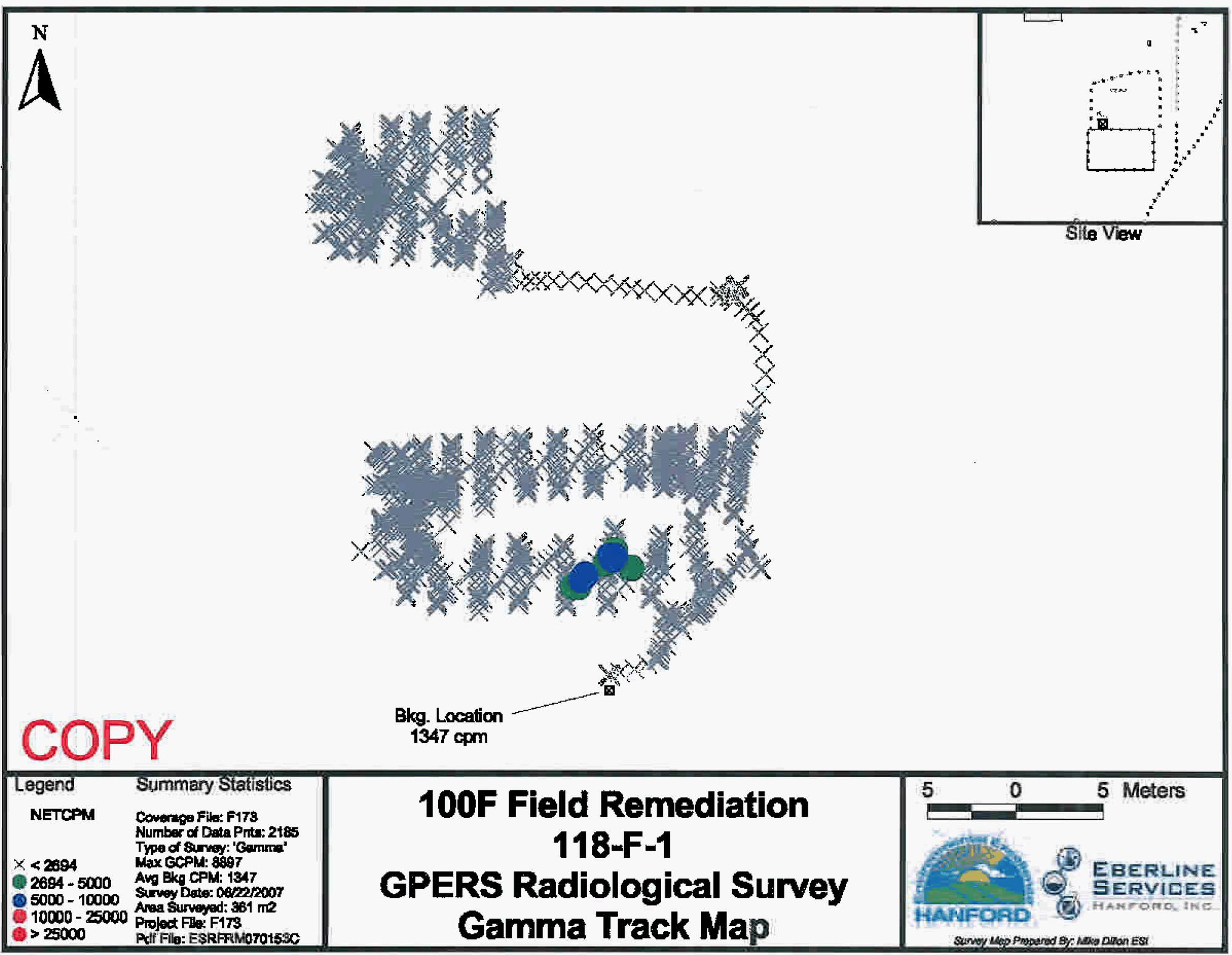

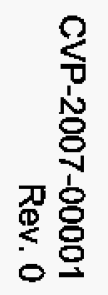




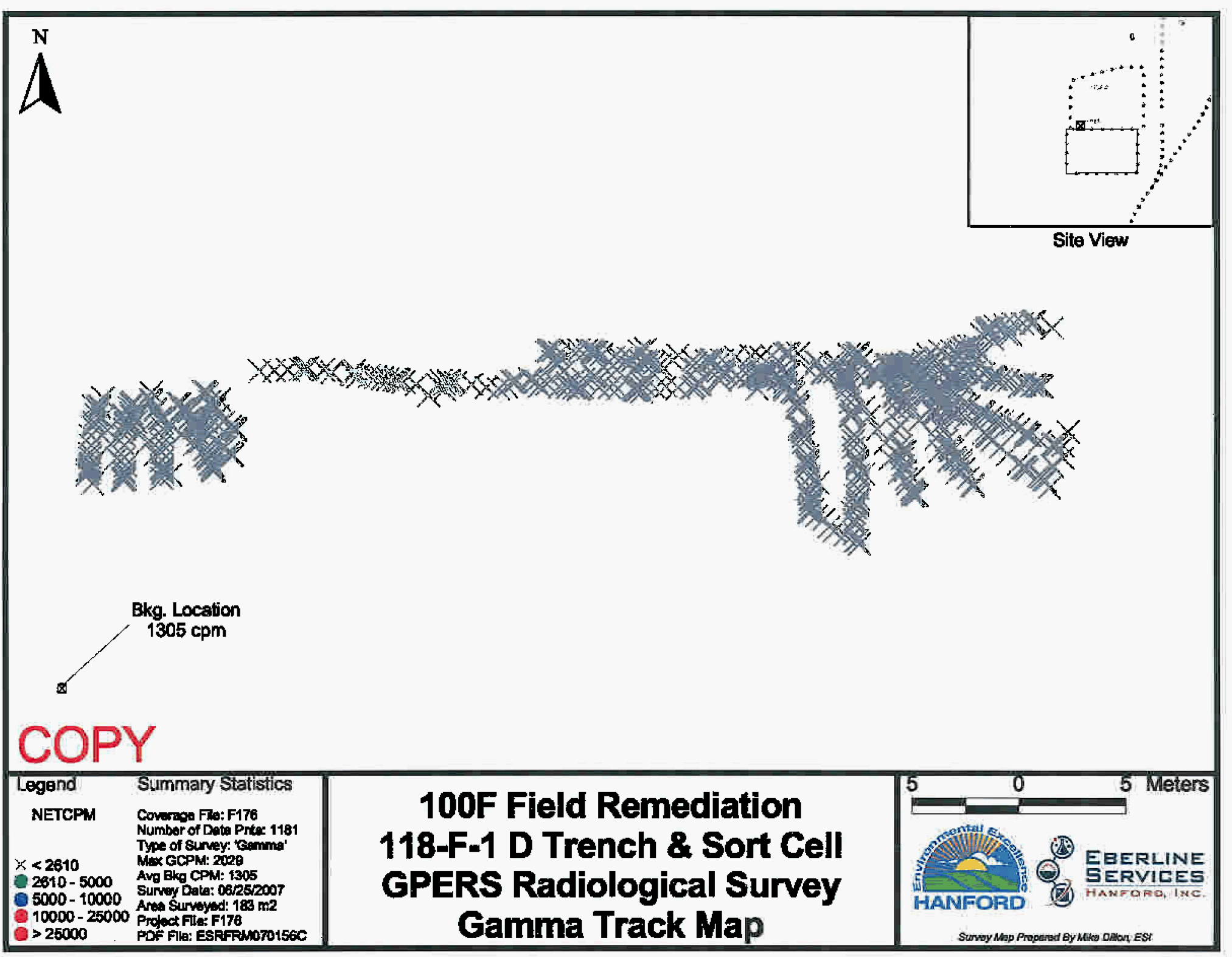

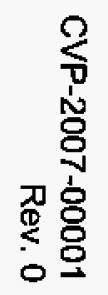


$\stackrel{n}{\wedge}$

8
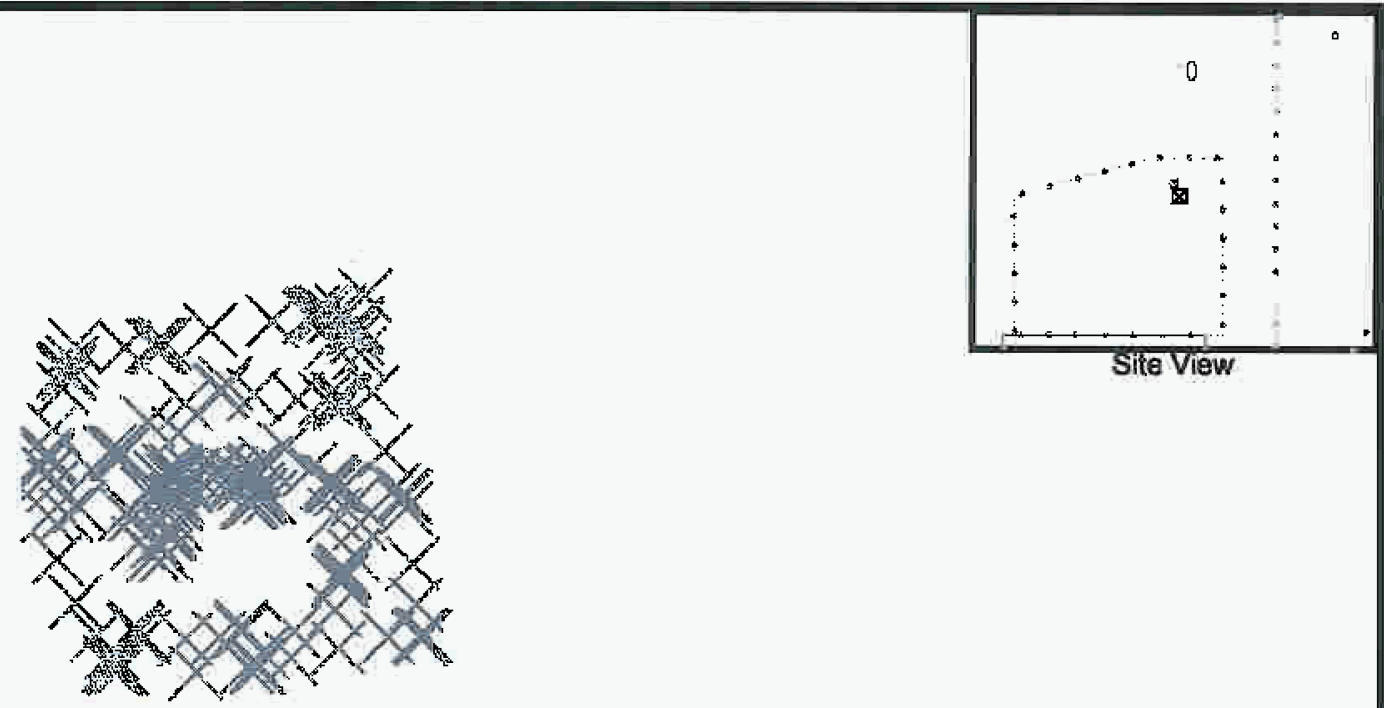

Bkg. Location

$1210 \mathrm{cpm}$

Coverage Fle: Fozes

'Typo of Survar 'Gamma'

Max GCPM: t723

Avg Bly CPM: 1210

Strves Data: OT/250

Ave Surnod.

PdF Fle: ESRFRMOTOOOBC

6 $10 \mathrm{~K}-25$

e $>25 K$

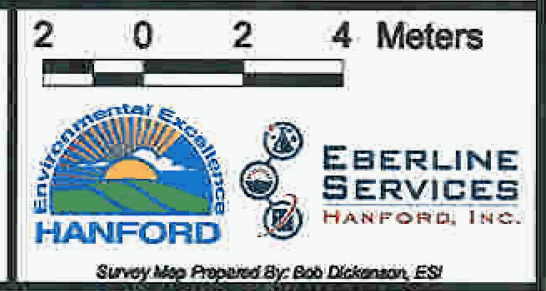




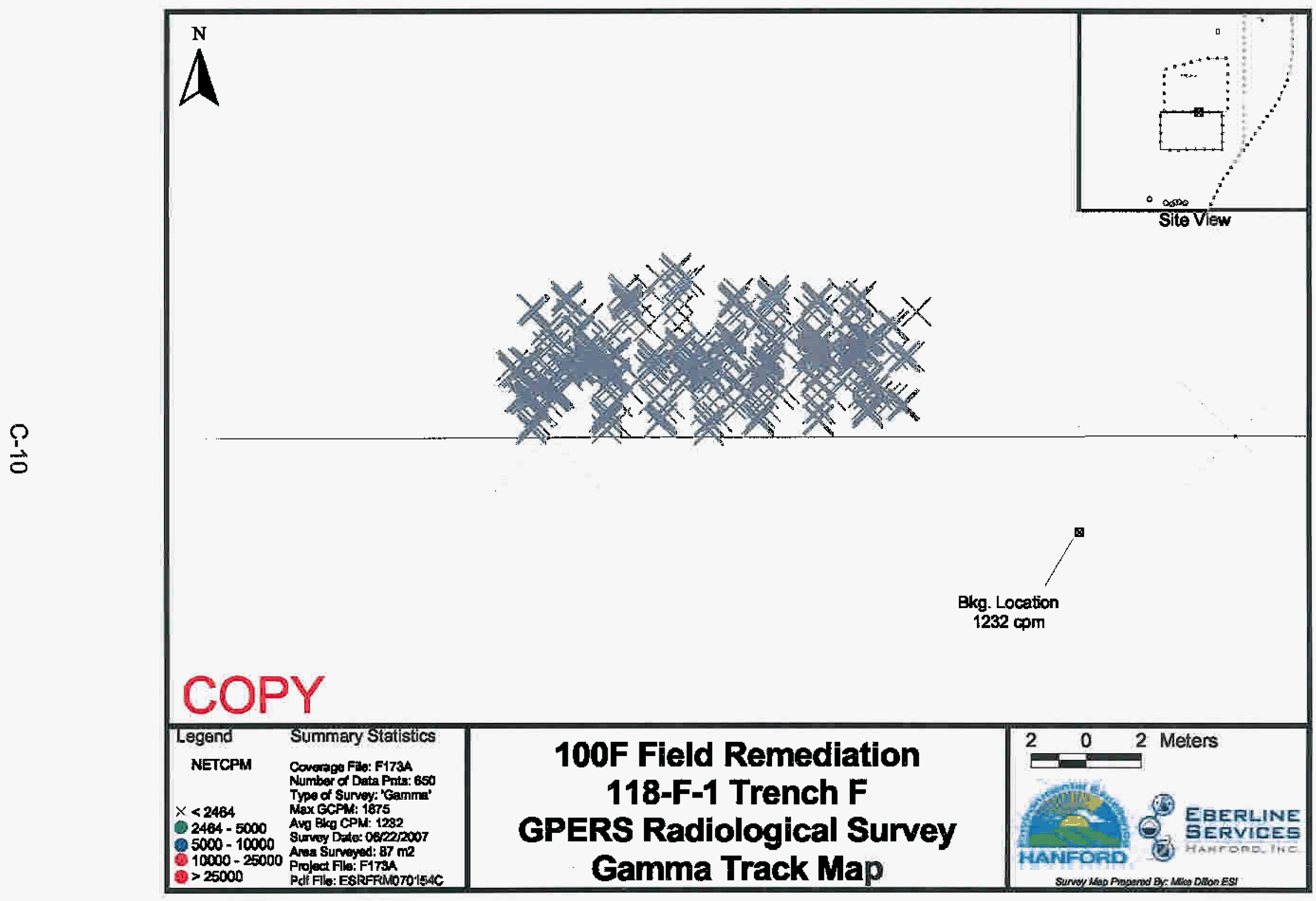




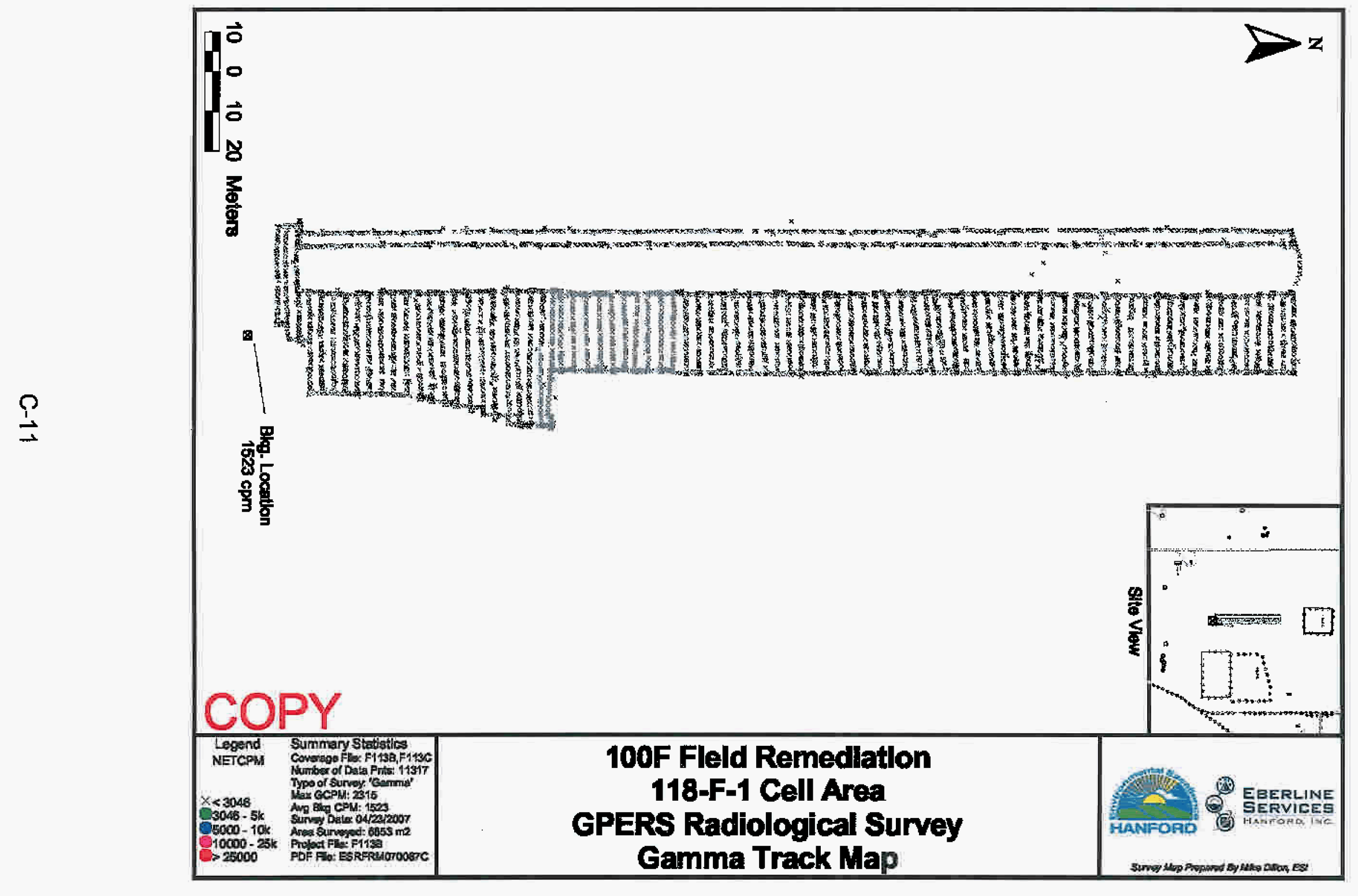

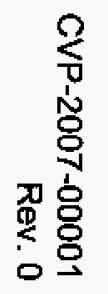




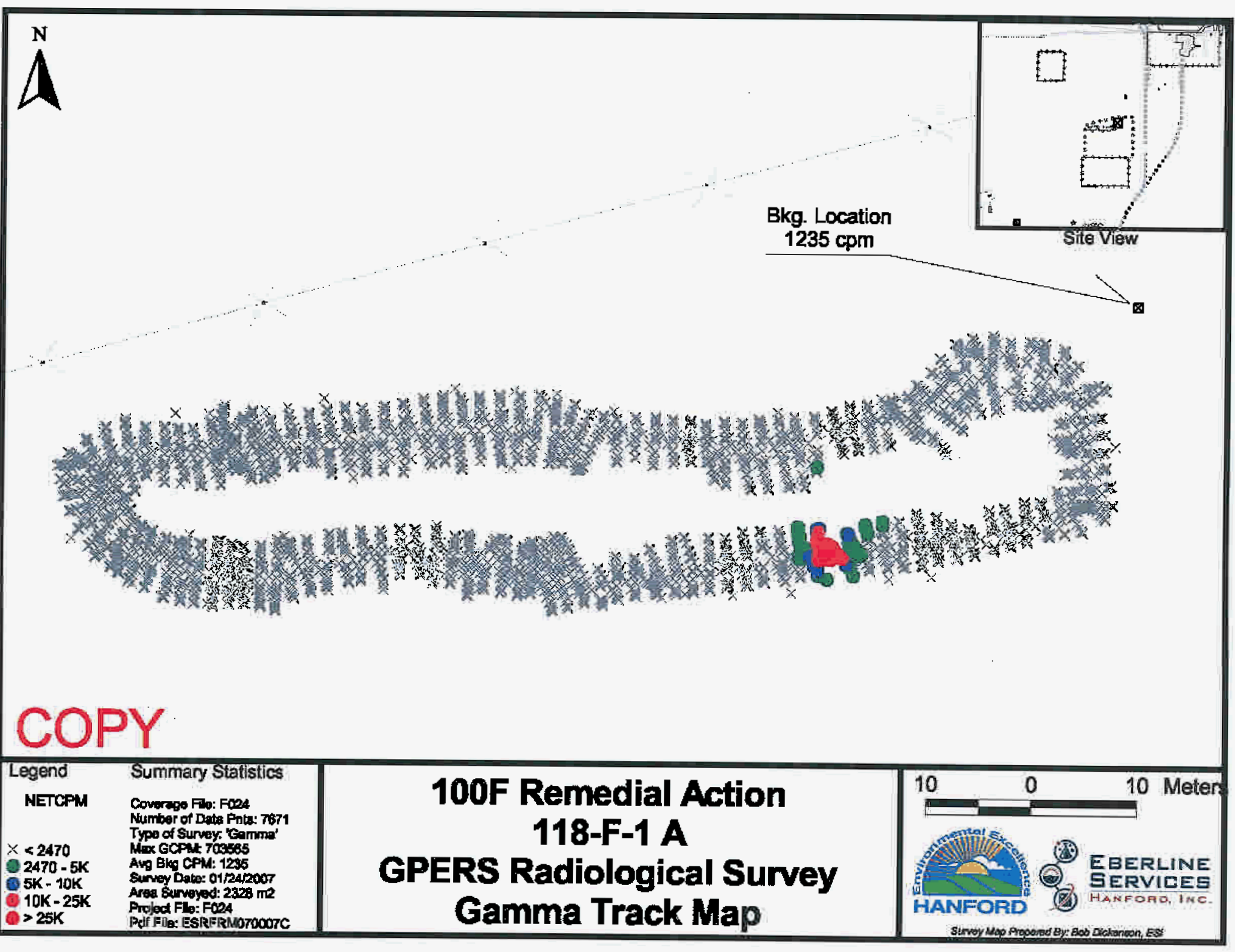

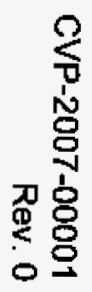




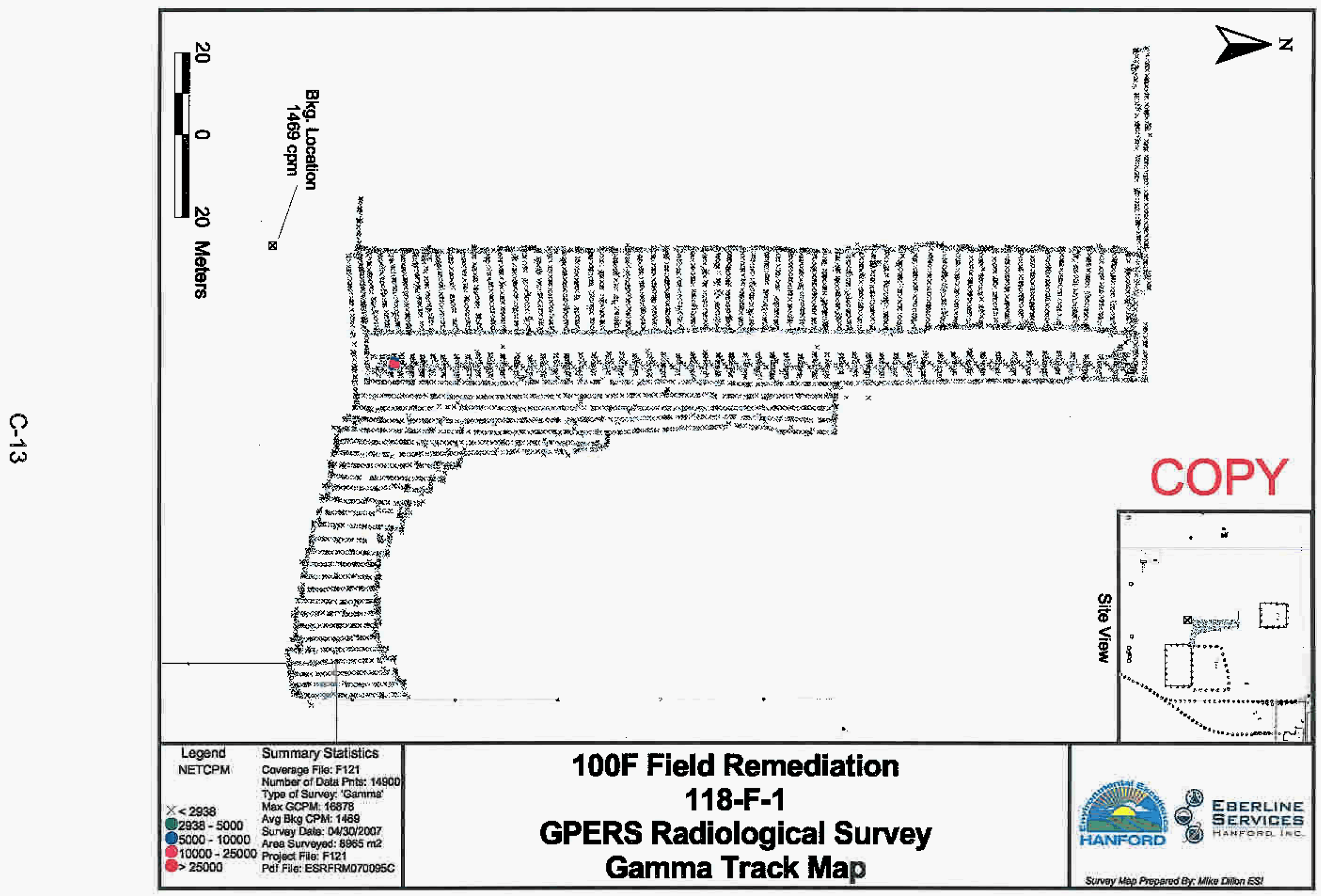




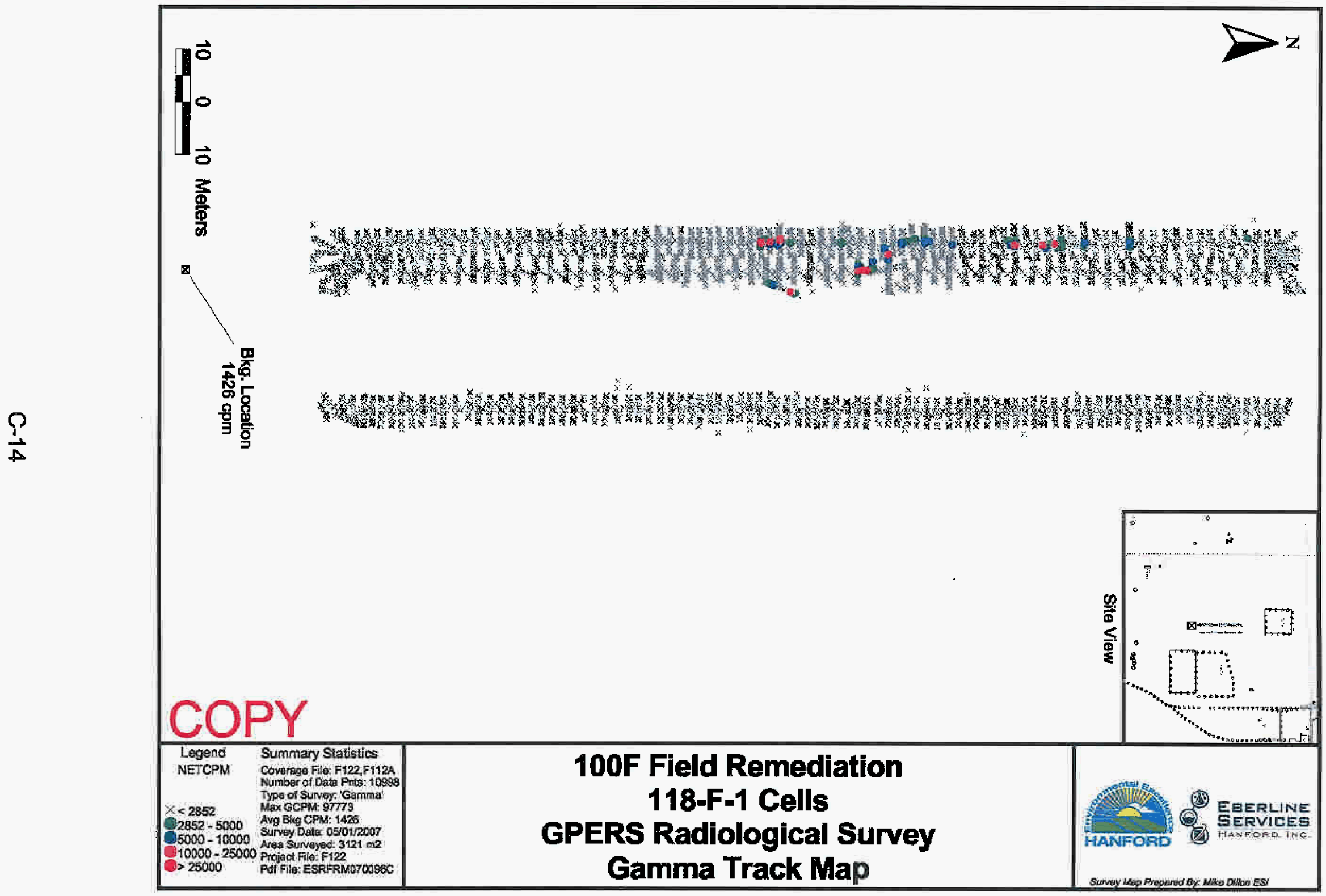




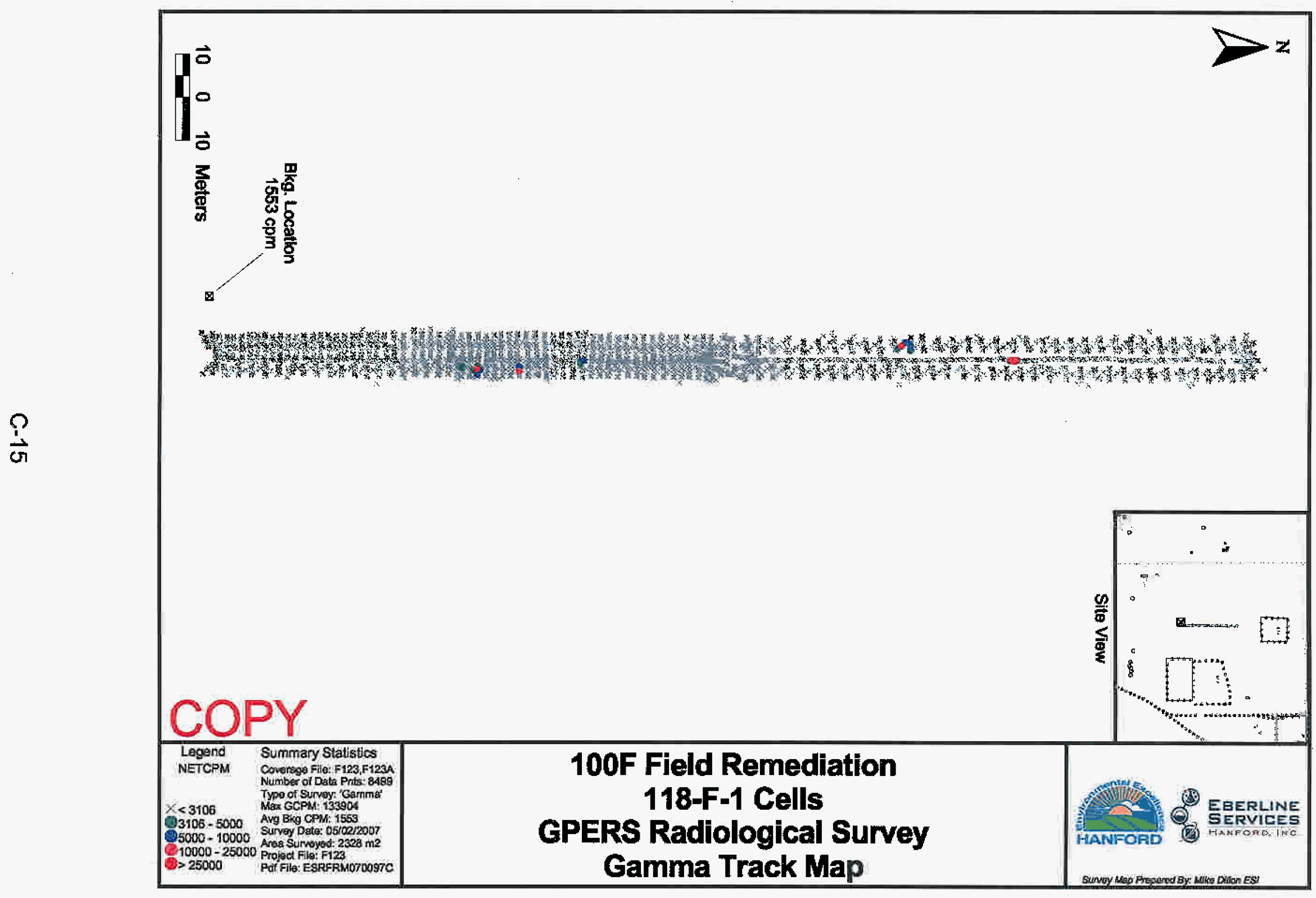

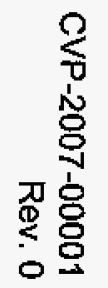




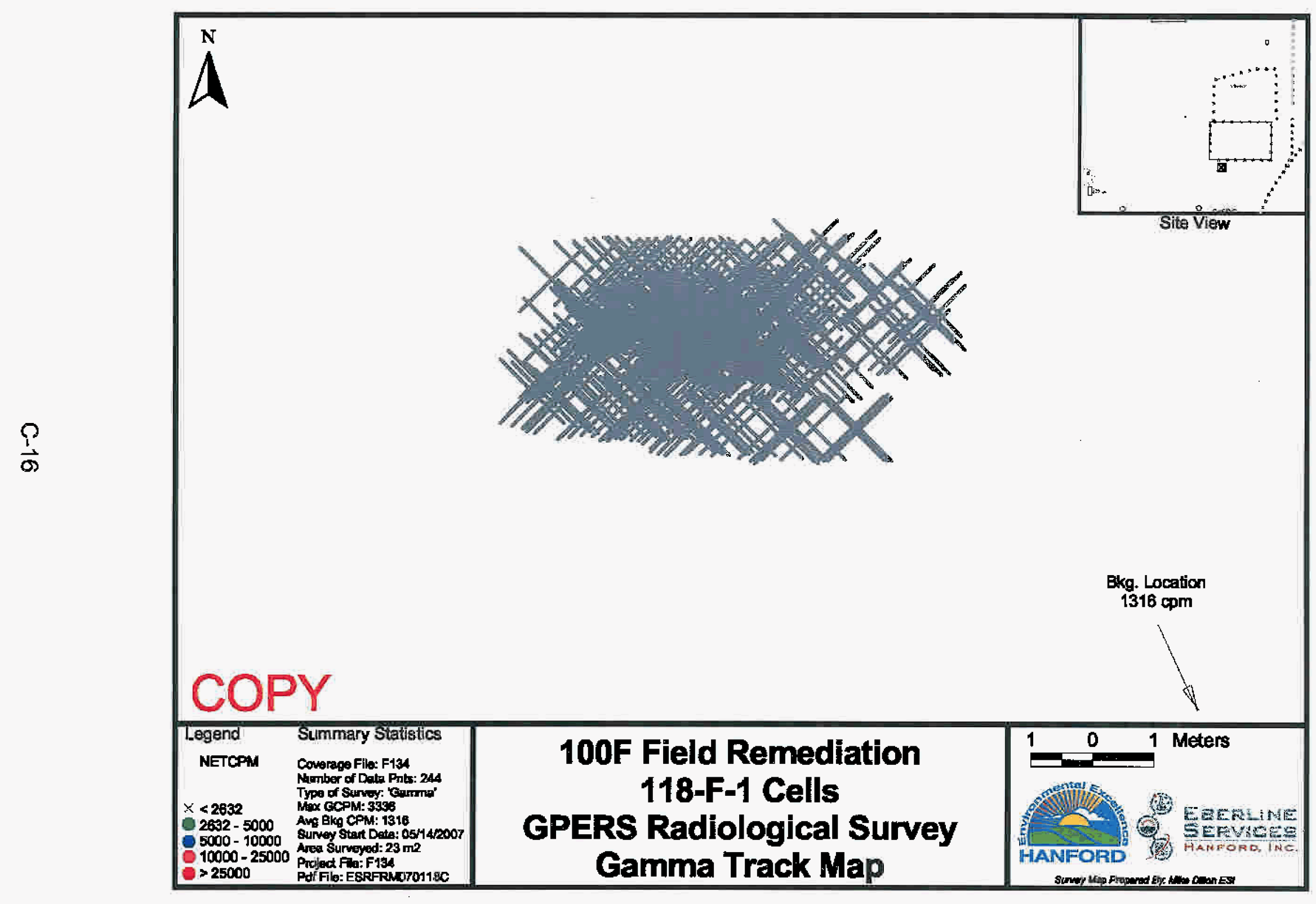




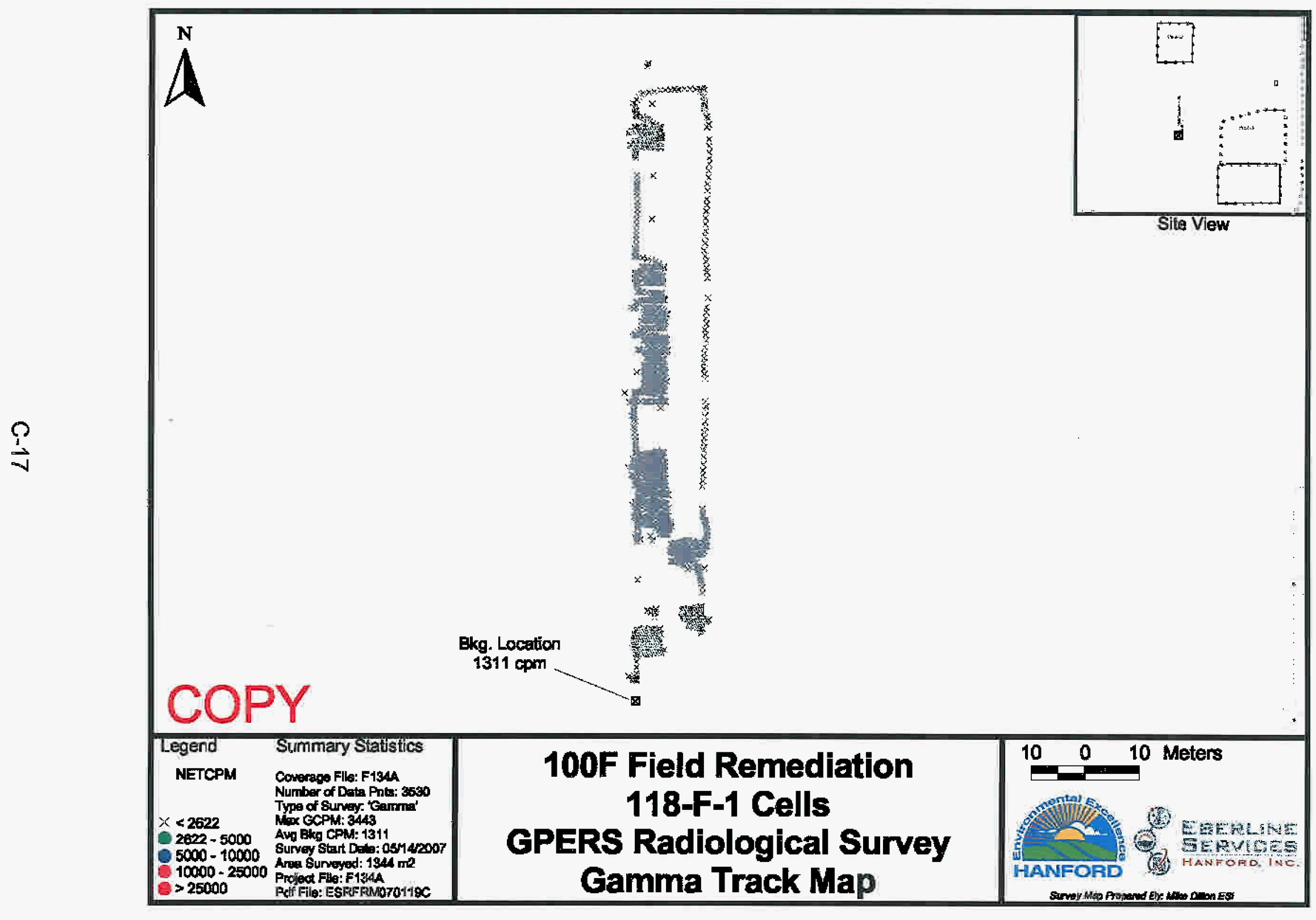




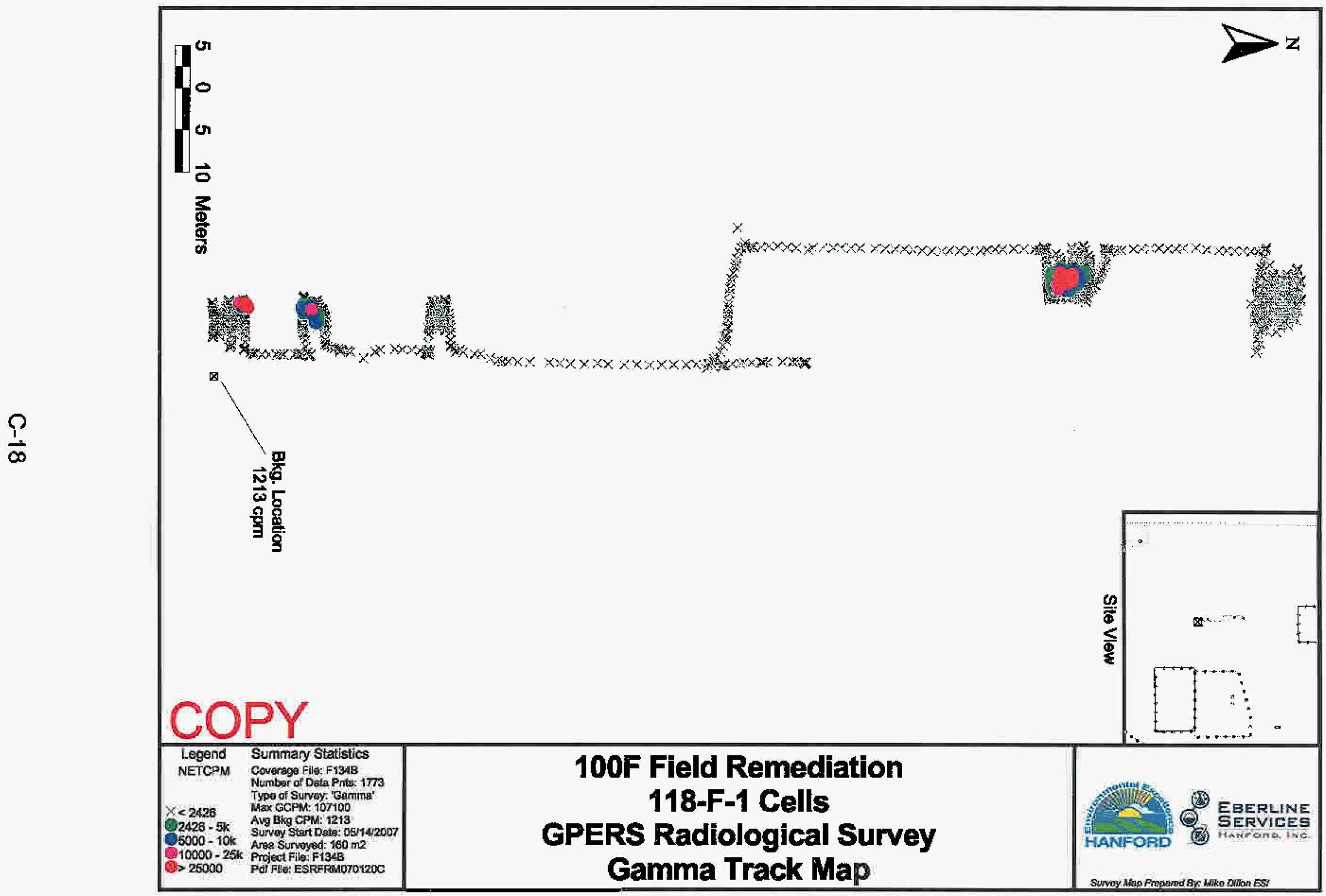




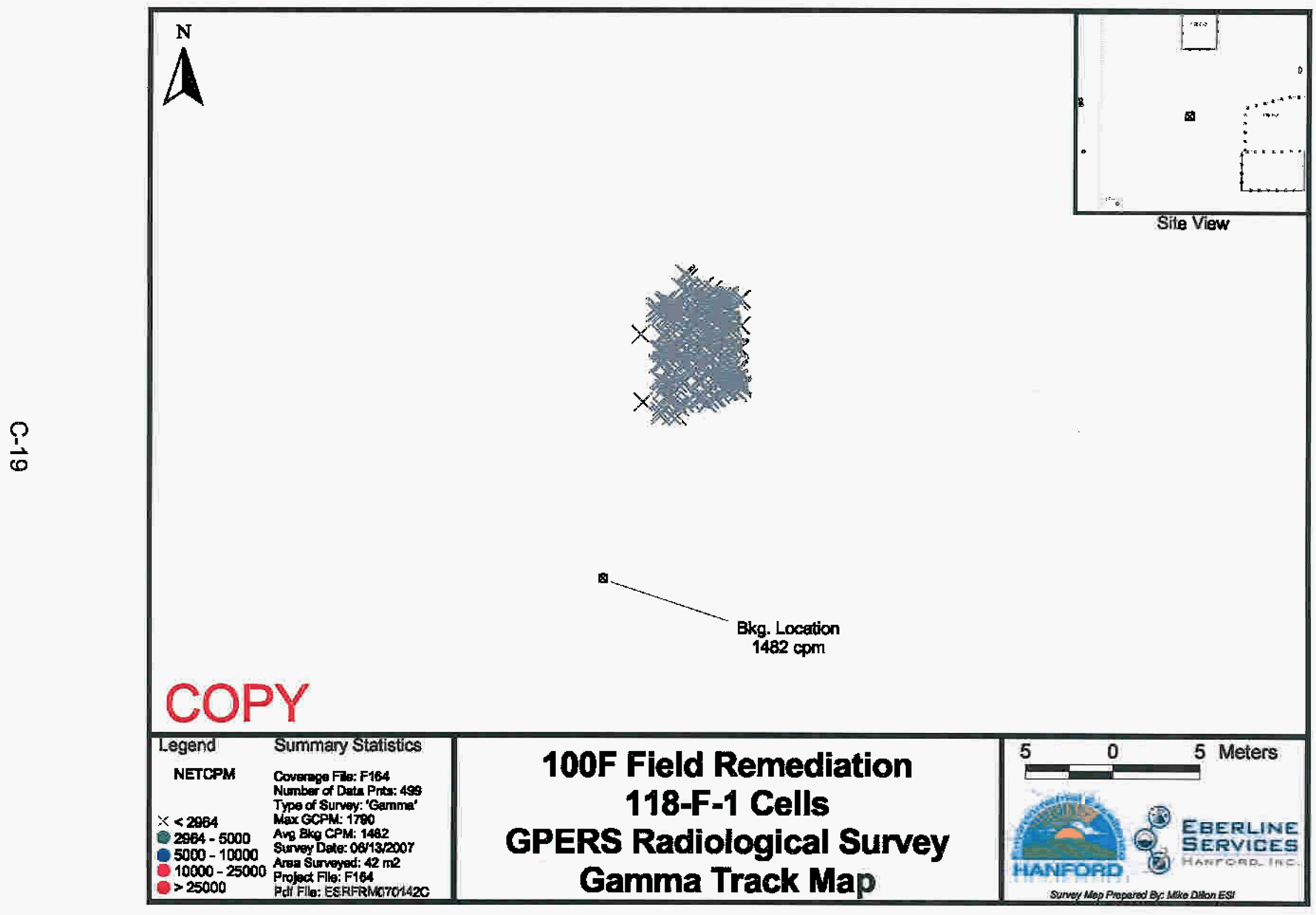




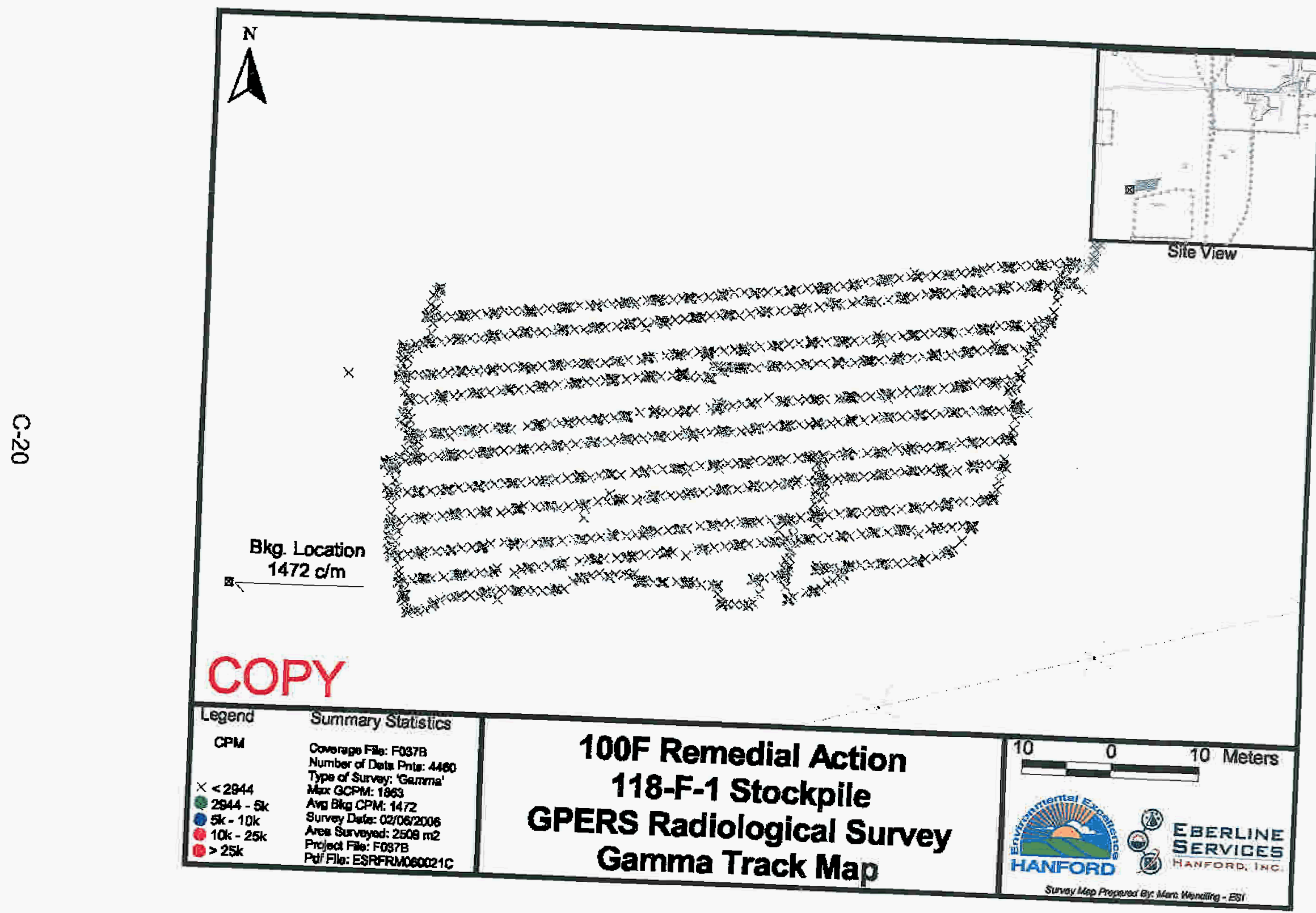

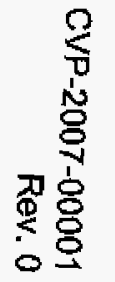




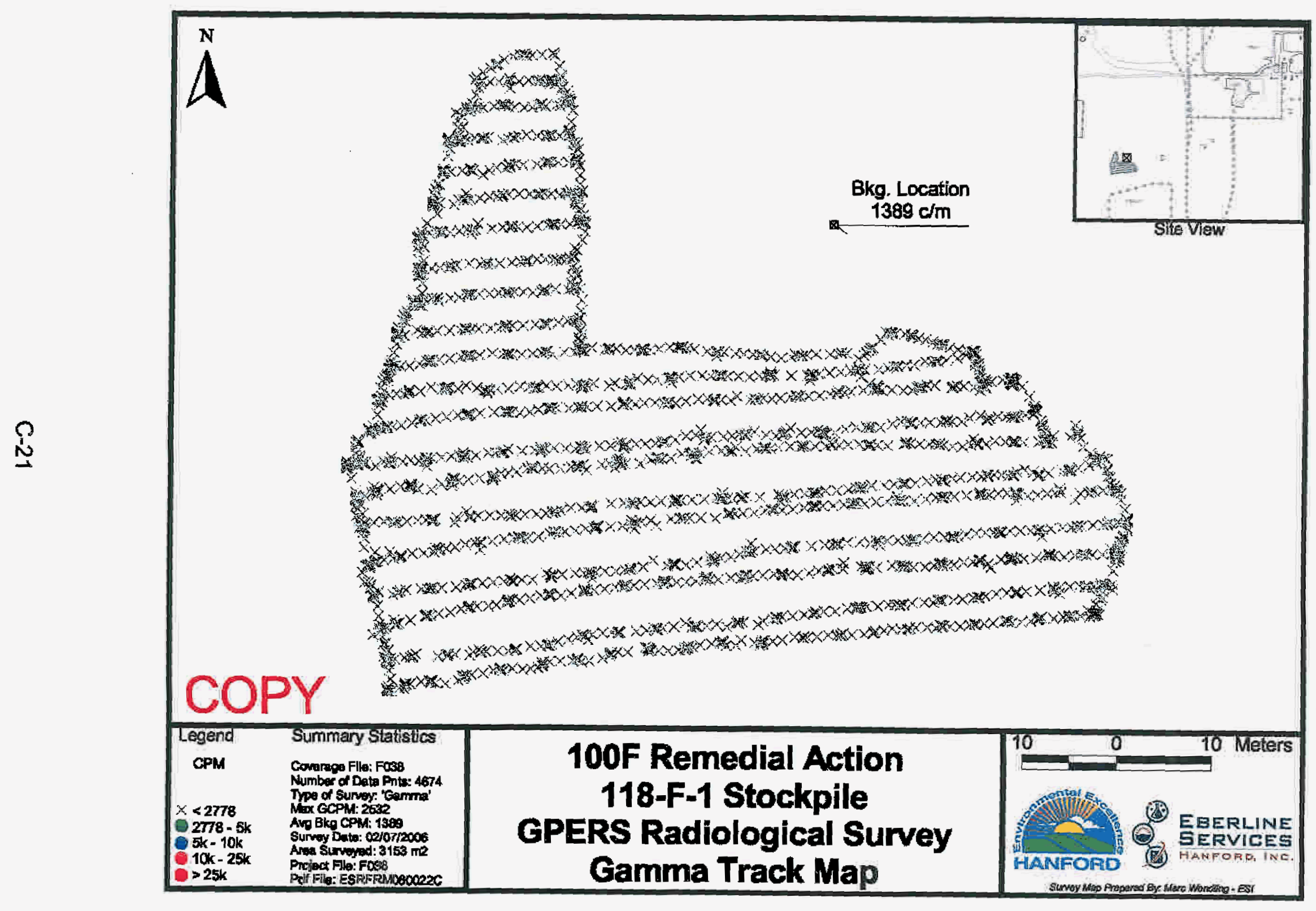

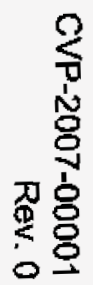




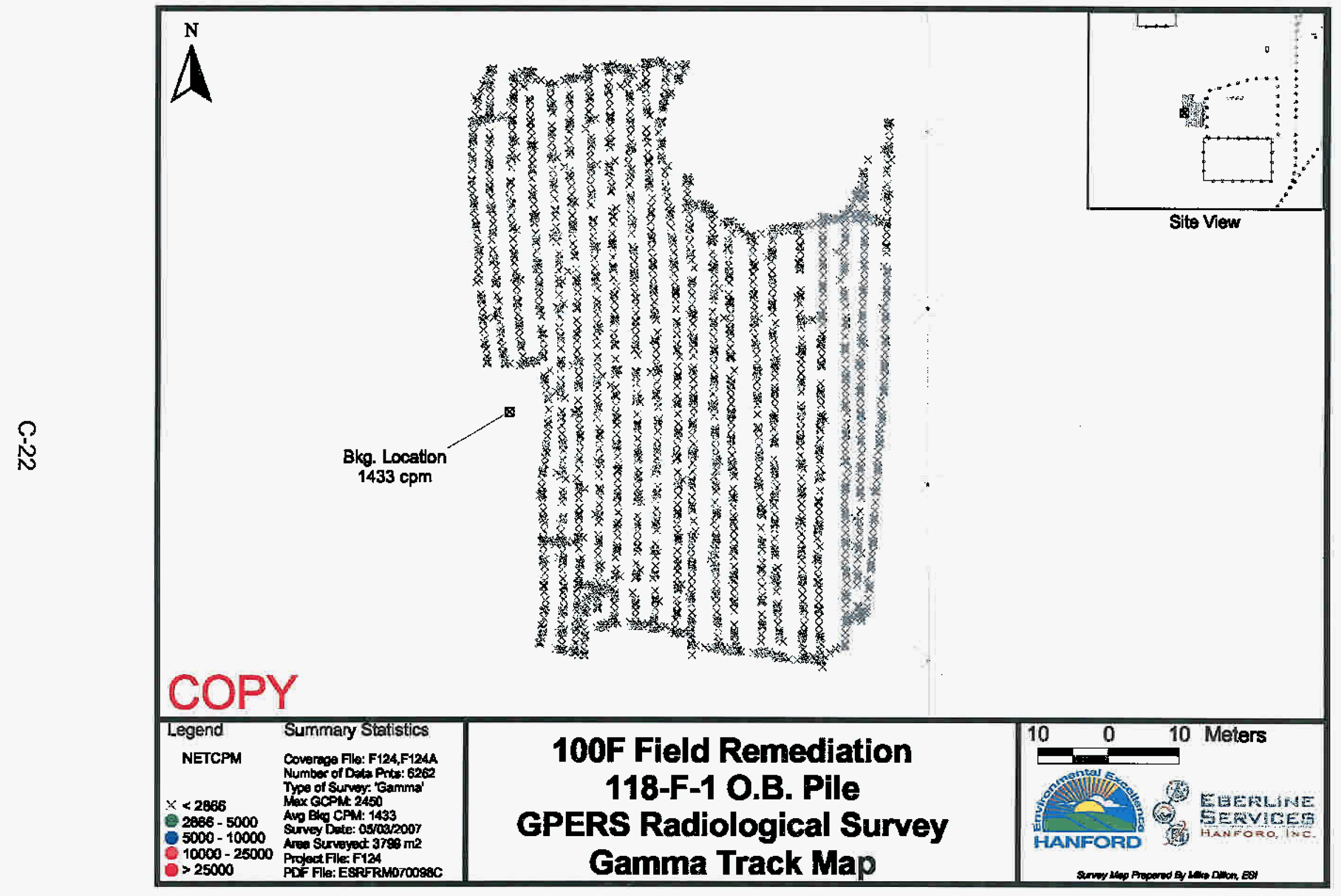




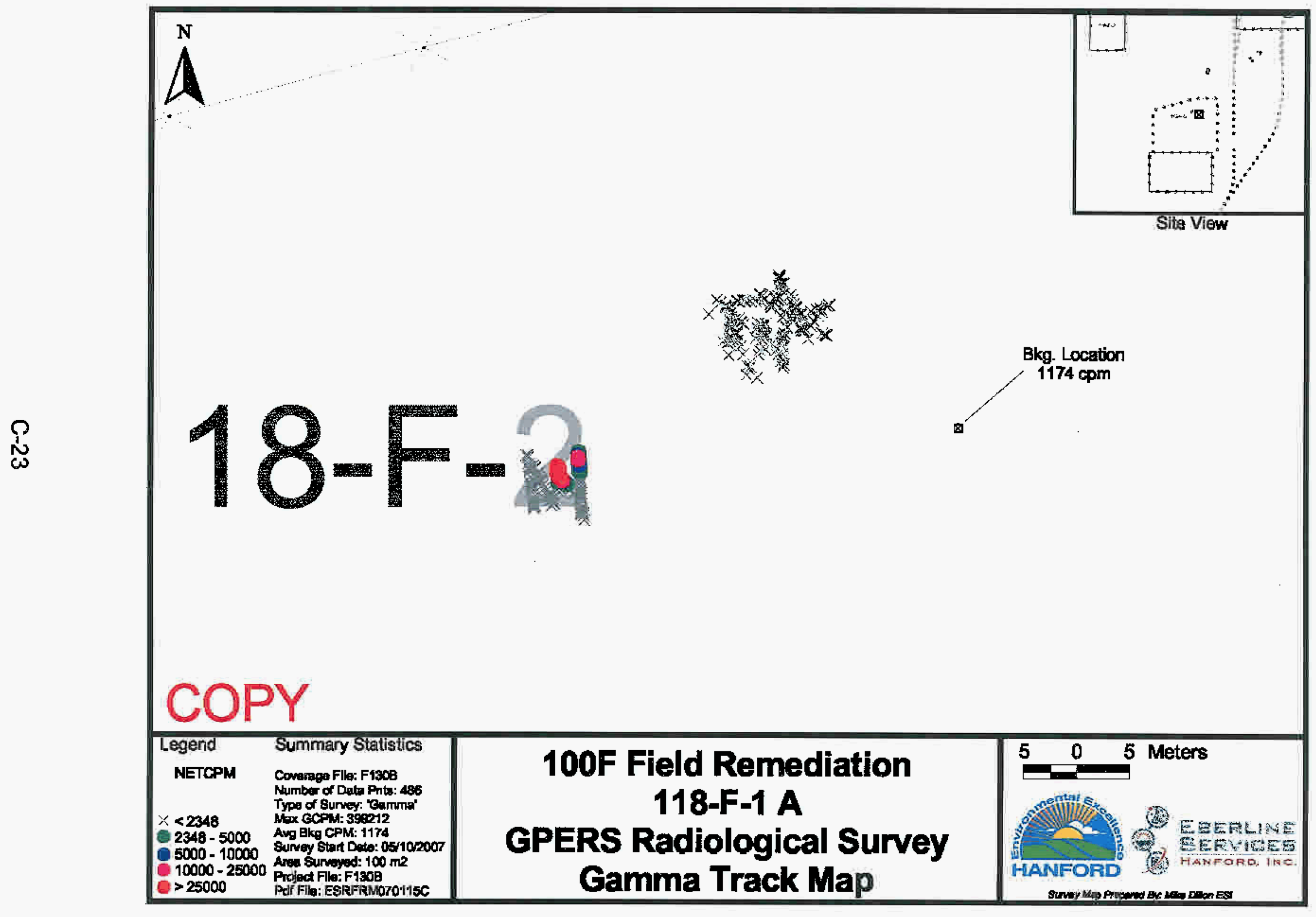

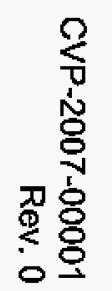



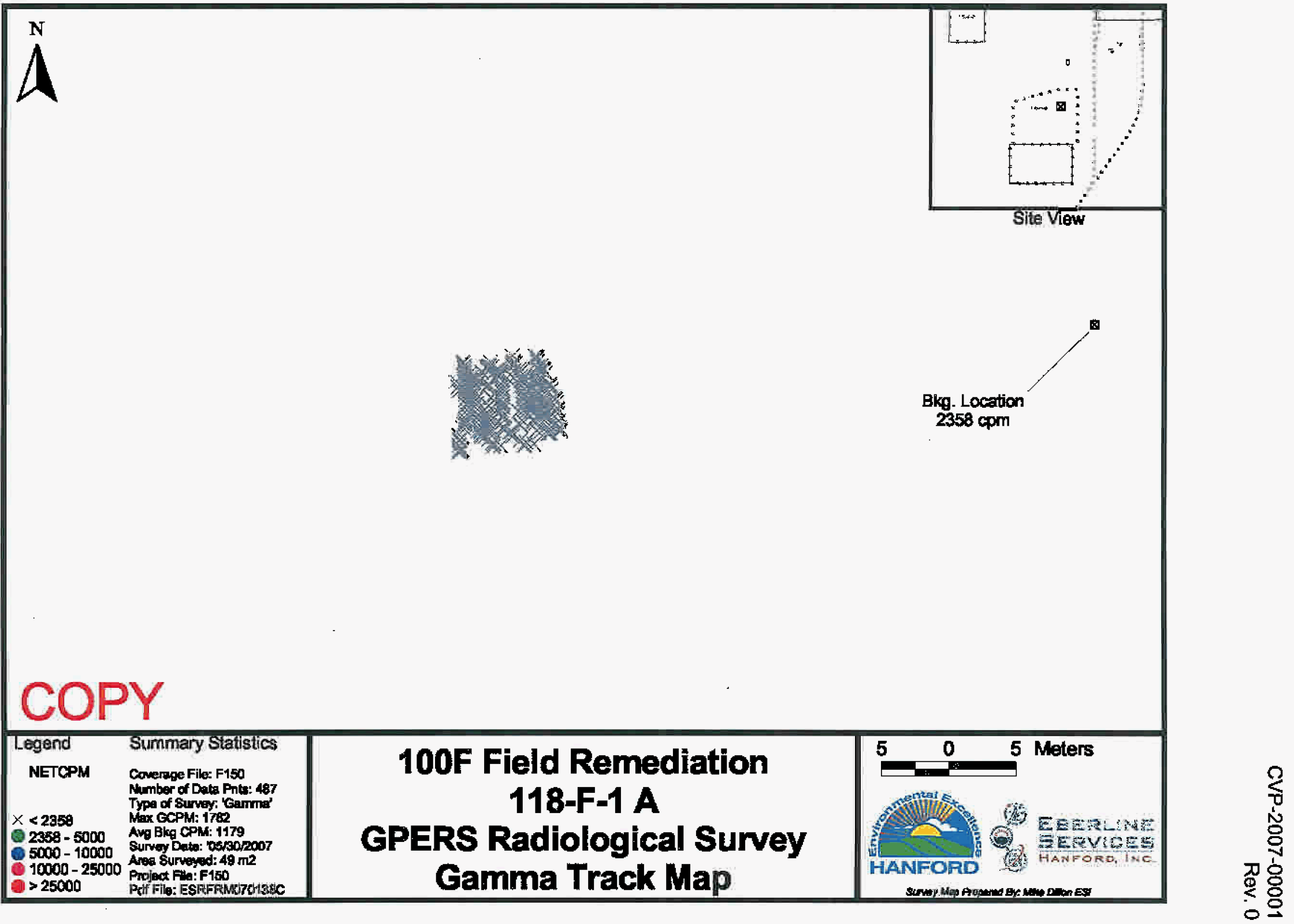


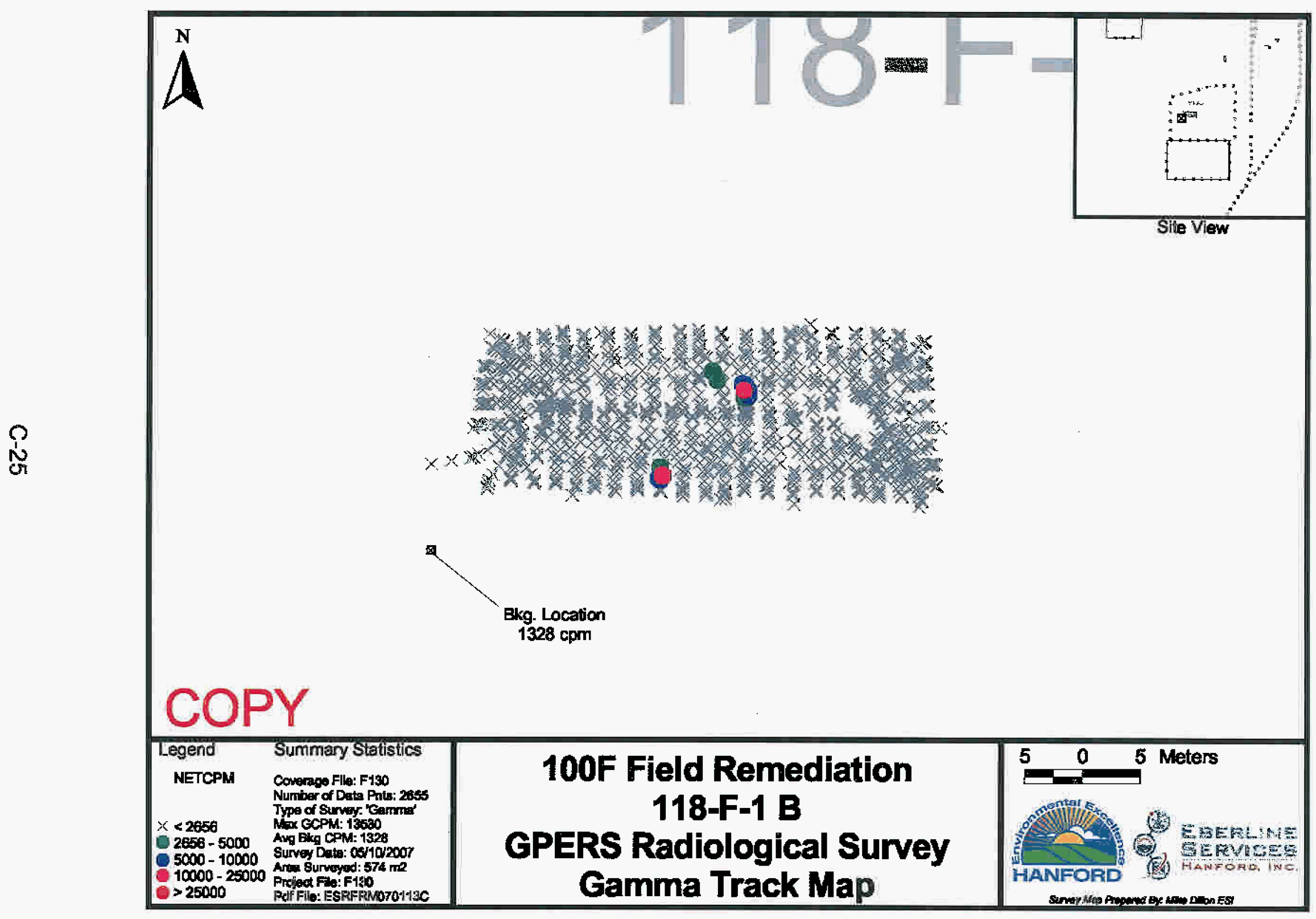

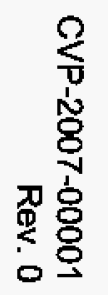




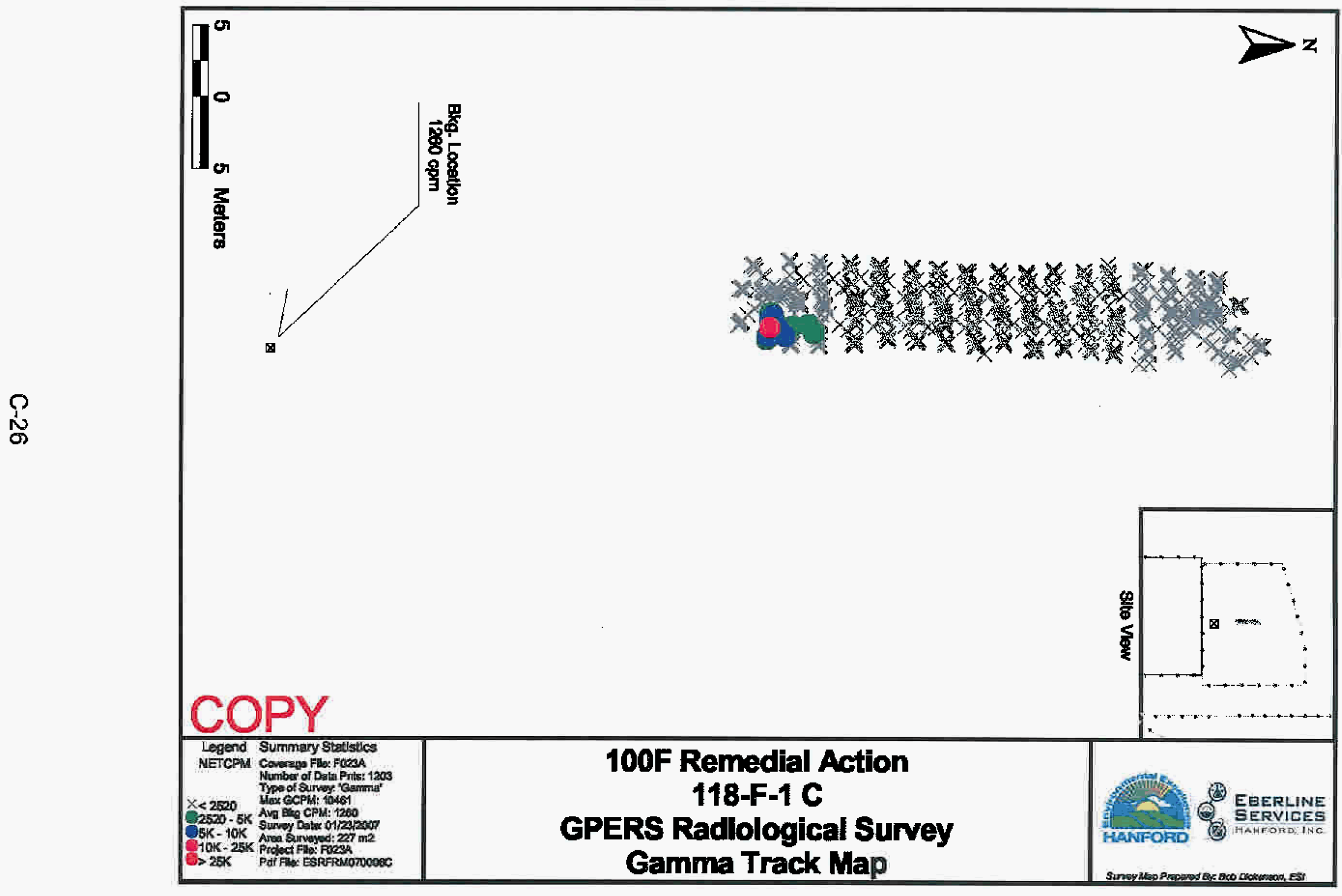

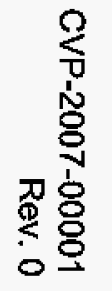




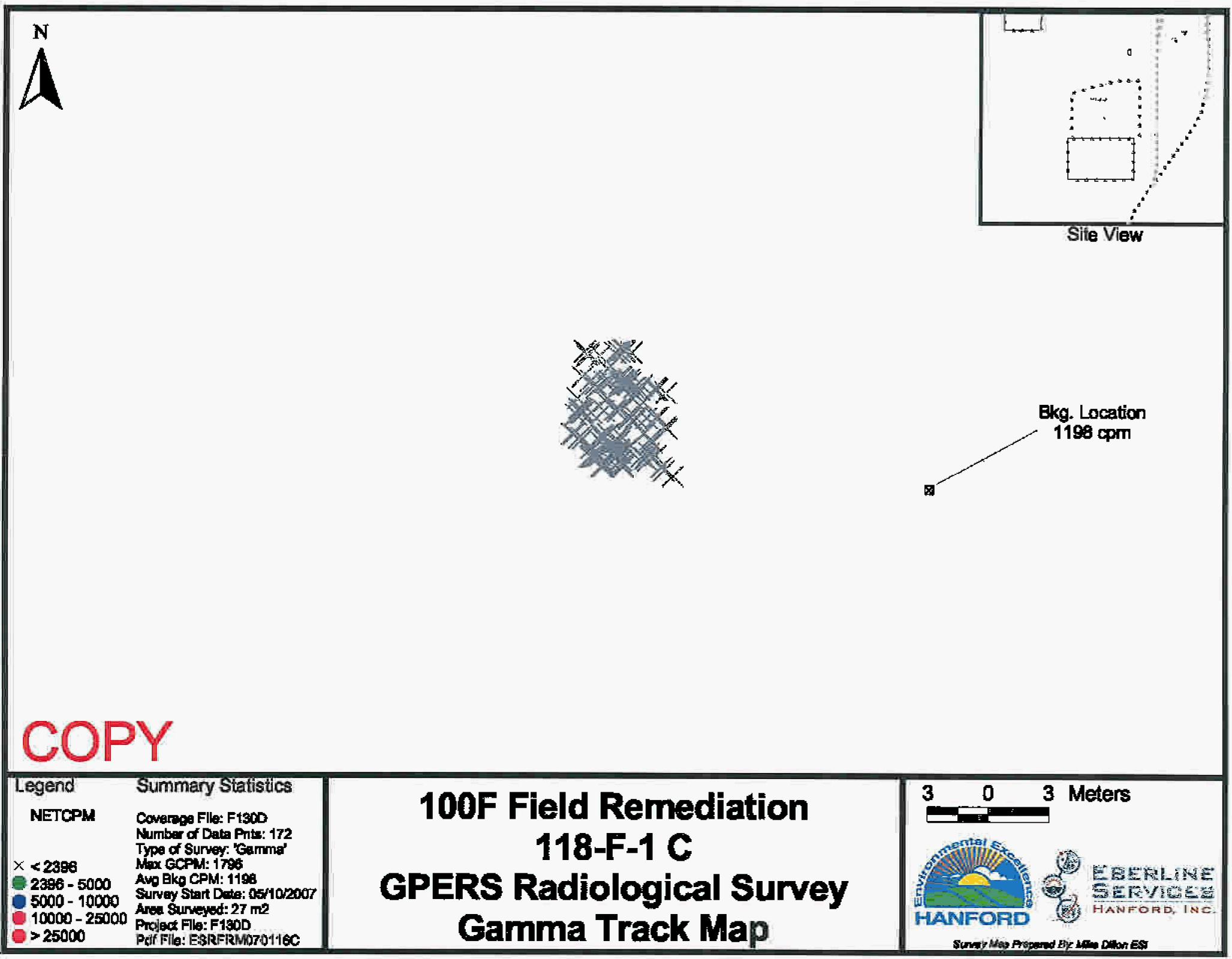




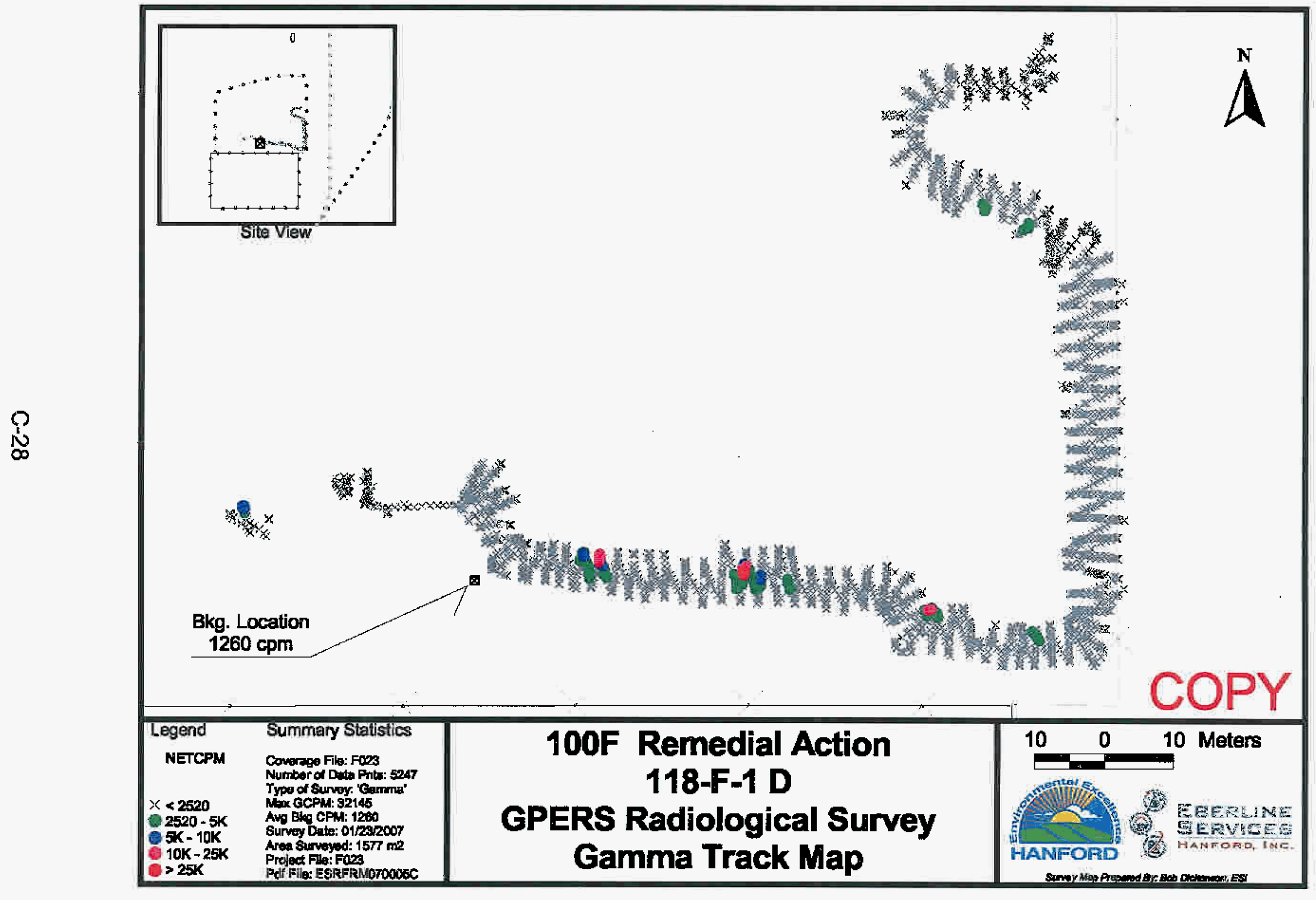




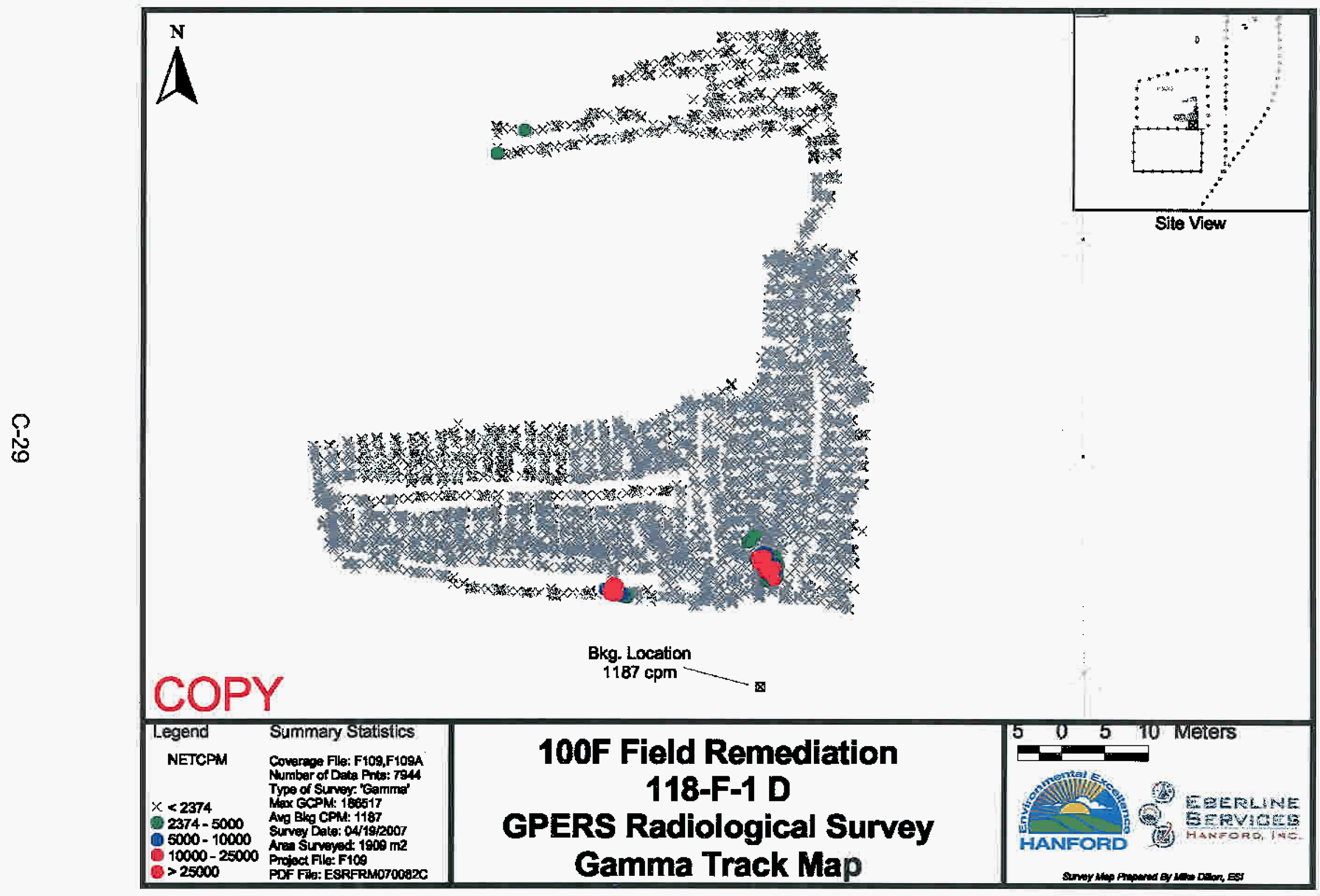

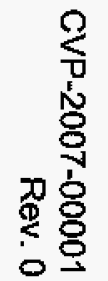


APPENDIX D

DATA QUALITY ASSESSMENT

D-i 
CVP-2007-00001

Rev. 0

D-ii 


\section{Verification Sampling Data Quality Assessment}

A data quality assessment (DQA) was performed to compare the verification sampling approach and resulting analytical data with the sampling and data requirements and site specific data quality objectives specified in the 100 Area Burial Grounds Remedial Action Sampling and Analysis Plan (SAP) (DOE-RL 2001).

A review of the sample design ( $\mathrm{WCH}, 2006 \mathrm{a})$, the field logbooks (WCH 2006b, c), and applicable analytical data packages has been performed as part of this DQA. All samples were collected per the sample design. To ensure quality data, the SAP data assurance requirements and the data validation procedures for chemical and radiochemical analysis (BHI 2000a, 2000b) are used as appropriate. This review involves evaluation of the data to determine if they are of the right type, quality, and quantity to support the intended use (i.e., closeout decisions). The DQA completes the data life cycle (i.e., planning, implementation, and assessment) that was initiated by the data quality objectives process (EPA 2000).

The closeout sampling approach for the 118-F-1 Burial Ground included a sample design with multiple subunit areas. Verification sample data collected at the 118-F-1 waste site(s) were provided by the laboratories in 6 sample delivery groups (SDGs), and one separate SDG for focus asbestos samples. This DQA addresses the SDGs by the subunits as they were designed in the Site Specific Instruction. As the 118-F-1 waste site(s) are comprised of multiple decision units, samples from several decision units may compose any one SDG. Refer to Appendix B for a breakdown of samples by decision unit/sampling location. Unless other wise noted, deficiencies listed below are specific to the individual SDG, but apply to all samples within that SDG.

For the below contaminant level $(B C L)$ stockpiles, verification sample data was provided in two SDGs: SDG K0775, and SDG J00109. For the shallow zone, verification sample data was provided in four SDGs: SDG K0779, SDG K0841, SDG K0781, and SDG J00110. SDG K0779 was submitted for third-party validation. The verification sample data for the process trenches at 118-F-1 Burial Ground are provided in two SDGs: SDG K0781 and SDG J00111. Verification sample data for bulk asbestos was provided in SDG 07-A2525. Major deficiencies were identified in the analytical data set, rendering some data unacceptable for decision-making purposes. Major and minor deficiencies are discussed below.

\section{Below Contamination Level (BCL) Stockpiles}

\section{SDG K0775}

This SDG comprises seventeen field samples collected from BCL stockpiles (J15249 through J15265). These samples were analyzed for ICP metals, mercury, and by alpha spectroscopy, beta counting, gamma spectroscopy, and liquid scintillation counting, as directed in the sample design ( $\mathrm{WCH}, 2006 \mathrm{a})$. One field duplicate pair is included in this SDG (J15261/J15262). No major deficiencies were found in SDG K0775. Minor deficiencies are as follows: 
In the ICP metals analysis, the LCS recovery for silicon is below the acceptance criteria at $29.5 \%$. Associated sample results for silicon are likely biased low. Silicon is not a COPC for the 100-F-1 waste site(s), and the silicon data do not impact completeness of the verification sampling data.

In addition, the MS recoveries for three ICP metals (aluminum, iron, and antimony) are out of acceptance criteria. For aluminum and iron, the spiking concentration is insignificant compared to the native concentration in the sample from which the MS was prepared. For these analytes, the deficiency in the MS is a reflection of the analytical variability of the native concentration rather than a measure of the recovery from the sample. To confirm quantitation, post digestion spikes and serial dilutions were prepared, and the results for the analytes are in the range of $101.2 \%$ and $104 \%$. Antimony did not have mismatched spike and native concentrations in the original MS. The original MS recovery for antimony is $53.2 \%$. Sample results for antimony are considered estimated and flagged "J". The data are useable for decision-making purposes.

The analytes barium, calcium, chromium, iron, manganese, sodium, silicon, and zinc are reported in the MB at concentrations that are below the CRQLs, however, the sample results are greater than 5 times the MB concentration. The data are useable for decision-making purposes.

The relative percent difference (RPD) value for molybdenum is above the laboratory acceptance criteria at $38 \%$. The duplicate pair is near the detection limit, analysis of RPDs is not considered to be useful in the precision determination. The data are usable for decision-making purposes.

In the radionuclides, the RPD calculated for uranium-233/234 in the laboratory duplicate pair for sample $\mathrm{J} 15249$ is above the acceptance criteria of $30 \%$, at $42 \%$. The RPD calculated for radium-228 and thorium-232 in the laboratory duplicate pair for sample $\mathrm{J} 15264$ are above the acceptance criteria of $30 \%$, with both results at $33 \%$. Elevated relative percent differences (RPDs) in environmental soil samples are attributed to natural heterogeneities in the soil matrix from which the sample and duplicate are prepared. The data are useable for decision-making purposes.

\section{SDG J00109}

This SDG comprises one field sample (J152D7), a split of sample J15261from SDG K0775. This sample was analyzed at Severn Trent Laboratories, Inc., with the analyses including ICP metals, mercury, and gamma spectroscopy. Initial data results from the of split sample J152D7 showed significantly greater results of lead and cadmium than seen in the primary sample, or any other samples. Based on this review of the data, the laboratory was requested to reanalyze the sample. Results from the second analysis 
correlate well with the other data and replaced the original data for J152D7. No major deficiencies were found in SDG J00109. Minor deficiencies are as follows:

In the ICP metals analysis, the analytes calcium, lead, and silicon are reported in the $\mathrm{MB}$ at concentrations that are below the CRQLs, however, the sample results are greater than 5 times the MB concentration, and the data are useable for decisionmaking purposes.

In addition, the MS recoveries for seven ICP metals (aluminum, cadmium, copper, iron, lead, silicon, and zinc) are out of acceptance criteria. For these analytes, the spiking concentration is insignificant compared to the native concentration in the sample from which the MS was prepared. Therefore, the deficiency in the MS is a reflection of the analytical variability of the native concentration rather than a measure of the recovery from the sample. The data are useable for decision-making purposes.

In the gamma spectroscopy analysis, there was insufficient material to perform a duplicate analysis. The sample was recounted on a different detector to provide a laboratory duplicate. Plutonium-238 and curium-243/244 were detected in the MB. The data are useable for decision-making purposes.

In the alpha spectroscopy analysis, the RPD calculated for uranium-234 in the laboratory duplicate pair is above the acceptance criteria at $78.1 \%$. Each sample result is just above the detection limit. When the duplicate pair is near the detection limit, analysis of RPDs is not considered to be useful in the precision determination. The data are useable for decision-making purposes.

\section{Shallow Zone}

\section{SDG K0779}

This SDG comprises 12 field samples (J15266 - J15268, J15271 - J15274, J15276J15280) collected from the shallow zone, and three focus samples associated with the graphite chip/dust area discovered in the burial ground (J152J4 - J152J6). These samples were analyzed for ICP metals, mercury, and by alpha spectroscopy, beta counting, gamma spectroscopy, and liquid scintillation counting. One field duplicate pair is included in this SDG (J15272/J15273). SDG K0779 was submitted for formal thirdparty validation. A major deficiency was found in SDG K0779. Major and minor deficiencies are as follows:

For the radionuclide analysis, six analytes exceeded the RQL. Under the $\mathrm{WCH}$ statement of work, no qualification is required, and these small exceedances were not qualified by third-party validation.

No matrix spike analysis was performed for tritium and carbon-14, and no laboratory control sample (LCS) analysis was performed for curium-242, in SDG K0779. Thirdparty validation has qualified the analytical data for tritium, carbon-14, and curium-242 
in all samples for SDG K0779 as estimated with "J" flags. The data are useable for decision-making purposes.

In the ICP metals analysis, the LCS recovery for silicon is below the acceptance criteria at $10.8 \%$. Third-party validation has qualified the analytical data for silicon in SDG K0779 as estimate and flagged "J". The data are useable for decision-making purposes.

The MS recoveries for five ICP metals (aluminum, iron, manganese, antimony, and silicon) are out of acceptance criteria. For most of these analytes, the spiking concentration is insignificant compared to the native concentration in the sample from which the MS was prepared. For these analytes, the deficiency in the MS is a reflection of the analytical variability of the native concentration rather than a measure of the recovery from the sample. To confirm quantitation, post digestion spikes and serial dilutions were prepared, and the results for the analytes are in the range of $88.9 \%$ and $101.9 \%$. Antimony did not have mismatched spike and native concentrations in the original MS. The original MS recovery for antimony is $57.6 \%$, and third-party validation has qualified antimony sample results for SDG K0779 as estimated and flagged "J". The data are useable for decision-making purposes.

The analytes barium, calcium, and potassium are reported in the $\mathrm{MB}$ at concentrations that are below the CRQLs, however, the sample results are greater than 5 times the MB concentration, and the data are useable for decision-making purposes.

\section{SDG J00110}

This SDG comprises one split sample: sample J152D8 is a split of sample J15272 from SDG K0779. This SDG was analyzed for ICP metals, mercury, and by alpha spectroscopy, beta counting, gamma spectroscopy, and liquid scintillation counting. No major deficiencies were found in SDG J00087. Minor deficiencies are as follows:

The analytes calcium, lead, and silicon are reported in the MB at concentrations that are below the CRQLs, however, the sample results are greater than 5 times the MB concentration. The data are useable for decision-making purposes.

The MS recoveries for six ICP metals (aluminum, cadmium, copper, lead, iron, silicon, and zinc) are out of acceptance criteria. For all six ICP metals, the spiking concentration is insignificant compared to the native concentration in the sample from which the MS was prepared. For these analytes, the deficiency in the MS is a reflection of the analytical variability of the native concentration rather than a measure of the recovery from the sample. All ICP metals data for SDG J00110 are useable for decision-making purposes.

In the gamma spectroscopy analysis, the laboratory reported that there was insufficient sample size to prepare a laboratory duplicate of sample J152D7. The duplicate result was obtained by recounting sample J152D7 on a second detector. 
The RPD calculated for alpha spectroscopy results in the laboratory duplicate pair are above the acceptance criteria for the sample results reported below the detection limit. For nickel-63, each of the samples results is below the detection limit. When the duplicate pair is below the detection limit, analysis of RPDs is not considered to be useful in the precision determination. The data are useable for decision-making purposes.

The radionuclides plutonium-238 and curium-243/244 are reported in the MB at a concentration similar to the MDL. Plutonium-238 in sample J152D7 is reported below the detection limit. Sample J152D7 has a curium-243/244 result similar to the result reported for the MB. The MB curium-243/244 result indicates that the J152D7 curium-243/244 result may be biased high. The J152D7 curium-243/244 result is considered estimated and flagged "J". The data are useable for decision-making purposes.

\section{SDG K0841}

This SDG comprises seven shallow zone samples (J15269, J15270, J15281, J15282, J15661, J15688, and J15689). These samples were analyzed for ICP metals, mercury, and by alpha spectroscopy, beta counting, gamma spectroscopy, and liquid scintillation counting. No major deficiencies were found in SDG K0841. Minor deficiencies are as follows:

In the ICP metals analysis, the LCS recovery for silicon is below the acceptance criteria at $38.6 \%$. The silicon data are considered estimated and flagged "J". The data are useable for decision-making purposes.

The MS recoveries for five ICP metals (aluminum, iron, antimony, and silicon) are out of acceptance criteria. For aluminum and iron, the spiking concentration is insignificant compared to the native concentration in the sample from which the MS was prepared. For these analytes, the deficiency in the MS is a reflection of the analytical variability of the native concentration rather than a measure of the recovery from the sample. To confirm quantitation, post digestion spikes and serial dilutions were prepared, and the results for the analytes are in the range of $98.2 \%$ and $101.1 \%$. Antimony and silicon did not have mismatched spike and native concentrations in the original MS. The original MS recovery for antimony is $76.8 \%$, and sample results are considered estimated and flagged "J". The original MS recovery for silicon is $28.6 \%$, and silicon data are qualified as estimated and flagged "J". The data are useable for decision-making purposes.

The analytes barium, calcium, copper, iron, magnesium, sodium, silicon, and zinc are reported in the MB at concentrations that are below the CRQLs, however, the sample results are greater than 5 times the MB concentration, and the data are useable for decision-making purposes. 


\section{Process Trenches}

\section{SDG K0781}

This SDG comprises five field samples collected from process trenches (J15283J15288), and one shallow zone field sample (J15275). Sample J15288 was replaced with sample J15688, and sample J15275 was replaced with sample J15661, both of which are reported in SDG K0841. These samples were analyzed for ICP metals, mercury, and by alpha spectroscopy, beta counting, gamma spectroscopy, and liquid scintillation counting. One field duplicate pair is included in this SDG (J15286/J15287). A major deficiency was found in SDG K0781. Major and minor deficiencies are as follows:

The analytes barium, calcium, magnesium, sodium, and silicon are reported in the MB at concentrations that are below the CRQLs. However, the sample results are greater than 5 times the MB concentration, and the data are useable for decision-making purposes.

In addition, the MS recoveries for five ICP metals (aluminum, iron, manganese, antimony, and silicon) are out of acceptance criteria. For most of these analytes, the spiking concentration is insignificant compared to the native concentration in the sample from which the MS was prepared. For these analytes, the deficiency in the MS is a reflection of the analytical variability of the native concentration rather than a measure of the recovery from the sample. To confirm quantitation, post digestion spikes and serial dilutions were prepared, and the results for the analytes are in the range of $96.4 \%$ to $104.7 \%$. Antimony had a native concentration in the original MS below the detection limit. The original MS recovery for antimony is $59.2 \%$. The antimony results in SDG K0781 are considered estimated and flagged "J". The data are useable for decisionmaking purposes.

Also, in the ICP metals analysis, the LCS recovery for silicon is below the acceptance criteria at $1 \%$. Silicon is not a COPC for the $100-\mathrm{F}-1$ waste site(s).

The RPDs calculated for silicon in the laboratory duplicate pair (sample $\mathrm{J} 15275$, and J15725 [duplicate]), are above the acceptance criteria with the value of $39.4 \%$. Elevated RPDs in environmental soil samples are attributed to heterogeneities in the sample matrix and not to deficiencies in the analytical methodologies. However, because there are multiple QC issues with the silicon samples, the silicon results for SDG K0781 are considered estimated and flagged "R".

In the alpha spectroscopy analysis, the RPDs calculated for uranium-238 in the laboratory duplicate pair is above the acceptance criteria at $37 \%$. Each sample result is just above the detection limit. When the duplicate pair is near the detection limit, analysis of RPDs is not considered to be useful in the precision determination. The data are useable for decision-making purposes. 


\section{SDG J00111}

This SDG comprises one field sample (J152D9), a split of sample J15286 in SDG K0781. This sample was analyzed for ICP metals, mercury, and by alpha spectroscopy, beta counting, gamma spectroscopy, and liquid scintillation counting. No major deficiencies were found in SDG J00111. Minor deficiencies are as follows:

The MS recoveries for seven ICP metals (aluminum, chromium, iron, magnesium, manganese, silicon, and antimony) are out of acceptance criteria. For aluminum, iron, and manganese, the spiking concentration is insignificant compared to the native concentration in the sample from which the MS was prepared. For these analytes, the deficiency in the MS is a reflection of the analytical variability of the native concentration rather than a measure of the recovery from the sample. Four of the analytes that did not have mismatched spike and native concentrations in the original MS have low MS recoveries. Antimony has MS and MSD recoveries of $53 \%$ and $51 \%$, respectively. Chromium has MS and MSD recoveries of $73 \%$ and $72 \%$, respectively. Magnesium has MS and MSD recoveries of $64 \%$ and $61 \%$, respectively. Silicon has a MS and MSD recoveries of $44 \%$ and $78 \%$, respectively. Antimony, chromium, and magnesium, and silicon are considered estimated and flagged "J". All ICP metals data for SDG J00111 are useable for decision-making purposes.

In the ICP metals analysis, the LCS recovery for silicon is above the acceptance criteria at $61 \%$. Silicon data for SDG J00111 are considered estimated and flagged "J".

In the radionuclides, the RPDs calculated for uranium-234 and uranium-238 in the laboratory duplicate pair for sample J152D9 are above the acceptance criteria of $30 \%$, at $72.2 \%$ and $56.1 \%$, respectively. Elevated RPDs in environmental soil samples are attributed to natural heterogeneities in the soil matrix from which the sample and duplicate are prepared. The data are useable for decision-making purposes.

\section{Bulk Asbestos SDG}

Six bulk asbestos samples were collected from 118-F-1 Burial Ground (J152H8, $\mathrm{J} 152 \mathrm{H} 9, \mathrm{~J} 152 \mathrm{JO}-\mathrm{J} 152 \mathrm{~J} 3$ ) and reported in SDG 07-A-2525. No major or minor deficiencies were found in SDG 07-A-2525.

\section{FIELD QUALITY ASSURANCE/QUALITY CONTROL}

RPD evaluations of main sample(s) versus the laboratory duplicate(s) are routinely performed and reported by the laboratory. Any deficiencies in those calculations are reported by SDG in the previous sections.

Field QA/QC measures are used to assess potential sources of error and cross contamination of samples that could bias results. Field QA/QC samples, listed in the 
field logbooks (WCH 2006a, c), are summarized in Table 2. The main and QA/QC sample results are presented in Appendix A.

Table 2. Field Quality Assurance/Quality Control Samples.

\begin{tabular}{|c|c|c|c|}
\hline Sample Area & $\begin{array}{c}\text { Main } \\
\text { Sample }\end{array}$ & $\begin{array}{c}\text { Duplicate } \\
\text { Sample }\end{array}$ & $\begin{array}{c}\text { Split } \\
\text { Sample }\end{array}$ \\
\hline BCL D3 & $\mathrm{J} 15261$ & $\mathrm{~J} 15262$ & $\mathrm{~J} 152 \mathrm{D} 7$ \\
\hline Area 2 B7 & $\mathrm{J} 15272$ & $\mathrm{~J} 15273$ & $\mathrm{~J} 152 \mathrm{D} 8$ \\
\hline Process Trenches A4 & $\mathrm{J} 15286$ & $\mathrm{~J} 15287$ & $\mathrm{~J} 152 \mathrm{D} 9$ \\
\hline
\end{tabular}

Field duplicate samples are collected to provide a relative measure of the degree of local heterogeneity in the sampling medium, unlike laboratory duplicates that are used to evaluate precision in the analytical process. The field duplicates are evaluated by computing the RPD of the duplicate samples for each COC. Only analytes with values above five times the detection limits for both the main and duplicate samples are compared. RPDs for the analytes for the field main and field duplicate samples for the $118-F-1$ burial ground are not calculated because an evaluation of the data shows the analytes are not detected in both the main and duplicate sample at more than 5 times the target detection limit. RPDs of analytes detected at low concentrations (less than five times the detection limit) are not considered to be indicative of the analytical system performance. The data are useable for decision making purposes. The 95\% upper confidence limit (UCL) calculation brief in Appendix B provides details on duplicate pair evaluation and RPD calculation. The data are suitable for the intended purpose of cleanup verification.

Split samples are collected to provide a relative measure of the variability in the sampling, sample handling, and analytical techniques used by commercial laboratories. The field main and split samples are evaluated by computing the RPD of the split samples for each COC to determine the usability of the verification data. The U.S. Environmental Protection Agency Contract Laboratory Program duplicate sample comparison methodology, USEPA Contract Laboratory Program National Functional Guidelines for Inorganic Data Review (EPA 1994), is used as an initial test of the data from the splits. Only analytes that had values above five times the CRQL for both the main and split sample are compared. RPDs for the analytes for the field main and split samples for the 118-F-1 burial ground are not calculated because an evaluation of the data shows the analytes are not detected in both the main and duplicate sample at more than 5 times the target detection limit. RPDs of analytes detected at low concentrations (less than five times the detection limit) are not considered to be indicative of the analytical system performance. The data are useable for decision making purposes. The 95\% UCL calculation brief in Appendix B provides details on split pair RPD calculation. The RPD acceptance criteria for project-split samples is $\leq 30 \%$ (less than or equal to $30 \%$ ). 
A secondary check of the data variability is used when one or both of the samples being evaluated (main and duplicate) is less than 5 times the target detection limit (TDL), including undetected analytes. In these cases, a control limit of \pm 2 times the TDL is used (Appendix B) to indicate that a visual check of the data is required by the reviewer. For the excavation shallow zone duplicate sample (J15273) and split sample (J152D8), the cesium-137, uranium-238, and lead results required this check. For the BCL duplicate sample (J15262) and split sample (J152D7), the cesium-137, uranium-238, and lead results required this check. For the process trench duplicate sample (J15287) and split sample (J152D9), the cesium-137, cobalt-60, europium-152, uranium-238, and lead results required this check. The nickel-63 result for the process trench split sample (J152D9) also required this check. All of these results are attributed to heterogeneities in the sample matrix from which the samples were collected. A visual inspection of all of the data is also performed. No additional major or minor deficiencies are noted. The data are useable for decision-making purposes.

\section{Summary}

Limited, random, or sample matrix-specific influenced batch quality control (QC) issues such as those discussed above, are a potential for any analysis. The number and types seen in these data sets are within expectations for the matrix types and analyses performed. The DQA review of the 118-F-1 verification sampling data found that the analytical results are accurate within the standard errors associated with the analytical methods, sampling, and sample handling. The DQA review for 118-F-1 waste site concludes that the reviewed data are of the right type, quality, and quantity to support the intended use. Detection limits, precision, accuracy, and sampling data group completeness were assessed to determine if any analytical results should be rejected as a result of QA and QC deficiencies. The analytical data were found acceptable for decision-making purposes, with the exception of the sample results reported for silicon within SDG K0781. The verification sample analytical data are stored in the ENRE project-specific database prior to being submitted for inclusion in the HEIS database. The verification sample analytical data are also summarized in Appendix B.

\section{REFERENCES}

BHI, 2000a, Data Validation Procedure for Chemical Analysis, BHI-01435, Rev. 0, Bechtel Hanford, Inc., Richland, Washington.

BHI, 2000b, Data Validation Procedure for Radiochemical Analysis, BHI-01433, Rev. 0, Bechtel Hanford, Inc., Richland, Washington.

DOE-RL, 2001, 100 Area Burial Grounds Remedial Action Sampling and Analysis Plan, DOE/RL-2001-35, Rev. 0, U.S. Department of Energy, Richland Operations Office, Richland, Washington. 
DOE-RL, 2005, Remedial Design Report/Remedial Action Work Plan for the 100 Area, DOE/RL-96-17, Rev. 5, U.S. Department of Energy, Richland Operations Office, Richland, Washington.

EPA, 2000, Guidance for Data Quality Assessment, EPA QA/G-9, QA00 Update, U.S. Environmental Protection Agency, Office of Environmental Information, Washington, D.C.

WCH, 2006b, 100F Remedial Sampling, Logbook EFL-1174-2 pp 1-29, 76-87 and 9192, Washington Closure Hanford, Richland, Washington.

WCH, 2006c, 100F Remedial Sampling, Logbook EFL-1174-3 pp 11-17, Washington Closure Hanford, Richland, Washington. 


\section{DISTRIBUTION}

U.S. Department of Energy

$\underline{\text { Richland Operations Office }}$

D. C. Smith (5)

A3-04

Fluor Hanford, Inc.

J. P. Shearer (WIDS)

E6-35

Washington Closure Hanford

S. W. Callison

$\mathrm{X} 2-07$

R. A. Carlson

$\times 4-08$

S. W. Clark

$\mathrm{H} 4-23$

L. A. Dietz

L. M. Dittmer

$\mathrm{H} 4-22$

J. D. Fancher

$\mathrm{H} 4-23$

L. J. Farris

X9-07

M. T. Hughes

$\mathrm{H} 4-23$

H. M. Sulloway

$\mathrm{H} 4-23$

$\mathrm{H} 4-23$

Records and Document Control

H4-11

DOE-RL Public Reading Room

$\mathrm{H} 2-53$

Hanford Technical Library

P8-55 
CVP-2007-00001

Rev. 0

Distr-2 